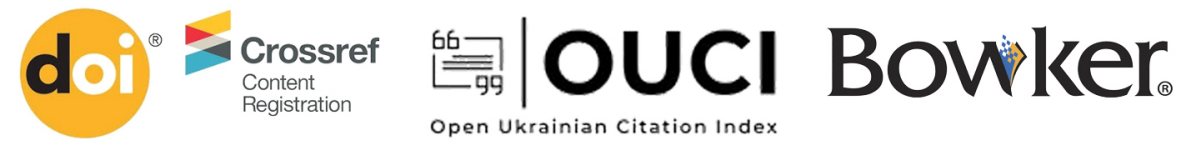

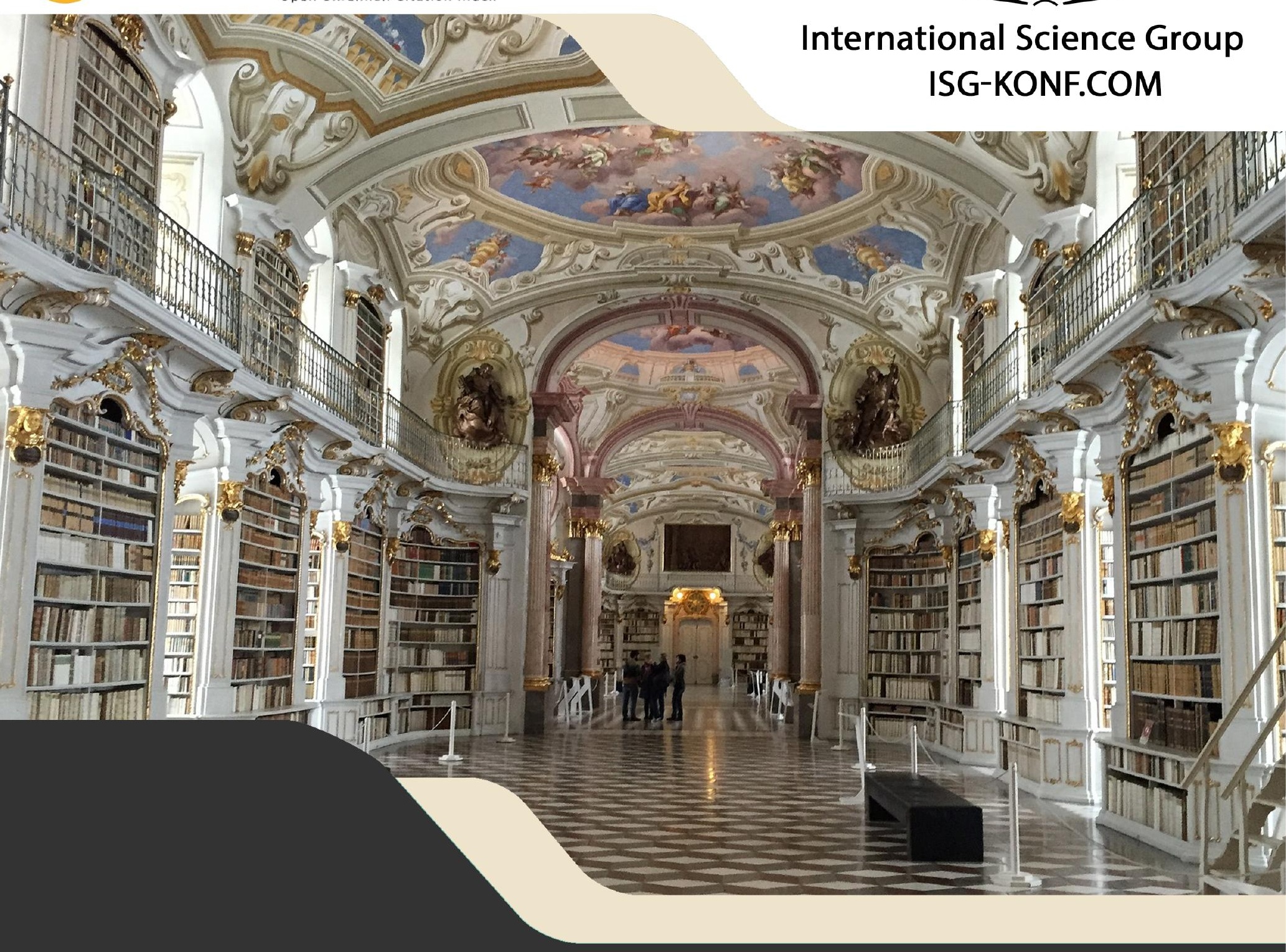

\title{
THEORETICAL FOUNDATIONS OF PEDAGOGY AND EDUCATION
}

Collective monograph

ISBN 978-1-63972-068-2

DOI 10.46299/ISG.2021.MONO.PED.III BOSTON(USA)-2021 
ISBN - 978-1-63972-068-2

DOI- 10.46299/ISG.2021.MONO.PED.III

Theoretical foundations of pedagogy and education

Gollective monograph $\mathscr{B}$ oston 2021 
Library of Congress Cataloging-in-Publication Data

ISBN - 978-1-63972-068-2

DOI - 10.46299/ISG.2021.MONO.PED.III

Authors - Жантикеев С.К., Бекбосынова Ж.С., Идрисова Л.С., Исмаил O.P., Hritchenko T., Loiuk O., Kadenko D., Ohrimenko Z., Voronina H., Грузевич Т., Мірошніченко В., Котова А., Савченко Н., Сердюк В., Шамаєва Ю., Бєляєва О., Кучерова О., Стратан-Артишкова Т.Б., Терлецька Ю., Boryn Н., Horopakha N., Ivanova N., Salii V., Storonska N. Гура О., Зубцова Ю., Gurtova T., Ponomarev S., Osinchuk V., Nezgoda S., Bulatov O., Kolyukh O., Polska I., Konovalova I., Кириченко М., Острянська О., Сіданіч І., Кифенко А., Голян Х., Вовк С., Косінська Н., Радіонова Л., Козирєва Н., Сакун А., Сакун І., Семенишина I., Совкова Т., Сук О., Холодова О., Ярмак Т., Шинкаренко В., Майданенко С., Тарабасова Л., Швидун Л., Кульбач Л., Barantsova I., Milko N., Denisenko N., Yurchenko O., Topbaşoğlu E.K., Yakushko K., Кравець К., Миронюк Л., Bashavets N., Horlov A., Zakhozhai Z., Романів Л., Пішак O., Хань Ч., Куруч А., Посохов В., Парфанович I., Bolotnikova A., Zaitseva G., Pushkarova Y. Honcharuk V., Lopushan T., Nikolaeva S., Chernysh V., Piven V., Stoliar S., Trembitska O., Klimenko T. Umbetova M., Umbetov А. Азарова Л., Пустовіт Т., Радомська Л., Горчинська Л., Бодик О., Щира В., Федорова Ю., Букатова О.М., Венгловська О., Комар О., Дячук П., Роєнко Л., Лантух I.В., Гульбс О.А., Лантух В.В., Кобець О.В., Балабанова К.В., Попова О., Лесик А., Тимченко А., Сулейманова Е., Дерпак Ю., Мороз Г., Видиборець С., Федорова О.В.

\section{REVIEWERS}

Kazachiner Olena - Doctor of Pedagogical Sciences, Associate Professor of the Department of Human Health, Rehabilitation and Special Psychology, Kharkiv National Pedagogical University named after G.S. Skovoroda.

\section{Published by Primedia eLaunch https://primediaelaunch.com/}

Text Copyright (C) 2021 by the International Science Group(isg-konf.com) and authors. Illustrations (C) 2021 by the International Science Group and authors.

Cover design: International Science Group(isg-konf.com). (C)

Cover art: International Science Group(isg-konf.com). (C)

All rights reserved. Printed in the United States of America. No part of this publication may be reproduced, distributed, or transmitted, in any form or by any means, or stored in a data base or retrieval system, without the prior written permission of the publisher. The content and reliability of the articles are the responsibility of the authors. When using and borrowing materials reference to the publication is required. 
Collection of scientific articles published is the scientific and practical publication, which contains scientific articles of students, graduate students, Candidates and Doctors of Sciences, research workers and practitioners from Europe and Ukraine. The articles contain the study, reflecting the processes and changes in the structure of modern science.

The recommended citation for this publication is:

Theoretical foundations of pedagogy and education: collective monograph / Hritchenko T., Loiuk O., - etc. - International Science Group. - Boston : Primedia eLaunch, 2021. 994 p. Available at : DOI - 10.46299/ISG.2021.MONO.PED.III 


\section{TABLE OF CONTENTS}

\begin{tabular}{|c|c|c|}
\hline \multicolumn{3}{|c|}{ 1. CORRECTIONAL PEDAGOGY } \\
\hline 1.1 & $\begin{array}{l}\text { Жантикеев С.К. }{ }^{1} \text {, Бекбосынова Ж.С. }{ }^{1}, \text { Идрисова Л.С. }{ }^{1}, \\
\text { Исмаил О.Р. } \\
\text { ИГРОВЫЕ ЗАНЯТИЯ ПРИ НАРУШЕНИЯХ } \\
\text { ПСИХИЧЕСКОГО РАЗВИТИЯ У ДЕТЕЙ СТАРШЕГО } \\
\text { ДОШКОЛЬНОГО ВОЗРАСТА } \\
\text { ' Университет «Туран-Астана», г.Нур-Султан, Республика Казахстан }\end{array}$ & 15 \\
\hline 2. & EDUCATION & \\
\hline 2.1 & $\begin{array}{l}\text { Hritchenko T. }{ }^{1} \text {, Loiuk O. }{ }^{1} \\
\text { FORMATION AND DEVELOPMENT OF JUNIOR } \\
\text { SCHOOLCHILDREN'S SCIENTIFIC CONCEPTS ON THE } \\
\text { LESSONS OF THE INTEGRATED COURSE "I EXPLORE THE } \\
\text { WORLD" } \\
{ }^{1} \text { Pavlo Tychyna Uman State Pedagogical University }\end{array}$ & 29 \\
\hline 2.2 & $\begin{array}{l}\text { Kadenko D. } \\
\text { НОРМАТИВНО-ПРАВОВА РЕГЛАМЕНТАЦІЯ ВЗАСМОДІЇ } \\
\text { УКРАЇНСЬКОЇ ДЕРЖАВИ З ГРОМАДЯНСЬКИМ } \\
\text { СУСПІЛЬСТВОМ } \\
\text { ' Educational and Scientific Institute of Public Management and Public Service of the } \\
\text { Taras Shevchenko National University of Kyiv } \\
\text { (National Academy for Public Administration under the President of Ukraine) }\end{array}$ & 45 \\
\hline 2.3 & 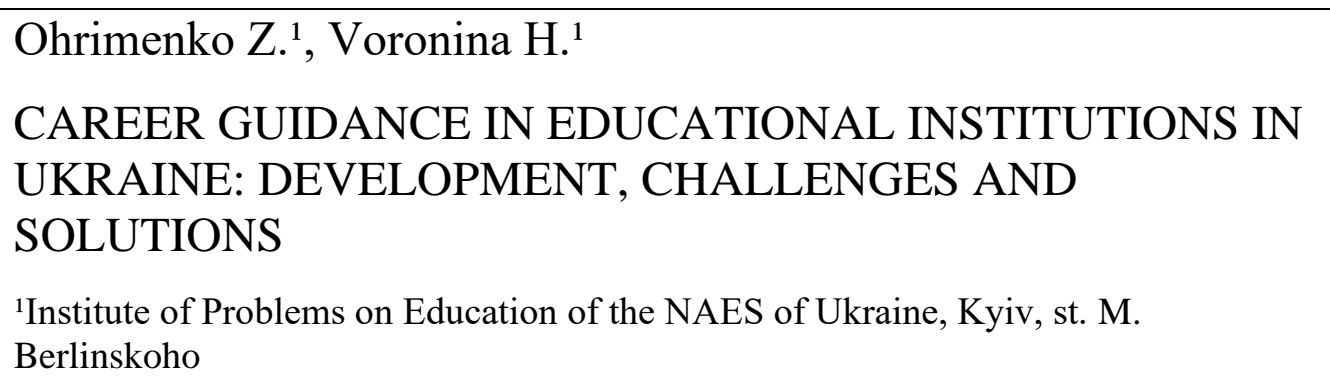 & 56 \\
\hline 2.4 & $\begin{array}{l}\text { Грузевич Т. }{ }^{1}, \text { Мірошніченко В. }{ }^{2} \\
\text { УРАХУВАННЯ ОСОБЛИВОСТЕЙ ВИХОВНИХ } \\
\text { КОНЦЕПЦІЙ У ГРОМАДЯНСЬКОМУ ВИХОВАННІ УЧНІВ } \\
\text { СТАРШИХ КЛАСІВ } \\
{ }^{1} \text { вчитель англійської мови Хмельницької гімназії № } 1 \text { імені Володимира } \\
\text { Красицького, м. Хмельницький, Україна } \\
\text { ² Національна академія Державної прикордонної служби України імені Богдана } \\
\text { Хмельницького, м. Хмельницький, Україна }\end{array}$ & 66 \\
\hline
\end{tabular}




\begin{tabular}{|c|c|c|}
\hline 2.5 & $\begin{array}{l}\text { Котова А. }{ }^{1}, \text { Савченко Н. }{ }^{1}, \text { Сердюк В. }{ }^{1}, \text { Шамаєва Ю. }{ }^{1}, \\
\text { Бєляєва О. } \\
\text { ФОРМИ ОРГАНІЗАЦІЇ САМОСТІЙНОЇ РОБОТИ } \\
\text { СТУДЕНТІВ У ДРУГІЙ ПОЛОВИНІ ХХ СТОЛІТТЯ } \\
{ }^{1} \text { Кафедра англійської мови, Харківський національний університет імені В. Н. } \\
\text { Каразіна } \\
\text { 5 Кафедра методики та практики викладання іноземної мови, Харківський } \\
\text { національний університет імені В. Н. Каразіна }\end{array}$ & 76 \\
\hline 2.6 & $\begin{array}{l}\text { Кучерова О. }{ }^{1} \\
\text { СИСТЕМА ПІДГОТОВКИ ПЕДАГОГІЧНИХ ПРАЦІВНИКІВ } \\
\text { У КАНАДІ } \\
{ }^{1} \text { кафедра англійської мови Харківського національного університету імені } \\
\text { В. Н .Каразіна }\end{array}$ & 90 \\
\hline 2.7 & $\begin{array}{l}\text { Стратан-Артишкова Т.Б. } \\
\text { ТВОРЧО-ВИКОНАВСЬКА ПІДГОТОВКА МАЙБУТНЬОГО } \\
\text { ВИКЛАДАЧА МУЗИЧНИХ ДИСЦИПЛІН У КОНТЕКСТІ } \\
\text { ВИЩОЇ МИСТЕЦЬКОЇ ОСВІТИ } \\
{ }^{1} \text { професор кафедри мистецької освіти Центральноукраїнського державного } \\
\text { педагогічного університету імені Володимира Винниченка }\end{array}$ & 105 \\
\hline 2.8 & $\begin{array}{l}\text { Терлецька Ю. } \\
\text { ВИЗНАЧЕННЯ КРИТЕРІЇВ ЯКОСТІ ПРОФЕСІЙНОЇ } \\
\text { ДІЯЛЬНОСТІ НАУКОВО-ПЕДАГОГІЧНИХ ПРАЦІВНИКІВ: } \\
\text { ОСОБИСТІСНО-ДІЯЛЬНІСНИЙ ПІДХІД } \\
\text { ' Department of Pedagogy and Innovative Education, Lviv Polytechnic National } \\
\text { University }\end{array}$ & 139 \\
\hline 2.9 & $\begin{array}{l}\text { Терлецька Ю. } \\
\text { ЯКІСТЬ ПРОФЕСІЙНОЇ ДІЯЛЬНОСТІ НАУКОВО- } \\
\text { ПЕДАГОГІЧНОГО ПРАЦІВНИКА ТА ІІЇ ЗАБЕЗПЕЧЕННЯ } \\
{ }^{1} \text { Department of Pedagogy and Innovative Education, Lviv Polytechnic National } \\
\text { University }\end{array}$ & 173 \\
\hline \multicolumn{3}{|c|}{ GENERAL AND PRE-SCHOOL PEDAGOGY } \\
\hline 3.1 & 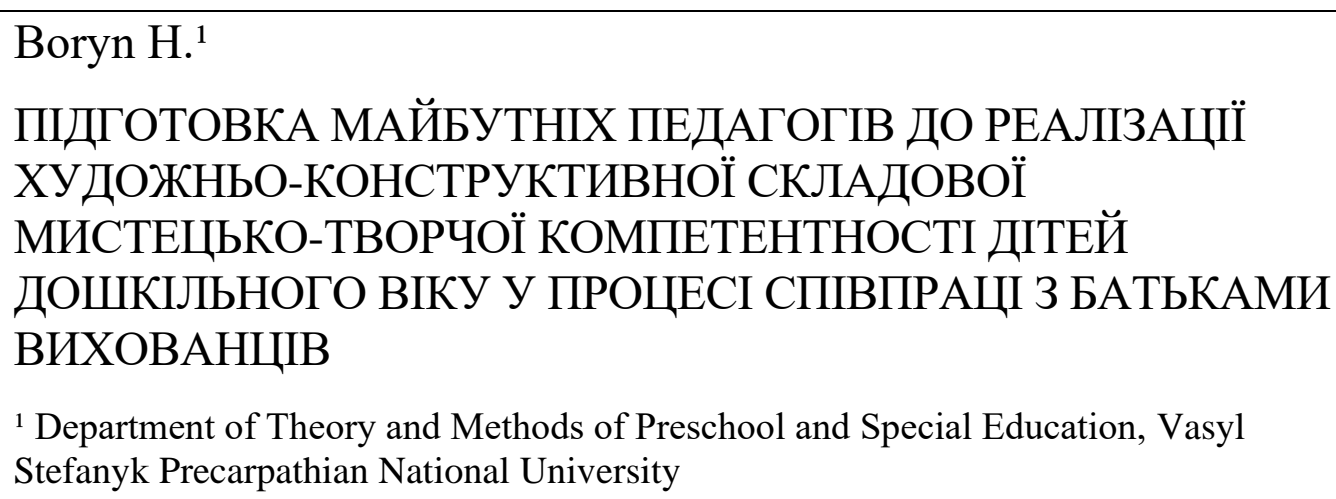 & 205 \\
\hline
\end{tabular}




\begin{tabular}{|c|c|c|}
\hline 3.2 & $\begin{array}{l}\text { Horopakha N. }^{1} \text {, Ivanova N. } \\
\text { METHODOLOGICAL FOUNDATIONS OF ECOLOGICAL } \\
\text { EDUCATION OF PRESCHOOL CHILDREN } \\
{ }^{1} \text { Department of Preschool Pedagogy and Psychology and Special Education, Rivne } \\
\text { State University for the Humanities } \\
{ }^{2} \text { Faculty of Preschool Education and Music Arts of the Lutsk Pedagogical College of } \\
\text { the Volyn Regional Council. }\end{array}$ & 227 \\
\hline 3.3 & $\begin{array}{l}\text { Salii V. }{ }^{1}, \text { Storonska N. }{ }^{1} \\
\text { УМОВИ ФОРМУВАННЯ ТА РОЗВИТКУ МУЗИЧНОЇ } \\
\text { КУЛЬТУРИ ШКОЛЯРІВ У ПРОЦЕСІ НАВЧАННЯ } \\
{ }^{1} \text { Department of Folk Musical Instruments and Vocals, Drohobych Ivan Franko State } \\
\text { Pedagogical University }\end{array}$ & 237 \\
\hline 3.4 & $\begin{array}{l}\text { Гура О. }{ }^{1}, \text { Зубцова Ю. } \\
\text { ПЕДАГОГІЧНИЙ КОЛЕКТИВ ЯК СУБ’СКТ } \\
\text { ІНКЛЮЗИВНОГО ОСВІТНЬОГО ПРОСТОРУ } \\
{ }^{1} \text { Кафедра педагогіки та психології освітньої діяльності, Запорізький } \\
\text { національний університет } \\
{ }^{2} \text { Кафедра дошкільної та початкової освіти, Запорізький національний } \\
\text { університет }\end{array}$ & 247 \\
\hline 4. & INNOVATION IN EDUCATION & \\
\hline 4.1 & $\begin{array}{l}\text { Gurtova T. }{ }^{1} \text {, Ponomarev S. }{ }^{1} \text {, Osinchuk V. }{ }^{1}, \text { Nezgoda S. }{ }^{1}, \\
\text { Bulatov O. } \\
\text { MODERNIZATION OF SCIENTIFIC AND PEDAGOGICAL } \\
\text { APPROACHES IN TRAINING OF PERSONNEL FROM } \\
\text { PHYSICAL CULTURE ON THE BASIS OF ACADEMIC } \\
\text { MOBILITY } \\
{ }^{1} \text { Department of physical education, Lviv Polytechnic National University }\end{array}$ & 263 \\
\hline 4.2 & $\begin{array}{l}\text { Kolyukh О. }{ }^{1} \\
\text { ПСИХОЛОГИЧЕСКИЕ ОСОБЕННОСТИ ГЕНДЕРНОЙ } \\
\text { СОЦИАЛИЗАЦИИ ДЕТЕЙ В ДЕТСКОМ ДОМЕ В } \\
\text { УСЛОВИЯХ КАРАНТИНА } \\
{ }^{1} \text { Higher School of Pedagogy, Pavlodar Pedagogical University }\end{array}$ & 270 \\
\hline 4.3 & $\begin{array}{l}\text { Polska I. }{ }^{1}, \text { Konovalova I. } \\
\text { MODERN HIGHER MUSICOLOGICAL EDUCATION (PHD) } \\
\text { IN UKRAINE: TRADITIONS AND INNOVATIONS } \\
{ }^{1} \text { Department of the Theory and History of Music, Kharkiv State Academy of Culture }\end{array}$ & 291 \\
\hline
\end{tabular}




\begin{tabular}{|c|c|c|}
\hline 4.4 & $\begin{array}{l}\text { Кириченко М. }{ }^{1}, \text { Острянська О. }{ }^{1} \text { Сіданіч І. }{ }^{1} \\
\text { РОЗБУДОВА УНІВЕРСИТЕТСЬКОЇ СИСТЕМИ } \\
\text { АКАДЕМІЧНӦ̈ ДОБРОЧЕСНОСТІ ЯК ОСНОВИ } \\
\text { ПРОФЕСІЙНОГО РОЗВИТКУ В УМОВАХ ЦИФРОВІЗАЦІЇ } \\
\text { СУСПІЛЬСТВА } \\
\text { ' Державний заклад вищої освіти "Університет менеджменту освіти" } \\
\text { Національної академії педагогічних наук України }\end{array}$ & 299 \\
\hline 4.5 & $\begin{array}{l}\text { Кифенко А. }{ }^{1}, \text { Голян Х. }{ }^{1}, \text { Вовк С. } \\
\text { КОМПОНЕНТНА СТРУКТУРА МУЗИЧНО-СЛУХОВОЇ } \\
\text { АКТИВНОСТІ ТА ІІЇ ХАРАКТЕРИСТИКА } \\
{ }^{1} \text { Фаховий коледж «Універсум» Київського університету імені Бориса } \\
\text { Грінченка, м. Київ } \\
\text { ² Дитяча музична школа № }{ }^{13} \text { імені М.І. Глінки, м. Київ }\end{array}$ & 317 \\
\hline 4.6 & $\begin{array}{l}\text { Косінська Н. } \\
\text { МЕТОДОЛОГІЯ ФОРМУВАННЯ СЦЕНІЧНО-ОБРАЗНОЇ } \\
\text { КУЛЬТУРИ МАЙБУТНЬОГО ВЧИТЕЛЯ МУЗИЧНОГО } \\
\text { МИСТЕЦТВА У ПРОЦЕСІ ВОКАЛЬНОЇ ПІДГОТОВКИ } \\
\text { '1 викладач сольного співу Фахового коледжу “Універсум” Київського } \\
\text { університету імені Бориса Грінченка }\end{array}$ & 328 \\
\hline 4.7 & $\begin{array}{l}\text { Радіонова Л. }{ }^{1}, \text { Козирєва Н. } \\
\text { ІННОВАЦІЙНО-ВИПЕРЕДЖАЛЬНА СИСТЕМА ОСВІТИ } \\
\text { ДЛЯ ПІДПРИСМНИЦЬКОГО УНІВЕРСИТЕТУ } \\
{ }^{1} \text { кафедра філософії і політології, Харківський національний університет } \\
\text { міського господарства імені О. М. Бекетова }\end{array}$ & 342 \\
\hline 4.8 & $\begin{array}{l}\text { Сакун А. }{ }^{1}, \text { Сакун І. }{ }^{2} \\
\text { РЕАЛІЗАЦІЇ ІННОВАЦІЙНИХ ОСВІТНІХ ПРОЦЕСІВ У } \\
\text { РАМКАХ ОРГАНІЗАЦІЙНО-ПЕДАГОГІЧНОЇ СПІВПРАЦІ } \\
\text { ШКОЛИ ТА УНІВЕРСИТЕТУ } \\
{ }^{1} \text { Херсонський державний аграрно-економічний університет } \\
\text { ² Херсонський загальноосвітній навчально-виховний комплекс № } 48 \\
\text { Херсонської міської ради }\end{array}$ & 393 \\
\hline 4.9 & $\begin{array}{l}\text { Семенишина І. } \\
\text { ОСВІТНІ ІННОВАЦЇ̈ - ЦЕ ОСНОВНИЙ ФАКТОР } \\
\text { ЕФЕКТИВНОСТІ НАВЧАЛЬНО-ВИХОВНОГО ПРОЦЕСУ У } \\
\text { ЗВО } \\
{ }^{1} \text { Кафедра математики, інформатики та академічного письма } \\
\text { Заклад вищої освіти «Подільський державний університет» }\end{array}$ & 400 \\
\hline
\end{tabular}




\begin{tabular}{|c|c|c|}
\hline 4.10 & $\begin{array}{l}\text { Совкова Т. }{ }^{1} \\
\text { ВПРОВАДЖЕННЯ ІННОВАЦІЙНИХ ТЕХНОЛОГІЙ У } \\
\text { НАВЧАННЯ ФІЗИКИ В ЗАКЛАДАХ ВИЩОЇ ОСВІТИ } \\
{ }^{1} \text { Кафедра фізики, Південноукраїнський національний педагогічний університет } \\
\text { імені К. Д. Ушинського, Одеса, Україна }\end{array}$ & 408 \\
\hline 4.10 .1 & 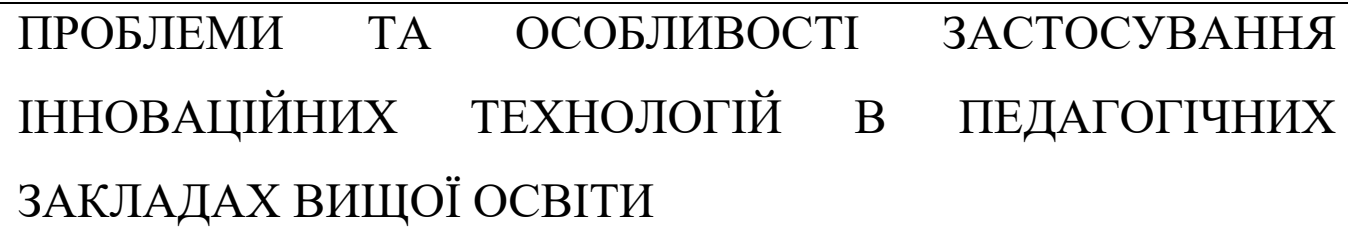 & 408 \\
\hline 4.10 .2 & ПРОБЛЕМНЕ НАВЧАННЯ & 413 \\
\hline 4.10 .3 & $\begin{array}{l}\text { СПЕЦИФІКА ТА ЗАВДАННЯ МЕТОДУ CASE-STUDY ПРИ } \\
\text { НАВЧАННІ ФІЗИКИ В ПЕДАГОГІЧНИХ ЗВО }\end{array}$ & 415 \\
\hline 4.10 .4 & $\begin{array}{l}\text { ІННОВАЦІЙНІ МЕТОДИ ТА ПРИЙОМИ АСОЦІАТИВНОГО } \\
\text { НАВЧАННЯ }\end{array}$ & 419 \\
\hline 4.10 .5 & $\begin{array}{l}\text { ТЕХНОЛОГІЇ МЕНТАЛЬНИХ ТА КОНЦЕПТУАЛЬНИХ } \\
\text { КАРТ }\end{array}$ & 428 \\
\hline 4.10 .6 & $\begin{array}{l}\text { ВІРТУАЛЬНИЙ ЕКСПЕРИМЕНТ ТА ЙОГО РОЛЬ І МІСЦЕ В } \\
\text { НАВЧАННІ ФІЗИКИ }\end{array}$ & 437 \\
\hline 4.10 .7 & $\begin{array}{l}\text { ТЕХНОЛОГІЯ ПЕРЕВЕРНУТОГО НАВЧАННЯ (FLIPPED } \\
\text { LEARNING) }\end{array}$ & 442 \\
\hline 4.11 & $\begin{array}{l}\text { Сук О. }{ }^{1}, \text { Холодова О. }{ }^{1}, \text { Ярмак Т. }{ }^{1} \\
\text { АКАДЕМІЧНА ЕТИКА ЯК ФУНДАМЕНТАЛЬНА ЦІННІСТЬ } \\
\text { ОСВІТИ } \\
\text { ' Харківський національний автомобільно-дорожній університет }\end{array}$ & 446 \\
\hline 4.12 & $\begin{array}{l}\text { Шинкаренко В. }{ }^{1}, \text { Майданенко С. }{ }^{1}, \text { Тарабасова Л. }{ }^{1}, \text { Швидун Л. }{ }^{1}, \\
\text { Кульбач Л. }{ }^{1} \\
\text { ІННОВАЦІЙНІ АСПЕКТИ ОСВІТНЬОЇ МОБІЛЬНОСТІ У } \\
\text { СИСТЕМІ ПІСЛЯДИПЛОМНОЇ ОСВІТИ } \\
{ }^{1} \text { Комунальний заклад вищої освіти «Дніпровська академія неперервної освіти» } \\
\text { Дніпропетровської обласної ради» }\end{array}$ & 453 \\
\hline
\end{tabular}




\begin{tabular}{|c|c|c|}
\hline 5. & PHILOLOGY AND LINGUISTICS & \\
\hline 5.1 & $\begin{array}{l}\text { Barantsova I. }{ }^{1} \text {, Milko N. }{ }^{2} \text {, Denisenko N. }{ }^{2} \text {, Yurchenko O. }{ }^{3} \\
\text { LANGUAGE AS THE MANIFESTATION OF CULTURE } \\
{ }^{1} \text { Department of Methods of Teaching Germanic Languages, Bohdan Khmelnytsky } \\
\text { Melitopol State Pedagogical University } \\
{ }^{2} \text { Department of Germanic Philology, Bohdan Khmelnytsky Melitopol State } \\
\text { Pedagogical University } \\
{ }^{3} \text { Department of Ukrainian Language, Bohdan Khmelnytsky Melitopol State } \\
\text { Pedagogical University }\end{array}$ & 460 \\
\hline 5.2 & $\begin{array}{l}\text { Topbaşoğlu E.K. }{ }^{1} \\
\text { RUS DİLİ DİZGESİNDE ÖZNE (ПОДЛЕЖАЮЩЕЕ) VE } \\
\text { EYLEMCİ (СУББЕКT) MODELLERİ } \\
{ }^{1} \text { Slav Dilleri ve Edebiyatları Bölümü, Kafkas Üniversitesi, Kars, Türkiye }\end{array}$ & 467 \\
\hline 5.3 & $\begin{array}{l}\text { Yakushko K. }{ }^{1} \\
\text { THE DEVELOPMENT OF FUTURE AGROBIOLOGISTS' } \\
\text { FOREIGN LANGUAGE COMMUNICATIVE SKILLS } \\
{ }^{1} \text { Department of English for Technical and Agrobilogical Specialities, } \\
\text { National University of Life and Environmental Sciences of Ukraine }\end{array}$ & 475 \\
\hline 5.4 & $\begin{array}{l}\text { Кравець К. } \\
\text { КРЕОЛІЗАЦІЯ РЕКЛАМНИХ ПОВІДОМЛЕНЬ У СФЕРІ } \\
\text { КОСМЕТОЛОГІІ (НА МАТЕРІАЛІ ЯПОНСЬКОЇ І } \\
\text { УКРАЇНСЬКОЇ МОВ) } \\
{ }^{1} \text { Кафедра японської філологї̈, Київський національний лінгвістичний } \\
\text { університет }\end{array}$ & 539 \\
\hline 5.5 & $\begin{array}{l}\text { Миронюк Л. } \\
\text { ЕКОЛОГІЧНИЙ АСПЕКТ СПІВІСНУВАННЯ ЛЮДИНИ Й } \\
\text { ПРИРОДИ (НА ПРИКЛАДІ ПОЕЗІЙ Л. КОСТЕНКО) } \\
{ }^{1} \text { кафедра українознавства та загальної мовної підготовки } \\
\text { Національного університету «Запорізька політехніка», Україна }\end{array}$ & 546 \\
\hline
\end{tabular}




\begin{tabular}{|c|c|c|}
\hline 6. & DUCATION AND SPORTS & \\
\hline 6.1 & $\begin{array}{l}\text { Bashavets N. }{ }^{1} \\
\text { THE CHALLANGE OF IMPROVING THE EDUCATIONAL } \\
\text { AND PROFESSIONAL PROGRAM "PHYSICAL CULTURE } \\
\text { AND SPORTS" OF PERSONS OF THE SECOND (MASTER'S) } \\
\text { LEVEL OF HIGHER EDUCATION IN SPECIALTY } 017 \\
\text { PHYSICAL CULTURE AND SPORTS } \\
\text { ' professor of the department of theories and methods of physical culture and sports } \\
\text { of the State Institution "South UkrainianNational Pedagogical K.D. Ushinsky } \\
\text { University" }\end{array}$ & 553 \\
\hline 6.2 & 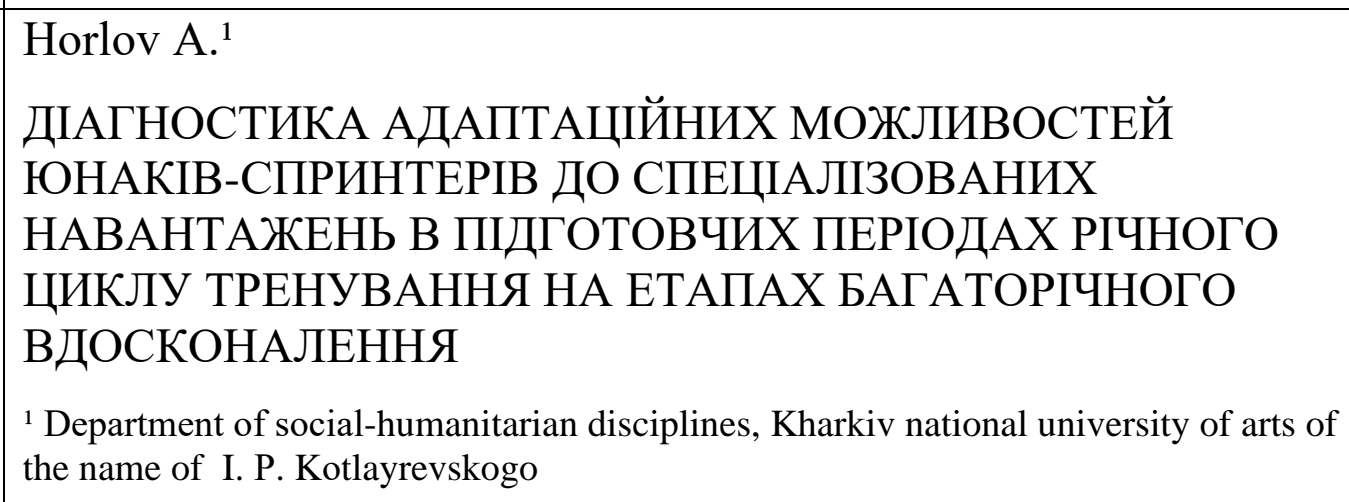 & 590 \\
\hline 6.2 .1 .1 & $\begin{array}{l}\text { ДИНАМІКА ЗМІНИ ПОКАЗНИКІВ РУХОВОЇ ФУНКЦІЇ ПІД } \\
\text { ВПЛИВОМ ВІДНОВНИХ МІКРОЦИКЛІВ ПІДГОТОВЧИХ } \\
\text { ПЕРІОДІВ У ЮНАКІВ-СПРИНТЕРІВ 14-15 РОКІВ }\end{array}$ & 592 \\
\hline 6.2 .1 .1 .2 & $\begin{array}{l}\text { ЗМІНИ ФІЗІОЛОГІЧНИХ ПОКАЗНИКІВ РУХОВІЙ } \\
\text { ФУНКЦІЇ У ЮНАКІВ-СПРИНТЕРІВ МОЛОДШОЇ ВІКОВОЇ } \\
\text { ГРУПИ }\end{array}$ & 497 \\
\hline 6.2 .1 .1 .3 & $\begin{array}{l}\text { УЗАГАЛЬНЕННЯ РЕЗУЛЬТАТІВ ПЕДАГОГІЧНИХ } \\
\text { ДОСЛІДЖЕНЬ У ЮНАКІВ-СПРИНТЕРІВ УЧБОВО- } \\
\text { ТРЕНУВАЛЬНОЇ ГРУПИ 3-4 РОКУ НАВЧАННЯ }\end{array}$ & 601 \\
\hline 6.2.1.2 & $\begin{array}{l}\text { ПОКАЗНИКИ РУХОВОЇ ФУНКЦІЇ І ЇХ ДИНАМІКА В } \\
\text { ПРОЦЕСІ ВІДНОВНИХ МІКРОЦИКЛІВ ПІДГОТОВЧИХ } \\
\text { ПЕРІОДІВ ЮНИХ БІГУНІВ НА КОРОТКІ ДИСТАНЦІЇ 16-17 } \\
\text { РОКІВ }\end{array}$ & 603 \\
\hline 6.2 .1 .2 .1 & $\begin{array}{l}\text { ЗМІНИ ПЕДАГОГІЧНИХ ПОКАЗНИКІВ РУХОВОЇ ФУНКЦІЇ } \\
\text { У ЮНАКІВ-СПРИНТЕРІВ СТАРШОЇ ВІКОВОЇ ГРУПИ }\end{array}$ & 604 \\
\hline
\end{tabular}




\begin{tabular}{|c|c|c|}
\hline 6.2.1.2.2 & $\begin{array}{l}\text { ЗМІНИ ФІЗІОЛОГІЧНИХ ПОКАЗНИКІВ РУХОВОЇ } \\
\text { ФУНКЦЇ У ЮНАКІВ-СПРИНТЕРІВ 16-17 РОКІВ }\end{array}$ & 607 \\
\hline 6.2 .1 .2 .3 & $\begin{array}{l}\text { УЗАГАЛЬНЕННЯ РЕЗУЛЬТАТІВ ПЕДАГОГІЧНИХ } \\
\text { ДОСЛІДЖЕНЬ У ЮНАКІВ-СПРИНТЕРІВ ГРУПИ } \\
\text { СПОРТИВНОГО ВДОСКОНАЛЕННЯ }\end{array}$ & 610 \\
\hline 6.3 & $\begin{array}{l}\text { Zakhozhai Z. }{ }^{1} \\
\text { SPORT DEVELOPMENT IN EASTERN GALICIA (THE } \\
\text { SECOND HALF OF THE XIX CENTURY -BEGINNING OF } \\
\text { THE XX CENTURY) } \\
{ }^{1} \text { Department of philosophy and history V. I. Vernadsky Taurida National University, } \\
\text { Kyiv }\end{array}$ & 618 \\
\hline 6.4 & $\begin{array}{l}\text { Романів Л. }{ }^{1}, \text { Пішак О. }{ }^{1} \\
\text { ЦІННІСНО-МОТИВАЦІЙНА ОРІЄНТАЦІЯ СТУДЕНТІВ } \\
\text { ВИЩИХ НАВЧАЛЬНИХ ЗАКЛАДІВ НА } \\
\text { ЗДОРОВ'ЯЗБЕРЕЖЕННЯ } \\
{ }^{1} \text { Чернівецький національний університет ім.Ю.Федьковича }\end{array}$ & 626 \\
\hline 6.5 & $\begin{array}{l}\text { Хань Ч. }{ }^{1} \\
\text { СИСТЕМА ПІДГОТОВКИ ВЧІТЕЛІВ СПОРТИВНИХ } \\
\text { ДІСЦИПЛІН В КНР } \\
{ }^{1} \text { факультет фізичної культури та спорту Лішуейського університету, пров. } \\
\text { Чжецзян, КНР }\end{array}$ & 640 \\
\hline \multicolumn{3}{|c|}{ SOCIAL PEDAGOGY } \\
\hline 7.1 & $\begin{array}{l}\text { Куруч А. }{ }^{1}, \text { Посохов В. }{ }^{1} \\
\text { РОЛЬ ОСВІТНЬОГО КОМПОНЕНТУ У ВЕТЕРАНСЬКИХ } \\
\text { ЦЕНТРАХ ДЛЯ ЗАБЕЗПЕЧЕННЯ ПРОЦЕСУ РЕІНТЕГРАЦЇ } \\
\text { УЧАСНИКІВ БОЙОВИХ ДІЙ ДО ЦИВІЛЬНОГО ЖИТТЯ } \\
{ }^{1} \text { Національна академія Національної гвардії України } \\
\text { Харків, Україна }\end{array}$ & 652 \\
\hline 7.2 & $\begin{array}{l}\text { Парфанович І. } \\
\text { ОБ'ЄКТИВНІ ТА СУБ'СКТИВНІ РИЗИКИ ПРОФЕСІЙНОГО } \\
\text { ВИГОРЯННЯ ФАХІВЦЯ СОЦІАЛЬНОЇ СФЕРИ } \\
\text { '1 кафедри соціальної роботи та менеджменту соціокультурної діяльності } \\
\text { Тернопільський національний педагогічний університет імені Володимира } \\
\text { Гнатюка }\end{array}$ & 659 \\
\hline
\end{tabular}




\begin{tabular}{|c|c|c|}
\hline \multicolumn{3}{|c|}{ 8. THEORY, PRACTICE AND TEACHING METHODS } \\
\hline 8.1 & $\begin{array}{l}\text { Bolotnikova A. }{ }^{1}, \text { Zaitseva G. }^{1}, \text { Pushkarova Y. } \\
\text { APPLICATION OF MODERN TEACHING METHODS IN } \\
\text { DISTANCE EDUCATION } \\
{ }^{1} \text { Department of Analytical, Physical and Colloid Chemistry, Bogomolets National } \\
\text { Medical University }\end{array}$ & 666 \\
\hline 8.2 & $\begin{array}{l}\text { Honcharuk V. }{ }^{1} \text {, Lopushan T. }{ }^{1} \\
\text { MORAL AND ETHICAL IMPERATIVES OF FAMILY } \\
\text { EDUCATION OF UKRAINIANS IN THE WORKS OF } \\
\text { UKRAINIAN WRITERS OF THE LATE XIX - EARLY XX } \\
\text { CENTURY } \\
{ }^{1} \text { Department of Ukrainian Studies and Relevant Teaching Methodologies, Pavlo } \\
\text { Tychyna Uman State Pedagogical University }\end{array}$ & 681 \\
\hline 8.3 & $\begin{array}{l}\text { Nikolaeva S. }{ }^{1} \text {, Chernysh V. }{ }^{1} \\
\text { TRAINING FUTURE DOCTORS OF PHILOSOPHY WRITING } \\
\text { A SCIENTIFIC ARTICLE } \\
{ }^{1} \text { Kyiv National Linguistic University, } \\
\text { Department of pedagogy, methods of teaching foreign languages and information and } \\
\text { communication technologies }\end{array}$ & 696 \\
\hline 8.4 & $\begin{array}{l}\text { Piven V. } \\
\text { DEVELOPMENT OF AVIATION ENLGLISH SKILLS IN } \\
\text { DISTANCE LEARNING } \\
{ }^{1} \text { Foreign Languagies Department } \\
\text { Flight Academy of National Aviation University of Ukraine, } \\
\text { Kropyvnytskyi, Ukraine }\end{array}$ & 705 \\
\hline 8.5 & $\begin{array}{l}\text { Stoliar S. }{ }^{1} \text {, Trembitska O. }{ }^{2} \text {, Klimenko T. } \\
\text { TECHNIQUE OF DEVELOPMENT AND TEACHING A } \\
\text { SUBJECT MATTER AT THE HIGHER SCHOOL } \\
{ }^{1} \text { Department of Plant Protection, Polissia National University, Ukraine } \\
{ }^{2} \text { Department of Soil Science and Agriculture, Polissia National University, Ukraine }\end{array}$ & 712 \\
\hline 8.6 & $\begin{array}{l}\text { Umbetova M. }{ }^{1} \text {, Umbetov A. } \\
\text { STRUCTURE OF DEVELOPMENT OF CONSTRUCTIVE } \\
\text { SKILLS OF PRIMARY SCHOOL TEACHERS THROUGH } \\
\text { COLLABORATIVE LEARNING } \\
{ }^{1} \text { Faculty of pedagogy and psychology, Astana International University } \\
{ }^{2} \text { Faculty of Natural Sciences and informatization, Arkalyk Pedagogical Institute }\end{array}$ & 727 \\
\hline
\end{tabular}




\begin{tabular}{|c|c|c|}
\hline 8.7 & $\begin{array}{l}\text { Азарова Л. }{ }^{1}, \text { Пустовіт Т. }{ }^{1}, \text { Радомська Л. }{ }^{1}, \text { Горчинська Л. }{ }^{1} \\
\text { СИСТЕМА МЕТОДІВ І ВПРАВ ДЛЯ ВИВЧЕННЯ } \\
\text { ФРАЗЕОЛОГІЗМІВ У КУРСІ УКРАЇНСЬКОЇ МОВИ ЯК } \\
\text { ІНОЗЕМНОЇ } \\
{ }^{1} \text { Кафедра мовознавства, Вінницький національний технічний університет }\end{array}$ & 735 \\
\hline 8.8 & $\begin{array}{l}\text { Бодик О. }{ }^{1}, \text { Щира В. }{ }^{1}, \text { Федорова Ю. }{ }^{2} \\
\text { АКТИВІЗАЦЯ ПІЗНАВАЛЬНОЇ ДІЯЛЬНОСТІ УЧНІВ У } \\
\text { НАВЧАЛЬНОМУ ПРОЦЕСІ: ЕЛЕМЕНТИ ДЛЯ УСПІШНОГО } \\
\text { ВИВЧЕННЯ ІНОЗЕМНОЇ МОВИ } \\
{ }^{1} \text { Кафедра англійської філології, Маріупольський державний університет } \\
{ }^{2} \text { Кафедра англійської мови та методики ії викладання, Херсонський державний } \\
\text { університет }\end{array}$ & 745 \\
\hline 8.9 & $\begin{array}{l}\text { БукаТова О.М. } \\
\text { ФОРМУВАННЯ ПОЛІПРЕДМЕТНИХ НАВЧАЛЬНИХ } \\
\text { КОМПЕТЕНЦІЙ НА ОСНОВІ ІНТЕГРАЦІЇ ПРЕДМЕТІВ } \\
\text { ПРИРОДНИЧОГО ЦИКЛУ } \\
{ }^{1} \text { Ізмаїльський державний гуманітарний університет }\end{array}$ & 779 \\
\hline 8.10 & $\begin{array}{l}\text { Венгловська О. }{ }^{1} \\
\text { ФОРМУВАННЯ ПОШУКОВО-ДОСЛІДНИЦЬКИХ УМІНЬ } \\
\text { МАЙБУТНІХ ПЕДАГОГІВ: ПРАКТИЧНИЙ АСПЕКТ } \\
{ }^{1} \text { Кафедра педагогіки та психології, Київський університет імені Бориса } \\
\text { Грінченка }\end{array}$ & 789 \\
\hline 8.11 & $\begin{array}{l}\text { Комар О. }{ }^{1}, \text { Дячук П. }{ }^{2}, \text { Роєнко Л. }{ }^{1} \\
\text { ПЕДАГОГІЧНІ УМОВИ ФОРМУВАННЯ САМООЦІНКИ } \\
\text { МОЛОДШИХ ШКОЛЯРІВ В ОСВІТНІЙ ДІЯЛЬНОСТІ } \\
{ }^{1} \text { кафедра фахових методик та інноваційних технологій у початковій школі } \\
\text { Уманського державного педагогічного університету імені Павла Тичини Умань, } \\
\text { Україна } \\
{ }^{2} \text { кафедра теорії початкового навчання Уманського державного педагогічного } \\
\text { університету імені Павла Тичини }\end{array}$ & 797 \\
\hline 8.12 & $\begin{array}{l}\text { Лантух І.В. }{ }^{1}, \text { Гульбс О.А. }{ }^{2}, \text { Лантух В.В. }{ }^{3}, \text { Кобець О.В. }{ }^{2}, \\
\text { Балабанова К.В. } \\
\text { ПРОБЛЕМА МОДЕЛЮВАННЯ РОЗВИТКУ ОСОБИСТІСНОЇ } \\
\text { НАДІЙНОСТІ У НАВЧАННІ МАЙБУТНІХ ПІДПРИСМЦІВ } \\
{ }^{1} \text { Харківський національний університет ім. В.Н. Каразіна } \\
\text { ² Уманський державний педагогічний університет ім. Павла Тичини } \\
{ }^{3} \text { Українська інженерно-педагогічна академія } \\
{ }^{4} \text { Національний аерокосмічний університет ім. М.Є.Жуковського }\end{array}$ & 833 \\
\hline
\end{tabular}




\begin{tabular}{|c|c|c|}
\hline 8.13 & $\begin{array}{l}\text { Попова О. }{ }^{1}, \text { Лесик А. }{ }^{1} \\
\text { МОВЛЕННСВА ПІДГОТОВКА МАЙБУТНІХ ПЕДАГОГІВ } \\
\text { ДО ПРОФЕСІЙНОЇ ДІЯЛЬНОСТІ В УМОВАХ НОВОЇ } \\
\text { УКРАЇНСЬКОЇ ШКОЛИ } \\
{ }^{1} \text { Бердянський державний педагогічний університет }\end{array}$ & 886 \\
\hline 8.13 .1 .1 & $\begin{array}{l}\text { ПРОФЕСІЙНЕ МОВЛЕННЯ ВЧИТЕЛЯ ПОЧАТКОВОЇ } \\
\text { ШКОЛИ ЯК НАУКОВА ПРОБЛЕМА }\end{array}$ & 886 \\
\hline 8.13 .1 .2 & $\begin{array}{l}\text { УДОСКОНАЛЕННЯ МОВЛЕННСВИХ УМІНЬ МАЙБУТНІХ } \\
\text { ПЕДАГОГІВ ЯК ОСНОВА ГОТОВНОСТІ ЇХ ДО } \\
\text { ПРОФЕСІЙНОЇ ДІЯЛЬНОСТІ В УМОВАХ НОВОЇ } \\
\text { УКРАЇНСЬКОЇ ШКОЛИ }\end{array}$ & 903 \\
\hline 8.14 & $\begin{array}{l}\text { Тимченко А. }{ }^{1}, \text { Сулейманова Е. }{ }^{1}, \text { Дерпак Ю. }{ }^{2}, \text { Мороз Г. }{ }^{2}, \\
\text { Видиборець С. } \\
\text { СУЧАСНІ ЛЕКЦІЯ ТА СЕМІНАР: ІННОВАЦІЙНІ } \\
\text { МЕТОДОЛОГІЧНІ ПІДХОДИ ДО ЇХ ПРОВЕДЕННЯ } \\
{ }^{1} \text { Загальновузівська кафедра фізичного виховання, спорту і здоров’я людини } \\
\text { Таврійський Національний університет імені В.І. Вернадського, Київ, Україна } \\
\text { ² Кафедра гематології і трансфузіологї } \\
\text { Національний університет охорони здоров’я України імені П.Л. Шупика, Київ, } \\
\text { Україна }\end{array}$ & 913 \\
\hline 8.15 & $\begin{array}{l}\text { Федорова О.В. }{ }^{1} \\
\text { ДЕЯКІ ПИТАННЯ НАВЧАННЯ ФІЗИКИ В } \\
\text { ІНТЕГРОВАНОМУ КУРСІ } 3 \text { ПРИРОДНИЧИХ НАУК } \\
{ }^{1} \text { Ізмаїльський державний гуманітарний університет }\end{array}$ & 923 \\
\hline & REFERENCES & 934 \\
\hline
\end{tabular}




\section{SECTION 1. CORRECTIONAL PEDAGOGY}

DOI 10.46299/ISG.2021.MONO.PED.III.1.1

\section{1 Игровые занятия при нарушениях психического развития у детей старшего дошкольного возраста}

Игра, для детей дошкольного детства, имеет решающее значение, в развитии познавательных психических процессов и развития личностных образований.

Игровую деятельность определяют как ведущую в дошкольном возрасте, она осуществляется самостоятельно ребенком, имеет творческий характер и выраженный эмоциональный фон [1,2].

Общение в процессе игровой деятельности дает возможность ребенку усвоить закономерности процесса и применять их в повседневной жизнедеятельности.

Игра предполагает активное взаимодействие детей друг с другом, создается микрогруппа, для целенаправленной и продуктивной совместной деятельности.

В процессе игры дошкольники осваивают нормы и правила поведении в группе, отрабатывают игровые умения и навыки, приобретают практический опыт.

Для старшего дошкольного возраста, в процессе игровой деятельности предоставляется возможность проигрывать в игровой ситуации жизнь взрослых людей, подражают их поведению и ситуациям, воспринятыми ими в реальной повседневной жизни.

Игровая деятельность помогает детям выстраивать отношения с сверстниками, усваивают азы взаимодействия, получают информацию и реагируют с учетом индивидуальных особенностей, получают эмоциональное подкрепление от самого процесса общения.

Дошкольники, имеющие некоторые нарушения, в частности, страдающие различными речевыми расстройствами, игра является важным средством для 
коррекции познавательных процессов, развития речи и посредство нее и общения и в целом влияет на развитие личности ребенка.

Особенности речевых нарушений, а именно недостаток словарного запаса, не сформированный грамматический строй предложений, развернутость речи, ритм и темп ее, оказывает влияние на продуктивность игровой деятельности.

Дети, имеющие речевые нарушения быстро утомляются, замедлены процессы речевой и общефизической моторики, слабая сосредоточенность внимания и выраженная переключаемость с одного вида деятельности на другой.

По мнению, Л. С. Выготского, игра преобладает у дошкольников и своим участием в игре влияет на процесс развития речи и общения, усвоения навыков социального общественного поведения и тем самым создает зону ближайшего развития [3].

Игровая деятельность, в которую активно вовлекается ребенок, создает условия для развития так называемых доречевых навыков, умение видеть особенности совместной игры, соблюдать правила очередности и группового поведения, концентрировать свое сознание на определенных предметах и игровых ситуациях.

Усвоение игровых действий и активное их продуцирование дает возможность детям с речевыми расстройствами приобретать навыки разговорной речи, использовать слова и предложения в свободной и естественной форме.

Развивающее значение игры можно констатировать при ее организации и целью развития той или иной способности ребенка. Необходимо, постоянно вовлекать детей в творческие игры, помогающие им организовать собственное поведение, следовать правилам и регулировать и дисциплинировать свое поведение в соответствии с целями и задачами игры,

Игра влияет на развитие таких личностных качеств, как нравственный уровень, формирует смелость, отзывчивость, чувства сопереживания и эмпатии. Значимый эффект для развития речи детей представляют театрализованные игры, на которых в процессе инсценировки сюжетной линии, 
дети активно продуцируют, тем самым развивается эмоциональная раскованность, выраженная интонационная составляющая, положительного восприятия участников игрового процесса.

Важным видом игры для детей с нарушениями речевого развития являются применение игр с правилами, которые позволяют организовать поведение и деятельность ребенка, овладеть правилами игры, последовательность выполнения тех или иных игровых действия.

Роль дидактических игр важна при отработке и усвоении грамматических навыков речи, позволяет детям активно с интересом вовлекаться в игровой процесс, эмоционально еe сопровождать и благодаря повторениям и запоминаниям усваивать необходимые формы слов.

Для формирования коммуникативных навыков, специалисты выделяют соответствующие игры, цель которых развитие навыков общения и взаимодействия и отработка коммуникативных игровых действий.

Все коммуникативные игры направлены на использовании в конкретной игровой ситуации неречевых и речевых действий, они взаимосвязаны и дополняют друг друга для эффективной реализации игровой роли.

В процессе игровой деятельности, помимо формирования речевой коммуникации, активно происходит рост и развитие физических, умственных и нравственных сторон, общения и познавательных процессов.

Таким образом, психолого-педагогический анализ игровой деятельности обнаружил роль этого феномена в развитии процесса общения, имеющий свою цель, задачи и средства, оказывающий влияние на развитие речевых навыков, вербальных и невербальных составляющих, установлению положительного настроения и эмоционального контакта.

Особенности развития навыков общения у детей, имеющих нарушения речи, а именно недостаточная степень развития коммуникативных умений и навыков, слабое развитие групповой совместной деятельности с сверстника, не выраженность невербальной коммуникации, низкий эмоциональный фон 
предполагает необходимость активного применения игровых занятий и в целом, игровой деятельности.

Общение со сверстниками в дошкольном возрасте оказывает влияние на уровень социализации ребенка, на усвоение социальных общественных навыков коммуникации и поведения, влияет на психическое здоровье и благополучие.

Важной составляющей социально-психологического компонента общения является формирование умений взаимодействовать с сверстниками и строить полноценные отношения во время игровой деятельности.

Важным аспектов психологической готовности ребенка к общению и взаимодействию является уровень сформированности социально коммуникативных навыков и возможность эффективно их применять во взаимодействии.

В исследованиях Т.В. Чирковой, отмечено, что коммуникативные навыки ребенка проявляются во всех видах его деятельности, в общении с взрослыми и сверстниками [4].

Возможность диагностики выраженности коммуникативных навыков дошкольников можно определить путем создания ситуации, когда ребенок вовлекается в совместную, групповую деятельность, совместно с сверстниками выполняет задания по изготовлению каких либо поделок, лепки, игрушке, при которых ребенок начнет активно актуализировать коммуникативные умения.

Исследователь, выделяет три показателя, по которым можно изучать уровень коммуникативной деятельности, а именно скоростные, эргические и вариативные.

Скоростные показатели, позволяют определить скорость вовлеченности ребенка в общение и взаимодействие, отклик на реакции сверстников, участвующих в контакте и возможность быстрой интеракции дошкольника.

Показатель активности в общении, вовлеченность и коммуникабельность, расширение круга взаимодействия, выносливость в процессе постоянного общения является эргическим показателем. 
Вариативные показатели представлены $\mathrm{y}$ детей $\mathrm{c}$ выраженной общительностью, легкой сменой партнеров по общению и взаимодействию, эмоциональной открытостью, использованием множества вариантов в установлении контактов с сверстниками.

Коммуникативные навыки в старшем дошкольном возрасте проявляются в использовании в речи слов, характерных для определения уровней общения и взаимодействия между ребенком и взрослыми и сверстниками, обозначающих нормативные и общепринятые правила деятельности в обществе, сформированностью его образной речи.

Психологическая готовность ребенка к школе предполагает развитие коммуникативных навыков в достаточной части словарного запаса, использования этикета речи и общения, умению отвечать на предложенные вопросы анкеты, строить предложения в логической последовательности, со смысловым основанием в форме монолога.

Диагностика развития коммуникативных навыков предполагает изучение межличностных отношений, путем привлечения экспертов (родителей, воспитателей), тех людей хорошо знающих ребенка и участвующих в формировании речевых умений и способностей.

Успешное развитие коммуникативных навыков дошкольников предполагает соблюдение учебно-воспитательных принципов, способствующих формированию важных личностных качеств, познавательную и интеллектуальную сферу, всестороннее гармоничное развитие личности ребенка.

Ю.Б. Гиппенрейтер предлагает строить отношения с детьми, опираясь на принципы любви и принятие его как личности, со всеми качествами и характерными особенностями [5].

Следующий принцип, на который обращает внимание профессор, не отвлекать ребенка от основного вида деятельности, которым занят ребенок и который ему интересен. Тем самым мы направляем ему посыл, что он сам может справиться с этим делом и выполнить самостоятельно данный вид деятельности. 
Не ограждать ребенка от возможных отрицательных последствий своих действий, а возможно и бездействий. Таким образом, он научиться выполнять действия, возможно, путем проб и ошибок, сознательно подходить к выполнению практических действий и научиться понимать и таким образом, взрослеть.

Важным принципом, влияющим на формирование коммуникативных навыков дошкольников, является активное слушание ребенка со стороны взрослого, используя понятие «обратной связи», чтоб ребенок понимал, что его слушают, он вызывает интерес и эмоциональный отклик собеседника.

Систематизация игровых занятий с детьми способствует повышению степени развития коммуникации и общения у дошкольников, формируют групповую сплоченность и защищенность, получают эмоциональный комфорт и поддержку.

Игровые занятия улучшают взаимодействие и взаимоотношение детей друг с другом, снижают конфликтные моменты и ситуации в процессе общения, возрастает уровень коммуникативных способностей, дети более дружелюбны и уважительны.

На развитие коммуникативных навыков и игр на общение влияет не только на уровень вербальной коммуникации у детей, но и не вербальную, усилились мимические и пантомимические проявления, и повысился их словарный запас.

Проведение занятия с использованием игровых методов повлияло и на общий эмоциональный фон, как отдельного ребенка, так и группы в целом. Проявления радостного, эйфорического настроения, эмоционального комфорта, дружелюбия, творческий подход и самоуверенность явились показателями эффективности организации занятий, и показывает необходимость их проведения.

Игротерапия является одним из действенных средств в коррекции личностных качеств дошкольника, его самости и индивидуальности. Игротерапия проводится под руководством, дети через проигрывание ролей, 
обучаются технике выразительных, эмоциональных движений, учатся управлять своим телом, через систему телодвижений.

В игротерапии дети используют ролевые образы, могут принимать на себя роль героев из народных сказок, животного мира, имитируя их голос, движения, мимику и жестикуляции..

Еще одним из интересных методов, используемых для формирования коммуникативных навыков является психодрама, который позволяет детям с опорой на сюжеты игр разыгрывать определенные роли. Часто, для активизации игровой деятельности и их интереса к развитию коммуникации и общения используют пальчиковую драматизацию, то есть разыгрывание сюжета с помощью пальцев.

Важным качеством в процессе развития личности дошкольника является формирование произвольности и умение организовать и направить свое поведение и деятельность, элементы самоконтроля и управление своим эмоциональным состоянием.

Отдельно используются игры для развития воображения и творческого потенциала ребенка, обучения таких качеств как умение устанавливать контакты с сверстниками, сотрудничать и взаимодействовать, усвоению вербальной и невербальной коммуникации.

Н.В. Клюева и Ю.В. Касаткина, рекомендуют придерживаться правил, касающихся организации и проведения игр на развитие коммуникативных навыков, а именно обратить внимание на быструю утомляемость ребенка и не включать на занятия по несколько игр подряд. Важным моментом также является поддержание интереса к игре и его активность в процессе самой игровой деятельности [6].

Перед началом игры необходимо обратить внимание на настроение ребенка, его эмоциональный фон, активен или пассивен, спокоен или возбужден. Немаловажным фактором является психологическое и физическое здоровье ребенка, его самочувствие, не голоден ли, но начинать игру желательно через полчаса после обеда. 
Необходимо поддерживать ребенка похвалой и положительными комментариями, не акцентировать внимание на допущенных ошибках и указывать на них, это может вызвать некоторое отторжение в коммуникации ребенка и его открытости.

Исследователи рекомендуют учитывать желание ребенка включиться в игровую деятельность, его настрой и готовность, что в целом будет влиять на успех и эффективность усвоения коммуникативных навыков [4].

Ученые, изучающие проблемы формирования коммуникативных навыков в дошкольном возрасте выделяют ряд неблагоприятных причин, связанных с органическими и физиологическими проблемами у детей, семейное неблагополучие, частые конфликты и ссоры в между родителями, игнорирование потребностей ребенка, а иногда и безразличие.

Среди благоприятных условий формирования коммуникативных навыков у детей выделяют, удовлетворенность актом общения и коммуникации с взрослыми и сверстниками, самостоятельность и самоуверенность в действиях и самой деятельности, самокритичность и самодостаточность.

Ю.В. Полякевич и Г.Н. Осинина предлагают применять игровые ситуации в комплексе, использовать методические подходы и приемы, учитывая возрастно-психологические особенности детей, их готовность к усвоению системы межличностных отношений и речевых навыков [7].

Эффективное развитие коммуникативных навыков в игре зависит от умения и готовности ребенка уделять пристальное внимание процессу занятий и активно участвовать в самом усвоении, слушать и слышать педагога, задавать вопросы и уточнения при возникающих трудностях обучения.

Процесс игровых занятий предполагает активность ребенка и его вербализация предмета усвоения, использовать логику изложения материала, высказывать свое видение и ссылаться на примеры их своего практического и социального опыта.

Успех овладения средствами коммуникации и общения зависят и от умения ребенка использовать свой опыт общения с сверстниками, представлять 
ситуацию общения, протекание и исход, а также использовать этические приемы окончания процесса общения.

Выраженность выделенных качеств, способствуют эффективной социализации ребенка в социально-общественной среде, устанавливать контакты и взаимодействие со всеми участниками и представителями социума, избегать конфликтные моменты, и находить оптимальные пути выхода из создавшихся трудных ситуаций [8].

Таким образом, формирование коммуникативных навыков с использование игровых занятий оказывает важное и решающее значение на развитие общения и взаимодействия ребенка, определяет весь дальнейший путь нормального психического и личностного развития дошкольника.

Практика взаимодействия и общения взрослого и детей дошкольного возраста показывает, что ребенок, часто не имеет опыта понимания и проявления собственных эмоций.

Для решения актуальной проблемы эмоционального благополучия дошкольников, специалисты предлагают организовать обучение детей и их знакомства с некоторыми эмоциями и эмоциональными состояниями и возможными проявлениями и реакциями у самих детей. Исследователи, рекомендуют создать игровую ситуацию с детьми на выражение эмоций, используя игры-этюды, с целью обучения наличия данной эмоции, ее проявления и ее демонстрации взрослым и своим сверстникам. 76\%

Коррекционные занятия с детьми предполагает несколько подходов, посредством которых возможно воздействия с целью регулирования эмоционального состояния и развития дошкольников.

Первый тип воздействия обучающе-корректирующий характеризуется обучением дошкольников элементами невербальной коммуникации, отработкой выразительности эмоций и ее движений, как у самих детей, так и у сверстников и взрослых.

Организация индивидуальных и групповых занятий в различных видах деятельности ребенка, в игре, рисовании для обучения применения 
выразительных эмоций с демонстрацией образов на фотографиях, в музыкальных произведениях, книгах. Обязательными условием обучения является правильность передачи выразительных эмоций, их демонстрация и при допущенных ошибках коррекция и повторная отработка.

Второй тип направляюще-корректирующий, направлен на необходимость осознанного восприятия и понимания ребенком выразительного образа, самостоятельного выбора средств их передачи, информированием педагогом об особенностях выразительных средств и специфики их применения самим ребенком.

Для направляющего типа характерно индивидуализация и самостоятельность в выражении эмоциональных состояний и отработка их в игровой деятельности.

Одним из действенных методов воздействия при эмоциональных нарушений дошкольников специалисты отмечают способность имитировать детьми различных эмоциональных состояний $[9,10]$.

Имитация служит средством профилактики возможного проявления патологических форм, благодаря активной работе нервно-мышечных действий при мимических и пантомимических проявлений.

Посредством имитации происходит активная работа выразительных движений и стимулирования соответствующей эмоции и это может вызвать эмоциональное воспоминание прошлого негативного опыта, что позволит ребенку уйти от возможных реальных страхов.

Ученые отмечают, что дошкольный период является благоприятным для развития эмоциональной сферы и ее сензитивность проявляется в накоплении эмоционального опыта усвоения различных эмоциональных состояний, проявления их в мимике, пантомимике у окружающих. Имитация способствует отработке эмоционального состояния в процессе общения и взаимодействия, развиваются свойства внимания, регулируется поведение и деятельность ребенка. 
Посредством имитации ребенок изображает состояния сверстников и взрослых, усваивает образцы поведения принятые в обществе и учится адекватно строить отношения и контролировать свое поведение, что, несомненно, способствует усвоению социального опыта и социализации в целом.

Нарушения в эмоциональной сфере дошкольника отражаются в поведении и деятельности ребенка, их отличает выраженная неуверенность и заниженная самооценка, плохой сон, часто пугаются и потребность в постоянном внимании и поддержке со стороны взрослых. По исследованиям ученых уровень тревожности очень высокий, в процессе общения и взаимодействия с окружающими проявляют сильное беспокойство, страх одиночества и неуверенность в действиях.

Метод игровой терапии в коррекции эмоциональных состояний включает ряд программ, направленность на снятие уровня тревожности и напряжения, формирования открытого и доверительного отношения с сверстниками и взрослыми, неуверенности и чувства страха.

После проведения коррекционной программы проведена контрольная серия, посредством которой была проверена эффективность проведения обучения и показано, что у детей снизились симптомы эмоционального дискомфорта и частота их проявления.

Дети проявляли более уверенные действия в поведении и деятельности, стали более коммуникабельны, инициативны, активны в процессе общения и взаимодействии, направлены на обслуживании себя, улучшились сон и аппетит.

В настоящем дети часто и активно продуцируют свои эмоции в межличностных отношениях, информируют через эмоции о своем состоянии и отношений к окружающим, получают сигналы о допустимых формах поведения и социальных нормах и стандартах [11].

Однако, концентрируя свое внимание на электронных средствах коммуникации, дети стали проявлять пассивность в контактах со сверстниками и соответственно меньше получать обратную связь во взаимодействии, что в целом влияет и на формирование эмоциональной реакции и и их проявления. 
Л.С. Выготский считал, что эмоции являются центральным звеном в психическом развитии ребенка и для педагога одной из важных видов деятельности является эмоциональное развитие детей, а для детских учреждений приритетной составной частью должна быть организация эмоционального воспитания.

Эмоциональное развитие при нарушениях речи у детей имеет свою специфику и выражено в понимании их отличия от детей с нормальным развитием речи и применения ее в общении. Дети с выраженным нарушением речи обычно не в полной мере осваивают экспрессивные формы выражения эмоций, выраженные в интонации, мимике и пантомимике. Дети с не достаточными возможностями их проявления в общении ограничены, в понимании переживаний сверстников, что отражается на их деятельности и в целом на социализации ребенка [12].

Особенно дети чувствительны в понимании своего дефекта и это часто приводит к возникновению тяжелых эмоциональных состояний, к замкнутости, не полноценности, эмоциональным негативным проявлениям

Необходимость более внимательного отношения к детям, страдающим такого рода нарушениями, не фиксировать свое внимание и внимание окружающих на ошибках в произношениях и не вербализовать их, одни из важных правил коррекционного направления работы педагога.

Как было показано выше, эмоциональная сфера детей активно формируется в процессе игровой деятельности. Игра вызывает ряд положительных эмоций, развивает ее выразительность и мотивацию.

В процессе игры ребенок приобретает специфические умения общения и новые навыки поведения, готов к восприятию нового и интересного, творчески решает возникшие нюансы во взаимодействии, что, в общем, влияет на адекватное развитие эмоционально-волевой составляющей.

Игра обладает специфическими эмоциогенными качествами, усиливает и разнообразит эмоции, появляется возможность инсценирования эмоций, тем 
самым создает условия для развития самостоятельности, инициативы, уверенной реализации своего поведения и деятельности.

Известны ряд исследований, направленных на использование игр для развития эмоций детей, например, Минаева В.M. предлагала игры на распознавание эмоций, в которых ребенок свободно выражает себя, исполняют роли и эмоционально переживают за героев сказок. Например, в игре «Пиктограмма», у детей происходит развитие экспрессивных эмоциональных действий, в соответствии с предложенными эталонами [13].

Чернецкая Л.В. в своем исследовании выявила ряд игр, влияющих на развитие эмоциональной составляющей ребенка, и определила, что игры благоприятно формируют положительный отклик на события и на сопереживание детей, на позитивные тенденции во взаимодействии в процессе контактного действия, на понижение агрессивного поведения и перенапряжения [14].

Положительным в формировании эмоции у детей являются игры, отрабатывающие и включающие гимнастические упражнения на артикуляцию, которая проводится в форме приветствий, мимики и пантомимики для тренировки лицевых мышц и мимических действий.

Эффективными для развития эмоционального фона детей оказались и использование карточек пиктограмм с представленными на них эмоциями, при получении которых, дети активно их воспроизводили и передавали своим сверстникам для продолжения игры. Такого рода игры позволили детям тренировать артикуляцию, выражению своих эмоций и имитировать многообразие эмоциональных состояний.

Таким образом, анализ психолого-педагогических исследований, показал актуальность игровой деятельности в формировании навыков коммуникаций и общения, взаимодействия, эмоционально-волевой составляющей детского развития. 
Коммуникационные игры, в частности игры с правилами, способствовали речевому развитию, служили средством коррекции при нарушениях речевых, коммуникативных и эмоциональных навыков.

Игры позволили детям формировать вербальную и не вербальную стороны общения, овладеть средствами передачи и приема информации, понять специфику межличностной коммуникации, отработать выразительность и эмоциональность своих действий, понимание эмоциональной картины своих сверстников и взрослых.

Эффективность игровых форм и организации деятельности детей дошкольного возраста по коррекции нарушений способствовали формированию самостоятельности и организованности своих действий, волевой активности, формированию внимания и понимания партнеров по общению, включенность и принятие совместных и групповых видов занятий, развитию эмоций и восприятия собственных эмоциональных состояний и состояний сверстников. 


\section{SECTION 2. EDUCATION}

DOI 10.46299/ISG.2021.MONO.PED.III.2.1

\subsection{Formation and development of junior schoolchildren's scientific concepts on the lessons of the integrated course "I explore the world"}

In the modern information society with its socio-economic demands - intensivee growth of high-tech industries and communications, high dynamism of change, globalization processes, rapid growth of knowledge - the direct and main productive force is education and personal intelligence. Only a highly educated person is capable of successful life and further improvement in changing living conditions. That is why the education of the XXI century should become an important resource for the society intellectualization.

The time challenges led to the development of the Concept of the New Ukrainian School [24]. The document emphasizes the learning subjectivity, the need for pupils to master the educational activities methods, the experience of interaction with other people, the formation of the world scientific picture foundations, which is impossible without pupils' development of conceptual apparatus and knowledge, skills and competencies.

Scientific concepts are one of the most important elements of scientific knowledge system, the logical basis of laws and theories. They play an important role in the knowledge system of objects and phenomena of the surrounding world, as they serve as a basis for perception of reality and are a kind of result of its knowledge.

The junior school age deserves special attention in the context of scientific concepts formation. It is at this age that mental operations and actions are formed, moral and intellectual feelings, thinking are actively developed. Characteristic of primary school is the intellectualization of the child's life, meaningfully differentiated process of his personality's individualization. The main task of educating the junior schoolchildren's thinking is to learn new concepts.

The formation and development of ideas and scientific concepts has been and remains the most pressing problem in the junior schoolchildren's education. In the 
context of the research problem modern scientific works are very important. They consider some of its aspects: general issues of scientific concepts formation in junior schoolchildren (T. Barakina), natural ideas and concepts formation in six-year-old first-graders (O. Bida); formation of natural concepts system in the course of studying natural sciences in primary school (O. Varakuta); the role of reference schemes in natural science concepts formation (O. Postnikov); the role of subject lessons in natural science concepts formation (L. Burova); natural science concepts formation and their mental development (T. Bogdanets, M. Sheptukhovsky); didactic conditions for the formation of natural science ideas about the world around us in primary school (M. Matveeva), etc. Scientists emphasize that it is the primary school age that is extremely favorable for the formation and development of scientific concepts.

Long experience in primary education gives confidence to say that junior schoolchildren often learn the concept definition without understanding its essence, operate on terms without realizing the essential features.

Despite the fact that the urgency of this problem is evidenced by modern school practice, the use of scientific concepts in the formation and development of junior schoolchildren's didactic opportunities for lessons of the integrated course "I explore the world" has not been studied.

The article aim is systematization of experience in the formation and development of scientific concepts in junior schoolchildren; disclosure of didactic possibilities of the integrated course "I explore the world" in the process of formation and development of scientific concepts in junior schoolchildren (on a specific example).

World cognition around a person is one of the most important worldview problems. Cognition is "the process of purposeful active reflection of the objective world in people's minds" [20, p. 261].

Levels of cognition are:

- sensory (empirical) cognition, within which, interacting with certain objects, people receive primary knowledge about the world in sensory cognition forms, such as: sensations, perceptions, ideas, which are the result of object and subject interaction; 
- abstract (rational) cognition, forms of which are the concept, judgment, inference, by which the results of sensory data are recorded and processed in the second stage of cognition.

Human world cognition begins with the sensory reflection of reality in such forms as sensation, perception, imagination [28].

Sensation is "elementary mental process, which consists of reflecting certain properties of objects and reality phenomena, as well as the state of internal organs under the direct influence of stimuli (sound, visual, mechanical, taste, olfactory) on the senses" [23, p. 180]. In the brain there is a reflection of certain properties, external aspects of objects, phenomena that directly affect the senses. From sensations arises perception, in which the pupil already reflects the set of properties characteristic of the object, "builds" the sensory-visual image. Perception already reflects the object as a whole, in conjunction of its features [18].

Perception is "the mental process of reflection of objects, phenomena, events in general in the human brain, in the aggregate of all their qualities and properties under the direct action of stimuli on the analyzers" [23, p. 185]. A characteristic feature of perception is the naming of objects or phenomena that are perceived, i.e. inclusion of the second signal system in the perception process. It is thanks to verbal notation that people so easily and instantly perceive objects, recognize and understand them [29].

The result of sensory perception is imagination.

Imagination is "sensory images that arise on the basis of recollection of previously perceived objects (phenomena) or productive imagination" [22, p. 36].

Since representations of an object arise in the absence of the object itself, they are usually less vivid and detailed than perceptions, but more schematic and generalized: they reflect the most characteristic visual features inherent in the class of such objects. Thus, representations are not just visual images of reality, they are always to some extent generalized images of reality. Representation is always the result of individual perceptions generalization [29]. 
Further development of cognition forms that go beyond direct sensuality, makes it possible to achieve a qualitatively new level of reality reflection - rational cognition. The form of rational cognition is abstract thinking [28].

Abstract thinking is one of the types of human thinking, which consists of the formation of abstract concepts and their operation [15].

Concept is a thought expressed in a word / symbol that reflects the general, essential and necessary features in the objects of cognition [21, c. 12]. The concept is the result of the separation of general and essential features of objects or phenomena through understanding and generalization. For example, a child already has an idea of birch, linden, oak, etc. Thinking distinguishes their essential common features: one thick stem, trunk; crown of branches and leaves; plant is tall. Thus the concept of the tree is formed. As we can see, this process is already detached from sensory perception and has taken place at the level of abstract thinking.

There are two types of concepts depending on the form of objects cognition:

1. Empirical (life) concepts are pre-scientific concepts that reflect sensory features, properties. Among these signs can be significant and accidental [26].

2. Scientific concept is a form of thinking that reflects the objectively true in objects or phenomena [26].

The concept performs the following functions:

1) the discovery of new aspects of the recognizable object in the full disclosure of its essential properties [16];

2) communicative. Concepts are used as a communication means. By consolidating their knowledge in the form of concepts, people have the opportunity to share them in communication [21];

3) cognitive. The concepts that have been the result of the previous cognition process are the basis, the means of further cognition. Any concept is always revealed through a system of other concepts, and through a system of concepts of the highest generalization level [16]. 
Concepts system is knowledge of any science as a reflection of a certain part of reality, which is the subject of its knowledge.

In the context of the stated study, we consider it necessary to specify the definitions of "formation" and "development".

Formation is a process in which for some reason stability, completeness, a certain type or something is created, organized, composed, combined [30].

Development is seen by science as a process of natural change of something, the transition from one qualitative state to another - new, more perfect [27, p. 631].

Before considering the processes of formation and development of scientific concepts in junior schoolchildren, it is worth focusing on the process of forming ideas in recent years.

The idea of various objects and world phenomena is a necessary basis for mental processes. They do not arise instantly and not in the finished form, but are formed, gradually improved, changed under the influence of new, purposeful acts of perception.

Ensuring the correct perceptions formation contributes to:

1) taking into account the already existing ideas on this issue, identifying their correctness or erroneousness;

2) organization of children's communication with objects and phenomena of nature / society (direct observations, experiments performed by children independently in extracurricular activities or in lessons during work with natural objects; sometimes a natural object can be replaced by a visual aid. Methods should be accompanied by special tasks aimed at clarifying perception);

3 ) creating an image in words, when it is not possible to organize work with natural objects or their images. Such perceptions are created by the power of the creative imagination. It is useful to rely on existing perceptions and ideas [17].

It is clear that the higher the uncertainty of cognition, the more active the imagination is. But the more carefully a person studies an object or phenomenon of the world around him with the involvement of as many analyzers as possible, the less room is left for the imagination, which seems to replace knowledge and complements it. Therefore, in order for pupils to have a correct idea of the subject, phenomenon, 
process, or natural situation, the teacher must create conditions for them to irritate the receptors of as many analyzers as possible.

When organizing the process of sensory cognition of the world around, the teacher should not rely on the fact that pupils only need to provide a subject, a phenomenon to study, believing that the process of sensory cognition will occur automatically, without any help and guidance from the teacher. The process of sensory cognition is not a mechanical reflection of reality.

The effectiveness of a particular type of communication with the objects of the world is enhanced by:

- creating a problem situation with the help of correctly asked questions and tasks;

- setting a clear goal of activities and communication for children;

- asking consistent questions that direct children's attention to certain features, object properties and make them watch and listen (their wording should be short, specific, simple, but not prompted by the answer);

- organization of subjects' comparison in order to distinguish common and distinctive features;

- mastering the terms that denote the subject or its individual properties;

- creating sketches from memory, etc. [25, p. 103-104].

To form an idea, it is necessary to create the following conditions:

1) the organization of purposeful feeling and perception of signs, objects properties, and their external connections;

2) combination of sensory perception essence with verbal definition (naming of objects, phenomena, etc.);

3) the organization of the idea content awareness;

4) organization of sensory-visual image memorization of an object or group of objects;

5) the organization of the formed representation consolidation through reproduction of its maintenance without object existence; 
6) the organization of the formed representation application at the problems decision on a sample, in similar and new situations.

Thus, ideas arise on the basis of sensations and perception as a result of awareness, memorization and reproduction of objects and phenomena and become the basis for the formation of primary scientific concepts, simple in content, which are then combined into complex and more meaningful ones.

Since it is important to perceive the objects of study directly, it is necessary to involve the junior schoolchild in active, cognitive, research activities through observation, examination, experiment, practical work, measurement, systematization, classification, critical evaluation of what is seen (heard), etc. These activities form the basis of the integrated course "I explore the world" study.

Integrated course "I explore the world" is a subject aimed at forming a holistic world view in junior schoolchildren through the development of natural, civic and historical, social and health, technological, information, mathematical, linguistic and literary educational areas of the State Standard of Primary Education.

The content of the integrated course "I explore the world" covers a certain system of ideas and basic scientific concepts, which are defined in the Standard educational programs, and adapted to the age characteristics of the primary school children's mental development and general learning goals. This course involves the development of junior schoolchildren's knowledge of: objects and phenomena in nature and society; relationships and dependencies in nature and society; different types of educational and cognitive activities; special methods of objects cognition in nature and society; ways of practical activity with natural / social and man-made objects; ways of valeological and ecological behavior; general ways of educational and cognitive activities self-management; norms of ethical, aesthetic, moral attitude to objects of nature and society; norms of pupil's communication and behavior in the process of joint activities with classmates and the teacher.

The integrated course "I explore the world" in primary school involves the formation of primary concepts that bring pupils to understand the world laws for the first time. Each concept must be characterized by such a number of essential features 
that would be sufficient to interpret as primary ones. However, it must have the amount of knowledge necessary for further development.

The effectiveness of pupils' concepts mastery is reflected in two forms: concepts knowledge (not limited to definitions knowledge) and their correct operation in specific mental activity types (if pupils of $1^{\text {st }}-2^{\text {nd }}$ grades allocate, first of all, the most obvious external signs characterizing object action or its value, then in $3^{\text {rd }}-4^{\text {th }}$ grades pupils should be able to establish concepts hierarchy, to find connection between generic and specific concepts).

However, it should be noted that these forms of learning scientific concepts are often in different relationships to each other, namely:

$\checkmark$ on the one hand - the concept is mastered, but it is difficult or impossible for the pupil to operate with it, and he uses it incorrectly. This is manifested primarily when it is necessary to perform other (not similar) types of tasks;

$\checkmark$ on the other hand - the pupil is able to operate with the concept, but does not sufficiently understand its essence, i.e. cannot identify the essential features of its content.

Conscious concepts operation requires them not to be formally mastered (terms or definitions memorization), but meaningful during a specially organized cognitive activity.

Thus, the concepts formation is a specially organized, complex, holistic psychological and pedagogical process. In pedagogical practice, its components are closely intertwined. However, they perform their function in ensuring that pupils learn the concept at certain stages of this process. Each of them is dominated by a certain component: perception, awareness, comprehension, among the elements of which are generalization and systematization.

Integrating the results of psychological and pedagogical research of S. Vasiliev, P. Halperin, V. Davydov， G. Kovalyova， O. Savchenko, G. Uvarova, A. Usova, M. Shardakov and other scientists, we can distinguish five stages of scientific concepts formation process:

1. Motivational and semantic preparation for concept mastering. 
2. The organization of sensory perception of signs, objects or phenomena properties, the ideas formation or previously formed ideas actualization.

3. Mental activity organization aimed at highlighting the essential features in the cognition objects.

4. Generalization and verbal definition of the concept essence, marking it with the appropriate term.

5. Formed concept introduction in the system of available knowledge.

Specifically, we will focus on the theoretical justification and practical implementation of each of the selected stages on the example of the concept of "water cycle in nature" formation in the $2^{\text {nd }}$ grade.

First stage. Motivational and semantic preparation for concept mastering.

In order for pupils to get involved in the work during a specially organized process of concept formation, they should realize:

1) why they need to know the essence of the concept being formed;

2) what needs to be done to learn this concept consciously, i.e. to find out the motive for their activities.

The task of the first stage is to provide pupils' constant motivation to the concept formation process.

Pupils' cognitive interest and positive attitude to master the concept is provided by:

- selection of accessible, interesting material, in particular, reading excerpts from stories, fairy tales;

- demonstration of video fragments, photos, natural objects, guessing riddles, puzzles, crossword puzzles, conducting experiments, etc.

The first stage of the concept of "water cycle in nature" formation can begin with listening to the fairy tale "Dewdrop" by V. Sukhomlynskiy.

Early in the morning a drop of dew woke up on a rose.

- How did I get here? - Drop thought. - In the evening I was high in the sky. How did I get to earth?

And she wanted to go back to the sky again. 
The sun warmed up. The Drop evaporated, went high into the blue sky, to the Sun. And there were thousands of other drops! They gathered in a dark cloud and replaced the Sun.

- Why did you covered me from people? - the Sun said angrily. And sent an arrow of fire into the dark cloud. A fiery arrow struck, thunder rumbled. The dark cloud was frightened and scattered. It rained. A drop fell to the Earth.

- Thank you, Drop, - said the Earth. - I missed you so much!

After listening to the fairy tale, the teacher asks the children:

- Where did the Drop get on the rose in the morning and how was she able to rise high in the sky to the Sun?

At this stage, the teacher also reveals pupils' basic knowledge, which is the basis for the new concept formation (What types of precipitation do you know? Where does water disappear from puddles? What is water vapor? What is evaporation? How does sunlight affect water-liquid?).

It is important to find out whether pupils have realized the essence of the basic concepts, whether they know how to operate in any situation.

The second stage. Sensory perception organization of signs, objects or phenomena properties, ideas formation about them or actualization of previously formed ideas.

Theoretical assimilation of scientific concepts is impossible without the child's sensory experience, which consists of objects and phenomena of nature and society that are perceived. Perception occurs through the sensation of their individual characteristics (size, color, shape, weight, place in space and time, etc.), which act on the subject analyzers. All these features do not exist themselves, but belong to a specific object. Therefore, in the child's mind there is his image.

The task of this stage is to ensure that pupils consciously perceive objects and phenomena of nature / society.

The conscious perception of environmental objects and phenomena is influenced by properly organized observation in nature, observation of natural objects, experiments, organization of independent educational search, use of various teaching 
aids, previously acquired knowledge and practical experience, accurate and figurative teacher's words, exercises that clarify perceptions.

At this stage, the teacher can offer an experiment demonstration.

Experiment. On a tripod one under another the teacher puts: alcohol, a vessel with water, a plate with ice. Pupils watch as the steam from the boiling water in the vessel rises, touching the cold plate from below, turns into water, and the ice in the plate begins to melt and turn into water. That is, there is an observation of water evaporation and steam condensation.

The teacher conducts a conversation (based on what has been seen):

- What do you see in the vessel?

- Is there anything in common between a vessel with water, which we heat, and a plate with ice?

- Where did the water droplets come from?

- What happened to them?

At this stage, the educator teaches children to distinguish objects' features and properties.

The third stage. Mental activity organization aimed at highlighting the essential features in objects of cognition.

Mental activity begins when the pupil has a sufficient number of facts, ideas, i.e. material for thinking, in his mind obtained at the previous stage. In scientific concept formation the understanding of material plays an important role, which in the process of assimilation is carried out through the analysis of perceived features of objects or phenomena of the world, comparison, abstraction and logical sorting of their essential and insignificant features through mental transition from individual features or phenomena to the essential ones, the establishment of interdependencies and relationships between them, as well as the generalization of essential features.

The task of this stage is to identify the essential features in the objects of cognition, to establish relationships and interdependencies between them. 
To implement these tasks, pupils need to have the techniques of mental activity (analysis, synthesis, abstraction, generalization, systematization, etc.), the ability to reason, express their own opinions, to prove their objectivity.

At this stage, it is appropriate to conduct a research workshop.

Research workshop. Where does the water from the puddles disappear?

- After the rain, the streets and roofs of houses are wet, there are puddles everywhere. But the sun will come up and everything will dry up. Where does the water go? (It evaporates, turns into an invisible vapor). What happens to water in rivers, lakes, seas? (It also evaporates).

- Where does water evaporate faster: from a plate or a glass? (Water evaporates faster from the plate. The larger the surface of the water, the faster it evaporates).

- Does water evaporate in cold weather? (It also evaporates, but not as fast as in the heat).

The fourth stage. Generalization and verbal definition of the concept essence, marking it with the appropriate term.

In the process of understanding the essential concept features there is a conceptual (local) generalization, which leads to the individual concepts formation. The concept meaning is summarized in the definition.

The task of this stage is to generalize the cognition objects features singled out at the previous stage in the form of an accessible definition and mark it with the appropriate term.

At this stage, based on what he saw and as the analysis result, the teacher introduces a new concept of "water cycle in nature."

- With the help of experiments, we observed the transformation of water-liquid into water vapor, ice into water-liquid. And how in nature are the transformations of one state into another?

- On Earth, under the sunlight, water constantly evaporates from the surface of rivers, lakes, seas, oceans, moist soil, plant leaves, animal and human bodies. When invisible steam cools, it forms very small droplets of water that collect in the clouds. Small drops in the clouds, merging with each other, gradually increase. Heavy drops 
of water cannot stay in the air, so they fall to the ground in summer as rain, and in winter as snow.

- Returning to land in the form of precipitation, water flows down the slopes and collects in streams and rivers flowing into lakes, seas and oceans. Part of the water seeps through the soil and rocks, reaches groundwater, which also flows into rivers or other water bodies.

- Thus, the continuous process of moving water from the oceans to land through the air and from land back to the ocean is called the water cycle in nature.

The fifth stage. Introduction of the formed concept into the system of available knowledge.

At this stage it is necessary to make generalizations. It consists of uniting the learned concepts into a system, in revealing connections and relations between the elements of this system, in arranging them in a certain order and rational sequence. Pupils learn to consider and apply the concept of "water cycle in nature".

- Look at the picture and analyze it. How does the water cycle in nature?

- Why is there less water in rivers, ponds and lakes in summer?

- At what times of the year is there water transformation in nature from liquid to gaseous? From solid to liquid?

- How do you understand the phrase: "Water is an eternal traveler"?

The children express their ideas, and the teacher writes them on the board. The collected ideas are grouped, analyzed, and those that answer the question are selected. A concept is considered formed if pupils are free to operate with it in different educational and life situations.

Each concept at a certain stage of the learning process has its initial and final formation level, contained in the program and textbook. It is introduced gradually, in several stages. The concepts formation in the learning process of the integrated course "I explore the world" should be carried out in different ways. Their choice depends on the concept content, children's general development level, their cognitive abilities and the basic knowledge and skills availability. 
It should be noted that individual concepts are formed on the basis of ideas, and general ones - on the basis of concepts that are characterized by a smaller volume.

The concept acquires an evidential and convincing character if its essential features are confirmed by the optimal number of facts and if its interrelations with other concepts are considered. This indicates the importance of building a logically connected concepts system. Therefore, an important feature of the integrated course "I explore the world" is the systematic concepts introduction, which involves the connection of each new concept with the already studied one.

The formation of scientific concepts is a long process because pupils continue working with the same objects in different parts of the course. There is a gradual concept development by expanding its scope and deepening its meaning.

In its development, the concept goes through three stages.

The first stage of concept development is characterized by the fact that its essential features are still based on sensory experience. They are abstracted on the basis of direct perception of objects and phenomena or their images and contain a fairly small number of knowledge elements, a low degree of generalization. These are elementary or primary concepts.

In the second stage of development, the concept is characterized by a higher degree of abstraction. Its essential features are hidden from "living contemplation" and are a generalization of elementary concepts characteristics. Such concepts can be concretized indirectly, through a number of simple concepts.

The third stage of concept development is characterized by the highest degree of generalization, abstraction, when the concept acquires the status of regularity or theory. The degree of its distance from the sensory expeience is so great that it gives the impression of its non-involvement in this experience and is often seen as the result of pure abstraction.

Concepts can remain at the elementary level, and the whole stock of child's knowledge will be a set of disparate, chaotic truths, if this process is not controlled by the teacher. 
The knowledge repetition, the revival of existing sensory experience are important in the development of concepts. Repetition, which is carried out not immediately after the first material perception, but after some time, after 2-3 days, is extremely effective for the concepts development. It is important that the repetition takes place in the form of in-depth understanding and even rethinking of the studied material, the establishment of new associative connections.

As a rule, enrichment with new characteristics of already existing concepts is at the stage of new knowledge formation. So that the new characteristics do not turn out to be isolated, the teacher must refer to the previously studied material and establish logical connections with at the stage of learning new material. Sometimes it is necessary to refer to the educational material of previous years. For example, mastering the concept of "Sun is the central body of the solar system" in 4th grade requires the knowledge reproduction about the importance of the Sun for life on Earth, the influence of the Sun on seasonal phenomena in nature, the Sun as an energy source on Earth, which are obtained in 1st, 2nd and 3rd grades. This, in turn, will enrich the above concept, and previously studied will not just be mechanically reproduced, but included in a certain knowledge system at another, higher level. Meanwhile, the assimilation of each new concept characteristic goes through the same stages as the original concept formation. But now this new feature is linked to the already known ones.

Deeper understanding and development of concepts is facilitated by various exercises and practical work, where knowledge is tested in practice. The concepts development is accompanied by an increase in pupils' vocabulary, as the concepts are fixed in terms, symbols, definitions, which are their material carriers.

Thus, the concepts formation and development is a long process in which the concept is enriched with new characteristics with the constant acquisition of new knowledge, their understanding and connection with existing knowledge. The management of this process is carried out by the teacher through: repetition system and practical knowledge mastering; increasingly complex issues application; tasks to establish logical connections between individual learned concepts. In this process, the integrated course "I explore the world" is extremely important, as it involves the 
formation of ideas and concepts about the world integrity; natural and social environment as an environment of human life, its belonging to nature and society; empirical and generalized ideas and concepts that reflect the basic properties and patterns of the real world, expand and organize pupils' social and cognitive experience.

The study does not claim to be a comprehensive consideration of all aspects of this problem. The factors of junior schoolchildren's scientific concepts formation, as well as the selection and use of technologies, methods, teaching aids in the lessons of the integrated course "I explore the world" in the context of scientific concepts formation and development in junior schoolchildren need further study. 
DOI 10.46299/ISG.2021.MONO.PED.III.2.2

\section{2 Нормативно-правова регламентація взаємодії української держави 3 громадянським суспільством}

Громадянське суспільство як суспільство громадян рівних у своїх правах; суспільство, яке не залежить від держави, але взаємодіє з нею заради досягнення загального блага; $\epsilon$ основою держави, в якій забезпечується захист демократичних принципів самооцінки уряду усіх неурядових організацій, спрямованих на формування громадянського суспільства. Для цивілізованого розвитку обох явищ необхідно створити надійний, дієвий і гармонійний механізм їх взаємодії та взаємозбагачення.

Метою створення правової держави в Україні є забезпечення цивілізованого функціонування та розвитку громадянського суспільства, яке є структурним об'єднанням населення певної держави 3 розвиненими економічними, політичними, духовними та іншими відносинами, а також зв'язки, які взаємодіють 3 державою і діють на засадах демократії та верховенства права. Проблемою при цьому є існування прогалин в законодавстві, правовий нігілізм, збільшення кількості випадків порушення прав, свобод та інтересів громадянина, як протиправні дії (бездіяльність) органів державної влади, їх посадових осіб, причини відсутності ідеального прямого і безпосереднього впливу права на суспільні відносини, низький рівень правової культури громадян України. Також процес розвитку України як правової держави гальмує не лише необізнаність населення, а й відсутність чіткої злагодженої діяльності гілок влади, їх роз'єднаність, наявність суперечок, через які механізм регулювання правовідносин втрачає силу, власне значення.

Серед основоположних принципів відносин держави та особи, які отримали конституційне визнання,особливе місце займає відповідальність держави перед особистістю. 3 одного боку, це одне з найважливіших ознак верховенства права. 3 іншого боку, відповідальність перед індивідом відноситься до фундаментальної характеристики безпосередньо громадянського суспільства, 
оскільки існують основи його нормального функціонування в режимі демократії, свободи та соціальної справедливості [31].

Відносини громадянського суспільства та верховенства права має базуватися на певних принципах, основними з яких є:

1. Законодавчий захист прав і свобод людини як пріоритет державної політики у всіх сферах суспільного життя. У цьому випадку цивільні права і закони повинні бути чітко розмежовані і не суперечити один одному. Відповідно, це надасть можливість розвивати певні взаємини громадян і держави.

2. Відпрацьовано регламентацію повноважень на основі поділу влади за системою всеосяжного конституційно-правового контролю за їх діями від інститутів громадянського суспільства.

3. Наявність механізму, що запобігає монополії влади, зосередження іiі в руках однієї особи, завдяки діяльності громадського чи суспільно-політичного інституту, окремої групи людей.

4. Дотримання демократичних вимог у розвитку, прийнятті та застосуванні законів із взаємними правовими закріпленнями на нормативно-правовому рівні принципів і механізмів демократії, притаманної громадянському суспільству [32, c. 19].

При розгляді становлення громадянського суспільства та правової держави в Україні з точки зору забезпечення конституційних прав людини і громадянина головним завданням держави $\epsilon$, насамперед, реалізація прав і свобод особистості. Проте, аналізуючи цей аспект конституційного права сучасної України, є всі підстави вважати, що права і свободи особи, незважаючи на їх грунтовне закріплення та детальне врегулювання в Конституції України, ще не стали вищою соціальною цінністю для української держави (ст. 3 Конституції), що зумовлено, по-перше, колишньою історією нашої країни, яка тривалий час була частиною тоталітарного утворення, i, по-друге, сучасними складними політичними та соціальними проблемами [33].

Правове регулювання діяльності громадських організацій є необхідною умовою їх успішного функціонування, оскільки саме через законодавчу базу, 
вирішуються суттєві питання економічної й раціональної спільності людей в умовах цивілізованого розвитку, створення умов для підвищення соціальної активності учасників взаємин, кожної особистості. Процес формування громадянського суспільства в Україні безпосередньо залежить від правового визначення статусу установ i зокрема найефективнішого законодавчого закріплення узгодженого порядку створення та діяльності громадських організацій. Законодавство має базуватися на достатньо збалансованому, розумному балансі інтересів держави та громадянського суспільства [34].

В українському суспільстві права людини є важливим еталоном цінностей, який, на жаль, має досить декларативний зміст: хоча вони і закріплені в Конституції України, але все одно їх важко реалізувати, оскільки держава i суспільство не в змозі розвинути ефективні правові механізми їх визнання, легалізації, реалізації, гарантування та захисту. I причина не лише в історичних традиціях українського суспільства, де права людини не посідали гідного місця ні в суспільній свідомості, ні в практиці держави, а в нестабільній ситуації переходу, неналежній правосвідомості громадян, їх правового нігілізму та інфантилізму, відсутність можливостей покращити самопочуття людей. Крім того, державна бюрократія поки що не цікавиться правами людини. Турбота про власні інтереси затьмарює їхні конституційні вимоги про те, що повага та захист прав людини є першочерговим обов’язком держави.

В Україні, яка вже має розвинене та соціально стратифіковане індустріальне суспільство, проблема побудови громадянського суспільства за часом збігається 3 процесом державного будівництва. Але, на жаль, соціокультурним фоном цих процесів є залишки радянського світогляду. Тому інструментом побудови нового суспільства може бути лише держава, точніше, демократична держава. Оскільки діяльність держави є стрижнем, центром, домінантою, концепцією організації та перетворення суспільства на громадянське суспільство.

На сьогодні фундамент державної політики сприяння розвитку громадянського суспільства обумовлено головним нормативним документом Національною стратегією сприяння розвитку громадянського суспільства в 
Україні на 2021-2026 роки (затверджено Указом Президента України від 27 вересня 2021 року № 487 / 2021).

Національна стратегія розвитку громадянського суспільства на 2021-2026 роки спрямована на визначення комплексу взаємопов'язаних стратегічних цілей держави у сфері сприяння розвитку громадянського суспільства до 2026 року.

Фундаментальною основою діяльності української держави в контексті розвитку громадянського суспільства є повага до автономії. Органи державної влади та місцевого самоврядування, прагнучи залучення до формування та діяльності представників громадянського суспільства, мають створювати оптимальні умови для розвитку громадянських ініціатив, застосовувати прозорі механізми підтримки функціонування інститутів громадянського суспільства та запроваджувати інструменти для залучення представників громадськості під час прийняття рішень та їх подальшої реалізації.

Діяльність держави у цій сфері має базуватися на підході «немає рішень для громадянського суспільства без громадянського суспільства» та співпраці органів державної влади, місцевого самоврядування та інститутів громадянського суспільства на всіх етапах: аналіз державної політики у відповідній сфері та визначення тенденцій,висвітлення проблем, розробка варіантів їх вирішення, розробка проектів рішень, їх впровадження та моніторинг виконання, оцінка ефективності [35].

Уповноважений в Уряді 3 питань реалізації Ініціативи «Партнерство відкритого уряду» та сприяння розвитку громадянського суспільства:

- виконує представницькі функції у взаємодії з Інститутом громадянського суспільства в рамках Ініціативив Україні;

- організовує розробку пропозицій щодо впровадження заходів, спрямованих на налагодження співпраці Кабінету Міністрів, центральних та місцевих органів виконавчої влади 3 Інститутом громадянського суспільства, громадськими радами;

- сприяє координації та організації методичного забезпечення роботи органів виконавчої влади з питань дотримання демократичних стандартів 
відкритості та прозорості своєї діяльності, залучення громадськості до формування та реалізації державної політики;

- організовує співпрацю з міжнародними організаціями щодо залучення та використання міжнародної технічної допомоги для реалізації заходів, спрямованих на забезпечення відкритості та прозорості державної політики;

- подає до органів виконавчої влади пропозиції щодо залучення представників Інститутом громадянського суспільства, науковців, експертів врозробка проектів нормативно-правових актів.

Проект створення онлайн-платформи «ВзаємоДія» виник завдяки взаємодії Секретаріату Кабінету Міністрів, Мінцифри, Фонду «Східна Європа» (програма EGAP) та представників організацій громадянського суспільства. Його мета запровадити зручні онлайн-інструменти комунікації громадян, організацій громадянського суспільства з органами виконавчої влади. Платформа об'єднує усі наявні на сьогодні механізми взаємодії та інструменти електронної демократії.

Наявність єдиної онлайн-платформи, призначеної для забезпечення взаємодії органів виконавчої влади 3 громадянами та інститутами громадянського суспільства, позитивно впливає на можливість цифровізації таких конституційних прав людини і громадянина, як право громадян на участь у державному управлінні, право на індивідуальне або колективне письмове звернення до органів державної влади та посадових осіб цих органів, право вільно збирати, зберігати, використовувати та поширювати інформацію.

Громадянське суспільство активно сприяе процесам політичної демократизації, набуття державою правового статусу, відстоювання матеріальної та духовної незалежності людини від держави, домагаючись правової гарантії такої незалежності, захисту приватних і громадських інтересів. Водночас має бути зворотний зв'язок 3 державними установами та громадськістю, оскільки верховенство права має реагувати на запити та потреби асоційованого громадянства, видавати відповідне законодавство та 
контролювати його виконання. Іншими словами, вона повинна створити ситуацію правового захисту громадян, сформувати сприятливу правову базу для діяльності створених ними державних інституцій.

Особливе значення набуває проблема взаємодії інститутів громадянського суспільства з органами державної влади України. В даний час ця взаємодія відбувається в наступних правових формах:

1. Участь Інституту громадянського суспільства в нормотворчій діяльності держави, яке забезпечує участь у розробці та обговоренні проектів нормативноправових актів. Участь у правотворчій діяльності $\epsilon$ найбільш поширеною формою участі громадських організацій у державному управлінні.

Громадське обговорення проектів нормативно-правових актів $\epsilon$ обов’язковим етапом нормотворчого процесу в системі органів виконавчої влади. Громадські консультації в процесі нормотворчості проводяться з метою притягнення громадян до управління державними справами, надання їм вільного доступу до інформації про діяльність органів виконавчої влади, а також забезпечення прозорості та відкритості діяльності цих органів[36].

Громадські консультації також повинні сприяти налагодженню системного діалогу між виконавчою владою та громадськістю, покращенню якості підготовки та прийняття рішень щодо важливих питань державного та громадського життя 3 урахуванням думок громадськості, створення умов для участі громадян у підготовці таких рішень. Громадські консультації проводяться 3 питань соціально-економічного розвитку держави і життєво важливих інтересів широких верств населення.

2. Участь Інституту громадського суспільства в правоохоронній діяльності держави забезпечується:

- передачею повноважень державних органів;

- громадським контролем.

Платформа громадянського суспільства створена відповідно до статті 469 Угоди про асоціацію між Україною та ЄС з метою інформування сторін про виконання Угоди та врахування їхнього внеску в їі виконання[36]. 
Платформа громадянського суспільства складається 3 представників громадянського суспільства України, з одного боку, та членів Європейського економічного та соціального комітету, 3 іншого, як форум для проведення зустрічей та обміну думками.

Засідання Платформи громадянського суспільства проводяться на регулярній основі, які вона визначає самостійно.Очолюють Платформу громадянського суспільства по черзі представники громадянського суспільства від української сторони та представник Європейського економічного та соціального комітету відповідно до положень, викладених у Правилах іiі процедури [37].

Платформу громадянського суспільства слід інформувати про рішення та рекомендації Ради асоціації. Платформа громадянського суспільства може давати рекомендації Раді асоціації. Комітет Асоціації та Парламентський Комітет Асоціації повинні підтримувати регулярні контакти з представниками Платформи громадянського суспільства, щоб отримати їхню думку щодо досягнення цілей Угоди.

У рамках виконання Угоди про регулярні контакти між представниками Платформи громадянського суспільства та Комітету асоціації Уряд України на засіданні 24 лютого 2016 р. ухвалив рішення щодо проведення Урядового офісу 3 питань європейської інтеграції щоквартальних зустрічей двосторонніх членів [38].

Повноваження Платформи громадянського суспільства досить обмежені, оскільки це не єдиний орган, який буде контролювати виконання Угоди про асоціацію, оскільки вона вироблятиме лише піврічний висновок, тоді як питання української сторони охоплюють широкий спектр питань.

Крім того, відповідно до свого Регламенту, Платформа громадянського суспільства може висловлювати свої погляди в межах своєї компетенції лише у формі рекомендацій, думок, заяв, оцінок, звітів, доповідей, листів або будь-яких подібних засобів, які вона вважає доцільними. Тобто, як бачимо, інструменти, якими володіє Платформа громадянського суспільства, переважно представлені 
актами рекомендаційного характеру, але вони будуть дійсними, якщо їх візьмуть до уваги Уряд та інші органи, створені згідно з Угодою про асоціацію.

Проте, незважаючи на обмежену компетенцію, Платформа громадянського суспільства $є$ унікальним інструментом прямого двостороннього співробітництва України з Європейським Союзом з метою забезпечення участі громадськості в реалізації Угоди про асоціацію. Перш за все, Платформа громадянського суспільства є діалогом у плані демократії, прав людини та солідарності, водночас є неурядовою громадською платформою для підтримки репрезентативності, демократичності, ротації та неупередженої оцінки виконання Угоди про асоціацію.

Тільки зробивши євроінтеграційні реформи завданням для всього українського суспільства, виникне можливість втілення в реальність повноцінної європейської перспективи для України. Водночас, оскільки ця справа є новою для українського громадянського суспільства, потрібно освоїти демократичні процедури європейського стандарту, навчитися знаходити компроміси та порозуміння 3 фундаментальних питань європейської інтеграції. Щодо результатів

Громадські організації беруть участь у наданні адміністративних послуг на підставі повноважень, наданих їм законом або нормативно-правовим актом органу виконавчої влади. Це також:

- залучення інститутів громадянського суспільства до надання соціальних послуг;

- інститути громадянського суспільства здійснюють громадський контроль за діяльністю органів державної влади у формі громадського моніторингу підготовки та виконання рішень, перевірки їх ефективності; внесення експертних пропозицій до органів державної влади;

- створення спільних дорадчих та експертних органів, рад, комісій, груп для забезпечення громадської думки при формуванні та реалізації державної політики; 
- органам державної влади здійснювати моніторинг та аналіз громадської думки, забезпечувати своєчасне реагування громадськості на пропозиції та зауваження громадськості;

- ознайомлення широких верств населення 3 формами його участі у формуванні та реалізації державної політики, реалізації спільних проектів інформаційної, аналітичної, дослідницької, благодійної та соціальної спрямованості тощо [39].

Наприклад, участь інститутів громадянського суспільства у правоохоронній діяльності держави забезпечує:

- здійснення права на складання протоколів про адміністративні правопорушення;

- участь інститутів громадянського суспільства у діяльності органів внутрішніх справ із забезпечення охорони громадського порядку;

- здійснення права спільно з працівниками поліції вживати заходи щодо припинення адміністративних правопорушень та злочинів;

- участь інститутів громадянського суспільства 3 органами Державної прикордонної служби України в охороні державного кордону.

Практична участь інститутів громадянського суспільства, які є партнерами держави у здійсненні регуляторних та правоохоронних функцій, у перетвореннях, що відбуваються у сфері правопорядку, відкриває широкі можливості для виховання правової культури громадянського суспільства. Зусилля держави, спрямовані на впровадження європейських стандартів у всі сфери життя суспільства, у політико-правову практику цінностей світової цивілізації, активізацію процесів формування громадянського суспільства, висуваються перед органами виконавчої влади України [40].

Беручи до уваги роботи вчених у цій галузі, ми маємо можливість сформулювати перелік основних елементів адміністративного права механізму забезпечення взаємодії інститутів громадянського суспільства з Національною поліцією України [41]. Такими, на нашу думку, є: 
- норми адміністративного права, яке закріплює права та обов'язки суб’єктів, які беруть участь у процесі такої взаємодії;

- адміністративно-правові відносини, формується в процесі спільної діяльності суб’єктів взаємодії, тобто правовідносини, що виникають у процесі взаємодії поліції та установ громадянського суспільства, що регулюється адміністративним правом (переклад інструкцій, що містяться в нормативних актах, практична площина);

- акти реалізації прав та обов’язків учасників взаємодії,які виражаються у реалізації положень адміністративного права в процесі взаємодії суб’єктів [42].

Оптимізація роботи представників української держави на основі співпраці з громадськими формуваннями та населенням потребує вирішення наступних завдань:

- максимально наблизити свою діяльність до потреб громадян, рухатися від декларацій про встановлення партнерських відносин з населенням, реальні кроки в цьому напрямку;

- викорінювати будь-які факти 3 діяльності представників української держави зневажливе ставлення до громадян та їх проблем, недобросовісність і байдужість;

- постійно підвищувати свій професійний та культурний рівень, розширювати світогляд, формувати повагу до представників української держави - від рівня спілкування з громадянами, чесності, відкритості, професійних навичок;

- посилити співпрацю з органами місцевого самоврядування, забезпечити консолідацію зусиль держави та громадянського суспільства;

- широко інформувати громадськість та 3МI про роботу представників української держави, активно залучати громадян та громадські об'єднання, всебічне сприяння журналістам та об’єктивне висвітлення подій;

- своїми діями досягти нового сприйняття представників української держави в суспільстві, отримати активну підтримку широких верств 
населення, відновити довіру громадян і загальну повагу до представників української держави, створити нове обличчя державних інститутів.

Таким чином, у формуванні державної політики сучасне суспільство має не лише вимагати від влади ефективних рішень, а й брати безпосередню участь в управлінні державою та нести спільну відповідальність 3 державою, 3 цією метою приймаються рішення і формується державна політика. При цьому проблемним питанням є низький рівень інституційного розвитку громадянського суспільства, відсутність стабільного залучення професійних кадрів та фінансовоматеріальних ресурсів, стійких практик партнерства з органами державної влади, місцевого самоврядування та бізнесом.

Для досягнення ефективної взаємодії держави і суспільства та наближення iï до ідеальної моделі необхідно реформувати систему внутрішнього права, спрямовуючи його на захист прав інститутів громадянського суспільства, встановлення пріоритету громадянських прав як умови встановлення рівноправних відносин між державою і суспільством. 
DOI 10.46299/ISG.2021.MONO.PED.III.2.3

\subsection{Career guidance in educational institutions in Ukraine: development, challenges and solutions}

Introduction. Career guidance is a mandatory element of the labor market that combines personal and social interests. On the one hand, high-quality performance of professional activity is possible in case of conformity of individual features to the occupation requirements. On the other hand, professionalism and conscientious performance of professional duties ensure the development of certain industries in particular and the state in general.

However, due to a number of negative factors, namely the crisis in the transition economy, unemployment, lack of hours in thematic plans for career guidance, low level of motivation of educators in career guidance activities, the predominant orientation of high school students to higher education, career guidance has virtually ceased to be an integral part of the educational process in Ukraine.

This has led to the fact that high school students having no working experience and being neither fully aware of their own individual characteristics nor oriented to the labor market choose the professions with a deceptive perception of easy success and financial well-being like psychologist, lawyer, journalist, economist, manager. To the contrast, teachers, doctors and representatives of vocational occupations are at the highest demand according to the rating of the most popular professions in Ukraine [45].

Thus, it could be concluded that the problem of professional self-determination of students requires the introduction of effective technologies in the educational process that will contribute to the formation of students' valuable attitude to the process of self-determination which is a subjective need of the individuals at high school and future professional activity. One of such technologies is the career guidance system, which has a large resource of forms and methods to support students in the process of professional self-determination and career learning and development.

Historical review. There are several stages in the formation of career guidance system in Ukraine. The first stage began in the first half of the $20^{\text {th }}$ century and was characterized by the fact that career guidance was a part of psychotechnics. Psychotechnics solved the problems of professional selection and career counseling on 
the basis of studying individual characteristics of a person with the help of tests. In addition, such problems as fatigue, monotony, adaptation of technology to mental human characteristics, vocational training were also at focus. However, the main task of psychotechnics was to comply with the production interests for the labor market, whereas the individual with the individual psychological characteristics was left aside.

In the summer of 1928, according to the Directive of Commissariat of the USSR in the largest industrial centres of Ukraine (Kyiv, Dnipropetrovsk, Odesa) the first Bureaus of Professional Consultation were established with a main task to integrate adolescents into the production process considering the needs of enterprises and future workers (professional contraindications).

All career guidance work (vocational counseling offices, career offices, research and psychological offices) was coordinated and directed by the Interdepartmental Council under the Commissariat of Labor, established in 1929, and then by the Central Laboratory for Vocational Counseling and Selection of the Trade Union Confederation. The tasks of the Central Laboratory included generalization of experience of career guidance work of separate vocational counseling bureaus, exchange of experience, development of methodical instructions on issues of career guidance widespread for implementation among the heads of various departments. By the early 1930s, the theory of occupational selection was formed by F. Dunaevsky and the first experience in developing a system of career guidance was introduced by A. Boltunov and P. Blonsky. During this period, the forms and methods of career guidance were widely studied and tested (A. Shcherbakov, N. Levitov), methods of studying personality (A. Boltunov, A. Bilibin, F. Dunaevsky, N. Levitov) as well as problems of psychological study and classification of professions (S. Gellerstein, V. Chebisheva, I. Spielrein) were developed. Much attention was paid to the study of the social environment influence on career choice. After a devastating criticism in 1936 the development of the national career guidance system was virtually stopped.

At those times active career guidance activities were also carried out in the western part of Ukraine. "The Council for the choice of knowledge" was opened in Lviv in 1933 to play an important role in career guidance for young people. The 
Council carried out extensive work on career guidance based on the real situation of the local economy and guided young people to choose a profession considering their natural abilities, real opportunities and needs of the labor market. In 1938 the Council began to publish a "Press Information Abstract" to supply the Ukrainian press with articles and information on the topic of appropriate job choice. The Council constantly improved its work and spread it outside of Lviv (Ternopil, Stanislav, Przemysl, Zolochiv). In 1939 the "Council for the choice of knowledge" was abolished.

The next development stage in career guidance (1936 - late 50's) is characterized by its sharp decline, reduction of scientific and methodological research. In these years the youth career choice was determined mainly by the content and level of education, as well as health status. The specifics of career guidance and professional selection did not fit into the official policy of those years, according to which public interests should completely dominate over personal ones, and to assess individuals' capabilities it was considered sufficient to determine their social motives, moral and political maturity.

The rapid acceleration of scientific and technological progress, the use of increasingly complex and advanced technologies in the national economy led to the fact that, since 1959, one of the primary problems of society was the problem of purposeful preparation for conscious and balanced career choice, again this issue received state support. Due to this, requests for scientific developments and implementation of their results and recommendations in the practice of general schools, vocational schools and enterprises became relevant.

The impetus for the deployment and organization of all career activities in the country and their gradual transformation into a single system were government Decrees "On measures to further improve the work of secondary schools" (1966) and "On the career guidance of young students" (1969). These program documents defined a single line of organization of work on career guidance, coordinated the efforts of various institutions, departments, organizations, resolved the issue with a single coordination centre within the country, which became a special Interdepartmental Council. All these measures contributed to the creation of a certain system of management services in the country for all career guidance work, which, in the end, significantly improved the 
preparation of the individual for a conscious and free career choice.

In 1966, the first scientific conference on career guidance was held in Kyiv, organized by the Ministry of Education of the Ukrainian Republic and the Research Institute of Psychology. As part of its work, the scientific and practical achievements of recent years were summarized and the main directions of development of career guidance for the future were identified. Attempts were also made in the 1970s to draw public attention to the problem of career guidance. Some work in this direction was carried out by the State Institute of Psychology.

A new stage in the development, intensification and improvement of work on career guidance, coordination of efforts of various organizations in implementing a system of measures to prepare young people for career choice began with the adoption of a government Decree "On improving vocational education, training and guidance" (1984). Starting in 1986, the material base and the organizational structure of the centres for career guidance of young people was announced and realised [48, c. 4].

Summing up the soviet period of career guidance in Ukraine, we can note the following: firstly, career guidance always was ideologically oriented and served to provide workers with numerous manufacturing enterprises; secondly, the most active development of scientific principles of career guidance took place with active support of government, thirdly, although it was a mandatory element of the educational process at school (career guidance lessons, career tests, field trips, active vocational training, etc.) career guidance was often formal in its nature.

In the first half of the 90s' career guidance received its greatest development in the sphere of educational and developmental approaches. At that time, "Concept of career guidance for school" and "Regulations on career guidance for youth" were developed (V. Zinchenko, Ye. Pavlyutenko, M. Tymenko, M. Yantsur). The initial position in these legal documents was the vision of personality primarily not as an object, but as a subject of self-development. Under such conditions, the means of career guidance were defined as aimed primarily at self-knowledge and self-development of the individual. Thus, career guidance was to promote the development of activity, independence, logical thinking, creativity, stimulate self-knowledge, education of the 
need for self-improvement, self-education of professionally important qualities.

During this period the works of Ukrainian scientists appeared, building the theoretical and methodological foundations of modern career guidance (G. Ball, I. Bekh，G. Kostyuk，E. Pavlyutenko， N. Pobirchenko， V. Rybalka，V. Synyavsky, B. Fedoryshyn, etc.). Thus, career guidance was determined as a set of scientifically approved forms, methods and means of personal assistance in career choosing or changing, employment based on individual psychological characteristics, interests, opportunities and needs of the labor market.

Challenges and solutions for today's career guidance. Currently career guidance in educational institutions of Ukraine is an integral part of a holistic system of educational services, the purpose of which is to form the individual's ability to choose a certain type of career activity that best meets individual psychological characteristics, capabilities, interests and needs of the labor market; to help strengthen the competitiveness of the employee in the labor market and achieve effective employment. The tasks of career guidance are the following: each student should learn life skills, discover and develop inner resources, determine future plans; identify further learning or training path. A holistic system of career guidance is built on appropriate principles. The general principles of career guidance include: the principle of consciousness in career choice (expressed in the desire to satisfy both personal and social needs, interests); the principle of activity (activity of the individual in professional self-determination); the principle of development (orientation of the individual to professional development) [48, c. 7].

In recent decades a number of specific studies have appeared in Ukraine that significantly deepened and expanded the content of career guidance (I. Vilsh, O. Vitkovska, L. Gutsan, D. Zakatnov, O. Morin, N. Otroshchenko, Z. Okhrimenko, M. Piddiachyi). These studies have proved that professional self-determination (its course and outcome) depends on the inclusion of reflexive mechanisms, selfawareness, knowledge of the requirements of the desired career and the ability to match individual characteristics with the requirements of future career.

Later an interest to career guidance has also been intensified by specializing of 
high school defined by law. This has required relevant changes in approaches to building a system of school career guidance in general. However, the lack of working hours for a systematic, purposeful, scientifically verified system of career guidance has led to the fact that in recent years career guidance in Ukrainian education has virtually ceased to be a mandatory element of the educational process, and the level of theoretical knowledge in various subjects has become one of student performance indicators. This has contributed to the emergence of such a phenomenon as the postponement of professional self-determination (high school students try to enter any institution of higher education to then orient themselves in the labor market).

That is why one of the vectors for improving modern education in Ukraine is the implementation of changes identified in the key reform of the Ministry of Education and Science of Ukraine - New Ukrainian School, where one of the priorities is to conduct cross-curricular career guidance for students.

In our opinion, the practical implementation of this direction may be to some extent difficult, due to a number of objective factors. First of all, the modern labor market is in the process of transformation and radical change: some professions are disappearing, others are just emerging, much is changing (due to the automation and robotization of professional activities). Accordingly, modern career information should be constantly updated, meet the age characteristics of students, be objective, interesting and accessible, intensify interest in various careers and professional selfdetermination. Forms of presentation of career information should be diverse enough to ensure the activation of perception and mental activity of students. It is important to reveal not only the socio-economic significance of the profession and its production technology, but also the factors that determine the success of job activity, satisfaction or dissatisfaction of the individual with job activity. Thus, in order to provide effective career information, a career counselor must have information on the development and prospects of various areas of job activity for several years to come. However, at the moment such information has no scientific and methodological justification and systematization. Often analysis of the labor market development trends in Ukraine is fragmentary and not objective. Therefore, in order for the content of career information 
to meet all the requirements and fulfil its tasks, it is necessary to conduct large-scale research and adapt them to educational needs in the context of career guidance [47].

It should also be noted that recently there has been a false superficial and simplistic attitude to psychodiagnostic tools in the implementation of school career guidance activities. Sometimes a psychological test is any set of tasks that has no scientific basis and has not passed the required assessment. In addition, most of the career guidance psychodiagnostic techniques were developed either in the last century, or partially lost their relevance. And the development of new tests requires significant human and material resources, the presence of an innovative idea on which the methodology would be based. Given the significant reduction in costs for the development of psychodiagnostics in Ukraine, unfortunately, large-scale development and implementation of available psychodiagnostic methods of career guidance is virtually impossible. Therefore, the career counselor should consciously use the available career diagnostic tools not for the sake of diagnosis, but only for the sake of confirming his/her career guidance hypothesis in the process of career counseling.

One of the key unifying points around which the content of career guidance unfolds is the sphere of values. It is known that each type of job activity has certain requirements for career values of a person, which create a stable, non-contradictory individual system of orientations, able to provide self-regulation and motivation of professional behavior and activity. On the other hand, profile and professional selfdetermination is determined by the peculiarities of the student's values, which further create a core in job activity and in the inner personal world. Thus, the content of career guidance of students should be clear, purposeful and axiological. However, the modern globalized world is characterized by unpredictability, dynamism, constant challenges, threats and imbalance of social ties. This significantly affects the transformation of value orientations in the direction of reducing the significance of spiritual values, instead actualizes consumption, selfishness, materialism and more. According to N. Shcherbakova, such a situation creates anomie, i.e. a state of the social system, which is characterized by the lack of generally accepted values and norms as universal regulators of social behavior [50]. Significant differences in values, disintegrate 
society, deepening social inequality. But the greatest danger is that young people are extremely sensitive to value transformations in society, which undoubtedly affect the formation of a holistic individual system of orientations, able to provide morally oriented self-regulation and motivation of behavior and activities. It should be noted that the similarity of value orientations of different segments of the population in Ukraine (one of which is career value orientations) is an important condition for the effective implementation of the main directions of Ukraine's development.

In our opinion, the above aspects are key points in the implementation of an effective system of career guidance in Ukraine. That is why it is expedient to introduce career guidance in the educational process in the form of career guidance technologies (starting from primary school), which will allow modernizing the content of career guidance and fully use its potential to help students make informed and effective career choices and further professional development.

Career guidance is aimed at the professionalization of the individual, contributes to both the humanization and technologicalization of career choice. Under this approach, career guidance technology appears as a set of methods, techniques and principles of career guidance, due to the purpose and objectives, the sequence of implementation, the availability of appropriate tools [48]. The important component of career guidance technology are diagnostic procedures that contain criteria, indicators and tools for measuring performance [44]. In our opinion, the specificity of career guidance technology is that it should consider primarily the position of the student, his attitude, activity in relation to their own professional self-determination. That is why the interests of the student, his capabilities, abilities and potential, recognition of autonomy, respect for individuality should be at the centre of the career guidance process. Under such conditions, career guidance interaction with the student is to shift the emphasis from orientation to self-orientation, from development to selfdevelopment, from definition to self-determination.

Thus, I. Bekh notes that the selection of educational situations should be borne in mind to encourage self-realization. And embodied in a certain ideal model, this realization must be realistic. Young personality has to set the goal of creating an 
individual fund "I can" and "I want". And these formations should act together, supporting each other and passing into each other. In practical terms, this unity is manifested in the fact that the individual knows what he/she wants and has an appropriate plan of action, and, moreover, acts, not just dreams. At the same time, it should be noted that this ideal model should not be considered as a model of ultimate perfection. It should appear as a concrete, realistic scheme of internal and external life, which, however, is not stable one [43].

According to the above, career guidance should be based on a personalityoriented approach, which consists of forms, methods and techniques that meet such requirements as dialogic, creative, aimed at supporting individual development, providing an individual with the necessary space for freedom to adopt independent decisions, creativity, choice of content and means of learning and behavior. Thus, career guidance technology should be based on the principles: the principle of humanization, the principle of continuity, the principle of integration, the principle of system, continuity and consistency, the principle of diversity of forms and methods of career guidance, the principle of emotional saturation of professional selfdetermination. The best way to organize such interaction is innovative methods (trainings, discussion clubs, mutual support clubs, consultations). These forms will allow students in informal communication to find unifying points in solving problems, to deepen knowledge, to review values and priorities, to clarify career choice, etc. [47].

Conclusions. The system of school career guidance is designed to ensure the effectiveness of career self-realization of adolescents. The current paradox is that being of high demand career guidance as a holistic system has almost disappeared from the educational process or it has been reduced to fragmentary activities.

Analysis of the formation and development of career guidance in Ukraine proves that its active development is possible only in case of significant involvement of policy makers and relevant stakeholders. Reforming modern education in Ukraine in the context of the NUS concept gives hope for the introduction of purposeful, systematic, accessible and effective career guidance which would integrate the achievements of past and present, to help students make informed career choices and manage their 
career in the future.

In our opinion, all this is possible in case of updating scientific and methodological approaches to career guidance in education, gradually starting from primary schools and improving the content at all stages with a focus on building a consistent system of students' career values. 
DOI 10.46299/ISG.2021.MONO.PED.III.2.4

\section{4 Урахування особливостей виховних концепцій у громадянському вихованні учнів старших класів}

Слід зазначити, що серед науковців існують певні розбіжності у поглядах на суть виховання, його мету і способи реалізації. У зв'язку з цим можна говорити про наявність різних концепцій виховання.

У рамках цих концепцій можна виділити три базові моделі виховання: директивну, прихованого впливу та сприяння. У відповідності до першої моделі виховання тлумачиться як безпосереднє цілеспрямоване формування особистості відповідно до задуму наставника; до другої - як маніпуляція, прихований вплив на особистість 3 метою розвитку в неї бажаних 3 погляду вихователя якостей; до третьої - як сприяння самоактуалізації особистості, створення умов для спонтанного розвитку ії нахилів та здібностей [51].

Директивна модель виховання. У контексті директивної моделі, яка базується на засадах ортодоксального християнства та соціально-педагогічного детермінізму, вихователь уподібнюється скульптору, який за допомогою певних методів і засобів з необробленої брили творить досконалий образ, заздалегідь сформований у його уяві. Вихованця він розглядає як пасивний, аморфний матеріал, з якого можна «ліпити» все, що завгодно.

Директивна модель виховання грунтується на явному визнанні за вихователем як більш зрілою, досвідченою, знаючою людиною права визначати мету виховання, а також педагогічні шляхи, способи і засоби ії реалізації. В цій моделі від вихованців вимагають виконання розпоряджень і вказівок педагога, визнання його ведучої ролі як людини, що покликана спрямовувати їхній розвиток, розв'язувати важливу соціальну проблему - виховувати інших людей.

Директивне виховання грунтується на припущенні, що для повноцінного життя в суспільстві люди повинні засвоїти певні соціальні ролі (громадянина, члена сім'ї, представника професійної групи тощо). А для цього їм необхідно оволодіти певними способами діяльності і спілкування, нормами поведінки, знаннями і цінностями, що створені попередніми поколіннями і втілюють у собі 
в тому чи іншому обсязі соціокультурний досвід людства. Тобто йдеться про те, що педагог (держава, суспільство) краще, ніж сама дитина, знає, якою їй треба стати, у якому напрямку розвиватися. Вихованець може не усвідомлювати необхідність того шляху розвитку, який визначений міркуваннями педагогічної доцільності.

Громадянське виховання має на меті сприяти соціалізації учня. Соціалізацію розуміємо як процес засвоєння культурних цінностей, формування соціальних якостей, завдяки яким людина стає дієздатним учасником соціальних відносин. Водночас у контексті директивної моделі громадянське виховання учнів старших класів здебільшого набуває форми прямого виховного впливу педагога на вихованця. При цьому наставник не приховує своєї позиції ведучого. Навпаки, він відверто демонструє це учневі, закликаючи і зобов'язуючи його наслідувати його, дотримуватись певних вимог.

Директивне виховання за своєю суттю $є$ нормативним. Його метою є долучення підростаючого покоління до тих надбань історичного досвіду людства, які необхідні для життя в суспільстві. А серед його завдань значне місце посідає введення дитини в світ культури, створити умови для засвоєння нею необхідних моделей поведінки, певних соціальних ролей i функцій, сформувати у неї відповідні риси і моральні переконання. Директивне виховання, яке інколи асоціюється з авторитаризмом, не обов'язково передбачає застосування примусу до вихованців, придушення їх ініціативи і самостійності. Лише у своїй крайній, репресивній формі воно проявляється у жорсткому контролі, диктаті над особистістю дитини. Але в дійсності переважає позитивний, продуктивний варіант, що орієнтує на те, щоб педагог, спираючись на свій авторитет, домагався перетворення вихованця в свого однодумця, партнера в реалізації поставлених ним педагогічних завдань. При цьому обов’язок педагога полягає не в тому, щоб примусити вихованця до певних дій i вчинків, а в тому, щоб зацікавити кожну дитину, обгрунтувати необхідність того, що їй пропонується, сформувати позитивне ставлення до завдань, способів i засобів виховного процесу. 
Серед актуальних проблем директивного виховання виокремлюється неузгодженість та розбіжності природних інтересів дітей і виховних завдань дорослих. Безпосередні інтереси i прагнення дітей часто не збігаються 3 вимогами педагога. В умовах директивного виховання дитина відчуває певний тиск вихователя, який спрямовує іiі розвиток, тією чи іншою мірою обмежує їі свободу, аж ніяк не сприяє соціалізації старшокласника. Вихованець у багатьох випадках звільняється від необхідності робити самостійний вибір, тому що за нього все вирішує вихователь. Він стримує розвиток самостійності дитини, їі здатності жити в умовах свободи і відповідати за свої дії.

У контексті громадянського виховання, говорячи про негативні риси його директивної моделі, слід звернути увагу й нате, що культурні цінності та норми, які старшокласник засвоює в процесі такого виховання, він сприймає найчастіше як «чужі», нав'язані йому ззовні, а не як свої власні. Особливо чітко це виявляється в прилученні дітей до норм і правил поведінки, цінностей, які безпосередньо не пов’язані з реаліями їхнього життя, а привносяться в нього дорослими і у зв’язку з цим вимагають зовнішнього підкріплення. Це становить певні ризики, оскільки метою громадянського виховання, перш за все, є виховання поваги до закону, формування умінь взаємодіяти з суспільством та ухвалювати важливі суспільні рішення, керуючись демократичними принципами та цінностями.

Проте, не варто характеризувати саму по собі директивну модель виховною процесу як «негативну», чи «позитивну». Все залежить від тих ситуацій, у яких ми маємо намір застосувати їі, для вирішення яких завдань і за допомогою яких засобів іï використовують. 3 одного боку, директивна модель дозволяє чітко планувати, контролювати і коректувати розвиток дитини, сприяє засвоєнню об’єктивно значущих елементів культури незалежно під тю наскільки сама дитина усвідомила цю необхідність. Значною мірою саме цим можна пояснити той факт, що директивна модель виховання була і залишається провідною. Водночас, така застосування такої моделі може бути підставою вчинення опору з боку вихованця педагогічним зусиллям вихователя, який нав'язує йому мету 
розвитку. Тому вважаємо лише окремі елементи цієї моделі варто застосовувати у громадянському вихованні учнів старших класів.

Модель прихованого виховного впливу. В контексті цієї моделі виховання розуміється як маніпуляція - прихований вплив педагога на вихованця з метою формування у нього бажаних якостей.

Слід зауважити, що поняття маніпуляції у багатьох гуманістично налаштованих педагогів викликає насторожене ставлення або ж цілковите неприйняття. При цьому під маніпуляцією розуміють так зване корисливе маніпулювання, до якого люди вдаються 3 метою одноосібного виграшу. Насправді, маніпуляція як наукове поняття - це вид психологічного впливу, який забезпечує приховане збудження в іншої людини намірів, що не збігаються з їі актуальними бажаннями. Маніпуляцію здійснює, наприклад, учитель, який приховано створює для учня ситуацію успіху в певній діяльності або ж починає урок з цікавої розповіді, щоб заінтересувати дітей матеріалом, який інакше здався б їм нудним. Навряд чи в цих діях є щось погане. Маніпуляція - це засіб, етична оцінка якого можлива лише в контексті тієї діяльності й тієї міжособистісної взаємодії, в які цей засіб включено. Звичайно, маніпуляції можуть здійснюватися як на користь, так і на шкоду людині. У моделі прихованого виховного впливу під маніпуляцією розуміють ті поширені в педагогічній практиці ситуації, коли вихователь щиро прагне до блага вихованця, але при цьому сам вирішує, у чому це благо полягає. Домагаючись своєї мети, вихователь прагне непомітно для дитини викликати в неї наміри, які не збігаються 3 іiі актуальними прагненнями. В результаті здійснюється приховане програмування думок і прагнень дитини, а з іншого боку - вона не усвідомлює педагогічного впливу і не знає кінцевої мети вихователя.

Модель маніпулятивного виховання постає як досить ефективний спосіб організації взаємин учасників виховного процесу. Вона аж ніяк не передбачає маніпулювання дитиною всупереч iі інтересам. Навпаки, конструктивна маніпуляція у вихованні стає позитивним засобом розвитку особистості, іiі самосвідомості, самостійності та відповідальності. 
Ідея про прихованість виховного впливу як важливу передумову його ефективності висловлювалась багатьма відомими педагогами. В. О. Сухомлинський, наприклад, вважав, що «однією 3 умов високої ефективності педагогічного впливу є обстановка невимушеності цього впливу. Іншими словами, учневі не слід у кожний момент знати, що вчитель його виховує... Виховний намір повинен бути прихований обстановкою дружніх, невимушених взаємин. ...зробити свій виховний задум непомітним - один з дуже важливих елементів педагогічної майстерності».

Дотримуючись моделі прихованого виховного впливу, педагог прагне так організувати виховний процес, щоб не ставити перед вихованцем педагогічної мети в явному вигляді, уникати прямого, нехай і відповідного його інтересам впливу, не демонструвати свою керівну роль у вихованні. Це сприяє формуванню у вихованця самостійності, відповідальності за свої вчинки. Причому сам процес виховання сприймається ним як вияв власної активності, а не результат організаційних впливів педагога.

У контексті маніпулятивної моделі виховання старшокласник виступає суб’єктом педагогічного впливу, тому що суб'єктивно він діє самостійно, не усвідомлюючи, що напрямок і рамки його активності визначає педагог. Це запобігає неузгодженості прагнень учасників виховного процесу, зіткненню їхніх інтересів. У дитини формується здатність жити в умовах свободи, приймати відповідальні рішення, робити самостійний життєвий вибір, незважаючи на те, що цю свободу і самостійність програмує і спрямовує вихователь.

Поняття «маніпуляції» часто тлумачать як негативне. Відомо, що під впливом певних стереотипів люди починають вірити в те, у що до цього не вірили. Тому стереотипи транслюють окремі ЗМI, щоб досягти своїх маніпулятивних цілей. Маніпуляції формують стереотипи. Тому аудиторією, яка мислить стереотипами, легко маніпулювати. В основі стереотипного мислення лежать спрощенні уявлення, образи, які не випливають із власного життєвого досвіду. Вони нав’язуються людині, закріплюються в свідомості. Педагог має довести, що найкращою протидією стереотипам є життєвий досвід та критичне 
мислення.

В історії педагогіки першу серйозну спробу теоретичного осмислення маніпулятивної моделі виховання, не використовуючи самого терміну «маніпуляція», здійснив Ж.-Ж. Руссо у романі «Еміль, або про виховання». На його переконання, головним засобом виховання має бути спрямована свобода. Суть концепції «спрямованої свободи» полягає в прихованій організації вихователем ситуацій, які викликають у вихованця ті чи інші потреби i спонукають його до запланованих вчинків. Маніпулятивна модель виховання в порівнянні 3 директивною створює значно сприятливіші умови для

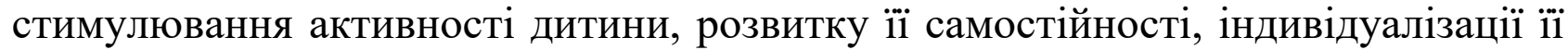
виховання. Будучи педагогікою «спрямованої свободи», вона в прихованій формі зберігає за вихователем функцію керівника й організатора педагогічного процесу, який визначає мету виховання, шляхи і засоби їі досягнення.

Маніпулятивне виховання 3 етичних позицій часто критикують. Стверджують, зокрема, що воно не забезпечує перетворення вихованця в повноправного партнера вихователя, а їхні взаємини - у справді суб'єктносуб’єктні. Непокоїть сам факт прихованості виховного впливу, який часто асоціюється 3 обманом i нещирістю у людських стосунках. Але завдяки маніпулятивній моделі, на нашу думку, можна досягти певного покращення результативності громадянського виховання учнів, зокрема щодо формування поняття суспільної комунікації, свободи слова, етики спілкування, громадянської позиції, критичного сприймання мас-медіа, усвідомлення суспільного добробуту та лобіювання інтересів певних соціальних груп. Елементи цієї виховної моделі, вважаємо, доцільно, якщо ситуація того вимагає, використовувати в громадянському вихованні учнів старших класів.

Вихованець стає повноправним партнером вихователя, а їхні взаємини справді суб’єктно-суб’єктними в рамках третьої моделі виховного процесу моделі сприяння (підтримки). В основі цієї моделі - віра в конструктивне, активне, творче начало людської природи, в їі первісну моральність і доброту, у здатність учня спрямовувати власний розвиток, розуміти власне «Я». 
Відповідно до установок педагогіки сприяння вихователь повинен не вести дитину за собою і навіть не спрямовувати ії розвиток, а йти за нею, підтримувати iï в самореалізації, допомагати їй у розв'язанні власних проблем. Це позиція помічника, який створює умови для саморозвитку особистості: «Мені не треба від тебе більшого, ніж ти сам від себе вимагаєш. Але я радий вислухати тебе і допомогти тобі самому зрозуміти, чого ж ти бажаєш».

Визначені К. Роджерсом умови передбачають стимулювання внутрішніх джерел особистісного розвитку дитини, а саме:

а) природність, щирість, відвертість педагога у вираженні своїх почуттів, його здатність «бути самим собою»;

б) тепла турбота і сприйняття дитини такою, якою вона $є$, повага до дитини як особистості, що заслуговує уваги;

в) емпатія, уміння бачити дитину з її власної точки зору, розуміти ії почуття [52-53].

За цієї моделі першочерговим завданням педагога після знайомства 3 вихованцем $\epsilon$ налагодження контакту, продуктивного спілкування, що грунтується на взаємній повазі і довірі. Наступним кроком є зрозуміти учня. Учитель, спостерігаючи за учнем і спілкуючись з ним, намагається делікатно і ненав'язливо проникнути в його внутрішній світ, з'ясувати його потреби і здібності, розкрити його потенційні можливості, зрозуміти актуальні інтереси, мотиви, якими він керується у своїй поведінці, визначити життєві проблеми, які хвилюють дитину. Після успішного виконання цих завдань, вихователь робить наступні кроки у своїх педагогічних діях. Насамперед він сприяє дитині в самопізнанні, усвідомленні нею набутого досвіду, осмисленні власних інтересів і можливостей, свого місця у соціумі. На цій основі вихованець визначає завдання власного розвитку та соціалізації. Отже, виховну мету педагог визначає не на основі власних уявлень про те. яким має стати вихованець, а з урахуванням його внутрішнього потенціалу та життєвого досвіду. 3'ясувавши разом з учнем мету його громадянського виховання, точніше, створивши умови для визначення учнем шляхів власного громадянського розвитку, педагог сприяє їх реалізації. 
Сприяюча модель виховання практично виключає неузгодженість педагогічних завдань вихователя i життєвих прагнень вихованця, тому що педагогічні завдання формулюються на основі життєвих реалій і за участю самого вихованця. Відтак він сприймає їх не як нав’язані ззовні, а як свої власні. Це запобігає зіткненню прагнень учасників виховного процесу, підвищує його ефективність. При цьому позиція педагога постає як позиція старшого товариша, порадника і помічника вихованця, приховувати ії немає потреби, тому що вона є продуктом їхньої взаємодії.

У процесі сприяючого виховання педагог i вихованець виявляються рівноправними суб'єктами, співтворцями педагогічного процесу, відносини між ними набувають справді суб’єкт-суб’єктного характеру. Учитель виступає як суб’єкт, тому що саме від нього залежить, чи буде обрано дану модель педагогічної взаємодії. При цьому він налаштований на те, щоб не підганяти дитину під державні, суспільні чи свої власні уявлення про виховний ідеал, а свідомо прагне до того, щоб формувати уявлення про майбутній образ дитини, виходячи з неї самої, стимулюючи їі самостійну й дедалі зростаючу участь у цьому процесі. За такого підходу дитина стає справжнім суб'єктом власного розвитку. Саме від iï внутрішнього світу, іiі потенціалу, інтересів і проблем залежить мета виховання і засоби їі досягнення. Дитина перетворюється з засобу реалізації ззовні визначених виховних завдань, як це відбувається в моделі директивного виховання, у суб’єкт і мету власного розвитку.

Історичні корені педагогіки сприяння сягають у глибину століть. Ї̈ елементи наявні, наприклад, у педагогіці Я. А. Коменського, який вбачав педагогічний ідеал у самій людині, що реалізує своє природне обдарування, i трактував виховання як спосіб його розвитку. Сприяти природному розвитку дітей закликав вихователів і реформатор західної педагогіки Ж.-Ж. Руссо. У творчості швейцарського педагога Й. Г. Песталоцці також йдеться про виховання як підтримку дитини в їі самостійному розвитку. Серйозні спроби теоретично обгрунтувати й реалізувати на практиці виховні підходи педагогіки сприяння зробили педагоги-гуманісти на межі XIX-XX ст. в умовах так званої 
«педоцентричної революції», головним ідеологом якої був Дж. Дьюї. У другій половині XX ст. ідеї педагогіки сприяння знайшли своє втілення в «гуманістичній педагогіці», засновниками якої є А. Маслоу, К. Роджерс, Е. Фромм та ін.

Слід підкреслити, що різниця між розглянутими моделями виховання полягає не в мірі симпатії, любові, поваги вихователя до вихованців, а в джерелах визначення і способах реалізації виховних цілей. У кожній з цих моделей педагоги керуються гуманними намірами, піклуються про дітей, однак по-різному бачать шляхи визначення і досягнення виховної мети. В директивній моделі виховні завдання визначаються і відкрито реалізуються вихователем за допомогою прямого впливу на дітей. У маніпулятивній моделі педагогічна мета теж визначається вихователем, однак, досягається приховано, шляхом непрямих впливів, відповідної організації предметного та соціального оточення дітей. У контексті сприяючої моделі виховні завдання визначає сам вихованець, а не педагог, який лише допомагає дитині реалізуватися самостійно.

Закономірно виникає запитання: «Яка 3 розглянутих моделей виховання найкраща для громадянського виховання учнів старших класів? I чи не варто, визначивши найкращу, відмовитись від інших?»

Педагогічні дослідження і практика свідчать, що універсальних, абсолютно ефективних моделей виховання не існує. Кожна з них має певні переваги і сферу свого застосування. Перекручення починаються там, де позитивні моменти того чи іншого підходу переоцінюються. Розгляну ті моделі виховання не слід вважати альтернативними, 3 яких потрібно вибрати «найефективнішу» i відкинути як непродуктивні всі інші. Правильніше розглядати їх як етапи єдиної виховної стратегії, що поступово змінюється одночасно 3 особистісним розвитком вихованців. Доцільність і ефективність тієї чи іншої виховної моделі суттєвим чином залежать від конкретних обставин, рівня особистісної зрілості вихованців, їх вікових та індивідуальних особливостей. Звісно, елементи різних моделей виховання тією чи іншою мірою можуть використовуватися на різних 
етапах громадянського виховання учнів. Але при цьому простежується така закономірність: чим вищого рівня розвитку досягає особистість, тим меншою стає потреба у зовнішньому керівництві, прямих виховних впливах на неї.

Отже, у процесі громадянського виховання слід поступово переходити від прямого формування особистості (директивна модель) через приховані (маніпулятивні) виховні впливи на неї до сприяння іiі саморозвитку. Важливо у міру особистісного становлення вихованця поступово розширювати межі його свободи, надавати йому більший простір для вияву власної ініціативи та самостійності, готувати його до вільного відповідального вибору i самовизначення. 
DOI 10.46299/ISG.2021.MONO.PED.III.2.5

\section{5 Форми організації самостійної роботи студентів у другій половині XX століття}

Спадщина українських педагогів другої половини $\mathrm{XX}$ ст. засвідчує використання різноманітних форм організації самостійної роботи студентів у різноманітному їх поєднанні. Науковцями також доведено, що вибір форм самостійної роботи залежить від мети та завдання навчальної діяльності. 3'ясовано, що організації самостійної роботи студентів у вітчизняних університетах другої половини XX століття приділялася значна увага як на аудиторних заняттях, так і в їхній позааудиторній діяльності. Дослідження засвідчило, що у вітчизняних університетах другої половини $\mathrm{XX}$ століття (Донецький, Київський, Харківський, Одеський та ін.) використовували різні форми самостійної роботи студентів: фронтальну (під час проведення лекцій, конференцій та ін.), групову (на семінарах, практичних і лабораторних заняттях, консультаціях, колоквіумах, у роботі наукових студентських гуртків і товариств), індивідуальну (підготовка рефератів, курсових, дипломних проектів тощо).

Аналіз педагогічної літератури досліджуваного періоду засвідчив, що викладачі вищої школи наголошували на необхідності деяких організаційних та методичних змін під час проведення занять. У плані організаційних змін викладачі вітчизняних університетів спрямовували свої зусилля на визначення місця та характеру самостійної роботи студентів на аудиторних заняттях та заохочували студентів до активної діяльності, стимулювали формування позитивної мотивації навчання та установки на засвоєння навчального матеріалу, підготовку молодих людей до сприйняття нового навчального матеріалу, організацію зворотнього зв'язку для з'ясування ступеня розуміння нової інформації, планування бюджету часу студентів тощо. У методичному плані було переглянуто співвідношення аудиторної та позааудиторної самостійної роботи студентів, лекційних, семінарських, лабораторних та практичних занять, розроблено відповідні рекомендації з організації та керування самостійною роботою студентів [54, с. 2, с. 3]. 
У ході наукового пошуку встановлено, що лекції в університетах другої половини XX ст. вміщували узагальнений матеріал фундаментальних наукових посібників, спеціальних монографій та інформацію з наукових праць, які не були включені до списку обов'язкових джерел. Досвід проведення лекційних занять засвідчив, що у процесі викладання лекції доцільно висвітлювати тільки основні питання 3 дисципліни, забезпечувати концептуально-методологічний або проблемний характер лекції, розкривати логіку основних положень дисципліни та засоби їх використання у майбутній професійній діяльності, а головне - орієнтувати студентів на самостійну роботу [57, с. 24].

Аналіз педагогічної спадщини другої половини XX ст. дозволив виділити різні види лекцій, які відрізнялися ступенем участі студентів у пошуковій пізнавальній діяльності. Зокрема, проводилися лекції, які характеризувалися:

- найменшим ступенем спонукання до самостійності (лекція-монолог);

- невисоким рівнем самостійності, під час яких однак проявляється зацікавленість студентів (бінарна лекція, лекція-інцидент);

- середнім ступенем спонукання до самостійності (лекції-дискусійні бесіди, лекції-консультації);

- високим ступенем самостійності (проблемні лекції, лекції 3 „навмисними” помилками, „мозкова атака”) [58].

Вважаючи головним призначенням лекції грамотне керування пізнавальною діяльністю студентів, педагоги вітчизняних університетів другої половини XX ст. приділяли значну увагу управлінню цією діяльністю, розвитку їхніх пізнавальних інтересів, забезпеченню творчого оволодіння знаннями, формуванню самостійного наукового мислення та світогляду, що сприяло системному керуванню процесом становлення особистості спеціаліста. Педагоги організовували лекції таким чином, щоб у процесі пізнавальної діяльності вони виховували майбутніх спеціалістів, вчили міркувати та робити адекватні висновки, пробуджували у студентів бажання засвоювати нові знання. На підставі цього особливе місце займали проблемні лекції, на яких 
студенти осмислювали сутність певного процесу чи явища та засвоювали матеріал у процесі активної пізнавальної діяльності [58, с. 6, с. 7].

Сутність проблемного викладення лекції викладачі вітчизняних університетів убачали в активізації самостійної роботи майбутніх фахівців. Для цього вони залучали студентів до спільного обговорення та вирішення навчальних питань, підводили молодих людей до самостійних умовиводів. На етапі постановки гіпотез викладачі спрямовували свої зусилля на те, щоб студенти навчилися пропонувати своє бачення проблеми, вчитися доводити свою правоту, відбирати найбільш адекватні варіанти вирішення проблеми. Підтримка зворотнього зв’язку з аудиторією відбувалася за допомогою таких питань до студентів, як: Чим можна пояснити? Як ви аргументуєте? Як довести? Чому? тощо [57].

Досвід роботи педагогів вищої школи другої половини ХХ ст. засвідчив, що проблемні лекції сприяли розвитку самостійності майбутніх спеціалістів, їх активної участі у науковій праці, створювали умови для поглибленої самостійної творчої діяльності студентів. Причому важливо, щоб новий матеріал базувався на отриманих раніше знаннях, а завдання були посильними для студентів. Педагоги наголошували, що саме такий підхід стимулює студентів до активної самостійної роботи не тільки під час проведення лекції, але й на семінарських, лабораторних та практичних заняттях [54, с. 4, с. 6].

Незважаючи на появу окремих цінних доробків у галузі організації самостійної роботи студентів на лекційних заняттях, викладачі констатували, що у більшості випадків такі заняття все ж таки часто мали лише інформативний характер, що було пов'язано 3 неготовністю студентів сприймати велику кількість нового матеріалу. Вивчення передового досвіду засвідчило, що для покращення ситуації деякі педагоги з самого початку навчання студентів у вищому навчальному закладі центральне місце відводили саме самостійній роботі студентів під керівництвом викладача, що дозволяло на лекційних та семінарських заняттях працювати зі студентами, які вже ознайомилися 3 
навчальним матеріалом, визначили незрозумілі для себе моменти та підготували питання до викладачів.

Разом $з$ тим, педагоги університетів другої половини ХХ ст. розуміли, що навіть на проблемних лекціях складно, а інколи взагалі неможливо створити умови для самостійної роботи студентів. Тому значна увага організації самостійної роботи приділялася на семінарських, практичних і лабораторних заняттях. Причому її функції і види змінювалися залежно від дидактичної мети заняття.

У ході дослідження встановлено, що важливу ролі у становленні студентів як майбутніх спеціалістів в університетах другої половини XX ст. відігравали семінарські заняття. Досвід проведення таких занять засвідчив, що за умови грамотної організації такі заняття сприяють розвитку у студентів наукового мислення, поглибленому вивченню дисципліни, вчать вибірково використовувати отримані знання відповідно до навчальної ситуації, прищеплюють студентам активну життєву позицію, самостійність, вміння творчо працювати 3 літературою, аналізувати отримані результати тощо. Кандидат економічних наук В. Нестеренко (Київський державний університет) зазнав, що семінарські заняття дозволяють вирішити навчальні та виховні завдання, здійснити контроль за самостійною роботою студентів, перевірити їі результати, узагальнити та закріпити матеріал, що вивчався [57, с. 6, с. 8].

Як з’ясовано, мету семінару педагоги вітчизняних університетів вбачали у формуванні у студентів власної точки зору на проблему та визначення шляхів іiі вирішення на основі вивченого матеріалу, формуванні самостійного мислення студентів. Досвід проведення семінарських занять засвідчив, що у цьому випадку під час сумісних пошуків студенти засвоюють не готові істини, а майже самостійно відкривають для себе ті чи інші закономірності [57, с. 9].

Аналіз педагогічної літератури та архівних джерел другої половини ХХ ст. дозволив зробити висновок, що у багатьох університетах приділялася велика увага поліпшенню якості проведення семінарів. Традиційно у вітчизняних університетах другої половини ХХ ст. перед проведенням семінару студенти 
самостійно вивчали матеріал з відповідної теми, використовуючи різноманітні джерела інформації, виконували завдання або готували відповіді з наступним колективним обговоренням та оцінюванням результатів самостійної роботи під керівництвом викладача. На таких заняттях під час колективного обговорення матеріалу спостерігалося підвищення самостійності та активності студентів [57, c. 10].

Було виявлено, що в тих випадках, коли викладачі приділяли значну увагу організації самостійної роботи з першоджерелами та обмірковували методику проведення семінарів, заняття проходили цікаво та відрізнялися високою активністю студентів. Як підтверджено досвідом викладачів, семінарські заняття, які проводилися на високому методичному та професійному рівні, озброювали майбутніх фахівців грунтовними теоретичними знаннями та розвивали в них самостійне мислення. Навпаки, формальна організація самостійної роботи під час проведення семінарських занять призводила до виявлення студентами низького рівня знань.

Для підвищення ефективності семінарських занять кафедри проводили різні заходи. Наприклад, для допомоги студентам більшість кафедр Харківського державного університету розробляли плани семінарських занять, в які було включено ключові теоретичні питання та вказані джерела для самостійного опрацювання У цьому ж університеті записували окремі заняття на плівку 3 метою подальшого їх аналізу [64, с. 87].

Як констатували викладачі вітчизняних університетів другої половини XX ст. на семінарських заняттях студенти зазвичай виступали із доповідями за заздалегідь підготовленим питанням або з обговоренням проблемних питань без попередньої підготовки, доповнювали відповіді товаришів, брали участь у дискусіях тощо. На основі своєї практичної роботи викладачі (Г. Аллік, Т. Аллік, Ю. Козирєв) виділили деякі правила щодо підготовки молодими людьми усної доповіді, а саме: виступ із доповіддю має не перевищувати 10-15 хвилин, студенти можуть використовувати свої записи та опорні схеми, але читати їх 3 
листа не дозволялося, перед доповіддю необхідно ознайомити аудиторію із ключовими термінами або поняттями тощо [63, с. 12, с. 13$]$.

Певну цінність для нашого дослідження має досвід роботи таких викладачів, як Г.Гержод та А. Курас, які, намагаючись створити творчу атмосферу на занятті, активізували розумову діяльність студентів шляхом виділення та формулювання основних питань, виявлення проблемних ситуацій. Аналіз проведення семінарських занять дозволив педагогам зробити висновок, що вміло створена та вирішена проблемна ситуація під час семінарських занять дає позитивний ефект: збільшується пізнавальна активність молодих людей, усі студенти беруть участь у вирішенні проблемної ситуації, самостійно здобуті знання швидше запам'ятовуються та міцніше засвоюються. До провідних на семінарських заняттях науковці відносили пошукові та дослідницькі методів навчання, причому вони намагалися забезпечити діалектичну єдність репродуктивної та творчої діяльності студентів [57].

Аналіз наукової та педагогічної літератури досліджуваного періоду дозволив виділити основні види семінарських занять, що проводилися у вітчизняних університетах, а саме:

- семінари-брифінги, семінари-дискусії; семінари-конференції;

- семінари-дослідження;

- проблемні семінари;

- семінари-практикуми;

- семінари-прес-конференції;

- спецсемінари.

Як 3'ясовано, семінари-брифінги (семінари-дискусії; семінариконференції) проводилися з метою залучення студентів до участі в обговоренні навчального матеріалу. Під час їх проведення студенти репрезентували свою точку зору та вчилися самостійно ії відстоювати. Семінари цього типу, як правило, включали питання для інтелектуальної розминки, основою якої була проблемна стаття з теми або порівняння декількох точок зору на матеріал, що вивчався. У процесі навчання викладач спрямовував пізнавальну діяльність 
студентів у потрібному напрямку, допомагав студентам об'єктивно оцінити інформацію [57, с. 6 , с. 14$]$.

Для участі у семінарі-дослідженні студентам також необхідно було провести попередню самостійну роботу: написати реферат, доповідь, тези виступу тощо. Участь у семінарі цього типу передбачала, перш за все, діалог студента, що виконував завдання, 3 викладачем, а потім продовження обговорення зі всією групою. Під час підготовки до участі у семінарідослідженні студенти аналізували результати теоретичних досліджень 3 цього питання, складали план доповіді та бібліографію до неї. У світлі цього цікавим є досвід організації семінарських занять в Одеському державному економічному університеті (у минулому кредитно-економічному інституті). Так, на кафедрі грошового обігу для активізації семінарських занять та самостійної роботи студентів широко застосовувалося реферування проблемних статей зі спеціальних журналів, рецензій та монографій із навчальної теми. У процесі своєї педагогічної діяльності Ю. Козирєв переконався, що такий метод роботи змушує ретельно ознайомитися 3 питаннями та виключає зубріння студентами матеріалу [66].

Проблемний семінар вимагав від викладача грунтовної підготовки до його проведення, урахування традиційних та нетрадиційних підходів до вирішення проблеми, добору проблемних та контрольних питань до нього. Від студентів підготовка до таких семінарів вимагала ретельної самостійної праці не тільки 3 підручниками та конспектами, але й іншими джерелами інформації: довідниками, науковими статтями, журналами тощо.

Семінари-практикуми у вітчизняних університетах другої половини ХХ ст. проводилися, як правило, студентами старших курсів після консультації 3 викладачем, що стимулювало в них творчу активність. Досвід засвідчив, що студенти охоче обирали в групі ведучого. Після цього організовувалося активне обговорення навчального матеріалу, що сприяло закріпленню їх професійних навичок [62, с. 85]. Педагоги підкреслювали, що проведення таких семінарів дозволяло готувати студентів до майбутньої професійної діяльності вже 3 
перших місяців навчання. Для цього на кожне заняття зі спеціальності призначався черговий студент, який самостійно проводив частину пари. Під час підготовки до такого виду діяльності викладачі звертали увагу на основні положення в навчальному матеріалі, вчили студентів передбачати труднощі, які могли виникнути під час викладання навчального матеріалу та можливі помилки 3 боку інших студентів. Після проведення міні-пари викладач коментував правильність її проведення з методичної точки зору [68].

Семінари-прес-конференції у визначений історичний період проводилися декількома студентами, які розподіляли завдання між іншими студентами своєї групи та формували підгрупи керівників (молоді люди, які будуть проводити семінар), спеціалістів (ставлять запитання) та експертів (оцінюють роботу групи). Така форма семінарських занять дозволяла студентам випробувати себе в усіх вищеназваних підгрупах та набути досвід участі у кожній з них.

Аналіз педагогічної літератури засвідчив, що завдання спецсемінарів науковці досліджуваного періоду розуміли по-різному. Г. Гержод та А. Курас під час проведення спецсемінарів ознайомлювали студентів із завданнями для самостійної роботи, які вони будуть виконувати, зі специфікою майбутньої самостійної роботи, допомагали студентам засвоїти методи узагальнення та аналізу навчального матеріалу, надавали методичну літературу для виконання завдання.

Інший підхід до проведення спецсемінарів висловлювали викладач Київського державного університету Г. Соболєва та співробітник науководослідного інституту проблем вищої школи М.Гарунов. Основною метою спецсемінарів вони вважали поглиблене вивчення окремої навчальної теми та першоджерел. Основною формою підготовки студентів до таких семінарів була їхня самостійна робота, яка дозволяла ознайомитися $з$ методологією науки та вивченням розвитку суспільства. Аналогічну думку висловлювала й викладач Білоруського державного педагогічного університету О. Панько. Під час проведення спецсемінарів педагог також акцентувала увагу студентів на необхідності вивчення наукової літератури, складення бібліографії з теми, що 
опрацьовується, картотеки методики дослідження, забезпечення глибокої підготовки до виступів із доповідями та рецензіями на роботи своїх одногрупників [57, с. 6, с. 16$]$.

Значну роль у становленні студентів як майбутніх спеціалістів та активізації їхньої самостійної роботи відігравали й практичні заняття, практикуми. Як свідчить дослідження, метою практичних занять другої половини XX ст. було відпрацювання умінь та навичок, узагальнення, систематизація та закріплення нової навчальної інформації, набуття практичних умінь, які були необхідними для подальшої професійної діяльності. Педагоги вітчизняних університетів досліджуваного періоду чітко усвідомлювали, що практичні заняття не можуть бути корисними та ефективними без організації самостійної роботи студентів.

Так, деканатом та радою філологічного факультету Харківського державного університету для активізації самостійної роботи студентів на практичних заняттях 3 профільних дисциплін було розроблено конкретні вказівки щодо проведення практичних занять з метою посилення контролю за їх якістю. Як наслідок - студенти стали більш систематично опрацьовувати матеріал, що вивчався, значно підвищився рівень їх знань [64].

У напрямку активізації самостійної роботи під час проведення практичних занять працювали й інші викладачі вищої школи другої половини ХХ ст. (Л. Александров, А. Борбат, К. Латишева, М. Рудіцин, А. Федорченко та ін.), які дійшли висновку, що практичні заняття, під час яких один студент вирішує на дошці завдання, а інші переписують його у свій зошит є мало ефективними. Тому професор А. Федорченко та доцент А. Борбат (Київський державний університет) більшу частину практичних занять проводили у вигляді самостійної роботи студентів.

Схожі ідеї щодо організації практичних занять упроваджувалися і в Одеському національному політехнічному університеті (у минулому політехнічному інституті). Так, на першому вступному практичному занятті 3 фізики студентам видавалися всі задачі, які вони мали розв’язати протягом 
семестру, та список необхідної літератури. На цьому ж занятті розв’язувалися типові задачі під керівництвом викладача. На решті практичних занять студенти самостійно розв’ язували задачі. Для отримання заліку з фізики кожен із них мав самостійно розв’ язати 2-3 задачі біля дошки та показати викладачу зошит зі всіма виконаними завданнями. Причому біля дошки студентам не дозволялося користуватися своїми записами, для отримання інформації щодо розв'язання задачі їм видавалися довідники. Як зазначив викладач фізики В. Лотоцький, така методика проведення практичних занять сприяла розвитку активності та самостійності студентів, підвищенню їхньої рефлексивності у виконанні завдань, виключала можливість несамостійного виконання завдань та стимулювала дострокове отримання заліків. Аналогічний досвід побудови практичних занять накопичено і в інших вищих навчальних закладах [70, с. 18].

У ході дослідження виявлено, що у другій половині XX ст. багато викладачів дійшли висновку, що традиційна методика проведення лабораторних занять мала низку недоліків. Найбільш типовим 3 них був однаковий темп роботи студентів, що значно знижувало їх пізнавальну активність. 3 урахуванням цього $з$ деяких дисциплін педагоги розробляли та впроваджували інші методики проведення лабораторних занять. Так, М.Гарунов в основу організації лабораторних занять поклав ідею про те, що найефективніший розвиток самостійності та творчості проявляється у тому випадку, коли вони максимально наближені до професійної діяльності. Посилення творчої самостійної роботи студентів він досягав насамперед за рахунок проведення лабораторних практикумів на основі дослідження єдиного об’єкта, практикумів-досліджень, які організовувалися безпосередньо на виробництві, а також залучення студентів до участі в технологічних ділових іграх, під час яких ігрові ситуації вимагали здійснення експериментальної роботи з боку студентів [59].

Як з’ясовано, кафедри вищих навчальних закладів весь час систематично працювали над покращенням якості проведення лабораторних занять. Причому особлива увага приділялася прищепленню практичних навичок i вмінь, проведенню самостійних дослідів та експериментів. Перед проведенням 
лабораторних занять викладачі обов'язково перевіряли попередню готовність студентів до виконання лабораторних робіт, що надавало можливість виявити ступінь володіння студентами навчальним матеріалом. Тільки після цього педагоги вирішували, чи можна допустити студентів до виконання лабораторної роботи. Студентам такі попередні співбесіди дозволяли виявити недоліки у своїх знаннях та своєчасно ліквідувати їх.

Дослідження свідчить, що у вищезазначений період студенти після ретельного вивчення методичних вказівок до кожної конкретної лабораторної роботи знайомилися 3 об'єктом дослідження, отримували уміння та відпрацьовували навички роботи 3 технікою, спеціальним обладнанням, приладами та іншою апаратурою, на практиці оволодівали методами досліджень, самостійно виконували лабораторні завдання, вчилися аналізувати отримані результати та робити 3 них логічні висновки. На молодших курсах особлива увага 3 боку викладачів зверталася на формування навичок 3 лабораторної роботи та закріплення їх систематичними вправами на практиці $[64$, c. 19$]$.

Зокрема, викладач Харківського державного університету В. Махінько організовувала виконання лабораторних робіт таким чином, щоб на цих заняттях студенти виявляли ініціативу та творчо підходили до поставленого завдання, вносили свої поправки до тієї чи іншої методики, знаходили нові варіанти рішення завдань. Накопичений педагогами досвід роботи в університеті дозволив їм зробити висновок, що отримані на молодших курсах уміння та навички з кожним роком вдосконалювалися та збагачувалися, що надавало можливість знайомити студентів старших курсів зі складними методами науково-дослідної роботи, які надавали можливість проводити самостійні наукові дослідження [73].

Необхідно підкреслити, що для підвищення самостійної роботи студентів у вітчизняних університетах розроблялися також методичні рекомендації, вказівки, поради, плани семінарських занять, які містили ключові теоретичні 
питання та джерела для самостійного опрацювання, формулювалися поради щодо організації самостійної роботи студентів

Для вдосконалення навичок самостійної роботи студентів вітчизняних університетів велике значення мали й позааудиторні форми навчальної роботи, метою яких було набуття навичок самостійної роботи з літературою, уміння організовувати власну працю, логічно мислити, аналізувати та узагальнювати інформацію.

Як свідчить аналіз архівних документів та наукових праць педагогів другої половини XX ст., особлива увага викладачів під час організації самостійної роботи студентів приділялася навчально-дослідницькій та науководослідницькій роботі, які реалізовувалися під час написання рефератів, курсових, дипломних робіт, під час участі студентів у наукових студентських гуртках, товариствах, семінарах, конференціях, конкурсах на кращі студентські роботи, підготовки публікацій тощо.

У другій половині XX ст. навчально-дослідницька робота студентів розглядалася як складова навчального процесу, яка реалізовувалася як у процесі проведення аудиторних занять, так і у позааудиторній роботі. До основних завдань навчально-дослідницької роботи студентів проректор Тернопільського національного педагогічного університету (у минулому державний педагогічний інститут) М. Кас'яненко відносив такі: оволодіння студентами сучасними прийомами та методами досліджень, формування у них методів та засобів творчої діяльності, набуття молодими людьми відповідних навичок та вмінь 3 дисципліни, що вивчається [64, с. 21].

Науково-дослідницька робота студентів була органічним продовженням навчально-пошукової діяльності студентів та спрямовувалася на ознайомлення 3 науковою літературою, технікою та методикою проведення експериментів, тогочасними методами наукового пізнання, на поступове збільшення самостійності у виконанні дослідницьких робіт. Як правило, науководослідницька робота студентів здійснювалася на засіданнях наукових гуртків, в лабораторіях, на наукових семінарах та конференціях та виконувалася під 
керівництвом викладача. У цьому плані важливим $є$ зауваження професора Одеського державного університету О. Розанова стосовно того, що студентів необхідно привчати не тільки до самостійного проведення експериментів, ретельного фіксування результатів своїх досліджень, але й до підтримання порядку на робочому місці. Педагог зазначав, що це важливо не тільки 3 естетичної точки зору, але й впливає і на якість експериментів, що проводяться $[75]$.

Відзначимо, що значну роль в організації самостійної роботи студентів відігравали і студентські конференції, які дозволяли встановити зв’язок курсу, що вивчається, зі спеціальними дисциплінами та досягненнями науки, поглибити знання. Аналіз педагогічної літератури засвідчив, що студентські наукові конференції проводилися у багатьох вітчизняних університетах. Так, в Київському державному університеті імені Т. Шевченка: у 1958 р. 3 доповідями на студентській конференції виступили 245 осіб із 1000 членів наукового товариства, тоді як у 1959 р. у такій конференції взяли участь вже 347 студентів iз 2000. Разом 3 тим, П. Кононенко (Київський державний університет) акцентував увагу на зміні не тільки кількісного показника, але й якісного: науковою роботою займалися ті студенти, які дійсно прагнули здійснювати науковий пошук [76].

Як правило, студентські конференції у другій половині ХХ ст. охоплювали діяльність декількох груп або цілого потоку. Усна доповідь складала 7-10 хвилин, причому під час доповіді студенти мали формулювати ідеї своїми словами, користуючись тільки наочним матеріалом, а не читати з листка.

Досвід організації конференцій 3 іноземної мови було описано й Л. Болговою та В. Яровою. Педагоги зазначали, що для підвищення мотивації щодо самостійної підготовки до конференції ними було оголошено, що найкращі доповіді будуть відзначені й нагороджені журі. У зв’язку з високим рівнем підготовки до конференції цей захід викликав значний інтерес як у студентів, що виступали з доповідями, так і у слухачів. Після кожної доповіді проводилося обговорення англійською мовою [68]. 
У ході наукового пошуку встановлено, що правильно організована навчально-дослідницька та науково-дослідницька діяльність забезпечувала здатність до самостійної творчої роботи, формування навичок грамотного проведення експериментів та аналізу їх результатів.

Підсумовуючи, необхідно зазначити, що вивчення педагогічної спадщини вищої школи другої половини ХХ століття дозволяє переосмислити підходи до організації самостійної роботи студентів університетів та творчо використовувати здобутки педагогів у сучасному процесі навчання. 
DOI 10.46299/ISG.2021.MONO.PED.III.2.6

\section{6 Система підготовки педагогічних працівників у Канаді}

Вдосконалення педагогічної освіти привертає увагу політиків та науковців усіх розвинутих країн світу. Цікавим є досвід організації формування майбутніх вчителів в Канаді, адже, по-перше, в цій країни система вищої освіти швидко реагує на всі зміни, які відбуваються у суспільстві, по-друге, професія вчителя в Канаді має суттєвий соціальний статус, що обумовлює високий прохідний бал для вступу на педагогічні спеціальності та грунтовну підготовку абітурієнтів. Розглядаючи систему підготовки майбутніх вчителів в Канаді, необхідно враховувати той факт, що Канада $є$ федеративною державою, тому в країні не існує єдиного підходу до підготовки спеціалістів. На систему підготовки майбутніх спеціалістів впливають соціально-культурні реалії та особливості кожного окремого регіону. До того ж, заклади освіти Канади мають значну автономію у формуванні освітніх програм [77].

Освіта в Канаді є дуже високим пріоритетом уряду. Країна може пишатися системою державної освіти, яка забезпечується, фінансується та керується федеральними, провінційними та місцевими органами влади. Юрисдикція системи державної освіти, а також іiі навчальний план контролюється кожною провінцією. Рада міністрів освіти $є$ форумом для міністрів освіти з обговорення питань, пов'язаних з освітою, координацією освітньої діяльності та обміном інформації.

У кожній провінції існує свій власний Департамент чи Міністерство освіти. Центральним органом управління освітою є Міністр освіти. У деяких провінціях вища освіта та навчання підпорядковуються окремому міністру та департаменту, тоді як в інших - обидві галузі включені в одну юрисдикцію. Міністр освіти, виборний член законодавчого органу провінції, призначається до освітнього портфеля Прем'єр-міністром; він або вона також є членом Кабінету Міністрів. У канадській парламентській системі Кабінет Міністрів відповідальний перед законодавчими органами та залежить від підтримки більшості його членів, а 
також є ключовим органом планування та керівництва Урядом. Він визначає, які закони висуваються Урядом,

Роль, яку виконує Міністр освіти у будь-який конкретний період часу, залежить від загальних пріоритетів Прем'єр-міністра та Уряду, а також від здатності міністра впливати на ці пріоритети. Міністри приймають або затверджують рішення з усіх видів освіти: від нових навчальних планів, які мають бути введені, правил, що регулюють атестацію вчителів, до кількості кредитів, необхідних для закінчення середньої школи. Міністр повинен захищати перед суспільством політику Уряду щодо освіти, навіть якщо він чи вона виступає проти цієї політики. I коли сторони в місцевому спорі на рівні шкільної ради чи району не можуть дійти згоди, вони часто закликають Міністра втрутитися і вирішити суперечливе питання.

Державну службу департаменту очолює Заступник міністра, який $є$ державним службовцем, що призначається Кабінетом Міністрів. Свого часу провінційні Заступники міністра майже завжди мали педагогічну освіту та досвід, багато з яких раніше були вчителями, директорами та шкільними інспекторами. Заступник міністра координує роботу департаменту за всіма його функціями. Типовий Відділ освіти має підрозділи, які займаються такими сферами, як планування, фінансування шкіл, розробка та оцінювання навчальних програм, спеціальна освіта, мовні програми та ремонт і будівництво шкільних споруд. Усі ці завдання вимагають постійної уваги та певного технічного досвіду; таким чином, сьогодні Відділи освіти, як правило, є великими організаціями, в яких працюють сотні людей, багато 3 яких є професійними педагогами .

Департамент освіти є поєднанням політичної і професійної влади, який втілює контроль якості освіти. Державні службовці, як правило, керуються своєю професійною підготовкою та педагогічною освітою. Їх погляди на потреби освіти часто схожі на погляди вчителів у школах. Ця напруженість є частиною процесу управління і може сприяти розробці політики, яка враховує як професійні навички, так і потреби суспільства [78, с. 34] 
Необхідно зазначити, що освітні програми для вчителів в Канаді значно відрізняються одна від одної як за тривалістю, так і за кількістю студентів. В залежності від університету та освітньої програми кількість випускників може бути від 30 до 1200 на рік. До освітніх програм, які користуються найбільшою популярністю можна віднести підготовку вчителів для викладання різних дисциплін у середній та старшій школі (математика, іноземна мова, хімія, біологія, фізичне виховання) та вчителів молодшої школи. Дещо меншою популярністю серед здобувачів освіти користуються освітні програми, спрямовані на підготовку дітей дошкільного віку, вчителів для корінного населення, педагогів для роботи з дорослим населенням та фахівців з лікувальної педагогіки [79, с. 24].

На основі аналізу педагогічної літератури можна стверджувати, що формування майбутніх вчителів в Канаді здебільше відбувається за паралельною (concurrent) та послідовною (consecutive) моделлю освіти. Паралельна модель освіти включає програму подвійного диплому. Тривалість навчання за такими програмами складає від чотирьох до шести років. Навчаючись в університеті студенти паралельно вивчають спеціальні дисципліни та дисципліни психологопедагогічного блоку, які дозволяють здійснювати викладацьку діяльність. Після закінчення навчання студенти отримують подвійний диплом: за спеціальністю, які вони вивчали, та диплом з педагогіки (Bachelor of Education) [77, с. 2, с. 4, с. 5]. Наприклад, в Королівському університеті в Кінгстоні, який розташовано у провінції Онтаріо, випускники педагогічного університету отримують диплом спеціаліста у галузі мистецтва, музики або природничих наук та диплом 3 педагогіки [82].

Послідовна модель освіти побудована іншим чином. Спочатку студенти отримують ступінь бакалавру 3 природничого або гуманітарного профілю (бакалавр мистецтва - B.A. або бакалавр наук - B.Sc), а вже після цього навчаються за освітньою програмою професійної педагогічної підготовки, тривалість якої може бути від декількох семестрів до двох років [83, с. 211]. 
Прикладом послідовної моделі освіти може бути педагогічний факультет Університету Оттави (провінція Онтаріо). Цей університет $\epsilon$ одним із найбільших двомовних університетів не тільки в Канаді, але й в усьому світі. Процес навчання забезпечується як англійською, так і французькою мовами. Для того, щоб вступити до педагогічного університету, студентам спочатку необхідно закінчити навчання за будь-якою іншою програмою бакалаврського рівня не менше, ніж три роки. Навчання на педагогічному факультеті триває два роки, після чого здобувачі освіти отримують ступень бакалавра з педагогіки та можуть працювати вчителем початкової або середньої школи або вчителем іноземної мови в залежності від обраної спеціалізації. У рамках цієї моделі навчання, навчаючись на педагогічному факультеті, студенти переважно вивчають основи педагогіки та методику викладання, а також проходять практику на базі шкіл під керівництвом досвідчених менторів.

Третьою моделлю педагогічної освіти, яка здебільше застосовується в французькій провінції Квебек, є так звана єдина модель (sole model). Ця модель освіти дуже схожа на паралельну, але відмінністю $є$ те, що студент отримує тільки один диплом - бакалавра педагогіки. Ще однією особливістю цієї моделі $€$ велика кількість годин, що відводиться на проходження педагогічної практики: 700 годин або 20 відсотків загального навантаження освітньої програми [83, с. 212].

Отже, підсумовуючи, можна зазначити, що кожна із моделей має свої переваги та недоліки. Так, навчаючись за послідовною моделлю освіти із подвійним дипломом, студенти мають більше можливостей для працевлаштування, але разом із тим, практична педагогічна складова їх підготовки $\epsilon$ не така грунтовна, як у тих, хто навчається за паралельною або єдиною моделями. Перевагою послідовної моделі є грунтовна фундаментальна підготовка із знань за фахом. До того ж, вже до вступу на педагогічний факультет студенти мають не тільки знання за фахом, але й певний особистий та професійний досвід, що дозволяє сприймати та аналізувати інформацію 3 позицій зрілої особистості. 
Так, у Британській Колумбії існують досить суворі вимоги до здійснення педагогічної діяльності. На території провінції функціонує професійна організація, Коледж вчителів Британської Колумбії (BC College of Teachers), які визначає критерії вимог, що висуваються до сертифікації вчителів. Для акредитації освітніх програм заклади вищої освіти штату мають узгодити їх із Коледжем та довести, що їх програми відповідають восьми стандартам, які $є$ обов'язковими для цього штату.

До основних видів діяльності Коледжу вчителів Британської Колумбії можна віднести організацію та проведення моніторингу серед студентів, викладачів та випускників педагогічних університету штату, аналіз непрофесійної поведінки вчителів та дисциплінарні слухання, сертифікація вчителів $[84$, с. 76$]$.

Найбільшим університетом, який здійснює підготовку педагогічних кадрів, є Університет Британської Колумбії, який було створено понад 60 років тому. Щорічно в університеті виконується близько 4 тис. досліджень, загальний їх бюджет становить 250 млн. Таким чином, університет має відношення до 60\% всіх досліджень, що проводяться в провінції Британська Колумбія. Університет Британської Колумбії відомий в академічному середовищі завдяки своїм інноваційним дослідженням і досягненням не лише у галузі науки і освіти, а також і в інших сферах. Він входить в список кращих навчальних закладів світу, а його престиж дозволяє запрошувати висококваліфікованих фахівців. Також університет Британської Колумбії співпрацює з іншими навчальними закладами на міжнародному рівні. Факультет освіти та виховання (Education Faculty) $\epsilon$ найбільшим факультетом провінції Британська Колумбія та відіграє важливу роль у розвитку освіти регіону, формуючи можливості та потенціал освіти як соціального блага.

На факультеті освіти та виховання здійснюється підготовка близько $45 \%$ вчителів початкової та середньої освіти в Британській Колумбії, а також значну частину шкільних радників, адміністраторів, спеціалістів із спеціальної освіти та 
шкільних психологів Британської Колумбії. За роки свого існування факультет підготував більше 50 тисяч випускників, які працюють у 100 країнах світу.

На факультеті створено умови для організації навчального процесу за допомогою інноваційних технологій із використанням результатів передових досліджень у галузях освіти, педагогіки та виховання та iз урахуванням найвищих стандартів науки та принципів співпраці, соціальної справедливості, інклюзії та рівності. Студенти можуть обрати програми як на рівні бакалавру, так i на рівні магістру. Перевагою цього факультету є те, що згідно із рейтингом QS World University Rankings 2021, факультет займає 10 місце у світі [85].

До складу факультету входять чотири кафедри та дві школи:

- Кафедра педагогіки та організації освітнього процесу;

- Кафедра освітньої та консультативної педагогіки та спеціальної освіти;

- Кафедра освітніх досліджень;

- Кафедра мовної підготовки.

- Школа кінезіології

- Школа педагогіки в Оканаган.

В основі діяльності кафедри педагогіки та організації освітнього процесу є дослідження у галузі педагогіки та методики викладання окремих дисциплін протягом усього життя, міждисциплінарні дослідження, a саме теорія навчального плану, проектування та оцінка, освіта вчителів, цифрові медіа та технології навчання, навчальна програма та педагогіка у вищій школі, організація навчання в неформальних освітніх умовах. Кафедра пропонує низку програм як на рівні магістру, акт і на рівні доктора філософії, більшість з яких структуровано як дослідницькі тематичні когорти.

Крім того, викладачами кафедри розробляються та проводяться літні програми підвищення кваліфікації вчителів, які розраховані на 3-6 кредитів та тривають один -два тижні в залежності від програми. Зокрема, такі програми присвячені удосконаленню у галузі викладання мистецтва, математики, фізичного виховання та технологій [86]. 
В основі діяльності кафедри освітньої та консультативної психології та спеціальної освіти полягають програми використання та застосування психологічних основ та дослідження для розуміння та вирішення проблем особистості протягом усього життя та в різних контекстах, зокрема сім'ї, громади, школи та робочих місць. Під час роботи зі студентами викладачі надають перевагу поєднанню практики та досліджень, тісно співпрацюючи зі школами, громадськими організаціями та політиками. На кафедрі створено умови для плідної співпраці як студентів між собою, так і викладачів та студентів.

Вибір освітніх програм $є$ також досить широким: консультативна психологія; розвиток людини, навчання та культура; методологія та оцінювання дослідження; шкільна та прикладна психологія дитини; спеціальна освіта; орієнтація та мобільність Причому ці програми пропонується як на рівні магістрів, так і докторів філософії [87].

Робота кафедри освітніх досліджень спрямована на розширення знань про критичні проблеми, з якими стикаються освіта, викладачі та студенти в різних контекстах. Професорсько-викладацький склад кафедри намагається створити умови для навчання, які трансформують і підтримують життєві цілі студентів. Освітні програми спрямовані на формування лідерства у різних сферах освіти, підготовку до роботи з корінним населенням, навчання протягом усього життя, контексту освіти K-12, політики та управління у галузі вищої освіти, а також культурні, історичні, соціологічні, політичні та філософські основи освіти [88].

Кафедра мовної підготовки є лідером у своїй галузі та пропонує до уваги студентів такі освітні програми як викладання мов в багатомовному, багатокультурному та мультимодальному контекстах; цифрові медіа, культури та технології в мовній та освітній грамотності; навчання на основі мистецтва, літератури та мови; корінна мова та навчання грамоті; критичні та фасілітуючи підходи до навчання грамоті та мовної освіти; теорії та методології дослідження грамоти та мовної освіти [89]. 
При школі кинезіології студенти мають змогу вивчати рухи людини, особливості іï фізичної активності та спорту та їх впливу на здоров'я, працездатність та якість життя. Дослідження та викладання в кінезіології розглядають рух людини з різних точок зору в межах анатомії, фізіології, біомеханіки, спортивної медицини, психології, соціології та гуманітарних наук. Школа заохочує до участі у фізичній активності через свої програми та спонукає вести активний спосіб життя для підтримки розвитку здорових людей, груп і суспільств.

Диплом з кінезіології дозволяє працювати у різних сферах, таких як освіта, фітнес та відпочинок, спортивний менеджмент, медицина, фізіотерапія та харчування. Випускники-кінезіологи можуть працювати в школах, університетах, лікарнях, військових середовищах, готелях, центрах відпочинку, спортивних клубах, водних закладах, клініках, оздоровчих центрах та інших приватних і державних установах [90].

Школа педагогіки в Оканаган пропонує здобувачам освіти як програми на рівні бакалавру та магістру, так і освітні програми з підвищення кваліфікації вчителів, які вже працюють.

Зокрема, у рамках послідовної моделі навчання студентам пропонують курс навчання тривалістю 16 місяців з такою спеціалізацією: робота 3 дітьми у віковому діапазоні від 5 років до п'ятого класу та робота із підлітками шостого - дев'ятого класів. Велика увага у рамках цієї освітньої програми приділяється набуттю практичних знань та умінь. Так, студенти обов'язково проходять 15 тижнів практики під керівництвом досвідчених педагогів [91].

Магістерські програми 3 педагогіки пропонують студентам можливість розвивати спеціалізовані сфери інтересів та інтегрувати свою практику в рамках досліджень і індивідуальної траєкторії. Освітні програми призначені для вчителів, координаторів предметних областей, адміністраторів освіти, нетрадиційних педагогів та дослідників у сфері позашкільної освіти.

Здобувачі освіти разом зі своїми науковими керівниками розробляють програми, які однозначно відповідають їхнім інтересам і цілям, обираючи курси, 
які охоплюють такі основні теми: планування та організація освітнього процесу, цифрове навчання, різноманітність та освітнє лідерство та політика. I магістр освіти, і магістр мистецтв в галузі освіти розраховано на 30 кредитів навчального навантаження; кожна освітня програма надає студентам теоретичний, практичний та аналітичний досвід, а також місце в спільноті вчених-практиків, присвячених організації навчання протягом усього життя [91].

У провінції Онтаріо також існує професійна асоціація, яка регулює педагогічну освіту. Педагогічний коледж Онтаріo (Ontario College of Teachers) було створено у 1994 році. До його основних видів діяльності також належить розробка етичних стандартів для вчителів та настанов для молодих учителів. Необхідно зазначити, що тільки в Онтаріо є Рада з забезпечення якості вищої освіти (Higher Education Quality Council of Ontario). Її було створено відповідно до Закону про Раду з якості вищої освіти у 2005 р. як незалежного представництва уряду Онтаріо для аналізу та покращення доступу, якості та звітності відділу вищої освіти, а також для розробок рекомендацій щодо покращення вищої освіти в провінції. Рада забезпечення якості вищої освіти також здійснює перевірку якості освітніх програм педагогічних університетів та розподіляє фінансування для проведення науково-дослідної роботи на базі провінції $[84$, с. 76$]$.

На території провінції Онтаріо представлено 7 програм педагогічних університетів, що підтверджується сертифікатом або ступенем бакалаврата, магістратури та аспірантури 3 педагогіки. Педагогічним факультетом Університету Західного Онтаріо пропонується загальна наукова програма 3 педагогіки, а Університет Ніпісінга запрошує взяти участь у педагогічній школі ім. Шуліха за спеціалізацією: «Викладання і педагогіка». Решта педагогічних університетів запрошує до більш вузьких програм: «Педагогіка фортепіано» або «Психологія і педагогіка фізичної активності та спорту».

Крім того, у Західному Онтаріо пропонуються курси додаткової кваліфікації (AQ), які спеціально розроблені для сертифікованих викладачів і зосереджені на навчальній програмі Онтаріо. Проходження курсів AQ може 
допомогти педагогам підвищити свої навички, розширити знання та просунути кар’єру у сфері надання освітніх послуг.

Крім того, ASPIRE пропонує курси професійного розвитку, сертифікати та семінари, які використовують досвід у різних галузях. Ці курси підвищення кваліфікації можна проходити окремо або об'єднувати для формування сертифікатів.

Університет Торонто, який є одним 3 найперших не тільки в провінції Онтаріо, а й в Канаді в цілому, пропонує кілька сотень курсів в рамках 14 факультетів; близько 2000 курсів в рамках одного тільки факультету мистецтва i науки, а також 85 докторських програм. Педагогічна освіта в Університеті Торонто представлена двома програмами: Магістр гуманітарних наук у галузі навчання дітей та освіти (МА) та Магістр викладання\навчання (MT).

Програма «Магістр гуманітарних наук у галузі навчання дітей та освіти» (МА) триває 2 роки, або 5 триместрів, i супроводжується широкою практикою викладання та плідною співпрацею із власною лабораторною школою. Кожен студент-викладач має більш, ніж 450 годин практики викладання. Випускники університету мають право подати заяву в Педагогічний коледж Онтаріо для отримання сертифіката учителя початкової або молодшої школи.

Програма Магістр викладання\навчання (MT) пропонує складне академічне середовище, спрямоване на спільну освіту у галузі педагогічної теорії та провідної педагогічної практики. Кандидати можуть вибрати за бажанням одну з програм початкових, молодших, середніх, старших класів. Програма складається 318 напівкурсів і 3 практик викладання. Більш того, практиці приділяється значна увага, адже для того, щоб стати сертифікованим вчителем у провінції Онтаріо, необхідно успішно завершити 80-денну практику. Кандидати у вчителі проходять два одномісячних блоки практики на 1-му році і розширену практику на 2-му році програми [92]. 
На відміну від провінції Онтаріо, уряд Манитоба, на думку деяких науковці, не втручається у розвиток педагогічної освіти у штаті. Для того, щоб працювати учителем в цьому штаті достатньо мати:

- 150 залікових годин з курсів післясередньої освіти , 60 з яких - курси 3 педагогіки та методики викладання;

- два наукові ступеня бакалавра мистецтва, які були отримані послідовно або паралельно;

- 30 кредитів з вивчення дисципліни, яку було обрано для викладання [93].

Разом із тим, не зважаючи на досить невелике навантаження на майбутніх фахівців, університети штату намагаються утримувати якість освіти на гідному рівні [94].

Наприклад, на факультеті педагогіки університету Манітоба існує можливість опанувати освітню програму за будь-яким рівнем освіти: бакалавр, магістр або доктор філософії. Освітні програми бакалаврського рівня передбачають обрання однієї із вікових груп: робота із дітьми дошкільного віку, робота із дітьми 5-8 класів та старших класів за однією із спеціальностей:

- робота з корінним населенням;

- інклюзивна освіта;

- міжкультурна освіта;

- технічні науки;

- іноземні мови;

- освіта для сталого розвитку.

Факультет також запрошує до магістерських програм, які є гнучкими i пропонують студентам можливість отримати ступень магістру освіти (Med), навчаючись неповний робочий день 3 численними курсами, доступними у вечірній час або літні місяці. Факультетом пропонуються наступні спеціалізації:

- освіта для дорослих та післясередня освіта;

- консультативна психологія; 
- міжкультурні, соціологічні та філософські основи освіти;

- адміністрація освіти;

- інклюзивна освіта;

- мова та грамотність;

- іноземні мови;

- дослідження в навчальній програмі, викладання та навчання [95].

На відміну від Манітоби уряд Альберти має більш практичний підхід. У цьому штаті на початку XXI століття були проведені реформи, спрямовані на формулювання та узгодження стандартів щодо знань, умінь та навичок, якими мають володіти вчителі. Велика увага також приділяється організації навчального процесу в школі, оцінюванню навчальних досягнень учнів та розробці стандартизованого тестування, яке виявляє сильні та слабкі сторони учнів та дозволяє коригувати роботу вчителя.

Відповідно до законодавства штату, міністр може бути ініціатором проведення тестування як учнів, так і учителів. Ще однією особливістю організації навчального процесу цього штату є те, що з 2006 року всі учні, починаючи з четвертого класу, розпочинають вивчати другу мову [96].

Основним факультетом, на якому здійснюється підготовка вчителів у цій провінції, є педагогічний факультет університету Альберта, який зайняв 47 місце iз 800 у світовому рейтингу університетів QS 2019 за предметами. Це найстаріший педагогічний факультет у країні, його було засновано ще у 1942 році. До складу факультету входить чотири кафедри та одна освітня школа, кожна 3 яких має свої особливості та спеціалізацію. Зокрема, в університеті працюють кафедри початкової освіти, середньої освіти, вивчення освітньої політики, педагогічної психології та школи бібліотекознавства та інформації. Диплом цього факультету визнається не тільки в країні, але й в усьому світі. Як і в інших університетах країни, здобувачам пропонуються освітні програми різних рівнів, які відповідають потребам студентів та вимогам різних освітніх контекстів. Під час викладання викладачі використовують новітні методики та освітні технології [97]. 
Разом із тим, підписання у 2006 р. між провінціями Альберти та Британської Колумбії двосторонньої згоди про торгівлю, інвестиції та мобільності робочої сили мало певний вплив на уніфікацію підходів до підготовки вчителів. У рамках цієї угоди зросла мобільність вчителів цих двох провінцій. До того ж, була розроблена форма Згоди деканів про початкову педагогічну освіту [98].

У таблиці 1 представлено узагальнену інформацію щодо вимог, які висуваються до підготовки вчителів у рівних провінціях. Зокрема узагальнено інформацію щодо сертифікації вимог у кожній провінції, механізм регулювання професійного вдосконалення педагогів, кількість закладів педагогічної вищої освіти та стандартів, які є необхідними для отримання сертифікату.

Таблиця 1

Вимоги щодо проходження сертифікації вчителів Канади

\begin{tabular}{|c|c|c|c|c|}
\hline \multicolumn{5}{|c|}{ Провінції } \\
\hline 1 & 2 & 3 & 4 & 5 \\
\hline & Альберта & $\begin{array}{l}\text { Британська } \\
\text { Колумбія }\end{array}$ & Манітоба & Онтаріо \\
\hline $\begin{array}{l}\text { Професійне } \\
\text { регулювання }\end{array}$ & $\begin{array}{l}\text { Державне } \\
\text { регулювання }\end{array}$ & $\begin{array}{l}\text { Саморе- } \\
\text { гулювання } \\
\text { (Коледж вчителів } \\
\text { Британської } \\
\text { Колумбії) }\end{array}$ & $\begin{array}{l}\text { Мінімальне } \\
\text { державне } \\
\text { регулювання }\end{array}$ & $\begin{array}{l}\text { Саморегулювання } \\
\text { (Педагогічний } \\
\text { коледж Онтаріо) }\end{array}$ \\
\hline $\begin{array}{l}\text { Вимоги до } \\
\text { сертифікації }\end{array}$ & $\begin{array}{l}\text { Постійний } \\
\text { сертифікат } \\
\text { викладання у } \\
\text { штаті не менше } \\
2 \text { років; } \\
\text { отримання } \\
\text { другої } \\
\text { педагогічної }\end{array}$ & $\begin{array}{l}\text { Сертифікація } \\
\text { Коледжем } \\
\text { вчителів } \\
\text { Британської } \\
\text { Колумбї } \\
\text { наявність } \\
\text { диплому } \\
\text { бакалавра; }\end{array}$ & $\begin{array}{l}\text { Постійний } \\
\text { сертифікат } \\
\text { Отримання } \\
\text { диплому } \\
\text { бакалавру } \\
\text { правом } \\
\text { викладання; }\end{array}$ & $\begin{array}{l}\text { Загальний } \\
\text { сертифікат } \\
\text { кваліфрікаиіi } \quad \text { ma } \\
\text { регістращії } \\
\text { Отримання } \\
\text { диплому } \\
\text { бакалавру }\end{array}$ \\
\hline
\end{tabular}




\begin{tabular}{|c|c|c|c|c|}
\hline & $\begin{array}{l}\text { освіти у штаті; } \\
\text { тимчасовий } \\
\text { сертифіка; } \\
\text { відсутність } \\
\text { педагогічного } \\
\text { стажу або } \\
\text { педагогічний } \\
\text { стаж до двох } \\
\text { років }\end{array}$ & $\begin{array}{l}\text { наявність } \\
\text { педагогічного } \\
\text { стажу; } \\
\text { рекомендація } 3 \\
\text { місця роботи, } \\
\text { характеристика; } \\
\text { базовий } \\
\text { сертифікат } \\
\text { відсутність } \\
\text { диплому } \\
\text { бакалавра, але } \\
\text { наявність } \\
\text { сертифікату } \\
\text { іншої провінції }\end{array}$ & $\begin{array}{l}\text { Тимчасовий } \\
\text { сертифікат } \\
\text { Для вчителів, } \\
\text { які отримали } \\
\text { освіту в інших } \\
\text { провінціях } \\
\text { діє три роки, } \\
\text { потім необхідно } \\
\text { оновлювати }\end{array}$ & $\begin{array}{l}\text { правом } \\
\text { викладання; } \\
\text { Право викладання } \\
\text { у певній віковій } \\
\text { категорії } \\
\text { Перехідний } \\
\text { сертифікат } \\
\text { кваліфікації та } \\
\text { регістраиії; } \\
\text { Немає профільної } \\
\text { освіти } \\
\text { Тривалість - } 6 \\
\text { років }\end{array}$ \\
\hline $\begin{array}{l}\text { Кількість } \\
\text { закладів вищої } \\
\text { педагогічної } \\
\text { освіти та } \\
\text { особливості } \\
\text { організації } \\
\text { освітнього } \\
\text { процесу }\end{array}$ & $\begin{array}{l}5 \\
\text { Послідовна та } \\
\text { паралельна } \\
\text { модель; } \\
\text { Програми } \\
\text { навчання - 12- } \\
\text { та 24-місяці } \\
\text { (послідовно) } \\
\text { •Кампус лише } \\
\text { для французької } \\
\text { мови } \\
\text { •1 } \\
\text { супутниковий } \\
\text { кампус } \\
\text { для U он Alberta } \\
\text { • } 2 \text { релігійні } \\
\text { установи }\end{array}$ & $\begin{array}{l}8 \\
\text { 12-, 16-, 18- і } \\
\text { 24-місячні } \\
\text { програми } \\
\text { (послідовна } \\
\text { модель) } \\
\text { •корінні, } \\
\text { французьські } \\
\text { програми; } \\
1 \\
\text { пелігійна } \\
\text { програма }\end{array}$ & $\begin{array}{l}4 \\
\text { Послідовна та } \\
\text { паралельна } \\
\text { модель; } \\
\text { Програми } \\
\text { навчання - 12- } \\
\text { та 24-місяці } \\
\text { (послідовно) } \\
\text { •Лише } \\
\text { французька } \\
\text { мова навчання } \\
\text { •альтернатива } \\
\text { педагогічній } \\
\text { освітня } \\
\text { програмі } \\
\text { нетрадиційної } \\
\text { школи }\end{array}$ & $\begin{array}{l}18 \\
\text { Послідовна та } \\
\text { паралельна } \\
\text { модель; } \\
\text { • 12-, 16-, 18- i } \\
\text { 24-місячні } \\
\text { програми } \\
\text { (послідовно) } \\
\text { •Включає } \\
\text { кампуси- } \\
\text { супутники } \\
\text { США(1) та } \\
\text { Австралії (1) }\end{array}$ \\
\hline
\end{tabular}

$[84$, c. 22, c. 23, c. $]$ 
Отже, можна побачити, що існують три різні підходи до управління освітою в провінціях: сильний урядовий контроль в Альберті, мінімальне державне регулювання у Манітобі та саморегулювання в Британській Колумбії та Онтаріо, згідно з яким вчителя мають право викладати за умови демонстрації певного рівня знань, умінь та навичок.

Не зважаючи на широку автономію закладів вищої освіти та різні вимоги до вчителів у провінціях, у країні функціонують структури, які аналізують та контролюють якість навчання. До таких структур належить Рада міністрів Канади, Асоціація ректорів Канади, Канадська асоціація вищої освіти та Канадську федерація викладачів.

Варто зазначити, що більшість науковців виступає за створення загальнонаціональних вимог до базової освіти педагогів. У 2006 році ректорами закладів вищої освіти було підписано угоду про базову освіту освітян з метою створення загальної нормативної бази. Основною складовою угоди було прагнення зберегти самостійність та індивідуальність кожної провінції та запобігати уніфікації та стандартизації системи освіти. Разом із тим, ця угода носить лише характер рекомендацій, тому не отримало широкої підтримки в країні [99].

Підсумовуючи, можна зробити висновок, що в Канаді склалася унікальна система педагогічної освіти, яка відрізняється різноманітністю за тривалістю підготовки та освітніми програмами, що дозволяє задовільнити потреби здобувачів освіти. У країні існує три основні моделі отримання вищої освіти (послідовна, паралельна та єдина), що також сприяє диверсифікації освітніх програм та максимально враховує освітні потреби населення. Більшість випускників педагогічних факультетів Канади вважають, що підготовка на педагогічних факультетах канадських закладів вищої освіти є сучасною, повною, грунтовною та органічно поєднує теоретичну та практичну підготовку. 
DOI 10.46299/ISG.2021.MONO.PED.III.2.7

\section{7 Творчо-виконавська підготовка майбутнього викладача музичних дисциплін у контексті вищої мистецької освіти}

Динамічні інтеграційні соціально-економічні процеси вимагають розв'язання актуальних завдань, зумовлених об’єктивною потребою суспільства у конкурентоспроможних фахівцях, здатних демонструвати високий рівень професіоналізму, освіченості й культури, визначати способи особистісного розвитку й саморозвитку. У зв’язку з цим, перед вищою мистецькою освітою постали важливі завдання: підготовка свідомої національної інтелігенції, оновлення та збагачення інтелектуального генофонду нації, виховання іiі духовної еліти, примноження культурного потенціалу, що має забезпечити високу ефективність діяльності майбутніх фахівців як провідників високої художньої культури, творців, активних учасників освітньо-культурного процесу.

3 огляду на такі завдання постала потреба реконструкції змісту професійної підготовки майбутніх фахівців, інтенсивного впровадження в практику навчання i виховання інноваційних методик, технологій i підходів, спрямованих на активізацію суб’єктних можливостей кожного студента, розвиток його духовності і творчої індивідуальності, культури мислення і почуттів.

Вища освіта - це процес і результат поєднання навчання і професійної підготовки, що передбачає оволодіння найновішими досягненнями науки i практики, грунтовне і фундаментальне засвоєння систематизованих знань, спроможність самостійно і відповідально виконувати службові чи виробничі функції, творчо використовувати i розвивати досягнення науки, техніки i культури; розвиток особистості студента, його інтелектуальних і моральних якостей, формування гармонійної індивідуальності, потреби у подальшому самовдосконаленні та безперервній освіті [105, с. 99].

Освіта - це знання, компетентності, професіоналізм, світогляд, цінності, фізичний і духовний стан особистості. I саме від того, які якості останньої ми сформуємо у процесі освіти і виховання, багато в чому буде залежати вигляд нашого майбутнього світу [100, с. 16]. 
Тлумачення поняття «освіта» в Українському педагогічному словнику С. Гончаренка містить спрямованість освіти на духовний розвиток особистості, формування іï внутрішнього світу, особистісних якостей (культурологічний, антропологічний, аксіологічний, особистісно зорієнтований аспекти) й розкривається як «духовне обличчя людини, яке складається під впливом моральних і духовних цінностей, що є надбанням ії культурного кола, а також процес виховання, самовиховання, впливу, шліфування, тобто процес формування обличчя людини. При цьому головним $є$ не обсяг знань, а поєднання останніх з особистісними якостями, вміння самостійно розпоряджатися своїми знаннями» [102, с. 242].

Здійснюючи системне дослідження освіти та педагогічної освіти як складноорганізованих соціокультурних феноменів, як спеціалізованого компонента в соціальному організмі (який самоорганізовується, самозберігається, саморозвивається), протистоїть стихійним i тому малоефективним культурним механізмам передачі досвіду, необхідного для відтворення суспільного життя [108, с. 13]. В. Луговий трактує освіту як процес і результат цілеспрямованого формування культури людини, уточнюючи, що мова йде не про культуру людини, а про культуру суб'єкта діяльності, яким можуть бути і окрема людина, і соціальна група, і людство загалом [108, с. 12].

На підставі аналізу наукових праць можемо зробити висновок, що до особистості вчителя, до якості його професійно-педагогічної діяльності й до самого вчителя як суб'єкта навчально-виховного процесу висуваються нові вимоги, що ефективно впливають на розширення комплексу взаємопов'язаних завдань, які покладаються на педагогічну освіту загалом й музично-педагогічну зокрема. Основними 3-поміж них Н. Ничкало виокремлює [111, с. 25]:

- створити необхідні соціально-культурні і соціально-економічні умови для розвитку особистості студента вищого навчального закладу - майбутнього педагога, для його фундаментальної загальнокультурної підготовки, формування високих морально-етичних якостей, любові до педагогічної професії, відданості їй; 
- сприяти професійному становленню, самовдосконаленню педагога;

- стимулювати інноваційну діяльність у різних освітньо-виховних системах, педагогічну творчість, що дає можливість досягти рівня педагогічної майстерності [120, с. 255].

Подамо оригінальні концептуальні визначення освіти та їі мети:

- «пакетне поняття», простір адекватних інтерпретацій якого за обсягом змістового i функціонального навантаження співвідноситься 3 терміном «культура», конституюється в просторі як індивідуального, так і соціального (Л. Масол) [109, с.6];

- процес або результат засвоєння визначених суспільством рівнів культурної спадщини та пов'язаний з ним рівень індивідуального розвитку; передача і присвоєння культурного досвіду як трансляція цілісної картини світу, поза якою неможлива цілісна особистість як повноцінний суб'єкт культури (О. Олексюк) $[112$, с. 6];

- процес і результат засвоєння систематизованих наукових знань, умінь і навичок про соціальну сутність і зміст конкретної професійної діяльності, як необхідну умову для підготовки людини до здійснення соціально-професійних функцій на належному освітньо-кваліфікаційному рівні О. Єременко [106];

- забезпечення кожному, хто навчається, широкі можливості для здобуття знань про людину, суспільство, формування наукової картини світу як основи світогляду, досвіду суспільних і особистісних відносин, комунікативної і творчої діяльності, що відкриває простір для розвитку індивідуальних здібностей особистості, забезпечує ії підготовку до активної участі у житті країни (Л. Дичківська) [104, с. 9-10];

- підготовка учня до життя, до його самовираження в різних галузях діяльності, а для цього, додає педагог, насамперед потрібно забезпечити готовність учня до навчальної і трудової діяльності, його здатність переносити знання про об’єкт і способи дії з однієї галузі в іншу, формування раціонального стилю самостійної діяльності, здатність застосовувати знання в житті [М. Ржецький 116, с. 11]; 
- формування і розвиток особистості, яка характеризується творчою індивідуальністю, високим рівнем соціальної зрілості, освіченості, культури, розумінням сутності суспільства і людини та їх взаємозв'язку у процесі розвитку [О. Семеног 119, с. 81].

- ціннісне світоглядне ставлення особистості до соціального і природного навколишнього світу і самої себе, розвитку свідомості, культури мислення і культури почуттів особистості, що передбачає усвідомлення нею, перш за все моральних, духовних, естетичних цінностей, які становлять мету існування людини [Л. Хомич 121, с. 89];

- процес і результат формування якостей особистості засобами навчання і виховання відповідно до норм духовної культури і цінностей суспільства. Освіченість означає різнобічний розвиток особистості і $є$ результатом реалізації багатоаспектного змісту освіти (О. Рудницька) [118, с. 22].

Вченою уведена у науковий обіг категорія «мистецька освіта», яка визначається як «освітня галузь, що спрямована на розвиток у людини спеціальних здібностей і смаку, естетичного досвіду і ціннісних орієнтацій, здатність до спілкування з художніми цінностями у процесі активної творчої

Метою мистецької освіти визначається:

- подолання художньої однобічності сприймання і розуміння образного змісту художніх творів різних видів мистецтв [118, с. 29-30].

- розв'язувати завдання підготовки особистості до аматорської i професійної мистецької діяльності, оволодіння її технікою та технологією [114, c. 40].

стимулювання художнього самопізнання, сприяння творчій самореалізації особистості, формування ставлення учня до себе, свого внутрішнього світу [109, с. 22];

цілеспрямоване засвоєння музичної культури; взаємодія діяльності викладача (поєднанням навчання i виховання) i діяльності вихованця (формування та творче використання музичних знань, умінь і навичок) [112, с. $6]$; 
- процес і результат засвоєння музичних знань, умінь і навичок, що свідчить про відповідний рівень опанування музичних явищ в аналітичнотеоретичному або практично-виконавському аспектах $[110$, с. 73 - 74];

- складний діалектичний процес розвитку художньо-творчих здібностей учнів, їх здатності до естетичного сприймання, переживання i творення музики; розвиток особистості учня [117, с. 193];

- ормування духовного світу людини, закономірності гармонізації іiі життя, забезпечення природного входження до соціального середовища» $[115$, с. $5]$;

- спрямованість на «індивідуалізоване становлення професійно значущих якостей і здібностей, професійних знань та вмінь, перетворення особистістю свого внутрішнього світу та творчу самореалізацію у професії» [113, c. 73].

В умовах сучасного осмислення i підходу вища мистецька освіта розглядається в трьох взаємозумовлених аспектах: змісту, функціонування i розвитку, є системою, що саморозвивається й характеризується фундаментальністю, універсальністю, гуманітарною і науково-дослідною спрямованістю. Ця система орієнтує студентів мистецьких спеціальностей на освоєння фундаментальних і грунтовних загальнотеоретичних, спеціальних, психолого-педагогічних знань, на набуття науково-дослідницьких і практичних умінь для творчого оперування ними під час розв’язання професійних завдань.

У системі музично-педагогічної освіти дисципліни компонуються за напрямами і передбачають професійно орієнтовану гуманітарну та соціальноекономічну, професійно-педагогічну підготовку i виконують функцію соціалізації студентів завдяки системі знань, розкривають узагальнений i науково осмислений досвід ставлення людини до себе, інших, суспільства, спонукають особистість до самовизначення, сприяють формуванню життєвої позиції, світогляду, допомагають у самовизначенні, формуванні життєвих установок, адекватного ставлення до навколишнього середовища. 
У змісті професійної підготовки особливе значення має фахова підготовка майбутнього вчителя як система музично-теоретичних (у тому числі музичноісторичних), музично-виконавських, практично-методичних, науково-дослідних дисциплін, що здійснюється безперервно упродовж всього терміну навчання. Під час вивчення фахових дисциплін майбутні учителі музичного мистецтва оволодівають грунтовними музично-теоретичними, культурологічними, музично-історичними знаннями, художньо-інтерпретаційними і сценічновиконавськими вміннями, набувають знань 3 методики музичного виховання та фахових методик, трансформують їх в освітню практику.

Відзначаючись власною специфікою, характеризуючись внутрішньою спорідненістю й інтеграційністю, фахові дисципліни тяжіють до взаємодоповнення, взаємозумовленості та співіснування й складають окремий блок. Їх складний внутрішній зв’язок виявляється в єдності методології та принципів музично-педагогічної діяльності: від набуття грунтовних музичнотеоретичних знань, художньо-інтерпретаційного, музично-виконавського, практично-методичного досвіду до втілення у практичній діяльності і власній творчості. Завданням фахових дисциплін є розкриття унікальних особистісних якостей майбутнього вчителя, які виявляються у здатності адекватно сприймати й оцінювати художні явища, критично мислити, оволодівати здатністю до самостійного пошуку, що дають змогу успішно здійснювати педагогічну діяльність.

Основу фахової підготовки майбутнього вчителя музичного мистецтва становлять предмети музично-теоретичного циклу - «теоретичні науки», які спрямовані на розвиток музичної грамотності, художньої свідомості, формування у студентів логіки мислення.

Набуття грунтовних музично-теоретичних знань здійснюється через виконавську діяльність на основі художнього осмислення музичних уявлень від елементарної музичної грамоти до музичної грамотності, інтонаційності, цілісного аналізу, розуміння музичної форми, самостійності музичнотеоретичного i музично-виконавського мислення. Музично-теоретична 
підготовка як фундаментальна, передбачає оволодіння закономірностями музичної мови у комплексі з виконавськими вміннями та навичками. Теорія як i граматика, необхідна і важлива у процесі художнього сприймання, музичного виконання, оскільки розширює світогляд, надає знання різних композиційних структур музичного твору, жанрів, розкриває суспільно-історичний розвиток.

У процесі вивчення музично-теоретичних дисциплін розвиваються природжені здібності, інтонаційний слух, почуття метро-ритму, ладу, гармонії, форми, тембру, навички сприйняття і відтворення окремих елементів музичного твору. Студенти не тільки набувають знання, вміння та практичні навички, а усвідомлюють їх якісне перетворення, виробляють прагнення до інтенсифікації творчої самостійності, що збуджує їх дослідницький хист, потребу у самовираженні у всіх видах музичної творчості - сприйнятті - інтерпретації творенні. У цьому поягає універсальність музично-теоретичних дисциплін, адже саме вони покликані формувати вміння i навички, необхідні і вчителю, i музиканту-фахівцю для творчого самовираження i самореалізації, творчої самостійності, в якій взаємодіють різні аспекти психічної діяльності, теоретичні знання, художньо-образне мислення, творчо-виконавські вміння, культура художнього сприйняття, професійна емпатія і рефлексія.

Важливим завданням професійної підготовки $\epsilon$ розвиток творчої особистості майбутнього викладача музичного мистецтва, який уміє орієнтуватися в історико-стильових тенденціях та в закономірностях мистецтва, проникати у зміст музичних творів способом аналітичного мислення-пізнання та емоційно-образного сприйняття-інтерпретації, самовиражатись у різних видах музично-виконавської діяльності. Забезпечення умов адекватного розумінняпізнання мистецького твору, його сприйняття-інтерпретації і творення, розвиток особистості, яка творчо мислить і творчо діє - мета творчо-виконавської підготовки майбутнього викладача музичного мистецтва.

Мистецтво є особливим рівнем людинознавства. Людина звертається до мистецтва у пошуках істини й сенсу життя. Спираючись на ідею гуманності,

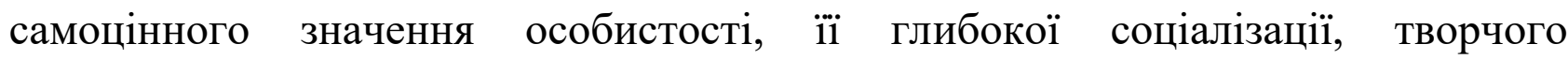


самоствердження та індивідуального світосприйняття, усвідомлюємо, що мистецтво, як ніяка інша форма суспільної свідомості, цілісно й гармонійно впливає на внутрішній світ особистості, сприяє іiі духовному вдосконаленню, розвитку емоційно-інтелектуальної сфери, формуванню культури міжособистісного спілкування, усвідомленню понять про загальнолюдські цінності, критеріїв самооцінки та оцінки навколишньої дійсності, залучає до участі в навколишньому житті, задовольняє потребу особистості в духовному спілкуванні.

Творча глибина мистецьких творів, зазначає О. Рудницька, криється в здатності осмислювати людський досвід на такому рівні, на якому він водночас виявляється і як універсальна загальність, і як неповторна індивідуальність, завдяки чому стає можливим залучити до світу художньої реальності кожну людину. Під впливом художніх образів безпосередні почуття переходять в естетичні, духовні, етичні уявлення суб’єкта як ціннісний акт осягнення світу та самопізнання власної індивідуальної сутності [118].

Оскільки мистецтво є невід’ємною складовою становлення духовно розвиненої особистості, а тому має бути важливим предметом ii навчання i виховання вже з раннього дитинства. Залучення до художньої творчості значно розширює духовний світ людини, узагальнює ієрархію іiї цінностей та смислів, гармонізує внутрішній світ. У цьому відношенні універсальна природа мистецтва надає значні можливості. Як своєрідна «філософія серця», що поєднує мудрість розуму та мудрість серця силою уяви, фантазії художника, мистецтво, в якому закладені ідеї високого гуманізму і «живе краса людського духу» (В. Сухомлинський) найвищою мірою здатне не лише сприяти пробудженню та поглибленню людських почуттів, а й спонукає працювати думку, формує моральні принципи, розширює світогляд, породжує ідеали. Тобто, за допомогою мистецтва людина не тільки пізнає навколишню дійсність, а також формує себе як всебічно розвинену духовну особистість, що є важливим кроком на шляху до духовності як вираження пізнавальної, творчої та моральної активності людини. У цій триєдності творчо-виконавська діяльність займає особливе місце, оскільки 
саме завдяки художньому універсалізму здатна спонукати до дії, породжувати інтерес і потребу в художньому спілкуванні, поєднувати і тісно взаємодіяти 3 інтелектуально-пізнавальною, морально-етичною, особистісно-аксіологічною сферами особистості. Це уможливлюється тим, що об’єктивне й суб’єктивне, свідоме й несвідоме, чуттєво-інтуїтивне й емоційно-образне, інтелектуальнорозумове й рефлексивно-оцінювальне в процесі сприйняття, інтерпретації і творення постають у тісній взаємодії, взаємопроникненні й взаємозбагаченні.

Мистецтво є засобом розвитку людини, оскільки в процесі художнього спілкування особистість одночасно формує у собі щось нове, i насамперед, здатність творити. Творча діяльність в мистецтві постає тому як самодіяльність, самозміна, саморозвиток людини. Можна виокремити два основоположних принципи, завдяки яким мистецтво набуває пріоритетного значення у процесі духовного становлення особистості: художній універсалізм і спрямованість на творчий саморозвиток. Художній універсалізм гармонізує внутрішній світ особистості, розширює межі їі духовного збагачення, спрямованість на творчий саморозвиток удосконалює особистісну сферу, сприяє розвитку творчих можливостей.

Процес художнього спілкування у різних видах творчо-виконавської діяльності найвищою мірою відповідає змісту діалектичної категорії творчості, яка передбачає зміну об'єкта та самозміну, саморозвиток суб'єкта як взаємопов’язані сторони єдиного художнього процесу. Зазвичай, здобутком творчості є процес художнього пізнання, предметним результатом - художня інтерпретація мистецьких творів, адже, щоб стати надбанням соціокультурного універсуму, потенціал художньої творчості має втілитися у реально існуюче багатство художньої культури - твори мистецтва.

Унікальним засобом духовно-творчого розвитку i саморозвитку особистості є музичне мистецтво, котре, узагальнюючи багатовіковий людський досвід духовно-емоційного ставлення до світу, має найбільшу силу емоційного впливу на особистість. Різноманітність почуттів, що запрограмовані митцем, спричиняють неоднозначність художнього переживання, яке містить у собі i 
позитивні, і негативні емоції. Саме вони створюють ефект співпереживання, що здатний змінити систему цінностей особистості, іiі життєві установки, погляди, переконання.

Упродовж всієї історії людства музичне мистецтво $є$ одним із найпотаємніших і найзагадковіших з мистецтв, якому «притаманна абстрактна форма передачі поняттєвого змісту», що об’єктивно зумовлено значно меншою здатністю музичного слуху порівняно із зором інформувати особистість про конкретні матеріальні ознаки певного явища.

На всіх рівнях свого здійснення, унікально-особистісне самовираження художника наповнене соціальним змістом. Але поворотним стрижнем, спрямовуючим вектором цього соціального буття завжди $\epsilon$ індивідуальне начало, елемент «авторства», що міститься в особистісно-духовному досвіді митця. Ця позиція $є$ особливо важливою у процесі творчо-виконавської підготовки майбутніх учителів музичного мистецтва, коли пріоритетними мають виступити не тільки прагнення набувати знань, співчувати й співпереживати, сприймати музичні твори і художні образи не як «щось надособистісне», а як здобуток власного творчого досвіду, усвідомити особистісну здатність творити, потребу розкривати власні почуття і ставлення до навколишнього світу через «інтонаційну мову» мистецтва.

Проблема функцій мистецтва належить до фундаментальних теоретичних питань естетики. Функції визначають закономірно-необхідний характер мистецтва, дають змогу здійснювати художній діалог на рівні епох і культур, розуміти мистецькі твори далеких часів, різних країн і народів.

Основу функцій зумовлює історичний чинник, адже функції мистецтва виникають і складаються впродовж усього розвитку цивілізації у зв'язку 3 формуванням нових потреб і особливостей побуту і поведінки людини. Тому внутрішня мета будь-якої діяльності - це завжди функція, «служба» в системі цілого соціального організму або окремої особистості як суспільної цілісності.

Своєрідною ознакою мистецтва є його тяжіння до поліфункціональності, що сприяє створенню універсальної цілісної художньої моделі світу. 
Поліфункціональність мистецтва спирається на ідею гуманності, самоцінного

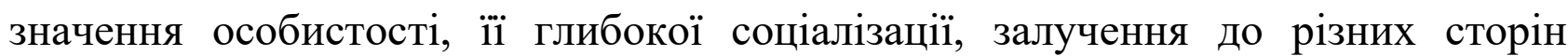
навколишнього життя, творчого самоствердження та індивідуального світосприйняття і набуває своєї значущості в процесі художнього пізнання й далі формує потребу у власному творенні.

Питанням функціональності мистецтва естетична наука займалася ще 3 часів античності, зокрема цій проблемі було приділено значну увагу у теоретичних розробках Аристотеля. Давньогрецький філософ чітко виокремив три основні функції мистецтва: пізнавальну, виховну та функцію емоційного впливу. У процесі подальшої розробки проблеми функціональності естетична думка цілком підтримала ідеї Аристотеля щодо пізнавальної та виховної функцій. Певних коригувань зазнала також інтерпретована античним мислителем функція емоційного впливу. Аристотель тлумачив іiі через давньогрецьке поняття «гедонізм» - чуттєва насолода, тоді як естетика XIX - XX ст. емоційно-чуттєве начало перевела у площину естетичного, розширила аристотелівську модель і визначила такі функції мистецтва: соціальну, пізнавальну, сугестивну, виховну, компенсаційну комунікативну, функцію передбачення, які взаємозумовлені і взаємопов'язані, оскільки мистецькі твори існують як цілісне явище.

На світоглядну функцію мистецтва як на основну вказує О. Рудницька. Мистецтву, зазначає педагог, властива висока чутливість до всього, що відбувається навколо. Воно завжди узагальнює і синтезує найсуттєвіші та найзначніші проблеми людського життя, викликає до них суспільний інтерес. [118].

Долучитись до мистецтва - означає вступити в діалог «соціальних мов», стати причетним до «висловленого чужими словами» світу, пізнати міру причетності митця до універсалій всесвіту, відчути й усвідомити гармонію й ритм його душі у складній структурі художнього діалогу (М. Бахтін, М. Каган). Без художнього діалогу гуманістична і духовна сутність мистецьких творів перестає діяти й функціонувати в полікультурному просторі, втрачає свою 
цінність, а отже, й здатність впливати на особистість. Саме тому «мова» творів відомих митців долає часові кордони, стає зрозумілою, пробуджує в людині творця.

Факт діалогічності $€$ визначальною сутністю і особливістю процесу художнього пізнання, яким притаманні такі атрибути людської свідомості й підсвідомості: ціннісне осягнення, емпатійне чуття, евристичне осяяння, рефлексивний злет тощо. Тож пізнання історичних закономірностей розвитку мистецтва, його поліфункціональності, інтегрувальних та диференціювальних тенденцій, розуміння художньо-образного змісту твору уможливлює здійснення духовного спілкування. У цьому спілкуванні знаходить віддзеркалення «єдність особистостей у рамках духовної культури, їх спільне прагнення до Істини, Добра, Краси.

Саме у формі художнього спілкування реалізується духовний діалог на рівні художніх культур, художніх епох, художніх образів, виникає потреба у повторному спілкуванні 3 навколишнім світом через мистецтво, виникає здатність переживати життя іншої людини зі своїми радощами, тривогами, інтересами, проблемами. У такий спосіб, виявляється гуманістична соціальна потреба, відбувається усвідомлення особистості як найвищої цінності, здійснюються спонуки до саморозвитку і самоформування (В. Біблер), оскільки «дух животворить» (Г. Сковорода).

Як зазначалось, всі функції мистецтва взаємозумовлені і взаємопов’язані, оскільки мистецькі твори існують як цілісне явище. Найбільш обгрунтованими вважаються концептуальні підходи щодо функцій мистецтва відомих філософів Ю. Борєва та М. Кагана. Аналізуючи феномен мистецтва, представники філософської думки різних історичних періодів вказували на його комунікативну перевагу над іншими формами суспільної свідомості. Так, однією із основних функцій М. Каган визначає комунікативну (від лат. соттипісо - спілкуюся), яка має поліфункціональний, інтегративний характер. Для педагогіки продуктивним $\epsilon$ розуміння мистецтва як своєрідного «практичного людинознавства» (М. Каган), об’єктивно-суб' єктивної реальності, невід’ємної від творчості людини, 3 
одного боку, і від культури - 3 іншого. Через мистецтво, зазначає Л. Масол, людина самоактуалізується, усвідомлює власну унікальність [109, с. 41].

До важливих функцій мистецької освіти, науковець додає функції, що забезпечують «входження» особистості як в універсум, так і в культуру певного етносу. Це глобальні феномени людинотворення $i$ культуротворення, які $\epsilon$ інтегрованими, адже «культура суспільства і культура людини як результат привласнення соціокультурних цінностей в індивідуальному досвіді, - це ніби «дві сторони однієї медалі: духовної зрілості людина може досягти шляхом успадкування й розвитку культурних цінностей, а підвищення культури особистості приводить до збагачення культури загалом. Культурноантропологічний вимір акцентує різні форми трансляції культури через систему освіти та виховання, і водночас засоби ії особистісного успадкування людиною» $[109$, c. 54].

Екстраполюючи названі взаємопов’язані функції мистецтва у площину творчо-виконавської діяльності майбутнього вчителя музичного мистецтва, які засобами мистецтва і мають вплинути на цілісний розвиток своїх вихованців, їі функціями визначаємо такі:

- цүіннісно-орієнтаџійну, що полягає в спонуканні особистості до самовизначення, формування життєвої та світоглядної позиції;

- виховну, що зумовлена фундаментальною потребою і здатністю педагога і студента залучати у процес творчості, духовної спільності інших, впливати на внутрішній світ, виховувати цінності, формувати особистісні якості;

- пізнавальну, що передбачає залучення студентів до художньо-образного пізнання світу у процесі художнього сприйняття-інтерпретації-власного творення;

- комунікативну (художньо-діалогічну), завдяки якій студентам надається можливість у процесі художнього полісуб'єктного спілкування здійснити діалог з автором художнього твору;

- творчо-спонукальну, що передбачає активізацію творчо-діяльнісної сфери студента, спонукає студентів до самовираження у власній творчості, 
знаходженні викладачем ефективних практичних методів і прийомів, методичних підходів до розвитку індивідуально-творчої особистості майбутнього вчителя;

- культурологічну, що орієнтує майбутніх учителів музичного мистецтва у процесі творчо-виконавської підготовки на поліхудожній розвиток, формування особистісної культури, культури художнього сприйняття, здатності до адекватного сприйняття й розуміння художнього образу;

- гедоністичну $і$ катарсичну, що передбачає акцентування ролі художньої насолоди у процесі сприйняття-інтерпретації, співтворчості і самотворчості.

Педагогічними важелями у досягненні стану художньої задоволеності і насолоди мають стати такі, які пов'язані 3 осягненням, усвідомленням і розумінням художньо-образного змісту художніх творів, здатністю пережити глибокі почуття, відтворені автором в художньому творі, пройнятися тими переживаннями, що їх втілив автор в художньо-образному змісті твору, усвідомити формотвірні засоби i неповторну красу змістових вимірів художнього образу [115].

Як складне системно-інтеграційне і процесуально-результативне утворення, творчо-виконавська підготовка визначає якісно новий рівень професійної підготовки майбутнього вчителя музичного мистецтва, передбачає розвиток його професійно-особистісних якостей, емоційно-ціннісного ставлення до мистецьких цінностей, явищ педагогічної реальності, здатності до самовираження і самореалізації у професійній діяльності і життєтворчості.

Творчо-виконавська підготовка охоплює фахові дисципліни, передбачає зв’язки $з$ дисциплінами інших циклів, грунтується на оптимальній кількості вихідних і логічно пов’язаних наукових підходів і принципів, що визначають иї методологічно-концептуальні основи та організаційно-методичний супровід.

Виявити творчі можливості студента, які ще є прихованими, не очікувати, коли майбутній учитель виявиться як творча особистість у майбутній діяльності, а в умовах навчання у ВНЗ «вивільнити» його творчі здібності і можливості, виявити його унікальність і неповторність, спрямувати творчу діяльність у 
педагогічне русло - важливе завдання творчо-виконавської підготовки майбутнього викладача музичного мистецтва.

Творчість все більше стає характерною рисою фахівців різних напрямів професійної підготовки і спеціальностей, особливо вчителів музичного мистецтва. Багатогранна творчо-виконавська діяльність вимагає від викладача музичного мистецтва бути соціально зрілою, освіченою, ерудованою, інтелектуальною особистістю зі сформованим світоглядом, поглядами, переконаннями, уявою, мисленням, справжнім творцем навчально-виховного процесу, здатним розкрити свій духовний, індивідуально-неповторний творчий потенціал, реалізувати його у різних видах художньо-творчої діяльності, спрямувати цю діяльність на духовний розвиток особистості учня.

Таке широке розуміння музичної творчості містить у собі всю ємність і багатовекторність конкретно-специфічних виявів творчості у видах музичнопедагогічної діяльності майбутнього фахівця. 3 цієї позиції творчо-виконавська діяльність $є$ основою реалізації творчого потенціалу, самовираження, самоактуалізації і самореалізації особистості майбутнього вчителя у різних їі формах і видах. Акцентуючи увагу на розвитку творчої особистості в процесі активного оволодіння нею різноманітними видами творчої діяльності, педагогимузиканти вказують на значущість пї зворотного зв’язку й впливу на особистісний розвиток, зокрема, розвиток творчої індивідуальності (Г. Падалка, О. Отич), найповнішого розкриття творчих здібностей особистості (О. Ростовський), вияву власного художньо-педагогічного стилю і гуманістичного почерку (В. Орлов), емоційної обдарованості і самовираження (О. Олексюк, О. Рудницька), унікальності, самобутності, індивідуальної неповторності.

Творчість за законами краси, ядро якої становить мистецтво, є універсальною формою художньої діяльності. Творча діяльність - це діяльність майбутнього вчителя музичного мистецтва в їі особистісній, педагогічній i загальнолюдській значущості, передбачає інтеграцію естетикомистецтвознавчих, загальнохудожніх, фахових, педагогічних знань, їх застосування і реалізацію у практичній діяльності. 
У процесі творчо-виконавської діяльності реалізується особистісна креативність студента, яка, з одного боку, як суб’єктивна детермінанта творчості є iї мотиваційною основою, а 3 другого, як об’єктивна детермінанта творчості, розвивається й формується відповідно до особливостей та умов здійснення цієї діяльності, поступово досягаючи власної духовної вершини майбутнім учителем музичного мистецтва. Тому важливо знайти способи розкриття творчого потенціалу майбутнього вчителя, «розбудити» потребу i знайти способи реалізації цієї потреби у самовираженні. Здійснити це цілком можливо на основі пошуку музично-творчих рішень і їх матеріалізації у «композиторстві» як ключовому виді діяльності у творчій самореалізації і самовираженні. Така спрямованість на композиторсько-виконавську діяльність змінює позицію майбутнього вчителя не тільки як виконавця (інструменталіста, вокаліста, диригента), а й посилює його роль як учителя-композитора, вчителя-творця, розвиває потенційно-творче мислення, сприяє його прагненню до самовдосконалення, розвитку професійних якостей, бажанню виконати й оприлюднити власні твори.

У сфері музичного мистецтва творчість - це органічне начало, основа всіх інтонаційних практик, які охоплює система художньої діяльності. Основою цієї системи є тріада - композитор-виконавець-слухач, музична діяльність яких розрізняється за змістом, матеріалом і формою творчості, є конкретним способом вираження творчої дії, спрямованої на створення музичного твору, його виконання і сприйняття.

Музичний твір, який можна порівняти із живим організмом, - від його народження (задум та художня ідея композитора) до самостійного об'єктивного існування (інтерпретація, осмислення, критичне судження, оцінка), є цілісною інформаційною системою.

Основне завдання автора - залучити суб'єкта сприйняття у процес співтворчості. Через спів-творчість як певний спосіб діалогового спілкування здійснюється діалогічність свідомостей, розуміння іншого як самого себе, переживання «духу» музичного твору. У такій творчій діяльності, зазначають 
науковці, яскраво виявляється креативна активність людини, що має культурогенний характер. Так, у просторі художньої культури функціонують смисли, ейдоси (В. Бичков, О. Лосєв), які вступають у глибинний зв'язок із внутрішнім світом людини, актуалізуючи й стимулюючи іï духовно-творчий потенціал. Така принципова незавершеність художнього твору, його семантична відкритість передбачає спів-творчість з автором, характеризується граничною відкритістю до індивідуальних інтерпретацій. Поліваріантність творчих тлумачень та індивідуальних реакцій в процесі сприйняття-пізнання художнього образу уможливлюють визначення смислової конкретизації твору суб’єктом сприйняття як співтворчість. Такої ж думки дотримуються педагоги-музиканти (I. Кевішас, О. Олексюк, Г. Падалка, О. Ростовський, О. Рудницька та ін.), які зазначають, що суб’єкт художньо-діалогової взаємодії, використовуючи власний індивідуально-інтелектуальний, індивідуально-емоційний досвід художнього сприйняття, проникає в образний світ твору, осягає його світоглядний контекст, створюючи власну версію розуміння текстуального значення $[107$, с. 13, с. 16 , с. 18 , c. 19].

Здатність до співтворчості визначає рівень художнього пізнання i мислення і того, хто сприймає музичний твір, і виконавця-інтерпретатора. Як процес співтворчості аналізує виконавський процес С. Гуренко, стверджуючи, що цей процес є складною системою, містить художнє проектування результату виконавського мистецтва, процес формування виконавського задуму; реалізацію цього проекту як матеріального утворення [103]. Розкриваючи художній образ, виконавець привносить у художній образ свої переживання і співпереживання, видозмінюючи тим самим авторську інформацію, намагається її переосмислити, трансформує, бере участь у художній творчості, конкретизує, доповнює створені та втілені автором образи музичного твору, тобто є співтворцем. Як процес співтворчості, художню інтерпретацію визначають В. Асмус, Л. Виготський, Б. Мейлах, С. Раппопорт, П. Якобсон, Н. Яранцева та ін.

Отже, музичне виконавство як складний творчий процес не є первинною творчістю виконавця, а спів-творчістю, що не можна сказати про творчість 
автора (композитора), який, зазвичай, і є виконавцем-інтерпретатором власних творів. У цьому виявляється відмінна риса творчості і виконавства. А поєднує їх єдиний творчий процес, котрий містить елементи власне творчості і елементи виконавства: у процесі власного творення - композитор виконує, виконуючи, виконавець творить. У процесі творення творчість та виконання для автора єдині, нерозривні, взаємодоповнювальні й взаємозумовлені явища, - основою композиторської творчості завжди певною мірою $є$ виконавське начало, а основою виконавської творчості - композиторське начало.

Процес творчості («композиторства») і виконавства поєднує інтерпретація. У працях відомих філософів, психологів, музикознавців і педагогів, зазначається, що специфічною ознакою композиторської творчості і виконавства $\epsilon$ інтерпретація. Поняття «інтерпретація» як свого роду «супутник» або «тінь»супроводжує кожен феномен культури, будь-який мистецький твір. Мистецтво існує доти, поки існує його інтерпретація - виконавська, вербальна, тобто тлумачення словом і ділом. «Інтерпретація» (від лат. interpretatio посередництво - тлумачення, роз'яснення смислу) у мистецтві визначається як фундаментальна операція мислення, творче розкриття змісту художнього твору, що визначається ідейно-художнім задумом та індивідуальними особливостями артиста, співака, інструменталіста, диригента музичного твору у процесі його виконання.

Категорія інтерпретації посідає важливе місце в естетиці Р. Інгардена, Ф. Шлейєрмахера, В. Дільтея, М. Хайдеггера, Г. Гадамера, в естетичних концепціях яких ставиться питання про незавершеність художнього твору як особливої, унікальної якості мистецьких творів, що стимулюють творчу активність суб’єкта пізнання, оскільки в процесі художнього діалогу реципієнт доповнює образ власною уявою, фантазією. Питання інтерпретації як однієї з найактуальніших проблем музичної діяльності розглядаються у наукових працях Л. Бочкарьова, В. Блудової, Л. Гінзбург, Н. Горюхіної, А. Готсдинера, В. Григорьєва, Е. Громова, Є. Гуренко, А. Зися, М. Кагана, Г. Когана, 
Н. Корихалової, О. Костюка, К. Мартінсена, Л. Мазеля, В. Медушевського, Б. Мейлаха, Є. Назайкінського та ін.

Художня інтерпретація як трактування музичного твору в процесі його виконання $\epsilon$ результатом складних процесів, які являють собою систему взаємодіючих елементів із специфічними функціями, властивостями, структурою та змістом. Вона є активним творчим процесом, в якому воля композитора має стати волею інтерпретатора (С. Фейнберг), повноцінним самостійним видом художньої творчості (Л. Мазель), як діалектична єдність об'єктивізм і суб'єктивізм водночас - продуктом та функцією виконавця (Н. Корихалова); складним творчим процесом, що передбачає задум, творення художнього образу, проникнення в його інтонаційний зміст, розуміння i розкриття семантичного значення (Є. Гуренко); переведення семантичної конкретизації в художнє узагальнення, оформлення драматургічного задуму (В. Блудова); як суспільно-значущою цінністю (М. Каган), що розкриває соціальну реальність через світосприйняття композитора у процесі надання адекватної форми, змісту і значення відповідно до уявлень і художніх фантазій автора, розуміння художньо-образної сфери музичного твору.

Теоретичні концепції щодо структуризації, внутрішніх механізмів і змісту процесу художньої інтерпретації розробляються й досліджуються в наукових працях Л. Виготського, С. Рубінштейна, Б. Теплова, С. Фейнберга та ін. Вони містять визначення художньої інтерпретації як активного творчого процесу, художнього трактування музичного твору; як кінцевого результату виконавської діяльності, індивідуального художньо-образного відтворення й ставлення до музичного твору; як особливої духовно-практичної діяльності, у складній інтегративній структурі якої діалектично взаємодіють інтелектуальні та емоційні реакції, співпереживання, ідентифікація й співтворчість.

Представники сучасної теорії художньої інтерпретації розкривають питання впливу художньої форми та образного змісту на виконавця, значення дії та впливу засобів художньої виразності та їхніх специфічних особливостей на емоційно-почуттєву сферу інтерпретатора, здатність впливати на суб'єкта 
сприйняття і відтворювати складні процеси людської психіки. Важливими $є$ висновки науковців про те, що особистість майбутнього вчителя музичного мистецтва розвивається, формується і реалізується в художній інтерпретації і через художню інтерпретацію.

Отже, музичне виконавство $\epsilon$, безперечно, творчим процесом, a «творчість» передбачає створення нової продукції і не існує без виконавства. Але в контексті нашого дослідження поняття «творчо-виконавська підготовка майбутнього вчителя музичного мистецтва» набуває значущості та інноваційності, оскільки грунтується не тільки на здатності творчо сприймати, виконувати та інтерпретувати музичні твори (інструментальні, вокальні, хорові), самовиражатися у виконавській діяльності, а й передбачає здатність майбутніх учителів до самотворчості, бути водночас автором і виконавцем власного твору. Тому у творчо-виконавській діяльності особливого значення набувають такі види творчості, як композиція та імпровізація, що мають велике значенні для розвитку всього комплексу музичних здібностей, музично-образного мислення, зростання ефективності процесу засвоєння знань, формування умінь і навичок, необхідних i музиканту-фахівцю, i вчителю музичного мистецтва у їx професійній діяльності. Отже, у структурі творчо-виконавської діяльності виокремлюємо композиторсько-виконавську діяльність. Оптимальна цінність цієї діяльності досягається у тому разі, коли композитор і виконавець «зливаються» воєдино, тобто композитор є водночас інтерпретатором своєї музики. Він виконує дуже відповідальну роль в комунікативному процесі композитор - виконавець - слухач (аудиторія). Зазначимо, що ця схема-тріада фіксує остаточний результат диференціації видів музичної творчості, що склався у європейській культурі Нового часу й свідчить про структуру художньотворчого спілкування.

Варіантом «композиторства» є мистецтво імпровізації, яка в епоху бароко і класицизму, спираючись на традиції ренесансного мистецтва, була хранителем пам'яті про одвічну цілісність творчості як феномена, про первісний синкретичний характер творчого процесу, в якому імпровізатор - це творець 
музики і виконавець в одній особі, а створення музики та їі звукова реалізація становлять нероздільну єдність.

Навчання імпровізації $є$ фактором розвитку спеціальних здібностей, (слухових уявлень, почуття ладу і ритму), особистісних якостей (креативності, емоційної чуттєвості), здатності переживати «форму як процес» (Б. Асаф’єв), творчо «мислити звуками», «реалізувати в діяльності специфічну музично-мовну здатність» (М. Арановський). Крім цього, імпровізація допомагає глибше зрозуміти закономірності гармонічної мови, усвідомити художньо-виражальну та формотвірну роль гармонії у комплексі 3 іншими засобами музичної виразності в художньо-цілісній побудові. Основними показниками сформованості вмінь імпровізаційної художньої техніки як варіативного потенціалу композиторсько-виконавської діяльності студентів $є$ : високорозвинена інтонаційно-слухова підготовка, усвідомлення музичних уявлень; розвиненість мелодичного та гармонічного слуху, музичного мислення, почуття форми, стилю і жанру; розвиненість художньо-стильового і художньослухового досвіду, володіння інтонаційними, метро-ритмічними, фактурними, структурними стереотипами музики різних стилів і жанрів; розвиненість музично-виконавської техніки, володіння навичками творчо-виконавської інтерпретації; розвиненість умінь миттєвого перетворення музичних образів на внутрішні слухові уявлення та їх реалізація у звучанні на інструменті або голосом; здатність перетворювати наявні у пам’яті музичні образи, створювати на цій основі нові, власні. Володіння імпровізаційною технікою, як варіативним потенціалом композиторської творчості, передбачає й, водночас, впливає на розвиток музичного слуху, асоціативно-образного мислення, сприяє удосконаленню виконавської техніки (вокальної, інструментальної), здатності миттєвого перетворення музичних образів на внутрішні слухові уявлення та їх реалізацію у звучанні голосом або на інструменті; формує почуття форми, художнього стилю і жанру; здатність розуміти закономірності музичної мови, усвідомлювати виражальну та формоутвірну функцію засобів музичної виразності (гармонії, мелодії, метро-ритму та ін.), метро-ритмічні, інтонаційно- 
фактурні, структурні стереотипи музичних творів різних стилів; здатність перетворювати наявні у пам’яті музичні образи та здатність створювати на цій основі нові, «вплітати» до індивідуального досвіду та аксіологічної сфери студента нові смисли, стимулювати творчу самоактуалізацію, виникнення потреби у творчому самовираженні, збагаченні творчо-виконавського досвіду, розкріпаченні й розкритті власних творчих можливостей.

Основи композиторської та імпровізаційної техніки закладаються у всіх фахових дисциплінах, розвиваються і формуються у процесі цілеспрямованої навчально-творчої діяльності у їі специфічних формах (композиція, імпровізація, творче музикування). Особливістю цих креативних якостей $\epsilon$ те, що вони $\epsilon$ точкою перетину різних видів художнього мислення, зокрема, історикостильового, інтонаційного, інтерпретаційного, наближають навчання до художньої практики. Широкі можливості у цьому плані надають музичнотеоретичні дисципліни, зокрема «Історія музичного мистецтва», «Теорія музики та сольфеджіо», «Гармонія», «Аналіз музичних творів», «Поліфонія», «Акомпанемент та імпровізація», «Основи музичної композиції», «Основи композиторської майстерності» за умов тісного зв’язку з предметами музичновиконавського і практично-методичного циклів. Тісний зв'язок між творенням і виконанням музики, композитором i виконавцем, функції яких часто поєднувались (композиторська діяльність виконавця і виконавська діяльність композитора) зумовлюються самою художньою практикою, системою виховання i навчання музиканта, нерозривним зв'язком композиторського i виконавського таланту.

Шлях до «композиторства» пролягає у тріаді взаємодійних i взаємозумовлених понять «сприйняття-виконання-творення» у їх логічній послідовності, що передбачає наявність складних взаємозв’язків, які грунтуються на художній інтерпретації, здатності творчо осмислювати зміст художніх творів.

Розкриваючи педагогічний аспект «композиторства», акцентуємо увагу на відмінності підготовки композитора на композиторських відділеннях 
консерваторій (музичних академій), які готують професійних композиторів і формування особистості композитора-виконавця на музичних відділеннях мистецьких і музично-педагогічних факультетів, підготовка якого здійснюється у тісному зв'язку індивідуально-особистісного, творчо-виконавського й педагогічного напрямів й спрямовується на музичне виховання підростаючого покоління, що у результаті дає змогу схарактеризувати майбутнього вчителя музичного мистецтва як цілісну особистість, самостійну, ініціативну, мобільну, винахідливу, креативну, компетентну, здатну до адекватної інтерпретації музичних творів, власного творення у різних жанрах, стилях і формах; (пісні для дітей, окремі музичні твори, музично-театральні вистави, мюзикли, творчі проекти, видовищні заходи), котрий володіє методикою навчання, залучає й навчає власного творення студентів інших курсів та інших мистецьких спеціальностей (майбутні учителі хореографічного та образотворчого мистецтва), встановлює творчий діалог з аудиторією, виявляє відповідальність та ініціативу у творчо-виконавській діяльності в інших навчальних закладах, застосовує i винаходить власну методику творчо-виконавської діяльності, спонукає до творчості своїх вихованців. Тому мета «композиторства» як інтегративної дефініції має полягати не тільки у навчанні студентів створювати власні твори у рамках певної дисципліни, а у спрямуванні цієї діяльності на майбутню професію - вчитель музичного мистецтва, а також на можливість саморозвитку, самовираження і самореалізації майбутнього фахівця в інших сферах соціально-культурного середовища (гімназії, коледжі, музичні школи, дитячі юнацькі центри, школи мистецтв, театр, філармонія та ін.).

Композиторсько-виконавська діяльність як процес духовно-практичного втілення художньої ідеї у чуттєво сприймані художні образи , своєю кінцевою метою і результатом передбачає досягнення максимальної відповідності між творчим задумом композитора та його адекватним утіленням у своєрідній образній мові музичного мистецтва. Цей процес об’єктивації художніх образів у засобах музичної виразності, відповідній формі, стилі, образі, змісті, що склалися 
в уяві автора, набуває життєвої повноти, внутрішньої потреби і необхідності художньо висловитися і втілитись у творі як цілісна художня ідея.

Складний процес композиторсько-виконавської діяльності має об’єктивний і суб’ єктивний аспекти. Автор розкриває проблеми навколишнього життя, відтворює складні процеси людської психіки, відображує реальне життя у формах самого життя й виражає власні почуття і прагнення. У такому творчому процесі реалізується внутрішній ресурс, відбувається народження унікального неповторного художнього образу.

Композиторсько-виконавський процес $\epsilon$ складним i відповідальним. Автор, використовуючи єдину об'єктивну основу - навколишній світ, життя в усій його складності та багатогранності, пізнаючи об’єктивну реальність, не обмежений у пошуках життєвого матеріалу, вільний у доборі тем майбутнього твору, індивідуально планує процес творення, добирає такий тематичний матеріал, що найбільш розкриває його внутрішній світ і світоглядну позицію.

Об’єктивний фактор - це прагнення об’єктивації духу в матерії формування, причому воно набуває характеру мети; суб'єктивний - це здатність суб’єкта (автора) заглиблюватися у сутність явищ та формувати образи їх життєвості як ідеальну реальність у у засобах художньої виразності, вміння у художньо-творчому процесі досягати адекватності втілення художніх образів, що живуть у свідомості митця, у матеріалі мистецтва.

Важливою закономірністю творчого процесу $є$ акцент на самоцінності потреби об’ єктивації духовного досвіду у власній творчості. Жодні інші мотиви, на думку психологів, не можуть виконувати конструктивну роль у процесі творчості. Це якісно відрізняє практичне і духовне формування. У діяльності практичного формування метою зусиль суб'єкта постає задоволення певних життєвих потреб, тоді як метою практичного формування постає творення як «свободи від...», тобто звільнення від життєвих потреб способом їх задоволення. Простір свободи створюється саме завдяки можливості задовольнити життєві потреби. У процесі художнього творення має місце інша закономірність: митцем рухає потреба входження у простір «свободи для...», i для розгортання 
життєвості духу в матерії художнього формування. Процес художнього творення вимагає, щоб автор жив власним твором, надихався і проникався в задум, утримував його образи та окремі деталі до завершального етапу художньоінтерпретаційного процесу, в якому «дух животворить» (Г. Сковорода) i «здобуває реальне життя», втілюючись у своєрідні художні образи. Композиторсько-виконавська діяльність як процес розгортається у формах внутрішньої потреби, котра набуває характеру необхідності та реалізує себе в музичній формі і змісті, досконалих художніх образах як вільна внутрішня життєвість духу. Художньо-формувальні вміння як суб’єктивна здатність - це, 3 одного боку, розвиток та концентрація у суб'єкті родових духовних якостей: багатої уяви, фантазії, пам’яті, творчого мислення, що дають змогу свідомості формувати цілісні образи, рознюансовуючи багатство їх життєвості. 3 іншого боку, - це уміння досконало, майстерно, життєво втілювати образи свідомості у матеріалі конкретного виду мистецтва. Оскільки суб’єктом рухає потреба об’єктивувати творчий дух в художніх образах, вона (потреба) є активною силою, що спонукає вміння та здібності на формування і втілення художнього образу у відповідній формі. Тому, саме творчий дух є тією силою, що стійко утримує потребу формування, визначає змістовність процесу та спонукає волю на втілення художнього задуму в матеріалі мистецтва, тобто організує здатність суб’єкта до художнього творення.

Духовна потреба суб’ єкта - надати чуттєво сприйманого втілення образам, що склалися в уяві, набули виразних форм і внутрішніх зв’язків і постають у пам’яті сповненими життєвої повноти та переконливості. Митець (композитор, художник, поет) бачить їх у найменших деталях. Думки, почуття, уява, пам’ять стійко утримують образи, що заволоділи свідомістю і «вимагають» втілення $\mathrm{i}$ відображення себе специфічною мовою твору, надихають на художнє формування, коригують початком творчого формування, «підказують» способи, внутрішню спрямованість свого ідеального життя в музичній формі, зумовлюють необхідність постійно уточнювати попередній задум згідно 3 об’ єктивною логікою його розвитку і формування як художнього цілого. Автор 
реалізує свій задум у діалектичному зв'язку з ідеєю та ії втіленням в художньообразній мові твору, використовуючи комплекс художньо-формувальних умінь.

Схильність до мотивованої композиторсько-виконавської діяльності зумовлена наявністю індивідуальних здібностей, здатностей і властивостей особистості, котрі розкривають специфіку і зміст цієї діяльності більш повно і глибше, а отже, й особистість автора. Інтерес, захоплення і схильність, що виникли, є потребою самовираження особистості у цій діяльності. Отже, основною спонукою до творчості є внутрішня потреба автора (композитора) надати реального життя художнім образам, що живуть в уяві та утримуються пам'яттю. Потреба зосереджує на собі, породжує велику творчу наснагу. Тому метою формувального процесу в композиторсько-виконавській діяльності $\epsilon$ закріплення цієї потреби, ставлення у його найбільш повному, цілісному, художньо-переконливому виявленні. Внутрішня правда художніх образів, що живуть у свідомості автора, дає можливість поглиблювати, вдосконалювати, наповнювати їх новими рисами життєвості, внутрішньої досконалості і завершеності, є джерелом творчої наснаги, спонукає на подальшу творчовиконавську діяльність.

Композиторсько-виконавська діяльність, що грунтується на сприйняттіінтерпретації, пов'язана передусім з «афективними» процесами (емоції, почуття, бажання), що становлять основу спонукальної регуляції як вираження активного ставлення, викликаного зіткненням наявного 3 належним, прагнень i можливостей їх реалізації, ідеалів і дійсності. Емоції як «енергетичне пальне» аферентного синтезу всіх наявних подразників у поєднанні з минулим досвідом, сигналізують про значущість відображуваного, дають установку до сприйняття i дії, активізують організм, об’єднують усі компоненти психіки, сприяють формуванню як ідеальних моделей реальних процесів і явищ, так і тих, що передбачається створити і відобразити. Художня емоція набуває особливого значення у формуванні творчого потенціалу особистості. Ї̈ї відносять до «стенічних» емоцій, що стимулюють життєдіяльність людини, активізують, мобілізують і актуалізують творчі сили особистості. 
Повноцінне творення відбувається тоді, коли композитор-виконавець розкриває не тільки загальні риси образного змісту і форми, а й своєрідне, неповторно індивідуальне авторське втілення, вступає у діалог із самим собою. Такий складний процес творення й осягнення змістової форми передбачає мобілізацію різноманітних знань (загальнохудожніх, музично-теоретичних, музично-історичних тощо) i вмінь (художньо-інтерпретаційних), які уможливлюють вияви власних почуттів і переживань, що є «надпредметним» результатом композиторсько-виконавської діяльності. Цей процес передбачає оригінальні вияви особистісних художніх вражень, емоційне забарвлення, індивідуально-неповторні, суб’єктивно-асоціативні уявлення.

Провідними компонентами композиторсько-виконавської діяльності $є$ логічне мислення, пізнання, переживання, інтуїтивне осягнення змісту художніх образів, уява, душевно-емоційна і практично-діяльнісна сфери особистості. Художнє пізнання - це розуміння смисло-образів, які підносяться і над звичайними образами, і над поняттями в осягненні різних аспектів буття і співбуття з іншими, це шлях до духовних вимірів у злагоді розуму, волі і почуттів.

У сфері мистецької освіти «пізнання» інтерпретується як узагальнення, як процес і результат усвідомлення тих значень, які притаманні мистецтву, як феномен образного відображення дійсності, взаємодія суб'єкта (учня) і об'єкта (художнього твору), спрямована на усвідомлення змісту і форм художніх образів, на досягнення нового знання щодо мистецтва [115, с. 88].

Мислення у мистецтві набуває в художньо-образних формах особистісного сенсу, оскільки воно завжди емоційно забарвлене. Мислення $\epsilon$ основою композиторсько-виконавського процесу і спирається на пізнання i розуміння «інтонаційного словника» епохи, ii художньо-стильових особливостей, що не може відбуватися без пізнання і розуміння навколишньої дійсності. Логічне мислення передбачає пошук оптимальних способів вираження власного художнього задуму, його втілення в художню форму. Раціональноінтелектуальні способи пізнання, логічно-оперативні дії автора, аналіз, синтез, узагальнення, систематизація спонукають до пошуку нестандартних рішень, 
створення нового, раніше небувалого, внаслідок чого відбувається активізація мисленнєвих процесів.

Процес композиторсько-виконавської діяльності передбачає інтуїтивнологічне оперування образами-симолами, вимагає від інтерпретатора суттєвого переосмислення, подолання педагогічного стереотипу щодо інформативнопізнавальної домінанти, виявлення й увиразнення специфіки музичної семантики, що передбачає участь таких когнітивно-почуттєвих механізмів як індивідуальне «вчуття», внутрішне «вживання» в художній образ, асоціативність, емоційно-естетичний резонанс.

Аналітико-синтетична діяльність свідомості автора зумовлює виникнення емоцій, що завжди супроводжують творчу дію, впливають i стимулюють продуктивність когнітивно-розумового процесу, поступово набувають осмисленості й концентрованості, містять значні інтелектуальні потенції й виконують пізнавальні функції, є «глибокодумними» (Б. Теплов) і «розумними» (Л. Виготський). Саме емоції істотно доповнюють інтелект людини при творчому розв’ язанні проблеми. Вказуючи значення емоцій і почуттів у процесі художньої творчості, Л. Виготський у відомій науковій праці «Психологія мистецтва», зазначає, що «всіляке почуття, всіляка емоція прагне втілитись у певні образи, що відповідають цьому почуттю» [101].

Раціонально-інтелектуальні й емоційно-мисленнєві процеси передбачають проектувальні підходи, постановку мети, iї інтелектуальне обгрунтування, осмислення творчого завдання й активізують процес творчості. Внаслідок такої складної творчої взаємодії емоційно-інтелектуальних процесів, асоціативнообразного мислення, вмінь знаходити різні зв’язки в цілісному художньому об'єкті стає можливим процес співпереживання, проникнення, інтеріоризація художнього змісту, повноцінне художньо-діалогового спілкування, як у процесі безпосередньої художньої комунікації, так і на посткомунікативному етапі, що передбачає внутрішній діалог автора зі своїм внутрішнім «Я» (М. Бахтін, М. Каган). 
У композиторсько-виконавській діяльності значну роль відіграє натхнення як особливий стан людської психіки, що передбачає підвищену творчу активність індивіда, високу інтенсивність процесу мислення. Але при всій мимовільності, як це вважається, натхнення визначене. Умовою натхнення є усвідомлення суспільної значимості художнього завдання, захоплення художньою ідеєю, що має втілитися в художньо-образний зміст музичного твору. Передумовою натхнення є минулий досвід, праця, роздуми, міркування. Результатом натхнення є виникнення і реалізація художнього задуму та ідеї.

Процес власного творення, сприймання і розуміння художніх творів учені тлумачать як «діалог», адже автор, як взаємодійна сторона художнього діалогу, постає у свідомості інтерпретатора зі своєю художньо-смисловою позицією, що спричиняє внутрішній діалог інтерпретатора (діалог між внутрішнім світом особистості й духовним «Я» музичного твору, образно-художньою моделлю). У працях «Світ спілкування», «Мистецтво і спілкування» М. Каган виокремлює таку форму художнього діалогу у процесі спілкування з музичними творами, як творча імпровізація (автор та співавтор-інтерпретатор), діалог яких спричиняється програмою музичного твору, «спільною темою», взаємодія окремих партій в ансамблі, діалог виконавця і слухача).

Процес композиторсько-виконавської діяльності як творчий процес передбачає вияв індивідуального стилю автора (композитора) як у процесі творення, так і у процесі художнього виконання (інтерпретації), що, зазвичай, сприяє формуванню активного творчого ставлення особистості до навколишньої дійсності й до самого себе. Створюючи свої творіння, композитор «мислить своїм слухачем», котрий присутній в авторському творчому процесі як мета, для якої створюються твори. Здійснення такої духовної «взаємності», взаємопрагнень до художнього спілкування - це стиль, у якому здійснюється художня комунікація (реальність - творець - твір - виконавець - реціпієнт дійсність), засвідчується особистість автора, що закладена в ритмі, інтонації, гармонії, засобах виразності. 
У інтегративній духовно-практичній діяльності автора-інтерпретатора діалектично взаємодіють інтелектуальні та емоційні реакції, співпереживання, ідентифікація і співтворчість, що відзеркалюють динаміку емоційних реакцій від безпосередньо-чуттєвих виявів до вищих емоцій художньої насолоди. Саме в такому творчому процесі здійснюється художньо-образне трактування й ставлення до музичного твору, стає можливим процес співпереживання, проникнення і «вживання» в художній образ, інтеріоризація художнього змісту, повноцінного діалогового спілкування.

У процесі власного творення розвивається творче, художнє мислення, оскільки це перш за все створення нової реальності, адже художній твір народжується в уяві митця (композитора, художника, архітектора, драматурга, хореографа, режисера тощо) й, водночас, спрямовується до художньо-творчих обдаровань особистості, без яких неможливий процес композиторськовиконавської творчості

Провідну роль у процесі композиторсько-виконавської діяльності відіграє розвинута уява та фантазія автора, що грунтуються на емоційно-почуттєвих процесах. Досліджуючи проблеми сутності уяви, психологи одним із механізмів iï виникнення називають емпатію як своєрідний різновид уяви, оскільки в процесі емпатійного сприймання людина «переносить» себе до думок, почуттів i дій іншого та структурує власне сприймання за цим зразком. «Я» нібито поділяється на реальне «Я» і уявне «Я». Це уявне «Я» і $є$ творчим компонентом. Емпатія, як у процесі слухацького сприймання, так і в процесі власного творення передбачає тісну взаємодію когнітивно-розумових, емоційно-почуттєвих і художньо-творчих актів, характеризується багатством асоціативно-образних уявлень, вміннями суб'єкта художнього творення-інтерпретації осмислювати організацію художнього матеріалу, розуміти виразний сенс художньої інтонації і є генералізованою професійно значущою особистісною якістю майбутнього вчителя музичного мистецтва.

У процесі власного творення активно діють механізми синтонії та ідентифікації, тобто перенесення життєвих станів інших людей на себе, свою 
долю, співчуттєве ставлення до сприйнятого, що містять елементи взаєморозуміння, безкорисливої допомоги. і посідає центральне місце в процесі формування здатності суб’єкта до самопізнання та саморозвитку (А. Фройд, Д. Рапопорт). Зумовлюючи виникнення ефекту емоційної ідентифікації (Г. Андреєва, Т. Шибутані), глибокого співпереживання й співчуття, здатність до емпатії позитивно позначається на духовному міжособистісному спілкуванні, гуманізує систему педагогічних дій i впливів, сприяє встановленню повноцінного діалогу в процесі художньо-педагогічної взаємодії викладача i студента, набуває педагогічного сенсу. Саме через нього (співпереживання) відбувається збагачення внутрішнього світу особистості досвідом почуттів інших людей. Через пристосування до емоцій інших студенти можуть відчувати соціальні, моральні, естетичні почуття, яких у їхньому практичному досвіді ще не було. Особливо важливо зауважити гуманістичну спрямованість співпереживання, у процесі якого формується ставлення до людини.

Одним із положень психології мистецтва $є$ теза про те, що в процесі художнього сприйняття-інтерпретації здійснюються психологічні перетворення, аналогічні авторським, що їх він переживає у процесі створення твору; душа виконавця і того, хто сприймає, «зливається» 3 душею автора, і що саме у цьому поєднанні і є головна приваблювальна сила та властивість мистецтва. Тож стає зрозумілою значущість композиторсько-виконавської творчості майбутніх учителів музичного мистецтва, в процесі якої відбувається особлива активізація свідомості через власне відтворення цінності буття засобами специфічної мови музичного мистецтва. Процес власного творення не тільки збагачує майбутніх фахівців життєвим і художнім досвідом, a й спонукає їх до ціннісного переживання, що становить важливий компонент їхньої світоглядної i гуманістичної позиції.

Художня насолода, що охоплює автора-виконавця і слухача в момент оприлюднення твору і є оцінкою здатності автора створювати твір як художнє ціле, є реакцією на його творіння як на високу соціальну цінність. 
Здатність насолоджуватися мистецтвом характеризує високий рівень емпатійного проникнення в його образний зміст $\mathrm{i}$ водночас багатство внутрішнього світу суб'єкта художньої взаємодії. Катарсис, як форма вияву почуттів, у процесі художнього спілкування виникає завдяки здатності суб'єкта ототожнювати, ідентифікувати, емоційно переживати, перевтілюватись у художні образи, проникати в їхній внутрішній світ, «пропускати через себе». Отже, емоційно-емпатійне співпереживання автора-виконавця $є$ показником володіння ним почуттєвою проникливістю, багатством асоціативно-образних уявлень, вміннями художньо мислити, розуміти організацію музичного матеріалу, виразний сенс інтонації.

Психолого-педагогічний аналіз процесу художньої творчості, внутрішніх механізмів сприйняття-інтерпретації, творення дає змогу констатувати, що у процесі композиторсько-виконавській діяльності формуються універсальні особистісні професійно значущі якості (логічне мислення, творча уява, асоціативність, креативність, здатність до емпатії і рефлексії, ціннісні орієнтації) і таким чином, набуває потужності духовно-творчий потенціал особистості.

У процесі композиторсько-виконавської творчості передбачається «вивести» студента на такий рівень самосвідомості, де творче самовдосконалення у різних видах «композиторства» i творчо-виконавській діяльності стане природним станом майбутнього фахівця. Це, в свою чергу, стимулює творчу активність, опосередковує формування внутрішніх мотивів $\mathrm{i}$ цінностей щодо своєї професії, творчості і значущості самого себе у цій діяльності, формує якісно нову професійно вагому якість майбутнього вчителя музичного мистецтва - авторську спроможність.

У формуванні авторської спроможності майбутніх фахівців особливої значущості набуває метод проектів. Творчий проект «Я - композитор» визначається своєю динамічністю, оскільки забезпечує зміну форм надання $\mathrm{i}$ одержання знань - від формування художнього сприйняття - до активної участі у різних видах творчо-виконавської діяльності і самовираження у власній творчості, від індивідуальної до групової і колективної співтворчості. Вимогами 
проектної технології є: усвідомлення теоретичної, пізнавальної і практичної значущості передбачуваних результатів; спрямованість на розвиток пізнавальних умінь та навичок, здійснення самостійної пізнавальної діяльності студентів; здатність до самостійної пошукової діяльності, структурування змістовної складової творчого проекту з поетапним узагальненням результатів; оприлюднення і впровадження отриманих результатів творчого застосування набутих знань, узагальнення та інтеграція музично-теоретичних, музичновиконавських, практично-методичних, науково-дослідних знань і вмінь, набутих у процесі теоретичного, практичного навчання та самостійної роботи, здатність орієнтуватися в інформаційному просторі та добирати необхідні знання, узагальнювати та інтегрувати набутий досвід, використовувати його у нових умовах і власній продукції. Окрім того, залучення майбутніх фахівців до проектної діяльності сприяє розвитку ініціативи, комунікативності, організаторських та творчих здібностей. Участь у творчо-проектувальній діяльності надає можливість майбутньому вчителю (викладачеві, вихователю) самовдосконалюватися, відкриває можливості для вибору своєї ролі у творчому проекті: автор художньої ідеї, композитор, виконавець, артист, організатор або студент, який виконує власний твір, виступає в одній особі в усіх ролях (монопроект), самостійно його проектує i моделює, інтерпретує, доповнює презентацією (мультипроект).

Ефективність проекту «Я - композитор» зумовлюється основними його характеристиками: орієнтованість на самостійну діяльність; можливість використання різноманітних методів, засобів, що грунтуються на інтеграції набутих поліхудожніх, музично-теоретичних знань, художньо-інтерпретаційних умінь 3 різних дисциплін, галузей мистецтва і педагогічної науки. Названі характеристики відображають провідні закономірності музично-педагогічної освіти: самостійність у прийнятті рішень; здатність до творчості, усвідомлення внутрішніх спонук, мотивів, потреби, інтересів, які виступають регуляторами поведінки; міждисциплінарність, інтеграційність, здатність до самовираження і самореалізації, оцінки і самооцінки. 
Авторська спроможність набуває інтегративного характеру, містить внутрішні індивідуально-особистісні характеристики, здатності, якості і властивості, що виявляються у композиторсько-виконавській діяльності майбутнього вчителя музичного мистецтва. Надаючи «життя» своїм індивідуальним цінностям, досягаючи свідомої мети, реалізуючи її у діяльності, майбутній фахівець утверджує себе як неповторну особистість, спроможну досягнути широких творчих узагальнень, демонструвати високий рівень культури, грамотність, глибоку ерудованість й інтелектуальність, гармонію і красу внутрішнього світу, небайдужість до навколишнього середовища, усвідомлення його цінностей і свою причетність до створення цих цінностей. 
DOI 10.46299/ISG.2021.MONO.PED.III.2.8

\section{8 Визначення критеріїв якості професійної діяльності науково- педагогічних працівників: особистісно-діяльнісний підхід}

В Україні здійснюється системне реформування освіти, в тому числі й вищої, яке спрямовано на успішність підготовки фахівців нової генерації, здатних якісно працювати в умовах інформаційного суспільства за постійної та швидкої зміни знань і технологій у світі. Таке реформування передбачає зміну парадигми, підходів, принципів, форм і методів професійної підготовки фахівців, перехід до інноваційних процесів у закладах вищої світи, готовності до постійних змін і пошуків та ін. Як зазначено в комюніке, котре стало результатом зустрічі європейських міністрів (м. Прага, 19 травня 2001р.), які у своїх державах відповідають за вищу освіту, на даному етапі розвитку людства особливу увагу потрібно приділити роботі щодо забезпечення і якості освіти, і якості знань.

Україна долучилася до Болонського процесу. За 30 років незалежності нею втілено десятки реформ, які спрямовані на докорінні зміни освіти, вірніше іiі якості. Реалізовано широкомасштабні заходи щодо вивчення, осмислення й впровадження досвіду передових країн у галузі вищої освіти. Проте слід констатувати, що значних успіхів у підвищення якості вищої освіти в Україні ще досягнуто. Тому залишається нагальною потреба у змінах на основі наукового осмислення цілого комплексу завдань та визначення чинників, пов'язаних 3 підвищенням рівня якості вищої освіти. При цьому власне викладач є тією центральною постаттю, яка має генерувати такі зміни на підгрунті постійного оволодіння новими знаннями, інформаційними та педагогічними технологіями, підходами, формами, методами тощо.

Загалом, постає питання, якою на сучасному етапі розвитку людства має бути професійна діяльність освітян України, зокрема, науково-педагогічних працівників закладів вищої освіти, щоб забезпечити якісне оволодіння не лише підростаючим поколінням, а й фахівцями, які вже мають стаж, знаннями, вміннями та компетентностями 3 метою постійного інтенсивного розвитку й високої конкурентноздатності економіки держави у світовому рейтингу. Цілком ясно, що мова йде про якість професійної діяльності науково-педагогічних 
працівників. Однак на сьогодні відсутні критерії, за якими на практиці реально можна було б оцінити якість професійної діяльності конкретного науковопедагогічного працівника в контексті його вкладу в професійну підготовку майбутніх фахівців.

Аналіз праць з проблеми критеріїв якості професійної діяльності науковопедагогічних працівників свідчить, що, з одного боку, в прямій постановці це питання в науці не ставилося, а з іншого - такі критерії, фактично, закладені в тих багаточисельних завданнях, які мають вони розв’язувати в ході освітнього процесу. Таким чином, критеріями якості професійної діяльності науковопедагогічних працівників будуть ті вміння і здатності, які, власне, дозволяють ефективно розв’язувати всю цю сукупність завдань освітнього процесу. Виходячи $з$ цього, необхідно розкрити сутність і зміст професійної діяльності науково-педагогічних працівників у контексті розв’язання всієї сукупності освітніх завдань через призму їх проекції на результати навчання, які мають досягнути здобувачі вищої освіти.

Так, науково-педагогічні працівники забезпечують здобуття особами різного віку вищої освіти, яка, згідно зі Законом України «Про вищу освіту», являє собою «сукупність систематизованих знань, умінь і практичних навичок, способів мислення, професійних, світоглядних і громадянських якостей, моральноетичних цінностей, інших компетентностей, здобутих у закладі вищої освіти (науковій установі) у відповідній галузі знань за певною кваліфікацією на рівнях вищої освіти, що за складністю є вищими, ніж рівень повної загальної середньої освіти» [123, ст. 1, п. 1, пП. 5].

Власне, «науково-педагогічні працівники - це особи, які за основним місцем роботи у закладах вищої освіти провадять навчальну, методичну, наукову (науково-технічну, мистецьку) та організаційну діяльність» [123, ст. 53]. Тих, хто вступив до закладу вищої освіти і навчається в ньому, називають здобувачами вищої освіти або просто студентами.

Науково-педагогічні працівники зобов’язані: «1) забезпечувати викладання на високому науково-теоретичному і методичному рівні навчальних 
дисциплін відповідної освітньої програми за спеціальністю, провадити наукову діяльність (для науково-педагогічних працівників); 2) підвищувати професійний рівень, педагогічну майстерність, наукову кваліфікацію (для науковопедагогічних працівників); 3) дотримуватися норм педагогічної етики, моралі, поважати гідність осіб, які навчаються у закладах вищої освіти, прищеплювати їм любов до України, виховувати їх у дусі українського патріотизму і поваги до Конституції України та державних символів України; $3^{-1}$ ) дотримуватися в освітньому процесі та науковій (творчій) діяльності академічної доброчесності та забезпечувати їі дотримання здобувачами вищої освіти; 4) розвивати в осіб, які навчаються у закладах вищої освіти, самостійність, ініціативу, творчі здібності; 5) дотримуватися статуту закладу вищої освіти, законів, інших нормативно-правових актів» [123, ст. 58].

Отже, до основних видів професійної діяльності науково-педагогічного працівника закладу вищої освіти належать: 1) навчальна діяльність; 2) методична діяльність; 3) наукова (науково-технічна, мистецька) діяльність; 4) організаційна діяльність.

Зауважимо, що виховна діяльність не відноситься до основних видів професійної діяльності науково-педагогічного працівника, але вона $є$ органічною частиною освітнього процесу. Так, у статті 26 Закону України «Про вищу освіту» зафіксовано, що до основних завдань закладу вищої освіти також належить «формування особистості шляхом патріотичного, правового, екологічного виховання, утвердження в учасників освітнього процесу моральних цінностей, соціальної активності, громадянської позиції та відповідальності, здорового способу життя, вміння вільно мислити та самоорганізовуватися в сучасних умовах» [123, ст. 26. п 4]. Таке завдання може бути реалізованим лише через науково-педагогічних працівників.

У Законі України «Про вищу освіту» у загальному плані висунуті такі вимоги і завдання до професійної діяльності науково-педагогічного працівника:

- проводити «наукову, науково-технічну, інноваційну та/або методичну діяльність», забезпечувати «організацію освітнього процесу і здобуття особами 
вищої освіти, післядипломної освіти з урахуванням їхніх покликань, інтересів і здібностей» на певних рівнях вищої освіти [123, ст.1, п.1, пп.7];

- забезпечити формування у здобувачів вищої освіти на певних рівнях вищої освіти певної сукупності загальних і фахових компетентностей, кожна 3 яких являє собою динамічну комбінацію «знань, вмінь і практичних навичок, способів мислення, професійних, світоглядних i громадянських якостей, морально-етичних цінностей <..>» [123, ст.1, п.1, пп.13];

- зорієнтувати свою професійну діяльність на отримання здобувачами вищої освіти визначених результатів навчання, якими $\epsilon$ «знання, уміння, навички, способи мислення, погляди, цінності, інші особисті якості, які можна ідентифікувати, спланувати, оцінити i виміряти та які особа здатна продемонструвати після завершення освітньої програми або окремих освітніх компонентів» [123, ст.1, п.1, пп. 19].

Зауважимо, що в цілому професійна діяльність науково-педагогічного працівника спрямована не лише на передання здобувачам вищої освіти знань, умінь і навичок, формування у них загальних і фахових компетентностей, а й на створення умов для їхньої соціалізації, адаптації, гармонійного розвитку, на формування готовності до безперервного навчання протягом життя, самостійного пошуку новітніх знань, а також професійних, моральних i громадянських якостей тощо.

Виходячи з вищевикладеного, видно, в яких аспектах у професійному плані має бути підготовлений науково-педагогічний працівник, щоб якісно виконувати свою професійну діяльність. Власне ці аспекти професійної діяльності науково-педагогічних працівників і підготовка до неї розкриті у великій кількості публікацій, серед яких праці А. Алексюка, Б.Г. Ананьєва, Ю. Бабанського, О. Барабанщикова, С. Змеєва, О. Зубова, I. Ісаєва, I. Кобиляцького, В. Ковальчука, Н. Кузьміної, А. Кузьмінського, Л. Макарової, Н. Нікітіної, Е. Петрова, І. Подласого, Л. Подоляк, П. Самойленка, В. Сластьоніна, І. Соколової, Ю. Фокіна та ін.

3 аналізу цих праць слідує, що професійна діяльність науково- 
педагогічних працівників розглядається як:

- системне планування, організація, виконання та оцінювання навчального процесу у відповідності з поставленими цілями, а також підвищення його ефективності на основі доцільного використання людських і технологічних ресурсів [124];

- «безперервне керівництво діяльністю тих, хто навчається, котре забезпечує розвиток головних сфер їх особистості» [125, с. 19];

- складно-організована система сукупності різних видів діяльності;

- система «науково обгрунтованих дій активних елементів (учасників) процесу навчання, реалізація котрих з високим ступенем гарантії забезпечує досягнення поставлених цілей навчання» [126, с. 42];

- системно-діяльнісний спосіб організації навчання, котрий полягає в упорядкуванні множини дій та операцій щодо постановки педагогічних цілей і завдань, визначення змістових, організаційних, інформаційно-предметних, методичних і процесуальних аспектів засвоєння знань, формування різного виду вмінь та особистісних якостей [127, с. 27];

- процес формуванням у здобувачів вищої освіти вмінь майбутньої фахової діяльності та умов для їх всебічного гармонійного розвитку, в тому числі й фахового [128];

- спрямований процес проектування, формування, організації та управління навчальною діяльністю того, хто навчається [129, с. 53];

- процес, що охоплює такі ланки: 1) усвідомлення потреби; 2) формування мотивації; 3) вибір способу здійснення діяльності; 4) планування діяльності 3 визначенням конкретних дій; 5) їх виконання [130];

- система, котра розвивається за синергетичними закономірностями, що, як міркує В. Ковальчук, «<..> разом із системою діалектичних законів, принципів та категорій є методологічним інструментом пояснення головних характеристик, окремих рис, атрибутів освітянського процесу як цілого, до якого педагогічна теорія та практика входять невід'ємною складовою частиною» [131, c. 147]; 
- реалізація гносеологічного, або науково-дослідницького, конструктивного, прогностичного, організаторського і комунікативного компонентів [132];

- «процес, у якому опосередковується й контролюється інформаційний обмін, відтворюється і формується культура, відбувається становлення суспільної свідомості, здійснюється регуляція процесу розвитку економічної, духовної та соціальної сфер і загалом суспільства [133, с. 432];

Проте, аналіз свідчить, що у вищезгаданих працях поняття “якість професійної діяльності викладача”, “якість професійної діяльності науковопедагогічного працівника”, “якість педагогічної діяльності”, “якість викладання” та ін., навіть, не вживаються, але, безперечно, під тими вимогами, які висуваються до професійної діяльності викладача (науково-педагогічного працівника), розуміється потреба в ефективній, якісній діяльності.

Разом з цим у науці також йде мова про успішність діяльності, в тому числі й професійної педагогічної.

Вияснимо, як співідносяться поняття “успішність” і “якість”.

Поняття “успішність” є похідним від поняття “успіх” у Великому тлумачному словнику сучасної української мови, успіх тлумачиться як: «1. Позитивний досвід роботи, справи і т. ін.; значні досягнення, удача, талан. // <..> Досягнення в навчанні, у вивченні чого-небудь. 2. <..> Громадське визнання, схвалення чого-небудь, чиїхось досягнень. // Визнання кимось чиїх-небудь позитивних якостей, особливостей; захоплення з боку осіб іншої статі» [134, с. 1516].

Так, дослідник Г. Тульчинський педагогічну успішність тлумачить з таких позицій: 1) соціально-психологічної; 2) психологічної; 3) педагогічної. Так, із соціально-психологічної позиції успішність розуміється ним як оптимальне співвідношення між чеканнями людей, які оточують особистість, самої особистості викладача і результатами його діяльності. Адже будь-який суб'єкт педагогічної діяльності завжди оточений низкою експектацій (чекань) від його професійних дій, поведінки тощо. Щодо викладача формується ціла система різних експектацій з боку соціуму, в якому він знаходиться. В цей самий час 
викладач чекає певних успіхів, досягнень 3 боку студентів, у яких задовольняються (або не задовольняються) його експектації. У разі, коли чекання викладача збігаються або перевершують чекання людей, котрі його оточують, i їхня оцінка є значущою як для нього, так і ля колег і студентів, можна говорити про успішність педагога. 3 психологічної позиції вчений визнає успішність як переживання викладачем емоцій радості, натхнення, задоволення від отриманого результату, якого особистість прагнула у своїй діяльності, тобто такого, котрий щонайменше збігся з їі чеканнями (із рівнем домагань), або перевершив його. На основі цього формуються і стійкі почуття задоволення, і натхнення, і більш сильні мотиви педагогічної діяльності, а також змінюється рівень його самооцінки, самоповаги. 3 педагогічної позиції успішність професійної педагогічної діяльності визначається як певне цілеспрямоване поєднання психолого-педагогічних прийомів та умов, що сприяють усвідомленому включенню кожного суб'єкта в активну освітню діяльність у залежності від індивідуальних можливостей, та забезпечують студентам позитивний емоційний настрій на виконання навчальних завдань й адекватне сприйняття результатів своєї діяльності [135].

На думку В. Коновалової, «успішність професійної діяльності викладача є складним психолого-педагогічним утворенням на засадах стійких мотивів, системи професійних знань, професійно-педагогічних умінь і самооцінки, що забезпечує йому успіх, тобто досягнення поставленої мети і позитивних результатів діяльності, а також стабільний емоційний настрій від того, що результат, до якого викладач прагнув у своїй діяльності, або збігся 3 його чеканнями, або перевершив їх» [136, с. 27]. Проте, вона робить висновок, що успішність професійної діяльності викладача, будучи пов’язаною з усіма сферами його особистості, $є$ показником його професійного становлення [136, с. 27].

3 точки зору А. Бєлкіна, «успішність є цілеспрямованим, організованим сполученням умов, за яких створюється можливість досягти значних результатів 
у діяльності як окремо взятої особистості, так і колективу в цілому» [137, с. 31$].$ А успіх служить засобом досягнення успішності лише тоді, коли:

- представлений повним розмаїттям умов і способів для його створення;

- формується на всіх етапах взаємодії викладача і студента;

- реалізується викладачем з урахуванням можливостей та особливостей кожного студента у процесі організації пізнавальної діяльності;

- сприяє переведенню освітнього процесу із контексту загальної педагогічної взаємодії на рівень особистісної взаємодії з кожним студентом [137].

Далі дослідник розгортає думку щодо використання терміну “успішність”. Він пояснює, що оскільки міжособистісні відносини опосередковані діяльністю, їі цінностями, змістом та організацією, то, безсумнівно, саме успішна діяльність $\epsilon$ запорукою розвитку відносин більш високого порядку, тобто відносин співробітництва. На цьому підгрунті А. Бєлкін виділяє суб'єктивну й об'єктивну успішність професійної діяльності. У разі, коли особистість швидко і якісно виконала завдання і не доклала при цьому навіть мінімальних зусиль, то така діяльність є об'єктивною успішністю, оскільки високий результат діяльності констатовано лише стороннім спостерігачем. 3 таких позицій об'єктивна успішність діяльності не є успіхом у повному розумінні, оскільки якість виконаного не є результатом фізичного та психічного напруження суб'єкта діяльності. А коли власні досягнення суб'єкта діяльності є результатом його фізичного та психічного напруження, то це суб'єктивна успішність [137]. Тому, ведучи мову про професійну успішність, дослідник має на увазі лише суб'єктивну успішність.

Отже, виходячи з розуміння сутності й змісту понять “успішність" i “успіх”, доходимо висновку, що вони лише в окремих випадках відображають якість професійної діяльності науково-педагогічного працівника, а саме тоді, коли якість досягла високого рівня розвитку. В принципі, науково-педагогічний працівник може переживати успіх, коли він і мінімально підвищив рівень якості своєї професійної діяльності, приміром, з низького до нижчого за середній. Але 
це його суб’ єктивне досягнення успіху, оскільки насправді такий результат не є успіхом у контексті якісної підготовки фахівців.

Щодо якості, то у Великому тлумачному словнику сучасної української мови, це слово тлумачиться як: «<..> Ступінь вартості, цінності, придатності чого-небудь для його використання за призначенням. 3. Та чи інша характерна ознака, властивість, риса кого-, чого-небудь. 4. Сукупність характеристик продукції або послуг щодо їі здатності задовольнити встановлені та передбачені потреби. <..>» [134, с. 1423].

Проте аналіз літературних джерел свідчить, що вчені вживають поняття “якість освіти”, “якість вищої освіти”, але тлумачать їх по-різному. Так, у педагогічному словнику російських вчених Г. Коджаспірової та А. Коджаспірова під поняттям “якість освіти” розуміють: 1) набуття особою певного рівня знань і вмінь, розумовий, моральний і фізичний розвиток учнів чи студентів, на певному етапі, відповідно до визначеної мети; 2) ступінь задоволення потреб різних учасників освітнього процесу освітніми послугами, які надаються. Згідно 3 їхніми поглядами, якість освіти вимірюється іiі відповідністю освітнім стандартам, залежить від рівня престижності освіти в суспільній свідомості та системі державних пріоритетів, фінансування i матеріально-технічного стану освітніх закладів, а також сучасних технологій управління ними [цит. за 138].

Певна частина дослідників розглядає “якість освіти" як соціальну категорію, за допомогою котрої визначається і стан, і результативність процесу освіти в суспільстві, і іï відповідність потребам різних соціальних груп щодо розвитку та формування громадських, побутових i професійних компетентностей особистості. 3 цих позицій С. Шишов і В. Кальней “якість освіти” визначають як «ступінь задоволення потреб різних учасників освітнього процесу» [139].

Російський вчений М. Поташник пропонує визначати якість освіти за критерієм співвідношення результату і мети [140, с. 33]. А дослідник Б. Жебровський вказує на те, що якість освіти слід розглядати у процесуальному 
та результативному контексті. Власне у процесуальному контексті “якість освіти” постає як задоволення потреби особистості та їі відповідність інтересам суспільства і держави, а в результативному (як результат діяльності навчального закладу) - як відповідність рівня підготовки учнів, згідно з вимогам діючих освітніх програм. У цьому випадку, на думку автора, в якості освіти відображаються всі напрями та аспекти діяльності навчального закладу, тобто і результати навчально-виховної діяльності, і рівень професійної підготовки педагогічного колективу, і здатність адміністрації створити відповідні умови для функціонування та розвитку навчального закладу [141].

Згідно з поглядами О. Запесоцького, для забезпечення та підвищення якості освітньої діяльності в закладі вищої освіти необхідні певні умови, а саме: 1) організаційні; 2) технологічні; 3) змістові; 4) особистісні; 5) світоглядні [142].

Власне організаційні умови являють собою підгрунтя оптимізації організаційної моделі закладу вищої освіти, пріоритетним завдання якого $є$ забезпечення в ньому стабільності, гнучкості та рівноваги задля самозбереження, автономності й саморозвитку. На думку дослідника, провідна роль в оптимізації організаційної моделі закладу вищої освіти належить доцільній системі менеджменту, котра охоплює ефективні методи планування, обліку, діагностики, контролю та врегулювання. Вдосконалення чинників умов цієї групи забезпечує відмову від процедур, які є непотрібними та другорядними, а також виключення дублювання споріднених функцій, зменшення обігу кількості документів і вдосконалення інформаційних зв’язків між підрозділами закладу вищої освіти. Мова йде про створення системи менеджменту, що базується на чітких критеріях якості всіх етапів і ланок управлінського процесу [142].

Зауважимо, що обстоюючи такі позиції, О. Запесоцький надає цій групі статусу провідної щодо вимог Болонської декларації стосовно створення в закладі вищої освіти внутрішньої системи якості (цілеспрямованої організаційної діяльності закладу вищої освіти щодо забезпечення якості освіти), котра, своєю чергою, дає потрібний результат - високий фаховий рівень підготовки випускника. 
Технологічні умови в контексті забезпечення високої якості освіти, на думку вченого, полягають у повному інноваційному технологічному оснащенні закладу вищої освіти сучасними технічними та інформаційними засобами.

Змістові умови забезпечують оптимізацію змісту освіти, що визначається освітнім стандартом, і являє собою сукупність знань, умінь, загальних і фахових компетентностей, котрими має оволодіти здобувач вищої освіти за час навчання у закладі вищої освіти. Слід зауважити, що з приводу змісту освіти постійно ведуться дебати щодо з'ясування співвідношеня різних її складових - загальних, фахових, фундаментальних, гуманітарних, соціальних та ін. компонентів.

Світоглядні умови забезпечують контекст реалізації цілеспрямованої політики, мета якої полягає у створенні “корпоративної ціннісної єдності”, тобто усвідомлення всіма працівниками світоглядного підгрунтя діяльності закладу вищої освіти як соціального інституту (розуміння сутності й змісту освіти, іiі місії, мети й пріоритетів). Для вітчизняних закладів вищої освіти така політика $\epsilon$ дещо незвичною. Однак, у системі управління якістю освіти, приміром, в американських закладах вищої освіти часто зустрічається поняття «policy», котре відображає власну траєкторію руху, розвитку цього навчального закладу.

Особистісні умови визначають певнну сукупність характеристик викладача, які обумовлюють ефективність його професійної освітньої діяльності. До таких особистісних характеристик викладача О. Запесоцький відносить: відповідальність та сумління; креативність; знання та володіння сукупністю інноваційних методів активізації пізнавальної діяльності студентів; системне бачення освітньої та професійної реальності; здатність до рефлексії та комунікативної культури; здатність до організації групового співтовариства (як діалогічного, так і полілогічного характеру) для досягнення мети освіти; вміння налагоджувати «зворотний зв’язок» та долати комунікативні бар'єри та ін. Разом 3 цим забезпечення якості освітнього процесу має також передбачати систематичну оцінку його ефективності у площині реалізації головних стратегій розвитку особистості студента: 1) духовного розвитку в єдності з цінніснонормативною, когнітивною i технологічною сторонами; 2) соціального i 
фізичного розвитку особистості. А для виявлення й оцінки успішності розвитку особистості студента за вказаними напрямами вимагається розвиток бази критеріїв, яка дозволятиме оцінювати ефективність всесторонньої діяльності закладу вищої освіти та його підрозділів. Такими головними критеріями є:

- знання (філософські, етичні, естетичні, правові, політичні, педагогічні тощо); індикаторами наявності чи відсутності цих знань є традиційні форми поточного, семестрового і підсумкового контролю;

- рівень розвитку потреб у спілкуванні, свободі, повазі до людей, взаєморозумінні, пізнанні, самореалізації, самоповазі, самопізнанні (рефлексії), розумінні сенсу буття тощо;

- наявність ціннісних орієнтацій (загальносвітоглядних, духовних, соціальних, етичних, правових, художньо-естетичних тощо);

- дотримання чи недотримання студентами норм поведінки в суспільсті та ін. [142].

На думку Є. Владімірської, «якість вищої освіти має визначатися в координатах освітньої діяльності та розглядатися системно. Тому якість вищої освіти - це, передусім, інтегративна властивість, утворена в результаті діяльності системи вищої освіти взагалі, якщо йдеться про національний рівень, або ж, як інтегративна властивість, утворена в результаті діяльності університету (у випадку якогось, цілком конкретного університету)» [143].

Якщо спиратися на міжнародні позиції, то, наприклад, ЮНЕСКО у “Доповіді про стан системи освіти у світі”, виголошеній у 2004 році, в поняття “якість освіти” вкладає кілька змістових значень, визначаючи його як: 1) доступ до здобуття формальної освіти і термін навчання; 2) доступ до здобуття вищої освіти; 3) рівність можливостей громадян реалізувати прав на освіту; 4) ресурсне забезпечення (тобто частка ВВП, котра виділяється на задоволення потреб освіти, у тому числі і з розрахунку на одного студента, і з розрахунку на заробітну плату викладачів тощо); 5) можливість вибору траєкторії освіти; 6) наявність стандартів навчання та освіти [144]. 
Однак, з вищевикладеного розуміємо, що якість професійної діяльності науково-педагогічного працівника у прямій постановці не розглядається. Згадуються хіба що власна відповідальність викладача, його сумління, необхідність бути професіоналом, володіти певними якостями, виконувати всі вимоги, що висуваються до професійної діяльності, та ін.

Дійсно, до науково-педагогічного працівника сучасного закладу вищої освіти висувається значна кількість вимог, які вважаються тими чинниками, котрі, за умови їх успішного виконання, забезпечують якість їх професійної діяльності. До таких вимог належать:

- необхідність володіння науково-педагогічним працівником значною сукупністю загальних і фахових знань, вмінь, компетентностей;

- здатність до постійного пошуку нових зннь, і вміння їхнього впровадження в освітній процес підготовки здобувачів вищої освіти;

- особиста відповідальність науково-педагогічного працівника за ефективність своєї професійної діяльності та досягнуті результати в підготовці фахівців;

- креативність у професійній діяльності;

- володіння сучасними педагогічними та інформаційними технологіями, комп'ютерними програмами;

- знання, володіння та вміння застосовувати інноваційні методи активізації освітнього процесу;

- системне бачення освітньої та професійної реальності в контексті постійного стрімкого розвитку науки, техніки і технологій, способів виробництва та ін.;

- здатність до рефлексії явищ і процесів, які мають місце в освітньому просторі;

- здатність до ефективного управління освітнім процесом здобувачів вищої освіти;

- наявність високої комунікативної культури, у тому числі й вмінь долати комунікативні бар'єри; 
- наявність високих організаторських здібностей;

- здатність здійснювати інтелектуальний, фаховий, моральний, психологічний, громадянький і патріотичний розвиток особистості здобувача вищої освіти;

- вміння взаємодіяти зі здобувачами вищої освіти, налагоджувати співпрацю для досягнення ними високих результатів навчання і саморозвитку;

- здатність до налагодження “зворотного зв’язку” з усіма суб’єктами освітнього процесу та ін.

Загалом на сьогоднішній день соціальні вимоги до вищої освіти в Україні визначаються відповідним стандартом вищої освіти. Але значна кількість публікацій указує на невідповідність наших закладів вищої освіти європейським вимогам якості. Тому не дивно, що здобуття вищої освіти в закладах вищої освіти України непривабливе для іноземців, не зважаючи на ії низьку вартість у порівнянні з вартістю вищої освіти в Європі та США.

Виникає питання: чому якість надання освітніх послуг у закладах вищої освіти України є нижчою, ніж в Свропі та США?

Безумовно, на це впливає ціла низка об'єктивних (нестача фінансування, застаріла матеріально-технічна база, у тому числі й для проведення науководослідної роботи, і под.) і суб’єктивних (насамперед, попередній рівень підготовки здобувачів вищої освіти, їх світогляд, мотивація тощо, неефективна професійна підготовка науково-педагогічних працівників, яка не відповідає сучасним реаліям розвитку науки, техніки і технологій, потребам і викликам сучасного інформаційного суспільства, а також неякісна їх професійна діяльність та ін.) чинників.

Але дарма деякі дослідники вказують на те, що в Україні не звертають увагу на якість надання освітніх послуг. Звертають! I запроваджують заходи щодо підвищення рівня їх якості. Так, у Законі України "Про вищу освіту" визначаються: 1) якість вищої освіти як «відповідність результатів навчання вимогам, встановленим законодавством, відповідним стандартом вищої освіти та/або договором про надання освітніх послуг [123, ст.1, п. 1, пп. 23]; 2) якість 
освітньої діяльності як «рівень організації освітнього процесу у закладі вищої освіти, що відповідає стандартам вищої освіти, забезпечує здобуття особами якісної вищої освіти та сприяє створенню нових знань» [123, ст. 1, п. 1, пп. 24].

Однак, у Законі України “Про вищу освіту” поза увагою залишилася якість професійної діяльності самого науково-педагогічного працівника, без якої неможливі ні якість вищої освіти, ні якість надання освітніх послуг.

У закладах вищої освіти на цей час розроблені десятки документів, у яких визначені та окреслені внутрішні стандарти забезпечення якості освітньої діяльності та вищої освіти. Фактично, ці документи охоплюють усі аспекти діяльності закладу вищої освіти - від правил прийому на навчання до випуску і працевлаштування випускників. Наочним прикладом є "Внутрішні стандарти забезпечення якості освітньої діяльності та вищої освіти”, частина I в Національному університеті “Львівська політехніка” [145], в котрому прослідковується дуже серйозно ставляться до якості надання освітніх послуг. Однак, і у них, на нашу думку, критерії та методика оцінки якості професійної діяльності науково-педагогічного працівника $є$ недосконалою.

Проаналізуємо, як у закладах вищої освіти України визначається й оцінюється якість професійної діяльності науково-педагогічного працівника.

Як правило, у закладах вищої освіти України якість професійної діяльності окремого науково-педагогічного працівника визначають рідше на основі успішності здобувачів вищої освіти (що вищий середній бал студентської групи і якість навчання здобувачів вищої освіти, яка обчислюється у відсотках як відношення суми оцінок “добре” і “відмінно” до загальної кількості оцінок у групі), а частіше у вигляді щорічного рейтингу на основі виданої кількості наукових праць, особливо у наукових базах Scopus i Web of Science, підручників, навчальних посібників та ін., затрати часу на навчальну, методичну, наукову та організаційну роботу (до якої, до слова, входить і виховна робота), підготовка електронних дидактичних матеріалів до курсу, розроблення і сертифікація навчально-методичного комплексу з навчальної дисципліни та розміщення його у віртуальному навчальному середовищі, розробка та викладання англомовного 
курсу в закладі вищої освіти, читання лекцій в іноземних закладах вищої освіти, участь у роботі навчально-методичних семінарів/тренінгів в Україні та за кордоном, керівництво та участь у міжнародних проєктах, керівництво держбюджетною науковою темою, керівництво захищеною дисертацією, рецензування різних наукових праць та багатьох інших параметрів.

У цьому контексті слід зауважити, що це повністю не відображає реальну якість професійної діяльності науково-педагогічного працівника в контексті професійної підготовки здобувачів вищої освіти, оскільки здобувачі вищої освіти в групі могли мати різну успішність у середній школі (коледжі, гімназії та ін.), бути більш чи менш підготовленими, здібними чи не здібними тощо, а велика кількість праць різного характеру, видана ними, підготовка різнобічних дидактичних матеріалів та ін. не завжди прямопропорційно впливає на підвищення рівня якості освітнього процесу в закладі вищої освіти.

Разом $з$ цим, в Україні, за мовчазною згодою, також вважається, що високий рівень педагогічної майстерності науково-педагогічного працівника (чи його висока педагогічна культура, чи високий рівень професійно-педагогічної компетентності, чи високий рівень педагогічного професіоналізму та ін.) уже автоматично забезпечує високу якість його професійної діяльності. Мабуть тому, не вживаючи самого слова “якість”, вчені розкривають її опосередковано. Так, у багатьох працях вона розкривається через наявність у науково-педагогічного працівника високої педагогічної культури, чи високого рівня педагогічної майстерності, професійної педагогічної компетентності, загалом професіоналізму та ін.

Але слід зауважити, що ні детальні знання всіх аспектів професійної діяльності у закладах вищої освіти, ні високий професіоналізм науковопедагогічних працівників (далі ми будемо вести мову лише про науковопедагогічних працівників, оскільки зміст їхньої діяльності відрізняється від професійної діяльності педагогічних і наукових працівників у закладах вищої освіти, згідно зі Законом України “Про вищу освіту" [123, ст. 53, 58]) ще не забезпечує якості його освітньої діяльності та вищої освіти. 
Результати наших досліджень свідчать, що науково-педагогічний працівник може мати необхідну сукупність педагогічних умінь, достатньо сформовані загальні й фахові компетенції, може володіти різними здібностями, навіть мати високі особистісні якості, видавати наукові праці, підручники, навчальні посібники та ін., але внаслідок різних причин не застосовувати їх під час виконання завдань освітнього процесу. Іншими словами, якість його професійної діяльності може бути як високою, так і знаходитися на вищому за середній, середньому, нищому за середній чи низькому рівнях.

Таким чином, на основі вивчення праць з проблеми якості професійної діяльності науково-педагогічних працівників, нами встановлено, що вона не тотожна ні поняттю “педагогічна майстерність”, ні поняттю “педагогічна культура", ні поняттю “педагогічна компетентність”, ні поняттю “педагогічні здібності”.

Здійснюючи свою професійну діяльність, науково-педагогічний працівник в освітньому процесі має ефективно виконувати різні функції та багаточисельні завдання, які вимагають відповідних загальних і фахових знань, навичок, вмінь, компетентностей, здібностей, особистісних якостей тощо. Тому, щоб забезпечити якість професійної діяльності науково-педагогічного працівника в цілому, необхідно розв’язати комплекс психолого-педагогічних проблем.

Аналіз літературних джерел свідчить, що першою проблемою, яка суттєво впливає на якість професійної діяльності науково-педагогічного працівника, $є$ проблема постійного підтримування в нього високого рівня базових знань $і$ вмінь, а також загальних і фахових компетентностей, необхідних для забезпечення всіх видів діяльності у закладі вищої освіти та надання якісних освітніх послуг.

Значення й роль базових знань $\mathrm{i}$ вмінь достатньо висвітлено у багаточисельних публікаціях, серед яких праці О. Антонової, Ю. Бабанського, В. Бондара, А. Петровського, О. Щербакова, О. Роботової, М. Кухарєва, О. Пашковської, С. Самигіна, В. Попкова і О. Коржуєва, Ю. Реп’єва, О. Гури та ін. У науково-педагогічного працівника на основі знань і вмінь формуються 
загальні та фахові компетентності, тому часто ведуть мову про компетентнісний підхід до його професійної підготовки. Різні аспекти цього підходу висвітлені у працях Т. Браже, Ю. Варданян, Б. Гершунского, С. Огарьова, В. Онушкіна, Н. Острікової, С. Пеняєвої, А. Прокоф’євої, О. Спіріна, В. Стенькова, М. Степка, В. Шадрикова та ін.

Так, за М. Степком, сутність компетентнісного підходу полягає у зміщенні акцентів 3 накопичення нормативно визначених знань, умінь і навичок до формування та розвитку в студентів здатності практично діяти, застосовувати індивідуальні техніки й досвід успішних дій в ситуаціях професійної діяльності та соціальної практики. Таким чином забезпечується висока готовність випускників до успішної діяльності в різних галузях [146, с. 59].

Компетентність, як готовність та здатність фахівця доцільно використовувати теоретичні знання й наявний досвід для розв’язання відповідних завдань, пояснює Ю. Варданян [147] та ін.

Дослідник В. Онушкін розглядає компетентність як здатність діяти “"зі знанням справи”, під якою розуміється відповідність їхнього розуміння справи, знань та вмінь реальному змісту, складності завдань, які вони виконують, і проблем, котрі розв’язують [148, с. 105].

Неординарними є погляди М. Чошанова, який виводить формулу компетентності у такому вигляді: компетентність - це мобільність знань + гнучкість методу + критичність мислення [149, с. 9].

Щодо фахової компетентності, котра забезпечує продуктивну діяльність особистості, то Т. Браже підкреслює, що вона визначається не лише фаховими науковими знаннями, а й ціннісними орієнтаціями, мотивами іï діяльності, розумінням навколишнього світу і свого місця в нім, ставленням до людей, 3 якими вона працює, іiі загальною культурою, здатністю до розвитку свого творчого потенціалу [150].

Фахову компетентність учителів i викладачів більшість науковців досліджують на підгрунті педагогічної компетентності, включаючи до неї креативність, уміння орієнтуватися в науково-педагогічній проблематиці, 
нестандартне мислення, організаційні, комунікативні та ін. здібності, толерантність, тактовність тощо. Своєю чергою, тлумачення науковцями педагогічної компетентності еволюціонує від простого іiі визначення, як сукупності рис особистості, котра має високий рівень психолого-педагогічної підготовки, що разом забезпечує високий рівень професійної педагогічної діяльності, до виявлення їі складної інтегрованої природи, котра гармонійно поєднує досконале знання предмета, певний світогляд, методику викладання, особистісні якості педагога, вміння і навички (культуру) педагогічного спілкування, організаційні здібності та інші компоненти, котрі дозволяють педагогу ефективно здійснювати інтелектуальний та діяльнісний розвиток i саморозвиток особистості.

Напочатку XXI ст. зроблена спроба прийти до одного визначення компетентності - науковці та експерти в освітній сфері на міжнародному рівні у 2004 році запропонували використовувати два їі визначення. Перше визначення компетентності тлумачиться, як здатність ефективно i творчо застосовувати знання та вміння в міжособистісних стосунках - в ситуаціях, які передбачають взаємодію з іншими людьми і в соціальному контексті, і в професійних контактах [151].

Друге визначення компетентності, за поданням Міжнародного департаменту стандартів для системи освіти, професійної реалізації й розвитку особистості, розкривається через “спроможність кваліфіковано проводити діяльність, виконувати завдання або діяльність на підставі набутого набору знань, навичок і ставлень, що дає змогу особистості ефективно діяти або виконувати певні функції, котрі спрямовані на досягнення стандартів у професійній галузі або певній діяльності” [152].

Проте часто плутають поняття “компетенція” i “компетентність”. Ми не будемо вияснювати позиції дослідників щодо цих понять, оскільки вони окреслені досить широко у низці публікацій, серед яких праці Г. Вялікової, I. Зімньої, Г. Коджаспірової, О. Спіріна, I. Чемериса, В. Шадрикова, С. Шишова та ін. 
Приміром, Г. В'ялікова указує на те, що відмінність між поняттями “компетенція” і “компетентність” полягає в тому, що «остання 3 цих дефініцій носить суб'єктивований характер, тобто компетентний фахівець - це суб'єкт, який володіє визначеними компетенціями (знаннями, вміннями, досвідом), що дозволяє йому продуктивно здійснювати професійну діяльність у будь-якій сфері» $[153$, с. 16]. А дослідники С. Шишов і В. Кальней відмінність між даними поняттями вбачають у тому, що «бути компетентним не означає бути вченим чи освіченим. Бути компетентним означає вміти мобілізувати в конкретній ситуації отримані знання та досвід, виявити ставлення до цієї ситуації через конкретну діяльність» [139, с. 83].

На думку В. Шадрикова, коли мова йде про компетентність, то акцентують увагу на тому, якими мають бути набуті знання, навички і досвід особистості, щоб вона могла вирішувати різні ділові та життєві ситуації, працювати в групі тощо. А компетенція, навпаки, пов'язується з кількістю різноманітних груп знань і навичок, які взаємопов'язані між собою [154, с. 28].

За I. Зимньою, компетентність є завжди актуальним проявом компетенції. Оскільки компетенція відбиває когнітивний та операційно-технологічний аспекти діяльності особистості, то компетентність, крім перелічених, набуває ще й мотиваційних, гуманістично-ціннісних та дієвих ознак $[155$, с. 6$]$.

У європейському освітньому просторі заявлено про три групи компетентностей, котрими повинен володіти сучасний фахівець: ключові, загальні та специфічні для конкретних напрямів професійної діяльності. В Україні та країнах ближнього зарубіжжя в педагогіці до цього часу не вироблений єдиний погляд на ієрархію компетентностей. Приміром, А. Хуторськой, виділяе ключові компетентності, котрі належать до загальної освіти; загальнопредметні компетентності, які відображають загальні предметні знання й досвід в одному з напрямів діяльності; предметні компетентності, які відображають специфічні аспекти в обраній сфері діяльності [156, с. 63]. Також на три групи поділяе всі компетентності фахівця В. Шадріков. До першої групи належать соціально-особистісні компетентності, до другої - загальнопрофесійні 
компетентності, які служать основою гнучкого орієнтування фахівця на ринку праці, до третьої - спеціальні, котрі забезпечують конкретизацію загальнопрофесійних компетентностей [154, с. 31].

Так, ключові компетентності - це такі, якими повинна володіти будь-яка особистість незалежно від сфери діяльності. Наприклад, до ключових компетентностей В. Хутмахером віднесено політичні й соціальні компетентності; компетентності, котрі пов’язані з життям у багатокультурному суспільстві (полікультурна компетентність); компетентності володіння усним i писемним спілкуванням; компетентності, що пов'язані 3 розвитком інформаційного суспільства; здатність (компетентність) учитися протягом всього життя [157, p. 11]. До цього переліку низка освітніх європейський організацій додатково вводить такі компетентності як підприємливість, загальна обізнаність у сфері науки й техніки, культурне самовираження [146, с. 44].

На думку деяких науковців, у тому числі й Байденка [158], ключові компетентності мають забезпечити особистості участь у багатьох соціальних сферах, покращити якості суспільства та сприяти особистому успіху.

Отже, наявність ключових компетентностей, фактично, має забезпечити особистості ефективну соціалізацію в суспільстві та стати підгрунтям їі професійної реалізації.

У європейському просторі в освітньому проекті “Tuning Educational Structures in Europe", загальні компетентності представлені як взаємопов’язаний блок компетенцій, який охоплює: 1) інструментальні компетенції - це базові загальні й професійні знання; здатність особистості аналізувати й синтезувати, організовувати й планувати; комунікативні вміння; комп'ютерні навички; навички управління інформацією; здатність розв'язувати проблеми та ухвалювати рішення; 2) міжособистісні, що відображають індивідуальні здібності людини, які пов'язані 3 умінням виражати почуття, критичним мисленням і здатністю до самокритики, а також навички соціальної взаємодії, співробітництва, здатності до роботи в групі; можливість брати соціальні та етичні зобов’язання; 3) системні, котрі поєднують різні інструментальні й 
міжособистісні компетенції у відповідні системи, що дозволяє особистості самовдосконалюватися й ефективно здійснювати професійну та соціальну діяльність [159].

Важливою психолого-педагогічною проблемою забезпечення якості професійної діяльності науково-педагогічного працівника с формування розвиток у нього сукупності необхідих особистісних якостей. Зауважимо, що в науковій літературі використовують поняття: “професійні якості”, “професійно значущі якості”, “професійно важливі якості”, “професійно-психологічні якості” та “особистісні якості”. Фактично, ці поняття є синонімічними з огляду на те, що у працях різних авторів вони вживаються переважно в одному значенні, хоча кожний науково-педагогічний працівник, як особистість, є неповторним.

Ми використаємо поняття “особистісні якості”, маючи на увазі, що вони інтегрують особистісні риси і властивості, що найбільш притаманні науковопедагогічним працівникам. Так, наприклад, Г. Мешко, до важливих якостей викладачів відносить педагогічне покликання, інтерес до професії, педагогічні нахили, педагогічний обов'язок і відповідальність, професіоналізм, педагогічну культуру, професійно-педагогічну компетентність, педагогічну майстерність, професійно-педагогічний потенціал, педагогічні здібності, педагогічну техніку, педагогічну творчість [160].

За іншими критеріями особистісні якості К. Гнєзділова поділяє на загальні (свідомість), моральні (відображення соціальної характеристики особистості), інтелектуальні (розумові), вольові та емоційні (саморегуляція особистості). Однією з важливих загальних якостей є суспільна спрямованість, компонентами якої є суспільно цінна мета, соціально значущі мотиви поведінки та діяльності, наявність переконань, ціннісні орієнтації тощо. Так, до моральних якостей належать гуманізм, працелюбство, принциповість, чесність, відповідальність, порядність тощо; до інтелектуальних - логічність, усвідомленість діяльності, розсудливість, об’єктивність тощо; до вольових - самостійність, дисциплінованість, незалежність, активність тощо [161, с. 151].

Загалом, до особистісних якостей І. Підласий відносить: людяність, чесність, 
порядність, відповідальність, справедливість, обов'язковість, об'єктивність, високу моральність, доброту, оптимізм, емоційну врівноваженість, доброзичливість, самокритичність, скромність, дружелюбність, принциповість та ін. [162, с. 243].

У Західній Європі до професійно важливих якостей учителів відносять, приміром, комунікабельність, високий рівень самоконтролю, впевненість у собі, готовність до співробітництва, емоційну врівноваженість та ін. [163, p. 5].

Важливою психолого-педагогічною проблемою забезпечення якості професійної діяльності науково-педагогічного працівника є розвиток у нього сукупності здібностей, які сприяють ефективній професійні діяльності.

Багатьма дослідниками, у тому числі Б. Ананьєвим, О. Леонтьєвим, К. Платоновим， Б. Тепловим， Л. Рубінштейном， В. Шадриковим，У. Торндайком, Ч. Спірменом, В. Штерном та ін., доведено, що на результативність (якість зауваж. автора) професійної діяльності науково-педагогічного працівника впливають його педагогічні здібності.

Переважно, вчені розуміють здібності як індивідуально-психологічні властивості особистості, котрі відрізняють ії від інших і сприяють швидкому та ефективному формуванню професійної компетентності. Проте, здібності особистості виявляються, за В. Шадриковим [164], як іiі функціональна характеристика.

Разом 3 цим, як стверджують В. Крутецький і С. Рубінштейн, кожна здібність завжди проявляється як деякі операції або способи дій, за допомогою котрих виконується діяльність. Не зважаючи на те, що здібності актуалізуються в процесі оволодіння особистістю відповідними операціями, їх суб' єктивною основою, тобто ядром, $є$ перебіг психічних явищ, які забезпечують регулювання цих операцій, їх цілісність та якість діяльності [165, с. 49].

В науці здібності класифікують по-різному. Так, Б. Теплов їх класифікує, беручи за основу головні види діяльності [166]. На цій підставі він поділяє здібності на загальні (за загальних умов діяльності) та спеціальні (за специфічних умов окремих видів діяльності), котрі, своєю чергою, надалі поділяє на компоненти. 
Дослідник В. Шадриков [167] на основі традиційного розподілу психічних процесів усі здібності класифікує як здібності відчуття (сенсорні процеси), здібності сприйняття (перцептивні процеси), здібності пам'яті (мнемічні процеси), здібності уявлення, здібності уяви (імажинітивні процеси), здібності мислення (мисленнєві процеси), здібності уваги (атенційні процеси), психомоторні здібності.

Однак, на думку І. Підласого, «низка фахівців схильні до висновку, що відсутність яскраво виражених здібностей може бути компенсована розвитком інших важливих професійних якостей - працелюбністю, чесністю і серйозним ставленням до своїх обов'язків, постійною роботою над собою. Педагогічні здібності (талант, покликання, задатки) ми повинні визнати важливою передумовою успішного оволодіння педагогічною професією, але аж ніяк не вирішальною професійною якістю» [168, с. 242].

Приміром, серед педагогічних здібностей Ф. Гоноболін виділяє дидактичні, перцептивні, експресивні, особистісні та ін. [цит. за 169, с. 108]. А дослідник В. Дружинін класифікує здібності як комунікативні, регулятивні та пізнавальні, відповідно від комунікативної, регулятивної та пізнавальної функцій психіки (за Б. Ломовим) [170, с. 14].

Всі здібності, в принципі, є похідними від знань, умінь і навичок, а також особистісних якостей. Проте, на нашу думку, організаційні та комунікативні здібності є провідними у професійній діяльності науково-педагогічного працівника, оскільки в ній організаційна діяльність і взаємодія зі здобувачами вищої освіти становлять іï основу.

Оскільки в основі розвитку здібностей особистості, як стверджують О. Леонтьєв, С. Рубінштейн, С. Смірнов і Б. Теплов, лежать знання, вміння і навички, то, власне, їх наявність у науково-педагогічного працівника водночас свідчить і про наявність у нього відповідних здібностей.

Проте, як свідчить практика, науково-педагогічний працівник може мати високий рівень педагогічних знань, умінь, здібностей, необхідні для професійної діяльності властивості та якості, але, в силу об'єктивних і суб’єктивних причин, не використовувати їх в науково-педагогічній діяльності. 
У цьому випадку найчастіше виявляється, що в таких науковопедагогічних працівників відсутня мотивація до якісної професійної діяльності. Тому наступною важливою психолого-педагогічною проблемою якісноӥ професійної діяльності науково-педагогічного працівника с формування підтримання у нього відповідної позитивної мотивації (мотивацї до досягнення успіху).

Дослідник С. Занюк [171] мотивацію поведінки та діяльності розуміє як сукупність рушійних сил, що спонукають людину до здійснення певних дій. Ці сили змушують їі усвідомлено чи неусвідомлено здійснювати відповідні вчинки.

Дослідник Б. Додонов [172] визначає мотив, як психологічний фактор людської діяльності, котрий виникає на основі почуттів та думок людини і збуджує її до тієї чи іншої діяльності, скерованої на задоволення її потреб. Таким чином, мотив - це спонукання до діяльності, пов’язане із задоволенням потреб суб’єкта.

Згідно з поглядами Б. Ломова, поведінка людини має складну структуру потреб зі своєрідними їх взаємозв'язками, у рамках єдиного вектору “мотивціль”. Власне цілі виступають силою, яка спонукає прикладати відповідні зусилля для їх досягнення, при цьому, що конкретнішою $є$ загальна ціль, проміжні етапи іiі досягнення, тим чіткіше визначені засоби досягнення цілі, тим більшою $є$ сила спонукаючого впливу та ймовірність реалізації цілі. Це підтверджує О. Леонтьєв, указуючи на те, що людина під впливом певного мотиву розпочинає виконувати дії, а потім - заради них самих, в силу того, що мотив змінився на мету.

Дослідник П. Якобсон веде мову про “мотивацію” у більш вузькому та у більш широкому значенні. У першому випадку це - «мотивація конкретних форм поведінки людини, а в другому - сукупність тих психологічних моментів, якими визначається поведінка людини в цілому» [цит. за 173, с.214].

Вивчаючи проблеми людини, А. Маслоу дійшов висновків, а саме, що: 1) потреби задовольняються у певному порядку, при чому, якщо існують дві однаково сильні потреби, то домінує потреба нижчого рівня; 2) з розвитком 
людини як особистості ії потенціал постійно розширюється, тому потреба в самореалізації ніколи не буде повністю задоволена, звідси, процес мотивації поведінки через потреби нескінченний; 3) будь-яка поведінка виявляє тенденцію до детермінації кількома або навіть усіма базовими потребами одночасно, а не однією; залучення якомога більшого числа потреб (актуалізація більшого числа спонукальних факторів) підвищує загальний рівень мотивації діяльності [174].

Важливою психолого-педагогічною проблемою якісної професійної діяльності науково-педагогічного працівника с його здатність ефективно реалізувати широке кола функцій, при цьому, залежно від стану освітнього процесу, рівня пізнавальної активності здобувачів вищої освіти, їх мотивації, виділяти серед них найголовніші, ті, від яких залежить якість результатів навчання здобувачів вищої освіти.

Щодо сутності й доцільності використання науково-педагогічним працівником тих чи інших функцій в освітньому процесі, то погляди дослідників А. Барабанщикова, 3. Ссарєва, І. Ісаєва, А. Маркової, Г. Матушанського, та інших розходяться. Серед функцій професійної діяльності науково-педагогічного працівника у закладі вищої освіти насамперед виділяють педагогічні функції, до яких переважно відносять навчальну, інформативну, розвивальну, орієнтаційну, виховну, адаптивну, корегувальну, компенсаторну та самоосвітню.

Разом $з$ цим у низці праць прослідковується тенденція до їх систематизації за іншими ознаками. Так, І. Зимня [175] всі функції педагогічної діяльності зводить у дві групи за цільовими та організаційно-структурними ознаками. До першої групи функцій цілепокладання - належать орієнтаційна, мобілізаційна, розвивальна, інформаційна, що співвідносяться з дидактичними здібностями педагога; до другої групи - організаційно-структурних функцій - конструктивна, комунікативна, організаційна та гностична.

Використовуючи інші підходи, розглядає функціональний склад педагогічної діяльності В. Семиченко, яка виокремлює термінальні функції-цілі, інструментальні функції-засоби та операційні функції-прийоми. Власне змістовно-цільовий, організаційно-процесуальний та операційно-технологічний аспекти дають змогу 
виявити цілісність професійної діяльності науково-педагогічного працівника. Разом з цим В. Семиченко указує на те, що термінальні функції, або функції-цілі пов'язані зі стратегічними напрямами освітньої діяльності та відображають їі сутнісні цілі й завдання, виділяють не лише навчальну функцію, а й розвивальну та виховну, котра охоплює світоглядну та культурологічну функції. Своєю чергою, інструментальні, або функції-засоби, містять групу функціональних завдань, у результаті чого цілі освітньої діяльності перетворюються на безпосередній процес взаємодії науковопедагогічного працівника 3 конкретними здобувачами вищої освіти в реальних умовах освітнього процесу в закладі вищої освіти. До таких функцій належать інформаційна, ілюстративна, науково-дослідницька, комунікативна, діагностична, мотиваційна, стимулююча та прогностична. Всі вони спрямовані на стимулювання пізнавальної, навчальної та наукової активності здобувачів вищої освіти [176].

До операційних функцій професійної діяльності науково-педагогічного працівника, або функцій-прийомів, належать: методична, управлінська, організаційна, корегувальна та констатуюча функції. Усі вони ретельно описані у працях Н. Кузьміної [177], В. Семиченко [176] та ін.

Важливою психолого-педагогічною проблемою якісної професійної діяльності науково-педагогічного працівника також $є$ забезпечення його позитивної (ефективної) професійної спрямованості.

Реалізувати завдання освітнього процесу науково-педагогічний працівник може, лише взаємодіючи зі здобувачами вищої освіти та іншими його учасниками. Безумовно, важливим іï аспектом є встановлення з ними ділових стосунків, оскільки це допомагає спрямувати їх на якісне оволодіння вміннями й формування компетентностей, доцільно впливати на їхні вчинки, міжособистісні стосунки, взаємини у групах, поведінку, розв’язувати конфлікти тощо. Стосунки науково-педагогічного працівника і здобувача вищої освіти реалізуються у двох площинах - офіційній та неофіційній. Для офіційних стосунків характерні формальні зв'язки і стосунки; для неофіційної - простота, доступність, свобода висловлювань, думок і пропозицій, можливість обстоювати свою точку зору, заперечувати та ін. Від особливостей цього соціально-психологічного контакту 
залежить не лише динаміка настроїв студентів, але й динаміка їхньої пізнавальної активності.

Стосунки між науково-педагогічним працівником і здобувачами вищої освіти, фактично, відображаються у професійній спрямованості науковопедагогічного працівника, яку одні вчені прирівнюють до його фахових якостей, а інші - цілеспрямованої поведінки.

3 роками у деяких науково-педагогічних працівників відбувається психолого-педагогічна професійна деформація. Тому постає психологопедагогічна проблема щцоо попереджсення ії розвитку в науково-педагогічного працівника, вірніше забезпечення його високої психолого-педагогічної професійної надійності протягом діяльності в закладах вищчої освіти, яка не найшла належного висвітлення в науці. Як правило, опосередковано психологопедагогічну професійну надійність науково-педагогічного працівника визначають через протилежні поняття - “професійну деструкцію”, “професійну деформацію”, “деформацію особистості”, “професійне вигоряння”.

До слова, поняття "професійна деформація" введено напочатку XX ст. відомим соціологом П. Сорокіним. Загалом, вчені доводять, що професійна деформація науково-педагогічних працівників найчастіше виникає внаслідок розвитку в них синдрому вигоряння. Проте тлумачать цей синдром по-різному.

Вигорянню, як психологічному феномену, вчені присвятили сотні праць як у вітчизняній, так і закордонній науці. Воно розкривається як багатогранне явище у працях Н. Водоп'янової, Л. Карамушкі і Т. Зайчикової, А. Ленгле, В. Орела, Т, Формалюка, М. Буріш, С. Маслач, Л. Морроу, К. Мача, Б. Перлмана, Г. Робертса, П. Ротіна, В. Шауфелі та ін.

Найчастіше професійне вигоряння розглядають як довготривалу стресову реакцію, яка виникає внаслідок тривалих професійних стресів середньої інтенсивності.

У цьому контексті дослідник В. Бойко веде мову про емоційне вигоряння як первинне поняття. Він пропонує розглядати структуру синдрому емоційного вигоряння як таку, що становить собою послідовність перебігу трьох фаз: 
1) напруження: переживання психотравмуючих обставин, незадоволеність собою, “загнаність у клітку”, тривогу і депресію; 2) резістенції: неадекватний вибір емоційного реагування, емоційно-моральну дезорієнтацію, розширення сфери економії емоцій, редукцію професійних обов'язків; 3) виснаження: емоційний дефіцит, емоційна відстороненість, особистісна відстороненість (деперсоналізацію), психосоматичні та психовегетативні порушення. Дослідник виявив такі особистісні чинники розвитку синдрому емоційного вигоряння як схильність до: емоційної холодності, інтенсивного переживання негативних обставин у професійній діяльності, слабкої мотивації емоційної віддачі у професійній діяльності [178].

У своєму описі Е. Махер (1983) розширює перелік симптомів “емоційного вигоряння”, включаючи до них: 1) втому, стомлення, виснаження; 2) психосоматичне нездужання; 3) порушення сну; 4) негативне ставлення до інших людей; 5) негативне ставлення до своєї діяльності; 6) убогість репертуару робочих дій; 7) зловживання хімічними агентами (кава, тютюн, алкоголь, наркотики, ліки); 8) переїдання або відсутність апетиту; 9) негативна "Я-Концепція"; 10) агресивні почуття (дратівливість, тривожність, напруженість, занепокоєння, схвильованість, гнів); 11) поганий настрій й пов'язані з ними емоції: цинізм, песимізм, почуття безнадійності, апатія, депресія, почуття безглуздості; 12) переживання почуття провини [179].

Загалом сучасній науці відомі три моделі “вигоряння”. Згідно з першою моделлю, “вигоряння” - це стан фізичного та психічного виснаження, що викликані тривалим перебуванням в емоційно перевантажених ситуаціях.

Друга модель описує “вигоряння” як двомірний конструкт, який складається з емоційного виснаження і деперсоналізації, що виявляється у зміні ставлення або до себе, або до оточуючих.

Третя модель синдрому “вигоряння" належить американським дослідникам К. Маслач і С. Джексон, котрі розуміють його як синдром емоційного виснаження, деперсоналізації та редукції особистих досягнень. 
Емоційне виснаження розглядається як основна складова професійного “вигоряння” і виявляється у пониженні емоційного фону, байдужості або емоційній перенасиченості; деперсоналізація як деформація стосунків з іншими людьми. Це може бути підвищення залежності від інших, або підвищення негативізму, поява цинічних установок i почуттів до інших. Редукція особистісних досягнень виявляється або в тенденції до негативного оцінювання себе, своїх професійних досягнень і успіхів, у появі негативізму до професійних досягнень і можливостей, або в обмеженні своїх можливостей, обов'язків стосовно до інших [180].

На сьогоднішній день синдром вигоряння входить до Міжнародної класифікації хвороб (МКХ-10). У класифікаційній рубриці “Проблеми, пов’язані 3 труднощами подолання життєвих ускладнень” його можна знайти під номером Z73.0. Згідно з визначенням ВOO3 (2001), «синдром вигоряння - це фізичне, емоційне чи мотиваційне виснаження, що характеризується порушенням продуктивності праці, стомленістю, безсонням і зниженням імунітету, а також вживанням алкоголю та інших психоактивних речовин 3 метою отримання тимчасового полегшення, яке має тенденцію до розвитку фізіологічної залежності та (у багатьох випадках) суїцидальної поведінки».

Згідно з поглядами дослідника А. Чіра, головним чинником емоційного вигоряння є емоційне виснаження, а додатковими компонентами - поведінка (копіювання стресу), що веде до деперсоналізації, або власне когнітивноемоційного вигоряння, котре виражається в скороченні особистісних досягнень (деформації суб’єктивної оцінки власних можливостей). Однак, те й інше виявляється в деформації особистості та має безпосереднє значення для іiі соціального здоров’я [цит. за 181].

У своєму дисертаційному дослідженні емоційного вигоряння викладачів вищих навчальних закладів Н. Чепелєва розглядає його «як варіант дезадаптації, при якому порушується контакт з реальністю; на безпосередньо-психологічному рівні емоційне вигоряння являється наслідком неадекватних дій, в основі яких лежить використання шаблонних і неадекватних ситуації засобів вирішення 
проблем, що неминуче виникають у професійній діяльності» [182, с. 65]. Деперсоналізація науково-педагогічних працівників проявляється в деформації його властивостей, якостей, стосунків, почуттів, установок, “Я-образу” тощо, редукція особистісних досягнень - у ревізії, переоцінці, переосмисленні своїх професійних досягнень і успіхів, життєвих цінностей, установок та ін., на підгрунті чого деформуються професійні й життєві цінності, мотивація до професійної діяльності, поведінка і взаємини, змінюється ставлення до людей, діяльності, своїх обов'язків тощо. На неї певним чином може впливати і психологічна залежність.

Власне редукція професійних досягнень науково-педагогічних працівників також виявляється як переживання ним усвідомлення реальної чи уявної некомпетентності, неуспіху в професійній педагогічній діяльності, безперспективності, а також як скептичне ставлення до них.

Найбільш негативними наслідками професійного вигоряння $\epsilon$ розчарування науково-педагогічного працівника у власному професійному “Я”, коли він починає сумніватися у своїй професійній компетентності, у правильності вибраної професії, в доцільності своєї науково-педагогічної діяльності та ін. На цій основі у нього розвивається неадекватно занижена професійна самооцінка, підвищується рівень професійної тривожності, відбувається спотворення професійного розвитку, з'являються раніше відсутні негативні якості та ін.

Дослідники довели, що на виникнення професійного вигоряння науковопедагогічних працівників впливає низка соціальних чинників, а саме: невідповідність його особистісних особливостей специфіці науково-педагогічної діяльності; невизнання його реальних досягнень, або таких, які вважає за досягнення сам працівник; обмеження права на свободу вибору (стилю спілкування, стилю життя, програми і методики викладання навчальної дисципліни, педагогічних і дидактичних технологій здійснення виховного впливу, керування пізнавальною діяльністю студентів, їх самостійною роботою та ін.); невідповідність особистісно-етичних вимог змісту професійної 
діяльності; конфлікти зі здобувачами вищої освіти; нездоровий моральнопсихологічний клімат у педагогічному колективі та закладі вищої освіти; зниження соціального статусу, в тому числі в моральному, соціальному i матеріальному плані; сімейно-побутові проблеми; незадоволеність кар'єрою; низька оплата професійної діяльності; наявність формалізму в організації та здійсненні освітнього процесу; незадоволеність якістю і результатами своєї власної професійної діяльності та ін.

Виникнення професійного вигоряння у науково-педагогічних працівників швидше за все $є$ результатом складної взаємодії внутрішніх і зовнішніх чинників, у тому числі й психічної депривації.

Таким чином, на основі результатів аналізу праць 3 психологопедагогічних проблем якості професійної діяльності в закладах вищої освіти вияснено, що поняття “якість педагогічної діяльності”, “якість професійної діяльності викладача", “якість викладання”, “якість професійної діяльності науково-педагогічного працівника" та їм подібні не вживаються i не розглядаються. Реально в науково-теоретичній площині досить активно й широко обговорюються питання якості освіти в цілому та якості вищої освіти, але без обговорення критеріїв якості професійної діяльності окремого науковопедагогічного працівника.

Встановлено, що на сьогодні у прямій постановці проблема критеріїв якості професійної діяльності науково-педагогічного працівника в науці не розглядалася. Такі критерії розкриваються опосередковано: 1) у найширшому розумінні - через тлумачення якості освіти та якості вищої освіти; 2) у широкому розумінні через вимоги, які висуваються до професійної діяльності викладача (науково-педагогічного працівника); 3) у звуженому розумінні - в теоріях педагогічної культури, педагогічної майстерності, професійної педагогічної компетентності та педагогічного професіоналізму - через їхні складові. Проте, якість професійної діяльності науково-педагогічного працівника не тотожна ні поняттю “педагогічна майстерність”, ні поняттю “педагогічна культура", ні поняттю “педагогічна компетентність”, ні поняттю “педагогічні здібності”. 
Виявлені психолого-педагогічні проблеми забезпечення якості професійної діяльності науково-педагогічного працівника, які водночас слугують теоретико-методологічним підгрунтям пошуку й визначення іiі (якості) критеріїв. До таких належать проблема: 1) постійного підтримування в науковопедагогічного працівника високого рівня базових (нових) знань і вмінь, а також загальних і фахових компетентностей, необхідних для забезпечення всіх видів діяльності у закладі вищої освіти та надання якісних освітніх послуг; 2) формування і реалізації в освітньому процесі загальних і фахових компетентностей, при чому 3 урахуванням постійної зміни знань, методів, технологій; 3) розвитоку в науковопедагогічного працівника сукупності необхідних особистісних якостей та здібностей, їх ефективна реалізація в освітньому процесі; 4) формування і підтримування мотивації науково-педагогічного працівника до професійного успіху та попередження розвитку в нього мотивації до уникнення невдачі; 5) формування в науково-педагогічного працівника спроможності ефективно реалізувати широке коло функцій, особливо управління освітньою діяльністю здобувачів вищої освіти; 6) забезпечення позитивної (ефективної) професійної спрямованості науковопедагогічного працівника; 7) забезпечення психолого-педагогічної надійності науково-педагогічного працівника 3 метою недопущення його професійного вигоряння та деформації.

На основі цих психолого-педагогічних проблем найголовнішими групами критеріїв якості професійної діяльності науково-педагогічного працівника виявляються: 1) володіння ним найсучаснішими у світі знаннями, вміннями та компетентностями і здатністю до їх безперервного оновлення, в тому числі й через вивчення зарубіжних джерел мовою оригіналу, відбору найцінніших та ефективне їх упровадження в освітній процес; 2) наявність і прояв в освітній діяльності професійно важливих особистісних якостей та здібностей; 3) володіння цифровими технологіями, вміле використання комп'ютерної техніки та мережі Інтернет, різних комп'ютерних програм, уміння працювати в on-line режимі; 4) здатність до пошуку новітніх (передових) форм, методів, педагогічних, дидактичних та інформаційних технологій; 5) висока мотивація до 
ефективної професійної діяльності; 6) вміння ефективно організовувати i управляти освітнім процесом здобувачів вищої освіти, спілкуватися з ними; 7) здатність вибудовувати зі здобувачами вищої освіти такий вектор професійної спрямованості, який приносять найбільшу користь освітньому процесу i забезпечує досягнення ними високих програмних результатів навчання; 8) висока психолого-педагогічна надійність, яка перешкоджає розвиткові в нього професійного вигоряння та деформації. 
DOI 10.46299/ISG.2021.MONO.PED.III.2.9

\section{9 Якість професійної діяльності науково-педагогічного працівника та її забезпечення}

Сьогодні частіше говорять про якість вищої освіти, якість надання освітніх послуг, ніж про якість професійної діяльності науково-педагогічних працівників, хоча сумнівно, щоб без останньої можуть бути можливими дві попередні.

Насправді, якість професійної діяльності науково-педагогічних працівників важко визначити практично, оскільки вона виявляється в результатах навчання здобувачів вищої освіти, які також залежать від їхніх здібностей, попередньої підготовки, мотивації тощо. Разом з тим, на основі вивчення праць з проблем якості професійної діяльності науково-педагогічних працівників нами встановлено, що вона не тотожна ні поняттю “педагогічна майстерність", ні поняттю “педагогічна культура", ні поняттю “педагогічна компетентність”, ні поняттю “педагогічні здібності”, хоча й спирається на них.

Тому, щоб зрозуміти, в чому полягає якість професійної діяльності науково-педагогічних працівників, насамперед, розкриємо саму категорію “якість".

Вважають, що вперше до категорії “якість” звернувся Аристотель у своїх працях “Метафізика” і “Категоріі”, в яких розглядав якість предмета з точки зору його сутності, тобто предикаменту, що відповідає на запитання “який? ”. У відповіді передбачалася варіація з чотирьох можливих контекстів: 1) наявність чи відсутність уроджених (початкових, вихідних) здібностей та характеристик; 2) наявність і набутих, і стабільних властивостей; 3) наявність властивостей стану предмета чи явища, у процесі їхнього існування; 4) зовнішній вигляд предмета чи явища.

У гносеологічному вимірі Гегель під якістю розуміє початковий ступень пізнання речей, а в онтологічному - визначеність, яка $є$ тотожною $з$ поняттям “буття”. Разом з цим вчений пов'язує поняття якості з поняттями “кількість” і "міра", формулюючи закон про перехід кількості в якість. Розглядаючи діалектичну природу якості, Гегель указує на можливість вимірювання через неї істотної визначеності предмета. Власне, виходячи з цього, категорія “якість” у 
філософському вимірі і сьогодні розглядається як така, яка виражає істотну визначеність предмета, завдяки чому він існує у вигляді саме такого, а не іншого предмета [183, с.237].

Філософська думка така: «<..> Існують не якості, а речі, яким властиві певні якості, яких незліченна кількість» [184, с. 33]. Звідси слідує, що сутність поняття “якості” (у множині) одного об'єкта практично відповідає, тобто є ідентичною поняттю “властивості”».

I ще один важливий момент: у теорії управління якістю використовується поняття “процес", а не поняття “діяльність”. А якість процесів у певній системі залежить від їхніх властивостей. Відтак, вивчення якості професійної діяльності науково-педагогічних працівників пов’язане 3 виокремленням властивостей різних складових цієї діяльності, які відтворюють у собі їі істотні ознаки. Власне властивості є похідними від способів і змісту діяльності. I такою властивістю якості професійної діяльності науково-педагогічних працівників є іiі ефективність, яка, залежно від змісту і способів діяльності, обраної мети тощо, змінюється.

Оскільки професійна діяльність науково-педагогічних працівників - це процес, неперервний і складний, з багатьма невідомими, в якому переплетені та інтегровано проявляються його знання, вміння, компетентності, професійні здібності, особистісні якості, а також різні психологічні детермінанти тощо, то іiі кінцевий результат залежить від властивостей, що визначають ефективність цього процесу.

Власне професійна діяльність науково-педагогічних працівників є функціональною системою, то пï якість описується у прикметникових детермінантах. Так само описуються їі підсистеми. Але якість функціонування системи визначається якоюсь інтегративною властивістю. Оскільки якість процесів у системі індивідуальної професійної діяльності науково-педагогічних працівників зумовлюється результативністю цієї діяльності, то вона має бути ефективною. 
Отже, інтегрованою властивістю якості професійної діяльності науковопедагогічних працівників є її ефективність. Іншими словами, якість професійної діяльності науково-педагогічного працівника прямопропорційно залежить від іiі ефективності. В принципі, про це йдеться і у Великому тлумачному словнику сучасної української мови, в якому слово “якість” тлумачиться як: «<... Ступінь вартості, цінності, придатності чого-небудь для його використання за призначенням. 3. Та чи інша характерна ознака, властивість, риса кого-, чогонебудь. 4. Сукупність характеристик продукції або послуг щодо іiі здатності задовольнити встановлені та передбачені потреби. <...>» [185, с. 1423]. А слово “ефективний” означає такий функціональний стан, «1. Який приводить до потрібних результатів, наслідків, дає найбільший ефект (у 2 знач.). 2. Який викликає ефект (у 1 знач.)» [185, с. 358].

3 цих позицій, якість професійної діяльності науково-педагогічного працівника являс собою похідну від їі ефективності, котра с доцільно спрямованою за змістом, освітніми функціями та завданнями його керованою, мотивованою, емоційно позитивною, результативною психолого-педагогічною взаємодісю зі здобувачами вищої освіти, повною реалізацісю ним власних знань, умінь, загальних i фахових компетентностей, здібностей, особистісних властивостей та якостей.

Якісна професійна діяльність науково-педагогічного працівника на практичному рівні має виявляється як, по-перше, ефективно керований ними процес передання-оволодіння здобувачами вищої освіти професійними знаннями, вміннями і навичками, ефективний процес формуванням у них загальних і фахових компетентностей; по-друге, процес ефективної психологопедагогічна взаємодії зі здобувачами вищої освіти та іншими учасниками освітнього процесу; по-третє, процес ефективного здобуття новітніх фахових знань посередництвом наукової діяльності та їх доцільне (ефективне) впровадження в освітній процес; по-четверте, ефективний процес формування у здобувачів вищої освіти якостей, необхідних для професійної діяльності, суспільного й громадського життя. 
Постає питання про практичне забезпечення якості професійної діяльності науково-педагогічного працівника у закладі вищої освіти. Безумовно, є різні шляхи розв'язання цієї проблеми. Ми пропонуємо одну із моделей забезпечення якості професійної діяльності науково-педагогічного працівника. Для іiі розроблення, насамперед, уточнимо, що розуміється під терміном модель, який досить широко вживаний і в науковій літературі, і в різних галузях діяльності.

У більшості словників значення цього терміну розкривається так: «Модель (англ. model, нім. Modell, фр. modèle, від лат. modulus - “міра, аналог, зразок, взірець”) - відтворення чи відображення об’єкту, задуму (конструкцій), опису чи розрахунків, що відображає, імітує, відтворює принципи внутрішньої організації або функціонування, певні властивості, ознаки чи/та характеристики об’єкта дослідження чи відтворення (оригіналу).

У короткому словнику з логіки пояснюється, що “модель” (від лат. modulus - міра, зразок) у широкому сенсі розуміється як спеціально створений або спеціально підібраний об'єкт, котрий відтворює характеристики об'єкта, що вивчається [186, с. 112].

У найширшому значенні під поняттям “модель” розуміють певний образ об'єкта (зокрема, умовний чи уявний), котрий цікавить суб'єкта, або, навпаки прообраз деякого об’єкта чи певної системи об’єктів.

Часто під моделлю розуміють опис об’єкта (предмета, явища або процесу) на будь-якій формалізованій мові, складений 3 метою вивчення його властивостей. Це може бути i модель процесів, явищ (експеримент) для дослідження їх відтворюваності чи аналізу їхніх складових та ін.

Згідно з поглядами А. Катренко, модель є засобом осмислення дійсності, котра дозволяє впорядкувати та певним чином формалізувати первинні нечіткі або навіть, суперечливі уявлення про те чи інше явище, об'єкт, систему $[187$, с. 82$]$.

Для науковця А. Уємова модель являє собою систему, дослідження функціонування якої дозволяе одержати інформації про іншу систему [188, с. 48$]$. 
За В. Загвязінським, моделювання є однією 3 процедур дослідницької діяльності педагога, котра пов'язана 3 педагогічним проектуванням. Власне моделювання має за мету створення і моделі вихідного стану процесу чи об’єкта, який необхідно змінити, і моделі бажаного стану об'єкта на кінець запланованого періоду. Для цього потрібно виділити істотні ознаки, які присутні в оригіналі, та оптимізувати чи вдосконалити діяльність об'єкта, котрий вивчається [189, с. 45-46].

У педагогіці моделювання прирівнюють до теоретичного методу, за допомогою якого уточнюють, розширюють і систематизують наукові факти, розкривають і передбачають появу тих чи тих явищ, переходять від абстрактного до конкретного знання, встановлюють взаємозв'язки між різними поняттями й гіпотезами, виокремлюють серед них найбільш суттєві та другорядні за допомогою їх реальних чи ідеальних моделей [190, с. 12].

Дослідниця Л. Семушіна звертає увагу на те, що моделювання є одним із способів удосконалення професійної підготовки фахівців вищої школи. На іiі думку, матеріальним вираженням моделі професійної підготовки викладача або окремих його боків $є$ складові, зміст і послідовність надання студентам відповідних завдань, вправ, створення ситуацій, спрямування їхньої діяльності, що дозволяє охопити всі види його майбутньої професійної діяльності [191, с. 25].

Загалом моделі можуть бути:

- за змістом - повністю або переважно описовими;

- за складом, ієрархією компонентів - структурними;

- за характером зв'язків і засобів у дієздатності системи - функціональними або функціонально-динамічними;

- за можливістю встановлювати нові зв'язки та виявляти нові залежності евристичними;

- за принципами відображення в наявній моделі інших моделей інтегрованими.

Отже, більшість дослідників педагогіки розуміє моделювання як процес 
наукового пізнання У педагогіці на цей час розроблені різні моделі, в тому числі моделі фахівця, професійної діяльності, професійної підготовки тощо.

Приміром, О. Сердюкова розробила структурно-функціональну модель формування педагогічної компетентності майбутніх інженерів-педагогів у навчальному процесі закладу вищої освіти [192]. Дана модель складається 3 трьох взаємопов’язаних блоків: 1) орієнтувально-цільового, за допомогою якого передбачається «чітке визначення цілей i завдань діяльності професорськовикладацького складу щодо психолого-педагогічної підготовки майбутніх інженерів-педагогів, а також проведення попередньої діагностики сформованості в студентів педагогічної компетентності» [192, с. 117]; когнітивно-процесуального, що «передбачає конструювання цілісного педагогічного процесу, який забезпечує сформованість педагогічної компетентності майбутніх інженерів-педагогів...»; контрольно-оцінного, який «передбачає здійснення контролю, аналізу та корегування експериментальної роботи й отриманих результатів» [192, с. 131].

На підставі вищевикладених теоретичних аспектів моделювання вважаємо можливим розробити функціональну модель забезпечення якості професійної діяльності науково-педагогічного працівника. Вона має відповідати таким вимогам:

1) змістовності, тобто здатності моделі відображати істотні властивості та риси реального процесу професійної підготовки і професійної діяльності науково-педагогічного працівника в закладі вищої освіти;

2) відповідності, тобто відповідати тим завданням, які розв'язує науковопедагогічний працівник у ході своєї професійної діяльності під час досягнення мети освітнього процесу в сучасному інформаційному суспільстві;

3) системності, тобто відтворювати певну систему здобування науковопедагогічним працівником необхідних знань, навичок, вмінь, загальних i фахових компетентностей $з$ урахуванням постійної зміни знань, розвитку інформаційних технологій, а також формування особистісних властивостей i якостей та попередження їхнього руйнування; 
4) індуктивності, тобто урахування того, що якість професійної діяльності науково-педагогічного працівника забезпечується внаслідок трансформації сукупності окремих груп знань, навичок, вмінь, загальних i фахових компетентностей, особистісних властивостей і якостей до загальної здатності ефективного управління освітнім процесом здобувачів вищої освіти, ефективної взаємодії з ними, досягнення високих результатів у освітньому процесі тощо;

5) дедуктивності, тобто відображати можливість аналізу складових якості професійної діяльності науково-педагогічного працівника на основі результатів освітнього процесу і власної професійної діяльності;

6) синергійності, тобто надавання можливості, за умови функціонування всіх складових моделі, отримання бажаного кінцевого результату - високого рівня якості професійної діяльності науково-педагогічного працівника;

7) корегованості, тобто можливості зміни складових, що забезпечують якість професійної діяльності науково-педагогічного працівника, їх періодичне коригування;

8) прогнозованості, тобто забезпечувати можливість прогнозувати кінцевий результат - рівень якості професійної діяльності науково-педагогічного працівника;

9) вимірювальності, тобто можливість оцінювати якість професійної діяльності науково-педагогічного працівника;

10) адекватності, тобто адекватно відображати і наявні професійні знання, навички, вміння, загальні та фахові компетентності, і професійні здібності, і особистісні якості, і професійну спрямованість, і вибраний стиль управління освітнім процесом здобувачів вищої освіти, і мотивацію до ефективної професійної діяльності, і психолого-педагогічну професійну надійність, і в цілому якість професійної діяльності науково-педагогічного працівника, що є основою для корегування і прогнозування процесів, що перебігають у ній.

У процесуально-концептуальному контексті функціональна модель забезпечення якості професійної діяльності науково-педагогічного працівника це опис процесу забезпечення і підтримування в нього на високому рівні 
розвитку професійних знань, навичок, вмінь, загальних i фахових компетентностей, його особистісних якостей і властивостей, професійних здібностей, професійної спрямованості, мотивації до ефективної професійної діяльності та психолого-педагогічної професійної надійності.

За структурно-функціональним характером модель забезпечення якості професійної діяльності науково-педагогічного працівника являє собою систему психолого-педагогічних елементів (блоків) зі заданими характеристиками i властивостями, певним чином узгоджених за змістом, часом i метою, що відтворюють спрямовану професійну активність науково-педагогічного працівника та його особистісної організації в процесі взаємодії зі здобувачами вищої освіти з метою формування у них знань, навичок, вмінь, загальних i фахових компетентностей та особистісних якостей.

Функціональна модель забезпечення якості професійної діяльності науково-педагогічного працівника, як система, складається 3 певної сукупності відносно незалежних підсистем, функціонування яких здійснюється за своїми закономірностями. Приміром, окремими підсистемами $є$ формування i підтримування в науково-педагогічного працівника професійних знань, навичок, вмінь, загальних і фахових компетентностей; розвиток професійних здібностей та особистісних якостей; забезпечення позитивної професійної спрямованості; формування вмінь ефективного управління освітнім процесом здобувачів вищої освітив; формування мотивації до ефективної професійної діяльності; забезпечення психолого-педагогічної професійної надійності та ін. Кожна така підсистема у функціональному плані розгортається як своєрідний процес, що перебігає за своїми закономірностями, але разом з іншими підсистемами, не зважаючи на їх синергійний характер, у цілісному процесі функціонування моделі забезпечують певний рівень якості професійної діяльності науковопедагогічного працівника..

Дана модель відтворює реальний процес забезпечення якості професійної діяльності науково-педагогічного працівника щодо виконання всіх завдань освітнього процесу. Разом 3 цим вона дає можливість вивчення істотних 
властивостей складових, що визначають рівень розвитку професіоналізму і в цілому якості професійної діяльності науково-педагогічного працівника.

Результати наших досліджень свідчать, що функціональна модель забезпечення якості професійної діяльності науково-педагогічного працівника включає такі взаємопов’язані функціональні блоки: 1) знаннєвокомпетентнісно-особистісний; 2) професійно-мотиваційний; 3) професійноуправлінський; 4) професійно-орієнтаційний; 5) професійно-конструктивний.

Перший блок моделі - знаннєво-компетентнісно-особистісний забезпечує оволодіння науково-педагогічним працівником необхідною сукупністю загальних і фахових знань, постійне здобуття нових знань, формування вмінь, компетентностей, здібностей і особистісних якостей, a головне їх ефективну реалізацію ним в освітньому процесі.

Ми не будемо описувати, якими знаннями і вміннями повинен володіти НПП, оскільки вони добре розкриті в багаточисельних працях. Лише зробимо посилання на працю О. Гури [193], в якій, у принципі, як варіант, згруповані й систематизовані базові знання і вміння науково-педагогічного працівника, котрі необхідні йому для реалізації завдань освітнього процесу.

Але проблема забезпечення наявності у психолого-педагогічного працівника базових знань і вмінь, а також загальних і фахових компетентностей ускладнюється тим, що він має постійно використовувати в освітньому процесі нові знання, передові новітні (інноваційні) методи, технології та ін., якими, насамперед, має оволодівати самостійно. Виходячи з того, що в сучасному світі знання “старіють” дуже швидко, а новітні методи, технології та ін. з’являються часто, то науково-педагогічним працівникам не так легко оволодівати ними, оскільки їх потрібно, по-перше, вибрати із великого масиву інформації та осмислити, провести апробацію; по-друге, розробити на їх основі нові лекції, практичні й лабораторні заняття, практики, теми і методичні вказівки до курсових робіт (проектів) та ін.; по-третє, змінити відповідні програми, затвердити їх і под. 
Отже, у науково-педагогічного працівника має бути сформована готовність до безперервного процесу оволодіння новими знаннями самостійно i/чи колективно (коли заклад вищої освіти організовує здобуття нових знань у формі семінарів, конференцій, симпозіумів та ін.). Під такою готовністю розуміється наявність у нього і вмінь до здобуття нових знань, і мотивації, і засобів.

На основі професійних знань і вмінь у науково-педагогічного працівника формуються загальні та фахові компетентності як здатності до розв'язання різних завдань освітнього процесу.

Таке визначення компетентності базується на розгорнутій у 1997 році в країнах Європи програмі “Визначення та відбір компетентностей: теоретичні й концептуальні засади", основне завдання якої полягало в систематизації та узагальненні результатів десятирічних досліджень 3 проблем компетентностей, які необхідні фахівцю сучасного суспільства. На основі цієї програми експерти визначають компетентність як «здатність успішно задовольняти індивідуальні й соціальні потреби, діяти та виконувати поставлені завдання» [194]. 3 цих позицій компетентність складається 3 низки компетенцій, кожна 3 яких побудована на комбінації (поєднанні, переплетенні) взаємовідповідних пізнавальних зв'язків і практичних навичок, цінностей і поведінкових компонентів, знань і вмінь, емоцій і волі, іншими словами, всього того, що уможливлює активну діяльність.

Загалом, експертами Європейського освітнього фонду $(1997$ р.) компетентність описується як, по-перше, здатність виконувати будь-що гарно та ефективно; по-друге, критерій відповідності певним вимогам при прийомі на роботу; по-третє, спроможність виконувати особливі трудові функції [195].

У матеріалах ЮНЕСКО окреслена сукупність компетентностей, котрі визнаються як результат освіти. У цьому контексті в доповіді міжнародної комісії з освіти XXI ст. “Освіта: приховані скарби” Ж. Делор визначив чотири базові чинники сьогоднішньої освіти: навчити пізнавати, навчити працювати, навчити жити спільно, навчити жити самостійно [196].

Ми підтримуємо позицію О. Сердюкової, згідно 3 якою, «сутність компетентності особистості як цілісного наукового феномену, що виявляється як 
інтегрована характеристика особистості й визначає іiі готовність використовувати засвоєні знання, вміння, навички й набутий досвід та особистісні якості для успішного розв'язання різноманітних за змістом і складністю завдань, що виникають у процесі життєдіяльності та професійній cфepi» [192].

Важливою складовою першого блоку також $\epsilon$ наявність у науковопедагогічних працівників особистісних якостей, необхідних для реалізації завдань сучасного освітнього процесу.

Зауважимо, що особистісні якості викладача часто розглядаються через призму його компетентності. Так, в американській моделі “компетентнісного працівника”, яка розроблена Д. Меридлом, Д. Джюлом та І. Стевіком, визначені такі професійно-важливі якості фахівця, як дисциплінованість, самостійність, комунікабельність, прагнення до саморозвитку. Особливо звертається увага на наявність такої якості як спроможність особистості до саморозвитку, котра, на їхню думку, має забезпечити не лише усвідомлений процес формування фахової майстерності, самоосвіти й самовдосконалення, а й мотивований, цілеспрямований вільний вибір і прагнення фахівця досягнути бажаного рівня професійної компетентності.

На думку Б. Гершунського, «професійна компетентність, по-перше, - це функціональна грамотність, яка використовується й актуалізується на власне професійному рівні; по-друге, це такі іiі компоненти, які можуть бути віднесеними не стільки до предметного змісту, скільки до якостей особистості, що формуються, - відповідальності, творчості, допитливості, наполегливості, прагнення до набуття нових знань і, звичайно ж, до високої моральності, без якої не мислиться справжній професіонал своєї справи» [198, с. 123].

Всі особистісні якості науково-педагогічних працівників мають певну професійну значущість. Так, для успішної взаємодії зі здобувачами вищої освіти науково-педагогічний працівник має бути дисциплінованим, цілеспрямованим, ініціативним, обов’язковим, вимогливим до себе та інших. Разом з цим важливими для нього є такі якості як витримка, здатність до гальмування у 
поєднанні зі швидкою реакцією й винахідливістю, емоційна толерантність, доброзичливість, емпатійність, співчутливість тощо. Необхідними якостями науково-педагогічних працівників $є$ педагогічна спостережливість, яка допомагає йому отримувати інформацію про індивідуальні особливості студентів, їхнє ставлення до навчання, інших студентів і науково-педагогічних працівників, розуміння навчального матеріалу, про стосунки між ними, настрої, бажання, характер їхнього реагування на зауваження, оцінку (бал) тощо.

Загалом науково-педагогічний працівник має:

- досконало володіти мовою, що забезпечує логічність і чіткість подання навчального матеріалу, переконливість, впливовість, здатність викликати у студентів позитивні почуття;

- бути людяним, доброзичливим, толерантним, емоційно стійким, емоційно привабливим, виваженим, доступним для здобувачів вищої освіти, наполегливим, дисциплінованим, відповідальним, порядним, у міру принциповим, справедливим,

- педагогічно мислити, тобто застосовувати теоретичні положення філософії, психології, педагогіки, методики у конкретних педагогічних ситуаціях освітнього процесу;

- бути оптимістом, оскільки його оптимізм позитивно впливає на ефективність навчальної діяльності студентів, їх виховання, викликаючи у них позитивні емоції, захопленість справою тощо;

- виявляти педагогічний такт, який полягає в його здатності тактично, урівноважено, толерантно, з повагою і розумінням ставитися до студентів та їхніх проблем, ні в якому разі своєю поведінкою не показувати свою неповагу, байдужість, неприязнь, зверхність та ін.

До цього блоку також належать організаційні і комунікативні здібності.

Дослідник Л. Подоляк і В. Юрченко доводять, що «одним із складників професіоналізму діяльності викладача вищої школи $є$ його організаторські здібності <..> » [199, с.129]. Розгортаючи думку, вони пояснюють, що «управління в системі “особистість-особистість” полягає в реалізації керівником 
конструктивної, регулятивної, комунікативної та оцінно-корегувальної функцій, які забезпечують ефективний вплив на людей, щоб гарантовано виконувати завдання сумісної діяльності. Сутність такої діяльності полягає в організації мотивованих відносин у колективі задля успішного вирішення навчальновиховних завдань» [199, с.134].

Власне організаційні та комунікативні здібності науково-педагогічних працівників є провідними, оскільки вони найбільшою мірою необхідні в освітньому процесі, а у практичному контексті в них інтегровано відображаються майже всі інші здібності.

Як відомо, здібності $є$ індивідуально-психологічними особливостями особистості, які сприяють успішному здійсненню будь-якої діяльності. Вони, безумовно, залежать від навичок і вмінь, але не зводяться до них. Згідно 3 Б. Тепловим, здібності утворюються в діяльності та проявляються в таких іiі динамічних характеристиках, як швидкість, глибина, міцність засвоєння [200]. Науково-педагогічний працівник, як організатор, повинен володіти сукупністю організаторських здібностей, необхідних для реалізації завдань освітнього процесу.

Науково-педагогічний працівник має вміти організовувати роботу здобувачів вищої освіти щодо вивчення конкретного предмету. Надзвичайно важливими для організаторської діяльності науково-педагогічних працівників $\epsilon$ такі його риси характеру, як дисциплінованість, самоорганізованість, енергійність, самоволодіння, рішучість, принциповість, вимогливість, логічність, тактовність та ін. Разом з цими також важливими $є$ такі його риси як простота, доступність, природність у поводжені, привітність та ін.

Ефективність організаторської діяльності науково-педагогічних працівників тісно пов'язана з рівнем розвитку його організаторських здібностей. Дослідник О. Ковальов стверджує, що організаторські здібності тісно пов'язані 3 характерологічними рисами особистості, а комунікативні риси характеру чуйність, уважність до людей і справедливість, своєю чергою, є допоміжними 
властивостями організаторських здібностей, оскільки за їх посередництва особистість розуміє інших людей та особливості спілкування з ними [201].

3 цих позицій організаторські здібності науково-педагогічного працівника виявляються як його індивідуально-психологічні властивості, за допомогою яких він має змогу встановити контакт зі здобувачами вищої освіти, визначити підходи та умови, шляхи i способи досягнення ними найефективніших результатів навчання, організувати взаємодію, визначити місце i час консультування, доцільного використання інформаційних технологій та ін.

Отже, організаторські здібності науково-педагогічного працівника - це його здатність організувати свою власну діяльність у відповідності до потреб перебігу освітнього процесу, а також навчальну діяльність здобувачів вищої освіти, розв'язувати проблеми, що виникають, та ін.

За результатами дослідження Л. Мотозюк, структурними елементами організаторських здібностей є наявність: 1) високого рівня вольової організації особистості; 2) інтелекту, що відповідає високому та середньому рівню; 3) високого рівня розвитку специфічних якостей особистості (психологічної впливовості, комунікативної компетентності, психологічної проникливості, схильності до лідерства) [202].

Завдяки своїм організаторським здібностям науково-педагогічний працівник реалізує функцію планування, контролю, корегування та регулювання i стосунків зі здобувачами вищої освіти, студентськими групами, i їхньої діяльності, і своєї власної діяльності.

Надзвичайно важливими для науково-педагогічного працівника $є$ його комунікативні здібності.

Різні боки комунікативних здібностей розкриті у багатьох працях, у тому числі К. Абульханової-Славскої, В. Галузяк, Ю. Жукова, О. Кідрона, І. Коваля, Ж. Максименко, Є. Михайлової, О. Опалюк, Г. Почепцова, М. Савчина, А. Смірнова, Т. Чмут, Х. Яусс, Р. Чуваттанакуль, Г. Гладштейн, Дж. Сабіні, С. Уорнер, М. Уілтс. 
Так, дослідник О. Кідрон під комунікативними здібностями розуміє загальну здатність, пов'язану з різноманітними підструктурами особистості, що виявляється в навичках суб'єкта спілкування вступати в соціальні контакти, регулювати ситуації взаємодії, а також досягати в міжособистісних стосунках комунікативну мету. Автор вважає, що здатність особистості до комунікації в найбільш загальному вигляді виражається в його вмінні встановлювати соціальні контакт з іншими людьми, входити в різні ролі, досягати взаєморозуміння в різних умовах інтеракції і на різних рівнях обміну інформацією. На особистому рівні у структурі комунікативних здібностей О. Кідрон виділяє чотири рівні: 1) базовий рівень, який відображає комунікативний потенціал людини і суспільні та особистісні передумови спілкування: комунікативні засоби, схема орієнтації інтеракції, зовнішність, темперамент, статус індивіда; 2) нижчий рівень, для якого характерно володіння лише певними навичками спілкування; 3) середній рівень, на якому сформовані вміння спілкуватися; 4) вищий рівень, коли використовуються форми інтеракційного пристосування і реалізується спрямованість поведінки.

Комунікативні здібності науково-педагогічного працівника виявляються в його комунікативній успішності, котра відображає результативність комунікації зі здобувачами вищої освіти. Зазначимо, що комунікативна успішність досить часто ставиться поряд із поняттям “комунікативна компетентність” і “соціальна компетентність”, “соціальний інтелект”, соціально-перцептивні вміння і навички, соціальна обдарованість, лідерство та ін. [204].

Комунікативні здібності виявляються за умови доцільного та успішного використання вербальних і невербальних засобів спілкування, оскільки словами передається чиста інформація, а по невербальних каналах трансформується ставлення до партнера по спілкуванню, емоційний стан співрозмовника та ін. За результатами дослідження Ф. Зимбардо i M. Лейппе через невербальну поведінку розкривається внутрішній світ особистості, здійснюється формування психічного змісту спілкування та спільної діяльності. Люди досить швидко 
можуть найти способи пристосування до обставин, які змінюються, але мова тіла виявляється менш пластичною [205, с. 88].

Отже, комунікативні здібності науково-педагогічного працівника являють собою його здатність до ефективного спілкування та взаємодії зі здобувачами вищої освіти, спрямовану на організацію та оволодіння ними знаннями, навичками, вміннями і загальними та фаховими компетентностями.

Науково-педагогічний працівник у процесі своєї професійної діяльності застосовує ділову (офіційну) і не ділову (не офіційну) комунікацію. У діловій комунікації, на що вказує А. Панфілова, предметом спілкування є діяльність і справа, а партнер по спілкуванню розглядається як значуща особистість [206].

Головними завданнями ділової комунікації науково-педагогічного працівника зі здобувачами вищої освіти $є$ створення ділової академічної атмосфери, в якій можливі продуктивна співпраця, взаєморозуміння, особиста відповідальність учасників освітнього процесу, визначення спільної мети i шляхів іiі досягнення, звітування за виконану навчальну роботу, адекватне принципове оцінювання результатів навчання, критика і самокритика та ін.

Психолого-педагогічними умовами ефективної ділової комунікації науково-педагогічного працівника зі здобувачами вищої освіти $є$ :

- вміння чітко окреслити предмет розмови, доступно і зрозуміло довести його до співрозмовників;

- здатність доречно говорити і вчасно замовчати;

- $\quad$ вміння слухати і розуміти проблеми здобувачів вищої освіти;

- здатність бути емоційно толерантним до всіх учасників спілкування;

- здатність “розшифровувати” невербальні засоби комунікації та адекватно реагувати на них;

здатність доброзичливо і неупереджено ставитися до всіх учасників спілкування, незалежно від симпатій та антипатій до них;

- знання і розуміння психологічних особливостей молодих людей студентського віку; 
- вміння дотримуватися формально-рольових принципів взаємодії 3 урахуванням субординації та ділового етикету;

- вміння робити зауваження і критикувати так, щоб не зашкодити честі й гідності особистості здобувача вищої освіти;

- вміння вести розмову зрозумілою і доступною мовою;

- здатність не перебивати співрозмовника доти, доки той повністю не висловився;

- вміння створити сприятливу психологічну атмосферу в процесі спілкування;

- здатність визначати мотиви і потреби здобувачів вищої освіти;

- вміння використовувати практичні прийоми переконання в ході комунікації;

- здатність здійснювати комунікацію зі здобувачами вищої освіти на основі сумісності й психологічного партнерства, за яких головним способом комунікації є розмова "рівного з рівними”.

Ділова комунікація науково-педагогічного працівника $є$ складним процесом, що уможливлюється внаслідок наявності в нього комунікативних здібностей, в яких інтегровано відображені вміння критично осмислювати власний комунікативний досвід, комунікативна культура, світогляд, знання психологї̈ спілкування та психологічних вікових особливостей здобувачів вищої освіти, їхнього ставлення до навчання, знання змісту освітнього процесу, характер його організації та перебігу тощо.

Сучасний заклад вищої освіти - це комунікаційна система, яка постійно розвивається, реагуючи на актуальні зміни, що відбуваються в суспільстві та у світовому освітньому просторі, через яку здійснюється вплив на здобувачів вищої освіти 3 метою і оволодіння ними загальними та фахових знаннями, вміннями, компетентностями, і формування у них адекватного світогляду, особистісних та громадянських якостей, і підготовки до суспільного життя.

Отже, знаннєво-компетентнісно-особистісний блок можна виразити через такі його складові як: 1) сукупність знань, умінь, компетентностей, необхідних 
якостей та їх ефективна реалізація в освітньому процесі; 2) організаційні здібності; 3) комунікативні здібності.

Другим блоком моделі є професійно-мотиваційний, котрий забезпечує формування в науково-педагогічного працівника мотивації до професійної діяльності.

Наявність у науково-педагогічного працівника професійних знань, умінь, компетентностей та особистісних якостей ще не гарантує їх ефективну реалізацію ним в освітньому процесі. Потрібно, щоб науково-педагогічний працівник бажав, прагнув реалізувати їх в освітньому процесі, тобто, щоб він був мотивований до ефективної професійної діяльності. Адже буває, що у процесі професійної діяльності науково-педагогічний працівник утрачає мотивацію до ії якісного виконання. Це найчастіше виявляється і як відсутність мотивації до досягнення успіхів у професійній діяльності, і як поява мотивації до уникнення в ній невдачі, тобто уникнення ризику отримати негативний результат унаслідок впровадження в освітній процес чогось нового, передового, такого, що раніше не використовувалося.

Мотиваційна сфера науково-педагогічних працівників суттєво детермінує якість професійної діяльності науково-педагогічного працівника, оскільки спонукає до свідомого вибору ним того або іншого типу поведінки, що визначається комплексною дією зовнішніх (стимулів) і внутрішніх (мотивів) чинників.

Цілком вірно зазначає М. Ярошевський, який вказує на те, що мотивація є енергетичним компонентом будь-якої діяльності: «Які б дії не розпочинала людина, яким би високим не був ступінь їхньої усвідомленості й логічної продуманості, жоден зовнішній або внутрішній акт поведінки не може бути виконаний без його мотиваційної, а значить - енергетичного забезпечення».

Значна кількість дослідників, у тому числі й О. Леонтьєв, С. Рубінштейн і Д. Узнадзе вважають, що мотив є центральним, системоутворювальним фактором діяльності.

На ефективність професійної діяльності науково-педагогічних працівників 
впливають різні мотиви. На думку Л. Орбан-Лембрик, мотиваційну сферу відповідальної поведінки керівника (а науково-педагогічний працівник керує освітнім прочесом здобувачів вищої освіти - Ю.М.) 3 погляду ієрархії потреб утворюють такі групи мотивів: 1) прагматичні мотиви (намагання розглядати свою поведінку, управлінські вчинки крізь призму користі, насамперед для себе; виявляється у задоволенні власних потреб); 2) соціальні мотиви (оскільки робота керівника є однією з найвідповідальніших у суспільстві, то багато управлінців прагнуть діяти відповідально, дбаючи про наслідки своїх вчинків для суспільства, намагаються поведінкою, справами принести користь державі); 3) мотиви самопізнання, саморозвитку, самоаналізу, саморегуляції, самореалізації (зумовлені потребою реалізувати у конкретній спільній справі свої управлінські можливості й здібності, пов'язані 3 необхідністю пізнати себе, оцінити свої сили та вміння); 4) мотиви морального самоствердження (зумовлені прагненням утвердити себе в статусі керівника - моральної особистості); 5) правові мотиви (погляд на свою управлінську діяльність і відповідальність з позицій закону); 6) мотиви спілкування і взаємодії (вони є однією з передумов спільної управлінської діяльності); 7) мотиви егоїстичного самоствердження (викликані намаганням привернути до себе увагу, продемонструвати свою перевагу над іншими); 8) мотиви, пов'язані із специфічними особливостями особистості керівника (залежність керівника від вищого управлінського апарату, який нав'язує свій варіант розв'язання управлінської проблеми; намагання уникнути критики, покарання, осуду тощо) [208].

В структурі мотивації науково-педагогічного працівника домінують соціальні та прагматичні мотиви. Отже, це свідчить, що науково-педагогічні працівники діють відповідально тоді, коли одночасно задовольняють власні потреби та потреби суспільства. Вчений $Є$. Ільїн називає це явище мотиваційноцільовим резонансом. «Мотиваційно-цільовий резонанс - співпадіння особистих цілей та мотивів з соціально-цінними мотивами» [209, с. 344].

Спонукальні чинники особливо сильні тоді, коли здобувачі вищої освіти і 
науково-педагогічні працівники відчувають відповідальність за досягнення поставленої мети та їі результати. Що більшу відповідальність відчувають учасники педагогічної взаємодії за наслідки своєї діяльності, тим сильніше мотивовані їхні різнобічні дії.

Важливою для ефективності професійної діяльності науково-педагогічних працівників є мотивація до досягнення успіху, яка, на думку Г. Мюррея, виражається у потребі долати перешкоди, досягати високих показників у діяльності, постійно самовдосконалюватись, конкурувати 3 іншими та випереджувати їх, реалізовувати свої здібності і таким чином підвищувати самоповагу.

Мотивація до досягнення успіху полягає у прагненні рухатися вперед та покращувати свої результати, шукати нові шляхи досягнення мети, не задовольнятися досягнутим та ін. Так, В. Ковальов указує на те, що існує тісний взаємозв’язок між рівнем мотивації досягнення та успіхом у життєдіяльності [211]. Виявлено, що науково-педагогічні працівники, які мають високий рівень цієї мотивації, шукають шляхи і способи досягнення мети, вони впевнені в успішному результаті, використовують нові ідеї, діють рішуче у невизначених ситуаціях, не розгублюються, сміливо долають перешкоди.

Мотивація до досягнення успіху, яка є провідною у процесі професійної діяльності науково-педагогічних працівників, забезпечує розвиток їх здатності оперативно і творчо розв'язувати нові педагогічні завдання і проблеми в умовах освітнього процесу. Відсутність вираженого прагнення до успіху та вдосконалення, намагання уникнути невдач може призвести до виникнення у науково-педагогічного працівника професійної кризи, але точно негативно впливає на якість його професійної діяльності.

Отже, професійно-мотиваційний блок якості професійної діяльності науково-педагогічного працівника виражається такими складовими, як: 1) мотивація до успіху; 2) відсутність мотивації до уникнення невдачі, що має обернено пропорційну залежність від мотивації до уникнення невдач. 
Третій блок моделі - професійно-управлінський, котрий забезпечує ефективне управління НПП освітнім процесом здобувачів вищої освіти.

Психолого-педагогічні та психологічні аспекти управління науковопедагогічними працівниками освітньою діяльністю здобувачів вищої освіти розглядали дослідники педагогічної психології та педагогіки вищої школи А. Алексюк, Ю. Бабанский, О. Власова, І. Зазюн, Д. Столяренко, Н. Творогова, Є. Шиянов, В. Якунін та ін.

Сутність управління науково-педагогічного працівника освітнім процесом, як виду діяльності, можна розуміти, виходячи 3 досліджень Б. Ломова, який наголошує, що «психологія саме і розглядає в діяльності той аспект, який пов'язаний із вивченням різних форм, видів і рівнів суб'єктивного відображення об’єктивної дійсності діючою людиною. У дослідженні діяльності її передусім цікавлять мотиви, цілеутворення, воля, емоції та ін., які становлять собою специфічні форми суб'єктивного відображення суспільних відносин <..>» [212, с. 205]. Наголошуючи на універсальності будови будь-якого виду діяльності, Б. Ломов виділяє в ній такі головні функціональні блоки як: мотив, мета, планування, перероблення інформації, оперативний образ або концептуальну модель, прийняття рішення, дії, перевірка результатів дій та їх корекцію [212, с. 216].

Загалом професійна діяльність науково-педагогічного працівника закладу вищої освіти $\epsilon$ поліфункціональною, оскільки він в освітньому процесі водночас реалізує багато функцій. Здавалося б, що ці функції незалежні одна від одної, проте прискіпливий аналіз освітнього процесу в сучасному інформаційному світі свідчить, що провідною, точніше його головною функцією є управлінська. Власне всі інші функції реалізуються в освітньому процесі через її призму.

Так, згідно з поглядами А. Алексюка [213], у закладі вищої освіти предметом педагогічної діяльності є управління освітнім процесом здобувачів вищої освіти, у тому числі і їхнім професійним розвитком. Проте ще раніше російський дослідник В. Якунін весь процес освіти загалом розглядає в ракурсі системного підходу і теорії управління [214, с. 19-52]. 
Стосовно управлінської функції, то в деяких працях цілком вірно наголошується, що науково-педагогічний працівник повинен “не вчити, а спрямовувати учіння” [215, с. 232].

Ми повністю підтримуємо позицію дослідників, які стверджують, що управлінська функція $є$ головною у професійній діяльності науковопедагогічного працівника, оскільки в умовах наявності великої кількості знань (інформації), котрі постійно розширюються, змінюються й оновлюються, він повинен організувати освітній процес так, щоб здобувач вищої освіти, по-перше, навчився сам вибирати найефективніші 3 них для розв’язання конкретної проблеми, яка перед ним виникла; по-друге, був готовим вчитися все життя i творчо розв'язувати будь-яке завдання. Адже, навіть, одне й те саме завдання можна розв’язати багатьма способами, в тому числі й неординарними.

Українські дослідники Л. Подоляк і В. Юрченко прямо заявляють, що «студент є об єктом управління викладача, оскільки діяльність останнього спрямована на зміни особистості майбутнього фахівця». «Функція управління це та роль, яку виконує керівник на певному етапі управління відповідно до поставленої мети». До головних функції управління освітнім процесом автори відносять: 1) проективну функцію, тобто визначення мети і завдань навчання; 2) конструктивну функцію, тобто розробка інструментарію (методів, прийомів тощо) забезпечення освітнього процесу; 3) організаторську і регулятивну функції, тобто практичну організацію освітнього процесу; 4) комунікативну функцію; 5) оцінно-корегувальну функцію. Автори пояснюють: «Залежно від стратегії навчання студентів реалізація кожної 3 функцій педагогічного управління має свою специфіку, на основі якої можна визначити різні моделі управління: модель 1 - авторитарна, пряма й жорстка (у минулому); модель 2 демократична, опосередкована й гуманістична» [199, с. 130-134].

Автори навчального підручника “Вікова та педагогічна психологія”, показуючи “лінії руху досліджень з проблем психології навчання” дійшли висновку, що вони «групуються навколо двох характеристик: по-перше, навчання розуміють як управління процесом учіння, по-друге, виявлення 
можливостей пізнавальної активності учнів, формування умінь “добувати", знання самостійно» [216, с. 316-317].

Дослідники А. Нісімчук, О. Падалка і О. Шпак прямо вказують на те, що педагогічна діяльність «спрямована на реалізацію управління і формування навчальної діяльності того, хто навчається <...>» [217, с. 53].

За допомогою ефективного управління науково-педагогічний працівник спрямовує та активізує пізнавальну діяльність здобувачів вищої освіти, зменшує вплив дестабілізуючих чинників, оптимізує освітнє середовище з метою їх підготовки до фахової діяльності та суспільного життя. Проте здійснення такого управління можливе за умов використання адекватного психологічного підгрунтя.

Вчений М. Найдьонов важливу роль відводить “рефлексивному управлінню", котрому «надається значення спеціалізації управління, яке містить у собі підсистему управління рефлексивним процесом і відбувається як щодо сталих суб’єктів, так і щодо суб'єктів, які перебувають на стадії становлення <...> $[218$, с. 295$]$.

Психолого-педагогічні впливи, взаємодію, контроль і оцінювання рефлексують як науково-педагогічні працівники, так і здобувачі вищої освіти. Таким чином відбувається управління рефлексивним процесом у континуумі індивідуально-групового суб'єкта. Фактично мова йде про особистісну і групову рефлексію. Взаємодія, взаємоузгодження і взаєморозуміння в ході навчальної діяльності здійснюються посередництвом інтелектуальної та особистісної рефлексії як студентів, так і науково-педагогічних працівників.

Можливість особистісної, групової, міжсуб’єктної, змістовної та інтелектуальної рефлексії в ході розв'язання змістовно-смислових педагогічних завдань і порівняння результатів 3 наявною моделлю дає можливість науковопедагогічному працівнику переосмислити форми, методи i засоби управлінського впливу. 3 іншого боку це забезпечує змістовно-смисловий аналіз освітнього процесу.

Звернемо увагу на те, що на центральності управлінської функції 
грунтується і головна ідея Болонського процесу, яка полягає в тому, що здобувач вищої освіти повинен сам “здобувати” знання, а завдання науково-педагогічного працівника полягає у здійсненні управління цими процесами, його поведінкою і мотивацією.

Стиль управління науково-педагогічного працівника освітньою діяльністю здобувачів вищої освіти може бути авторитарним, демократичним або ліберальнопотуральним, які досить повно представлені та охарактеризовані у працях Р. Бойца, В. Болотова та Є. Ісаєва, Л. Макарової, В. Мерліна та ін.

Проте той чи інший стиль майже не зустрічається в чистому вигляді - як правило, реально спостерігається поєднання різних стилів при домінуванні одного. Приміром, сучасні дослідники доводять, що існують такі ситуації, коли найбільш продуктивним та адекватним може бути лише авторитарний стиль [219].

Нами виявлено, що якість управління освітнім процесом студентів визначається доцільністю поєднання науково-педагогічним працівником авторитарного та демократичного стилів управління.

Головними позитивними характеристиками демократичного науковопедагогічного працівника є справедливість, повага до здобувачів вищої освіти, турбота про них, урахування їхніх думок, висування своїх вимого у формі пропозицій, порад, прохань тощо.

Однак, коли здобувач вищої освіти не прикладає зусиль до виконання окремих педагогічних завдань, наприклад, формально ставиться до написання курсової роботи, замість самостійної праці “завантажує” ії з мережі Інтернет, то науково-педагогічному працівникові у цьому випадку доцільно застосувати авторитарний стиль управління, не зарахувавши іiі і примусивши здобувача вищої освіти заново самостійно написати курсову роботу.

Ліберальний (пасивний) стиль управління характеризується тим, що науково-педагогічний працівник надає здобувачам вищої освіти майже повну волю у виборі форм і методів учіння, виконання освітніх завдань, уникає спілкування і взаємодії з ними, або навпаки, говорить багато, але в загальному, щоб сподобатися, не ініціює нові справи, виявляє невимогливість і 
безконтрольність до виконання ними навчальних завдань, не виконує обіцянки та ін. [220].

Для якісної професійної діяльності науково-педагогічний працівник має не лише вміло поєднувати авторитарний i демократичний стилі управління, уникаючи пасивного (ліберального), але і здійснювати науково обгрунтоване управління освітнім процесом, розвитком (саморозвитком) i фаховою підготовкою здобувачів вищої освіти.

Отже, професійно-управлінський блок можна виразити через такі його складові, як: 1) авторитарно-одноосібний стиль управління освітнім процесом здобувачів вищої освіти; 2) одноосібно-демократичний стиль управління освітнім процесом здобувачів вищої освіти; 3) відсутність пасивного стилю управління освітнім процесом здобувачів вищої освіти, що має обернено пропорційну залежність від пасивного стилю управління.

Четвертий блок моделі - професійно-орієнтаційний, через який забезпечується позитивна професійна спрямованість науково-педагогічного працівника.

Ми вважаємо, що професійна спрямованість науково-педагогічного працівника є похідною від його поведінки і взаємин зі здобувачами вищої освіти, котра в цілому являє собою активну ланку його управлінської функціональнопроцесуальної системи.

Професійна спрямованість особистості залежить від спрямованості іiі психіки. На це звертає увагу дослідник В. Москалець, який підкреслює, що «суспільна природа особистості формовиявляється у іï знаннях, уміннях, навичках та утвореннях, що належить сфері спрямованості ii психіки» [221, с. 22].

На нашу думку, це лише доповнює зміст професійної спрямованості науково-педагогічного працівника, оскільки і вона реалізується мотивованою цілеспрямованою поведінкою, що становить собою діяльність щодо досягнення корисного, в даних умовах, результату. 
До основних критеріїв цілеспрямованої поведінки закордонні дослідники А. Ньюелл і Г. Саймон відносять: 1) визначені підцілі; 2) засоби досягнення підцілей і мети; 3) уникнення повторень; 4) насичення. За умови досягнення системою бажаного стану чи близького до нього, вона завершує своє функціонування на тому підгрунті, що мети досягнуто.

Рівень якості змісту професійної спрямованості науково-педагогічного працівника, на нашу думку, адекватно можна виразити через три вектори його активності: перший вектор - “спрямованість на себе”, другий - “спрямованість на формальну взаємодію”, третій - “спрямованість на справу”.

За вектором “спрямованість на себе”, науково-педагогічний працівник закладу вищої освіти більшою мірою вирішує свої проблеми, залишаючи поза увагою проблеми освітнього процесу.

Діяльність викладача за вектором “спрямованість на формальну взаємодію” характеризується формальним його ознаками ставленням до виконання своїх обов'язків, імітацією науково-педагогічної активності. Головна мета такого викладача, з одного боку, - сподобатися здобувачам вищої освіти, а з іншого уникнути скарг, нарікань, критики за безплідну діяльність. Тому він всяко старається не конфліктувати зі здобувачами вищої освіти, не критикувати їх, навіть, за серйозні недоліки. Але разом з цим він не вникає в їхні справи і проблеми, не контролює виконання ними освітніх завдань тощо.

Позитивним вектором професійної спрямованості, який суттєво впливає на якість освітнього процесу, є “спрямованість на справу”, що характеризується його зосередженістю на освітньому процесі, на вивченні та розв'язанні проблем здобувачів вищої освіти, наданням їм практичної допомоги з різних питань. Такий викладач виявляе принциповість і вимогливістю до здобувачів вищої освіти, завжди намагається покращити умови освітнього процесу, впровадити нові форми, методи, педагогічні та інформаційні технології тощо.

Отже, професійно-орієнтаційний блок охоплює такі головні складові: 1) відсутність спрямованості на себе, що має обернено пропорційну залежність від спрямованості на себе; 2) відсутність спрямованості на взаємодію, що має 
обернено пропорційну залежність від спрямованості на взаємодію; 3) спрямованість на справу.

П'ятий блок моделі - професійно-конструктивний, через який забезпечується психолого-педагогічна професійна надійність науковопедагогічного працівника.

Роками на професійну діяльність науково-педагогічного працівника впливають різні як суб’єктивні, так і об’єктивні чинники, які, безумовно, можуть погіршувати їі якість. У випадку, коли якість професійної діяльності науковопедагогічного працівника залишається високою тривалий час, то доречно говорити про його психолого-педагогічну професійну надійність, під якою найчастіше розуміють сталість його фахових компетентностей, особистісних якостей та здібностей, здатності завжди будувати найдоцільніші взаємини зі здобувачами вищої освіти, реалізовувати найефективніший стиль управління освітнім процесом, постійно здобувати найсучасніші передові знання і втілювати їх в освітній процес тощо.

Психолого-педагогічна професійна надійність науково-педагогічного працівника формується за наявності в нього: 1) професійно-когнітивної надійності; 2) професійно-вольової надійності; 3) професійно-емоційної надійності; 4) персоналізації; 5) значущості особистісних досягнень.

Так, професійно-когнітивна надійність науково-педагогічного працівника являє собою стійку, стабільну інтелектуальну його здатність до якісного розв’язання освітніх завдань, креативність та ефективність мислення, інтелектуальну активність і творчість; професійно-вольова надійність високий рівень вольової стійкості, дисциплінованості, самоорганізації, цілеспрямованості й наполегливості в досягненні високих результатів у науковопедагогічній діяльності; професійно-емоційна надійність - здатність генерувати позитивні емоції, бути емоційно чуттєвим до здобувачів вищої освіти, емоційно стійким та толерантним у процесі педагогічної взаємодії з ними; персоналізація (лат. Persona - особистість) - потреба в прояві своєї особистості, усвідомлення власної особистості як суспільно значущої, результатом чого 
виступає його активна освітня діяльність, спрямована на трансляцію іншим своєї індивідуальності; значущість особистісних досягнень - ціннісне ставлення до результатів своєї професійної діяльності, визнання їхньої важливості, значущості.

Психолого-педагогічна професійна надійність науково-педагогічного працівника пропорційно обернена до його психолого-педагогічної професійної деформації, яка розвивається на підгрунті професійного вигоряння, під яким ми розуміємо втрату ним фахової здатності до якісного розв'язання освітніх завдань унаслідок руйнування або старіння попередньої системи знань, умінь i компетентностей, викривлення фахових і особистісних якостей та властивостей, утрати професійної мотивації до досягнення успіху на основі когнітивного, вольового та емоційного вигоряння, деперсоналізації та редукції особистісних досягнень.

Отже, в основі психолого-педагогічної професійної деформації науковопедагогічного працівника лежить його професійне вигоряння, яке охоплює: 1) професійно-когнітивне вигоряння; 2) професійно-вольове вигоряння; 3) професійно-емоційне вигоряння; 4) деперсоналізацію; 5) редукцію особистісних досягнень.

Професійно-когнітивне вигоряння науково-педагогічного працівника являє собою: у процесуальному плані - поступову втрату ним інтелектуальної активності, креативності та ефективності мислення; на результативному рівні інтелектуальну пасивність, ригідність і шаблонність мислення, відсутність новизни і творчості.

Професійно-вольове вигоряння науково-педагогічного працівника відображає: у процесуальному плані - поступову втрату волі до навчальної, наукової, методичної, виховної та організаційної діяльності, розв'язання різнобічних завдань освітнього процесу; в результативному аспекті - нездатність проявляти наполегливість, послідовність і твердість у реалізації завдань освітнього процесу. 
Професійно-емоційне вигоряння науково-педагогічного працівника полягає у поступовому зменшенні позитивних емоцій від професійної діяльності та її результатів аж до повного їх зникнення, а на результативному рівні - повну чи часткову відсутність позитивних емоцій, байдужість, емоційну холодність, емоційну відстороненість від професійної діяльності та її результатів.

Дослідниця Н. Чепелєва у своєму дисертаційному дослідженні емоційного вигоряння викладачів вищих навчальних закладів розглядає його «як варіант дезадаптації, при якому порушується контакт з реальністю; на безпосередньопсихологічному рівні емоційне вигоряння являється наслідком неадекватних дій, в основі яких лежить використання шаблонних і неадекватних ситуації засобів вирішення проблем, що неминуче виникають у професійній діяльності» [223, c. 65].

Деперсоналізація науково-педагогічного працівника - це відсутність у нього потреби в прояві своєї особистості, байдужість до оцінки іншими своїх особистісних, професійних i ділових якостей; деформація стосунків зі здобувачами вищої освіти й колегами по роботі тощо.

Редукція професійних досягнень науково-педагогічного працівника, яка виявляється як тенденція: 1) переоцінки ним своїх професійних досягнень та скептичного ставлення до них; 2) усвідомлення реальної чи уявної некомпетентності, неуспіху в професійній педагогічній діяльності, безперспективності.

Між психолого-педагогічною професійною надійністю науковопедагогічного працівника i його професійним вигорянням (психологопедагогічною професійною деформацією) наявна обернено пропорційна залежність (табл. 1). 
Обернено-пропорційна залежність між психолого-педагогічною професійною надійністю і професійним вигорянням науково-педагогічного працівника

\begin{tabular}{|l|l|}
\hline $\begin{array}{c}\text { Складники психолого- } \\
\text { педагогічної професійної надійності } \\
\text { НПП }\end{array}$ & \multicolumn{1}{c|}{$\begin{array}{c}\text { Складники психолого- } \\
\text { педагогічної професійної } \\
\text { деформації нпП }\end{array}$} \\
\hline Професійно-когнітивна надійність & Професійно-когнітивне вигоряння \\
\hline Професійно-вольова надійність & Професійно-вольове вигоряння \\
\hline Професійно-емоційна надійність & Професійно-емоційне вигоряння \\
\hline Персоналізація & Деперсоналізація \\
\hline Значущість особистісних досягнень & Редукція особистісних досягнень \\
\hline
\end{tabular}

Отже, психолого-педагогічна професійна надійність науковопедагогічного працівника утворює обернено пропорційну залежність 3 його психолого-педагогічною професійною деформацією, котра, своєю чергою, розвивається внаслідок професійного вигоряння, яке відображає професійнокогнітивне, професійно-вольове та професійно-емоційне вигоряння, деперсоналізацію і редукцію особистісних досягнень.

Тому професійно-конструктивний блок якості професійної діяльності науково-педагогічного працівника відображає наявність у нього таких складових як: 1) професійно-когнітивну надійність, що має обернено пропорційну залежність від професійно-когнітивного вигоряння; 2) професійно-вольову надійність, що має обернено пропорційну залежність від професійно-вольового вигоряння; 3) професійно-емоційну надійність, що має обернено пропорційну залежність від професійно-емоційного вигоряння; 4) персоналізацію, що має обернено пропорційну залежність від деперсоналізації; 5) значущість особистісних досягнень, що має обернено пропорційну залежність від редукції особистісних досягнень. 
Таким чином, доведено, що якість професійної діяльності науковопедагогічного працівника являє собою похідну від iï ефективності, котра $є$ доцільно спрямованою за змістом, освітніми функціями та завданнями його керованою, мотивованою, емоційно позитивною психолого-педагогічною взаємодією зі здобувачами вищої освіти, повною реалізацією ним власних знань, умінь, загальних і фахових компетентностей, здібностей, особистісних властивостей та якостей.

Нами розроблена та обгрунтована функціональна модель забезпечення якості професійної діяльності науково-педагогічного працівника, котра відтворює і процес забезпечення його ефективної професійної діяльності, і педагогічні умови, в яких досягається ефективність цього процесу, і можливість оцінювання результату іiі функціонування.

За структурно-функціональним характером модель забезпечення якості професійної діяльності науково-педагогічного працівника являє собою систему психолого-педагогічних елементів (блоків) зі заданими характеристиками i властивостями, певним чином узгоджених за змістом, часом i метою, функціонування яких відтворює процес спрямованої професійної активності науково-педагогічного працівника та його особистісної організації в ході взаємодії зі здобувачами вищої освіти з метою формування у них знань, навичок, вмінь, загальних і фахових компетентностей та особистісних якостей. Дана модель включає такі взаємопов'язані функціональні блоки: 1) знаннєвокомпетентнісно-особистісний, через котрий забезпечується підтримування необхідної сукупності знань, умінь, компетентностей, особистісних якостей і здібностей; 2) професійно-мотиваційний, через який забезпечується формування i підтримування в нього мотивації до досягнення успіху в професійній діяльності; 3) професійно-управлінський, котрий забезпечує ефективне управління ним освітнім процесом здобувачів вищої освіти; 4) професійноорієнтаційний, через який забезпечується його позитивна професійна спрямованість; 5) професійно-конструктивний, через який забезпечується його психолого-педагогічна професійна надійність, попередження розвитку 
професійної деформації. Кожний блок є відносно незалежною підсистемою в системі моделі, яка у функціональному плані розгортається як своєрідний процес, що перебігає за своїми закономірностями, але разом 3 іншими підсистемами, виходячи 3 їх синергійного характеру, в цілісному процесі функціонування моделі забезпечує певний рівень якості професійної діяльності науково-педагогічного працівника.

На основі функціонування знаннєво-компетентнісно-особистісного, професійно-мотиваційного, професійно-управлінського, професійноорієнтаційного та професійно-конструктивного блоків виявлено шістнадцять складових, які в сукупності забезпечують якість професійної діяльності науковопедагогічного працівника, а саме: 1) сукупність знань, умінь, компетентностей, необхідних якостей та їх ефективна реалізація в освітньому процесі; 2) комунікативні здібності; 3) організаційні здібності; 4) мотивація до успіху; 5) відсутність мотивації до уникнення невдачі, що має обернено пропорційну залежність від мотивації до уникнення невдач; 6) авторитарно-одноосібний стиль управління освітнім процесом здобувачів вищої освіти; 7) одноосібнодемократичний стиль управління освітнім процесом здобувачів вищої освіти; 8) відсутність пасивного стилю управління освітнім процесом здобувачів вищої освіти, що має обернено пропорційну залежність від пасивного стилю управління; 9) відсутність спрямованості на себе, що має обернено пропорційну залежність від спрямованості на себе; 10) відсутність спрямованості на взаємодію, що має обернено пропорційну залежність від спрямованості на взаємодію; 11) спрямованість на справу; 12) професійно-когнітивна надійність, що має обернено пропорційну залежність від професійно-когнітивного вигоряння; 13) професійно-вольова надійність, що має обернено пропорційну залежність від професійно-вольового вигоряння; 14) професійно-емоційна надійність, що має обернено пропорційну залежність від професійно-емоційного вигоряння; 15) персоналізація, що має обернено пропорційну залежність від деперсоналізації; 16) значущість особистісних досягнень, що має обернено пропорційну залежність від редукції особистісних досягнень. 


\section{SECTION 3. GENERAL AND PRE-SCHOOL PEDAGOGY}

DOI 10.46299/ISG.2021.MONO.PED.III.3.1

\section{1 Підготовка майбутніх педагогів до реалізації художньо-конструктивної складової мистецько-творчої компетентності дітей дошкільного віку у процесі співпраці з батьками вихованців}

Батьки часто недооцінюють роль мистецько-творчої складової у вихованні та розвитку своїх дітей. Тому майбутнім педагогам важливо сформувати готовність з приводу того, щоб пояснити батькам важливість образотворчої та художньо-конструктивної діяльності підростаючого покоління як вагомого засобу всебічного розвитку дітей, активізації їхніх творчих здібностей. Важливо спонукати батьків навчити дітей способам і прийомам передачі вражень від навколишнього, озброїти їх зображувальними, технічними та композиційними вміннями в конкретному виді образотворчої чи художньо-конструктивної діяльності.

Робота з сім’єю у напрямі художньо-естетичного розвитку дітей дошкільного віку базується на вивченні і врахуванні у педагогічній взаємодії багатьох чинників, що забезпечують умови для саморозвитку та соціалізації дитини за межами родини. Розповіді батьків дітям про образотворче мистецтво, допоможуть вихованцю глибше пізнати світ культури. Консультуючи батьків в означеному напрямі, майбутнім педагогам слід бути готовими доносити до батьків думку про те, що для художнього розвитку дитини важливо ознайомлюватися 3 оригіналами творів мистецтва в музеях, на виставках. Художнє виховання $є$ важливим напрямом естетичного розвитку дітей дошкільного віку. Його зміст полягає у вихованні засобами мистецтва та спрямований на розвиток естетичного сприймання змісту i форми творів мистецтва, формування художніх смаків, творчих здібностей, відповідних умінь та навичок творчої діяльності. Художнє виховання вважають цілеспрямованим процесом впливу на особистість, завдяки якому у дітей дошкільного віку формуються художні відчуття, смак, цікавість до мистецтва. 
Слід взяти до уваги, що художні здібності у дітей дошкільного віку проявляються індивідуально у різний час і в різних формах. А природні задатки та здібності дітей відіграють у художньому вихованні значну роль, проте без систематичного і цілеспрямованого навчання розвиток їх сповільнюється. Існують різні підходи до визначення поняття художньо-естетичне виховання: це процес цілеспрямованого виховання почуття прекрасного; формування здатності сприймати й бачити красу в мистецтві й житті, оцінювати їі; завдання художньоестетичного виховання полягають у формуванні художнього смаку; розвиток здатності до самостійної творчості й створення прекрасного, розвиток уміння творчо створювати продукти творчості; художньо-естетичне виховання містить діяльну і творчу спрямованості, та повинно формувати здатність створювати прекрасне в мистецтві і житті.

Художньо-естетична діяльність $є$ важливим елементом художньоестетичного виховання дітей дошкільного віку, оскільки під час означеної діяльності здійснюється знайомство дитини із основними надбаннями культури, розвиваються розумові здібності дітей, їх інтелект; збагачується емоційна сфера дошкільників і культура почуттів; у дітей формується система моральних цінностей; формуються художні смаки тощо. Ефективним шляхом всебічного гармонійного розвитку особистості $є$ залучення дошкільників до художньоестетичної діяльності, яка включає зображувальну, музичну, театралізовану, художньо-мовленнєву діяльність. Ці види діяльності виконують функцію позитивно-емоційного збагачення, викликають емоції радості, захоплення, натхнення, витісняють тривожність, напругу, почуття безпорадності.

Варто навчати студентів умінню зацікавити батьків напрямами образотворчої діяльності дітей з метою їх залучення до активної взаємодії 3 вихователями та дітьми о означеному напрямі. А саме:

1. Розробити план роботи з батьками щодо художньо-конструктивної діяльності дітей старшого дошкільного віку.

2. Ознайомити батьків з видами образотворчого мистецтва. 
3. Дати рекомендації батьками дітей старшого дошкільного віку щодо художньо-естетичного виховання дітей в умовах сім’ї.

Важливо сприяти усвідомленню батьками важливості художньоконструктивної діяльності дітей задля їх повноцінного виховання та розвитку. Це варто здійснювати під час таких форм роботи: батьківські збори, семінарипрактикуми, індивідуальні та групові консультації для батьків, відкрите заняття 3 художньої праці чи малювання нетрадиційними техніками. При цьому майбутнім фахівцям слід бути готовими до створення міцного ланцюжка взаємодії в означеному напрямі:

між вихователем і батьками (вихователі діляться 3 батьками практичними уміннями та порадами, а також діляться необхідною інформацією 3 приводу того, як організували означену взаємодію батьків з їхніми дітьми в умовах сім'ї. Майбутнім педагогам слід усвідомити, що у цій роботі важливо створити у мови, за яких батьки могли б поділитися своїми проблемами із вихователем, підійти до нього 3 метою отримати потрібну консультацію (індивідуальну чи групову);

- між батьками та дітьми (батьки працюють зі своїми дітьми: в домашніх умовах разом виконують малюнок (виріб) чи діти діляться із батьками своїми враженнями від заняття в дошкільному закладі освіти і демонструють цікаві техніки художнього конструювання чи малювання, 3 якими вони працювали;

спільна художньо-конструктивна чи образотворча робота дітей 3 батьками: спілкування, споглядання, милування об’єктами, явищами природи, навколишнього середовища, цілеспрямовані спостереження, обмін враженнями, спільне вправляння в конструюванні виробів, малюванні та ін.;

між вихователем і дітьми (під час занять з художньої праці чи образотворчої діяльності вихователь вчить дітей малювати чи конструювати у різноманітних техніках, а діти в процесі такої роботи розвивають свої уміння та навички). У процесі такої роботи можна використовувати дидактичні ігри, вправи, виготовлення різних творчих робіт для оформлення групової кімнати, 
подарунків тощо.

Наведемо орієнтовний план роботи з батьками

\section{План роботи з батьками}

\begin{tabular}{|c|c|}
\hline Місяці & Назва заходів \\
\hline Вересень & $\begin{array}{l}\text { 1. Батьківські збори на тему: «Виховуємо дітей старшого } \\
\text { дошкільного віку». } \\
\text { 2. Опитування для батьків на тему: «Дитина в образотворчій } \\
\text { діяльності». } \\
\text { 3. Консультація на тему: «Роль сім’ї у вихованні дошкільників». } \\
\text { 4. Оформлення батьківського куточка. }\end{array}$ \\
\hline Жовтень & $\begin{array}{l}\text { 1. Консультація для батьків «Як провести вихідний день } 3 \\
\text { дитиною». } \\
\text { 2. Анкетування «Ваша дитина», «Чи талановита ваша дитина?» }\end{array}$ \\
\hline Листопад & $\begin{array}{l}\text { 1. Індивідуальні бесіди з батьками за запитами. } \\
\text { 2. День відкритих дверей. } \\
\text { 3. Консультація «Які умови слід створити вдома, щоб виявити } \\
\text { творчі здібності дитини?» }\end{array}$ \\
\hline Грудень & $\begin{array}{l}\text { 1. Бесіда з батьками «Одяг дітей в різні сезони». } \\
\text { 2. Участь батьків у конкурсі «Новорічна іграшка». } \\
\text { 3. Новорічний ранок «Перетворення Діда Мороза». } \\
\text { 4. Залучити батьків до будівель снігових фігур «У світі казкових } \\
\text { героїв» (за відповідної погоди). }\end{array}$ \\
\hline Січень & $\begin{array}{l}\text { 1. Розвага «День здоров’я». } \\
\text { 2. Спільний конкурс малюнків дорослих і дітей на тему «Зимові } \\
\text { розваги». }\end{array}$ \\
\hline Лютий & $\begin{array}{l}\text { 1. Батьківські збори на тему «Світ мистецтва очима батьків та } \\
\text { дітей». } \\
\text { 2. Рекомендації для батьків щодо організації харчування дітей. } \\
\text { 3. Зустріч з психологом «Підготовка дітей до школи». } \\
\text { 4. Конкурс-виставка «Наші таланти». }\end{array}$ \\
\hline
\end{tabular}




\begin{tabular}{|l|l|}
\hline Березень & $\begin{array}{l}\text { 1. Спільне свято «Любі, милі, рідні». Посиденьки з мамами. } \\
\text { 3. Бесіда з батьками «Гігієнічні вимоги до дитячого одягу та } \\
\text { взуття». } \\
\text { 4. Конкурс «Подарунок мамі». }\end{array}$ \\
\hline Квітень & $\begin{array}{l}\text { 1. Участь батьків у святах, розвагах. } \\
\text { 2. «Суботник разом з нами». } \\
\text { 3. Консультація на тему: «Чим і як зайнята дитина». } \\
\text { 4. Залучення батьків до оформлення дитячого майданчика. }\end{array}$ \\
\hline Травень & $\begin{array}{l}\text { 1. Батьківські збори на тему «Чарівний світ книги». } \\
\text { 2. Виставка робіт художньо-продуктивної діяльності «Наші } \\
\text { досягнення». } \\
\text { 3. Випускний вечір. енциклопедії для батьків «Цікаве дозвілля } \\
\text { влітку». } \\
\text { 4. Участь батьків у конкурсі на оформлення літніх ділянок. }\end{array}$ \\
\hline
\end{tabular}

Ефективним шляхом гармонійного розвитку майбутньої особистості $є$ залучення дошкільників до художньо-конструктивної та художньо-естетичної діяльностей, які виконують функцію позитивно-емоційного збагачення, викликають емоції радості, захоплення, натхнення, витісняють тривожність, напругу, почуття безпорадності. Художньо-естетична діяльність задовольняє потребу дітей старшого дошкільного віку у самовиявленні і $\epsilon$ одним із найулюбленіших занять, що позитивно впливає на емоційний стан, загальний психічний розвиток дитини і разом $з$ тим ця діяльність є засобом всебічного розвитку дитини. У такій роботі виділяють низку компонентів, пов'язаних між собою: мотиваційний, цільовий, дійовий, оскільки художньо-естетична діяльність потребує наявності у дітей чітких образних уявлень про предмети та об’єкти, які вони зображають. Ці уявлення формуються на основі естетичного сприймання. При цьому сприймання повинно бути емоційно-естетично забарвленим. Під час навчання у дошкільному закладі освіти дорослим важливо сприяти вихованню в дитини таких якостей особистості, які дозволять їй досягти 
успіху на лише в мистецькій, а й у будь-якій іншій діяльності. Окрім формування художньо-естетичного ставлення дітей дошкільного віку до дійсності i мистецтва, художньо-естетичне виховання також вносить вклад у всебічний розвиток особистості, оскільки різноманітні творчі завдання на заняттях із зображувальної діяльності, художньої праці, самостійної образотворчої діяльності в умовах родини сприяють розвитку мислення і уяви, фантазії вихованців, формують у них наполегливість, виховують організованість, дисциплінованість.

Важливо, щоб батьки зрозуміли, що можна заохочувати дітей до розмальовування нескладних замальовок, пропонувати вихованцям робити доповнення предметних чи сюжетних малюнків, при цьому звертати увагу на підбір відповідних кольорів, охайність розфарбовування. Батькам можна пропонувати милуватись разом 3 дитиною охайно виконаним малюнком, заохочувати, демонструвати своє задоволення ii образотворчістю; залучати дитину до облаштування своєї кімнати, запропонувати прикрасити стіни самостійно розфарбованими шпалерами, розписати глиняний іграшковий посуд, намалювати килимки, доріжки, серветки; прикрасити візерунками паперовий ляльковий одяг.

Слід пояснити, що художньо-творча діяльність дітей є продуктивною: у своїх малюнках, аплікаціях, зліпках вони розповідають батькам про власне ставлення до життя, показують свій психічний стан, прагнення, життєві пріоритети. Аналізуючи продукти творчої діяльності дитини батьки можуть глибше пізнати внутрішній світ дошкільника: інтереси, здібності, потреби, відчуття. Проте їм потрібно уважно ставитися до дитини і цінувати ії творчість. Вміння читати дитячі малюнки, спілкуватися 3 дитиною на їхній основі допоможе досягти діалогу, порозуміння і покращити стосунки батьків і дітей у сімейному колі.

Спілкування батьків 3 дитиною щодо мистецтва є надзвичайно тонкою справою. Тому важливо сприймати дитину як рівноправного партнера художньотворчої діяльності, бути уважними до неї, відчувати ï інтереси, потреби, 
зображувальні можливості і враховувати це у процесі спільної творчої діяльності.

Варто розповісти батькам про те, що одним із завдань художньоестетичного виховання дітей $є$ розвиток у них елементів творчості. Дитяча творчість - перша ланка розвитку творчої діяльності, в якій дитина виявляє своє розуміння довкілля, своє ставлення до нього. Це допомагає дітям старшого дошкільного віку розкрити їх внутрішній світ, інтереси та здібності. Від того, наскільки сприятливими є умови для прояву дітьми здібностей на основі задатків до того чи іншого виду художньої діяльності, залежить формування елементів творчості. При цьому слід враховувати, що зображувальна діяльність у цьому віці має неабиякий позитивний вплив на всебічний розвиток дитини. Важливими 3 цього приводу є міркування О. Горошко яка наголошує на тому, що розвиток зон мозку, які відповідають за мовлення, відбувається під впливом імпульсів, що йдуть від пальців. Якщо розвиток рухів пальців відстає, то затримується й розвиток мовлення, хоча загальна фізична активність дитини при цьому може бути активною. Стимулювання мовленнєвого розвитку дітей шляхом тренування рухів пальців рук є одночасно й підготовкою руки до письма» [226, с. 7]. Задля того, щоб підтримати та гармонізувати художньо-конструктивну та образотворчу діяльність дітей необхідно підтримувати позитивний емоційний настрій у дітей; заохочувати вихованців до довільного малювання, виконання цікавих рухів та інших спонтанних проявів творчої уяви; під час малювання дітьми, дорослому (педагогу, батькам) варто застосовувати творчі методики та ігри зі словами, рухами тіла, звуками, тактильними відчуттями тощо.

Майбутні педагоги повинні бути готовими пояснили батькам те, що феномен дитячого малюнка полягає у його цінності для дитини, є своєрідною формою та засобом комунікації з іншими людьми й однолітками, своєрідною картиною світу; для батьків - це шлях до порозуміння з нею та гармонізації родинних стосунків; для фахівців з дошкільної освіти, педагогів і психологів це засіб розвитку всіх сфер майбутньої особистості дитини. Саме завдяки малюнку дорослі отримують можливість зазирнути у внутрішній світ маленької людини, 
зрозуміти логіку дитячої творчості, бо малювати й думати для неї - одне і те ж came [228, c. 32].

Під час консультації на тему: «Роль сім’ї у вихованні дошкільників», варто наголосити, що художньо-конструктивна діяльність дітей дошкільного віку в сімейному колі закладає основи формування естетичної культури дітей: відбувається перше естетичне сприйняття прекрасного в природі та навколишній дійсності; формуються естетичні смаки й почуття; закладаються передумови для оволодіння дитиною надбань національного мистецтва, музики, побуту, ремесел; формується потреба створювати навколо себе прекрасне; розвиваються задатки та здібності дітей. Надзвичайно важливу роль у вихованні дітей відіграє особистий приклад батьків, їх авторитет, який $є$ дуже індивідуальним та здебільшого грунтується на конкретних вчинках. Батьки в основному послуговуються поясненням, настановою, порадою, розповіддю, навіюванням та ін. Також ефективними є використання вправ і привчань, організація різних доручень та обов’язків дітей, дотримання певного режиму; залучення дітей до навчання, праці та відпочинку; заохочення (похвала, подарунки).

Слід пояснити, що художньо-творча діяльність дітей є продуктивною: у своїх малюнках, аплікаціях, зліпках вони розповідають батькам про власне ставлення до життя, показують свій психічний стан, прагнення, життєві пріоритети. Аналізуючи продукти творчої діяльності дитини батьки можуть глибше пізнати внутрішній світ дошкільника: інтереси, здібності, потреби, відчуття. Проте їм потрібно уважно ставитися до дитини і цінувати їі творчість. Вміння читати дитячі малюнки, спілкуватися 3 дитиною на їхній основі допоможе досягти діалогу, порозуміння і покращити стосунки батьків і дітей у сімейному колі. Спілкування батьків 3 дитиною щодо мистецтва є надзвичайно тонкою справою. Тому важливо сприймати дитину як рівноправного партнера художньо-творчої діяльності, бути уважними до неї, відчувати їі інтереси, потреби, зображувальні можливості і враховувати це у процесі спільної творчої діяльності. 
Партнерство педагогів з родинами вихованців щодо художньо-естетичного виховання полягає в досягненні позитивних результатів внаслідок впровадження тісної взаємодії, що у результаті сприятиме різнобічному та гармонійному розвитку дітей. Така співпраця передбачає орієнтацію на особистість дитини, на iï здатність творчо себе реалізовувати, що в свою чергу потребує створення сприятливих умов для формування творчо-пізнавальних здібностей дитини в образотворчій діяльності. Повага до особистості дитини під час образотворення, передбачає індивідуальний підхід до неї, потребує активного ставлення батьків і також вихователів до художніх інтересів дошкільника задля реалізації іiі здібностей, нахилів. Важливо об’єднати виховні зусилля дошкільного закладу освіти та сім’ї на користь художньо-естетичного виховання дитини.

Майбутнім педагогам слід враховувати і те, що сприятливий розвиток творчості дитини залежить від вмілого планування дорослими (педагогами, батьками) художньо-естетичного впливу на вихованців. Значну роль в організації художньо-конструктивної і образотворчої діяльності дітей, на думку науковців, має здатність дорослого (педагога, батьків) пов'язати особливості створення художнього образу в мистецтві із власне творчою діяльністю дітей дошкільного віку; адаптувати виразні засоби мистецтва живопису, графіки у власну творчу діяльність дітей. Згідно тверджень О. Сухорукової, «образотворча діяльність становить інформаційний простір дитини, з якого вона отримує інформацію і переробляє iï у знання та уявлення про світ, його красу, мінливість i різнобарвність; про культуру та художню спадщину, людину творця; про себе та свої можливості щодо створення моделі світу у художніх образах і набуває досвіду чуттєво-емоційного, художньо-образного, естетичного ставлення до дійсності» [230, c. 197].

Ураховуючи зазначене вище, під час консультації для батьків «Як провести вихідний день 3 дитиною» можна рекомендувати заохочувати дітей до розмальовування нескладних замальовок, пропонувати дітям робити доповнення предметних чи сюжетних малюнків, при цьому звертати увагу на підбір відповідних кольорів, охайність розфарбовування. Батькам можна пропонувати 
милуватись разом 3 дитиною охайно виконаним малюнком, заохочувати, демонструвати своє задоволення їі образотворчістю; залучати дитину до облаштування своєї кімнати, запропонувати прикрасити стіни самостійно розфарбованими шпалерами, розписати глиняний іграшковий посуд, намалювати килимки, доріжки, серветки; прикрасити візерунками паперовий ляльковий одяг. Можна провести з батьками невеличку практичну роботу: ознайомити їх із особливостями використання нетрадиційних технік зображення (наприклад, навчити прийомам кляксографії, спонукати дітей бачити певні образи та домальовувати поодинокі елементи). Для цього можна радити батькам використовувати гуашеву, акварельну фарби, фломастери, аркуші паперу різного формату та розмірів тощо.

Важливим засобом у співпраці педагогів з батьками є організація такої спільної діяльності, у якій батьки не пасивні спостерігачі, а активні учасники освітнього процесу. Педагоги мають можливість залучати батьків до спільної роботи над різними напрямами освітнього процесу, зокрема долучати їх до художньо-естетичного виховання дітей дошкільного вік через засоби естетичного виховання: вони можуть брати участь в художньому оформленні ЗДО, в оформленні групових приміщень, дитячих майданчиків; в оформленні побуту можна використовувати малюнки дітей, вихователів батьків. Членів родини варто залучати брати активну участь у підготовці та проведенні тематичних свят та розваг. А це радість, веселощі, які об’єднують дорослих та дітей, зміцнюють співпрацю між сім’єю та дошкільним закладом освіти. Якщо батьки є зацікавленими у справі повноцінного розвитку, навчання й виховання своїх дітей, спільна участь у творчих звітах, літературних ранках об'єднують сім’ї, ставлять в інші умови та обставини.

Наведемо приклад розповіді-казки, яку можуть використовувати батьки під час образотворення із своїми дітьми: «Жили - були фарби. Вони були дуже веселі, яскраві, радісні і мріяли подарувати свою радість світу, почути завзятий сміх навколо себе. Але життя їх проходило спокійно і тихо у рідному будиночку - маленькій баночці. Одного ранку двері їх дому відчинились - до них завітав 
старий добрий друже пензлик і запросив фарби до прогулянки. Просяяла жовта фарба ласкавою посмішкою і виплеснулась плямою на середину білого поля. За нею зареготала червона фарба і через мить біля них опинилась духмяна зелень це було справжнє свято». Кольорові плями перетворитись у .... (діти разом 3 батьками дофантазовуюють, домальовують своєрідні образи у своїй уяві).

При цьому майбутнім педагогам слід враховувати, що формування творчої особистості дитини це - складний процес, в основі якого лежить гармонійний розвиток почуттів. Тому особливу увагу слід зосередити на комплексному використанні творів образотворчого мистецтва в сенсі загальнолюдської i національної культури, організовуючи цілеспрямоване педагогічне спілкування дітей у середовищі мистецтва (живопису, скульптурі, архітектурі тощо). Реалізація такого підходу сприятиме збагаченню досвіду дітей щодо естетичного бачення навколишньої дійсності, активізації дитячої творчості в процесі художньо-практичної діяльності шляхом поетапного спостереження об’єктів, явищ довкілля у природному середовищі, розглядання творів образотворчого, декоративно-прикладного мистецтва [225, с. 35].

Bce більшої популярності серед дошкільників набувають види нетрадиційного малювання такі, як кляксографія, малювання удвох на довгій смужці паперу, пластилінографія, крапковий малюнок, малювання губкою, малювання через копіювальний, малювання долонькою та пальцями, монотипія, малювання по-мокрому, гратаж, малювання мильними бульбашками, роздмухування плям, воскографія та ін. Як зазначає О. Сухорукова, «дітям подобається усе нетрадиційне» [230, с. 205]. Зокрема учена наполягає на тому, що «періодично слід ознайомлювати дошкільників 3 неординарними методами зображення предметів: зображати чим завгодно на основі різних матеріалів (малювання ганчіркою, паперовою серветкою (складеною в кілька разів); малювання брудною водою, чайною заваркою, кавовою гущею, вижимками із ягід і таке інше; корисно розфарбовувати банки і пляшечки, коробочки, камінчики) i зазначає : «немає межі, повинні бути бажання і творчість самого малюка» [230, с. 205]. Найважливіше - зацікавити 
дитину - спонукати іiі до активної образотворчої діяльності. Так, діти старшого дошкільного віку із «задоволенням працюють в техніках кляксографії, монотипії, штрихування, ниткографії, малюванні восковою свічкою. Їм цікава техніка штампування за допомогою штампів, виготовлених з овочів. Можна пропонувати дітям об'єднувати у своїй роботі декілька технік. Нетрадиційні техніки малювання забезпечують сприятливі умови задля розвитку творчих здібностей дітей старшого дошкільного віку, викликають естетичну насолоду» $[233$, c. 8$]$.

Відтак батькам можна запропонувати відвідати заняття 3 малювання нетрадиційними техніками на тему «Кольорові метелики». При цьому увагу батьків ми зосередити на тому, що виконання зображень у техніці «монотипія» (створення малюнка на основі відбитка) сприяє розвитку уяви, фантазії, логічного мислення; формує умінні аналізувати, порівнювати; потребує зосередженості, охайності, уважності; дає змогу закріпити поняття колірної гами, засвоїти елементарні закони кольорознавства. Така робота дає можливість дитині подивитись на навколишній світ очима творця; активізує інтелектуальну і творчу активність, сприяє розвитку естетичних почуттів та формуванню художніх здібностей дошкільників.

Підчас роботи з батьками в означеному аспекті, варто знайомити їх 3 віковими особливостями образотворчої діяльності дитини старшого дошкільного віку. Так, у 5-6-річному віці дошкільник уже володіє вже певним обсягом образотворчих знань, умінь та навичок, необхідних для художньотворчої діяльності. У процесі створення зображення у дитини формується спостережливість, естетичне сприйняття, художній смак, творчі здібності. Зображувальна діяльність надає можливість доступними засобами виразити емоційний стан дитини, її ставлення до навколишнього світу, вміння самостійно створювати прекрасне. Дитина старшого дошкільного віку уже усвідомлює, що за допомогою образотворчих матеріалів можна передавати об'єкти та явища довкілля. Для цього вона прагне дотримуватись правильних форм, пропорцій, кольору, передавати характерні особливості деталей предметів. Зображувальні 
вміння дають змогу дітям передавати форму предметів та об’єктів за допомогою кольорів та відтінків. Технічні уміння передбачають вибір необхідних прийомів роботи 3 певним матеріалом, володіння способами користування зображувальними інструментами. Композиційні вміння потребують здатності розміщувати предмети чи групи предметів на аркуші паперу (площині) та у просторі, передавати взаємозв'язок між ними. У процесі образотворчої діяльності створюються умови задля розвитку естетичного сприймання, яке поступово переходять в естетичні почуття, що є в основі художньо-естетичного виховання дітей дошкільного віку. Дитина дошкільного віку здатна аналізувати та синтезувати об’єкти задля відтворення їх у художній творчості, проявляє самостійність у виконанні творчих завдань, демонструє інтерес до виконання колективних робіт. Володіючи певними знаннями про сенсорні еталони, у свої

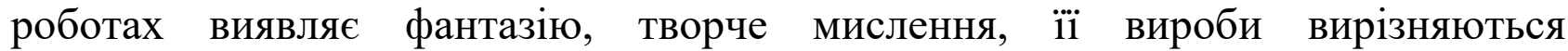
неповторністю та оригінальністю.

Можна розповісти батькам про те, як навчити дитину малювати долонькою та пальчиками: дитина вмочує палець у ємність 3 фарбою і робить відбитки на папері відповідно до запропонованого завдання. Пояснити, що в цьому випадку рука - природне «знаряддя», тому дитині легше отримати зображення через природні рухи самої руки. Примочування по всій площині: «Пальчик гуляє», «Сукня в горошок», «Чашки в горошок». Примочування на обмеженій поверхні: «Гілка горобини», «Вишеньки на тарілочці». Малювання долонькою: «Сонечко», «Дощик», «Тюльпани», «Дерево».

Якщо така робота правильно організована, нетрадиційне малювання нагадує захопливу гру, дає змогу створити позитивну емоційно-психологічну атмосферу, підвищує ефективність оволодіння зображувальними уміннями та навичками, покращує якість виконавської роботи, сприяє розвитку інтересу до зображувальної діяльності.

Також майбутнім педагогам слід бути готовими пояснили батькам, що творчість у дитинстві не самоціль, а засіб та умова всебічного гармонійного розвитку майбутньої особистості, виявлення свого розуміння навколишнього та 
ставлення до нього. Вона допомагає розкрити внутрішній світ, особливості сприймання, уявлень, інтересів, здібностей. Щоб зняти бар’єри у спілкуванні на теми образотворчого мистецтва, варто застосовувати суб'єкт-суб'єктні (діалогічні), інтерактивні (рефлексивні) педагогічні технології, спрямовані на підвищення духовного потенціалу навчально-виховного процесу [229].

На думку науковців та практиків, художньо-кнструктивна та зображувальна діяльність тісно пов’язані із сенсорним вихованням. Чуттєве знайомство дітей старшого дошкільного віку із предметами та явищами, їх властивостями складають лінію сенсорного виховання. Для того, щоб дитині сконструювати виріб, намалювати певний предмет чи явище, потрібно попередньо з ним ознайомитися. Натомість формування уявлень про предмети потребує засвоєння знань про певні властивості та якості предмета чи явища, форму, колір, величину, розміщення у просторі [231, с. 45]. Отож художньоконструктивна та образотворча діяльності вихованців сприяють їх сенсорному вихованню та розвитку у них наочно-образного мислення.

Для того, щоб ознайомити батьків 3 такою інформацією, можна підготували для них папку-пересувку «Ми у мистецтві», у якій розмістити інформацію щодо різних видів конструювання, нетрадиційного малювання та зразків різноманітних технік, поради батькам для проведення занять 3 цього виду діяльності в умовах родини.

Цікавою для батьків може бути консультація на тему «Які умови слід створити вдома, щоб виявити творчі здібності дитини?» Батькам слід пояснити, що художньо-творча діяльність дітей $є$ продуктивною: у своїх малюнках, аплікаціях, зліпках вони розповідають батькам про власне ставлення до життя, показують свій психічний стан, прагнення, життєві пріоритети. Аналізуючи продукти творчої діяльності дитини батьки можуть глибше пізнати внутрішній світ дошкільника: інтереси, здібності, потреби, відчуття. Потрібно уважно ставитися до дитини і цінувати ії творчість. Спілкування батьків 3 дитиною щодо мистецтва є надзвичайно тонкою справою. Тому важливо сприймати дитину як рівноправного партнера художньо-творчої діяльності, бути уважними до неї, 
відчувати іï інтереси, потреби, зображувальні можливості і враховувати це у процесі спільної творчої діяльності.

Художньо-конструктивна діяльність вихованців, мобілізуючи водночас їх розумову діяльність, прискорює розвиток просторового мислення, образного бачення, розвиває розумові здібності, спостережливість та відчуття гармонії. Цей процес є складним, обумовленим віковими та індивідуальними особливостями дитини старшого дошкільного віку. Феномен виробу чи малюнка, створеного дитиною, полягає у його цінності для неї, іiї батьків [232, с. 18].

Художньо-конструктивна діяльність дітей спрямована на розвиток в них перцептивної сфери: формування уявлень про форму, будову, пропорції, динаміку і пластику предметів, реалізацію природної потреби дитини в самостійній, ініціативній, творчій активності, задоволенні особистих інтересів у спілкуванні, грі. Дитина за допомогою зображувальних матеріалів створює об’ємні образи повної або часткової тривимірності, що мають висоту, ширину, товщину. Отож перед батьками постають наступні завдання: викликати інтерес у дітей до творчої діяльності; ознайомити 3 різними матеріалами для виготовлення виробів; навчити різних способів конструювання й допомогти осмислити вихованцям етапи виконання виробів та ужиткові можливості конкретної техніки. Дітям старшого дошкільного віку цікаві й доступні такі прийоми роботи з папером: різання, вирізування, обривання, склеювання, складання і фальцювання (згинання) [231, с. 24]. Зокрема техніка «вирізування зі смужки паперу, складеного навпіл, дає змогу отримати симетричну форму; зі стрічки, складеної «гармошкою», можна отримати зображення, яке стане основою для візерунка; вирізування окремих геометричних форм відкриває можливості для виготовлення мозаїки з кольорового паперу» [231, с. 24].

Художньо-конструктивна діяльність відіграє важливу роль у розумовому, моральному й естетичному розвитку дітей. Вона спонукає дитину дошкільного віку аналізувати, порівнювати, сприяє розвитку пам’яті, уяви і фантазії. Формуються певні спеціальні уміння: формулювати задум і зберігати його в пам’яті впродовж художньо-конструктивної діяльності; використовувати такі 
засоби виразності як колір, форма, композиція; оцінювати свої вироби, відзначаючи при цьому їх якість, зміст, естетичну привабливість тощо. Також діти навчаються планувати свою діяльність; діяти відповідно до інструкції дорослого; здійснювати самоконтроль; самостійно знаходити способи розв’язання поставленого завдання; доводити розпочату справу до завершення $[227$, c. 35$]$.

Під час організації художньо-конструктивної діяльності дітей дошкільного віку бажано дотримуватись певних умов :

- організацію середовища варто будувати за принципами: «культуровідповідності, полікультурності, поліхудожності, природовідповідності, емоціогенності, відкритості закритості, випадковості, проблемності, довіри, діалогу тощо» [230, с. 165];

- забезпечити наповненість освітнього середовища творами мистецтва, потрібною кількістю та різноманітністю якісних зображувальних матеріалів, обладнання;

- творчий підхід до використання матеріалів і технік;

- глибоке розуміння внутрішнього світу дитини, феномена дитячої творчості [230, с. 165];

- синтез і взаємодія мистецтв: активне залучення музики, театрального мистецтва, які визначають зміст діяльності дітей, виступають засобами стимулювання творчої діяльності [230, с. 165].

Художньо-конструктивна діяльність у старшому дошкільному віці потребує цілеспрямованих дій, які, в свою чергу, залежать від багатьох обставин: складності завчання та часу, потрібного для його виконання, від успіху чи невдачі у результаті втілення дитиною власного творчого задуму, від ступеня участі дорослого в реалізації цієї мети. Майбутнім педагогам слід враховувати, що старший дошкільний вік - це вік найбільш інтенсивного розвитку та збагачення різних видів творчої діяльності, яка вирізняється більшим ступенем усвідомленості, стійкості естетичних почуттів, уявлень, оцінок, переконань. У цей період відбувається активне засвоєння дитиною сенсорного досвіду, 
вдосконалення вмінь з оволодіння різними засобами виразності та використання вже знайомих матеріалів у створенні власних робіт; відбувається подальше пізнання краси навколишнього оточення й формування естетичної свідомості; 56-річна дитина повніше відображає предмети та явища навколишньої дійсності, активно виражає емоційне ставлення до них; творчі роботи дітей характеризуються наївністю та щирістю естетичних почуттів, яскравістю барв; формуються найпростіші узагальнені способи побудови образу: поєднання різних технік виконання роботи, навички просторового розміщення елементів, інтеграція різних видів мистецтв тощо; безпосередньому процесу створення робіт передує етап задуму: дитина спочатку уявляє, обдумує спосіб виконання, а потім уже творить.

Варто заохочувати участь батьків у конкурсі «Новорічна іграшка». В домашніх умовах батьки разом $з$ дітьми конструюють 3 кольорового чи білого паперу іграшки, якими можна оздобити групову кімнату та актову залу до свята. Задля того, щоб художньо-конструктивна діяльність дитини старшого дошкільного віку стала засобом формування мистецько-творчої компетентності вихованців, необхідно навчити дітей способам передачі вражень від навколишньої дійсності, озброїти зображувальними та композиційними вміннями в кожному із видів образотворчої діяльності. Адже дитина сприймає мистецький твір з позиції краси та вирізняє його як естетичний; виявляє себе естетично чуйним цінителем; емоційно-ціннісно відноситься до проявів естетичного в житті; реалізує здатність насолоджуватись мистецтвом; переймає духовний потенціал мистецького твору у власний досвід; виховує в собі риси улюблених персонажів; володіє комунікативними навичками спілкування 3 приводу змісту і краси твору; із задоволенням наслідує мистецькі образотворчі зразки; інтегрує в творчих завданнях власні інтереси, уподобання; випромінює благополуччя під час власної мистецької творчої діяльності; має навички рефлексії стосовно свого мистецького досвіду [225, с. 19].

Для налагодження співпраці педагогів дошкільних закладів освіти 3 родинами щодо художньо-естетичного виховання дітей, педагогам варто 
ознайомлювати батьків з тим, як створити в сім'ї умови для успішної художньотворчої діяльності дітей. Форми і методи роботи ЗДО з родинами у напрямі розвитку дітей в царині образотворчого мистецтва мають бути найрізноманітнішими i такими, які сприяють зближенню дітей, батьків i педагогів. Дієвими є запрошення батьків на відкриті заняття з образотворчої діяльності дітей (малювання, ліплення, аплікація, декоративна діяльність).

Задля взаємодії педагогів і батьків щодо художньо-естетичного виховання дітей дошкільного віку ефективними є залучення батьків до організації та проведення свят театралізованих вистав, оскільки така робота дає можливість продемонструвати батькам способи інтеграції різних видів мистецтва задля повноцінного різнобічного розвитку дитини, допомогти усвідомити те, що один вид мистецтва може підсилювати вплив іншого.

Найпопулярнішими у просвітницько-консультативній роботі педагогів 3 родинами вихованців є групові та індивідуальні консультації. За змістом вони можуть бути найрізноманітнішими. Наприклад, педагог радить як саме організувати в умовах сім'ї нетрадиційне малювання дітей; спонукати дошкільників ділитися своїми творчими планами, задумами, розповідати про зміст майбутнього малюнка, про намальовані теми, сюжети. Батькам варто радити співпрацювати 3 дитиною, спостерігати за тим, що їй подобається у образотворчій діяльності, милуватися різнобарв'ям кольорів, пропонувати пояснювати зображення на малюнках. Також батькам варто радити залучати дітей до художньо-дослідницької діяльності, оскільки це розвиває уяву, фантазію, сміливість образотворчих дій, інтерес до самостійних пошуків образів і сюжетів.

Важливо, щоб батьки зрозуміли, що можна заохочувати дітей до доповнення предметних чи сюжетних малюнків, при цьому звертати увагу на підбір відповідних кольорів, охайність розфарбовування. Батькам можна пропонувати милуватись разом 3 дитиною охайно виконаним малюнком, заохочувати, демонструвати своє задоволення iï образотворчістю; залучати дитину до облаштування своєї кімнати, запропонувати прикрасити стіни 
самостійно розфарбованими шпалерами, розписати глиняний іграшковий посуд, намалювати килимки, доріжки, серветки; прикрасити візерунками паперовий ляльковий одяг.

Батьківські збори на тему «Світ мистецтва очима батьків та дітей» допомагають зауважити, що дітям важко самостійно створювати цілісну композицію, яка включає групу об’єктів з урахуванням перспективи - далекоблизько, орієнтуватись на площині аркуша, передавати зовнішні ознаки предметів, обриси яких максимально наближені до реальних. Також не усі діти володіють вмінням малювати мазки в різному положенні пензлика і різного розміру, тонкі лінії, крапки, накладати фарбу на фарбу, добирати відповідні кольори, а також кожна нова нетрадиційна техніка зображення на перших порах викликає труднощі у роботі. Під час створення малюнків на основі відбитків, діти вчаться поєднувати різні матеріали: папір, картон, фарбу, викидні матеріали (корки, кришечки, коробки, шматочки синтетичних матеріалів, пінопласт, губку, сірникові коробки), природні матеріали (листя різної форми, картоплю, яблука, лимони, селеру тощо), пластилін, нитки, скло. Використовуючи в роботі різноманітні матеріали, діти старшого дошкільного віку дізнаються про їхні нові (інші) властивості, способи застосування. Така робота сприяє розширенню світогляду дітей, вони отримують нові знання про навколишній світ. Працюючи із природним матеріалом, вихованці набувають умінь та навичок 3 їх обробки (наприклад, штампуючи листям «осінній ліс»). Природа забезпечує необхідні умови для вивчення властивостей предмета, оскільки надає можливість сприймати його на зір, дотик, слух. Експериментування з природним матеріалом - неодмінна умова розвитку чуттєвого досвіду, розумової діяльності як основи творчої діяльності, конструювання [224].

Задля усвідомлення батьками означеного вище можна провести практикум для батьків, де вихователь дошкільного закладу освіти проаналізує твори образотворчого та декоративного мистецтва, продемонструє творчі роботи дітей; проведе майстер-класи 3 навчання батьків та членів родини різним образотворчим технікам, які можна втілювати разом, поряд 3 дитиною. Результати такої спільної художньо-творчої діяльності дітей та їх батьків можна 
експонувати на:

- образотворчих конкурсах;

- виставках творчих робіт;

- на тематичних виставках у дошкільних навчальних закладах,

- на батьківських зборах;

- зустрічах за «круглим столом»;

- вечорах запитань і відповідей тощо.

Ефективними у співпраці батьків і педагогів щодо художньо-естетичного виховання дітей є спільне розглядання робіт, обмін думками. Зокрема учені радять рекомендувати батькам потурбуватись, щоб у куточку образотворчої діяльності було більше сюжетних картинок про природу, побут, працю, ігри дітей, книжок з ілюстраціями до казок, оповідань, віршів. Педагогам варто радити батькам перейматися почуттями щирої поваги до продукту художньої творчості дітей, висловлювати своє захоплення творчою дитячою ініціативою, образотворчими уміннями, оригінальністю зображення.

Доволі цікавою та результативною є співпраця, яка передбачає взаємодію дітей та батьків. Батькам та дітям можна запропонувати спільно намалювати малюнки, використовуючи нетрадиційні техніки зображення. Зі створених робіт у роздягальні оформити виставку «Світ мистецтва очима батьків та дітей».

Батьки відчувають деяку потребу в порадах з питань ознайомлення дітей дошкільного віку 3 образотворчим мистецтвом (живописом, графікою, скульптурою). Треба радити по можливості привносити його у свій побут i розповідати дітям про нього. Наприклад, про декоративно-ужиткове мистецтво (сервізи, посуд, килими, скриньки, шкатулки, фігурний посуд тощо), яке повсякчас оточує дитину.

Окремої уваги у художньо-естетичному вихованні дітей заслуговує дитяча художня книжка і педагогічна робота батьків 3 нею. Педагоги радять формувати у дітей ціннісне ставлення до книги як до цінного здобутку людської культури. Книжка не тільки розширює уявлення дітей про навколишнє середовище, вводить в особливий витончений світ почуттів, переживань, емоційних почуттів. 
Через єдність мистецтва слова і графіки дошкільник пізнає світ не лише розумом, а й серцем. Батькам, працюючи з книжкою, варто розповісти дитині про те, що вона $є$ мистецьким здобутком письменника, художника-ілюстратора i поліграфістів-видавців. Робота 3 дитячою книжкою та ілюстраціями в сім'ї має бути різноманітною за формами і методами. Це спілкування 3 мистецтвом. Потрібно вернути увагу на те, що на ній художники-ілюстратори зображають головних героїв або кульмінаційні ситуації твору. Особливо цінними для розвитку дитини дошкільного віку є розповіді батьків і дітей за ілюстраціями (наприклад, уявне входження дитини в картину, ілюстрацію). Така робота $\epsilon$ засобом розвитку творчої уяви, фантазії, активного мислення та мовлення. А зі старих книг, педагоги радять зробити фланелеграф: вирізати з журналів малюнки різних предметів, людей, тварин, птахів, транспорт, будинки і т. д. Нехай дитина малює на фланелеграфі різні ситуації. Надалі розповідає, що роблять герої викладених нею картинок, хто з них намальований.

Ще однією ефективною формою роботи є групове родинне свято «Любі, милі, рідні»:

- конкурс «Подарунок мамі» - кожній дитині пропонується розрізана на частини вітальна листівка, діти грають гру «Хто швидше складе картинку»;

- естафета «Намалюємо хатину» - команда обирала художника, який буде малювати із закритими очима, а інші учасники підтримувалти його та підказували.

Значну увагу у співпраці вихователів дошкільних закладів освіти 3 батьками щодо розвитку художніх вмінь та навичок старших дошкільників засобами образотворчого мистецтва слід приділяти індивідуальним та груповим консультаціям. За результатами роботи дітей на заняттях, батьки отримують індивідуальні рекомендації з малювання та конструювання разом зі своїми дітьми. Слід враховувати, що у дитини може проявитися відсутність бажання займатися художньою діяльністю (наприклад, мала певний досвід незадоволення своїх потреб у цьому виді діяльності; не впевнена що зможе успішно виконати завдання). Іноді така ситуація виникає з тієї причини якщо дитина тривалий час 
не відвідувала дошкільний навчальний заклад, що призвело до відставання від інших дітей групи щодо засвоєння художніх умінь та навичок. Часто причиною небажання займатися художньою діяльністю є тимчасове переживання неуспіху. У таких випадках варто застосувати такий прийом спільної художньої діяльності батьків та дитини. Наприклад: «Давай з тобою удвох зробимо красиву аплікацію на хустинці. Якщо нам не сподобається (вона буде не красивою), ми зробимо іншу».

Виставки дитячих малюнків є одним з ефективних засобів естетичного впливу на дитину. Організація виставки в груповій кімнаті мобілізує і згуртовує дитячий колектив, а вихователю дошкільного навчального закладу дає можливість пізнати краще дітей своєї групи. Окрім того, виставки мають i пізнавальне і виховне значення як для тих дітей, які беруть участь в експозиції, так і тих, які лише оглядають iї.

Отже, співпраця з батьками щодо формування мистецько-творчої компетентності дітей має бути спрямованою на вирішення таких завдань, як: формування у дітей художньо-естетичного відношення до дійсності, художнього пізнання світу та його образної оцінки; розвиток специфічних для художньотворчого процесу універсальних якостей особистості, художньо-творчої уяви, оригінального, нестереотипного асоціативно-творчого мислення, художньообразних якостей зорового сприйняття, спостережливості, зорової пам'яті та ін.; формування знань і уявлень про образотворче мистецтво, навичок розуміння мови різних видів образотворчого мистецтва; формування у вихованців потреб і здібностей до продуктивної художньої творчості, вміння створити виразний художній образ, оволодіння основами художньо-образної мови і виражальними можливостями художніх матеріалів і різних видів художніх технік. 


\subsection{Methodological foundations of ecological education of preschool children}

Екологічна освіта поза всяким сумнівом $є$ одним із найважливіших напрямів сучасної педагогічної науки. Ї̈і актуальність обумовлена необхідністю виховати наступні покоління на нових світоглядних засадах, завдяки чому лише й можливе подолання екологічних проблем людства. Крім того, екологічна освіта розглядається сучасними науковцями та практиками як провідний чинник гуманізації освітнього процесу, важливий фактор особистісного розвитку дитини.

У сучасній філософській та психолого-педагогічній науці немає дискусії про те, коли саме слід розпочинати екологічну освіту. Сензитивним періодом для формування основ екологічної культури є дошкільний вік, коли дитина починає пізнавати навколишній світ. Саме тоді закладається система цінностей, якими вона керуватиметься у своїй взаємодії з цим світом. На дошкільний вік припадає надзвичайно важливий етап становлення екологічної культури, пов'язаний із формуванням у дитини первісних уявлень про природу, виробленням емоційнопозитивного ставлення до неї, усвідомленням себе як частини природи, яка існує у нерозривній єдності з іншими компонентами довкілля. На цій основі у дитини виникає відчуття відповідальності за те, що відбувається навколо неї та внаслідок їі дій у довкіллі.

Результативність екологічної освіти дошкільнят значною мірою залежить від особистої позиції дорослих, які їх виховують, їх екологічного світосприймання та вміння передати малюкам своє ставлення до природи, розуміння власної ролі у її збереженні. Хоча, безперечно, роль батьків у формуванні ціннісних орієнтацій та базису особистісної культури дитини величезна, але в цьому випадку ми маємо на увазі в першу чергу педагогів, вихователів закладу дошкільної освіти, де уже 3 перших років життя малюка здійснюється систематичне, цілеспрямоване ознайомлення дітей із світом природи. Актуальність екологічної освіти підростаючого покоління привела до 
надання усій роботі по ознайомленню дошкільників з природним довкіллям екологічного спрямування.

У зв’язку з цим особливе місце серед загальних питань дошкільної педагогіки та методики ознайомлення дітей з природою займає проблема вибору методологічних засад, на яких, у свою чергу, грунтується визначення конкретних завдань та принципів, що стануть найголовнішими у роботі 3 дітьми. Від цього залежатиме уже й розробка власне методики екологічної освіти: визначення змісту природознавчих уявлень, які складуть основу екологічного світосприйняття, обгрунтування методів, методичних прийомів та форм пізнання дітьми дошкільного віку світу природи.

Для визначення методологічних основ екологічної освіти проаналізуємо філософські та філософсько-педагогічні концепції, у яких розглядаються питання про місце людини у довкіллі, взаємозв'язок людини, природи та суспільства. Серед них найбільший вплив на розвиток сучасної освіти, у тому числі, й дошкільної, має концепція сталого розвитку. Як зазначають О. Ватченко та В. Ільченко [234], усвідомлення того, що основою формування майбутнього людства є сталий (збалансований, стійкий) розвиток, яке почало з’являтися у останній чверті XX сторіччя, стало новим етапом у розвитку суспільства i сформувало нову парадигму наукового мислення. Автори наводять визначення поняття «сталий розвиток», зафіксоване у документах Міжнародної комісії 3 навколишнього середовища і розвитку (1987р.): «Це такий розвиток, який задовольняє потреби сьогодення, але не ставить під загрозу можливість майбутніх поколінь задовольняти свої потреби» [234, с. 65].

Отже, «Сталий розвиток» (англ. «Sustainable development») - це загальна концепція стосовно необхідності встановлення балансу між задоволенням сучасних потреб людства і захистом інтересів майбутніх поколінь, включаючи їх потребу в безпечному i здоровому довкіллі [234, с. 65]. Саме на цій методологічній основі можливе формування екологічної культури і дорослих, i дітей, починаючи з дошкільного віку. 
Інтерес педагогіки до цієї філософсько-екологічної концепції не випадковий, адже з іï аналізу серед іншого випливає, що екологічна освіта має розвиватися випереджальними темпами, оскільки, вона може стати основою нової моделі освітньої системи як необхідного елемента переходу сучасної цивілізації до сталого розвитку [235, с. 46]. Саме з огляду на це, у Базовому компоненті дошкільної освіти [236] визначено основну мету ознайомлення дітей 3 природою як формування у них природничо-екологічної компетенції та навичок, орієнтованих на сталий розвиток. Зрозуміло, що ці два важливих завдання між собою тісно взаємопов'язані. Природничо-екологічна компетенція - це здатність дитини до доцільної поведінки в різних життєвих ситуаціях, що грунтується на емоційно-ціннісному ставленні до природи, знаннях іiі законів та формується у просторі пізнавальної, дослідницької, трудової, ігрової діяльності. Навички, орієнтовані на сталий розвиток, виявляються у сформованості в дітей початкових уявлень про сталі дії і поведінку, усвідомленні необхідності збереження ресурсів планети й особистої причетності до цього; розвиненості ефективних звичок соціальної поведінки, економного споживання ресурсів та збереження природи [236].

О. Каверін та Д. Массеров наголошують, що освіта для сталого розвитку має складний міждисциплінарний характер, який вимагає поєднання традиційних освітніх методів з активними методами освіти, такими як імітаційні ігри, ігрові методи створення команд, робота в малих групах, ділові ігри [235, с. 50] тощо. Зразком такого підходу є науково-методичні розробки українських вчених Н. Гавриш та О. Пометун «Дошкільнятам - освіту для сталого розвитку» [237]. Програма спрямована на формування у дітей, а через них - і у їхніх батьків та самих педагогів, які іï реалізовують у закладах дошкільної освіти, життєво важливих навичок екологічно-, економічно- й соціально доцільної поведінки, без якої неможливе створення та існування суспільства, орієнтованого на сталий розвиток. Перелік запропонованих авторами програми тем охоплює взаємодоповнюючі сфери сталого розвитку: соціальну, економічну та екологічну й є традиційним для освіти для сталого розвитку [237]. 
3 філософської точки зору в основі концепції сталого розвитку за великими рахунком лежить біоцентризм, який є одним з відгалужень екоцентризму - течії біоетики, що виходить 3 уявлень про явний пріоритет збереження екологічної сфери планети (включаючи і їі неживі елементи) над задоволенням поточних потреб людини, і розглядає як самостійну цінність екосферу в цілому. На жаль, у нашому суспільстві ще й досі не зжиті погляди, в основі яких лежить протилежне до біоцентризму філософське спрямування - антропоцентризм, при якому в системі люди - природа людина розглядає себе як головну дійову особу, яка може змінити своє оточення як їй заманеться, для власного блага і спрямовує свою діяльність на підкорення природи. Історико-педагогічний аналіз доводить, що впродовж майже всього періоду становлення i розвитку методика ознайомлення 3 природою дітей дошкільного віку, як і методика вивчення природознавства у школі, будувалися переважно на антропоцентричній методології. Тому при доборі конкретного змісту освітньої роботи 3 дошкільниками, розробці методів та технологій важливо уникнути ситуації, коли мета і завдання екологічної освіти базуються на новій екологічній парадигмі (біоцентризмі, концепції сталого розвитку), а добір змісту і методик мимоволі повертає до старої парадигми - антропоцентричної. До прикладу, відлунням антропоцентричного підходу у змісті уявлень дошкільників про природу $є$ традиція поділу рослин і тварин на корисних і шкідливих, красивих і потворних і навіть подекуди «хороших» і «поганих». Хоча у більшості випадків вихователі уникають таких прямих означень, але часто підштовхують дітей до подібних висновків непрямо. Скажімо, такі, здавалося б «правильні» теми, як лікарські рослини, їстівні та отруйні гриби, свійські тварини, за неправильно розставлених акцентів можуть вести до формування споживацького погляду на навколишній світ, виробляти у дітей уявлення про необхідність дбайливо ставитися тільки до тих об'єктів природи, що мають практичне значення для людини, i про необов'язковість такого ставлення до інших, що суперечить ідеї самоцінності природи, яка лежить в основі біоцентризму. 
Пошук методологічних засад екологічної освіти дітей дошкільного віку примушує звернути увагу також на філософське вчення про соціальноекологічний ідеал - образ досконалого навколишнього світу, який виникає у свідомості людини чи всього людства в результаті опанування знаннями про навколишній світ та набуття досвіду його перетворення. У реальній практиці функціонування сучасного суспільства соціально-екологічний ідеал трансформується через систему освіти у своєрідний ідеал стійкого розвитку людини і біосфери [238]. В його основі лежать ті ж самі філософські концепції стійкого розвитку та біоцентризму, які умовно можна об'єднати у так звану філософію виживання людства загалом та його окремих складників зокрема.

Оскільки формування соціально-екологічного ідеалу відбувається саме у процесі пізнання дитиною навколишнього світу, важливо не лише зрозуміти сутність ідеалу та його складові. У освітній роботі слід врахувати, які $з$ цих складників формуються уже в дошкільному віці, і обрати ефективні засоби впливу на дитину. Аналізуючи проблему соціально-екологічного ідеалу, дослідники А. Гайдамак та Т. Тійтанен [238] зазначають, що його формування базується на певній сукупності знань, зокрема, основ екології, які дитина починає опановувати 3 дошкільного віку. Численними дослідженнями i практикою дошкільної освіти доведено, що дошкільнятам доступні чимало екологічних понять (знання про залежність живих організмів від умов існування: екологічні потреби рослин, пристосувальні властивості тварин, сезонні зміни в живій та неживій природі тощо), тому їх засвоєння передбачається більшістю програм розвитку і виховання дітей дошкільного віку. Однак для повноцінного ідеалу самих знань недостатньо, тому екологічна освіта дошкільників - це не тільки сума знань, але й оцінка, усвідомлення екологічної цінності природи в іiі єдності з людиною. Послідовність формування соціально-екологічного ідеалу особистості та його зміст з точки зору біоцентричної філософської концепції можна подати у вигляді наступної схеми (таблиця 1). 
Таблиця 1

Послідовність формування соціально-екологічного ідеалу

\begin{tabular}{|c|c|c|}
\hline $\begin{array}{c}\text { Складові частини } \\
\text { соціально - } \\
\text { екологічного ідеалу }\end{array}$ & $\begin{array}{c}\text { Зміст з точки зору } \\
\text { біоцентричної парадигми }\end{array}$ & $\begin{array}{l}\text { Віковий період, } \\
\text { сензитивний для } \\
\text { формування }\end{array}$ \\
\hline $\begin{array}{c}\text { Ідеал світу красивого } \\
\text { (Естетичний } \\
\text { компонент) }\end{array}$ & $\begin{array}{c}\text { Емоційно-позитивне ставлення } \\
\text { до природи; естетичне } \\
\text { сприймання природи. }\end{array}$ & $\begin{array}{c}\text { Ранній та молодший } \\
\text { дошкільний вік. }\end{array}$ \\
\hline $\begin{array}{c}\text { Ідеал світу доброго } \\
\text { (Моральний } \\
\text { компонент) }\end{array}$ & $\begin{array}{c}\text { Усвідомлення самоцінності } \\
\text { природи; уявлення про } \\
\text { моральне ставлення людини до } \\
\text { природи. }\end{array}$ & $\begin{array}{l}\text { Середній та старший } \\
\text { дошкільний вік. }\end{array}$ \\
\hline $\begin{array}{l}\text { Ідеал світу } \\
\text { розумного } \\
\text { (Когнітивний } \\
\text { компонент) }\end{array}$ & $\begin{array}{c}\text { Знання основ екології - науки } \\
\text { про взаємозв'язки у природі. }\end{array}$ & $\begin{array}{c}\text { Старший дошкільний та } \\
\text { шкільний вік. }\end{array}$ \\
\hline $\begin{array}{c}\text { Ідеал світу } \\
\text { активного } \\
\text { (Дієвий компонент) }\end{array}$ & $\begin{array}{c}\text { Спілкування з природою; } \\
\text { перетворення природи } 3 \\
\text { врахуванням її законів; охорона } \\
\text { природи. }\end{array}$ & $\begin{array}{c}\text { Старший дошкільний та } \\
\text { шкільний вік. }\end{array}$ \\
\hline
\end{tabular}

Як бачимо з таблиці, для трьох-чотирьохрічних малюків ідеальний світ це світ красивий, яскравий, сприймання якого дарує естетичну насолоду. У чотири-п'ять років починається усвідомлення цінності природи, яке виростає на основі емоційно-позитивного ставлення до природи, пов'язаного з ії естетичним сприйняттям. Досить часто діти цього віку пояснюють своє ставлення до того чи іншого об'єкта природи саме красою (те, що було сприйняте, як прекрасне, вже тільки через це є цінним). У зв'язку з цим, як наголошують А. Гайдамак та Т. Тійтанен [238], у дошкільний період у процесі формування екологічного ідеалу основна увага має приділятися саме естетичній і моральній його сторонам, конкретніше, вихованню морально- і естетико-екологічних знань. Важливою особливістю формування естетичного та морального компонентів екологічного ідеалу є їх нерозривна єдність, де моральне (а виходить, і прекрасне) ставлення до природи розглядається як моральне (і тому прекрасне) стосовно інших людей, тому що природа $є$ тим середовищем, без якого немислиме людство [238]. 
Не можна не погодитися 3 думкою А. Гайдамак та Т. Тійтанен [238], що основним засобом формування соціально-екологічного ідеалу в дошкільному віці може стати казка. Вчені справедливо зазначають, що історично казка виступає як певний рівень вираження знань і вимислу, ціннісних орієнтації $\mathrm{i}$ сподівань, кращої поведінки людини, тобто як певний рівень вираження ідеалу людства. Саме в казці в дивному сплаві поєднуються у ставленні до природи добре і прекрасне, зле і потворне, що знаходить висвітлення не тільки в змісті, але й в емоційно-образній формі, у мові. Тому пізнавальні, естетичні і моральноповедінкові завдання формування соціально-екологічного ідеалу вирішуються через казку в їхній єдності.

Казки про тварин, які традиційно використовують у роботі з дітьми раннього та молодшого дошкільного віку, виступають для малюків своєрідним джерелом першої екологічної інформації: саме 3 казок діти дізнаються про зовнішній вигляд, умови життя та деякі повадки багатьох тварин, в казках відображаються також окремі аспекти ставлення людей до природи, екологічні взаємозв'язки у довкіллі. Сюжети добре відомих дітям народних казок можуть стати основою для проведення заняття у формі гри, метою якої є формування у малят перших узагальнень та природничих понять. Так, українські народні казки «Колобок», «Рукавичка», «Солом'яний бичок» допоможуть сформувати узагальнене поняття про диких тварин та середовище їх існування (ліс), а ознайомлення дітей $з$ домашніми тваринами можна провести, використавши казки «Курочка Ряба», «Котик і Півник» або «Півник і двоє мишенят».

У середній групі, де на перший план повинні вийти моменти активнодієвого та морально-естетичного ставлення до природи, вихователь може використовувати казкових персонажів як приклади такого ставлення. Особливо цінні в цьому плані чарівні казки, у яких яскраво показані позитивне та негативне ставлення до природи. За рахунок уже наявного в казці протиставлення наслідків правильної та неправильної поведінки персонажів дітям легко її оцінити, а також перенести цю оцінку за межі казки, у відповідні ситуації реального життя. Оскільки у цьому віці значно зростає інтерес дітей до художньо-виконавської 
діяльності, 3'являється можливість поєднати казку із провідною діяльністю дошкільнят - грою. Ігри-драматизації, у яких діти відображають у ролях ті чи інші форми екологічної поведінки, даючи при цьому їм оцінку, допомагають дітям набувати досвіду втілення в життя своїх екологічних знань та своїх перших ідеалів.

Розуміння закономірностей формування біоцентричного за змістом соціально-екологічного ідеалу дозволяє проаналізувати з позиції біоцентричної парадигми не лише зміст, а й методи, які найчастіше застосовують вихователі 3 метою екологічної освіти дітей дошкільного віку, Зрозуміло, що казка - не єдиний ефективний засіб формування соціально-екологічного ідеалу в дошкільному віці. Не менш важливим засобом є безпосереднє спілкування дітей 3 природою. Тому особлива увага науковців звернена до тих методів, які можуть забезпечити взаємодію дошкільнят з природним довкіллям. Мова йде у першу чергу про спостереження - метод, що передбачає безпосереднє сприймання дітьми природи. Мета будь-якого спостереження у природі - дати можливість дітям поспілкуватися 3 живим об'єктом, розглянути його, закласти основи для появи у дітей емоційно-позитивного, турботливого ставлення до цього об'єкта. Безперечно, під час спостереження у дітей також потрібно формувати уявлення про рослини та тварин як живі істоти, показувати взаємозв’язки, що існують в природі [239]. Однак, коли мова йде про дітей молодшого дошкільного віку, то у спостереженні головним має бути все ж не пізнавальний, а естетичний аспект. Тобто, перші спостереження, це, швидше, милування природою, адже саме це відповідає потребам дитини сприймати світ з позиції краси. Проводячи спостереження, вихователь повинен пам'ятати, що дитина спочатку помічає в предметі найяскравіше, те, що впадає в око, й емоційно відгукується на нього. Тому під час спостереження слід не лише дати дітям можливість помилуватися явищем природи, а й вільно висловити свої почуття дорослому та один одному. Вже $з$ перших хвилин спостереження дітям необхідно відчути ставлення самого вихователя до спостережуваних явищ природи. У цьому можуть допомогти сюрпризний момент, влучні вислови та описи, яскраві порівняння. Варто 
врахувати, що маленькі діти легко знаходять красу в будь чому (для них красива не тільки троянда, а й колючий будяк; не лише яскравий метелик, а й зелена гусінь чи майже прозорий черв’ячок; як дорога породиста кішка, так і маленьке замурзане дворове цуценя тощо), у них відсутнє сприйняття природного об'єкта як потворного та почуття гидливості до нього, якщо, звичайно, дорослі вже не передали дитині свої негативні установки щодо окремих об'єктів довкілля. А саме цього і слід, в першу чергу уникнути, щоб не повернути уявлення дитини про ідеальний світ у старе антропоцентричне русло.

Отже, проводячи спостереження 3 молодшими дошкільниками, краще використовувати для підвищення пізнавального інтересу дітей прийоми, що впливають на емоційну складову пізнання (загадки, ігрові прийоми, побудовані на персоніфікації об’єктів природи, музика чи художнє слово).

В подальшому, коли діти стають старшими, вихователь має урізноманітнювати методику керівництва спостереженнями, поступово включаючи до іiі структури такі прийоми, які активізують самостійну думку дітей, спонукають до елементарного пошуку, розмірковування [239].

Загалом у екологічній освіті старших дошкільників вже значно більше уваги має надаватися формуванню наступних складових соціально-екологічного ідеалу, когнітивній та дієвій, оскільки саме у цьому віці, який невипадково названо віком чомучок, ідеальний світ дитина уявляє вже не лише як красивий $\mathrm{i}$ добрий, а й як розумний і активний. Дієвими у пізнанні природи стають такі методи, які дозволяють досліджувати світ, перетворювати його (елементарні досліди, творчі ігри та праця у природі, навчальні дослідження, екологічні проєкти тощо).

Підсумовуючи, можемо зробити висновок, що нові світоглядні орієнтири та соціальні завдання, які стоять нині перед людством, вимагають корекції ставлення людини до природи, нових ціннісних орієнтацій та утвердження гуманістичних соціально-моральних позицій щодо використання природи суспільством. Це надає особливої ваги питанню вибору методологічних засад екологічної освіти дітей починаючи 3 дошкільного віку. Найповніше мета 
екологічної освіти може бути досягнута, якщо робота 3 дітьми буде здійснюватися з позицій біоцентричної парадигми, що приведе до формування у підростаючих поколінь екоцентричного соціально-екологічного ідеалу та навичок, орієнтованих на сталий розвиток. 
DOI 10.46299/ISG.2021.MONO.PED.III.3.3

\section{3 Умови формування та розвитку музичної культури школярів у процесі навчання}

Учитель музичного мистецтва перед тим як приступити до дослідження рівня розвитку музичної культури школярів підліткового віку, перш за все, повинен врахувати особливості, які притаманні дітям даної вікової категорії. Зазвичай, оцінюючи підлітка просто зі сторони, буває доволі непросто дізнатися про його смаки, уподобання, схильності. Проте уважний та досвідчений вчитель розуміє, що те, що знаходиться у дитини в глибині душі, i те, який у неї внутрішній світ досить часто проявляє себе зовні в таких виявах як посмішка, погляд, голосова інтонація. Сказати про людину, що вона є духовно багатою можна у тому випадку, коли іï вчинки збігаються зі словами і доводять наявність у неї особливого внутрішнього світу, який прикрашений зовні проявами доброти, щирості і глибини. У такий же спосіб нам вдається визначити чиюсь внутрішню порожнечу і духовну убогість. Це, у переважній більшості випадків, відбувається тоді, коли неозброєним оком видно, що людина живе лише практичними і матеріальними інтересами.

Проте, перш за все необхідно враховувати незаперечні моменти, що «... підлітковий період - це лише етап, який характеризує формування особистості, $\mathrm{i}$ тому, очевидно, в жодному разі не можна впевнено і переконливо вважати учня свідомо «духовно нерозвиненим», «мало емоційним» і т. д.» [240, с.23]. Також, учитель музичного мистецтва повинен пам'ятати, що в житті кожної дитини, а особливо дитини-підлітка, отримують свого розвитку дві течії. «Одна із них видима - це те, що відбувається з дитиною зовні, зовнішні події; інша - яка $є$ непомітною і незрозумілою сторонньому недосвідченому погляду - це те, що насичене потаємними думками, глибинними переживаннями, пошуками духовного начала, і свого власного «Я». Доволі часто саме у цьому зосереджено основний зміст людського буття» [240, с.23].

Крім усього зазначеного зауважимо, що для учителя музичного мистецтва важливо знати, що взаємовідносини в колективі дітей підліткового і юнацького 
віку вибудовуються на основі суперечливої взаємодії двох потреб: відокремлення від усіх, занурення у свій внутрішній світ і афіліації - потреби у приналежності, долучення в якусь групу чи спільноту. Найчастіше відокремлення виявляється у прагненні до незалежності від контролю батьків і вчителів. Проте, воно діє також і в стосунках з особами однієї вікової категорії.

У підлітковому віці зростає потреба не лише в соціальній автономії, а також і в автономії просторовій, територіальній, в дотриманні дистанції та обмеженні втручання у свій особистий простір. У перехідному віці змінюється трактування змісту таких понять, як «самотність» і «усамітнення». Підлітки намагаються наповнити ці значення психологічним змістом, водночас приписуючи їм не лише негативний, а також і позитивний сенс і цінність. Деякі науковці вважають, що від підліткового віку до юнацького позитивне значення перебування на самоті, усамітнення поступово зростає, а його негативний сенс - поступово зменшується і нівелюється.

Спостереження доводять, що чим більш самостійною і цілеспрямованою є молода людина, тим сильнішою буде у неї бажання і потреба перебувати на одинці. Проте, на думку багатьох науковців в галузі педагогіки та психології, у молодої людини окрім умиротвореного та спокійного усамітнення трапляється також і напружена і болісна самотність. Цей стан супроводжується тугою, ізоляцією духовною і душевною, почуттям незадоволеної людської близькості, потреби у спілкуванні. Згідно результатів масових опитувань у 1990-1991 роках діти підліткового віку і юнаки почувають себе самотніми і незрозумілими значно частіше, аніж люди старшого віку.

Відчуття самотності та неприкаяності, що пов’язані з віковими труднощами становлення особистості, саме і породжують у підлітків неймовірну спрагу до спілкування з однолітками в певних групах чи угрупуваннях, в товаристві яких знаходять чи мають надію знайти те, чим не можуть їх задовольнити старші, а саме спонтанність, порятунок від нудьги, емоційне тепло, визнання власної значущості. 
Спілкування є провідною діяльністю дітей підліткового віку, враховуючи нездоланну потребу підлітка у спілкуванні. У багатьох дітей ця потреба перетворюється в стадне почуття, яке неможливо подолати, і тоді вони не можуть не лише дня, але й години пробути за межами свого чи будь-якого іншого товариства. Вважається, що особливо яскраво вираженою і сильною така потреба $\epsilon$ у хлопчиків.

«При зовнішній схожості контурів соціальної поведінки глибинні мотиви, що ховаються за юнацькою потребою в афіліації, насправді є індивідуальними і різноманітними. Адже, один шукає в товаристві однолітків підкріплення відчуття самоповаги, визнання своєї цінності і неповторності. Для іншого важливе почуття емоційної неподільності і співпричетності з групою. Третій у своєму оточенні черпає досі відсутню інформацію і оволодіває комунікативними навичками. Четвертий прагне задовольнити свою потребу домінувати над іншими, брати правління і керування у свої руки. У переважній більшості випадків ці мотиви переплітаються і не сприймаються на свідомому рівні» [241, c.34].

Однією з типових рис підліткових груп є те, що вони палко боронячи їх незалежність від старших, у той же час мають зовсім некритичне ставлення до вчинків і думок власної групи та іiі лідерів. «Незміцніле, дифузне «Я» має потребу в сильному «Ми», яке, в свою чергу, затверджується на противагу якимсь «Вони». Причому все це повинно бути у доволі грубій формі і показово» [242, c.87].

Щире бажання і прагнення бути «як усі» (а «усі»- це виключно «свої») отримує свого поширення на одяг, естетичні смаки, включаючи уподобання у стилі поведінки, а також спільні музичні смаки.

У цьому виникає неабияке протиріччя, яке може хвилювати підлітків - це той момент, коли індивідуальні прояви затверджуються через однаковість. Ця однаковість, проте, старанно підтримується, і тому, хто наважується кинути їй виклик, доводиться протистояти усій груповій системі і витримувати нелегку боротьбу за своє власне, індивідуальне і неповторне «Я». 
Дослідження даної проблеми показують, що вчителі подекуди надають неадекватні оцінки, які стосуються музичних пристрастей підлітків. Доволі часто дитина може говорити про те, що вона слухає і любить тільки якусь типову сучасну популярну музику, щоб раптом не стати «немодним», «не таким, як усі», «дивним» і т. п. У такому випадку думка однолітків переважно є більш значимою для підлітка, аніж думка дорослого, незважаючи навіть на те, що взаємини і спілкування між учителем музичного мистецтва і школярем підліткового віку складаються у конструктивному руслі, і є довірливими.

Невиважений погляд учителя, неадекватна оцінка рівня музичної культури підлітка, не враховуючи його вікові особливості, які є природними і властивими для даного (перехідного) періоду розвитку особистості, можуть у подальшому призвести у вихованні та навчанні до суттєвих помилок.

Також, варто зазначити, що доволі часто в самому класі утворюються вікові угрупування, які, насамперед, задовольняють потребу їх учасників у вільному спілкуванні, яке не контролюється батьками і вчителями.

Згідно результатів багатьох спостережень доведено, що вільне спілкування - це не лише спосіб проведення вільного від навчання часу (слухання музики, спільне відвідування танцювальних заходів, концертів тощо), але й (можливо, перш за все!) засіб самовираження, встановлення контактів з новими людьми, 3 яких поступово викристалізовується щось своє індивідуальне. На початкових стадіях юнацьке спілкування є неминуче екстенсивним, яке вимагає доволі частих ситуативних змін і широкого кола учасників. Належність підлітка до групи, яка розділяє ті чи інші музичні уподобання, підвищує його впевненість у собі i додає додаткові імпульси та можливості для самоствердження i самореалізації.

Проаналізувавши міжособистісні відносини школярів підліткового віку в колективі, учитель музичного мистецтва має змогу розставити правильні пріоритети стосовно питання формування музичної культури учнів, враховуючи усю складну систему зв'язків, які з'являються у підростаючої особистості 3 оточуючим ï зовнішнім світом. Для підлітків спілкування з собі рівними - це 
необхідний обмін різноманітними ідеями, уявленнями, інтересами, почуттями, настроями і т. д.

При формуванні музичної культури школяра особливо важливими є дві проблеми. Першою з них вважаємо пошук вдалих і адекватних методичних засобів, які дозволяють 3 високою ймовірністю встановити рівень музичної культури школяра підліткового віку, який надає підстави для ефективної роботи 3 метою подальшого розвитку музичної культури учня. Побудова системи методик, які були б максимально придатними для визначення та вивчення рівня розвитку музичної культури школярів-підлітків, на сучасному етапі вивчення даної проблеми залишається все ще доволі складним завданням, яке потребує поглибленого вивчення.

Друга проблема, яка є не менш важливою - це більш конкретний і повний опис змін видимих, які помітні неозброєним оком, і які відбуваються 3 підлітками, що брали участь в процесі експерименту під час проведення спеціальної роботи з розвитку музичної культури. Проаналізувавши відповідну літературу можемо зробити висновок, що результати зазначеної роботи до цього часу не узагальнені; саме тому для дослідника особливий інтерес представляють дані результати процесу розвитку музичної культури школярів підліткового віку.

Підсумовуючи зазначимо, що виокремлюючи проблему формування i розвитку музичної культури школяра-підлітка як самостійного розділу в загальному дослідженні музичної культури учня має вагоме методологічне значення, яке є важливим як для вікової, так і для музичної психології. Певні психолого-педагогічні умови, які існують при формуванні музичної культури школяра підліткового віку, пов'язані, насамперед, із особливостями, які стосуються віку та індивідуальних рис дитини як особистості. Окрім того, сучасна ситуація, яка створилась в нашому суспільстві, на жаль, ускладнює процес формування музичної культури підлітка. Адже сформоване істотне роз'єднання різноманітних музичних напрямків, яке призводить до досить чіткого поділу загальної музичної продукції на легку - «естрадну» і справжню «класичну» музику, представляє неабиякі труднощі при здійсненні роботи по 
формуванню та розвитку музичної культури, яка проводиться в загальноосвітній школі.

Загалом, проблема розвитку музичної культури учня в загальноосвітній школі, яка є доволі новою в структурі психологічно-педагогічних знань, надає стимул для поглибленої праці над певними напрямками з метою переосмислення багатьох моментів, які вже було накопичено у сфері музичної психології та психології дітей підліткового віку. Адже ця проблема та іiі компетентне вирішення представляють собою новий підхід до питань всебічного розвитку дитини загалом.

Варто зазначити, що у закладах освіти навчально-виховний процес налаштований відповідно до можливостей, нахилів та інтересів індивідуальних задатків кожного учня, їх особливостей та вікових психологічних і фізіологічних розбіжностей. Цей процес наповнений системою педагогічних методик i технологій, взаємопов’ язаних між собою, завдяки яким стає більш ширший вибір змісту, засобів і форм навчання учнів.

Багато науковців у своїх дослідженнях виокремлюють три основні педагогічні завдання, реалізація яких відображається у діяльнісно-практичному до музичного мистецтва завданні, визначають різні межі долучення особистості до самого процесу осягнення музичної культури.

Завданням першим $є$ формування чуттєвого ставлення до музики спираючись на їі сприйняття. Це означає, що школярам потрібно розвивати стан чуттєвого відгуку на музику, їх емоційного проникнення в сферу музичних образів; намагатись пробудити щире бажання до прослуховування і виконання музики. Якщо братись за вирішення цього завдання, обов'язковою умовою буде врахування специфіки музичного мистецтва, яке є емоційним по своїй природі.

Другим завданням буде спрямування школяра на те, щоб він ставився до музики свідомо. Для учня важливим моментом буде набуття досвіду сприйняття творів цілісно; уміння набуті музичні знання застосовувати; характер музичних композицій не лише відчувати, а також і розуміти логіку розвитку даних творів. 
Ці два завдання знаходять свою реалізацію у єдності, адже усвідомлене відношення до музики формується на грунті досвіду ії образного і емоційного сприймання.

Третім педагогічним завданням $\epsilon$ процес формування діяльніснопрактичного ставлення до музики під час іiі виконання. Вирішення цього завдання спрямовано на формування музичної культури, яка має безпосередній зв'язок з розвитком уявлень музично-слухових, а також виконавських умінь i навичок.

Усі ці три завдання перебувають у тісному взаємозв'язку в практичній діяльності у процесі музичного навчання.

Для учителя їх усвідомлення стає базою, грунтом 3 метою виявлення вихідного рівня учнівського музичного досвіду, також фіксації проміжного ступеня і результатів формування музичної культури адаптованих до навчальних умов у позашкільних спеціалізованих закладах освіти.

Отже, базуючись на наукових здобутках робимо наступний висновок про навчання учнів, яке відбувається у напрямах, що взаємопов'язані між собою:

$$
\text { сфера емоцій - розвивається завдяки розширенню кола асоціацій }
$$
школяра, чуттєвого переживання образного змісту музичних творів, а також суджень естетичних;

сфера інтелекту - розвивається завдяки накопиченню музичнотеоретичних знань, а також осягненню музичних композицій, які $\epsilon$ різноманітними за жанрами;

сфера виконавства - розвивається через практику застосування знань, умінь і навичок у діяльності музично-інтерпретаційній.

Наука психологія розглядає це питання 3 урахуванням фізіологічних розробок, які є пов'язані з проблемою розвитку сфери емоційної, здібностей музичних, також виконавського апарату музиканта, механізмами творчого процесу та рухової діяльності.

Так, у музичній психології декларується поняття, що психічні можливості школярів бажано розглядати з урахуванням потенціалу їх розвитку і тих вимог, 
які пред’являються до результатів педагогічного процесу школою. У тому випадку, якщо мета навчання музики буде включати соціальні вимоги, а також враховувати особливості віку учнів, тенденції їх розвитку, то воно (музичне навчання) не лише випереджатиме музичний розвиток школяра, а й надасть йому певної цілеспрямованості.

Проте, обгрунтовуючи проблему психічного розвитку учнів 3 сучасних позицій сьогодення, науковці намагаються враховувати реальні умови, в яких живе і перебуває суспільство, а також розвивається школа сучасності. Дані умови трактуються як можливості розвитку особистості у психічному напрямку. Науковці підкреслюють як значимість соціального досвіду учня для формування музичної культури, так і роль змісту музики, який виявляє життєві ситуації, події і враження.

Дослідження науковців-психологів у галузі музичної освіти засвідчили інтелектуальні якості школяра сьогодення посеред його психічних особливостей. Сьогодні ні для кого не є секретом, що вже школярі молодшого шкільного віку володіють таким рівнем інтелектуальних можливостей, які ще на початковому етапі навчання дозволяють їм засвоювати основи наукових знань.

Психологи сьогодення у музичній сфері визнають, що музичний розвиток школяра $\epsilon$ процесом доволі складним i багатогранним. Однією 3 його найважливіших граней є та, яка пов’язана із розвитком спеціальних здібностей учня у комплексі: це стосується розвитку музичного слуху, музичної пам'яті, а також почуття музичного ритму. Проте, звичайно ж, музичний розвиток учня не може обмежуватись лише розвитком цих спеціальних здібностей. Доволі важливими є також і ті перетворення, внутрішні зміни, які відбуваються i фіксуються у його художній свідомості, а також музичному мисленні.

Діяльність людини, і це є загальновідомим фактом, пов’язана безпосередньо iз мисленням, і у переважні більшості випадків в своїй основі містить знання про предмет та засновується на поняттях про цей предмет. Інтелектуальних проявів не може бути за межами таких знань. Розум людини розвивається лише у іï діяльності та справжніх знаннях. 
Ця дидактична аксіома залишається актуальною і у специфічній сфері музичного мислення. Тут також необхідне знання матеріалу, певний багаж знань, який є необхідною складовою будь-якої діяльності у духовній сфері.

Процес формування і розвитку музичного інтелекту відбувається 3 поповненням досвіду власного. Це (здобуття цієї якості) іде шляхом від незнання до знання, згодом від знань нижчого гатунку до знань глибших. «Знати музичну літературу, тобто музичні твори у найбільшій кількості» - саме таке визначення надає передова музична педагогіка стосовно питань становлення та розвитку учнівської музичної свідомості [243].

Отже, якщо вважати, що розвинутий музичний інтелект з'являється завдяки накопиченню знань, їх асиміляції переробки, то можемо зробити наступні умовиводи: чим більш різноманітними і широкими будуть музичні знання (як загальні, так і спеціальні) учня, тим глибшим і більш широким буде його музичний тезаурус, i, як наслідок, більш розвинутою буде також і його музична загальна культура.

Зазначимо, що знання і розуміння музичного матеріалу, який включає в себе музичні явища, базові закономірності музичної мови, $\epsilon$ обов'язковою передумовою музичного мислення. Проте, знання про музику не лише виступають трампліном для тих чи інших мислячих операцій, але й формують їх, у такий спосіб визначаючи зміст і структуру. Знання, здобуті під час навчання, долучаються у природний спосіб до процесу музичного мислення, таким чином підіймаючи його на вищий та якісно новий рівень. Варто зазначити, що завдяки цьому стають доступними можливості, які сприятимуть засвоєнню знань, які будуть якісно новими і глибшими.

Тому, важливо, щоб на початковому етапі навчання знання були наче орієнтирами, які сприяють залученню у процес засвоєння музичної композиції учнями їх життєвого досвіду. Згодом, ці знання стануть основою, на якій буде базуватись пізнавальна діяльність дитини.

Таким чином, вектори, які впливають на формування музичної культури в учнів молодших класів та школярів-підлітків, є розвитком (у комплексі) якостей 
як особистісних, так і творчих здібностей, умінь та виконавських навичок, формування свідомості духовного та естетичного смаку, що в результаті сприятиме забезпеченню творчої самореалізації, яка зможе отримати свій розвиток в умовах діяльності, пов'язаної з музикою. 
DOI 10.46299/ISG.2021.MONO.PED.III.3.4

\section{4 Педагогічний колектив як суб'скт інклюзивного освітнього простору}

Сучасний розвиток освіти в Україні передбачає демократизацію і гуманізацію освітнього процесу, спрямовує педагогів на розуміння індивідуальних відмінностей дітей і врахування їх при організації навчання та виховання. Впровадження інклюзивної освіти доводить, що суспільством визнається різноманітність потреб усіх тих, хто хоче вчитися.

Теоретико-методологічні основи організації інклюзивного навчання в закладах освіти розглядаються вітчизняними та зарубіжними дослідниками, серед яких О. Глоба, Е. Данілавічюте， В. Засенко， Дж. Кларк， Л. Коваль, А. Колупаєва, С. Литовченко, Ю. Найда, Т. Сак, Н. Софій, Г. Стангвик, А. Таранченко, О. Федоренко та ін.

Аналіз робіт вчених доводить, що інклюзивне навчання вимагає специфічних педагогічних умов, дотримання яких сприятиме всебічному гармонійному розвитку особистості і формуванню активної життєвої позиції.

Серед основних умов інклюзивного навчання $є$ створення освітнього середовища і позитивного мікроклімату для задоволення освітніх потреб учнів, формування міжособистісного спілкування дітей в інклюзивну класі; забезпечення диференційованого супроводу учнів 3 особливими освітніми потребами; надання консультативної допомоги сім'ям.

Педагогічному колективу належить важлива роль у створенні сприятливої освітньої ситуації в закладі загальної середньої освіти, в якому відкрито інклюзивні класи. Суб’єктами інклюзивного освітнього простору виступає адміністрація (директор та його заступники), вчителі-класоводи початкових класів, вихователі груп продовженого дня, вчителі-предметники та класні керівники учнів середньої та старшої ланки, асистенти вчителів, психолог, соціальний педагог, корекційні педагоги та інші.

Впровадження інклюзивного навчання в закладі загальної середньої освіти зумовлює особливі вимоги до професійної та особистісної підготовки педагогів, які, крім базового рівня знань за фахом, повинні мати уявлення і розуміння 
сутності інклюзивної освіти, володіти знаннями про психологічні закономірності особистісного розвитку дітей з особливими потребами, про шляхи здійснення їх соціальної та освітньої інтеграції, способи адаптації (модифікації) навчальнорозвивальних програм для дітей 3 різними порушеннями психофізичного розвитку.

Так, в професійному стандарті за професіями «Вчитель початкових класів закладів загальної середньої освіти», «Вчитель закладу загальної середньої освіти», «Вчитель 3 початкової освіти (з дипломом молодшого спеціаліста)», інклюзивну компетентність включено в перелік професійних компетентностей. Відповідно педагог повинен мати здатність створювати умови, що забезпечують функціонування інклюзивного освітнього середовища; здатність до педагогічної підтримки осіб з особливими освітніми потребами; здатність забезпечувати в освітньому середовищі сприятливі умови для кожного учня, залежно від його індивідуальних потреб, можливостей, здібностей та інтересів [244].

Готовність педагогічного колективу до роботи з дітьми 3 особливими потребами передбачає їх позитивне сприйняття ідеї включення в середовище нормотипових однолітків.

На думку Г. Стангвик, практична реалізація ідеї інклюзії залежить перш за все від готовності педагогічних працівників здійснювати професійну діяльності в нових умовах; сама ідея інклюзії повинна стати складовою їх професійного мислення і володіння професійними ролями, необхідними для інклюзивного навчання [245, с. 7].

Важливими умовами забезпечення доступу до освіти дітей з особливими потребами є використання внутрішніх і зовнішніх ресурсів членів педагогічного колективу. Так, Ю. Богинська виділяє п’ять видів ресурсів, достатніх для соціально-педагогічної підтримки учнів з особливими потребами: нормативнометодичні, матеріальні, організаційно-функціональні, індивідуальноособистісне забезпечення (орієнтація на психологічні та мотиваційні особливості), інформаційно-просвітницькі [246, с. 123].

Інклюзія є потужним ресурсом для будь-якого закладу освіти. Виховне 
значення інклюзивного навчання для всіх дітей важко переоцінити. Інклюзія $є$ випробуванням на міцність і професіоналізм всього освітнього середовища та значний ресурс, який може дати імпульс для розвитку школи.

Основна відповідальність за використання цих ресурсів і формування сприятливого інклюзивного середовища покладається на керівника закладу освіти.

Міністерство освіти і науки України листом від 13.08.2014 №0 / 9-414 «Про забезпечення безперешкодного доступу до навчальних закладів» звертає увагу керівників дошкільних, загальноосвітніх, позашкільних та інших навчальних закладів, незалежно від їх типу і підпорядкування, на необхідність забезпечити відповідні умови для навчання дітей 3 особливими освітніми потребами. Особливу увагу рекомендується звернути на архітектурну доступність всіх функціонуючих навчальних закладів, а також тих, які капітально ремонтуються, і новобудов.

Керівник закладу освіти має піклуватися про те, щоб середовище інклюзивного класу повинно бути доступним для всіх дітей, так, щоб кожна дитина могла брати участь в освітньому процесі і взаємодіяти при цьому з усім класом. Доступність класного приміщення - це найважливіша умова навчання в інклюзивному освітньому середовищі. Установка спеціальних пристосувань, не обмежується одними лише пандусами. Необхідно розширити дверні отвори; клас, в якому навчається дитина з порушенням руху, повинен бути досить просторим, таким, щоб дитина могла вільно пересуватися по ньому.

Отже, керівники закладів освіти повинні сприяти адаптації шкіл до дітей 3 особливими освітніми потребами. Вони повинні розробляти і застосовувати більш гнучку процедуру управління, перерозподілу навчальних ресурсів, мобілізації взаємодопомоги, підтримки учнів, які відчувають труднощі в навчанні і розвитку тісних відносин з батьками і суспільством.

М. Малик функціональний компонент готовності менеджерів освіти до управління навчальним закладом інклюзивного типу характеризує за такими показниками: вміння визначати стратегію розвитку навчального закладу 
інклюзивної типу; вміння вдосконалювати організаційно-функціональну модель установи відповідно до вимог базових принципів інклюзивної освіти та структурної організації системи регіональної освіти; вміння впроваджувати педагогічні інновації в діяльність закладів освіти інклюзивної типу на загальному i локальному рівнях; вміння розвивати інклюзивне освітнє середовище закладу; вміння управляти соціально-педагогічними проєктами в рамках програм соціального партнерства; вміння формувати команду професіоналів 3 інклюзивної освіти та планувати їх професійний розвиток; вміння управляти ризиками в умовах впровадження інклюзивної освіти в закладах загальної середньої освіти [247, с. 26].

Директор та його заступники повинні формувати склад мультидисциплінарної команди супроводу, організовувати і контролювати іiі роботу; контролювати співпрацю з фахівцями інклюзивного ресурсного центру; залучати до співпраці батьків дітей з ООП; здійснювати моніторинг виконання індивідуальних програм розвитку дітей з ООП і ін. С. Миронова, М. Буйняк, Н. Плохотнюк відзначають, що виконання цих функцій вимагає мотиваційної, когнітивної, операційної складових інклюзивної компетентності керівника.

Так, мотиваційна складова передбачає психологічну готовність директора до спільного навчання дітей з ООП і типовим розвитком; його позитивний настрій до впровадження в закладі інклюзивного навчання. Когнітивна складова містить професійні знання про психофізичні особливості дітей з ООП; специфіку ïх навчання i корекційно-розвивальних послуг; цілісність психологопедагогічного супроводу в умовах інклюзії; особливості внутрішкільного контролю; шляхи формування інклюзивного простору в установі. У свою чергу операційний компонент передбачає володіння необхідними вміннями для виконання функцій, передбачених законодавством для керівника інклюзивного закладу [248, с. 171].

Застосування успішних стратегій адміністративної роботи в інклюзивну закладі загальної середньої освіти передбачає налаштування, заохочення, підтримку керівництва педагогів установи, забезпечення позитивної командної 
взаємодії. Наприклад, з метою сприяння формуванню ефективних відносин між учителем i помічником вчителя директор повинен розробити чіткі посадові інструкції для асистентів учителя і показати вчителям, як проводити оцінку їх діяльності.

3 вищезазначеного зрозуміло, що керівнику закладу освіти варто приділити увагу як питанню комплектуванню школи відповідними фахівцями психологами, логопедами, дефектологами, асистентами вчителів, так і питанню підвищення професійного рівня педагогів. Оскільки від професіоналізму вчителя, педагога як особистості, перш за все, залежить успіх інклюзивної освіти, підготовка кадрів повинна стати безперервним системним процесом.

Одночасно суб’єктами освітнього процесу інклюзивних класів і суб'єктами педагогічної діяльності виступають педагоги - вчителі-класоводи та вчителі-предметники. Як суб'єкт освітнього процесу інклюзивного класу педагог виступає проєктувальником, організатором та безпосереднім учасником освітнього процесу.

Суб’єктність педагогічної діяльності передбачає володіння відповідними принципами, формами, методами і прийомами їі здійснення. У цьому педагог виступає як носій діяльнісної позиції, необхідної для досягнення цілей освіти та розвитку особистості.

Зрозуміло, що при організації інклюзивної освіти вимоги до діяльності педагогів підвищуються, а їхні функціональні обов’язки розширюються.

В обов’ язки вчителя входить визначення навчальних потреб учнів з ООП, планування дій на уроці та підготовка необхідних навчальних матеріалів, впровадження ефективної системи управління в класі, правил поведінки та очікувань від учнів, розробка планів уроків і проведення навчальних занять, оцінки результатів успішності учнів.

Е. Данілавічюте та С. Литовченко визначаючи стратегії викладання в інклюзивній освітній установі зазначають, що завдання педагога полягає в пошуку актуальних для дитини ситуацій, в яких би вона могла діяти у відповідності зі своїми можливостями і, спираючись на делікатну підтримку 
педагога, досягати відчутних позитивних результатів.

Фактори, пов’язані 3 особистістю вчителя, грають важливу роль у плануванні і реалізації навчання учнів з особливими потребами в інклюзивну класі. Характер планування та подальшого навчання залежить від обсягу попередньої підготовки вчителя, його досвіду роботи $з$ такими дітьми, установок і поглядів щодо побудови та впровадження навчального процесу для них, рівня інтересу до предмета, а також від того, наскільки впевнено вчитель підходить до вирішення своїх професійних завдань щодо учнів з особливими потребами. У той же час в контексті інклюзивної освіти найважливіші фактори - ціннісні установки вчителя щодо навчання і викладання. Так, на кожному уроці дітей потрібно залучати до змістовних видів діяльності; за своїм характером навчання і викладання повинні бути позитивним; в процесі навчальної діяльності учні повинні постійно переживати ситуацію успіху; все більше регулювати власну навчальну діяльність і бути здатними набувати нових знань, умінь і навичок, заповнюючи прогалини між наявними знаннями і поставленими навчальними цілями. До того ж школярам необхідно надавати наочні і зрозумілі приклади і рекомендації; слід створювати умови для набуття ними різноманітного досвіду, який посилює навчальну діяльність, забезпечувати можливості для практики, спонукати до активного пізнання, надавати більше часу для відповіді. Важливо, щоб процес навчання піддавався модифікації, мав динамічний характер [249, с. 52].

При прийнятті рішень про модифікацію (адаптацію) навчальної програми вчителя враховують інформацію, яку отримують від інших фахівців, асистентів учителя і батьків. Фахівці в своїх галузях, а саме психологи, логопеди, соціальні педагоги, дефектологи, забезпечують вчителів інформацією і пропозиціями для конкретного учня відповідно до своїх професійних компетентностей. Вчителі використовують цю інформацію при складанні та впровадження індивідуальних програм розвитку, за які саме вони несуть остаточну відповідальність.

Варто відзначити, що методи навчання, які застосовує учитель, повинні мати корекційно-розвивальну спрямованість. Тобто крім дидактичної мети, 
метод повинен містити і корекційну складову, спрямовану на розвиток учнів. Вчителю в умовах інклюзії важливо враховувати індивідуальні особливості учня; конкретне порушення; рівень актуального і зону найближчого розвитку дитини; особливості пізнавальних процесів; темп діяльності; динаміку стомлюваності; самооцінку; особливості емоційно-вольової сфери та характеру тощо.

Таким чином, педагог, який працює в інклюзивному класі повинен мати:

- здатність організувати спільну та індивідуальну діяльність дітей 3 різними типами порушень;

- готовність застосовувати рекомендовані методи і технології, що дозволяють вирішувати діагностичні та корекційно-розвиваючі завдання;

- здатність здійснювати збір та первинну обробку інформації про історію розвитку і захворювання дітей з ООП;

- здатність контролювати свій емоційний стан у взаємодії з дітьми з ООП та їхніми батьками;

- здатність здійснювати психологічне просвітництво вчителівпредметників, асистента і батьків з питань особливостей психічного розвитку дітей з ООП;

- здатність зібрати і підготувати документацію про дитину для обговорення із членами команди супроводу.

У сучасних дослідженнях 3 питань інклюзивної освіти дослідники визначають сутність та структуру поняття «інклюзивна компетентність» педагога. Вчені розглядають інклюзивну компетентність як складову професійної компетентності педагога і визначають iї, як усвідомлену, закріплену суб'єктивним досвідом, систему знань, умінь і навичок, що використовується в процесі діяльності для вирішення різних професійних завдань. Зокрема I. Хафізуліна, в структуру інклюзивної компетентності вчителів відносить: мотиваційний, когнітивний, рефлексивний i операційний компоненти. Ці компоненти трактуються як здатність до усвідомлення змісту професійної діяльності в умовах інклюзивного навчання [250, с. 11]. 
В. Хитрюк, в професійно-педагогічної діяльності педагога інклюзивного освітнього закладу такі групи компетентностей:

1) робота 3 інформацією - збір, обробка, перетворення інформації відповідно до потреб; передача інформації за допомогою різних каналів; отримання зворотного зв’язку; акумуляція інформаційних ресурсів;

2) спілкування і взаємодія з учасниками інклюзивного освітнього простору - робота в команді; управління відносинами;

3) реалізація педагогічної діяльності та досягнення освітніх результатів цілепокладання; прогнозування; планування; вибір i адаптація методів соціалізації та навчання; реалізація діяльності; аналіз результатів; корекція;

4) професійне вдосконалення - професійне зростання; професійна самодіагностика, інноваційна професійна мобільність.

Дослідниця надає важливого значення формуванню у педагогів цінностей інклюзивного навчання, до яких відносить наступні позиції:

- цінність людини не залежить від її здібностей і досягнень;

- кожна людина здатна відчувати і думати;

- кожна людина має право на спілкування і на те, щоб бути почутою;

- все люди потребують один одного;

- для всіх, хто вчиться, досягнення прогресу швидше може бути в тому, що вони роблять, ніж в тому, що не можуть;

- різноманітність підсилює всі сторони життя людини;

- кожна дитина має унікальні особливості, інтереси, здібності та навчальні потреби;

- школи зобов'язані створити умови для забезпечення освітніх потреб кожної дитини [251, с. 106].

У свою чергу М. Чайковський виділяє соціально-педагогічну складову поняття «інклюзивна компетентність». Він розглядає інклюзивну компетентність педагога як інтегративне особистісне утворення, що обумовлює здатність здійснювати освітні функції в процесі інклюзивного навчання, враховуючи освітні потреби дітей з особливими потребами, забезпечити їх 
соціально-педагогічну адаптацію в навчально-виховному середовищі, створювати всі умови для їх повноцінного розвитку і саморозвитку [252, с. 18].

Розкриваючи зміст і структуру інклюзивної компетентності педагога, він виділяє в пї структурі три основних компоненти: мотиваційно-ціннісний, когнітивно-операційний і рефлексивно-оцінний.

Так, на думку М. Чайковського мотиваційно-ціннісний компонент передбачає наявність сукупності соціальних мотивів, установок, потреб, інтересів, ціннісних орієнтацій, сформованість психологічних властивостей особистості педагога, які йому необхідні для вирішення як освітніх, так i соціально-педагогічних завдань i, які обумовлені характером його професійної діяльності.

Відповідно до цього виділені три основні групи мотивів, які повинні входити в структуру інклюзивної компетентності - професійні, соціальні та особистісні.

До соціальних мотивів віднесені приналежність до нового типу освітньої діяльності - до інклюзивної освіти; можливість особистого реального вкладу в його розвиток; формування особистості дитини з особливими потребами.

Професійні мотиви М. Чайковський умовно поділяє на дві підгрупи. Перша пов'язана 3 процесом організації та проведення, а також з формами i методами інклюзивної освіти: проведення уроків, позакласних заходів, організація виконання домашніх завдань 3 дітьми 3 особливими потребами. Друга підгрупа - це соціально-педагогічні мотиви: потреба та інтерес до спілкування з дітьми з особливими потребами, організація їх життєдіяльності, змістовної адаптації в новому освітньому середовищі.

Мотиви особистісного розвитку включають можливість розвивати свій творчий потенціал; необхідність долати труднощі і проблеми в стосунках 3 дітьми з особливими потребами; здатність знаходити нові, інноваційні форми педагогічної взаємодії з учнями.

Когнітивно-операційний компонент інклюзивної компетентності педагога, містить систему психолого-педагогічних та інклюзивних знань і спеціальних 
умінь, володіння якими необхідно для виконання інклюзивної діяльності, успішного і адекватного вирішення різних педагогічних ситуацій в інклюзивну освітньому просторі.

Рефлексивно-оцінний компонент проявляється в здатності до аналізу і самоаналізу власної професійної діяльності, пов'язаної із завданнями інклюзивного навчання та соціальної адаптації учнів з особливими потребами $[253$, c. 223$]$.

В основі цього компонента виникає феномен рефлексії, пов'язаний 3 такими аспектами діяльності людини, як самоспостереження, самопізнання, самосвідомість, самооцінка [254, с. 26].

Отже, при проєктуванні освітнього процесу в інклюзивному класі педагогічні працівники стикаються 3 необхідністю відбору оптимальних способів організації спільного навчання нормотипових дітей та дітей з ООП, а ефективність інклюзивної освіти можлива лише в тому випадку, якщо сутність та ідеї інклюзії стають для педагога цінністю.

У здійсненні навчального процесу вчителям інклюзивних класів допомагає асистент. Крім цього асистент вчителя є сполучною ланкою, що забезпечує координацію педагогів, спеціальних педагогів, психологів, інших необхідних дитині фахівців на кожному етапі освітнього процесу.

У постанові Кабінету Міністрів України від 15.08.2011 №872 «Про затвердження Порядку організації інклюзивного навчання у загальноосвітніх навчальних закладах» зазначено, що «особистісно орієнтований напрям навчально-виховного процесу забезпечує асистент вчителя, який бере участь у розробленні та виконанні індивідуальних навчальних планів і програм, адаптує навчальні матеріали з урахуванням індивідуальних особливостей навчальнопізнавальної діяльності дітей з особливими потребами ».

В інструктивно-методичні рекомендаціях щодо організації навчання осіб 3 особливими освітніми потребами у закладах загальної середньої освіти у 2020/2021 навчальному році (Додаток до листа Міністерства освіти і науки 
України від 31 серпня 2020 р. № 1/9-495) визначено вимоги до посади та обов’язки асистента вчителя в класі з інклюзивним навчанням.

Так, серед посадових обов'язків асистента вчителя зазначено такі:

- забезпечувати особистісно орієнтоване спрямування освітнього процесу для учня з особливими освітніми потребами;

- допомагати у навчанні не лише дитині 3 особливими освітніми потребами, а усім іншим учням класу;

- брати участь у розбудові інклюзивного освітнього середовища разом 3 іншими педагогічними працівниками закладу освіти;

- забезпечувати партнерство з вчителем та іншими учасниками освітнього процесу з метою виконання освітньої програми для досягнення усіма учнями класу результатів навчання, формування відповідних компетентностей, їхнього особистісного та соціального розвитку та ін.

В інструктивно-методичних рекомендаціях також визначено обов’язки асистента в умовах використання технологій дистанційного навчання. До прикладу, асистент вчителя зобов’ язаний організовувати спільно з учителем/ями освітній процес 3 використанням технологій дистанційного навчання; координувати дистанційне навчання 3 батьками (іншими законними представниками) дитини, у тому числі завчасно попереджає про зміни розкладу, необхідні навчально-дидактичні матеріали тощо; забезпечувати підготовку індивідуальних завдань та адаптацію їх до використання в умовах дистанційного навчання; асистувати вчителю під час проведення дистанційних занять тощо [255].

Щоденні обов’язки асистентів вчителів часто стосуються декількох сфер. Асистент вчителя під керівництвом вчителя може працювати з учнями індивідуально або в невеликих групах, проводячи різну роботу для посилення $\mathrm{i}$ поліпшення засвоєння навчальної програми. За сприяння вчителів асистенти допомагають учням, пояснюючи, демонструючи і моделюючи необхідні навички i ставлення до навчання, щоб мотивувати і підтримувати учнів. Асистенти вчителів повинні знати про спеціальні навчальні потреби та переваги школярів. 
Це може допомогти побудувати з учнями дружні стосунки, що, в свою чергу, значно збільшує ефективність підтримки в навчанні учня.

Асистент вчителя повинен мати комунікативні та організаторські здібності, здатність співчувати, співпереживати; ціннісні орієнтації, спрямовані на розвиток людини як особистості та найвищої цінності суспільства, на творчу педагогічну діяльність.

Отже, асистент вчителя допомагає в навчанні дітей з ООП, а саме, виконувати дії, вправи і використовувати матеріали так, як пропонує вчитель; допомагає учням оформлювати їх письмові роботи; показує учням, як правильно і безпечно користуватися обладнанням та інструментами. При необхідності він уточнюе формулювання учням завдання, надає підказки. Асистент сприяє інтеграції учнів 3 особливими потребами та формування ключових компетентностей $\mathrm{i}$ наскрізних умінь. Також асистент забезпечує умови, необхідні для виконання звичних дій в класі; допомагає учням виконувати призначені їм психотерапевтичні процедури.

Багато асистентів вчителів працюють 3 учнями, яким протягом усього дня потрібні спеціальна медична допомога і догляд за станом здоров'я. Вчителі повинні розробити детальний план і вказати, які дії потрібно виконувати постійно і що робити в надзвичайних ситуаціях, а також те, хто відповідальний за затвердження цих дій і їх виконання. Згода на надання будь-якої медичної допомоги учневі можна отримає ти не тільки у батьків, а й у медичних працівників [256, с. 39].

Асистенти вчителів займаються також безпекою учнів, створенням позитивного і сприятливого оточення, а також рішенням ситуацій, які можуть вплинути на навчальні можливості учнів або поставити їх під певну загрозу. Вони ж визначають заходи безпеки і вживають попереджувальних заходів, слідуючи прийнятої політики безпеки та її процедур [257, с. 16].

Важливо, щоб сформувалися ефективні відносини між учителем i помічником вчителя на основі спільної відповідальності. Для формування ефективних відносин вчителя можуть використовувати різні стратегії, зокрема: 
- спільне обговорення ролей і завдань асистента вчителя;

- встановлення чітких критеріїв успішної діяльності асистента вчителя;

- наголос на важливості та конфіденційності;

- спільне обговорення філософії та підходів до навчання і управління класом;

- проведення регулярних зустрічей з асистентом учителя для обговорення результатів спостережень за учнями, надання та отримання зворотного зв'язку $і$ звітів, обговорення проблемних ситуацій і стратегій впровадження навчальної програми.

Вчителі також можуть полегшити роботу своїх асистентів за допомогою таких підходів.

1. Призначити час для регулярних зустрічей вчителів зі своїми асистентами.

Вчителі повинні наполягати на тому, щоб адміністрація навчального закладу виділяла окремий час для робочих зустрічей з асистентами вчителя. Особливо важливо провести такі зустрічі на початку навчального року або відразу ж після прийняття на роботу асистента вчителя для того, щоб учитель зі своїм асистентом могли чітко з'ясувати свої ролі і визначити способи комунікації між собою. Крім того, адміністрація навчального закладу повинна відводити час для регулярних зустрічей вчителів зі своїми асистентами.

2. Встановлення ефективних способів комунікації.

Знання та володіння засобами ефективної комунікації дозволяє здійснювати більш продуктивну, цілеспрямовану професійну та особистісну діяльність.

Для створення здорової робочої атмосфери вчителі повинні ефективно спілкуватися зі своїми асистентами. Почати слід з чіткого розуміння сторонами своїх ролей і обов'язків, а також створити можливості для їх постійного вільного обговорення.

Ефективна комунікація залежить від того, наскільки обидві сторони чують одна одну і враховують отриману інформацію. Такі якості, як уважність, 
урівноваженість, почуття такту, толерантіність, доброзичливість, важливі як 3 боку вчителя, та к і з боку асистента.

3. Забезпечити обізнаність асистентів вчителів.

Щоб асистенти вчителів були постійно поінформовані про останні вказівки адміністрації закладу освіти та події в житті школи, вчителі можуть забезпечити їх поштовими скриньками, куди б поступала найсвіжіша інформація; асистенти вчителя можуть брати участь в засіданнях педагогічного колективу.

4. Допомога асистентам вчителів у розвитку навичок створення баз даних. Щоб робота асистентів вчителів в класі була ефективною, вони повинні володіти інформацією про різні дані, що стосуються розвитку та знань дітей 3 особливими освітніми потребами. Асистенти вчителя повинні знати про навчальні цілі, зазначені в індивідуальній програмі розвитку дитини, вміти відслідковувати прогрес у досягненні цих цілей, знати, як звітувати вчителю про результати спостережень. Інакше кажучи, асистенти вчителя повинні знати: які дані слід збирати; які стандартизовані форми і перевірочні завдання слід використовувати при документуванні поведінки i знань учнів, які спостерігаються; як кваліфікувати поведінку, за якої вони спостерігають, за такими параметрами, як тривалість, частота та інтенсивність; як написати чіткий звіт про надзвичайний випадок.

5. Моделювання базових поведінково-управлінських стратегій.

Вчителі несуть відповідальність за управління класом і дисципліну в ньому. Однак будь-якій людині, який працює з учнем індивідуально або з групою учнів, буде корисно вивчити такі поведінково-управлінські стратегії роботи 3 дітьми, а саме: як наблизитися до учня під час розмови з ним, як відповідати на запитання дітей і спонукати їх до комунікації, а не до конфліктів, і інші. Оскільки вчитель користуються цими стратегіями постійно, вони можуть навчити цьому $\mathrm{i}$ своїх асистентів та інших людей, які працюють 3 учнями, через рольове моделювання або безпосереднє навчання.

6. Контроль і оцінка.

Контроль і оцінка роботи асистента вчителя повинні базуватися на чітких 
посадових інструкціях. Вчителі повинні часто встановлювати 3 асистентам зворотний зв’язок, який стосується їх професійної діяльності. Таке поєднання зворотного зв'язку, позитивної підтримки і використання практики самооцінки полегшують вчителю процес офіційного контролю. Вчителі повинні брати безпосередню участь в оцінці роботи асистентів.

Вчителі повинні чітко розуміти процес контролю і оцінки, включаючи регулярне ведення документації, проведення спостережень, встановлені безперервного зворотного зв'язку за такими критеріями виконання: пунктуальність; сильні і слабкі сторони; здатність слідувати інструкціям; комунікативні навички; ставлення до роботи; управління часом; робота i організаційні навички; здатність сприймати пропозиції і критику; ініціатива i наявність ресурсів; ставлення до учнів; залежність.

\section{7. Виникнення проблем}

Коли у вчителів виникають труднощі у взаєминах з іншим персоналом, їм завжди слід прагнути вирішити проблеми шляхом обговорення саме 3 тією людиною, яку це стосується. Вчителі повинні залучати до процесу інших людей тільки за умови, що безпосередні переговори не зможуть вирішити існуючу проблему.

Вони повинні викласти свої проблеми письмово в короткому документі на основі зафіксованих фактів і випадків, а не на суб’єктивному трактуванні ситуації.

Так само, як учитель повинен говорити безпосередньо зі своїм асистентом про труднощі і проблеми в стосунках з ним, асистенти теж повинні обговорювати подібні проблеми саме з учителем. Керівництво навчального закладу потрібно залучати до цього процесу тільки тоді, коли ці переговори не дадуть прийнятного для обох сторін результату.

Керівництво школи зі свого боку не повинно просити асистентів вчителів звітувати йому про роботу вчителя, оскільки в даному випадку мова йде про репутацію обох сторін. Однак, якщо вчитель або асистент вчителя мають підстави підозрювати, що співробітник або волонтер здійснює кримінальні дії, 
наприклад, фізичне або сексуальне насильство, вони повинні доповісти про це безпосередньо відповідним органам [256, с. 89].

Умова ефективного співробітництва полягає в тому, щоб вчителі і асистенти вчителів чітко розуміли свої ролі і відповідальність і разом працювали над досягненням спільної мети.

Отже, всі члени педагогічного колективу закладу освіти 3 інклюзивним навчанням повинні оволодіти базовими знаннями і навичками, необхідними для успішної роботи з дітьми з особливими потребами, а саме:

- ознайомитися з соціальним, культурним, філософським, історичним і педагогічним обгрунтуванням залучення дітей 3 особливими освітніми потребами до навчання в закладах освіти;

- навчитися визначати, оцінювати і створювати сприятливе середовище навчання для дітей з різними потребами;

- вивчити основні принципи і стратегії колективної командної роботи, розуміти важливість співпраці адміністрації, педагогів, фахівців, стати активними членами команди.

Bсі, хто працює 3 дитиною 3 особливими освітніми потребами, повинні допомагати один одному, обмінюватися досвідом. Варто намагатися максимально використовувати ресурси закладу освіти для досягнення головної мети - реалізації дитиною іiі потенційних можливостей і підготовки до незалежного життя в суспільстві. 


\section{SECTION 4. INNOVATION IN EDUCATION}

DOI 10.46299/ISG.2021.MONO.PED.III.4.1

\subsection{Modernization of scientific and pedagogical approaches in training of personnel from physical culture on the basis of academic mobility}

The leading task of national education, the success of which largely determines the development of the country and its place in the world community, is the training of productive professionals, in accordance with European standards [259]. The development of the educational field cannot be realized without the modernization of the professional progress of scientific and pedagogical staff of universities, the use of tools to update the knowledge of teachers, their skills and abilities; reforming education and deepening its content; expansion of educational offers in accordance with modern requirements. The importance of forming highly qualified specialists in the field of pedagogy, able to act at the level of international professional standards, is due to the context of Ukraine's entry into the world educational space.

Modernization of modern education in the field of physical culture necessitates the development of a new model of this process, based on interdisciplinary integration processes of academic mobility and requires a search in a certain direction to meet today's challenges [261]. The leading feature of the new educational system should be the global nature, which is manifested in the fact that many phenomena that previously had a purely national dimension, today acquire a universal mobile form. The need to find ways to improve the training of specialists in physical education, which occupies a proper place in pedagogical theory and practice and which as a function of general pedagogy is, in fact, the technology of health care, is now growing significantly.

We focus on projects and ideas that shape the international space of higher education institutions. In an effort to inspire students and potential entrants, higher education institutions embody themselves as part of the global world of internationalization, as a promising educational institution with great opportunities for educational, personal, professional development and comfortable conditions for selfrealization. The positions and directions of exploration of educational development pathways should be directed firstly to a radical restructuring of the educational sector, 
and secondly to the modernization of this process through the use of innovation [261]. The following direction are distinguished: the implementation of interdisciplinary and project approaches, globalization and internationalization of education, intensive development and widespread use of information and communication technologies, taking into account andragogical principles of training, professional mobility of a specialist in the vertical and horizontal dimensions, the insurance of possibilities for lifelong education.

The university defines priority development goals, including modern space and provision of educational infrastructure, efficiency of the educational process, internationalization, choosing a European vector of integration. The strategic choice of the latter is to integrate into the global educational community through competitive development, for which the mobility resources of students and teachers should be actively used. The main task is to actively implement large innovative international projects based on the concentration of external and internal resources [262].

Academic mobility increases the chances of physical education teachers for professional self-realization. It becomes the response of the national system of pedagogical education to the challenges of the global educational space, fierce competition in the market of educational services. The European Commission notes that studying abroad should become a standard element of university education. International academic mobility is a common world practice, which is the exchange of experience in educating teachers abroad. In particular, it provides an opportunity to receive additional education according to new professional educational standards, monitor the quality of education and ratings of higher education institutions, update the content of educational programs in accordance with the requirements of employers at the level of promising research in physical culture.

The most important factors that actualize intelligence in a certain direction are a deep understanding of the phenomenon of academic mobility. First of all, let us clarify that such mobility is the opportunity for participants in the educational process to study, teach, train or conduct research in another institution of higher education (scientific institution) in Ukraine or abroad. This problem is becoming especially popular 
primarily in the context of the formation of professionally mobile future specialists in physical culture. The need to integrate national education into the European educational space requires the definition of conceptual strategies for further improvement and development of physical education of students. According to the postulates of the Conceptual Principles of Development of Pedagogical Education of Ukraine and its integration into the European educational space, one of the main tasks of its development is: modernization of educational activities in all fields of knowledge.

This requires the development of a new educational concept, the creation of an updated system of education, the transition from archaic methods to advanced methods of supporting educational activities. Therefore, this necessitates a radical change in professional activities and professionals, as they have to work in a situation of permanent innovation. Emphasis is placed [263] on the need for their professional development to provide high quality educational services and improve scientific, pedagogical, innovative activities.

Improving the effectiveness of pedagogical education in the field of physical culture, ensuring its mobility, attractiveness, competitiveness in the labor market not only domestic but also European, necessitates continuous improvement of this process to meet modern challenges. The implementation of the strategic task of training competitive teachers is also due to profound changes in the system and structure of higher pedagogical education and the need for its integration into the European educational space [258]. This requires a number of urgent measures for further improvement and development of pedagogical education and training in the field of physical culture.

Recently, the topic of reforming the education sector, in particular the modernization of training of physical education, has become extremely relevant, especially in the context of the Ministry of Education and Science of Ukraine's attempt to develop new state standards in various specialties. Thus, the guidelines for the transition to a new educational paradigm include rethinking the doctrine of training teachers in physical culture at the level of European quality, the corresponding 
modernization of content and optimization of its technological support to achieve new quality.

Undoubtedly, today the system of training specialists in physical culture faces the problem of transition from the traditional pedagogical paradigm to the teaching of the discipline of physical education of innovative type. This approach is designed to ensure the proper health of the younger generation, which is the genetic, cultural and professional potential of the nation. Today, in the new pandemic reality, the health of young people is one of the most pressing problems of modern pedagogy.

With the acceleration of social progress, economic and social transformations, increasing the volume and intensity of information exchange, ensuring the use of the latest achievements of mobile exchange remains the most important strategic priority of sustainable development of pedagogical education in physical culture [259].In the context of accelerating social progress, economic and social transformations, increasing the volume and intensity of information exchange, ensuring the use of the latest advances in mobile exchange remains the most important strategic priority for sustainable development of pedagogical education in physical culture [264]. international cooperation in the field of education and science will allow physical education teachers to get better opportunities to choose the country (place and time) for development and self-realization in order to achieve competitiveness in the domestic and global labor market.

At the heart of our proposals is a change of emphasis in the teaching of the discipline "Physical Culture", namely the acquisition of future skills by future professionals based on the concept of health management. The latter involves the training of specialists who further direct their potential to preserve and strengthen health, increase its resources. This is how it is possible to solve an important state task in the field of physical education - to ensure the formation of a healthy personality, which determines the general level of economic and social status of the country and outlines the trend of search in solving this problem. The implementation of this doctrine is aimed at radical changes, to update the system of physical education of students, to 
change and develop the educational process in order to achieve higher results and the formation of qualitatively different pedagogical practice of physical education.

We support the provisions [260] on the innovative development of the education system, which is characterized by high quality educational services regardless of temporal and spatial factors based on current trends in the international educational space. Today's society needs highly qualified physical education professionals who are able to adapt to the challenges of the new millennium.

For the formation of professional mobility of future specialists in physical culture, actions to modernize the content of higher education and strategic ways to update it are fundamental. Given the above, we highlight a number of urgent measures aimed at improving the system of teacher education. First of all, radical modernization of all parts of the field of physical culture attracts attention. In Ukraine, the policy of modernization of the physical education system at all levels is a component of public policy [261].

In our opinion, it is necessary to create a single space of the system of physical culture of Ukraine, which requires competent personnel to guarantee its functionality and efficiency. Today, academic mobility is a necessary condition for the formation of the most common educational space. It becomes a response of national education systems to the challenges of the global educational space, fierce competition in the market of educational services. Academic mobility increases a person's chances for professional self-realization, as well as improves the quality of labor resources of the national economy.

Formation of professional mobility of future specialists of physical culture is considered as the educational process directed on mastering by applicants of higher education of key competences: instrumental, general, professional. Such competencies include knowledge, skills and abilities to analyze situations and apply professionally oriented knowledge to solve them.

In the context of strategic objectives of the state educational policy of Ukraine, external academic mobility should be considered as an essential article not only of educational but also cultural exchange. We believe that such mobility provides an 
opportunity to see the foreign education system and part of the innovative educational space.

Professional mobility of teaching universities should be considered as a mechanism for raising the level of the national educational system through the study of foreign experience. Creation of an updated system of training in the field of physical culture, the transition from archaic methods to advanced methods of supporting this process on the basis of advanced foreign experience, in accordance with modern educational development [263]. Academic mobility of physical culture specialists characterizes the presence of their individual educational trajectory through study on the territory of Ukraine or abroad. Therefore, it implies the acquisition of new experience in the application of pedagogical technologies in the field of physical education and the ability to participate in national and international educational and health projects. From the point of view of European standards, the content of such education, methods and forms of its organization should be subordinated to the purpose of adaptation of pedagogical education to the new type of education that characterizes the modern period of development of the educational community. Using the potential of modernization in the modern scientific space, it is possible to significantly increase the possibilities of introducing new tools to increase the efficiency of this process.

It is safe to say that only the widespread introduction of new pedagogical technologies, taking into account the trends of world development, will change the paradigm of pedagogical education and most effectively implement the opportunities inherent in such forms. The mobility project involves the creation of resources not only for research, project implementation, but also for opportunities for self-realization and gaining positive experience by teachers. Mobility technologies create the conditions for solving the global problem of internationalization of the educational environment, the priority of which should be the global unification of all possible resources for the development of specialists. The implementation of such a doctrine is aimed at radical changes, to update the system of pedagogical training, which will be able to change and develop the educational process in order to achieve higher results and the formation of highly effective pedagogical practice of physical education. 
Thus, improving the quality of the educational process is due to a number of factors, in the list of which an important place is occupied by the development of education on the basis of modernization. Active introduction of modernization technologies in the educational process corresponds to modern social development and is the most important strategic priority of sustainable development of the industry.

We believe that innovative trends at the present stage of modernization of teacher training in the field of physical culture require powerful evolutionary changes. Such changes are necessary in order to find new, more advanced forms and methods of forming the skills and abilities of teachers of the new generation, which are able to implement a qualitatively new pedagogical practice. It is the implementation of the mobility of all university policy measures that can ensure the coordination of scientific and educational development of students, which will further become a powerful participant in the global competitive European space. 
DOI 10.46299/ISG.2021.MONO.PED.III.4.2

\section{2 Психологические особенности гендерной социализации детей в детском доме в условиях карантина}

Проблема оказания психолого-педагогической помощи детям-сиротам ставит в ряд приоритетных задач изучение вопросов, связанных с адаптацией и интеграцией воспитанников детских домов в обществе. У детей, оставшихся без попечения родителей, возможно, затруднено формирование эталонов гендерных нормативных ориентаций и стереотипов поведения. Это может быть обусловлено недостаточностью мужского/женского воспитания; недостаточностью психолого-педагогической подготовленности воспитателей по формированию гендерной идентификации воспитанников; разрывом с семьей и помещением ребенка в детский дом.

Одним из возможных способов предупреждения нарушений процесса гендерной социализации и идентификации подростков, оставшихся без попечения родителей, является изучение ее специфических особенностей, что позволит обоснованно подходить к организации гендерной социализации детей в детском доме.

В марте 2021 г. мы провели психологическое тестирование детей с целью изучения психологических особенностей гендерной социализации детей в детском доме в условиях карантина. Тестирование проводилось в онлайн формате через платформу Google. Данное исследование выполнено в рамках государственного заказа для реализации научного проекта бюджетной программы 217 «Развитие науки», подпрограммы 102 «Грантовое финансирование научных проектов» (Республика Казахстан).

В тестировании приняли участие 49 человек, из них - 27 девочек и 22 мальчика. Возраст детей, которые приняли участие в тестировании, от 9 до 17 лет (см. рисунок 1): 


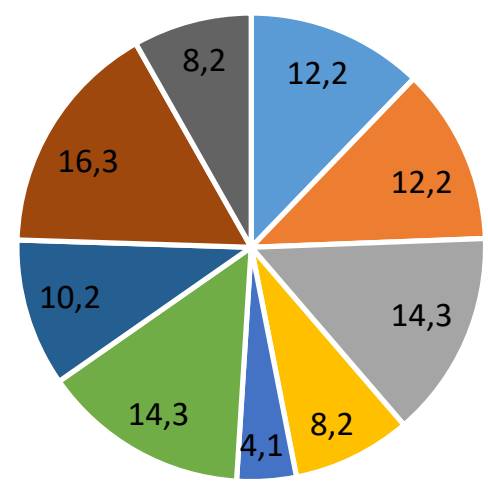

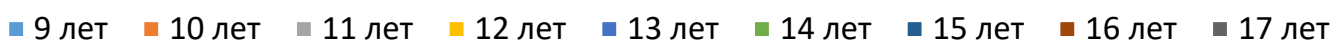

Рисунок 1. Возрастной критерий участия в тестировании, \%

Мы использовали следующие методики: Опросник «Я - мальчик / девочка...» Л. Н. Ожиговой; Полоролевой опросник (С.С. Бем); Опросник «Кто Я?» (М. Кун и Т. Макпартленд) [266, с. 2].

Опросник «Я - мальчик / девочка...» Л. Н. Ожиговой был использован с целью изучения особенностей гендерной идентичности и степени приверженности гендерным стереотипам, а ответы детей позволили раскрыть сущность того «какой я мальчик», «какая я девочка» и определить с чем себя они идентифицируют, т.е. с социальным статусом и связанными с ним чертами характера.

Полоролевой опросник С.С. Бема был использован с целью изучения степени выраженности маскулинных и фемининных характеристик девочек и мальчиков и определения полоролевых типов личности.

Опросник «Кто Я?» М. Куна и Т. Макпартленда был использован для выявления роли гендерных характеристик в структуре Я-концепции личности девочек и мальчиков, а также для изучения содержательных характеристик идентичности их личности.

Нами были получены следующие результаты. По опроснику Л. Н. Ожиговой мы определили особенности гендерной идентичности детей и степени 
приверженности гендерным стереотипам, т.е. с чем себя идентифицируют девочки и мальчики. Мы выявили следующие особенности.

Внутреннее самоощущение детей, их представления и установки относительно социальных и культурных стереотипов о поведении и качествах представителей разных гендеров выражены в соответствии с полом ребенка. Результаты представлены на рисунках 2-5.

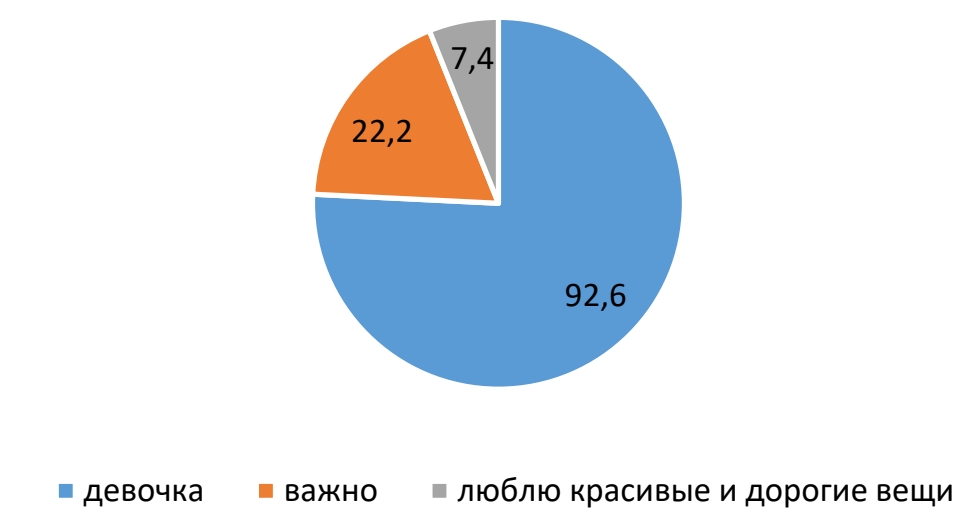

Рисунок 2. Внутреннее самоощущение девочек, \%

Из рисунка 2 мы видим, что девочки самоощущают себя как «девочка» $(96,2 \%)$ и «люблю красивые и дорогие вещи» $(7,4 \%)$. Для 22,2\% девочек это важно, остальные - не отмечают этот критерий как важный. То есть внутреннее самоощущение девочек соответствует их гендерной идентичности.

Также мы видим, что небольшой процент девочек $(7,4 \%)$ находится под влиянием социальных стереотипов о поведении девочек - это установка на то, что у девочек должны быть красивые и дорогие вещи. 
нежность

любовь

- умение постоять за себя

- забота

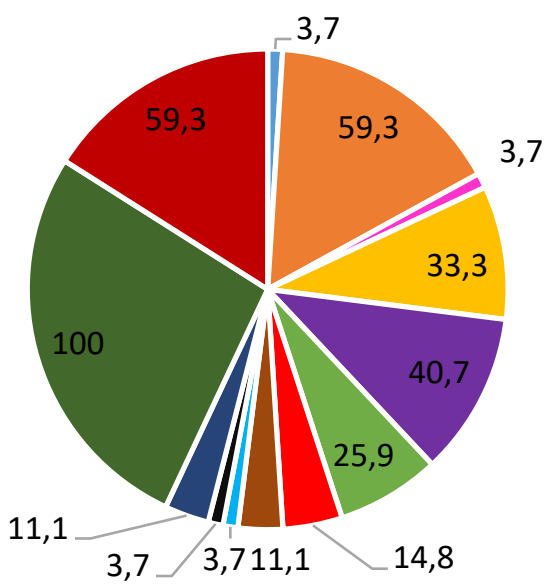

уважение

- доверие

- верность

- умение готовить

п помощь

- семья

- понимание

- красивая

\section{Рисунок 3. Представления и установки относительно социальных и} культурных полоролевых стереотипов о поведении и качествах у девочек, $\%$

Из рисунка 3 мы видим, какие представления и установки относительно социальных и культурных полоролевых стереотипов о поведении и качествах выражены у девочек. Перечень качеств, характеризующих личность и относящих ее к гендерному типу следующие.

Так, девочки должны обладать такими качествами характера, как: красивая (100\%), умение постоять за себя (14,8\%), умение готовить $(11,1 \%)$, нежность $(3,7 \%)$.

Установки относительно поведения выражаются в следующем: уважение (59,3\%), «многого в жизни добьюсь» (59,3\%), доверие (40,7\%), любовь (33,3\%), помощь $(25,9 \%)$, семья $(11,1 \%)$, понимание $(3,7 \%)$, забота $(3,7 \%)$. 


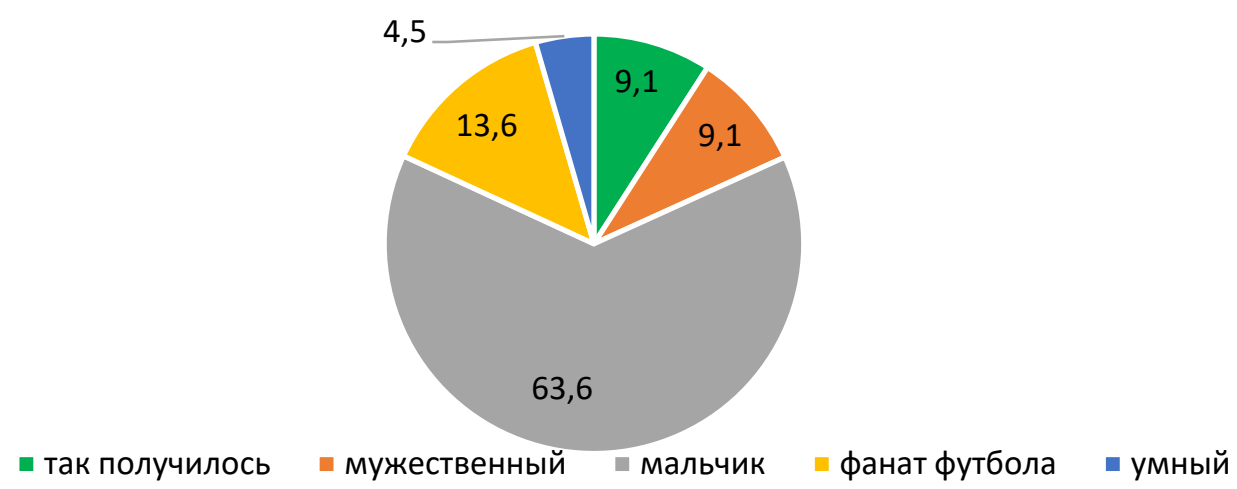

\section{Рисунок 4. Внутреннее самоощущение мальчиков, \%}

Из рисунка 4 мы видим, что мальчики самоощущают себя как «мальчик» $(63,6 \%)$, «фанат футбола» $(13,6 \%)$, «мужественный» $(9,1 \%)$ и «умный» $(4,5 \%)$. То есть у этих мальчиков внутреннее самоощущение соответствует их гендерной идентичности.

Но вместе с этим есть 9,1\% мальчиков, которые отмечают - «так получилось». Это может говорить о том, что эти дети находятся в трудной жизненной ситуации и выполнять социальные установки относительно стереотипов мужского поведения и мужских качествах им в настоящий период времени достаточно сложно и нелегко.

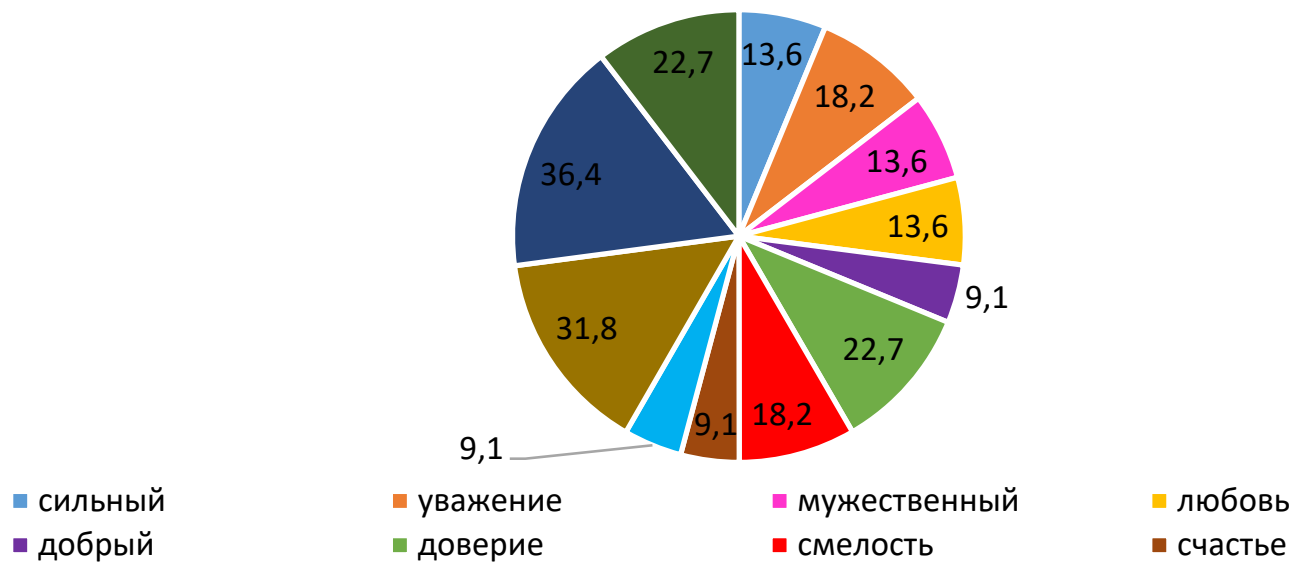

Рисунок 5. Представления и установки относительно социальных и культурных полоролевых стереотипов 0 поведении и качествах мальчиков, \% 
Из рисунка 5 мы видим, какие представления и установки относительно социальных и культурных полоролевых стереотипов о поведении и качествах выражены у мальчиков.

Перечень качеств, характеризующих личность и относящих ее к гендерному типу следующие. Так, мальчики должны обладать такими качествами характера, как: быть успешным (36,4\%), смелость (18,2\%), сильный $(13,6 \%)$, мужественный $(13,6 \%)$, добрый $(9,1 \%)$.

Установки относительно поведения выражаются в следующем: доверие $(22,7 \%)$, забота $(22,7 \%)$, уважение $(18,2 \%)$, любовь $(13,6 \%)$, здоровье $(9,1 \%)$, счастье $(9,1 \% \%)$.

Сравнительный анализ полоролевых стереотипов о поведении и качествах у девочек и мальчиков показал следующие результаты, представленные на рисунке 6.

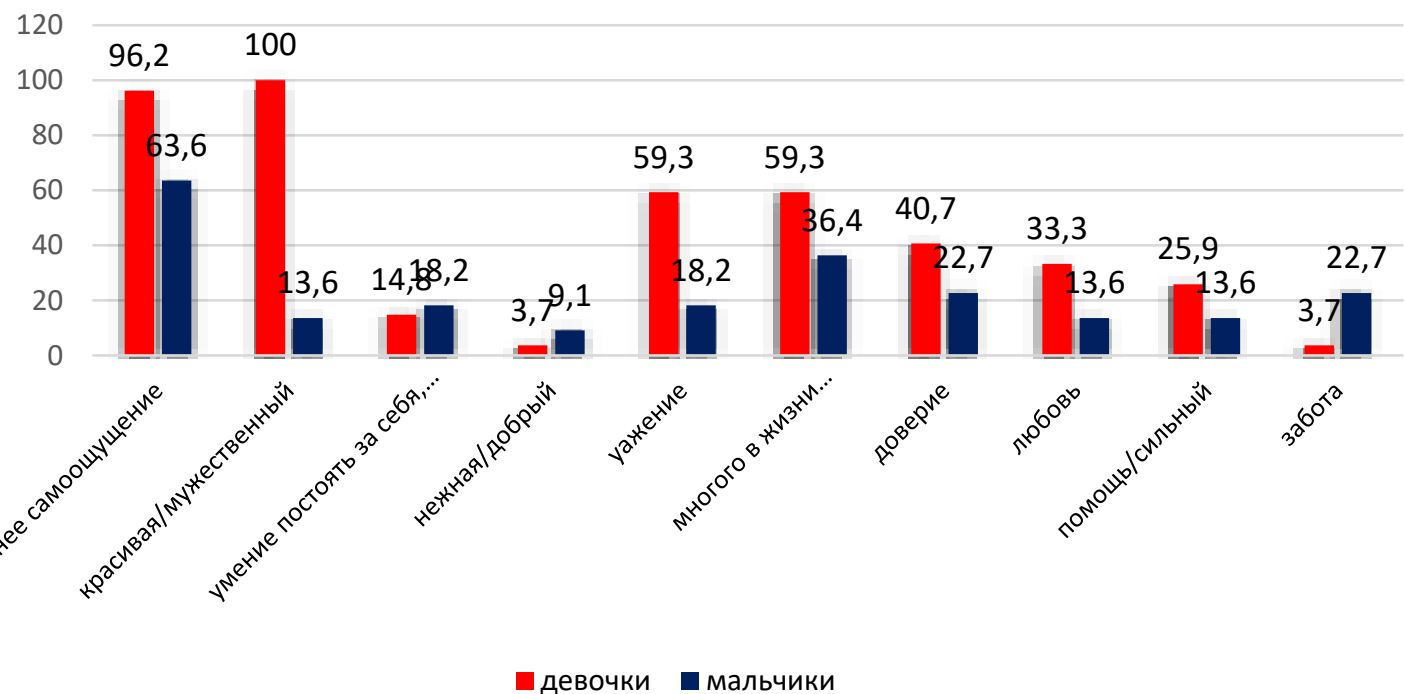

Рисунок 6. Сравнительный анализ полоролевых стереотипов о поведении и качествах у девочек и мальчиков, \%

На рисунке 6 мы видим сравнительный анализ наиболее выраженных критериев полоролевых стереотипов о поведении и качествах у девочек и мальчиков. Так, внутреннее самоощущение как принадлежность к своему 
гендеру более выражено у девочек $(96,2 \%)$, в то время как мальчики больше сосредоточены на мужских чертах характера.

Критерии качеств характера, которыми должны обладать девочки и мальчики, распределились следующим образом. На характеристиках внешности более сосредоточены девочки: красивая (100\%). На чертах характера - смелость $(18,2 \%)$, добрый $(9,1 \%)$ - мальчики сосредоточены немного больше девочек. Но на успешности и проекции на будущее девочки сосредоточены намного больше мальчиков (59,3\%).

Установки относительно поведения выражены в следующих критериях: уважение, доверие, любовь, забота. У девочек ярко выражены уважение (59,3\%), доверие $(40,7 \%)$, любовь $(33,3 \%)$ в сравнении с мальчиками. Забота ярко выражена у мальчиков (22,7\%). Но оказание помощи - у девочек $(25,9 \%)$.

Сравнительные данные говорят о том, что внутреннее самоощущение девочек и мальчиков, хоть и выражено по-разному, но соответствует их гендерной идентичности. Если девочки больше сосредоточены на внутреннем самоощущении как принадлежности к своему гендеру, то мальчики - на мужских чертах характера.

Представления и установки относительно социальных и культурных полоролевых стереотипов о поведении и качествах выражены и у мальчиков, и у девочек. Но вместе с тем, девочкам характерна такая мускулинная черта характера, как «многого в жизни добьюсь», т.е. целеустремленность. В то время как мальчикам - феминная черта характера - добрый.

Степень приверженности гендерным стереотипам у девочек - в норме; у мальчиков - в норме, но важно отметить, что несколько мальчиков находятся в трудной жизненной ситуации и выполнять социальные установки относительно стереотипов мужского поведения и мужских качествах им в настоящий период времени достаточно сложно и нелегко.

Особенности гендерной идентичности детей: у девочек маскулинные и феминные характеристики выражены в равной степени; у мальчиков маскулинные характеристики. 
По полоролевому опроснику С.С. Бема мы определили степень выраженности маскулинных и фемининных характеристик девочек и мальчиков и определили их полоролевые типы личности. Результаты представлены на рисунке 7.

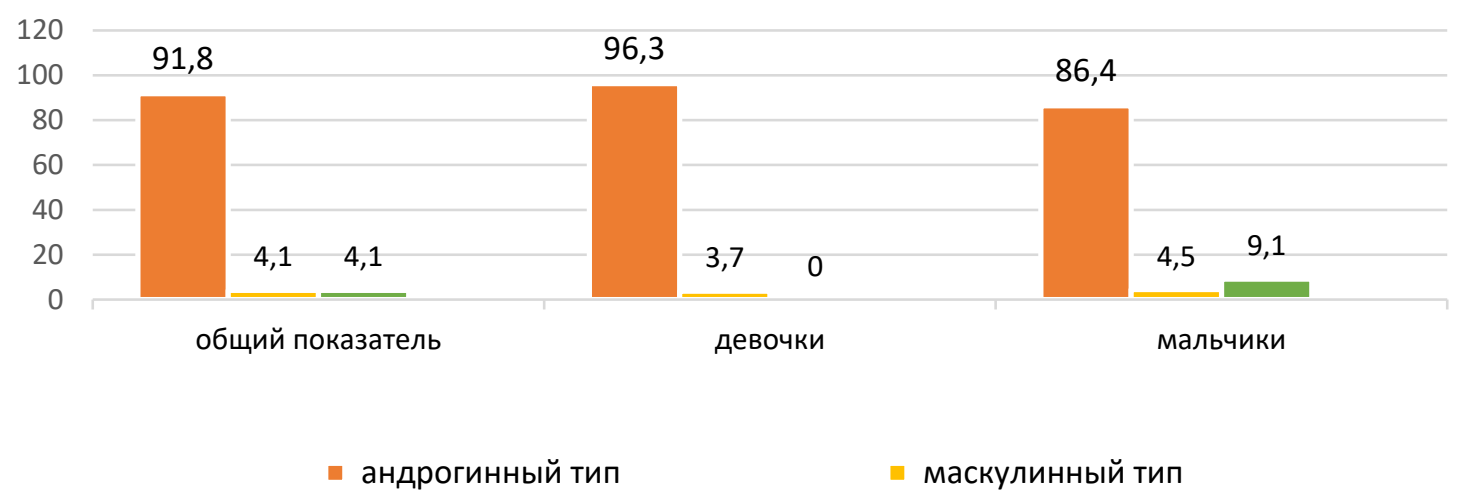

Рисунок 7. Полоролевые типы личности и степень выраженности маскулинных и фемининных характеристик девочек и мальчиков, \%

Из рисунка 7 мы видим, что наиболее выражен андрогинный тип личности (91,8\%). В группе девочек и в группе мальчиков данный тип также выражен наиболее ярко $(96,3 \%$ и 86,4\%). Андрогинный полоролевой тип личности объединяет в себе маскулинные и феминные черты поведения, т.е. мужские и женские черты характера: агрессивность, напористость, рискованность и мягкость, нежность, застенчивость одновременно.

В группе девочек незначительно выражен маскулиный тип личности (3,7\%), т.е. черты характера, которые принято считать мужскими: стремление к доминированиею, грубость, рискованность. Другие типы не выражены.

В группе мальчиков незначительно выражены маскулиный тип $(4,5 \%)$ и фиминный тип личности (9,7\%). При фиминном типе личности мальчикам свойственны черты характера, которые принято считать женскими: застенчивость, нежность, эмоциональность. Недифференцированный тип не выражен, который не предусматривает стабильного выбора стратегии поведения в группе. 
Сравнительный анализ показывает незначительные различия в группе мальчиков и группе девочек. Полоролевой тип личности, наиболее выраженный в поведении, у девочек и мальчиков - андрогинный.

По опроснику «Кто Я?» М. Куна и Т. Макпартленда мы выявили роли гендерных характеристик в структуре Я-концепции личности девочек и мальчиков и изучили содержательные характеристики идентичности их личности. Результаты представлены на рисунках 8-10.

Данные в рисунках представлены не в процентных показателях, а в количественных, с использованием метода контент-анализа.

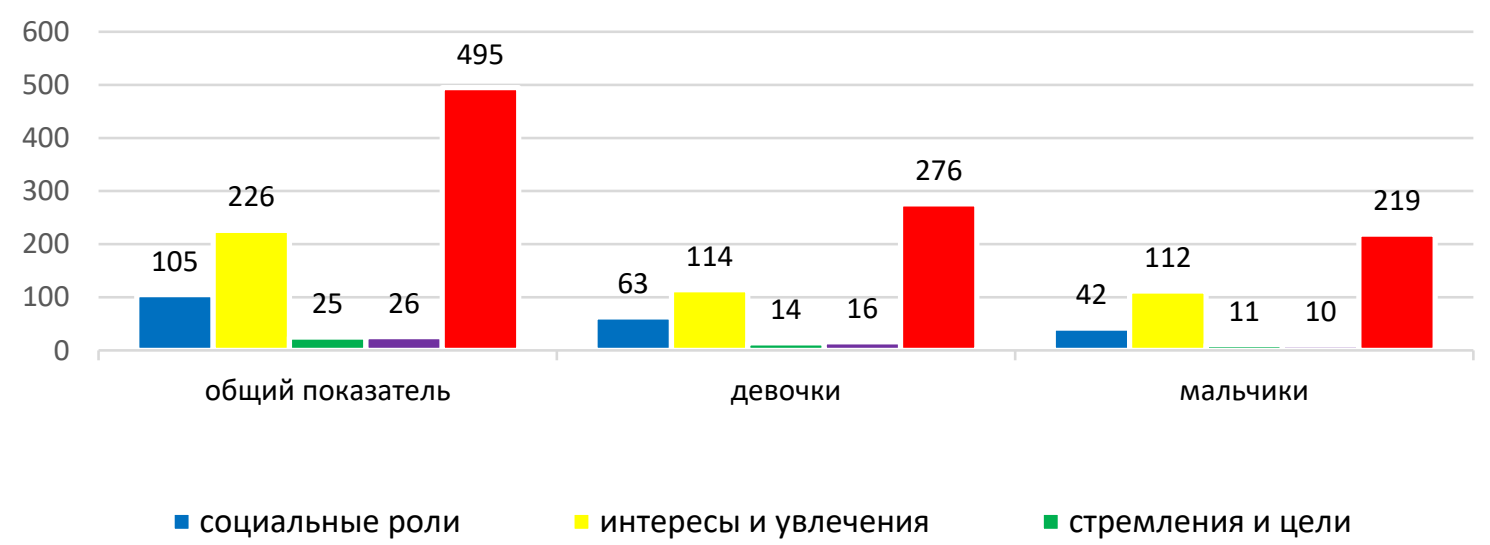

Рисунок 8. Роли гендерных характеристик в структуре Я-концепции личности девочек и мальчиков, \%

Вопрос «Кто я?» связан с характеристиками собственного восприятия человеком самого себя, т.е. с его образом Я. Отвечая на вопрос «Кто я?», девочки и мальчики указывают роли и характеристики-определения, с которыми они себя соотносят, идентифицируют, т.е. с социальным статусом и теми чертами, которые, по их мнению, связываются с ними.

Из рисунка 8 мы видим, что наиболее выражена категория «личная идентичность» и у девочек, и у мальчиков. Менее выражена категория «интересы и увлечения». Незначительно выражены категории «социальные роли», «стремления и цели» и «самооценка». 
Сравнительный анализ показывает незначительные различия в группе мальчиков и группе девочек по всем категориям ролей гендерных характеристик в структуре Я-концепции личности. Наиболее выражена у мальчиков и девочек характеристика «личностная идентичность».

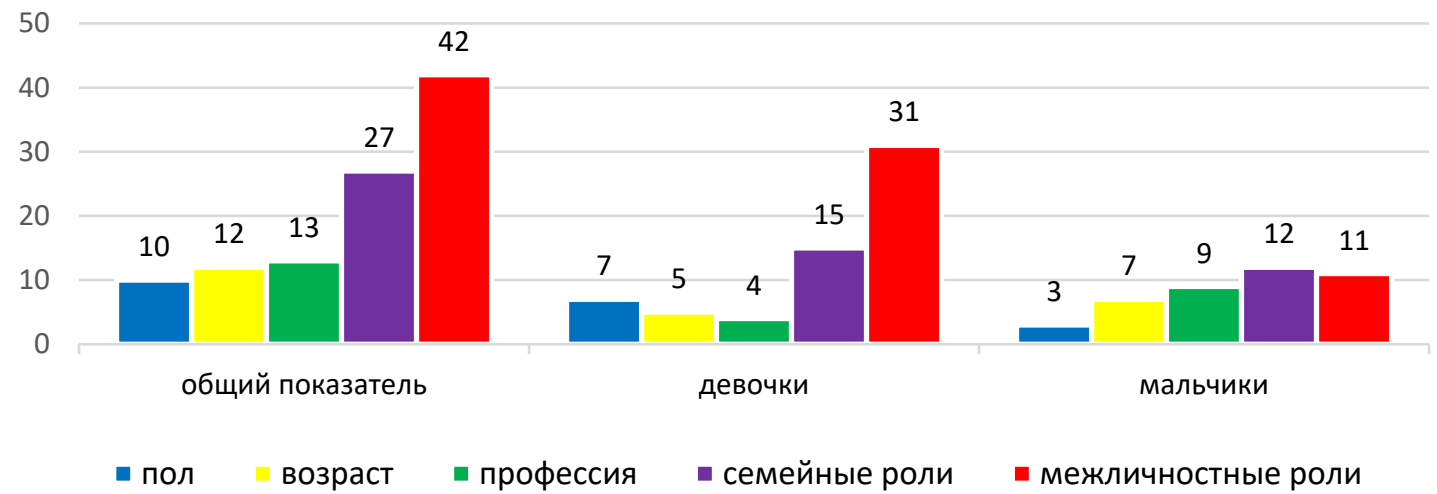

Рисунок 9. Содержательные характеристики социальных ролей девочек и мальчиков, \%

Из рисунка 9 мы видим содержательные характеристики категории «социальные роли» девочек и мальчиков. Наиболее выражен критерий «межличностные роли» и незначительно выражены критерии «профессия», «возраст» и «пол». Если у девочек наиболее выражен критерий «межличностные роли», то у мальчиков все содержательные характеристики социальных ролей выражены примерно в равной степени.

В самоописаниях присутствовала характеристика, обозначающая пол (я мальчик/ девочка), порядок ее упоминания - первые два места. Это свидетельствует о значимости этой характеристики в структуре Я-концепции личности (10 человек: 7 девочек и 3 мальчика).

Сравнительный анализ показывает значительные различия в категории «межличностные роли». По остальным категориям различия незначительные. 


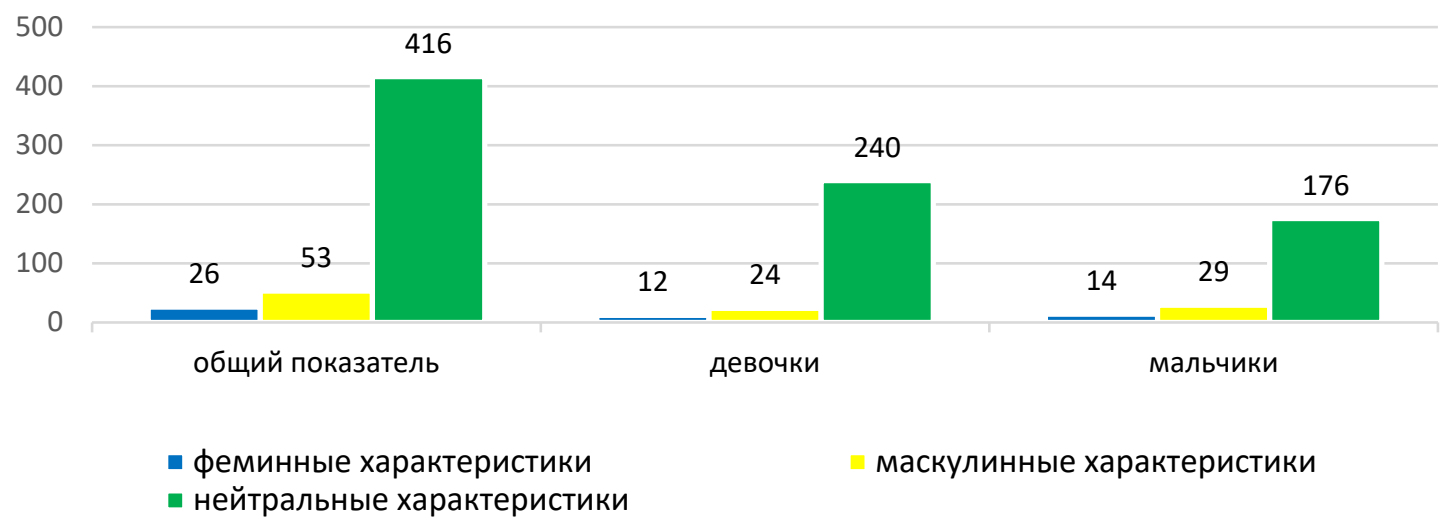

Рисунок 10. Содержательные характеристики личностной идентичности девочек и мальчиков, \%

Из рисунка 10 мы видим содержательные характеристики категории «личностная идентичность» девочек и мальчиков. Наиболее выражен критерий «нейтральные характеристики» и незначительно выражены критерии «маскулинные характеристики» и «феминные характеристики».

Сравнительный анализ показывает значительные различия в категории «нейтральные характеристики». Несмотря на значительные различия, данный критерий ярко выражен и у девочек, и у мальчиков. По остальным категориям различия незначительные.

Полученные данные по опроснику «Кто Я?» М. Куна и Т. Макпартленда совпадают с результаты по полоролевому опроснику С.С. Бема.

Таким образом, проведенное нами исследование с целью изучения психологических особенностей гендерной социализации детей в детском доме в условиях карантина позволило сделать следующие выводы:

1. Внутреннее самоощущение детей, их представления и установки относительно социальных и культурных стереотипов о поведении и качествах представителей разных гендеров выражены в соответствии с полом ребенка. Внутреннее самоощущение как принадлежность к своему гендеру более выражено у девочек (96,2\%), в то время как мальчики больше сосредоточены на мужских чертах характера; 
2. 9,1\% мальчиков находятся в трудной жизненной ситуации и выполнять социальные установки относительно стереотипов мужского поведения и мужских качествах им в настоящий период времени достаточно сложно и нелегко;

3. Представления и установки относительно социальных и культурных полоролевых стереотипов о поведении и качествах выражены в норме и у мальчиков, и у девочек. Девочкам характерна такая маскулинная черта характера, как «многого в жизни добьюсь», т.е. целеустремленность. В то время как мальчикам - феминная черта характера - добрый;

4. Наиболее выражен такой полоролевой тип личности в группе мальчиков и в группе девочек, как андрогинный тип личности, который объединяет в себе маскулинные и феминные черты поведения личности;

5. Роли гендерных характеристик в структуре Я-концепции личности имеют незначительные различия в группе мальчиков и группе девочек по всем категориям.

Таким образом, отклонений в гендерной социализации детей не выявлено.

В мае 2021 г. мы провели дополнительное тестирование с целью определения самооценки и некоторых личностных особенностей поведения девочек и мальчиков, чтобы: 1) выявить корреляционные связи и определить степень влияния самооценки на полоролевой тип личности и гендерные характеристики в структуре Я-концепции; 2) определить поведенческие факторы, влияющие на гендерную социализацию.

Для дополнительного тестирования девочек и мальчиков исследуемой группы мы использовали методики: Тест-опросник «Определение уровня самооценки» С.В. Ковалёва; Методика «Индикатор копинг-стратегий»; Методика акцентуации характера и темперамента личности Г. Шмишека, К. Леонгарда.

Тест-опросник «Определение уровня самооценки» С.В. Ковалёва был использован с целью определения самооценки девочек и мальчиков в 
исследуемой группе: завышенная, заниженная или адекватная самооценка и возможного влияния самооценки на гендерную социализацию.

Методика «Индикатор копинг-стратегий» была использована с целью доминирующих копинг-стратегий мальчиков и девочек и определения поведенческих факторов, влияющих на их гендерную социализацию.

Методика акцентуации характера и темперамента личности Г. Шмишека, К. Леонгарда была использована с целью изучения акцентуированных свойств характера и темперамента мальчиков и девочек, влияющих на их гендерную социализацию.

Мы получили следующие результаты. По тесту-опроснику «Определение уровня самооценки» С.В. Ковалёва мы определили особенности самооценки девочек и мальчиков в исследуемой группе. Результаты представлены на рисунке 11.

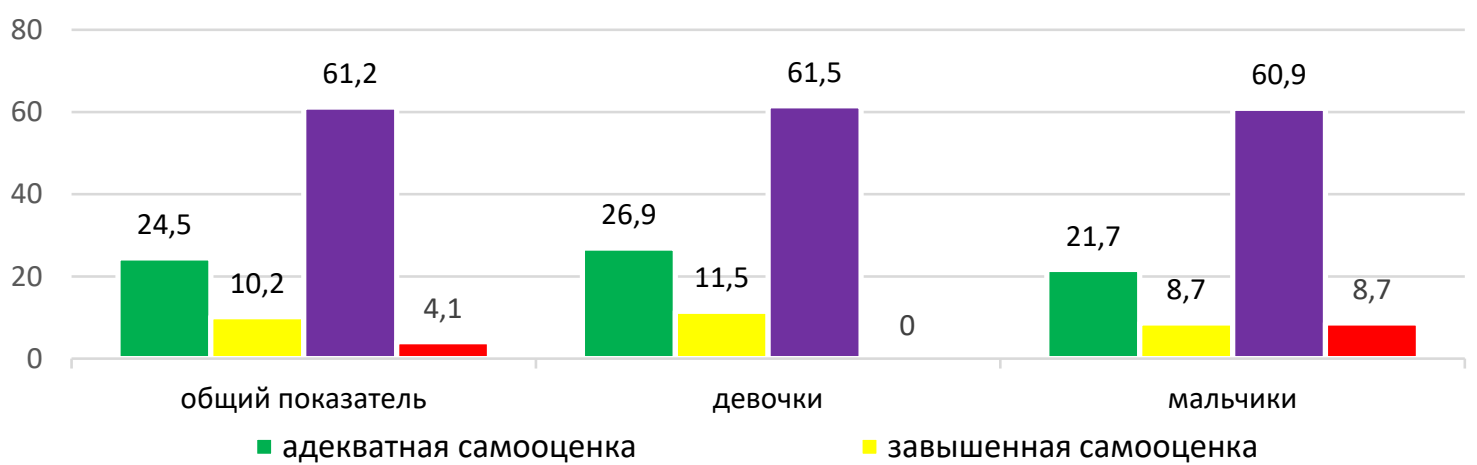

Рисунок 11. Особенности самооценки девочек и мальчиков, \%

Из рисунка 11 мы видим, что общий показатель самооценки в исследуемой группе детей - это заниженная самооценка $(61,2 \%)$, также есть дети с очень низкой самооценкой $(4,1 \%)$. При низкой самооценке дети болезненно переносят критические замечания в свой адрес, стараются подстроиться под мнение окружающих, сильно страдают от застенчивости и неуверенности в себе, недооценивает себя и свои способности без достаточных на то оснований.

Сравнительные данные также показывают высокий процент наличия заниженной самооценки у девочек и мальчиков с незначительным различием 
(61,5\% и 60,9\%). Различия наблюдаются в уровне адекватной самооценки (26,9\% девочек и 21,7\% мальчиков), эти дети адекватно реагирует на замечания окружающих, реально оценивает свои способности и возможности. Завышенная самооценка больше проявляется в группе девочек (11,5\%), т.е. девочки, оценивая свои способности и возможности, преувеличивают их. Очень низкая самооценка характерна только группе мальчиков $(8,7 \%)$, они неуверенны в себе, очень тревожны и сильно занижают свои способности и возможности.

По методике «Индикатор копинг-стратегий» мы определили доминирующие копинг-стратегии мальчиков и девочек: стратегия разрешения проблем, стратегия поиска социальной поддержки и стратегия избегания. Результаты представлены на рисунках 12-14.

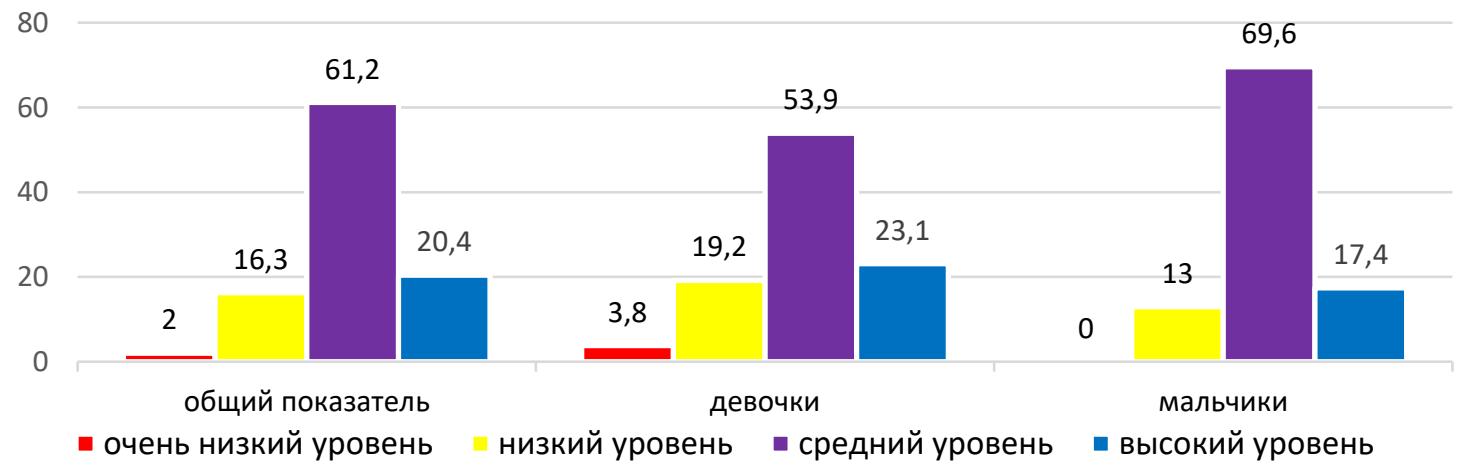

Рисунок 12. Особенности проявления стратегии разрешения проблем у девочек и мальчиков, \%

Из рисунка 12 мы видим, что общий показатель стратегии разрешения проблем у девочек и мальчиков выражен на среднем уровне $(61,2 \%)$. Стратегия разрешения проблем - это активная поведенческая стратегия, при которой человек старается использовать все имеющиеся у него личностные ресурсы для поиска возможных способов эффективного разрешения проблемы.

Сравнительные данные показывают незначительные различия по всем уровням проявления данной стратегии. У мальчиков более ярко выражен средний уровень (69,6\%), в то время как у девочек больше выражены высокий 
$(23,7 \%)$, низкий $(19,2 \%)$ и очень низкий $(3,8 \%)$ уровни стратегии разрешения проблем.

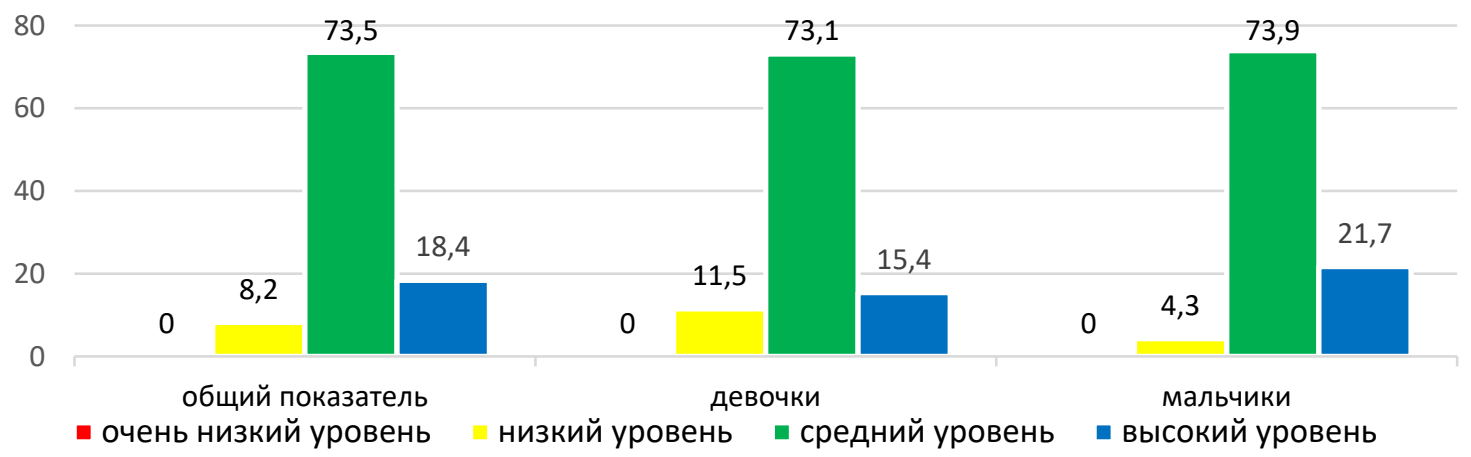

Рисунок 13. Особенности проявления стратегии поиска социальной поддержки у девочек и мальчиков, \%

Из рисунка 13 мы видим, что общий показатель стратегии поиска социальной поддержки у девочек и мальчиков выражен на среднем уровне (73,5\%). Стратегия поиска социальной поддержки — это активная поведенческая стратегия, при которой человек для эффективного разрешения проблемы обращается за помощью и поддержкой к окружающей его среде: семье, друзьям, значимым другим.

Сравнительные данные показывают незначительные различия по всем уровням проявления данной стратегии. У мальчиков более выражен высокий уровень $(21,7 \%)$, в то время как у девочек больше выражен низкий уровень (11,5\%) стратегии поиска социальной поддержки.

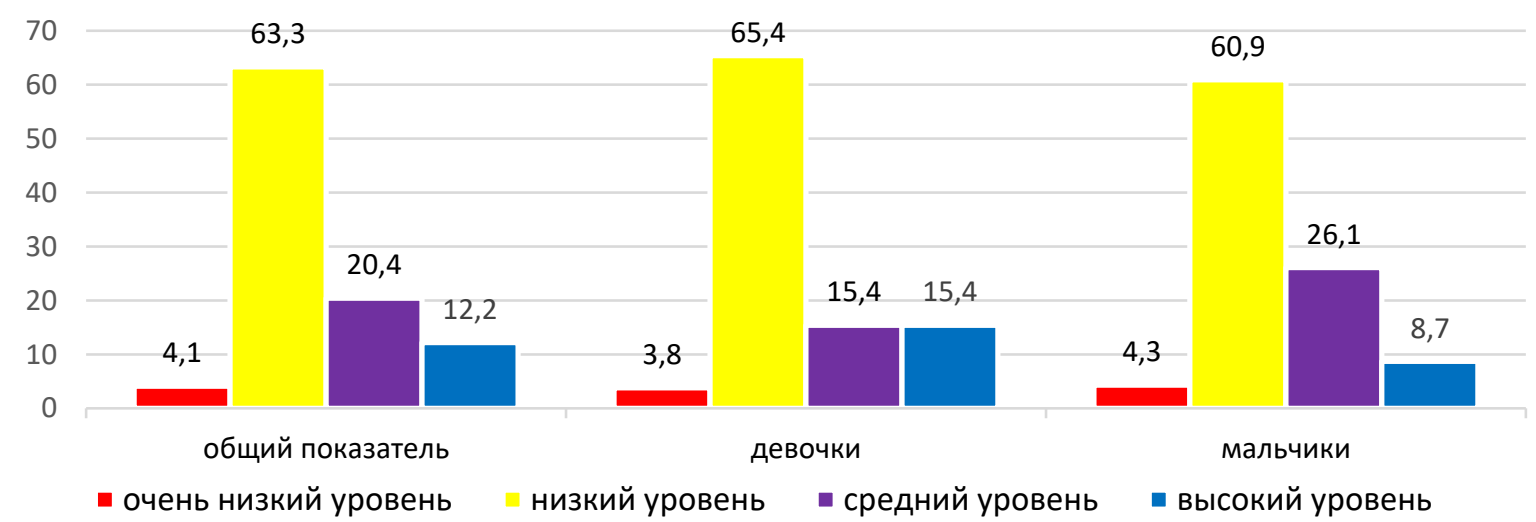

Рисунок 14. Особенности проявления стратегии избегания у девочек и мальчиков, \% 
Из рисунка 14 мы видим, что общий показатель стратегии избегания у девочек и мальчиков выражен на низком уровне (63,3\%). Стратегия избегания это поведенческая стратегия, при которой человек старается избежать контакта с окружающей его действительностью, уйти от решения проблем.

Сравнительные данные показывают незначительные различия по всем уровням проявления данной стратегии. У мальчиков более выражен средний уровень (26,1\%), в то время как у девочек больше выражен высокий уровень $(15,4 \%)$ стратегии избегания.

Таким образом, стратегия избегания — это одна из ведущих поведенческих стратегий при формировании дезадаптивного поведения. Она направлена на преодоление или снижение дистресса человеком. Использование этой стратегии обусловлено недостаточностью развития личностно-средовых копинг-ресурсов и навыков активного разрешения проблем. Однако она может носить адекватный либо неадекватный характер в зависимости от конкретной стрессовой ситуации, возраста и состояния ресурсной системы личности.

Наиболее эффективным является использование всех трех поведенческих стратегий в зависимости от ситуации. В некоторых случаях человек может самостоятельно справиться с возникшими трудностями, в других ему требуется поддержка окружающих, в-третьих он просто может избежать столкновения с проблемной ситуацией, заранее подумав о ее негативных последствиях.

Данные показывают, что наиболее выражена в исследуемой группе стратегия поиска социальной поддержки, менее выражена стратегия избегания. Все три стратегии более выражены в группе мальчиков.

По методике акцентуации характера и темперамента личности $Г$. Шмишека, К. Леонгарда мы определили акцентуированные свойства характера и темперамента мальчиков и девочек. Результаты представлены на рисунке 15. 


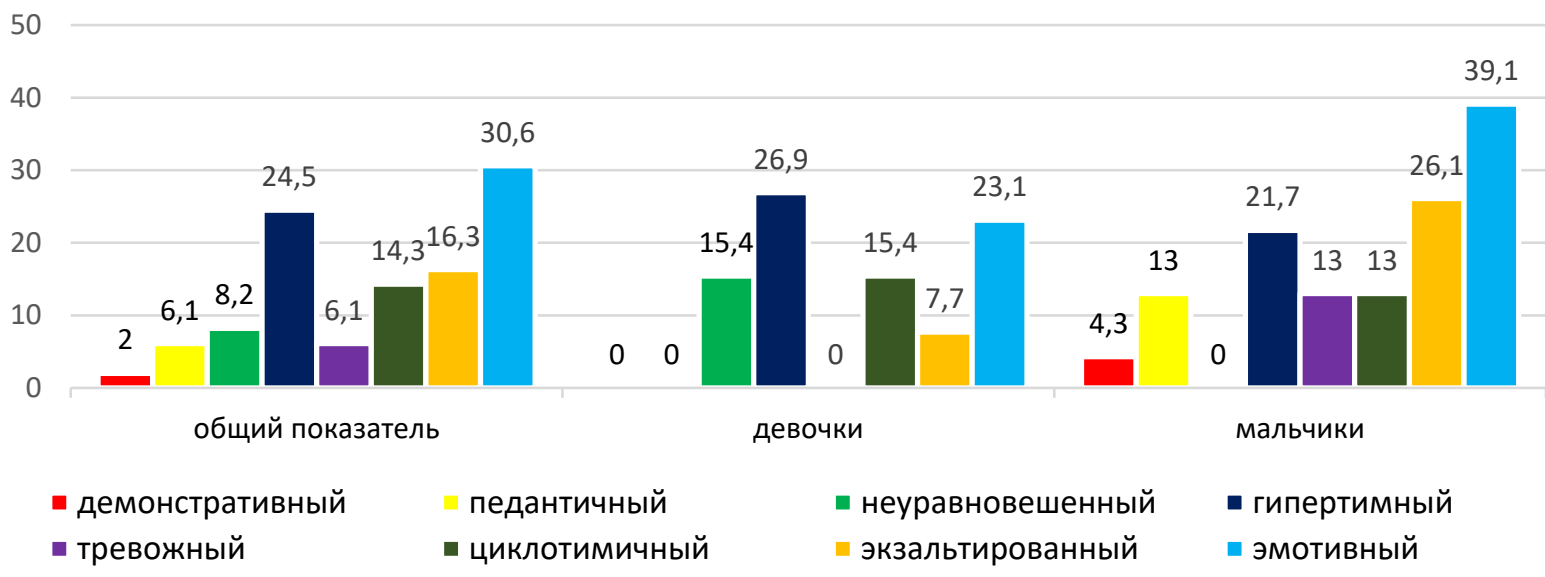

Рисунок 15. Особенности проявления акцентуаций характера и темперамента у девочек и мальчиков, \%

Из рисунка 15 мы видим, что из 10 типов акцентуаций, выражены 8. Не выражены застревающий и дистимичный типы: умеренная общительность, занудливость, склонность к нравоучениям и подавленность настроения, медлительность, слабость волевых усилий. Наиболее ярко выражены эмотивный тип (30,6\%) и гипертимный тип (24,5\%): эмоциональность, чувствительность, тревожность и большая подвижность, общительность, болтливость, выраженность жестов.

Сравнительные данные показывают значительные различия по некоторым критериям в группах мальчиков и девочек. У мальчиков более выражены эмотивный тип (39,1\%), экзальтированный тип $(26,1 \%)$, тревожный (13\%), педантичный тип (13\%). У девочек более выражен неуравновешенный тип (15,4\%). То есть мальчикам характерны такие черты характера, как: инертность психических процессов, долгие переживания травмирующих событий, в конфликты вступают редко, очень сильно реагируют на любое проявление нарушения порядка, аккуратны, с охотой уступает лидерство другим людям; робость, пугливость, способность восторгаться, восхищаться, улыбчивость, ощущение счастья, радости, наслаждения; эмоциональность, чувствительность, тревожность, болтливость, боязливость, гуманность, сопереживание другим людям или животным, отзывчивость, мягкосердечность. Девочкам характерны такие черты характера, как: повышенная импульсивность, 
грубость, занудство, угрюмость, гневливость, склонность к хамству и брани, к конфликтам.

С целью рассчитать, как взаимосвязаны между собой исследуемые признаки мы провели корреляционный анализ. Для расчета корреляционных связей мы выбрали коэффициент ранговой корреляции $r$ - Spearman, т.к. признаки измерены в порядковой шкале. Взаимодействие данных факторов является статистически достоверным (p <0,05). Результаты представлены на рисунке 16.

\begin{tabular}{|c|c|c|c|c|c|c|c|c|c|c|c|c|c|c|c|c|c|}
\hline \multirow[b]{2}{*}{ Variable } & \multicolumn{17}{|c|}{$\begin{array}{l}\text { Spearman Rank Order Correlations (Spreadsheet2) } \\
\text { MD paimise deleted } \\
\text { Marked correlations are significant at } p<, 05000\end{array}$} \\
\hline & Var1 & Var2 & Var3 & Var4 & Var5 & Var6 & Var7 & Var8 & Var9 & Var10 & Var11 & Var12 & Var13 & Var14 & Var15 & $\begin{array}{c}\text { NewVa } \\
r\end{array}$ & $\begin{array}{c}\text { NewVa } \\
r\end{array}$ \\
\hline Var1 & 1,000000 & 0,765690 & 0,626840 & 0,033004 & $-0,113847$ & 0,049655 & 0,118600 & 0,046697 & 0,001123 & 0,018774 & 0,130052 & 0,118096 & 0,168194 & $-0,083626$ & $-0,003768$ & \begin{tabular}{|l|l|}
3 & 0,154014
\end{tabular} & $-0,137030$ \\
\hline Var2 & & 1,000000 & 0,046120 & 0,032560 & $-0,029513$ & 0,166789 & 0,176055 & 0,033230 & 0,029132 & 0,021527 & 0,170419 & 0,155114 & + 0,085639 & $-0,157342$ & $-0,054977$ & 70,042230 & $-0,119739$ \\
\hline Var3 & & & 1,000000 & 0,052784 & $-0,051561$ & 0,100377 & 0,085043 & 3 0,019854 & 0,121456 & 0,103233 & 0,060264 & 0,011772 & 0,244583 & 0,025715 & $-0,040065$ & \begin{tabular}{|l|l|}
5 & 0,065043
\end{tabular} & $-0,162626$ \\
\hline Var4 & & & & 1,000000 & \begin{tabular}{|l|}
0,064019 \\
\end{tabular} & 0,188659 & 0,039159 & 0,090686 & 0,067697 & 0,015632 & 0,050516 & 0,231934 & t 0,048117 & 0,021591 & 0,353637 & $7 \quad 0,134804$ & $-0,044801$ \\
\hline Var5 & & & & & 1,000000 & 0,645723 & 0,443206 & 0,032930 & 0,048654 & 0,144835 & \begin{tabular}{l|l}
0,000157 \\
\end{tabular} & 0,279933 & 30,021995 & $-0,024494$ & $-0,001353$ & $3 \cdot 0,096629$ & $-0,106064$ \\
\hline Var6 & & & & & & 1,000000 & 0,490811 & 0,119310 & 0,104405 & 0,064797 & 0,080711 & 0,089035 & 0,035566 & $-0,082107$ & 0,131152 & \begin{tabular}{|l|l|l}
2 & 0,034669
\end{tabular} & $-0,091918$ \\
\hline Var7 & & & & & & & 1,000000 & 0,120812 & 0,105218 & 0,124716 & 0,011132 & 0,082206 & \begin{tabular}{l|l} 
& 0,004964
\end{tabular} & 0,016950 & \begin{tabular}{|l|}
0,185174 \\
\end{tabular} & $4 \quad 0,009326$ & $-0,012222$ \\
\hline Var8 & & & & & & & & 1,000000 & 0,349018 & 0,053614 & 0,163956 & 0,467992 & 0,391099 & 0,014274 & 0,428789 & 9 0,097084 & 0,241881 \\
\hline Var9 & & & & & & & & & 1,000000 & 0,107683 & \begin{tabular}{l|l}
3 & 0,346254
\end{tabular} & $\begin{array}{l}0,273906 \\
\end{array}$ & 0,214295 & $-0,048276$ & 0,411807 & 70,393469 & 0,524502 \\
\hline Var10 & & & & & & & & & & 1,000000 & 0,428022 & $-0,052540$ & 0,278795 & 0,321053 & 0,012335 & \begin{tabular}{|l|l|}
5 & 0,317934
\end{tabular} & 0,325297 \\
\hline Var11 & & & & & & & & & & & 1,000000 & 0,049985 & 0,357560 & \begin{tabular}{|l|}
0,519526 \\
\end{tabular} & $-0,152234$ & $\begin{array}{l}4 \quad 0,473995 \\
\end{array}$ & 0,226419 \\
\hline Var12 & & & & & & & & & & & & 1,000000 & 0,401156 & $-0,006455$ & 0,425582 & \begin{tabular}{l|l|}
2 & 0,297368
\end{tabular} & \begin{tabular}{l|l}
3 & 0,206688
\end{tabular} \\
\hline Var13 & & & & & & & & & & & & & 1,000000 & \begin{tabular}{|l|}
0,334305 \\
\end{tabular} & $-0,431300$ & \begin{tabular}{|l|l|}
0,127184 \\
\end{tabular} & $-0,119155$ \\
\hline Var14 & & & & & & & & & & & & & & 1,000000 & 0,085890 & 0,450448 & \begin{tabular}{l|l}
3 & 0,221348
\end{tabular} \\
\hline Var15 & & & & & & & & & & & & & & & 1,000000 & 0,247465 & \begin{tabular}{l|l} 
& 0,388862
\end{tabular} \\
\hline NewVar & & & & & & & & & & & & & & & & 1,000000 & 0,353379 \\
\hline NewVar & & & & & & & & & & & & & & & & & 1,000000 \\
\hline
\end{tabular}

Рисунок 16. Результаты корреляционного анализа

Мы выявили (рисунок 16) положительную и отрицательную корреляционные связи между исследуемыми признаками. Так, отрицательная корреляционная связь обнаружена между дистимным и циклотимным типами акцентуации, т.е. тем больше подавленность настроения, тем меньше частая смена настроения и зависимость от внешних событий.

Положительная корреляционная связь обнаружена между большинством исследуемых признаков. Так, например, чем выше самооценка, тем больше выражены частая смена настроения и зависимость от внешних событий. Чем больше выражена стратегия разрешения проблем, тем больше выражены стратегии избегания и поиска социальной поддержки. Чем больше выражена демонстративность поведения, тем больше выражены частая смена настроения, склонность к нравоучениям, общительность, слабостью волевых 
усилий. Чем больше выражены занудливость, настороженность и недоверчивость по отношению к людям, подозрительность, тем больше выражены повышенная импульсивность, грубость, склонность к хамству и к конфликтам, частая смена настроения, способность восторгаться, восхищаться, высокая общительность, эмоциональность, чувствительность, тревожность. Чем больше выражен андрогинный полоролевой тип, тем больше выражены у детей характеристики феминного и маскулинного типов. Чем больше выражены педантичность, аккуратность, тем больше выражены тревожность, робость, пугливость, неуверенность в себе, экзальтированность, эмоциональность, чувствительность, повышенная импульсивность, грубость. Чем больше выражены повышенная импульсивность, грубость, тем больше выражены тревожность, робость, пугливость, экзальтированность, пессимистическое отношение к будущему, заниженная самооценка. Чем больше выражены общительность, хорошее настроение, тем больше выражены экзальтированность, пессимистическое отношение к будущему, заниженная самооценка, частая смена настроения. Чем больше выражено пессимистическое отношение к будущему, заниженная самооценка, тем больше выражена тревожность.

Таким образом, мы обнаружили, что самооценка зависит от частой смены настроения и от внешних событий. Копинг-стратегии взаимосвязаны между собой и влияют друг на друга. Полоролевые типы (андрогинный, феминный и маскулинный) также взаимосвязаны между собой и влияют друг на друга. Частая смена настроения зависит от демонстративного поведения, настороженности и недоверчивости по отношению к людям, общительности. Общительность зависит от демонстративного поведения, настороженности и недоверчивости по отношению к людям, подозрительности, заниженной самооценки и пессимистического отношения к будущему. Заниженная самооцена зависит от педантичности, повышенной импульсивности, грубости и пессимистического отношения к будущему, тревожности. Настороженность и недоверчивость по отношению к людям зависят от повышенной 
импульсивности, грубости, эмоциональности, чувствительности и тревожности. Тревожность зависит от педантичности, повышенной импульсивности, грубости. Эмоциональность, повышенная импульсивность и грубость зависят от педантичности, пессимистического отношения к будущему.

Данные результаты свидетельствуют о том, что исследуемые признаки взаимосвязаны между собой следующим образом. Копинг-стратегии взаимосвязаны между собой и влияют друг на друга, также, как и полоролевые типы. Данные критерии включают определенные черты характера. При взаимодействии этих черт, наблюдается положительная и корреляционная связи. Таким образом, изучаемые критерии, выявленные в нашем исследовании, проявляются во влиянии друг на друга, т.е. одна черта характера усиливает или подавляет другую. То есть мы можем предположить, что ребенок с заниженной самооценкой, будет грубым, тревожным, импульсивным и др.

Таким образом, проведенное нами дополнительное исследование с целью выявления корреляционных связей и определения степени влияния самооценки на полоролевой тип личности и гендерные характеристики в структуре Яконцепции, определения поведенческих факторов, влияющих на гендерную социализацию, позволило сделать следующие выводы:

1. У детей выражена заниженная самооценка;

2. Различия в копинг-стратегиях незначительные и проявляются на среднем уровне. У девочек более выражена стратегия поиска социальной поддержки $(73,1 \%)$, у мальчиков более выражены стратегии поиска социальной поддержки (73,9\%) и разрешения проблем $(69,6 \%)$;

3. Акцентуированные свойства характера и темперамента мальчиков и девочек показывают значительные различия по некоторым критериям. У мальчиков более выражены эмотивный, экзальтированный, тревожный и педантичный типы. У девочек более выражен неуравновешенный тип. То есть мальчикам характерны такие черты характера, как: инертность психических процессов, долгие переживания травмирующих событий, робость, пугливость, улыбчивость, эмоциональность, тревожность, гуманность, отзывчивость и др. 
Девочкам характерны такие черты характера, как: повышенная импульсивность, грубость, занудство, угрюмость, гневливость и др.;

4. Полоролевой тип личности и гендерные характеристики взаимосвязаны между собой и влияют друг на друга, т.е. нет прямого влияния на самооценку детей, свойства характера и темперамента. Но каждый полоролевой тип личности включает в себя определенный набор личностных черт, которые, в свою очередь, взаимосвязаны между собой и влияют друг на друга, т.е. одна черта характера усиливает или подавляет другую. При взаимодействии этих черт, наблюдается положительная и корреляционная связи.

В заключении можно отметить, что в исследовании изучены психологические особенности гендерной социализации детей в детском доме в условиях карантина. Отклонений в гендерной социализации детей не выявлено, но личностные характеристики, влияющие на гендерную социализацию выражены по-разному у девочек и мальчиков. 
DOI 10.46299/ISG.2021.MONO.PED.III.4.3

\subsection{Modern higher musicological education (PhD) in Ukraine: traditions and innovations}

Music education and music pedagogy are integral components of music art as a complex system. It is at the level of these important areas is the process of comprehensive professional training of future musicians, associated with the translation and acquisition of professional knowledge, skills and abilities in all areas of music performance practice and music science.

The modern methodology of teaching a set of music-historical, music-theoretical and music-performing disciplines, which are basic for the formation of professional competencies at the third (educational-scientific) level of higher music education $(\mathrm{PhD})$, is based on close interaction of modern music-pedagogical science with the latest achievements in art history and humanities.

Today in this area there is a significant semantic renewal, generated by the requirements of modern art life and the huge expansion of the problem field of modern musicology and the growth of its scientific areas and new branches.

Music-pedagogical science as one of the fundamental branches of musicology and as a research area functions and develops in a wide cultural space of general humanities in constant integrative relations with socio-culturological (culturology, philosophy, aesthetics, history of culture, general history, pedagogy, psychology, etc.) and art (literary studies, theater studies, choreology) sciences.

At the beginning of the XXI century, an integral part of modern strategies for the development of theory and practice of music art is the widespread introduction of scientific achievements of musicology in the pedagogy of higher music education.

The philosophical and cultural component plays an extremely important role in music science and practice in recent decades. Modern musicology is increasingly saturated with culturological semantics, philosophical and aesthetic issues and methodology and is largely becoming a kind of philosophy of music or musical culturology. 
There are many reasons for such a sharp increase in the share of philosophicalaesthetic and musical-culturalogical thought in the field of musicology. On the one hand, "in modern musicology there is a clear tendency to self-knowledge as a specific worldview system, associated with the current total socio-cultural crisis of traditional humanistic (and primarily humanitarian) spiritual values and rethinking music science and music art of its place in a changing world and of its cultural functions" [268, p. 177]. On the other hand, the very range of branches of music science is expanding. Along with its fundamental components, relatively powerful new directions are actively and fruitfully developing, which have been formed both within the system of musicology itself and at the "junction" of musicology and related branches of science.

These substantive and structural transformations of music science have recently been increasingly reflected in music practice, including in the field of higher music education. An example of the above processes of structural-semantic and methodological self-renewal of music science of our time and their practical implementation at the level of training young scientists is the educational-scientific program "Musical Art" for the preparation of graduate students $(\mathrm{PhD})$ in this specialty [269]. This program is created by a team of scientists-musicologists, professors and lectures of the Department of Theory and History of Music of Kharkiv State Academy of Culture (among them - both authors of these article).

Describing the quality of this program, Doctor of Art Criticism, Professor, Head of the Department of Musical Medieval Studies and Ukrainian Studies of the Lysenko Lviv National Academy of Music Natalia Syrotynska notes: «The peer-reviewed educational and scientific program in the specialty 025 "Musical Art" was developed by $\langle\ldots\rangle$ leading Ukrainian scientists and teachers of music-theoretical, musichistorical and music-performing disciplines» [270, p. 1].

Emphasizing that «the priority of education quality as the core of modern educational policy, a determining factor in improving the efficiency of educational institutions and the development of their creative potential actualizes and intensifies the search for effective approaches to training future scientists and forms of its implementation» [271, p. 1], Doctor of Art Criticism, Head of the Department of 
Screen and Performing Arts and Cultural Studies of the Institute of Art History, Folklore and Ethnology after M. T. Rylsky of NAS of Ukraine O. Nemkovych accentuates that «exactly these priorities are inherent in the peer-reviewed educational and scientific program "Musical Art"》 [271, p. 1]. According to the scientist, "meaningful strategies of the program provide a combination of scientific and practiceoriented discourses of teaching future doctors of philosophy" [271, p. 1].

The purpose of this program, as noted by its authors, is primarily "training of highly qualified and competitive scientific and pedagogical staff and scientists of the new generation, capable of self-improvement and solving complex problems in research and innovation, scientific and creative, scientific and pedagogical, expert, informationalcommunicative, organizational and methodological activities in the field of music" [269, p. 6]. Meaningful strategies of the educational-scientific program envisage: 1) «combination of research-innovative and scientific-pedagogical components in the preparation of future doctors of philosophy; 2) interdisciplinary connections, synthesis of musical, philosophical and artistic-cultural discourses during research initiatives of graduate students; 3) realization of tasks of integrated musicology, which actualizes a new paradigm of scientific, in particular musicological thinking and provides unity of knowledge on history, theory and performing practice of musical art; 4) focus on the integration of domestic musicology in the world educational and scientific space in the context of cultural dialogue "East-West"» [269, p. 7].

Basic musicology disciplines are represented in the program at the level of both compulsory and elective educational components. Among such fundamental disciplines are the courses "Problems of modern musicology", "Methodology of theoretical musicology", "Methodology of historical musicology", "Organization and methods of musicological research", "Problems of performing musicology", "History and theory of musical performance", "Philosophy of music", "Musical aesthetics", "Ethnomusicology", "Ukrainian musical culture", "Innovative methods of teaching in higher educational institutions", etc. For example, in the curriculum of the discipline «Innovative teaching methods in higher education» the leading role belongs to the disclosure of the innovative nature of music pedagogy XX - early XXI century, 
highlighting the evolutionary transformations of higher music education XX - early XXI century in the context of changing artistic and pedagogical paradigms. Among the main content areas of the course - identifying innovative trends in professional music pedagogy and higher music education in the twentieth - early XXI century, identification of conceptual differences between modern and past music pedagogy, coverage of methodological principles and innovations in the system of music education in Ukraine, study of innovative methods of outstanding national musicianspractitioners, analysis of modern problems of distance learning in higher music education and prospects for its further development, as well as determining the characteristics of the leading author's innovative musical and pedagogical methods, systems and concepts of the XX - early XXI centuries [272].

In the context of actualization of research activities in the field of music art and professional development of scientific and pedagogical staff, the importance of mastering special methodological tools of musicology, an important component of which is theoretical musicology, is especially important.

The discipline «Methodology of Theoretical Musicology» is aimed at mastering the theoretical methods of studying musical phenomena and processes of development of musical art. A significant role in the course program belongs to the coverage of fundamental musicological categories and current issues of music in theoretical coverage, as well as the disclosure of features of music-theoretical concepts and the development of musicological thought of the past and present.

The concept of the course is aimed at forming a scientific and theoretical basis and enriching the experience of research musicology and professional competencies of graduate students, the ability to apply the acquired knowledge in the process of working on a dissertation in the field of music [273].

The course «Methodology of Theoretical Musicology» is designed to promote the expansion of professional thesaurus, the development of the intellectual level of graduate students, their research thinking, the pursuit of professional self-realization.

The main tasks of studying the discipline are: 1) awareness of the essence and specifics of theoretical musicology as a cognitive field; 2) formation of a holistic view 
of the content and structure of theoretical musicology and its role in the system of music sciences; 3) coverage of theoretical and methodological foundations of research activities in the field of musicology; 4) mastering the fundamental categories of theoretical musicology; 5) mastering the scientific-analytical and conceptual apparatus and methodology of theoretical musicology; 6) improvement and deepening of acquired and acquisition of new music-theoretical knowledge, skills, abilities and other competencies necessary for solving complex problems, implementation of independent scientific research and production of own ideas in the field of music art; 7) coverage of methodological approaches to the study of the phenomena of musical art and mastering the principles of using the methods of theoretical musicology in research activities; 8) determining the specifics of the historical development of theoretical musicology; 9) comprehension of the essence of leading music-theoretical concepts and application of their provisions in scientific-creative and practical activity; 10) creation of a theoretical basis for understanding the methodological foundations of the development of modern musicological knowledge; 11) mastering the technology of scientific and analytical generalization of the phenomena of musical art; 12) theoretical coverage of innovative musical-linguistic, stylistic and compositional technological processes in the practice of modern times; 13) revealing the artistic meaning and specifics of the phenomena of musical culture and art in theoretical discourse; 14) defining the essence of the leading music-theoretical concepts of the past and present; 15) determination of current issues and directions of research of modern domestic and foreign scientists in the field of theoretical musicology [273].

In the above-mentioned educational and scientific program of training doctors of philosophy in music in the graduate school of the Kharkiv State Academy of Culture a significant place is occupied by the study of the specifics and problem field of the performing musicology, presented at this level by the disciplines «Problems of Performing Musicology» and «History and Theory of Musical Performing». The leading role in the program of the course «Problems of Performing Musicology» is to reveal the specifics of performing musicology, highlighting its main problem areas, determining the place and role of performing musicology in modern musicology, as 
well as research phenomenology, theory and history of musical performance, modern methods of its study (first of all - problems of the performance-style analysis, determination of methodological features of performance comprehension of music of different epochs and styles, music-performance interpretation, communicativepsychological specifics of music-performance activity, etc.) [274].

The main theoretical and practical objectives of this course are 1) the formation of a holistic system of knowledge of performing musicology as a scientific field related to its formation and development, theoretical and methodological principles, structure, functions, major problem areas and leading current trends; 2) coverage of the history, theory and practice of musical performance, its phenomenological specifics, nature and role in the system of musical art; 3) identification of the fundamental role and specifics of the application of historical-stylistic, textological, genre and interpretive methods in modern theory and practice of performing musicology; 4) practical mastering of knowledge about historically determined performance-style and textual features of musical works of different epochs and about the corresponding methodological principles of their modern performance reproduction; 5) determination of historical and phenomenological specifics of performing styles, performing genres, performing interpretation, etc. [274].

The course «Contemporary Performing Arts in the Context of Intercultural Dialogue» is also aimed at providing graduate students with in-depth knowledge of the current state, general and specific patterns of contemporary performing arts in the context of intercultural dialogue. This course contains leading philosophical and musicological approaches to the study of contemporary performing arts, including the characteristics of world music performing schools and national artistic traditions.

In addition, the program contains a large number of the latest author's training courses (primarily at the level of elective educational components), which significantly expand the scientific horizons of graduate students and deepen their knowledge in various fields and problem areas of modern musicology.

A separate block of disciplines is related to the coverage of the specifics of nonEuropean musical cultures and the peculiarities of their interaction with the musical 
culture of Europe. Studying the courses «Musical Orientalistics», «History of Chinese Musical Art», «Traditional Musical Culture of the Asian Region» allows to significantly deepen the scientific ideas of graduate students about the musical art of non-European civilizations in the context of cross-cultural dialogue «East - West».

The course «Musical Orientalistics» aims to understand the nature of European musical orientalism in general and the musical images of the East as exotic objects of art. The concept of the course «Traditional musical culture of the Asian region countries» is aimed at expanding the professional thesaurus, the development of intellectual level and research thinking of graduate students, the pursuit of professional self-realization. The course aims to help enrich graduate students with new knowledge and creative experience in understanding the determinants and specifics of the development of musical art of non-European cultural tradition and the nature of modern attitude to it. The discipline is aimed at forming a theoretical basis for research musicological activities and professional competencies of graduate students, the ability to apply the acquired knowledge in the process of working on a dissertation in the field of music. The main emphasis in the study of the discipline is on the cultural problems of the history of musical art in Asian region on the original artistic material of its national music. Disclosure of the general picture of Asian musical cultures and highlighting the consistent evolution of national styles and genres is carried out in the dialectic of tradition and innovation and chronologically covers the range from the model of musical thinking of the ancient world to contemporary music [275].

The course «History of Chinese Musical Art» should help graduate students to get an idea of musical sinology as a field of musicology, learn the basic features of the formation and development of Chinese musical art as a cultural phenomenon, identify its cultural-historical, philosophical, ethical and literary-poetic principles, to reveal the specificity of genre-stylistic evolution of China music, to highlight the creative activities of prominent Chinese musicians of the XX - early XX centuries. XXI century, as well as to characterize contemporary Chinese musical art and determine its role in the world culture of the late XX - early XXI centuries [276]. 
In turn, the courses «Sociology of Music», «Phenomenology of Music», "Philosophy of Music", «Psychology of Musical Art», «Evolution of Musical Styles and Directions» represent, first of all, thorough directions of modern music science and practice. The course "Philosophy of Music" studies the specifics of musical life, ontological principles and phenomenology of musical creativity, reveals the essence of musical and aesthetic ideas and views on music as a sound model of the universe and an analogue of personality [277]. Problems of musical creativity are considered in philosophical, aesthetic and artistic discourses, using knowledge of the history of musical culture, the specifics of genre and style development of music, as well as modern transformational processes in art and information space and the latest laws of artistic communication. This determines the close ties of the course with the humanities and professionally-oriented professional musicological disciplines, which by their generalizations enrich of the idea of music as an art and expand the analytical tools of musicology [277]. The course «Musical Sociology» forms graduate students' knowledge of the specifics, methodology and problem field of musical sociology as an important branch of modern musicology, highlights the historical development of musical and sociological thought in European culture, reveals leading musical and sociological ideas and concepts of prominent musicologists XX - XX centuries [278]. The course is aimed at providing graduate students with a modern theoretical and methodological basis for qualified research work in the field of sociology of music.

Courses «Modern Composer Technologies», «Music Journalism», «Types of Music Communication», «Jazzology», «Management of Art Research Projects» contribute to the deepening of the professional and technological specifics of various areas of activity important for the functioning of modern music.

The course «Musical Culture of Slobozhanshchyna» deepens the knowledge of the past and present of the musical culture and art of the Kharkiv region.

Thus, modern Ukrainian musicological education at the level of postgraduate study organically combines basic music-theoretical and music-historical disciplines with a wide range of new author's courses, which significantly expand the worldview and professional horizons of future scientists $-\mathrm{PhD}$ in speciality Musical Art. 
DOI 10.46299/ISG.2021.MONO.PED.III.4.4

\section{4 Розбудова університетської системи академічної доброчесності як основи професійного розвитку в умовах цифровізації суспільства}

У сучасних умовах цифровізації суспільства та інтеграції України до світового освітнього та Європейського дослідницького простору різнобічне дослідження ц̌ ефективне вирішення проблеми дотримання науковопедагогічними працівниками i здобувачами вищої освіти академічної доброчесності як основи професійного розвитку $\epsilon$ вельми актуальним. Важливість зумовлена тим, що питання правових, технологічних, етичних засад академічної доброчесності знайшли законодавче закріплення в низці чинних державних нормативно-правових документів в Україні й за кордоном i потребують консолідації зусиль академічної спільноти для широкого впровадження принципів академічної доброчесності у вітчизняний та міжнародний освітній простір. Крім того, актуальність дослідження полягає в нагальній необхідності розбудови у кожному закладі вищої освіти університетської системи академічної доброчесності як невід’ємної складової корпоративної культури і внутрішньої системи забезпечення якості освіти iз метою систематичного залучення суб'єктів освітнього процесу (науковопедагогічних працівників, здобувачів вищої освіти, слухачів курсів підвищення кваліфікації) до неперервного професійного розвитку як конкурентоздатних фахівців, основою якого $\epsilon$ академічна доброчесність. Важливим у цьому контексті є вдумливе вивчення, різнобічний порівняльний аналіз, чітке стратегічне i тактичне осмислення кращ⿻их практик побудови системи академічної доброчесності, запропонованих вітчизняними та зарубіжними вишами, із метою творчого застосування у конкретному закладі вищої освіти.

Теоретичним підгрунтям дослідження стали праці відомих науковців і практиків: 1) у сфері академічної доброчесності (Артюхов А., Буяк В., Гужва О., Гунчак В., Дегтярьова І., Лічман Т., Мельниченко А., Ніколаєв С., Пшенична Л., Рудик В., Сацик В., Семененко Л., Слободянюк О., Сорокіна Н., Сурай I., Хименко О., Христинченко Н., Чепіга М., Черенеко Н., Чумак О., Чуканова С., 
Фініков Т. та ін.); 2) у сфері професійного розвитку науково-педагогічних працівників, здобувачів вищої освіти, слухачів курсів підвищення кваліфікації (Кириченко М., Отич О., Сорочан Т. та ін.); 3) у сфері цифровізації науковоосвітньої діяльності (Биков В., Спірін О. та ін.); 4) у сфері дослідження досвіду зарубіжних країн у формуванні культури академічної доброчесності й запровадженні кращих практик у вітчизняну систему освіти (Батечко Н., Дурдас А., Лічман Т., Хмарський В. та ін.).

Мета дослідження - схарактеризувати процес розбудови університетської системи академічної доброчесності як основи професійного розвитку науковопедагогічних працівників та здобувачів вищої освіти Державного закладу вищої освіти «Університет менеджменту освіти».

Слід зазначити, що на сучасному етапі розвитку системи освіти науковопедагогічна спільнота постала перед низкою цивілізаційних викликів, передовсім, пов’язаних із глобалізацією, диджиталізацією та світовою пандемією COVID-19, що спричинили кардинальні зміни у всіх сферах життєдіяльності соціуму $[281,283]$. Наразі зростає кількість рейтингів і методів оцінювання конкурентоспроможності закладів вищої освіти, що змушує їх постійно дбати про престиж у суспільстві, невід'ємною складовою якого є професійний розвиток та дотримання суб'єктами освітнього процесу академічної доброчесності. На ці виклики Державний заклад вищуої освіти «Університет менеджменту освіти» реагує системно, комплексно та оперативно, адже від ефективності модернізації системи освіти в цілому, і вищої зокрема, залежить досягнення цілей сталого розвитку України, формування й збереження суспільних цінностей, забезпечення національної безпеки держави. У Стратегії розвитку Державного закладу вищої освіти «Університет менеджменту освіти» на період до 2024 року зазначено, що його перевагою $є$ належність до структури Національної академії педагогічних наук України, зорієнтованість на формування цілісної системи неперервної освіти і поступальне входження до європейського освітнього простору [287, с. 4]. 3 поміж стратегічних изілей розвитку ДЗВО «Університет менеджменту освіти» на 2020-2024 роки 
виокремлено: розвиток Університету як вільного освітнього, наукового, інноваційного простору, що об'єднує спільними цінностями і завданнями здобувачів освіти і персонал закладу; створення умов для навчання і розвитку здобувачів вищої освіти - особистостей зі сформованими компетентностями фахівця XXI століття з активною громадянською позицією, відповідальністю за свою долю i долю держави, конкурентоздатних на ринку праці; розвиток університету як центру дослідно-експериментальної роботи і експертної діяльності у системі післядипломної освіти; формування моделі інноваційного університету системи вищої освіти, спроможного успішно конкурувати на ринку європейських освітніх послуг; входження ДЗВО «УМО» до ТОП-100 кращих університетів України за показниками освітньої і наукової діяльності [287, с. 5]. Пріоритетним завданням ДЗВО «УМО», як закладу вищої освіти і освіти дорослих є формування інноваційного середовища підготовки, професійного й особистісного розвитку фахівців у системі формальної, неформальної й інформальної освіти завдяки модернізації форм і змісту їхнього навчальнометодичного і наукового супроводу, активного використання можливостей відкритої освіти, системи мотивації особистісного і професійного розвитку [287, c. 5]. ДЗВО «УМО» покликаний обгрунтувати i розкрити можливості професійного розвитку кожного науково-педагогічного працівника для оволодіння новими технологіями і методиками, що сприятиме якості освітнього процесу, усвідомленому вибору кожним студентом і слухачем своєї освітньої траєкторії, здатності приймати зважені рішення, активній участі у конструюванні та коригуванні освітнього контенту [287, с. 6].

Із метою розбудови у Державному закладі вищзої освіти «Університет менеджменту освіти» системи академічної доброчесності, забезпечення дотримання принципів академічної доброчесності й етики академічних взаємовідносин та сприяння професійному розвитку науково-педагогічних працівників адміністрація університету та фахівці відділу наукової роботи здійснюють науково-методичний супровід із таких актуальних проблем:

1) ознайомлення з теорією і практикою академічної доброчесності в галузі 
освіти і науки [279, 280, 282, 284, 285];

2) вивчення міжнародних та державних нормативно-правових документів iз проблеми академічної доброчесності в галузі освіти і науки; опрацювання структурними підрозділами університету вимог Міністерства освіти і науки України та Національного агентства із забезпечення якості вищої освіти до наукових, науково-педагогічних, педагогічних працівників, здобувачів вищої освіти із проблеми академічної доброчесності;

3) відпрацювання категоріального апарату 3 проблеми академічної доброчесності в галузі освіти і науки та проявів її у вищій школі (академічна доброчесність, принципи академічної доброчесності, етика академічних взаємовідносин, соціальна відповідальність за результати наукової та освітньої діяльності тощо);

4) вивчення кращих практик розбудови системи академічної доброчесності та здійснення порівняльного аналізу, узагальнення, систематизації передового вітчизняного й зарубіжного досвіду вирішення проблеми академічної доброчесності в галузі освіти і науки;

5) опрацювання вимог НАПН України та Державних стандартів до наукової, виробничо-практичної, навчальної, довідкової продукції, готової до впровадження (оприлюднення, розповсюдження, використання) на теренах України й зарубіжжя;

6) ознайомлення науково-педагогічних працівників із ефективними формами оприлюднення і розповсюдження наукової, виробничо-практичної, навчальної, довідкової продукції, готової до впровадження, серед представників науково-педагогічної спільноти України й зарубіжжя;

7) аналіз ефективності індивідуальної і колективної участі науково-педагогічних працівників у наукових і освітніх заходах різного формату та статусу, зокрема, із проблематики академічної доброчесності;

8) урахування в календарі проведення подій університету періодичності проведення заходів із академічної доброчесності з метою включення їх до плану роботи закладу вищої освіти, планомірної участі у цих заходах структурних 
підрозділів, педагогічних і науково-педагогічних працівників закладу відповідно до планів роботи кафедр та індивідуальних планів роботи;

9) наукове рецензування, експертиза, моніторинг якості конкурсних робіт, наукових заходів (наприклад, Конкурси Національної академії педагогічних наук України, науково-методичний супровід підготовки і подання творчими колективами кафедр ДЗВО «Університет менеджменту освіти» пакетів документів на науково-дослідну тему для участі науково-педагогічних працівників у Конкурсному відборі для виконання наукових досліджень із проблем розвитку освіти, що потребують невідкладного розгляду (http://naps.gov.ua/ua/press/announcements/2180/);

10) специфіка роботи структурних підрозділів та уповноважених комісій, що забезпечують впровадження принципів академічної доброчесності в освітню, наукову, методичну, організаційну діяльність університету й виконують наглядову і контролюючу функції.

Слід зазначити, що принципи академічної доброчесності в Державному закладі вищої освіти «Університет менеджменту освіти» закладено в основу організаційної культури університету загалом та кожного структурного підрозділу зокрема. Значна увага адміністрації та фахівців відділу наукової роботи приділяється доведенню цінності, політики та процедур академічної доброчесності до науково-педагогічних, наукових, педагогічних працівників, здобувачів вищої освіти та слухачів курсів підвищення кваліфікації.

Однією з ключових складових внутрішньої системи забезпечення якості в Державному закладі вищої освіти «Університет менеджменту освіти» $\epsilon$ університетська система забезпечення академічної доброчесності, розбудова якої ефективно здійснюється згідно з чинними законодавчими нормативноправовими документами з урахуванням вимог Міністерства освіти і науки України [285], рекомендацій Національного агентства із забезпечення якості вищої освіти [284].

Слід наголосити, що на сучасному етапі розвитку освіти істотну допомогу адміністрації та науково-педагогічним працівникам закладів вищої освіти 
України надало Національне агентство із забезпечення якості вищої освіти, що рекомендувало здійснити розбудову Університетської системи забезпечення принципів академічної доброчесності та етики академічних взаємовідносин [284, c. $4-5]$.

Метою університетської системи забезпечення академічної доброчесності є визначення та утвердження основних пріоритетних принципів і цінностей внутрішнього забезпечення якості вищої освіти, дотримання яких представниками академічної спільноти Університету $є$ необхідною умовою створення сприятливого освітнього середовища, обміну знаннями та їх примноження, упровадження інновацій, інтелектуального розвитку здобувачів вищої освіти, слухачів курсів підвищення кваліфікації, замовників освітніх послуг і науково-педагогічних, педагогічних працівників.

Завдання університетської системи забезпечення академічної доброчесності: 1) підтримка особливих взаємовідносин на засадах людино(студенто- викладацько-)центризму, відкритості, чесності, порядності, взаємної довіри, справедливості, рівної відповідальності, взаємоповаги, толерантності та ін.); 2) запобігання будь-яких проявів недоброчесної поведінки, дискримінації та порушення академічної доброчесності; 3) утвердження чесності й етичних цінностей в освітньому процесі й науковій діяльності університету; 4) формування високої академічної культури, носіями якої повинні бути науково-педагогічні, педагогічні працівники та здобувачі вищої освіти, слухачі курсів підвищення кваліфікації, замовники освітніх послуг; 5) запобігання порушенням академічної доброчесності тощо.

Система включає такі елементи: 1) політику, стандарти та нормативну базу університету 3 питання академічної доброчесності; 2) інституційне забезпечення (структурні підрозділи (посадові особи), що опікуються питаннями академічної доброчесності та чіткий розподіл відповідних функцій i повноважень між структурними підрозділами (посадовими особами) університету; 3) інформаційно-технологічні засоби університету 3 питання академічної доброчесності. 
Розглянемо складові елементи системи забезпечення академічної доброчесності в освітній і науковій діяльності Державного закладу вищої освіти «Університет менеджменту освіти», які логічно пов’язані між собою та об'єднані в такі блоки (малюнок 1):

I. Політику, стандарти та нормативну базу (внутрішню, зовнішню) Державного закладу вищої освіти «Університет менеджменту освіти» 3 академічної доброчесності, яка на системному рівні описує механізми впровадження принципів академічної доброчесності в науковий та освітній процеси, заходи із забезпечення процесу дотримання принципів академічної доброчесності, процедури попередження та боротьби з порушеннями принципів академічної доброчесності. Нормативні питання академічної доброчесності регламентовано у системі внутрішніх документів Державного закладу вищої освіти «Університет менеджменту освіти» [286], а саме: 1) Стратегії розвитку Університету менеджменту освіти на період до 2024 р.; 2) Положенні про академічну доброчесність у Державному закладі вищої освіти «Університет менеджменту освіти»; 3) Наказі «Про затвердження порядку перевірки текстів на академічний плагіат у Державному закладі вищої освіти "Університет менеджменту освіти"»; 4) Положенні про комісію з питань етики та академічної доброчесності; 5) Наказі «Про затвердження складу комісії з питань етики та академічної доброчесності у Державному закладі вищої освіти "Університет менеджменту освіти"»; 6) Положенні про систему внутрішнього забезпечення якості освітньої діяльності та якості вищої освіти у Державному закладі вищої освіти «Університет менеджменту освіти»; 7) Положенні про моніторинг якості освітньої діяльності та якості вищої освіти здобувачів першого (бакалаврського), другого магістерського), третього (наукового) рівнів, слухачів підвищення кваліфікації ДЗВО «Університет менеджменту освіти»; 8) Етичному кодексі університетської спільноти. 
Система забезпечення академічної доброчесності в освітній і науковій діяльності

Державного закладу вищої освіти «Університет менеджменту освіти»

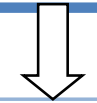

I БЛОК - Політика, стандарти, нормативна база Державного закладу вищої освіти «Університет менеджменту освіти» $з$ академічної доброчесності

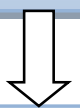

II БЛОК - Відповідальні особи у структурних підрозділах Державного закладу вищої освіти «Університет менеджменту освіти» та Комісія з питань етики та академічної доброчесності

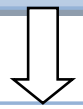

III БЛОК - Інформаційна база Державного закладу вищої освіти «Університет менеджменту освіти» з академічної доброчесності

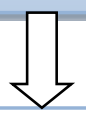

IV БЛОК - Інструменти впровадження принципів академічної доброчесності у освітню і наукову діяльність Державного закладу вищої освіти «Університет менеджменту освіти»

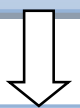

V БЛОК - Інструменти контролю дотримання академічної доброчесності у освітній і науковій діяльності Державного закладу вищої освіти «Університет менеджменту освіти»

Малюнок 1. Складові системи забезпечення академічної доброчесності в освітній і науковій діяльності ДЗВО «Університет менеджменту освіти» (підготовлено авторами на основі рекомендацій НАЗЯВО України [284, с. 4-5])

II. Відповідальних осіб у структурних підрозділах Державного закладу вищої освіти «Університет менеджменту освіти» та уповноважену Комісію 3 питань етики та академічної доброчесності, яка забезпечує популяризацію принципів академічної доброчесності, їх упровадження в освітньо-наукову діяльність університету, а також виконує наглядову та контролюючу функції.

III. Інформаційну базу Державного закладу вищої освіти «Університет 
менеджменту освіти» $з$ академічної доброчесності, за допомогою якої здійснюється популяризація принципів академічної доброчесності та підвищення рівня обізнаності всіх учасників освітньо-наукової діяльності в університеті у питаннях академічної доброчесності та основними складовими якої є:

а) рубрики сайту університету із висвітленням актуальних питань академічної доброчесності;

б) інформаційні та методичні матеріали, присвячені інформаційній грамотності та попередженню плагіату;

в) інформаційні матеріали щодо корпоративної культури на робочому місці та переваг чесного навчання, наприклад, Етичний кодекс університетської спільноти.

г) матеріали, присвячені популяризації принципів академічної доброчесності серед осіб, що здобувають вищу освіту (інфографіка, роздаткові матеріали).

IV. Інструменти впровадження принциипів академічної доброчесності $у$ освітню і наукову діяльність Державного закладу вищої освіти «Університет менеджменту освіти», які виконують просвітницьку функцію та за допомогою яких стає можливим попередження випадків порушення принципів академічної доброчесності, зокрема:

а) інформаційно-консультативний супровід фрахівизів університету (педагогічних, науково-педагогічних, наукових працівників та інших категорій співробітників) та здобувачів вищої освіти через створення відповідних ресурсів на сайті, діяльність із промоції принципів академічної доброчесності;

б) інтернет-посилання для викладачів $і$ студентів на масові відкриті онлайн-курси за тематикою академічної доброчесності та основ інформаційної грамотності;

в) реалізація у освітніх програмах здобувачів вищьої освіти та програмах підвищення кваліфікащії науково-педагогічних i педагогічних працівників окремих актуальних питань академічної доброчесності. 
$V$. Інструменти контролю додержання академічної доброчесності $y$ освітній і науковій діяльності Державного закладу вищої освіти «Університет менеджменту освіти», які передбачають:

a) проведення анкетування учасників наукового та освітнього процесів на предмет порушень академічної доброчесності;

б) обов'язкову перевірку наукових, навчально-методичних, кваліфікаційних та навчальних робіт на наявність ознак академічного плагіату відповідно до створеної нормативної бази.

Таким чином, університетська система забезпечення академічної доброчесності спрямована на:

1. Дотримання моральних і правових норм поведінки всіма учасниками освітнього проиесу Державного закладу вищої освіти «Університет менеджменту освіти», зокрема вимог до професійної (наукової, освітньої, методичної, інноваційної, творчої) діяльності науково-педагогічних і педагогічних працівників, реалізацію їхньої місії з обміну знаннями та їх примноження в суспільстві, яке навчається, державної політики у сфері вищої і професійної (професійно-технічної) освіти.

2. Реалізаиію освітньої і науково-дослідної діяльності здобувачів вищої освіти в академічному середовищі при здійсненні наукової, освітньої, інноваційної і творчої діяльності для забезпечення високого рівня довіри до результатів освітнього процесу, наукових і творчих досягнень.

3. Інструменталізацію академічної доброчесності як цінності, необхідної академічному середовищу, переведення академічної доброчесності в набір повсякденних професійних дій і сталих освітніх практик.

Важливим кроком для утвердження високих етичних норм і доброчесності в академічній спільноті університету є ознайомлення із Положенням про академічну доброчесність та підписання науково-педагогічними, педагогічними працівниками та здобувачами вищої освіти Декларачіï про академічну доброчесність, яке здійснюється в такі терміни: 1) науково-педагогічні, 
педагогічні працівники - під час прийому на роботу; 2) здобувачі вищої освіти - впродовж місяця з дня зарахування до університету [286].

Положення про академічну доброчесність у Державному закладі вищої освіти «Університет менеджменту освіти» регулює якість і дотримання етичних вимог науково-педагогічними, педагогічними працівниками, здобувачами вищої освіти, слухачами курсів підвищення кваліфікації, замовниками освітніх послуг в основних сферах діяльності Університету: 1) освітній (освітня діяльність здобувачів вищої освіти, слухачів курсів підвищення кваліфікації, викладацька діяльність науково-педагогічних працівників), 2) науковій (написання випускних, магістерських, бакалаврських робіт, дослідницьких проєктів, наукова діяльність, публікація результатів наукових досліджень тощо), 3) методичній (науково-методичний супровід професійного розвитку фахівців в умовах формальної, неформальної, інформальної освіти), 4) у міжособистісному спілкуванні [286]. У Положенні про академічну доброчесність у ДЗВО «УМО» визначено: 1) сутність поняття «академічна доброчесність»; 2) основні види порушень академічної доброчесності; 3) компетентності із дотримання принципів академічної доброчесності в університеті; 4) засоби запобігання академічному плагіату та його виявлення; 5) повноваження Комісії 3 питань етики й академічної доброчесності; 6) форми відповідальності за порушення академічної доброчесності науково-педагогічними, педагогічними працівниками, здобувачами вищої освіти, слухачами курсів підвищення кваліфікації; 7) права осіб, стосовно яких порушено питання про притягнення до відповідальності за порушення академічної доброчесності [286].

Слід наголосити, що у межах розбудови університетської системи академічної доброчесності (представленої на Міжнародній виставці «Освіта та кар’єра - 2020» (21 листопада 2020 р.) здійснено розробку і розпочато реалізацію освітнього проєкта «Академічна доброчесність у науковому та освітньому nросторі: духовність, якість, сталий розвиток» для суб'єктів освітнього процесу Державного закладу вищої освіти «Університет менеджменту освіти». 
Автор-розробник проєкта: Острянська О. А., доцент відділу наукової роботи Державного закладу вищої освіти "Університет менеджменту освіти" Національної академії педагогічних наук України, кандидат педагогічних наук, доцент. Базова кафедра від університету для реалізації проєкта: кафедра педагогіки, адміністрування і спеціальної освіти Навчально-наукового інституту менеджменту та психології ДЗВО «Університет менеджменту освіти» за очільництва Сіданіч І. Л., завідувача кафедри, доктора педагогічних наук, доцента.

Мета освітнього проєкта «Академічна доброчесність у науковому та освітньому просторі: духовність, якість, сталий розвиток»: 1) навчальна ознайомити суб'єктів освітнього процесу із поняттям «академічна доброчесність» як основоположним принципом якісної освітньої і науководослідної діяльності; із чинною законодавчою базою та нормативно-правовим забезпеченням Міністерства освіти і науки України, Національного агентства із забезпечення якості вищої освіти, ДЗВО «Університет менеджменту освіти» 3 питань дотримання академічної доброчесності як складової академічної культури у закладах вищої освіти України; видами порушень академічної доброчесності та академічною відповідальністю за ці порушення; основними функціями антиплагіатних систем; вибраними освітніми практиками й комплексом дій щодо забезпечення академічної доброчесності при підготовці наукових публікацій і кваліфікаційних робіт; формувати у суб'єктів освітнього процесу академічну доброчесність як складову академічної культури особистості, наскрізні академічні компетентності та соціальну відповідальність як складові конкурентоздатності особистості; 2) розвивальна - розвивати у суб'єктів освітнього процесу дивергентне мислення, пізнавальний інтерес, мовлення, мотивацію до дотримання принципів академічної доброчесності у процесі реалізації освітньої та науково-дослідної діяльності, оприлюднення і розповсюдження іiі результатів; 3) виховна - виховувати у суб'єктів освітнього процесу доброчесність як стрижневу якість особистості; повагу до праці педагогічних і науково-педагогічних працівників; шанобливість до академічної 
спільноти та організаційної культури ДВО «Університету менеджменту освіти»; прагнення дотримуватися академічної доброчесності та культивувати іiї серед представників студентської та науково-педагогічної спільноти.

У межах заходів, спрямованих на реалізацію названого проєкта, підготовлено методичний посібник «Академічна доброчесність у сучасному науковому та освітньому просторі» (упорядники: О. А. Острянська, І. Л. Сіданіч. Київ: ДЗВО «УМО», 2021). Крім того, розроблено документацію для забезпечення успішної діяльності студентського наукового гуртка та наукової лабораторї «Академічна синергія», що функціонують при кафедрі педагогіки, адміністрування і спеціальної освіти Навчально-наукового інституту менеджменту та психології ДЗВО «Університет менеджменту освіти» (Бібліографічні дані: Організація діяльності студентського наукового гуртка у закладі вищої освіти: Методичний посібник / упорядники: О. А. Острянська, І. Л. Сіданіч. Київ: ДЗВО «УМО», 2021).

Також у межах реалізації освітнього проєкта «Академічна доброчесність у науковому та освітньому просторі: духовність, якість, сталий розвиток» здійснено розробку навчально-методичного комплексу з навчальної дисципліни для магістрантів «Академічна доброчесність та основи академічного письма» (автор-розробник - Острянська О. А., кандидат педагогічних наук, доцент), що включає такі складові: 1) навчальну програму дисципліни; 2) робочу програму навчальної дисципліни; 3) силабус із навчальної дисципліни; 4) критерії оцінювання результатів навчання; 5) тексти лекцій із навчальної дисципліни (конспекти лекцій із методичними вказівками щодо проведення); 6) розробки та методичні рекомендації до проведення практичних занять; 7) навчальнометодичне та організаційне забезпечення самостійної роботи магістрантів із навчальної дисципліни; 8) навчально-методичне та організаційне забезпечення виконання магістрантами індивідуальних навчально-дослідних завдань із навчальної дисципліни; 9) методичне забезпечення поточного та підсумкового контролю навчальних досягнень магістрантів із навчальної дисципліни, зокрема: а) завдання і тести для поточного (модульного) контролю знань, умінь і навичок 
магістрантів; б) питання і завдання до семестрового контролю 3 навчальної дисципліни; в) критерії оцінювання навчальних досягнень магістрантів; г) комплексну контрольну роботу 3 навчальної дисципліни; 10) навчальнометодичне забезпечення практичної підготовки магістрантів (завдання для роботи під час проходження практики); 11) навчально-методичне забезпечення виконання магістрантами кваліфікаційних робіт.

Активно здійснюється розробка науково-методичного та інформаційного забезпечення освітнього процесу з навчальної дисцииліни «Академічна доброчесність та основи академічного письма» у вигляді окремих видань (монографії, навчально-методичного посібника, хрестоматії, глосарію (понятійно-термінологічного словника), методичних рекомендацій із навчальної дисципліни).

Яскравим прикладом організащуї масових науково-методичних заходів для студентів, спрямованих на формування академічної доброчесності, $\epsilon$ розроблений захід «Естафета академічної доброчесності: від конкурентоспроможного випускника до першокурсника», який дозволяє об’єднати у спільній справі дотримання академічної доброчесності першокурсників університету зі студентами середніх i старших курсів бакалаврату та магістратури, а також спонукає старшокурсників при символічному передаванні «естафети академічної доброчесності» до подання першокурсникам власного прикладу дотримання принципів академічної доброчесності як невід'ємної складової етичних норм діяльності членів університетської спільноти. Цей захід розроблено у творчій співпраці структурних підрозділів університету: науково-педагогічних працівників відділу наукової роботи, кафедри педагогіки, адміністрування і спеціальної освіти. Важливою для студентів є систематична плідна співпраця із Радою молодих учених Національної академї педагогічних наук Украӥни, зокрема із проблематики академічної доброчесності. У межах функціонування Літньої школи для молодих дослідників розроблено тренінг для магістрантів $i$ аспірантів «Академічна доброчесність у науці та освіті: успішні сходинки для 
освітянина, науковця, управлінця». Слід підкреслити, що дуже важливим у розбудові якісної університетської системи академічної доброчесності $\epsilon$ застосування принципу перспективності й наступності у систематичному дотриманні академічної доброчесності від першокурсника до конкурентоспроможного випускника Державного закладу вищої освіти «Університет менеджменту освіти», а тому інформацію про політику академічної доброчесності закладено в силабуси та робочі програми навчальних дисциплін як стрижневі компоненти змісту навчання майбутніх фахівців конкретних освітньо-професійних (наприклад, «Педагогіка вищої школи», «Християнська педагогіка») ma освітньо-наукових програм (наприклад, «Спеціальна освіта (за нозологіями)»). У межах співпраці наукової бібліотеки 3 іншими структурними підрозділами ДЗВО «Університет менеджменту освіти» проводиться копітка систематична робота по наповненню Репозитарію електронних ресурсів Університету. Цікавими й змістовними для здобувачів вищої освіти є тематичні виставки літератури «Академічна доброчесність: віртуальний путівник», різноманітні заходи до Тижня академічної доброчесності. Також створено електронні опитувальники для науковопедагогічних працуівників $і$ здобувачів вищзої освіти з проблематики академічної доброчесності; науково-методичну документацію для провадження групової та індивідуальної проєктної діяльності з означеної проблеми. Слід наголосити, що розроблення навчально-методичних матеріалів із академічної доброчесності здійснюється на компетентнісній основі та спрямовується на забезпечення принципу студентоцентрованості.

Перспективними є: 1) розробка Програми підвищення кваліфікащіï $з$ академічної доброчесності та основ академічного письма для керівників, науковцүів, освітян; 2) організація секиійних засідань із проблематики академічної доброчесності, наприклад, на традиційних науково-практичних конференціях здобувачів вищої освіти і молодих учених; 3) публікація наукових статей у збірнику матеріалів «Наука $і$ молодь: пріоритетні напрями 
глобалізаційних змін» Навчально-наукового інституту менеджменту та психології ДЗВО «Університет менеджменту освіти» та ін.

Здійснюється перевірка на академічну доброчесність наукових результатів діяльності науково-педагогічних працівників, отриманих у процесі виконання науково-дослідних тем, зокрема результатів наукових досліджень та науково-технічних (експериментальних) розробок, які можуть бути представлені: в офіційній продукиії (стандарти, інструкції, нормативні, нормативно-інструктивні видання); в науковій продукиії (монографії, препринти, збірники наукових праць); y виробничо-практичній продукцї (практичні посібники, методичні посібники; методичні рекомендації, практичні порадники); y навчальній продукції (навчальні програми, підручники, навчальні посібники (навчально-методичні, навчальні наочні посібники, хрестоматії, практикуми, робочі зошити); у засобах навчання (навчально-наочні ігрові посібники; атласи; навчальні карти; відео- та аудіовізуальні засоби навчання; електронні засоби навчального призначення; електронні засоби загального призначення); 8 довідковій продукції (енциклопедії (енциклопедичні словники); мовні, лінгвістичні словники; довідники, каталоги).

Із метою успішного впровадження наукових здобутків ДЗВО «Університет менеджменту освіти» важливим $є$ оприлюднення i розповсюдження їх на масових міжнародних наукових заходах, які мають високий статус та популярність серед представників науково-педагогічної спільноти. Саме тому, Національна академія педагогічних наук України, Державний заклад вищої освіти «Університет менеджменту освіти» та Громадська спілка «Всеукраїнська академія інноваційного розвитку освіти» виступили організаторами й активними учасниками вебінару «Академічна доброчесність у сучасному науковоосвітньому просторі: правовий, технологічний та морально-етичний аспекти» (21 листопада 2020 р.) у межах Міжнародної виставки «Освіта та кар’єра - 2020». Метою вебінару $\epsilon$ об’єднання зусиль науковців, практиків, державних і громадських діячів у вирішенні актуальних проблем імплементації принципів академічної доброчесності у сучасний науково-освітній простір, висвітлення 
вітчизняного і європейського досвіду вирішення правового, технологічного й морально-етичного аспектів академічної доброчесності у підготовці та професійному розвитку студентів і науково-педагогічних працівників в умовах диджиталізації суспільства. Цільовою аудиторією вебінару стали науковопедагогічні, педагогічні працівники, керівники закладів загальної середньої, вищої освіти, докторанти, аспіранти, здобувачі вищої освіти. Змістовна програма вебінару передбачала різнобічне обговорення актуальної проблеми академічної доброчесності, яка комплексно висвітлювалася висококваліфікованими, досвідченими спікерами вебінару. Значний інтерес учасників викликало обговорення таких проблем: 1) правові аспекти академічної доброчесності; 2) технологічні аспекти академічної доброчесності $y$ сучасному науково-освітньому просторі; 3)морально-етичні аспекти академічної доброчесності в умовах диджсталізаиї суспільства; 4) зарубіжний $i$ вітчизняний досвід упровадження принципів академічної доброчесності $y$ сучасний науково-освітній простір. Наукова платформа вебінару, який тривав понад чотири години поспіль, стала унікальним місцем для творчої співпраці, плідного науково-освітнього й соціального партнерства представників різних галузей, обговорення й вирішення актуальних проблем академічної доброчесності, розгляду шляхів налагодження й зміцнення дієвої співпраці між науковцями і практиками. Актуальні ц̆ змістовні доповіді спікерів, супроводжувані цікавими інформаційно насиченими мультимедійними презентаціями, сприяли висвітленню кращого вітчизняного і європейського досвіду вирішення правового, технологічного й морально-етичного аспектів академічної доброчесності, який учасники вебінару (науково-педагогічні, педагогічні працівники, керівники закладів загальної середньої, вищої освіти, докторанти, аспіранти, здобувачі вищої освіти) мали змогу сприйняти, обговорити, вдумливо осмислити і творчо застосувати у процесі професійної підготовки, особистісного і професійного розвитку й саморозвитку суб'єктів освітнього процесу в умовах диджиталізації суспільства.

Таким чином, ефективність процесу розбудови системи академічної 
доброчесності як основи професійного розвитку науково-педагогічних працівників і здобувачів вищої освіти в умовах цифровізації суспільства залежить від урахування прогресивного вітчизняного й зарубіжного досвіду та злагодженої індивідуальної й колективної (командної) роботи адміністрації університету, науково-педагогічних працівників кафедр із науковими підрозділами закладу вищої освіти.

Якісна розбудова системи академічної доброчесності за визначеними складовими допомагає науково-педагогічним працівникам університету в повній мірі вирішувати складні стратегічні й тактичні завдання представлення результатів наукової та освітньої діяльності на теренах вітчизняного й міжнародного науково-освітнього простору, систематичного впровадження результатів наукових досліджень, розширення доступу до інновацій, технологій і спільних проектів, зміцнення взаємовигідних ділових міжрегіональних і міжнародних зв'язків, отримання фахового визнання творчих здобутків науковопедагогічною спільнотою та стейкхолдерами.

Перспективи подальших наукових досліджень убачаємо в глибокому науково-методологічному осмисленні прогресивного вітчизняного й зарубіжного досвіду з формування основ академічної доброчесності у суб'єктів освітнього процесу, науковому обгрунтуванні та експериментальній перевірці технології формування академічної доброчесності як основи професійного розвитку науково-педагогічних працівників у процесі інтернаціоналізації вищої освіти. 
DOI 10.46299/ISG.2021.MONO.PED.III.4.5

\section{5 Компонентна структура музично-слухової активності та їі характеристика}

3 метою з'ясування сутності, змісту та структури музично-слухової активності у музично-виконавському процесі розглянемо поняття «активність». У довідникових енциклопедичних виданнях дефініція «активність» трактується на базі семантики іноземного слова: «активність» (від лат. activus - діяльнісний). Енциклопедичний словник тлумачить термін «активність» як енергійну, посилену діяльність, діяльний стан. Під «активністю» у широкому сенсі найчастіше розуміється його первинне значення, що в перекладі 3 латинського «aktivus» означає енергійну діяльність, діяльну поведінку людини. У психологічному словнику за науковою редакцією В. Войтко, активність особистості розуміється як «здатність до свідомої трудової діяльності, міра цілеспрямованого, планомірного перетворення нею навколишнього середовища і самої себе, яка виявляється в їі ініціативності, діловитості, психологічному настрої на діяльність. У наукових дослідженнях поняття «активність» не отримало на сьогодні однозначного трактування, що зумовлено широким розмаїттям теоретичних підходів у різних наукових галузях (фізіології, психології, філософії, соціології, педагогіці та ін.).

Звернення до історії розвитку уяви про активність суб’єкту і про шляхи іiі формування в філософії і соціальних вченнях, психології і педагогіці показує, що це питання розглядалося у багатьох наукових дослідженнях.

За І. Джидар'ян, виокремити самостійну «чисту» лінію розвитку і становлення поняття активності дуже важко. Проблема активності бере свій початок з глибин інших, достатньо глобальних категорій «і перш за все таких, як душа, рух, форма, мета, зовнішня і внутрішня детермінація, свобода, тощо. В елліністичний період, зароджуються уявлення про активність суб’єкта по відношенню не тільки до зовнішнього предметного світу, а й до своїх внутрішніх психічних процесів. Період Відродження змінив розуміння пізнавальної активності суб’єкта. Активність суб'єкта у цю епоху пояснюється не в 
накладанні на рух апріорних знань, а в можливості впливу на нього з боку чуттєвих мотивів, устремлінь людини. Французькі матеріалісти XVIII ст. (Е. Кондільяк, Ж. Ламетрі, Ж-Ж. Руссо, К. Гельвецій, Д. Дідро, П. Гольбах і П. Кабаніс) приділяли значну увагу «зв’язку активності» (а також і пізнавальній активності) живих систем 3 їх матеріальною організацією. Саме складністю організації, а не наявністю особливої субстанції пояснювалась здатність матерії відчувати і мислити..

Пізніше, головним висновком із вчення Канта був такий, що пізнання не може бути безпосереднім відображенням дійсності, воно опосередковане суб’єктивною дійсністю, навіть на рівні чуттєвого відображення. Гегель першоосновою світу вважає абсолютну іде, iіi саморух породжує реальний матеріальний світ. Суть пізнання, за Гегелем, - в саморозвитку, тобто в пізнанні свого власного змісту, філософ, трактує пізнання як активну людську діяльність. Проте вміння людини пізнавати світ не є вродженим - від народження дається лише здатність до пізнання.

Аналіз літературних джерел показав, як із розвитком філософської та психологічної думки розвивалися і погляди дослідників на природу активності. Активність - не тільки прояв життя людської особистості, але й умова іiі розвитку. Активність - одна із основних характеристик особистості, яка полягає у здатності виступати джерелом змін у стосунках з оточуючим світом (на відміну від реактивності, коли джерелом є зовнішній стимул).

Але при всій багатогранності трактування даного поняття, все ж єдиного визначення активності не існувало. Більш того - діапазон вжитку поняття «активність» надзвичайно широкий, що приводить до різних його трактувань та визначень. Розробляючи проблему активності особистості, вітчизняна психологія виходить із визнання того, що активність особистості - це і умова i результат психічного розвитку індивіда, що виявляється в його діяльності (І. Бех,
О. Безпалько, М. Бернштейн,
С. Ковальова,
Є. Крохіна,
М. Лисина,

О. Мачушник, Т. Саєнко та ін.). 
M. Бернштейн проблему активності розглядав через ствердження визначальної ролі внутрішньої програми в актах життєдіяльності організму. Принцип активності він протиставляв принципові реактивності, згідно з яким той чи інший акт - рух, дія - визначається зовнішнім стимулом. М. Бернштейн, вважав, що поведінкові реакції організму детерміновані внутрішньою активністю організму, який діє по закодованій програмі.

Прийнятий А. Леонтьєвим аналіз проблеми формування активності особистості показує, що активність розкривається «у взаємодії особистісних, вроджених або набутих особливостей, які безпосередньо не входять в характеристику його особистісної сфери». Активність та іï розвиток, за А. Леонтьєвим, підпорядковується тій самій формулі, яка характеризує i трансформацію людських потреб.

Активність як набута якість особистості розвивається на основі потреб. Ці потреби детермінуються потребами суспільства. Для того, щоб потреба перейшла в активність, необхідно, щоб вона була усвідомлена особистістю, переросла у стадію зацікавленості. Усвідомлена потреба і цілеспрямований інтерес активізують людину до виконання будь-якої діяльності.

У педагогічній науці проблемі активності присвячені дослідження педагогів Ю. Акименко, А. Алексюк, $\quad$ В. Андрущенка, I. Бех, С. Гончаренка Д. Богоявленської], В. Лозової, О. Олексюк, А. Сбруєва, С. Сисоєвої та ін.

У педагогіці поняття «активність» використовується у двох значеннях:

1) активність як стан пов'язаний із викладанням якого-небудь акту дій;

2) активність як властивість особистості яку треба формувати.

А. Алексюк розрізняє відтворюючу (репродуктивну) та творчу (продуктивну) активність. Репродуктивна активність спрямована на сприйняття, розуміння, збереження в пам'яті та практичне використання. Творча ж пов'язана 3 запитаннями, що виникають чи поставлені. Обидва види активності поєднуються між собою. Творча активність характеризується ініціативою у визначені мети, завдань у прагненні виявити причинні зв'язки та залежності, уміння переходити до теоретичних узагальнень, готовність до самостійного 
творення нового. Тому показниками творчої активності $\epsilon$ ініціатива, самостійність, засоби пізнання, інтереси, характер діяльності.

Творча активність полягає в намаганні і готовності особистості свідомо і добровільно, за внутрішнім переконанням, здійснювати на користь суспільства ініціативні новаторські дії в різноманітних сферах людської діяльності. Важливою складовою творчої активності $\epsilon$ прагнення до самовираження. Залежно від характеру взаємодій суб’єкта та об’єкта творчу активність можна поділити на три види: реконструктивна творча активність, конструктивна творча активність, дослідницько-творча активність.

Для першого виду творчої активності характерним є те, що людина намагається реконструювати предмет або явище, внаслідок чого одержує щось нове $з$ кращими якостями. Другий вид творчої активності передбачає створення чогось принципово нового або принципово новий спосіб розв’язування того чи іншого завдання. Третій вид - дослідницько-творча активність є найвищим рівнем творчої активності. Вона характеризується самостійним пошуком проблем та їх самостійним розв’язанням.

Розгляд питання розвитку творчої активності майбутніх педагогівмузикантів має відбуватися 3 урахуванням загально-педагогічних, психологічних особливостей становлення особистості вчителя та потреби творчої реалізації його, як музиканта-виконавця (вокаліста, інструменталіста). Зміст творчої діяльності педагога полягає у пошуку принципово нових, оригінальних підходів у вирішенні педагогічних завдань, переосмисленні, вдосконаленні шляхів передачі багажу знань та вмінь вихованцям. Процес формування творчої активності студентів має включати розвиток творчої фантазії, уяви, інтуїції, здатності вирішувати проблемні ситуації творчо, 3 опорою на грунтовні фахові знання. У ході роботи визначна роль належить формуванню навичок експериментальної, дослідницької, пошукової діяльності.

Прояви творчої активності пов’язані з механізмами внутрішньої мотивації особистості, а також рівнем розвиненості вольової сфери. Так, лише у випадку наявності чітких внутрішніх мотивів, потреби і бажання займатися музично- 
педагогічною діяльністю, які не стимулюються ззовні, можливим стає прояв активності у професійній діяльності.

Вивчаючи структуру активності особистості вчителя музичного мистецтва С. Ковальова, виокремлює такі її основні компоненти: психолого-педагогічний та музичний, - в яких і виявляється її специфіка.

Психолого-педагогічний компонент, пов'язаний iз мотиваційнопотребовою, інтелектуальною й емоційно-вольовою сферою особистості, визначається індивідуальними психологічними властивостями та якостями психічних процесів. Він охоплює додаткові мотиви, характерологічні особливості, творчі якості особистості, механізм творчості (мислення, уяву, почуття, психомоторику, енергопотенціал), педагогічні здібності (комунікативність, перцептивні здібності, динамізм особистості, емоційну стабільність, креативність). Зазначаємо, що цей компонент є характерним для творчої активності вчителя будь-якого фаху.

Інтегральний музичний компонент розкриває специфіку праці педагогамузиканта і включає музикальність (музичний слух - ритмічний, мелодійний, гармонійний, творчу уяву, чуття цілого, емоційність), виконавські здібності (інструментальні, вокальні), психомоторні здібності (диригентські, виконавські, інструментальні, вокальні), творчі вміння (мистецько-інтегровані, музичнопрактичні, інтерпретаційні, імпровізаційні, композиторські, пошуководослідницькі, проблемно-ситуаційні).

Розглянемо визначення поняття «музично-слухова активність».

Сучасні науковці, феномен «музично-слухова активність» розглядають як здатність до творення музично-слухових уявлень (С. Миколінська); як «звукотворчу волю» (С. Сливко); як необхідну умову розвитку рельєфного та гнучкого внутрішнього музичного слуху (Л. Дашицька).

С. Миколинська, музично-слухову активність розглядає як форму організації психічної діяльності особистості, що забезпечує регуляцію слухової діяльності, аналіз та синтез слухових об’єктів і полягає у спрямуванні слухового аналізатора на звучання музичної тканини (хорового твору, фрагменту, звука 
тощо) та зосередженні слухової діяльності на ньому в даний момент. У безпосередньому виконанні, за словами 3. Корінця, активність слуху стає на заваді механічному озвученню окремих звуків, інтерваліки та ритміки музичних епізодів, репродуктивному відтворенню нотного тексту за «усталеними нормами техніки». Головна спрямованість слуху - контроль музичного виконання на основі співвіднесення еталонного внутрішньо-слухового враження та реального виконавського звучання. Завдяки цьому виконавець здатен оцінити та проаналізувати якість виконання, з'ясувати причину звукової розбіжності між уявним і отриманим виконавським результатом.

О. Карпенко у контексті дослідження шляхів і методів активізації музичнослухового самоконтролю в процесі музично-виконавської підготовки студентів також підкреслює значущість розвитку «активного слуху». На переконання дослідниці це досягається при засвоєнні прийомів слухо-аналітичної діяльності, формуванні «слухо-рухової координації», розвитку внутрішньо-слухової сфери музиканта-виконавця.

Формування музично-слухової активності виконавців у сучасних науковопедагогічних дослідженнях аналізується здебільшого як супутній продукт музично-виконавської підготовки.

У музичній педагогіці формування музично-слухової активності пов’язується з такими засобами:

- розвитком чуттєвих механізмів естетичного сприймання - різних видів, музичного слуху: спрямування уваги на відтворення (сприймання) точної висоти звуків (звуковисотний слух); ладове відчуття окремих звуків, їх стійкості (нестійкості); одночасне сприймання декількох звуків різної висоти і визначення їх консонансно-дисонансної якості, характеру зв’язку з іншими співзвуччями (гармонічний слух); диференційоване сприймання одночасно декількох звукових ліній у їх розвитку (поліфонічний слух); відчуття своєрідності забарвлень і сили звуку (темброво-динамічний слух) тощо;

- формуванням навички активізації слухотворчої уваги в процесі роботи над музичним твором; 
- розвитком музично-слухового уявлення, як основи музичності (Б. Теплов).

Проблема формування музично-слухової активності теоретично обгрунтована у роботах Г. Ципіна. Сутність структурних складових зазначеної якості науковець вбачає в зосередженості музичного слуху на «головних провідниках» музичної змістовності (мелодичній лінії, гармонічних співзвуччях, динаміці розвитку) та утворенні «яскравих, емоційно багатих і змістовних» музично-слухових уявлень про твір.

За визначенням С. Миколинської, музично-слухова активність $є$ необхідною професійною якістю художньо-інтерпретаційної діяльності, яка реалізується через усвідомлену зосередженість слухової уваги на смислових елементах музичного твору, що забезпечує формування інтерпретаційної версії виконання, самостійний відбір художньо-доцільних засобів виконавської виразності та виступає першоосновою поточного контролю й оперативного коригування музично-виконавського результату. Структура музично-слухової активності логічно узгоджується із структурної організації художньо-інтерпретаційного виконавського процесу й охоплює орієнтувально-контролювальний та контролювально-коригувальний компоненти.

Музично-слухова активність сприяє диференційованому ставленню до хорового твору, яке виявляється у цілеспрямованому зосередженні уваги на його певних моментах: мелодичній лінії, гармонічних співзвуччях, тембровому забарвленні, стилістичності, динамічних нюансах тощо.

Отже, спираючись на наукові дослідження психологів та практичні здобутки педагогів-музикантів, ми розробили власне визначення означеного феномену. Музично-слухова активність розглядається нами як інтегрована особистісна психофізіологічна якість, щзо характеризується взаємозв'язком фізіологічних, емоційних, вольових $i$ мотиваційних компонентів музичноперцептивної діяльності особистості. 
Нами розроблена та визначена компонентна структура музично-слухової активності, що охоплює взаємозв'язок та взаємодію мотиваційно-ціннісного, акустично-фізіологічного та емоційно-вольового компонентів.

Мотиваційно-ціннісний компонент характеризує особистісну зорієнтованість майбутнього вчителя музичного мистецтва до вокально-хорової діяльності. Мотиваційно-ціннісний компонент посідає вагоме місце у структурі формування музично-слухової активності майбутнього вчителя музичного мистецтва, оскільки мотив $є$ спонукальним поштовхом будь-якої дії, вирішальним елементом формування будь-якої особистісної якості. Саме через мотив інформація всіх спонукачів людської поведінки отримує вихід, реалізується в практичних діях.

Для нашого дослідження є важливими висновки науковців (Д. Кикнадзе, Н. Кузьміної, О. Леонтьєва та ін.), щодо формування мотивації діяльності: мотив викликається тільки тією потребою, що в конкретній ситуації набуває найбільш об'єктивної та суб'єктивної цінності. Знання й здібність оцінювання дії відіграють одну з вирішальних ролей у виникненні мотиву, за Д. Кикнадзе, однією з умов виховання мотиву $є$ інтелектуальне виховання й освіта. У процесі мотивації людина не тільки усвідомлює свої потреби, способи та засоби їх діяльності їх задоволення, а й обирає предмет потреби, 3 урахуванням індивідуального характеру самих потреб. Мотив як усвідомлене спонукання для певної дії, власне, і формується, в міру того, як людина враховує, оцінює, зважує обставини в яких вона перебуває й усвідомлює мету, що постає перед нею.

Сучасні вчені (О. Олексюк, О. Ростовський, О. Рудницька, Г. Падалка, О. Щолокова та ін.), інтерпретуючи поняття «мотив» 3 сучасних позицій визначають його як внутрішню спонуку особистості до того або іншого виду активності, пов'язаної із задоволенням визначеної потреби, а під мотиваційною сферою особистості розуміють сукупність стійких мотивів, що мають чітку ієрархію і відображають спрямованість особистості.

Із важливих структурних елементів мотиваційно-ціннісного компонента $є$ вивчення мотивів навчальної діяльності та аналіз спеціальних знань (щодо 
вокально-хорової діяльності) учасників навчального хорового колективу. Мотиви навчальної діяльності мають такі складові: мотиви (тиску) відповідальності й обов’язку (з примусу або під тиском); позиційні мотиви (намагатися зайняти конкретну позицію у стосунках 3 оточуючими); навчальнопізнавальні мотиви (орієнтир на здобуття знань, самостійне здобуття знань); широкі пізнавальні мотиви (орієнтир на отримання нових знань, явищ, закономірностей); мотиви самоосвіти (орієнтир на здобуття додаткових знань $\mathrm{i}$ потім побудова соціальної програми самоосвіти). До знань вокально-хорового циклу ми відносимо знання хорознавчого змісту, системоутворювальні знання про основи вокальної техніки (співацька опора, кантилена, висока співацька позиція), загальні знання про хорові колективи.

Отже, мотиваційно-ціннісний компонент виконує пізнавальноперетворювальну функцію, що передбачає розширення системи знань, удосконалення професійних умінь і навичок та сприяє формуванню професійнопедагогічного мислення майбутнього вчителя музики.

Акустично-фізіологічний компонент пов’язаний із готовністю до засвоєння комплексу акустичних та психолого-фізіологічних основ хорового співу.

Одним iз важливих структурних елементів акустично-фізіологічного компоненту музично-слухової активності є формування співацьких та вокальнохорових навичок в кожного з учасників навчального хорового колективу. До співацьких навичок віднесено: спосіб звуковедення, силу й тембральні якості голосу, співацьке дихання, дикцію, вокальний слух. Вокально-хорові навички, в контексті нашого дослідження, базуються на умінні чути себе в багатоголоссі та «тримати» свою партію.

Зв’язки «співак - хорова звучність»у процесі колективного музикування неоднозначні. 3 одного боку, співак, «вливаючись» своїм голосом в загальнохорову масу, підлаштовується до неї, «спирається» на звучання інших голосів. 3 іншого боку, хорова звучність є для співака серйозною перешкодою у здійсненні слухового самоконтролю: усі компоненти звучання власного голосу, маскуються в хорі звучанням інших голосів і стають для співака невиразними або зовсім 
непомітними в потоці хорового звучання. На відміну від співака-соліста, завдання якого - виділитися на фоні інших голосів або інструментального супроводу, співак хору, підкоряючись законам хорового ансамблю, повинен співати «разом» 3 іншими голосами, не виділятися із загального звучання.

Емоиійно-вольовий компонент характеризує спроможність до стабільного виконавського втілення художнього образу хорового твору.

Однією з головних перешкод у формуванні еталонного співу $є$ наявність сценічного хвилювання. Цю ситуацію можна розглядати як стрес - прояв напруженої взаємодії людини із середовищем (виконавець - аудиторія), що змушує його до виходу за межі звичних виконавських реакцій.

Переважною причиною виникнення страху перед публікою є надмірна емоційність, яка породжує хвилювання i дискомфорт. Концентруючись на негативних очікуваннях, студент програмує себе на невдачу, в результаті впадає в паніку і втрачає над собою контроль.

За А. Занковським причини страху, можуть бути різні: страх забути нотний текст, страх виглядати безглуздо перед іншими студентами, неприйняття свого співу, непередбачуваність обстановки та ін.

Ю. Цагареллі у структуру надійності публічного виступу включає такі компоненти: саморегуляція, «завадостійкість», психоемоційна стійкість, стабільність, стійкість уваги мотиваційність, підготовленість. Важливо, що педагогічна дія відбувається ззовні, опосередковано, через саморегуляцію. Розглядаючи структуру саморегуляції автор виділяє: самооцінку, самоконтроль, самокорекцію і самоналаштування. Від адекватності самооцінки залежить об’єктивність самоконтролю і самокорекції. Самоконтроль, за Ю. Цагареллі, розглядається як «здатність слухати себе» і має три складові контроль, еталон, прямий і зворотний зв’язок. Конролююча складова є процесом виконавської інтерпретації твору у вигляді послідовності рухових дій, в нашому випадку вокально-виконавських дій. Еталонна складова простежується на трьох рівнях:

- $\quad$ на рівні діяльності - симультанний музичний образ (цілісне, закінчене за формою виконання); 
- $\quad$ на рівні дії - сукцесивний музичний образ (виконання фрагментів);

- на рівні операції - антиципуюча уява слухомоторного характеру (окремі звуки акорду.

Наближення співу під час концертних виступів до еталону передбачає формування у хористів художньо-виконавських здібностей та артистизму. Художньо-виконавські здібності являють собою складний комплекс раціонально-інтелектуальної, емоційної і творчої діяльності. Вони виявляються в якісних показниках процесу художнього сприйняття, емоційного переживання музичного образу, розумово-аналітичного мислення, глибини осягнення й усвідомлення сутності твору, розвиненості асоціативно-образного мислення, адекватного оцінювання художньої інформації. Проте найяскравіше музичновиконавські здібності розкриваються в художньо-інтерпретаційному процесі, що характеризується суб'єктивністю висловлювання-розуміння, творчим пошуком особистісно-значущих смислів, співзвучних власному духовному світу, самореалізацією виконавця як творчої особистості.

Отже, структура музично-слухової активності характеризується сукупністю мотиваційно-ціннісного, акустично-фізіологічного та емоційно-вольового компонентів, що є важливим елементом музично-перцептивної діяльності особистості 


\section{DOI 10.46299/ISG.2021.MONO.PED.III.4.6}

\section{6 Методологія формування сценічно-образної культури майбутнього вчителя музичного мистецтва у процесі вокальної підготовки}

Володіння сценічно-образною культурою, яка $є$ складовою професійної культури вчителя музичного мистецтва, дозволяє здійснювати світоглядний, естетичний, етичний, творчий розвиток дитини на основі інтерпретації художніх образів, їх вокального оформлення та сценічного вираження. Відповідно виникає необхідність у розробленні і впровадженні авторської методики формування сценічно-образної культури майбутнього вчителя музичного мистецтва.

В сучасній педагогічній науці й освітній практиці науковці і педагоги оперують поняттями «методика» і «технологія». Відповідно виникає необхідність сутнісного аналізу означених понять, що дозволить обгрунтувати доцільність обгрунтування авторської методики формування сценічно-образної культури майбутнього вчителя музичного мистецтва у процесі вокальної підготовки.

У довідникових виданнях поняття «технології навчання» визначається як: за визначенням ЮНЕСКО, це в загальному розумінні системний метод створення, застосування й визначення всього процесу навчання й засвоєння знань, 3 урахуванням технічних і людських ресурсів та їх взаємодії, який становить своїм завдання оптимізацію освіти [295]; продумана у всіх деталях спільної педагогічної діяльності 3 проектування, організації і проведення навчального процесу 3 обов'язковим забезпеченням комфортних умов учнів та вчителів; технологія, що має включати відомості про методи і прийоми викладення, зміст, характеристику й послідовність пізнавальних дій та операцій учнів, способи педагогічного керування їх пізнавальною діяльністю; інтегративна модель навчально-виховного процесу 3 чітко визначеними цілями, діагностикою поточних $\mathrm{i}$ кінцевих результатів, розподілом навчально-виховного процесу на окремі компоненти.

Аналіз довідниково-енциклопедичних ресурсів дозволив виявити низку дефініцій поняття «методика», що диференціюється у таких категоріях, як «методика навчання», «методика виховання», «методика навчального предмета» тощо. Зауважимо, що науковці розглядають методику процесом формування 
певної якості, визначаючи переважно це поняття: як сукупність технічних прийомів, пов'язаних 3 певним методом, охоплюючи окремі операції, їхню послідовність і взаємозв’язок; як сукупність впорядкованих знань про принципи, зміст, методи, засоби і форми організації навчально-виховного процесу, які забезпечують розв’ язання поставлених завдань; як організаційні форми навчання, які застосовуються в кожному навчальному предметі.

У результаті студіювання педагогічних праць, довідникових видань можемо визначити відмінності між методикою і технологією:

- методика представляє собою алгоритм застосування певних форм, методів і засобів з метою формування відповідних знань, умінь, навичок, а технологія послідовний, деталізований процес формування певних якостей, компетентностей, що передбачає більш гарантоване досягнення мети і завдань навчання, що конкретизуються на кожному визначеному етапі;

- методика включає фрагментарні процедури формування знань, умінь i навичок у процесі вивчення окремих дисциплін, а технологія зумовлює керованість процесу формування якостей, компетентностей, що розгорнутий у часі, спроектований на реалізацію деталізованих етапів застосування комплексу методів, форм, оновлення змісту;

- методика переважно застосовується у процесі оновлення змісту, форм і методів базових, фахових дисциплін відповідно до затверджених навчальних планів підготовки фахівців, а технологія передбачає розробленні і впровадження авторських спецкурсів, спрямованих на формування відповідних якостей, компетентностей.

Відповідно можемо зробити висновок про доцільність використання поняття методики до формування сценічно-образної культури майбутніх учителів музичного мистецтва у процесі вокальної підготовки, що представляє собою використання спектру форм і методів, збагачення змісту вокальної підготовки на основі визначених методологічних підходів, загальнодидактичних і специфічних принципів. 
У результаті аналізу праць з проблем мистецької освіти, підготовки вчителя музичного мистецтва, узагальнимо зміст, форми, методи і засоби, які доцільно застосовувати у процесі формування професійно значущих якостей майбутнього фахівця.

Одним із завдань авторської методики $є$ оновлення змісту вокальної підготовки $з$ урахуванням специфіки формування сценічно-образної культури майбутнього вчителя музичного мистецтва. Упровадження змістових модулів 3 метою оновлення змісту вокальної підготовки майбутнього вчителя музичного мистецтва передбачає наповнення проблемним матеріалом 3 питань досвіду формування сценічно-образної культури майбутніх фахівців. У педагогічній теорії зміст освіти розглядається як обсяг навчальної інформації, засвоєння якої забезпечує особі можливість здобуття освіти і певної кваліфікації, а також обумовлена потребами суспільства система знань, умінь і навичок особи, іiі професійних, світоглядних і громадських якостей, що має бути сформована у процесі навчання з урахуванням перспектив розвитку суспільства, науки, техніки, технологій, культури, мистецтва. Упровадження змістових модулів з проблем сценічно-образної культури майбутніх учителів музичного мистецтва передбачає поглиблене ознайомлення 3 досвідом національного і світового вокального мистецтва 3 позиції вияву акторської майстерності, імпровізаційних умінь, вокальної техніки тощо.

Характеризуючи провідні форми підготовки вчителя музики в закладах вищої освіти, визначено, що основними формами є: лекційно-практичні та індивідуальні заняття; позааудиторні концерти; концерти-лекції, конкурси, фестивалі, майстер-класи, творчі зустрічі, тематичні вечори, вечори відпочинку, свята, обряди, огляди художньої самодіяльності, походи до театрів, кінотеатрів, музеїв, на художні виставки, літературні вечори Нам імпонує класифікація форм, узагальнена О.Олексюк, яка визначає критерії їх систематизації: 1) за кількістю студентів (індивідуальні, групові, колективні, масові); 2) за місцем навчання (шкільні (аудиторні) - урок, робота в майстерні, лабораторії тощо) та позашкільні (позанавчальні) - екскурсії, домашня робота, тощо); 3) за часом навчання - урочні 
і позаурочні (факультативні, предметні гуртки, вікторини, конкурси, олімпіади, предметні вечори та ін.); 4) за дидактичною метою - теоретичного навчання (лекція, факультатив, гурток, конференція); комбінованого, або змішаного (уроксемінар, домашня робота, консультація)); практичного (практикуми) тощо; 5)за тривалістю навчання (класичний урок (заняття), спарені заняття, спарені скорочені заняття, заняття («без дзвінків») [297].

Охарактеризувавши спектр методів підготовки вчителя музики О. Рудницька визначає такі з них: наочні (показ тих чи інших прийомів художньої діяльності); словесні (доповнюють наочні й спрямовані на розв'язання закономірностей мистецтва); опорно-ілюстративні (слугують орієнтиром самостійного пошуку власних художніх версій); евристичні (пов'язані з виробленням індивідуального стилю художньої діяльності) [299]. Практико обгрунтованою є класифікація методів підготовки вчителя музичного мистецтва О. Олексюк, яка визначає чотири критерії класифікації: 1) за джерелом знань (словесний, наочний, практичний, відеометод та ін.); 2) за призначенням (набуття знань, формування умінь і навичок, застосування знань, творча діяльність, закріплення набутих знань, перевірка знань, умінь і навичок); 3) за характером пізнавальної діяльності (пояснювально-ілюстративний, репродуктивний, евристичний, дослідницький, ігровий); 4) за дидактичними цілями (сприяють первинному засвоєнню матеріалу, закріпленню та удосконаленню набутих знань) - такі методи виконують навчальну, розвивальну, виховну, мотиваційну та контрольно-коригувальну функції [298].

3 метою реалізації методики формування сценічно-образної культури майбутнього вчителя музичного мистецтва нами було відібрано спектр форм i методів, які, на нашу думку, є більш доцільними й ефективними.

Проведення віртуальних екскурсій у процесі формування ціннісних орієнтацій, мотивації щодо формування сценічно-образної культури майбутніх учителів музичного мистецтва дозволяє активізувати мотиваційну студентів щодо ознайомлення зі спадщиною відомих вокалістів, яких вирізняє талант 
акторської майстерності, вокального таланту, володіння художньо-естетичним смаком, сценічною образністю щодо відтворення ідеї музичного твору. Крім цього, одним із пріоритетів використання цієї форми виступає залучення сучасних мережевих ресурсів, засобів музейної педагогіки, оцифрованих за допомогою комп’ютерно-інформаційних технологій (віртуальний музей класичної музики у Львові, віртуальна екскурсія Андріївською церквою, віртуальні екскурсії по українським оперним театрам).

3 метою формування мотивації щодо формування сценічно-образної культури майбутніх вчителів музичного мистецтва, їх спрямованості на здійснення художньої, вокальної, сценічної інтерпретації музичних творів, що значно поглиблює ї ціннісні смисли, доцільно використовувати відповідний репертуар. Добір репертуару (народних пісень, авторських музичних творів українських і зарубіжних митців), що мають ціннісний потенціал формування мотивації щодо формування сценічно-образної культури, має відбуватися 3 урахуванням спектру вимог. На нашу думку, у процесі добору репертуару з метою формування сценічно-образної культури необхідно враховувати саме ціннісносмислове наповнення музичних творів, можливості для реалізації їх етикоестетичного потенціалу під час вокального виконання і сценічної інтерпретації. Відібраний музичний матеріал повинен бути благодатним тлом для розвитку артистичності, умінь перевтілюватися під час вокального виконання музики різних стилів і жанрів, мати високий рівень ціннісно-смислового насичення тексту.

Вагомим ресурсом для формування ціннісно-мотиваційної спрямованості на відбір відеотеки - зразків виконання вокальних творів з урахуванням рівня акторської майстерності відомих особистостей або фрагментів уроків музики, які демонструють вчителі-практики, на широкий загал через посередництво інтернетресурсів. Вибір цієї форми формування сценічно-образної культури зумовлений загальною тенденцією упровадження інформаційно-комунікативних технологій, мережевих засобів, що зумовлено тенденцією комп’ютеризації навчання, зокрема процесу підготовки педагогічних кадрів. Відповідно використання відеотеки у 
процесі формування сценічно-образної культури майбутнього вчителя музики значно активізує творчий потенціал майбутнього фахівця, дозволяє змоделювати педагогічні ситуації, спроектувати фрагменти уроків з музики з урахуванням елементів вокальної і акторської майстерності.

На етапі формування мотивації і спрямованості на формування сценічнообразної культури майбутнього вчителя музичного мистецтва ефективними формами пізнавальної діяльності є відвідування театрів 3 метою ознайомлення 3 досвідом вокального мистецтва сучасності. Особливо цінною для нашого дослідження є положення про те, що педагогічний потенціал театральних методів ... криється у проживанні, переживанні і оцінці ними реальних або уявних ігрових ситуацій «тут і зараз» у процесі послідовної зміни ролей, активній дії і взаємодії, досвіді подолання конфліктів і комунікативних ситуацій, які потребують рефлексії, стану, що переживається, осмислення свого відношення до ситуації».

Відповідно на етапі розвитку мотиваційно-ціннісних орієнтирів у процесі формування сценічно-образної культури майбутніх учителів музичного мистецтва $є$ потреба у використанні методу інтерпретації, що доцільно застосовувати у процесі аналізу художньо-стильового, змістового плану музичних творів. У процесі застосування методу інтерпретації 3 метою формування сценічно-образної культури майбутнього вчителя музичного мистецтва доцільно передбачати поетапність декодування художньо-образного наповнення твору, основних прийомів звуковибудовування, художньої природи музичного матеріалу, що проявляється «у вмінні дотримуватися балансу у співвідношенні художніх і технічних завдань; ефективному подоланні технічних труднощів; концентрації уваги на звучанні і свободі виконавського апарату; здійсненні слухового самоконтролю».

Інтерпретаційний процес передбачає застосування асоціативного мислення, застосування рефлексивних оцінок, прийомів герменевтичного аналізу, елементів сценічної майстерності і виразної вокальної техніки адже вчитель музичного мистецтва має володіти умінням конструювати музичний твір, ретранслювати його ідейну спрямованість у процесі педагогічної дії на учня, відповідно 
доповнити, збагатити його зміст своєю творчою уявою, фантазією, асоціаціями. Відповідно предметно-асоціативний зміст музичного твору доцільно розкодовувати за допомогою вокальної техніки і акторської майстерності. Високий рівень інтерпретації забезпечує знання фактологічних відомостей про життя і діяльність автора твору, особливостей історичного періоду, в який він жив i творив, інформацію про різних виконавців твору, зіставлення елементів виконання за допомогою відеозаписів тощо.

3-поміж інтерактивних методів навчання у процесі вокальної підготовки майбутніх учителів музичного мистецтва доцільно застосовувати метод лекціїконцерту, яка 3 метою формування сценічно-образної культури дозволяє продемонструвати в дії вокальну й акторську майстерність, спроектувати можливості використання театралізованих елементів під час викладу теоретичного матеріалу, інформаційний матеріал подати більш емоційно, експресивно, що створює ефект запам'ятовування, конструктивної діалогічної взаємодії. Кожна лекція-концерт - це «зустріч-діалог», у якому один ціннісний світ людської особистості розвивається назустріч іншому, взаємодоповнюючи та збагачуючи один одного. Отже, студент має можливість на практиці перевірити результативність діалогової стратегії педагогічної взаємодії, що поступово стає пріоритетною у вітчизняній системі освітніх технологій. Ця форма проведення занять 3 вокальних дисциплін особливо доцільна у процесі формування сценічнообразної культури майбутніх учителів музичного мистецтва, що дозволяє представити досвід вияву артистизму, вокальної майстерності, елементів сценічної інтерпретації музичних образів, що можливо ретранслювати, індивідуально осмисливши на особистісному рівні, у процесі педагогічної роботи, під час організації виховних заходів, їх музичного супроводу, театрального супроводження.

Інтерактивною формою поєднання викладу теоретичного i практико орієнтованого матеріалу під час вивчення дисциплін з вокальної підготовки $є$ бінарні лекції (лекції-дуети), що «передбачають викладення матеріалу у вигляді діалогу двох педагогів», при цьому «студент перетворюється на активного глядача 
«лекційного шоу». Ця форма заняття є однією з найскладніших за підготовкою та проведенням, адже потребує розробки сценарію, вміння працювати у парі, імпровізувати, «тримати удар». Ефективність бінарної лекції у процесі формування сценічно-образної культури уможливлюється за умови структурування матеріалу на основі проблемного змісту (теорії герменевтичного аналізу, сценічної майстерності тощо) та безпосереднього діалогічного спілкування двох фахівців з однієї проблеми, яка розглядається ними на основі міжпредметних зв'язків Особливий когнітивний та емоційний вплив бінарної лекції на майбутніх учителів музичного мистецтва здійснюється за умови використання викладачами елементів «мозкової атаки», методу асоціацій, моделювання педагогічних ситуацій тощо. Особливий інтерес викликають бінарні лекції, які проводяться двома фахівцями, наприклад, філологом i музикантом, щодо літературознавчої і музичної інтерпретації літературних творів, зокрема драматичних. 3-поміж репертуарних творів, які доцільно розглядати 3 позиції літературознавчого і музичного «декодування», $є$ такі, як: опера «Наталка Полтавка» (І.Котляревський, М.Лисенко); опера «Енеїда» (І.Котляревський, М.Лисенко).

Ефективним методом формування сценічно-образної культури майбутнього вчителя музичного мистецтва у процесі вокальної підготовки $є$ сценічновиконавські вправи, що спрямовані на збагачення знань 3 теорії сценічної, акторської і вокальної майстерності, ознайомлення з прийомами вокальної і театральної інтерпретації образів музичних творів. Цей метод дозволяє формувати інтерпретаційні уміння, є певною підготовкою до роботи у сценічно-вокальній студії на етапі творчої самореалізації, тобто формування власне практичних умінь, виконання дуетних творів у межах творчих проектів тощо. Відповідно з метою збагачення знань щодо теорії сценічно-виконавської майстерності, акторської $\mathrm{i}$ вокальної інтерпретації музичних творів у процесі виконання сценічновиконавських вправ доцільно запропонувати аналіз відомих творів у виконанні різних співаків на основі зіставлення вокальної техніки, артистизму, вербальних і невербальних засобів виразності, художньої стилістики, імпровізаційності тощо. 
У результаті аналізу мають враховуватися позитивні i негативні аспекти вокального і сценічного виконання та на основі їх урахування необхідно продемонструвати власну версію твору. Наприклад, таким матеріалом для аналізу можуть слугувати твори: «Стоїть гора високая», муз. народна, сл. Л. Глібова (С. Мірошніченко, Квітка Цісек, А. Солов’ яненко); «Місяць на небі» український романс (Р. Кириченко і Д.Гнатюк, Т.Повалій, А.Солов’яненко) та ін.

Ефективною формою формування сценічно-образної культури майбутнього вчителя музичного мистецтва у процесі вокальної підготовки є семінари-дискусії, на яким поповнюються знання 3 проблеми теорії сценічної $\mathrm{i}$ вокальної майстерності, водночас активізується творчий потенціал студентів, розвивається здатність до артистичності, імпровізаційності, креативності, формується комунікативна культура, доказовість власної позиції. У межах проведення семінарських занять 3 дисциплін вокальної підготовки доцільно проводити дискусії з проблем сценічної майстерності, акторства у педагогічній професії, імпровізаційності під час викладання музики в шкільній практиці, специфіки використання різних вокальних технік в освітньому процесі, стилістичного вокального виконавства тощо. Зокрема активізації творчого потенціалу майбутніх учителів музичного мистецтва, збагаченню їх когнітивного досвіду з проблем сценічної і вокальної інтерпретації музичних творів сприятиме проведення дискусій на теми: «Фольклорна основа національного вокального мистецтва: традиційне виконання чи імпровізаційна «неофольклорна» стилістика?», «Доцільність використання досвіду українських вокальних шкіл в сучасній освітній практиці».

Ефективною формою формування сценічно-образної культури є вокальносценічна студія, залучення до діяльності якої сприятиме створенню умов для творчої самореалізації кожного студента, розвитку його за індивідуальною освітньою траєкторією на засадах ефективної діалогічної взаємодії з викладачем, а також дозволить змоделювати соціокультурну діяльність, метою якої $\epsilon$ збереження i примноження національних традицій вокальної і сценічної майстерності. 
Однією з ефективних форм роботи студії є тренінг з акторської майстерності. На сьогодні театральною педагогікою розроблено систему тренінгів, що розвивають пам’ять, увагу, уяву, сценічну свободу й віру, асоціативне мислення, здатність до дії та інші елементи творчості. Тому в професійну підготовку не лише майбутніх акторів, але й учителів покладено систему К. Станіславського, адже вона надає нам методологію підготовки й реалізації творчого результату. Ретельно вивчаючи природу сценічної дії, автор систематизував ті елементи творчості, які дозволяють зробити дію цілеспрямованою і продуктивною в обставинах життя ролі. До творчих елементів належать: увага до об'єкта; органи сприйняття (зір, слух, дотик, нюх, тощо); пам'ять на відчуття і створення на їі основі образних бачень; уява та фантазія; здатність до взаємодії; віра та наївність; відчуття перспективи дії і думки; відчуття ритму; привабливість і витримка; м'язова свобода та пластичність; володіння голосом та правильною вимовою; відчуття фрази; уміння діяти словом.

В сучасній мистецькій освіті, зокрема у підготовці вчителів музичного мистецтва, доцільно використовувати елементи театральної педагогіки, які закріплені насамперед у теорії театрального режисера i педагога К. Станіславського, який, «досліджуючи елементи творчості, спирається на природні, психологічні закономірності взаємодії людини з навколишнім іiї світом. Такий універсальний підхід К. Станіславського дозволяє нам говорити про те, що перераховані вище елементи слід використовувати у процесі педагогічної дії в обставинах уроку» [300].

У процесі формування сценічно-образної культури майбутніх учителів музичного мистецтва у межах вокально-сценічної студії доцільно проводити тренінги 3 акторської майстерності, спрямовані на розвиток музичного сприймання, візуальної дії, образної пам'яті, імпровізаційності, прийомів сценічної інтерпретації образів музичних творів. На переконання Л.Лимаренко, тренінги 3 акторської майстерності вибудовуються $з$ метою пізнання природи творчості, іiі рушійних механізмів, бажання навчитися бути у творчому стані щодо навколишнього світу», тому «перш ніж навчати учнів творчості, викладачеві 
необхідно зрозуміти й відчути той стан, де приховані власні ресурси, знайти спосіб відкриття й поступового поповнення їх, уміння побачити свої творчі результати» [296].

Науковці акцентують увагу на тому, що створення сценічного етюду вимагає насамперед використання що передбачає здатність до акторської імпровізаційності, використання спектру позамовних засобів (мімічні рухи, жестикуляція, пластика), врахування специфіки синтезу музичних засобів i словесного вираження, акустичних ефектів, стильового виконавського обрамлення, просторове знаходження акторів-виконавців тощо. Активний діалог різних мистецтв може вважатися повноцінним тільки в тому випадку, якщо в ньому будуть задіяні всі аспекти театралізації: ідейний, змістовний, виразний, ілюстративний, а також враховані зовнішні фактори (акустика, костюми, сценічне оформлення), що впливають на якість контакту «сцена -зал»

Для створення сценічних етюдів майбутнім вчителям музичного мистецтва варто запропонувати музичні твори, які потребують добору акторіводногрупників, учасників вокально-сценічної студії, імпровізаційних умінь, інтерпретаторської здатності щодо декодування образно-смислового контексту (Д. Боньковський укр. нар. пісня «Гандзя», М.Кропивницький укр. романс «Соловейко»). Студенти виступають у ролі режисерів, реалізують власний творчий задум на основі інтерпретації музичних творів, що розвиває їхню творчу уяву, художній смак, акторські задатки, педагогічну техніку, вербальні і невербальні комунікативні засоби передавання сутності музичних образів.

3 метою формування сценічно-образної культури майбутніх учителів музичного мистецтва, іiі вияву у педагогічній роботі у процесі моделювання педагогічних ситуацій доцільно особливу увагу звернути на створенні комфортної творчої атмосфери 3 метою подолання страху перед аудиторією, сценою, учнівським колективом. Майбутній фахівець має можливість у процесі відпрацювання навчальної ситуації навчитися долати психологічні бар'єри, негативний емоційний стан, знівельовувати почуття страху, хвилювання перед виходом на сцену. 
Роботу доцільно організовувати на основі використання технології драмогерменевтики, яка, за визначенням О.Олексюк, виявляється через інсценізацію, рольову гру та драму, характеризується активізацією творчих виконавських дій, що відображають різноманітні художні образи, їх зіставлення і взаємодію, через що формує бачення глибинних життєвих колізій, в основі яких конфлікт, суперечності, що має наслідком перетворення буття. Технологія драмогерменевтики передбачає використання ефективних форм і методів, що грунтуються на використання потенціалу драми i безпосередньо положень герменевтики, відповідно вимагає застосування інтерпретаційних умінь, акторської майстерності, вокальної техніки. Серед найбільш доцільних методів і форм - творчий проєкт, метод емоційної драматургії, майстер-клас тощо.

За результатами участі у діяльності вокально-сценічної студії майбутніх учителі музичного мистецтва мають представити творчі проекти, які передбачали підготовку дуетних композицій, презентацій до них, «занурення» в історію їх створення і виконання. Проєкти варто готувати відповідно до вимог, тому передбачено «враховувати логічний виклад матеріалу, аналіз художніх явищ у всій їхній цілісності й контекстності відповідно до принципу історизму, розкриття «духу» епохи, творчого портрету i методу митця, зосередження уваги на конкретному творі, до змісту якого студенти самостійно добирають твори іншого виду мистецтва, здійснюють пошуки взаємозв'язків мистецтв і в такий спосіб відбувається аналітико-синтетична діяльність свідомості, детальне заглиблення в суть твору, осмислення спільних ознак і формотворчих елементів, тонких нюансів, що в кінцевому підсумку сприяє розвитку емоційно-ціннісної, емоційнокомпетентнісної сфер студентів. У межах роботи вокально-сценічної студії 3 метою формування сценічно-образної культури майбутніх учителів музичного мистецтва нами запропоновано творчі проекти на основі презентації, виконання та інтерпретації дуетних композицій. Учасники студії мають підготувати презентаційні матеріали, власну версію виконання дуетного твору на основі особистісної інтерпретації його ціннісно-смислового навантаження, виявляючи креативність, імпровізаційність, музичність, емпатійність тощо, а також 
залучаючи до сценічної і вокальної інтерпретації різні види мистецтва (образотворче, літературне тощо). Зокрема запропоновано такий дуетний репертуар для формування сценічно-образної культури майбутніх учителів музичного мистецтва у межах вокально-сценічної студії: Дж.Верді опера «Травіата» дует Віолетти і Альфреда; М.Лисенко опера «Наталка Полтавка» дует Наталки і Петра; І. Поклад, Ю.Рибчинський «Скрипаль»; С.Гулак-Артемовський дует Карася й Одарки з опери «Запорожець за Дунаєм» та ін.).

У процесі виконання творчих проектів доцільно використовувати метод емоційної драматургії, що варто запропонувати майбутнім вчителям музичного мистецтва 3 метою формування їхньої сценічно-образної культури, розвитку інтерпретаційних умінь, вокальної техніки, акторської майстерності. Емоційна складова уроку з музичного мистецтва або виховного заходу передбачає ретельне планування, створення експресивного супроводу, що зумовлює зацікавленість, захопленість учнівської аудиторії музичними творами, формує відчуття причетності до здобутків національного і світового музичного мистецтва. Саме тому, метод емоційної драматургії Д.Кабалевський інтерпретував як метод, за допомогою якого виконується режисура уроку, складається план до плануконспекту - конспект сценарію виховного заходу. Залежно від підготовки кожного окремого учня й класу в цілому вчитель готує різні сценарії уроку для кожного паралельного класу.

Використання методу емоційної драматургії уроку передбачає створення творчої атмосфери зацікавленості, надає учням досвіду емоційно-естетичного переживання під час опанування музичного мистецтва, сприяє відчуттю причетності до збагачення i примноження культурно-мистецького досвіду. Учитель музичного мистецтва має володіти здатністю розставляти акценти уроку чи виховного заходу - емоційні, художньо-естетичні, ідейні, наповнювати заняття смисловими відтінками, залучати учнів до реалізації творчого задуму автора музичного твору чи драматичного дійства в цілому.

Ефективною формою діяльності вокально-сценічної студії є майстер-класи, що сприяє унаочнення дієвості й ефективності володіння сценічно-образною 
культурою вчителем музичного мистецтва. 3-поміж вагомих ознак проведення майстер-класів виокремлюємо такі, як: створення умов для залучення студентів в активну діяльність; постановка проблемного завдання і вирішення його через «програвання» різних професійних ситуацій.

У процесі проведення майстер-класів важливо демонструвати інноваційні прийоми, вокальні техніки, практикуми, які дозволяють підвищити рівень сценічної культури, вокального професіоналізму. Можливе використання підібраного матеріалу відеотеки, за допомогою якого можливо представити презентації досвіду колег, учителів-практиків.

3-поміж основних засобів підготовки майбутнього вчителя музичного мистецтва виокремлюємо такі: комбіновані засоби комунікації (поєднують вербальну i невербальну комунікації, одночасне використання голосового, мімічного і жестикуляційного показу); наочно-ілюстративні (підручники, навчальні посібники, методичні рекомендації, нотні матеріали, комп’ютерні навчальні програми, електронні підручники, ілюстрації наочні, ілюстрації звукові, таблиці, карти, макети тощо); музично-технічні (інструмент (рояль, піаніно), DVD- та CD-програвачі); інформаційні та технічні засоби навчання. 3-поміж наявних засобів вокальної підготовки майбутнього вчителя музичного мистецтва найбільш доцільними для реалізації методики формування сценічно-образної культури майбутнього вчителя музики у процесі вокальної підготовки є засоби вербальної і невербальної комунікації та музично-технічні засоби.

Таким чином, структурування змісту вокальної підготовки майбутніх учителів музичного мистецтва 3 урахуванням специфіки формування їхньої сценічно-образної культури, визначені форми, методи і засоби підвищення рівня означеної якості дозволяють системно, послідовно удосконалювати знання, уміння, здійснювати рефлексивне оцінювання власної сценічно-образної культури. 


\section{DOI 10.46299/ISG.2021.MONO.PED.III.4.7}

\section{7 Інноваційно-випереджальна система освіти для підприсмницького університету}

Історія університетської освіти налічує кілька століть, протягом яких вона переконливо продемонструвала свою життєздатність, здатність до змін, сприяння перетворенням і прогресу в суспільстві. Перші університети виникли в Свропі в XI - XII століттях і давали в основному гуманітарну освіту. Університет першого покоління - це університет середньовічний, який був заснований дуже давно і зазнав ряд змін. В ті часи викладалися тільки історичні науки, розповідалося, яким чином відбувалося становлення світу. Кількість студентів була невеликою, в межах однієї спеціальності рідко перевищувала число 10. Для керівництва ними зі складу учнів обирався староста десятки - декан (від лат. decem - десять). На чолі університету стояв rector magnificis - simus (лат. rector управитель). Обидві посади займали особи, які мали високий духовний сан. У 1158 р статус університету отримала школа в Болонії (Італія), а потім статус університету було присвоєно школам в Оксфорді та Кембриджі та ін. Незважаючи на те, що освіта тільки починала здобувати свою популярність в суспільстві, випускники перших факультетів вже допомагали вирішувати основні державні завдання: брали участь в управлінні державою і підтримці правопорядку, забезпечували розвиток духовного життя суспільства і охорони здоров'я.

Від самого початку університети і університетська освіта не мали яскраво виражених національних традицій і спрямованості. Біля витоків сучасної університетської освіти лежать дві протилежні тенденції: одна - націленість на отримання та тиражування знань; інша - прагнення отримати практичну, висококласну, професійну підготовку. Ці дві тенденції дали початок двом основним теоріям розвитку університету: теорії ліберальної і теорії утилітарної освіти. Прихильники ліберальної освіти, спрямованої на формування духовно вільної особистості на основі вивчення класичної літератури, вважали, що культурно може розвиватися будь-яка людина незалежно від змін в суспільстві. 
Тому освіта повинна бути спрямована на потреби окремої особистості, а не суспільства вцілому.

Інших поглядів дотримувалися утилітаристи. Вони на перший план висували корисність освіти. Система освіти повинна бути доступна всім, вирішувати нагальні соціальні проблеми і не обов'язково розвивати внутрішній світ окремої особистості.

Суперечки утилітаристів і прихильників ліберальної освіти тривали кілька століть і тільки в XIX столітті завдяки реформам В. фон Гумбольдта в теорії університетської освіти була зроблена спроба об'єднати погляди опонентів, з'єднати потреби суспільства і окремої особистості в процесі здобуття освіти. 3 цього часу роль і значення вищої освіти ще більше зростає, воно стає не просто знанням окремих людей, а починає приносити користь всьому суспільству. Нова модель університетської освіти - це університет другого покоління - це класичний університет, основна ідея якого сформована Гумбольдтом в відомому меморандумі: вищий навчальний заклад - «не що інше, як духовне життя людей, дозвілля або внутрішне прагнення яких призводять до науки і досліджень». ${ }^{1}$ При цьому відносини викладача і студента засновані тут на принципі спільного служіння науці, внесення свого вкладу в осягнення істини, а держава проводить політику невтручання, лише забезпечуючи інфраструктуру та підтримуючи достаток людей, що вибрали науку як життєве покликання. В основу нової моделі університетської освіти були покладені три принципи. Перший полягав у запереченні примітивного утилітарного погляду на освіту, коли знання цінуються лише 3 практичної точки зору. Другий - застерігав від засилля дослідної (емпіричної) науки, яка протидіяла фундаментальному теоретичному пізнанню. Нарешті, третій принцип стверджував перевагу гуманітарної освіти, без якої не може бути освіченої особистості².

\footnotetext{
${ }^{1}$ Гумбольдт В. О внутренней и внешней организации высших научных учреждений в Берлине. Неприкосновенный запас. 2002. № 2 (22). URL : http: //ecsoc

2 Захаров И. В., Ляхович Е. С. Миссия университета в европейской культуре. M., 1994. 85 c.
} 
В основу Гумбольдської моделі університету покладені ідеї німецької класичної філософії від Канта і Фіхте до самого фон Гумбольдта. Виникнення нової моделі відбувалося одночасно 3 підйомом національних прагнень і підвищенням значення держави в XIX столітті. Між владою і наукою склалася домовленість. Вчені бажали мати дозволені державою безпрецедентні інституційні можливості. У свою чергу держава ставила вимога до університетів щодо підтримки національної культури, допомоги у формуванні національних символів, особистості громадян своєї держави. Тому в основі формування «ідеальної моделі» університету лежить союз між освітою і владою.

«Ідеальна модель» університету - це, насамперед, культурно-історична модель, згідно з якою університет залежить від соціокультурного оточення. Суспільство й культура, в яких виникає університет, визначає його форму, завдання, функції, висуває певні вимоги.

Ефективне функціонування нової моделі університету з одного боку, i зміни соціально-економічних і політичних тенденцій в державі і світі дозволили змінити місце і роль університету.

У 1998 р. дослідник вищої освіти Бертон Кларк запропонував ідею «підприємницького університету» ${ }^{3}$ як «усвідомленого зусилля по створенню інституту, яке вимагає цілеспрямованої роботи і напруги», де головним принципом $€$ «прийняття ризиків при освоєнні нових практик, результат яких не визначений» ${ }^{4}$.

Університет третього покоління в інтерпретації Й. Вісеми ${ }^{5}$ або підприємницький університет в термінології Б. Кларка, повинен не тільки реалізовувати свою суспільно значиму функцію, а й відповідати конкретним запитам бізнесу і держави. Ця концепція - продукт XX століття, наслідок ряду

\footnotetext{
${ }^{3}$ Кларк Б. Создание предпринимательских университетов. М. : Изд-во ГУ ВШЭ, 2011. $240 \mathrm{c}$.

${ }^{4}$ Clark B. Collegial Entrepreneurialism in Proactive Universities: Lessons from Europe. Change. 2000. Vol. 32. No. 1. Pp. 10-19. URL : man. hse.ru/univman/msg/144983.html ${ }^{5}$ Wissema J. Towards the Third Generation University: Managing the University in Transition. Cheltenham: Edward Elgar, 2009. 272 p.
} 
фундаментальних змін, що закріпили нові форми відносин між наукою i суспільством. Зокрема, можна відзначити:

(a) посилення приватного сектора у виробництві наукового знання, стрімке зростання числа і якості дослідних проєктів в недержавній сфері, коли потенціал корпоративних дослідних відділів навіть в області фундаментальних досліджень практично зрівнявся з державними; i

(б) збільшення значимості регулювання державної та міжнародної політики в області науки і технології, викликане не тільки глобальними проблемами сучасності, але і закріпленням сцієнтизму в ідеологічному плані (П. Бурдьє, Ю. Хабермас та ін.), а також формуванням нових форм «громадянської відповідальності» і посиленням суспільних інтересів в цій області. Зазначені чинники змінили підстави, на яких до того будувався соціальний контракт між наукою і суспільством. У епістемологічному сенсі авторитет науки по суті не змінився, але сталася зміна парадигми розвитку університетів, сформувалася концепція «академічного капіталізму». Під «академічним капіталізмом» розуміють весь спектр дій університету, спрямованих на пошук додаткового фінансування як для функціонування установи, так i для реалізації індивідуальних дослідницьких проектів ${ }^{6}$.

Основний агент академічного капіталізму - підприємницький університет - $€$ по суті велика капіталістична корпорація, становлення якої визначається перетворенням формального підпорядкування академічної праці капіталу в реальний. Вітчизняна вища освіта поки в меншій мірі порушена цим процесом, ніж сфера академії в розвинених країнах Заходу, і страждає швидше від спадщини минулого, ніж від тенденцій перетворення вищої освіти в сферу реального підпорядкування праці капіталу.

Багато століть вища освіта розглядалася як суспільне благо, і викладачам вдавалося зберігати певну дистанцію між потребами ринку та тими знаннями, які вони дають в університеті. Ситуація почала змінюватися в 1980 - ті р., коли

\footnotetext{
${ }^{6}$ Slaughter S., Leslie L. Academic Capitalism: Politics, Policies and the Entrepreneurial University. Johns Hopkins UP: 1997. $296 \mathrm{p}$.
} 
виникла економіка знання, в якій конкуренція грунтується швидше на інтелектуальних властивостях людей, ніж на їх фізичних здібностях і природних ресурсах країни.

Функції університету також стали змінюватися разом з фундаментальними економічними і політичними змінами. С. Слотер і А. Леслі ${ }^{7}$ бачать в глобалізації чотири далекосяжних наслідки для вищої освіти:

1) скорочення грошей, доступних для вільного використання університетом;

2) збільшення ролі технологічних наук і тих напрямків, які тісно пов'язані 3 ринком; однак, в західній літературі зазначається, що $є$ інститути i департаменти, які легше і швидше зможуть знайти собі зовнішнє фінансування (технічні напрями і економіка), а є напрямки досліджень, зокрема соціальні i гуманітарні науки, які можуть відчувати певні складності. Всередині університету вони відіграють роль оплоту академічної культури, і тут дуже важливо адекватно оцінювати тенденцію на видалення 3 навчальних планів гуманітарних дисциплін;

3) посилення взаємодії між транснаціональними корпораціями та державними структурами в області розробки нових продуктів та інновацій;

4) збільшується конкуренція транснаціональних корпорацій і промислових країн в сфері інтелектуальної власності.

Отже, підприємницький університет докорінно змінює свої характеристики:

1) займається фундаментальними дослідженнями, що формують основу будь-якого прогресу, не тільки в області науки, але також в сфері економіки;

2) багато років тому дослідження було сфокусовано на одній дисципліні. Зараз акцент робиться на міждисциплінарність. Наприклад, дослідження Центру регіонального розвитку університету та Центру стратегічної аналітики та антикорупційного менеджменту. Основними завданнями Центру регіонального

\footnotetext{
${ }^{7}$ Slaughter S., Leslie L. Academic Capitalism: Politics, Policies and the Entrepreneurial University. Johns Hopkins UP: 1997. $296 \mathrm{p}$.
} 
розвитку є: моніторинг актуальних міжнародних програм і проектів міжнародної технічної допомоги які спрямовані на регіональний розвиток; консультування та допомога у розробці грантових проектів для подання у міжнародні фонди; участь у підготовці цільових програм та грантових проектів; участь у підготовці та здійсненні заходів щодо реалізації регіональних цільових програм, тощо. Центр є полігоном для підготовки фахівців спеціальностей: публічне управління та адміністрування, економіка, менеджмент.

У Центрі регіонального розвитку університету виконувались роботи на замовлення Міністерства регіонального розвитку, будівництва та житловокомунального господарства України; Департаменту комунального господарства Харківської міської ради; Балаклійській, Барвінківській та Ізюмській районних адміністрацій.

Центр стратегічної аналітики та антикорупційного менеджменту утворений 3 метою вдосконалення навчального та науково-методичного забезпечення підготовки фахівців зі спеціальності облік і оподаткування безпеки; інформаційно-аналітичної та антикорупційної діяльності для підприємств, установ, організацій; сприяння розвитку недержавної системи безпеки та їі імплементації до системи національної безпеки України, утворення системи підготовки, перепідготовки та підвищення кваліфікації фахівців 3 безпеки, антикорупційної діяльності, обліку i аудиту для державного та приватного секторів економіки.

3) Тісна співпраця 3 промисловими компаніями, які згодом виведуть наукові розробки університету не тільки на внутрішній, але і на міжнародний ринок. Наш ууніверситет підписав угоду про співпрацю між навчальним закладом та АТ «Турбоатом». Мета підписання документу - взаємодія університету i «Турбоатома» в питанні інтеграції наукового, освітнього i виробничого потенціалу для виконання спільних науково-дослідних, освітніх проєктів та робіт інноваційного характеру з пріоритетних напрямків розвитку науки, техніки і технологій в сферах енергетичної інженерії, автоматизації технологічних процесів, зокрема, рішення задач енергоефективності. Угода 
дозволить підвищити рівень дослідження та інноваційних розробок, якість навчального процесу при підготовці студентів, аспірантів і докторантів, а також якість кадрового забезпечення навчального процесу, наукових досліджень та інноваційних розробок. Крім цього, забезпечить умови ефективного використання наукового та матеріально-технічного потенціалу університету та «Турбатома» для вирішення актуальних соціально-економічних проблем.

Так, на базі кафедри хімії інтегрованих технологій нашого університету відкрито нову дуальну магістерську програму «Технології та дизайн кераміки та скла», яка включає дві основні складові: аудиторно-лабораторну підготовку в університеті та одночасне працевлаштування студентів на ПАТ «Харківський плитковий завод». А лабораторний центр «Centr ceramic laboratory» тa Laboratory «Paints. Varnishes. Coatings» дозволяють студентам займатися науководослідною роботою, що відповідає сучасним викликам.

4) Важливо розуміти, що університет третього покоління - це відкритий університет. Він не тільки повинен працювати під егідою Міністерства освіти, але також бути відкритим промисловості, новим студентам, нової моделі освіти і виховання.

Таким новим для вузу, на наш погляд, $є$ облік теорії поколінь як методології освіти і виховання.

Теорія поколінь - це нове вчення, що інтенсивно розвивається i застосовується практично. Рушійною силою історичних подій багато хто вважає зміну поколінь (О. Кант, Дж. Мілль, Г. Феррарі, О. Лоренц). Альтернативна точка зору, згідно з якою зміна поколінь $є$ наслідком історичного процесу, була вперше чітко сформульована німецьким філософом В. Дильтеєм в роботах, опублікованих у 60-70-ті роки XIX ст. Існує багато різних точок зору у визначенні поняття «покоління». Ми під поколінням будемо розуміти сукупність однолітків зі схожими цінностями, що формується в певний історичний період під впливом одних подій і схожих соціальних норм ${ }^{8}$. Таким чином, крім

\footnotetext{
${ }^{8}$ Радионова Л. А. Теория поколений и воспитательная работа в современном вузе. URL :

https://core.ac.uk/download/pdf/78068467.pdf
} 
демографічної, історичної, хронологічної і символічної детермінант в розгляд буде включений аксиологічний підхід до диференціації поколінь.

У такому контексті теорія поколінь розглядалася американськими вченими Нейлом Хоув і Вільямом Штраусом. В основі цієї теорії - цінності людей, саме цінності і їх схожість, а не вік формують і визначають покоління. Розрізняють: «мовчазне» покоління (1923-1943 роки народження), покоління «бебі-бумерів» (1943-1963 рік народження), покоління Х (1963-1983), покоління Y (1983-2000), покоління Z (2000-2020) 9 .

Теорія поколінь передбачає аналіз співіснування наступних життєвих вимірів в освіті: покоління Y i Z це і є наші студенти, і покоління «бебі-бумерів» - викладачі. Соціокультурне середовище відносин між поколіннями або скорочує дистанцію між ними, або спричиняє тотальне дистанціювання, що призводить до кризи. Спроба уникнути ці крайнощі спонукала філософів на обгрунтування «етики дискурсу» - вчення про моральність, яке змістом своєї роботи ставить проблеми комунікації і дискурсу. Саме «етика дискурсу» орієнтує представників різних поколінь не на розбрат і деградацію, а на єдність, відповідальність, згоду, на комунікацію. Йдеться про співпрацю. Викладач в змісті і способі побудови навчального предмета відображає не тільки поняття, закони, теорії та факти, а й спосіб мислення, властивий даному етапу його розвитку і ті методи пізнання, які застосовуються в науці. Такий системноструктурний підхід до побудови змісту дозволяє студентам, не втрачаючи часу на вивчення кожного окремого випадку, бути підготовленим до самостійного освоєння всіх таких випадків, причому не тільки відомих, але й тих, які з'являться в майбутньому. Тому, освітній процес поступово стає адаптивним і повинен все більше прискорювати темпи та включати те, що з'явиться або може з'явитися в майбутньому. До IQ i EQ потрібно додати AQ - адаптивний інтелект, здатність до адаптації. Адаптивність як здатність прийняття змін.

\footnotetext{
${ }^{9}$ Шамис Е., Антипов А. Теория поколений. Маркетинг Менеджмент. 2007. № 6. URL: http://old.executive.ru/publications/
} 
У сучасній культурі присутній яскраво виражений шар інновацій, який постійно зламує і перебудовує культурну традицію, ускладнюючи тим самим процеси соціалізації і адаптації людини до постійно мінливих умов і вимог життя. Ускладнення соціокультурної реальності супроводжується зламом традицій і норм. I проблема це не біологічна, а соціокультурна.

Це проблема зміни способів і типів наступності, відмови від наступності, знищення традицій, а значить i руйнування культури. Культура може розвинутися, лише спираючись на традиції. Зміна типів наступності, відносини до традиції зовсім не пов'язана з запереченням власної історії, вона передбачає вироблення ідеалу та пошук адекватних йому способів життєдіяльності.

Наш час несе в собі культ молодості. Наприклад, представники авангардизму вбачають у молодіжній контркультурі єдино надійну, ефективну, радикальну опозицію щодо всього застійного, консервативного в суспільстві. Цінність людини визначає вміння швидко $\mathrm{i}$ ефективно діяти, легко пристосовуватися до нових технологій та інновацій. Сьогодні спостерігається культ темпу новизни. Як цей культ проявляється в системі взаємозв'язків студент - викладач?

Зараз ключові позиції в вузі займають представники покоління бебібумерів - існує чітка різниця між ними і наступними поколіннями. Головне питання освіти і виховання - як забезпечити спадкоємність між поколіннями, щоб відхід бебі-бумерів не спричинив за собою втрату унікальних знань і відносин.

Одна 3 ключових цінностей покоління бебі-бумерів - «бути молодими». Поняття «молодості» пов'язане у представників цього покоління з позитивними емоціями про їх власну молодість, яка включає досвід втілення великих планів і гігантських будівництв в масштабі країни, а також грандіозних подій загальнолюдського масштабу - як, наприклад, політ людини в космос. Крім того, молодість цього покоління була наповнена активним дозвіллям - походами, а також підприємницьким і лідерським досвідом - комсомолом, будзагонами, суботниками. Бебі-бумерам подобається «бути молодими» в різноманітних 
сценаріях - відчувати себе молодими, виглядати молодо i спортивно, розбиратися в молодіжних питаннях, бути 3 молоддю. Результати впливу цінності «бути молодим» проявляються різних аспектах та все ж є області, де ця цінність перебуває ніби «у себе вдома»: це освіта.

Сьогодні у вузі покоління студентів Y змінюється поколінням Z, поки тільки на молодших курсах, це особливо актуалізує не просто розуміння цінностей покоління Z, а й зміна парадигми університетської освіти. У покоління $\mathrm{Z}$ проявляється гіперопіка - вони постійно знаходяться під наглядом дорослих. Після школи вони займалися в гуртках або з репетиторами, в результаті «зети» відчувають дефіцит спілкування з однолітками. У гаджетах і технологіях вони розбираються краще, ніж в емоціях людей. Тут викладачі університету повинні бути гранично обережними.

Брак спілкування з зовнішнім світом часто компенсується увагою до свого внутрішнього світу, і студенти покоління $Z$ активно цікавляться мистецтвом $\mathrm{i}$ наукою. 40\% «зетів» визнають, що для них важливіше справний Wi - Fi, ніж справні крани у ванній. Поколінню $\mathrm{Z}$ не довелося бути свідками створення $\mathrm{i}$ розвитку соціальних мереж, технології миттєвого обміну повідомленнями, смартфонів, пошукових систем і мобільної революції, вони при них народилися. Зв'язок з будь-якої точки, вільний доступ до глобальної інформації, будь-яке відео за запитом, новини 24/7 - це звичний світ для «зетів». Їм, звиклим 3 дитинства до візуальної інформації, складніше сприймати тексти, а це вимагає перебудови всієї вербальної культури викладання у ВНЗ.

Якщо студенти мілленіали вивчили соціальні мережі, стали публікувати свої думки, висловлювати свою думку і повідомляти всьому світу про кожну значимому подію свого життя. Покоління $Z$ діє 3 міркувань безпеки i самозбереження, поводиться стриманіше і викладає в інтернет тільки обрану інформацію. Щорічно в курсі соціології студенти нашого університету отримують практичне завдання - аналіз параметрів i факторів для самостратифікації, так зовсім недавно мілленіуми називали в показнику «час в 
соціальних мережах» - до 12 годин. Сьогодні «зети» не називають більше 8 годин (це максимальні показники).

Покоління Z - реалісти: вони живуть не тільки в умовах глобальної економічної кризи, а й системної кризи в нашій країні. Згідно з даними фонду Pew Charitable Trusts, за час Великої рецесії середній рівень добробуту батьків «зетів» знизився приблизно на $45 \%{ }^{10}$, а в нашій країні показник витрат тільки на їжу становить $50,3 \%{ }^{11}$.

Мілленіали вагаються - чи варто було вкладати стільки сил і грошей у вищу освіту? Особливо враховуючи, що 44\% вузівських випускників працюють за фахом, який потребує престижного диплому, а кожен восьмий випускник безробітний. Покоління Z прагне до освіти, їм цікаво отримувати знання в різних форматах: навчання на вимогу (on - demand learning) або навчання точно в строк (just - in - time learning) - наприклад, курси на YouTube.

Соціологічне дослідження, яке ми проводили серед студентів першого курсу в вересні 2020 році, показало: на питання про причини вступу до нашого університету першокурсники покоління Z назвали «можливість стажування, практики за кордоном, подвійних дипломів» - 39\%, а в 2015 таких було (мілленіалів) менше 10\%. «Зети» орієнтовані отримати будь-який цінний досвід в різних ролях або проєктах під час навчання в університеті. Відповіді по альтернативі: «Вкажіть, які можливості, що надаються університетом, хотіли б Ви використовувати для особистісного розвитку» розподілилися таким чином: «додатково вивчати іноземні мови» передбачувано переважають - майже 57\%. Друге місце - «брати участь в міжнародних навчальних програмах» майже 42\%. Третє місце - «відвідувати спортивні секції» - більше 34\%. Майже 34\% наших студентів хочуть отримати водійське посвідчення.

\footnotetext{
${ }^{10}$ Ryan Jenkins, HR Daily Advisor. Generation Z vs. Millennials: The 8 Differences You Need to Know By Ryan Jenkins, Author. International Keynote Speaker Sep 25, 2017 HR Management URL :

https://hrdailyadvisor.blr.com/2017/09/25/generation-Z-vs-millennials-8-differences-need-know/

${ }^{11}$ Стало відомо, скільки українці витрачають на їжу URL : https://economics.unian.ua/finance/10250745-stalovidomo-skilki-ukrajinci-vitrachayut-na-jizhu.html
} 
I природно, «Зети» підуть в більш відкритий вуз, який може запропонувати їм більше можливостей для подальшої роботи, для наукової діяльності, а підготувати їх до цієї ролі повинен університет 3.0.

5) В університеті повинен бути визначений масштаб діяльності. В іншому випадку він не зможе успішно працювати: повинні бути бібліотека, лабораторії, інфраструктура, які забезпечать якість освіти. Наш університет приділяє цьому пильну увагу. Так на кожному факультеті є сучасні лабораторії, що відповідають передовим досягненням науки і техніки. Наприклад, галузева науково-дослідна лабораторія по обстеженню та випробуванню будівельних конструкцій та матеріалів кафедри будівельних конструкцій. У лабораторії виконуються дослідження і роботи на замовлення: Міських рад; Обласних державних адмінінстрацій; ОТГ та районих адмінінстрацій; ТОВ «Стальконструкція ЛТД»; ДП «УкрНТЦ «Енергосталь»; «ЖБК Авантаж»; ТОВ «Житлобуд-1»; ТОВ «Житлобуд-2». У Харківському національному університеті міського господарства імені О. М. Бекетова вже понад п'ять років студенти можуть працювати в сучасній лабораторії BIM технологій. BIM - це, в широкому розумінні, віртуальне будівництво, інформаційне моделювання майбутніх будівельних об'єктів. Одним 3 перших провайдерів VDC послуг у світі стала харківська команда UA Team. Саме в рамках співпраці з цією компанію у 2014 році було відкрито перший в Україні навчальний центр з ВІМ на базі ХНУМГ ім. О. М. Бекетова. Тоді це був офлайн курс, що проходив в лабораторії, оснащеній за останніми потребами, із залученням практикуючих спеціалістів. Після закінчення курсу 18 людей приєдналися до команди, що стало значним поштовхом розвитку компанії ${ }^{12}$.

Вже декілька років Харківський національний університет міського господарства імені О. М. Бекетова активно співпрацює з Національною енергетичною компанією «Укренерго». Університет для цього має потужну інфраструктуру - провідні лабораторії і центри університету, які забезпечують

\footnotetext{
${ }^{12}$ Офіційний сайт Харківського національного університету. URL : https://www.kname.edu.ua/index.php/ru/
} 
підготовку фахівців зі спеціальності електроенергетика, електротехніка та електромеханіка. Це лабораторія альтернативної енергетики, лабораторія інтелектуальних систем управління освітленням, лабораторія «Електрообладнання систем міського електропостачання», лабораторія цифрового релейного захисту та автоматики, науково-дослідний Центр світлотехнічних вимірювань, лабораторія світлового дизайну, інноваційна освітньо-наукова лабораторія «Сонячна електростанція» та інші. Лабораторії призначені для забезпечення потреб університету в електричній енергії, підготовки студентів та проведення наукових досліджень. На їх базі студенти отримують теоретичні і практичні навички проектування і обслуговування такого виду електроустановок. Напрямками діяльності лабораторій є ефективна підготовка докторантів, аспірантів, магістрів та бакалаврів 3 акцентом на міждисциплінарність; підготовка персоналу енергопостачальних компаній, промислових, транспортних та житлово-комунальних підприємств за наступними програмами підвищення кваліфікації для спеціалістів.

На факультету інженерних мереж та екології міст створений уніфікований лабораторний комплекс «Еколого-енергетичної безпеки». Центр включає лабораторію інноваційних енергозберігаючих технологій та лабораторію екологічного моніторингу. $\mathcal{C}$ також лабораторія «Видобування і підготовки нафти і природного газу», лабораторія «Транспортування нафти і природного газу», лабораторія газових та теплових систем і кондиціювання повітря.

Факультет архітектури, дизайну та образотворчого мистецтва створений сучасний комплекс архітектурно-художніх майстерень і лабораторій «Arhouse». Комплекс створено з метою забезпечення сучасних умов навчання студентам архітектурного та художнього напрямів підготовки із урахування особливостей та тенденцій сучасної освіти. До архітектурно-художніх майстерень «Arhouse» входять: лабораторія комп'ютерного моделювання; майстерня малюнка i живопису; скульптурна майстерня; лабораторія архітектурного моделювання; ландшафтно-архітектурна майстерня; виставковий зал; конференц-зал; студентське архітектурно-проектне бюро. 
На факультету транспортних систем та технологій створено лабораторію навчального центру SmaLog «Розумний транспорт і логістика для міст». Лабораторію створено в рамках реалізації міжнародного проекту програми КА2 «Еразмус+». Під час навчання в лабораторії за допомогою програм Vissim, Visum, Anylogic, StatGraphic можна виконувати наступні види робіт:

- аналізувати параметри i показники функціонування транспортних процесів і систем;

- проводити дослідження транспортних технологій на основі моделювання транспортних процесів.

- проводити моделювання транспортних потоків;

- розробляти технології логістичного управління на транспорті;

- оцінювати ефективність управління транспортними технологіями;

- проводити дослідження фактору людини на транспорті;

- виконувати статистичний аналіз ймовірнісних процесів.

6) Дуже важливо, щоб всі в університеті вміли розмовляти англійською мовою, іншими іноземними мовами. Так, в Харківському національному університеті міського господарства дуже активно діють міжнародні культурноосвітні та мовні центрі: Українсько-канадського культурно-освітнього центру;

Українсько-польського культурно-освітнього центру; культурноосвітнього центру «Інститут Конфуція»; Чеського мовно-культурного центру; Українсько-Азіатського культурно-освітнього центру; Українсько-Турецького культурно-освітнього центру; Українсько-Арабського культурно-освітнього центру; Лівансько-українського культурно-освітнього центру. Це створює можливості для участі в програмах студентських обмінів, долучення до міжнародних наукових програм, участі у культурних заходах, що проводяться міжнародними центрами протягом навчального року.

7) В університетах другого покоління займалися, в першу чергу, академічною діяльністю, а тільки потім наукою. Зараз ситуація змінилася: в університетах третього покоління першочергово виходить виробництво i комерціалізація розроблених ноу-хау. Це актуалізує такі питання, як захист 
інтелектуальної власності. За останній час в університеті здійснено суттєве покращення патентно-ліцензійної роботи. Так, наприклад, на кафедрі електричного транспорту налагоджено інтенсивну роботу з підготовки об'єктів інтелектуальної власності, завдяки чому тільки за період з 01.01.2019 р. по 10.01.2020 p. науково-педагогічними працівниками кафедри електричного транспорту отримано 96 патентів України із загальної кількості 111 по університету.

8) В університетах третього покоління - децентралізація: в більшості країн університети не можуть самостійно розробляти освітні програми, видавати власні дипломи. Для цього вони повинні отримати дозвіл від міністерства. За оцінками західних дослідників, в майбутньому ця ситуація зміниться. Університети будуть, як і раніше, отримувати фінансування з боку держави, але іншими способами. Всі директиви, які на поточний момент університети отримують від держави, спускаються ректору і далі на професорів, при цьому витрачається дуже багато часу і не дозволяють найбільш ефективно працювати.

Природно, що викладання теж зазнає значних змін. Якісне викладання не менш важливо в порівнянні з якісним дослідженням. Часто наші курси $є$ непопулярними, нецікавими не тому, що предмет нецікавий, а тому що нецікаво працює викладач, неякісно ведеться викладання.

Дипломи, якими ми бачимо їх зараз, теж змінюються. Ступінь бакалавра каже роботодавцю про те, якими знаннями володіє випускник. На поточний момент це не важлива інформація. Тому що роботодавці хочуть найняти певну людину під певний функціонал. Дуже важливо на даний момент, щоб наші випускники відповідали вимогам і щоб вони чітко розуміли, чому вони можуть виконати якісно ту чи іншу роботу.

Таким чином, підприємницький університет, це відповідь вищої освіти на виклики епохи, це зміна моделі функціонування університету в напрямку більшої адаптивності, гнучкості, в напрямку більш активної взаємодії 3 оточенням - державними інститутами, бізнесом, венчурним капіталом, в напрямку створення всередині університетів центрів комерціалізації (трансферу 
технологій, патентної підтримки і захисту, бізнес - інкубації і т. п.), тобто по суті - центрів прибутковості, як це відбувається всередині великих корпорацій, які прагнуть знайти друге дихання на ринку за рахунок внутрішньокорпоративного підприємництва, інтрапренерства.

На наш погляд, кращою ілюстрацією зміни моделі функціонування університету $є$ дослідницький університет Чалмерса ${ }^{13}$, що випустив 40\% шведських інженерів і архітекторів. Він отримує державне фінансування і при цьому приватний з 1994 року. Університет Чалмерса був заснований в 1829 році і за сто з гаком років виріс з промислової школи для бідних дітей у вищу технічну школу, далі виріс спочатку в дослідницький університет, а потім - в підприємницький. Історія приватизації Чалмерса належить до категорії зразково - показових в політиці вищої освіти. У 90-х роках шведський уряд оголосив тендер: вуз, який надасть стратегію розвитку і готовий працювати в контактному режимі, може отримати статус університету - фонду. Ряд вищих навчальних закладів подали заявки, але до кінця дійшов тільки один Університет Чалмерса.

Фонд - це закрите акціонерне товариство, актив, який сам собою володіє, що дозволяє вступати в довготривалі партнерства 3 індустрією, створювати компанії, володіти акціями, дійсно бути інтелектуальною корпорацією. В університеті Чалмерса три управлінських рівні: фонд, наглядова рада і президент зі своєю командою. Члени фонду призначаються урядом, туди входять не тільки представник від індустрії, президент, студенти, викладачі, але й професійний фінансист, політик і літератор. Фонд розпоряджається інвестиціями, наглядова рада вибудовує довготривалу стратегію, президент керує операційною діяльністю. Викладацький сенат, який раніше контролював університет повністю, зберіг за собою лише дорадчий голос.

3 урядом Чалмерс взаємодіє в режимі короткочасних і довготривалих контрактів: гроші в обмін на чіткий план і виконувані обіцянки. Це звична для північноєвропейських країн схема: датські університети домовляються 3

\footnotetext{
${ }^{13}$ Сайт университета Халмерс. - URL : http://www.chalmers.se/en/
} 
міністерством з «контрактами розвитку» на столі, в Фінляндії, наприклад, також є декілька університетів - фондів.

У 1517 році Мартін Лютер прибив 95 тез реформування католицизму на дверях однієї з німецьких церков, поклавши початок Реформації. В університеті Чалмерса прибивання тез перетворилося на академічну традицію. Дисертація публікується у вигляді невеликої книги і урочисто, в колі друзів, іноді з науковим керівником і іншими професорами, іноді без, прилаштлвується або прибивається на стіну так, щоб іï зручно було читати. Із вступу навіть для неспеціалістів в цілому зрозуміло, про що йдеться. В університеті Чалмерса більшість кафе і ресторанів знаходяться в власності Студентського союзу.

Інженерна освіта в Чалмерсі побудована на системі CDIO, Conceive Design - Implement - Operate. Ініціатіва CDIO була розроблена в кінці 90-х у відповідь на невдоволення індустрії рівнем практичної підготовки випускників і офіційно запущена в 2000-му в коллаборації 3 трьома шведськими університетами, включаючи Чалмерс. Зараз в мережі більше ста вузів. Спочатку система відповідала на запит індустрії на більш цілісно підготовлених інженерів і з'єднала дисциплінарні знання, професійні навички, командну роботу і власне здатність розробити інженерний проєкт.

Освітній простір Чалмерса вибудовано як складну матрицю, в трьох вимірах: 13 департаментів, чотири школи, нова система треків. Матриця складалася поступово, крок за кроком. Спочатку існували департаменти, які тримали освітні програми. Потім поступово були введені школи, тепер вони тримають освітні програми, «викуповуючи» курси у департаментів. Це було зроблено, щоб уникнути конфлікту інтересів, коли кафедри намагаються розробляти курси під інтереси своїх викладачів. Нові треки прошивають департаменти i школи по діагоналі, дозволяючи студентам працювати над проєктами, які вимагають різнорідної дисциплінарної експертизи. Матричні рішення схожі на оксамитові революції в організації університету.

Матриця використовується і для організації дослідних робіт. У Чалмерсі є вісім «Зон переваги» (Areas of Advance). Вони також були сформовані недавно i 
проходять крізь департаменти, збираючи компетенції, необхідні для вирішення комплексних завдань в областях транспорту, енергії, виробництва і так далі. «Зони переваги» спрощують вхід для потенційних замовників, чиї проблеми завжди міждисциплінарні ${ }^{14}$.

Університет Чалмерса хоче, щоб на нього дивилися як на партнера номер один - того, кому подзвонять в першу чергу, коли потрібно буде технічне рішення, фахівці з певним набором компетенцій або поради.

У університету Чалмерса багато контрактів з індустрією, але всього16 стратегічних партнерів. В основному це концерни: Volvo, Saab aбо Ericsson. Договори укладаються на $10+$ років, і 3 кожним партнером президент університету зустрічається особисто двічі на рік. Партнерство складно організоване і багаторівневе: контрактні дослідження, запрошені $з$ індустрії професори - практики, стажування, програми «прокачування» персоналу, індустріальні $\mathrm{PhD}$ (рішення задач корпорацій в рамках дисертаційного проєкту) і так далі ${ }^{15}$.

Зростає конкуренція між університетами (за державне i приватне фінансування, за кращих і більш платоспроможних студентів), яку формують рейтингами і ренкінгами. Так в уряді заявили, що «є ціла історія, що потрібно робити з університетами, певною мірою їм передали автономію і повноваження. Ми повинні стимулювати якість і ефективність. Гроші має отримувати передусім той, хто кращий, а не той, кому треба..., у нас з'являться рейтинги університетів i все таке інше» ${ }^{16}$. В міністерстві освіти і науки зазначали, що додаткове фінансування буде виділятися на підставі ряду критеріїв, які повинні «прямо або опосередковано свідчити про те, які університети сильніші, а які слабші». Один 3 них - включення університету в престижні міжнародні рейтинги. The QS World University Rankings ${ }^{17}$. В нашій країні в цей рейтинг входять шість університетів. Зокрема, на 481 позиції рейтингу знаходиться Харківський університет імені

\footnotetext{
${ }^{14}$ Сайт университета Халмерс. - URL : http://www.chalmers.se/en/

${ }^{15}$ Сайт университета Халмерс. - URL : http://www.chalmers.se/en/

${ }^{16}$ В уряді розповіли про плани перебудови фінансування освіти і науки URL:

https://www.unn.com.ua/uk/news/1834855-v-uryadi-rozpovili-pro-plani-perebudovi-finansuvannya-osviti-i-nauki

${ }_{17}$ Рейтинги ВУЗов URL: https://ru.osvita.ua/vnz/rating/64752/
} 
Каразіна (в минулому році - на 401-410 позиціi). Позицію 531-540 займає Київський національний університет імені Шевченка (в 2018 році - 411-420 позиція). Національний технічний університет «Київський політехнічний інститут імені Сікорського» зайняв позицію 601-650 (у 2018 році - 501-550 позиція). Національний технічний університет «Харківський політехнічний інститут» - 701-750 позиція (в 2018 році також 701-750 позиція). Цього року до рейтингу увійшов Львівський політехнічний національний університет, який розділив з Сумським державним університетом 751-800 позиції. У минулому році Сумської держуніверситет зайняв 801-1000 позицію) ${ }^{18}$.

Ще одним критерієм $є$ наукова діяльність. Також в Міносвіти розглядають критерій обсягу позабюджетних коштів, отриманих за наукові замовлення. Четвертий критерій, який буде враховуватися при виділенні додаткового фінансування, - це контингент студентів. «На сьогоднішній день кількість студентів - це найбільш визначальний показник. Кількість студентів впливає на кількість ставок, а за ставками і надають фінансування ... 32020 року контингент студентів буде набагато менше впливати на розмір фінансування. Це потрібно для того, щоб розв'язати руки університетам і викладачам, щоб вони повернули собі святе право відраховувати студентів, які не навчаються. Також ми в контингент вставляємо різні коефіцієнти для спеціальностей. Наприклад, медична спеціальність цінніша, ніж філософія або економіка, тому пов'язана 3 різноманітним обладнанням. Там, де немає додаткових витрат, буде меншим i коефіцієнт (один студент-медик фінансово буде «важити», як три студентаекономіста» ${ }^{19}$.

П'ятий критерій - це «масштаб університету». У Міносвіти його розглядають як «інструмент для об'єднання університетів». «Чим більша установа вищої освіти, тим більше у неї буде грошей. «Ми будемо застосовувати певну градацію - наприклад, «університети до трьох тисяч студентів», «від трьох до шести тисяч» і т. д. Цілком можливо, що буде багато ситуацій, коли при

\footnotetext{
18 Там же

${ }^{19}$ В уряді розповіли про плани перебудови фінансування освіти і науки. URL :

https://www.unn.com.ua/uk/news/1834855-v-uryadi-rozpovili-pro-plani-perebudovi-finansuvannya-osviti-i-nauki
} 
об'єднанні дві установи матимуть більше фінансування, ніж кожен окремо. Тобто, це позитивний стимул об'єднуватися» ${ }^{20}$.

Ще один критерій - зайнятість випускників того чи іншого університету. «3 наступного року ми запустимо моніторинг зайнятості випускників, результат якого так само буде впливати на те, скільки грошей отримає університет. Зрозуміло, що людині після випуску потрібен час на адаптацію, пройде два-три роки, і ми подивимося, де на ринку праці перебуває випускник» ${ }^{21}$.

У контексті вищевикладеного вже відбуваються зміни в структурі та ієрархії ролей і завдань основних акторів університету. У сучасній західній літературі про підприємницький університет досить добре описано. В першу чергу, видимим свідченням вбудовування університетів в суспільство «академічного капіталізму» стає поява багатьох незвичних підрозділів, які доповнюють традиційні структурні одиниці (факультети, школи і т. д.) - такі, як інженерно-технологічні підрозділи, курси підприємництва, центри інкубування бізнесу та ін. Це формує новий вигляд вузів, наближаючи до вигляду багатогалузевих бізнес-корпорацій. Далі, відбуваються важливі зміни в структурі та ієрархії ролей і завдань основних акторів університету, професорів i викладачів. Освітні завдання все більше підпорядковуються завданням досліджень і просування їх результатів. Відповідно, для цього необхідна потужна лабораторна база з новітнім обладнанням і технологами, здатними іï обслуговувати, а також потужні фандрайзингові підрозділи по роботі зі спонсорами та випускниками, які допомагають залучати кошти для фінансування досліджень. Наприклад, Центр трансферу технологій «Мегаполіс» в нашому університету створено за фінансової підтримки Фінансовопромислової групи DCH, друзів, випускників та студентів Університету. В основу діяльності Центру трансферу технологій «Мегаполіс» закладено принципи наукової кооперації, вільного доступу до ресурсів, міждисциплінарних досліджень, що сприяють підвищенню наукового та

\footnotetext{
20 Там же

${ }^{21}$ Там же
} 
науково-технічного потенціалів студентів, аспірантів, докторантів та викладачів Університету.

Роль такого «допоміжного» персоналу для успішного функціонування університету стає настільки ж важливою, як і роль академічного персоналу.

Нарешті, все частіше викладачам доводиться брати на себе, крім «академічних» також «неакадемічні» функції, тобто відбувається втрата розмежувань між ролями і формування якогось сукупного працівника вищої освіти.

На цьому тлі, природно, відбуваються і зміни в сфері організаційної та корпоративної культури. Традиційний університет представляв собою особливий вид громадського інституту, який відрізнявся від комерційних організацій, виступаючи свого роду «вежею зі слонової кістки» для тих інтелектуалів, кому не близькі цілі і цінності зовнішнього світу. Ця відмінність підкреслювалося академічної свободою - незалежністю університету від зовнішніх впливів і колегіальністю як особливим способом організації внутрішньої діяльності. «Підприємницькі» ж університети стали втрачати цю свою колишню ідентичність.

На зміну горизонтальному академічному самоврядуванню в багатьох сферах життя університетів приходить вертикальне «управління за результатами»; на зміну обраним 3 числа самих професорів тимчасових керівників - наймані менеджери від освіти; на зміну атмосфері задумливого відокремлення - атмосфера пошуку швидкого результату, ринкової ефективності. Сучасні умови функціонування університетів, а також досвід перших університетів підприємницького типу дозволяють позначити основні джерела додаткових коштів, що залучаються вузом:

- збільшення приватних пожертвувань, в тому числі створення цільових фондів - ендаументів; Так, ендаумент Гарварда заробляє 35\% прибутків університету 22.

\footnotetext{
22 Акции, стартапы, недвижимость: куда инвестируют Гарвард, Йель, Стэнфорд и другие зарубежные университеты. URL : https://www.rvc.ru/press-service/media-review/venture/157912/
} 
- розвиток нових форм навчання (онлайн, корпоративного, контрактного і т. д.);

- розвиток торгівлі на території студентського містечка;

- введення карт оплати і електронних карт на території студентського містечка;

- розробка програм для випускників;

- надання в оренду майна на території студентського містечка;

- доходи від прав на інтелектуальну власність (результати дослідницької роботи).

Політика академічного капіталізму, що проводиться в університетах, поставила їх перед дилемою часткової відмови від академічної свободи на користь діяльності, спрямованої на залучення додаткових коштів, необхідних для забезпечення наукового та освітнього процесів. Зокрема, це виражається в необхідності вибирати напрямок дослідження, що представляє інтерес: для самого дослідника, для бізнесу (комерційних структур, промислових підприємств) $)^{23}$.

Зі зміцненням ринкової логіки в сфері вищої освіти стало вкорінюватися поняття «новий менеджеріалізм» («нове управління»), яке означає прийняття структурами громадського сектора тих організаційних форм i технологій, управлінських практик i цінностей, які існують в сфері приватного підприємництва ${ }^{24}$. Менеджеріалізм характеризує принципи управління, прийняті в приватних корпораціях, але поширювані на державні і громадські інститути ${ }^{25}$. Розвиток ідей менеджеріалізма в останнє десятиліття пов'язаний з проникненням неоліберальних принципів в державне управління та суспільний сектор. Зміни в системі управління вузом пов'язані з введенням моделі управлінських рішень «зверху вниз», а також 3 укоріненням самого поняття «менеджмент

\footnotetext{
${ }^{23}$ Прохоров А. В. Влияние ценностей академического капитализма на функционирование современных университетов. Вестник ТГУ. Сер. «Гуманитарные науки». 2012. № 5. С. 271-278.

${ }^{24}$ Мирча М. Институциональные подходы к предпринимательству: анализ и опыт университета Бабеш-Больяй в Клуж-Напоке. Высшее образование в Европе. 2006. Т. XXXI, № 2.

25 Абрамов, Р. Н. Менеджериализм и академическая профессия. Конфликт и взаимодействие. Социологические исследования. 2011. № 7. С. 38.
} 
університету». Сфера вищої освіти зазнала змін, для яких Дж. Келлер запропонував формулювання «управлінська революція в університеті» («the management revolution in the academy»). В результаті «революції» управлінська ланка університету змушена посилити стратегічний контроль над діяльністю вузу і його підрозділами ${ }^{26}$.

Ухвалення ідей нового менеджеріалізма пояснює посилення уваги до проблеми управління діяльністю i внутрішньою культурою університету. Керівник вузу тепер розглядається не тільки як академічний лідер, але і як управлінець штатом, студентами, фінансами, системою викладання. Ускладнення університетської структури в умовах менеджеріалізму пов'язане 3 появою професійних груп всередині вузу, які мають власні уявлення про пріоритети університетського життя. Новий менеджеріалізм виступає умовою виникнення ціннісних протиріч між представниками менеджменту i академічного персоналу. Для академічної спільноти ключовою цінністю є науково-дослідницька робота, результати якої можуть виражатися у вигляді публікацій. Представникам адміністративного персоналу важливим $\epsilon$ дотримання процедур і формальних інструкцій, що упорядковують управління університетом ${ }^{27}$. Протиріччя менеджеріалізму в університетському середовищі пов'язано 3 дилемою «ефективне управління - академічна свобода», яка відображає цінності «адміністраторів» в першому випадку і «академіків» - у другому.

Дослідження діяльності вузів Великобританії продемонстрували, що зміни, які відбуваються в культурі та цінностях вищої школи, як правило, виражаються в появі нових цінностей i ̈̈х співіснування поруч зі старими (традиційними) цінностями. Новий менеджеріалізм зачіпає, 3 одного боку, організаційну культуру університету (організаційну структуру, систему управління, стиль управління), з іншого боку, об'єктом уваги стає корпоративна

\footnotetext{
26 Дим Р. «Новый менеджериализм» и высшее образование: управление качеством и продуктивностью работы в университетах Великобритании. Вопросы образования. 2004. № 3. С. 38

${ }^{27}$ Мирча М. Институциональные подходы к предпринимательству: анализ и опыт университета Бабеш-Больяй в Клуж-Напоке. Высшее образование в Европе. 2006. Т. XXXI, № 2. С. 46.
} 
культура (цінності, норми академічної спільноти) і ціннісні основи функціонування університетів.

Новий менеджеріалізм ставить перед академічною спільнотою кілька складних виборів, пов'язаних:

- зі співіснуванням старих і нових типів управлінських структур;

- 3 поєднанням різних стилів управління, наприклад «м'яких» $\mathrm{i}$ «жорстких» форм управління;

- зі зміною характеру відносин між управлінцями і «підлеглими»;

- 3 поєднанням старих i нових цінностей внутрішньої культури університету.

Які ж реалії України в реалізації концепції підприємницький університет? Біди переважної більшості наших вузів не в «академічному капіталізмі», який в Україні поки відомий в основному з чуток, а в «успадкованих лихах», тобто у вкоріненій інституційній інерції, збереженні принципів і практик, які майже в незмінному вигляді перекочували з радянських вузів - виробників кадрів для соціалістичної індустрії.

У вузівському співтоваристві спостерігаються дві тенденції: з одного боку, передова частина вузівської спільноти активно просуває нові формати навчання, включаючи онлайн-курси, формує інноваційну інфраструктуру, щоб стимулювати навчання підприємництву студентів і спонукати на створення високотехнологічних стартапів своїх професорів і викладачів, вбудовується в процес експорту освітніх послуг і в міжнародні колаборації.

3 іншого боку, тягне назад накопичений «багаж»: досить віковий викладацький склад, який упирається будь-яким нововведенням уже тому, що «раніше так не було»; застаріла фізична інфраструктура, включаючи лабораторне обладнання і верстатний парк; низька якість абітурієнтів, які не бажають і часто просто не здатні вчитися у вузі (при середньому балі ЗНО трохи вище «трійки»).

На жаль, багато викладачів сприймають те, що відбувається, не як конвульсії радянської по суті моделі вузу в нових умовах, а як результат 
підступів чи то «глобальної закуліси», чи вітчизняних реформаторів освіти, які зловмисно роблять замах на нашу прекрасну і все ще життєздатну вищу школу. Не розуміє їх і переважна більшість самих університетських працівників: звідси - численні скарги на «університетську бюрократію», на примат зовнішніх показників, що на форумах інтернету отримало назву «хіршеманія».

Сучасний вуз повинен готувати не інженерів для неіснуючих державних підприємств, а фахівців, що володіють, поряд 3 навичками в професії, також здатністю управляти проєктами, приймати на себе ризики, тобто проявляти підприємницькі навички. Відповідно, сучасний вуз повинен багато уваги приділяти вдосконаленню змісту освіти. Працюючи разом 3 регіональними роботодавцями, створюючи спільні майданчики для проєктної діяльності студентів і стимулюючи підприємців і венчурних капіталістів приходити до вузу, стаючи бізнес-коучами i менторами вузівських стартапів. Наприклад, наш університет підписав договор про науково-освітнє співробітництво з Спілкою підприємців Харківської області. Метою договору є забезпечення співробітництва у сфері підготовки фахівців та підвищення кваліфікації слухачів, студентів та викладачів університету 3 питань розвитку, підприємництва та реалізації суспільно корисних ініціатив шляхом участі у проектах, програмах та заходах, які реалізуються університетом та Спілкою підприємців Харківської області.

Вуз повинен вміти діяти проактивно - тобто аналізувати тренди в області науки і вищої освіти і формувати ті елементи власної внутрішньої структури, які стануть тригерами змін. Потрібно звернути увагу на ті види і форми освіти, які поки знаходяться на периферії їхньої уваги - додаткова освіта дорослих, а також навчитися пропонувати частину освітнього контенту своїм студентам факультативно, на платній основі, бо ні в який формат освіти, ні в 2-річну магістратуру, ні в 4-річний бакалаврат, неможливо втиснути все те, що може стати в нагоді студентам на їхньому кар'єрному шляху.

Крім того, вузам слід відмовитися від уявлень про вічність і незмінність напрямів навчання - хоча б тому, що нинішнім випускникам доведеться жити в 
суспільстві, де цикл життя професій істотно скорочується, причому сучасні інформаційні технології (зокрема, блокчейн) зроблять в найближчому майбутньому надлишковими професії, які ще недавно були цілком респектабельні. Кафедри, Центр доуніверситетської освіти і кар'єри, інші структури університету повинні аналізувати «Атлас нових професій», бо майбутнє залежить від прикладених зусиль і його можна створити, майбутнє варіативно, що не виникає з минулого, а залежить від рішень і дій сьогодення. I ось, за підтримки Департаменту освіти Харківської міської ради і у колаборації 3 рухом шкільних «Євроклубів», Центр доуніверситетської освіти і кар'єри започаткували нову школу розвитку для покоління $Z$, яка допомагатиме процесам євроінтеграції на рівні доуніверситетської освіти, використовуючи професійну спеціалізацію саме нашого вишу, - «Європейські урбаністичні студії». Знайомитися з проблемами глобалізації, визначати провідні тенденції в урбаністиці, світові стратегї розвитку міст. Покоління $Z$ знайомиться 3 потрібними професіями для міста майбутнього. Звідси - необхідність поступового переходу до моделі «освітнього супермаркету», в якому «клієнт» вибирає ті продукти, які сам вважає необхідними, а не (тільки) ті, які держава поставила йому в вигляді «освітнього прожиткового мінімуму».

В подальшому, нашим вузам доведеться відмовитися від аксіоми про те, що ядром освітнього курсу є аудиторні лекції, а фундаментом самопідготовки студентів - читання i конспектування підручників. Вже зараз найбільш цілеспрямовані студенти можуть замість курсів (або на додаток до курсів) своїх професорів отримати доступ до світових зірок академії на різних платформах відкритої інтерактивної освіти, а підручник вмирає прямо на наших очах, і його з успіхом витісняють аналогічні ресурси інтернету. Вище ми вже говорили про покоління Z, яке робить ставку не на володіння, а на користування. Вони думають про екологію, раціональне використання природних ресурсів. Це можна пояснити: нам продають речі, в яких вже закладено знос, навіщо брати кредити на покупку приставки, якщо через рік вона морально застаріє, а машина на 80\% потребує серйозних вкладень. 
Метатренди останнього десятиліття показують, що люди хочуть працювати, вчитися, спілкуватися і грати, коли й де вони бажають, інтернет стає глобальною мережею мобільного зв“язку, хмарні технології полегшують швидке зростання он-лайн відео та мультимедіа. Світ стає відкритим - поширюються відкритий контент, відкриті дані, відкриті ресурси, відкриті он-лайн курси. Інтернет постійно закликає нас переосмислити навчання та освіту, зростає доля неформального навчання, переглядаються індивідуальні потреби університетів і сам процес навчання. Відповідно, щоб утримати студентів, вузам потрібно зробити дуже багато - зокрема, значно змінити формат навчального процесу, переглянути сформовану структуру академічного персоналу, провести масове перенавчання частини викладачів, щоб навчити їх використанню нових методів і технологій освіти.

Як зробити все це, перебуваючи в рамках досить жорстких ресурсних обмежень? Тільки одним способом - перебудувавши управлінську модель вузу на засадах підприємництва, тобто пошуку ресурсів (людських, фінансових), яких ніколи не вистачає, на зовнішньому ринку, пропонуючи учасникам цього ринку співпрацю, включаючи і интрапренерства.

Дана діяльність інтрапренер пов'язана 3 подоланням опору «всього старого» в прагненні домогтися того, щоб нові ідеї були прийняті. В університетах підтримка интрапренерства виражається в заохоченні винахідників і новаторів, тобто заохочення своїх співробітників за прояв ініціативи в реалізації нових освітніх, дослідницьких, соціальних та інших проектів, що зміцнюють репутацію і підвищують переговорну силу вузу в спілкуванні з регіональними керівниками і бізнес-структурами.

Викладачі вузів можуть підтримати такого роду зміни, розуміючи, що «новий прекрасний світ» університету буде іншим, але не менш важким; він створить не тільки нові можливості для університетів, а й нові проблеми - в тому числі, буде відбуватися подальше статусне i прибуткове розшарування викладацького складу, що супроводжується переходом значної частини викладачів на непостійні позиції, розширення підтримуючих функцій, типу 
прокторінга (супроводу онлайн-курсів), на противагу «повноцінних» аудиторних занять, конкуренція 3 боку неакадемічних форматів освіти, починаючи з різних онлайн-курсів і закінчуючи корпоративною освітою великих компаній, і багато інших, поки ще не цілком усвідомлених ризиків і небезпек.

Але тільки таким чином можна уникнути головної небезпеки, яка загрожує вищій освіті, - заколисуючи себе минулими досягненнями, залишаючись в колії вищої освіти другої половини ХХ ст., остаточно випасти з контексту сучасних глобальних тенденцій іiі розвитку, про що вже попереджають видатні теоретики освіти.

У центрі «Порядку денного 2030» ООН є 17 Цілей сталого розвитку, що чітко означують світ, якого ми прагнемо для всіх націй без винятків. Нові Глобальні цілі є результатом процесу, що був інклюзивнішим, ніж будь-коли: уряди залучили бізнеси, громадянське суспільство та місцян. Усі ми маємо спільне бачення того, куди має рухатись світ. Реалізація цих амбіцій потребує безпрецедентних зусиль усіх секторів суспільства - i освіта має відіграти надзвичайно важливу роль у цьому процесі. Світ, у якому ми живемо, стає все більш взаємозалежним та складним. Усі ми рухаємося нестійким курсом, використовуючи природні ресурси планети у такому величезному масштабі, що під загрозу ставиться благополуччя наступних поколінь. Вища школа, яка усвідомлює свою відповідальність перед суспільством, відстежує зміни у світі. Одночасно вона намагається знайти гідні відповіді на всі нагальні питання сучасності; прагне підготувати наше спільне майбутнє.

Різноманітність та стійкість світу залежать від розуміння його цілісності та різноманіття, від усвідомлення складної реальності, властивої світові, від розуміння того, які кроки необхідно зробити. Освіта і чітке усвідомлення нашої особистої відповідальності повинні зробити свій внесок у розвиток суспільства, підвищити рівень відповідальності за вибір, який ми здійснюємо, сформувати почуття поваги до інших народів, природи та різноманітності. Наукові дослідження, нові знання повинні вплинути на зміни в освітньому процесі у напрямку визначення того, що свідомо не можна робити, а що потрібно зробити. 
Мета освіти - готовність до спільного майбутнього, постійно мінливого, повного викликів та можливостей.

Яким чином вища освіта реагує на процес глобалізації? Які стратегії вона може запропонувати для сталого розвитку? Відповідь досить банальна i зрозуміла - необхідно переходити до інноваційної моделі розвитку.

Розвиток інновацій, технологій, науковотехнічного прогресу та інтенсифікація народного господарства сьогодні $є$ невід'ємними компонентами стійкого зростання економіки світу. У сучасному ринковому середовищі значну конкурентоспроможність та ефективний розвиток отримали саме інноваційнотехнологічні системи. Імператив інноваційного розвитку України серед ключових ставить завдання модернізації освіти, саме освіта - як система формування інтелектуального капіталу нації та як одна з головних сфер генерації інновацій - створює базові умови для швидкого зростання ринку на основі оновлення технологій та продуктів. Вона виступає першою ланкою в інноваційному ланцюжку «освіта - дослідження - венчурні проєкти - масове освоєння інновацій». Про необхідність кардинальних змін у стратегії розвитку освіти особливо говорити не доводиться: сьогодні про це багато хто пише. Щоправда, «кардинальність» найчастіше обмежується пропозицією «модернізації» (латання дірок). Тим часом, мову потрібно вести про те, що освіті належить стати одним з головних чинників у творенні того суспільства, яке дозволить людству вижити в умовах катаклізмів, що насуваються. Пріоритетним завданням освіти є розвиток і формування у людини таких здібностей, які дозволили б їй комфортно адаптуватися до мінливих соціальних умов $\mathrm{i}$ створювати новий соціальний простір. Вперше ці завдання прозвучали у Доповіді Римському клубу «Немає меж навчанню» у 1979 році ${ }^{28}$. Тоді ж з явився новий термін «інноваційне навчання» як навчання, що стимулює інноваційні зміни у культурі і соціальному середовищі, як реакція на проблемні ситуації, що виникають у житті людини чи суспільства. Ця доповідь констатувала стан кризи, в якому опинилась система сучасної освіти. Спробою подолати цю ситуацію

\footnotetext{
${ }^{28}$ Botkin J.W., Elmanda M., Malitza M., 1979
} 
стали реформи освіти, які були проведені у передових країнах світу: США, Великобританії, ФРН, Японії.

В Україні тільки в останні роки розпочались обговорення й декларування заяв на тему серйозної модернізації освіти. $€$ надія, що слідом за деклараціями 3'являться і конструктивні рішення, і реальні економічні дії на користь модернізації освіти. Швидкозмінна ситуація в глобальному світі висуває до інституту освіти нові вимоги, пов'язані з необхідністю забезпечити інноваційновипереджальний характер підготовки фахівців щодо задоволення потреб як суспільства (у тому числі і стратегічних), так і самої освіти. В цих умовах неминучий перехід від політики модернізації освіти до політики, яка виходитиме 3 уявлення про неминучість його випереджального розвитку.

Вже зараз слід передбачати нові можливості та потреби суспільства. Тим часом ситуація у світовій освіті (включаючи й українську) свідчить про збереження орієнтації іï інститутів на минуле, на передачу і освоєння давно застарілої інформації.

Звернемося хоча б до домінуючих уявлень про зміст навчальної літератури. Як добре відомо, вона орієнтована на викладення матеріалу, перевіреного практикою та теорією. Таке уявлення тісно пов'язане із традиційним тлумаченням освіти як засобу трансляції знань, уміння та навичок від професора до студента. На практиці ж сказане означає, що часто мова йде про циркуляцію в освітньому середовищі застарілих знань і цінностей, які втратили свою значущість. На сторінках підручників і посібників вкрай рідко можна зустріти гіпотези і припущення, які активно обговорюються. Часто студент отримує інформацію про минуле наукового пошуку.

Між іншим, подібний підхід все частіше дає збої. І справа не тільки в тому, що різко збільшився потік інформації (подвоєння кількості інформації відбувається у світі менше ніж за рік), у тому числі й у сфері фундаментальних наук, а ще й тому, що відбуваються такі фундаментальні відкриття, які навіть зруйнують збудований «науковий будинок». Принаймні більшість 3 них свідчить 
про те, що всі отримані людиною знання - лише невелика прибудова до будівлі майбутньої науки.

Через посилення тенденцій переходу до постіндустріального суспільства, швидкість технологічного оновлення виробництва досягла такої величини, що професійні знання стали старіти ще до того, як випускники встигають застосувати їх на практиці. У зв'язку з цим в США була введена спеціальна одиниця вимірювання - «період напіврозпаду компетентності», що показує тривалість часу з моменту закінчення вузу, коли нова науково-технічна інформація викликає зменшення компетентності фахівців на 50\%. Відповідно до їх статистики в американських інженерів випуску 1940 р. знання застаріли наполовину через 12 років, 1960 р. - через 8-10 років, 1970 р. через 5 років. Що стосується сучасності, то цей термін, на думку авторів, обчислюється 2-3 роками $^{29}$.

Трансформація освітнього процесу, мабуть, буде проходити декількома напрямками. У цій статті виділимо лише два досить очевидні. По-перше, зміст освіти має включати найбільш нове, фундаментальне та міждисциплінарно загальне, не чекаючи на той час, коли воно застаріє. Іншими словами, освіта має стати процесом не просто трансляції вже відомого, а процесом, готовим до сприйняття принципово іншого.

Говорячи про майбутню освіту підприємницького університету як інноваційний процес, мається на увазі, що нову інформацію необхідно генерувати не тільки в науці, а й у самому освітньому процесі. Звичайно йдеться, не лише про те, що студенти отримуватимуть більш загальні фундаментальні знання, а й про те, що це нове може виникати і як результат процесу взаємодії викладача та студента з освітнім та життєвим середовищами.

Крім того, освіта як інноваційний процес має бути випереджаючою, що прокладає шлях у майбутнє, в результаті чого вона може стати інноваційновипереджальною, одночасно виступаючи і як освіта для сталого розвитку.

\footnotetext{
${ }^{29}$ Ільїч Л. М. Структурні зрушення транзитивного ринку праці: теорія і методологія регулювання. Кваліфікаційна наукова праця на правах рукопису. Дис. на здобуття наук. ступеня д-ра ек. наук. Ін-т демографії та соціальних досліджень імені М. В. Птухи НАН України, Київ, 2018.
} 
У вирішенні цього завдання корисним може виявитися підхід, що розробляється М. Піщуліним, в рамках якого освіта розглядається не тільки як індивідуальна, громадська, а й загальна світовпорядкова форма розвитку, де еволюціонує весь пов'язаний 3 людиною універсум - соціокультурний, природний, космічний, антропологічний, тобто онтологічний і це, по-друге. ${ }^{30}$

3 погляду онтологічного підходу М. Піщуліна, освіта має на меті формування людини, що лише частково враховується в концепції освіти, яка розглядає останнє в контексті «передачі наукових знань та формування мінімально необхідного для включення до суспільного виробництва набору умінь та навичок розумової роботи» ${ }^{31}$.

Говорячи про майбутнє, важливо мати на увазі суспільство і діяльність людини: для них ця проблема особливо актуальна, на що потім звернув увагу А. Тоффлер ${ }^{32}$. У нашій свідомості міцно утвердилося уявлення, що треба вивчати минуле як предмет (у плані вивчення людського суспільства) історичної науки. Передбачається, що знання минулого формує в людини розуміння сьогодення. Тільки в цьому випадку можна дати адекватну оцінку тому, що відбувається сьогодні, виявити причини, а можливо, і наслідки за умови, що час не виявиться нелінійним феноменом.

Таке розуміння минулого в сучасній культурі, науці та освіті $є$ загальновизнаним. I це справді так, коли розвиток суспільства йде досить спокійно, еволюційно, а зв'язок між минулим, сьогоденням та майбутнім виявляється лінійним. Революції, звичайно, додавали в таке розуміння лінійності часу свій внесок, який частково порушує лінійне мислення. Але, оскільки більш спокійні періоди часу домінували, «аксіома» лінійності також превалювала, що знаходило свій відбиток у багатьох соціальних процесах зокрема й у освіті.

Розуміння освіти як процесу формування особистості тим, що було у минулому, умовно можна назвати його «історичною» інтерпретацією. Таке

\footnotetext{
${ }^{30}$ Пищулин Н. П. Философия образования: законы, доктрина, принципы. М., 2001.265 с.

${ }^{31}$ Куликовская А.В. Дидактика креативного автопоэзиса человека и его знания / Что такое постнеклассическое знание. М. Александров. 2007. с.169.

32 Тоффлер А. Шок будущего / Кравченко А. И. Социология. Хрестоматия. М., 2002. С. 290-315
} 
«історичне» розуміння є цілком прийнятним для періоду, коли людству не загрожують біфуркації у вигляді глобальних катастроф, здатних його занапастити.

Як зазначив колишний Генеральний директор ЮНЕСКО у передмові до книги «Освіта для майбутнього: сім уроків минулого»: «Коли ми дивимось в майбутнє, то виникає чимало сумнівів про той світ, у якому житимуть наші діти, онуки та правнуки. Переконані ми лише в одному: якщо тільки ми дійсно хочемо, щоб ця земля змогла задовольнити потреби іiі мешканців, то суспільство має стати іншим. Світ завтрашнього дня буде істотно іншим порівняно з тим світом, який ми знаємо. Ми маємо створити умови для «стійкого майбутнього» ${ }^{33}$. В результаті система відносин між суспільством і природою, яка існувала раніше, отримала назву моделі нестійкого розвитку.

На конференції ООН з навколишнього середовища та розвитку (1992р.) було запропоновано нову форму (модель) розвитку суспільства - «модель сталого розвитку», перехід до якої, за ідеєю, повинен забезпечити виживання та невизначено довгий розвиток людства в умовах збереження навколишнього природного середовища.

Однак, щоб перейти до нової стратегії, необхідно не лише реалізувати вимоги екологічних імперативів, на що на згаданих форумах ООН було звернено основну увагу, а й кардинально перебудувати всі галузі та напрямки людської діяльності, причому в пріоритетному порядку доведеться трансформувати сучасну освіту. Освіті належить провідна роль: саме освіта зорієнтована на фундаментальні зміни в шляхах, що визначають наше життя та поведінку. Освіта - «сила майбутнього»; вона - у числі найважливіших інструментів змін. При цьому одна 3 найскладніших проблем, 3 якими ми зіткнулися, пов'язана 3 питанням формування такого мислення, яке дозволило б зустріти і відповісти на виклики все більш складного, швидко мінливого і непередбачуваного світу. Має бути заново продуманий сам спосіб організації знання. Останнє передбачає

\footnotetext{
${ }^{33}$ Морин Э.Образование для будущего: семь уроков прошлого / Alma mater. 2008. №3. C. 44-50
} 
руйнування традиційних міждисциплінарних бар'єрів, вихід на нові способи інтерпретації того, що нібито, вже розпалося на частини. Має бути перегляд усієї освітньої політики та змісту навчального процесу. Людина, яка навіть і оволоділа знаннями та культурними досягненнями моделі нестійкого розвитку, не зможе побудувати нове суспільство.

У чому ж полягатиме кардинальна відмінність освіти для сталого розвитку від традиційного? Одностайності думок 3 цього питання поки що не досягнуто. Екологи та представники природничих наук часто вважаючи, що освіта для стійкого розвитку в істотному ступені включитить екологічну складову, розглядають процес становлення освіти для сталого розвитку як перехід від екологічної освіти до утворення в інтересах сталого розвитку. Безсумнівно, розвиток екологічної освіти та екологізація останньої - один із напрямків формування освіти для сталого розвитку. Проте до суттєвого інноваційного перетворення будуть схильні інші види та напрями освітнього процесу економічний, гуманітарний, інженерний тощо, які будуть не лише екологізуватись, a, й головне, все більше акцентуватимуть увагу на майбутньому, тією чи іншою мірою включатимуть майбутнє у процес навчання. Хоча ООН проголосила мету номер чотири: «Забезпечення всеосяжної та справедливої якісної освіти та заохочення можливості навчання протягом усього життя для всіх» ${ }^{34}$.

Зосередивши увагу на минулому і частково теперішньому, світовий освітній процес опинився у ролі застарілого механізму соціально-економічного розвитку. Трансляція застарілого «освітнього знання» від попередніх поколінь до наступних, на що в основному і зорієнтована сучасна освіта, аж ніяк не означає, що вона допомагає вирішувати нагальні проблеми сьогоднішнього дня, а тим більше - завтрашнього. Причина такої ситуації полягає в тому, що вже наявні знання та досягнення культури, які циркулюють в освіті, виявляються не просто застарілими, а є відображенням моделі нестійкого розвитку. Тому,

\footnotetext{
${ }^{34}$ Цілі у сфері сталого розвитку. URL : https://www.un.org/sustainabledevelopment/ru/education/
} 
освітній процес, щоб поступово ставати інноваційним, повинен дедалі більшими темпами включати те, що з'явиться або може з'явитися в майбутньому.

Як навчати тому, чого ще немає і чому нові знання мають з'являтися в освіті? Здивування розсіється, якщо уважно досліджувати процес входження майбутнього та нового у процес освіти.

Оскільки трансляція застарілого знання в освітньому процесі не допоможе переходу до стійкого майбутнього, то, треба кардинальним чином змінити сам цей процес, роблячи його все більш інноваційним, адаптуючи до майбутніх змін, порушуючи традиційну лінійність педагогічного мислення. Адже для виживання людства, його переходу до сталого розвитку важливо включати випереджаючі механізми, механізми передбачення та прогнозування. I якщо вже зрозуміло, що необхідний інноваційний перехід від нестійкого розвитку до сталого, важливо і в освітній процес включити всі існуючі та можливі форми та механізми, які здатні допомогти вирішити цю основну цивілізаційну проблему третього тисячоліття.

Отримання знань - основна проблема. Дійсно, як розвивати шляхи пізнання, щоб забезпечити умови для сприйняття найбільш загальних, фундаментальних проблем та включення приватного, обмеженого знання в індивідуальний контекст?

Домінування фрагментарності, поділу знання на дисципліни часто робить людину нездатною до поєднання частин у ціле. Очевидно, що на зміну такому стану справ має прийти навчання, що передбачає, яким чином можна побачити предмети в їхньому контексті, складності та тотальності.

Отже, потрібно розвивати природну здатність людського розуму включати всю інформацію в певний контекст і цілісність. Іншими словами, необхідно подати такі методи, що дозволяють у складному світі вловлювати взаємовідносини та взаємовплив частин та цілого.

Цілком очевидно, що знання про майбутнє не можуть містити істини та факти, які перевіряються практикою, що реалізується лише в минулому та 
сьогоденні. Майбутнє в цьому сенсі відторгнуто від фактологічної науки, хоча передбачення і прогнозування і є функцією теоретичного рівня пізнання.

У дослідженнях майбутнього, їхньої представленості в освітньому процесі необхідно реалізовувати нові принципи, способи та форми освоєння майбутнього. Одна з форм, що активно розвиваються - моделювання того, що може статися, тобто випереджальне моделювання у різних його формах, особливо за допомогою нових інформаційних технологій. Це той спосіб входження майбутнього в інноваційно-освітній процес, який пов'язаний 3 інформатизацією, оскільки лише на інформаційному рівні можна будувати та вивчати моделі майбутнього як нормативні (типу сталого розвитку) чи як дослідницькі прогнози і передбачення. Тут можливі і лінійні виходи в майбутнє 3 минулого i сьогодення, i нелінійно-інноваційні, або навіть можуть створюватися моделі, що не мають прототипів у минулому чи аналогів у теперішньому. I якщо навчання в минулому грунтується на запам'ятовуванні, то включення до цього процесу випереджуючого моделювання базується на принципах більш творчої, розвиваючої освіти.

Таким чином, майбутній спеціаліст як «синтезатор» знань у різних галузях науки не може відбутися, якщо в його свідомості не утворюються «міжсистемні асоціації», які охоплюють різні системи, утворюючи узагальнені поняття, взаємозв'язки теорій. Відсутність реально налагоджених зв'язків між навчальними дисциплінами призводить до того, що, маючи об'єктивні, достатні знання, студент часто не може перенести їх на вирішення завдань нової дисципліни.

У нашому університеті вже накопичено певний досвід вирішення цієї проблеми через формування узагальнених знань, умінь та навичок, що реалізуються у певних видах діяльності (наприклад, при безперервному проектуванні на спеціальності «Архітектура»). Підсумком роботи в семестрі студентів - архітекторів є захист проєкту, де цілісно, діалектично відображені всі курси, що вивчаються. У цих проєктах представлені всі елементи знань та всі їх відносини, способи отримання та зміни, тобто вони містять не тільки 
узагальнені знання, вміння і навички, а й здібності, i розумові операції, i загальний світогляд. Захист проходить перед комісією, до якої входять усі викладачі, які викладають курси у відповідному семестрі. Це, в свою чергу, мобілізує викладачів на те, що у процесі підготовки архітектора-фахівця йому потрібно дати не тільки «суму знань», як це і прийнято за традиційного навчання, а й сформувати в них систему взаємозалежних знань, які утворюють цілісну, узагальнену структуру.

Викладач у змісті та способі побудови навчального предмета відображає не тільки поняття, закони, теорії та факти, які відповідають науці, а й спосіб мислення, властивий даному етапу його розвитку та ті методи пізнання, які в ній застосовуються. Власне, зміст має бути побудований на нових принципах, у контексті завдання забезпечення умов для сталого розвитку, виходячи з яких у навчальній дисципліні необхідно виявити сутність, яка лежить в основі будьякого приватного явища даної дисципліни, тобто виділити інваріант системного змісту. Фахівець починається там, де доводиться змінювати і застосовувати нові комбінації знань, де починається елемент творчості в малому та великому, або, за термінологією В. Вернадського, де стикається з проблемою побудови цілісної картини з фрагментів, які отримують з різних наук або різних підходів в межах однієї і тієї ж науки.

Ми живемо в умовах дедалі стрімкішого потоку інновацій, інтенсивного розширення та оновлення знань. Швидко з'являються нові спеціальності, зникають старі. За оцінками, нині у світі існує понад сто тисяч спеціальностей, причому їх кількість зростає з кожним роком. Сказане з неминучістю спрричиняє перехід до безперервної освіти, але не варто плутати безперервність 3 наступністю, тобто спочатку - школа, потім - ВН3, а потім - післявузівська освіта. Безперервність означає необхідність постійного підвищення своєї кваліфікації, рівня своєї освіти.

Незважаючи на скепсис прихильників традиційної (контактної) очної форми здобуття освіти, по відношенню до перспективи дистанційного навчання, віртуальні вузи, на думку європейських аналітиків, до 2025 р. стануть основними 
постачальниками вищої освіти. Глобальний ринок електронного навчання у 2015 p. - \$ 107 млрд до 2015 року. (у 2010 році - \$32,1 млрд), темпи річного зростання приблизно 9,2 \% протягом п“яти років. Темпи зростання електронного навчання по країнах: Індія $-55 \%$; Китай $-52 \%$; Малайзія $-41 \% ; \ldots$ Україна $-20 \% .^{35}$

Наприклад, Єльський університет відкрив доступ до своїх навчальних матеріалів. Тепер на сайті університету в розділі «Відкриті курси Сльського університету» можна отримати не тільки програми курсів і всі належні навчальні посібники з них, а також відеозаписи лекцій та їх розшифровки. Вперше такий доступ було відкрито п'ять років тому Массачусетським технологічним інститутом. Входження України до Болонського процесу відкрило шлюзи для відтоку української молоді до вишів Свропи. Вже зараз велика кількість наших студентів навчається у системі дистанційної освіти США, Англії та ФРН. Цього року їхня кількість значно збільшилася у зв'язку з COVID 19. На Азіатському ринку успішно працює Туреччина, яка має мільйонну аудиторію студентів системи відкритої освіти. Їх завдання найближчими роками довести цю цифру до трьох мільйонів осіб. Окрім того, українська освіта практично відсутня на ринках СНД.

У цьому контексті, звісно, на перший план виходить проблема якості освіти. Дуже болюча тема - якість освіти. Якість - останній оплот ретроградів. Щоразу, коли починається щось нове, відразу ж задаються питанням про якість. Але чим визначається якість? Згідно 3 результатами, отриманими американськими дослідниками, якість випускника на 68\% залежить від його генетичних факторів і лише на 32\% - від освітнього середовища навчального закладу.

Таким чином, є два шляхи досягнення високої якості підготовки. Перший орієнтований на здібності студентів, відбираючи найбільш здібних на конкурсній основі, звичайно, можна досягти високої якості підготовки випускників. Обдарована людина - вона і є обдарована: вчи іiі, не вчи - сама

\footnotetext{
${ }^{35}$ Кухаренко В. Тенденції розвитку електронної освіти. URL : http://education-ua.org/ua/analytics/438-tendentsijirozvitku-elektronnoji-osviti-v-2015-r
} 
всьому навчиться. Інший шлях пов'язаний із створенням досконалого освітнього середовища.

Нині серед економічно активного населення України вже близько 20\% мають вищу освіту. За даними психологів, частка досить обдарованих у нас становить близько 5\% у своїй віковій категорії. Таким чином, 16\% від загальної кількості людей 3 вищою освітою - носії середніх здібностей. Висновок очевидний: система вищої освіти має пристосуватись до навчання студентів середніх здібностей.

Хосе Ортега-і-Гассет, іспанський філософ, у роботі «Місія університету» писав, що «інститути існують - необхідні та мають сенс - тому, що існує середня людина. Якби були лише визначні діти, цілком можливо, що не було б ні педагогічних установ, ні громадської влади. Тому необхідно співвідносити будьякі інститути з людиною середніх здібностей: для неї вони створені, вона має бути їхньою мірою» ${ }^{36}$.

Якими можуть бути потреби у вищій освіті в недалекому майбутньому? В умовах постіндустріального суспільства, приблизно 20\% населення повинні мати вищу освіту. На думку професора Давидова, в умовах інноваційної економіки частка людей з вищою освітою має становити вже 60\%. Що стоїть за цією цифрою? Аналізуючи стан освіти в умовах постіндустріальної економіки на прикладі великої та невеликої країни (США та Нідерланди), бачимо, що у сільському господарстві в цих країнах зайнято 4\% населення, у промисловості (включаючи транспорт та зв'язок) - 15\% та $81 \%$ - у сфері послуг, у тому числі приблизно половина зайняті у сфері управління, фінансів, культури, освіти, науки (саме у цих галузях найбільш затребувана вища освіта).

Які зміни відбудуться під час переходу до інноваційної економіки? Сфера послуг дещо зросте (з 81 до 85\%). У цих областях понад 90\% зайнятих повинні мати вищу освіту. Причому, якщо звернутися до прикладів дуже розвинених економік (наприклад, у Японії), то виявиться, що багато робочих посад там уже передбачають вищу освіту. Цей висновок докорінно суперечить нашому

\footnotetext{
${ }^{36}$ Ортега -и-Гассет Х. Миссия университета / Пер.с исп. М.Н. Голубевой. Мн.: БГУ. 2005. С.104.
} 
прагненню розвивати ПТУ та технікуми. У світі технікумів немає. Майже ніхто не користується фахівцями середньої ланки.

В Україні також є постійна тенденція розвитку послуг. Темпи зростання відповідних галузей випереджають динаміку ВВП. Індекс розвитку реалізованих послуг у 2003 році становив 121,0\%, 2004 p. - 131,2, 2005p. - 128,8, 2006 p.126,2\% і 2007 року - 132,0\%, причому така закономірність простежується не тільки щодо загального обсягу послуг, а й сфери реалізації на зовнішньому ринку. Так, у 2007 році експорт послуг становив 9038,9 млн. дол. США, що у 2,6 рази перевищує рівень 2000-го, а питома вага їх в українському експорті - 15,5\%. Незважаючи на те, що розвиток експорту послуг має стійку тенденцію до зростання, можливості України у підвищенні ролі третинного сектора у формуванні нової економіки далеко не вичерпані. Отже, посилення експортної орієнтації сфери послуг має стати головним чинником інноваційної структури економіки нашої країни.

Серед завдань розвитку третинного сектора слід визначити формування лідерських позицій у міжнародній сфері освіти. При цьому варто врахувати, що на світовому ринку конкурують не лише (щодо окремих країн можна стверджувати, що й не так) освітні послуги як такі, як самі суспільства, їх репутація, перспективи та багатовікові культурні традиції. Лідером на ринку сфери освітніх послуг (приблизно 15 млрд. дол. на рік) є США, для яких, як і для колишнього СРСР, вища освіта іноземців - це, скоріше, довгострокова глобальна політика, ніж короткострокова локальна економіка. Попит на освіту зростає у всьому світі. За даними ЮНЕСКО, чисельність студентів за останні 40 років зросла у 6 разів. Якщо у 2000 році у ЗВО світу навчалось 82 млн. осіб, то у 2015 році студентів буде 97 млн., а у 2025 році їх кількість перевищить 100 млн. ${ }^{37}$

Стратегія експорту освітніх послуг України має базуватися на тому, що наша країна як європейська має розвинені навчальні системи, які багато століть

\footnotetext{
${ }^{37}$ Академічна мобільність як фактор інтеграції України у світовий науково-освітній простір. URL : https://niss.gov.ua/doslidzhennya/gumanitarniy-rozvitok/akademichna-mobilnist-yak-faktor-integracii-ukraini-usvitoviy
} 
та особливо в останні десятиліття забезпечували підготовку конкурентноспроможної на світовому ринку робочої сили фахівців. Враховуючи українські реалії, експансія (якщо намагатися концентрувати політику у цьому напрямі) освітніх послуг на зовнішній ринок мала б переслідувати як мінімум такі цілі. По-перше, розширення можливостей для розвитку та утримання інтелектуального потенціалу країни. По-друге, отримання додаткових джерел прориву у науковому просторі. По-третє, розвиток освіти та науки як певного напряму бізнесу.

Не менш важливим викликом глобалізму $є$ ризик втрати духовності людини. Ця загроза виходить із загальної ліберальної стратегії розвитку.

На Родоському форумі 2019 «Глобальний (біс)порядок: на шляху до світоглядів, заснованих на діалозі», у рамках секція «Стратегія освіти ХХІ ст. освіта у нових умовах», мова йшла про панування технократичного знання, завдаючи шкоди знанню гуманітарному, яке якраз і передає смисл того, що відбувається, дозволяє дати йому оцінку і намітити реальні шляхи виходу з тих кризових ситуацій, які ми маємо: глобальні кризи - це криза втрати сенсу в світі людини, екології, демографії, міжцивілізаційних відносин 38 . Виступачі підкреслювали, що технократичне знання не пропонує нам вирішення проблем, які надалі тільки загострюватимуться.

Що нам дають нові знання техніки? Нові знання науки? Дуже багато в плані нашого економічного життя, нашого фізичного існування, комфорту. Але при цьому в технічному прогресі розчиняється сенс та взагалі існування. Олюднення прогресу не відбувається. Тому для вищої освіти визначено такі вектори розвитку:

гуманізація освіти як докорінний поворот від його технократичної мети (забезпечення виробництва кадрами, їх пристосування до потреб виробництва)

\footnotetext{
38 Родоський форум 2019: глобальний (біс)порядок: на шляху до світоглядів, заснованих на діалозі. https://docresearch.org/ru/2019/03/\%D1\%80\%D0\%BE\%D0\%B4\%D0\%BE\%D1\%81\%D1\%81\%D0\%BA\%D0\%B8\%D0\%B9$\% \mathrm{D} 1 \% 84 \% \mathrm{D} 0 \% \mathrm{BE} \% \mathrm{D} 1 \% 80 \% \mathrm{D} 1 \% 83 \% \mathrm{D} 0 \% \mathrm{BC}-2019-$ \%D0\%3\%D0\%BB\%D0\%BE\%D0\%B1\%D0\%B0\%D0\%BB\%D1\%8C\%D0\%BD\%D1\%8B\%D0\%B9$\% \mathrm{D} 0 \% \mathrm{~B} 1 \% \mathrm{D} 0 \% \mathrm{~B} 5 \% \mathrm{D} 1 \% 81 \% \mathrm{D} 0 \% \mathrm{BF} \% \mathrm{D} 0 \% \mathrm{BE} \% \mathrm{D} 1 \% 80 \% \mathrm{D} 1 \% 8 \mathrm{~F} /$
} 
до гуманістичних цілей становлення та розвитку особистості, створення умов для іiі самореалізації;

демократизація освіти як перехід від жорсткої централізованої і однакової системи організації навчання до створення умов і можливостей для кожного вищого навчального закладу, викладача, студента якнайповніше розкрити свої можливості та здібності;

випереджувальний розвиток вищої освіти щодо рівня розвитку виробництва, його техніки й технологій;

прагнення до неперервної освіти як перехід від, «освіти на все життя» до, «освіти впродовж усього життя»;

технологізація освіти як процес упровадження в навчальний процес педагогічних технологій, здатних значно підвищити ефективність освіти; інформатизація освіти як комплекс соціально-педагогічних перетворень, пов'язаних з насиченням освітніх систем інформаційною продукцією, засобами й технологіями.

XXI століття - це століття боротьби культур і людських ресурсів, пов'язаних 3 освітніми системами. Тому освіта має бути переорієнтована 3 інтересів суспільства та виробництва на інтереси й можливості тих, хто навчається. Гуманізація освіти протистоїть іiі технократизації, тобто спрямованості на служіння суспільству й передусім виробництву та науковотехнічному прогресу. Гуманізація освіти означає створення оптимальних умов для всебічного розвитку особистості. Отже, навчання повинне носити особистісно орієнтований характер. Основними характерними рисами такого навчання $€$ :

пріоритет розвитку над навчанням; суб`єкт - суб`єктні стосунки між викладачем і студентами;

знання, уміння й навички як засіб розвитку особистості; використання інтерактивних методів навчання; включення в процес навчання рефлексії, самоаналізу та самооцінювання. 
Гуманізація вищої освіти у поєднанні 3 гуманітаризацією сприяє вихованню у студентів основних компонентів базової структури особистості: культури життєвого та професійного самовизначення;

інтелектуальної, моральної, технологічної, інформаційної, екологічної та інших культур.

Терміни «гуманістичний» $\mathrm{i}$ «гуманітарний» дуже близькі за своїм змістом, проте їх розрізняють у дискусіях про гуманізацію та гуманітаризацію освіти. Гуманізм - «система поглядів, що історично змінюється, яка визнає цінність людини як особистості, їі право на волю, щастя, розвиток і прояв своїх здібностей, яка вважає благо людини критерієм оцінки соціальних інститутів, а принципи рівності, справедливості, людяності бажаною нормою між людьми» 39 . Гуманізм означає систему цінностей, що підносить людську особистість, покладає в основу будь-яких проектів або дій благо і щастя людини, ії невід‘ємні і природні права на гідне життя.

Слово «гуманітарний» міцно закріплене за комплексом наук (гуманітарні науки), предметом яких є ті чи інші прояви людської духовності, тобто за філологією, етикою, філософією, історією, естетикою, юриспруденцією тощо. Відповідно представників цих наук називають гуманітаріями, на відміну від гуманістів, тобто тих людей (безвідносно до їхнього роду занять), що керуються у своїй діяльності гуманістичними ідеалами. Але, разом з тим, загальне кореневе слово (homo), що лежить в основі зазначених термінів, говорить про їхню смислоутворювальну єдність.

Якщо звернутися до вихідного трактування гуманітарних наук, що сходить до великих гуманістів Відродження, то відомо, що під гуманітарними знаннями вони мали на увазі не просте вивчення поезії, риторики, античної філософії (ця інтенція завжди існувала в історії), а дещо більш високе - пізнання мудрості через слово, що підносить людину. Іншими словами, гуманітарні науки лише тоді відповідають своїй споконвічній функції, коли відкривають у людині

\footnotetext{
${ }^{39}$ Токман О.В. Гуманізм як поняття і соціальне явище / Мультиверсум. Філософський альманах. К. : Центр духовної культури. 2004. № 40. http://www.filosof.com.ua/Jornel/M_40/Tokman.htm
} 
особистість, їі неповторність і унікальність, їі найвищу самоцінність, коли вони служать гуманістичним ідеалам.

Тепер можна більш конкретно спроектувати ці терміни на завдання освітнього процесу. Гуманізація освіти буде означати створення такої освітньої соціальної системи, що відповідає гуманістичним цінностям та ідеалам. Гуманітаризація ж освіти означатиме наповнення або доповнення освітньої програми гуманітарним змістом, тобто вона передбачає включення у навчальний процес циклу гуманітарних дисциплін. Отже, бачимо, що концепти «гуманізація освіти» i «гуманітаризація освіти» характеризують дещо різні вектори у реформуванні вищої школи. Якщо «гуманізація освіти» у широкому сенсі означає створення у суспільстві гуманної системи освіти, що відповідає гуманістичним ідеалам (насамперед, особистісній волі, соціальній справедливості і людській гідності), то «гуманітаризацію освіти» пов“язують із навчально-методичним змістом викладання у ЗВО. Гуманітаризація жодним чином не зводиться лише до завдання розширення інформаційного змісту гуманітарних дисциплін порівняно з професійним блоком, але, у принципі, повинна відповідати більш високим цілям: залученню молодих людей до гуманістичних цінностей, до гуманітарної культури людства. Іншими словами, гуманітаризація розглядається як додатковий i необхідний компонент професійної освіти. Так, гуманітаризація освіти переслідує дві основні i взаємозалежні цілі: по-перше, 3 іï допомогою намагаються перебороти «частковість» людини (молодого фахівця), ïi одномірність, що задається професійною підготовкою; по-друге, за допомогою гуманітаризації намагаються закласти у молодого фахівця основи гуманістичного світогляду. Отже, гуманітаризація розглядається як спосіб залучення молодої людини до духовних цінностей цивілізованого світу, як їі окультурення у широкому значенні слова, яке ніяк не зводиться лише до вузької професіоналізації.

Хоча необхідність гуманітаризації зараз ні у кого не викликає сумнівів, зіткнення спостерігаються якраз у питанні гармонізації професіоналізації $\mathrm{i}$ гуманітаризації, у їх збалансованому співвідношенні у межах навчального 
процесу. Варто відзначити, що без якісної професіоналізації не може бути сформований фахівець, професіонал у своїй справі, i, таким чином, навчання у ЗВО взагалі втрачає свій сенс. Однак, без гуманітаризації не може бути сформована повноцінна особистість.

Професія допомагає людині функціонально включитися у соціум, у розгалужену систему суспільної діяльності. Однак, крім цієї функціональної адаптації до соціуму через професію людина повинна ще органічно увійти до простору культури, засвоїти іï смисл і цінності, у процесі чого формується духовність людини, їі світогляд, розуміння нею свого місця і ролі суспільстві.

Поза цією духовністю ми маємо обмежену, неповноцінну людину, функціонера у заданій системі суспільного поділу праці.

Особистість - це завжди, насамперед, індивідуальність, яка формується у культурі і на основі культури. Вона є спадкоємницею і одночасно творцем культури. Професія наповнюється людським змістом для особистості лише тоді, коли за нею виявляється щось більш високе і самоцінне, а саме: надбання своєї індивідуальності у багатогранному і суперечливому світі культури, свого неповторного «людського обличчя».

Гуманізм в освіті здебільшого i повинен сприяти самовираженню особистості у світі культури, іiі вільному самовизначенню. Допомогти у цьому свідомому виборі майбутньому молодому фахівцю і повинна продумана гуманітаризація освіти. Отже, гуманітаризація виявляється органічно пов 'язаною з гуманізацією. Гуманітаризація повинна відкривати перед молодою людиною найвищий сенс культури, вводити їі у простір світової культури. Особливо гострою нині є проблема гуманітаризації технічної освіти, трудової підготовки молоді.

Проблеми гуманізації та гуманітаризації освіти в Україні найбільш повно висвітлені у працях С. У. Гончаренка, який наголошував, що проблеми гуманізації «останнім часом стали особливо актуальними у зв'язку з новим розумінням мети освіти, яка має забезпечити розвиток здібностей цілісної особистості, необхідних і їй, і суспільству, залучення іï до активної участі в 
житті, поєднання буття індивідуальної людини 3 культурою» ${ }^{40}$. На думку науковця, гуманізація передбачає становлення та вдосконалення унікальної цілісної особистості, яка прагне до максимальної реалізації своїх можливостей, відкрита для сприймання нового досвіду, здатна на свідомий і відповідальний вибір у різноманітних життєвих ситуація ${ }^{41}$.

Вища школа має надати таку освіту, яка у подальшому давала б можливість вчитися самостійно, стимулювала б у студента необхідність у самоосвіті та самовдосконаленні для власного інтелектуального зростання, для підвищення освіченості й становлення інтелігентності.

Для успішного розв'язання проблеми гуманітаризації, для прискорення процесу проникнення гуманітарної культури у зміст технічної освіти, необхідні:

1) забезпечення методологічної єдності у викладанні гуманітарних i спеціальних дисциплін;

2) переорієнтація фахових дисциплін на гуманістичну спрямованість, у центрі якої стоїть особистість;

3) організаційно-структурні зміни у системі освіти та виховання студентів, викладання навчальних дисциплін максимально наблизити до реальних, змінних умов життя;

4) гуманітаризація всього освітнього процесу у В3О, а саме: посилення ролі гуманітарних дисциплін за рахунок створення міцних міжпредметних зв'язків; підвищення рівня етичного та естетичного виховання студентів; активізація інтересу студентів до вивчення вітчизняної історії, світової культури та загальної психології.

Поряд із посиленням професійної підготовки майбутнього фахівця перше місце має посідати розвиток особистості, зорієнтований на загальнолюдські інтереси та цінності, формування високого почуття патріотизму. Проте виховання технічної інтелігенції неможливе без подолання технократичного

\footnotetext{
${ }^{40}$ Гончаренко С. У. Український педагогічний енциклопедичний словник. 2-ге вид., доповн. й виправл. Рівне: Волин. обереги, 2011. 519 с.

${ }^{41}$ Там же, с. 131.
} 
підходу до освіти і посилення гуманітарного впливу на весь перебіг навчального процесу.

Одним із суттєвих недоліків професійної підготовки майбутнього фахівця є недостатнє залучення студентів до діяльності у художній сфері, відсутність мотивації до підвищення культурного рівня, умов і засобів активації їхнього духовного, творчого потенціалу. У результаті професійна освіта втрачає культурний, моральний та особистісний контекст і значення.

Одним із чинників подолання технократизму у вищій школі вважаємо створення культурно-художнього середовища. Уже в стародавні часи була провідною ідея про елементи естетики і краси праці у творчій діяльності людини. Деякі стародавні філософи бачили у праці джерело краси й закликали творити красу, перебудовуючи світ. Вивчення культури та традицій свого народу допомагають розвинути свідомість і почуття особистості, а зокрема почуття патріотизму, іiі стійкі погляди та переконання. Тому лише усвідомлення себе продовжувачем справи багатьох поколінь, гордість за свій народ, уміння бачити красу освіти і красу праці, можуть стати тією моральною основою, яка дозволить викладачеві формувати у студентів любов до праці, природи, свого народу, своєї країни.

Отже, гуманізація та гуманітаризація освіти є перспективними засобами підвищення ефективності вищої школи і об‘єктивною соціальною потребою. Ці концепти хоча й характеризують дещо різні вектори у реформуванні вищої освіти, але в своїй органічній єдності можуть розглядатися як додатковий i необхідний компонент професійної освіти, і мають за мету допомогти студенту, як повноцінному суб‘єкту динамічних і суперечливих суспільних процесів, у формуванні наукової інтелектуальної культури, громадянської гідності, соціальної саморефлексії, постійного нарощування духовного й творчого потенціалу.

Демократизація - ще один з провідних векторів розвитку вищої освіти. Демократизація освіти будується на таких принципах: самоорганізація навчальної діяльності студентів, співпраця викладачів і студентів, різноманіття 
освітніх систем, рівні можливості у здобуванні освіти, громадсько-державне управління. Демократизація сприяє реалізації права кожної людини на освіту, незалежно від іiї соціального стану, статі, національності, релігійної та расової належності.

Головне у новій парадигмі освіти - це орієнтація на інтереси особистості, адекватні сучасним тенденціям розвитку суспільства, визнання унікальної сутності кожного студента та індивідуальності його навчальної траєкторії. А тому перспективним напрямом оптимізації освітнього процесу у вищій школі є ефективне впровадження особистісно зорієнтованих технологій (технологізація освіти).

У суспільстві поширена точка зору, відповідно до якої наднизький рівень народжуваності обумовлений соціально-економічними проблемами, невлаштованістю побуту та іншими труднощами, що наповнюють наше суспільство. Однак соціологи, які досліджують сімейно-родинні відносини, довели, що основна причина депопуляції пов'язана зі змінами в репродуктивних установках людей, викликаних змінами в ціннісних орієнтирах сучасної людини.

Коли досягнення науки і техніки пов'язані з вищими потенціями людини, ми є свідками справжнього прогресу. Коли ж вони зав'язані на масовій культурі, на суспільстві споживання та інстинктах, властивих масовій культурі, то ми бачимо, що історія рухається вперед і вгору, вперед і вниз.

Саме тому важливо розуміти роль гуманітарного знання. У розумінні зв'язків між релігією, філософією, історією, літературою, мовою, вони дозволяють бачити те, що відбувається, не повторюючи того, що було в історії, яка породжувала свої суперечності та безвиході. Тому важливе завдання гуманітарного знання полягає в тому, щоб займатися не тільки інноваціями, промисловістю, машинобудуванням, а й людинобудуванням: майбутнє залежить від того, що відбувається у внутрішньому світі людини. Тому-то такий важливий синтез наукових і культурно-історичних знань, який би розроблявся в цілісну освітню систему. 
Гуманітаризація технічної освіти в вузі не пов'язана 3 майбутньою професією, але за своєю значимістю для формування фахівця з вищою освітою, для становлення особистості вона в ряді випадків може виявитися навіть більш значущою, ніж підготовка власне за основним фахом. При аналізі цієї складної проблеми ми неминуче зіткнемося з поняттям «світова культура», форми якої не тільки різноманітні, а й надзвичайно великі. I ніхто не може точно сказати, що і скільки треба знати інженеру з вищою освітою, крім знання металознавства, зварювання тощо, щоб претендувати на статус «інтелігента» з усіма властивими цьому поняттю якостями.

Освічені люди - таке базове уявлення про інтелігенцію. I з ним мало хто сперечається.

Як соціальне явище люди, які здобувають освіту для роботи головою за допомогою рук, а не руками за допомогою голови, формуються паралельно 3 розвитком індустріального капіталізму. У поділі суспільних функцій, що склався, вони є виробниками знання; зайняті організацією чужої праці; керуванням ними; розподілом одержаних результатів.

У постіндустріальному, інформаційному суспільстві жива фізична праця мінімізувалась. Управління, розподіл, організація/ дезорганізація стало масовим заняттям; будь-які знання та компетенції продаються на ринку, в результаті інтелігенція як особливий шар соціуму поступово зникає. Якщо, працюючи замість рук мовою, більшість населення «виробляє дискурси», то інтелігенції як конкретного соціального власника розуму більше немає. Перемігши i, по суті, ототожнившись із соціумом, вона розчиняється в масі.

Якщо на Заході працівники розумової сфери, як правило, не претендували на вихід за межі своїх професійних обов’язків, в кращому випадку дозволяючи собі критикувати владу, то в нашій історії, вони культивували ідеали відповідальності перед народом, навіть поклоняючись йому; брали на себе місію його освіти; піклувалися про щастя суспільства і навіть про долю людства вцілому. 
Людина культури не може бути просто знаючою, інтелектуальною: вона має бути ще й соціально залученою, моральною, тобто бути «інтелігентом». Ї̈̈ думка у найширшому значенні цього слова вплетена в життя. Ця історична особливість самосвідомості вітчизняних освічених верств визнана у світі i, як відомо, у багатьох іноземних словниках слово «інтелігент» маркується позначкою «рос.».

Інтелігент не відокремлює себе від нижчих соціальних груп. Більше того: він стурбований їхніми проблемами. Узагальнено кажучи, він орієнтований на принцип служіння, принцип, який лежить в основі духовності, це - людина зі світоглядом, ціннісним, а не тільки пізнавальним чи технологічним ставленням до світу. Йому недостатньо гарного виконання своєї професійної ролі: він хоче проєктувати те, що існує.

У контексті панівної нині ліберальної ідеології не передбачається ціннісних - релігійних і моральних - регуляторів соціальності. Вона не передбачає ніякого «служіння», а керується лише принципом розумного егоїзму, взаємної вигоди та обміну. Тим самим відмовляється від культури як способу «внутрішнього» духовного освоєння світу людиною і позиціонує себе як цивілізація.

У цьому суспільстві особистість трансформується в «актора», в діяча і ділка, який у всьому керується раціональними міркуваннями, в інтелектуала. Відмова від культури та особистості означає, відповідно, кінець інтелігентності як прояву особистісних та культурних характеристик буття освічених людей.

Інтелектуал - це актор, ділова людина, зайнята у сфері розумової праці. Він - глибокий теоретик, який знає свою конкретну справу, високий професіонал, але він не вважає за потрібне і можливе думати про суспільство в цілому, його болі і проблеми. У нього є розум, але немає світогляду, що виражається зовні, i пов'язаних з ним переживань, а його духовність перетворювалася на менталітет. Перед нами - теоретичний прагматик або, що все одно, прагматичний теоретик. Якщо в остаточній формі елементи духовності все-таки зберігаються, то для приватного користування. 
Узагальнюючи, можна сказати, що якщо інтелігент - це суб'єкт культури, духовності, служіння і моралі, то інтелектуал - суб'єкт науки і техніки, носій раціоналізму та технологій. Зрозуміло, сказане - ідеалізація; очищене від емпіричних протиріч моделювання поточних явищ, але воно дозволяє зрозуміти напрямок їх розвитку та оцінити, що несе людству переважання того чи іншого ідеалу, припустити результат їх взаємодії.

Життя, на щастя, не до кінця логічне і можна бачити, як, зокрема в Україні, що спрямувалась в ринок шляхом глобалізму та цивілізації, національні традиції та культура борються, опираються. Занадто сильна традиція і позитивна аура інтелігентності.

Таким чином, університет 3.0 розширює спектр соціальних і економічних гравців - це і великі компанії, i малі фірми, і мережеві організованості, i некомерційні організації. Університет 3.0 - інституційна форма для здійснення цілого пакета діяльностей, при цьому природничо-наукових і інженерних знань вже недостатньо, розгортаються нові предметності - знання про економіку і ринки, про соціум і культуру.

В університеті 3.0 на перший план виходять навчальні і наукові підрозділи економічного і технологічного профілю. В університеті 3.0 крім раціонального обгрунтування, потрібне власне проектування діяльності всіх компонентів, відповідно, важливими предметами стають управління змінами; менеджмент і управління інноваціями; цифровий технічний дизайн. Університет 3.0 протистоїть «індустріальним» університетам з їх інертним освітнім процесом, який включає стандартні пакети курсів, які швидко стають застарілими; він проблематизує їх академічне середовище. «Матеріальне тіло» Університету 3.0 включає, крім аудиторій, бібліотеки, лабораторій, також бізнес-інкубатори і технопарки, конструкторські бюро, проектні офіси, спеціальні майданчики для комунікацій із зовнішнім світом - виставкові простори, громадські центри. Вища школа, діалектично пов'язуючи освіту та виховання, зберігає традиції підготовки інтелігенції, опираючись переходу до інтелектуалізму. 
DOI 10.46299/ISG.2021.MONO.PED.III.4.8

\section{8 Реалізації інноваційних освітніх процесів у рамках організаційно- педагогічної співпраці школи та університету}

Сьогодні зрозуміло, що зміна століть і тисячоліть веде до неминучих змін у суспільному житті. Перехід до посттехнологічного етапу суспільного розвитку, що супроводжується стрімким поширенням інформаційних технологій у всіх сферах життя, вимагає переосмислення існуючих освітніх підходів та пошуку нових.

У зв'язку з цим необхідно створити якісно нову освітню систему, здатну проектувати і відтворювати в реальності весь спектр явищ i зв'язків у матеріальному і духовному житті суспільства.

Виховні цілі відповідають історично та соціально відмінним ідеалам особистості та освіченої людини. Соціальні цілі та цілі учнів також взаємопов'язані: чим нижчий рівень освіти молодої людини, тим більше ії спонтанні цілі відхиляються від соціально-виховних. Розв'язання цього протиріччя передбачає поступове зближення, а в кінцевому підсумку - зближення особистісних смислів тих, хто займається освітою. У цьому контексті особливий інтерес і важливість представляє аналіз тих тенденцій, які виникли в минулому столітті і можуть тривати в сучасному, оскільки вони мають значний вплив на формування системи освіти.

Розгляд структури, типології і змісту інноваційного педагогічного процесу передбачає використання ідей загальної методології педагогічних нововведень $\mathrm{i}$ педагогічних інновацій, що були в центрі уваги таких науковців, як Р. Арцишевського, В. Безпалько, В. Бондар, С. Гончаренко, В. Гузеєва, I. Дичківськоъ, О. Дубасенюка, М. Ларіна, І. Козловськоъ, І. Мельничук, Л. Ребухи, Т. Назарова, Г. Селевко та ін.

На думку провідних експертів 3 питань освіти Ради Європи [324], зусилля світового співтовариства спрямовані на вирішення таких протиріч: 
- між загальним i особливим: поступове перетворення людини на громадянина світу, не втрачаючи свого коріння та $з$ активною участю в житті нації та її регіональних спільнот;

- між традицією та сучасністю: адаптація без заперечення свого коріння, діалектичний зв’язок між незалежністю та свободою, управління технічним прогресом, пов’язаним із розвитком нових технологій у сфері інформації;

- між істотним збільшенням інформації та здатністю людини іiі засвоювати;

- між змаганням за успіх і прагненням до рівних можливостей в економічній, соціальній та освітній політиці;

- між ринковою економікою та соціально орієнтованим ринковим суспільством.

Крім того, до ключових елементів навчання слід віднести три керівні освітні принципи: навчання здобувати знання; працездатність; навчитися жити.

Поняття «інновація» вперше з'явилося в дослідженнях культурології в 19 столітті і означало інтеграцію одних елементів однієї культури в іншу. На початку 20 століття сформувалася нова галузь знань - наука про інновації, в рамках якої вивчалися закономірності технічних нововведень у сфері матеріального виробництва.

Інноватика розвивалися як міждисциплінарна галузь досліджень на стику філософії, психології, соціології, теорії управління, економіки та культурології. Розвиток педагогічної інноватики в нашій країні пов’ язаний із масовим суспільнопедагогічним рухом, з виникненням протиріччя між наявною потребою швидкого розвитку школи та неспроможністю вчителів іiі реалізувати. У зв'язку з цим потреба в нових знаннях, в осмисленні нових понять «нове», «інновація», «інноваційний процес» тощо, постала більш гостро.

У педагогічній інноватиці дослідники, коли трактують поняття «інновація», у багатьох випадках йдуть за його розумінням у загальній інноватиці. Наприклад, А. Ніколлс у монографії «Управління педагогічними інноваціями» визначає інновацію як ідею, мету або практичну діяльність, що сприймається індивідом як дещо нове. У його розумінні інновація в освіті - 
це процес, що має життєвий цикл від зародження ідеї і створення нововведень до їі широкого розповсюдження в галузі освіти [325, с. 24].

Більшість дослідників визначають інноваційні процеси в освіті як систему, яка, активно відповідаючи на виклики соціокультурної дійсності та не відкидаючи існуючих традицій, вносить докорінні зміни в освіту, виховання та розвиток особистості.

В інноваційних процесах здійснюється трансформація не тільки самої педагогічної діяльності, притаманних ій ресурсів i механізмів, а й суттєво перебудовуються цільові установки та ціннісні орієнтації. Громадське сприйняття інноваційних ідей в освіті може бути досягнуто за умови забезпечення педагогічної взаємодії всіх суб’єктів освітнього процесу.

Одним із аспектів педагогічної взаємодії $\epsilon$ інноваційний навчальновиховний процес.

Інноваційні процеси передбачають відкритість до культури та суспільства, а також відкритість до свого «Я», власного внутрішнього світу. Педагогічне середовище організовано таким чином, щоб сприяти формуванню i розвитку образу «Я». В умовах інноваційної освіти створюються умови для розвитку особистості, використовується іï право на власний творчий внесок, за власною ініціативою, у свободу саморозвитку.

Інноваційні освітні процеси грунтуються на різних формах взаємодії, що розвиваються в логікі перебудови рівнів саморегуляції - від максимальної допомоги вчителя дітям у вирішенні виховних завдань до послідовного підвищення їхньої власної активності до повноцінної саморегуляції об’єктної діяльності. дії та виникнення партнерської позиції з учителем (В.Я. Ляудис) [326].

Розуміння педагогічних інновацій вимагає розгляду понять «інтеграція» та «педагогічна інтеграція», оскільки в сучасній педагогічній літературі існує неоднозначне тлумачення. Так, у тлумачному словнику української мови інтеграція (лат. integer — один, ціле) позначається як «об’єднання чогось в одне» [327]. Науковці І. Козловська, Л. Загорулько розглядають поняття «інтеграція» як колективне взаємопроникнення компонентів/елементів одного об'єкта в 
структуру іншого. Результатом цього процесу є вдосконалення певних якостей цих об’єктів, які постали як абсолютно новий об'єкт зі своїми властивостями [328]. Поняття «інтеграція» нероздільне iз словосполученням «педагогічна інтеграція», що тлумачиться як форма прояву єдності мети, принципів, змісту, форм організації процесу навчання i виховання [327]. Педагогічна інтеграція як різновид наукової інтеграції, здійснюється в межах педагогічної теорії i практики. Основою інтеграції педагогічних технологій, на переконання О. Мариновської, слугує побудова освітнього процесу на засадах виявлення в різних навчальних дисциплінах подібних елементів i поєднання їx $\mathrm{y}$ якісно нову цілісність для результативного формування життєво-важливого професійного образу майбутнього фахівця[329]. Наслідком такого об’єднання є інтегративна інноваційнопедагогічна технологія.

Цілісне розуміння інноваційних процесів вимагає розкриття провідних тенденцій і протиріч їх розвитку. Інноваційні процеси, що поєднують створення, розвиток та застосування педагогічних інновацій, завдяки своїй єдності можуть значно прискорити процеси оновлення системи освіти в цілому. I тому вивчення та впровадження всіх трьох ланок інноваційних процесів не випадкові; вони все більше інтегруються в систему освіти на різних рівнях, аж до окремих шкіл.

Одним із важливих завдань сучасної педагогічної інноватики є класифікація інновацій, знання якої необхідно вчителю, щоб зрозуміти особливості педагогічних інновацій, зрозуміти, що їх об’єднує та відрізняє одне від одного. Зазвичай вважають, що закони виражаються пропорціями, а класифікація та їх особливий випадок — типологія — лише передують відкриттю законів [330]. Сучасні дослідження наукової методології показують, що класифікації - це також закони науки, тільки іншого типу.

У навчальній літературі виділяють два типи інноваційних процесів в освіті. Перший тип - це інновації, що виникають переважно спонтанно, без точного відношення до самої генеративної потреби або без повного усвідомлення всієї 
системи умов, ресурсів і способів реалізації інноваційного процесу. Такі інновації не завжди пов’язані з повнотою наукового обгрунтування, а відбуваються частіше на емпіричній основі під впливом ситуативних вимог. Інновації такого роду охоплюють діяльність вчителів-новаторів, вихователів та батьків. У деяких випадках сюди входять i інновації, які здійснені адміністраторами проектувальниками освіти, які працюють у навчально-виховній практиці (художники, музиканти, архітектори, бізнесмени, екологи тощо). Сказане про спонтанний характер інновацій підкреслює необхідність поглибленого аналізу цього виду інновацій з метою виділення позитивних сторін його діяльності.

Другим типом інновацій є інновація в системі освіти, яка є продуктом свідомої, цілеспрямованої та науково культивованої міжпредметної діяльності.

Загальноприйнятої системної класифікації інновацій в освіті досі не створено, хоча багато дослідників намагаються встановити таку класифікацію на основі типології інновацій[331].

Залежно від виду, всі інновації можна поділити на дві групи: матеріальнотехнічні та соціальні. До другої групи належать освітні інновації. Вважається, що соціальні інновації особливо складні для реалізації, оскільки невизначеність їх параметрів i результатів дає змогу моделювати необхідні зміни без їх впровадження. Соціальні інновації більш тісно пов’язані 3 соціальними відносинами, культурою, більш широким охопленням, більшою опорою на особистісні якості новаторів, а переваги не настільки очевидні та доказуємо. Об’єктами змін є самі люди, їхнє становище, статус, звички, стосунки. Інновація створює напругу змін, виявляються стресові ситуації.

Нововведення, інновації, інноваційні процеси мають своїх носіїв. Визначення основних понять інноватики не може бути повним без характеристики людей, які впроваджують інновації. Йдеться про педагогічних новаторів, які вносять конструктивні інновації в педагогічну реальність. Творчі здібності та індивідуальність вчителя не дозволяють автоматично і без змін відтворювати педагогічний досвід. Суб'єктивний фактор відіграє вирішальну роль на етапі впровадження та поширення інновації. На цій фазі освітній новатор 
виступає в ролі носія конкретної інновації і водночас творця чи редактора в процесі впровадження. У більш загальному вигляді новатори можуть набувати таких характеристик. Новатори - це ті, хто хоче запровадити щось нове. Вони можуть виходити як від самої організації (вчителі, шкільні адміністратори) так і ззовні (представники органів управління освітою, дослідники освіти тощо). Вчителів-новаторів відрізняє не лише високий інтелектуальний потенціал, а й критичне ставлення до дійсності, пошук альтернативи іï недосконалості. Як наслідок, такі вчителі часто вступають у конфлікти з оточуючими. У зв’ язку з цим слід працювати з педагогами-новаторами як з окремою соціальною категорією, яка займає особливе місце в освітньому співтоваристві, має свою структуру, психологію та потреби. Без цього розуміння неможливо розвивати інноваційні процеси, поширювати інновації в школах [332].

Учитель, залучений до інноваційних освітніх процесів, повинен володіти високорозвиненою індивідуальною культурою обробки інформації (в тому числі 3 використанням сучасних комп'ютерних технологій), вміти адаптувати іï до здібностей дітей, а також мати дидактичні здібності.

Учитель може реалізувати себе творчо і продуктивно, якщо надати йому можливість грамотно відбирати різні напрямки навчальної діяльності через формування індивідуального пошукового стилю та знаходити адекватні шляхи і засоби реалізації своєї індивідуальності.

Така можливість виникає при різноманітних взаємодіях 3 факторами інноваційного навчального середовища, яке покликане забезпечити як особистісне зростання, так і формування нових психолого-педагогічних утворень. Продуктивна взаємодія зовнішніх обставин і суб'єктивних характеристик педагога забезпечує його творче самовизначення, що встановлює відповідність особистісних вимог професійній діяльності та глибину розуміння змісту освітніх інновацій. На цій основі сам учитель будує суб'єктивно прийнятні моделі навчання та вибору індивідуальних технологій навчання. Рух викладача в особистісному, технічному та професійному сенсі також пов'язаний iз впровадженням інноваційних методів і прийомів[333]. 
Теоретичний аналіз дав можливість припустити, що інноваційні технології можуть бути успішно реалізовані вчителем за таких умов: проблематизація, виявлення протиріч, виявлення та формування особистісних смислів, творча переробка та переосмислення власного та педагогічного досвіду; рефлексія.

Рефлексивна культура як системоутворюючий фактор професіоналізму - це набір навичок, методів і стратегій, які пробуджують стереотипи особистого досвіду та дій шляхом їх переосмислення і тим самим сприяють інноваціям, які ведуть до подолання тих проблемно-конфліктних ситуацій, які виникають під час вирішення професійної справи, завдання.

Дубасенюк О. А., Вознюк О. В. [334] визначають такі умови, які гарантують готовність педагога до розвитку до інноваційної діяльності: свідоме управління професійною діяльністю на основі мотивів і настроїв; проблематизація i суперечливість педагогічної дійсності - бачення зіткнень і невідповідностей, що не спостерігаються безпосередньо; критичне ставлення до педагогічних норм; відображення та побудова смислової системи (смислотворення); відкритість до навколишнього середовища та професійних інновацій; творчо-перетворююче ставлення до світу, що виходить за рамки нормативної зумовленості; прагнення до самореалізації, до втілення своїх намірів і способу життя у професійній діяльності; суб’єктивація елементів в особистісному смисловому змісті, тобто наділення особистісним змістом.

Головна роль інтеграції педагогічних технологій полягає в якісному підвищенні освітнього процесу, що вчиняється на основі спільної педагогічної реалізації всіх уможливлених складників педагогічних технологій.

Таким чином, інноваційні процеси навчання створюють новий вид професійної свідомості та поведінки вчителя, що стає предметом навчальної діяльності. Засобом реалізації інноваційних освітніх процесів у рамках організаційно-педагогічної співпраці школи та університету має стати проектування інноваційного освітнього середовища, що гарантує підвищення ефективності освітніх структур. 
DOI 10.46299/ISG.2021.MONO.PED.III.4.9

\section{9 Освітні інновації - це основний фактор ефективності навчально- виховного процесу у ЗВО}

Сучасний етап розвитку національної системи освіти визначається освітніми інноваціями, спрямованими на збереження досягнень минулого й, водночас, на модернізацію системи освіти, відповідно до вимог часу, новітніх надбань науки, культури та соціальної практики.

Законом України «Про вищу освіту» передбачено,що метою вищої освіти є всебічний розвиток людини як особистості та найвищої цінності суспільства, розвиток іï талантів, розумових і фізичних здібностей, виховання високих моральних якостей, формування громадян, здатних до свідомого суспільного вибору, збагачення на цій основі інтелектуального, творчого, культурного потенціалу народу, підвищення освітнього рівня народу, забезпечення народного господарства кваліфікованими фахівцями [337].

Обравши курс на Європейську інтеграцію, Україна активно відстоює зроблений вибір і деталі гучніше заявляє про себе, як про країну, орієнтовану на інноваційний розвиток. Відтак в усіх сферах і на всіх рівнях життєдіяльності суспільства розпочалися численні інноваційні зміни. Це стосується й національної системи освіти. Сьогодні неможливо знайти жодну сферу життя та діяльності людини, яку б не заполонили інновації.

Термін інновація є новою економічною категорією, яку ввів у науковий обсяг австрійський (пізніше американський) вчений Йозеф Алоіз Шумпетер та професор В. Спенсер. А. Шумпетер у своїй праці «Теорія економічного розвитку» виділив п’ять нових комбінацій змін у розвитку це: використання нової техніки; технологічних процесів нового ринкового забезпечення виробництва; упровадження продукції з новими якостями; використання нової сировини; зміни в організації виробництва та його матеріально-технічного забезпечення. Поява нових ринків збуту [338].

Поняття «інновація» трактують як нововведення, новизну, зміну, оновлення, новий підхід, створення якісно нового. Автори «Енциклопедія 
освіти» визначають головну мету інновацій в освіті у «необхідності відповідати викликові глобалізаційних трансформаційних, екологічних проблем у світі. Характерним для нашого часу є утворення пріоритету інноваційного розвитку освіти» [339].

Провідні країни світу у своєму розвитку дедалі більше просуваються до інноваційного суспільства.

Головним інноваційним ресурсом суспільства стають знання, а його основним постачальником - сфера освітніх послуг. Набувають актуальності інноваційна діяльність та інноваційний розвиток університетів: підготовка фахівців для інноваційної діяльності та випуски фахівців за інноваційною моделлю.

У такому контексті проблему аналізують наші провідні вчені, за останні десятиліття 3'явилися праці низки науковців присвячені інноваціям в освіті. Дослідженнями даної наукової галузі займаються Л. Ващенко, І. Дичківська, О.Попова [340,341,342].

Інтерес до інновацій світової педагогічної громадськості виявляється у створенні інформаційних служб (Центр дослідження інновацій в освіті під егідою ЮНССКО, Азіатський центр педагогічних інновацій для розвитку освіти), проведення міжнародних конференцій, що узагальнюють педагогічні нововведення в різних країнах світу. Зокрема, Міжнародні бюро з питань освіти (Франція, Париж) публікує такі періодичні видання, як «Педагогічні інновації», «Інформація та інновація в освіті».

Інноваційна діяльність університету спрямовується на створення та освоєння інновацій, тобто оновлення освітніх продуктів i послуг, форм i технологій навчання на різних етапах інноваційного процесу (від появи ідеї або нової технології до їі ринкової реалізації) в освітній та науковій сферах, а також післядипломній професійній освіті, що забезпечує необхідну економічну та соціальну вигоду. Професор Л.С. Шевченко погоджується з О.О. Латухою стосовно доцільності виокремлення трьох видів інноваційної діяльності ЗВО: 
1. Діяльності зі створення інновацій: виконання фундаментальних i прикладних наукових дослідження, розробки та реалізації комплексних проектів і програм інноваційного розвитку;

2. Навчання інноваційній діяльності викладачів, наукових працівників, аспірантів, докторантів, здобувачів вищої освіти - як фактор відтворення інноваційних кадрів, що має важливе значення в умовах сучасної науки;

3. Власне освітньої діяльності як традиційного напряму діяльності 3ВО, створенням різного роду курсів підвищення кваліфікації, проведенням семінарів-тренінгів, круглих столів 3 проблем розвитку галузі, тощо [342].

Інновація це деяке нововведення, яке сприяє переведенню певної досліджуваної системи на новий, якісно відмінний рівень розвитку. Впровадження інновацій в освіті покликане сприяти вдосконаленню методів та форм освітнього процесу з метою підвищення його якості. Дослідник В. Вакуленко вважає, що інноваційні процеси, що відбуваються в освіті, можуть бути представлені так: блок побудови нового, блок сприйняття нового, блок практичної реалізації нового [343]. Покликання інноваційних процесів в освіті пришвидшення процесів модернізації освіти у відповідності до вимог сучасності. Науковці констатують той факт, що інноваційні концепції без практичної реалізації взагалі не можуть вважатися інноваціями. Інновації в освіті потребують нових підходів до вирішення освітніх завдань, якісних змін у цілях освітньої діяльності та способах їх досягнень, нових видів співпраці викладачів там здобувачів вищої освіти.

Для впровадження інновацій в освіті необхідно залучення до організації освітнього процесу потенційних працедавців із метою допомоги у формуванні вимог до майбутніх фахівців галузі, до їх особистості. Також повинна бути співпраця між різними рівнями закладів вищої освіти в умовах іiї неперервності. Вчена В. Радкевич вважає, що важливим для кожного викладача закладу освіти $€$ володіння педагогічною майстерністю, яка проявляється в умінні спрямувати кожні теоретичні знання в русло майбутньої професії [343]. Авторка наголошує, 
що лише викладач, що володіє низкою професійних компетентностей та якостями, які відіграють важливу роль у професійній діяльності, може допомагати формуватися майбутнім фахівцям стати конкурентоспроможними.

Ось до прикладу вивчення дисциплін математичного циклу є складним для більшості здобувачів вищої освіти, але водночас і важливим, оскільки сприяє розвитку, як загальних, так і спеціальних предметів технічного напряму. Тому виникає необхідність у процесі освітньої діяльності так подавати навчальний матеріал, щоб одні здобувачі вищої освіти працювали над ним проблемно (проблемно-пошуковий підхід або частково-пошуковий), а іншим навпаки, давалось пояснення всього матеріалу до найменших деталей разом із ліквідацією прогалин у знаннях зі шкільного курсу математики. Головна ідея: кожен здобувач освіти це особистість, якій треба допомогти розвинути свої здібності, стимулювати до навчальної, пізнавальної,творчої діяльності.

Важливе значення набувають практичні завдання, які здобувачі вищої освіти виконують при вивченні кожної теми.

При викладанні вищої математики необхідно реалізувати дві основні задачі: 3 одного боку представити математику як цілісну фундаментальну науку, яка є абстрактною моделлю реального світу, а з іншого показати широкі можливості математичних методів при їх використанні в інших навчальних дисциплінах i застосуванні до розв’язування прикладних задач. 3 цього приводу академік Б.В. Гнеденко зауважує: «Математику відносять до фундаментальних наук, і це правильно. Але щоб учень зрозумів це, йому потрібно неодноразово продемонструвати фундаментом чого і як вона стає. А для цього необхідно показати на чисельних прикладах, як і чому методи математики дозволяють розв’язувати задачі практики та як задачі практики неодмінно приводять до необхідності подальшого розвитку самої математики та її методів» [344].

Порівняно 3 іншими навчальними предметами природничого циклу, математика як наука вирізняється чи не найвищим рівнем абстрактності понять та тверджень, тому при їі викладанні, поряд з іншими, мають бути забезпечені такі дидактичні принципи як доступність, послідовність, систематичність та 
символічна наочність навчання. При ньому виклад матеріалу має проводитись зрозумілою для здобувача вищої освіти мовою. Мається на увазі те, що при читанні лекцій необхідно використовувати термінологію та символіку, які $є$ найбільш доступними для здобувача вищої освіти та використовувалась раніше чи використовуються тепер (або будуть використовуватись) у суміжних дисциплінах.

Практика показує, що випускники шкіл, вивчаючи математику протягом тривалого часу, так і не засвоїли деяких основних понять i, в кращому випадку, можуть давати формальні відповіді, не усвідомлюючи належно їх суті. Наприклад, строге означення границі функції, яке пропонується учням у школі, є настільки абстрактним, що вони, в основному, не спроможні його зрозуміти: число $b$ називається границею функиії $y=f(x)$ при $x \rightarrow a$, якщуо для всіх значень аргументу $x \neq a$ i таких, щзо $|x-a|<\delta$, де $\delta>0-$ дійсне число, існує як завгодно мале число $\varepsilon>0$, щзо виконується умова $|f(x)-b|<\varepsilon$. Чи не доступнішим для здобувача є нестроге означення границі функції в точці $x=a$, яке ми даємо на основі графічних уявлень: число $b$ називається границеею функцї $y=f(x)$ при $x \rightarrow a$, якщуо при прямуванні аргументу $x$ до числа а відповідні значення функиї̈ $y$ наближаються як завгодно близько до числа $b$, щуо записується так: $\lim _{x \rightarrow a} f(x)=b$ ?

Здобувачі інженерних спеціальностей у теоретичній механіці вивчають рух точки $M(x ; y)$, траєкторія якої описується графіком функції $y=f(x)$, причому в цьому процесі береться до уваги не лише рух точки $M$, а також розглядаються закони руху їі проекцій $x$ i $y$ на осі координат. Тому такий підхід до означення границі функції є більш сприятливим для розуміння, адже в означенні, поряд 3 наочним представленням процесу, використовуються знайомі поняття та терміни.

При вивченні векторної алгебри вводиться поняття координат вектора. Відповідно до шкільного курсу, а також у переважній більшості підручників і навчальних посібників з вищої математики для студентів 3ВО під координатами 
вектора розуміють коефіцієнти його розкладу в базисі $(\vec{i}, \vec{j}, \vec{k})$, а в чому полягає їхній геометричний зміст, залишається невідомим. Ми вважаємо, що доцільно ввести поняття проекції вектора на вісь, розглянути її властивості і координати вектора визначати як його алгебраїчні проекції на осі координат. Перевага такого підходу очевидна: в загальнотехнічних та спеціальних дисциплінах координати вектора розглядаються саме так, причому здобувач вищої освіти повинен вміти, розпочинаючи з вивчення векторної алгебри, проектувати систему векторів на осі координат та визначати числові значення компонентів векторів.

Для здобувачів освіти технологічних спеціальностей, наприклад, ми пропонуємо комплексну задачу на розрахунок оптимальних габаритних розмірів так званих багатосекційних траншей для зберігання силосу. Така задача за своєю суттю $\epsilon$ абсолютно зрозумілою для здобувачів-першокурсників, причому іiі розв’язання проводиться за схемою дипломного проекту: показується перевитрата будівельних матеріалів при спорудженні існуючих силосних траншей та неекономічність їх експлуатації, розраховуються оптимальні габаритні розміри запропонованих траншей та обчислюється у відсотках економія будівельних матеріалів, яка може бути досягнута при їх спорудженні.

Здобувачі вищої освіти розв'язують задачу на розрахунок оптимальної ширини загінки поля при проведенні його оранки, причому їі оптимальність визначається із умови мінімізації холостих переїздів тракторного агрегату під час оранки поля врозгін i до складу. Подібною $\epsilon$ задача про розрахунок оптимального розміщення пунктів заправки технологічних агрегатів посівним насінням, пестицидами чи гербіцидами на краю поля. Результати таких досліджень можуть бути використані на практиці при складанні технологічних карт по обробітку даного поля.

Практично вся сучасна навчальна література 3 курсу вищої математики вводить поняття означеного, криволінійних і кратних інтегралів традиційними методами, тобто інтеграл розглядається як границя відповідної інтегральної суми. Такий же підхід використовують викладачі при викладанні цих понять. Це 
певною мірою суперечить уявленням здобувачів-першокурсників про означений інтеграл, адже в школі інтеграл розглядається як приріст первісної на даному проміжку числової прямої.

Досвід викладання показує, що ефективнішим є підхід, який розвиває та поглиблює поняття інтеграла, що розглядається в шкільній програмі, причому це стосується не лише означеного, а й усіх інших типів інтегралів. Саме така методика, на наш погляд, дозволяє зекономити навчальний час і представити поняття інтеграла у простішому вигляді, який є доступнішим для розуміння. Водночас при застосуванні інтегралів до розв’язування прикладних задач варто реалізовувати метод «диференціала», який інакше називають «фізичним» методом. Суть методу полягає в тому, що спочатку знаходять не саму невідому в даній задачі величину, а пї елементарне значення (елементарну роботу, елементарний момент інерції тощо), тобто диференціал цієї величини, а саму величину шукають після цього шляхом інтегрування обох частин одержаної рівності по відповідних змінних у заданих межах. Перевага цього методу перед традиційними визначається тим, що здобувачі, замість формального використання формули, замислюються глибше над змістом прикладної задачі, за власною ініціативою зручно розміщують геометричну фігуру відносно системи координат, виділяють на ній елементарну площадку, виражають елементарне значення шуканої величини та обчислюють іiі в цілому шляхом інтегрування, тобто поступають саме так, як це вони роблять в аналогічних випадках при вивченні споріднених та інженерних дисциплін.

Надзвичайно складною для багатьох здобувачів освіти спеціальності «Електроенергетика, електротехніка та електромеханіка» $\epsilon$ задача про розкладання періодичної функції в тригонометричний ряд Фур’є. Складність обумовлена проблемами, що виникають при інтегруванні точними методами. Однак ми акцентуємо увагу здобувачі вищої освіти, в першу чергу, не на проблемі інтегрування, а на необхідності розв'язання цієї задачі та піi використанні, наприклад при вивченні такого предмету як «Теоретичні основи електротехніки». Намагаємось довести до свідомості кожного здобувача 
інженерно-технічне розуміння цієї задачі, трактуємо формальне розкладання періодичної функції в ряд Фур'є як представлення складного гармонічного коливання у вигляді нескінченної суми простих гармонік, причому його необхідність пояснюється потребою вивчення закономірностей коливного процесу. Пропонуємо розкладати в ряд Фур'є найпростіші функції, а в складних випадках рекомендуємо цю задачу розв'язувати за допомогою комп'ютера чи наближеного методу, який називається практичним гармонічним аналізом.

У здобувачів вищої освіти цієї ж спеціальності викликає певний інтерес задача про розрахунок надійності електричних схем, яка входить до складу розрахунково-графічної роботи. Це пояснюється тим, що виконаний аналіз схеми електричного кола з точки зору надійності ії роботи в залежності від видів сполучень між собою ï елементів і надійності безвідмовної роботи кожного 3 них, приносить іноді несподівані результати та спонукає здобувача замислюватись над ними, тим більше, що така задача може бути наближеною до реальних умов експлуатації електричних мереж [345].

Таким чином педагогічна інноватика полягає у постійному пошуку та впровадженні нових максимально ефективних технологій навчання та виховання, результатом яких має бути формування високо адаптованої до змінних умов, активної діяльності, творчої особистості, яка вміє аналізувати.

Орієнтація на нове, пошук і впровадження нового це є мета педагогічної інноватика. Це спонукає до постійного оновлення змісту та форм навчання там виховання. Інноваційна діяльність в освітній сфері $є$ надзвичайно сучасним явищем. Це зумовлює гнучкість системи освіти, іiі відкритість до нового та є запорукою конкурентоспроможності національної освіти. 
DOI 10.46299/ISG.2021.MONO.PED.III.4.10

\subsection{0 Впровадження інноваційних технологій у навчання фізики в закладах вищої освіти}

\subsection{1. Проблеми та особливості застосування інноваційних технологій в педагогічних закладах вищої освіти}

Основними пріоритетами державної політики у сфері вищої освіти на сучасному етапі їі реформування наголошено:

• забезпечення якості вищої освіти;

- інтеграція до європейського простору вищої освіти i наукових досліджень;

- освіта впродовж життя.

Питання забезпечення якості вищої освіти зараз є світовим трендом. Інтернаціоналізація української вищої освіти, входження вітчизняних університетів до Європейського простору вимагає від закладів вищої освіти (3ВО) визнання та дотримання європейських освітніх стандартів, побудови на основі європейських стандартів і рекомендацій власної системи внутрішнього забезпечення якості освіти в університетах.

3 введенням нових стандартів підготовка кваліфікованих спеціалістів, конкурентноспроможних на міжнародному ринку праці, здатних орієнтуватись в суміжних галузях діяльності, готових до компетентної, відповідальної та ефективної діяльності, до постійного професіонального росту, неможлива без впровадження інноваційних технологій, які в практиці навчання є обов'язковою умовою підвищення якості навчання [346].

У проєкті «Стратегія розвитку вищої освіти в Україні на 2021-2031 роки» на основі проведеного аналізу проблем і переваг системи вищої освіти України як їі слабкі сторони визначено низький рівень залученості до наукової та інноваційної діяльності учасників освітнього процесу, їх вмотивованості, слабка практична підготовка фахівців. Виходячи 3 цього й зважаючи на глобальні тренди. пріоритетними принципами розвитку вищої освіти в Україні зазначено:

- орієнтація на найвищі наукові досягнення; 
• орієнтація на досягнення найвищої якості освіти.

Інтеграція України у світовий освітній простір вимагає постійного вдосконалення національної системи освіти, пошуку ефективних шляхів підвищення якості освітніх послуг, апробації та впровадження інноваційних педагогічних систем.

Впровадження інноваційних технологій і дистанційного навчання у вищій освіті при цьому визначене як операційна ціль, для досягнення якої потрібно вирішити наступні завдання [347]:

- створення індустрії інноваційних технологій та засобів навчання, що відповідають світовому науково-технічному рівню;

- диджиталізація усіх процесів у системі вищої освіти;

- унормування дистанційного навчання як форми здобуття вищої освіти.

Сутність інноваційної педагогічної діяльності, iї структура та класифікація розглядалися в працях Л.І. Антошкіної, В.А. Сластенина, В.І. Загвязинського, М.М. Поташника, Н.Р. Юсуфбекової, М.Ф. Баймухамедова, І.В. Тимошенкова, Л.І. Даниленко, О.А. Дубасенюк, О.Г. Козлової, І.С. Каленюк, А.І. Пригожина, М.В. Кларіна, А.М. Бронської, Н.І. Клокар. Проблеми, пов’язані з механізмами застосування та впровадження педагогічних нововведень вивчали I.М. Дичківська, С.А. Безгородько, І.Ф. Ісаев, Г.С. Беккер А.Г. Кругліков, С.Д. Поляков, А.А. Орлов, проблеми творчого саморозвитку вчителя, педагогічного колективу в умовах інноваційної діяльності, труднощів, стимулів і перешкод - В.А. Кан-Калик, Н.Ш. Чинкина, А.В. Попов, В.П. Кваша, К.А. Алібай, О.Г. Хмарка, А.В. Лоренс. Велика частина досліджень присвячена проблемам підготовки студентів університетів до інноваційної діяльності, до застосування інноваційних технологій навчання в школі (Н.М. Анісімов, С.Д. Поляков, Н.А. Щербаков, В.С. Пилаєва, В.Е. Тамарін, С.П. Морозов, І.В. Штих та ін.).

Дослідженнями проблеми розробки, аналізу та впровадження інноваційних технологій у навчання фізики в середній та вищій школі займалися В.Ю. Биків, П.С. Атаманчук, С.П. Величко, В. Слободчиков, В.Ф. Заболотний, М.I. Жалдак, О.І. Іваницький, Н.В. Леонова та інші. Водночас багато дослідників, 
такі як В.С. Кагерманьян, А.Я. Савельєв, О. Голубєва, відзначають, що структура курсу фізики у вищій школі не піддавалася перегляду, принаймні, протягом останніх п'ятдесяти років. Весь цей час модернізація відбувалася лише за рахунок механічного додавання нового матеріалу без оцінки і обліку його впливу на осмислення фізичної картини світу в цілому.

Аналіз сучасних досліджень проблеми педагогічних інновацій показує, що питання їх впровадження і реалізації залишається досить актуальним і широко обговорюваним. У сучасній освіті не існує певної і загальноприйнятої концепції інноваційної діяльності. Крім того, педагогічні інновації розглядаються частіше 3 прикладної точки зору, як результат освітньої практики. Проте, незважаючи на відсутність єдиної концепції завдання, впровадження інновацій ставлять перед собою більшість освітніх установ.

Основними цілями інноваційного навчання є наступні:

- розвиток критичного мислення;

- проблемне навчання;

- диференційований підхід до навчання;

- створення ситуацій успіху.

У теорії та практиці педагогічної освіти накопичено чималий банк активних, практико-орієнтованих форм, методів і технологій навчання, що враховують закономірності розвитку, рівень, особливості тих, хто навчається, їх готовність до самостійного набуття знань i ефективного використання в практичній діяльності. Існує безліч освітніх та навчальних технологій, заснованих на інноваційних підходах. Вони розрізняються по цілях, завданнях, структурі, специфіці здійснення конкретного виду педагогічної діяльності, організаційній формі, методиці навчання, передбаченій мірі активності суб’ єктів освітнього процесу, виду взаємодії викладача і навчального контингенту тощо.

До відомих інноваційні технології відносяться технологія проблемного навчання (А.М. Матюшкін, С.Л. Рубіншгейн, М.И. Махмутов, И.Я. Лернер); технологія модульного навчання (Т. І. Шамова, П.І. Третяков), технологія розвиваючого навчання (В. В. Давидов, Л. В. Занков), технологія навчання за 
В.Ф. Шаталовим, технологія навчання «Кластерн», технологія групової пошукової діяльності Дж. Гордона, мультимедіа технології навчання та багато інших.

Вибір освітніх технологій, особливості методики їх застосування визначаються, зокрема, цільовою аудиторією. Так організація освітнього процесу в середній школі й вищих навчальних закладах потребують різних підходів, що обумовлено наступними факторами:

1) особливостями організації освітнього процесу в закладах вищої освіти, які детально розглянуте у Законі України «Про вищу освіту»;

2) відмінностями в цілях навчання: спрямованості навчання у вищій школі на формування у студентів професійного мислення, здатності до майбутньої професійної діяльності в галузі обраної професії;

3) відповідними відмінностями в змісті освіти: залежністю складу навчальних дисциплін та їх змісту від професійної спрямованості; збільшенням обсягу навчального матеріалу з профільних дисциплін тощо;

4) 3 вимогою більш глибокого поєднання навчання 3 науководослідницькою роботою студентів у порівнянні з учнями середньої школи;

5) з віковими відмінностями здобувачів вищої освіти, зокрема, з більшою здатністю до самостійного опанування навчальних дисциплін, до абстрактного мислення, зростанням ролі уваги в пізнавальному процесі, активізації розвитку всіх видів почуттів, зокрема, відчуття особистості тощо.

Професійний розвиток особистості майбутніх педагогів здійснюється засобами цілеспрямованої, систематичної, педагогічно організованої підготовки в процесі діяльності та спілкування в освітній сфері. Становлення студента як суб'єкта освітньої сфери проходить шляхом включення його в педагогічний процес, що має творчу спрямованість та забезпечує умови для набуття ним досвіду наукової та творчої діяльності, а саме:

- професійно-творчий розвиток студентів, оволодіння ними досвідом наукової та творчої роботи; 
- формування мотиваційно-споживчої сфери їх особистості з установкою на науковий пошук та педагогічні інновації, розвиток здатності створювати атмосферу творчості, пошуку авторських рішень;

- індивідуалізація, підтримка самобутності особистості, що дозволяє студентам реалізувати ідеї та вирішення педагогічних проблем у практиці педагогічної роботи.

Здійснення цих напрямів пов'язане 3 моделюванням та реалізацією цілеспрямованої, систематичної підготовки у проблемно-інноваційній сфері діяльності. Зміст іiі покликаний розкривати сутність, виховний потенціал, функції освітнього середовища як фактору формування професійного вигляду майбутнього педагога та достатнього рівня його готовності до створення атмосфери наукового пошуку та педагогічної творчості у майбутній професійній діяльності.

Джерелом та результатом ефективного професійного розвитку професійного розвитку майбутнього вчителя виступає освоєння нових видів діяльності, нових освітніх сфер та нових відносин, у тому числі і проблемноінноваційної сфери педагогічної діяльності.

На становлення творчої особистості великий вплив має проблемноінноваційна сфера іiї діяльності. Проектування проблемно-інноваційної сфери діяльності в процесі підготовки майбутніх вчителів виступає важливим фактором розвитку їх творчих здібностей, формування творчого стилю діяльності та активної професійної позиції, без чого неможлива педагогічна творчість та педагогічні інновації. Ця сфера забезпечує кожному студенту можливість нестандартно діяти, самостійно робити вибір способів вирішення навчальних проблем, налаштування на перспективу професійного саморозвитку, самоствердження у професійній діяльності та досягнення професійного успіху. Вона орієнтує на створення у вищій школі такої обстановки, яка б стимулювала кожного студента на нестандартність дій, пошук творчого виходу із проблемних ситуацій. 
Застосування інноваційних технологій у освітньому процесі з фізики в педагогічних 3ВО має на меті ще й наступні цілі:

- показати студентам можливості застосування інноваційних технологій у навчанні фізики на різних рівнях освіти;

- продемонструвати можливості адаптації застосованих у ЗВО технологій до урочної та позаурочної діяльності в школі, чому, зокрема, сприятиме приведення аналогій та встановлення зв'язків зі шкільним курсом фізики;

- залучити студентів до творчої діяльності з аналізу ефективності різних інноваційних технологій, задля чого освітній процес повинен бути побудований таким чином, щоб студенти мали можливість не тільки навчатися за інноваційними технологіями, а й набували модельний досвід їх застосування в навчальному процесі.

Як ключові тенденції, що прискорюють впровадження інноваційних освітніх технологій у сучасні сектори вищої освіти, українські та міжнародні експерти відмічають наступні:

1. Підвищення уваги до вимірювання навчання.

2. Розширення сфери використання моделей зміманого навчання.

3. Переформатування навчальних просторів, оновлення навчального середовища, реалізація різних форми віддаленої роботи, розвиток навичок роботи в циифровому світі.

4. Впровадження проблемно-, проектно-, дослідницько-орієнтованого навчання, які мотивують студентів, забезпечують усвідомлення ними чіткого зв'язку між навчальним планом і реальним світом довкола; розвиток нових технологій, таких як перевернуте навчання.

5. Сприяння адаптації до постійно змінюваних економічних потреб суспільства, синергія між освітою, наукою та інноваціям.

\subsection{2. Проблемне навчання}

Проблемне навчання - це система прийомів, що пробуджує інтерес студентів до пошуку розв'язання проблем, на відміну від механічного засвоєння 
готових знань, включення механізмів мислення шляхом створення проблемних ситуацій.

Проблемна ситуація - стан інтелектуального утруднення, необхідність робити вибір, приймати рішення, вирішити утруднення, що виникле, включати мислення й тим самим активізувати навчальний процес.

Проблемне навчання включає як творче засвоєння знань, так і оволодіння способами, прийомами пізнання, отже вчить студентів мислити, включаючи емоційно-психологічну мотивацію, справляє позитивний вплив на загальний розвиток особистості.

3 формами і рівнем проблемного навчання пов’язані й відповідні методи:

1) метод проблемного викладу, коли викладач демонструє зразок постановки проблеми, шляхів, засобів, прийомів проблемного мислення i вирішення поставленої пізнавальної задачі;

2) евристичний метод - частково-пошуковий, коли викладач створює проблемну ситуацію, формулює проблему i залучає студентів до процесу іï розв’язання;

3) дослідницький метод - найскладніший рівень самостійної роботи студентів, коли студенти самі бачать протиріччя, формулюють проблему та іiі розв’язують.

Проблемно-оріснтоване навчання або PtBL (Problem Based Learning) навчання на основі проблеми - навчальний підхід, заснований на процесі пошуку вирішення спеціально сформульованої проблеми, для розв’язання якої здобувачам освіти потрібно звертатися до теоретичного матеріалу. У такий спосіб, викладач не дає готову інформацію, а задає проблему і виступає в ролі помічника, консультанта, модерує дискусію щодо розв’язання проблеми [348].

Проблемно-орієнтоване навчання може здійснюватися як:

- навчання через дію - проблема і рішення повинні виражатися в діях, наприклад, створення нового формату підручника - PBL (Project Based Learning), навчання на основі проекту (метод проектів) [349]; 
- навчання на місці - слухачі повинні вчитися вирішувати проблему не в аудиторії, а в тому місці, де вона виникає, наприклад в компанії, на заводі, в лікарні, в школі;

• навчання на кейсах.

До переваг технологій проблемно-орієнтованого навчання можна віднести наступне:

- правильно сформ ульована проблема затягує слухачів у процес іiі розв'язання;

- групова дискусія на занятті підвищує мотивацію і дозволяє почути думку інших;

- здобувачі набувають навички самостійно шукати теоретичний матеріал $\mathrm{i}$ працювати з ним, оцінювати джерела на достовірність, самостійно розв'язувати проблеми;

- здобувачі на практиці уявляють, де їм можуть знадобитися одержані знання.

Головним недоліком моделі є те, що незацікавлені в проблемі або не готові до такого виду роботи студенти можуть випасти 3 процесу обговорення $\mathrm{i}$ навчання.

\subsection{3. Специфіка та завдання методу Case-study при навчанні фізики} в педагогічних $3 B 0$

До чисельних інноваційних методів навчання, що базуються на створенні проблемних ситуацій, відноситься метод кейсів (case-study).

Кейсом у науковій літературі називають опис ситуації і комплекс завдань до нього, які є ядром, дидактичним супроводом методу проблемних ситуацій (кейс-методу).

Метод кейс-стаді може бути названий методом аналізу конкретних ситуацій. Суть методу полягає в наступному: для організації навчання здобувачам освіти пропонують осмислити конкретну ситуацію, змодельовану або реальну, опис якої одночасно відображає не тільки будь-яку практичну проблему, а й актуалізує певний комплекс знань, який необхідно засвоїти при 
розв’язанні даної проблеми. При цьому ти, хто навчається, повинні проаналізувати ситуацію, розібратися в суті проблем, запропонувати можливі рішення і вибрати найкраще з них.

Однією з головних вимог, що пред’являються до кейсів, та їх відмітною особливістю є відсутність єдиного правильного рішення, що дозволяє побачити неоднозначність розв'язання проблеми в реальному житті, вимагає формування умінь оцінювати запропоновані варіанти, прогнозувати результати, вибирати оптимальне рішення. Кейс-метод орієнтований на постановку питань, в той час як інші методи - на пропоновані рішення. В структурі кейса часто відсутній ряд питань, на які необхідно давати відповіді. Замість цього студенту слід цілком осмислити ситуацію, викладену в кейсі, самому виявити проблему і питання, які потребують вирішення. Таким чином забезпечується розвиток самостійності та ініціативності, вміння орієнтуватися в широкому колі питань, пов’язаних 3 різними аспектами професійної діяльності. Метод спрямований не стільки на освоєння конкретних знань, або умінь, скільки на розвиток загального інтелектуального і комунікативного потенціалу студента і викладача.

Реалізація навчання за технологіями, грунтованими на методі кейс-стаді, завдання досить складне, яке вимагає не лише попередньої роботи по відбору навчального матеріалу та розробці самих кейсів, але й можливості їх ефективного використання: часу, що виділяється на вивчення дисципліни, навчально-методичного забезпечення, попередніх знань, навичок самостійної роботи, міждисциплінарних зв’язків.

Кейс-метод тільки розпочинає впроваджуватися в систему фізичної освіти, тому розробка, обгрунтування та апробація теоретичних і методичних аспектів цього методу на сьогодні є актуальною проблемою. Основна функція кейсметода у навчанні фізики в ЗВО - навчити студентів розв'язувати неконструйовані проблемні задачі 3 різними контекстами на основі фундаментальних фізичних знань, які повинні стати опорою при формуванні загальних і спеціальних професійних компетентностей. 
В структурі кейса виділяють два основних розділи: ситуацію та завдання. Найбільш доцільно використовувати такі його розділи: ситуація, завдання, допоміжна інформація, критерії оцінювання [350].

Розділ «Ситуація»є описом реальної (або реально-можливої) проблеми, що вимагає від студента засобами предмета фізики опанувати нове знання й відшукати новий спосіб розв'язання.

Розділ «Завдання» уявляє систему питань і завдань різного рівня, кожне 3 яких повинно дає свій внесок у розуміння і рішення ситуаційної задачі та формування нових уявлень щодо предметних знань і вмінь.

Розділ «Допоміжна інформація» може містити посилання на навчальну та наукову літературу, адреси тематичних веб-ресурсів, таблиці, опорні схеми, методичні рекомендації та інші матеріали. Об'єм допоміжної інформації не повинен бути надмірним, щоб не обмежувати студенту свободу вибору джерела інформації і самостійності пізнавальної діяльності.

Розділ «Критерії оцінювання» знайомить студентів 3 вимогами до якості розв'язання ситуації, допомагає їм об'єктивно оцінювати свої досягнення, мотивує до більш відповідальної роботи над кейсом. Критерії містять наступні параметри:

- володіння понятійним апаратом фізики;

- розуміння змісту фізичних явищ і законів, уміння застосовувати їх на практиці;

- логічність і структурованість розв'язання;

- повнота аналізу та аргументованість висновків;

- самостійність і оригінальність рішення.

При розробці кейса для студентів педагогічного університету слід враховувати, що основним завданням майбутніх вчителів фізики є освітня діяльність. Тому головний акцент при формулюванні проблеми, на постановку якої викладач націлює студентів, повинен бути зроблений на пошук найбільш ефективного, яскравого і наочного пояснення ситуації, зв’язаної с цією 
діяльністю, на зв’язку між матеріалом, що вивчається, зі шкільним курсом фізики.

Джерелами проблемних ситуацій для розробки навчальних кейсів 3 фізики можуть бути описані демонстраційні досліди, в яких результати не відповідають прогнозованим. Наприклад, в дослідах по електризації на результат експерименту можуть істотно впливати такі фактори як стікання заряду при високій вологості, електризація по індукції сусідніх тіл. Ефективним в навчанні за кейс-технологією в подібному випадку може буде виділення групи найбільш активних студентів, яких викладач попередньо знайомить 3 експериментом i проблемами, що виникають при демонстрації. Потім студенти висувають свої пропозиції розв’язання проблем для обговорення в групі.

Для формування навичок наукового дослідження ефективні кейси, які імітують структуру і процес наукового дослідження, застосування тих чи інших методів до розв'язання завдань. Як основу для розробки таких кейсів можна використовувати ситуації, що виникають при проведенні лабораторних занять, при виконанні студентами експериментальної частини курсових і дипломних робіт. При розгляді ситуацій, зв'язаних 3 експериментом, формулювання проблеми може відноситись до вдосконалення техніки або методики проведення експерименту, можливості врахування факторів, що впливають на результати експерименту, заміні досліду іншим.

Ще одним джерелом кейсів можуть служити матеріали, що публікуються в мережі Інтернет і містять фізичні похибки. У такому разі недоліки можуть бути перетворені на переваги завдяки формуванню в студентів критичного відношення до інформації, навичок іiї оцінювання.

Кейс-метод можна представити як складну систему, в яку залежно від ролі кейса в процесі навчання можуть бути інтегровані інші, простіші методи пізнання, такі як моделювання, системний аналіз, проблемний метод, дискусія, уявний експеримент, «мозковий штурм», методи опису, класифікації, інцидентів, проектів, ігрові методи тощо. 
Як показує аналіз літературних джерел, у навчанні фізики в вищій школі, зокрема в педагогічних закладах, кейс-технології застосовуються доволі рідко, переважно при розгляданні окремих тем або питань. Пояснюють це специфікою самої дисципліни, у якій значне місце займають фундаментальні знання про явища природи і матеріальні об'єкти. Кейс-технологія ж призначена для розв'язання проблем прикладного характеру, безпосередньо пов'язаних 3 професійною діяльністю [351]. Але, якщо простежити історію розвитку фізики, практично на кожному етапі нові винаходи, відкриття, теорії з'являлися завдяки проблемним ситуаціям, які потрібно було розв'язати, і які мали не одне, а різні способи й шляхи розв'язання. Щодо прикладного характеру кейс технологій, у роботі викладача або вчителя школи часто виникають проблеми, зв'язані 3 навчанням фізики, які він повинен вміти розв'язувати, такі як необхідність розробки чи вдосконалення методики експерименту, що буде враховувати умови, у яких він виконується, особливості застосованого обладнання; пошук нових прийомів навчання при утрудненнях сприймання інформації студентами тощо.

Опитування студентів показує, що вони дають методам кейс технологій високу оцінку, проте зауважують, що не готові як до навчання за таким методом, так і до його впровадження у своїй професійній роботі. Тобто така технологія, на їх думку, яку висловлюють і більшість дослідників, потребує відповідної підготовки студентів починаючи 3 перших курсів, що вимагає не тільки детальної розробки кейсів і завдань до них, але й структурних змін у організації навчального процесу.

\subsection{4. Інноваційні методи та прийоми асоціативного навчання}

Під час зіткнення 3 проблемною ситуацією (завданням) той, хто навчається, відчуває, що для іï розв'язання йому не вистачає чогось дуже важливого. Саме розв'язання виступає як пошук відсутньої ланки в ланцюжку: завдання - усвідомлення проблеми - поява асоціацій і поява припущень перевірка припущень - виключення непідтверджених припущень - виникнення i перевірка нових припущень - розв'язання задачі. Спонукання робити 
порівняння, зіставляти нові факти, приклади і положення з тим, що було відомо раніше $\epsilon$ ефективним прийомом створення проблемної ситуації. Асоціативні зв'язки у даному випадку використовуються не для запам'ятовування інформації, а як евристичні прийоми (методи) активізації творчості, нестандартного мислення, ненаправленого пошуку. Вони спрямовані на актуалізацію «прихованих» знань для створення нових продуктів (нових знань, ідей, досліджень тощо). Асоціативно-образне мислення є основою творчого процесу.

На застосуванні асоціативних зв'язків базується багато інноваційних методів навчання - методи асоціативних ланцюжків та кущів, сенкан (синвейн), метод фокальних об’єктів, метод ментальних карт, метод кроссенсів, метод аналогій, метод синектики та інші - у яких реалізуються основні принципи інноваційного навчання:

• креативність (орієнтація на творчість);

- засвоєння знань в системі;

• нетрадиційні форми занять;

- використання наочності.

Метод асоціативних ланцюжків. Ланцюжок асоціацій являє собою сукупність понять, де кожне наступне пов'язано не з основним поняттям, а 3 попереднім.

Два навіть зовсім не пов'язані об'єкти або слова можуть бути об'єднані в єдине ціле за допомогою зв'язку таким чином, щоб при виникненні в пам'яті людини одного відразу було відтворено друге, якого бракує. Ланцюжок неконтрольованих, випадкових асоціацій допомагає зазирнути в підсвідомість людини і зрозуміти корінь його проблем. Створюючи незвичайні асоціації можна активізувати творчі здібності, розвинути образну пам'ять, асоціативне мислення за допомогою спеціальних вправ.

Наприклад, під час заняття 3 дисципліни «Інноваційні технології у навчанні фізики» студентам магістратури спеціальності 014 Середня освіта (Фізика) було дано завдання на створення асоціативних ланцюжків, мета якого 
сформувати в студентів здатність встановлювати між двома словами або об'єктами зв'язок, який створює 3 предметів, що не мають між собою нічого спільного, єдине ціле.

Завдання 1. Придумайте два не пов’язаних між собою слова, перше з яких є початком ланцюжка, а друге - кінцем, та побудуйте асоціативний ланцюжок 3 п’яти слів, який пов'яже між собою перше і останнє слово.

Для виконання завдання використовувалась онлайн-дошка Padlet. Варіанти створених студентами ланцюжків приведено на рис. 1.

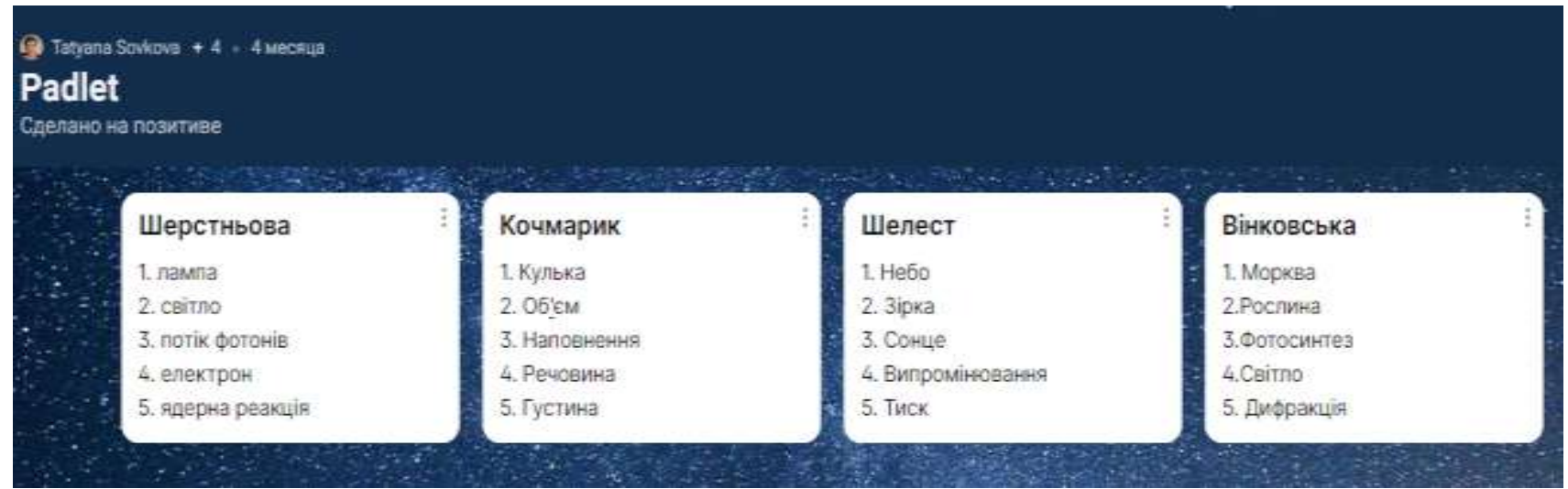

Рисунок 1. Вправа на побудову асоціативного ланцюжка

Наступне завдання може бути на побудову більш складних асоціативних ланцюжків, які пов’язують різні теми, розділи фізики, або ланцюжки, що встановлюють міжпредметні зв’язки. Прикладом таких завдань може бути побудова ланцюжка, який відповідатиме переходу по схемі:

механіка $\rightarrow$ молекулярна фізика та термодинаміка $\rightarrow$ електрика та магнетизм $\rightarrow$ оптика $\rightarrow$ атомна та ядерна фізика

Перше слово може задати викладач, проаналізувавши можливі варіанти створення ланцюжка. Наприклад:

гіперболічна траєкторія (графік руху, графік процесу) $\rightarrow$ ізотерма (температура, вимірювання) $\rightarrow$ термопара (прилад, подвійне) $\rightarrow$ біпризма (інтерференція, спектр) $\rightarrow$ теорія Бора (спектр атому водню)

Метод фокальних (випадкових) об’єктів. Основою методу є асоціативний пошук і евристичні властивості випадковості. Це метод пошуку нових ідей і характеристик об'єкта на основі приєднання до нього властивостей 
інших об'єктів, обраних випадково. Обирається об'єкт, який необхідно вдосконалити. Потім рандомним чином до нього підбирається кілька випадкових іменників (об'єктів). Їх ознаки або властивості переносяться на вихідний об'єкт, який знаходиться «у фокусі» дій. Саме тому метод отримав назву фокальних або випадкових об'єктів.

Найчастіше метод фокальних об'єктів застосовується для пошуку інноваційних та незвичайних рішень. Наприклад, метод часто використовується в теорії розв'язання винахідницьких завдань, 3 метою реконструювання, модифікації пристроїв і технологій.

Наведемо приклад виконання завдання, яке студенти магістратури виконували із застосуванням технології мозкової атаки.

\section{Завдання 2.}

1. Обрати об’єкт, який потрібно перетворити (удосконалити).

2. Обрати три-чотири довільних (випадкових) об’єкта.

3. Скласти списки характерних ознак цих випадкових об'єктів (чим ширше охоплення, тим краще).

4. Спираючись на вільні асоціації сформулювати ідеї, щодо можливості приєднати до фокального об'єкту ознаки випадкових об'єктів.

5. Оцінити отримані ідей і відібрати корисні рішення. (Обговорення і вибір декількох хороших варіантів рішень, що мають свої переваги в різних умовах застосування).

Виконання завдання.

Об’єкт для перетворення - освітлювач (був обраний викладачем, студентам це заздалегідь не повідомлялося).

Випадкові об'єкти та надані їм характерні ознаки (обрано студентами, кожний студент вносив свій об'єкт та пропонував варіанти ознак до усіх об'єктів):

Вікно: скляне, пластикове, дерев’яне, прозоре, відкривається, штори, ізолює, захищає. 
Колесо: кругле, дерев'яне, пластикове, симетричне, крутиться, рухається, котиться, взаємодіє.

Апельсин: помаранчевий, фрукт, їжа, котиться, круглий, солодкий, пориста кожура, складається з дольок.

Озеро: вода, блакитне, глибоке, горне, холодне, гладка поверхня, брижі на поверхні, відбиває та розсіює світло.

Описання кінцевого варіанту об’єкту, прийнятого після сумісного обговорення:

Освітлювач складається 3 декількох окремих дольок, які, в свою чергу, містять джерела (світлодіоди), що випромінюють помаранчеве або блакитне світло. Працює у трьох режимах: 1) включені тільки помаранчеві світлодіоди (теплі), 2) тільки блакитні (холодні), 3) усі джерела. Освітлювач має фільтр, який рівномірно розсіює світло, й шторки, що можуть обмежувати світловий потік. Розташований на дерев'яній основі з чотирма колесами, що дозволяє легко перекочувати освітлювач з одного місця на інше.

Метод «Кроссенс». Слово «кроссенс» означає перехрестя смислів перетин значень. Це асоціативна головоломка, яка уявляє з себе ланцюжок, замкнутий у стандартне поле, що складається як правило з дев'яти квадратів. У кожному квадраті розташовується зображення (картинка, формула, знак), яке має зв'язок із попереднім і наступним, а центральне картинка може об'єднувати всі зображення або деякі з них. Знайти таки зв'язки (асоціативні та логічні) і є завданням до кроссенсу. Кроссенс потрібно читати зліва направо і зверху вниз.

Перед виконанням завдання слід спочатку розібирати, що зображено на кожній картинці. При переході від одного зображення до іншого бажано використовувати не тільки асоціації (аналогії), що безпосередньо стосуються теми кроссенса. Можна спиратися й на асоціації, які пов'язані з життєвим досвідом, на вільні асоціації, що виникають при розгляданні картинок. Оскільки у завданнях такого типу велика роль суб'єктивного сприйняття образів і зображень, то студенти (учні) можуть знаходити різні варіанти зв'язків. Важливо, щоб при цьому вони обгрунтовували свою версію. Усі запропоновані 
зв’язки потрібно проаналізувати 3 точки зору їх вагомості, характеру (поверхневі, глибокі, за формою, за суттю тощо), зв’ язку з іншими дисциплінами. Потрібно оговорити важливість знайдених аналогій 3 урахуванням теми кроссенсу, знайти зв’язок з іншими темами, дисциплінами, фізичними явищами, зокрема природними.

Проблема, з якою часто зустрічаються автори кроссенсів, - це трактування зображень, які можуть бути не зовсім зрозумілі або досить загадкові. У такому випадку при використанні кроссенсу або його частин (пари картинок) можна давати короткі текстові підказки, підказки у вигляді інших картинок.

Робота 3 кроссенсами сприяє розвитку логічного, образного i асоціативного мислення, розвитку уяви, прояву нестандартного мислення, креативності й самовираження.

До розробки кроссенсів доцільно залучати студентів. Для цього можна використати їх досвід зі складання асоціативних ланцюжків, замінюючи слова картинками. Наприклад, обрати дві картинки, вихідну (першу) й узагальнюючу (дев'яту), та розмістити між ними ще сім картинок за правилами кроссенсу (асоціативних чи логічних зв’язків).

Приклад кроссенсу до теми «Сили в природі», розробленого студентами магістратури, приведено на рис. 2.
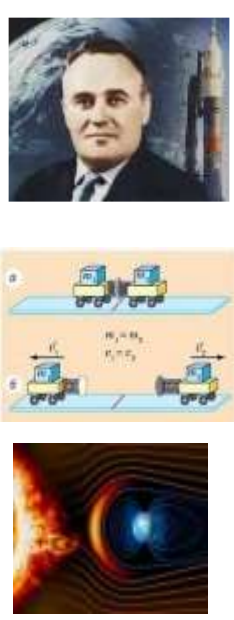
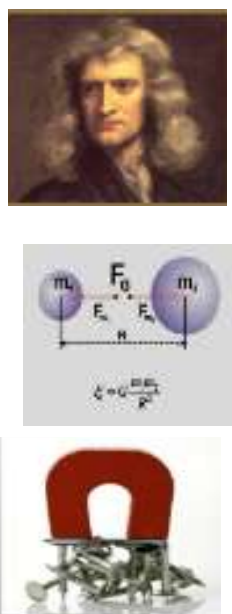
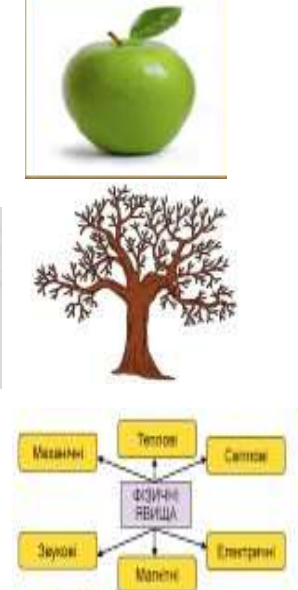
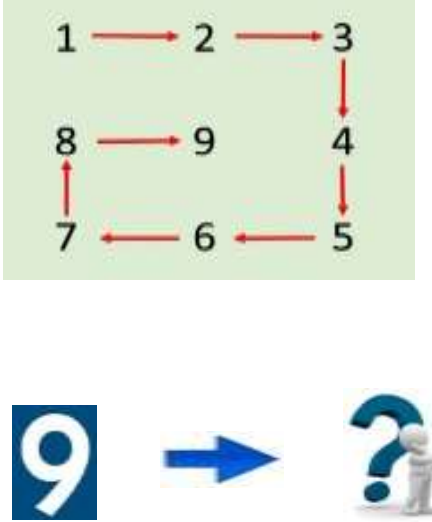

Рисунок 2. Кроссенс до теми «Сили у природі»

Цей кроссенс вони рекомендували використовувати в 9-му класі середньої школи після вивчення розділу «Рух і взаємодія. Закони збереження». 
Для підготовки студентів до розв'язання кроссенсів у процесі вивчення окремих тем та питань також можуть бути використані завдання на знаходження аналогій між двома картинками (рис. 3).

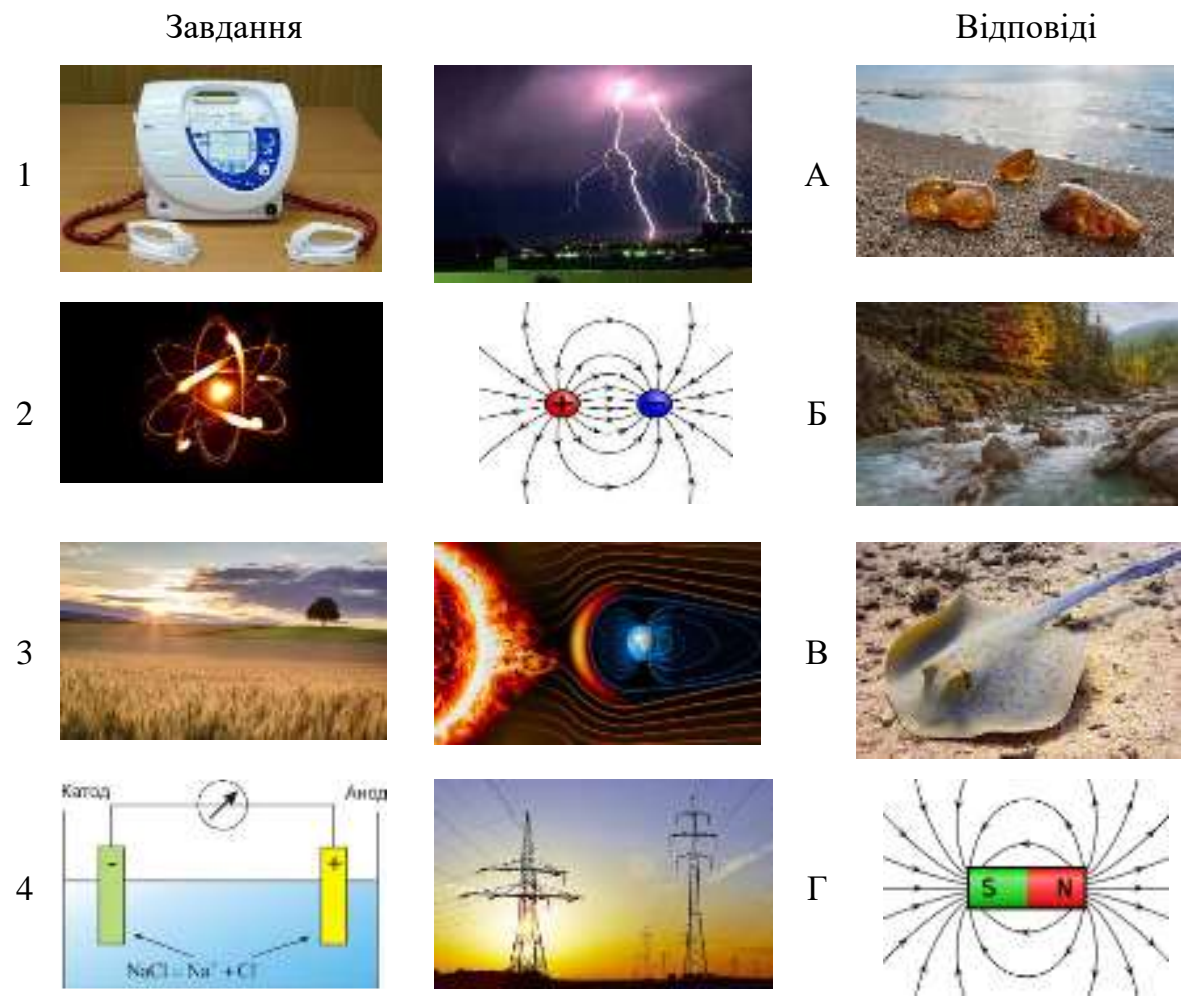

Рисунок 3. Завдання на встановлення відповідності

Тут у варіантах відповідей (А, Б, В, Г) потрібно знайти картинку, яка поєднує кожну пару $(1,2,3,4)$, представлену в завданнях. Слід зауважити, що відповіді повинні бути до кожної пари картинок. При цьому можливі різні варіанти поєднань. Студенти їх обговорюють і визначають найкращі варіанти.

Набір таких картинок може використовуватися як тестове завдання або для сумісного розв'язання на занятті.

Метод аналогій. Аналогія $є$ важливим засобом пізнання світу i загальновизнаним методом наукового дослідження. Однією з основних функцій методу аналогій є евристична, яка тісно пов'язана 3 асоціаціями (асоціативні аналогіï). Методи евристичного навчання - це методи, спрямовані на актуалізацію «прихованих» знань для створення нових продуктів (нових знань, ідей, досліджень тощо). На основі знаходжень аналогій з технічними об'єктами в іншій області, з біологічними об’єктами, з об’єктами і явищами неживої 
природи за допомогою групи евристичних прийомів здійснюється пошук нових ідей і рішень.

Застосування методу аналогій у навчанні - прийом, який використовується 3 давніх часів, починаючи з академії Платона і Ликея Аристотеля, де філософи представляли i обгрунтовували вчення, які переважно будувалися на міркуваннях і умовиводах, зроблених на основі аналогій. Проте, сьогодні метод аналогій ми можемо віднести до інноваційних методів навчання фізики, якій вимагає розробки нових підходів і нових методик [352]. Це пов’язано насамперед 3 новими можливостями, які відкриваються завдяки появі й розвитку мультимедійних засобів навчання, швидкого змінювання комп'ютерних технологій, які відігрівають все більшу роль у навчальному процесі.

Висновок за аналогією може бути як істинним, так і помилковим, тому необхідно обережно відноситися до застосування методу аналогій. Як і будь-яке припущення, умовивід, що базується на проведенні аналогій, вимагає ретельної експериментальної перевірки.

Водночас нестандартні випадкові аналогії можуть привести до креативних рішень, неочікуваних винаходів, оригінальних результатів.

Такий підхід покладено в основу синектики - одного 3 найбільш неординарних методів розвитку творчих здібностей i вирішення складних завдань [353]. Синектика - це процес пошуку і створення нових асоціативних зв’ язків.

Синектика у навчанні по суті $є$ мозковою атакою, мета якої полягає в рішенні задач шляхом підбору відповідних аналогій різного типу:

1. Пряма аналогія - даний об’єкт порівнюється 3 більш-менш схожим аналогічним об'єктом в природі або техніці.

2. Символічна аналогія - виявлення парадоксів i протиріч у звичних i зрозумілих фактах.

3. Особиста аналогія (емпатія) - дозволяє представити себе тим предметом або частиною предмета, про який йде мова в задачі. 
4. Фантастична аналогія - основний акцент робиться на символічний опис бажаного майбутнього або нереальних ситуацій.

Ця технологія була застосована на занятті 3 дисципліни «Інноваційні технології у навчанні фізики» на прикладі добору аналогій до поняття «електричний струм». Студентами було запропоновано наступні аналогії:

Прямі аналогї - течія води в річці, по трубах; водоспад, рух краплинок дощу з встановленою швидкістю; вітер; конвекція. Обговорювалися можливості застосування аналогії: аналіз поняття «стороння сила», ЕРС, порівняння причин, що обумовлюють рух (різниця потенціалів - різниця потенціальної енергії на різних висотах води, що «падає», різниця тисків, різниця температур); порівняння руху електронів по колу, що складається з провідників різного опору, зокрема різного поперечного перерізу, з рухом води по трубах різного діаметру; аналогії з рівнянням Бернуллі.

Символічні аналогї - словосполучення дискретна неперервність, суха річка, твердий вітер, електричний вітер, твердий дощ.

Особисті аналогї - я маленький електрон, що рухається між величезними іонами (металевими позитивно зарядженими кулями), які постійно коливаються, й постійно зіткається з ними. Але якась стороння сила змушує рухатися далі. При доборі аналогії застосовується метод «диспуту», на якому обговорюються, зокрема, способи зменшення опору, добір матеріалу провідників для використання в конкретних пристроях, з різною метою тощо.

Фантастичні аналогї - зводяться до вигадування різних варіантів проходження між чисельними перепонами на шляху до заповідної мети, наприклад, к спробам корабля (кораблів) пройти між Сциллою і Харибдою, що імітують іони у вузлах кристалічної решітки, які притягують електрони й забезпечують опір руху. Пропоновані варіанти розрізняються метою (причинами) руху (еквівалентом електрорушійної сили) та способами подолати перепони. Саме це стало переважно предметом обговорення за «круглим столом» після «мозкової атаки» з висунення ідей. 


\subsection{5. Технології ментальних та концептуальних карт}

До сучасних методів візуалізації інформації, що мають комп’ютерну реалізацію, відносяться конщептуальні карти (concept-maps) і ментальні карти (mind maps), створенню та застосуванню у навчальному процесі яких в наш час приділяється все більша увага. Ментальні карти також називають інтелекткартами, картами розуму, асоціативними картами.

Ментальна карта є графічним інструментом для організації та подання знань. Карти допомагають показати, як людина бачить взаємини між речами, ідеями, людьми. Концепт-карти є графи, причому вузлам графа (тобто, точкам) відповідають поняття, а ребрам графа - зв’язки між поняттями.

Карти розуму є багатоколірними, радіальними рисунками, які представляють в ієрархічному вигляді семантичні та інші співвідношення між елементами досліджуваного матеріалу.

На складанні і використанні ментальних карт базується освітня технологія, яка одержала назву технології майндмеппінгу (Mind Mapping).

Метод ментальних карт - одна з ефективних технік запам'ятовування, у основі якої лежить принцип «радіантного мислення», що базується на асоціативних розумових процесах. Основою радіантного мислення виступає певний об’єкт (основна концепція, ідея, тема, проблема), на основі якого виникають асоціації і будуються асоціативні ланцюжки: під-концепції першого, другого порядку й так далі.

Ментальна карта $є$ графічним відображенням процесу радіантного мислення на паперовому або електронному носії. У неї відображаються зв'язки між елементами або поняттями головної ідеї або предметної області, над якою ми працюємо або яку вивчаємо. Ці зв'язки можуть бути асоціативними, причинно-наслідковими, смисловими або іншими.

Інтелект-карти структуровані за аналогією пам’яті. При складанні таких карт виникає багатовимірне асоціативне мислення, що дозволяє бачити не тільки об'єкт навколишнього світу сам по собі, а у взаємоз'язку його 3 іншими об’ сктами [354]. 
Ментальні карти використовуються для візуалізації, структуризації i класифікації ідей, а також як засіб для навчання, організації, розв'язання задач, прийняття рішень, при написанні статей.

В освітньому процесі ментальні карти можуть бути застосовані як у професійній діяльності викладача (вчителя), так i в індивідуальній та колективній роботі студентів (учнів):

- при конспектуванні лекцій, книг, підручників;

- при підготовці викладача/студента до лекції, практичного заняття;

- для фіксування та структурування даних, систематизації наукової інформації;

- при підготовці презентацій, доповідей та виступів;

- при проведенні тренінгів, конференцій;

- при проведенні мозкового штурму;

- при плануванні та розробці проектів;

- при підготовці до екзамену, заліків, захисту кваліфікаційних робіт тощо;

- для перевірки знань студентів (учнів).

Характерними рисами ментальної карти є наступні:

- об'єкт вивчення/уваги зосереджений в центральному образі (стовбурі дерева);

- основні поняття, що зв'язані з центральним об'єктом, розходяться від нього у вигляді ліній (гілок);

- лінії позначаються ключовими словами або образами;

- другорядні ідеї теж зображені у вигляді ліній, які відходять від ліній більш високого порядку;

- лінії формують зв’язну вузлову систему.

Карта може необмежено рости i доповнюватися новими гілками, наприклад по мірі засвоєння навчального матеріалу.

Побудову карти знань 3 теми можливо здійснювати як виконання групового завдання, коли кожна група створює свою гілку відповідно до певного поняття або об’єкта, після чого вони об’єднуються в загальну карту знань. Такий 
вид роботи зручно використовувати при вивченні тем з великою кількістю понять і багатьма варіантами виконання робіт. Побудова карти знань може розглядатися і як індивідуальна підсумкова робота студента з заданої теми.

Одним 3 типових варіантів застосування інтелект-карт в навчальному процесі, який може бути раціонально використаний при самостійній роботі студентів, $\epsilon$ конспектування навчальних матеріалів 3 метою подальшого ефективного їх відтворення. Застосовуючи цей метод на всіх етапах майндмеппінга (формування масиву елементів майбутньої карти, графічне їх оформлення, встановлення логічних і асоціативних зв'язків між ними), студент при наявності належних навичок отримує індивідуалізований, більш зручний конспект.

При сучасному, компетентнісно-орієнтованому підході до навчання у ЗВО важливу роль відіграє діяльнісна компонента. Незважаючи на наявність відповідних нормативних вимог і рекомендацій в цьому питанні, насичення освітнього процесу практико-орієнтованими засобами та методиками навчання поки недостатня. Тому будь-які підходи, націлені на розвиток і придбання студентом практичних навичок по його майбутньої спеціальності, є цінними.

У випадку педагогічного ЗВО засвоєння технології побудови ментальних карт є необхідною складовою фахових компетентностей майбутніх вчителів та викладачів фізики. Тут реалізується й вимога набуття здатності працювати у команді, зокрема, віддаленого спільного складання інтелект-карт за допомогою веб-сервісів, й оволодіння електронними методами побудови ментальних карт. В результаті ментальні карти входять до складу електронних освітніх ресурсів; карти, створені студентами включаються в їх електронні портфоліо.

Сьогодні існує багато онлайн-сервісів для створення ментальних карт та спеціалізованих програмних додатків під різні платформи, що дозволяють економить час і ресурси. Всі вони характеризуються індивідуальними специфічними можливостями і дозволяють автоматизувати операції створення ментальних карт та представлення їх в електронному вигляді. На таких картах може бути забезпечена можливість додавання відео матеріалу, наприклад, за 
допомогою сайту YouTube. Зручною функцією є додавання активних посилань, при переході через яке користувач зможе отримати всю необхідну інформацію.

Coggle.it - безкоштовний сервіс, що дозволяє створювати красиві онлайнкарти.

Тут можна створювати будь-яку кількість гілок, викривляти їх, змінювати кольори, і переміщати елементи. Перетягування елементів здійснюється за заголовки, а не за тим, як це інтуїтивно хочеться зробити. На безкоштовному акаунті кількість карт необмежена. При створенні ментальної карти на цьому сайті можна використовувати надписи, формули, рисунки, посилання на віртуальні досліди. Можна поділитися картами в соцмережах, а також працювати над ними спільно зі студентами. Можна вбудувати карту в сайт або блог, а також зберегти іiі у вигляді PNG або PDF-файлу. $€$ функція збереження історії всіх змін, що дозволяє в будь-який момент повернутися до попередніх версій карти. Для використання Google потрібен обліковий запис в Gmail.

Mind42.com - характеризується простою у застосуванні, але має скупу функціональність на безкоштовному акаунті. Не можна вільно переміщувати елементи і редагувати стилі. Неможливо додавати картинки з файлів, додаються тільки посилання. Немає колірних схем і шаблонів. Потрібна реєстрація перед доступом до ресурсу.

Mindomo.com - доступні кілька шаблонів для складання карт. Можна вибирати колірні схеми-шаблони в один клік, прикріплювати до елементів картинки, іконки, завдання, коментарі. Дозволяє створювати карти, що містять фотографії, малюнки, звук, відео; можна додавати посилання. На безкоштовному акаунті діють обмеження.

Bubbl.us - дуже простий онлайн-інструмент. Дозволяє додавати посилання на відео та віртуальні лабораторії, легко ділитися своїми інтелекткартами з іншими людьми в режимі реального часу. Можна працювати без реєстрації, скачати створене як зображення.

XMind - крос-платформена програма, що дозволяє створювати діаграми, схеми, складні структури, щоб систематизувати і наочно уявити потік ідей i 
планів. Одна 3 найпопулярніших програма для складання ментальних карт. $\mathcal{C}$ безкоштовна версія 3 урізаними можливостями i платна 3 розширеним функціоналом.

Mindmeister.com - дозволяє прикріплювати іконки до елементів карти, виділяти окремі гілки своїм особливим кольором. На безкоштовному акаунті можна створити три карти. Сервіс Mindmeister доцільно використовувати для розробки карт, які створюються в процесі навчання теми У ньому можливо приховувати необхідні гілки, змінювати масштаб великої ментальної карти. Так само в ньому є можливість експорту карти в різні формати. При цьому можна зберігати не тільки всю ментальну карту цілком, але й окремі ії фрагменти, 3 якими студенти вже познайомилися і засвоїли. При включенні до карти посилань на комп'ютерні симуляції можна переходити по них і виконувати віртуальні роботи, розв’язувати задачі. Приклад такої карти, розробленої студентами магістратури до практичного заняття 3 теми «Побудова зображень в тонких лінзах» за допомогою ресурсу Mindmeister.com приведено на рис. 4.

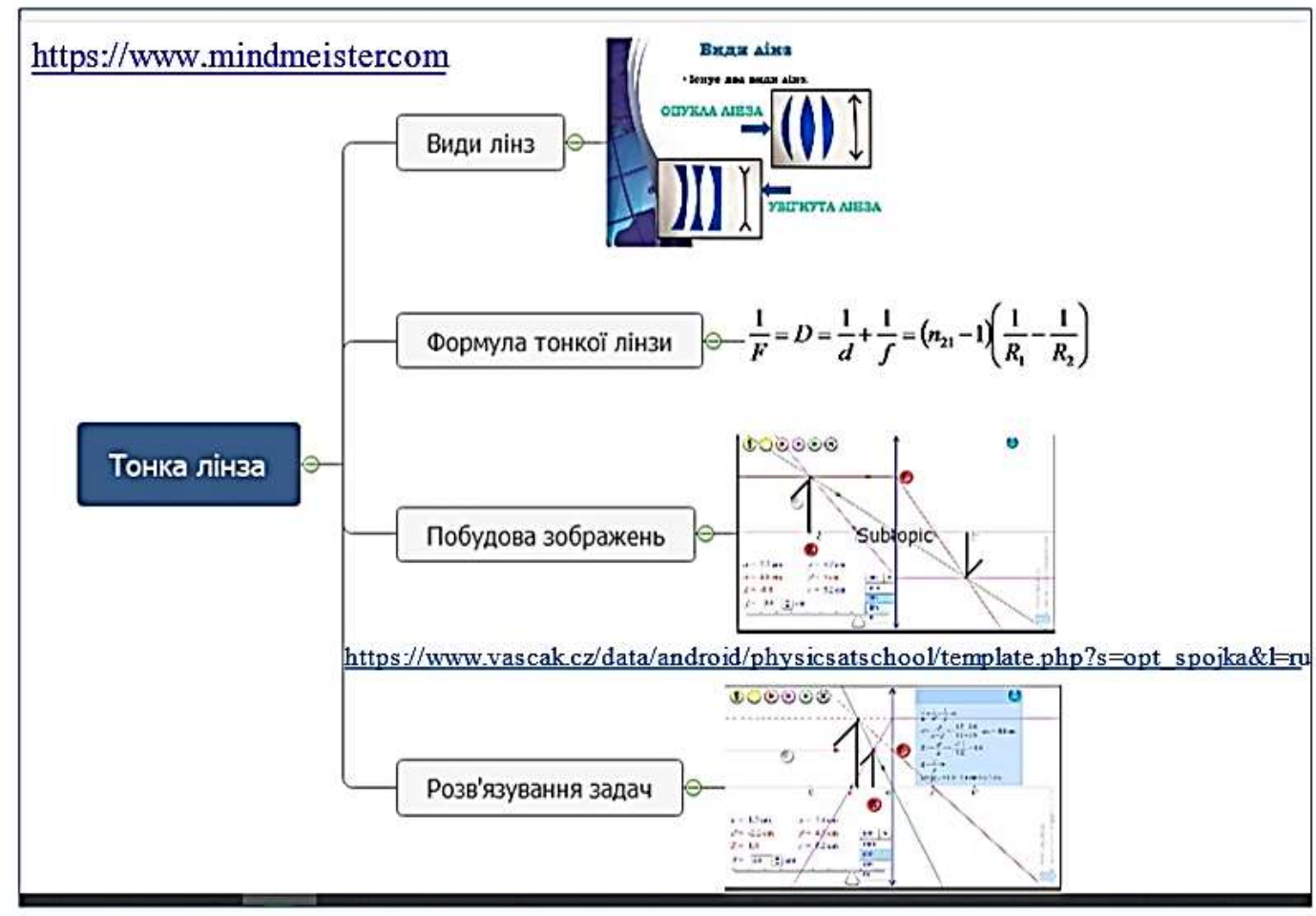

Рисунок 4. Ментальна карта до підтеми «Тонка лінза» 
Така карта також може бути використана при вивченні теми «Лінзи. Оптична сила й фокусна відстань лінзи. Формула тонкої лінзи. Отримання зображень за допомогою лінзи» у 9-му класі середньої школи.

\section{Методика застосування ментальних карт у навчальному процесі}

Можна виділити кілька моделей створення і використання ментальних карт в навчальному процесі залежно від мети.

1. Будується велика ментальна карта, яка захоплює весь досліджуваний розділ. До цієї карти входять всі теми, які необхідно вивчити студентам. Кожна гілка ментальної карти відповідає певній темі. Таку карту доцільно будувати або демонструвати за допомогою інтерактивної дошки.

2. Розробляються карті для кожного заняття з кожної теми розділу. На протязі вивчення теми ментальна карта поступово розкривається від центрального поняття, до гілок. Найефективніше в даному випадку, використовувати на заняттях вже готові ментальні карти, розроблені викладачем.

3. Використовуються готові ментальні карти, у які входить не теоретичний матеріал, а питання, на які повинні відповісти студенти по ходу знайомства 3 новою темою. В центрі карти при цьому розташовується головне питання, далі ментальна карта розбивається на головні гілки, в яких теж присутні питання по темі. Потім головні гілки розбиваються підгілки і так далі. У процесі навчання студенти поступово відшукують відповіді на ці питання.

4. Студенти розбиваються на міні-групи, в яких протягом усього заняття, будують свою власну ментальну карту і надають результат в кінці кожного заняття.

5. Протягом заняття, знайомлячись 3 новим матеріалом, студенти розробляють ментальну карту, працюючі в міні-групах над своєю гілкою і після закінчення формування всіх гілок, їх об’єднують в одну ментальну карту. Отриману ментальну карту обговорюють, коригують. Якщо заняття проводиться в аудиторії, процес об’єднання гілок має відбуватися на інтерактивній дошці.

Порядок дій і рекомендації до самостійного створення ментальної карти.

1. Визначте тему, призначення, мету й завдання, які хочете вирішити за допомогою карти. 
2. Запишіть першорядну думку, ідею або проблему, яка відіграватиме роль центрального образу (стовбура), наприклад, це може бути тема карти.

3. Залежно від мети визначте ключові слова (напрямки, підтеми, категорії, діï), які безпосередньо пов'язані з темою карти. Вони відповідатимуть першому рівню «гілок дерева». Виконання цього завдання студентами передбачає попередній збір та обробку та систематизація матеріалу (вивчення інформації і 110 аналіз) і класифікацію ключових слів на основні і похідні поняття для кожного рівня.

4. Візьміть окремий напрямок і почніть опрацьовувати його, розкриваючи зміст і доповнюючи другорядними (похідними) напрямками (гілками) наступного рівня.

5. Проробить таким чином усі вибрані напрямки.

6. Оберіть спосіб створення ментальної карти (малюнок олівцями, використання певного онлайн-сервісу) та спосіб, яким будете представляти обраний напрямок (елемент) у ментальній карті (слово, формула, малюнок, фотографія, умовне позначення, відеоролік). Тобто цей пункт може передбачати підбір малюнків і фотографій, формул до відібраного матеріалу.

7. Поєднайте все в одній ментальній карті, використовуючи при необхідності лінії (стрілки), які з'єднують окремі елементи карти (горизонтальні зв'язки в концептуальній карті).

Ментальна карта не є строгою, її наповнення, кількість гілок та рівнів можуть визначатися автором, але існує ряд базових правил, дотримання яких, дозволяє одержати найбільший ефект від застосування методу:

- центральний образ повинен виділятися на тлі інших елементів інтелекткарти;

- не слід використовувати довгих речень, це засмічує карту й відволікає від суті; формулювати думку краще в одному - трьох словах.

- у карті потрібно використовувати не тільки слова, а й графічні образи, малюнки, завдяки чому задіються декілька кортикальних здібностей нашого 
мозку одночасно (мовна i візуальна), що сприяє більш кращому запам’ ятовуванню;

- при створенні карти слід дотримуватись ієрархії думок, зв’язків, важливі і другорядні думки не повинні перемішуватися на одному рівні, це ускладнює роботу і може заплутати як творця, так і глядача.

Приклад розробки з певної теми загальної фізики та створення на її основі ментальної карти приведено у табл.1 та на рис. 5.

Карта розроблена та створена на практичному занятті спільними зусиллями викладача і студентів магістратури. Для побудови карти використано сервіс https://coggle.it.

Спільна робота з викладачем підсилює інтерес студентів до теми, підвищує мотивацію, що дозволяє їм краще засвоїти і запам’ятати навчальний матеріал, що викладається. Викладач допомагає їм сконцентрувати увагу на найважливішому, тим самим підвищується ефективність навчання.

Ця карта може використовуватися при вивченні розділу «Молекулярна фізика та термодинаміка» викладачем при представленні теми «Дифузія» та надання студентам інформації про те, що саме потрібно опанувати 3 представленої теми.

Карта, яка виконана студентами самостійно, дає можливість виділити неясні елементи, які необхідно освоїти або уточнити.

Концептуальні карти незважаючи на схожість 3 інтелект-картами відрізняються від них за багатьма аспектами. Концептуальні карти характеризують ясні відносини між описаними ідеями, вони більш структуровані, ніж інтелект-карти. Концептуальна картографія дозволяє бачити більш складні відносини між ідеями: тут їх концепти представлені не тільки ієрархічними зв'язками, але і частиною системи, пов'язаної 3 іншими концепціями, через зв’язки вхідні та вихідні. На відміну від ментальних карт, концептуальні карти зосереджені не тільки на одному слові або ідеї, а можуть з’єднувати кілька слів або ідей. Для них характерна наявність так званих «горизонтальних» або «перехресних» зв’ язків. 
Таблиця 1. До побудови ментальної карти

\begin{tabular}{|c|c|c|}
\hline \multicolumn{3}{|c|}{ Тема (ядро, стовбур) ментальної карти - Дифузія } \\
\hline 1-й рівень: & 2-й рівень & Додаткове позначення \\
\hline \multirow{5}{*}{ види дифузії } & стаціонарна & \multirow{5}{*}{-} \\
\hline & нестаціонарна & \\
\hline & самодифузія & \\
\hline & взаємна дифузія & \\
\hline & термодифузія & \\
\hline \multirow{6}{*}{$\begin{array}{c}\text { основні } \\
\text { характеристики }\end{array}$} & градієнт концентрацій & $d n / d x$ \\
\hline & градієнт густини & $d \rho / d x$ \\
\hline & \multirow{2}{*}{ дифузійний потік } & $I=d N /(d S \cdot d t)$ \\
\hline & & $M=d m /(d S \cdot d t)$ \\
\hline & коефіціснт дифузії & $D$ \\
\hline & $\begin{array}{l}\text { коефіцієнт дифузії ідеального газу, } \\
\text { самодифузія }\end{array}$ & $D=\bar{v} \bar{\lambda} / 3$ \\
\hline \multirow[b]{2}{*}{ рівняння дифузії } & дифузійний потік & $M=-D \frac{d \rho}{d x}, \quad I=-D \frac{d n}{d x}$ \\
\hline & $\begin{array}{c}\text { маса (кількість молекул), що } \\
\text { переноситься }\end{array}$ & $\begin{array}{l}m=-D \frac{d \rho}{d x} \cdot d S \cdot d t \\
N=-D \frac{d n}{d x} \cdot d S \cdot d t\end{array}$ \\
\hline \multirow{5}{*}{ дифузія у природі } & харчування рослин & \multirow{5}{*}{ Відеоролік } \\
\hline & $\begin{array}{c}\text { проникнення кисню з крові в тканини } \\
\text { людини }\end{array}$ & \\
\hline & дихання тварин & \\
\hline & $\begin{array}{c}\text { відносна однорідність земної } \\
\text { атмосфери }\end{array}$ & \\
\hline & відчуття запахів & \\
\hline \multirow{5}{*}{$\begin{array}{l}\text { застосування } \\
\text { дифузії }\end{array}$} & фарбування тканин & \multirow{5}{*}{ Відеоролік, картинки } \\
\hline & виготовлення сплавів & \\
\hline & зварювання металів & \\
\hline & $\begin{array}{c}\text { дифузне насичення вуглецем залізних і } \\
\text { сталевих поверхонь для підвищення } \\
\text { твердості }\end{array}$ & \\
\hline & дифузія в медицині & \\
\hline \multirow{5}{*}{$\begin{array}{l}\text { методи визначення } \\
\text { коефіцієнта дифузії }\end{array}$} & $\begin{array}{c}\text { застосування випаровування } \\
\text { (лабораторна робота) }\end{array}$ & $\begin{array}{c}\text { Посилання на інструкцію до } \\
\text { роботи }\end{array}$ \\
\hline & використання радіоактивних ізотопів & \multirow{4}{*}{-} \\
\hline & $\begin{array}{c}\text { локальний рентгеноспектральний } \\
\text { аналіз }\end{array}$ & \\
\hline & метод електрон-діркових переходів & \\
\hline & $\begin{array}{c}\text { побудовані на вимірюванні зміни } \\
\text { структури }\end{array}$ & \\
\hline $\begin{array}{l}\text { зв’ язок зі шкільним } \\
\text { курсом фізики }\end{array}$ & $\begin{array}{c}\text { Фізика: підруч. для } 7 \text { кл. загальноосвіт. } \\
\text { навч. закл. / [В. Г. Бар'яхтарта ін.] § } 2 . \\
\text { Будова речовини. Молекули. Атоми }\end{array}$ & $\begin{array}{l}\text { https://www.ranok.com.ua/resour } \\
\text { ces/files/pdf/Phisica_7_Uch.pdf }\end{array}$ \\
\hline $\begin{array}{l}\text { міжпредметні } \\
\text { зв’язки }\end{array}$ & $\begin{array}{l}\text { Калініченко Ю.Ю. Розвиток поняття } \\
\text { дифузії в шкільному курсі хімії та } \\
\text { біології. }\end{array}$ & $\begin{array}{l}\text { http://www.rusnauka.com/12_E } \\
\text { NXXI_2011/Chimia/2_85494.do } \\
\text { c.htm }\end{array}$ \\
\hline
\end{tabular}




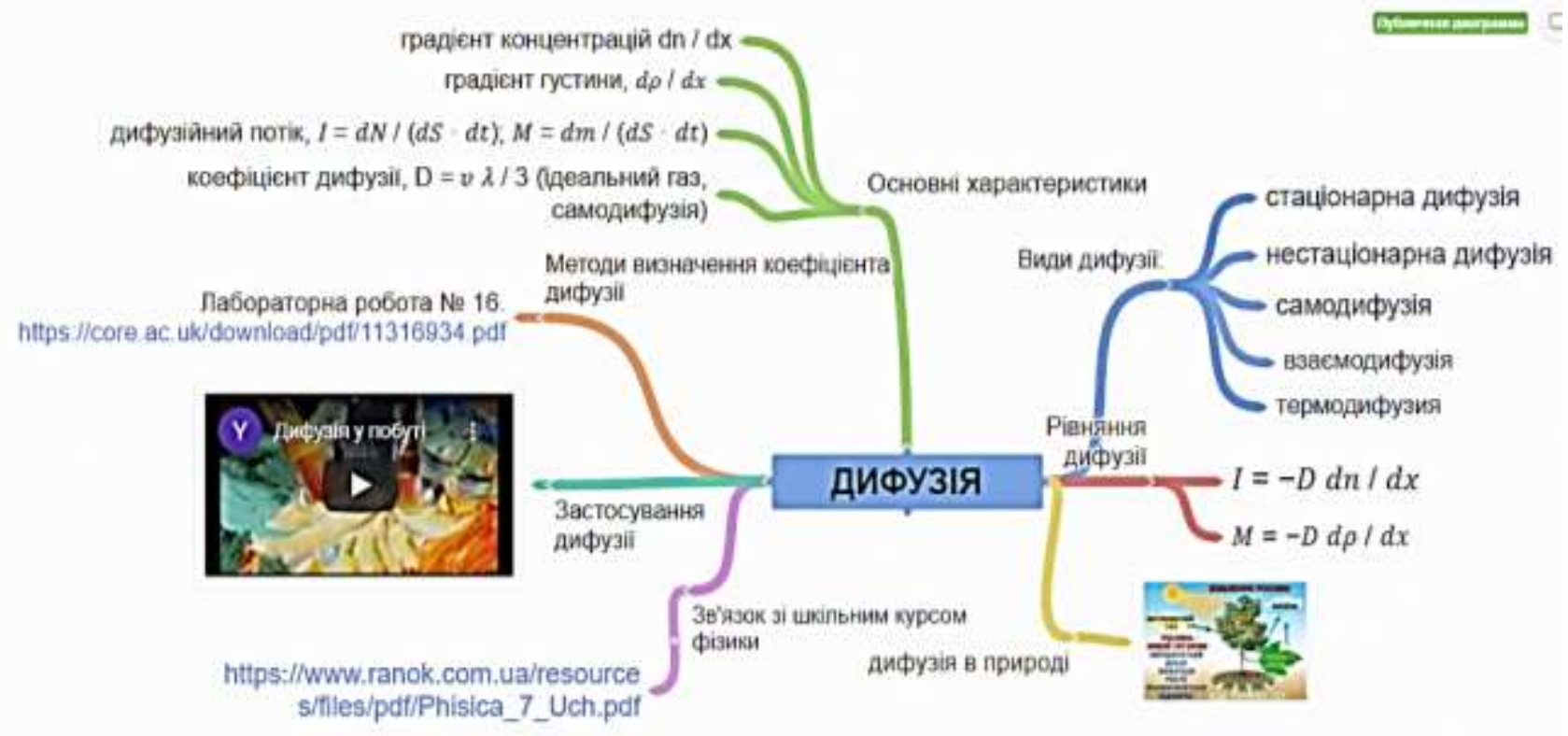

Рисунок 5. Ментальна карта теми «Дифузія»

Зазвичай концептуальні карти організовані ієрархічно. Це означає, що найбільш загальні і всеосяжні концепції розміщені у верхній частині карти. Ti, які більш специфічні, розташовані під ними. Відповідно, ієрархічні концептуальні карти читаються зверху вниз. Однак, структура концептуальної карти не обмежується цією структурою, вона може приймати й вільну форму починаючи з центру і поширюючись назовні.

\subsection{6. Віртуальний експеримент та його роль і місце в навчанні фізики}

Експеримент є однією з важливих складових наукових досліджень. На науковому експерименті базується навчальний фізичний експеримент, який $є$ основою вивчення фізики у закладах освіти різного рівня.

Поняття «експеримент» зазвичай визначають як проведення на реальному обладнанні у визначених умовах серії дослідів для спостереження за станом об'єкта дослідження, які дозволяють стежити за його змінами і відтворювати їх кожний раз під час повторення дослідів. Такий експеримент називають реальним або натурним.

Водночас часто процес пізнання передбачає абстрагування, ідеалізацію природних явищ, побудову ідеалізованих моделей, які не враховують усі властивості, ознаки, зв'язки між об'єктами. Прикладами такої ідеалізації об'єктів $\epsilon$ моделі матеріальної точки, ідеального газу, абсолютно твердого тіла, 
абсолютно чорного тіла. На таких ідеальних моделях грунтується багато фізичних теорій: молекулярно-кінетична теорія ідеального газу, теорія ідеальної рідини, випромінювання абсолютно чорного тіла тощо, при побудові яких зазвичай використовується так званий мислений експеримент, якій також називають уявним.

Уявний (мислений) експеримент як вид діяльності людини належить до теоретичного, але має риси реального (натурного), бо в ньому виникає перебіг певного фізичного явища. Термін «мислений експеримент» уособлює, таким чином, поєднання ідеального та реального.

У ході уявного експерименту можливо будування моделей об'єктів або явищ, що з різною глибиною відображають їх сутність, вивчення окремих сторін явищ, з'ясування їх фізичного змісту, дослідження на моделях залежності між параметрами об'єкту, характеристиками процесу, забезпечувати візуалізацію процесів у віртуальному середовищі. Такий експеримент одержав назву віртуального. Хоча єдиного підходу до визначення поняття «віртуальний експеримент» не існує. Часто віртуальним називають будь-який мислений експеримент (дифракція електронів на двох щілинах), іноді - експеримент, здійснений за допомогою спрощеної моделі реального приладу, або у якому застосовано умовну (механічну) модель процесу (механічна модель розподілу молекул за швидкостями). Але останнім часом переважає поняття віртуального експерименту як візуалізованого за допомогою комп'ютерних технологій.

Комп'ютерне моделювання у системі навчального експерименту може бути запроваджене в трьох напрямах:

1) як самостійна форма експерименту;

2) як доповнення до реального експерименту, коли частина дослідження проводиться віртуально (наприклад, обробка результатів, графічна інтерпретація), або, у випадку, коли деякі роботи проводяться віртуально, а деякі - реально;

3) як невід’ємна частина експериментального дослідження, інтегрована із реальним (комплекти обладнання у поєднанні з ІКТ). 
Перший підхід $\epsilon$ доцільним у тому випадку, коли проведення експерименту обмежено можливостями існуючого лабораторного обладнання. Другий підхід дозволяє значно розширити тематику експериментальних досліджень, але для отримання результатів експерименту та їх аналізу найбільш достовірні дані будуть отримані за умови комплексного проведення дослідження.

Інтеграція віртуального та реального фізичного експерименту, їх обгрунтований взаємозв'язок, дасть можливість студенту вивчати навколишній світ, його закони та закономірності розвитку на більш високому рівні, одночасно стимулюючи самостійну пізнавальну діяльність, творчість, саморозвиток та самоосвіту. Для успішної реалізації названих аспектів необхідне подальше вдосконалення і розвиток методичних аспектів упровадження засобів IКТ та створення на їх основі сучасних навчально-методичних комплексів.

Сьогодні віртуальний експеримент стає невід’ємною складовою практично будь-якої навчально-дослідної діяльності здобувачів освіти, що віддзеркалює тенденції поступового переходу до дистанційних форм навчання. Базою для впровадження таких методів навчання можуть слугувати віртуальні лабораторії, мультимедійні та інтерактивні програми, навчальні ігри та багато іншого.

Використовуючи навчальні комп'ютерні моделі можна подати досліджуваний матеріал більш наочно, продемонструвати його нові й несподівані сторони невідомим раніше способом, що, в свою чергу, підвищує інтерес студентів до досліджуваного предмета і сприяє поглибленню розуміння навчального матеріалу.

Навчальний фізичний експеримент може бути використаний на різних етапах навчання та 3 різною дидактичною метою. Система навчального експерименту охоплює такі його види: демонстраційні досліди, роботи фізичного практикуму; експериментальні задачі, позааудиторні досліди [355].

Сучасні електронні засоби дозволяють гармонійно поєднати дидактичні принципи 3 науковістю матеріалу, зрозуміло описувати експеримент i відтворювати досліджуване фізичне явище у довільному масштабі часу, 
проводити імітаційне моделювання явищ, недоступних для класичних методів спостереження, таких, як процеси мікросвіту та космосу, візуалізувати уявний експеримент тощо.

За допомогою таких віртуальних моделей (симуляцій) можна не тільки спостерігати, а й «управляти» процесом. Так, наприклад, симуляція «Боровська модель атому» допомагає проілюструвати перехід атомів між стаціонарними орбітами при поглинанні або випромінюванні кванта енергії. Модель може бути застосована як демонстраційна на традиційній лекції, пропонована студентам для самостійного спостереження, та використана для створення проблемної ситуації (рис. 6).

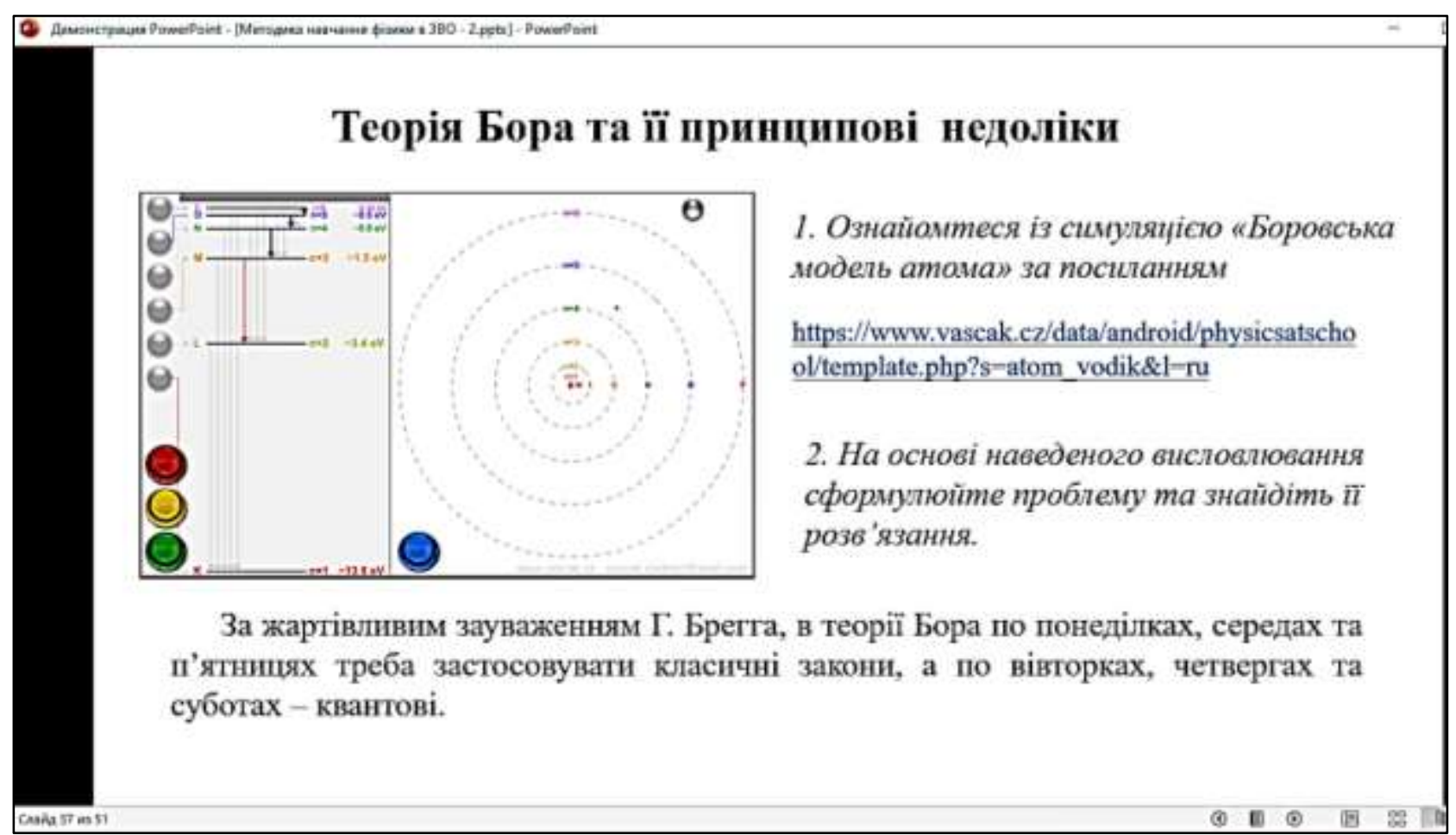

Рисунок 6. Теорія Бора та іï̈ принципові недоліки.

Фрагмент презентації курсу «Методика навчання фізики в 3ВО»

Багато комп’ютерних симуляцій дозволяють на тільки демонструвати та аналізувати фізичні явища та процеси, а й складати та розв'язувати різні типи задач: якісні, графічні, аналітичні; розробляти тестові завдання [356].

Різноманітні програми, що дозволяють проводити як фізичний експеримент, так і лабораторну роботу з фізики, містять велику кількість задач, умова яких побудована на даних експерименту. Змінюючи умови експерименту 
можна змінювати умови задачі. Програми дозволяють перевірити правильність розв'язання задачі за будь-яких умов експерименту.

Студенти краще засвоюють матеріал, якщо вони не тільки розв'язують запропоновані їм готові задачі, а й навчаються їх складати самостійно, набуваючи компетентності, необхідні майбутнім учителям і викладачам фізики. Так при вивченні теми «Фотоефект» можна використати відповідну симуляцію й запропонувати студентам скласти до неї задачі різного рівня складності (рис. 7).

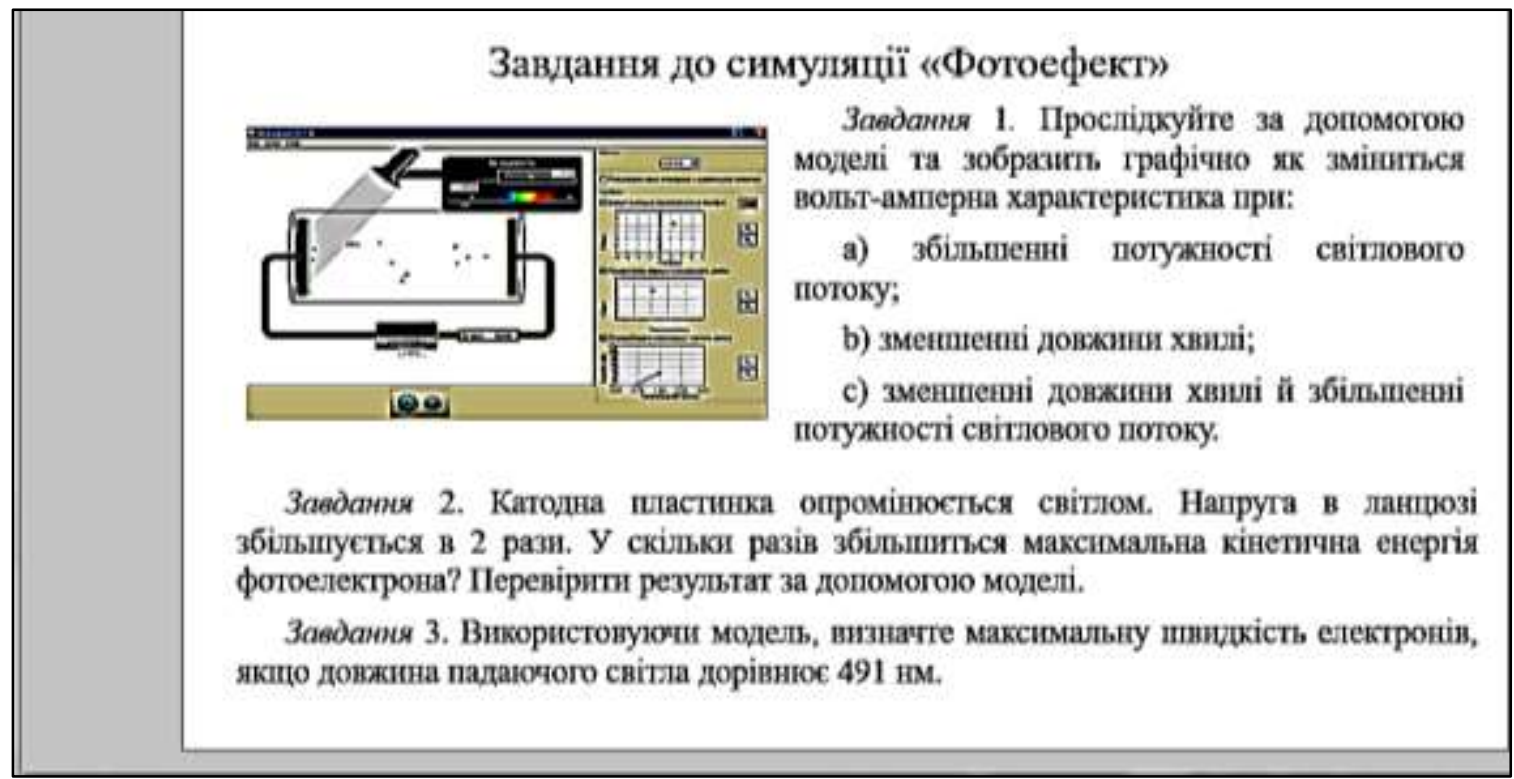

Рисунок 7. Фрагмент презентації, розроблений студентами при виконанні проєкту «Явище фотоефекту в навчанні фізики»

Симуляція «Інтерференція хвиль» порталу Phet.Colorado (https://phet.colorado.edu) дозволяє проводити аналогію між інтерференцією механічних поверхневих та звукових хвиль і електромагнітних (світлових) хвиль, аналізувати залежність інтерференційної картини від виду та розміру об'єктів, на яких відбувається дифракція, складати завдання до практичних занять з відповідних тем, зокрема, із залученням до складання студентів (рис. 8). 


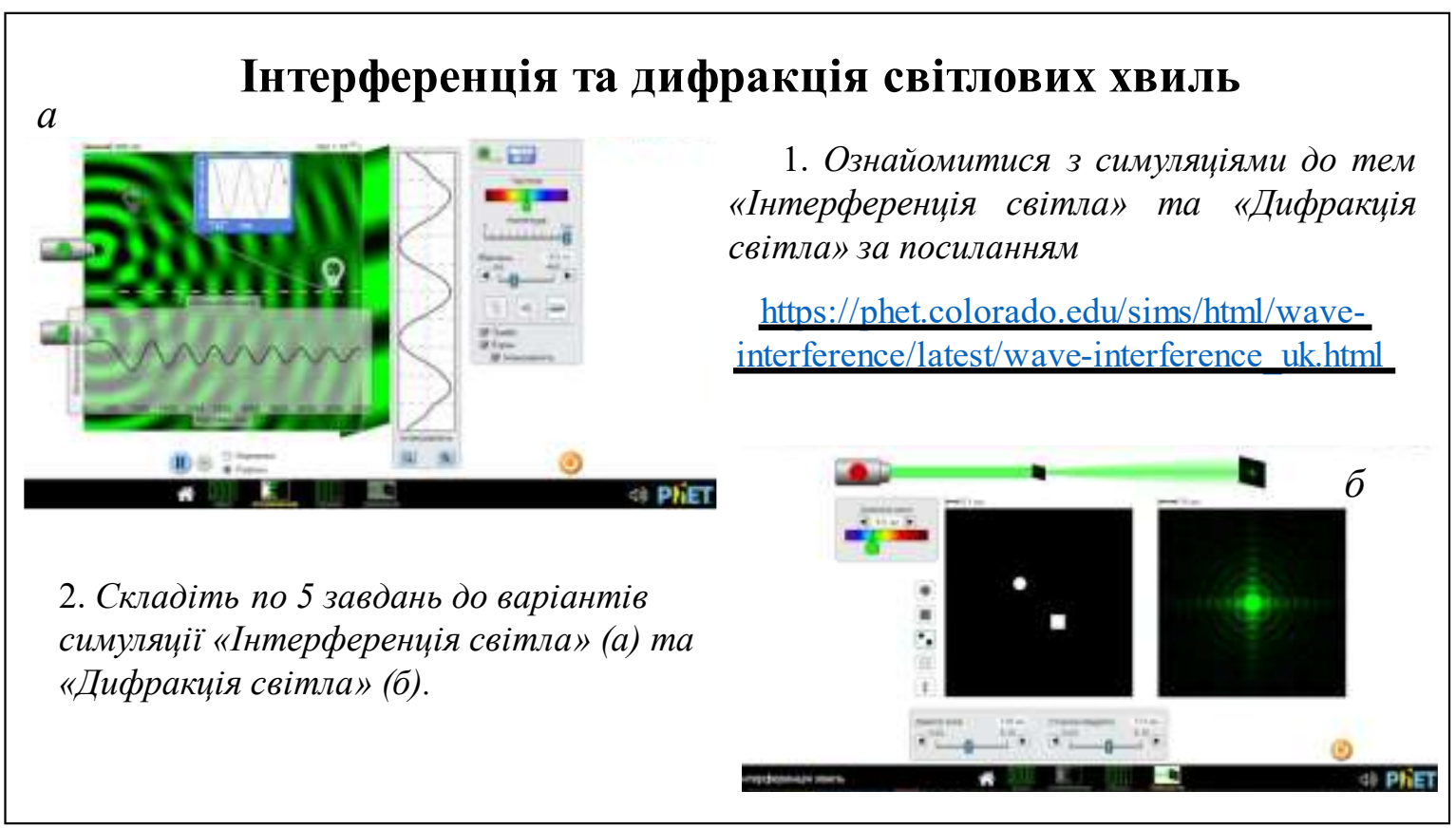

Рисунок 8. Інтерференція та дифракція світлових хвиль.

Фрагмент презентації курсу «Методика навчання фізики в 3ВО»

При демонстрації вказаних симуляцій може бути встановлений зв'язок зі шкільним курсом фізики, проведено порівняння пояснення процесів, що ілюструються симуляціями, при навчанні відповідних тем у школі та вищому навчальному закладі.

\subsection{7. Технологія перевернутого навчання (flipped learning)}

Єдиного визначення технології перевернутого навчання не існує. Його можна визначити як «педагогічний підхід, при якому пряме навчання переміщається 3 простору групового навчання в простір індивідуального навчання, а результуючий груповий простір трансформується в динамічну інтерактивну середу навчання» [357]. Роль викладача у такому просторі зводиться до спрямування тих, хто навчається, мотивування студентів до самостійного пошуку знань за межами аудиторії, формування навичок не тільки шукати інформацію, а й перевіряти іiі достовірність, аналізувати, критично осмислювати. Роль студента при цьому переходить від пасивного одержувача до активного конструктора знань [358].

Перевернуте навчання поділяється на 3 фази: Pre-Phase (до проведення аудиторних занять), face-to-fase (активне навчання в аудиторіï), Post-Phase - (після 
аудиторної роботи, рефлексія), які можуть бути реалізовані 3 використанням електронних навчальних курсів на основі технології мікронавчання [359].

Виділяють декілька форм перевернутого навчання.

1. Класична модель перевернутого навчання, яка передбачає:

- попереднє ознайомлення студента 3 матеріалом, якому буде присвячено майбутнє заняття; переважно матеріал готує або рекомендує викладач (опорний конспект лекцій, підрозділ підручника, презентація, подкасти, водкасти та інші форми представлення інформації);

- обговорення вивченого матеріалу в аудиторії 3 поясненням складних моментів, відповіді викладача на питання;

- закріплення теоретичних знань на практичному занятті, набуття практичних вмінь;

- виконання завдань для самостійної роботи, оцінювання засвоєння нового матеріалу.

Отже навчання за цією моделлю продовжує нагадувати традиційну систему освіти.

2. Основними етапами «просунутої» моделі перевернутого навчання $є$ наступні:

- попередня підготовка, в ході якої викладач лише задає тему, а студенти самостійно здійснюють пошук інформації та індивідуально або поєднуючись у міні-групи готують іiі представлення на майбутньому занятті;

- розміщення студентами підготованого матеріалу (тез, слайдів) на спільній електронній платформі, що дає можливість усім студентам та викладачу заздалегідь з ним ознайомитися й забезпечує моніторинг самостійної роботи кожного студента;

- презентація підготованого матеріалу в аудиторії (на занятті) з обговоренням i аргументованим аналізом роботи кожної групи, що може відбуватися в різних формах, наприклад виступ представника від кожної групи с подальшим обговоренням усіх пропозицій за «круглим столом». 
3. Системна або комбінована модель перевернутого класу, яка може розглядатися як комбінування перших двох моделей. Застосування цієї моделі передбачає наступні етапи:

- дистанційний етап: студенти працюють самостійно або в міні-групах, за наданими завданнями або проблемною ситуацією здійснюють пошук і аналіз необхідної інформації, пропонують варіанти рішень;

- представлення знайденої інформації і варіантів розв'язання завдань в аудиторії, аналіз матеріалу й пропозицій під керівництвом викладача, оцінювання переваг і недоліків кожного з пропонованих рішень;

- другій дистанційний етап, в ході якого студенти в міні-групах аналізують та узагальнюють досвід сумісної діяльності із зазначеної проблеми;

- заключний етап в аудиторії, на якому підводяться підсумки роботи, обговорюються можливості застосування одержаних знань та результатів в інших ситуаціях.

Дана модель перевернутого навчання є педагогічним підходом, найбільш наближеним до реальності, оскільки в повсякденному і професійному житті дуже часто доводиться приймати рішення в умовах невизначеності або ризику.

Різні моделі перевернутого класу дозволяють використовувати більш широкий арсенал форм контролю знань, вмінь та компетентностей студентів, відбувається оцінювання використаних підходів для пошуку інформації, якості самої інформації, внеску кожного в колективне знання, здатності до комунікації в групи, ефективності взаємного навчання, оцінка діяльності кожного його однолітками, самооцінка.

Ефективність методу перевернутого навчання щодо підвищення якості, забезпечується завдяки його гнучкості, можливості використовувати в кожній конкретній ситуації той варіант, який найбільшою мірою відповідає цілям викладача. Проте перевернуте навчання передбачає значне збільшення обсягу самостійної роботи студентів, що вимагає наявності методичного та матеріальнотехнічного забезпечення процесу навчання, створення інформаційного простору педагога і студентів. Зокрема, вивчення теоретичного матеріалу здійснюється 
студентами самостійно через роботу з онлайн-ресурсами, що вимагає забезпечення постійного доступу в Інтернет.

Результативність навчання залежить від якості використовуваних матеріалів. Під час їх розробки слід брати до уваги ізольованість студента, який навчається дистанційно. Матеріали повинні мати необхідні пояснення, бути привабливими, всі труднощі процесу вивчення повинні заздалегідь передбачатися авторами.

Поряд 3 навчальним текстом або відеоматеріалом викладач може представити структурно-логічну схему теми, що вивчається, й запропонувати студентам заповнити пробіли, самостійно скласти опорні конспекти, розробити ментальну карту, заповнити певні таблиці [360]. Потім на занятті відбувається обговорення варіантів, які пропонують різні студенти, i формулювання правильного, найбільш ефективного розв’язання. Звичайно, підготовка методичного забезпечення для таких різноманітних форм навчальної роботи вимагає від викладачів значних витрат часу та креативного підходу.

Ефективність застосування методу також залежить від рівня мотивації, самостійності, свідомості, активної участі в навчанні, до чого студенти не завжди готові. Таким чином, виникає потреба використання інноваційних технологій i методів навчання, які дозволяють вивчати матеріал в процесі самостійної пізнавальної діяльності студента при ключової і організуючої ролі викладача.

Перевернуте навчання перетинається 3 різними підходами, такими як особистісно-орієнтоване навчання, системно діяльнісний підхід проблемне навчання, зокрема за методом Case-study, тощо.

Всі підходи дозволяють за допомогою опори на систему взаємопов'язаних понять, ідей, способів і дій забезпечувати та підтримувати процеси самоорганізації, самовдосконалення, самореалізації, самопрояву суб’єкта пізнавальної діяльності, усвідомлення цінності особистісного сенсу наукового мислення та значущості метазнань як основ духовно-моральної та інтелектуальної культури професійного менталітету, соціалізації особистості.

Проектування нових способів отримання знань та рішення педагогічних проблем є основою інноваційної діяльності викладача. 
DOI 10.46299/ ISG.2021.MONO.PED.III.4.11

\subsection{1 Академічна етика як фундаментальна цінність освіти}

Тема академічної доброчесності сьогодні $€$ досить актуальною на українському освітньому просторі, оскільки шлях до європейського суспільства потребує фахівців, що отримали у вишах не лише професійні знання, але й знання про закони, загальноприйнятні етичні правила і норми, що забезпечують академічну доброчесність як основний принцип академічного життя.

Під терміном «академічна доброчесність» прийнято розуміти сукупність моральних цінностей, таких як чесність, довіра, повага, справедливість, відповідальність.

Саме такі етичні стандарти, що мають впливати не лише на науковий розвиток академічної спільноти, але й допоможуть у формуванні моральності суспільства в цілому, закріплені в Бухарестській Декларації з етичних цінностей та принципів вищої освіти в Свропейському регіоні [361]. У другому розділі Декларації «Цінності та принципи», задекларовані ключові цінності академічної доброчесності та принципи їх втілення в освітній процес. Зокрема, зазначено, що «виховання чесності слід починати з себе, а вже потім домагатися її поширення серед всіх членів академічної спільноти, не допускаючи ніяких форм обману, брехні, шахрайства, крадіжки або інших форм нечесної поведінки, які негативно впливають на якість отриманих академічних ступенів».

В Декларації зазначається, що забезпечення справедливості у викладанні, оцінюванні освітніх досягнень студентів наукових дослідженнях, кар’єрному просуванні персоналу, отриманні будь-яких нагород, відзнак, ступенів повинно грунтуватися на законних, справедливих, передбачуваних, послідовних i об'єктивних критеріях. Особлива увага в документі привертається до довіри та відповідальності всіх членів академічної спільноти, як до підгрунтя існування науки в Україні, запоруки їі розвитку. В першу чергу це стосується закладів освіти, оскільки їх особливим призначенням є підготовка вмотивованих на академічну доброчесність фахівців, від яких залежить подальший розвиток нашої країни. Однак, на жаль, велика частка здобувачів вищої освіти 
мотивована не стільки на отримання та розвиток знань, скільки на такі атрибути вищої освіти, як бали, стипендія, диплом. Така ситуація має транзитивний характер, складаючись ще в період отримання освіти у закладах загальної середньої освіти, тому впровадження принципів академічної доброчесності необхідно починати ще зі шкільної лави, роз’яснюючи учням зміст нормативних категорій, прописаних у вітчизняному законодавстві та міжнародних правових документах. Перш за все, необхідно роз'яснювати статті Української Конституції, що стосуються захисту результатів інтелектуальної та творчої діяльності. Так, стаття 41 діючої Конституції України закріплює право «володіти, користуватися і розпоряджатися своєю власністю, результатами своєї інтелектуальної, творчої діяльності» [362, с. 45]. Стаття 54 гарантує громадянам України свободу «літературної, художньої, наукової і технічної творчості, захист інтелектуальної власності, авторських прав, моральних і матеріальних інтересів, що виникають у зв'язку з різними видами інтелектуальної діяльності». [362, с. 59].

XX1 ст. стало часом радикальних трансформацій української системи освіти. Такі фактори, як розвиток нових інформаційно-комунікаційних технологій та створення на їх основі міжнародної мережі знань, зростання соціальної мобільності студентської молоді, певним чином спровокували зниження академічних стандартів вищої школи, навіть, їх деформацію. Інтелектуальне запозичення торкнулося всіх рівнів науково-освітнього процесу, починаючи 3 середньої школи i закінчуючи професорсько-викладацьким складом будь-якого вишу [364].

Чітке визначення поняття академічної доброчесності закріплене в рамковому законі «Про освіту». Відповідно до 42 статті цього Закону академічна доброчесність - це сукупність етичних принципів та визначених законом правил, якими мають керуватися учасники освітнього процесу під час навчання, викладання та провадження наукової (творчої) діяльності з метою забезпечення довіри до результатів навчання та/або наукових (творчих) досягнень [365]. Як бачимо, академічна доброчесність це, з одного 
боку, «сукупність етичних принципів», а 3 іншого - сукупність чітких, «визначених законом правил». Тобто має місце поєднання ціннісних складових з їх практичним значенням та застосуванням.

Нормативно-правове забезпечення впровадження принципів академічної доброчесності у вищих навчальних закладах регламентується Законами України «Про освіту», «Про вищу освіту», «Про наукову та технічну діяльність».

Закон України «Про вищу освіту» [366] вимагає від всіх учасників освітнього процесу дотримання у своїй діяльності правил, визначених Законом «Про освіту», що допоможе протистояти академічній недоброчесності в освіті.

Треба зазначити, що поширення різних форм академічної недоброчесності не $\epsilon$ суто вітчизняною проблемою, це світова тенденція, викликана розвитком інформаційних технологій, легкістю доступу до інформації в мережі інтернет (інтернет-плагіат). 3 кожним роком ця проблема стає все більш глобальною. Сьогодні до прояву академічної недоброчесності відносяться використання абро дублювання інформації, результатів досліджень; посилання на джерела, які не використовувалися в роботі; надання допомоги для здійснення акту академічної нечесності - навмисна чи усвідомлена допомога або спроба допомогти іншому вчинити акт академічної нечесності; придбання в інших осіб чи організацій 3 наступним подання як власних результатів діяльності [367, с.22-26].

Міжнародною академічною спільнотою сформульовані та визнані загальні критерії академічної доброчесності, такі як: чесність, відповідальність, повага до інтелектуальної власності та авторських прав на неї, добросовісність, прозорість тощо. Незважаючи на певну розмитість та розпливчастість цих понять, є зрозумілим що норми права і норми моралі взаємопов'язані i виступають підгрунтям якісної освіти.

Для підтримки співробітництва вищих учбових закладів в галузі академічної чесності були створені та функціонують такі міжнародні організації, як «Міжнародний центр академічної чесності ("The International Center for Academic Integrity" (ICAI) та «Свропейська мережа академічної чесності ("European Network for Academic Integrity"). 
В Україні задля вирішення цих проблем було створено Проект сприяння академічній доброчесності (Strengthening Academic Integrity in Ukraine Project SAIUP). Цей проект є ініціативою Американських Рад 3 міжнародної освіти за сприяння Міністерства освіти і науки України, спрямованою на системні зміни в українській вищій освіті, покращення іміджу українських вишів. Метою проекту є підтримка стійких змін в освіті України, формування академічної доброчесності як важливої складової трансформації української освітньої системи.

Пошук шляхів підвищення академічної доброчесності в освітній спільноті $€$ предметом наукових досліджень та дискусій в Україні. Аналіз робіт, що присвячені цій проблемі показує, що вітчизняними дослідниками багато уваги приділяється етиці чеснот. Так, Н. Бойченко зауважує, що бурхливий розвиток наукового знання висуває перед вченими низку етичних проблем і вимагає їх дотримання. «Наукова діяльність не може бути нейтральною в етичному плані, етика повинна бути невід'ємною складовою підготовки кожного фахівця» [368].

На думку С. Мовчана важливим i, навіть, необхідним є "усвідомлення науковцями себе як певної духовної спільноти» [369, с. 398]. Автор звертає увагу на запропонований К. Поппером підхід до процесу творення достовірності знання внаслідок складності його перевірки, і вважає, що наукова спільнота має виступати носієм морально-ціннісного відношення до змісту знання та процесу його творення.

На важливості формування етичного аспекту поведінки вченого наполягає В. О. Зінченко [370].

Автори колективного наукового дослідження 3 проблем дотримання академічної доброчесності, здійсненого за науковою редакцією Н. Сорокіної, значну увагу приділяють академічній доброчесності як основі сталого розвитку університетів [371].

3 точки зору постановки етичних проблем в академічній сфері, заслуговують на увагу роботи І. Тодорової [372]. А. Колєснікова[373]. 
Більшість дослідників вважають, що науковий процес, як і будь-яка сфера діяльності, пов'язаний з моральними, етичними аспектами і мета освітньої та наукової діяльності може бути досягнена лише в тому середовищі, де підтримуються стандарти етики. Дотримання цих стандартів в освітній діяльності передбачає перш за все дотримання педагогічними, науковопедагогічними працівниками та здобувачами освіти принципів академічної доброчесності.

Неможна залишити поза увагою проголошення у 2009 році Етичного кодексу вченого України [374]. Кодекс наголошує, що кожна практика має свої правила, однак, ці правила не повинні виходити за межі етичних цінностей науки, вони повинні забезпечувати відкритість і чесність будь-яких наукових досліджень, концептуалізувати освіту як поширення академічних чеснот на всі інші суспільні взаємини.

Практичне втілення етики чеснот науково-педагогічними працівниками передбачає дотримання таких норм, як дотримання законодавства про авторське право і суміжні права, надання достовірної інформації про методики та результати досліджень, контроль за дотриманням академічної доброчесності здобувачами освіти, посилання на джерела інформації у разі використання ідей.

Науково-педагогічні працівники повинні озвучувати етичні чесноти, робити їх частиною діалогу зі студентами, використовувати потенціал етичних цінностей в контексті інформування щодо різних аспектів життя в університетському середовищі та поза його межами, адже навчальні заклади повинні виконувати не лише освітні завдання. Не менш важливим $є$ й завдання виховання поваги до загальноприйнятих етичних правил та норм. Саме тому академічна доброчесність має фундаментальне значення і повинна стати основним принципом академічного життя.

Заклади вищої освіти мають затверджувати правила та норми поведінки, які містять такі елементи, як: законність, етичність, рівність, прозорість, незалежність, взаємодовіра, толерантність[375]. . 
Дотримання цих принципів залежить від усіх учасників освітнього процесу. Зміст політики і правил академічної доброчесності має бути донесений до кожного учасника. Студентам мають бути доступні консультації з питань академічного письма, уникнення порушень академічної доброчесності, процедур розгляду таких порушень, можливих видів академічної відповідальності. Дуже важливо, щоб заклади вищої освіти мали можливість створювати власну політику у сфері академічної доброчесності, власні документи, кодекси етики, курси академічного письма тощо. Всі ці речі, на думку голови Національного агентства із забезпечення якості вищої освіти С. Квита, - важать набагато більше для розвитку академічної доброчесності, ніж покарання за порушення[376].

Розвиток академічної етики - це основний засіб, за допомогою якого університети можуть робити реальний внесок у побудову цивілізованого суспільства. Тому університети, як і інші освітні установи, часто є останнім шансом на подолання «кризи порядності» i, отже, несуть особливу відповідальність. Адже зрозуміло, що якщо звички порядності не будуть щеплені студентам, перш ніж вони закінчать навчальні заклади і підуть працювати, то дуже малоймовірно, що ці звички зможуть бути розвинені в них пізніше[377].

Будь-яка студентська робота $є$ демонстрацією наявності та ступеня сформованості академічної етики. Тому необхідно навчати студентів працювати 3 інформацією, формувати у них цілісну систему цінностей і норм академічної етики, звичку до академічної сумлінності, до етичного використання інформації. Під рівнем академічної сумлінності мається на увазі свідома відмова студентів від академічного шахрайства (чесне виконання робіт, дотримання авторських прав, самостійність у наукових дослідженнях, відмова від списування, плагіату, коректне використання запозиченої інформації).

Визначення власних моральних стандартів, їх зіставлення з найкращими зразками академічної культури, втілення у життя у всіх напрямках роботи вищого навчального закладу $є$ проявом прагнення вітчизняної освітньої спільноти взяти на себе відповідальність у захисті норм права та базових 
академічних та моральних цінностей, забезпечення якості та результатів навчання. Тому сьогодні особливо актуальною стає проблема соціальнопрофесійного становлення студентів через поширення доброчесності в академічному середовищі України та ії̈ вплив на весь академічний простір.

Система академічної доброчесності в закладах вищої освіти є постійно діючим процесом над яким потрібно працювати усім учасникам освітнього процесу та удосконалювати механізми ефективної взаємодії. 
DOI 10.46299/ISG.2021.MONO.PED.III.4.12

\subsection{2 Інноваційні аспекти освітньої мобільності у системі післядипломної освіти}

На сучасному етапі розвитку та уніфікації освітніх систем, глобалізації та активізації міжнародної діяльності, швидкого застарівання знань, переходу від концепції «освіти на все життя» до концепції «освіти впродовж життя» мобільність стає однією із ключових характеристик сучасної освіти і науки. Освітня мобільність є невід’ємним компонентом дискурсу щодо питань глобалізації освіти, найбільш розвиненою формою іiі інтернаціоналізації, забезпечує доступ по провідних наукових здобутків розвинених країн, підтримує розвиток міжкультурної взаємодії, є принциповою характеристикою єдиного освітнього простору. За твердженням М. Култаєвої, навчання протягом усього життя - це відкрита освіта, яка принципово не може бути завершеною. Структура безперервної освіти є гнучкою, включає в себе альтернативні можливості і форми. Вона є просторово і інституційно відкритою і відповідає вимогам активного і мобільного суспільства [378].

Сьогодні явище мобільності пов’язують з багатьма науками, зокрема, філософією, соціологією, педагогікою, психологією, демографією, географією, економікою, державним управлінням, правом, політологією, історією. У довідникових джерелах мобільність розглядається як «рухливість, здатність швидко орієнтуватися в ситуації, знаходити потрібні форми діяльності» [379]. У працях сучасних науковців найчастіше зустрічаються такі трактування поняття «мобільність»:

- міра здатності фактора виробництва до переміщення між сферами використання [380];

- рухливість, готовність до швидкої реакції, швидкого включення в діяльність [381];

- одна із сутнісних характеристик людини, яка проявляється в процесі праці, тобто професійній діяльності. Мобільний фахівець повинен являти собою людину як універсум [382]; 
- як специфічний освітній феномен, асоційований із процесами забезпечення взаємодії національних освітніх просторів, з іншого - як метафора соціального розвитку [383].

Мобільність науковці також розглядають не лише як рух суб’єкта чи предмета, але й процеси, причини, результати, вона стає атрибутом людей, ідей, інформації, цінностей тощо.

Слід зазначити, що зміна парадигми освіти викликала інтерес науковців і педагогів-практиків до «підвищення кваліфікації викладачів, що зумовлений переходом від масово-репродуктивних форм i методів викладання до індивідуально-творчих, коли готується фахівець зі сформованою потребою в професійній самоосвіті, здатний до саморозвитку і повноцінної самореалізації в обраній професії» [384].

А професійна мобільність, за визначенням дослідниці Л. Сушенцевої, це якість особистості, що є необхідною для успішної життєдіяльності в сучасному суспільстві, яка забезпечує ії самовизначення, самореалізацію і саморозвиток у праці, завдяки сформованим ключовим компетенціям та ключовим кваліфікаціям і прагненню особистості змінити не тільки себе, а й професійне поле та життєве середовище [385]. Вперше поняття «професійна мобільність учителів шкіл» використано у 1913 році у звіті бюро освіти США, розглядалося «у професії [вчителя] дуже бажана як розумна мобільність, так й розумна стабільність [386].

На нашу думку, професійна мобільність є якісною складовою особистості як фахівця; іï формування має розпочинатися ще під час навчання в закладі вищої освіти. У Свропі поняття «професійна мобільність» розглядається через фундаменталізацію освіти. Французький учений Ф. Ваніскотт обгрунтував концепцію мобільності вчителя-європейця, яка розглядається як здатність до змін, до прийняття нового.

Тому феномен освітньої мобільності ми трактуємо як один із засобів організації освіти нового типу, яка б гармоніювала із сучасними соціальними 
запитами та відповідала б вимогам щодо флексибільного характеру своєї сутності.

Під професійною мобільністю ми розуміємо прагнення людини досягти визнання, самореалізації та творчості шляхом здійснення професійної діяльності, яка приносить моральне та психологічне задоволення паралельно із високим матеріальним доходом, а також готовність до зміни професійної діяльності та здобуття нової освіти у зв'язку із попитом на них соціального кола рівня особистості або за власним бажанням.

У рамках неперервної професійної освіти розглянемо особливості організації діяльності закладів післядипломної педагогічної освіти та розвиток професійної мобільності педагогів. У контексті нашого дослідження важливого значення набуває галузева Концепція розвитку неперервної педагогічної освіти, яка $є$ стратегічним документом, що визначає основні напрями розвитку педагогічної освіти в Україні [387]. Основними принципами розвитку неперервної педагогічної освіти в цьому документі визначено: неперервність, поєднання національних освітніх традицій та найкращого світового досвіду, інноваційність, прогностичність, гнучкість у реагуванні на суспільні зміни.

Під розвитком професійної мобільності педагога науковці розуміють процес набуття нових та удосконалення існуючих компетенцій, знань, умінь та навичок, які він використовує або буде використовувати в своїй професійній діяльності. Становлення й розвиток професійної мобільності педагога забезпечується особистісним творчим перетворенням освітньої й професійно-педагогічної дійсності.

В умовах системи неперервної професійної освіти розвиток професійної мобільності вчителя відбувається за рахунок залучення потенціалу системи додаткової професійної освіти, використання досвіду закордонних систем освіти, а також з урахуванням особистісних якостей і потреб педагога.

Відкрите суспільство зацікавлене у фахівцях, які самостійно думають, творчо вирішують різноманітні завдання, володіють критичним мисленням, здатні до самонавчання і самоосвіти. Тому сучасні умови професійної 
діяльності у сфері освіти вимагають від педагога мобільності, оволодіння такими якостями, як педагогічна реакція, цілеспрямованість, передбачення, прогнозування 3 метою досягнення цілей і попередження виникнення ризиків. Система післядипломної освіти може забезпечити розвиток професійної мобільності педагога, якщо буде: створювати умови для всебічного гармонійного розвитку, незалежно від віку, попередньо здобутої професії або спеціальності, місця проживання, але 3 обов'язковим урахуванням іiі індивідуальних особливостей, мотивів, інтересів; запроваджувати форми, методи і технології розвитку професійної мобільності педагога для здобуття та вдосконалення професійно педагогічних знань високого рівня, узагальнення та уміннями їх ефективно застосовувати; сприяти попередженням професійної деформації, вибудові та реалізації напряму свого подальшого професійного зростання.

Сучасна система післядипломної освіти має великі можливості для забезпечення розвитку професійної мобільності педагога, адекватного реагування на зміни в сфері освіти, впровадження технологій, які забезпечуватимуть професійне вдосконалення, підвищення кваліфікації педагогічних працівників згідно з вимогами інноваційного розвитку освіти та забезпечення випереджувального характеру підвищення кваліфікації відповідно до потреб реформування системи освіти.

Професійний розвиток тісно пов'язаний з особистісним. Особистісні якості у процесі професійної діяльності забезпечують спрямованість особистості на самовдосконалення. Розвиток професійної мобільності педагога $є$ засобом активізації професійних якостей фахівця, актуалізації його внутрішніх резервів і можливостей, формування здатності самореалізації у професійній діяльності.

Ми вважаємо, що розвиток професійної мобільності - це безперервний процес оновлення знань та вдосконалення професійних компетенцій, який зумовлений ускладненням та мобільністю сучасного суспільного життя, розширенням сфер діяльності людини, обмеженням набутих компетентностей, 
що, в свою чергу, зумовили необхідність розвитку професійної мобільності педагогів у системі післядипломної освіти.

В Україні післядипломну освіту офіційно визначено як «спеціалізоване вдосконалення освіти та професійної підготовки особи шляхом поглиблення, розширення та оновлення їі професійних знань, умінь та навичок або отримання іншої професії, спеціальності на основі здобутого раніше освітнього рівня та практичного досвіду» [388]. Стаття 59 Закону України «Про освіту» для професійного розвитку педагогічних $\mathrm{i}$ науково-педагогічних працівників передбачає постійну самоосвіту, участь у програмах підвищення кваліфікації та будь-які інші види і форми професійного зростання. Заклади освіти, в яких працюють педагогічні та науково-педагогічні працівники, сприяють їхньому професійному розвитку та підвищенню кваліфікації [389].

Післядипломну освіту здійснюють заклади післядипломної освіти або відповідні структурні підрозділи вищих навчальних закладів і наукових установ [389]. Заклади післядипломної педагогічної освіти - це вищі навчальні заклади, що здійснюють підвищення кваліфікації та перепідготовку педагогічних кадрів на основі здобутого раніше освітньо-кваліфікаційного рівня, практичного досвіду відповідно до замовлень управлінь освіти і науки обласної державної адміністрації, закладів освіти, юридичних та фізичних осіб. Як зазначають науковці, завданням післядипломної освіти $\epsilon$ розвиток та вдосконалення особистісних якостей фахівця та створення умов для самореалізації, самоактуалізації педагога, вдосконалення самоосвітньої діяльності, виходячи 3 цього основними функціями післядипломної освіти є: підвищення кваліфікації, підготовка та перепідготовка фахівців відповідно до потреб ринку праці у фахівцях певного профілю; постійне оновлення знань, умінь та навичок згідно 3 вимогами суспільства, ринку праці, техніки і технологій; створення умов для професійного та особистісного розвитку фахівця.

Система післядипломної педагогічної освіти забезпечує оптимальні умови для самореалізації особистості, розкриття всіх закладених у ній потенційних ресурсів, здібностей шляхом: 
•переходу від одноразового курсового підвищення кваліфікації до моделі неперервного професійного розвитку в умовах формальної, неформальної та інформальної післядипломної освіти;

•надання сервісних послуг на принципах бенчмаркінгової діяльності, що передбачає створення гнучкого, конкурентного освітнього середовища 3 домінуванням мобільних програм підвищення кваліфікації, перевагою активних i практико зорієнтованих технологій навчання, модернізацію змісту, форм, методів, технологій навчання залежно від суспільних та індивідуальних освітніх потреб замовників, відповідно до темпів застарівання і оновлення інформації, можливостей та особливостей, компетентнісного досвіду фахівців;

•розроблення й упровадження в систему підвищення кваліфікації багатоваріантних, різнорівневих, диверсифікованих за профілем освітньопрофесійних програм, форм освіти дорослих, метатехнології відповідно до соціально-педагогічних запитів і особистісно-професійних потреб фахівців, що забезпечують їм свободу вибору місця, термінів, змісту навчання за індивідуальною освітньою траєкторією впродовж життя;

•забезпечення андрагогічних, аксіологічних, акмесинергетичних, культурологічних, інтегративних, навчально-розвивальних, праксеологічних, інформаційних функцій системи підвищення кваліфікації;

•випереджувального характеру надання освітніх послуг в умовах глобалізації і відкритості інформаційного освітнього простору;

•участі фахівців у різних формах академічної мобільності (навчання за програмами академічної мобільності; мовне стажування; наукове стажування, спільні проекти; викладання; наукове дослідження; підвищення кваліфікації);

•підготовки андрагогів для ефективного науково-методичного супроводу професійного розвитку фахівців упродовж життя тощо;

•акумулювання кращих практик розвитку професійної мобільності педагогічних працівників. 
Із розвитком відкритих освітніх ресурсів учитель нового покоління має широкий вибір побудови самоосвітньої діяльності на основі інформаційнокомунікаційних, цифрових, мережевих технологій, на дистанційних платформах тощо. Все це сприяє підвищенню фахового рівня педагогів та розвитку їх професійної мобільності.

Розширення функцій та відповідно сфер діяльності освіти для дорослих, на наш погляд, $є$ загальносвітовою та загальноєвропейською тенденцією, що створює соціокультурні передумови для інноваційного розвитку даної освітньої галузі.

Результати моніторингового дослідження, проведеного Дніпровською академією неперервної освіти у 2021 році серед педагогічних працівників показують, що 95\% опитаних педагогів підтримують ідею впровадження професійної мобільності, 65\% респондентів назвали мобільність фактором, який здатний стимулювати розвиток творчого потенціалу вчителя. Тобто можемо стверджувати, що запровадження мобільності відбувається не лише у вищій школі, але й у системі неперервної професійної освіти.

Мобільність окреслює сучасні тенденції інноваційного розвитку неперервної освіти, є інструментом формування, вдосконалення фахівців, результатом функціонування системи неперервної освіти, а також впливає на етапи формування поняття професійної компетентності. 


\section{SECTION 5. PHILOLOGY AND LINGUISTICS}

\section{DOI 10.46299/ISG.2021.MONO.PED.III.5.1}

\subsection{Language as the manifestation of culture}

The issue of "language and culture" is multifaceted. A cultural historian and linguist, a philosopher and psychologist, an ethnographer and a literary critic will approach it in different ways. However, the linguistic aspect of the problem is at least two-dimensional, as language and culture interact. Therefore, two questions immediately arise: 1) how do different cultural processes affect language? 2) how does language affect culture? However, first of all, a legitimate question about the relationship between the concepts of "language" and "culture": to what extent is language a culture?

Culture is opposed to nature. Lat. cultura (from colo - cultivate, breed) meant something grown by human labor, in contrast to the wild. Culture is a product of social, not biological activity of people. Language acts as a phenomenon of both culture and nature. Undoubtedly, language is one of the most important achievements of human social history, a component of culture and its tools. However, on the other hand, in the very matter of language, in a number of essential characteristics of the language structure affected the biological nature of man. Here a lot is determined by the possibilities of physiology and psychophysiology of language activity. Thus, the presence in all languages of vowels and consonants and the predominance of sound chains with alternating vowels and consonants is due not to culture but to nature: man is unable to pronounce or perceive language from one vowel or one consonant. Psychophysiological possibilities of human sign activity determine the multilevel organization of language, the quantitative parameters of individual levels, for example, the volume of the phonological system, which varies in different languages in the range from 10 to 100 units; the volume of the dictionary in the range from 10 thousand to half a million words; manifestation of redundancy in language. The amount of human operative memory is limited by the average length of a sentence, the average depth and width of subordinate clauses when developing an expression, the average length of a 
synonymous series, and the size of lexical-semantic groups. Nature determines in language the deepest features of its structure and patterns of generation and perception of the text. Culture determines the plan of language content.

Modern knowledge reveals an impressively deep interpenetration of nature and culture, and language is one of its brightest manifestations. Isomorphism (structural similarity) of the genetic code and language has been found in molecular biology and semiotics. They are considered as information systems that serve to generate texts by combining some of the initial elements: in the mechanisms of genetics - four chemical radicals in the development of the "chemical text" of heredity; in the mechanisms of language - a set of phonemes in the generation of language. R.O. Jacobson suggested that the similarity of language with the genetic code arose as a result of the fact that in the process of phylogeny man unconsciously constructed language on the model of the genetic code. This copying of the genetic code in the language is possible because the organism unconsciously has information about its structure, in particular - about the structure of its genetic code.

The question of the relationship between innate and acquired in human language activity remains debatable. It is generally accepted that a person has an innate language ability, i.e. a psychophysiological mechanism that provides the ability to speak. According to most researchers, this means the ability of the human brain in the first years of ontogenesis to learn, firstly, the system of signs of a particular language and, secondly, the rules that allow you to build texts by selecting and combining the right signs. The realization of language ability occurs in the process of human communication with others - native speakers of a particular language (or languages). According to the radical concept of the famous American researcher Noem Chomsky, the innate component of language ability is the most meaningful, so language acquisition in ontogenesis does not start "from scratch". Speech ability includes some innate and universal knowledge with which a person builds and understands sentences. Thus, according to Chomsky, the deepest features of language structure and semantics have a natural-genetic basis. 
In different cultures, even the same phenomena are unique. For example, a city bus can evoke a different range of ideas, in one country it is a coupon, a composter, a controller, a ticket, a travel ticket; in the other - a token, a conductor; in the third - cash register, automatic machine; somewhere else - expensive (cheap) seats, discount, seasonal, children's (adult) ticket. In the linguistic sense, the differences of equivalent words due to differences in reality are called the lexical background of the word. Lexical background - a phenomenon that borders between language and culture. Differences in the lexical background are reflected in different thematic and syntactic connections of words and can cause difficulties in communication or language learning.

Differences in the lexical background cover most of the vocabulary of languages. The terms usually coincide in the background, and in a non-special dictionary, the complete coincidence of lexical backgrounds is a rare phenomenon. However, it is natural that the closer the culture and way of life of the two peoples, the less differences in the lexical background of the respective languages. Conversely, cultural isolation leads to lexical divergence.

Already in the middle of the XVIII century. in London, noted with dissatisfaction that new words are coming from the New World, violating the language custom and tastes. Americans were enthusiastic about "their" words and called them Americanisms (there was also the word yankeesm).

Differences in cultures may be reflected in the fact that in different languages words, coinciding with denotations (with the same visual reference), may differ in connotative semantics (i.e., their emotional and evaluative nuances).

Hungarian linguist F. Papp wrote about the differences in associations associated with the image of the swamp in different languages. If in the Hungarian perception, the swamp evokes the idea of rot, decay, etc., in the Finnish language the swamp is something quite good. A well-known Finnish scholar compared the Finnish language to a swamp in which tree branches fell, because the language has preserved ancient borrowings for centuries. Therefore, for him, the swamp is something quite beautiful, with which you can compare the native language, that is, the swamp is not so much a 
place of decay as a place of preservation. In Ukrainian and Russian, the swamp is an image of routine, backwardness, and stagnation. Therefore, for example, to Voznesensk swamps, "treacherous and routine", he opposed the flight: "If you want to fly - consider the swamps."

In the Ukrainian language, the swamp is a symbol of moral dirt, petty material interests as opposed to high impulses of spirituality (He sits like a devil on money in the swamp). I. Franko explains the folk tale "Water does not laugh from the swamp, only the swamp from the water" as follows: of course, it happens that all morally dirty people try to pull honest people into the swamp, and not vice versa, all fools laugh at the honest and smart, calling them naive and idealistic.

The Uzbek writer Timur Pulatov spoke interestingly about the interlingual differences in the emotional coloration of the word: - a man entered with a celestial light, so he expressed them in language. After all, an Uzbek who lives most of the year under the scorching rays of the sun will never say kindly-diminishing sun, just as the Russian has no feeling that the sun can be not only fruitful and earth-renewing, but also hostile. But the Uzbek has a completely different attitude to the moon, this night light that brings coolness and calm - he calls everything beautiful and desirable lunar, moonshaped, and with such intonation that it may seem at least bizarre to our hearing.

Thus, the vocabulary is strongly connected with the culture of the people: 6-7\% of words are inequivalent due to background differences; idiomatic (untranslatable) all phraseology; the borrowed word is also usually not completely equivalent in meaning to its prototype in the source language; common borrowings in different languages are always more or less "wrong" equivalents. In addition, the designations of natural phenomena (such as the sun or swamp) can have different connotations. That is why complete mastery of the language is inconceivable without mastering the culture of the people.

S.S. Averintsev once noted that in any language all the best words are untranslatable. Of course, such "best" words are the majority, because each word brings into today's use the memory of yesterday: its contexts and circumstances, its history. Only do we always know how to listen to the word? 
The internal form of a word is the literal essence that consists of the meanings of the morphemes that make up a word (that is, of the meanings of its root, prefix, and suffix). For example, in the word flyer the internal form is as follows: he who flies, in the words forget-me-not - the one who does not forget; yolk - something yellow. The internal form makes the meaning of the word motivated, but this conditionality is incomplete, because the internal meaning is permissible, the words ATV - one who walks everywhere could mean not only a car, but also, for example, a tourist, a tramp or an athlete walking. A.A. Potebnya called the internal form of the word its "closest etymological meaning". The closest etymological meaning is created by living wordformation connections of a derived word. Thus, the internal form is a way of representing the meaning felt by the speakers in the word. In different languages, the same meaning is usually represented differently. For example, the Belarusian word match is related to the verb to light; Ukrainian token match is motivated by the name of the substance for ignition - sulfur; the Russian correspondence is motivated by the word "wooden or metal rod", so in its internal form the Russian word is closer to a luchina than to a lighter; Germ. Streichholz "matc" motivated streichen "smear, paint" and Holz - "wood"; English match is unmotivated, i.e. for modern linguistic consciousness (English) this word is devoid of internal form (as well as any nonderivative word in any language; historically English match goes back to Latin myxus “oppression”).

According to Potebnya, the word is created by human creativity - as well as proverbs, sayings, songs. Therefore, he compared the internal form of the word with such phenomena as direct (literal) meaning in metaphor, allegory or proverb, as composition or plot in a work of art. Indeed, the internal form of the word for historians of the people's worldview is of exceptional interest. Due to the etymology that reveals the primary motivation of words, linguistics is called the "shovel of history".

Studying the history of popular perception of Christianity, one cannot ignore the fact that in the Russian language (the only one of all Slavic languages) the name of the stratum that made up the majority of the population is motivated by the name of the 
peasant religion from the Old Words. In other Slavic and non-Slavic languages of Europe, the corresponding designation is motivated differently.

Interlingual differences in the internal form of lexical correspondences are more common than similarities, so coincidences need to be explained. The similarity of the internal form is either the result of tracing (for example, Latin impressio, German Eindruck, Russian impression, Slovenian utis), or the consequence of the typological similarity of the name processes (for example, in many languages one of the adjectives meaning "kind, sensitive, sincere" is formed from a word meaning "heart" - English hearty, cordial, Hungarian szives, szivbeli, lit. sirdingas, German herzlich, Ukrainian cordial, Slovenian prisrcen, Turkish yurekli, French cordial).

The semantic development of the dictionary, the processes of rearrangement and simplification of the morpheme structure of words lead to the fact that the internal form may fade, be forgotten or come into conflict with the lexical meaning of the word. Ink is not only black, but also linen - not only white, boletus is not necessarily found under the aspen, the atom has long been divisible, and the antibiotic - not against life. Yet the "closest etymological meaning" of the internal form lives in the semantics of derived words. It is as if the historical memory of language available to the creator follows yesterday's vision of the subject, which overshadows its current understanding. Faced with the lexical meaning, the internal form creates a kind of stereoscopic verbal representation of the world. It is important that the associations and semantic nuances created by the internal form of the word have a greater national and cultural identity than the denotative component of lexical meanings.

The effect of culture on language is clearly and holistically manifested in the forms of existence in which a language is represented. There are languages where there are almost no dialects and, conversely, languages where the differences between dialects are very significant. There are languages that have not yet developed superdialectal forms of communication (literary language), and languages with a strong centuries-old literary tradition of superdialectal nature. In young literary languages, stylistic differentiation can only begin; in this case, for example, in stylistics the comparison of neutral and colloquial language means prevails; journalism can be close 
to the colloquial language, then to the office and business; and scientific, popular science and educational texts are still written in almost the same stylistic key. On the contrary, in languages with a long and rich written tradition, the stylistic differentiation of language means is deep and definite, triple comparisons prevail: "book (or high)" "neutral" - "conversational" (the latter - with a gradation of neutral-spoken, spokenfamiliar and spatial-slang language tools, which is well felt by speakers).

The relationship between literary language and non-literary forms of language, the depth and nature of stylistic differentiation of language are determined by the entire cultural history of society: the history of its state, worldview, its cultural and ideological sympathies and participation in interethnic contacts, history of writing, literature, and school.

Is that really so? Hypotheses about the influence of language on culture and thinking have not yet grown into evidence-based theories. The phenomenon of culture is complex. Its structure, significance of separate levels and subsystems of culture are still not clear. The typology of cultures is not created, the laws of their development are not clear. For example, we do not know how many different components led to the emergence of writing in a particular culture. How to compare the strength of different factors that have formed a certain appearance of a particular written culture? What is more important here: the predominant types of syntactic structure of the sentence, or the nature of the sound organization of language, or the cult of writing in a neighboring state? Alternatively, maybe the composition and nature of sign systems already used in this society? Everything is significant, but to what extent and how?

The question of the influence of language on culture is open. However, we have no other way to find an answer than to build hypotheses and test them with the facts of the cultural and linguistic history of nations. 


\section{DOI 10.46299/ISG.2021.MONO.PED.III.5.2}

\subsection{Rus dílİ dİzgesİnde özne (подлежающее) ve eylemci் (субьект) modellerí}

Dil kural ister, aydınlığa yönelir ama, diller çelişkilerle karanlık noktalarla dolu. Dilleri birbirleriyle karşılaştırdığımızda da onların her birini kendi yapısı içinde incelediğimizde de bu gerçeği görürüz. Bir yandan değişkendir yapısı dillerin ve bu durum çok defa telafi edilmeyen kayıplara yol açar; bir yandan da olanaklarını çok kötü kullanır diller; bazen gereksiz yere harcarlar bunları, bazen de nedensiz yere kısıtlamalar içinde kıvranırlar [404, s. 23].

Vendryes'in dile dair bu tarifi, kuşkusuz, yabancı dil öğrenen veya ikinci dil edinim sürecinden geçenlerin duygu ve düşünce dünyasına tercüman niteliğindedir. Nitekim yabancı dil ve çeviri eğitiminin ana hedeflerinden biri öğrencilerin gerek hedef gerekse erek dil dizgesine yönelik farkındalığını geliştirip dil dizgesindeki yapıların ve birimlerin doğru kullanımını öğretmektir. Bunu yapabilmek için erek dil dizgesinin betimlenmesine ve öğrencinin ana dilinin dizgesi (kaynak dil) ile karşılaştırılmasına başvurulmaktadır [405, s. 252]. Özellikle Rusça odaklı bakıldığında açığa çıkan birbirinden derin, karmaşık parametrelerin ve de son derece kurallı, aynı zamanda da birbiriyle her daim ahenk içerisindeki yapıların (Rus grameri için sıklıkla kullanılan ifadelerdendir) kavranması ve de uygulanması çoğu zaman, bu dili öğrenenler için olanaksız görünebilmektedir.

İşte bu çalışmanın amacı, Rusçanın karmaşık görünen gramer yapısı içerisinde ve de özellikle söz dizim çerçevesinde hatırı sayılır yer tutan özne ve eylemci modellerine 1şık tutmak, bu bağlamda söz konusu kategorilerin dil bilgisel ifade araçlarını öne çıkararak benzer/ farklı yönlerini ortaya koymaktır. Özellikle odağa alınan eylemci modelinin Rus dili dizgesinde açı̆̆a çıkan semantik alanların saptanması ve söz konusu alanların başta çeviri süreci olmak üzere Rusça Türkçe dil çifti çalışmalarına sağlayacağı katkının değerlendirilmesi amaçlanmaktadır. 


\section{Rusçada Özne (Подлежающее) Kavramı ve Özneyi İfade Etme Yolları}

Предложение (cümle), konuşmacı ve dinleyici tarafindan gramer bir bütün olarak algılanan ve düşünce biriminin sözlü ifadesine hizmet eden bir konuşma birimidir. Düşüncelerimizin psikolojik temeli, önceki deneyimlerimizin bize verdiği ve bunun yanında mevcut deneyimlerimizle de artan fikirlerin stoğudur; cümlenin psikolojik temeli, düşüncede meydana gelen bu temsiller kombinasyonunu diğer insanlara iletme amacına sahip özel düşünme eylemindeki birleşimidir; buna iletişim adı vermekteyiz [406, s.19].

Cümlenin temel öğelerinden biri (подлежающее) öznedir. Özne, yüklemin tanımlayıcı özelliğinden farklı olarak cümlede tanımlanabilir özelliğiyle dikkat çekmektedir. Rusça odaklı bakıldığında, öznenin karakteristik iki biçimi öne çıkmaktadır: İsim (номинативное) ve mastar (инфинитивное).

Nominal yani isim (soylu) öznenin (номинативное подлежающее) nesnel bir anlamı vardır. İsim (nominal) özne içeren cümlelerde «предмет- признак» ilişkisi ifade edilmektedir: Лес зеленеет; Лес зелен; Яблони были в иявету. Öznenin morfolojik standardı ismin yalın halindeki isimlerdir. Mastar özne (инфинитивное подлежающее) ise, eylemin bağımsız bir işaretine dikkat çeker. Mastar özneli ve iki öğeli/ bileşenli (двусоставные предложения) cümlelerde «признак- признак» ilişkisi dikkat çekmektedir: (bağımsız işaret- potansiyel eylem, onun niteliği ve değeri): Oтступить - значит погибнуть- Geri çekilmek- yok olmaktır; Учиться — это нелегкое дело- Okumak- zor iştir/ kolay değildir [407, s.23].

Rus dili dizgesinde cümlenin temel öğelerinden biri olarak özne (подлежсююее) aşağıdaki dil bilgisel araçlarla ifade edilebilir [408, s.127]:

$>\quad$ İsmin yalın halinde (И.п.) bir isim ya da zamir ile: Наступила осень- Sonbahar geldi; Мальчик здоров- Şimdi oğlan (çocuk) sağllklı(dır). 
$>$ Bir isim anlamında konuşmanın herhangi bir bölümü tarafından: Сытый голодного не разумеет- Tok, açın halinden anlamaz; Tри- нечетное число- Ü̧̧- tek bir sayıdır.

> Nicel anlam taşıyan kelime gruplarıyla: Пришло несколько человек- Birkaç kişi geldi. Накопилось много вопросов- Çok fazla soru birikti.

$>\quad$ Около + ismin -in hali (Р.п.), до+ ismin -in hali (Р.п.), $c+$ ismin ile hali (Т.п.) ve yaklaşık/ yaklaşıklık anlamı veren edatlarla: Около двадцати человек остались- Yaklaşık yirmi kişi kaldı.

$>$ Deyim formlu kelime gruplarıla: Мало кто способен это сделать-Bunu çok azı / az insan yapabilir.

\section{Rusçada Eylemci (Субъекm) Kavramı ve Eylemciyi İfade Etme}

\section{Yolları}

Rusça bir cümlede eylemci (субьекm), eylemi gerçekleştiren aktif bir karakter veya nesneye işaret eden özneden (подлежающеe) farklı olarak, çoğunlukla aktif (faal) olmayan bir kişiye (bir eylemin, hareketin taşıyıcısı veya dışarıdan etkiye sahip bir nesne) olarak tanımlanmaktadır. Dolayısıyla dil bilgisel ifade araçları özneden farkl11ık göstermektedir.

Yapılan tarifle de uyumlu olarak bir eylemi, durumu gerçekleştiren ya da bir eylemin, durumun taşıyıcısı olan kişiye (nesneyi) işaret eden sözcüklerle ifade edilen eylemci kimi zaman tek öğeli (bileşenli) bir cümlenin isim veya edat-durum formlarıyla gösterilebilir: Осень- Sonbahar; Дожљь- Yӑ̆тиг; Отношения между коллегами- Meslektaşlar arası iliş̧kiler.

Bunun yanında eylemcinin öne çıkan ifade araçları ise ismin çeşitli hallerdeki formlarıdır (ad durumları). Örneğin eylemci, ismin yalın hal (И.п.) formları ile ifade edilir ki bu formlar genellikle hem özne hem de yüklem içeren cümlelerde açığa 
çıkmaktadır: Наступила осень- Sonbahar geldi; Мальчик здоров- Çосиk sağglklı(dır). Yine ismin farklı hallerinde farklı şekillerde karşımıza çıkan yapı, çeşitli kaynaklar ve de özellikle Glazunova 'Grammatika russkogo yazıka' eserinde yer alan bilgiler ışığında aşağıdaki gibi kategorize edilebilir [408, s. 127-128]:

$>\quad$ İsmin -in hali (Р.п.) formlarıla: У меня нет времени-Zamanım yok; Не прошло и недели- Bir hafta bile olmadl/ geçmedi; Больного лихорадиm- Hastanın ateşi var.

$>\quad$ İsmin -e hali (Д.п.) formlarıla: Мне скучно- Siklliyorum; Больному стало хуже- Hasta daha da kötüleşti.

$>\quad$ Pasif yapılarda ismin -ile hali (Т.п.) instrümental formlarıyla: Исследование проводится ассистентом- Araştırma asistan tarafindan yürütülüyor; Проект разработан архитекторами- Proje, mimarlar tarafindan tasarlandi.

$>\quad$ İsmin -de hali (П.п.) formlarıla: В городе беспорядки- Şehirde isyanlar var; В семье всё хорошо- Ailede her şey yolunda; В душе тоскаİçimde (ruhumda) sıkıntı var.

\section{Rus Dili Dizgesinde Eylemci Modelinin Semantik Alanları}

Eylemci (субьекm) modelinin ifade yolları ve araçları, söz konusu araçlar ve de örnekler 1şığında değerlendirilmeye çalışılmıştır. Bu bağlamda Rus dili dizgesinde eylemcinin semantik alanlarının, kiplik (model) anlamlarının irdelenmesi hususuna değinme ihtiyacı doğmaktadır. Bu noktadan hareketle eylemci (субьекm) modelinin, stilistik (üslupbilim) hususlara da dayanarak açığa çıkan çeşitli anlamları ve bu anlamların işlevselliği özellikle dikkat çekicidir.

İsmin -e hali (Д.п) formlarıyla ifade edilen eylemci, içsel (duygusal veya entelektüel) bir durumu veya dışarıdan gelen fiziksel bir etkiye vurgu yapan zarflarla 
birlikte, genellikle fiilin mastar formuyla karşımıza çıkabilir: Ему трудно ходитьYürümekte zorlaniyor. Yine zarflar söz konusu olduğunda ve bu zarflar karşılaştırma, derecelendirme gibi durumlarda kullanıldığında kimi zaman bir mastar yerleşebilir; kimi zaman ise mastar olmadan da ifade edilebilir: Нам было трудно понять информацию в брошюре- Broşürdeki bilgiyi anlamakta zorlandık/ broşürdeki bilgiyi anlamak bizim için zor oldu.

Olması gereken bir durum ya da eylemcinin gerçekleştirmesi gereken bir eyleme işaret edildiğinde, zarf yapılarıyla karşılaştırmalı derecelendirmenin yanında надо (необходимо) yapılarının kullanımı dikkat çekmektedir. Böylesi durumlarda cümle karşımıza şu şekilde çıkabilir: Раньше вам надо было идти в банк- Bankaya daha önce gitmeniz gerekirdi; Раньше надо было думать- (Önceden) Daha önce düşünmek gerekirdi. Kimi zaman özellikle de anlatı cümlelerinde (повествовательное предложение) bu gereklilik ya da zorunluluk anlamları mastar yapılarla da işaretlenebilir.

Надо (необходимо) ile kurulan yapılar cümle içerisinde potansiyel bir tavsiye niteliği taşıyabilir. Bu durum eylemin gerekliliğini vurgulamanın yanında, alternatifler ve de tüm seçenekler göz önünde bulundurularak duruma yönelik söz konusu tavsiye/ öğ̈̆t formunda yerleşmektedir. Karşılaştıralım: Вам сдавать экзамен в пятнииу (bu karar nettir; başka alternatif/ şans olmayacaktır); Вам надо сдавать экзамен 6 пятнииу (bu senin için en iyi seçenek); Вам надо сдать экзамен в пятнииу (geçerli/iyi bir puan almalısın).

Tavsiye/ öğüt anlamının açığa çıktığı bir diğer yapı, bünyesinde kiplik parçacığı bulunduran mastar yapılardır. Ancak burada anlam bir dualite çerçevesinde şekillenmektedir. Şöyle ki, söz konusu yapılarda eylem geleceğe yönelik bir durumu işaretliyor ya da geleceğe atıfta bulunuyorsa bu noktada bir tavsiye anlamından söz edilebilir. Ancak artık gerçekleşmiş, geçmişte kalmış bir durum ya da eylem işaretleniyorsa, böylesi durumlarda bu anlam bir pişmanlık ifadesine dönüşebilmektedir. 
Karşılaştıralım: Тебе стоит сдать экзамен во вторник (прямой совет- direkt tavsiye/ öğüt) - Тебе бы сдать экзамен во вторник (1. dolaylı tavsiye/ öğüt; 2. pişmanlık. Pişmanlığı ifade ederken sıklıkla karşıtlık (muhalefet) ifadesi kullanılır: Тебе бы сдать экзамен во вторник, а ты не сдал- (keşke) salı günӥ sinava girseydin/ salı günü sinavl verseydin, ama yapmadın [408, s.133].

Eylemcinin belirli bir eylemi gerçekleştirme noktasında sahip olduğu yetenek ve becerilere vurgu yapan мочь/смочь vе уметь fiilleri semantik bazı farklılıklar içerdiği gibi, bağlama (konteks) dayalı olarak işlevsellik noktasında da ayrışmaktadır. Çeviri süreçlerinde önemli rol oynayan özne ve eylemci, bu tür cümlelerdeki konumuyla da ayrıca önemlidir.

Мочь/смочь fiili, eylemcinin kimi eylemleri gerçekleştirme noktasında sahip olduğu fiziksel ve zihinsel yeteneği gösterir ve karşımıza Я могу yитать- okuyabilirm (здесь достаточно светло- burası yeterince aydınlık) gibi cümlelerde çıkabilmektedir. Ancak уметь + несов. вид (bitmemiş fiil türü) / суметь + сов. вид (bitmiş fiil türü) yapısı, eylemcinin belirli becerilere sahip olduğunu, yani herhangi bir eylemi gerçekleştirmek için eğitildiğini (bu alanda eğitim aldığını) bildirmektedir: Я умею читать по-русски- Rusça okuyabiliyorum. Я сумею решить задачу- Sorипи çözebileceğim [408, s. 134]. Можно (нельзя) zarfları ise, eylemi gerçekleştirme noktasında başka bir eylemcinin izni veyahut yasağına vurgu yapmaktadır: (Мне) нельзя читать эту книгу- Bu kitabr okuуaтат (мама не разрешает- annem izin vermiyor).

Stilistik açıdan bakıldığında, eylemcisi ismin -e hali (Д.п.) formunda bir isimle ifade edilen mastar yapıların genellikle daha bürokratik ortamlarda, resmi konuşmalarda ve kamusal diyaloglarda tercih edildiğini söylemek gerekmektedir. $\mathrm{Bu}$ tür konuşmalarda açığa çıkan model (kiplik) anlam kategorik bir emir ifadesidir: BceM провожающим покинуть вагоны- Tüт sakinler vagonlart terk etsin (boşaltsın); Bce прожающие, пожалуйста, покиньте вагоны- Tüm sakinler, lütfen vagonlarl terk ediniz (boşaltınız); ki bu tür emir anlamı bünyesinde özne barındırmayan fiilin mastar formunda da açığa çıkmaktadır: Bcmamb!- Ayă̆a kalk! Bu tür yapılara emir- komuta 
zincirinde öne çıkan keskin ve de kategorik emirler olarak da rastlamaktayız.

Кого (чего?) нет когда? (где?) yapıları eylemcinin belirli bir yer veya zamanda yokluğunu ifade etmektedir. У кого (у чего?) есть что? (нет чего?) yap1lar1 ise, nesnenin belirgin bir özneye ait olduğunu veya ondan yoksunluğunu işaretlemektedir. Eğer nesne, öznenin içinde bulunduğu dış dünyanın bir olay ya da durumunu belirtiyorsa, кому (чему?) есть что? (нет чего?) уapıları kullanılmaktadır: Емунет спасения (спасение не зависит от субъекта- kurtulma eylemciye bağlı değildir) -

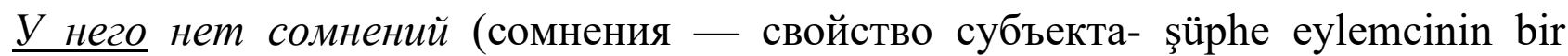
özelliğidir) [408, s. 137].

Как она себя чувствует? - Она болеет- O kendini nasll hissediyor? hastalanıyor; Она плохо себя чувствует- O kendini kötü hissediyor; Ей все время холодно- Sürekli üşӥуоr; Унеё высокая температура-Ateşi yüksek gibi cümlelerde görüldüğü üzere eylemcinin fiziksel ve duygusal durumuna işaret edilmektedir. Rusçada eylemcinin içinde bulunduğu durumu ifade ederken sıklıkla ismin hal formları kullanılmaktadır. Zira böylesi cümlelerde eylemcinin durumuna dair verilen mesajın yanında инволютивность- istemsiz anlamı da açığa çıkmaktadır [409, s. 9]. Инволюнтивные предложения (Latince involens- istemsiz, kasitsı) cümleler, eylemcinin iradesinden bağımsız olarak istemsiz bir durumu aktarmaktadır: Eŭ страшно- korkuуor [409, s. 122-131 \& 7, s. 67].

İçsel bir ihtiyacı işaretlemek için не хватает/не хватит fiilleriyle kurulan ve ismin -e halinde (Д.п.) yerleşen yapılarda ayrıca (кому (чему)? нужно ...) ifadeleri açığa çıkmaktadır: В Турциии в университетах не хватает преподавателей: Türkiye'de üniversitelerde yeterli ögretim elemanı yok/ Türkiye üniversitelerinde ögretim elemanı yetersiz. Şayet gerekli olan/ gerek duyulan bir nesne veya parçanın harici bir yokluğu işaretleniyorsa, böylesi durumlarda ise ismin -in hali (Р.п.) уa da ismin -de (П.п.) hali formları kullanılmaktadır: У рубашки не хватает пуговииGömleğin düğmeleri eksik; В журналах не хватает страниц- Dergilerde eksik sayfalar var.

He parçacığı olmadan kurulan хватает/ хватит yapılarında, 'yetersiz/ yeterli 
değil' olumsuz anlamının zıttı olarak 'достаточно' (yeterli) anlamı öne çıkmaktadır. $H u$ parçacığı ile birleşmelerde ise bir nesnenin en küçük yapısal parçasını ifade eden bir kelimeden faydalanılmaktadır. Sıklıkla один- bir (1) уa da единый- tek sayıları kullanılırken; eğer soyut bir isim söz konusu ise капля- damla sözcüğü kullanılmaktadır: У тебя нет ни капли таланта-Bir damla (zerre kadar/ bir gram) yeteneğin yok.

\section{Sonuç}

Çalışma süresince öncelikli olarak dikkat çeken nokta, Rus dili dizgesinde özne ve eylemcinin durduğu yer ve semantik ayrışmalarıdır. Rusçayı yabancı dil olarak öğrenen öğrenciler, özellikle de ana dili Türkçe olan öğrencilere Rusça öğretiminde gerek kavram gerekse de kullanım noktasında açığa çıkan karmaşa, söz konusu öğretim sürecini zorlaştırabilmektedir.

Rusça Türkçe dil çifti üzerine yapılan çalışmalarda, özellikle de söz konusu dillerin kaynak/ erek dil olarak çeviri süreçleri ve dönüşümlerinde, dilbilimsel tipoloji noktasında da değerlendirildiğinde genellikle çeviri hataları ortaya çıkmaktadır. $\mathrm{Bu}$ hataların büyük bir bölümü çalışma içerisinde odağa alınan özne- eylemci ekseninde gerçekleşmektedir. Bu noktadan hareketle, genel anlamda aynı şeye karşılık geldiği varsayılan, bu algıdan kaynaklı olarak hatalara yol açan özne- eylemci modellerinin öğretisi üzerinde itinayla durulmasının gerekliliğini açıktır. Ayrıca, Rusça Türkçe dil çifti özelinde, Türkçede eylemcinin daha aktif göründüğü gerçeği de göz önüne alınarak, daha kapsamlı ve de karşılaştırmalı çalışmalara olan ihtiyacı özellikle dikkate almak gerekmektedir. 
DOI 10.46299/ISG.2021.MONO.PED.III.5.3

\subsection{The development of future agrobiologists' foreign language communicative skills}

Nowadays it's important to develop communicative skills for the representatives of different technical and agrobiological specialties meaning future agrononomists and specialists in biotechnologies to be with no doubts very perspective trends of higher educational establishments students' training among others.

According to recent investigations the professional communication skills formation is correlated with the elaboration of adequate behavior style and interaction with colleagues, tolerance, understanding to conclude the atmosphere of respect, reliance for the productive professional and social mobility either in class off-line or distant online regimes involving the resources of professional language Moodle platform courses sources [411], [412].

However the most of researchers do not concretize the means to be applied to reach such aim during the work with technical foreign texts on the practical lessons of professionally oriented English for agrarian engineers. They used to know that technical scientific literature is mostly to be studied in the aspects of its informative contest, logicality, objectivity etc [414].

Basing upon the experiment to be conducted within the National University of Life and Environmental Sciences of Ukraine in the first 2021/2022 studying year term including participation of bachelor's degree program 88 students from the Agrobiological Faculty and the Faculty of Plant Protection, Biotechnology and Ecology there are some conclusions and the adequate samples to be noted in our following report to spread our previous conclusions concerning main stages to develop future agrobiologists' foreign language communicative skills while adding some following seven stages- steps (familiarization and narrowing of the actual professional topics to general one, at which simultaneously several reports are prepared; clarification of the plan, vocabulary, key questions and answers of each of the participants in the future dialogue to avoid coincidences; preliminary formal general dialogue start with constant colloquial cliché; the actual entry into the dialogue 
according to a specific topic; providing dialogue with the elements of the discussion; a reversible asking to specify unpublished pre-prepared items; the formal general ending of the conversation with the stable conversational clichés) with the eighth stage of philological word to analyze the professional terms.[414]

The experience to involve the above named algorithm may be considered to be successful because of the adequate questionnaire in which students evaluated such experience as positive to adapt them to foreign speech.

In order to conduct such experiment some adequate scientific practical methods like explanation, specialized terms and communicative schemes acquaintance, studying the algorithm of action, discerning of terms meaning, stimulating of communicative motivation etc. were applied.

The first conclusion deals with the statement that the future agrobiologists successfully used to develop their communicative skills through important previous traditional tasks which gave background for creative tasks.

We consider that no students' foreign speech developing can not do without concluding some dialogues which combine real life situation and professional agrobiologists' speech or biotech professional terms explanation after working thematic materials manuals out as well as familiarization with basic communicative intentions phrases as well as grammar material repetition involving biological thematic enrolment like recognition of modal verbs, if-clauses, passive voice or other grammar phenomena in some statements like «....The skilled agronomist must check the degree of fruit maturity without faulties....All people must, had to and we'll be to get life vigor to survive like seeds...You ought to soak seeds in water overnight....You can, could and will be able to end dormancy of these seeds...It may, might and will be permitted to be too cold for seeds to germinate...If he comes, we will together cover seeds while soil raking... When he came, we would together cover seeds while soil raking....A new seed variety is improved by him.... Sowing methods are improved by our agronomists every season. ....They were improved by him last spring. ...Consumer's interest in bulk order will be improved by them next autumn...Buds are always cut before they flower by him.... Sowing methods are improved by us....The 
situation with seed aeration can be improved by me» etc or answering thematic questions like «What is biotechnology and what are its colours? How can genetically modified organisms help farmers? How do consumers feel about genetically modified organisms in your country? What does biotechnology deal with in general? What nonfood products come from plants? Why is good soil important? How do farmers plant seeds? What do seeds need to grow? How do plants change as they grow? What function does each part of plant serve? What are the main agricultural operations? What are agricultural crops to add fruit and vegetables categories?» or filling gap exercises up like «increasing the size of a harvest is ... and...is a test of the effects of a product the ability to use minimal nitrogen is...and ...is able to withstand dryness organism produced by genetic engineering is... and b...... can resist herbicides. Laboratory ... suggests that the product is safe.... seeds counter pest population and... seeds let farmers kill weeds. Scientists are enhancing desirable... and some farmers prefer...to GMOs.... is the appearance of a trait and...making a copy of an organism....is a segment of DNA and ... is a banning something....is altering genetic material and... having artifically introduced genetic material....can create stronger anomals and there is a strict $r$......of genetic research. There are many... about cloning and Robert wants to work in the... field, ....A crop that grows underground is... and ... is a crop to produce grain,... is a material made of small pieces of rock and mineral and... is a material that is deposited by water. Those... will grow into flowers and plants absorb nutrients from the soil with their.... and...is a strong plant that is grown for its seeds.......is a substance added to improve soil and...is a method of scattering seeds, .... is a crop that has pods and... is crops that have been gathered....is rock and mineral that eventually form soil and is the size of particles in a soil.... The farmer used...to improve soil and the weeds died after Mary used.......It is still too cold to plant the seeds- the ... is 25 degrees.... is a type of large sweet fruit and... is a group of farmers selling crops....is a firm outer layer of a seed and to... is to sprout from a seed....During droughts the...can be blown away by strong winds and the farmer was pleased to have 90 percent... of newly planted crop...The field's... is 10 pounds per 
acre and each plant has a different number of days until it can be harvested...» etc.[414]

It's worth to say that the theoretic above named tasks are necessary as the background of the further creative tasks as well as concluding own sentence concerning different grammar rules with the used professional terms words representing of which may be introduced in two ways.

The first of such ways is mentioning only English variant predicting further English explanation like crossword concept definition exampling such English variants as genetic engineering,transgenic organism, biotechnology application, gene enhancement, regulation, plant traits, herbicide-resistant, animal performance assessment, conventional seed, GMOs, insect-resistance, yield enhancement, nitrogen efficiency, weeds, biotech seed) or mentioning native language parallel variants (like acidity- кислотність, abundance- велика кількість, to adjust- регулювати, against pests- проти шкідників, agriculture - сільське господарство, agricultural operations- c/2 dï̈,amendmentпокращувач, animal husbandry-тваринництво, апnиаl- щорічний, annualsоднорічні рослини, aromatic variety- ароматний сорт, barley - ячмінь, to beat fruit- плодоносити, beеt- буряк, bitter variety- гіркий сорт,blossom- ивіт, branch- галузь або гілка, broadcast seeding-трансмісійний висів, biennialsдворічні рослини, buckwheat -гречка, bud- брунька, to bиy-купувати саbbageкаnуста, cauliflower- иявітна капуста, сапе-стебло або тростина, cellклітина, cereals- зернові, clay- глина, combine harvesting- механізоване збирання врожаю, to change- змінювати, to check - перевіряти, to check weedy growth- здійснювати стримуючий вплив на рicm бур'янів, to chooseобирати, to соver- покривати, сrор rotation - сівозміна, coulouring intensityінтенсивність забарвлення, сrop growing- рослинництво, cross-pollutionперехресне запилення, сrисіfers- хрестоцвіті. сиситber- огірок, сrитb and peel density- щільність м'якуша і шкірки, to deal with- мати справу з, to demand- потребувати, dense- щільний, to determine-визначати, dill-кріn, to dig- копати, disease -хвороба,draught- resistant- посухостійкий, to dry out- 
висушувати, emergence- поява сходів, eggplant- баклажан, farmer's incomeприбуток фермера, to favour-сприяти, fertile- pодючий, fertilizingудобрення, fertilizer- добриво,fodder plants- кормові рослини, garlic-часник , to germinate- проростати,grain crops- зернові культури, grains -зернові культури, greепhоusе- теплиця, to grow-вирощувати, hard coat- икарапупа, harvest - урожай, to harvest- збирати, horse-raddish - хрін, horticultureсадівництво, hоse- иланг, hotbed- парник, hое- сапа, to hoe- сапувати, immature- незрілий, іпосиlate- щзепити, irrigation- зрошення, leguтеs- бобові, liquid- piдина;lime - вапно, loam- суглинок, тапиre- добриво, marshy заболочений, miscalculation- хибні розрахунки, to тіх- змішувати, таrrow, mature-дозрілий, nutrients- поживні речовини, onion- цибуля, oat- овес, to overwinter- перезимувати, parsley- петрушка, реа- горошина, реапитapaxic, peаch-персик, perennials- багаторічний, persipitation- onaдu, plant density- щзільність насаджень, plum- слива, pear- груша, pest- шкідник, picking time- час збору урожаю, to plant-садити в землю, plot- город (присадибна ділянка), plowing- оранка, pod-стручок, рот-вазон (горичик), pollution- забруднення або запилення, powder- порошок, роwns- пасльонові, to predict- передбачити, to prevent- запобігти, to рrипе- обрізати гілки, raddish- редuc, rainfall - достатня кількість опадів, rainfall -fed вологолюбивий, rake-граблі, to ram-утрамбувати, to release-розпушувати, to rake- згрібати. resistant- стійкий, to ripe- дозрівати, ripening proofознака стиглості, ripen- дозрілий, root-корінь, root out-викорінювати, rowрядок, гуе- жито, sеed- насіння, seеdbed- рілля, seedbed preparationnідготовка до посівної, seed drill- точний nociв, seedling, silt, sowing methodsметоди посіву, soil- грунт,shoot- паросток, shoot gapping- проріджування сходів, ), to soak- замочувати, to sow-сіяти,spade-лопата, spider plantповзуча рослина, spraying- обприскування, sprout- проростання, stemстебло, straw- солома, sulfur- сірка, to support- niдтримувати, surfaceповерхня, tangerine - мандарин,tillage -обробіток грунту, tор- гичка, tор soil- поверхневий шар-грунту,tuber- бульба, vine plant- в'юнка рослина, 
water-вода,to water- полити, weed- бур'ян, wheat- пшениця, windraw harvesting- немеханізоване збирання врожаю,winter-killing- вимерзання , winter wheat- озима пшениця, towithstand-витримувати, yield-yрожай yield growth- приріст урожайності, thallus - слоевщще (одноклітинне, багатоклітинне або диферениійованне на клітини тіла водоростей, грибів, лишайників, та подібних)ропdscum - ставкова піна,tissuе - павутина або тканина,отnivore - всеїднаістотарира - лялечка,отпіvorous всеїдний,algae - водорості, bivalve - двостулковіоffspring - виплід,nисleus ядро,larva - личинка,kelp - ламінарія,hibernation - зимова сплячка, greenhouse effect - парниковий ефект,to hatch - вилупитисяtentacles щупальияя ,flock - зграя, natural selection - природний відбір,embryo ембріон, diversity - різноманітність, cell - клітиннаabsorption - поглинання binary fission - подвійне диханнясhloroplast - хлоропласти,deciduous plant листяна рослина,cloning vector- вектор клонування,DifferentiatedCells диференційовані клітини,DNA Sequencing- секвенування ДНК,Gene Cloning - клонування генів,Genetic Engineering-генетичнаінженерія,Gепе Expression-експресіягенівGenetically Modified Organisms- генетично модифікованіорганізми,TransgenicAnimals-трансгенні твариниShort Tandem Repeats (STRS)-короткі тандемні повториIn vitro Mutagenesisмутагенезін-вітро, NuclearTransplantationядерна трансплантаціяPolymerase Chain Reaction (PCR)-полімеразно ланцуюгова реакиія,Recombinant DNA-рекомбінантна ДНК Restriction Fragmentsфрагменти обмеження, enzyme-linked immunosorbent assay (ELISA)імуноферментний аналіз,Insect-resistant crops-cmійкі до комах культуриMolecularbiology-молекулярнабіологія,Plantbreeding-селекція рослин,Plantpests-икідникирослин,Selective Breeding-вибіркове розведення,Insecticide resistance-стійкістьдоінсектицицівGeneflowпотікгенів,Agricultural Biotechnology-c/2 біотехнологія, Allelicexclusionалельневиключення,aminoacid-амінокислота,acetic-yксусна кислота,washing - мийний засіб,vortex - вихрова мішалка, alcohol - 
cпирт,algae - водорослі, lactic-acid-молочно-кислі бактерії, callus - калюс ,catabolism - катаболізм, cellcultured - культивованакультура клітин, daтаge - пошкодження, diploid - диплоїд, писlear - ядернаДНК, donation віддача, передача, adverse effect - несприятливий, ехоп - екзон, extraction екстракиія,feature - особливість,industrial - промисловий,file - pяд, flask колба, склянка, foodstuff- продовольство, харчові продукти, fungus - грибок, genеsis - походження ,gепоте - геном,теssenger- перенощик еtc.

The choice of the way to represent terms depends upon the level of students' audience and is personally oriented [413].

The background of our further research concerning biotech students' and future agronomists' speech deals with our previous investigations being dealt with the formation of foreign communication culture of the future agrarian engineer to be fulfill in several stages concerning text «Vehicle parts» [414].

Thus we remember that firstly it was a need previous exercise block to be proposed for student's first steps to enter the system of own communicative intentions and reactions through own version presentation and exchanging the reactions with other group-mates. For that purpose the students had to analyze the existing and no existing Ukrainian- English equivalents. At the end of such work we'd recommend to exchange the notes with the done exercise with imaginable colleague to check the another student's answers basing upon the keys- correct answers(to be proposed by scholar) and to comment the accuracy or mistakes using the communicative schemes «Comments and Reactions».

Positive comments were represented in such helping start of phrases as «This work is proper», "You are well done», "No mistakes», «Without negative comments», «Excellent! I have never seen better work than this one ».

Negative comments were represented with such schematic statements as «This work is good in general but pay attention on...», "I noticed only such mistakes in...», «I'm afraid you are mistaken in...», «Please, try to improve... », «Excuse me but be more attentive in ...». 
Working with such communicative schemes we'd pay attention of future engineers on the importance to use some tolerant negative comments and adequate tolerant reaction on them like "Thanks for your comments», "I'll do the best to improve...», "I 'll pay attention on ...», "I'll be more attentive in future...», «I promise I 'll improve these mistakes».

Besides it is in place to stress on need to convince the interlocutor of his thoughts and troubles understanding basing upon usage of communicative scheme «Positive results hope and Understanding». Positive results hope might be expressed through phrases «Don't be afraid! Everything will be done in time», "You'll get all you've planned 》, "We'll do the best to help you», «Your problem will be solved», «You'll reach your aim». Understanding dealt with the usage of such statements as «I hear you!», "Your problem is important for me», "I have enough time to discuss your problem», «Share your troubles», «I understand you», «We'll seek convenient solution for both of us», "Don't be nervous. We'll find the way».

In order to add our future practical observation of the biotech students and future agronomists dealt next stage of previous studying and practical usage of the technical text term system was the task to read, to translate and to add the missed abstracts of the text «Vehicle Parts» too: «There are different types of .... internal combustion engines, external combustion gins, hybrid, steam or jet ones. Let us describe the internal combustion one. Internal combustion is the process of ... within the engine combustion chambers. Stationary engine parts are the cylinder block, the crankcase and the cylinder head. The cylinder block is one of the basic ... of the engine. Rotary engine... are the crankshaft, the flywheel and the camshaft. The crankshaft changes reciprocating motion of pistons to rotary motion. The camshaft opens the valves of the engine. Reciprocating engine ... are pistons, valves, rings and connecting rods. These ... cause engine vibration. The piston moves up and down within the cylinder. The rings provide ...compression for the piston. The valves open and close the combustion chamber where the burning of fuel takes place. The connecting rod links ... There are four separate ... of engine: electrical, fuel, lubricating and cooling. The gasoline engine has no pump but carburetor to transmit mixture of fuel and air to ... . Oil pumps 
of ... kinds provide lubrication. The oil filters reduce engine wear. The strokes of ... are intake, compression, power and ...».

After that work future agrarian engineers started to express own agreement ( $I t$ is true », «It's correct», "I agree », "I 'm glad to support the thought about...», «I 'm glad to support the statement about...») or disagreement (Sorry, but it seems to be false», «Sorry, but it seems not to be correct», «Sorry, but I must disagree», «I'm afraid I can't support the thought about...», «Sorry, but I can't support the statement about...»).

We'd recommend to regard the previous tasks as the stage to prepare any future biotech student a and future agronomist's foreign speech development in close connection with the task for agrarian engineer to choose redundant and combining terms and to represent his choice for the discussion through «Model: Look! I think that the word to be missed is «crankcase» (№1). Also I think that the word to combine meaning of others is «systems» (№5). Am I right?».

To fix the usage of terms system in own speech was fulfilled through the set of questions to be asked (1. What are the kinds of engines? 2. What are the main parts of internal combustion engine in general? 3. What is internal combustion? 4. What are strokes of internal combustion engine? 5. What are systems of internal combustion engine? 6. What do oil filters do? 7. What are titles of various engine parts? 8. What are titles of various parts of vehicles?) with the possibility to discuss separate version in collective body using the model «Internal combustion is the fuel burning within the engine (№3). Am I right?».

The mentioned work might be in the form of creative retelling or own separate versions representation to be further generalized in subgroup reporting dialogue starting from the first adaptive versions up to the complicated improved samples.

To illustrate such statement we'd propose student works exampling topics «GMO», «Biotechnology» as well as «Seeds», «Soil» or «Plant Growth» on the basis of foreign writer's book «Agriculture» to be fixed in two e-learn courses to be placed on Moodle platform [413], [411], [412]. 
There were several variants to introduce «GMO» topic in some dialogues varieties.

The first sample of «GMO» topic dialogue deal with such replicas as «-Hello. Hello. - How are you doing? - Great, I after all got a cat, moreover as two catsWhat did you call it? -V and Tani- Such interesting names- What's about you?Also great, on weekends I want to go out of town to friends-That's coolWhy did you get me? - I wanted to discuss a few issues with you.-Oh, great -So, what are the challenges of agricultural bioengineering?

Well consumers fear that genetically modified foods are not safe-Should not people be worried a bout eating genetically modified food? - Notatall. The science says that genetically modified food is safe to eat. We just need to do a better job of communicating this with the public. -What do you think will happen? - We need to educate the public about genetically modified foods? In some countries consumers have been very vocal. We have responded by increasing their regulation of agriculture. In some cases, they have responded by prohibiting all genetically modified products. This is not what we want to be.- Of course not. Thank you for the conversationThank you, too- You want to go to lunch with me? - Yes, with pleasure.- Good then at 1 a.m. in the lobby-Ok, See you soon-Bye- bye» or «-Hello. What brought you here?: Hi. I came to you to tell you about my invention.- Carol, please come in. I understand your new seed is almost readyformarketing.- $\quad$ It is. After the animal performance assessments, it will be ready to go.- Wonderful. Tell me all about it I want to know the best way to advertise it.- Well, the main benefit is that it's extremely drought-resistant Okay. So we'll do well selling it to farmersindryregions.- Yes. We'll target talials where rainfalls are unpredictable.- Okay. What else?We should emphasize the dependability of our seed.

Tests showed that the yields produced during rainy seasons and those produced $d$ uring droughts varied very little and they're better for the environment than conven tional seeds.- How?- With fewer crops failingduring drought seasons, 
there'll be greater yields. That means this land will the used per season.- Excellent, Carol.- Can you sell my seeds as the mostexpensive?-Of course, the development is very good. I 've already known who to offer your invention to.Thank you. Goodbye!- Goodbye!» or "- Good day, how are you? - Good day, I'm fine. And you?-I'm fine too. What are you going to do now? Do you have a little time for me?- Oh, I'm going to drink a cup of coffee. - Fine! Can I have coffee with you and ask a few questions?- Of course. I will be glad.- So, what are the challenges of bioengineering?- Well, consumers, because of their ignorance and each of interest just fear that genetically modified foods are not safe.-So, you consider that people shouldn't be worried about eating genetically modified food?- Exactly. The science says that genetically modified food is safe to eat. We just need to do a better job of communicating this to the public.- What do you think will happen if you don't educate the public about genetically modified foods? - If some countries consumers have been very vocal. Some governments have responded by increasing their regulation of agriculture, what is not correct in some cases, they've responded by prohibiting all genetically modified food what made people believe that they were right and this products are dangerous. This is not what we want to happen.- Of course not! I'll take care of it, so my company will. You' re hired, I need more employees like you.- Thanks, I appreciate that. I'll do my best.- Hope so, I have great plans on you, don't disappoint me.- Ok. Sorry, I don't have any more free time.- That's ok. Good bye!-Good bye!» as well as: Good day, how are you? - Good day, I'm fine. And you?- I'm fine too. What are you going to do now? Do you have a little time for me?- Oh, I'm going to drink a cup of coffee -Can I have coffee with you and ask a few questions?- Of course. I will be glad.- So, what are the challenges of bioengineering?-Well, consumers, because of their ignorance and each of interest just fear that genetically modified foods are not safe.- So, you consider that people shouldn't be worried about eating genetically modified food?-Exactly. The science says that genetically modified food is safe to eat. We just need to do a better job of communicating this to the public.- What do you think will happen if you don't educate the public about genetically modified foods? - If some countries consumers have been very vocal. Some governments have responded by 
increasing their regulation of agriculture, what is not correct in some cases, they've responded by prohibiting all genetically modified food what made people believe that they were right and this products are dangerous. This is not what we want to happen.Of course not! I'll take care of it, so my company will. You' re hired, I need more employees like you

The second sample of «GMO» topic dialogue deal with such replicas as «- $\mathrm{Hi}$, do you know any professional concepts definitions?-Yes, I can tell you that fusion proteins or chimeric (kī-'mir-ik) proteins (literally, made of parts from different sources) are proteins created through the joining of two or more genes that originally coded for separate proteins. Translation of this fusion gene results in a single or multiple polypeptides with functional properties derived from each of the original proteins. Recombinant fusion proteins are created artificially by recombinant DNA technology for use in biological research or therapeutics. Chimeric or chimera usually designate hybrid proteins made of polypeptides having different functions or physicochemical patterns. Chimeric mutant proteins occur naturally when a complex mutation, such as a chromosomal translocation, tandem duplication, or retrotransposition creates a novel coding sequence containing parts of the coding sequences from two different genes. Naturally occurring fusion proteins are commonly found in cancer cells, where they may function as oncoproteins. The bcr-abl fusion protein is a well-known example of an oncogenic fusion protein, and is considered to be the primary oncogenic driver of chronic myelogenous leukemia.-Thanks, I appreciate that. I'll do my best. - Hope so, I have great plans on you, don't disappoint me.- Ok. Sorry, I don't have any more free time.- That's ok. Good bye! -»

The third sample of «GMO» topic dialogue deal with such replicas as «- Hello. How are you? - Not bad. Are you ready to start an interview?- So of course, I want to talkmore about genetically modified food - So, what are the challenges of agricultural bioengineering? - Well, consumers are scared that genetically modified food is not safe.- Should people be worried about eating genetically modified food? - I think that fears are in vain. The science says that genetically modified products safe to eat. 
We just need to do a better job of communicating this with the public .What do you thinkwill happen if you don't educate the society about genetically modified foods?

In some countries consumers have been very vocal. State establishments there responded by increasing their regulation of agriculture. In some cases they have responded by prohibiting all genetically modified prod ucts. !- Thank you for the interview. It was a pleasure to talk about an important topic today. -Which kicks the whole world.Thank you too. It was nice to spend time. See you! - Bye!» as well as «-HelloHello Carol, please come in. I understand yournew seed is almost readyf or marketing. -Yes, it is. I agree. After the animal performance assessments, it will be ready to go.- $\quad$ Wonderful. tell my all about it. I want to know the best way to advertise it.- Well, the main benefit is that it is extremely drought-resistance- Okay. It is well for farmers in dry regions.- Well done for inventions .-I have another question: how long have you been working on this product.-About three years- Oh, that's cool-Thanks and I suggest going to the café for lunch and and discussing a few more details. -Well then meet at 2 p.m - Okay, see you.-Bye»

The fourth sample of «GMO» topic dialogue deal with such replicas as ««Please come in- Hi. Do you have some time to listen to me?- Yes of course. I understand your new seed is almost ready for marketing.- It is. After the animal performance assessments, it will be ready to go- Wonderful. Tell me all about it I want to know the best way to advertise it.- Well, the main benefit is that it's extremely drought-resistant - Okay. So we'll do well selling it to farmers in dry regions.- Yes. We'll target talials where rainfalls are unpredictable.- Okay. What's else? We should emphasize the dependability of our seed. Tests showed that the yields produced during rainy seasons and those produced during droughts varied very little and they're better for the environment than conventional seeds.- How?- With fewer crops failing during drought seasons, there'll be greater yields. That means this land will the used per season.- Excellent, Carol.- Do you think my invention will be in demand in the market? 
- Of course, your seed has great prospects, but it needs a little refinement. - And how do genetically modified organism help farmers? - We can improve the necessary characteristics in the organism, exampling these seed. Well, the main benefit is that it's extremely drought-resistant. - Okay. So we'll do well selling it to farmers in dry regions.-Yes. We'll target areas where rainfalls are unpredictable.-Okay. What else?We should emphasize the dependability of our seed. Tests showed that the yields produced during rainy seasons and those produced during droughts varied very little and they're better for the environment than conventional seeds.-How? - With fewer crops failing during drought seasons, there'll be greater yields. That means less land will be used per season. - Excellent, Carol.- Can I get any award?-Yes, you can. I give you some free days to have a rest».

Thus the discussing plant products gave basic three version students' dialogues.

It's worth to say that the above named GMO discussing attracted attention to the wide spread topic of not only scientists but every country social community too as well as discussing the role of biotechnology as the to the modern perspective biological science. That was the reason to introduce «Biotehnology» topic in several dialogues varieties too.

The first variant of «Biotechnology» topic dialogue deals with such replicas as «-Hello, nice to meet you-Hi, nice to meet you too. Can I help you?- Yes, you can. Let us discuss real life story concerning biotechnology. I agree, with pleasure. What real life story do you mean? - Well, listen. Once upon a time, scientist Tim decided to take a weekend job because he had been busy writing a science paper, "The Endangered Species», last week. In it, he explored the process of the aclosing butterflies. There are a lot of unfinished tasks in the laboratory. Firstly, he checked the state of the new pea species that his $l$ aboratory had developed.The scientist determined that the plant had entered declev ation phase and the symptoms of $a$ mosaic disease also appeared. So he decided to give drugs and fertilizers. but got tired and went home for a rest.Oh, it's interesting. And what professional terms did you apply in it? 
For example drugs means chemical substances that can change how organism wo rk and fertilizers mean natural or synthetic origin that is applied to soil or to plant tis sues to supply plant nutrients. Other terms are to be specified.-

Thank you for explanation. May I ask you more?- I'm afraid not. I'm short of time. We need to postpone our conversation.- OK, see you later. -Bye»

The second variant of «Biotechnology» topic dialogue deals with such announcement:«-Hello, nice to meet you?-Hi, nice to meet you too. Can I help you?Yes, you can. Let us discuss real life story concerning biotechnology. -I agree, with pleasure. What real life story do you mean? - Well, listen. Once upon a time, scientist Tim decided to take a weekend job because he had been busy writing a science paper, «The Endangered Species» last week. In it, he explored the process of the aclosing butterflies. There are a lot of unfinished tasks in the laboratory. Firstly, he checked how the new pea species that his laboratory had developed was doi ng.The scientist determined that the plant had entered declevation phase and the sym ptoms of $a$ mosaic disease also appeared. So he decided to give in drugs and fertilizers. To improve the condition of the plant that was under threat.-Oh, it's interesting. And what professional terms did you apply in it?- I applied such terms as «fertilizers», «drugs» as well as «declevation» phase. What do these biotech terms mean?- For example «drugs» mean medical substance being used to treat some adequate disease and «fertilizers» mean substances to improve plant nutrition.-And what do you know about a fusion gene?Well, it is a hybrid gene formed from two previously independent genes. It can occur as a result of translocation, interstitial deletion, or chromosomal inversion. Fusion genes have been found to be prevalent in all main types of human neoplasia. The identification of these fusion genes play a prominent role in being a diagnostic and prognostic marker. - Other terms are to be specified.- Thank you for explanation. May I ask you more?-I'm afraid not. I'm short of time. We need to postpone our conversation.-Ok, see you later.-Bye». 
The third versions of dialogue to discuss biotechnology may also be represented as the following statements: «-Hello, nice to meet you.-Hi, nice to meet you too. Can I help you?-Yes, you can. Let us discuss real life story concerning biotechnology.-I agree, with pleasure. What story do you mean?-Well, listen. Once upon a time I attended lecture and learned a lot about biotechnology. Now I know that biotech specialists use living biological organisms, their systems, processes and genetic material, applying scientific methods of genetic engineering, in order to create new varieties of products, plants, vitamins, medicines, as well as improve the properties of existing species in plant and animal environments that are resistant to unfavorable climatic conditions, pathogens and diseases. In medicine, biotechnologists play an invaluable role in the creation of new drugs for early diagnosis and successful treatment of the most complex diseases. -Oh, it's interesting. And what professional terms did you apply in it?-I applied such terms as "genetic material», as well as «pathogen» and «genetic engineering». -What do they mean?-For example «pathogen» means a biological agent that causes disease in another host organism and «genetic material» means carrier of genetic information of any organism. Other terms are to be specified.-Thank you for explanation. May I ask you more?-I'm afraid not. I'm short of time. We need to postpone our conversation.-OK, see you later.-Bye»

The fourth variant of «Biotechnology» topic dialogue deals with «Hello, nice to meet you.-Hi, nice to meet you too. Can I help you?-Yes, you can. Let us discuss real life story concerning biotechnology. - I agree, with pleasure. What real life story do you mean?- Well, listen. Once upon a time my mother and I used to be in Kyiv and we went to a biotechnology laboratory. There I became interested in all the processes, but I liked watch the creation of stem cells. most of all -Oh, it's interesting. And what professional terms did you apply in it? I applied such terms as «stem cells» as well as «cryofreezing» and «differentiation»-Can you give one definition?-Yes, I can.-For example «stem cells» are non-specialized cells that can be used on any cell-Thank you for explanation. May I ask you more?- Yes, you may/-So what are the challenges of agricultural bioengineering? - Well consumers fear that genetically modified foods are not safe.- Shouldn't people be worried about eating genetically modified food? - Not at 
all. The science says that genetically modified food is safe to eat. We just need to do a better job of communicating this with the public. - What do you think will happen if you don't educate the public about genetically modified foods? - In some countries consumers have been very vocal. State structures there have responded by increasing their regulation of agriculture. In some cases they have responded by prohibiting all genetically modified products. this is not what we want to happen. - Of course, not!Thank you for the interview. It was a pleasure to talk about an important topic today. Which kicks the whole world.-Thank you too. It was nice to spend time.-Thanks for answer. See you!- See you later.-Bye!».

As it was shown some above named samples directly combined real life stories with professional terms definitions.

Besides represented version we'd like to represent such interview between. interviewer and speaker as the fifth dialogue concerning with biotechnology «- So what the challenges of agricultural bioengineering?- Well consumers feel fear that genetically modified products are dangerous for our body. Shouldn t people be worried about eating genetically modified food?- Not at all. With recent research, scientists have proven that genetically modified food is safe to eat. We just need to do a better job of communicating this with the public.-What do you think will happen if you don`t tell the whole truth about genetically modified foods? - In my opinion, at present people are not ready to take modified products as something ordinary, but see it as a threat. The government is also not informed about GMO. In some cases, they have responded by prohibiting all genetically modified products. This is not what we want to happen. -In some cases, they have responded by prohibiting all genetically modified products. -But what are basic concepts about plants to be further used while biotech investigations?- For example, I 's like to know about wild and cultivated plants, something about tropism, why plants store starch, reproduction, the use of sunlight by plants for photosynthesis etc. exampling definition of «tropism» as reaction of movement to the stimulus and starch-Thanks for you being interviewed.-See you later.Bye»

Thus the discussing biotechnology gave basic four version students' dialogues. 
It's worth to say that GMO and biotechnology became important for discussion but such discussion was mostly related to the second year students' interest. The adaptive period being related to freshmen demanded search of the more common topics for conversation starting from the agricultural products and processes discussion. That was the reason to unite basic idioms from agronomists' professional speech and communicative intentions for the topic «Plant products and processes» exampling some dialogues .

The first version to discuss plant products may be represented in the next dialogue: «- Hello! Welcome to the farmer`s market. Can I help you with something?Hello! Yes, you can. I want to buy fresh fruit from you.- What fruits are you interested in? = Oranges, apples and strawberries.- These fruits are perfect, we only picked them yesterday.- Oh, that's good! I would also like to buy some potatoes. How much does it cost?- One kilogram costs one dollar.- Good. I will take 3 kilograms.- What else are you interested in?- I saw an ad for you selling cereals. Do you have it?- Yes, we grow cereals on a neighboring farm. What cereals are you interested in?- I need buckwheat and wheat.- It's nice choice-I am interested in the following question.- What exactly?How is your farm preparing for the field?- On our farm fields are prepared for a few months leading up to planting. Fields are tilled with tractors, plows and field cultivators. This softens the soil and aerates it. Fertilizer and nutrients are also added. Weeds are removed through tilling and the use of herbicides.-Thank you for the interesting information!-Total Price: 20\$.-Thanks for your help! Goodbye!Goodbye!».

The second version of dialogue about plant products may be represented in following sample: «Good afternoon! You have such beautiful watermelons! -Oh, yes, these are the best watermelons in Ukraine, brought from the Kherson region -Wow, that's cool! How much do they cost? 5 UAH per kilogram - Can I taste? - Yes, of course, help yourself, please.-Wow, what a delicious and juicy watermelon. Apparently, a lot of effort was involved in growing these watermelons.- Oh yes, firstly farmers sowed seeds and planted plants into the ground, watered, sprayed, weeded, as well as they raked, harvested yield, and now they brought all products to our market.- I can give 
you 3 watermelons for 4 UAH per kilogram. Thanks, let's have three . I'll weigh it now! ... three watermelons weigh 21 kilograms, so 84 UAH are from you.- Here they are, take it, thank you! - Thank you too! we have a wide range of products to attract your interest Yes, I see that you have potatoes, onions, cabbage, tomatoes, zucchini, and all this at a good price, but I'm short of money! No problem, welcome to as next time! Have a nice day - You too, see you later, goodbye».

The third version to discuss plant products may be represented in such dialogue as «-Good afternoon. May I help you-Yes, please. I'm looking for a nice feed for my pigs and chickens. Is there anything not expensive?-For pigs I can offer beet of varieties or carrot as well as millet or maize.- I prefer beets.- The price of one $50 \mathrm{~kg}$ is $25 \$$, the price of the second item is $32 \$$ for $45 \mathrm{~kg}$.- Why is it too expensive-It rained a lot this year. So, weeding, declining and spraying cost a pretty penny.- Okay. I believe you. Can I take $49 \mathrm{~kg}$ of the first kind and 20 of the second one-Sure!- What's about chicken forage?- I offer you ta find corn.- How much does it cost?-10\$ per 30 kg.-I'm buying it.- That's all-Yes, thanks for your help. Have a good day!-You too!» or «-Hello, welcome to our agricultural company. What would you like to know ?-Hi, I'm wondering what crops do your agronomists grow? Thanks for your question. We are focused on cultivation of peaches, apricots and plums- What are your favorite items? Actually I prefer figs most of all.-OK, our partners from the southern Ukrainian region are engaged into such figs cultivation. Wait a minute while we 'Il contact them .-I agree and I'll wait .-Mm, unfortunately, due to the heavy rain the yield suffered a little and they are waiting for the next year for new fig planting-I see. I'll take apricots then.-Nice choice but what are your favorite fruits and vegetables in general?- I like tomatoes, carrots, apple and bananas.-Tomatoes and bananas cost 20 UAH each, apples and carrots cost 15 UAH each. Buy fresh fruit and vegetables for a good price! Ok, I will take 1 kilogram of tomatoes and 1 kilogram of apples as well as above named apricots!- Fine, the opposite offers some industrial crop products, such as hemp shoes, shirts, and hats.-Ok, I will observe them another time. Goodbye.-Thank you for your purchases, see you next time» or «-Welcome to the farmer's market. Can I help you.Yes, please. I want some fresh vegetables.-These tomatoes are perfect-Oh good. I like 
some tomatoes-A three pound bag costi 70 UAH.-I'll take a bag, thanks-Okay. Anything else today-No, I will cook borsht for dinner, so I need $1 \mathrm{~kg}$ of red beet, as well as potato, onion, pepper, cucumber, dill. I think that growing is difficult. You dealt with watering as well as harvesting, transporting to the storehouse, crop rotation planning. -Yes, I am glad that understand me. It will cost 100 UAH for whole order. -Bye-Bye. Come again!» as well as «-Good afternoon -Good afternoon -Do you have ripe tomatoes?Yes, of course, how many kg- How many kilograms do you need?- It will 10 UAH per kilogram Well, give me these tomatoes-So you will like these tomatoes of the best quality».

The update the fourth version of the dialogues to represent plant products would be represented as the following replicas: «- Hi, let as specify the representatives of different plant products items. -Well, I agree but what are they in general? What do you exactly mean?-I mean such fruit as pear, plum, apple, peach, melon etc. and such vegetables as potato, cabbage, tomato, cucumber, red beet etc. -Well, I think that they are known to the majority offarmers to grow and common people to consume. I agree but do you know about the cereals? - Well, I know only wheat. Is it anything else? Yes, There are buckwheat, millet, rice, rye and oats. -Oh, are all of them grown in Ukraine?- Well almost all crops are in need and process of growing and consumption but meaning rice as the experimental crop.- I see, you are so clever.- But what about the berries? - Oh, do you know that the watermelon is considered to be a berry but not a fruit from the agronomist's point of view - Well, it's difficult to adopt such information but tell me please about the titles of real berries? - They are raspberry, blueberry, strawberry, cherry etc. But why is strawberry called in such way because I know that straw is the died grain crop stem?-well, I do not know exactly but may be it's word game-the false translator's friend or may be it means that it's worth to save a proper form of berries without damages while laying straw between the rows.- Oh, nice version but let us specify it according to scientific agronomists' manuals.- Yes we'll be able to take it into consideration but we need to carry philological work out too.-I agree but what do you know about the representatives of fodder and industrial plants?-They are rape, sunflower, maize, sugar beet, clover etc to be mostly used for 
cattle forage or the raw material for the further processing. Well, it's interesting. But may the word nut be used only as plant product title? -It may be used as a false translator's friend too meaning detail to be screwed by technical worker. -I see but can you tell me about main representatives of mushrooms, herbs and nuts themselves?Oh, too many questions I'm tired. Leave me alone please.- I see, sorry to have troubled you. -Not at all, you are welcome but not today. We need to postpone further specification of plant products titles-I agree, bye.-See you later.

Another plot of discussing plant products in general was focused within the fifth dialogue version as«-Hi, what is your thought about visiting farm which grows different agricultural products- Well, I am glad that I have already gained some valuable experience and can even give advice to those who come to our farm to learn the same technolo gies. I advise on the processes of growing lettuce, greenery, melons, celery, cherries, sweet cherries, and peaches. This is my profile -I see but must modern agronomist know different machinery to plant, to cultivate or to harvest plant products?- $\quad I \quad$ am convinced that automation and IT technologies will be necessary for control and optimization in the use of mobile equ ipment tractors, sprayers.

But an agronomist'ss assistant in the field of gadgets can be mobile laboratory to identify certain plant diseases in current regime as well as we in need to obtain weather forecast station because of unpredictable weather conditions.-But is the machinery main in the work of agronomist?.The most important thing will still be the direct presence of a specialist in the field, his observation, experience.-I see but what are your breaks and relax while plant products

growing?-

The profile of our farm does not allow us to relax all year round. Even in winter there are permanent works, for example, in greenhouses. The last time I managed to go home was before the beginning of June. I can visit relatives several times a year, cutting out 4-5 days. However, agronomists we go for Christmas for a couple of weeks.-oh, It's difficult schedule and time-table. 
How long does agronomist's working day last?

Friends and family know that in high season we work almost during seventeen hours a day. Those who are going to become an agronomist, I advise you to prepare yourself for hard work. If you have some doubts about your love for this profession, do not take it. - Do you regret about your choice? I didnot regret mychoicefor a second! Because the future of Ukraine is $100 \%$ agricultural. An IT specialist sitting in an office or a salesman does not feed the country with tomatoes, bread and potatoes. As we do, we are agronomists».

It was also an interesting aspect of dealing plant products with the agronomy in general in such sixth dialogue version as «-Hi, let us discuss agronomy as the science to find the best ways to plant and to cultivate different plant products.-I agree, Agronomy is the science whose objective is to improve the quality of the processes of the production and the transformation of agricultural and food products.-what does agronomy study?- Based on scientific and technological principles, it studies the physical, chemical, biological, economic and social factors that influence or affect the production process.-Oh, you know a lot. But what is its object of investigation? - Its object of study is the complex phenomenon or social process of the agroecosystem, understood this as the specific model of the intervention of the human being in nature, for purposes of production of food and raw material. And do you know that crop growing is an important branch of agriculture as well as animal husbandry but with the larger amount of agronomists to be engaged into it.- They are techniques to produce plant products using the resources provided by nature»

As it was earlier mentioned this discussin plant products attracted much biotech students' interest other versions of discussing plant products selling situation may be represented in such seventh version samples as-« Hi, let s discuss interesting facts about plant products economy.-I agree. Let's start.-Do you know that Ukraine is one of the three world leaders in barley production, is one of the largest producers of sugar beets, and is one of the seven world leaders in sugar production?-I think so.-What 
mathematic calculations are dealing with the agricultural products and their production? -Oh, there are a lot of them to be mentioned. Please announce the first fact.-Well, please know that to accommodate the entire crop of corn grown in Ukraine in one year, you will need 43 Olympic stadiums, or a train with a length of $3700 \mathrm{~km}$.Well, it's interesting but what is the second fact?-You see that Ukraine produces more sunflower oil than the whole world - olive oil: 1852 swimming pools can be filled with domestic sunflower oil. What do you know about nuts?- I know that Half a billion Kyiv cakes can be baked from Ukrainian nuts and every fifth Ukrainian works in the agricultural sector. Oh, you are so clever. May you represent the last mathemetic facts being related to plant products and their producers? - I know that Ukrainian farmers feed 140 million people on the planet and some decades ago the area of Ukrainian chernozem reserves is equal to the area of Great Britain-Oh, wonderful answers.I have never heard better explanation.-Tanks for your attention.-See you later.-Bye» or «Hello -Hello, how can I help you?-I want some potato, do you have it? -Yes, we have. Our potato is the tastiest and the freshest in the market. -How did you grow it? -First of all, we weeded topsoil then sowed tubers and watered. After some week we sprayed against pests and diseases and regularly fertilized. -Nice, I think your potato is great. How much will five kg cost?-Fifty hryvnas. -Also, what fruits you can recommend me?We have many types of fruits: pear, cherry, plum, apple, peach, melon, watermelon, grapes, banana and orange. What do you want?-I'd like to have two $\mathrm{kg}$ of oranges. -It cost two hundred hryvnas.-Oh, it's very expensive for me. Do you have radish and how much it costs? -We have Ukrainian radish, which cost one hundred hryvnas, and European radish, which cost fifty UAH. -I want one kg of Ukrainian radish. -OK, you should pay one hundred fifty UAH.-Here you are.-Thank you».

Thus the discussing plant products gave basic seven version students' dialogues.

We can not avoid topic «Soil» because land is the the main treasure of society to represent adequate dialogues too on the basis of some theoretical data to connect the sphere of land management with agronomic interst several versions too. 
The additional material dealing with land for agronomists was transfored from the electronic course for future land managers[412] mentioning working the next abstacts out: «Land cadastre describes the plot from the material point of viewr Land cadastre deals with land bonitet inventory. It is the list of land properties and its quality evaluation for cost definition like soils boning. Cadastral map may be periodically changed due to repeated cadastral photoplan surveying data to conclude general land management project. -Thus, every land manager must know about 9 categories of land purpose being described in Article 19 of the Land Code: 1) farm use land; 2) the land of residential and public buildings; 3) the land of natural reserve and other nature conservation purposes; 4) land of sanitary purpose; 5) recreational resort use lands; 6) land of historical and cultural destination; 7) forest plants land; 8) the land of the water fund; 9) industrial use lands, transport use lands, communication; energetic lines use lands, defense use lands etc. -Also land cadastre pays attention on bad degradated land and arable land.

A land manager deals with environmental protection in general and with soil and land protection. Soil is the surface layer of the earth on which land plants grow. Its protection involves soil rational use, soil stabilization, land melioration, land recultivation through fertilization, irrigation and crop rotation apartly.

A land manager must know about such kinds of soils as clay, sandy, peat, silt, soil and rock soils, saline soils, highly organic land( black soil), loam containing sand, clay and organic matter etc as well as methods of soil conservation like rotation of cover crops or green manure with other crops, planting windbreaks to stop topsoil loss from wind, perimeter runoff control to prevent erosion as well as grassways or plowing rows perpendicular to the hills.

A land manager must detect the samples of bad unproductive lands and must be able to detect and to map marshland, brook or lake basin, estuary, preserve, gardens and fields, grasslands and meadows vineyards for every separated locality area. He must know about drio irrigation system ti prevent overwatering during rain or high wind.[412]) 
The adopted, retold dialogue was be adapted and mentioning in the first version dialogue being dedicated to soil problems dialogue: «- Good afternoon!-Good afternoon!- Welcome to our store! How can I help you?- I have a question. Why is good soil important?-Good soil is the key to a good harvest, the better the soil, the greater the harvest. The parent material is also very important.- Thanks! Can you please give me 3 kilograms a soil for citrus.- 3 kilograms cost 30 UAH. Anything else today?- No. I will planted tangerine, so I needs 1 kilograms of humus as well as loam, sand and clay.- Tangerine need good parent material and beautiful aeration. It will cost 95 UAH per whole order.- Thank you very much but can you tell me about the main types of soil?-There are such kinds of soils as clay, sandy, peat, silt, soil and rock soils, saline soils, highly organic land ( black soil), loam containing sand, clay and organic matter etc.-You are so clever but what are the methods of soil conservation? -There are some methods of soil conservation like rotation of cover crops or green manure with other crops, planting windbreaks to stop topsoil loss from wind, perimeter runoff control to prevent erosion as well as grassways or plowing rows perpendicular to the hills. At school we were told about the importance of soil conservation. For a good harvest, people need to know what to plant. The land manager must identify suitable planting areas. Soil is the surface layer of the earth on which land plants grow. Its protection involves soil rational use, soil stabilization, and land melioration, land recultivation through fertilization, irrigation and crop rotation apartly. - But must every biotech student know about soil?-Yes, he must be able to distinguish such kinds of soils as clay, sandy, peat, silt as well as irrigation system to prevent overwatering during rain or high wind». Other samples of students' dialogues being devoted to soil are in following variants: «Hi, Mike. May you borrow me textbook «Soil»?-No, because I need it myself. Can I help you more ?- Yes, can you tell kinds of soil in general and in native region?- They are clay, sandy, peat, silt, soil and rock soils.What are your favorite words according to topic«Soils»? - I liked such terms as «clay» and «soil recultivation». - OK. And what is adequate conversational situation applying these terms?- Once upon a time a land manager worked with clay. For this he needed to study the land code. Only then could he work with clay, peat, estuaries. 
The customer liked his work and he decided to conclude a vineyard map with him. And what happened further? Well, next time my dad decided to write an article about soils. He got acquainted with different types of soils. The surface layer of the earth consists of clay, sandy, black soil, loam, saline and green manure. He also wrote about the rational use of soil and soil stabilization to reduce the amount of bad degradated land. Thus, he brought people together to protect the soil» or «Hello, do you know that soil is the upper layer of the earth?-Yes, but what kind of soil is there in your country?There are such kinds of soil as forest steppe, black soil as well as silt, sand, loam, etc.You are clever. Well done.-Have you ever planted any crop into soil? Yes, I have an practical experience to sow wheat, barley, maize and buckwheat. -And have you ever observed real soil samples? Yes, a little bit and have already know that the sample from the north field had a lot of sandy soil in it and poorly suited for growing any crops despite this type of soil quickly warms up, aerates well, is easily processed, but at the same time it cools quickly, dries up soon, and weakly retains mineral substances in the root zone.-Thanks for your answers.-Not at all. You are welcome»

The second version of the dialogue about the soil was involved into the following phrases: «-Welcome to the farmer's market. Can I help you.-Yes, please. I want some good soil.-I have a question "Why is good soil important?-Healthy soil is the background of productive, sustainable agriculture-Thanks. I will take two bags.-A two bags cost 70 hryvnia. Anything else today?-No. I will plant flowers, so I need $1 \mathrm{~kg}$ of humus as well as clay, loam, and sand.-Flowers need good soil parent material and beautiful aeration.-Thanks for the advice.-it will cost 200 UAH for whole order.-Bye!Bye. Come again!» or dialogue like «-Hello, agronomist, I want to ask you about recent 2021 yield.- Hi, this year was actually dry and central Ukraine was hit by hot weather and more adequate weather conditions are more desired for crops to withstand. -But what type of soil is more suitable for maize?-The best soils are nitrogen rich chernozems, loams and sandy soils. Therefore drought leads to yield decreasing and there must be some steps to improve soil like improvement of soil structure, creation of optimal conditions for the growth and soil aeration» . 
The third version dialogue about the soil may be introduced in such dialogue as «Good afternoon!-.Good afternoon! - Sir, can you tell me how to properly care for the soil?- And what exactly are you interested in, do you have any problems?- Yes, I am a young agronomist, but I have a problem with the soil. It is too dense. That is why I want to address you as an experienced agronomist.- Well, I understand well, it's a very long process.- I still have a lot of time to pass the job- In wet weather, yields decrease with any increase in compaction. Soil compaction in wet years reduces aeration, increasing denitrification. The risk of root diseases may also increase. All of these factors add stressto the crop and ultimately lead to crop loss. so, and what's next.- When soil compaction increases above the optimum, yields begin to decrease. In dry years, soil compaction can lead to plant growth retardation. Without timely rains and timely fertilizers, yields will decrease.- Okay, thank you very much!- Please, goodbye!».

The fourth kind of soil dialoguemay be noted as the next one: «-Hello, can I ask you some questions?-Hi, of course.-First of all, what type of soil have your fields?Our fields have only loam. For our opinion it's one of the best types of soil because loam has good aeration and holds water well. -What is about sand or clay? -Sand is a material made of small pieces of rock and mineral. Sand particles are too loose to hold enough water. Clay is very dense, so has bad aeration. -Why is good soil important? Good soil is important because all start in it. Soil like house for plants. Soil must have enough amount of water, air and nutrients. A soil's parent material determines what nutrients are in it. You can improve the nutrients by adding humus. -How do you measure soil acidity?-We have special device, which measure acidity.-What else are important issues with the soil?-I want to say about soil texture. It's the size of particles in a soil. It really very important, so be careful.-Ok, thank you a lot.-No problem!»

The fifth version of soil dialogue deals with the following phrases: «Hi. Can I help you with anything?-Yes. I need some soil.-What kind of soil is it in your region?Sand, I need soil for tomatoes, carrots and pumpkins.-Acidic soil is suitable for them, I advise you to take loam.-Thanks, I also need something to help the houseplants grow well.-You need a soil mixture of sand and humus. One bag of this mixture costs 100 
UAH.-Give me two bagsplease-Ok, anything else?-No, thank you.-Okay, thank you for buying. Goodbye-Goodbye» or Greetings, Constantine. And hello to you, Ivan. Konstantin, I wanted to ask you about the soil on your territory? Okay, I'm listening to you.-I heard that you are engaged in grapes in large quantities and I would like to ask, what is the essence of the soil? There must be some kind of zest. -That's right, my soil is light, sandy, loose, and permeates heat easily. -For this, some additives are used, but for them something like that later.- Ok, thanks Constantine! Still wondering what kind of soil you have, for example, for blueberries and raspberries? Yes, blueberries need soil with an acidity of 4.0-5.0 ph, or peat bogs and soil with humus, but raspberries need dry soil, that is, loamy. -Thank you very much Konstantin. -Please always contact. -OK, good bye. -Have a nice day».

The sixth dialogue version about soil which attracted students' scientific interest and was archived within electronic courses Moodle platform is «Hi, let us discuss some interesting facts about land and soil. What is the first fact?-In terms of their total biomass, the earth (Earth's land) is almost 700 times larger than the ocean, although land accounts for less than 1/3 of the earth's surface. The most valuable arable land occupies only $11 \%$ of the world's land fund-Oh, it's really interesting but do you know any adequate mathematic calculations dealing with land and soil? -Due to soil erosion, the planet loses 3 million hectares of land, Ukraine has 650 types of soil, and 130 thousand worms are able to turn over 30 tons of land. - You really know a lot. But do you know anything about World Soil day?-Well, I know that every year on December 5, humanity celebrates the International Soil Day which was initiated by the Food and Agriculture Organization of the United Nations .-Excuse me but I've asked about World Soil Day but not about International Soil Day. -These determinations are the synonyms. -Oh, I see. But why must we save the soil?- The process of soil formation is very slow. In the middle latitudes of the temperate zone, a fertile layer of soil 0.5 - 2 centimeters thick is formed in about 100 years -A lot of thanks for your detailed explanation. See you later-Bye».

Thus there were six main versions of dialogue about the soil to be represented by future agronomists and biotech students during their first semester studying. 
Also it's worth to mention that above named soil discussion undoubtely may be added with discussing seeds as the objects to be put into soil to continue earth and people life.

Besides the represented dialogues about soil it was important to discuss the topic «Seeds» exampling some dialogues too.

The first version of seeds discussion may be represented as "-Hello.-Hello, David, long time no see.-Do you have anything to tell me?-Yes, I have one trouble.Which?-My plow, soil plowing mechanism, has been broken.-You should have been more accurate. Take it to a mechanical engineer. I also have another question.Which?- For growing tomatoes a good soil is loam with a high content of silt, right? Yes, it's true. And what is another question?-Good soil is important for high crop, right?-I suppose that you are right but each concrete crop need to be planted into adequate soil mostly suitable for it- And do agronomists study how to make the soil more productive?- They classify soil types and study them to determine if they contain vital substances for plant development--Can I help you with anything directly now?Yes I need some soil samples.-Ok it is for indoor or outdoor plant?-It's for outdoor plants.-What kind of plants is it for? It's for vegetables-I have some tomatoes I would like soil being the mostly adequate to this crop.-In that case you should use doom. It has good aeration and holds water well to -What kind of soil is therein your country? We have many different types of soil. Dark, rich soil is used for drawing crops loose sandy soil is found in the deserts, and day which is not very fertile can be found throughout the Ukraine -Ok I'II take it. Thanks for your help»

The second version of the seed dialogue is the next «Hello, welcome to our store. How can I help you?-Hi, I'd like to buy some seeds.-Which seeds is of interest to you?I'm interested in cucumber seeds.-We have the following varieties: «Asterix», «Cuckoo», "Crane», «Alliance», «Amarok» and «Accord».-Give me two packets. So how did you grow them?- Any disinfectant infusion should be prepared for seeds. We mainly use manganese of low concentration. Soak the seeds for 15-20 minutes, remove the seeds from the solution, rinse and allow to dry or leave to germinate. Seeds for seedlings can be planted in one wide container, and when it's time to grow tomatoes 
on the windowsill, just transplant the seedlings into large pots. Seeds should not be sown close to each other and deep. Try to leave a distance between the seeds of $2 \mathrm{~cm}$ and a depth of $1 \mathrm{~cm}$. When the seedlings appear two leaves will need to transplant the plants into separate containers. It is necessary to select capacity proceeding from the sizes of this or that grade. For example, for ordinary tomatoes you can take a pot with a capacity of at least 4 liters, short - 2 liters, and plant tomatoes planted in pots of at least 5 liters. For tomatoes, it is important to provide additional nutrition, as well as to organize watering every 15 days with a weak solution of manganese.-Oh, you have the technology of growing tomatoes, I think they taste the same as your technology, that is, perfect.-Bye.

Another third version to discuss seed need situation touches upon such replicas as «-Hi, you will like these tomatoes of the best quality. So how did you grow them?Any disinfectant infusion should be prepared for seeds. We mainly use manganese of low concentration. Soak the seeds for 15-20 minutes, remove the seeds from the solution, rinse and allow to dry or leave to germinate. Seeds for seedlings can be planted in one wide container, and when it's time to grow tomatoes on the windowsill, just transplant the seedlings into large pots. Seeds should not be sown close to each other and deep. Try to leave a distance between the seeds of $2 \mathrm{~cm}$ and a depth of $1 \mathrm{~cm}$. When the seedlings appear two leaves will need to transplant the plants into separate containers. It is necessary to select capacity proceeding from the sizes of this or that grade. For example, for ordinary tomatoes you can take a pot with a capacity of at least 4 liters, short - 2 liters, and ampelnye tomatoes planted in pots of at least 5 liters. For tomatoes, it is important to provide additional nutrition, as well as to organize watering every 15 days with a weak solution of manganese.-Oh, you have the technology of growing tomatoes, I think they taste the same as your technology, that is, perfect. Everything is well!» of «Asterix» and «Alliance», and what do you need seeds to grow?-Ok, maybe you need something else?-Yes, give me one more bag of «Dobrodar» watermelon seeds.-Ok, but for good growth of this variety of watermelon requires a lot of water, so 4 times a week water the rows.-Ok, thanks for the advice. Goodbye.-Good day» or «-Hello, I'd like to buy some seeds.-Hi, what seeds do you 
need?-I want cucumber seed, do you have it?-Yes, of course. I recommend these seeds, which is titled as «Amur». Many farmers like this because from them grow big, tasty, and green cucumbers.-Great, but how do farmers plant seeds?-Sowing method is very interesting. Use a pen or similar shaped object to prepare holes $0.5 \mathrm{~cm}$ deep, $2 \mathrm{~cm}$ apart Drop one seed per hole. Cover with soil. Water.-What do need seeds to grow?Seeds need enough amount of water, air, nutrients. -Thanks, I understand.

The fourth veriion of dialogue concerning seeds may be introduced in the following way: Hi, How long will your seeds grow?-Days to maturity: 25. But first seedlings will after 3-5 days. -Cool, how much should I pay for 1 packet of seeds?-Fifty UAH.-OK, thank you, here you are. What varieties are you interested in?-Seed of wheat and corn will be required.-Sorry but in us there is no chance of this variety of seeds.But, to me need tomorrow it is a seed. For tomorrow rain is forecast-Fine. I will try buy this variety of seeds tomorrow. l'll dial tomorrow at 8 o'clock» .

The fifth type of the dialogue to discuss seed is the next one: «Good afternoon!Good afternoon!- Welcome to our store! How can I help you?- Yes, I collected cucumber seeds and want to know what do you need seeds to grow?- Sufficient moisture, sunlight, heat and good aeration are required for seed germination.Thanks!- Maybe you want to germinate some more seeds? We have a wide range! Maybe you are interested in watermelon seeds?-Yes, I'm interested, give me one package, please.-1 package costs 10 UAH.-Thank you, have a nice day!- You too! Goodbye!»

The sixth kind of seed conversation is the next:«Hi, there, welcome to our Fruit Farm.How can we help you? hello, I'd like to take a consultation about the proper way of watermelon growing. What do seeds need to grow? Well, listen to some useful information. Before soaking you need to warm the seed up. This can be done not at moderate temperature. You must soak dried watermelon seeds in potassium humate solution. This procedure can increase yields up to 20-50 per cent, And when will the seeds be ready.-As soon as they have swollen and increased in size you should proceed to germination. I want some good seeds.-Great. What varieties are you interested in?I want some watermelon, the Super King. And some melon, the Royal Gold-I am sorry. 
I didn't catch that. -Super King watermelon and Royal Gold melon.-Get it.-I need two packets of each I have a question. How do farmers plant seeds?-Farmers often till the land by loosening the soil and mixing in fertilizers. Then, they sow seeds or plant seedlings.-Thanks for the advice.-Bye!-Bye. Come again!»

The seventh version of seed dialogue deals with the next replicas:«- Good afternoon-Good afternoon-Can I buy a kilo of the best seeds from you?-What kind of seed crop do you want?-I need sunflower seeds so I can grow them and make a lot of money on them. -Yes, I have the best sunflower seeds.-This is what i need as cool.-As much as you need. -Give me 100 pounds. It will be about 1 and a half bagsю-And how much does it cost?- 4000 UAH. How wonderful, I just have 4000 UAH with me, thank you, have a nice day.-You too, good bye»

The eighth version of the conversation to discuss something about the seeds from the agronomist's point of view is the next: «-Hello.-Hello, David, long time no see.-Do you have something to tell me?-Yes, I have one trouble.-Which?- My seeder as seed spreading mechanism has been broken.-Well, you should have been more accurate. Take this to a mechanic.-I also have two questions.-Which?-Cold-weather hybrid broccoli survives in temperatures down to $37 \mathrm{~F}$, did not it?-Yes, it does, it's true. And what is another question?-Seeds need light, water and soil to grow, do not they?-Yes, they do. That's also true. Well, broccoli is very helpful to keep fit and agronomists should spread their activity in the point of growing broccoli as well as cabbage, carrot, parsley, marrow and dill -Okay, then, can I go?-Yes, you can ».

The ninth version of the dialogues about seeds may be represented in such samples as «-Hello! Hello.CanI help you?L:-Yes,we can.I want to plant wheat, but I don't know what type of soil is best for this ...-Chernozems are considered to be the best soils for growing. Wheat can also grow well on podzolic, chestnut and sod soils.L:Oh thank you. And what fertilizers are best to fertilize the soil, nitrogen or phosphate?It all depends on the variety. Winter wheat prefers phosphorus fertilizers, and spring wheat-potassium.: -What can be the yield of wheat from 1 hectare, subject to all conditions.:-It all depends on weather conditions and compliance with seeding rates. The maximum yield can be 7.2 tons per hectares.-Okay, thank you.-You welcome!» 
Another version of discussing soil problem : «-Sir Adam, sir Adam! Can you help meOh, hi Jackson! What you need-Tell me, how much fertilizer to take on 3 hectares of soil-I think, $86 \mathrm{~kg}$ per one hectare will be sufficient. Will you present at processing?No, I'm going on a business trip. At the moment we have everything what you need-I think, not this time. Humus doesn't provide nutrients for the soil.-Fine. Will the plants do well in light loam-Yeah, I guess so.- I hope it all works out.-Everything will be all right.»

It's worth to say that discussing seeds became the object of scientific and communicative interest not only for the freshmen- future agronomists which point of view was above named but also for the second-year students- future biotechnologists in more detailed tenth versions in a following way: «-Hello.-Hello, David, long time no see.-Do you have something to tell me?-Yes, I have one trouble.-Which?-My seeder as seed spreading mechanism has been broken.-Well, you should have been more accurate. Take this to a mechanic.-I also have two questions.-Which?-Cold-weather hybrid broccoli survives in temperatures down to $37 \mathrm{~F}$, did not it?-Yes, it does, it's true. And what is another question?-Seeds need light, water and soil to grow, do not they?-Yes, they do. That's also true. Well, broccoli is very helpful to keep fit and agronomists should spread their activity in the point of growing broccoli as well as cabbage, carrot, parsley, marrow and dill -Okay, then, can I go?-Yes, you can ».

The eleventh version of the dialogue about seeds may be noted bellow: Oh, Tony, hello! I'm happy to see you. Tony, please come in. We haven't seen each other for so long. I've heard about your working and I consider your new seed is almost ready for marketing. - Hello, George. I'm happy to see you too. Oh, these rumors are spreading too fast. Yes, it is. After the animal performance assessments it will be ready to go.Wonderful. Tell me about it in the first person. I want to know the best way to advertize it.- You always narrow everything down to profit you will achieve and money. I'm not interested in it. I just do my study and that's all I keen on.- Ok, come on, Tony. You have to make for a living and I 'll make your ideas come true to transfer brilliant projects into money, is it bad? I help you to make money from it for you equipment and apportunities you'll have in future. So, tell me about your project and don't force me 
being mad at you.- All right, well, the main benefit is that it's extremely droughtresistant.- There we go, that's great. We will do adequate selling it to farmers in dry regions.- Good point. I'll target areas where rainfalls are unpredictable.- Yes, what else?- We should emphasize the dependability at our seed. Tests should that the yields produced during rainy seasons and those produced during droughts varied very little and they're letter for the environment than conventional seeds. - That's your job. How you will do it?- With fener crops failing during drought seasons there'll be greater yields. That means less land will be used per season. - Excellent, Tony. - O my God, George. I'm late. My break is over. We can meet tomorrow and discuss this issue in more detail.- Oh, ok. No problems. See you tomorrow. B: Good bye!»

The twelfth type of seed dialogue is in the following sentences: «- Carol, please come in. I understand your new seed is almost ready for marketing. - It is. After the animal performance assessments, it will be ready to go. - Wonderful. Tell me all about it. I want to know the best way to advertise it.- Well. The main benefit is that it's extremely drought-resistant.-Okay. So well do well selling it to farmers in dry regions. - Yes. We'll target areas where rainfalls are unpredictable. - Okay. What's else?- We should emphasize the dependability of our seed. Tests showed that the yields produced during rainy seasons and those produced during droughts varied very little and they re better for the environment than conventional seeds.- How?- With fewer crops falling during drought seasons, there'll be greater yields. That means less land will be used per season. - I had a great idea. I will offer this seed to my brother, he has a lot of land and may want to try new seeds.- Yes, that would be great. And then he could advise these seeds to his fellow farmers.- I am sure that soon these seeds will enter the world market and will bring good harvests.- I really hope so and thank you for your help»

The thirteenth version of seed dialogue deals with the following expressions: «Carol, please come in. I understand your new seed is almost ready for marketing. - It is. After the animal performance assessments, it will be ready to go. - Wonderful. Tell me all about it. I want to know the best way to advertise it.- Well. The main benefit is that it's extremely drought-resistant.- Okay. So well do well selling it to farmers in dry regions. - Yes. We'll target areas where rainfalls are unpredictable. - Okay. What's 
else? - We should emphasize the dependability of our seed. Tests showed that the yields produced during rainy seasons and those produced during droughts varied very little and they're better for the environment than conventional seeds.- How?- With fewer crops falling during drought seasons, there'll be greater yields. That means less land will be used per season.- I had a great idea. I will offer this seed to my brother, he has a lot of land and may want to try new seeds.- Yes, that would be great. And then he could advise these seeds to his fellow farmers.- I am sure that soon these seeds will enter the world market and will bring good harvests. I really hope so and thank you for your help.-Excellent, Carol».

Thus the topic soil became the most productive and attracted the most of student's interest.

And now it's a turn to discuss plant growth as the last one to be represented in this article exampling.

The first version of dialogue to discussplant growth may be represented within the next dialogue: «Hi-Hi-Taras, you planted sunflower for the first time this year, didn't you?-I did, I was worried at first but it seems okay now.-Worried? Why?-it was growing so slowly. But it just took a while for the buds to flower--Oh so they'were doing well-yeah. They are we expect to harvest them next week-That's great. How much do you expect to harvest? Well we planted 6 acres. So probably for few acres or so-Haw do plants change as they grow? While their grow plants get bigger and more resistible to damages. Their roots grow longer in order to draw more water and to support the plant. Leaves increase in size and number and most plants produce flowers-Ok, thanks. Goodbye-Goodbye

The second version of seed dialogue is the following sample:: $« H i$, it is in need to provide at least 10 inches between rows of quinoa to give the roots plenty of space, is not it?-Yes, It is ,it' true and I support such version. -What is in need for barley growth?-Well, barley like every another crop, needs watering, weeding and fertilizing-Ok. Thanks for the advice And what is another question? I'd like to specify root functions. What are they? They are absorption of water and minerals and conduction of these to the stem-I see, thanks for answer. Do you want to know anything 
else? - I'm in doubt with need to waiting two weeks to plant after using some herbicides.-Is this true?-Yes, it is and I have practical experience with fertilizing and herbicide application. But can we avoid pesticides at all? May the pollute environment.- we must be careful but can not refuse while cultivation large fields area. Herbicides are used to avoid weeds which may made seedlings weak.-Is plant growth studying in need for Ukrainian agronomist?- I see tat it's true. Ukraine grows 7 times grain than coffee worldwide. Ukraine is one of the three world leaders in barley production, is one of the largest producers of sugar beets.-How do plants change as they grow? -Their roots grow longer ir order to draw more water and to support the plant. Leaves increase in size and number and most plants produce flowers-Thanks for your answers» .

The third version of plant growth dialogue is the next one: «-Hello-Hello. What did you plant this year?-So I planted corn, sunflower, wheat and I tried to plant quinoa.-What is quinoa?-Qquinoa is plant seeds which are used as spices in various dishes.-Oh, it is interesting. Is it difficult to grow quinoa?-No, it is not so difficult, but I don't know this plant well so I worry about that.-worried? Why?-I'm worried because of watering of quinoa and other plants. there was very little rainfall this year. -Well, it is the most popular problem in agronomy. -So how much do you expect to harvest this year?-I expect to harvest 6 tons per hectare of wheat, 8 tons per hectare of corn, 3,5 tons per hectare of sunflower. But I don`t know how much quinoa I will harvest.-OK, it was interesting to learn about quinoa. - But have you any agronomist's practical problem?- Last year my corn crops grew poorly but I don't know why.- May the problem be in the land on which it grows?- No, I do not think so, I have good soil.Then maybe the cause is in pesticides?-Obviously not, I have imported pesticides-I don't even know what to say, I can only advise good corn seeds. -And you're right I did not take care of the seeds that I plant.- In this case I can give you the phone number of my friend who sells various seeds. -Now I will find his business card.--Thank you for helping me a lot, I'm your debtor». 
The fourth version of plant growth dialogue is the next one: «What will we grow at this year?-I think, sunflower is cool decision.-What advantages of growing sunflowers? -First of all, sunflower grows quickly and has big harvest.-I can't disagree with you. But what about growing process?-Sunflowers grow very fast. First seedlings will be after 1-2 weeks. After 1 month sunflowers will have strong stalks and big, green leaves. Also, sunflowers like water, so we should regular water them and add in soil enough humus and fertilizers.-What function does each part of a plant?-Oh, it's great question. Roots up water and nutrients for upper part of plant. Leaves do photosynthesis. Stem holds the whole plant. -Is sunflower a popular plant?-Yes, of course. Sunflower oil is very popular and important product.-How much do you expect to harvest from this field.-We expect 20 tons from 10 hectares of field» or «-Welcome to the farmer's market. Can I help you.-Yes, please. I want to plant flowers.- What varieties are you interested in?-I want some roses. Do they grow fast?-No, roses grow slowly.-How do plants change?-The stem grows and then in formed bud.-Thanks. I need two packets of roses seeds.-It will cost 100UAH for whole order.-Thanks! Now I know more about plants» as well as $\mathrm{Hi}$, I have recently planted quinoa as an ornamental plant.-Cool, I also like her look, and you know what function does each part a plant serve?-Yes, roots-nutrition, leaves-photosynthesis, stem-support and branch. - And did you know that only few plants obtain as much protein as quinoa, and it can grow in many environments. -No, I did not, it's very interesting. And how it should be grown?-Sow the seeds where the plant will get plenty of sunlight, at a distance of 10 inches, so that the roots grow.-I understand, thanks for the info. Apparently also sowing quinoa. Looking forward to next time.-I will look forward to it too»

The fifth plant growth discussion is in the following sample :«-Hi, Ann, you planted broccoli for the first time, did not you?-Yes, I did. I worried about my new experience but I realized that it was not so difficult.-That case is interesting. Can you tell me about broccoli growth in details? -With pleasure This cool crop is rich in vitamins and minerals and is a proper source of vitamin A, folic acid, iron and fiber. Broccoli grows on areas with plenty of sun and well-drained fertile soil. Avoid sandy 
soil if it is possible- How do broccoli change as they grow? Broccoli seeds typically germinate within10 - 14 days period. During the first year the broccoli stalk grows on70-80 cm in height. Later they'll obtain comparatively thick stem. And what about the place where to grow? These seeds may germinated either indoors or outdoors because they are very adaptive. And what harvest do you expect? Well, it was experimental planting only in few balcony pots and can not even predict the amount of yield.-Thank you so much, we wish you the best harvest.-Thanks. bye».

The sixth plant growth discussion is in the following sample: "Good afternoon!.Good afternoon! -. Oleg, how do you grow plants, are they all well developed?-In general everything seems good, but there are some problems.- What exactly are your problems?- Buds in the orchad fall off. Oh, so these are serious problems for you. Yes, I didn't even think it was a big deal-I will help you in solving this problem. I'll be grateful.- Plants live on rocks and trees. They need air and a tropical climate for normal life and abundant flowering. Failure to comply with certain conditions of maintenance and cultivation - the main cause of aging of tropical flowers. As a result of violation of the microclimate in the room the plant sheds buds and flowers, leaf blades wither, turn yellow and fall off, the roots dry out. There are a number of factors that directly affect the growth, development and flowering of orchids. -Wow, does that mean you need to make their living conditions normal?-Yes, and then you will succeedOkay, thank you. Contact us in need».

The seventh plant growth discussion is in the following sample: «Good afternoon!-- Good afternoon!- I need fertilizer that will improve the growth of my tangerine tree.- To begin, you need to read the growth chart of the tangerine tree. Here hold.- Thanks! Now I know why the leaves of my plant turn yellow.- I can advise you here is this fertilizer.- How much does it cost?- 80 UAH per a jar.- Give one please.Hold on! Maybe you need something to improve photosynthesis, root growth, flowering plants?- No, thank you! - Okay, I look forward to our next meeting!- So I do, goodbye! - Goodbye»

The eighth plant growth discussion is in the next version: «- Hi aunt Sara! What are you doing-Hi, darling. I plant new seeds that I received as a gift. It's a aster 
Sow White-Can you tell little bit about them-Yes, of course, Megan. The petals of this plant are long and curved. The length of the aster stem reaches 70 centimeters and flowers white and double. Their diameter is about 12 centimeters. - It's so interesting! Tell me more!-Okay, my body-body! Aster prefer to grow in sunny areas and fertile non-acidic soil. They don `t require a lot of effort to grow. They good for beginners. Can I try to plant them with you-Of course, Megan. Let's go!»

Thus there were eight different attempts to discuss plant growth.

The parallel activity to dialogue conclusion dealt with the writing own opinion on the clever phrases by famous person concerning agronomist's activity to be in five portions blocks within inspirational gardening quotes and sayings([419]) or inspiriting gardening quotes to encourage plant growing ([418])

The first block dealt with several statements

The first statement «To plant a garden is to believe in tomorrow» by Audrey Hepburn may be understood that people believe in future because can not see the results at once. It may be destiny of agronomist who takes care of another next generation beauty and food, is sure of land fertility and no ecological damages and the second one «Gardening is a work of a lifetime: you never finish» by Oscar de la Renta prove the difficulty and nobility of agronomist's work as well everlasting inner development, improvement and studying being in similar meaning to Chinese proverb «The best time to plant a tree was twenty years ago. The second best time is now» as well as to the statement "Don't judge each day by the harvest you reap, but by the seeds that you plant» by Robert Louis Stevenson.

The majority of students supported the thought «To forget how to dig the earth and tend the soil is to forget ourselves» by Mahatma Gandhi mentioning linkage of everlasting land cultivation. Without this activity the human life may be interrupted. This statement may be regarded as the continuation of the phrase «When the world wearies and society fails to satisfy, there is always the garden» by Minnie Aumonier too.

Despite of the difficult physical labor communication with nature as a rule bring esthetic pleasure and sometimes agronomist may become the artist proving the 
statement «My garden is my most beautiful masterpiece» by Claude Monet or «In all things of nature there is something of the marvelous» by Aristotle.Agronomist may be called even an actor or singe basing upon the proverb "The garden is a love song, a duet between a human being and Mother» as well as "All gardening is landscape painting» by William Kent or « To create a garden is to search for a better world. In our effort to improve on nature, we are guided by a vision of paradise. Whether the result is a horticultural masterpiece or only a modest vegetable patch, it is based on the expectation of a glorious future. This hope for the future is at the heart of all gardening» by Marina Schinz as well as «Watching something grow is good for morale. It helps us believe in life» by Myron Kaufmann.

The second block of phrases like "Gardening is cheaper than therapy - and you get tomatoes» by Anonymous or «The healing of the land and the purification of the human spirit is the same process» by Masanobu Fukuoka as well as «Gardening is the greatest tonic and therapy a human being can have. Even if you have only a tiny piece of earth, you can create something beautiful, which we all have a great need for. If we begin by respecting plants, it's inevitable we'll respect people» by Audrey Hepburn or «Flowers are restful to look at. They have neither emotions nor conflicts» by Sigmund Freud were announced by students as a thing being related to the therapeutic pleasant influence on human health and prove the statement that the agronomists who spend a lot of time outdoors are considered to be the healthiest people.

The last block of phrases include philosophical cognitive activity in finding rational background -advices for general agronomist's life within such statements as «No single sort of garden suits everyone. Shut your eyes and dream of the garden you'd most love then open your eyes and start planting. Loved gardens flourish, boring ones are hard work» by Jackie French or "If you've never experienced the joy of accomplishing more than you can imagine, plant a garden» by Robert Brault or noting Greek proverb «A society grows great when old men plant trees whose shade they know they shall never sit in» as well as «You are also far less likely to waste food when you have nurtured it from a seed into a plant»by Darina Allen or noting Chinese proverb 
"Life begins the day you start a garden» as well as" Gardening adds years to your life, and life to your years» by unknown writer as well as Greek proverb «A society grows great when old men plant trees whose shade they know they shall never sit in. ", "If you wish to make anything grow, you must understand it, and understand it in a very real sense. 'Green fingers' are a fact, and a mystery only to the unpracticed. But green fingers are the extensions of a verdant heart. » by Russell Page «Everything that slows us down and forces patience, everything that sets us back into the slow circles of nature, is a help. Gardening is an instrument of grace.” May Sarton, «The single greatest lesson the garden teaches is that our relationship to the planet need not bezero-sum, and that as long as the sun still shines and people still can plan and plant, think and do, we can, if we bother to try, find ways to provide for ourselves without diminishing the world. » by Michael Pollan, «Gardens are not made by singing 'Oh, how beautiful,' and sitting in the shade. " „Trees and plants always look like the people they live with, somehow.. » byZora Neale Hurston, «God Almighty first planted a garden. And indeed, it is the purest of human pleasures. » by Francis Bacon, «A person cannot love a plant after he has pruned it, then he has either done a poor job or is devoid of emotion. » byLiberty Hyde Bailey, " love spring anywhere, but if I could choose I would always greet it in a garden. Ruth Stout, «The garden suggests there might be a place where we can meet nature halfway. » byMichael Pollan, «I like gardening - it's a place where I find myself when I need to lose myself. » by Alice Sebold, «It is only the farmer who faithfully plants seeds in the Spring, who reaps a harvest in the Autumn. » by B.C. Forbes, «There are no gardening mistakes, only experiments. 》by Janet Kilburn Phillips, «But always, to her, red and green cabbages were to be jade and burgundy, chrysoprase and prophyry. Life has no weapons against a woman like that.» by Edna Ferber,«Gardening simply does not allow one to be mentally old, because too many hopes and dreams are yet to be realized. " by Allan Armitage, «There are two spiritual dangers in not owning a farm. One is the danger of supposing that breakfast comes from the grocery, and the other that heat comes from the furnace. » by Aldo Leopold,«A garden always has a point» by Elizabeth Hoyt, The Raven 
Prince, «The greatest fine art of the future will be the making of a comfortable living from a small piece of land. » by Abraham Lincoln, Chinese proverb «All gardeners know better than other gardeners. ", «When the world wearies and society fails to satisfy, there is always the garden. » by Minnie Aumonier, "How fair is a garden amid the trials and passions of existence. By Benjamin Disraeli.

According to the students' opinion the fourth block of expressions deals the expression of time period attitude to the agronomists' actions in such expressions as «Essential advice for the gardener: grow peas of mind, lettuce be thankful, squash selfishness, turnip to help thy neighbor, and always make thyme for loved ones. " by unknown author "The love of gardening is a seed once sown that never dies» by Gertrude Jekyll or «Plan a garden for the future, but expect it to evolve and need changing, despite your well laid-out plans. Such is the temperament of Mother Nature» by Meredith Kirton as well as mentioning the phrase «There are no happier folks than plant lovers and none more generous than those who garden» by Ernest Wilson or Chinese proverb "All the flowers of all the tomorrows are in the seeds of today» as well as «Remember that children, marriages, and flower gardens reflect the kind of care they get» by H. Jackson Brown Jr. or«If you have a garden and a library, you have everything you need» by Marcus Tullius Cicero, «A garden requires patient labor and attention. Plants do not grow merely to satisfy ambitions or to fulfill good intentions. They thrive because someone expended effort on them» by Liberty Hyde Bailey.

Besides, future agronomists and biotech students consider such expression as «Despite the gardener's best intentions, Nature will improvise» by Michael P. Garofalo, «The single greatest lesson the garden teaches is that our relationship to the planet need not be zero-sum, and that as long as the sun still shines and people still can plan and plant, think and do, we can, if we bother to try, find ways to provide for ourselves without diminishing the world» by Michael Pollan. be also mentioned among the advices to follow some life rules as well as the phrase «Giving up your ego is the shortest way to unification with nature» by Masanobu Fukuoka or «A garden is a grand teacher. It teaches patience and watchfulness; it teaches industry and thrift; 
above all it teaches entire trust» by Liberty Hyde Bailey or "The love of gardening is a seed once sown that never dies. » by Gertrude Jekyll

And now it's time to represent the list of the phrases about agronomy to become the source either of professional vocabulary or the items of cognitive and personal interst to be placed in scale od students' gradation:

1) «Gardens are a form of autobiography» by Sydney Eddison , «Remember that children, marriages, and flower gardens reflect the kind of care they get. " by $\mathrm{H}$. Jackson Brown, Jr.; «My garden is my most beautiful masterpiece» byClaude Monetб«I cultivate my garden, and my garden cultivates me. » byRobert Breault, «My garden is my favorite teacher» and Betsy Cañas Garmon «Weed it and reap». by Gardening Saying;

2) «Everything that slows us down and forces patience, everything that sets us back into the slow circles of nature, is a help. Gardening is an instrument of grace» by May Sarton or «Flowers always make people better, happier, and more helpful; they are sunshine, food and medicine for the soul » by Luther Burbank;

3) «Keep love in your heart. A life without it is like a sunless garden when the flowers are dead. " by Good Morning Quote or«Little things seem nothing, but they give peace, like those meadow flowers which individually seem odorless but all together perfume the air. . " by Georges Bernanos and «I know that if odour were visible, as colour is, I'd see the summer garden in rainbow clouds. » by Robert Bridges;

4) «Show me your garden and I shall tell you what you are» by Alfred Austin «The flower which is single need not envy the thorns that are numerous. " by Rabindranath Tagore or «A lawn is nature under totalitarian rule. » by Michael Pollan;

5)«Flowers are restful to look at. They have neither emotions nor conflicts» by Sigmund Freud and «And do notforget not that the earth delights to feel your bare feet and the winds long to play with your hair. » by Khalil Gibran or «Garden as though you will live forever. " by Thomas Moore;

6) «A man has made at least a start on discovering the meaning of human life when he plants shade trees under which he knows full well he will never sit» by D. Elton 
Trueblood and «A garden requires patient labor and attention. Plants do not grow merely to satisfy ambitions or to fulfill good intentions. They thrive because someone expended effort on them. " by Liberty Hyde Bailey or «Remember that children, marriages, and flower gardens reflect the kind of care they get. » by $\mathrm{H}$. Jackson Brown, Jr.;

7) «A weed is but an unloved flower. » by Ella Wheeler Wilcox or «What is a weed? A plant whose virtues have never been discovered» by Ralph Waldo Emerson and «Plant and your spouse plants with you; weed and you weed alone. " by Jean-Jacques Rousseau;

8) «I want it said of me by those who knew me best, that I always plucked a thistle and planted a flower where I thought a flower would grow» by Abraham Lincoln and «We must cultivate our own garden. When man was put in the garden of Eden he was put there so that he should work, which proves that man was not born to » by Voltaire or «Love is the flower of life, and blossoms unexpectedly and without law, and must be plucked where it is found, and enjoyed for the brief hour of its duration. " by D. H. Lawrence;

9) «A flower falls, even though we love it; and a weed grows, even though we do not love it. » by Dogen and «Weeds are flowers too, once you get to know them. » by A. A. Milne or «Won't you come into the garden? I would like my roses to see you» by Richard Brinsley Sheridan;

10)«My passion for gardening may strike some as selfish, or merely an act of resignation in the face of overwhelming problems that beset the world. It is neither. I have found that each garden is just what Voltaire proposed in Candide: a microcosm of a just and beautiful society » by Andrew Weil;

11) «Every time I imagine a garden in an architectural setting, it turns into a magical place. I think of gardens I have seen, that I believe I have seen, that I long to see, surrounded by simple walls, columns, arcades or the facades of buildings - sheltered places of great intimacy where I want to stay for a long time. » by Peter Zumthor;

12) «Sometimes, as is the case of peach and plum trees, which are often dwarfed, the plants are thrown into a flowering states, and then, as they flower freely year after 
year, they have little inclination to make vigorous growth. » by Robert Fortune or «The lesson I have thoroughly learnt, and wish to pass on to others, is to know the enduring happiness that the love of a garden gives» by Gertrude Jekyll;

13) «Isn't it enough to see that a garden is beautiful without having to believe that there are fairies at the bottom of it too? " by Douglas Adams or «The glory of gardening: hands in the dirt, head in the sun, heart with nature. To nurture a garden is to feed not just on the body, but the soul» by Alfred Austin and «It is a good idea to be alone in a garden at dawn or dark so that all its shy presences may haunt you and possess you in a reverie of suspended thought. » by James Douglas;

14)«There's something about taking a plow and breaking new ground. It gives you energy» by Ken Kesey or "It is a golden maxim to cultivate the garden for the nose, and the eyes will take care of themselves. " by Robert Louis Stevenson and) «I've always felt that having a garden is like having a good and loyal friend. " by C. Z. Guest;

15)«He plants trees to benefit another generation» by Caecilius Statius or «The love of gardening is a seed once sown that never dies. » by Gertrude Jekyll and «You can cut all the flowers but you cannot keep spring from coming. » by Pablo Neruda or «How deeply seated in the human heart is the liking for gardens and gardening. " by Alexander Smith;

16) "What a man needs in gardening is a cast-iron back, with a hinge in it. " by Charles Dudley Warner or «It is only the farmer who faithfully plants seeds in the Spring, who reaps a harvest in the Autumn. » by B. C. Forbes and «By plucking her petals, you do not gather the beauty of the flower» by Rabindranath Tagore;

17) «I think this is what hooks one to gardening: it is the closest one can come to being present at creation. » by Phyllis Theroux and «When the flower blooms, the bees come uninvited. » by Ramakrishna or «Fertilizer does no good in a heap, but a little spread around works miracles all over» by Richard Brinsley Sheridan;

18) «In search of my mother's garden, I found my own» by Alice Walker and «One marked feature of the people, both high and low, is a love for flowers. " by Robert 
Fortune or "I don't like formal gardens. I like wild nature. It's just the wilderness instinct in me, I guess. » by Walt Disney;

19)«A brier rose whose buds yield fragrant harvest for the honey bee. 》 by Letitia Elizabeth Landon and «I plant a lot of trees. I am a great believer in planting things for future generations. I loathe the now culture where you just live for today. " by Penelope Keith or «No occupation is so delightful to me as the culture of the earth, and no culture comparable to that of the garden. » by Thomas Jefferson; 20) «There are two seasonal diversions that can ease the bite of any winter. One is the January thaw. The other is the seed catalogues. » by Hal Borland and «A gardener's best tool is the knowledge from previous seasons. And it can be recorded in a $\$ 2$ notebook. » byAndy Tomolonis

21) «If you've never experienced the joy of accomplishing more than you can imagine, plant a garden.» by Robert Breault and «Creating your own urban farm is as simple as planting your flowerbeds with edibles. " byGreg Peterson and «In order to live off a garden, you practically have to live in it. " byFrank McKinney Hubbard or «Gardeners learn by trowel and error.» by Gardening Saying

22) «One of the most delightful things about a garden is the anticipation it provides. » byW.E. Johns, The Passing Show and «I grow plants for many reasons: to please my eye or to please my soul, to challenge the elements or to challenge my patience, for novelty or for nostalgia, but mostly for the joy in seeing them grow. » by David Hobson and «There is no gardening without humility. Nature is constantly sending even its oldest scholars to the bottom of the class for some egregious blunder. " by Alfred Austin and "If you have a garden and a library, you have everything you need» by Marcus Tullius Cicero;

23)A garden requires patient labor and attention. Plants do not grow merely to satisfy ambitions or to fulfill good intentions. They thrive because someone expended effort on them» by Liberty Hyde Bailey and «The roots of all goodness lie in the soil of appreciation for goodness» by Dalai Lama and «The glory of gardening: hands in the dirt, head in the sun, heart with nature. To nurture a garden is to feed not just the body, 
but the soul» byAlfred Austin and «The roots of all goodness lie in the soil of appreciation for goodness» by Dalai Lama ;

24) «The soil is the great connector of our lives, the source and destination of all." byWendell Berry, The Unsettling of America and «An optimistic gardener is one who believes that whatever goes down must come up» byLeslie Hall and «If a tree dies, plant another in its place. ». by Carl Linnaeus or «The greatest service which can be rendered any country is to add a useful plant to its culture. " byThomas Jefferson and «Gardening gives one back a sense of proportion about everything - except itself.» by May

Sarton;

25) «There is no gardening without humility. Nature is constantly sending even its oldest scholars to the bottom of the class for some egregious blunder. ». byAlfred Austin and «A garden is a grand teacher. It teaches patience and careful watchfulness; it teaches industry and thrift; above all it teaches entire trust». by Gertrude Jekyll

Besides above mentioned favourite twenty five students' phrases students were able to introduce into their speech such phrases as «You have to get up and plant the seed and see if it grows, but you can't just wait around, you have to water it and take care of it. » by Bootsy Collins or «Well I do find the beauty in animals. I find beauty everywhere. I find beauty in my garden. » by Doris Day or «I love being in my garden. I don't plant a lot of exotic flora, but I do spend a lot of time outside doing manual labour. » by Jacqueline Bisset as well as «My extravagance is my garden - it's the first thing I look at every morning when I wake up. It gives me so much pleasure. » by Ina Garten or «A garden is a complex of aesthetic and plastic intentions; and the plant is, to a landscape artist, not only a plant - rare, unusual, ordinary or doomed to disappearance - but it is also a color, a shape, a volume or an arabesque in itself. » by Roberto Burle Marx or "Let us not forget that the cultivation of the earth is the most important labor of man. When tillage begins, other arts will follow. The farmers, therefore, are the founders of civilization. " by Daniel Webster

The food for philosophical thinking is in statement «No one will understand a Japanese garden until you've walked through one, and you hear the crunch underfoot, and you smell it, and you experience it over time. Now there's no photograph or any 
movie that can give you that experience. » by J. Carter Brown too as well as within the expression«The most lasting and pure gladness comes to me from my gardens. " by Lillie Langtry or «To dwell is to garden. » by Martin Heidegger or «The more help a person has in his garden, the less it belongs to him. » by W. H. Davies as well as«All gardening is landscape painting. » by William Kent, «Flowers are happy things. » by P. G. Wodehouse, «Use plants to bring life. » by Douglas Wilson or «God Almighty first planted a garden. And indeed, it is the purest of human pleasures. " by Francis Bacon.

There also were the slogans to be represented by students in posters to be brought on English lessons using theses «The garden suggests there might be a place where we can meet nature halfway. " by Michael Pollan, "Trees and plants always look like the people they live with, somehow» by Zora Neale Hurston, «Weather means more when you have a garden. There's nothing like listening to a shower and thinking how it is soaking in around your green beans. » by Marcelene Cox, «I love planting. I love digging holes, putting plants in, tapping them in. And I love weeding, but I don't like tidying up the garden afterwards. » by Jamaica Kincaid, «A vegetable garden in the beginning looks so promising and then after all little by little it grows nothing but vegetables, nothing, nothing but vegetables. » by Gertrude Stein, «I also like to garden. I grow things, vegetables, flowers... I particularly like orchids. I raise orchids. " by Beau Bridges or «The garden, by design, is concerned with both the interior and the land beyond the garden. » by Stephen Gardiner «I value my garden more for being full of blackbirds than of cherries, and very frankly give them fruit for their songs. " by Joseph Addison as well as «I need my friends, I need my house, I need my garden. » by Miranda Richardson, «I like solitary pursuits, such as reading or pottering about in the garden. " by Hayley Mills, "Well tended garden is better than a neglected wood lot. » by Dixie Lee Ray or «Gardening requires lots of water - most of it in the form of perspiration. " by Lou Erickson, "Gardening is cheaper than therapy and you get tomatoes. » by unknown author and «In every gardener there is a child who believes in The Seed Fairy. » by Robert Breault. 
It's worth to announce that there were two teams to support of deny the statement «Gardening is a matter of your enthusiasm holding up until your back gets used to it. » by unknown author, «A garden is always a series of losses set against a few triumphs, like life itself. » by May Sarton, «The greatest gift of the garden is the restoration of the five senses. » by Hanna Rion or «There can be no other occupation like gardening in which, if you were to creep up behind someone at their work, you would find them smiling. » by Mirabel Osler and «In my garden there is a large place for sentiment. My garden of flowers is also my garden of thoughts and dreams. The thoughts grow as freely as the flowers, and the dreams are as beautiful. » by Abram L. Urban, «It is good to be alone in a garden at dawn or dark so that all its shy presences may haunt you and possess you in a reverie of suspended thought. " by James Douglas or «God made rainy days so gardeners could get the housework done. " by unknown author.

Moreover students recognized statements «Don't wear perfume in the garden — unless you want to be pollinated by bees. » by Anne Raver, «Plant carrots in January and you'll never have to eat carrots. » by unknown author, «Weather means more when you have a garden. There's nothing like listening to a shower and thinking how it is soaking in around your green beans. " by Marcelene Cox or «Gardens are a form of autobiography. » by Sydney Eddison to be practically oriented and similar to saying «Science, or para-science, tells us that geraniums bloom better if they are spoken to. But a kind word every now and then is really quite enough. Too much attention, like too much feeding, and weeding and hoeing, inhibits and embarrasses them» by Victoria Glendinning or «Many things grow in the garden that were never sown there. »Thomas Fuller and «Despite the gardener's best intentions, Nature will improvise.

Michael P. Garofalo and «Coffee. Garden. Coffee. Does a good morning need anything else? »byBetsy Cañas Garmon.

Moreover future biotechnologists and future agronomists involved into their lesson speech such interesting facts as «The hum of bees is the voice of the garden. »byElizabeth Lawrence, «Let nature be in your yard. » by Michael P. Garofalo, «To forget how to dig the earth and to tend the soil is to forget ourselves» by Mahatma 
Gandhi, «We have descended into the garden and caught three hundred slugs. How I love the mixture of the beautiful and the squalid in gardening. It makes it so lifelike. » byEvelyn Underhill, «Gardening is about enjoying the smell of things growing in the soil, getting dirty without feeling guilty, and generally taking the time to soak up a little peace and serenity» by Lindley Karstens, «Half the interest of a garden is the constant exercise of the imagination. » by Mrs. C.W. Earle,Pot-Pourri from a Surrey Garden, 1897 or «It was such a pleasure to sink one's hands into the warm earth, to feel at one's fingertips the possibilities of the new season. » by Kate Morton, «Anybody who wants to rule the world should try to rule a garden first. " by Gardening Saying and "In almost every garden, the land is made better and so is the gardener. » by Robert Rodale (1930-1990) as well as "If you have a garden and a library, you have everything you need. " by Cicero or "I know the pleasure of pulling up root vegetables. They are solvable mysteries.» by Novella Carpenter or «The single greatest lesson the garden teaches is that our relationship to the planet need not be zero-sum, and that as long as the sun still shines and people still can plan and plant, think and do, we can, if we bother to try, find ways to provide for ourselves without diminishing the world. " by Michael Pollan.

The complicated expressions being related to this topic may be regarded in such sentences as «Odd as I am sure it will appear to some, I can think of no better form of personal involvement in the cure of the environment than that of gardening. A person who is growing a garden, if he is growing it organically, is improving a piece of the world. He is producing something to eat, which makes him somewhat independent of the grocery business, but he is also enlarging, for himself.I think the true gardener is a lover of his flowers, not a critic of them. I think the true gardener is the reverent servant of Nature, not her truculent, wife-beating master. I think the true gardener, the older he grows, should more and more develop a humble, grateful and uncertain spirit. » byReginald Farrer» in parallel of existence of short phrases like «Farming is a profession of hope» by Brian Brett or «Life's a garden — dig it. » byGardening Saying or short German proverb «The garden is the poor man's apothecary.» 
And now it's a turn to represent important factor to develop future agrobiologists communicative skills are hand-made pictures or posters to predict real life story as well as searching interesting facts or humoristic stories. That material may be concluded on the first stages of communicative work and be used as the basis of the above mentioned dialogues but in their turn this material may be applied separately to enhance like «An apple tree grew on the field. The worm, wholived on a tree, ate an apple at lunchtime and lay down to rest. In hour later, it became bad. It was poisoned.

To establish the reason, it went to the lab. It gave an apple for to analyze.

The research was carried out using chemical and biological methods.They deter mined the chemical and genetic composition of the product and the presence of pests, taste and smell. The next day, it received a conclusion. In conclusion it was written genetically modified and resistant to insects. The apple tree was cut down and a new tree was planted. Can a genetically modified apple be poisoned?» or «Once upon a time Tim opened his e-mail and saw the letter. The letter was asking for help to solve the problem with the harvest. Tim agreed had happened. The problem was the small amount of harvest. Tim developed special organic fertilizers. To make them, he cloned genes and derived antigen. He also suggested the use of methyl iodide and potassium iodate. Thanks to Tim's help, the harvest resumed and became even greater» as well as "One evening Bill and Mary heard a loud noise and lantern light filled the room. They were frightened and decided to go to their field to find the reason out. The light was so bright that they could not see what was placed in front of strange object looking in general like UFO. But when agronomists came nearer they recognized familiar tractor driver and his tractor which was aimed to plow the fields per night to be ready for the next day raking, making seedbeds and fertilizing. Bill and Mary asked tractor drive to have a rest and promised to finish seedbed preparation together».

The other versions of such real life stories which attracted students' interest in developing professional speech on the basis of the everyday use speech were represented some notes. It was important to involve biotech students all levels of 
preparation. There were taken into consideration either simple stories with the elements of professional biotech speech «One day Sandra come to the laboratory and her manager told her to do on experiment with a rat. Sandra began to prepare for the experiment, opened a cage with a rat and suddenly she was called. While she was talking on the phone, the animal ran away. While Sandra was away, the rat ran, hooked the tail of the reagent, which spilled on her and died. So we'd come to conclusion: you need to monitor your work and not be distracted by phone calls, as this can lead to various annoyances» or «One day Alise went to the Lab. On an autumn day, the girl saw a leaf with various spots on the road. She was interested in it and she decided to find out what kind of disease on the leaf. Alice conducted research and identified the disease in the laboratory. It was a viral leaf disease that infected all the surrounding plants. Now Alice needs to figure out how to destroy this virus» or «One man was very fond of plants. He was a biotechnologist and interested in science. He had red hair and round glasses. But he was very lonely. No one wanted to be friend with him because he was crazy. In secret from everyone, he decided to make a friend. He knew about the technology CRISPR-Cas9. He decided to remove the cell wall of the rose. Then be cut out the required part of the gene and used the required complementary DNA. He went to sleep. The next morning he had a real friend. His rose smiled at him» as well as «One man was very fond of plants. He was a biotechnologist and interested in science. He had red hair and round glasses. But he was very lonely. No one wanted to be friend with him because he was crazy. In secret from everyone, he decided to make a friend. He knew about the technology CRISPR-Cas9. He decided to remove the cell wall of the rose. Then be cut out the required part of the gene and used the required complementary DNA. He went to sleep. The next morning he had a real friend. His rose smiled at him».

Besides first steps professional real life stories there were the examples of more complicated ones like "Once upon a time, there lived a young handsome man. His name was Ermine. He had long dark hair and painful sight. Many of citizens who had known him before would say that it was because of his character or his past, maybe it was true but only partly. The main reason was - he had been almost blind for years. 
But he wasn't an ordinary guy, he was a biotechnologist, a man who could create almost everything. He had spent many years studying how to recover his vision, and finally he found the answer. Every person had genes who were responsible for receptor synthesis in the eyes called rod cells and cones. He tried to manipulate with them, but there was no success. Ermine knew that he had to try on himself, at least it could probably lead to progress. Also, he realized that it might be dangerous up to his death, but he decided to take a risk, because it was better to be dead rather than blind or crippled for rest of his life. After some days preparing he injected the solution of photoreceptors right in his eyes and waited. The result was incredible, his eyes changed their color and he could see again, even better than he used to. Some of them could call him insane, the others - genius, but sometimes you have to take risk to achieve the result you expect» The another example is "Before maternity leave my mother had been working as a Business Development Manager in a big agricultural company. And I helped her to organize field day for farmers. I sent emails with invitation to more than 3000 farmers. And I answered to their questions and explained why it was important to visit this event. I was really very proud of myself because this field day was attended by more than 1000 farmers. It was very useful for them to know about new technologies of growing corn and sunflowers from market leaders such as DuPont, Pioneer, Syngenta, Basf» or «This funny but very instructive story happened to me during a practical lesson on biotechnology. I came to class with the freshmen and I had to cut a leaf. I took an iron scalpel and held it over the fire, but I couldn't cut the leaf. One of the freshmen advised me to use a plastic spatula, as it is sharper. I took a plastic spatula and put the iron scalpel back - and then there was a fire. Everyone was scared, of course, but the teacher quickly came up to us and covered scalpels with a glass. The incident was over, but we learned a lesson to follow the instructions».

It's worth to inform that the task concerning real life stories concluding became the favorite activity of every student undependly of their English and they might become the background of the previous first step dialogues. The examples of them may be introduced in such statements as «Good afternoon, nice to meet you! Hi, nice to meet you too. Can I help you?- Yes, you can. Let us discuss real life story concerning 
biotechnology.- I agree, with pleasure. What real life story do you mean?- Well, listen. Once upon a time there lived a lonely man. His name was Jack. His wife died after illness. He created attenuated vaccine against bovine spongiform encephalopathy because of wife's death of this disease. Jack has many problems with this vaccine. He could solve the puzzle, he just had to anneal the culture and create a cloned stain. Oh, poor Jack, if he could save her.-: Oh, that's a pity, but it's interesting too. And what professional terms did you apply in it?-: I applied such terms as chromosome and complementary DNA.- What do they mean?- For example, chromosome - s a long DNA molecule with either a part or the all of the genetic material of the organism. Complementary DNA is a DNA synthesized from a single-stranded RNA or mRNA template in a reaction catalyzed by the enzyme reverse transcriptase. Other terms are to be specified. - Thank you for your explanation. May I ask you more?- I'm afraid you're not. I'm short of time. We have to postpone our conversation. - I get it, see you later.- Bye»

These background dialogues in their turn became the background for the further transformation into more complicated ones to be represented earlier.

We consider represented dialogue work to be organic part each future dialogue participant should choose one the most actual problem within a certain field of agronomic knowledge, to narrow the circle of scientific interest in gathering facts and illustrations in relation to a particular theme for example concerning determining the features of biofuels potential [416]. On this stage each future dialogue participant should elaborate his own presentation concerning the general group topic with a detailed description of a certain latest equipment or technology that will be of interest either to professionals in a certain area of agrochemistry or to the general public. On this stage each future dialogue participant should print out the main points with illustrations and a vocabulary of basic concepts. This first step is considered to be very important preparatory stage for the further conclusion of dialogue in accordance with the colloquial situation «Your are the members of scientific society. Represent your scientific interest and describe the structure of your presentation» . 
The second step is to review the guidelines for selecting the second participant in the dialogue with identical scientific interest. At the specified stage of the discussion of achievements, two relevant presentations about biofuels must be concluded. Please, pay attention that their content, vocabulary should not be repeated by another future dialogue participant. For the implementation of the indicated instruction between these two future dialogue participants, the emphasis is to be placed on the use of such lexical units as «biofuels - біопаливо», «digestion - розщеплення», «residues - залишки, відходи», «soybean - соя», «pellets - гранули», «luтber - пиломатеріали», «сrops - зернові культури», «biodegradable - той, що розкладається природнім шляхом», «fossil-копалини», «recycled -перероблений», «етіssions-викиди», «feedstocks-сировина» etc. According to the task to discuss the value of biofuels, a plan of reports about biofuels for the first participant should be updated on such items as «1) Biofuels as a term»; «2) The sources to obtain biofuels»; «3) The difference between ethanol and biodiesel» and for the second participant it should be updated on such items as «1) The nature of biogas»; «2) Pallets»; «3) Liquids». Also the future dialogue participants should preview content of each presentation and they should prepare some previous answers to specific questions. The previous review of replicas to be checked by the first dialogue participant should predict such previous answer as «A biofuel is a fuel that is produced through biological processes, such as agriculture and anaerobic digestion, rather than a fuel produced by geological processes (coal or petroleum)» for the question «What are biofuels?». Besides, the context may be specified by the first student with the answer «Yes, it is» for the question «Is biological fuel a safe alternative to existing vehicle engines? 》 and «Biofuels technology is capable of reducing greenhouse gas emissions and for the use of fossil fuels, is not it? » as well as «Is biofuel produced from renewable biomass material, commonly used as an alternative, cleaner fuel source to burning fossil fuels? » and «Is it difference between ethanol and biodiesel?» with the appendix in answer like «Ethanol is a flammable and renewable liquid produced by the fermentation of grain or from advanced technology such as agricultural waste, wood chips and waste paper. And biodiesel is produced through a combination of alcohol with recycled cooking 
grease, animal fat or vegetable oil» and the answer «No, they are not» for the question «Are biofuels high in carbon intensity?». This first participator of discussion must choose the most interesting questions among the above named list to be asked. The second participant of the dialogue in his own turn must choose his own five the most interesting answers among the answer «The process of anaerobic digestion of organic material by anaerobes leads to biogas. The use of energy crops fed into anaerobic digesters to supplement gas yields» for the question «What leads to biogas?», the answer «Grain, crop residue, cellulosic crops (e.g., switch grass, sugar canes and various tree species) are used for the production of biofuel. These products are processed further to generate liquid fuels such as ethanol or diesel fuel. These fuels release $\mathrm{CO} 2$ when burned, but this $\mathrm{CO} 2$ is of recent atmospheric origin (via photosynthesis) and displaces $\mathrm{CO} 2$ which otherwise would have come from fossil carbon» for the question «What materials are used to produce biofuels?» and the answer "They may be in solid form like pellets in gaseous form like biogas and in liquid state as biodiesel» for the question «What are the main kinds of biofuels?» as well as the answer «They are usually made from compressed industrial waste and coproducts, food waste, agricultural residues, lumber, energy crops» for the question «What are the features of pellet fuels (or pellets)?».

The next stage is to transform common dialoque into discussion. Following it every participant must get positive or negative attitude to biofuel usage choosing arguments among advantages or disadvantages. The first discussion participant may choose his arguments by shotering the provement of advantges on his own mind: «Unlike fossil fuel, biofuels are produced from renewable resources. Also there are less pollutant emissions from biofuels. Ethanol reduces carbon monoxide emissions as it ensures complete combustion. Besides, biofuel do not contribute to global warming as carbon dioxide released, is taken up by their feedstocks. There are also some advantages in some statements like biofuels are cost-efficient when compared to fossil fuels and some of the biofuels producing plants like Jatropha and oil-palms can be grown in dry land and fallow area. Also about 70-88 million biogas plants can be run with fresh/dry biomass residues. The substrate such as cattle waste and biomass used 
for this technology are easily available. Their availability to biogas plants can meet the requirement of 12-30 million families. The calculated global potential of biogas production is in theory sufficient to cover up to one-fourth of the present consumption of fossil fuels within the global transport sector. Using it within agriculture could reduce agriculture's dependency on fossil energy, improving food security. Making biofuels is a profitable process not only for the economy but for the environment. We can use this kind of fuels for agricultural machinery».

The second discussion participant may choose his arguments by shotering the provement of disadvantges on his own mind: «A larger area of land will be required to satisfy global biofuels demand. Projected growth of biofuels crops until 2030 may require over 30 million hectares of land. In many cases for current ethanol production from grain, the fossil fuel associated with use of chemical fertilizers, tractor power and so on, results in an unacceptably small net reduction in fossil fuel use. Besides, production systems with suitable enzymes for utilizing cellulosic feedstocks have not yet become commercially viable. Also it should be mentioned that the resources for biogas generation are not properly managed to generate its maximum biogas potential. Besides, the lack of availability and the structural operation of biogas digesters are not able to generate and develop family-size biogas plants. Despite our country has many resources to create a biofuels but we have some problems with funding» .

The next stage to involve English expressions into dialogue- discussion should be immediate introduction of it, starting with the indication of their roles, the greetings and the purpose of the communication: definition in such phrases as «I'm one member of scientific (sphere of knowledge) society and you are another scientist», «Hello. Nice to meet you», «Hi, nice to meet you too. Can I help you?», «Yes, you can. Let us discuss our reports», «You are welcome. What are you interested in?». On this stage future dialogue participants should be guided by a thematic approach to involve common English statements with some spaces for continuation basing upon explanation in brackets : «What is your scientific interest?», "I'm interested in (the title of presentation)», "What is the structure of your report?», "It is in the form of presentation to include ( quantity) slides», «What is your plan?», «The main points are 
(noting the points of the plan of the pre-prepared presentation)», "What are your main terms from vocabulary?», "They are (preprepared vocabulary)», "What are the most actual phenomenon to be represented?» (noting the title of preprepared presentation), «What are their usage and advantages?» noting advantages from preprepared explanation), «They are (preprepared theses) 》, «Is your topic important?», «Yes, it is. It is important because (explanation involving the answers to preprepared questions)》.

The elements of discussion may predict such phrases as «I'm afraid I can no agree», Is it good for environmental safety?» etc. The next stage is the reversible answering to specify the unannounced points by involving some English statements to be prepared by the second dialogue participant with the pre-stage addition «Will you be so kind to explain the specific points like the forms of biofuels?»

The seventh stage is to require the completion of the conversation in certain statements like «Well, I'm interested in your report», «Thanks for your interest. Your report is important too. See you while reporting», «Bye» to finish conversation.

The eight stage deals with philological studies here is a problem of supplementing the points of analysis of terms and practical analysis of the term «Agronomy» as a basis for research in both the field of linguistic and agrobiological field of knowledge in the implementation of linguistic studies in practical classes in English for professional purposes as well as the problem of comprehensive analysis of terms being related to the agrobiological field of knowledge. The basic approaches to the analysis of terms in general include eight items like: 1) by word origin; 2) by the scope of use; 3) by the number of parts in pronunciation; 4) by the number of letters, sounds and accents; 5) by parts of speech; 6) by the presence of synonyms and cognate words; 7) by stylistic features and the degree of general use; 8) the possibility of forming new terms in order to eliminate homonymy. It is proposed to supplement the list of analysis of terms with the category «Related foreign terms». An example of practical analysis in accordance with these categories is given with an addition. Actually the description of the term «Agronomy» according to the named general approaches and our addition looks as follows:1) (from agro... and Greek nómos-law), literally the science of the laws of agriculture, in a broad sense - the scientific basis; 2) 
use in professional speech among employees of agricultural companies, in advertisements and newspapers of the Ukrainian-speaking mentality; 3) the multisyllable is uncovered, because it has as many as five syllables and begins and ends in the same way with a loud sound; 4) 9 letters, 10 sounds -5 consonant sounds and 5 vowel sounds, the fourth syllable is stressed (of which vowel, unstressed - 4 representatives, consonant, hard, sonorous -3 representa-tives, vowel, stressed -1 representative, consonant, soft, sonorous - 3 representatives); 5) Agro, nom - roots, and-suffix, I - ending, agronomist - the basis of the word; 6) synonyms (horticulture, botany, meteorology, geodesy, selectivity, etc.), cognate words (agroclimate, agrocenosis, agrochemistry, agro-industry, agropolitics); 7) refers to the scientific style being used in scientific articles to describe technological processes, schemes, construction of plans, etc. Belongs to the class of professionalism in the field of science, production, fishing etc.; 8) analogues include such terms in one word or word combinations like land management, horticulture, agricultural production,etc.; 9) related foreign language terms: blossom - цвim, branch - галузь або гілка, broadcast seeding - трансмісійний висів, biennials - дворічні рослини, bисkwheat - гречка, bud - брунька; cabbage - капуста, cauliflower - цвітна капуста, сапе - стебло або тростина, cell - клітина, cereals - зернові, clay- глина, combine harvesting механізоване збирання врожаю еtс

The stage of the detailed description of the nesting phenomenon and making descriptive notes. On this stage the students have investigated that morpheme landis mainly nested in more than one hundred varieties exampling thirty five basic varieties and seventy four additional varieties [415]. Morpheme land- is mainly represented in following thirty five basic varieties: nine attribute-noun two components word combination (leased land,degradated land, sold land, purchased land, arable land, dry land, bad lad, fertile land, land measuring), one attribute-noun three components word combinations(land natural resources), two noun-noun three components word combinations (land cost definition, forest plants land, water fund land, land reconnoitre observation), sixteen two components noun-noun word combinations (land purpose, land quality, land administration, land recultivation, land 
cadastre, land domain, land estimation, land easement, land tax, land evaluation, land law, land melioration, land relief / terrain), land measurements, land redistribution, land surface), three multistructural word combinations etc.

In general it was distinguished that morpheme land- includes either 35 basic varieties (land, leased land, degradated land, sold land, purchased land, arable land, dry land, bad land, fertile land, land measuring, land natural resources, land cost definition, forest plants land, water fund land, land reconnoitre observation, land purpose, land quality, land administration, land recultivation, land cadastre, land domain, land estimation, land easement, land tax, land evaluation, land law, land melioration, land relief / terrain, land measurements, land redistribution, land surface, land of natural reserve and other nature conservation purposes, land of residential and public buildings, land of sanitary purpose). Besides, morpheme land-includes 74 additional varieties being included into 13 derivative compounds (land plan, land manager, land management, land code, land parcel, land plant, land use, land property, land samples, land probing, land crops, land owner)which have become nesting items themselves because of the regular usage for land management texts in such representation. The most nesting morpheme morpheme land- derivative compounds are land management, land plot, land parcel and land crops to be used together with 35 morpheme land- basic varieties for the future dialogue concluding on the basis of the shortened list of professional phrases. The majority of morpheme land- nesting varieties belongs either to noun-noun two components word combination or to attribute- noun two components word combinations. The majority of morpheme land- derivative compounds belong either to attribute- noun three -four component word combinations or to noun-noun three-four component word combinations. The main stages of linguistic must predict three previous stages like the stage of the agrobiologists' adapted foreign texts reading and analysis concerning searching landmorpheme representatives, the stage of the detailed description of the nesting phenomenon and making descriptive notes and the stage of making mathematic calculations, table columns context coding and adequate statistic linguistic tables concluding. The prospect of research is to observe a range of concrete real life 
communicative situations on the basis of the previously distinguished common adequate morpheme land- word combinations.

In our opinion, the submitted order of English statements involvement optimized the work of agrobiological direction students while preparation for discussion of reports-presentation of the latest technologies in the relevant field of knowledge. The experience to involve the above named algorithm may be considered to be successful because of the adequate questionnaire in which students evaluated such experience as positive to adapt them to foreign speech.

It's worth to say that real life stories concluding attracted either not advanced level students'interest starting from short stories like «The agronomist came to the field. He began to examine the state of winter wheat. He saw that there were too many pests on plant leaves. He consulted with the nearby farm agronomist. They decided to spray the field. A tractor arrived on the field. The pests were killed» and ending the advanced level wide stories: «Peter Johnson at wheat Pete real agriculture calm and its wheat planting season it's awesome I love it what are we doing wrong why does always have to be what are we doing wrong but we are doing some things that we really have to step back and question so first off biggest question of the season right now how deep do I plant my wheat and why is that the question because it is dry not everywhere in fact amazing the sweet spot of Ontario 74 bushel per acre soybeans planted wheat the day after those soybeans came off and four days later the wheat was out of the ground can you imagine that but they've got good moisture lots of areas very dry so here's the scenario either we have to plant deep to go to moisture or we plant in dust and get over this concept leave it in the dag till it rains that's all bad because once it starts to rain it may never stop and if it's in the ground at an inch and a quarter I like an inch but an inch and a quarter then once it rains it will start to grow so whatever you do plant the stinking wheat but if you plant at an inch and a quarter and you say l'll wait it rains yeah who knows when that'll be that might in fact go back far enough there was a grower who did that and his wheat emerged under the snow at Christmas time because it didn't rain until the end of October in Essex County that year if you can get to moisture that's the right choice so it's kind of interesting because we always talk lots 
about how deep can you plan and with soybeans in the spring we tell you don't go over two inches because that hypocotyl it doesn't extend enough and they won't emerge well if you remember Act two we talked about double crop soybeans when we plant double crop soybeans we can plant those three three and a haif inches deep and because the soil is so warm that hypocotyl elongation is way bigger same thing early in the fall it's warm so whereas normally I don't want you to plant three inches deep if you can find moisture at three inches deep plant three inches deep and it's so warm that even though it takes a little more heat to get that wheat out of the ground it'll still bounce out of the ground really really quickly and you'll have a nice even stand and you'll have way more yield because we've learned that yield is all about planning date so it's quite clear we have a big variability in this field in terms of where that's the stage of development side some of the wheat is already coming into the to leaf stage here I have nothing at all and what's going on here when we start to dig down and gosh we can see that no week that wheats not anywhere near deep enough and so this is the crux of the issue you really have to get this wheat in to moisture now it's interesting it is winter wheat and people say you know with with soybeans they need four times their weight in water to to germinate and with corn it needs at least twice its weight in water remember how easily wheat will gain moisture in the summertime when you're trying to combine the doggone stuff and it's 14 percent moisture or it's 16 percent moisture at 6 or 8 o'clock at night you shut the combine down and it's a heavy dew over night what's it go to 19 percent moisture 20 percent moisture so wheats a different beast it doesn't need a ton of moisture but it needs some moisture so actually wheat will germinate there's some research out there that says if you just can get into a humid environment you don't need real moisture you need just high humidity it will germinate and grow but if you put it into this dust and this is a pulled and wind road edible bean field and so they've dried it out a fair bit you don't get it deep enough then you don't get a stand so get that drill deep and that wheat up and growing a couple of other really really important things about this at this particular harvest and I see it again it drives me absolutely nuts residue spread what is the matter how many times you have to talk about this and so you can see here we've got six feet with no residue and we've got 24 
feet with residue that's not good enough it's not going to do the job that we want and the other one is weed control weed control this kaleipus eight resistant fleabane either you spray it with Aragon with your roundup before the week gets up or you spray it with infinity once the wheat is up they're both registered they'll both take out fleabane this year it's been another big challenge for us it's one of those things we can't let go meanwhile get the wheat in the ground get it deep enough to get it up and let's break out previous record grow wheat Peter Johnson at weed Pete real agriculture calm».

Thus, the abovenamed experiment within the National University of Life and Environmental Sciences of Ukraine during the first 2021/2022 studying year term including participation of bachelor's degree program 88 students from the Agrobiological Faculty and the Faculty of Plant Protection, Biotechnology and Ecology showed the adequacy of real life dialogues, humoristic stories and interesting facts application in combination with the parallel professional speech introduction while studying and discussing GMO, bioengineering, seeds, soil, plant growth, agricultural products and processes etc basing upon background of traditional tasks to be in general part of such seven stages of students' foreign speech development as) familiarization and narrowing of the actual professional topics to general one, at which simultaneously several reports are prepared; 2)clarification of the plan, vocabulary, key questions and answers of each of the participants in the future dialogue to avoid coincidences; 3) preliminary formal general dialogue start with constant colloquial cliché; 4) the actual entry into the dialogue according to a specific topic; 5) providing dialogue with the elements of the discussion; 6) a reversible asking to specify unpublished pre-prepared items; 7) the formal general ending of the conversation with the stable conversational clichés(0therminological work, the work with proverbs and statements by great writers and scientists as well as state figures which involve professional biotechnologists' and agronomists' vocabulary and speech mentioning the topics of the most students' interest. In our case the topic «Soil» was elaborated in 11 versions and plant «Growth» in nine versions of students' dialogues.

The perspective of investigation is the description of the practical experiment to develop communicative skills of future technicians in details. In parallel it's important 
analysis of the activity of fulfillment, the correctness of content design and understanding of the set tasks either aiming to represent general and personal recommendations to improve gaps in freshmen's foreign language knowledge, abilities and skills or further correction of topical content of studying course being based on the real future agronomists' and biotech students' demands 
DOI 10.46299/ISG.2021.MONO.PED.III.5.4

\section{4 Креолізація рекламних повідомлень у сфері косметологї̈ (на матеріалі японської і української мов)}

Пропоновану статтю присвячено дослідженню особливостей взаємодії вербального і невербального компонентів у сучасних японських та українських рекламних повідомленнях. Звернено увагу на специфіку рекламних повідомлень у сфері косметології. Основний зміст дослідження становить аналіз креолізації рекламних повідомлень 3 метою встановлення кореляцій мови реклами 3 параметрами менталітету і культури двох народів. Виявлено, що зображення займають більшу частину друкованої площини рекламного повідомлення, ніж текст, що свідчить про домінуюче положення візуального компонента у рекламі косметичної продукції. Проаналізовано тенденції щодо локалізації реклами і виявлення в рекламному повідомленні самобутності народу, його культури.

Сучасна лінгвістика звернула свою увагу на семіотично гетерогенні тексти, для опису яких ще не розроблений загальновизнаний термінологічний апарат і які, в найбільш загальному вигляді, звуться креолізованими [422, с. 165]. Зупинимося більш детально на змісті цього терміна, який орієнтовано на специфіку рекламного тексту. Термін "креолізований текст" було введено Ю.О. Сорокіним і Є.Ф Тарасовим, які розглядають його як текст, "фактура якого складається 3 двох негомогенних частин: вербальної (мовної/мовленнєвої) і невербальної (яка належить до інших знакових систем, ніж природна мова)" [423, с. 180-186].

О.Е. Анісімова визначає креолізований текст як "особливий лінгвовізуальний феномен, у якому вербальні і іконічні висловлення" створюють одне візуальне, структурне, змістовне і функціональне ціле, яке комплексно впливає на адресата [420, с. 148]. 3 огляду а те, що мовний і візуальний компоненти постають у певній взаємодії, Л.В. Головина виділяє три види кореляції тексту і зображення:

1) паралельна: зміст тексту і зображення повністю збігаються;

2) комплементарна: невербальна інформація частково перекриває вербальну;

3) інтерпретативна: інформація і текст пов’язані за змістом [421]. 
Ми розглядаємо креолізовані тексти, представлені рекламними повідомленнями, в яких зміст складається із нерозривного поєднання зображення та вербальної інформації.

овний рівень використовується для прив’язки повідомлення, тому що візуальний образ часто виявляється двозначним і може тлумачитися по-різному. У візуальній комунікації У. Еко виділяє n’ять кодифікаційних рівнів:

1) тонічний рівень, коли розуміємо, що та чи інша конфігурація зображує кота чи стілець і не задаємо питання, чому це так, а не інакше;

2) іконографічний рівень, при якому перед нами два типи кодифікації: одна - історичного типу, в якій рекламне повідомлення використовує конфігурації, що відсилають до певних значень, прийнятих класичною іконографією (від німбу, який означає святість, до поєднання фігур, пов’язаних з ідеєю материнства тощо); друга, яка склалася в рекламі, як такої, коли, наприклад, жінка, яка стоїть у характерній позі нога за ногу, повинна зображувати манекенницю;

3) рівень тропів включає візуальні еквіваленти словесних тропів. Троп може бути несподіваним, може набувати естетичного значення або може бути спробою візуального відтворення словесної метафори. 3 іншого боку, мова реклами використовує такі тропи візуальної комунікації, які буває важко звести до словесних;

4) рівень топосів: рівно включає як область так званих передумов, так і загальних місць аргументації, або топосів, тобто дві рубрики, за якими традиційно розподілялися аргументи. Кодифікація топосів могла б перетворитися на детальну класифікацію способів передачі словесних топосів візуальними образами. При аналізі

мови зображень стає очевидним наявність іконограм, що індукують ціле поле топосів;

5) рівень ентимем - це рівень аргументації як такої. У зв’язку 3 багатозначністю зображення і необхідністю закріпити за ним одне значення за допомогою слів, аргументація виходить або із словесного ряду, або їі джерелом є співвіднесення словесного ряду з візуальним [424]. 
Метою даної статті $є$ встановлення кореляції вербального i невербального компонентів у сучасних японських і українських рекламних повідомленнях у сфері косметології.

Рекламний текст як продукт комбінації знаків різних семіотичних систем принципово не відрізняється від гомогенного вербального тексту, йому притаманні ті ж самі текстові категорії - цілісність та зв'язність. Для належного декодування інформації, закладеної в полікодовому тексті, потрібно сприймати текст цілісно, беручи до уваги інтеграцію знаків як вербальної, так і невербальної семіотичних систем. Але між цими компонентами встановлюються автосемантичні відношення, де вербальна частина порівняно автономна від зображувальної. Іконографічні частини рекламних повідомлень, з одного боку, допомагають уникнути багатозначності, а 3 іншого, підсилює образність повідомлення.

Використання різних мовних і позамовних засобів, які репрезентують маніпулятивні прийоми в рекламних текстах, базується, за нашими спостереженнями, на низці популярних тем і мотивів, що становлять цінність для сучасної людини та її менталітету, який її формує: вступ у нове століття, прогрес, престижність, а також о́брази привабливих чоловіків і жінок, родини, пріоритети здорового способу життя, здоров'я загалом тощо. Лінгвальні і екстралінгвальні стратегії рекламного тексту створюють єдине структурне, візуальне, семантичне і функціональне ціле, яке забезпечує необхідний ефект рекламного повідомлення.

В українських рекламних повідомленнях косметичних засобів зображувальні елементи присутні у 100 \% текстів. Серед яких можемо виділити:

- зображення обличчя жінки (зазвичай знаменитість) разом із продукцією;

- візуалізачія метафоричного вербального компонента;

-іконічні знаки; 
- візуалізачія вербальних знаків.

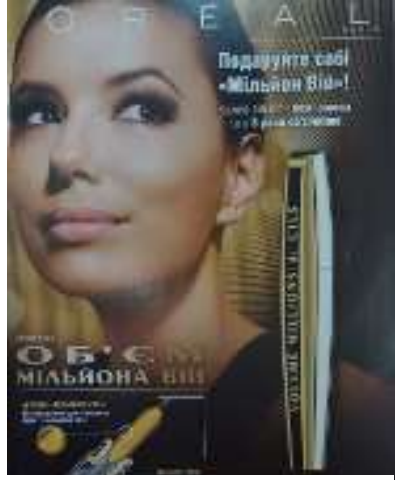

Рис 1.

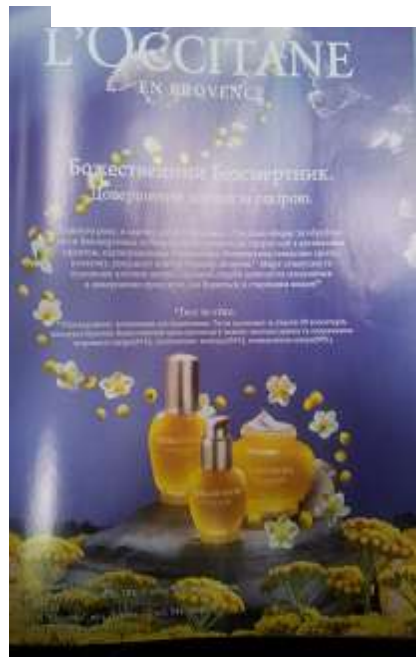

Рис. 2

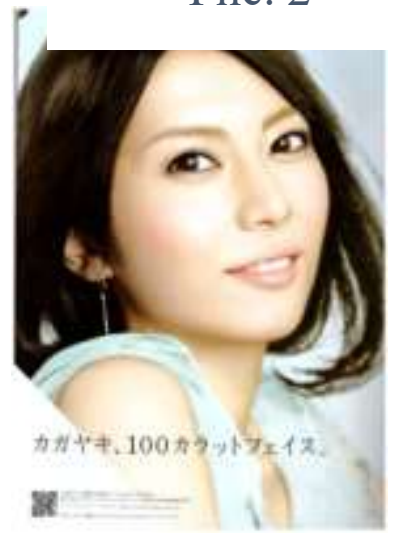

Рис.3

У цьому рекламному повідомленні спостерігаємо одразу два засоби: фото селебріті (Сва Лонгрія) і візуалізацію метафоричного вербального компонента (мільйон вій). Ефект сугестії забезпечується завдяки подвійному впливу на читача за допомогою фото обличчя відомої зірки і зображення “мільйона вій ”(рис.1).

На рис. 2 спостерігаємо метафоричну візуалізацію вербального компонента "Божествений Безсмертник" у вигляді сяючого світла 3 неба і доріжки 3 квіток, яка піднімається вверх. В Україні, як зрештою і в інших православних країнах світу, безсмертя асоціюється із вознесінням Ісуса Христа на небо на третій день після казні. В даному випадку вербальний компонент уточнює іконічний знак неба. А завдяки ефекту візуалізації, малюнок підсилює інформацію тексту.

В японських рекламних повідомленнях у сфері косметології також відмічаємо тенденцію щодо використання фото жіночого обличчя для доказу ефективності того чи іншого косметичного засобу. Вербальний компонент “100カラットフェイス” можна перекласти як обличчя у сто каратів. В даному випадку візуальний компонент домінує над вербальним, оскільки фото гарного жіночого обличчя $\epsilon$ дієвим доказом ефективності косметичного засобу (рис.3). 


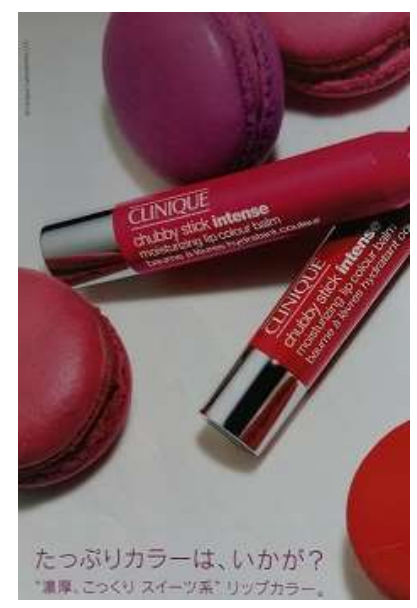

Рис. 4

На рис. 4 зображена помада фірми CLINIQUE, що корелює із кольором відомих і популярних в сучасній Японії солодощів макарон, які також присутні на сторінці рекламного повідомлення.. Вербальний компонент スイー ツ系 /suitsukei/ вказує на походження кольору помади, а відтак, що губи за насиченістю кольору і смаком будуть нагадувати найбажаніші солодощі.

Поняття іконічний знак вперше було запропоновано американським філософом і логіком Чарлзом Пірсом. За Пірсом, іконічний знак - це "знак, який має певні властивості означуваного ним об’єкта, незалежно від того, чи існує цей об'єкт в реальності". Іконічний знак - це поняття, яке пов'язане 3 зображенням будь-яких предметів, тварин, птахів, символів, орнаментів, персонажей тощо . Іконографічні частини рекламних повідомлень, з одного боку, допомагають уникнути багатозначності, а 3 іншого, підсилюють образність повідомлення. Під іконічними також розуміємо знаки, які базуються на відтворенні подібності між знаком та його значенням за кольором, формою, звучанням, структурою чи послідовністю. Зв'язність рекламного тексту проявляється в узгодженні і тісному взаємозв'язку вербального та іконічного компонентів на змістовому, змістово-мовному та змістово-композиційному рівнях. Знак виконує найважливішу функцію суспільної комунікації - якщо людина не знайома із суспільно обумовленими значеннями, прийнятими в цьому суспільстві і культурі символічного значення кольору або предмета, то комунікація або не відбудеться, або стане істотно ускладненою. Тому декодування цих знаків надає нам інформацію про суспільство і культуру певного народу.

В українських рекламних повідомленнях косметичної продукції виділяємо:

- іконічні знаки (67,8\%);

- вербалізовані іконічні знаки $(1,4 \%)$. 
Як приклад розглянемо рекламне повідомлення антивікової сироватки фірми VICHY. Після вислову Сьогодні я буду їсти на ходу бачимо іконічний знак - гамбургер. У різних країнах і культурах існує своя традиційна вулична їжа.

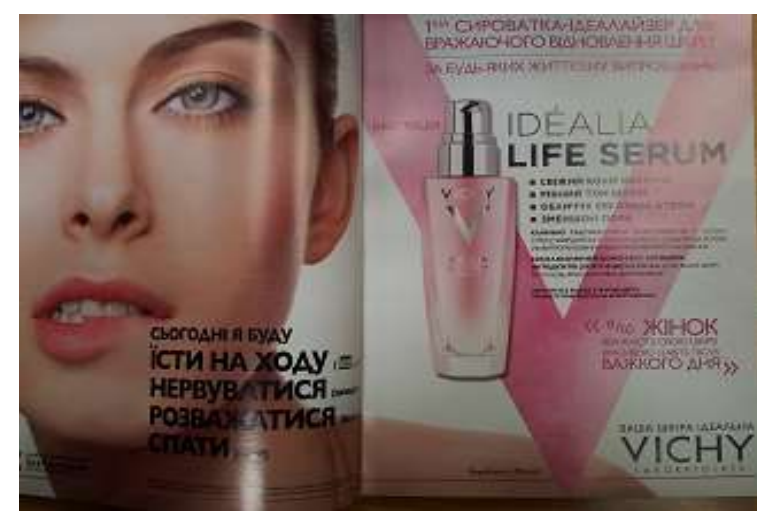

Рис. 5 Припустимо, у Греції продають на вулицях смажені початки молодої кукурудзи, у Камбоджі - смажених павуків, а 3 цого рекламного повідомлення стає зрозумілим, що в Україні на ходу їдять гамбургери (рис. 5).

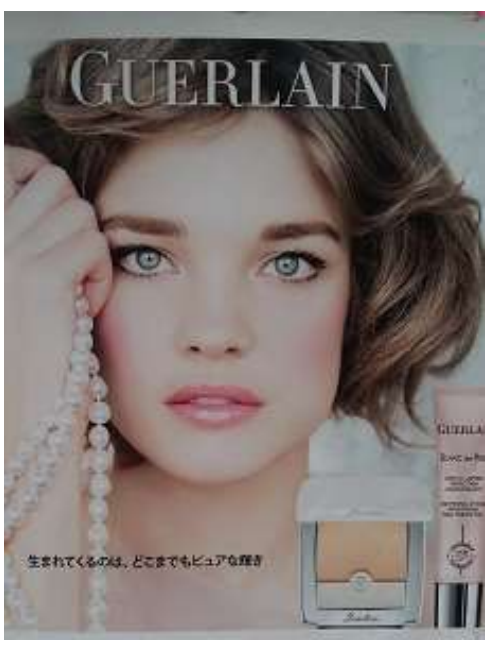

Puc. 6

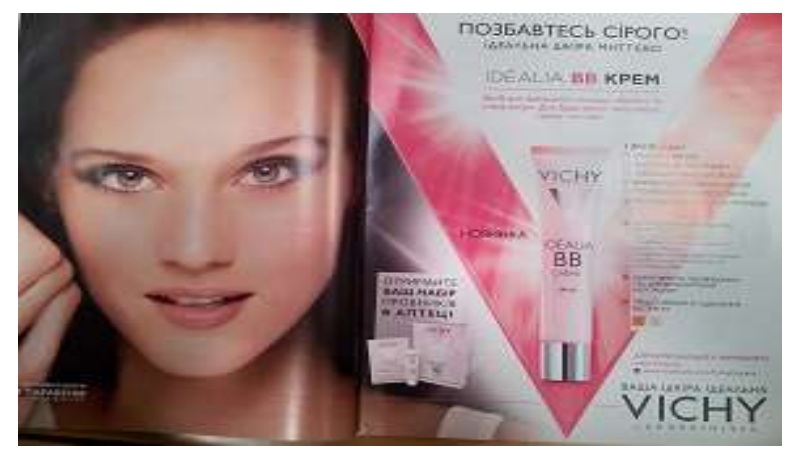

Рис. 7
В японських рекламних повідомленнях відмічаємо використання зображення перлин як еталону кольору і гладкості шкіри для японських жінок (рис. 6). Використання перлин $є$ національнозумовленим зважаючи на всесвітньо відомих японьських жінок ама, професією яких протягом багатьох століть є діставати перлини з морських глибин.
В українських рекламних повідомленнях літери латинського алфавіту відмічаємо здебільшого на позначення бренду (рис. 7) 


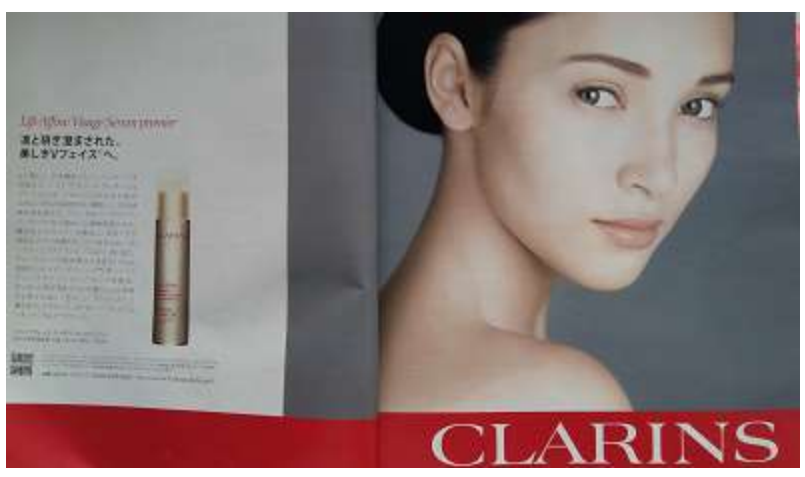

Рис. 8
В японській мові латинські літери позначають певні стандарти буття японських жінок. Часто великі літери поєднуються із запозиченими словами (2,2\%), наприклад: 凛と研ぎ澄まされた、 美しき $\mathrm{V}$ フェイスへ(рис. 8)

У першому прикладі V латиницею означає першу літеру слова victory (перемога), а словосполучення Vフェイス можна перекласти як обличчя перемоги. Але в цьому рекламному повідомленні літера V використана не через зміст слова victory, а через іï форму, яка відображає омріяний тип обличчя усіх японських жінок, що асоціюється 3 формою англійської літери V .

Проаналізувавши фактичний матеріал двох досліджуваних мов, можемо стверджувати, що візуальний компонент (обличчя, фото косметичної продукції тощо) займає більшу частину друкованої площини рекламного повідомлення, ніж текст, що свідчить про домінуюче положення візуального компонента у рекламі косметичної продукції. Поєднання національно-маркованих вербальних i візуальних засобів передачі інформації забезпечує цілісність і зв'язність рекламного повідомлення i комунікативний ефект в українській і японській лінгвокультурах.

Представлене дослідження відкриває перспективи подальших наукових розвідок як у межах лінгвокультурології, так і в суміжних науках, зокрема у когнітивній лінгвістиці, що фокусується на ментальних основах розуміння і продукування мови. 
DOI 10.46299/ISG.2021.MONO.PED.III.5.5

\section{5 Екологічний аспект співіснування людини й природи (на прикладі поезій Л. Костенко)}

Формування індивіда в процесі цілеспрямованої діяльності суспільства тісно пов'язане із духовно-естетичним сприйняттям довкілля. Адже людина й природа перебувають у безперевному органічному взаємозв’язку, впиваючи одна на одну як позитивно (наприклад, доглянуте екосередовище є запорукою формування міцного здоров’я, отримання естетичної насолоди від споглядання краєвидів тощо), так і негативно (зокрема, глобальні кліматичні зміни стали наслідком безвідповідальної діяльності людства).

В українському письменстві зображення природи є одним із традиційних елементів, що сягають корінням у вікові глибини духовних i народнопоетичних надбань. За допомогою образів природи митці передають почуття, виражають своє ставлення до світу, висловлюють захоплення й замилування мальовничими пейзажами рідної землі. Однак поліфункціональність творчого мислення спонукає майстрів слова й до порушення проблем морально-етичного гатунку, зокрема співіснування людини і природи. Якщо в доцивілізаційні часи людина відчувала себе частинкою круговерті буття, то вивчення його закономірностей та науковотехнічний прогрес призвів до формування іiі впевненості у власній безмежній могутності. I тільки 3 часом суспільство знову стало повертатися до усвідомлення всесвітньо взаємозалежних зв'язків. Наразі загострення екологічних проблем, зумовлених впливом людської діяльності на довкілля, перебуває в полі зору фахівців різних галузей міжнародного рівня й спричиняє зростання тривоги людства за майбутнє планети Земля. Щодо гуманітарної реакції на екологічні виклики сучасності, слушною видається думка Л. Статкевич, яка вбачає ii в переосмисленні взаємодії/ стосунків між природою та людиною й актуалізації екокритики [див.: 431, с. 101].

Екоцентричний дискурс української літератури має давні традиції. Він зреалізувався у творчості Г. Сковороди, Т. Шевченка, О. Кобилянської, 
О. Гончара, М. Рильського, Б. Олійника, В. Яворівського та інших. Серед українських митців, що порушують у своїй творчості питання про принципи взаємин людини і природи з погляду різнобічних проекцій, є Л. Костенко. Вивчення поетики художнього зображення світу природи у творах поетеси мала місце в роботах С. Барабаш, В. Брюховецького, М. Ільницького, Г. Клочека, А. Макарова, О. Ковалевського, Т. Салиги та інших. Розвідки, яка б містила вичерпне висвітлення екодомінанти у творчості Л. Костенко, поки що немає. Вибір теми, як і формулювання проблеми дослідження, зумовлено наявністю порушення зазначеної проблеми в ії поезії, що стосуються вивчення і трактування творчості поетеси. Це, власне, і є запорукою актуальності теми наукового студіювання. Мета та завдання роботи - вибрати з творчого доробку Л. Костенко поезії, що торкаються екологічних аспектів співіснування людини i природи, розглянути їх художні особливості крізь призму естетичної концепції творчості авторки загалом.

Природа і людина в мистецькому баченні Л. Костенко простежуються крізь призму обопільної й взаємозумовленої єдності людського та природного мікросвітів, які споконвіку перебувають у безмежжі макросвіту - Всесвіту - як невід’ємні складові. Позитивні чи негативні зміни в їх злагоджених стосунках неодмінно призводять до порушень на всіх рівнях співіснування. С. Ягодзінський, філософськи осмислюючи розвиток людського та природного світів, виокремлює три головні типи їх взаємодії, які умовно позначає «пізнання», «співробітництво» (діалог) та «співрозвиток» (коеволюція) [427]. I ми цілком погоджуємося 3 думкою Н. Криловець, що у творчості поетеси переважають два останні [428].

Лірична героїня Л. Костенко тонко відчуває гармонію й дисбаланс людського та природного світів і дуже чутливо, пропускаючи через серце й душу, їх сприймає: «Мене сьогодні голуб розбудив. / Він прилетів і плакав на балконі» [429, с. 534]. Ïї глибоко хвилює доля всього живого: «Ще назва є, а річки вже немає. / Усохли верби, вижовкли рови / і дика качка тоскно обминає / рудиментарні залишки багви» [429, с. 53], «Ластівки тікають із Свропи. / Що 
поробиш? Скрегіт, регіт, рев. / Чад, бензин, вібрації, галони, - / птиці мертві падають 3 дерев» $[429$, с. 54$]$; «екологічним зойком» спливають в уяві вимерлі види тварин: - «Останній дивогляд морської череди! - / жив тисячу століть, а я вже не застану» [429, с. 55]. Мотив осмислення місця людини і природи у світобудові є провідним у художній рефлексії Л. Костенко.

Концентрує екологічну свідомість реципієнта й спонукає до утвердження думки про обопільну зумовленість і залежність світу природи 3 екзистенційним світом людини поезія «Хутір Вишневий». У факті зникнення одного $з$ осередків поселення людей (а місць таких на території України чимало) - Хутора Вишневого - поетеса побачила втрати кожного на рівні духовному (на разі треба зазначити, що природа в іiі мистецькому стилі одухотворена й персоніфікована). Емоційна наснага розгортається навколо ключового твердження: «Вишневий Хутір... Ні душі». Уже в цій короткій фразі відчувається глибина й гіркота значної втрати, яку посилює образ «зальотного самосія», поважний вік якого підкреслює епітет «сизий, аж смушевий». Авторка наче ненароком зауважує, що лише у його пам'яті хутір «іще Вишневий», і далі перед читачем виринає фреска 3 його спогадом охопленої уяви: «Цвітуть іще ті вишняки, / за обрій стелиться пшениця, і йде у школу навпрошки / маленький хлопчик пішаниця», i «мати свій городець поле». Ця ідилія панувала «там, за порогами, в степах, де землі щедрі і розлогі», де «що не впало проросло» [430, с. 200]. Контрастом до цього є зображення світу природи без людей (це символізує образ хати із забитими вікнами): «Все обступили солонці. / Рілля вродила камінцями. / Стоять порожні криниці, / береться сіль до самих цямрин» [430, с. 201].

Духовні інтенції поезії підсилюються зображенням явних екологічних змін, що виражені у відтворенні образу землі, яка ніколи не звикне до розриву зв'язків між людським і природним світом. Руйнація вікової гармонії буття, спільного для людини й природи, призводить до порушення духовної рівноваги обох. Авторка через місткі лапідарні фрази утверджує думку, що природа ніколи не змириться з втратами, яких зазнало іiі лоно: «Землі хоч 
тисячу століть - / вона не втішиться, не звикне, / що кінь в степу не заірже, / що вже нема верби тієї, / де мертвий хутір стереже / могилу матері твоєї ...» [430, с. 201]. У вірші звучить ще й мотив незнищенності духовних основ, який передається через персоніфікований образ мертвого хутора, який у творі символізує хранителя пам'яті поколінь, i утверджується ідея, що рід безсмертний поки живі пам’ятають про мертвих. «Мертвий хутір»- міцний вузол у низці зруйнованого зв’язку між світом людини й природи.

Чорнобильська трагедія змінила буття пересічного українця й сколихнула світову громадськість, ставши вершиною в усвідомленні примарної техногенної безпеки, а в гуманітарній сфері збурила хвилю рефлексій щодо гострого осмислення проблеми земного співіснування людства. І. Дзюба, аналізуючи вірші Л. Костенко на чорнобильську тему, що ввійшли до збірки «Річка Геракліта», доречно зазначає: «Не справа поезії аналізувати чи облікувати «плюси» i «мінуси» шаленого технологічного прогресу... але хто і як захистить поезію від того суму, яким живе калічена людством природа?» [431, с. 84]. Лихо, що спіткало рідний народ, гострим болем озвалося в серці поетеси. Екологічні візії чорнобильської драми спостерігаємо у віршах «Цей дощ - як душ» [430, с. 152], «Чорні верби над ставом» [430, с. 153], «Страшні корчі вербових ікебан» [430, с. 154], «На березі Прип’яті спить сатана...» [430, с. 207], «Поховані чорнобильські ліси!» [430, с. 209] тощо. У них відчуваються сумні есхатологічні нотки: «...фантом іде, куди його не ждуть. / I тільки села мертвими очима / його у далеч тоскно проведуть» [430, с. 115], «Людей нема, а яблуні цвітуть. / І мертва річка зблискує, як ртуть» [430, с. 154], «День нахмуриться ніччю. Переглянуться зорі. / Озирнеться комета. Заплачуть дощі, / що Земля вже пустельна. І ріки вже хворі, / і немає ж куди повертатись душі» [430, с. 186]. У цих творах можна виокремити низку персоніфікованих художніх образів, що населяють поетичний всесвіт (зорі, комета) та світ природи (дощі, ріки тощо), яким протиставляється уособлений образ атомного реактора, що становить зловіщу глобальну загрозу: «той чорний реактор - i пекло, і трон. / Він спить на піску підібгавши коліна. / I 
сниться йому в ореолі ворон / вже вся Україна, вже вся Україна» [430, с. 207]. Поетеса схиляє до думки, що руйнування світу природи призведе не тільки до фізичного знищення людини, але й духовного.

Не байдужа до історії свого народу Л. Костенко, незважаючи на небезпеку (вважає: «Письменник повинен бачити все» [цит. за 431, с. 153]), взяла участь у експедиції Державного наукового центру захисту культурної спадщини від техногенних катастроф. Чорнобильська тема гірким болем осіла в її серці й рефлексувала в мистецькій творчості.

Уже 3 першого рядочка «Цей дощ - як душ» [430, с. 152] однойменної поезії авторка, використавши смисловий прийом порівняння, стрімко переносить реципієнта в географічно-історичний вимір («Чорнобиль. Зона. Двадцять перший вік» [430, с. 152]), запрошуючи заглянути в минуле, яке не тільки змінило долі мільйонів, але й призвело до безповоротного знищення великого пласту давніх етнокультурних надбань. Зона відчуження навколо Чорнобильської атомної електростанції (ЧАЕС) на тисячоліття залишиться екологічно небезпечною, а поліщуки («ареалом поширення назви... був в основному басейн Прип'яті та її приток» [432] назва унікальної етнографічної групи (субетносу) трапляється в історичних джерелах XV ст. [див: 433, с. 341]) як носії давніх територіальних традицій, елементів побутової культури, діалектних особливостей у мовленні тощо, що на жаль, можуть знівелюватися в національному ідентифікаційному просторі.

I хоч досліджувана поезія сповнена позитивного настрою у відтворенні пишної краси природи, однак контрастно звучать мінорно сумні нотки, що пронизують останню строфу: «Але кленочки проросли крізь ганки. / Жив-був народ над Прип'яттю - i зник. / В Рудому лісі виросли поганки, і ходить Смерть, єдиний тут грибник» [430, с. 152]. У поезії простежуються сумні есхатологічні мотиви. Уособлений образ Смерті, ненароком вкраплений у емоційно наснажений тон твору, змушує реципієнта зауважити, що між природою і людиною таки існує той споконвічний тісний взаємозв'язок, який має безпосередню причетність до світобудови загалом. Однак апріорі природа 
має потенціал відновлення й активно його зреалізовує, а техногенні катастрофи (зокрема, вибух атомного реактора на ЧАЕС), спричиненені людською діяльністю, обертаються глобальними трагедіями насамперед для самого суспільства.

У циклі поезій «Інкрустації», що ввійшли до збірки «Вибране», серед риторичних запитань, які змушують читача замислитися, такі: «Чому ЗвіздаПолин упала в наші ріки?! / Хто сіяв цю біду і хто її пожне? / Хто нас образив, знівечив, обжер? / Яка орда нам гідність притоптала? / Якщо наука потребує жертв, - / чому ж не вас вона перековтала?!» [429, с. 537]. Вони не тільки збуджують свідомість реципієнта, спонукаючи до висновків про відповідальність людей за власні дії та вчинки, а й значно розширюють межі екологічної проблеми, активізуючи питання переосмислення національнопсихологічної гідності, світосприйняття, історичного буття тощо.

Наслідки екологічних катастроф, на жаль, стосуються кожного земного мешканця і вже стали сумною часткою буття світу людей. У збірці «Мадонна Перехресть» [434], яку присвятила коханій доньці, Л. Костенко не змогла оминути цієї болючої теми, помістивши поезії «Не половіють в полі колоски» i «Сніги в снігах», які, треба зауважити, взаємодоповнюють одна одну. Твори об’єднані спільними мотивами та зримо виразною тональністю відтворення місць колишнього побутування людей - місто (Чорнобиль) і село в Зоні відчуження. Художній простір цих геолокацій поетеса зображує в притаманній ій лаконічній стильовій манері, зокрема через інформаційно місткі факти й зорові образи: «В Чорнобиль повертаються казки» [434, с. 60], «Біжить вовчиця... зеленим оком світить на село», «село давно уже як привид», «І виє в ніч вовчиця за селом» [434, с. 61]. Відтак, плавно занурившись у поетичний простір, реципієнт чітко уявляє світ природи без людей і навіть більше - після людей.

Емоційна наснага у творі «Не половіють в полі колоски» [434, с. 60] досягається протиставленням дій - подій, які вербалізовані дієсловами теперішнього часу як із значенням заперечення, так і ствердження: «не 
половіють», «не ходять», «не скачуть» - це про світ людей; «повертаються», «розказують», «плачуть» - про всевишні джерела духовності, що втілені в уособленому образі казок. Саме так бачить авторка той нетлінний місток, що поєднує світ природи та людини. Твір пронизує мотив смутку. Екологічна драма насторожує ліричну героїню.

Поезія «Сніги в снігах» [434, с. 61] - це фрагмент із нинішнього буття на території Чорнобильської зони відчуження, де залишене людьми село опанувала природа, яка заповнила постесхатологічний простір. Раніше заселений людьми топологічний континуум, тепер наповнений уособленими образами: сніги, засипані снігом; ріка, скована кригою; верби, яким «руки 3 холоду звело»; смерть, що «пройшла лісами напролом»; «хмари йдуть», «місяць губи кривить», - відродився й продовжує жити. У поезії простежуємо традиційний неоромантичний мотив вічного існування природи через іiі відродження (воскресіння).

Отже, осмислюючи в поезії проблему співіснування людини і природи, Л. Костенко зауважує їх обопільну залежність та тісний взаємозв'язок із макросвітом - Всесвітом. Безвідповідальна діяльність людства призводить не тільки до техногенних катастроф, знищення біосфери, але й до дисбалансу та руйнації на глибинних рівнях екзистенційного буття. Водночас авторка наголошує на здатності до швидкого самовідновлення природи, а відтак іiі вічного існування, але без людей. Майбутнє суспільства поетеса вбачає в гармонійних взаєминах людини й природи, які також є запорукою збереження основ духовності. 


\section{SECTION 6. PHYSICAL EDUCATION AND SPORTS}

DOI 10.46299/ISG.2021.MONO.PED.III.6.1

\subsection{The challange of improving the educational and professional program "Physical culture and sports" of persons of the second (master's) level of higher education in specialty 017 physical culture and sports}

Building a national education system in modern conditions with taking into consideration the radical changes in all spheres of public life and historical challenges of the XXI century requires critical reflection and concentration of efforts and resources on solving the most acute problems that hinder development and are the obstacles to providing a better quality of education.

Modernization and development of education must become proactive and continuous, respond flexibly to all processes taking place in Ukraine and the world. Quality education is a necessary condition for ensuring sustainable democratic development of society.

The efforts of education management departments, scientific and methodological services with the support of the whole society and the Country should be focused on the implementation of strategic directions of education development, overcoming the existing problems, fulfilling the perspective tasks, including:

- updating the goals and content of education on the basis of competence approach and personal orientation, taking into account world experience and the principles of sustainable development;

- ensuring the systematic improvement of the quality of education on an innovative basis, modern psychological and pedagogical and scientific and methodological support of the educational process;

- creating a safe educational environment;

- ensuring the functioning of an effective system of inclusive education, organization of classes with students of special medical groups;

- creation of a modern material and technical base for the functioning of higher education institutions; 
- development of interaction between education management departments and public self-government departments of educational institutions, ensuring objective assessment of the quality of education;

- development of standards of higher education focused on the competence approach, agreed with the new structure of educational and qualification (educational and scientific) levels of higher education and with the National Qualifications Framework;

- making changes to the organizational, regulatory, personnel, logistical, financial, scientific and methodological, medical and information support of physical education and sports in higher education institutions;

- ensuring the effective functioning and improvement of the network of sports facilities, development of sports infrastructure, including the construction and modernization of sports facilities using the funds raised by the authorities and local governments;

- provision of paid sports services at sports facilities of educational institutions outside of their own use;

- providing medical support for sports activities of student-athletes;

- providing medical examination of students for admission to physical education classes (medical certificates for entrants are canceled);

- holding sports competitions and participation in All-Ukrainian, World Universiades, European Games, world and European championships and other competitions among students.

Taking into account the modernization of education, it is necessary to modernize curricula, programs and textbooks in accordance with the updated state standards of education;

- development of integrated curricula of higher education institutions;

- interaction of higher education institutions and educational institutions, education management departments, youth public organizations, business representatives, broad sections of society in the education and socialization of youth; 
- development of a holistic system of identification and psychological and pedagogical support of gifted youth, ensuring the creation of conditions for its development, socialization and further professional growth;

- formation of a healthy lifestyle as a component of education, preservation and strengthening of health of youth;

- improvement of physical culture and health and sports-mass work in educational institutions (expansion of the number of sports clubs, sections and clubs with mandatory personnel, financial, logistical support of their activities);

- increase the number of student youth engaged in physical culture and sports during active leisure and ensure a healthy lifestyle;

- involvement of public organizations in supporting the development of sports among student youth;

- modernization of sports facilities;

- proud representation of the country in the international community.

In order to achieve the development of physical culture and sports, it is necessary not only to realize what end results we want to achieve, but also to comprehensively anticipate specific quantitative and qualitative resources of this process, sociopedagogical and organizational-methodological conditions of its successful transition in a certain period of time, taking into account social and economic changes. In this regard, the process of improving the training of physical culture and sports professionals who are able to solve these problems, have a high level of personal qualities and professional abilities, professionally significant skills and abilities, have in-depth knowledge of the profession is extremely important. Thus, purposeful recovery of the nation, training of modern, highly qualified and hardy, competitive professionals requires increased attention to the personality of the future specialist in physical culture and sports, maximum disclosure of his abilities, talents, aspirations and motives.

Purposeful motivation of students and teachers to study and professional activity in the field of physical culture and sports:

- taking into account the general cultural and educational level of students; 
- meeting the requests and needs of the future specialist;

- humanization of pedagogical interaction of teachers and students;

- a combination of educational and upbringing influences aimed at the activities of the specialist;

- intensification of educational and cognitive activities, involvement of students in various components of the educational process;

- measures to make students aware of the need for training and self-training, education and self-education;

- taking into consideration the influence of the teacher's personality on the professional and pedagogical development of students;

- creation of friendly interpersonal and group relationships, creating an atmosphere of empathy, cooperation, motivation for success; formation of a positive socio-psychological climate in educational and pedagogical teams;

- orientation of the educational process on the disclosure, development and improvement of socially and professionally important qualities of the future specialist;

- determination and approval of the socio-pedagogical status of subjects of study; - stimulating activity and development of reflection of students and teachers;

- realization of creative cooperation of teachers and future specialists in the field of physical culture and sports;

- conducting competitions and Olympiads in psychological and pedagogical disciplines that contribute to the acquaintance, perception and testing of innovative approaches to physical education by students;

- focus of professional training on continuous self-development and selfactualization of students and teachers.

To implement this, high-quality professional training of specialists in the field of physical culture and sports is required.

Problems of professional training of specialists in the field of physical culture and sports were developed by M. Vilensky, M. Vorobyov, Y. Dragnev, L. Matveev, O. Tymoshenko, O. Shabalina, B. Shiyan, and others. Scientists emphasize the high 
efficiency of modern teaching methods in physical education (S. Neverkovich and others), but their use for the study of pedagogical disciplines is insufficiently covered.

Analysis of the concept of "professional training in the field of physical culture and sports" revealed the following basic understandings of this phenomenon: the process of providing a qualitatively new level of professionally oriented training, including pedagogical, in higher education; a significant component of the personality structure and professional activity of the future specialist; integrative qualitative characteristics of the specialist, which is a complex dynamic system of professionally important personality traits that determine the success of professional duties.

The activities of the subjects of physical culture and sports are aimed at ensuring the physical activity of people in order to harmoniously, especially physically, develop and lead a healthy lifestyle.

The professional activity of a specialist in the field of physical culture and sports is a holistic phenomenon that includes two aspects: physical work and mental work which are closely related to each other due to the unity of the tasks. The results of research allow us to conclude that the more developed the cognitive system is, the deeper the personality analyzes and differentiates its movements and, consequently, the better the motor structures are assimilated and memorized.

Thus, the preparation of students of higher education in the field of physical culture and sports - future professionals for professional activities includes: awareness of the purpose and objectives of education of harmoniously developed personality, knowledge of psychological and biological characteristics of human taking into account age and gender, mastering methods of pedagogical research, principles and methods training and education, the formation of moral qualities of personality (humanity, honesty, tolerance, integrity, etc.), as well as the ability to think creatively, creativity in activities.

Therefore, taking into account the content of the concept of "professional training", the professional training of future specialists in physical culture and sports will be considered as: 
- continuous process of acquisition by students of the necessary level of education (acquisition of knowledge, development of abilities and skills, development of professionally and socially significant qualities, formation of value orientations and primary experience of activity providing readiness for performance of labor functions);

- creation by scientific and pedagogical workers and administration of the institution of higher education of the corresponding educational environment and appropriate conditions for purposeful formation and development at future experts of set of the competences defining ability to professional activity;

- as the result of the educational process - is the professional readiness of graduates for professional activities (professional competence).

In general, the problem of improving the effectiveness of professional and pedagogical training of specialists in the field of physical culture and sports remains poorly understood. At the same time, the features of training future specialists in the field of physical culture and sports are even less studied. Despite the pedagogical orientation of pedagogical institutions, the current system of professional training in them is aimed more at the development of sportsmanship and general scientific component of education of future specialists in physical culture and sports, which does not provide graduates with pedagogical competence according to social demand.

Thus, despite the importance of conducted scientific researches, the problem of training future professionals in the field of physical culture and sports in higher education is insufficiently studied in theoretical and methodological terms, and the traditional education system is unable to ensure the smooth entry of a new generation of these specialists in a complex and rapidly changing field of diverse needs of educational activities in a modern children's and youth sports school.

Scientific and methodological developments do not adequately ensure the introduction of fundamentally new approaches to the educational process of higher education institutions in the field of physical culture and sports. The contradictions are becoming more acute between:

- the urgent need of society for harmonious physical and mental development of the population, teaching the younger generation how to preserve and promote health 
and reduce the prestige and social status of a specialist in physical culture and sports, which leads to lack of motivation and unsatisfactory professional orientation of education;

- social demand for highly qualified specialists capable to analyze educational realities, producing pedagogical ideas, modeling the process of physical education based on professional values, creative abilities, professional activity and pedagogical reflection, and insufficient level of professional competence and pedagogical skills of graduates;

- the need to quickly solve problems and non-standard tasks, to implement existing competencies, to show readiness for innovative pedagogical activities based on the provisions of the new paradigm of education, modern concepts of physical culture and sports and the traditional system of training future specialists in physical culture and sports where narrow-functional approaches, formative, imperative methods and technologies prevail;

- requirements of the educational sector to strengthen the projectivity, dialogue, personal and creative initiative in the activities of future specialists in the field of physical culture and sports and insufficient efficiency of design, organization and implementation of their training in connection with outdated target guidelines in the system of physical culture and sports. These guidelines do not take into consideration the world trends and the best experience of pedagogical education, undeveloped theoretical and methodological principles of advanced education of future specialists in this field;

- the need to modernize the training of future specialists in physical culture and sports in accordance with modern pedagogical theories, guidelines and strategies and the lack of a single concept of training of future specialists in physical culture and sports, mechanisms for improving educational methodological support, personal development programs for the development of the personality of the future specialist in the educational process of the institution of higher education in the field of physical culture and sports; 
- tendencies of specialized sports education on introduction of new methods and technologies of training and insufficient awareness of students about essence of pedagogical disciplines and lack of mechanisms of improvement of educational and methodical maintenance, complex application of innovative pedagogical technologies, orientation of training on professional pedagogical development, integrity and systematic preparation of future specialist for professional activity.

An important role in resolving these contradictions belongs to modern methodological approaches, theories and technologies of social and professional development of creative personality, which are used in the professional training of a specialist in the field of physical culture and sports. To ensure the effective functioning of the national system of physical education it requires a review of the principles of professional training in the field of physical culture and sports.

A holistic, theoretical-methodological, empirically substantiated and methodologically developed concept is needed, on the basis of which it would be possible to carry out advanced professional and personal development of educational subjects. These circumstances have identified the problem of research, which is the need for scientific justification and practical implementation of professional training of future professionals in the field of physical culture and sports as a holistic system.

Thus, the relevance of the study is caused by:

- the objective importance of the problem of professional training of specialists in the field of physical culture and sports in higher education and the state of its solution in pedagogical science and practice;

- a problematic situation related to the inconsistency of the content, forms and methods of training specialists in the field of physical culture and sports to the social needs of them, able to provide quality physical education and sports activities of students;

- prevalence of partial organizational and scientific-methodical decisions, which does not contribute to the effective formation of professional and pedagogical competence in future specialists in the field of physical culture and sports during training; 
- lack of systematic connection between pedagogical theories and practice of training specialists in the field of physical culture and sports, the need to substantiate the theoretical and methodological foundations of the system of professional training of specialists in the field of physical culture and sports in higher education;

- tasks of improving the methodology of training specialists in the field of physical culture and sports, development of modern technologies for studying pedagogical disciplines and scientific and methodological support that meets country standards, provides for the implementation of methodological approaches, didactic principles, optimizes education on the basis of subject-subject interaction students and teachers.

Professional training of future specialists in the field of physical culture and sports should reflect the conceptual provisions of physical culture: meet the requirements of logic and methodology of modern science; organically fit into the general theory of culture of the individual and society; provide an opportunity to pose and solve philosophical, cultural, sociological, psychological and pedagogical problems.

The theoretical concept defines the system of analysis and research of the set of components of training of specialists in physical culture and sports in higher education institutions, which are internally interconnected and are the basis for formulating the initial theoretical aspects of training of future specialists as an open socio-pedagogical system that contains target, semantic, technological, diagnostic and analytical structural elements.

The theoretical foundations of the study are: the fundamental role of physical culture as a multifunctional factor of education; humanistic direction of physical culture activity; integrity, projectivity and continuity of the process of formation of socially and professionally significant personality qualities.

The activity of a specialist in the field of physical culture and sports is a certain technological scheme, the algorithm of which should be not only scientifically sound, pedagogically expedient, but also methodically verified, productive, optimal. This requires from him the development and structural-component coherence of dynamic 
professional and pedagogical competencies aimed at adequate implementation of pedagogical actions in the educational process.

The methodical concept provides: scientific and prognostic substantiation and introduction of the offered innovations, development of methods and technologies of designing, realization, expert estimation, experimental check, monitoring and adjustment of innovations in the educational environment of institutions of higher education of physical culture and sports, implementation of which requires an appropriate level of training of scientific and pedagogical staff of higher education, updating and structuring the content of professional training in accordance with modern didactic requirements and the national system of physical education, updating and optimizing software and methodological support of research and teaching activities, developing criteria, indicators and levels of formation of professional and pedagogical competence of students.

Professional training of future specialists in the field of physical culture and sports should provide high professionalism, opportunities for self-realization of the individual and the formation of humanistic values.

Improving the professional training of future specialists in the field of physical culture and sports at the present stage requires more effective mechanisms for organizing the educational process.

Therefore, an important role in the educational process of a modern school belongs to the activities of a specialist in physical culture and sports, who must have professional thinking, fundamental and special knowledge and skills, practical skills, actively promote a healthy lifestyle.

The professional activity of a specialist in physical culture and sports, which largely ensures the reproduction of the intellectual potential and health of our society, is socially formative, creative, constructive, organizational, diagnostic, etc. In this regard, the socio-pedagogical tasks of this category of teachers are constantly expanding and becoming more complex, covering the functions of facilitator, mentor, educator, organizer, researcher, innovator. 
In building a system of professional training of future specialists in physical culture and sports, it is necessary to take into account the constant expansion of the professional sphere of various parts of the system of physical culture and sports, which is based on a real demand for educational services. institutions and other institutions and organizational structures of the field of physical culture and sports.

Thus, the improvement (modernization) of the system of vocational education in higher education facilitiesin the field of physical culture and sports is based on the creation of a developmental pedagogical system which would be based on the active use of innovations and innovative technologies in the educational environment and would allow to achieve the required quality of training. Innovative technologies in the training of future specialists in the field of physical culture and sports are aimed at improving the efficiency of the educational system and its entry into a qualitatively new level of functioning. These technologies should be basedon understanding the essence of psychological and pedagogical training in higher education as a system, as a process, as an activity and as a result -active, competent specialists with developed pedagogical skills, able to act creatively in accordance with the educational tasks in children's and youth sports schools, specialized children's and youth sports schools of the Olympic reserve and other institutions.

Educational and professional program "Physical Culture and Sports" is a normative document that regulates regulatory, qualification, competence, organizational, educational and methodological requirements in the preparation of applicants for the second (master's) level of higher education in the field of knowledge 01 Education / Pedagogy in specialty 017 Physical Culture and Sports of the State Institution "South Ukrainian National Pedagogical K.D. Ushinsky University".

The educational and professional program was developed in accordance with the Law of Ukraine "On Higher Education" of July 1, 2014 № 1556-VII (as amended on February 26, 2021), the Law of Ukraine "On Education" of September 5, 2017 № 2145VIII ( as amended on January 1, 2021), Resolution of the Cabinet of Ministers of Ukraine of December 30, 2015 № 1187 “On Approval of Licensing Conditions for Educational Activities" (as amended by the Resolution of the Cabinet of Ministers of 
Ukraine of May 3, 2020 № 180), Resolution of the Cabinet Of Ministers of Ukraine of November 23, 2011 № 1341 "On approval of the National Qualifications Framework" (as amended by the Resolution of the Cabinet of Ministers of Ukraine of June 25, 2020 № 519), Resolution of the Cabinet of Ministers of Ukraine of April 29, 2015 № 266 "On the peculiarities of the introduction of the list of branches of knowledge and specialties for which higher education is carried out"(as amended by the order of the Ministry of Education and Science of November 6, 2015 № 1151) letter of the Ministry of Education and Science of Ukraine dated 28.04.2017 №1 / 9-239 of the order of the Ministry of Education and Science of Ukraine dated 11.07. 2019 № 977 "On approval of the Regulations on accreditation of educational programs for the training of applicants for higher education", professional standard for the group of professions "Teachers of higher education" from 23.03.2021 № 610, standard of higher education in the specialty 017 "Physical Culture and Sports" for the second (master's) level of higher education, the order of the Ministry of Education and Science of Ukraine dated 11.05 .2021 № 516 [435, c. 2 , c. 3 , c. 4 , c. 5 , c. 6$]$.

Thus unsolved parts of the general problem of improvement of the specified educational and professional program are the search of a unique vector of its development.

This educational and professional program in the specialty 017 Physical Culture and Sports is implemented in various institutions of higher education in Ukraine, but each of those institutions has its own uniqueness and originality both in name and in its structural content. For example, in the State Institutions like "Luhansk National Taras Shevchenko's University", National Pedagogical N.P. Draghmanov's University this program is called "Sports"; in Prydniprovsk State Academy of Physical Culture and Sports, Yuri Fedkovych Chernivtsi National University, Ternopil National University of Economics, Chernovets National Petr Mogili's University, Kherson State University, National University "Yuriy Kondratyuk's Poltava's Polytechnic", Volodymyr Vynnychenko Central Ukrainian State Pedagogical University, Berdyansk State Pedagogical University, University of the State Fiscal Service of Ukraine, "Kharkiv Humanitarian and Pedagogical Academy" of the Kharkiv Regional Council 
- «Physical Culture and Sports»; Kamyanets-Podilsky National Ivan Ogienko's University- "Sports Coach"; National University of Defense of Ukraine named after Ivan Chernyakhovsky - "Physical Education and Sports in the Armed Forces - M"; The National University of Physical Education and Sport of Ukraine has several names of educational and professional program defining specializations "Sports training and coaching in Olympic sports", "Olympic sports and education", "Sports", "Management in sports", "Fitness and recreation", "Physical Education", "Cybersports (eSports)", "System of training athletes in water sports", "System of training athletes in athletics", "System of training athletes in martial arts", "Physical rehabilitation", "Physical culture and sports rehabilitation"; Zaporizhzhya National University - "Physical Education"; Kharkiv State Academy of Physical Culture - "Psychology of Physical Culture and Sports", Mariupol State University - "Physical Culture".

The study of the experience of many institutions of Ukraine shows that one of the notable shortcomings of professional training of future specialists in physical culture and sports is its underdeveloped system, which does not allow them to form a professional orientation, creativity and independence. The professional training of specialists in physical culture and sports should be based on the broad implementation of a set of modern learning technologies aimed at solving educational and practical tasks by students. However, it is necessary to take into account innovative approaches to the selection and updating of content, forms, methods and teaching aids, construction of theoretical and practical classes, as well as careful consideration of techniques to create an atmosphere of productive pedagogical interaction of subjects of educational process.

The purpose of the article is to outline the uniqueness of this educational and professional training program for the specialty 017 Physical Culture and Sports in the southern region of Ukraine and to identify possible perspectives for its improvement.

Above mentioned program provides for a master's degree, 90 ECTS credits and a period of study of 1 year and 4 months.

The purpose of this educational program is to train competitive professionals who are able to integrate knowledge and solve complex problems in the field of 
physical culture and sports, conduct research and implement innovations in conditions of uncertainty, taking into considerstionaspects of social and ethical responsibility.

Learning objectives: to prepare masters who are able to identify and effectively solve complex specialized tasks and practical problems of innovative and scientific nature in the field of physical culture and sports.

The objects of study are: theoretical and applied components of physical culture and sports; modern theoretical and methodological aspects of physical culture and sports; methods of physical education in higher education; modern methods of sports; professional training of specialists in physical culture and sports; the latest technologies in fitness and healthy living style.

The theoretical content of the subject area are ideas, notions, paradigms, concepts, theories of analysis of the functioning and forecasting of the components needed to solve professional-applied and research problems; educational components of professional training: concepts of sports training, selection and modeling of sports training; knowledge of socio-educational, program-normative, theoretical and methodological aspects of the organization of physical culture and sports, which are assimilated through the use of general scientific methods of cognition and research; observation, survey, testing and measurement in physical culture and sports; verbal, visual and practical methods of physical education and sports training; technologies of organization and carrying out of physical culture and improving and sports actions; providing pre-medical care; information and communication technologies.

Methods and tools (which should be mastered by the applicant for higher education for application in practice): general scientific research methods, methods and techniques of scientific research on the problems of physical culture and sports; technologies for solving theoretical and practical problems in certain areas of physical culture and sports.

This educational and professional program (EPP) is based on scientific principles, taking into account the essence of physical culture and sports, the peculiarities of formation and development trends. This program focuses on innovative 
modern concepts of sports training at different stages of training, sports selection and orientation, modeling of sports training.

The main focus of the educational program is aimed at training specialists for training, physical culture and health, organizational and educational activities in the field of physical culture and sports in the south of Ukraine.

Features of this program are mastering the basic professional competencies of the master of physical culture and sports, knowledge, skills in modern information technology, scientific communications in a foreign language, innovative technologies in physical education in higher education, technology training in the field. Particular emphasis of the educational and professional program is placed on internships in the chosen sport in children's and youth sports schools, specialized children's and youth sports schools of the Olympic reserve and sports clubs, industrial (assistant) practice in higher education and focus on continuity of higher education through continuing education at the third (educational and scientific) level of higher education - the program of training doctors of philosophy $\mathrm{PhD}$.

According to the National Classification of Occupations DK 003:2010, specialists who have been educated under the educational-professional program 017 Physical Culture and Sports may hold the following positions: 1210.1 - Chairman of the club (sports club); director (chief) of a professional educational institution; director of the training center; director of a school (higher sportsmanship, specialized children's and youth, sports and technical, etc.); 1229.6 - Head coach of the team (national team, club); head of the sports base; manager of the sports facility; chief (manager) of the gym (hall); head of the club (aeroclub, service dog breeding, sports and technical, shooting and sports); 1143.4 - Secretary General of the Federation of Sports; president of the sports federation; vice-president of the sports federation; state coach in sports (national team); executive director of the sports federation; 2310.2 - Teacher of Higher Education; 23.10 - Assistant; 2351.2 - Methodist in physical culture; 3431 - Executive Secretary of the Sports Federation; 3475 - Sports coach (federation, national team or club team, sports school, etc.); 3475 - Coach-teacher in sports (sports school, section); 
3475 - Athlete-instructor of the national team of Ukraine; 3475 - Instructormethodologist of sports school; 3475 - Aerobics instructor; 3475 - Fitness trainer.

Let's take a closer look at the general tasks and responsibilities of the specialists who will hold the following positions:

1210.1 - Chairman of the club (sports); director (chief) of a professional educational institution; director of the training center; School Director.

Tasks and responsibilities of the head of the club (sports). Head of the club (sports) provides management of the sports club. He organizes and plans all areas of physical culture, sports, financial and economic activities, is fully responsible for the implementation of areas of work in the workforce. He is responsible for the rehabilitation of employees and their families by means of physical culture, sports and tourism, provided by the plan of socio-economic development of the enterprise (organization), targeted comprehensive programs and inclusion of these issues in collective agreements between trade union organization (labor collective) and enterprise administration (organization). He maintains the documentation of the sports club, completes its staff and distributes functional responsibilities among staff. He promotes the development of sports at the enterprise and in the children's and youth sports school, which is developed by the sports club.

Tasks and responsibilities of the director (head) of a professional educational institution; director of the training center; school principal. He manages the activities of the educational institution in accordance with the current legislation of Ukraine. $\mathrm{He}$ represents the educational institution in all central and local executive, legislative, judicial authorities, as well as enterprises, institutions, organizations of all forms of ownership, including outside Ukraine in accordance with the powers granted to it. Within the limits of the powers he rationally uses budgetary funds, and also the means arriving from other sources of financing. He controls the quality of work of teachers, the organization of training and production and training process, ensures the creation of the necessary conditions for training, retraining and advanced training of employees.

He provides accounting, storage and replenishment of training facilities. $\mathrm{He}$ coordinates the work of his deputies, the activities of parent committees, provides 
assistance to local governments. He heads the pedagogical council of the educational institution, annually reports at the general meeting (conference) of the labor collective on the issues of statutory activity, in particular the collective agreement. He promotes the formation and implementation of initiatives of employees aimed at improving the work of the educational institution and improving the quality of education, creates conditions for the introduction of innovations. He organizes the activities of the team to ensure the quality of training, implementation of curricula and training programs, implementation of plans for production and economic activities, improvement of methodological support of the educational process, promotes the activities of methodological commissions. $\mathrm{He}$ is responsible for timely consideration of applications, complaints, compliance with the rights and guarantees of pupils and employees of the educational institution; observance of financial and labor discipline. He approves the staff list and the number of employees of the educational institution within the available salary fund, hires and dismisses employees, approves their job responsibilities in accordance with the qualification characteristics. He provides labor market monitoring and timely improvement of the structure of specialties through the mechanism of licensing of educational services and accreditation of specialties. $\mathrm{He}$ issues orders and instructions within its competence, encourages employees, pupils and applies to them the disciplinary sanctions provided by the current legislation of Ukraine. He concludes agreements on cooperation, establishes, in accordance with the current legislation of Ukraine, direct relations with educational institutions of other countries, international organizations, foundations, etc. He controls the provision of safe and harmless conditions of study and work in the school. He is responsible for compliance with the requirements and rules of labor protection, fire safety in accordance with current legislation of Ukraine. He annually reports on the results of work at the meeting of the staff of the educational institution. He exercises other powers provided by the regulations of the educational institution.

1229.6 - Head coach of the team (national team, club); head of the sports base; manager of the sports facility; chief (manager) of the gym (hall); head of the club. 
Tasks and responsibilities of the head coach of the team (national team, club). He provides general management of the national team of Ukraine in sports, the coaching board of the national team; is responsible for performing the tasks assigned to the team. He develops a calendar of sports events, a targeted program of training and participation of the national team of Ukraine in sports in competitions and is responsible for their implementation. He provides the organization of educational and training and educational process, takes care of a healthy moral and psychological climate in the team. He controls and adjusts plans for individual training of members of the national team of Ukraine in sports, maintains the necessary accounting and reporting documentation, cooperates with complex scientific groups.

He ensures the formation of the national team of Ukraine to participate in official international competitions in sports in accordance with the requirements of the approved selection system and is personally responsible for its performance in these competitions. He monitors compliance with anti-doping requirements. He supervises the activities of coaches and athletes of the national team of Ukraine. He prepares and submits proposals for logistical and medical-biological support of the national team of Ukraine in sports. He knows, understands and applies current regulations on its activities. He knows and complies with the requirements of regulations on labor protection and the environment, adheres to the rules, methods and techniques of safe work.

Tasks and responsibilities of the head of the sports base; the head of the sports facility. He carries out the general management of administrative and economic activity of a sports construction, bears responsibility for all directions of its activity. $\mathrm{He}$ organizes educational and sports work. He resolves all issues related to the preparation and holding of all sports and entertainment events. He organizes mass sports and health work among the population, advertising and promotion of sports. Within the limits of the rights granted to him, he solves the financial problems of the sports facility. $\mathrm{He}$ provides equipment of sports facilities with sports-technological, engineering equipment, materials and monitors their proper use. He organizes timely capital and current repairs of sports facilities and equipment. He takes measures to provide sports 
facilities with qualified personnel. He knows, understands and applies current regulations relating to its activities. He knows and complies with the requirements of regulations on labor protection and the environment, adheres to the rules, methods and techniques of safe work.

1143.4 - Secretary General of the Federation of Sports; president of the sports federation; vice-president of the federation for sports; state coach in sports (national team); executive director of the sports federation.

Tasks and responsibilities of the Secretary General of the Sports Federation. He organizes work on the implementation of decisions taken by the Presidium, which relate to the tasks of the federation, defined by the statute of the federation and other issues that do not contradict the statutory activities of the federation; he organizes work on the maintenance and preservation of current documentation, minutes of meetings of the presidium and executive committee, standing and temporary committees, other documents of the federation, formation of the archive of the federation; he organizes work on the providing information communication between the federation and its members, other organizations; he organizes work on the involvement of specialists in the staff of the executive committee. He knows, understands and applies current regulations relating to its activities. He knows and complies with the requirements of regulations on labor protection and the environment, adheres to the rules, methods and techniques of safe work.

Tasks and responsibilities of the president of the sports federation. He manages the work of the federation, represents the interests of the federation in other organizations and institutions of Ukraine and abroad. He is responsible for the financial and economic activities of the federation. He monitors the activities of the federation in accordance with its Statute and other regulations, as well as the implementation of agreements with other organizations. He signs the official documentation of the federation. He hires full-time employees of the federation and approves their job responsibilities. He knows, understands and applies current regulations relating to its activities. He knows and complies with the requirements of regulations on labor 
protection and the environment, adheres to the rules, methods and techniques of safe work.

Tasks and responsibilities of the state coach in sports (national team). He is directly responsible for the development and implementation of measures provided for by state programs for the development of sports in Ukraine, targeted programs for training athletes for world championships, Europe and the Olympic Games. He plans, organizationally provides and controls the development of infrastructure of sports (types) in Ukraine, he provides methodological assistance to sports schools, schools of physical culture, schools of higher sportsmanship, Olympic training centers. $\mathrm{He}$ supervises their work on the training of members and the reserve of the national team (teams) of Ukraine. He studies and analyzes the state and achievements of the sport (s) in Ukraine and worldwide. He carries out analysis and control over the preparation and performances of the national team (teams) of Ukraine and individual athletes in competitions. $\mathrm{He}$ is responsible for the development of legal documents on development, type (types) of sports, calendar of sports events in the type (types) of sports and organizes its implementation. He provides coordination of the coaching staff of the national team (teams) of Ukraine in the type (s) of sport with complex scientific groups. He controls the fulfillment of the requirements of the approved system of selection of athletes for participation in the world championships, Europe, Olympic Games. He controls the observance of anti-doping requirements by athletes.

He ensures the cooperation of the federation (federations) of the sport(s) with the relevant structural units of the Committee. He supervises the training of coaches in (sports) and coaches of the national team (teams) of Ukraine in (sports). $\mathrm{He}$ is responsible for the formation of staffing and personnel of the national team of Ukraine (teams) in the field(s) of sports, concluding contracts with athletes, coaches and professionals. He knows, understands and applies current regulations relating to its activities. He knows and complies with the requirements of regulations on labor protection and the environment, adheres to the rules, methods and techniques of safe work. 


\section{2 - Teacher of higher education.}

Tasks and responsibilities of a teacher of higher education. He plans educational material on the subject he teaches (working curricula, lesson-thematic, lesson plans). He provides implementation of curricula and programs. He provides educational and methodological and material and technical base for effective classes. He works on creation of an educational and methodical complex of a subject which teaches. $\mathrm{He}$ provides a sufficient scientific and methodological level of study of program material, using modern pedagogical and production technologies. He requires students to comply with the Rules of Procedure, the mode of operation of the institution. $\mathrm{He}$ provides appropriate conditions for identifying the level of educational and professional training of students.

He keeps in the journal of theoretical training the account of the fulfilled educational employments, success and attendance of employment by students, controls working off of the missed employment. He carries out control of quality of knowledge, adhering to the established criteria of estimation of educational achievements of students (current, thematic, final control). He conducts additional classes and consultations. He organizes extracurricular work on the subject. He participates in meetings of pedagogical councils, methodical commissions, seminars, etc. In order to improve the methodology of teaching the subject he: works on the implementation of the general scientific and methodological problem of the educational institution; studies promising pedagogical experience; works with periodical pedagogical press; creates own methods, textbooks, manuals, including in electronic version; attends and conducts open classes. He acts as head of the study. He is responsible for preserving the material values of the study. He performs career guidance work. In accordance with the Regulations on the certification of teachers, once every five years he improves his skills and is certified according to the results of his work in all areas of activity. $\mathrm{He}$ reports to the academic part on the implementation of curricula and programs, progress in the subject at the end of semesters and academic year. He adheres to the norms of pedagogical ethics, morality, respects the dignity of students, instills in them a love for Ukraine, instills in them patriotism and respect for the Constitution of Ukraine. In his 
activities he complies with the laws of Ukraine, the Charter and the Rules of Procedure of the educational institution.

23.10 - Assistant.

Tasks and responsibilities of the assistant. He helps another teacher in the organization and implementation of the educational process, supports the independence and active involvement of students in all types of work carried out in the institution during the educational process. He constantly improves his pedagogical skills. He provides a partnership with the teacher and other participants in the educational process in order to implement the educational program to achieve all students' learning outcomes.

\section{2 - Methodist of physical culture.}

Tasks and responsibilities of a physical education methodologist. At the enterprise (in the organization) he provides carrying out of mass physical culture and improving and sports work. He develops and takes measures to promote a healthy lifestyle. At the enterprise (in the organization) he promotes and conducts physical culture and health-improving actions which are provided by the Complex program "Physical education - health of the nation", plans of social and economic development of labor collectives and collective agreements. He organizes and conducts reviews, competitions and other events for the best staging of physical culture and health and preventive work, taking into account working conditions. He recommends comprehensive exercises that help to restore efficiency. He conducts educational and training work in physical culture and health groups and sports sections. He organizes consultations for those who are engaged in physical culture.

3431 - Executive Secretary of the Sports Federation.

Tasks and responsibilities of the executive secretary of the sports federation. $\mathrm{He}$ organizes work on the implementation of decisions taken by the presidium of the federation, relating to the tasks of the federation, defined by its statute, and other issues that do not contradict the statutory activities of the federation. He maintains and stores current documents, minutes of meetings of the presidium and executive committee of the federation, standing and temporary committees, other documents of the federation. 
He forms the archive of the federation. He provides information communication between the federation and its members, other organizations. He involves specialists to work in the staff of the executive committee of the federation. He knows, understands and applies current regulations relating to its activities. He knows and complies with the requirements of regulations on labor protection and the environment, adheres to the rules, methods and techniques of safe work.

3475 - Coach in sports (federation, national team or club team, sports school).

Tasks and responsibilities of a sports coach. He implements in practice and develops in the prescribed manner a scientifically sound system of training high-class athletes and sports reserves. He organizes and conducts sports events, as well as participates in the prescribed manner in state international competitions and training camps. He carries out systematic control over the work of coaching staff for the training of high-class athletes and sports reserves. He develops long-term plans for the development of sports, regulations on sporting events, forms calendar plans for competitions and training camps. He provides propaganda, studies and summarizes best practices in the development of sports and training of high-class athletes, organizes its implementation in the practical work of sports organizations. He participates in the organization and practical implementation of scientific and methodological and research work in sports. He coordinates and directs the work of federations, coaching councils, judges' boards in sports. He knows, understands and applies current regulations relating to its activities. He knows and complies with the requirements of regulations on labor protection and the environment, adheres to the rules, methods and techniques of safe work.

3475 - Athlete-instructor of the national team of Ukraine.

Tasks and responsibilities of the athlete-instructor of the national team of Ukraine. He performs an individual training plan, training and competitive tasks. $\mathrm{He}$ maintains a high level of general physical and special training, ensures the achievement of international class results. He keeps a sports diary, records of completed tasks provided for in the individual training plan. Together with the coaching staff he participates in the planning of the training process. He adheres to the rules that ensure 
the safe conduct of training sessions, the rules of sports competitions. He promotes physical culture and sports. He transfers the experience of sports achievements during the training process and provides practical assistance to young professionals. $\mathrm{He}$ worthily represents Ukraine at official international competitions.

3475 - Instructor-methodologist of sports school.

Tasks and responsibilities of a sports school instructor-methodologist. He carries out methodical work at school. He maintains statistical records of school performance. He analyzes and summarizes the results and content of the work of trainers-teachers. Is responsible for maintaining educational and methodological documentation, organization of educational work with athletes, for their training and recreation. $\mathrm{He}$ must know: methods of teaching and training athletes; current legislation on physical culture and sports, on the work of sports schools.

3475 - Aerobics instructor.

Tasks and responsibilities of an aerobics instructor. He organizes the recruitment of groups of sports and health-oriented people who want to do aerobics. He studies the "health history" of the client (general physical condition; the presence of diseases and physiological defects, which is expected to be eliminated by training; the presence of injuries; contraindications to certain types of training, strength training, etc.). He makes measurements of weight, pressure, parameters of work of heart. He invites the client to demonstrate their abilities to assess strength (muscle, speed, etc.), endurance, agility, flexibility, as well as identifies key elements for individual programs, assessing the possibility of group activities, grouping according to the person's condition engaged in. He makes calculations necessary for the choice of optimal forms and types of classes, types of loads (power, local, dynamic, static). He completes groups of persons involved, controls the quantitative and qualitative composition of groups. He conducts a set of practical activities and theoretical classes to ensure the safety of those involved. He makes a lesson plan and develops the most effective methods of training. $\mathrm{He}$ develops programs for safe and effective warm-ups, conducts warm-ups with those involved, focuses their attention on individual exercises. He informs the people involved in the main objectives of training, explains the rules of use of sports 
equipment and inventory, demonstrates the basic elements and sequence of exercises, conducts training. He advises the persons who are engaged in questions of performance of individual exercises, technique of group exercises, on questions of sports and improving food (diet); pays attention to mistakes made during classes and corrects them. He monitors compliance with the rules of use of sports equipment and equipment. He carries out step-by-step control of training of the persons engaged, and on its basis correction of this process. He works in close contact with medical staff (if any in the staff of the sports club) to provide medical supervision of persons involved in groups. He provides increase of physical, theoretical, moral and volitional, technical and sports preparation of the engaged persons, strengthening and protection of their health in the course of employment, safety of employment. He creates conditions that prevent injuries during training and exclude the use of doping. He provides emergency medical care for injuries, damage to health, etc. He constantly monitors compliance with sanitary and hygienic standards. He participates in the organization of activities to strengthen and develop the material and technical base for aerobics. He conducts systematic accounting and analysis of the results of group work.

3475 - Fitness trainer.

Tasks and responsibilities of a fitness trainer. He provides the selection of individual or group sports program; control of correctness of performance of exercises; observance of safety precautions and assistance in work with sports shells; development of a personal weight loss program or rapid muscle gain; interaction with rehabilitation specialists, nutritionists and representatives of other related professions.

Relevant tasks and responsibilities of these specialists include the possession of certain knowledge, skills and professional skills that must be acquired by students during the mastery of this educational and professional program.

The process of teaching and learning is student-centered, problem-oriented, proactive self-study process, while the main forms, methods and technologies of teaching are problem-based, multimedia, interactive lectures; practical, seminar, individual lessons; individual work; consultations; research work; discussions; disputes; brain storm; competitions in sports training and selected sports; presentations; 
role-playing, business, educational games. Assessment is based on a cumulative scoring and rating system, which provides for the assessment of students in all types of classroom and extracurricular (independent) learning activities: current control, final control, in particular, testing, presentations, essays, exams, defense practices, defense qualification (master's) work etc.

The educational-professional program provides mastering of program competences, namely, formation of integral competence provides ability to solve problems of research and innovative character in the field of physical culture and sports; general competencies: the ability to act socially responsibly and consciously, the ability to search, process and analyze information from various sources, the ability to adapt and act in a new situation, the ability to identify, pose and solve problems, the ability to generate new ideas, the ability to develop and manage projects, the ability to motivate people and move towards a common goal, the ability to work in an international contet, the ability to continuous self-education.

The formation of special competencies involves the ability to critically comprehend problems in the field of physical culture and sports, original thinking and research, the ability to develop and implement innovative projects in the field of physical culture and sports, the ability to carry out research and teaching activities in higher education, the ability to manage workers or educational processes in the field of physical culture and sports, which are complex, unpredictable and require new strategic approaches, the ability to solve problems in the field of physical culture and sports in new or unfamiliar environments with incomplete or limited information taking into account aspects of social and ethical responsibility, the ability to self-education, selfimprovement and self-reflection for successful professionalization in physical culture and sports, the ability to plan, organize and carry out independent research on the problems of physical culture and sports, the ability to implement in practice the results of scientific research aimed at solving applied problems in the field of physical culture and sports, to understand the principles of professional and academic ethics and the need to comply with them, the ability to develop effective practice-oriented programs in physical culture and sports projected results of sports activities, the ability to develop 
an algorithm for competitive activities and ensure its implementation, performance analysis.

The problem of competence in the new educational paradigm reflects the degree of ability and willingness of a specialist in physical culture and sports to fully implement their functions in solving practical problems and depends on the degree of unity of all components of their training. Thus, the formation of competence at the stage of study in a higher education institution significantly depends on the rational integration of academic disciplines and their focus on professional activities, in which a particular discipline serves as a means to achieve a common goal. At present, some disciplines are still preferred to be studied in isolation, the learning objectives of each of them are not sufficiently consistent with the main goal, which reduces the integrity of student training, does not ensure the formation of professionalism in future professionals.

A significant role in the professional development of a specialist in physical culture and sports belongs to pedagogical practice, which has repeatedly been transformed, but, in fact, has remained unchanged. Fragmentary involvement of students in the future profession does not solve the problems that practical training is designed to solve. First of all, the principle of connection between theory and practice is not properly implemented. At the same time, it is known that the professional and pedagogical development of the future specialist of physical culture and sports is not limited to working with symbolic information in the training process, and from the very beginning should be included in the context of further social life and activities. Thus training should be organized as process of inclusion of the person in system of public and professional relations, social practice, and educational process thus to reflect these relations and makes unity of professionally oriented activity, interaction and communication.

The true vocation of a specialist in physical culture and sports is determined only in practice, which allows to recommend an activity approach to learning in order to implement the professional orientation of training, as well as to use pre-professional skills as criteria for professional selection. And this applies not only to the sports 
training of future specialists in physical culture and sports, but also to their pedagogical talents.

Program learning outcomes in this educational and professional program include the ability to determine the goals and objectives of research, apply scientific methods and modern methods of solving them; the ability to organize the collection, processing, systematization and analysis of research data; the ability to analyze and summarize the existing scientific and methodological and research experience in the field of physical culture and sports; the ability to apply modern methods and technologies, including information, to ensure the quality of the educational and training process; the ability touse innovative methods in professional activity; the ability to develop new programs of sports and physical culture and health orientation; the ability to use educational, sports, health-improving, health-preserving technologies taking into account the modern level of development of science; the ability to integrate the acquired knowledge into innovative pedagogical technologies; the ability to develop new technologies, means and methods for adaptive physical education and sports; the ability to apply the acquired knowledge, skills and abilities in professional activities, form cultural and axiological aspects of the personality of subordinates; the ability to analyze, study and forecast the activities of sports and sports organizations in order to improve their functioning on the basis of modern trends and achievements of domestic and foreign experience; the ability to explain the principles, purpose, objectives, means and methods of sports training, features of the organization of competitive activities, the structure of the training process, the basics of selection and orientation of athletes, the basics of modeling and forecasting in the training of athletes; the ability to determine the means of stimulating efficiency and recovery processes; the ability to develop and be able to apply new technologies and methods of teaching physical education to students in higher education; the ability to know best practices, develop and be able to apply the latest technologies in fitness, recreation and healthy living style; the ability to apply the latest technologies in sports medicine, physical therapy and occupational therapy; to use analytical approaches to the analysis of situations in the field of physical culture and sports, to investigate objects and subjects of professional activity, to 
develop integral research programs in the field of physical culture and sports; demonstrate creativity in professional activities, flexible thinking, openness to new knowledge, be critical and self-critical.

Cycles of general and professional training are obligatory components of the educational program. The cycle of general training includes such disciplines like: Philosophy and methodology of science ( 3 credits, test), Scientific communications in a foreign language (4 credits, test), Information technology and methods of presentation of scientific results ( 3 credits, test), Pedagogy of higher education (3 credits, test), Psychology of higher education (3 credits, test). To the cycle of professional training - Adaptive physical education and sports (5 credits, exam), Theory, methodology and organizational and managerial activities of physical culture and sports ( 9 credits, exam), Methods of physical education in higher education (4 credits, exam), Methods of sports medicine, physical therapy and occupational therapy ( 5 credits, test), Modern technologies in the chosen sport ( 5 credits, test), Technologies of professional training in physical culture and sports (4 credits, test), Innovative technologies in fitness, recreation and healthy lifestyle (3 credits, test), Industrial practice (assistant) (in ZVO) (5 credits, test), Industrial practice (in sports / sports and health facilities) (4 credits, test), Preparation of qualification (master's) work ( 3 credits, test), Undergraduate practice (2 credits, test), Certification exam in "Theory, methodology and organizational and managerial activities of physical culture and sports"( 1 credit, defense), Defense of qualification ( master's) work (1 credit, exam). The total amount of required components includes 66 credits and optional components (24 credits).

A specific feature of the fundament alization of higher professional education in the field of physical culture and sports is the integration of theoretical, professional and special knowledge in the study of complex mental, biochemical, physiological processes occurring in the human body engaged in exercise. It is understood as a reorientation from highly specialized, utilitarian, prescription knowledge and ideas about man to general cultural and general scientific system knowledge related to the human personality in all its manifestations. 
Informational and educational-methodical support of the program provides the following: to each educational discipline the educational-methodical complexes of disciplines as a part of which: the working program of educational discipline is made; lecture annotations; plans of seminar, practical or laboratory classes and their methodological support; didactic support and methodical recommendations for independent work; questions and test tasks for current and semester knowledge control; list of basic and additional literature, Internet resources; evaluation criteria for each type of educational activity; the list of means of diagnostics of educational achievements and technical means of training; information support with textbooks in each discipline.

Availability of access to the Ukrainian scientific and educational telecommunication network "URAN", which, in addition to providing broadband access to the Internet, provides a number of services: video conferencing WEBclass, virtual connection of the subscriber's computer to EDUVPN, CLOUD - cloud processing and data storage, connection to the European Science and Education Network GEANT.

Certification of graduates of the educational-professional program "Physical Culture and Sports" in the specialty 017 Physical Culture and Sports is carried out in the form of public defense of qualification (master's) work.

Qualification (master's) work of the applicant of the second (master's) level of higher education for EPP "Physical Culture and Sports" in the specialty 017 Physical Culture and Sports. Qualification (master's) work is an independent study that reflects the integral competence of the applicant and summarizes the results of their program learning outcomes from the main components of the educational program.

Qualification work involves solving a complex problem or problem in the field of physical culture and sports that requires research or innovation.

The graduate must show general scientific and special training, certify that he has mastered the necessary competencies, their practical application in specific conditions. 
The state of readiness of the qualifying work of the applicant of the second (master's) level of higher education for defense is determined by the supervisor. Successful completion of the individual curriculum by the applicant is a prerequisite for admission to the defense.

Qualification (master's) work must be performed in the state language Certification of applicants for the second (master's) level of higher education and is carried out in the form of public defense of qualification (master's) work.

Qualification works performed by the applicant independently in compliance with the principles of academic integrity are allowed for defense. Qualifications are tested for plagiarism using Strike Plagiarism and Unicheck.

Public defense of qualification (master's) work can take place with the help of a presentation developed in the relevant program (Microsoft Office, PowerPoint, etc.).

The University has a system of quality assurance of educational activities and quality of higher education (internal quality assurance system), which provides for the implementation of the following procedures and measures: the principles of quality assurance in higher education are defined in the Regulations on quality assurance of educational activities KD Ushinsky South Ukrainian National Pedagogical University ", in the Regulations on the organization of the educational process for applicants for higher education at the first (bachelor's) and second (master's) levels in the State Institution "South Ukrainian National Pedagogical KD Ushinsky University", Regulations on the organization of control and assessment of knowledge of students of the State Institution "South Ukrainian National Pedagogical KD Ushinsky University", in the regulations on structural units of the University (dean's office, department, educational and methodical department), etc.

The procedure for ensuring and monitoring the quality of educational activities and the quality of higher education at Ushinsky University includes: review and constant control and modernization of educational programs; internal audit of the quality of education of higher education students, the activities of structural units of Ushinsky University, which organize and support the educational process; establishing feedback with participants in the educational process (survey of applicants for higher 
education, research and teaching staff, employees of the University); assistance in professional development of scientific and pedagogical workers, employees of Ushinsky University; ensuring the availability of information on the results of Ushinsky University to all interested parties on the official website of the institution; continuous improvement of the information system of Ushinsky University to create an effective information and educational environment; prevention and detection of manifestations of academic integrity in the works of University teachers and applicants for higher education (text works of students, in particular, qualifying works), articles in professional journals.

Measures to prevent and detect academic dishonesty are carried out in accordance with the "Regulations on academic integrity of participants in the educational process of Ushinsky University", "Regulations on the Integrity Commission of Ushinsky University", "Regulations on detection and establishment of facts of dishonesty at Ushinsky University".

Ushinsky University has developed an Instruction on the procedure of technical verification for the presence of textual borrowings (academic plagiarism), which defines how the verification is carried out by special computer programs Strike Plagiarism and Unicheck.

Monitoring the quality of training of applicants for EPP "Physical Culture and Sports" in the specialty 017 Physical Culture and Sports: analysis of results, adjustment of the working curriculum, work programs of disciplines, practice programs, is carried out by the Department of Theory and Methods of Physical Culture and Sports annually.

Periodic review of the educational and professional program "Physical Culture and Sports" in the specialty 017 Physical Culture and Sports is carried out at least once per full course of study in the educational and professional program.

Proposals for updating the EPP (objective changes in infrastructure, staffing, other resource conditions, review of the workload, loans, learning outcomes) are reflected in the relevant structural elements and submitted to the Academic Council of the University. 
Assessment of applicants'academic achievements is carried out on a 100-point ECTS scale and a national scale (excellent, good, satisfactory, unsatisfactory; enrolled, not enrolled). The system of assessment of learning outcomes of higher education seekers includes current, intermediate, final semester, applicant might get deferred or certified.

Annually, the results of assessing the quality of education of applicants are discussed at meetings of the Academic Council of Ushinsky University, of departments that are providing training for future masters of physical culture and sports as well as the Academic Council of the Institute of Physical Culture, Sports and Rehabilitation, and published on the official website of Ushinsky University.

Annual evaluation of research and teaching staff who provide the educational process for EPP "Physical Culture and Sports" in the specialty 017 Physical Culture and Sports, carried out by: research department, psychological service, student council of Ushinsky University, through surveys, questionnaires of students; reporting of teachers on the results of educational, scientific, organizational activities.

Regular discussion of evaluation results takes place at meetings of the Academic Council of Ushinsky University, departments and the Academic Council of the Institute and are published on the official website of Ushinsky University.

Ushinsky University has a system of professional development of research and teaching staff that provide the educational process for EPP "Physical Culture and Sports" in the specialty 017 Physical Culture and Sports in various forms: courses, internships, trainings, etc. (full-time, distance). The control over the implementation of the results of advanced training in the educational process at the level of the Department of Theory and Methods of Physical Culture and Sports of Ushinsky University is carried out.

The official website of the University (https://pdpu.edu.ua) contains a license (information on the right to carry out educational activities in the field of higher education), Rules of admission to the University of Ushinsky, contact information.

The page of the Department of Theory and Methods of Physical Culture and Sports Disciplines of the official website of the University contains information about 
EPP "Physical Culture and Sports" in the specialty 017 Physical Culture and Sports; scientific, educational, organizational activities of teachers who ensure the implementation of EPP; entrance exam program, presentation of the specialty.

Qualification (master's) works are published through public defense, on the page of the Department of Theory and Methods of Physical Culture and Sports Disciplines of the official website of Ushinsky University.

Self-analysis of the educational-professional program proves that the disciplines correspond to professional competencies and program learning outcomes. Much attention is paid to current issues in the field of sports and the generation of new creative projects that could guide the development of sports in our country.

The educational-professional program regulates the purposes, expected results, the maintenance, conditions and technologies of realization of educational process, an estimation of quality of preparation of the graduate on the given specialty.

The program is focused on innovative modern concepts of sports training at different stages of training, modeling of sports training, the ability to solve professional problems in the field of physical culture and sports.

The educational and professional program is logically composed. It defines the purpose, subject area, main focus, features of the program, suitability for employment, assessment and subject competencies that are formed as a result of mastering academic disciplines. The components of the educational and professional program reflect topics relevant to the field of sports and physical culture.

Staffing of the educational and professional program corresponds to the profile of academic disciplines in the specialty 017 Physical Culture and Sports.

Educational and methodological support of educational activities for the training of higher education "master" in the educational and professional program "Physical Culture and Sports" is generally developed at the appropriate level and meets the requirements of the license conditions for educational activities of higher education institutions.

To identify the shortcomings of this educational and professional program, a survey was conducted among participants in the educational process, the results of 
which identified some ways to improve it, namely, proposals were made to improve the resource provision of the program. First of all it is important to involve in teaching professionally oriented disciplines the scientific and pedagogical workers (possibly foreign lecturers) who have a degree or outstanding current trainers who are recognized professionals with experience in the field: research, organizational, innovative activities.

Secondly, it is important to improve the logistics of the educational institution, it concerns the provision of multimedia equipment for simultaneous use in classrooms at the appropriate level, improving social infrastructure: food outlets; gyms; stadium and sports grounds; medical centers, living conditions in the dormitory, to improve the provision of computer workstations, laboratories, equipment, facilities. Thirdly, it is important to use modern information and communication equipment; specialized software; physical culture and sports equipment; and to strengthen academic mobility, national and international credit mobility under the EU's Erasmus + program, based on bilateral agreements with partner countries'educational institutions.

The multifunctionality of physical culture and sports, their saturation with developmental, health, educational and upbringing technologies, innovative processes, requires special attention to the advanced updating of the content and methods of training for thi field. It should be borne in mind that their activities belong to the type of "Human- human", respectively, they must have modern psychological and pedagogical knowledge and skills.

Today, the institution of higher education in the field of physical culture and sports has put forward the concept according to which the unity of physical, mental, intellectual, moral and spiritual education is one of the leading principles of the educational process. At the same time, the need to increase the level of specializedprofessional and psychological-pedagogical training of students and to achieve on this basis the necessary professional competence of graduates is noted.

The modern system of training specialists in physical culture and sports requires from the teaching staff of the higher school a deep rethinking of the purpose of physical education, various aspects of harmonization of its models and technologies. The 
successful solution of new tasks facing higher physical education and pedagogical education depends on the readiness of the specialist to make the transition to a new pedagogical thinking, the essence of which is the perception of learning as a process of professional development of the future specialist.

The purpose of training is the maximum development of each student's abilities and abilities in the field of physical culture and sports. And this, in turn, changes the requirements for the student's personality as an active participant in the learning process. After all, as already mentioned, under the new educational paradigm, the teacher ceases to dominate, and the student is a full-fledged subject of pedagogical interaction. At the same time, to ensure high efficiency of education, it is important to develop a common pedagogical position of the entire teaching staff, distribute the tasks and functions of each department and each research and teaching staff so that all act in one direction, make common demands and, at the same time, creatively performed their educational and scientific work.

So, let's define the main directions of development of higher education in the field of physical culture and sports in the context of the ideas of the new educational paradigm:

- Creating conditions for the practical implementation of the main purpose of higher education - training of qualified professionals, competent and mobile in the field of physical culture and sports, ready for continuous professional growth, competitive in the labor market.

- Improving the content of higher education in the field of physical culture and sports, which should reflect changes in the requirements for professionals, including masters.

- Development and testing of effective innovative technologies of professional training and their inclusion in the educational process of the institution of higher education in the field of physical culture and sports.

- Establishing constant cooperation with education authorities, sports institutions, sports clubs in order to develop a common strategy for the practical 
implementation of the ideas of the new educational paradigm in educational practice, and, above all - effective innovative technologies of physical education of youth.

- Development, testing and implementation of innovative forms and methods of organization of educational, scientific and educational work of future specialists in the field of physical culture and sports.

Conclusions from this study and further prospects in this direction. The wide range of mandatory and optional components of the educational and professional program allows undergraduates to master professional competencies in coaching and health activities in order to achieve high sports results in this area, improve functionality, improve physical activity and health of various segments of the population, formation of skills and abilities of masters to teaching, research activities by conducting appropriate practices. But this program requires a constant search for new conceptual and methodological principles that harmoniously combine the achievements of previous versions of the standard with modern demands in this area. 
DOI 10.46299/ISG.2021.MONO.PED.III.6.2

\section{2 Діагностика адаптаційних можливостей юнаків-спринтерів до спеціалізованих навантажень в підготовчих періодах річного циклу тренування на етапах багаторічного вдосконалення}

Аналіз передової практики спорту і результатів досліджень, проведених останніми роками, дозволяє стверджувати, що основним резервом вдосконалення системи спортивної підготовки $є$ розробка і впровадження наукових основ її управління. Ефективність управління процесом спортивного тренування на будь-якому етапі багаторічної підготовки пов'язана 3 чітким кількісним вираженням структури тренувальної i змагальної діяльності, характерній для конкретної дисципліни того або іншого виду спорту. Найголовніше завдання управління - постійне збалансування програми тренування із станом і можливостями юного спортсмена. Нині особливого значення набула та частина управління, яка повинна забезпечувати оптимальну відповідність між функціональними можливостями юного спортсмена i навантаженням від одного тренувального дня. Щоб розміряти щоденне тренувальне навантаження 3 можливостями юного спортсмена, потрібно регулярно проводити і оцінювати діагностику його відновлення [441 ; 442; 443; $444 ; 445]$.

Підготовка, що проводиться з урахуванням індивідуальних особливостей юних спортсменів, дозволяє якнайповніше проявити їх здібності і природні завдатки. Проте індивідуальність атлета може бути плідно виражена тільки у рамках загальних станів, що визначають раціональні форми побудови тренування. Слід підкреслити, що, незважаючи на очевидну науково-теоретичну і практичну значущість, проблема вдосконалення організації тренувального процесу у великих тренувальних циклах не стала ще предметом досить великої кількості досліджень. На думку Л. П. Матвєєва $(1972,1991)$ і О. М. Воробйова (1986), К. П. Сахновського (1998) це пояснюється частково тим, що цілісна структура тренування в річному циклі є об'єктом надзвичайної складності, який майже не піддається лабораторному вивченню i вимагає довготривалих досліджень в реальних умовах спортивної практики [445, с. 6]. Потрібні нові 
педагогічні технології, засновані на біологічному моделюванні людини, як індивідуальній особині. Вони дозволяють відкрити нові підходи до сучасних інновацій управління підготовкою юних бігунів з урахуванням об'єктивнішої реалізації принципу спортивної «індивідуалізації». Побудова тренувального процесу у спортсменів в річному циклі повинна здійснюватися за принципом зв'язано-послідовного перманентного планування і реалізації навантаження.

Планування тренування юних спортсменів на основі сучасних методичних концепцій і управління нею на основі даних про стан працездатності спортсменів визначають нині науковий підхід до тренерської практики на будь-яких етапах багаторічної підготовки [447, с. 8, с. 9]. При цьому прогрес в юнацькому спорті, як правило, обумовлений оптимізацією контролю учбово-тренувального процесу і управління цим процесом на основі адекватної оцінки стану органів і систем, визначальних і лімітуючих загальну і спеціальну працездатність юного спортсмена [450].

Вивчення процесу управління руховою діяльністю юних легкоатлетівспринтерів особливо актуально, оскільки підготовка вітчизняних висококваліфікованих бігунів на короткі дистанції залишає бажати кращого. Останнє багато в чому визначається раціональною і ефективною підготовкою юних спринтерів. Організація спортивної тренування вимагає усебічних i глибоких знань про суть тренувального процесу - його зміст і структуру, закономірності, що визначають побудову цього процесу i зміну його спрямованості із зростанням майстерності спортсменів [441, с. 11, с. 12, с. 13, с. 14 ].

Зв'язок між станом спортсмена i тренувальним навантаженням надзвичайно складно опосередкований, залежить від багатьох чинників i визначається великою кількістю змінних. Об'єктивних даних, що характеризують цей зв'язок, поки дуже мало. Правильне рішення цього питання дозволить тренерам, використовуючи педагогічні методи, домагатися раціональної і ефективної організації тренувального навантаження для юнаків- 
спринтерів 3 метою збереження і поліпшення їх працездатності [451, с. 15, с. 16, c. 17].

У науково-методичній літературі питання розвитку адаптації юних бігунів на короткі дистанції до тренувальних навантажень доки ще недостатньо освітлені. 3 цієї причини традиційно прийнята система організації тренувального процесу в річному циклі у юних спортсменів різного віку вимагає переосмислення в плані двох або одноциклової структури її побудови [458, с. 19]. Тому актуальним напрямом вивчення оптимізації тренувального процесу юних бігунів на короткі дистанції $є$ дослідження i обгрунтування педагогічних i функціональних критеріїв в оцінці ефективності відновних мікроциклів підготовчих періодів.

\subsubsection{1 Динаміка зміни показників рухової функції під впливом відновних мікроциклів підготовчих періодів у юнаків-спринтерів 14-15 років}

Об'єктивні відомості про зміст і спрямованість відновних процесів після тренування дають надійну основу i для пошуку засобів прискорення відновлення, і для такого чергування навантажень, які зможуть полегшити, прискорити течію відновних процесів $[460$, с. 21, с. 22, с. 23]. 3 метою вдосконалення індивідуальної підготовки юнаків-спринтерів на дистанціях 100200 м в роботі була прийнята технологія ефективного педагогічного контролю у рамках етапного i поточного обстеження. Передбачасться, ицо знання закономірності адаптації юних спортсменів до спеціалізованих навантажень дозволять тренерам ефективніше $і$ раціонально організовувати тренувальний процес в підготовчих періодах, де, як відомо, повинні закладатися позитивні довгострокові відставлені тренувальні ефекти (ДОТЕ) з урахуванням збереження здоров'я і нормального фізичного розвитку юнаків. 
На першому етапі педагогічного експерименту була проаналізована динаміка зміни дев'яти показників рухової функції під впливом відновних мікроциклів двох підготовчих періодів: сили згиначів стопи, стрибка по Абалакову, диференціювання станової сили, коефіцієнта активності бігового кроку, потужності дихання (ПТХМ), затримки дихання (проби Штангє і Гєнчі), часу стартової реакції, тремора і диференціювання почуття часу.

У цих дослідженнях показники рухової функції реєструвалися на початку і кінці кожного відновного мікроциклу, запланованого тренерами. На термін двох підготовчих періодів річного тренування було представлено для дослідження вісім розвантажувально-відновних мікроциклів, які щомісячно завершували серію трьох тренувальних, починаючи з вересня по квітень місяці. В результаті експериментальних досліджень було відмічено, що різні показники по-різному визначають міру адаптації юних спортсменів впродовж тривалого періоду часу (табл. 1).

\subsubsection{1. Зміни педагогічних показників рухової функції у юнаків-спринтерів молодшого віку}

3 чотирьох педагогічних показників рухової функції юних спринтерів 1415 років (сили згиначів стопи, стрибка по Абалакову, диференціювання станової сили і коефіцієнта активності бігового кроку) жоден показник, під впливом восьми відновних мікроциклів двох підготовчих періодів, не має негативних значень. Динаміка кожного 3 них характеризується своєю специфічною тенденцією розвитку. Так, наприклад, такий показник, як сила згиначів стопи 3 кінця вересня по кінець квітня має хвилеподібну тенденцію змін (з $\Delta x_{1}=8,4 \%$ у вересні до $\Delta x_{8}=5,0 \%$ - в квітні), що знижується, 3 двома періодами позитивного зростання в жовтні і березні $\left(\Delta x_{2}=9,9 \%\right.$ і $\left.\Delta x_{7}=7,6 \%\right)$ і одним періодом відносної стабілізації $\left(\Delta x_{4}=7,6 \%, \Delta x_{5}=7,3 \%, \Delta x_{6}=7,5 \%\right)$ в грудні-лютому місяцях (рис. 1 , табл. 1). 


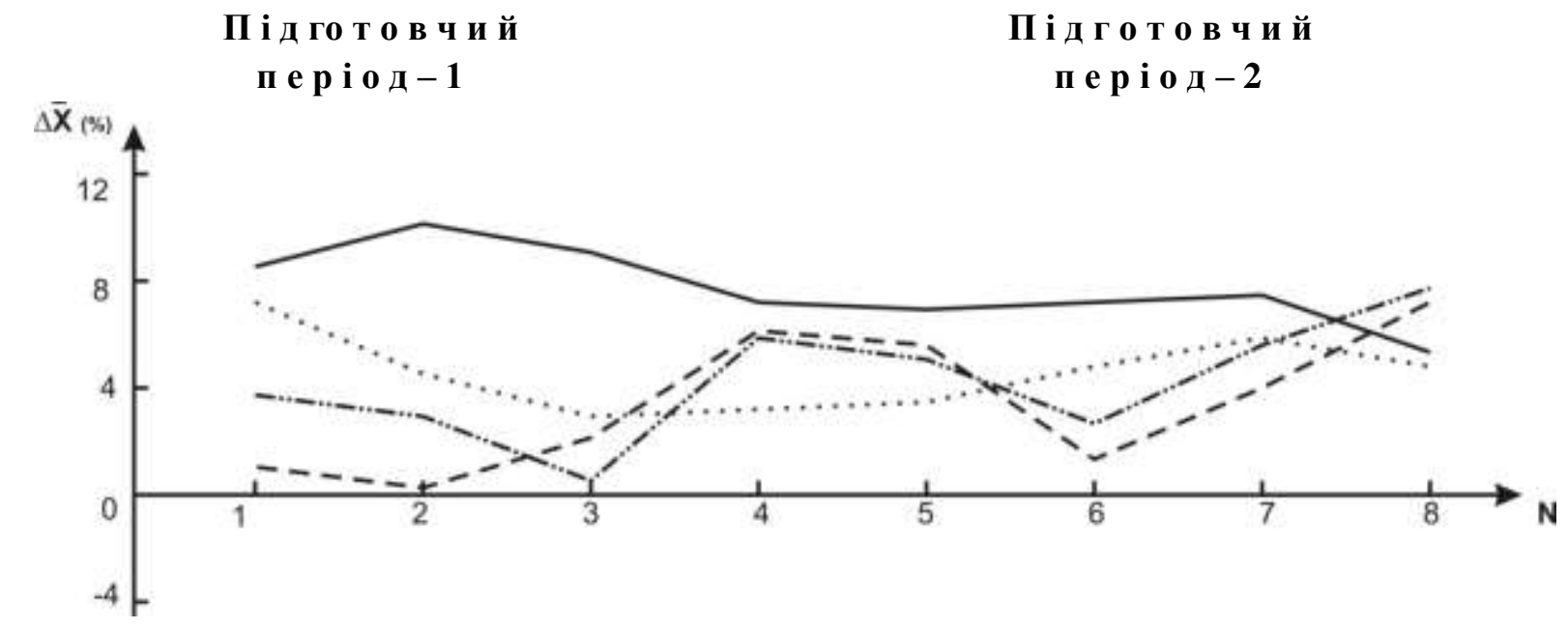

В ідновні мікроцикли

Рисунок 1. Динаміка зміни педагогічних показників, які визначають рухову функцію юнаків-спринтерів 14-15 років у підготовчих періодах цілорічного тренування.

Умовні позначки: — сила згиначів стопи; стрибок по Абалакову; - - - . диференціювання станової сили; - - - к коефіцієнт активності бігового кроку.

Динаміка зміни стрибка по Абалакову упродовж періоду часу, що вивчається, має тенденцію схожу з попереднім показником, але 3 нижчими значеннями приросту. Тривале зниження приросту цього показника 3 кінця вересня по кінець листопада місяця $\left(\Delta x_{1}=6,8 \%, \Delta x_{2}=4,6 \%, \Delta x_{3}=3,0 \%\right)$ змінюється двомісячною стабілізацією його в грудні-січні на рівні $\Delta x_{4}=3,2 \%$ i $\Delta x_{5}=3,4 \%$. Надалі, до кінця березня, відмічена ділянка значнішого приросту цього показника під впливом шостого і сьомого відновних мікроциклів $\left(\Delta x_{6}\right.$ $=4,75 \%$ i $\left.\Delta x_{7}=5,8 \%\right)$. А впродовж квітня зафіксовано зниження приросту показника до $\Delta x_{8}=4,5 \%$, при $p<0,05$.

Хвилеподібність коефіųiєнта активності бігового кроку відбиває позитивну, контрастнішу частоту хвиль в зміні значень цього показника під впливом восьми відновних мікроциклів двох підготовчих періодів. Значні зниження динаміки зміни цього показника по абсолютних величинах відмічені на двох ділянках - у кінці листопада і у кінці лютого $\left(\Delta x_{3}=0,6 \%\right.$ i $\Delta x_{6}=2,9 \%$, при $p<0,05)$. 
Схожу 3 коефіцієнтом активності бігового кроку тенденцію хвилеподібності представляє позитивна динаміка зміни диференціювання станової сили. Ділянки значного зниження динаміки зміни цього показника зафіксовані у кінці жовтня ( $\left.\Delta x_{2}=0,2 \%\right)$ і у кінці лютого $\left(\Delta x_{6}=1,4 \%\right)$, при $p<0,05$.

Таким чином, динаміка зміни чотирьох педагогічних показників рухової функції в процесі відновних мікроциклів двох підготовчих періодів юнаківспринтерів 14-15 років, окрім виявлення закономірності розвитку адаптації, вказує і про посилення інформативності цих показників в якості попередніх

Таблиця 1. Динаміка зміни педагогічних показників рухової функції в процесі відновних мікроциклів підготовчих періодів юнаків-спринтерів 14-15 років ( $\mathrm{n}=10)$

\begin{tabular}{|c|c|c|c|c|}
\hline \multirow{2}{*}{ Показники } & \multicolumn{4}{|c|}{ Відновні мікроцикли } \\
\hline & 1 & 2 & 3 & 4 \\
\hline Сила згиначів стопи, кг & $72,81 \pm 3,76$ & $72,30 \pm 3,73$ & $70,72 \pm 3,67$ & $73,60 \pm 3,34$ \\
\hline$\overline{\mathrm{X}} \pm \sigma$ & $78,97 \pm 4,08$ & $79,45 \pm 4,09$ & $76,80 \pm 4,04$ & $79,12 \pm 4,08$ \\
\hline$\Delta \overline{\mathrm{X}}$ & 6,16 & 7,15 & 6,08 & 5,52 \\
\hline Середьогруп. приріст, \% & 8,4 & 9,9 & 8,6 & 7,5 \\
\hline $\begin{array}{c}\text { Стрибок вгору по } \\
\text { Абалакову, } c м\end{array}$ & $42,72 \pm 3,21$ & $41,58 \pm 3,11$ & $43,11 \pm 3,24$ & $43,81 \pm 3,30$ \\
\hline$\overline{\mathrm{X}} \pm \sigma$ & $45,62 \pm 3,54$ & $43,49 \pm 3,29$ & $44,40 \pm 3,49$ & $45,21 \pm 3,62$ \\
\hline$\Delta \overline{\mathrm{X}}$ & 2,90 & 1,91 & 1,29 & 1,40 \\
\hline Середньогруп. приріст, \% & 6,8 & 4,6 & 3,0 & 3,2 \\
\hline $\begin{array}{l}\text { Диференціювання } \\
\text { станової сили, кг }\end{array}$ & $6,150 \pm 0,44$ & $6,220 \pm 0,45$ & $5,750 \pm 0,41$ & $5,690 \pm 0,40$ \\
\hline$\overline{\mathrm{X}} \pm \sigma$ & $6,058 \pm 0,42$ & $6,208 \pm 0,45$ & $5,635 \pm 0,40$ & $5,349 \pm 0,39$ \\
\hline$\Delta \overline{\mathrm{X}}$ & 0,092 & 0,012 & 0,115 & 0,341 \\
\hline Середньогруп. приріст, \% & 1,5 & 0,2 & 2,0 & 6,0 \\
\hline $\begin{array}{c}\text { Коефіцієнт активності } \\
\text { бігового кроку, у.о. }\end{array}$ & $1,240 \pm 0,091$ & $1,240 \pm 0,090$ & $1,240 \pm 0,091$ & $1,250 \pm 0,092$ \\
\hline$\overline{\mathrm{X}} \pm \sigma$ & $1,286 \pm 0,095$ & $1,277 \pm 0,094$ & $1,247 \pm 0,093$ & $1,320 \pm 0,111$ \\
\hline$\Delta \overline{\mathrm{X}}$ & 0,046 & 0,037 & 0,007 & 0,072 \\
\hline Середньогруп. приріст, \% & 3,75 & 3,0 & 0,6 & 5,75 \\
\hline
\end{tabular}


Продовження табл. 1

\begin{tabular}{|c|c|c|c|c|}
\hline \multirow{2}{*}{ Показники } & \multicolumn{4}{|c|}{ Відновні мікроцикли } \\
\hline & 5 & 6 & 7 & 8 \\
\hline Сила згиначів стопи, к2 & $73,28 \pm 3,91$ & $71,14 \pm 3,69$ & $72,50 \pm 3,74$ & $73,08 \pm 3,89$ \\
\hline$\overline{\mathrm{X}} \pm \sigma$ & $78,62 \pm 4,07$ & $76,47 \pm 4,04$ & $78,01 \pm 4,07$ & $76,73 \pm 4,05$ \\
\hline$\Delta \overline{\mathrm{X}}$ & 5,34 & 5,33 & 5,51 & 3,65 \\
\hline Середньогруп. приріст, \% & 7,3 & 7,5 & 7,6 & 5,0 \\
\hline $\begin{array}{l}\text { Стрибок вгору по } \\
\text { Абалакову, см }\end{array}$ & $40,92 \pm 3,07$ & $40,45 \pm 3,08$ & $41,93 \pm 3,13$ & $43,29 \pm 3,22$ \\
\hline $\bar{X} \pm \sigma$ & $42,31 \pm 3,15$ & $42,37 \pm 3,17$ & $44,36 \pm 3,48$ & $45,23 \pm 3,41$ \\
\hline$\Delta \overline{\mathrm{X}}$ & 1,39 & 1,92 & 2,43 & 1,94 \\
\hline Середньогруп. приріст, \% & 3,4 & 4,75 & 5,8 & 4,5 \\
\hline $\begin{array}{l}\text { Диференціювання } \\
\text { станової сили, кг }\end{array}$ & $5,510 \pm 0,39$ & $6,070 \pm 0,43$ & $6,330 \pm 0,47$ & $6,110 \pm 0,43$ \\
\hline$\overline{\mathrm{X}} \pm \sigma$ & $5,207 \pm 0,38$ & $5,986 \pm 0,42$ & $6,077 \pm 0,48$ & $5,671 \pm 0,40$ \\
\hline$\Delta \overline{\mathrm{X}}$ & 0,303 & 0,084 & 0,253 & 0,439 \\
\hline Середньогруп. приріст, \% & 5,5 & 1,4 & 4,0 & 7,2 \\
\hline $\begin{array}{c}\text { Коефіцієнт активності } \\
\text { бігового кроку, у.о. }\end{array}$ & $1,220 \pm 0,086$ & $1,250 \pm 0,093$ & $1,210 \pm 0,084$ & $1,190 \pm 0,077$ \\
\hline$\overline{\mathrm{X}} \pm \sigma$ & $1,281 \pm 0,094$ & $1,286 \pm 0,095$ & $1,280 \pm 0,093$ & $1,283 \pm 0,094$ \\
\hline$\Delta \overline{\mathrm{X}}$ & 0,061 & 0,036 & 0,07 & 0,093 \\
\hline Середньогруп. приріст, \% & 5,0 & 2,9 & 5,8 & 7,8 \\
\hline
\end{tabular}

критеріїв ефективності розвантажувальних мікроциклів до кінця кожного 3

періодів. Необхідно відмітити, що сила згиначів стопи і стрибок по Абалакову, унаслідок значніших змін у відновних мікроциклах, можуть мати абсолютну інформативність упродовж усіх восьми місяців підготовки юних спринтерів молодшої вікової групи (див. табл. 1, рис. 1). Проте слід сказати, що в той час, коли інформативність сили згиначів стопи і стрибка по Абалакову до кінця кожного з підготовчих періодів частково знижується, інформативність диференціювання станової сили і коефіцієнта активності бігового кроку значно зростає. У кінці другого підготовчого періоду в квітні місяці інформативність усіх чотирьох педагогічних показників ставати приблизно однаково значимою. На це вказує зближення кривих в період восьмого відновного мікроциклу. 


\subsubsection{2. Зміни фізіологічних показників руховій функції у юнаків- спринтерів молодшої вікової групи}

Про системні механізми адаптації до фізіологічних навантажень можна судити тільки на основі усебічного обліку сукупності реакцій цілісного організму, включаючи реакції з боку ЦНС, рухового і гормонального апаратів, серцево-судинною і дихальною систем, аналізаторів обміну речовин та ін. Не може бути якогось одного показника, що відбиває адаптаційні зміни в організмі - придатний лише комплекс показників, що характеризують діяльність різних органів і систем [444, с. 24, с. 25$]$.

У роботі була проаналізована динаміка п'яти фізіологічних показників рухової функції юнаків-спринтерів 14-15 років, що визначають працездатність юних спортсменів. Реєструвалися швидкість рухової реакції на слуховий аналізатор, тремор мускулатури ніг, потужність вдиху-видиху, затримка дихання на вдиху-видиху i диференціювання почуття часу. 3 п'яти фізіологічних показників рухової функції упродовж двох підготовчих періодів лише один показник - часу затримки дихання під впливом восьми відновних мікроциклів не має негативних значень (табл. 2; рис. 2).

Проби Штанге і Генчі впродовж першого підготовчого періоду проявляють хвилеподібну прогресуючу тенденцію з незначними зниженнями приросту у кінці листопада (на 0,27\% порівняно з жовтнем) і у кінці січня і лютого (на 1,35\% порівняно з груднем). Лише з кінця лютого по кінець квітня на всьому протязі другого підготовчого періоду динаміка носить безперервну позитивну тенденцію ( $\left.\Delta x_{6}=1,25 \% ; \Delta x_{7}=2,82 \% ; \Delta x_{8}=2,85 \%\right)$. Абсолютні значення цього показника вигідно відрізняються від інших, що вказує на його достатню попередню інформативність, особливо в останні три місяці підготовки (див. рис. 2).

Динаміка зміни показника потужності дихання має сходжу тенденцію 3 попереднім показником, але зі значнішим спадом середньогрупових значень в іншому і третьому відновних мікроциклах кінця жовтня і кінця листопада місяців (на 0,76\% порівняно з вереснем). Слід зазначити, що під впливом 3-го відновного 
мікроциклу (у кінці листопада) значення пневмотахометрії зафіксовані 3 негативним знаком $\left(\Delta x_{3}=-0,26 \%\right)$. Це вказує на факт помітної напруги адаптації юних бігунів до навантажень, визначальних даний показник. У інший же період часу тенденція характеризується позитивною динамікою ( на 2,26\% у кінці січня порівняно 3 листопадом і на 0,55 \% у кінці березня порівняно 3 лютим) лише 3 двома ділянками відносної стабілізації $\left(\Delta x_{6}=1,20 \%\right.$ i $\left.\Delta x_{8}=1,73 \%\right)$ у кінці лютого і в кінці квітня місяця (при $p<0,01)$.

Таблиця 2. Динаміка зміни фізіологічних показників рухової функції в процесі відновних мікроциклів підготовчих періодів юнаків-спринтерів 14-15 років (n $=10)$

\begin{tabular}{|c|c|c|c|c|}
\hline \multirow{2}{*}{ Показники } & \multicolumn{4}{|c|}{ Відновні мікроцикли } \\
\hline & 1 & 2 & 3 & 4 \\
\hline Затримка дихання, сек & $96,100 \pm 4,32$ & $96,640 \pm 4,435$ & $96,430 \pm 4,435$ & $96,970 \pm 4,438$ \\
\hline$\overline{\mathrm{X}} \pm \sigma$ & $96,820 \pm 4,436$ & $97,867 \pm 4,446$ & $97,394 \pm 4,442$ & $99,491 \pm 4,455$ \\
\hline$\Delta \overline{\mathrm{X}}$ & 0,720 & 1,227 & 0,964 & 2,521 \\
\hline Середньогруп. приріст,\% & 0,75 & 1,27 & 1,0 & 2,6 \\
\hline Пневмотахометрія, $л / c$ & $5,230 \pm 0,310$ & $5,150 \pm 0,305$ & $4,910 \pm 0,290$ & $4,840 \pm 0,285$ \\
\hline$\overline{\mathrm{X}} \pm \sigma$ & $5,256 \pm 0,308$ & $5,163 \pm 0,305$ & $4,897 \pm 0,388$ & $4,876 \pm 0,387$ \\
\hline$\Delta \overline{\mathrm{X}}$ & 0,026 & 0,013 & $-0,013$ & 0,036 \\
\hline Середньогруп. приріст, \% & 0,5 & 0,25 & $-0,26$ & 0,75 \\
\hline Тремор, $\boldsymbol{M M}^{2}$ & $10,740 \pm 1,093$ & $10,890 \pm 1,096$ & $11,310 \pm 1,207$ & $11,350 \pm 1,157$ \\
\hline$\overline{\mathrm{X}}+$ & $10,633 \pm 1,09$ & $10,765 \pm 1,09$ & $11,226 \pm 1,20$ & $11,418 \pm 1,16$ \\
\hline & 5 & 5 & 6 & 3 \\
\hline$\Delta \overline{\mathrm{X}}$ & 0,107 & 0,125 & 0,084 & $-0,068$ \\
\hline Середньогруп. приріст,\% & 1,0 & 1,15 & 0,75 & $-0,6$ \\
\hline Час стартової реакції, $м c$ & $186,00 \pm 10,73$ & $185,00 \pm 10,72$ & $187,00 \pm 10,76$ & $185,00 \pm 10,72$ \\
\hline$\overline{\mathrm{X}} \pm \sigma$ & $\mid 184,88 \pm 10,72$ & $183,61 \pm 10,60$ & $187,94 \pm 10,77$ & $\mid 185,49 \pm 10,72$ \\
\hline$\Delta \overline{\mathrm{X}}$ & 1,116 & 1,387 & $-0,935$ & $-0,499$ \\
\hline Середньогруп. приріст,\% & 0,6 & 0,75 & $-0,5$ & $-0,27$ \\
\hline $\begin{array}{l}\text { Диференціювання } \\
\text { чувства часу, сек }\end{array}$ & $0,660 \pm 0,04$ & $0,690 \pm 0,04$ & $0,720 \pm 0,04$ & $0,610 \pm 0,041$ \\
\hline$\overline{\mathrm{X}} \pm \sigma$ & $0,663 \pm 0,041$ & $0,694 \pm 0,044$ & $0,721 \pm 0,047$ & $\mid 0,610 \pm 0,039$ \\
\hline$\Delta \overline{\mathrm{X}}$ & $-0,003$ & $-0,004$ & $-0,001$ & - \\
\hline Середньогруп. приріст,\% & $-0,4$ & $-0,55$ & $-0,2$ & 0,00 \\
\hline
\end{tabular}


Продовження табл. 2

\begin{tabular}{|c|c|c|c|c|}
\hline \multirow{2}{*}{ Показники } & \multicolumn{4}{|c|}{ Відновні мікроцикли } \\
\hline & 5 & 6 & 7 & 8 \\
\hline Затримка дихання, сек & $96,520 \pm 4,434$ & $95,890 \pm 4,430$ & $96,780 \pm 4,436$ & $98,240 \pm 4,447$ \\
\hline$\overline{\mathrm{X}} \pm \sigma$ & $98,209 \pm 4,447$ & $97,088 \pm 4,440$ & $99,509 \pm 4,463$ & $101,039 \pm 4,460$ \\
\hline$\Delta \overline{\mathrm{X}}$ & 1,689 & 1,198 & 2,729 & 2,799 \\
\hline Середньогруп. приріст,\% & 1,75 & 1,25 & 2,82 & 2,85 \\
\hline Пневмотахометрія, $л / c$ & $4,820 \pm 0,284$ & $4,870 \pm 0,287$ & $4,890 \pm 0,288$ & $4,970 \pm 0,301$ \\
\hline$\overline{\mathrm{X}} \pm \sigma$ & $4,880 \pm 0,387$ & $|4,928 \pm 0,391|$ & $4,975 \pm 4,493$ & $5,055 \pm 0,502$ \\
\hline$\Delta \overline{\mathrm{X}}$ & 0,060 & 0,058 & 0,085 & 0,085 \\
\hline Середньогруп. прирост, \% & 1,25 & 1,2 & 1,75 & 1,73 \\
\hline Тремор, $м^{2}$ & $11,670 \pm 1,183$ & $11,720 \pm 1,185$ & $11,700 \pm 1,184$ & $11,680 \pm 1,183$ \\
\hline $\bar{X} \pm \sigma$ & $11,658 \pm 1,18$ & $11,685 \pm 1,18$ & $11,618 \pm 1,18$ & $11,532 \pm 1,17$ \\
\hline$\Delta \overline{\mathrm{X}}$ & 0,012 & 0,035 & 0,082 & 0,148 \\
\hline Среднегруп. приріст, \% & 0,1 & 0,3 & 0,7 & 1,27 \\
\hline Час стартової реакції,, с & $186,00 \pm 10,73$ & $186,50 \pm 10,74$ & $187,00 \pm 10,76$ & $187,0 \pm 10,76$ \\
\hline $\bar{X} \pm \sigma$ & $\mid \begin{array}{c}185,52 \pm 10,7 \\
4\end{array}$ & $\mid \begin{array}{c}186,13 \pm 10,7 \\
3\end{array}$ & $\begin{array}{c}185,60 \pm 10,7 \\
2\end{array}$ & $\mid \begin{array}{c}185,45 \pm 10,7 \\
2\end{array}$ \\
\hline$\Delta \overline{\mathrm{X}}$ & 0,484 & 0,373 & 1,403 & 1,552 \\
\hline Середньогруп. приріст, \% & 0,26 & 0,20 & 0,75 & 0,83 \\
\hline $\begin{array}{l}\text { Диференціювання } \\
\text { почуття часу, сек }\end{array}$ & $0,580 \pm 0,037$ & $0,709 \pm 0,048$ & $0,650 \pm 0,042$ & $0,600 \pm 0,040$ \\
\hline$\overline{\mathrm{X}} \pm \sigma$ & $0,581 \pm 0,038$ & $0,708 \pm 0,047$ & $0,649 \pm 0,043$ & $0,602 \pm 0,041$ \\
\hline$\Delta \overline{\mathrm{X}}$ & $-0,001$ & 0,001 & $-0,001$ & $-0,002$ \\
\hline Середньогруп. приріст,\% & $-0,25$ & 0,1 & $-0,2$ & $-0,28$ \\
\hline
\end{tabular}

Швидкість реакиії на слуховий аналізатор має деяку інформативність як показник рухової функції лише в першому, другому, сьомому і восьмому відновних мікроциклах, оскільки позитивні зміни його під впливом цих мікроциклів мають істотніші значення у кінці вересня, жовтня, березня і квітня місяців $\left(\Delta x_{1}=0,6 \%, \Delta x_{2}=0,75 \%, \Delta x_{7}=0,75 \%\right.$ і $\left.\Delta x_{8}=0,83 \%\right)$, при $p<0,05$. У решту часу цей показник не має достатньої інформативності, щоб його враховувати при програмуванні тренувального процесу у відновних мікроциклах юних спринтерів 14-15 років ( $\left.\Delta x_{3}=-0,5 \%, \Delta x_{4}=-0,27 \%, \Delta x_{5}=0,26 \%, \Delta x_{6}=0,20 \%\right)$ при недотриманні достовірності відмінностей тільки в 5-му і 6-му відновних мікроциклах. 


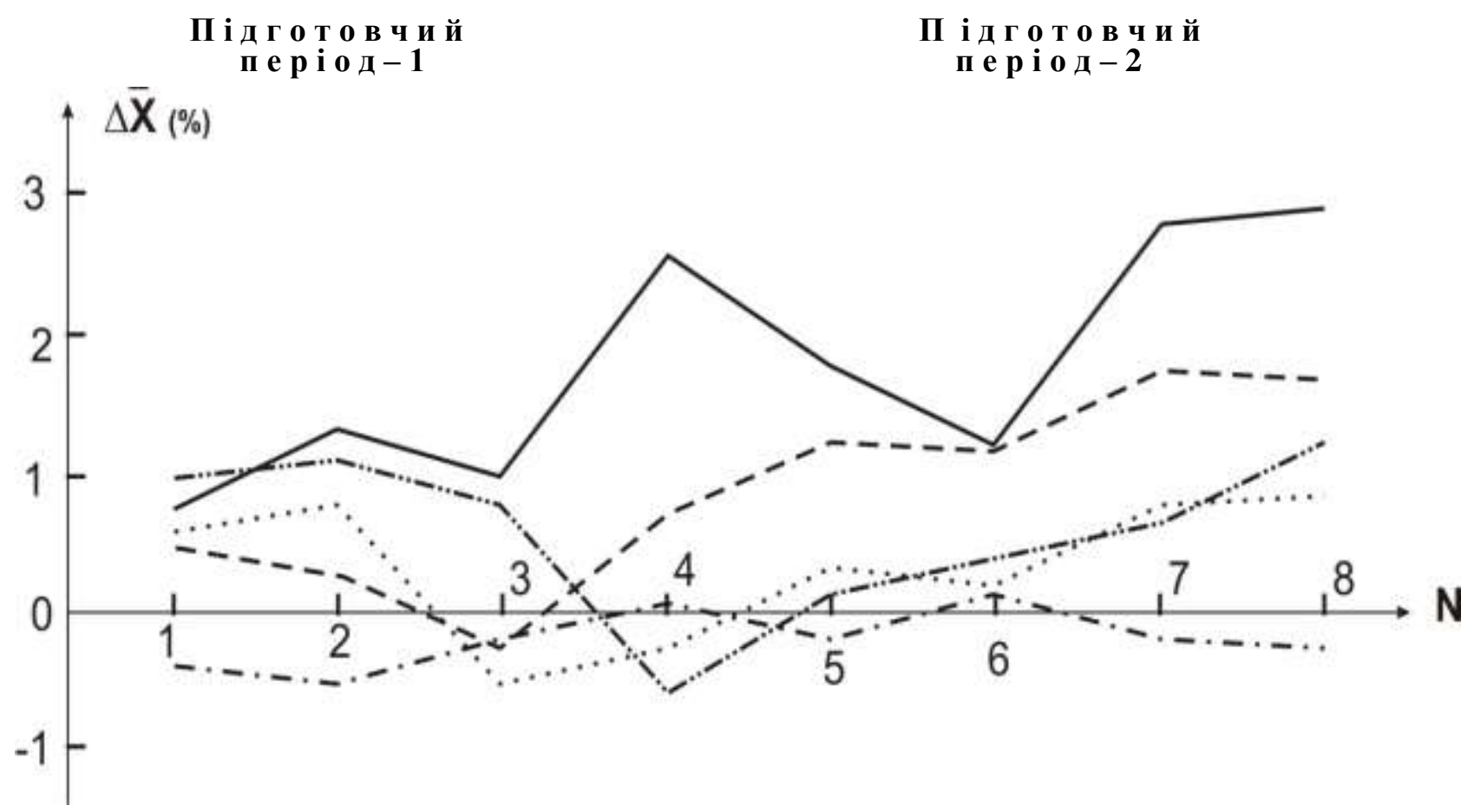

В і д но в н і м ікроцикли

Рисунок 2. Динаміка зміни функціональних показників, які визначають рухову функцію юнаків-спринтерів 14-15 років у підготовчих періодах річного циклу.

Умовні позначки:

— затримка дихання; - - - - потужність вдиху-видиху; - - - - д диференціювання почуття часу; - - - тремор; час реакції слухового аналізатору.

Тремор, як показник рухової функції має трохи більшу інформативність, ніж попередній показник в першому, другому, третьому, сьомому і восьмому відновних мікроциклах $\left(\Delta x_{1}=1,2 \%, \Delta x_{2}=1,35 \%, \Delta x_{3}=0,75 \%, \Delta x_{7}=0,7 \%, \Delta x_{8}\right.$ $=1,27 \%$ ) - по тих же термінах, що і швидкість рухової реакції, плюс додатково і у кінці листопада місяця. В період четвертого, п'ятого і шостого відновних мікроциклів 3 кінця грудня по кінець лютого інформативність цього показника занадто мала ( $\left.\Delta x_{4}=-0,6 \%, \Delta x_{5}=0,1 \%, \Delta x_{6}=0,3 \%\right)$. Як і у попереднього показника швидкості реакції, інформативність тремора починає зростати тільки до закінчення другого підготовчого періоду (див. рис. 2).

Диференціювання почуття часу на протязі двох підготовчих періодів під впливом восьми відновних мікроциклів змінюється занадто незначно $\left(\Delta x_{1}=-\right.$ $0,4 \%, \Delta x_{2}=-0,55 \%, \Delta x_{3}=-0,2 \%, \Delta x_{4}=0,00 \%, \Delta x_{5}=-0,25 \%, \Delta x_{6}=0,1 \%, \Delta x_{7}$ 
$\left.=-0,2 \%, \Delta x_{8}=-0,28 \%\right)$, що вказує на його абсолютну неінформативність в якості критеріїв оцінки ефективності відновних мікроциклів (при $p<0,05$ ).

\subsubsection{3. Узагальнення результатів педагогічних досліджень у юнаків-спринтерів учбово-тренувальної групи 3-4 року навчання}

В результаті завершення досліджень відносно зміни педагогічних показників рухової функції під впливом відновних мікроциклів двох підготовчих періодів у юних бігунів на короткі дистанції 14-15 років, встановлено, що значення кривих сили згиначів стопи і стрибка по Абалакову, як більше інформативних показників, у кінці другого підготовчого періоду відповідають рівню значень нижчих, ніж на початку першого підготовчого періоду $\left(\Delta x_{1}=8,4 \%\right.$ i $\Delta x_{8}=5,0 \%$ - сила згиначів стопи; $\Delta x_{1}=6,8 \%$ i $\Delta x_{8}=4,5 \%$ - стрибок по Абалакову), при $p<0,01$.

А значення кривих диференціювання станової сили і коефіцієнту активності бігового кроку в кінці другого підготовчого періоду підлягають рівню значень більш високих, ніж на початку року $\left(\Delta x_{1}=1,5 \%\right.$ i $\Delta x_{8}=7,2 \%$ диференціювання станової сили; $\Delta x_{1}=3,75 \%$ и $\Delta x_{8}=7,8 \%$ - коефіцієнт активності бігового кроку), при $p>0,05$ тіки в п’ятому відновному мікроциклі. Очевидно, в цьому простежуються adanmaціï до навантажень, що визначають одні показники і переадапmaціï до навантажень, визначальних інші.

Дворазове зближення кривих педагогічних показників у своєрідний пучок у кінці кожного підготовчого періоду (5-й і 8-й відновні мікроцикли) підтверджує ту обставину, що адаптація до цих показників у бігунів до закінчення періодів проходить як би завершальний цикл. Проте нижчі значення приросту сили згиначів стопи і стрибка по Абалакову у кінці другого підготовчого періоду в порівнянні з початком року вказують про зниження розвитку адаптації юних спортсменів до навантажень, що визначають ці показники до цього терміну часу. Цей результат підтверджують наші ранні дослідження по обгрунтуванню динаміки працездатності юних бігунів 14-15 
років в підготовчих періодах річного циклу тренування, в яких був відмічений факт напруги процесу адаптації за умови організації їх підготовки по двох цикловій системі $[455$, с. 26$]$.

Помічено також, що розширений спектр «кривих» на початку кожного 3 підготовчих періодів, очевидно, вказує на тимчасову втрату адаптації юних бігунів молодшої вікової групи до навантажень, що визначають ці педагогічні показники. Але, якщо на початку першого підготовчого періоду така втрата адаптації цілком з'ясовна, то на початку другого - зниження адаптації, це результат нераціонально вибраної періодизації юнацької підготовки для молодшої вікової групи.

Проаналізувавши динаміку зміни фізіологічних показників рухової функції у юнаків-спринтерів 14-15 років, можна відмітити, що до цих показників розвиток процесу адаптації упродовж двох підготовчих періодів проходить так само в два етапи, як і до педагогічних (див. рис. 1, 2). Вужчий спектр графічних кривих на початку першого підготовчого періоду (кінець вересня) вказує на ті обставини, що в цей період часу у юних спортсменів спостерігається ще не закінчений процес загасання спеціальної працездатності після літнього періоду змагання і тренувань в серпні місяці в спортивному таборі.

3 п'яти фізіологічних показників рухової функції юних спринтерів 14-15 років найбільшу інформативність упродовж двох підготовчих періодів має тільки показник затримки дихання (проби Штангє і Генчі), у якого позитивні зміни носять прогресуючий хвилеподібний характер. Інформативність таких показників, як пневмотахометрії, тремора і часу стартової реакції упродовж тривалого часу носить непостійний характер. На початку року упродовж двох місяців (1-й, 2-й відновні мікроцикли) незначну інформативність мають усі три показники і лише один показник, тремора залишається досить інформативним $і$ в подальшому місяці - у кінці листопада (3-й відновний мікроцикл). Слід зазначити, що до закінчення першого підготовчого періоду (з 4-го відновного мікроциклу) i увесь подальший час інформативність показника пневмотахометрії зростає і утримується на досить помітному рівні. А показники 
тремора і часу стартової реакції придбавають інформативність лише у кінці другого підготовчого періоду (7-й і 8-й відновні мікроцикли).

Динаміка змін показника диференціювання почуття часу, під впливом восьми відновних мікроциклів, не маючи істотних відмінностей до і після їх закінчення, вказує на неінформативність цього показника в плані обліку його при організації i програмуванні тренувального навантаження у відновних мікроциклах підготовчих періодів цілорічного тренування юнаків-спринтерів 14-15 років. А широкий спектр графічних кривих у кінці другого підготовчого періоду, напередодні травня місяця, свідчить про незавершений процес адаптації юних спринтерів до навантажень, що визначають їх фізіологічні показники рухової функції (див. рис. 2). Є усі підстави припускати, що розвиток адаптації до цих навантажень у юних бігунів завершиться пізніше, в літньому періоді змагання. Але для цього потрібні додаткові дослідження.

\subsubsection{2. Показники рухової функції і їх динаміка в процесі відновних мікроциклів підготовчих періодів юних бігунів на короткі дистанції 16-17 років}

Із-за великої різноманітності засобів спортивного тренування при оцінці роботи, виконаної тим або іншим спортсменом, часто виникають великі труднощі. Тренер в цьому випадку інтуїтивно стає на шлях порівняння одного спортсмена з іншим. Цей метод є скрутним, оскільки зіставлення йде за багатьма параметрами: по деяких з них навантаження вище у одного спортсмена, а по інших у іншого. Крім того, з позицій чітких кількісних оцінок існуючі поняття «велике», «середнє», «мале» навантаження є достатньою мірою умовними [449, с. 27]. Виникає необхідність у вивченні особливостей адаптації до спеціальних навантажень юнаків-спринтерів різного віку, а далі у формуванні чітких якісних і кількісних еталонів по кожному провідному параметру навантаження, пошуку надійних критеріїв побудови не лише тренувальних, але і відновних мікроциклів. 


\subsubsection{1. Зміни педагогічних показників рухової функції у юнаків-спринтерів старшої вікової групи}

У юнаків-спринтерів 16-17 років так само, як і 14-15 літніх бігунів, жоден педагогічний показник не має негативних значень зміни під впливом восьми відновних мікроциклів двох підготовчих періодів (див. рис. 1, 3).

Сила згиначів стопи 3 кінця вересня по кінець квітня показує не дуже вираженою позитивну динаміку (з 11,1\% у вересні до 11,3\% у кінці квітня) 3 однією лише ділянкою ( $\Delta x_{3}=9,8 \%$ проти $\Delta x_{2}=11,49 \%$ в листопаді місяці), де зафіксований зворотній характер (рис. 3, табл. 3).
П і д г о то в ч и й
п е р і о д- 1
П і дг о то в ч и й
пе р і о д-2

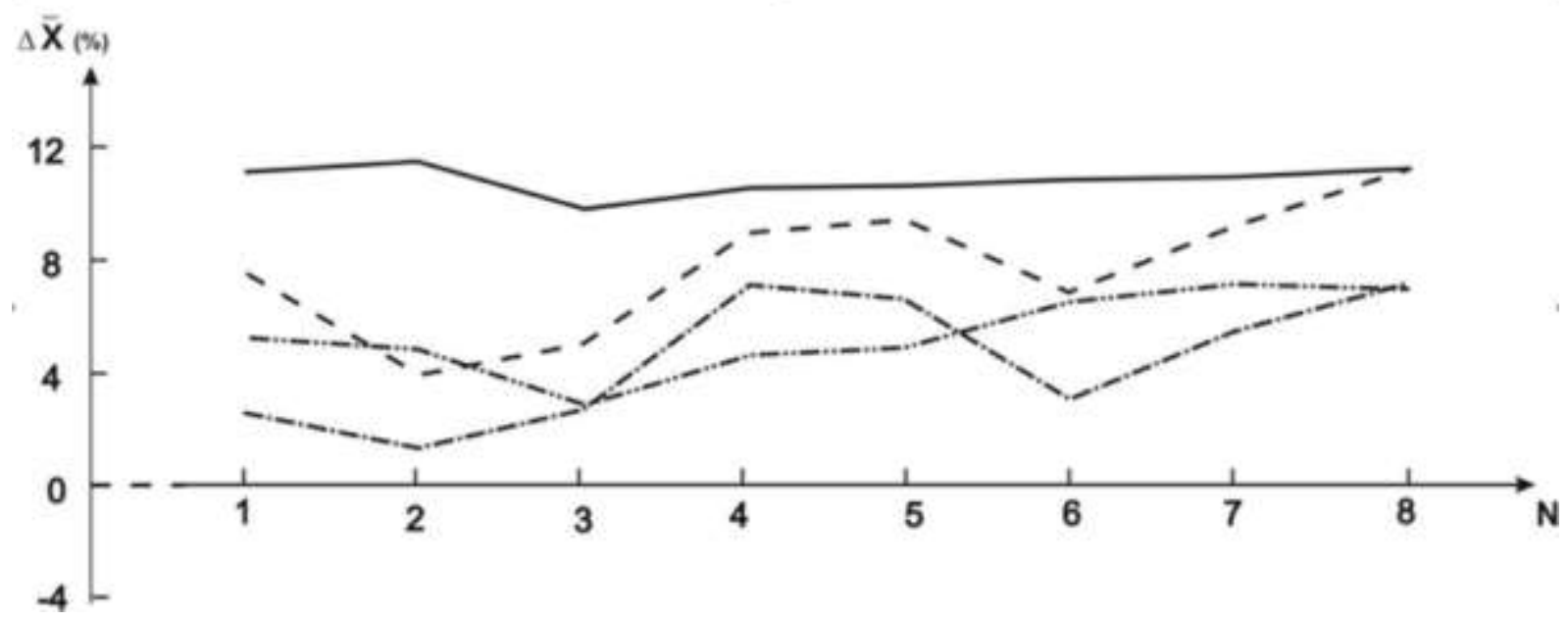

В ід н о в н і м і кроцикли

Рисунок 3. Динаміка зміни педагогічних показників, які визначають рухову функцію юнаків-спринтерів 16-17 років в підготовчих періодах річного циклу

Умовні позначки: — - сила згиначів стопи; - - - -стрибок по Абалакову; -. - - - д диференціювання станової сили; - - - ко коефіцієнт активності бігового кроку.

Динаміка змін стрибка по Абалакову упродовж двох підготовчих періодів носить хвилеподібний характер з тенденцією деякого зростання позитивної різниці цього показника до закінчення другого підготовчого періоду. Відмічені 
лише дві ділянки зниження - 3 кінця вересня по кінець жовтня $\left(\Delta x_{1}=7,7 \%\right.$ i $\left.\Delta x_{2}=4,0 \%\right)$, при $p<0,01$ і з кінця січня після закінчення лютого $\left(\Delta x_{5}=9,4 \%\right.$ і $\Delta x_{6}$ $=6,9 \%)$, при $p>0,05$.

Коефіиієнт активності бігового кроку має схожу тенденцію з попереднім показником: від першого у вересні до третього мікроциклу у листопаді $\left(\Delta x_{1}\right.$ $\left.=5,4 \% ; \Delta x_{2}=4,8 \% ; \Delta x_{3}=2,7 \%\right)$ і від сьомого у березні до восьмого в квітні $\left(\Delta x_{7}\right.$ $\left.=7,2 \% ; \Delta x_{8}=7,0 \%\right)$ відмічені позитивні зміни у бік зниження динаміки. У решту

Таблиця 3. Динаміка зміни педагогічних показників рухової функції в процесі відновних мікроциклів підготовчих періодів юнаків-спринтерів 16-17 років (n $=10)$

\begin{tabular}{|c|c|c|c|c|}
\hline \multirow{2}{*}{ Показники } & \multicolumn{4}{|c|}{ Відновні мікроцикли } \\
\cline { 2 - 5 } & 1 & 2 & 3 & 4 \\
\hline Сила згиначів стопи, к2 & $104,90 \pm 7,03$ & $104,50 \pm 7,02$ & $95,60 \pm 6,92$ & $106,14 \pm 7,05$ \\
$\overline{\mathrm{X}} \pm \sigma$ & $116,54 \pm 7,07$ & $116,51 \pm 7,05$ & $104,96 \pm 7,01$ & $117,28 \pm 7,08$ \\
$\Delta \overline{\mathrm{X}}$ & 11,64 & 12,01 & 9,36 & 11,14 \\
Середньогруп. приріст, \% & 11,1 & 11,5 & 9,8 & 10,5 \\
\hline Стрибок вгору по & $55,64 \pm 3,41$ & $54,37 \pm 3,65$ & $56,12 \pm 4,09$ & $57,28 \pm 4,78$ \\
Абалакову,см & $59,92 \pm 6,13$ & $56,54 \pm 4,50$ & $58,70 \pm 5,88$ & $62,43 \pm 6,09$ \\
$\overline{\mathrm{X}} \pm \sigma$ & 4,28 & 2,17 & 2,58 & 4,03 \\
$\Delta \overline{\mathrm{X}}$ & 7,7 & 4,0 & 4,6 & 9,0 \\
\hline ередньогруп. приріст, \% & & 4,0 & \\
\hline Диференціювання станової & $4,030 \pm 0,37$ & $2,420 \pm 0,21$ & $2,020 \pm 0,19$ & $1,910 \pm 0,17$ \\
сили,кг & $3,930 \pm 0,35$ & $2,394 \pm 0,22$ & $1,966 \pm 0,18$ & $1,792 \pm 0,15$ \\
$\overline{\mathrm{X}} \pm \sigma$ & 0,100 & 0,026 & 0,054 & 0,118 \\
$\Delta \overline{\mathrm{X}}$ & 2,5 & 1,1 & 2,7 & 6,2 \\
\hline Середньогруп. приріст, \% & 2,5 & & \\
\hline Коефіцієнт активності & $1,27 \pm 0,094$ & $1,27 \pm 0,095$ & $1,27 \pm 0,094$ & $1,28 \pm 0,095$ \\
бігового кроку, у.о. & $1,34 \pm 0,113$ & $1,33 \pm 0,111$ & $1,30 \pm 0,097$ & $1,34 \pm 0,112$ \\
$\overline{\mathrm{X}} \pm \sigma$ & 0,07 & 0,06 & 0,03 & 0,06 \\
$\Delta \overline{\mathrm{X}}$ & 5,4 & 4,8 & 2,7 & 4,7 \\
\hline \hline
\end{tabular}


Продовження табл. 3

\begin{tabular}{|c|c|c|c|c|}
\hline \multirow{2}{*}{ Показники } & \multicolumn{4}{|c|}{ Відновні мікроцикли } \\
\hline & 5 & 6 & 7 & 8 \\
\hline Сила згиначів & $104,64 \pm 7,02$ & $103,61 \pm 6,94$ & $105,82 \pm 7,01$ & $107,65 \pm 7,07$ \\
\hline$\overline{\mathrm{X}} \pm \sigma$ & $115,67 \pm 7,07$ & $114,69 \pm 7,08$ & $117,24 \pm 7,09$ & $119,81 \pm 7,10$ \\
\hline$\Delta \overline{\mathrm{X}}$ & 11,03 & 11,08 & 11,42 & 12,16 \\
\hline Середньогруп. приріст, \% & 10,55 & 10,7 & 10,8 & 11 \\
\hline $\begin{array}{l}\text { Стрибок вг } \\
\text { АбалакоI }\end{array}$ & $52,96 \pm 3,82$ & $52,65 \pm 3,75$ & $56,71 \pm 4,41$ & $58,01 \pm 5,90$ \\
\hline$\overline{\mathrm{X}} \pm \sigma$ & $57,93 \pm 4,64$ & $|56,28 \pm 4,53|$ & $61,98 \pm 5,22$ & $64,55 \pm 6,14$ \\
\hline$\Delta \overline{\mathrm{X}}$ & 4,97 & 3,63 & 5,27 & 6,54 \\
\hline Середньогруп. приріст, \% & 9,4 & 6,9 & 9,3 & 11,28 \\
\hline $\begin{array}{c}\text { Диференціювання станової } \\
\text { сили,кг }\end{array}$ & $2,740 \pm 0,24$ & $2,510 \pm 0,24$ & $2,050 \pm 0,21$ & $2,120 \pm 0,28$ \\
\hline$\overline{\mathrm{X}} \pm \sigma$ & $2,587 \pm 0,26$ & $2,433 \pm 0,21$ & $1,933 \pm 0,17$ & $1,959 \pm 0,18$ \\
\hline$\Delta \overline{\mathrm{X}}$ & 0,153 & 0,077 & 0,117 & 0,161 \\
\hline Середньогруп. г & 5,6 & 3,1 & 5,7 & 7,6 \\
\hline $\begin{array}{l}\text { Коефіцієнт активності } \\
\text { бігового кроку, у.о. }\end{array}$ & $1,25 \pm 0,093$ & $1,28 \pm 0,095$ & $1,24 \pm 0,092$ & $1,24 \pm 0,091$ \\
\hline$\overline{\mathrm{X}} \pm \sigma$ & $1,31 \pm 0,098$ & $1,36 \pm 0,114$ & $1,33 \pm 0,112$ & $1,33 \pm 0,111$ \\
\hline$\Delta \overline{\mathrm{X}}$ & 0,06 & 0,08 & 0,09 & 0,09 \\
\hline Середньогруп. приріст, \% & 5,1 & 6,4 & 7,2 & 7,0 \\
\hline
\end{tabular}

часу - під впливом відновних мікроциклів грудня, січня і лютого місяців ці зміни спрямовані у бік збільшення динаміки приросту цього показника (див. рис. 3).

Позитивні зміни показника диференціювання станової сили з кінця вересня по кінець листопада місяців (перший - третій відновні мікроцикли) мають невисокі абсолютні величини: $\Delta x_{1}=2,5 \% ; \Delta x_{2}=1,1 \% ; \Delta x_{3}=2,7 \%$. Такий факт вказує про недостатньо високу інформативність цього показника на цьому відрізку часу. На подальших етапах підготовчих періодів значення цього показника зумовлюють велику інформативність його використання в якості попереднього критерію ефективності відновних мікроциклів в грудні, січні, лютому, березні і квітні місяцях: $\Delta x_{4}=6,2 \% ; \Delta x_{5}=5,6 \% ; \Delta x_{6}=3,1 \% ; \Delta x_{7}=5,7 \% ; \Delta x_{8}$ 
=7,6\% при недотриманні достовірності відмінностей тільки в п'ятому відновному мікроциклі (див. рис. 3).

Таким чином, 3 чотирьох педагогічних показників найбільш інформативними в плані використання їх для оцінки ефективності відновних мікроциклів двох підготовчих періодів, у юнаків-спринтерів 16-17 років виявилися показники сили згиначів стопи і стрибка по Абалакову. Значно меншу інформативність мають показники коефіцієнта активності бігового кроку i диференціювання станової сили. Причому інформативність цих двох показників збільшується до закінчення кожного підготовчого періоду (при $p<0,05$ ).

\subsubsection{2 Зміни фізіологічних показників рухової функції у юнаків-спринтерів 16-17 років}

У старшій віковій групі юнаків-спринтерів 3 п'яти перелічених вище функціональних фізіологічних показників рухової функції упродовж двох підготовчих періодів лише час стартової реакції і диференціювання почуття часу під впливом декількох відновних мікроциклів мають негативні значення. Цей факт свідчить про те, що процес адаптації у спринтерів 16-17 років до фізіологічних показників проходить сприятливіше, ніж у юнаків-спринтерів 1415 років (табл. 4 , рис. 4 ).

Показники часу затримки дихання на вдиху і видиху з кінця січня по кінець лютого і з кінця березня по кінець квітня мають тимчасову тенденцію до зниження динаміки зміни $\left(\Delta x_{5}=2,95 \% ; \Delta x_{6}=2,65 \%\right.$; і $\left.\Delta x_{7}=3,45 \% ; \Delta x_{8}=3,35 \%\right)$ порівняно з попередніми відновними мікроциклами, де вона має зростаючий характер (див. рис. 4).

Динаміка змін потужності дихання (пневмотахометрія) має лише одну ділянку незначного зниження під впливом шостого відновного мікроциклу ( $\Delta x_{6}$ $=3,1 \%$ ). У решту часу позитивна динаміка зміни показників пневмотахометрії характерна тенденції зростання з $\Delta x_{1}=0,5 \%$ до $\Delta x_{8}=3,45 \%$, при $p<0,01$. Такі результати свідчать про високу попередню інформативність цього показника 
рухової функції в якості критерію оцінки ефективності відновних мікроциклів на період з початку грудня по кінець квітня (при $p>0,05$ тільки в п'ятому відновному мікроциклі).

Тремор, як показник рухової функції юних спринтерів 16-17 років відбиває динаміку помірного хвилеподібного характеру 3 схожими значеннями на початку першого підготовчого періоду і у кінці другого ( $\Delta x_{1}=1,4 \%$ i $\left.\Delta x_{8}=1,0 \%\right)$, що, очевидно, вказує про не завершення процесу адаптації юних спортсменів до навантажень тих, що визначають цей показник (див. рис. 4).

Таблиця 4. Динаміка зміни фізіологічних показників рухової функції в процесі відновних мікроциклів підготовчих періодів юнаків-спринтерів 16-17 років (n=10)

\begin{tabular}{|c|c|c|c|c|}
\hline \multirow{2}{*}{ Показники } & \multicolumn{4}{|c|}{ Відновні мікроцикли } \\
\hline & 1 & 2 & 3 & 4 \\
\hline Затримка дихання, сек & $103,54 \pm 6,85$ & $105,41 \pm 7,02$ & $103,67 \pm 6,87$ & $107,39 \pm 7,09$ \\
\hline$\overline{\mathrm{X}} \pm \sigma$ & $104,78 \pm 6,77$ & $107,307 \pm 6,96$ & $105,847 \pm 6,89$ & $111,041 \pm 7,17$ \\
\hline$\Delta \overline{\mathrm{X}}$ & 1,242 & 1,897 & 2,177 & 3,651 \\
\hline Середньогруп. приріст,\% & 1,2 & 1,8 & 2,1 & 3,4 \\
\hline Пневмотахометрія, $л / c$ & $5,51 \pm 0,61$ & $5,46 \pm 0,59$ & $5,62 \pm 0,62$ & $5,63 \pm 0,65$ \\
\hline $\bar{X} \pm \sigma$ & $5,537 \pm 0,63$ & $5,552 \pm 0,64$ & $5,726 \pm 0,66$ & $5,782 \pm 0,67$ \\
\hline$\Delta \overline{\mathrm{X}}$ & 0,027 & 0,092 & 0,106 & 0,152 \\
\hline Середньогруп. приріст, \% & 0,5 & 1,7 & 1,9 & 2,7 \\
\hline Тремор, $\boldsymbol{M M}^{2}$ & $7,61 \pm 0,83$ & $7,52 \pm 0,82$ & $7,56 \pm 0,85$ & $7,43 \pm 0,78$ \\
\hline $\bar{X} \pm \sigma$ & $7,504 \pm 0,81$ & $7,407 \pm 0,80$ & $7,507 \pm 0,83$ & $7,374 \pm 0,77$ \\
\hline$\Delta \overline{\mathrm{X}}$ & 0,106 & 0,113 & 0,053 & 0,056 \\
\hline Середньогруп. приріст,\% & 1,4 & 1,5 & 0,7 & 0,75 \\
\hline Час стартової реакції, $м c$ & $162,77 \pm 8,07$ & $167,23 \pm 8,75$ & $160,30 \pm 8,09$ & $161,26 \pm 8,05$ \\
\hline $\bar{X} \pm \sigma$ & $161,387 \pm 8,04$ & $164,889 \pm 8,07$ & $161,021 \pm 8,06$ & $160,937 \pm 8,07$ \\
\hline$\Delta \overline{\mathrm{X}}$ & 1,383 & 2,341 & $-0,721$ & 0,323 \\
\hline Середньогруп. приріст,\% & 0,85 & 1,4 & $-0,45$ & 0,2 \\
\hline $\begin{array}{l}\text { Диференціювання } \\
\text { чувства часу, сек }\end{array}$ & $0,48 \pm 0,025$ & $0,51 \pm 0,027$ & $0,561 \pm 0,029$ & $0,43 \pm 0,019$ \\
\hline$\overline{\mathrm{X}} \pm \sigma$ & $0,482 \pm 0,026$ & $0,511 \pm 0,028$ & $0,56 \pm 0,029$ & $0,431 \pm 0,02$ \\
\hline$\Delta \overline{\mathrm{X}}$ & $-0,002$ & $-0,001$ & 0,001 & $-0,001$ \\
\hline Середньогруп. приріст,\% & $-0,5$ & $-0,3$ & 0,25 & $-0,35$ \\
\hline
\end{tabular}


Продовження табл. 4

\begin{tabular}{|c|c|c|c|c|}
\hline \multirow{2}{*}{ Показники } & \multicolumn{4}{|c|}{ Відновні мікроцикли } \\
\cline { 2 - 5 } & 5 & 6 & 7 & 8 \\
\hline Затримка дихання, сек & $103,61 \pm 7,01$ & $104,9 \pm 6,88$ & $105,1 \pm 6,90$ & $104,6 \pm 6,84$ \\
$\overline{\mathrm{X}} \pm \sigma$ & $106,66 \pm 7,09$ & $107,679 \pm 7,13$ & $108,725 \pm 7,15$ & $108,104 \pm 7,14$ \\
$\Delta \overline{\mathrm{X}}$ & 3,056 & 2,779 & 3,625 & 3,504 \\
Середньогруп. приріст, $\%$ & 2,95 & 2,65 & 3,45 & 3,35 \\
\hline Пневмотахометрія, $л / c$ & $5,92 \pm 0,71$ & $5,75 \pm 0,66$ & $5,68 \pm 0,64$ & $5,78 \pm 0,68$ \\
$\overline{\mathrm{X}} \pm \sigma$ & $6,109 \pm 0,73$ & $5,928 \pm 0,70$ & $5,864 \pm 0,69$ & $5,979 \pm 0,71$ \\
$\Delta \overline{\mathrm{X}}$ & 0,189 & 0,178 & 0,184 & 0,199 \\
Середньогруп. приріст, $\%$ & 3,2 & 3,1 & 3,25 & 3,45 \\
\hline Тремор, мм & $7,43 \pm 0,81$ & $7,48 \pm 0,81$ & $7,51 \pm 0,82$ & $7,42 \pm 0,78$ \\
$\overline{\mathrm{X}} \pm \sigma$ & $7,46 \pm 0,79$ & $7,391 \pm 0,79$ & $7,412 \pm 0,79$ & $7,346 \pm 0,77$ \\
$\Delta \overline{\mathrm{X}}$ & 0,030 & 0,089 & 0,098 & 0,074 \\
Середньогруп. приріст, $\%$ & 0,4 & 1,2 & 1,3 & 1,0 \\
\hline Час стартової реакції, $м c$ & $158,25 \pm 7,96$ & $159,8 \pm 7,90$ & $160,7 \pm 8,10$ & $156,8 \pm 7,82$ \\
$\overline{\mathrm{X}} \pm \sigma$ & $157,775 \pm 7,88$ & $159,001 \pm 7,85$ & $159,093 \pm 7,88$ & $154,918 \pm 7,77$ \\
$\Delta \overline{\mathrm{X}}$ & 0,475 & 0,799 & 1,607 & 1,882 \\
Середньогруп. приріст,\% & 0,3 & 0,5 & 1,0 & 1,2 \\
\hline Диференціювання & $0,4 \pm 0,018$ & $0,55 \pm 0,028$ & $0,51 \pm 0,026$ & $0,41 \pm 0,017$ \\
чувства часу, сек & & & & \\
$\overline{\mathrm{X}} \pm \sigma$ & $0,401 \pm 0,018$ & $0,549 \pm 0,028$ & $0,509 \pm 0,026$ & $0,407 \pm 0,017$ \\
$\Delta \overline{\mathrm{X}}$ & $-0,008$ & 0,001 & 0,001 & 0,003 \\
Середньогруп. приріст, \% & $-0,2$ & 0,2 & 0,1 & 0,75 \\
\hline
\end{tabular}

Подібну тенденцію відбиває і показник швидкості реакції на слуховий аналізатор, який під впливом третього відновного мікроциклу, у кінці листопада має негативну величину зміни $\left(\Delta x_{3}=-0,45 \%\right)$. Слід зауважити, що істотних відмінностей у величинах тремора і особливо швидкості реакції на слуховий аналізатор, починаючи з грудня по квітень місяць не спостерігається, що говорить про недостатню інформативну цінність цих двох показників в якості критеріїв оцінки ефективності відновних мікроциклів на цьому відрізку часу (при $p<0,01$ ).

Проте, прояв істотніших відмінностей до і після закінчення шостого, сьомого і восьмого відновних мікроциклів з кінця лютого по кінець квітня, очевидно, так само може вказувати про посилення попередньої. 


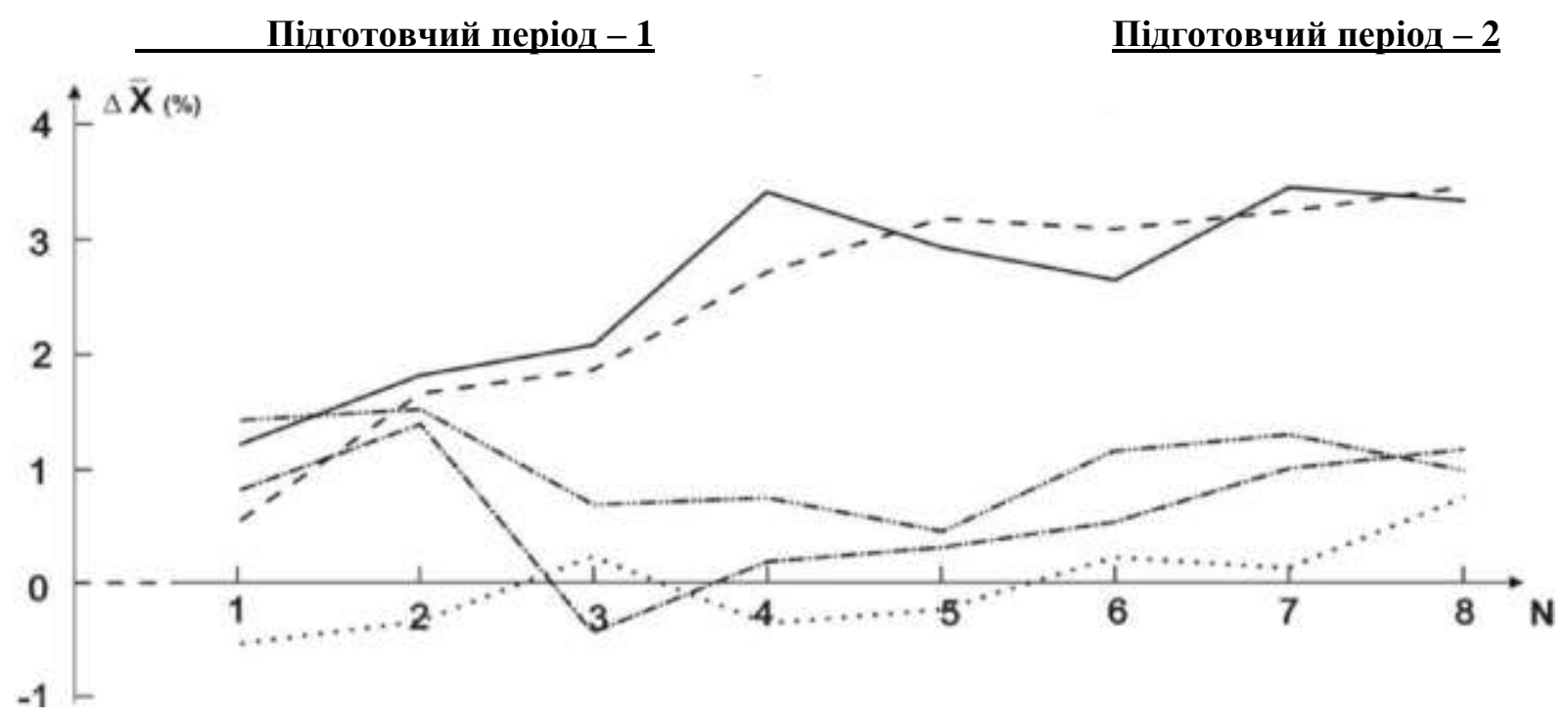

В ідн овні мікроцикли

Рисунок 4. Динаміка зміни функціональних показників, що визначають рухову функцію юнаків-спринтерів 16-17 років в підготовчих періодах річного циклу.

Умовні позначки: — затримка дихання; ---- потужность вдиху-видоху;

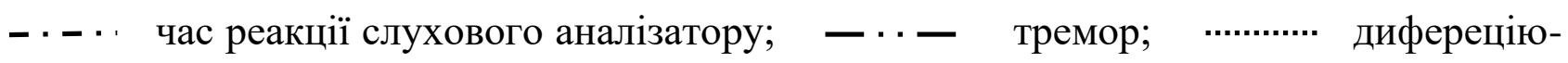
вання почуття часу.

інформативності цих показників напередодні літнього періоду змагань (див. рис. 4).

Показник диференціювання почуття часу під впливом восьми відновних мікроциклів упродовж двох підготовчих періодів змінюється украй з незначними величинами як в позитивному, так і в негативному напрямі $\left(\Delta x_{1}=-0,5 \% ; \Delta x_{2}=-\right.$ $\left.0,3 \% ; \Delta x_{3}=0,25 \% ; \Delta x_{4}=-0,35 \% ; \Delta x_{5}=-0,2 \% ; \Delta x_{6}=0,2 \% ; \Delta x_{7}=0,1 \% ; \Delta x_{8}=0,75 \%\right)$. Це вказує на його неінформативну і неефективність використання як критерію оцінки ефективності відновних мікроциклів підготовчих періодів (при $p<0,05$ ).

\subsubsection{3 Узагальнення результатів педагогічних досліджень}

\section{у юнаків-спринтерів групи спортивного вдосконалення}

Динаміка зміни педагогічних показників рухової функції у старших юнаків упродовж двох підготовчих періодів вказує на посилення інформативності їх не лише до кінця кожного з періодів, але і на усьому їх протязі. У свою чергу, це, 
очевидно, підтверджує сприятливіший розвиток процесу адаптації спортсменів цієї вікової групи до навантажень, що визначають ці показники. Потрібно відмітити, що в старшій віковій групі процес адаптації до педагогічних показників рухової функції розвивається один раз безперервно з вересня по квітень упродовж майже двох макроциклів. А зближення кривих до закінчення другого підготовчого періоду з величинами приросту більшими у кінці квітня, ніж у кінці вересня, початку першого підготовчого періоду, ймовірно, вказує на відносне завершення процесу адаптації у бігунів до навантажень педагогічного характеру.

Проаналізувавши зміни фізіологічних показників рухової функції у старших юнаків під впливом восьми відновних мікроциклів, встановлено, що процес адаптації у них проходить, як і до педагогічних, єдиний раз упродовж двох підготовчих періодів. Проте, широкий спектр кривих у кінці другого підготовчого періоду підтверджує незавершеність процесу адаптації юних спортсменів до навантажень, що визначають ці фізіологічні показники. Очевидно, як і у юнаків 14-15 років, передбачається, що розвиток адаптації до цих навантажень завершиться пізніше в літньому періоді змагання.

Математична обробка цифрового матеріалу цих наукових досліджень відносно рішення статистичної задачі - вплив зміни працездатності на зміни показників рухової функції, дозволила визначити рангову значущість дев'яти показників ефективності обліку програмування їх в різних відновних мікроциклах двох підготовчих періодів річного циклу тренування юнаківспринтерів середнього і старшого віку (табл. 5, 6).

На підставі діагностики адаптаційних можливостей юнаків-спринтерів до спеціалізованих навантажень в підготовчих періодах річного циклу тренування вдосконалення системи застосування педагогічних інноваційних засобів відновлення передбачає раціоналізацію тренувального процесу на основі науково-обгрунтованих методів планування ходу підготовки спортсменів в макро-, мезо- і мікроциклах. Тому пропонується система побудови річного 
циклу підготовки юнаків-спринтерів на основі технології зв'язанопослідовного планування і аналізу ефективності тренувального процесу кожного этапа-мезоцикла. Без аналізу і оцінки тренувального процесу на попередньому етапі немає, і не може бути зв'язано-послідовного (перманентного) ланцюга, який повинен вибудовувати логіку оптимізації цілорічного тренування юних спортсменів не лише у бігу на короткі дистанції, але, очевидно, і в інших видах спорту теж.

Таблиця 5. Таблиця функціональних критеріїв ефективності в першому відновному мікроциклі підготовчих періодів юнаків-спринтерів 14-15 років

\begin{tabular}{|c|c|c|c|c|c|c|c|c|c|c|c|}
\hline $\begin{array}{l}\text { ML } \\
\text { GR: } \\
\text { VM-1 }\end{array}$ & 1 & 2 & 3 & 4 & 5 & 6 & 7 & 8 & 9 & 10 & 11 \\
\hline 1 & 1,000 & & & & & & & & & & \\
\hline 2 & 0,169 & 1,000 & & & & & & & & & \\
\hline 3 & 0,212 & 0,226 & 1,000 & & & & & & & & \\
\hline 4 & 0,046 & 0,189 & 0,448 & 1,000 & & & & & & & \\
\hline 5 & $-0,387$ & $-0,068$ & 0,185 & 0,277 & 1,000 & & & & & & \\
\hline 6 & 0,0537 & $-0,059$ & $-0,598$ & $-0,486$ & 0,509 & 1,000 & & & & & \\
\hline 7 & $-0,104$ & $-0,289$ & $-0,649$ & $-0,159$ & $-0,107$ & 0,613 & 1,000 & & & & \\
\hline 8 & 0,23 & $-0,107$ & $-0,758$ & $-0,264$ & 0,219 & 0,753 & 0,519 & 1,000 & & & \\
\hline 9 & 0,375 & 0,428 & 0,033 & 0,22 & 0,37 & $-0,23$ & $-0,466$ & 0,259 & 1,000 & & \\
\hline 10 & 0,274 & 0,035 & 0,153 & 0,798 & $-0,117$ & $-0,24$ & $-0,086$ & 0,062 & 0,432 & 1,000 & \\
\hline 11 & 0,132 & $-0,649$ & $-0,233$ & $-0,196$ & 0,664 & 0,032 & 0,25 & 0,164 & $-0,268$ & $-0,108$ & 1,000 \\
\hline
\end{tabular}

Таблиця 6. Таблиця функціональних критеріїв ефективності в першому відновному мікроциклі підготовчих періодів юнаків-спринтерів 16-17 років

\begin{tabular}{|c|c|c|c|c|c|c|c|c|c|c|c|}
\hline $\begin{array}{l}\text { ST GR: } \\
\text { VM-1 }\end{array}$ & 1 & 2 & 3 & 4 & 5 & 6 & 7 & 8 & 9 & 10 & 11 \\
\hline 1 & 1,000 & & & & & & & & & & \\
\hline 2 & 0,135 & 1,000 & & & & & & & & & \\
\hline 3 & $-0,039$ & $-0,12$ & 1,000 & & & & & & & & \\
\hline 4 & $-0,18$ & 0,151 & $-0,166$ & 1,000 & & & & & & & \\
\hline 5 & $-0,022$ & $-0,093$ & 0,03 & 0,019 & 1,000 & & & & & & \\
\hline 6 & 0,014 & $-0,124$ & 0,312 & $-0,159$ & $-0,067$ & 1,000 & & & & & \\
\hline 7 & 0,106 & 0,328 & 0,553 & $-0,051$ & 0,099 & 0,198 & 1,000 & & & & \\
\hline 8 & $-0,131$ & $-0,162$ & $-0,086$ & 0,512 & 0,528 & 0,266 & 0,287 & 1,000 & & & \\
\hline 9 & 0,004 & $-0,11$ & $-0,224$ & $-0,147$ & 0,629 & $-0,642$ & $-0,393$ & $-0,171$ & 1,000 & & \\
\hline 10 & 0,351 & 0,052 & $-0,777$ & 0,206 & $-0,1$ & $-0,14$ & $-0,67$ & 0,055 & 0,098 & 1,000 & \\
\hline 11 & $-0,118$ & $-0,55$ & 0,608 & $-0,209$ & $-0,212$ & 0,504 & 0,422 & 0,151 & $-0,536$ & $-0,548$ & 1,000 \\
\hline
\end{tabular}

Умовні позначки: 1 - сила згиначів стопи; 2 - стрибок по Абалакову; 3 - час стартової реакції; 4 - тремор; 5 - диференціювання станової сили; 6 - потужність вдиху-видоху; 7 - коефіцієнт активності бігового кроку; 8 - затримка дихання; 9 - диференціювання почуття часу; 10 - загальна працездатність; 11 - спеціальна працездатність. 


\section{Висновки}

В результаті проведених досліджень по вивченню величини зміни педагогічних і фізіологічних показників рухової функції під впливом різних відновних мікроциклів підготовчих періодів цілорічного тренування юнаківспринтерів 14-17 років була визначена закономірність розвитку адаптації до спеціалізованих навантажень юних спортсменів молодшої і старшої юнацької вікової групи. Встановлено - чим вище відносно осі абцисс розташовані на графіках «криві» змін різних показників рухової функції під впливом відновних мікроциклів, тим сильніше прояв їх інформативності в оцінці ефективності розвантажувальних мікроциклів по відновленню втраченої працездатності юних бігунів різного віку в підготовчих періодах.

Встановлено, що серед чотирьох педагогічних показників рухової функції сила згиначів стопи і стрибок по Абалакову, під впливом восьми відновних мікроциклів в обох підготовчих періодах 3 вересня по квітень місяць мають більш високі позитивні зміни - від 3,0\% до 9,9\% у молодших юнаків і від 4,0 \% до 11,5 \% у старших. Значення таких результатів можуть вказувати на високу попередню інформативність цих показників рухової функції в оцінці ефективності і програмування тренувального процесу юнаків-бігунів на короткі дистанції 14-17 років в розвантажувальних відновних мікроциклах підготовчих періодів. Значно меншу інформативність мають показники коефіuієнта активності бігового кроку і диференціювання станової сили (від 0,2 до 7,8 \% i 1,1 до 7,6 \% відповідно в молодшій і старшій віковій групі). Інформативність цих двох показників збільшується до закінчення кожного підготовчого періоду.

Дворазове зближення графічних кривих у своєрідний пучок у кінці кожного підготовчого періоду (5-й і 8-й відновні мікроцикли) підтверджує ту обставину, що адаптація до педагогічних показників у бігунів обох вікових груп до закінчення періодів проходить як би завершальний цикл. Проте нижчі значення приросту сили згиначів стопи і стрибка по Абалакову в молодшій віковій групі у кінці другого підготовчого періоду, в порівнянні з початком року, 
вказують про зниження розвитку адаптації юних спортсменів до навантажень тих, що визначають ці показники до цього терміну часу.

Розширений спектр «кривих» (1,5-8,4\% i 1,4-7,5\% - молодша вікова група і 2,5-1 1,1\% і 3,1-10,7\% - старші юнаки) на початку кожного з підготовчих періодів (1-й і 6-й відновні мікроцикли), очевидно, говорить про тимчасову втрату адаптації юних бігунів обох вікових груп до навантажень, що визначають педагогічні показники після попередніх періодів змагань. Але, якщо на початку першого підготовчого періоду така втрата адаптації цілком з'ясовна для обох вікових груп, то на початку другого, ширша розбіжність між педагогічними показниками у юнаків 14-15 років - це результат значно гіршій їх адаптації, підтверджувальний факт про нераціонально вибрану періодизацію річної підготовки.

Якщо в молодшій віковій групі юнаків-спринтерів адаптація до навантажень, що визначають педагогічні показники юних спринтерів, проходить як би двічі до закінчення макроциклів, то в старшій групі процес адаптації розвивається один раз безперервно 3 вересня по квітень упродовж двох підготовчих періодів.

3 п'яти фізіологічних показників рухової функції юнаків-спринтерів 14-15 років (часу затримки дихання, потужності дихання, тремора, швидкості реакції на слуховий аналізатор, диференціювання почуття часу) найбільшу інформативність в оцінці ефективності відновних мікроциклів підготовчих періодів має час затримки дихання, у якого позитивні зміни під впливом восьми відновних мікроциклів носять прогресивний хвиле-подібний характер. Нижній рівень хвилі складає 0,75\% позитивного приросту (ВМ-1 у кінці вересня) а верхній - 2,85\% (ВМ-8 у кінці квітня місяця).

Другим за значимістю інформації є показник потужності дихання, у якого лише з кінця жовтня по кінець грудня-початку січня місяця зміни мають занадто низьку позитивну величину. А у кінці листопада після завершення розвантажувально-відновного мікроциклу середньостатистичні показники пневмотахометрії у молодших юнаків були навіть понижені на 0,26\% порівняно 
3 показниками початку відновного мікроциклу. У інший же період часу позитивні зміни потужності дихання під впливом подальших відновних мікроциклів були динамічніші (від 0,75 до 1,73\%).

Три інші показники - тремора, швидкості реакції на слуховий аналізатор і диференціювання почуття часу у молодших юнаків істотно не покращувалися після завершення більшості відновних мікроциклів. Показники часто погіршувалися порівняно 3 початковими середньостатистичними даними на початку відновних мікроциклів упродовж двох підготовчих періодів.

Проаналізувавши динаміку зміни фізіологічних показників рухової функції у юнаків-спринтерів 14-15 років, можна відмітити, що розвиток процесу адаптації до навантажень, що визначають ці показники упродовж двох підготовчих періодів проходить так само двічі, як i до раніше вивченим педагогічним. Широкий же спектр графічних кривих у кінці другого підготовчого періоду напередодні травня місяця свідчить про незавершений процес адаптації юних спринтерів до цих навантажень. $Є$ усі підстави припускати, що розвиток адаптації до цих навантажень у юних бігунів може завершитися в літньому періоді змагання. Для уточнення цього питання потрібні додаткові дослідження.

У юнаків-спринтерів 16-17 років 3 перелічених вище функціональних показників рухової функції упродовж двох підготовчих періодів лише час стартової реакиії і диференціювання почуття часу під впливом декількох відновних мікроциклів мають негативні зміни. Інші фізіологічні показники $є$ цілком інформативними для оцінки ефективності і програмування відновних мікроциклів. Проте з кінця березня (7-й і 8-й відновні мікроцикли) до завершення другого підготовчого періоду інформативність показника часу стартової реакції поступово зростає. Цей факт свідчить про те, що процес адаптації у старших юнаків до фізіологічних показників проходить сприятливіше, ніж у юнаків молодшої вікової групи. Висновок цілком узгоджується 3 дослідженнями, проведеними раніше по вивченню обгрунтування динаміки працездатності юнаків бігунів на короткі дистанції 14-15 і 16-17 років. 
Проаналізувавши динаміку зміни фізіологічних показників рухової функції під впливом восьми відновних мікроциклів у юнаків-спринтерів 16-17 років, встановлено, що процес адаптації у них проходить єдиний раз упродовж двох підготовчих періодів. Як і у молодшій віковій групі, широкий спектр кривих у кінці другого підготовчого періоду підтверджує незавершеність процесу адаптації юних спортсменів до навантажень, що визначають ці фізіологічні показники. Очевидно, як і у юнаків 14-15 років, передбачається, що розвиток адаптації до цих навантажень може завершитися в літньому періоді змагання.

Таким чином, при педагогічному контролі і управлінні тренувальним процесом юнаків-спринтерів середнього і старшого віку слід враховувати їх особливості адаптації до навантажень, що визначають педагогічні і фізіологічні показники рухової функції. Це дозволить тренерам раціонально і економно витрачати руховий потенціал за допомогою ефективного програмування $\mathrm{i}$ моделювання тренувального процесу не лише у відновних, але і тренувальних мікроциклах підготовчих періодів юних бігунів на короткі дистанції.

Достовірність відмінностей середніх арифметичних значень за деякими показниками рухової функції юнаків-спринтерів в обох вікових групах не дотримується лише в п'ятому відновному мікроциклі кінця січня місяця після завершення етапу зимових змагань. Очевидно, при необхідності вивчення подібних питань в періодах змагань потрібно проведення додаткових експериментальних досліджень.

Ці виведення цілком узгоджуються з концепцією основоположників теорії і методики вітчизняного спорту Л. П. Матвєєва і М. М. Яковлєва. Перший з них ще в 1965 році минулого століття писав, що біологічний процес не можна протиставляти педагогічному - вони єдині як за формою, так і за змістом; другий, в 1976 році стверджував - механізми управління тренувальним процесом можуть бути засновані тільки на знаннях законів адаптації людського організму. «Матеріальною» основою підвищення тренованості і спортивної результативності будь-якого спортсмена $є$ тренувальний процес, що базується на загальній теорії спорту, теорії і методиці обраного виду спорту і законах розвитку 
i адаптації людського організму. Закони адаптації визначають принципи i закономірності спортивно-педагогічного процесу. Незнання або неприйняття реально чинних законів адаптації обумовлює, у тому числі, множинне різночитання таких понять, як «тренованість» $\mathrm{i}$ «спортивна форма».

Подальші дослідження будуть спрямовані на узагальнення i систематизацію отриманих результатів з метою програмування і моделювання оптимального тренувального навантаження у відновних мікроциклах підготовчих періодів юнаків-спринтерів 14-17 років. 
DOI 10.46299/ISG.2021.MONO.PED.III.6.3

\subsection{Sport development in eastern Galicia (the second half of the xix century - beginning of the $\mathrm{XX}$ century)}

Sport has always been an integral part of Ukrainian life. Being strong, physically developed was a necessity due to numerous battles, because we had to fight for freedom and independence of the state. However, later the priorities changed and people started playing sports to keep fit and improve their health.

Eastern Galicia, during its stay in the Austro-Hungarian Empire, and later in Poland, became almost the first region of the Ukrainian lands where sports became the norm for young people. From the second half of the 19th to the 1930s, Lviv played a decisive role in sports development. The first sport club was established in the city and the first sport club in Ukraine also. The first competitions in the main sports, which are now represented in the Olympic Games, as well as the first large-scale sports competitions with the participation of regional offices were held in the city of Leva. Many interesting sporting events took place in Lviv more than a hundred years ago than in other regions of Ukraine, in particular: the first football match took place on July 14,1894 , the first hockey match on January 15, 1905, the demonstration matches of women's basketball teams on June 29, 1909. There was a show of a new game with a ball on the water - water polo in Lviv. The first professional stadiums and sports facilities also appeared here. In 1894 in Lviv in Stryj Park a stadium was built for 7 10 thousand seats, made in the British style, measuring 120 x 100 meters. Four years later, a stadium was built for the Society "Sokil" (Falcon), which impressed with its beauty: a beautiful field, treadmills, wooden stands for spectators. Gymnasiums for gymnastics and other sports were located nearby. Two parchments written in Ukrainian and Polish were laid under the foundation of the first Sokil sports complex, and Polish and Ukrainian priests also took part in the special service [477, p.13].

The Austro-Hungarian government paid great attention to the development of sports. In 1969, gymnastics lessons were introduced into school curricula [482, 472]. In the 90s, high school students and pupils were real fans of ball games [480, 479]. For people, sports of this period was really an exciting and spectacular phenomenon. None 
of the newspapers ignored even insignificant sporting events, illustrating them on their pages with numerous photographs. Sport was also attractive for Galicians - Ukrainians. According to certain indicators in athletics, Lviv athletes were ahead of the leading Austrian athletes - these figures are recorded in numerous local newspapers. Some Lviv athletes took part in the all-European championships from Austria.

A kind of "catalyst" of sport was the so-called "Sokil movement", which in the second half of the XIX century spread throughout Austria-Hungary. The first Falcon Society was founded in 1862 in Prague. The idea of creating a Czech sports association, which together with physical education awakened the national consciousness and contributed to the national-patriotic education of young people, was proclaimed by the well-known Czech public figure Myroslav Tirsch. Through physical exercises movement (athletics) falconry society implemented elements of military training of boys and girls [478, p. 141].

Later, similar organizations were established among other Slavic peoples: in Slovenia and Croatia, and in 1867 - in Lviv by Poles.

The founders of the Lviv Sokil were Clemens Zhukotinsky and Ludvik Gonteltal. At the time of the founding of the Polish "Sokil" in its environment there were 125 members, and in 1892 the society united more than a thousand [469, p. 16], in which Ukrainians were equal members.

The charter of the Polish "Falcon" provided: "... Education of the spirit of mutual assistance among members .., obedience and punishment through sports, organization of public holidays and events" [470, p. 68]. According to the organizers of the Polish falconry movement, these measures were to prepare Poles for the future struggle to restore their own statehood, which was lost as a result of the three divisions of Poland. It should be noted that until 1884 the Polish Sokil operated only in Lviv and only later began to establish its branches throughout Galicia. Thus, in 1909 in seven districts of Western Ukraine there were 150 Polish societies, the number of which was 20 thousand members [480, p. 72]. It is important that since 1895 the right to membership in the Polish Falcon Society has been acquired by women. 
In April 1881, the Polish Sokil in Lviv began publishing its monthly publication "Przewodnik gimnastyczny". By 1884 the circulation was 650 copies, and in 1907 it reached 20,000 copies [471, p. 23]. These statistics show that the falconry movement, and hence sport, in a relatively short time, gained widespread popularity in Galicia. The movement became especially popular among pupils and high school students. A characteristic feature of the Polish falconry was that it involved part of the Ukrainian population of Eastern Galicia, where the Galician peasantry had a real opportunity to see the positive aspects of social life.

On June 5-6, 1892, the first public performance of the Polish Sokils took place in Lviv in honor of the 25th anniversary of the Polish Sokil. Representatives of the Czech sports movement from Prague also came to this performance. This visit, according to the press of the time, made a great impression on the Ukrainian society of that time. The Prague Falcons were in the same uniform and spoke their native language. It was the Czechs who gave a spiritual impetus to the founding of the Ukrainian "Sokil" [474, p. 99].

However, the very idea of creating a Ukrainian "Sokil" originated even earlier among members of the student societies "Vatra" and "Academic Brotherhood", which emerged in Lviv in the late nineteenth century. Back in 1886, one of the organizers, and later the first chairman of the society V. Nagirny, in the article "Let's work, and God will help us!" which was published in the magazine "Batkivshchyna", called for the creation of fire and engine societies farms [478, p. 141]. On July 17, 1892, the People's House hosted a constituent assembly of representatives from all over Galicia, who decided to create a truly national Ukrainian motor gymnastics organization. The Sokil Society quickly gained the support of Ukrainian youth and in 1902 had more than 900 branches and united about 33,000 people throughout Galicia and Bukovina. The moral basis of the "Sokil" was the Law of God and on its basis the falcon's law was developed - the Ten Commandments of the "Sokil". These precepts were taken as a basis by other Ukrainian youth societies.

The Sokil movement became one of the most popular movements in Galicia in the 1900s and was closely intertwined with educational, ecclesiastical and socio- 
political and sports activities. In the beginning, only men were sokils, but from the 1890 s, women began to appear in sections. As of 1890, there were about 60 women in the society [477, p. 16]. And in 1902 the "women's engine department" was created.

One of the positive factors that contributed to the development of the Ukrainian Sokol's foreign relations was the holding of the annual All-Sokil Movements in Prague, which brought together falcons representing all Slavic peoples. Ivan Bobersky, who headed the society from 1908 to 1920, owes such success to the society. During his presidency, the Ukrainian Sokil became the largest Ukrainian gymnastics and sports organization in Eastern Galicia. Thanks to his constant work, physical education has reached a high level. He trained the first gymnastics teachers in the Sokil teacher's circle, wrote textbooks on various topics of physical education, and published descriptions of exercises for Sokil performances. Professor I. Bobersky translated and wrote a number of books on ball games, including football. His slogan of a healthy body and a healthy national spirit has become a credo for many representatives of Ukrainian youth. Besides two physical training classes per week, cultural and cognitive gatherings were held on Sundays: essays on the history of Ukraine were read, books and magazines were read and discussed, and rehearsals were held in amateur art circles. Physical education and cultural and educational activities were, ultimately, to form in Ukrainian youth such traits as national consciousness, understanding of their duty to Ukraine, physical perfection, discipline, willingness to sacrifice.

At the end of 1928, there were 421 Sokil branches with 32,601 members. Sports sections on athletics, football, volleyball, tennis, skiing and skating were opened. In 1935, the Sokil officer was actively working to get the Eastern Galician team to participate in the Olympic Games in Berlin, which were to take place in the summer of 1936, but this required the consent of the Polish National Committee, which Sokil never received. [468, p. 30].

In the interwar period in Eastern Galicia worked similar in spirit and form youth societies "Sich", "Lug", "Plast", in which much attention was paid to the physical development of youth, due not only to the desire to have a healthy generation in the 
future, but also to educate future soldier, ready for a difficult struggle for the restoration of Ukrainian statehood.

However, with the advent of Soviet power in the western Ukrainian lands, all societies ceased their activities. Thousands of active members have been repressed.

In the period 1900 - 1910 the most famous Lviv football clubs appeared. In 1906, Professor I. Bobersky founded the Ukrainian Sports Club (USC), whose members began regular training with the ball and played meetings with each other. Many Ukrainian high school students belonged to Polish or German sports clubs, so founding their own Ukrainian sports organization became a national need. The enthusiasm of Ukrainian youth for sports was significant. With the kicked ball circle, high school students later started creating other sports clubs. Thus, the preconditions for the establishment of Ukrainian society arose. In 1907, the football team of the USC (Ukrainian Sports Club) [472, p. 34] is called USC "Ukraine". The new name unites sports enthusiasts - around the football team there are sections on other sports: football, hockey, cycling, skiing [483, p. 84].

On November 12, 1911, the Sports Society "Ukraine" was established, which took over from "Sokil" the role of the leader of Western Ukrainian sports and the center of national education of youth. Thus began the activities of the sports society, which lasted intermittently until 1944, and later continued its journey in the organized sports life of the Western Ukrainian diaspora in Canada, the United States and Australia.

After the First World War, Eastern Galicia became part of Poland. Sports Society "Ukraine" resumed operations in 1921. At first there were only sections of football and athletics, cycling, boxing, hockey and chess, and in 1928, after the organization of the Polish Football Union "Lviv District League", the society became a member of PZPN (Polski Związek Piłki Nożnej) and began competitions in it. In 1937, sections of beating (volleyball), basket (basketball) and handball (handball) began to operate. After the arrival of Soviet troops in 1939, ST Ukraine was liquidated.

Hockey gained great popularity in Lviv. The beginnings of interest in it in Europe, in particular in Ukraine, date back to 20-30 years of the twentieth century. However, in 1904 the newspapers wrote about the organization in Lviv of the first 
games of hockey teams - "hockey", or "gakivka", as the Galicians called the ice game with clubs and a puck. Already in 1904, the oldest in Ukraine "Lviv Ski Association" and the club "Charny" concluded the rules of the game, and in 1905 organized the first hockey match in Ukraine. The initiators of the first hockey match were Lviv journalists who wrote about hockey competitions in Prague and ignited Lviv residents with the desire to go out on the ice themselves [471], [481, p. 85]. And the "Ski Society" embodied this idea.

In 1909, a hockey match took place on the skating rink of the Lviv Ski Association according to all the rules of the Hockey Association of Canada. Hockey was a mass hobby, both men and women loved to drive the puck. And although there was no artificial ice rink in Lviv - hockey life began only when the ice froze in winter - this did not prevent Lviv residents from actively forming teams and defeating Polish counterparts, who had the opportunity to train on special courts all year round.

Dozens of Ukrainians were members of Polish sports clubs. Thus, in "Pohonia", "Lechia", "Charny" the gates were defended by Ukrainians Vanchytsky, Bedrylo, Lukashevych, Sokolovsky, Stupnytsky, who were considered the best in Europe, and others came on the field in the colors of Polish teams. The same situation was in the Polish national team. The well-known Lviv athlete Buchatsky recalled: "... do you know that ... six Ukrainians played in the then national team of Poland? That half of the hockey representation of Poland is our Lemkos from the neighborhood..." [481]. In addition to purely sporting moments, political hockey was already manifested in the hockey of that time. Thus, representatives of the Lviv team "Ukraine" went to the site in black and red uniforms with blue and yellow ribbons. In this way, they wanted to convey to the audience certain ideals of their nation.

The first hockey goalkeepers did not have helmets and shields on their feet, the corners of the sticks were not rounded. Lviv hockey goalkeeper Mykola Skrypiy was one of the first in history to use a protective face mask in 1933. He constructed it from a military helmet, attaching a wire mask in front [479. p. 46-47].

In the 1920s, Lviv stores had special counters selling Canadian equipment, which was very expensive at the time. It took a lot of money to form a team. In the 
villages, people could not afford such a luxury, but they did not intend to give up hockey. So they made equipment for themselves from what was at hand.

After the war, Ukrainian hockey players from Lviv moved to Western Europe, the United States, Canada and Australia and created their own teams that had Ukrainian names and played in various championships.

In the times of Austria at the end of the 19th century, Lviv was one of the most powerful centers of figure skating. Proof of this is the All-Austrian championship in this sport, which took place in 1902 in the city of Leva. And in the 1930s, Lviv pair skaters constantly won prizes in Polish championships.

On July 27, 1914, water polo competitions of LKS (Lviv sports club) "Pohon" took place. In 1924, the Carpathian Skiing Club was founded in the city to develop ski (vise) skiing. In the 1930s, four international car races took place in Lviv, in which racers from Norway, Sweden, France, Germany, Italy and other countries took part. However, this route was closed because it was almost the most difficult in Europe.

On September 4, 1931, the first congress of FITA, the International Archery Federation, took place in Lviv. In August-September of the same year, Lviv hosted the first World and European Archery Championship.

In Lviv, sport spread among all major nationalities (Poles, Jews, Ukrainians, Germans) in the form of sports clubs or sports clubs at schools or gymnasiums.

No other city in the world has had as many national sports clubs as Lviv. For example, the first Jewish sports club was founded in Lviv in 1907 - the famous "Gasmoneia", which for the next three decades successfully developed sports in its various forms.

In addition, there were Austrian sports clubs in Lviv, English, Czech, Polish and, of course, Ukrainian. The development of national sports has led to the fact that the Ukrainian national sport has acquired an extremely interesting sound, such as for example, at the All-Sports Games in Krakow there was such a sport as throwing a Hutsul ax at a target.

And athletes from all over Galicia took part in these competitions. There were many invariant sports that no longer exist today. But then they were popular and 
aroused considerable interest. The first large-scale sports club - the Society of Motor Fun - was created in 1904 with the active participation, including financial, of Metropolitan Andrei Sheptytsky [479, p. 22].

During the period of its existence, sports associations actively developed new sports for Ukrainians, initiated national complex competitions and other sports events that were very popular among Galicians, and laid the foundations and created traditions of priority development of these sports in Lviv to this day. 
DOI 10.46299/ISG.2021.MONO.PED.III.6.4

\section{4 Ціннісно-мотиваційна оріснтація студентів вищих навчальних закладів на здоров'язбереження}

Розробка високоефективних промислових технологій, порушення екологічного балансу більшості територій і ціла низка інших об'єктивних факторів призвели до того, що спосіб життя сучасної людини все більше провокує такі явища в суспільстві, як низький рівень організації харчування молоді; відсутність продуктивної системи служб лікарського контролю за станом здоров’я; порушення фізіолого-гігієнічних вимог до організації навчально-виховного процесу у вищих навчальних закладах; відсутність планомірної і цілеспрямованої роботи з профілактики шкідливих для здоров’я звичок; недосконалість навчальних програм та методик організації здоров'язбереження в освітній установі; поширення нових видів залежностей (комп'ютерна, інтернет, ігрова), які негативно впливають на здоров’я особистості [488].

Формування здорового способу життя через освіту, створення здоров’язберігаючого освітнього середовища постає одним із пріоритетних напрямів державної політики у галузі освіти. Заклади вищої освіти найефективніші інституції формування здорового способу життя та культури здоров’я студентської молоді, намагаються використовувати свої можливості в напрямку гармонійного розвитку психофізичних здібностей молодих людей.

За дослідженнями науковців, суспільство перебуває в дуже нездоровому стані, аналіз кількісних та якісних характеристик населення за останнє десятиріччя свідчить про те, що Україна нині на межі глибокої демографічної кризи, яка характеризується депопуляцією, старінням населення, зменшенням середньої тривалості життя. Особливе занепокоєння викликає стан репродуктивного здоров’я молоді, яка є невід’ємною частиною здоров’я нації загалом i має стратегічне значення для забезпечення сталого розвитку суспільства [489]. 
Сучасна система освіти та умови життя можуть дати достатній обсяг знань, але не здатні зберегти здоров'я молодого покоління. Підтвердженням цього $є$ катастрофічне погіршення здоров'я дітей і молоді України, нестійка мотивація до збереження здоров’я. Дослідження вчених свідчать, що здоровими можна назвати лише 27\% дітей шкільного віку, 90\% здоров'я людина втрачає у віці до 2-х років, а 40-60\% хвороб дорослих беруть свої корені у віці 5-7 років. За даними Міністерства охорони здоров'я України та Держкомстата, у 42\% дітей шкільного віку спостерігаються різні хронічні захворювання, а в 50\% школярів - функціональні відхилення в різних системах організму [484].

Спосіб життя сучасних студентів, який вирізняється високими навчальними навантаженнями, низькою руховою активністю, насиченістю стресовими ситуаціями, пошуком позанавчапьних додаткових джерел доходу, нераціональним харчуванням, значною поширеністю шкідливих звичок, негативно позначається на стані їхнього здоров'я та якості життя, знижує ефективність навчання у вищій школі і надалі обмежує професійну успішність фахівців. Наукові дані свідчать, що майже 90\% учнів і студентів мають відхилення в стані здоров'я, 30-50 \% 3 них - незадовільну фізичну підготовленість [487]. Українські фахівці (В. Романенко, С. Канішевський, С. Захаріна, В. Гуменний, Т. Круцевич) стверджують, що серед більшості студентів, зазвичай, не сформована потреба піклуватися про власне здоров'я, наявний низький рівень знань про здоровий спосіб життя, практичних навичок занять фізичними вправами та масовими видами спорту, зневажливим і нерідко безвідповідальним ставленням до свого здоров'я [489].

Мотивація на здоровий спосіб життя - це система ціннісних орієнтацій, внутрішніх спонук до збереження, відновлення і зміцнення здоров'я [488]. Критеріями формування позитивної мотивації на здоров'язбереження молоді на рівні фізичного здоров'я можна вважати прагнення до фізичної досконалості, ставлення до власного здоров'я, як до найвищої соціальної цінності, фізична розвиненість, загальна фізична працездатність, загартованість організму, 
дотримання раціонального режиму дня, виконання вимог особистої гігієни, правильне харчування [485].

Основними напрямами, що $є$ вкрай нагальними для України щодо збереження здоров'я та формування здорового способу життя студентської молоді в закладах вищої освіти, є такі:

- проведення та публікація щорічних моніторингових досліджень щодо стану здоров'я студентської молоді та поширення негативних явищ у молодіжному середовищі, вивчення рівня ставлення студентів щодо усвідомлення здоров’я як цінності та потреб здорового способу життя, наукового супроводу та оцінки ефективності законодавчих актів, соціальних програм та проектів з питань формування здорового способу життя;

- удосконалення нормативно-правової бази;

- розробка науково-методичного забезпечення діяльності, підвищення кваліфікації фахівців організацій молодіжної, соціальної, управлінської сфери 3 питань формування здорового способу життя молоді;

- активізація участі студентської молоді у формуванні здорового способу життя;

- широкомасштабна інформаційна кампанія щодо пропаганди здорового способу життя, формування моди на здоровий спосіб життя.

Реалізація моделі формування здорового способу життя у студентської молоді у закладах вищої освіти базується на системному підході, що дозволив розкрити взаємозалежність компонентів моделі формування здорового способу життя, а також виступив методологічним засобом виявлення концептуальних підходів, принципів та організаційно-педагогічних умов проектування навчально-виховної діяльності як спеціально сконструйованої цілісної, динамічної та керованої системи. Програма реалізації моделі формування здорового способу життя включає наступні компоненти: зміст навчального матеріалу, методи й організаційні форми навчання, засоби навчання, умови та технології навчання. Результатами впровадження стали виявлені у процесі 
дослідження рівні і критерії ефективності оволодіння здоровим способом життя студентської молоді в умовах закладу вищої освіти.

Розроблена модель формування здорового способу життя студентської молоді в умовах закладу вищої освіти (О.Адаменко, О.Литвиненко, Н.Борецька) включає в себе наступні структурні компоненти: змістовний, мотиваційний та діяльнісний [488]. Змістовний компонент реалізується при умові усвідомлення студентами сутності культури здоров'я, необхідним є засвоєння певного обсягу знань, умінь і навичок з формування, а також розуміння того, що збереження й зміцнення здоров'я можливе про комплексній реалізації його на духовному, соціальному, психічному та фізичному рівнях. Мотиваційний компонент сприяє свідомому розумінню студентами здоров'я як найвищої цінності. Це можливо при системній роботі по вдосконаленню і прагненню кожного студента до здорового і щасливого життя і довголіття. Діяльнісний компонент реалізується при організації системної роботи в умовах закладу вищої освіти, що сприяє засвоєнню студентами на практиці оздоровчих технологій та створенням, здійсненням та удосконаленням протягом навчання власної оздоровчої системи.

Представлена модель заснована на принципах збереження та зміцнення і формування здоров'я, взаємозв'язку теорії і практики. Формування здорового способу життя студентської молоді та створення сприятливих умов для розвитку і виховання особистості з високою культурою здоров'я, здатної формувати свій життєвий потенціал. Аналіз науково-педагогічної, психологічної, медичної літератури, літератури із теорії фізичного виховання дає підстави стверджувати, що здоровий спосіб життя студентської молоді $\epsilon$ не тільки соціальною проблемою, але $є$ показником загальної культури людини. Втілення в життя здоров'язберігаючих педагогічних технологій починається із студентства, особливо у закладах вищої освіти педагогічного спрямування. Саме від педагогів залежить свідоме ставлення підростаючого покоління до власного здоров'я, формування культури здоров'я та здоров'язбереження.

Турбота про здоров'я, освіченість, духовну та фізичну досконалість студентства стають одними з першорядних завдань вищих навчальних закладів. 
Адже міцне здоров’я є підгрунтям професійної підготовки, гарантом реалізації набутих знань, головним чинником працездатності в процесі життєдіяльності. Підготовка у навчальному закладі всебічно загартованої особистості зараз розглядається як важливий компонент формування конкурентоспроможних фахівців, здатних ефективно працювати в умовах світової глобалізації ринку праці. Змінити ставлення студента до власного здоров’я і особистого способу життя можливо за умови розуміння ним цих цінностей, надання пріоритетності збереженню фізичного та психічного здоров’ я через освіту. Саме з цією метою в Чернівецькому національному університеті імені Ю.Федьковича був запроваджений у навчальний процес предмет «Здоров'язберігаючі технології та домедична допомога» і «Громадське здоров'я та медицина порятунку». Завдяки знанням, отриманим на заняттях 3 цього предмету, у студентів формується відповідний стереотип поведінки в повсякденному житті з точки зору гігієни, режиму харчування, рухової активності тощо, який і постає мотивацією до здорового способу життя. Причому, спілкування зі студентами по даній темі дає підстави говорити про безліч мотивів для ведення здорового способу життя. У кожного своя мотивація бути здоровим: хтось вважає, що для досягнення успішної кар'єри в певній професії треба мати гарне здоров’я; інший хоче бути гарним, струнким; для когось - це радість повноцінного життя та активне довголіття; дехто вбачає в міцному здоров’ї заощадження коштів на ліках. Проте, в будь-якому, випадку сьогодні треба говорити про культуру здоров'я як невід’ємну складову загальної культури особистості.

Сучасні дослідження феномену «здоровий спосіб життя» не дають однозначного його визначення. Якщо за традиційними уявленнями це поняття означало відсутність шкідливих звичок, наявність раціонального харчування, оптимального рухового режиму та загартування, то сьогодні до нього додалася потреба раціональної організації праці, побуту та підвищення імунітету людини. Так, на думку Т. Бойченко, Н. Колотій, «здоровий спосіб життя - це сукупність форм життєдіяльності людини, яка забезпечує їі здоров’я та успішний життєвий шлях. Власне, це - гармонійна життєдіяльність людини, що сприяє зміцненню і 
збереженню здоров'я» [486]. В медичному контексті здоровий спосіб життя являє собою гармонійний режим поєднання роботи та відпочинку, оптимальне харчування, фізичну активність, дотримання гігієни, відсутність шкідливих звичок, а також містить найважливішу складову - доброзичливе ставлення до оточуючих і до життя взагалі в будь-яких його проявах. Всесвітня організація охорони здоров'я характеризує здоров'я як стан повного фізичного, духовного та соціального благополуччя. За даними цієї організації здоров'я людини на 5055 \% визначається умовами і способом ії життя, на 25\% - екологічними умовами, на 15-20\% воно обумовлено генетичними факторами і лише на 10-15\% діяльністю системи охорони здоров'я. Очевидно, що першорядна роль у збереженні і формуванні здоров'я належить самій людині, пї цінностям та установкам, ступеню гармонізації ії внутрішнього світу та відносин з оточенням, іiї особистого способу життя. Щодо складових здорового способу життя, ВООЗ чітко визначила, що це - фізичне виховання і спорт, раціональне харчування, відповідальність кожного за стан свого здоров'я. Фізична активність є одним 3 ключових аспектів здорового способу життя. Вона робить людину не тільки фізично привабливішою, але й істотно покращує іï здоров'я, позитивно впливає на тривалість життя, в першу чергу активної ії частини. Як фізіологічний процес фізична активність властива будь-якій людині. Вона може бути низькою, якщо людина усвідомлено або вимушено веде малорухливий спосіб життя i, навпаки, високою, наприклад, у спортсмена. Низька фізична активність (гіподинамія) може бути причиною розвитку м'язової атрофії. Якщо гіподинамія поєднується 3 погрішностями в харчовому раціоні (прийом висококалорійної їжі у великій кількості), це неминуче приведе до розвитку ожиріння. Висока фізична активність супроводжується збільшенням м’язової маси (гіпертрофією), зміцненням кісток скелета, підвищенням рухливості суглобів.

Формування здорового способу життя студентської молоді - складний процес, який потребує активної участі в ньому якнайбільшої кількості людей: це і батьки, i викладачі, і вихователі гуртожитків, і насамперед - самі молоді люди. Якщо розглядати цей процес в сім’ї, то в більшості випадків він зводиться до 
виховання навичок гігієнічної поведінки та профілактики шкідливих звичок. Відомим є той факт, що з метою прищеплення здорового способу життя батьки в процесі виховання власних дітей застосовують різні психологічні механізми. Перш за все, це механізм підкріплення - батьки використовують заохочення (або покарання) тієї поведінки дитини, яку вони вважають правильною чи неправильною. У свідомості дитини формується певна система ціннісних норм, стандартів і життєвих планів, дотримання і прагнення реалізації яких для неї поступово стає внутрішньою потребою. Якщо ці стандарти і плани реалістичні, то, досягаючи їх, дитина, а згодом і доросла людина, підвищує рівень власної самоповаги, формує позитивний «Я-образ». У тому випадку, коли стандарти і плани батьків не відповідають наявним можливостям дитини, не враховують іiі власних інтересів і схильностей, у разі невдачі у дитини виникають труднощі із самовизначенням, втрачається віра в себе, знижується рівень самоповаги. Питання можливості (або неможливості) вести здоровий спосіб життя $є$ суб'єктивним, бо воно, перш за все, детерміноване ступенем усвідомлення особистістю важливості дій в цьому напрямі. Навіть при відсутності деяких об’єктивних умов (комфортне житло, належне харчування, достатній дохід тощо) особи з високим рівнем свідомості стосовно здорового способу життя прагнуть багато чого робити заради власного здоров’я. I навпаки, за достатньо об’єктивних умов нестача особистісних стимулів знижує бажання бути здоровим. Беззаперечним є той факт, що роль сім’ї у формуванні здорового способу життя молодої людини є важливою і вирішальною. Сім'я формує власний спосіб життя, мікрокультуру, основою якої виступають цінності i елементи культури суспільства або окремих його соціальних груп. Дитина включається в сім’ю з дня іiі народження, коли вона є найбільш сприйнятливою до виховних впливів (як свідомих з боку батьків, так і внутрішньосімейної атмосфери в цілому). Фактично, сім’я $є$ першою ланкою між людиною i суспільством, яка передає від покоління до покоління певні соціальні цінності, що на суб’єктивному рівні виступають як ціннісні орієнтації членів сім'ї. Сімейно-побутова культура родини виступає осередком, з якого вибудовується 
вся соціальна взаємодія, в тому числі, i в напрямку формування здорового способу життя. А безперервність і довготривалість сімейних відносин, постійний контакт осіб різної статі, віку, життєвого досвіду сприяють наслідуванню і засвоєнню дітьми зразків поведінки саме батьків і тільки потім - інших людей поза сім'єю. Таке складне поєднання об'єктивних і суб’єктивних чинників обумовлює значний виховний потенціал сім’ї, безпосередньо батьків, їхній визначальний вплив на процес формування способу життя їхніх дітей. Формування здорових звичок найбільш ефективно відбувається в дитинстві. Чим менший вік, тим безпосереднє сприйняття, тим більше дитина довіряє тим, хто іiі виховує. Це створює найбільш сприятливі можливості для формування потрібних для збереження здоров'я якостей i властивостей особистості. Наскільки успішно будуть сформовані й закріплені у свідомості навички здорового способу життя в молодшому віці, залежить в подальшому реальний спосіб життя, який або сприятиме, або перешкоджатиме розкриттю потенціалу особистості. Отже, ставлення молодої людини до власного здоров’я є наслідком реалізації виховної функції сім’ї. Від того, що закладено в людині з раннього дитинства, багато в чому будуть залежати її світогляд, культура і спосіб життя.

На нашу думку, процес виховання свідомого ставлення студентства до власного здоров’я, здоров’я інших людей варто здійснювати шляхом передачі знань і формування умінь та навичок зміцнення й збереження здоров’я, виконання практичних дій здорового способу життя. Саме в молоді роки відбувається сприйняття певних норм та зразків поведінки, усвідомлення потреб та мотивів, визначення ціннісних орієнтацій, інтересів та уявлень. Поведінкові чинники можуть бути як сприятливими, так і шкідливими для здоров’я, що залежить від вибору способу життя конкретною особою. Щоб вплинути на поведінку людини, необхідні зусилля з боку сім’ї, суспільства і безумовно самої людини. Тому так важливо проводити в життя послідовну систему активних дій усіх учасників навчально-виховного процесу. Сам процес має бути спрямований на створення здорового середовища для формування таких важливих життєвих навичок, які ведуть до збереження, зміцнення та відтворення здоров’я i 
орієнтують на утвердження здорового способу життя, розвиток духовно, психічно, фізично та соціально здорової особистості.

Процес виховання свідомого ставлення молоді до власного здоров’я починається 3 першого курсу навчання у вищому навчальному закладі i забезпечується рядом педагогічних умов, а саме:

1. поєднанням навчального процесу з практичною діяльністю студентів;

2. знайомством молоді з основами здорового способу життя, формуванням свого власного здорового стилю життя;

3. формуванням цільової настанови і мотивації студентів на зміцнення свого здоров’я і набування відповідних знань, умінь і навичок.

Особливе значення в умовах збереження і зміцнення здоров'я студентів мають фізичні вправи. Рухова активність покращує життя організму в цілому, стимулює інтелектуальну діяльність людини, підвищує продуктивність розумової праці, позитивно впливає на ii психічну та емоційну діяльність. Реалізація цих положень полягає в систематичному використанні доступних кожному студенту форм фізичної культури (ранкова гімнастика, прогулянки, заняття рухливими видами спорту, танцями). На думку вчених, низький рівень фізичної активності і підготовленості не дозволяє молодій людині повністю реалізувати свої природні здібності. Гіподинамія, на яку страждає 90 \% студентства, призводить до патологічних змін обміну речовин, зниження рівня активності ферментів, деструктивних змін у клітинах, що веде до дистрофії чи атрофії тканин і є наслідком зниження рівня функціонування систем організму [490]. Тому фізична культура в структурі освітньої і професійної підготовки майбутніх фахівців виступає не лише в ролі навчальної дисципліни, але і $€$ засобом направленого розвитку цілісної особистості.

Викликає занепокоєння стан репродуктивного здоров’я студентської молоді. Дошлюбні статеві відносини серед студентів стали поширеним явищем i, в окремих випадках, навіть нормою поведінки. Нерозбірливі статеві стосунки серед молоді сприяють поширенню венеричних хвороб, призводять до численних хірургічних втручань $з$ приводу переривання небажаної вагітності, що 
може бути причиною майбутнього безпліддя. Важливою ланкою в організації здорового способу життя у студентів є робота викладачів-кураторів. Відповідно до зазначеного, діяльність викладачів-кураторів зі студентами має бути спрямована на формування свідомого ставлення до власного здоров'я шляхом цілеспрямованої допомоги в раціональній організації життєдіяльності підопічних та оптимальній соціальній адаптації їх до середовища навчання та дозвілля. Діяльність медичних працівників пов'язана з комплексом спеціальних заходів, спрямованих на поліпшення здоров'я, підвищення санітарної культури, запобігання розвитку захворювань та інвалідності, ранню діагностику та лікування хвороб, реабілітацію хворих. Робота лікарів грунтується на принципах ранньої диспансеризації - системі лікувально-профілактичних заходів, яка включає активне спостереження за здоров'ям студентів, вивченням умов навчання та побуту, забезпечення фізичного розвитку і збереження здоров'я шляхом проведення лікувально-профілактичних та санітарно-гігієнічних заходів [492]. Згідно з вимогами Наказу Міністерства охорони здоров’я України «Про диспансеризацію населення» студенти вищих навчальних заходів підлягають обов'язковому щорічному медичному огляду. Таким чином, формування здорового способу життя студентів реалізується шляхом оздоровчої діяльності, створенням сприятливих для здоров’я санітарно-гігієнічних, психологічних $\mathrm{i}$ соціальних умов, а також вихованням позитивної мотивації до власного здоров'я, потреби у здоровому способі життя, сприянням у засвоєнні студентами знань, умінь і навичок, необхідних для збереження, зміцнення та відновлення здоров'я, і є невід'ємним елементом у навчально-виховному процесі. 3 цією метою необхідно створювати і реалізовувати програми та проекти на місцевому та державному рівнях, в яких би формувалась необхідність дотримання здорового стилю життя, розраховані на широке коло студентів.

Спостереження В.О. Бароненко показують, що у студентської молоді часто втрачається значимість мотивації самозбереження. Послаблене відчуття відповідальності за свою поведінку є запорукою, наприклад, венеричних захворювань після випадкових статевих стосунків, втягування в наркоманію чи 
пияцтво. Молодим людям здається, що ресурс їхнього особистісного здоров’я невичерпний. Частими є випадки, коли приведені вище положення не стають студентам керівництвом до дії. Це пов'язано 3 тим, що рекомендації до здоров’язбереження запроваджуються в повчальній, категоричній формі і не викликають у студентів позитивних емоцій; викладачі зрідка дотримуються вказаних правил у професійному житті; засоби масової інформації, мережа «Inter- Педагогіка, психологія та медико-біологічні 86 net» у привабливій формі культивують нездоровий спосіб життя. У зв’язку з цим формування мотивації до здоров'язбереження у студентів потребує значних зусиль. Оскільки ефективність таких намагань проектується на майбутнє і не кожен студент здатен вирішити це завдання самостійно, необхідна цілеспрямована система виховання і навчання, орієнтована формувати установку на здоров’я. Для цього педагогу потрібно врахувати, яким чином можна сприяти зміні переконань студентів, оскільки саме на основі них формуються установки, тобто готовність рухатися у певному напрямку, у нашому випадку - у напрямку здоров'язбереження [493].

Дослідження Л.Б. Дихана показують, що на переконання молоді впливає: 1) нова інформація. Інформація, почута вперше, здатна впливати на переконання людини; 2) особистісно значуща інформація, котра відповідає актуальній на сьогоднішній день потребі, проблемі; 3) інформація, яка викликає у людини сильні емоції. Збереження такої інформації на глибинному, рефлекторному рівні може відбутися 3 одного-двох разів, надовго залишаючись у пам’яті; 4) інформація, пов’язана 3 поважною особистістю; 5) поєднання тої чи іншої проблеми здоров'я 3 особистісними, внутрішніми цінностями людини за принципом їх розширення, доповнення; 6) практичні дії, досвід пересилювання чи переборювання себе. Успіх, досягнення мети викликають позитивні емоції, на основі чого виникає бажання повторної дії; 7) самооцінка, самоаналіз та самозбереження певних аспектів здоров’я. Це твердження покладено в основу методики навчання здоров’ю за Г.К.Зайцевим; 8) довіра до того, хто транслює інформацію. У цьому випадку інформація може сприйматися «на віру», без 
детального аналізу; 9) доведеність, реалістичність інформації, демонстрація безпосередніх, легко контрольованих ефектів.

За Д.Є. Вороніним та М.М. Оксою, здоров'язберігаюча компетентність передбачає не тільки медично-валеологічну інформативність, але й застосування здобутих знань на практиці, володіння методиками зміцнення здоров'я й запобігання захворюванням. Вивчення курсів «Основи медичних знань і охорона здоров’я», «Здоров'язберігаючі технології та домедична допомога», «Валеологія» дає можливість студентам по-новому подивитись на стан свого організму, виявити фактори, що призводять до захворювань (зайва вага, нераціональне харчування, малорухомий спосіб життя, неадекватний режим праці й відпочинку, неповноцінний сон, шкідливі звички тощо) і спробувати їх усунути, засвоїти методики профілактики патологічних станів. Потреба самооздоровлення є важливим показником здоров'язберігаючої компетентності студента [491]. Значне місце авторами відводиться вивченню нетрадиційних методів оздоровлення, які характеризуються відносною простотою в застосуванні, доступністю кожному i, головне, високою ефективністю, бо спрямовані на стимулювання й розвиток природних сил і здібностей людини. Вони наголошують, що формування здоров'язберігаючої компетентності починається 3 моменту народження людини й триває все життя. На рівень іiі розвитку впливає безліч факторів: родина, колектив, засоби масової інформації тощо. Значну роль у цьому відіграють усі навчально-виховні заклади й відповідальність за успішність процесу формування здоров'язберігаючої компетентності лягає на педагога. Виховання відповідного ставлення до свого здоров'я, здоров'я навколишніх, формування потреби в пізнанні самого себе, самовдосконаленні фізичних, психічних і розумових здібностей є безпосереднім завданням вищих навчальних закладів [487]. Формування у студентів спрямованості мислення на збереження й зміцнення здоров'я - невід'ємний компонент здоров'язберігаючої компетентності майбутніх фахівців. Він також включає й розвиток у них творчого мислення, пов'язаного 3 самовдосконаленням, потребу у набутті медично-валеологічних знань. 
Формування здоров'язберігаючої компетентності на заняттях фізичної культури реалізується потенціалом, формує гуманітарне мислення, поведінку ії діяльності, майбутніх фахівців наповнює гуманістичними цінностями, розвиває інтелектуальну, емоційну-вольову сферу людини, засоби саморегуляції його поведінки сприяє збагаченню морально-естетичного досвіду та інтеграції фізичної і професійної культу У найбільш загальному змісті «здоровий спосіб життя» розуміють як життєдіяльність особистості, яка грунтується на культурних нормах, цінностях, формах та способах діяльності, що зміцнюють здоров’я, адаптивні можливості організму людини і сприяють їі гармонійному фізичному, духовному i соціальному розвитку, виконанню нею соціальних функцій i досягненню активного довголіття. Здоровий спосіб життя $\epsilon$ багатогранним явищем, що включає фізичне, психічне, соціальне, культурне, духовне здоров’я. Він включає такі основні елементи: раціональний режим праці і відпочинку, викорінювання шкідливих звичок, оптимальний руховий режим, особисту гігієну, раціональне харчування. Ставлення до здоров’я являє собою сукупність індивідуальних вибіркових зв'язків особистості з різними явищами оточуючої дійсності, які сприяють або, навпаки, загрожують здоров’ю особистості, а також відповідну оцінку індивідом свого фізичного і психічного стану, оптимально організовану самою людиною життєдіяльність, яка сприяє збереженню здоров’я, особистому розвитку, творчому функціонуванню. «Здоров’язберігаюча компетентність людини» являє собою певний рівень іiі медично-валеологічної грамотності, стан соціального благополуччя, ступінь розвитку творчих сил, фізичних, психічних і розумових здібностей, виражених в організації ¥іi життєдіяльності, у ставленні до самої себе, інших людей, до природи. Основним критерієм здоров’язберігаючої компетентності є стан оптимальної відповідності, гармонії між біологічним, психологічним i соціальним у житті й діяльності людини і особистості [492].

3 огляду на важливість порушеної проблеми, актуальним є впровадження в освітнє середовище вищого навчального закладу здоров'яформувальних i здоров’язберігальних методів, прийомів, технологій, метою яких є формування 
ціннісного відношення та позитивної мотивації до здорового способу життя, збереження та зміцнення здоров'я, оволодіння навичками ведення здорового способу життя. 
DOI 10.46299/ISG.2021.MONO.PED.III.6.5

\section{5 Система підготовки вчітелів спортивних дісциплін в КНР}

Китай є лідером у багатьох сферах суспільного життя та у багатьох сферах значно випереджає інші країни. Система фізичної культури та спорту не стала винятком. Китай активно розвиває систему фізичної освіти в країні, у країні функціонує низка законів, відповідно до яких зорганізується діяльність 3 фізичної культури та спорту.

Зокрема, передбачено державне заохочення підприємств, установ і громадських організацій, які беруть участь у створенні і підтримці справи 3 розвитку фізичної культури і спорту. Також у документах наголошується на тому, що виховання спортсменів має грунтоваться на науковому підході в освіті, дотриманні принципів патріотизму, колективізму, соціалізму, етики та суворої дисципліни [494].

Відповідно до «Національної програми КНР щодо зміцнення здоров'я» заняття фізичною культурою та спортом сприяє посиленню мощідержави i процвітання всього суспільства. Метою цієї програми $є$ проведення координованогорозвитку фізичної культури і спорту в рамках національної економіки та із урахуванням національної специфіки. Характерною особливістю «національної програми» є розширення соціальної бази фізично активного населення, яке мешкає не тільки у містах КНР, але й у сільській місцевості. Таким чином, аналіз «Національної програми» свідчить про стратегічні плани керівництва КНР зі створення фізично активного і здорового населення, цілком включеного в спортивне життя країни [495].

В КНР існує досить розгалужена система підготовки вчителів спортивних дисциплін, що обумовлено необхідністю забезпечення освітнього процесу як у закладах середньої освіти, закладах позашкільної освіти та університетах, адже заняття фізичною культурою $є$ обов'язковим компонентом навчання як у середній школі, так і під час здобуття вищої освіти.

На території країни створено 17 університетів фізичної культури та спорту, більші 3 яких дорівнюються до педагогічних університетів. Університети 
фізичної культури поділяються на декілька інститутів, які забезпечують підготовку спеціалістів для розвитку масової фізичної культури та спеціалістів 3 розвитку різних видів спорту.

На базі цих закладів вищої освіти також працюють науково-дослідні університети, які здійснюють підготовку науково-педагогічних працівників у сфері фізичної культури та спорту; ці установи мають право присвоювати наукові ступені «магістру» та «доктора філософії» після навчання в аспірантурі та публічного захисту дисертації [496, 497, 498].

До провідних університетів країни у галузі спорту можна віднести:

-Пекінський університет спорту;

•Уханьський університет спорту;

•Столичний університет фізичної освіти та спорту;

•Шанхайський університет спорту;

•Шеньянський університет спорту;

•Університет спорту у Гуанчжоу;

•Університет спорту у Тіньяні тощо.

Розглянемо систему освіти майбутніх вчителів спортивних дисциплін на прикладі провідних університетів спорту. Так, до складу Пекінського університету спорту входить чотири підрозділи: інститут спорту та здоров'я, інститут гуманітарних та соціальних дисциплін, інститут олімпійських видів спорту, інститут спортивної інженерії.

У свою чергу інститут спорту та здоров'я включає такі факультети як: педагогічний факультет (для загальноосвітніх шкіл); факультет спортивної науки; факультет силової та фізичної підготовки; факультет активного відпочинку та туризму; факультет психології, факультет спортивної медицини та фізичної терапії; дослідницький факультет традиційних китайських видів спорту.

До інституту гуманітарних та соціальних дисциплін належать такі факультети як факультет марксизму, факультет ведення бізнесу у спорті, 
факультет іноземних мов, факультет гуманітарних дисциплін, факультет менеджменту, факультет журналістики та комунікації, факультет мистецтв та факультет підвищення кваліфікації. До факультету олімпійських видів спорту включено такі коледжі основних видів спорту: футболу, баскетболу, волейболу, плавання, фігурного катання, атлетики та коледж підготовки тренерів.

У світлі дослідження найбільший інтерес представляє педагогічний факультет, який $є$ найдавнішим факультетом цього університету. Наразі факультетом підготовлено понад 20000 видатних вчителів фізичного виховання, які працюють із дітьми різних вікових категорій, як у закладах середньої освіти, так і у позаосвітніх закладах освіти.

На базі педагогічного факультету працюють 4 кафедри та два науководослідні центри: кафедра педагогіки, кафедра фізичного виховання, кафедра фізичного виховання дітей дошкільного віку та кафедра історії фізичного виховання в Китаї, а також Центр дослідження розвитку спорту серед інвалідів та Науково-дослідний центр міжнародного та порівняльного фізичного виховання. На факультеті працює 28 викладачів, п'ять з яких - професори, 5доценти, 9- здобувачі наукових ступенів.

На факультеті приділяється значна увага як розвитку спортивних досягнень студентів, так і заняттям 3 педагогіки та методики викладання спортивних дисциплін. В останні роки педагогічний факультет виграв дві національні нагороди за досягнення у сфері педагогічної діяльності та три пекінські нагороди за досягнення у сфері педагогічної діяльності. До того ж, викладачі факультету отримали нагороди та премії на конкурсах «Викладач Пекіну», Пекінська педагогічна команда.

Значна увага приділяється також розробці навчальних програм та проведенню наукових досліджень, які відповідають тематиці науководослідницьких центрів, які працюють на базі факультету. Викладачами систематично розробляються та вдосконалюються навчальні курси, які впроваджуються не тільки на факультеті, але й на базі інших закладів освіти країни. 
Крім того, було реалізовано три проекти, що фінансуються Державною ключовою програмою національних суспільних наук Китаю, понад шістдесят проектів, що фінансуються Національним фондом соціальних наук, Фондом Міністерства освіти Китаю тощо. [SchoolofEducation].

Педагогічний факультет пропонує дві спеціальності: фізичне виховання та педагогіка. Необхідно зазначити, що спеціальність «Фізичне виховання» займає провідні позиції у рейтингу предметів фізичної культури у сфері вищої освіти в Китаї. У 2019 році ця спеціальність була успішно затверджена як «Якісна національна програма підготовки», студенти, які навчаються на цій спеціальності виграли першу премію на Національному конкурсі базових навичок для студентів-бакалаврів з фізичного виховання. 32017 на факультеті відкрито спеціальність «Педагогіка фізичного виховання».

Під час фахової підготовки студентів на факультеті намагаються постійно вдосконалювати свою роботу відповідно до стратегії розвитку країни, яка полягає у побудові могутньої країни спорту та могутньої країни освіти. Зусилля викладачів спрямовуються на організацію освітнього процесу відповідно до міжнародних вимог до підготовки талантів.

По-перше, спираючись на дисциплінарну систему «спорт + освіта», в університеті прагнуть реформувати та оптимізувати модель вступу до фізичної культури, розвивати педагогічну самоідентифікацію вчителів фізичної культури, які під час виконання професійних обов'язків зможуть демонструвати професійну етику, враховувати концепції вищої освіти, застосовувати обгрунтовані професійні знання та навички з фізичної культури, мати грунтовну підготовку з фізичної культури та базові науково -дослідницькі здібності, а також знати методи роботи позакласної діяльності у різних типах шкіл (таких як початкова школа, середня школа та університет тощо).

По-друге, відповідно до потреб практики фізичного виховання, на факультеті впроваджується національна програма підготовки вчителів фізичної культури, студентам надаються теоретичні знання та практичні навички 3 
фізичної культури для елітних спортсменів, вчителів початкової та середньої фізичної культури, що сприяє їх професійному розвитку.

По-третє, здійснюється зосередження уваги на дисциплінарних тенденціях фізичного виховання, зокрема, у сфері підвищення кваліфікації вчителів, політиціпідходів до викладання фізичного виховання в школі, історії фізичного виховання, фізкультури раннього дитинства, освіти вчителів, шкільної спортивної політики, історії фізичного виховання та спорту у ранньому дитинстві, спорту для інвалідів тощо.

По-четверте, завдяки розкриттю талантів та науковим дослідженням, які проводяться викладачами, факультет намагається реагувати на потреби шкільного фізичного виховання, брати участь у шкільних інноваціях у сфері фізичного виховання та наукових дослідженнях у вищій, середній та початковій освіті, надати освітню підтримку центральним та західним регіонам, а також сільським та віддаленим районам країни.

По-п’яте, факультет розширює обмін та співпрацю з іншими навчальними та фізичними навчальними закладами чи організаціями як у країні, так i за кордоном, є організатором конференції (або форумів) у сфері фізичного виховання як у країні, так і за кордоном, вивчає передовий досвід фізичного виховання в інших регіонах та країнах 3 метою його творчого використання в освітньому процесі [SchoolofEducation].

Робота факультету силової та фізичної підготовкиспрямовано на розробку та дослідження методів силової та фізичної підготовки як елітних спортсменів, так і широкої громадськості та спеціальних груп. До складу факультету входять 22 професори, 6 доцентів, 3 викладачі, 2 асистенти викладача, 3 національні тренери та 1 професіонал з надбавкою Державної ради, що забезпечує якісний процес викладання. На базі факультету працює дві ключові лабораторії: лабораторія відновлення фізичних сил та фізичних функцій та Лабораторія спортивної підготовки.

На факультеті приділяється велика увага як теоретичній, так і практичній підготовці студентів. Відповідно до академічного прогресу студентів, факультет 
активно використовує свої ресурси та переваги розташування, а також співпрацює зі своїми представницькими командами, спортивними командами університетів Пекіна, відомими фітнес-клубами, провінційними спортивними командами, професійними спортивними школами, професійними клубами та національними збірними за різними програмами, що дозволяє побудувати систематичну таефективну систему підготовки студентів до професійної діяльності [499].

Факультет психології Пекінського університету спорту було утворено на базі кафедри теорії фізичного виховання Пекінського інституту фізичного виховання (перейменовано на Пекінський університет спорту в 1993 році). Однією із основних дисциплін на сьогодні є спортивна психологія, викладання якої було започатковано у 2008 році. 32010 року на факультеті готують не тільки бакалаврів, але й магістрів з відповідної спеціальності. Діяльність викладачів факультету спрямовано на удосконалення робочих програм, покращення якості викладання та досліджень, задоволення потреб реформування та розвитку спорту та освіти Китаю та реагування на основні стратегічні потреби країни.

На базі факультету створено три навчально -дослідницькі відділи: відділ спортивної психології, відділ когнітивної та біологічної психології та відділ психології розвитку та освіти. Професорсько-викладацький склад факультету налічує 23 педагога, шість 3 яких - професори, чотири доцента та тринадцять викладачів.

На базі факультету психології працює шість лабораторій для здійснення різних видів навчально-дослідницької діяльності: базова психологічна лабораторія, лабораторія психологічного оцінювання, лабораторія вивчення рухів, лабораторія когнітивної спортивної психології, лабораторія навчання розумових навичок та лабораторія подолання стресу в спорті. Усі лабораторіє мають сучасне обладнання, що дозволяє проводити дослідження та експерименти на високому науковому рівні, які відповідають сучасним вимогам.

Під час вивчення спортивної психології студенти вивчають психологічні фактори, що впливають на спортивні результати, такі як стрес у спорті, 
самоконтроль спортсменів, вигорання у спорті та психологічний контроль під час великих спортивних подій. Останнім часом обов'язковим компонентом спортивної психологї̈ стала психологія здоров'я, яка зосереджується на взаємозв’язку між фізичними вправами та фізичним та психічним здоров'ям, а також прищеплення правильної поведінки під час тренувань.

На факультеті існує три напрямки дослідження:

- психологія здоров’я, яка зосереджується на стосунках між фізичними вправами та фізичним та психічним здоров’ям, а також пропагує поведінку під час тренувань. У цьому напрямку міждисциплінарна команда викладачів, що працює над національними проектами підтримки науки і технологій, була в авангарді сприяння локалізації теорії та практиці психології вправ. Результати досліджень сприяли започаткуванню проекту Національних наукових спільнот 3 демонстрації фітнесу для покращення здоров’я людей.

• когнітивна психологія, яка досліджує особливості пізнавальних процесів у конкурентних ситуаціях, таких як візуальна обробка рухів та прийняття тактичних рішень, щоб забезпечити основу для розуміння пізнавального процесу в стресових ситуаціях та стресовому тренінгу.

• контроль емоцій під час занять спортом, що спрямовано на ознайомлення студентів із спеціальними прийомами та методами опанування власними емоціями [499, 500, 501, 502$]$.

До провідних закладів вищої освіти у галузі спорту відноситься також Столичний університет фізичного виховання та спорту був заснований у 1956 р. 3 моменту свого заснування університет займає провідне місце серед університетів та коледжів у спортивній галузі щодо розміру, рівня, дизайну курсу, викладацького складу, якості викладання, досліджень та об'єктів. В університеті розроблено багаторівневу, багатотипну та багатоформатну модель освіти. Здобувачі освіти можуть навчатися як на рівні бакалавру, так у магістратурі та аспірантурі.

На рівні бакалаврату студенти можуть обрати такі спеціальності як бойові мистецтва та традиційні китайські види спорту, спортивне тренування, 
кінезіологія людини, публічне управління, журналістика, керівництво та управління соціальними видами спорту, спортивне дозвілля, фізичне виховання, хореографія, реабілітація спортсменів, економіка та управління спортом [503].

Професорсько-викладацький склад приділяє якості освіти дуже велику увагу, систематично проводячи відповідні тренінги та семінари 3 методики викладання спеціальних дисциплін, так і з вивчення завдань, які висуває Комуністична партія Китаю [502].

Шанхайський університет спорту був заснований у листопаді 1952 року та $\epsilon$ першим університетом такого типу у Новому Китаї. Раніше цей заклад вищої освіти перебував під безпосереднім керівництвом Генеральної адміністрації спорту Китаю, але з 2001 року він перейшов до муніципального уряду Шанхаю. За шістдесят років розвитку Шанхайський університет спорту перетворився набагато дисциплінований університет із шістьма категоріями освіти, менеджменту, науки, літератури, медицини та мистецтва, представлених наукою про спорт.

В університеті створено повну освітню систему, яка охоплює програми бакалавра, магістра та доктора філософії, а також створено базу для докторських досліджень у галузі спортивних наук. В даний час в університеті навчається більше 4000 студентів денної форми бакалаврату, 1000 аспірантів, 1400 іноземних студентів, 1400 студентів, які отримують другу вищу освіту та працює 700 викладачів та адміністраторів, серед яких 82 професори та 170 доцентів [504].

До Шеньянського університету входять такі факультети як факультет загального спорту, спортивно-гуманітарний факультет, факультет спортивного мистецтва, факультет управління, факультет ушу, факультет кінезіології, факультет фізичної культури, а також відділ аспірантури та докторантури.

Факультет фізичного виховання представляє найбільший інтерес, адже саме тут готують викладачів спортивних дисциплін. Аналіз сайту дозволяє стверджувати, що до основних дисциплін відносяться такі курси як спортивна анатомія, спортивна фізіологія, охорона спорту, спортивна психологія, 
педагогіка, шкільна фізкультура, легка атлетика, баскетбол, волейбол, футбол, гімнастика, художня гімнастика (для жінок), заняття єдиноборствами. Під час навчання студенти також мають лабораторні роботи з спортивної анатомії, спортивної фізіології та охорони спорту.

Разом із тим, можна стверджувати, що не зважаючи на те, що університети спорту в Китаї прирівняні до педагогічних університетів, їх випускники здебільше намагаються працевлаштуватися не у школи, а у інші заклади, які пов'язані зі спортом.

Підготовка вчителів спортивних дисциплін переважно відбувається на базі педагогічних університетів країни. У ході дослідження установлено, що у цих ВНЗ під час навчання студентів значна увага приділяється не тільки спортивній підготовці, але й дисциплінам психолого-педагогічного циклу. Розглянемо підходи до підготовки майбутніх вчителів спортивних дисциплін на прикладі факультету фізичної культури та спорту Нанкінського педагогічного університету.

Для вступу на цей факультет необхідно не тільки показати досить високу спортивну підготовку, але й представити характеристику, в якій зазначалось би, що абітурієнт володіє високими моральними якостями та культурними цінностями, що є необхідними рисами педагогів.

Як і у інших закладах вищої освіти цього напрямку студенти вивчають три основні блоки дисциплін: базові, обов'язкові та вибіркові. Базові та основні навчальні програми є обов'язковими для отримання ступеня бакалавра. Навчальна програма за вибором у списку включає розширені курси дисциплін, які пропонується факультетом, міждисциплінарні курси, які пропонуються іншими факультетами ВНЗ.

До базових дисциплін відносять такі предмети як «Введення у спорт», «Анатомія», «Фізіологія спорту та фізичної діяльності», «Психологія спорту», «Введення до соціального спорту», «Соціологія спорту», «Економіка спорту», «Спортивний менеджмент», «Виховання здоров'я». 
До дисциплін обов’язкового блоку належать «Спортивне харчування», «Спортивне законодавство», «Бізнес і спорт», «Теорія та методи бодібілдінгу», «Дослідницькі методи спортивної науки», «Спортивна анатомія», «Спорт та спортивне обладнання», «Експерименти спортивної психології», «Аеробіка», «Ушу», «Теніс», «Бадмінтон», «Плавання», «Баскетбол», «Волейбол», «Футбол як спеціальність», «Футбол», «Гімнастика», а також дисципліни загальної підготовки: іноземна мова (здебільше англійська або російська), педагогіка, психологія, теорія марксизму.

До блоку вибіркових дисциплін належать «Менеджмент та адміністрація у спорті», «Спортивні медіа та новості», «Брокерство у спорті», «Менеджмент спортивних подій», «Перемови у спорті», «Соціальні види спорту», «Спорт та довкілля», «Спортивне орієнтування», «Таеквандо» [505]

Після бакалаврського рівня студенти мають змогу навчатися на рівні магістратури. Навчання у магістратурі триває від трьох до п’яти років (якщо студенти беруть академічну відпустку). До основних предметів, які вивчаються у магістратури можна віднести «Принципи спортивної науки», «Логіка», «Вивчення спортивної навчальної програми та фізичного виховання», «Теорія та методи спортивних наукових досліджень», «Навчання та контроль рухових навичок» [506].

«Принципи спортивної науки» $є$ базовим курсом, під час якого вивчаються сутність та основні характеристики спорту і загальних правил на макрорівні. Курс характеризується універсальністю, абстрактністю, всеосяжністю, інноваційністю та застосовністю.

Основний зміст курсу включає: наукове пояснення питань у галузі спорту, що виходять за межі щоденного спортивного досвіду, а також зв'язок теорії та практики спорту; ознайомлення із різними видами відносин у спорті та спортивним законодавством; зміцненню дисциплінарного будівництва у сфері гуманітарнихта соціологічної науки спорту; питання керівництвау галузі спортивних реформ. До основних тем курсу включають :

• спортивні концепції; 
- сутність спорту

- спортивне призначення;

- спортивний процес та право;

- оцінювання фізичного виховання;

- спортивна культура;

- спортивна система;

• тенденції розвитку спорту [507]

Під час вивчення дисципліни «Логіка» студенти отримують знання щодо принципів та методів формальної логіки; у них розвивають звичку логічного мислення. Основний зміст курсу включає об’єкт та значення формальної логіки; основні концепції; прості пропозиції та їх застосування; складні пропозиції та міркування; модальні пропозиції та міркування; індуктивні міркування; аналогічні міркування та гіпотези; основні закони формальної логіки; демонстрація [508]

Дисципліна «Фізичне виховання» має на меті допомогти студентам зрозуміти основну теорію, фундаментальні та передові методи та підходи до викладання на сучасному рівні.Основний зміст курсу включає:

• історію розвитку методів викладання фізичних дисциплін;

- визначення мети та методів проведення занять із фізичної культури;

- керівництво навчальною діяльністю учнів під час занять 3 фізичної культури;

• ознайомлення з навчальними ресурсами з фізичної культури;

- макроскопічне розуміння модернізації фізичного виховання;

- метод елементного аналізу та метод системного аналізу у викладанні фізичної культур [509]

Дисципліна «Теорія та методика спортивних наукових досліджень» спрямована на формування свідомості під час проведення наукових досліджень, розвиток наукового світогляду, уміння використовувати основні методи наукових досліджень та розуміння загальнонаукової програми досліджень, використання відповідних методів для вирішення практичних проблем. 
Цей курс зосереджений на основних теоріях та методах спортивної науки та допомагає студентам зрозуміти поєднання методів дослідження та дослідницьких питань, розвиваючи здатність оцінювати та критикувати інші дослідження, базуючись на методології, підходах та методах на трьох різних рівнях. Цей курс спрямовано на допомогу у розробці своїх власних досліджень та написання диплому магістра.

Основний зміст курсу включає: уміння застосовувати відповідні методи дослідження, дослідницьких питань; огляд літератури; правила оформлення роботи; експериментальне проектування; метод спостереження; якісне дослідження та кількісне дослідження [510].

Курс «Вивчення спортивної навчальної програми та фізичного виховання» має на меті допомогти студентам досягти мети розробки спортивних навчальних кейсів. Основний зміст включає: поглиблення розуміння форми та функцій тіла; розвиток та особливості форм та функцій людського тіла; оцінювання форми та функцій тіла та уміння займатися спортом; розуміння значення спорту; формування свідомості занять спортом; розуміння необхідності участі у спорті; встановлення правильної концепції здоров'я; визнання взаємозв'язку між фізичним та психологічним здоров'ям; пояснити, що постійні фізичні вправи корисні для зміцнення здоров'я; розуміння впливуспорту на розвиток соціальної адаптації; розуміння основних понять, принципів та методів легкої атлетики, ігри 3 м'ячем, гімнастики, єдиноборства, аеробіку, танці, плавання; оволодіти методиками викладання під час проведення занять з фізичної культури [511]

Разом із тим, необхідно зазначити що незважаючи на те, що в Китаї існує поступова система формування вчителів спортивних дисциплін, яка спрямована на формування як фізичної майстерності студентів, так і їх педагогічних умінь та навичок, на сьогодні ще багато випускників педагогічних ВН3 не самоідентифікують або недостатньо самоідентифікують себе із професією, що вимагає необхідності вивчення досвіду інших країн. 


\section{SECTION 7. SOCIAL PEDAGOGY}

DOI 10.46299/ISG.2021.MONO.PED.III.7.1

7.1 Роль освітнього компоненту у ветеранських центрах для забезпечення процесу реінтеграції учасників бойових дій до цивільного життя

Ескалація конфлікту на сході України приводить до постійного збільшення учасників бойових дій в країні, що в свою чергу викликає нову проблему для суспільства - психологічну та соціальну реінтеграцію учасників бойових дій у цивільне життя.

Успішна реінтеграція учасників бойових дій у цивільне життя важлива не лише для самих ветеранів, а і для усього суспільства в цілому. Адже, у разі не забезпечення належних умов для реінтиграції, існує ризик маргіналізації цієї соціальної групи, що може призвести до різних проявів девіантної поведінки. Агресивна поведінка, наркоманія, алкоголізм, самогубства, радикалізація це лише поверхневі прояви маргіналізації які все частіше будуть повторюватися.

Варто зауважити що соціальна прірва, яка сьогодні існує між ветеранами та цивільними суспільством, може спричинити хаос у багатьох регіонах.

Нажаль, сьогодні в Україні не в повному обсязі реалізовані програми реабілітації учасників бойових дій на державному та місцевому рівні. Для успішної реінтеграції мають тісно взаємодіяти, як один механізм, такі структури:

- Міністерство ветеранів - одним із пріоритетних завдань це створення єдиної бази учасників бойових дій, інформування структур які забезпечують реінтеграцію о потребах цієї соціальної групи.

- Органи соціального захисту, які займаються питаннями матеріального забезпечення i правового захисту учасників бойових дій та членів їх сімей.

- Органи охорони здоров’я.

- Служба зайнятості, головним завданням якої в процесі реінтеграції учасників бойових дій має стати сприяння у працевлаштуванні, а також 
взаємодія у вирішенні питань професійної підготовки та перепідготовки учасників бойових дій.

- рромадські організації, цільовою аудиторією яких є учасники бойових дій та члени їх сімей. Саме громадські організації відіграють ключову роль в процесі реінтеграції учасників бойових дій. Адже вони є добре проінформованими у соціальних потребах і проблемах ветеранської спільноти.

- Спеціалісти профільні фахівці та викладачі, які забезпечують процес реінтеграції учасників АТО/ООС.

Із-за постійного збільшення бенефіціарів, деякі функції по забезпеченню соціальних прав гарантованих державою для учасників бойових дій, беруть на себе громадські організації.

Відповідно до ст. 1 Закону України «Про громадські об’єднання», поняття «громадські організації» визначено як добровільне об'єднання фізичних осіб та/або юридичних осіб приватного права для здійснення та захисту прав і свобод, задоволення суспільних, зокрема економічних, соціальних та інших інтересів певної соціальної групи [517].

Останнім часом з’являються дослідження присвячені вивченню процесу реінтеграції учасників бойових дій в Україні. Загалом реінтеграцію вбачають як процес адаптації та пристосування до умов ринку праці шляхом професійної перепідготовки. Різні аспекти працевлаштування колишніх військовослужбовців розкриті в дослідженнях А.Л. Красильщикова [515], Абрамова С.В. [512], О.О. Буряка М.І. Гіневського [513].

Заходи які сьогодні направлені на реінтеграцію учасників бойових дій є недостатніми. Загалом вони полягають у формі державних соціальних виплат i пільг. Однією із важливих проблем яка сьогодні існує у процесі реінтеграції учасників бойових дій - труднощі у працевлаштуванні.

Пов’язано це 3 несприятливою економічною ситуацією в країні та упередженим ставленням роботодавців до колишніх ексботантів. Цивільна робота та задоволення від неї відіграє важливу роль у реінтеграції 
учасників бойових дій та має надати нові цілі в житті, а також допомогти призвичаїтись до мирних реалій.

Варто зауважити, що успішна реінтеграція - це певною мірою індивідуальний процес. I механізм цього процесу варто виробити з урахуванням потреб громади де проживає ветеран бойових дій. Адже кінцева мета реінтеграції це мирна взаємодія ycix членів громади.

У той же час реінтеграція - це особистий досвід, і кожен окремий ветеран несе відповідальність за пошук свого місця в мирному житті. Якщо їм надають умови для успішної реінтеграції, ветерани мають хороші стартові позиції стати рушієм змін на краще в своїх громадах [514].

Сьогодні громадські організації спроможні використовувати виділені з державного та місцевих бюджетів кошти для надання соціальних послуг набагато раціональніше та навіть надавати деякі послуги безкоштовно.

Недержавні суб’єкти, що надають соціальні послуги в порівнянні 3 територіальними центрами, іншими державними соціальними закладами $\epsilon$ більш динамічними, гнучкішими та швидшими в реагуванні на індивідуальні потреби учасників бойових дій.

Протягом останніх років, громадські організації реалізують цілу низку інноваційних проектів, пов'язаних 3 наданням соціальних послуг, підвищенням рівня професіоналізму соціальних працівників, інших фахівців, що надають соціальні послуги. У громадських організацій існує велика мотивація у наданні допомоги та підтримки своїм побратимам.

Саме з метою допомоги та підтримки побратимів, сприянню консолідації та координації учасників бойових дій, їх сімей, створення належним умов для повноцінно реабілітації, допомоги у працевлаштуванні, наданню медичної, оздоровчої, психологічної допомоги членам громадської організації, інвалідам бойових дій, та членам сімей загиблих учасників бойових дій, перекваліфікація та допомога у працевлаштуванні, а також налагодження відносин між цивільним населенням та ветеранами, на базі громадських організацій створюються ветеранські простори. 
Ветеранський простір - це установа соціального захисту, діяльність якої спрямована на підтримку та відновлення здоров'я, повернення до активного повноцінного життя та інтеграцію у суспільство, зміцнення/відновлення родинних та суспільно-корисних зв'язків осіб, які брали участь в антитерористичній операції, операції об'єднаних сил по відсічі і стримування збройної агресії Російської Федерації в Донецькій та Луганській областях, та членів сімей загиблих та померлих осіб, які брали участь в антитерористичній операції, учасників бойових дій.

Ідея реабілітації колишніх воїнів, через спеціально пристосовані заклади у світовій практиці не нова - наприклад у Ізраїлі життя ветеранів збройних сил, які отримали інвалідність, забезпечується завдяки співпраці уряду та Beit Halochem - міжнародної мережі закладів допомоги в результаті участі у воєнних конфліктах. Великі центри площею від 5,500 до 10,000 квадратних метрів надають ветеранам та членам їхніх родин послуги фізіотерапії, гідротерапії та реабілітації. Окрім тренажерних залів і басейнів, такі центри пропонують низку освітніх та культурних заходів, а також творчих майстерень. Мережа центрів існує за підтримки неприбуткових організації різних країн, а також спеціального Відділу реабілітації при Міністерстві оборони. Щорічно колишні учасники бойових дій мають можливість отримати академічну стипендію для навчання. Подібна практика існує і у США, Канаді та інших країнах.

Сьогодні в Україні немає єдиної моделі ветеранського простору. У різних містах центри об лаштовані по-різному. Але є подібна концепція: психологічні та юридичні консультації, залучені викладачі які проводять тренінги та забезпечують переорієнтацію учасників бойових дій. На сьогодні такі простори діють у Києві, Одесі, Хмельницькому, Вінниці, Харкові, Рівному, Дніпрі та у деяких невеликих містах України.

Постійне збільшення кількості учасників бойових дій та членів їх сімей у країні, збільшення їхніх потреб, призвели до необхідності гідного забезпечення та розширення програм пов'язаних не лише з реабілітацією учасників бойових 
дій, а і їх перекваліфікацією на ті професії які є затребуваними саме в громаді ветерана.

Допомога у перекваліфікації або проходження корисних курсів та тренінгів є основою успішної трудової діяльності у майбутньому цивільному житті, а також гарантією що ветеран буде працювати на благо своєї громади.

Забезпечення на гідному рівні освітнього компоненту $є$ успішною запорукою реінтеграції учасників бойових дій у цивільне життя.

Освітній компонент у ветеранському просторі здатен забезпечити у перспективному плані розвитку процес демократизації та розбудови громадянського суспільства, розвитку соціальної сфери а також постійного підвищення якості життя громадян України.

Для успішної реалізації освітніх напрямків роботи в ветеранських просторах мають бути залучені фахівці різного профілю з закладів професійної та вищої освіти, які будуть кваліфіковано надавати свої послуги.

«Ветеранський простір»- відкритий для усіх, незалежно від здібностей, віку та професії. Залучення цивільних викладачів у таких центрах буде переслідувати не лише освітню мету: викладачі зможуть краще пізнати ветеранську спільноту, що в свою чергу ветеранам допоможе швидше інтегруватися до соціуму.

Варто зауважити, що професійна реінтергація це не лише адміністративно скорегований державою процес формування освітньопрофесійної сфери набуття чи відновлення навичок, необхідних для опанування професій, які мають найбільший запит на сучасному ринку праці, а i механізм підвищення існуючої виробничої кваліфікації учасника бойових дій.

Сьогодні в Україні згідно ст.12 Закону України «Про статус ветеранів війни, гарантії їхнього соціального захисту», ветерани мають право на освітні пільги. Існує дві пільгові категорії:

Перша - це безпосередньо учасники бойових дій, особи 3 інвалідністю внаслідок війни та постраждалі учасники Революції Гідності, незалежно від їхнього віку. Порядок віднесення особи до відповідних категорій регулюється 
Розділом II вищезгаданого Закону, а також відповідними актами Кабінету Міністрів України (КМУ) (наприклад, Постановою КМУ «Деякі питання соціального захисту постраждалих учасників Революції Гідності» від 28 лютого 2018 p. №119)

Друга - діти осіб, які належать до вищевказаних категорій (включаючи дітей 3 сімей учасників добровольчих формувань) а також діти, один з батьків яких загинув/помер внаслідок участі в АТО або ООС; діти, які мають статус ВПО, а також ті, які проживають на лінії зіткнення. Особи, які належать до цієї категорії мають право на освітні пільги до досягнення ними 23 років [516].

Важливим моментом в процесі реінтеграції учасників бойових дій $\epsilon$ створення або пошук відповідних робочих місць з боку держави для цієї категорії громадян. Якість і конкурентоспроможність робочої сили багато в чому залежить від того, згідно яких критерій були обрані особою професія і місце роботи, чи відповідають вони його схильностям і здібностям.

Варто зауважити що для учасників бойових дій заробітна плата як винагорода за працю, не відіграє першочергової ролі. Серед цієї соціальної групи існує інша першочергова мотивація до праці.

Серед учасників бойових дій є багато молоді, які до участі у конфлікті не встигли отримати професійну освіту. Така категорія потребує $\begin{array}{lllll}\text { iндивідуалізованого підходу } & \text { в }\end{array}$ напрямку. Тому правильний вибір молодою людиною конкретної професії $\epsilon$ досить складним мотиваційним процесом. При свідомому виборі професії людина орієнтується на наявні у нього соціальні цінності. Головною мотивацією у виборі професії, $\epsilon \quad$ ступінь $\quad$ відповідності $\quad$ трудової діяльності здібностям і схильностям особистості. Одні й ті самі схильності і здібності можна реалізувати в різних професіях.

Важливе значення під час навчання учасників бойових дій, має місце навчання та психологічний клімат у якому відбувається навчання. Саме тому, ми пропонуємо щоб таке навчання мало відбуватися на базі ветеранських просторів. 
Професійні викладачі, які підготовлені до професійного навчання учасників бойових дій зможуть виконати подвійну функцію: сформувати певні професійні навички та створити психологічно сприятливі умови для реінтеграції учасників бойових дій.

Повністю підтримуємо думку дослідника Шумейко А.П., у тому що дезінтегрованність спеціаліста на шляху до подолання суб'єктивних психологічних бар'єрів у ветерана неминуче призведе до невдач чи низької результативності. Саме тому, залучення викладачів до освітнього процесу, на базі ветеранських просторів, має проводитись виключно 3 урахуванням освіти, досвіду та певних навичок щодо роботи з ветеранською спільнотою [518].

Багато дослідників вважають за потрібне для перекваліфікації колишніх воїнів залучати військових спеціалістів, і запроваджувати освіту по принципу «рівний рівному». Ветеранські простори мають стати тим місцем в яких генеруються знання, та нові соціальні зв'язки.

Виходячи із зазначеного можна зробити висновок що успішна реінтеграція учасників бойових дій у суспільство потребує комплексного підходу і взаємодії державних і недержавних структур. Важливою складовою є освітній компонент, забезпечити який здатні висококваліфіковані фахівці, які спроможні працювати з ветеранською спільнотою, та мають певні професійні навички. 
DOI 10.46299/ISG.2021.MONO.PED.III.7.2

\section{2 Об'єктивні та суб'сктивні ризики професійного вигоряння фахівця соціальної сфери}

У найбільш загальному вигляді життєдіяльність людини пов’язана 3 сімейною сферою та професійною зайнятістю. Особливе місце займає сфера професійної діяльності, яка є визначальним фактором соціалізації, добробуту, самопочуття. Нераціональний підхід до організації роботи часто призводить до професійного вигоряння. Особливо це є актуальним, коли має місце робота психологічного характеру з людьми. Наслідками такого перенапруження можуть бути проблеми з фізичним і психічним здоров’ям. Соціальна, соціальнопедагогічна, соціально-психологічна діяльність має зазначені ризики.

Якщо підходити до поняття професійного вигоряння, то в узагальненому вигляді [519, с. 40; 520, с. 12] можна констатувати його як неспроможність виконувати професійні обов'язки на належному рівні внаслідок тривалого фізичного та/чи психічного перевантаження. Основною метою профілактики професійного вигоряння є забезпечити дотримання індивідом норм у ставленні до себе і свого здоров’я, передбачених можливостями суспільного укладу і відносин.

Констатується, що особи, які пережили стан професійного вигоряння, мають певні відмінності у поведінці. Вони стають замкненими в собі, віддаленими від суспільних реалій. Іноді це набуває характеру дивакуватості, надмірної агресивності, ексцентричності. Опосередкований негативний вплив полягає в тому, що не реалізуються здібності, задатки людини. Протидії цьому немає через відсутність впливу формальних колективів, формування культури міжособистісних стосунків, розвиток позитивних нахилів, здібностей, інтересів [521, с. 39]. Інформаційне перенасичення, психологічна перевтома людини й перевантаження складають основу погіршення психічного, тому i зростає актуальність профілактики таких негативних явищ.

Констатація факту професійного вигоряння свідчить про неправильно визначені особистісні цінності як орієнтири життєдіяльності людини. Оскільки 
особистісні цінності формуються на основі соціальних, зроблено такі узагальнення щодо їх сутності та значення: це соціальний феномен, який існує в діалектичному сенсі суб'єкт-об'єкт, важливий фактор, що стимулює поведінку й вчинки особи та соціальних груп; цінності визначають ставлення людини до світу, самої себе, спрямовують їі розвиток [522, с. 171-173]. Життя людини та їі здоров’я визначено як найголовніші суспільні цінності. І особливо це стосується професійного вигоряння відповідно до динамічних умов суспільного розвитку, коли існують екологічне забруднення, відсутність фізичної активності як фону для фізичного здоров’я людини.

В основі профілактики має бути здатність обрати певну лінію поведінки, самостійно формулювати моральні обов’язки, вимагати від себе їх виконання, здійснювати самооцінку, самоконтроль [523, с. 18]. Зазначається багатоаспектність профілактики: «Якщо ми хочемо попередити відхилення у розвитку й поведінці особистості, то повинні перш за все створити такі умови, при яких охоплено було би всі сторони життєдіяльності, що є невіддільною частиною всього буття соціуму, проникнення в усі сфери суспільних відносин» [524, с. 41]. Отже, профілактику професійного вигоряння (попередження, запобігання) варто розглядати як цілеспрямований процес організації i здійснення комплексу профілактичних заходів, спрямованих на забезпечення соціально-психологічного розвитку i життєдіяльності [525, с. 212]. Суб’єктивність профілактики полягає у ціннісному орієнтуванні індивіда або ж у дотриманні соціальних норм, що відповідають соціальним цінностям. Це має бути основою підходу до професійної діяльності, а у профілактиці професійного вигоряння це передбачає визначення такої лінії поведінки, яка б забезпечила високий рівень життєдіяльності.

Професійне вигоряння є наслідком порушення норм поведінки. Критеріями відхилень від норми виділяють: а) статистичний (норма для будь-якого явища шляхом підрахунку частоти, 3 якою вона зустрічається); б) якісно-кількісна оцінка поведінки (за ступенем вираження та рівнем загрози для життя); в) психопатологічний (медичний); г) соціально-нормативний (рівень соціальної 
адаптації індивіда) [520, с. 11]. Причиною професійного вигоряння може бути і гіпервідповідальність людини як члена колективу. Вирізняють чотири типи відповідальності: інтегральну (загальнолюдські норми і вимоги суспільства стали для індивіда особистісно значущими), групову (орієнтація на референтну групу, на досягнення вузькогрупових цілей), вузькоособисту (орієнтовану на особисті, корисливі інтереси), невизначену (або несправжню, удавану). Аналогічно до типів соціальної відповідальності, вирізняють чотири групи асоціальної [521, с. 3]. У такому ракурсі необхідно розглядати зв'язок віктимної і девіантної поведінки [526, с. 109]. Тобто професійне вигоряння залежить передусім від відповідального ставлення до себе самого суб'єкта професійної діяльності.

Причини професійного вигоряння можна диференціювати за характером детермінації:

•серед детермінант, що впливають на ставлення до себе і професійної діяльності, виділяють ті, що лежать в основі статевого диморфізму, стану здоров'я, самопочуття, захворювань, зокрема, враховуються деякі біологічні чинники, які можуть негативно впливати на психіку, що призводить до неадекватної поведінки [527, с. 115];

•широке коло проблем викликає екологічне забруднення навколишнього середовища; це має наслідки у погіршенні фізичного, а відтак і психічного здоров’я, підвищенні агресивності, зниженні впевненості у собі, підвищенні рівня тривожності, кількості пережитих стресів та посиленні дії стресових чинників (є свідчення про дезадаптаційний вплив погіршення співвідношення екологічної якості міського середовища з біологічними потребами людини [528, c. 22];

•серед психологічних детермінант, що призводять до професійного вигоряння, називають агресію, агресивність у стосунках людей; різні підходи до пояснення агресивності аналізує Охрімчук Р. [526, с. 4-7].

Фахівці соціальної сфери - це переважно жінки. Оскільки сьогодні особи жіночої статі дедалі частіше заявляють про свою рівноправність, на них 
покладено багато обов'язків і вдома, і на роботі. Проте це часто приводить до психічного перевантаження людини і прояв неврозів.

Щоб уникнути відхилень, потрібно вміти регулювати свої бажання, породжені суспільною думкою, й можливості, які дає нам фізичний та/чи психічний ресурс організму. Соціальна стратифікація, що панує у суспільних відносинах, створює перенапруження, коли людина прагне досягти більшого дорогою ціною здоров’я. Окрім того загальновідомо, що рівень навантаження неоднаковий серед різних вікових груп населення, чоловіків і жінок, людей різних професій.

Нами проведено анкетування серед фахівців соціальної сфери щодо стану професійного вигоряння серед них. Взято до уваги відповіді 22 респондентів, які працюють на посадах в органах державної виконавчої влади і місцевого самоврядування (м. Тернопіль, Тернопільська область). У табл. 1 наведено статистичні дані стосовно факторів впливу на професійне вигоряння фахівця, а також їх динаміка.

Таблиця 1

Фактори і динаміка впливу на професійне вигоряння (за свідченнями фахівців соціальної сфери)

\begin{tabular}{|c|c|c|c|}
\hline Професійні компоненти & $\begin{array}{c}\text { Значний вплив } \\
(\boldsymbol{\%})\end{array}$ & $\begin{array}{c}\text { Посередній } \\
\text { вплив } \\
(\boldsymbol{\%})\end{array}$ & $\begin{array}{c}\text { Незначний } \\
\text { вплив } \\
\mathbf{( \% )}\end{array}$ \\
\hline $\begin{array}{c}\text { Характер } \\
\text { роботи }\end{array}$ & 21,2 & 42,0 & 36,8 \\
\hline $\begin{array}{c}\text { Терміни виконання } \\
\text { професійних обов'язків }\end{array}$ & 42,6 & 34,6 & 22,8 \\
\hline $\begin{array}{c}\text { Внутрішньо- колективні } \\
\text { стосунки }\end{array}$ & 63,4 & 21,4 & 14.8 \\
\hline $\begin{array}{c}\text { Професійна здатність } \\
\text { виконувати обов'язки }\end{array}$ & 63.4 & 12,6 & 23,0 \\
\hline
\end{tabular}

Наведені статистичні дані переконують у тому, що внутрішньо колективні стосунки й здатність виконувати професійні обов'язки мають найбільш вплив на психоемоційний стан особи та рівень іiі професійного вигоряння. Це засвідчує, що мають значення як соціально-організаційна, так і психолого-педагогічна складова профілактики. 
Отже, в основі професійної діяльності має бути забезпечення умов для цього. Проте колективна співпраця, крім того, що має переваги, наділена й негативними рисами. У табл. 2 представлено ті показники колективного неблагополуччя, що безпосередньо впливають на професійне вигоряння індивіда як члена колективу.

Таблиця 2

Порівняльний аналіз показників колективного неблагополуччя, що мають вплив на професійне вигоряння

\begin{tabular}{|c|c|c|c|}
\hline $\begin{array}{l}\text { № } \\
\text { 3/II }\end{array}$ & Показники & $\begin{array}{c}\text { Особи, які не } \\
\text { зазнали } \\
\text { професійного } \\
\text { вигоряння } \\
\text { (\%) }\end{array}$ & $\begin{array}{c}\text { Особи, які } \\
\text { пережили } \\
\text { стан } \\
\text { професійного } \\
\text { вигоряння } \\
\text { (\%) }\end{array}$ \\
\hline 1.1. & $\begin{array}{l}\begin{array}{l}\text { Проблеми } \\
\text { культури }\end{array} \\
\end{array}$ & 16,7 & 65,3 \\
\hline 2.2 . & $\begin{array}{l}\text { Невдоволеність психологічною атмосферою, яка } \\
\text { панує в колективі }\end{array}$ & 42,5 & 88,8 \\
\hline 3.3 . & $\begin{array}{l}\text { Наявність конфліктних ситуацій, сварок, } \\
\text { інтриганства }\end{array}$ & 15,4 & 92,2 \\
\hline 4.4 . & $\begin{array}{l}\text { Відсутність чи проблеми міжособистісного } \\
\text { спілкування в колективі, поділ на групи }\end{array}$ & 25,8 & 74,9 \\
\hline 5.5 . & $\begin{array}{l}\text { Низький рівень взаємодопомоги і підтримки, } \\
\text { небажання підтримувати дружні стосунки }\end{array}$ & 34,2 & 86,3 \\
\hline 6.6 . & $\begin{array}{l}\text { Відсутність покарань за провини, реагування на } \\
\text { негативну поведінку колег, контролю за } \\
\text { суб’єктивними чинниками }\end{array}$ & 30,1 & 96,0 \\
\hline 7.7. & Відсутність перспектив розвитку колективу & 14,8 & 67,7 \\
\hline 8.8 . & $\begin{array}{l}\text { Відсутність умов особистісного розвитку й } \\
\text { формування }\end{array}$ & 45.8 & 95,5 \\
\hline 9.9. & $\begin{array}{l}\text { Відсутність заходів профілактики професійного } \\
\text { вигоряння }\end{array}$ & 33,4 & 77,5 \\
\hline
\end{tabular}

Так, особи, які пережили стан професійного вигоряння, мають значно глибші психоемоційні порушення. Їхній професійний досвід характеризується значними негативним досвідом й переконаннями. У їхньому житті зазнали деформації позитивні корпоративні соціальні зв’язки, що може призвести до відхилень в інших сферах: сімейній, особистісній, духовно-емоційній. Тобто це викликає і інші деформації. Названі компоненти рівноваги становища особи базуються на відсутності єдиної основи - тепла, любові, уваги, турботи, 
підтримки, піклування, взаєморозуміння. Не знайшовши їх, людина черствіє, стає байдужою не тільки до своїх проблем, переживань, а й до відчуттів інших людей.

Втрата життєвих орієнтирів, відсутність позитивних емоцій, душевна черствість з часом стають постійними, деформуючи особистість, роблячи iㅣ поведінку якщо не соціально небезпечною, то неадекватною. Компенсацією позитивних емоцій у життедіяльнтості часто стають адиктивні прояви. Такі, як пияцтво, алкоголізм, тютюнопаління, інтернет-залежність, комп’ютерна залежність та інші види адикцій. У табл. 3 наводимо статистичні дані щодо оцінювання наявних ризиків професійного вигоряння фахівцями різних соціальних структур для порівняння.

Таблиця 3

\section{Розподіл відповідей фахівців соціальної сфери}

щодо оцінювання наявних ризиків професійного вигоряння

\begin{tabular}{|c|c|c|c|c|}
\hline \multicolumn{5}{|c|}{ Фахівці соціальної сфери } \\
\hline $\begin{array}{c}\text { Працівники } \\
\text { центру } \\
\text { соціальних } \\
\text { служб } \\
(\%)\end{array}$ & $\begin{array}{c}\text { Працівники } \\
\text { відділу } \\
\text { у справах сім'i } \\
\text { та молоді } \\
(\%)\end{array}$ & $\begin{array}{c}\text { Працівники } \\
\text { служби у } \\
\text { справах } \\
\text { дітей } \\
(\%)\end{array}$ & $\begin{array}{c}\text { Працівники } \\
\text { центру } \\
\text { зайнятості } \\
\text { населення } \\
(\%)\end{array}$ & $\begin{array}{c}\text { Педагоги } \\
\text { загально } \\
\text { освітньої } \\
\text { школи } \\
(\%)\end{array}$ \\
\hline 18 & 21 & 20 & 26 & 24 \\
\hline 55 & 58 & 64 & 48 & 54 \\
\hline 22 & 21 & 8 & 24 & 22 \\
\hline 5 & - & - & 2 & - \\
\hline- & - & 8 & - & - \\
\hline
\end{tabular}

Як видно $з$ табл. 3: майже всі, крім 8 осіб, визнали факт професійного вигоряння різного ступеня; переважна більшість респондентів оцінює здатність виконувати професійні обов'язки переважно добре, проте відсутність абсолютної відповіді також свідчить про наявні ризики; переважною мірою наявність ризиків професійного вигоряння оцінюють посередньо.

Очевидно, що професійне вигоряння зумовлене різними факторами, серед яких на основі опитування, статистичних даних, експертного оцінювання проведеного експериментального дослідження можна виділити такі: соціальні й організаційні умови функціонування колективу, законодавче й нормативно- 
організаційне забезпечення процесу праці; індивідуальні та особистісні якості особистості, стресостійкість, мотивація діяльності; відповідність якостей і рис особистості вимогам обраної професії, професійна компетентність; здатність працювати у колективі, вміння враховувати думки i позиції інших, комунікабельність; наявність життєвого, професійного досвіду; психологічна сумісність окремих членів колективу; вміння контролювати ситуацією в колективі з боку керівництва; корпоративна культура, наявність спільних інтересів і заходів, зацікавленість у розвитку й процвітанні колективу.

Теоретичний аналіз й експериментальне дослідження проблем, що стосуються професійного вигоряння, свідчать про наявність ризиків у професійній діяльності фахівців різних соціальних структур. Тобто, це залежить як від об'єктивних факторів (суспільні негаразди), так і від суб'єктивного ставлення індивіда до себе і свого психічного та фізичного здоров'я: від того, як налаштовує себе фахівець, його мотивація і вміння організувати правильно себе, свій життєвий простій, свою діяльність.

Надалі варто приділити увагу тому, що це проблема не стільки суспільна, колективна, а індивідуальна. Потребують теоретичного аналізу й практична перевірка діагностичного інструментарію, ефективності заходів профілактики стосовно професійного вигоряння індивіда. 


\section{SECTION 8. THEORY, PRACTICE AND TEACHING METHODS}

DOI 10.46299/ISG.2021.MONO.PED.III.8.1

\subsection{Application of modern teaching methods in distance education}

The purpose of this work was to study the theory and methods of teaching disciplines in natural sciences and training of health professionals and the development of teaching methodology for students of higher pharmaceutical education in Ukraine in conditions of distance learning.

Today requires special conditions for the training of pharmacists who can work effectively in the dynamic conditions of modern reality [529]. This is due to the progress of world pharmaceutical and medical science, the rapid increase in the number of drugs, increasing requirements for quality control of drugs, as well as changes in the economic, legal and educational space [530].

The modern learning process combines a great variety of didactic techniques and methods. This allows the representative of education to qualitatively increase the effectiveness of students' learning material, visually reveal interdisciplinary links, activate and individualize the learning process, form and develop competencies provided by the objectives of the study profile [531-532].

Information educational resources create convenient and attractive conditions for attracting students of higher education institutions to the educational space and improve the effectiveness of learning the necessary material in disciplines, both training and general. [533].

Teachers of the Department of Analytical, Physical and Colloid Chemistry proposed an algorithm for compiling the structure of the discipline and the working curriculum for academic disciplines, taking into account distance learning.

In general, the working curriculum of academic discipline is a normative document that defines the content, scope, structure of the educational process for studying a particular academic subject, based on the state educational standard and exemplary curriculum on the recommended subject by education authorities. The main 
purpose is the planning, organization, correction of the educational process, management of the educational process for the study of the discipline [534].

The authors [535] identify the following subprocesses in compiling the curriculum of academic discipline:

1. Creating a work program passport.

2. Determining the results of mastering the course.

3. Describing the content of the work program.

4. Establishing the conditions for the implementation of the work program.

5. Defining methods for evaluating the results of the course.

In addition, the features of the elective curriculum were considered - it contains a large and significant amount of information in a relatively short period of time, as well as a focus on the basic and most striking concepts of the course. These tasks are especially difficult to perform for a theoretical discipline. This is due to the difficulty of perceiving the basic theoretical materials without practical consolidation. After all, theoretical courses usually consist of lectures and seminar lessons, where students can discuss various issues and solve complex situational problems. Although the practical lesson is a common type of science lessons, which is conducted under the guidance of a teacher and aimed at deepening scientific and theoretical knowledge and mastering certain methods of independent work. Therefore, in the process of such classes are formed practical skills (calculations, use of tables, reference books, etc.). However, the seminar is a lesson in the theoretical discipline, in which students acquire the ability to compose abstracts, learn to take notes on primary sources, orally present material, as well as defend scientific theses and conclusions. Therefore, seminars cannot completely fill the lack of practical skills. Therefore, the curriculum for such a discipline should contain structural blocks based on both case-study methods [536] and game methods [537].

Compilation curriculum of the elective discipline in the context of distance education creates new serious problems, but provides additional opportunities. For example, class discussion will be replaced by online conferencing using various programs (Zoom, Skype, Google Meeting) and information technology. Such a 
replacement can lead to a lack of full contact with students for a number of reasons (including poor Internet quality).

Thus, the main problem of distance learning is to create opportunities for the organization of the modern educational process at the full-time level. Distance learning should contain all the necessary factors that shape learning. Yes, the problem of communication with the teacher and students among themselves, conducting discussions, in other words, providing effective feedback is becoming relevant.

One of the most important problems facing the generally accepted model of distance education is the so-called transactional distance, which arises due to the lack of proper communication between student and teacher. Therefore, if there is no connection between the student and the teacher, this gap becomes larger. This factor affects the learning process and its quality. Today, various strategies, techniques and procedures are widely used to increase the interaction between students and teachers. Activities such as personal textbooks and the wider use of information and communication technologies, including teleconferencing and the Internet, are most commonly used [538].

In this paper, we propose certain algorithms to maintain quality and effective communication between student and teacher in distance learning. We offer to consider some classic examples of communication support [539].

1. Lesson - lecture. A modern lecture should be interactive and dynamic. It should not burden students in time. Thus, recording video lectures becomes the optimal choice for distance learning.

You can create discussion posts via social networks or mobile applications to keep in touch with the discussion material.

But in our opinion, creation "play modes" will be more effective activities. Interective modes are best suited for self-study or homework, because it allows your students to work on their own. Teachers can also use this play mode in the classroom if they have a projector: teachers'll elicit responses from students for each question, and input one of them. Such a lecture will be like an interactive game. Where students will have to answer interesting questions right in the middle of the lecture. 
2. Practical or seminar classes.

This type of activity allows closer contact with the classroom. Such classes can be held in conference programs. Communication should be maintained not only in the classroom, but also in non-class time. Here you can also turn to social networks or mobile applications for communication.

However, the most important thing for these types of classes is to create a learning space for students in non-classes. It is obvious that proper control of students' work and assessment of their knowledge should be created. In this case, it is interesting to create online tests or online quizzes.

Figure 1 illustrates the basic building blocks of effective online learning.

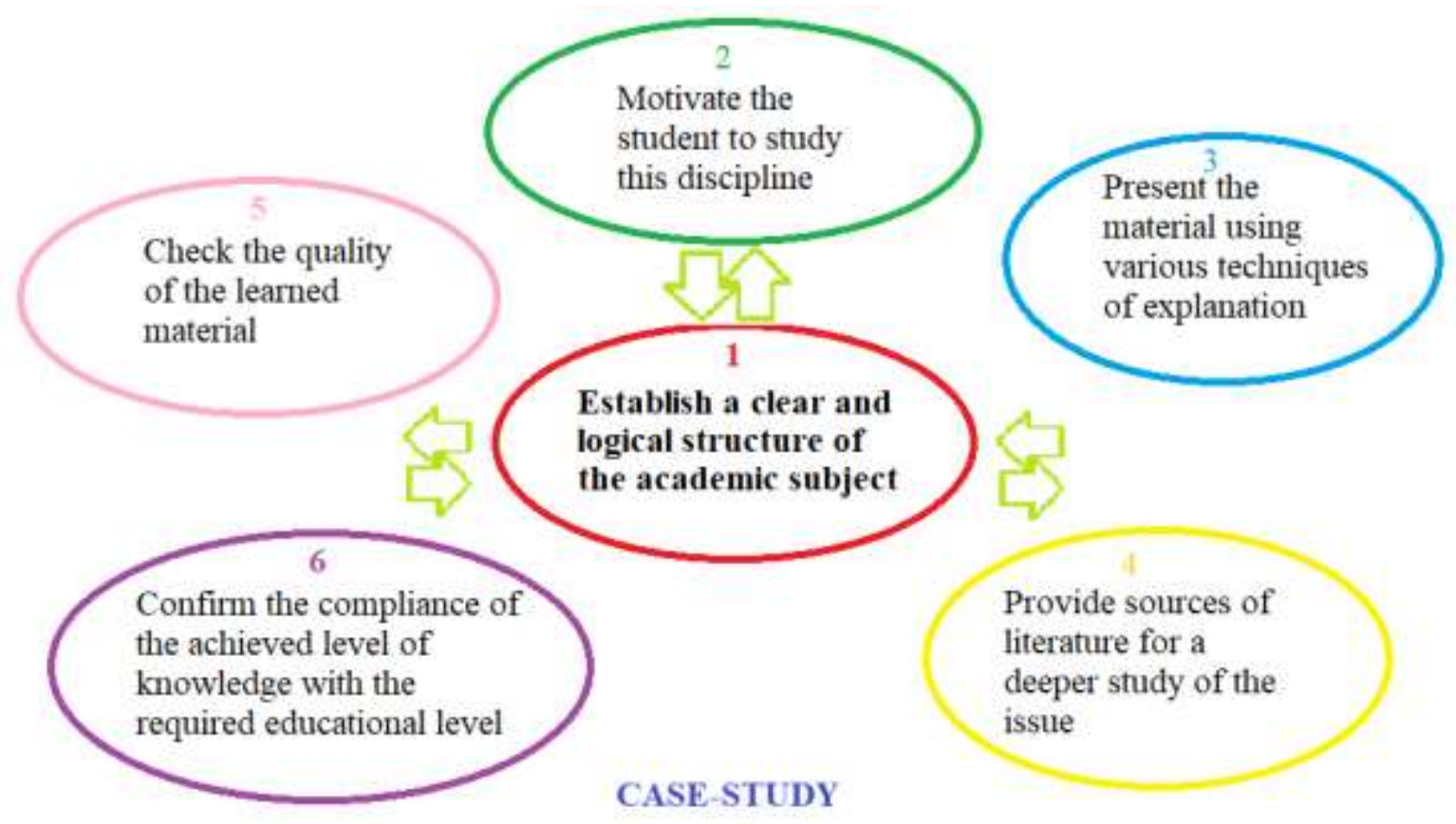

Figure 1. Algorithm for creating effective education [537]

In addition to the listed disadvantages of online classes, it can allow students and teachers to take full advantage of the Internet (interactive tests, games, online video and podcasts, etc.). It should be noted that the successful use of interactive tests created on the Quizzes platform. Figure 2 illustrates the use of interactive tests for teaching disciplines at the Faculty of Pharmacy at the Department of Analytical, Physical and Colloid Chemistry. 


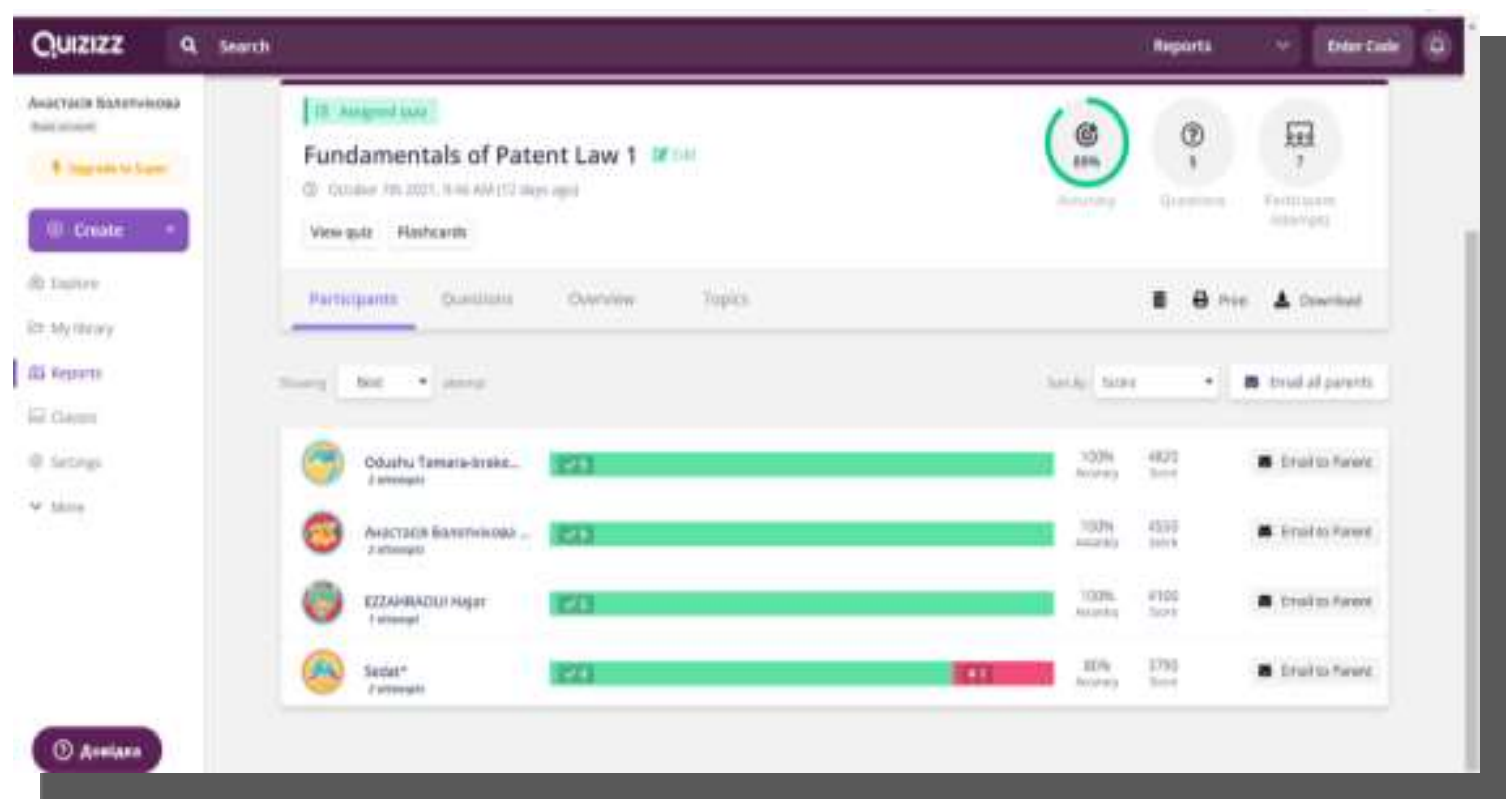

Figure 2. Fragment of interactive testing on the Quizizz platform (elective course "Fundamentals of Patent Law").

The solution to many of the problems associated with distance or blended learning is to conduct "flipped" lessons. Therefore, "flipped" lessons are very relevant today. This term is no longer new [540], but has gained the most popularity over the past few years. So, the description of motivation and cognitive load in an inverted classroom [541], how we flipped the medical classroom [542], flipped physics [543], quantitative and qualitative evaluation of transforming to flipped-classroom [544] - all this the actual topics of today's flipped lesson.

Flipped classroom is an instructional strategy and type of blended learning that aims to increase student engagement and learning by completing reading at home and working on problem solving in real time during class [545]. In the "flipped" lesson, the focus is on the student and his brain activity. The teacher no longer gives him readymade answers to his own questions. Students work actively and ask questions themselves, and in the learning process they themselves answer them. Students can conduct data analysis or even entire research at home, and in the classroom only establish certain concepts and goals of the work. Conversely, what students in traditional teaching did at home, they can now do in class. For example, they can watch 
online lectures and discuss them in class, conduct various creative projects in groups or in the whole class. To plan such lessons, it is necessary to develop methodological materials of different levels and purposes, the so-called didactic support. These materials should provide for the possibility of control by both the student and the teacher.

Such classes form certain positive aspects in the student's life:

- $\quad$ Presence of real motivation

- Curiosity

- Using a systems approach

- $\quad$ Attentiveness

- Hard work, hard overcoming of their own laziness

- Gradual formation of the habit of self-learning

- $\quad$ Positive competitiveness

- $\quad$ Analytical thinking

- Independence

In addition, the inverted lesson is extremely convenient. Conversely, the student chooses a convenient time to study. After all, the main idea of such an approach to classes is the possibility of conducting them on the Internet. In this way, the main elements of the lesson can be viewed online at any convenient time. The model of such a lesson is aimed at obtaining a proper effective education and in-depth knowledge. In this way, the teacher solves another serious problem. Namely, training to obtain a final grade. After all, "flipped" lesson encourages students to understand the material, not just memorize it. So to speak, the student is experiencing the discipline, he (she) is interested and fascinated by it. The knowledge gained in this way remains extremely deep in human memory [546].

We offer our own model of a "flipped" lesson. This model can be applied to technical, mathematical, natural and even humanitarian disciplines.

1. Basis of your flipped lesson.

An online lecture can form the basis of our inverted lesson. In this lecture, the teacher only outlines the main points and principles of the topic, but does not cover all 
issues. Such lectures can usually last from 5 to 30 minutes. They are usually recorded. So students can listen to the lecture at any convenient time. The teacher should intend to present the material in such a way that the student can formulate specific questions. That is, it was not the teacher who directly asked the student questions and gave answers to them, but the student himself asked certain questions. This encourages the student to gain deeper knowledge, to show creativity.

0. $\quad$ Preliminary preparation

This stage exists for preliminary preparation of students for the lesson. It can include different types of assignments that will help expand the topic of the lesson. For example, a teacher may only sketch out a preliminary outline of an online lecture, while a student, in turn, may prepare a short message, a short summary, or a presentation on these theses. This active learning encourages students to think critically [546].

1. Information tool

By information tool, we mean some supporting materials for obtaining information.

So, after the main lecture, the student has a few questions. However, you must be able to answer them remotely. How? You must provide him with a complete list of trustworthy resources where the student can get answers. It doesn't have to be resources with superficial answers. The student must do some analytical work. However, if the mentor does not provide him with reliable resources, he may find unverified sources. So, the student can make a mistake and remember the wrong information.

2. Task which reinforces interest in the topic of the lesson

After the lecture, the teacher must formulate the task for the student. This task does not have to have a clear framework in terms of the form of presentation of the material or its volume. However, the answer to the assignment must clearly correspond to the content of the assignment and fully disclose it. At the same time, this task should be, as it were, a stimulus for answering the questions formulated after the lecture. So even uninterested students will be forced to delve deeper into the material. Examples of such assignments include:

- Creation of various projects. 
- Writing abstracts, messages, articles.

- Creation of presentation and report on it.

- $\quad$ Solving problems of increased complexity.

\section{Testing yourself}

At each stage of self-study and preparation for the lesson, the student must test himself. He (she) must understand whether he is doing everything correctly, whether he makes mistakes. Usually, this stage is quite difficult to achieve. However, the teacher can use some tricks to complete this step. For example:

- Online testing at the preparation stage.

This testing should not be created to evaluate students by teachers, but to test students themselves. This is an exclusively computerized test, where each question is formulated in such a way as to calculate possible mistakes and problems of students. The teacher creating this type of activity should try to predict all possible difficulties for students.

- Online discussions between students of one group or several groups.

This type of activity does not involve a teacher. However, it helps to improve mutual understanding between students and increase the level of knowledge on the subject.

- Online discussions between students and the teacher. This discussion is not a scheduled seminar required for all students. This is something like a consultation for those in need.

\section{Closing the topic. Demonstration of completed tasks}

This is the last, but not the last, part of our flipped class model. This part of the lesson can be conducted as a workshop, seminar or conference. It all depends only on the imagination of the teacher and students.

\section{Teacher control}

This is the last stage of the lesson. You can choose any type of control, depending on the topic of the lesson, the discipline itself, etc. It may be:

- $\quad$ answer to control or test questions;

- $\quad$ checking the abstract; 
- $\quad$ checking abstracts;

- $\quad$ verification of solved problems;

- verification of calculations;

- $\quad$ check of the executed graphic exercises and tasks;

- $\quad$ verification of completed individual tasks

"Flipped" classrooms will provide an opportunity for active learning and student engagement in a variety of hands-on activities such as individual assignments, discussion, debate, workshops, problem solving, and critical thinking. Through the proposed lesson model, the teacher can offer more personalized guidance and interaction with each student. This method helps prevent lacks in the material, provides a better understanding of the subject and, accordingly, higher productivity.

The curriculum of the optional theoretical course in distance learning in accordance with these aspects may have approximately the following educational components:

1. Lectures using the program for online meetings or recording video lectures.

2. Seminars that can be combined with different methods of studying specific cases (using different Internet resources) [547].

In addition, a detailed lesson plan is a crucial element of a successful and effective course.

Creating a reliable lesson plan is an important part of classroom management. This requires the ability to apply effective strategies for student learning. There are many different types of lesson plans and ways to create them. Teachers can encourage critical thinking in the group by creating plans in which all students participate. Visual strategies are another component of lesson plans that help with classroom management. The lesson is usually better if the teacher has planned it correctly, because it provides a lesson structure and discipline for students [548].

Summing up, it should be noted that the preparation of working curricula of the elective course for the theoretical discipline is based on several key points: 
1. Determining the amount of educational materials in accordance with the main objectives of the discipline and the interval of study of this subject, as well as research of relevant literature and reliable Internet sources.

2. Selection of a list of topics for the creation of this discipline.

3. Selection of optimal types of classes (lectures, seminars, practical classes).

4. Drawing up a rich thematic plan for all types of classes.

5. Creating exciting tasks and situational tasks using case studies methods (case method) and game methods.

6. Strengthening tasks and exercises for students with various opportunities of Internet resources and modern IT. Students should keep in mind that they need to prepare carefully for the seminar: read the seminar plan, study the recommended literature, make a short plan of presentation for each question. In preparation for the seminar, you usually need to review one or more literature sources: books, brochures, articles. Of course, acquiring the skills of summarizing while working with a book is extremely important, but the implementation of various creative projects in preparation for the seminar not only develops analytical thinking, but also strengthens the functions of memorization, which increases learning productivity.

7. Establishing clear provisions and criteria for assessing student responses.

8. Compilation of guidelines and special manuals for students.

9. Forming a thorough plan for each lesson to achieve effective learning outcomes [546].

Curriculum is a dynamic process. Development means changes which are systematic. A change for the better means any adjustment, revision or improvement of existing condition. To produce positive changes, development should be purposeful, planned and progressive. It will take years to evaluate if the curriculum is effective and attuned to the needs of the learners and the society [549].

Simultaneously with the development of the curriculum, teachers systematize and supplement the existing teaching material, as well as create new teaching resources. Educators should rely on a number of fundamental principles. The traditional components of the curriculum are: goals, objectives, learning strategies, 
topics of study, types of work, assessment, sources of material and number of hours [546].

On the basis of the created working curricula of the course the peculiarities of teaching elective courses were studied. Consider the following features on the example of the elective course "Fundamentals of Chemical Metrology", which is studied by students of the Faculty of Pharmacy by correspondence in the 2nd year in the 3rd semester. This discipline is studied by students of the Faculty of Pharmacy by correspondence 5.5 years of study and 4.5 years of study ("Medicine", "Pharmacy", second higher education); total students in 2020-2021 academic year - 399. 90 hours of full-time study are devoted to the course "Fundamentals of Chemical Metrology", of which: 3 hours - lectures (Table 1), 6 hours - seminars (Table 2) and 81 hours independent work. The form of control of learning success is a differential test [550].

Table 1.

Thematic Plan of Lectures

\begin{tabular}{|l|l|l|}
\hline № & Title of the lecture & $\begin{array}{l}\text { Number } \\
\text { of hours }\end{array}$ \\
\hline 1 & $\begin{array}{l}\text { Chemical metrology as a science. Subject of chemical metrology, } \\
\text { purpose, tasks, methods. Specifics of chemical analysis as a } \\
\text { metrological discipline. }\end{array}$ & 1 \\
\hline 2 & $\begin{array}{l}\text { General metrological characteristics of the analysis. Errors in } \\
\text { chemical analysis, their classification. }\end{array}$ & 1 \\
\hline 3 & $\begin{array}{l}\text { The main stages and sources of errors in chemical analysis. } \\
\text { Statistical analysis of a chemical experiment. }\end{array}$ & 1 \\
\hline
\end{tabular}


Table 2.

Thematic Plan of Seminars

\begin{tabular}{|l|l|c|}
\hline$№$ & Title of the seminar & $\begin{array}{c}\text { Number } \\
\text { of hours }\end{array}$ \\
\hline 1 & $\begin{array}{l}\text { Statistical processing and presentation of quantitative analysis } \\
\text { results (calculation of metrological parameters). }\end{array}$ & 1 \\
\hline 2 & $\begin{array}{l}\text { Estimation of permissible discrepancy of results of parallel } \\
\text { determinations (estimation of convergence). }\end{array}$ & 1 \\
\hline 3 & The main concepts of probability theory. & 1 \\
\hline
\end{tabular}

Due to the COVID-19 coronavirus pandemic, the educational process in the autumn-winter semester of 2020-2021 in the Bogomolets National Medical University was organized by a mixed (classroom-distance) form of education (NMU order № 439 of 19.08.2020). On the web resource neuron.nmuofficial.com, structured educational content was created to study the elective course "Fundamentals of Chemical Metrology" by students of the Faculty of Pharmacy by correspondence and its current assessment. Seminars were conducted with students online using Zoom technology according to the class schedule [551].

The content of the online course on the Neuron platform includes the necessary learning materials that allow students to master the main points of the content of the discipline, namely:

1) working curriculum;

2) methodical manual for seminars and independent work on the course "Fundamentals of Chemical Metrology";

3) methodical recommendations for independent work of students in preparation for seminars;

4) video content of lectures;

5) testing to assess the current activities of students.

In addition, an instructional and methodical map is proposed for each seminar, which specifies the sequence of actions of students to achieve the goal of the lesson. 
Figure 3 illustrates excerpts from the Fundamentals of Chemical Metrology course on the Neuron distance learning platform.

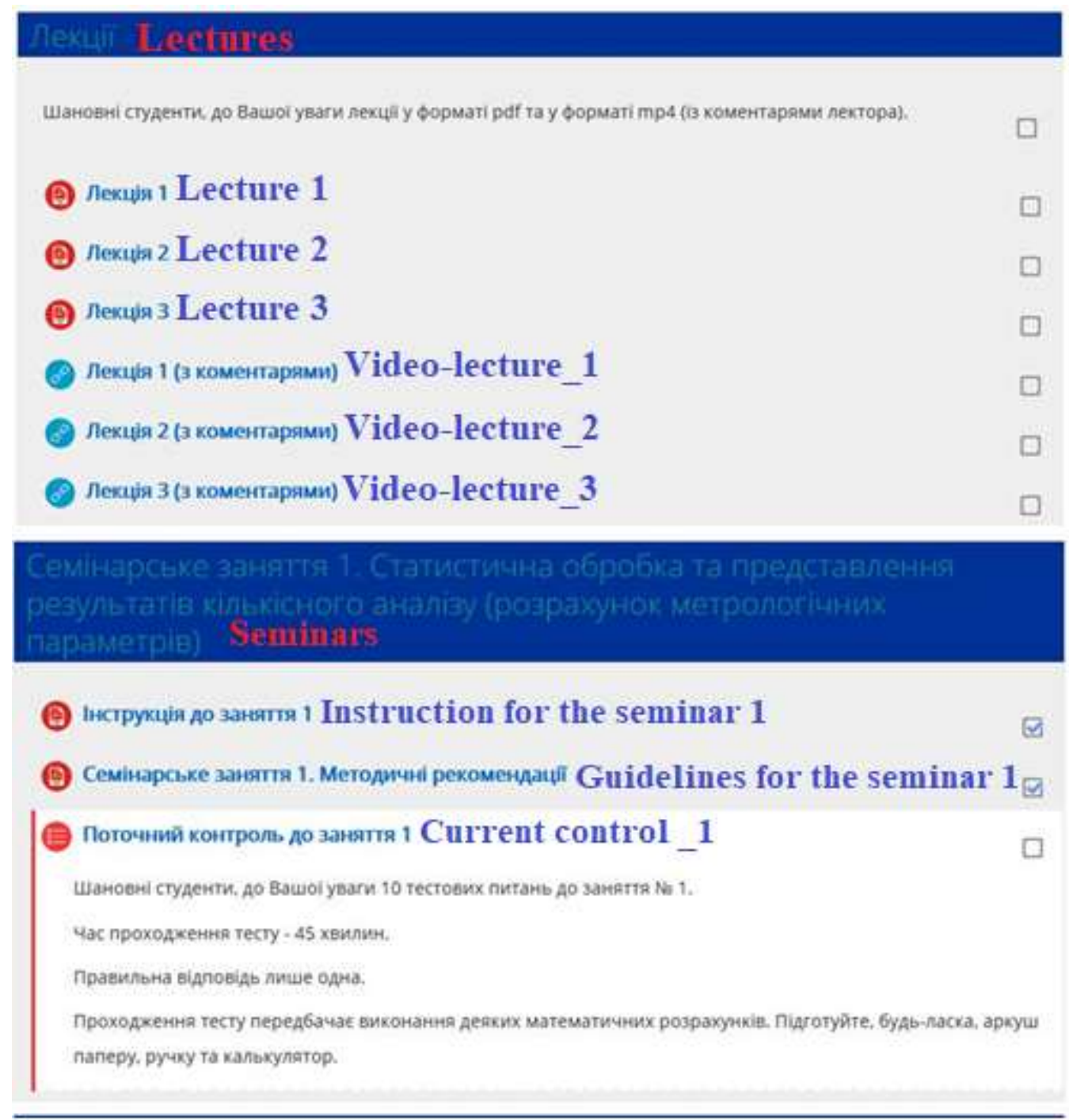

Figure 3. Fragments of the course "Fundamentals of Chemical Metrology" on the Neuron platform for distance learning.

After analyzing the indicators of student test results, we obtained a chart (Figure 4), which shows that 76 students gave the correct answer to less than $60 \%$ of questions; 171 students gave $60-80 \%$ correct answers; 152 students gave the correct answer to more than $80 \%$ of the questions [550]. 


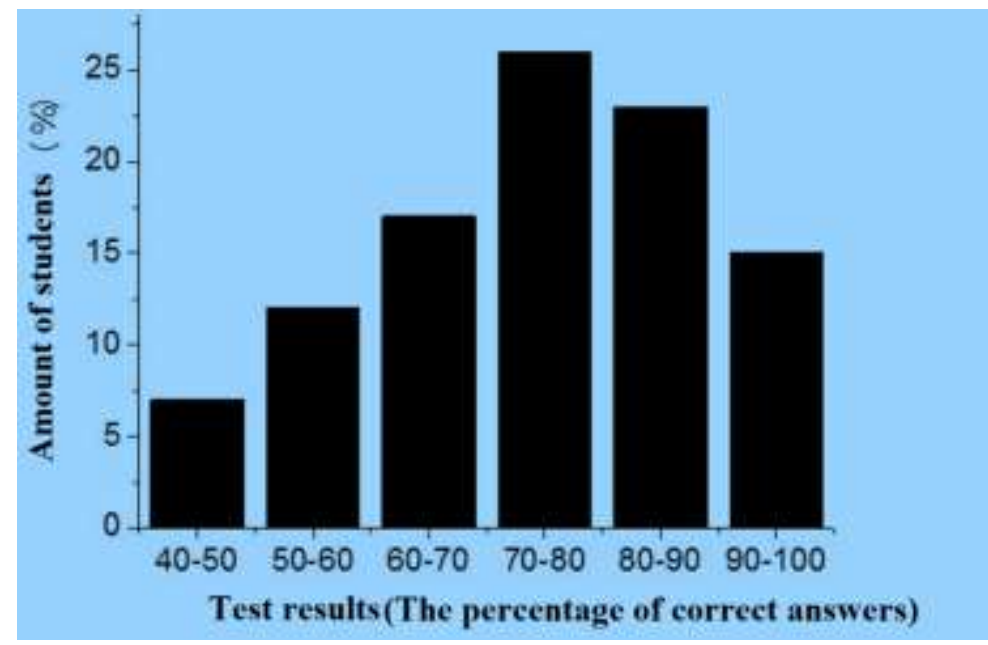

Figure 4. Test results of students of the Faculty of Pharmacy of distance learning

Employees of the Department of Analytical, Physical and Colloid Chemistry of the Bogomolets National Medical University is developing methodological support for teaching students of chemical disciplines. In the format of the content of the Internet platform methodical recommendations for independent work of students, materials for test control, electronic versions of lecture material for students, educational videos, electronic support of practical and laboratory classes are created. Methodical recommendations for students' independent work, control materials, electronic versions of lecture material, educational videos, electronic support of practical and laboratory classes are created and displayed on the educational platform on the Internet. Teaching technologies and methods, especially the experimental-demonstration base of chemical disciplines in higher pharmaceutical education in Ukraine, are improved through the process of further work with educational materials, modernization of innovative teaching methods for disciplines and disciplines of natural science training in health care [552].

Our research shows that feedback is the primary channel for communicating information about student performance and learning, so it is imperative that feedback constantly adapts to the ever-changing needs of students. It goes without saying that students must have a great responsibility to their mentors in order to take full advantage of the benefits of constructive communication [539]. Thus, this study provides a clear 
structure for organizing feedback. Moreover, "flipped" classrooms have been proposed as a solution to many problems associated with distance learning or blended learning. Indeed, this type of lessons will provide an opportunity for active learning and student participation in a variety of practical activities such as individual assignments, discussions, debates, workshops and problem solving. Through the proposed lesson model, the teacher can offer more personalized guidance and interaction with each student. This method helps to prevent gaps in the material, provides a better understanding of the subject and, accordingly, higher productivity. Furthermore, the structure of the elective course is presented, which optimally ensures the effectiveness of education of students. The example of teaching the elective course "Fundamentals of Chemical Metrology" for students of the Faculty of Pharmacy distance learning shows that distance learning, as a forced measure in the pandemic COVID-19, is an effective tool, as evidenced by the results of the session. 
DOI 10.46299/ISG.2021.MONO.PED.III.8.2

\subsection{Moral and ethical imperatives of family education of ukrainians in the works of ukrainian writers of the late XIX - early XX century}

Проблема родинного виховання є надзвичайно актуальною для українського суспільства загалом та окремої людини зокрема, адже саме сім'я сприяє первинному пізнанню і засвоєнню норм моралі та етики, формуванню характеру, розвитку волі та почуттів. Сформовані в родині морально-етичні імперативи визначають поведінку молодої людини, рівень їі духовної культури, впливають на процес іiі професійного самовизначення та самореалізації.

Сучасна криза соціально-політичної i економічної сфер в Україні призводить до відчуження молодих людей від споконвічних морально-етичних норм і вимог, підштовхує їх до здійснення неправильних кроків на шляху самореалізації.

Морально-етичні імперативи українського родинного виховання складалися упродовж тривалого історичного періоду й знаходяться в центрі уваги педагогів, психологів, культурологів, українознавців, філософів, батьків і вчителів. Проблеми здійснення морально-духовного розвитку дитини в сім'“і грунтовно розкриває Г. Авдіянц [553], роблячи невтішний висновок про те, що сучасний стан суспільства провокує кризу в родині, веде до нівелювання i. найважливішої виховної функції. Сучасні негативні тенденції в українському суспільстві не сприяють моральному становленню та духовному розвитку молодого покоління, що зрештою приводить до проявів морально-етичної незрілості у дорослому житті, а також до наростання соціальної нестабільності, політичної дезорієнтації, деморалізації значної частини суспільства.

Наше дослідження є вкрай необхідним ще й тому, що деякі сучасні наукові розвідки доводять певну втрату сім'єю своїх одвічних традиційних позицій. Автори цих публікацій переконані, що безшлюбність і бездітність, які згідно 3 українською традицією вважалися трагедією людини, насправді належать до переваг, тому що самотній людині легше виживати у технізованому й урбанізованому суспільстві. Цінність індивідуальності стає вищою, ніж цінність 
співтовариства. Якщо сім’я в історичному аспекті традиційно була гарантією соціальної безпеки, то сьогодні з'являються інші інституції, які у цій царині можуть їі замінити (страхові компанії, фонди, товариства тощо). Відповідно до цього у суспільстві все частіше лунають заклики до свободи від сімейних уз, пропагуються безшлюбність і бездітність, пропонуються альтернативи традиційній сім’ї тощо. Зрозуміло, що такі заклики не можуть позитивно впливати на процес збереження й утвердження традиційних родинних імперативів, зокрема морально-етичних.

Важливе місце у висвітленні структури, складу, функцій та способу утворення українських сімей кінця XIX - початку XX століття займають праці таких етнографів та істориків, як: Л. Артюх, М. Грушевського, В. Горленка, Ю. Гошко, П. Єфименка, О. Кравець, В. Наулка, В. Охрімовича, А. Пономарьова, Р. Чмелика та ін. Дослідниками окреслені характерні риси сімейного побуту українців; визначені особливості та специфічні риси різних типів сімей; здійснений аналіз функцій української сім’і та ії структури; простежена еволюція української сім'ї та вплив на неї соціально-економічних, політичних, національних і релігійних чинників.

Активно працювали над вивченням інституту сім’ї, дали конкретні настанови щодо врахування у процесі родинно-сімейного виховання кращих морально-етичних цінностей українські педагоги i психологи, зокрема: Т. Алєксєєнко, М. Боришевський, А. Вихрущ, О. Вишневський, О. Докуніна, К. Журба, Г. Кришталь, В. Мілясва, Т. Пантюк, Т. Руденко, М. Савчин, Н. Скотна, М. Стельмахович, І. Сіданіч, О. Сухомлинська, М. Чепіль та ін.. Велике значення інституту дитинства в традиційній культурі українців, у моральному розвитку дитини в селянській сім'ї досліджували М. Дерлиця, Н. Заглада, Д. Лепкий, Марко Грушевський та ін. Науковці доводять, що основу морально-етичного виховання дітей у родині становили загальнолюдські імперативи та християнські цінності. 
Насамперед з'ясуємо сутність понять «імперативи», «цінності», розкриємо зміст морально-етичного виховання й виокремимо головні морально-етичні імперативи родинного виховання.

За словником української мови [2, т.4], імператив - це беззастережна, категорична вимога; веління, наказ; за словником іншомовних слів [555], імперати́в (від лат. imperativus - владний) - веління, настійна вимога; категоричний імператив - в ідеалістичній етиці німецького філософа I. Канта безумовне моральне веління, яке нібито притаманне розуму, $\epsilon$ вічним i незмінним і покладене в основу моралі, імператив (в філософії) - безумовне моральне веління; категоричний імператив Канта - загальний усеохоплюючий моральний закон, внутрішньо притаманний кожній людині [556].За I. Кантом, існує єдиний фундаментальний моральний принцип: чинити так, аби завжди розглядати інших людей як цілі, а не як засоби. Цей принцип є імперативом (командою), і він є категоричним (застосовується без винятків, у всіх випадках, місцях і обставинах). Він $є$ класичним прикладом етичних теорій, систем моралі, що зосереджуються радше на істинному характері поведінки (і намірах особи), аніж на наслідках цих дій.

Філософську теорію моралі та їі цінностей значно збагатили зарубіжні та вітчизняні філософи. І. Кант першим звернувся до поняття цінностей, розрізнюючи сферу природного буття, підпорядкованого необхідності, й царині моральності; стверджував, що у сфері моралі і релігії зосереджуються кінцеві цілі життя. Подальшого розвитку концепція цінностей набула у вченнях неокантіанців. За теорією В. Віндельбанда, найвищими людськими цінностями $€$ істина, благо, краса і святість. Він наголошує, що цінність - це не реальність, це ідеал, носієм якої виступає наша свідомість [557, с.316].

Мораль і етику, загальнолюдські цінності у рамках християнського світогляду розглядали такі філософи, як Е. Берк, Тейяр де Шарден, М. Шелер. Е. Берк відстоював традиційні цінності добра, шляхетності, справедливості та правди [557, с.53].На думку Тейяра де Шардена, еволюцію людини визначає не лише технічний і науковий прогрес, а й значно більше - прогрес духовний [557, 
с.53]. М. Шелер вважав, що цінності можна осягнути тільки через переживання. До актів переживання цінностей він відносить співчуття, любов, ненависть. Бог для нього - це вища цінність, а любов до Бога - вища форма любові. На його думку, людині слід розвивати в собі духовне начало з тим, щоб досягнути царства вічних цінностей [558, с.23].На переконання вченого, високоморальною $\epsilon$ та людина, котра розуміє важливість християнських цінностей у своєму житті. Він розрізняв чотири групи цінностей: гедоністичні, вітальні, духовні (естетичні, етичні, епістемологічні) та релігійні, осягнення яких відбувається не раціональним шляхом, а на підставі інтуїції [557, с.53].

Сутність понять «цінності», «моральні цінності» розтлумачено у педагогічній, психологічній та філософській літературі. За словами Л. Чупрія, цінності - це ідеї, норми, процеси, відносини матеріального й духовного порядку, які мають об’ єктивну позитивну значимість і здатні задовольнити певні потреби людей. Він вважає, що воістину мудрою є та людина, яка, пройшовши великий життєвий шлях, побудувала цілісну картину світу, в основі якої лежить глибинне розуміння сутності явищ та процесів світу, що витікає із системи високих морально-етичних цінностей [558, с.23-24].

В. Шапар зазначає, що кожній людині властива індивідуальна, специфічна ієрархія особистісних цінностей, яка служить сполучною ланкою між духовною культурою суспільства і духовним світом особистості, між буттям спільним та індивідуальним [557, с.707]. Такої ж думки дотримувався В. Лісовий: цінності відіграють провідну роль в об’єднанні індивідів для спільних, колективних дій; є важливими у забезпеченні основи для єднання людей у нації, цивілізації чи навіть людства [557, с.707].

Отже, цінності виступають регулятором вчинків людини у їі діяльності, в основі яких лежить моральна значущість, i суттєво впливають на суспільне життя.

Виховний ідеал в українській сім’ї формувався протягом усієї історії українського народу. Цей ідеал викристалізувався у формі ставлення в народі до сім’ї і праці, особливостях засвоєння, збереження й розвитку духовної культури, 
вияву громадянських почуттів, дотримання обов'язку, захисту прав і свобод українського народу. Безперечно, досягнення цього ідеалу на практиці залежало від багатьох чинників - державного устрою, світогляду як окремого індивіда, так і суспільства в цілому, моралі та релігії, рівня розвитку культури, національних властивостей тощо.

В сучасних умовах на виховний ідеал має орієнтуватися державна політика, сім’я, освітні заклади, суспільство. Виховний ідеал української нації знаходить своє відображення не тільки в традиціях і звичаях народу, фольклорі, художній літературі, а й у національних освітніх та виховних системах. У виховному ідеалі таїться дух нації. Адже нація зберігається там, де іiі дух, традиції, інтереси визнаються пріоритетними, і захищається всіма засобами, аж до крайніх. Підтвердженням цьому є приклади усієї світової історії.

Виховний ідеал в української родині творився віками і за традицією сьогодні має переходити від старших поколінь до молодших, що його доповнять i вдосконалять. Він знаходиться в одному ряду 3 досягненнями інших цивілізованих народів. Це підтверджує спільність розвитку української сім’ї, иї педагогіки і загальноєвропейського процесу. Адже здобутки одного народу на великому європейському просторі швидко ставали надбанням інших народів. Свідченням цього є те, що педагогічні системи Я. Коменського, Ж. Руссо, Й. Песталоцці, К. Ушинського, А. Макаренка, В. Сухомлинського впевнено знаходили своїх прихильників і послідовників серед усіх народів Європи.

Зрозуміло, що значні зміни в житті українського народу на початку XX ст. призвели до змін у системі виховних орієнтацій, моральних i духовних цінностей. Ці зміни супроводжувалися боротьбою різних педагогічних теорій i позначені багатьма втратами кращих якостей української родини та викривленнями менталітету українця. Отож сьогодні у нашому поступу вперед важко переоцінити значення народних традицій. Відмова від них означала б відмову від своєї національності. Завдяки народній культурі, традиціям зберігається і розвивається культура й освіта сучасних поколінь, національна мова, без якої неможливе існування й самої нації, зберігаються звичаї, здобутки 
мистецької творчості, формується світогляд, народні ідеали, - все те, що творить обличчя народу, вирізняє його з-поміж інших. Виховний ідеал людини - це те найкраще, що створив український народ силою свого творчого генія, у ході віковічної боротьби за своє існування, економічний, культурний і духовний розвиток. Г. Ващенко виділив такі основи виховного ідеалу: національні фізичні і психічні особливості народу; усвідомлення народом свого призначення; християнство і загальноєвропейська культура; висока мораль, чистота і світлість душі; вище, божественне, одухотворене начало; служіння Україні, своєму краю як сенс життя людини; національна свідомість, почуття єдності 3 усією українською спільнотою; патріотична, здорова, національна гордість, національна гідність, любов до інших народів [559].

Виховний ідеал українця за Г. Ващенком складають християнські доброчинності, він має такий узагальнений вигляд: віра, надія, любов, правдивість, твердість у своїй вірі; уміння долати сумніви, зовнішні спокуси; християнський оптимізм, бадьорість; уміння зносити невдачі, нещастя, страждання; душевний спокій і радість; уважне ставлення до інших; піклування про ближніх, розуміння своїх хиб та провин, уміння їх виправляти; уміння боротися зі злом, шанувати батька i матір, не бути рабом своїх тілесних пристрастей, багатства i суєтної слави, бути лагідним i доброзичливим, стримуватися від заздрощів, гордощів і честолюбства, бути чесним і правдивим, не красти і не вбивати, співчувати ближнім, допомагати хворим, убогим, ув’язненим; прощати образи, не мститися, боротися зі злом, особливо, якщо воно поширюється в суспільстві [559]. Виховання в традиції християнської моралі це система формування духовності, де мають бути віра, знання, містичний досвід, моральний кодекс. Воно орієнтує на виховання ідеалу благочестивої людини, яка чітко виконує всі встановлені Богом заповіді і правила в поєднанні 3 духовною піднесеністю й постійним чеканням, готовністю постати перед божественним Суддею. Педагогічний ідеал - духовний розвиток людини, дитини, розкриття в неї містичного досвіду. Він постає як позасоціальний i позачасовий, всезагальний i звертається до соціуму тоді, коли потрібно 
продемонструвати негативні складові внутрішнього світу людини (пороки, недоліки, гріхи), за допомогою яких відбувається рух до ідеалу й ідеального. У християнській моралі більше, ніж у будь-якій іншій теорії, моральність, чесноти пов'язані з текстами, з розповіданням історій особливих, повчально-священних, імперативних [560, с.111-112]. Виходячи із вищеописаних концептуальних положень i наших узагальнень, робимо висновок про необхідність культивування в українській родині таких морально-етичних імперативів, як:

• вияву любові та поваги до своїх батьків, готовності їм допомагати;

• шанування культу предків, який становить основу народних традицій i звичаїв;

- сформованості національної свідомості і самосвідомості, любові до рідної землі і народу;

- розуміння і відчуття духовної єдності поколінь, ролі жінки-матері / чоловіка-батька в ії забезпеченні;

- сформованості високої мовної культури, усвідомлення мови як енергетичної субстанції;

• шанобливого ставлення до історії, культури, звичаїв, традицій свого народу й народів світу;

• усвідомлення власної національної гідності, честі, внутрішньої свободи;

- високої духовної культури особистості, сформованого світогляду, розуміння законів розвитку природи, суспільства;

- дотримання принципів народної і вселюдської моралі: правдивості, справедливості, доброти, працелюбності, гуманного ставлення до людини i довкілля;

- негативного ставлення до проявів безвідповідальності в праці і безгосподарності, утриманства і лінощів, крадіжок суспільної і приватної власності та варварського ставлення до природних багатств;

- високої художньо-естетичної освіченості і вихованості особистості; негативного ставлення до потворного, вміння відрізняти красиве від потворного в мистецтві, побуті, поведінці, зовнішньому вигляді; 
- екологічної культури особистості, гармонії ії відносин із природою; відчуття відповідальності за природу як національну і вселюдську цінність;

- спроможності розвивати пізнавальну активність і культуру розумової праці;

• уміння міжособистісного спілкування, культури спілкування, гуманізму, колективізму, товариськості, доброзичливості, взаємопідтримки, чесності, організованості і дисциплінованості, чемності й порядності.

Відтак родинне виховання є могутнім джерелом формування світогляду, національного духу, світовідчуття і світорозуміння, високої моральності, трудової підготовки, громадянського змужніння, глибоких людських почуттів, любові до матері і батька, бабусі і дідуся, роду і народу, пошани до рідної мови, історії, культури. Найголовнішими морально-етичними рисами українця $\epsilon$ лагідність, щирість, доброта, доброзичливість, гостинність, працьовитість, а ще прагнення до свободи, правди та захисту свого роду і Батьківщини.

Специфіка формування уявлень про засади національного родинного виховання в українському літературному просторі багато в чому завдячує ситуації модерного націєтворення, що позначилася на соціальних і культурних процесах Європи XIX століття. Конечну мету цієї місії української інтелігенції врешті артикулював Іван Франко, як потребу «витворити з величезної етнічної спільноти українського народу українську націю, суспільний культурний організм, здатний до самостійного культурного і політичного життя, відпорний на асиміляційну роботу інших націй, відки б вона не йшла, та притім податний на присвоювання собі в найширшій мірі і в найшвидшім темпі загальнолюдських культурних здобутків, без яких сьогодні жодна нація і жодна хоч і як сильна держава не може остоятися...» [561, с.71]

Для українців цей процес ускладнювався ситуацією занепаду давніх національних громадянських інституцій на користь загальноімперським та неможливістю їх відродження в умовах постійних утисків з боку метрополії. С. Скельчик, аналізуючи прикметні риси патріотично орієнтованого «українофільства», зауважує, що неможливість легальної політичної і навіть 
культурної роботи на ниві національній привела до того, що «...простір національних і опозиційних жестів обмежувався власним домом патріота чи патріотки, його чи їі одягом, стравами, напоями, зачісками, вусами й аркушем паперу, на якому можна було написати оповідання з народного життя і потім прочитати його в колі найближчих друзів або надрукувати під псевдонімом в Австро-Угорщині» [562, с.20]. Ці реалії змушували українську освічену спільноту зосередити свої зусилля на етнографічних та фольклорних студіях, питаннях просвіти, а також процесі, названому Еріком Гобсбаумом [563] «винайденням традиції», який включав у себе ритуалізацію окремих аспектів народного побуту та історичного минулого.

Слід зауважити, що на початку XIX століття становище української літератури переважно визначалося тією обставиною, що іiі творцями виступали українські за походженням дрібні провінційні дворяни, священники, урядовці, про яких М. Зеров зауважив, що «вся ця дрібна провінційна публіка живе переважно духовою справою російської журнальної лектури <..>, але не задовольняється нею цілком і для повного вдоволення естетичного переходить на «неочищенный слог», народну говірку, таку природну й мальовничу і під iii пером. Анекдот 3 народного життя, п’єса 3 сільського побуту, романс українською мовою складений, ефектна приказка, історичний спогад становлять живу естетичну потребу цієї громади, один 3 аксесуарів іiі побуту, оздобу коротких провінціальних сезонів, що припадають на ярмаркові тижні та на час дворянських виборів, розвагу хутірських з’їздів, храмових та іменинних свят» [564, с.101]. Однак таке судження, яке було висловлене більш ніж через століття і явно спрямоване на розв'язання проблем модерного часу має досить дражливі моменти. Звісно, період розвитку української літератури, який М. Петров у своїх досить спірних 3 погляду сьогодення «Нарисах історії української літератури XIX століття» називає «українським псевдокласицизмом», позначений домінуванням в ній «низьких» жанрів, досить нечисленних текстів комедійного характеру, вершинним досягненням серед яких стає «Енеїда» Івана Котляревського. Попри наявність у ній яскравих елементів українського 
побутописання, інтерес до принципів народної родинної моралі у ній відсутній. Український антураж стає засобом бурлеску, саме через неприпустимість для освічених любителів «неочищенного слога», можливості розкриття i обговорення ним проблем моралі. Звідси неоднозначність сприйняття «Енеїди» українськими національними і культурними діячами XIX століття.

Натомість сентименталізм 3 його посиленою увагою до простої людини сприяв ширшому залученню морально-етичної проблематики в український літературний простір. Чи не найвиразніше в цьому контексті виділяються імперативи родинних взаємин батьків і дітей в сентиментальних повістях та оповіданнях Григорія Квітки-Основ'яненка. Артикульовані письменником моральні імперативи визначили цілий ряд літературних канонів, які залишалися абсолютними i непорушними в читацькому середовищі патріотично налаштованого українства. Звісно, насамперед започаткований «Марусею» канон найяскравіше виявляється в образі головної героїні твору. Він надзвичайно збалансований: зовнішня краса стає виявом глибинної внутрішньої гармонії $\mathrm{i}$ цілісності духовного світу героїні. Опис зовнішності Марусі залишається орієнтиром для творення портретних дівочих образів українськими письменниками не лише в класичній літературі, але й в текстах, позначених стилістикою соцреалізму, наприклад, коли мова йде про героїнь романів Михайла Стельмаха: Олени («Правда і кривда»), Оксани, Мирослави («Чотири броди»), Ярини («Дума про тебе»). Водночас, зовсім не випадково його домінування намагається зруйнувати у своєму першому оповіданні «Сила i краса» Володимир Винниченко. Зовнішність його героїні Мотрі виписана як повна антитеза Марусі: «То була краса, що викохується тільки на Україні, але не така, як малюють деякі 3 наших письменників. Не було в неї ні «губок, як пуп’янок, червоних, як добре намисто», ні «підборіддя, як горішок», ні «щок, як повна рожа», і сама вона не «вилискувалась, як маківка на городі». Чорна, без лиску, товста коса; невисокий, трохи випуклий лоб; ніс тонкий, рівний, $з$ живими ніздрями; свіжі, наче дитячі губи, що якось мило загинались на кінцях; легка смага на матових, наче мармурових щоках і великі, надзвичайно великі, 3 
довгими віями, темно-сірі очі, з яких, здавалось, дивлячись, наче лилося якесь тихе, м’яке, ласкаве світло, - то була й уся краса сієї дівчини» [565, с.23]. Це не просто іронія супроти старої традиції, але й бунт В. Винниченка загалом супроти ідеалізації народного характеру в народовському каноні. На цих обставинах більш детально ми вже зупинялися, аналізуючи спроби подолання рустикального дискурсу Володимиром Винниченком [566]. Ще далі у формуванні образу «анти-Марусі» письменник рухається в драмі «Молода кров», в якій пародіюються шаблони старої української мелодрами. Традиційна романтична трагедійність образу зведеної паничем дівчини-покритки замінюється іронічним змалюванням наївності інтелігенції, котра сама виробила на основі романтичної традиції сюжет про ідеальну душу богоданого народу. Героїня п’єси сільська покритка Ївга власне виступає антиподом вже закоріненого в літературну традиції типажу жертви панських забаганок. Швидше вона $є$ втіленням тверезого селянського глузду і практицизму, уміння вдало маніпулювати Антосем, за допомогою педалювання стереотипів, в полоні яких він знаходиться.

Поряд 3 акцентуванням уваги на дівочих чеснотах Марусі, КвіткаОснов'яненко створює яскраву картину родинних стосунків, в основу яких покладено турботу іï членів про рідних, панування батьківського авторитету i поваги з боку молоді до старших, особливо до батька, як головного транслятора i охоронця родинної моралі. Батько Марусі Наум Дрот, заможний український господар, шанована громадою людина, - незаперечний авторитет і охоронець звичаю. Кожен його крок є виявом далекоглядності століттями випробуваних приписів патріархальної моралі. Коли він відмовляється піти назустріч щирим почуттям молодих закоханих і віддати заміж Марусю за Василя, це не трактується автором як батьківське самодурство чи користолюбство. Натомість мова йде про усвідомлення ним обов’язку щодо громади і власної родини, турботу про її гідність:: «...а як прийде набор, то певно тобі лоб забриють, бо ти сирота, за тебе нікому заступитись; і дядьки скажуть: «Ми тебе поїли, зодягали і до розуму довели, служи за нашу чергу». А що тогді буде з Марусею? Ні жінка, 
ні удова; звісно, як салдаток шанують: як саму послідню паплюгу, і ніхто і не вірить, щоб була салдатка, та й чесна. Та й троха чи й не так! Де їй за полками таскатись? А молоде, дурне, попадеться ледачим людям, наведуть на усе злеє. Худобу розтаскають, повіднімають, хто їі защитить? Діточки без доглядання, у бідності, у нищеті, без науки, без усього помруть або - не дай Боже! бездільниками стануть. А вона затим ізстаріється, немощі одоліють, бідність, калічество... тільки що в шпиталь, до старців! (Сказав се та й заплакав, як мала дитина). Не приведи, Господи, і ворогу такої судьби!..» [ 567, с.80]. Настанови батька спрямовані на утримання доньки в руслі традиції, що забезпечить їй запевнене становище в громаді і збереже від маргіналізації і втрати «чесності», що є головною чеснотою жінки в патріархальному суспільстві.

Натомість саме Г.Квітка-Основ'яненко пропонує українському читачеві й інший типаж, чи не більш широко розтиражований українською літературою образ дівчини, що переступила через заведений звичай і стала покриткою. Мова йде про повість «Сердешна Оксана» та іï однойменну героїню. Провину за життєву драму дівчини, що не змогла втриматися в рямцях заведеного звичаю, письменник покладає не лише на легковажність і норовливий характер самої героїні, яка прагнула досягнути життєвого успіху через стосунки з офіцером, але й на неповноцінність виховного процесу в родині, позбавленій батьківського керівництва та нагляду. Мати Оксани Векла не спроможна запобігти лихові, повсякчас викорінюючи в поведінці доньки вияви негідної 3 погляду патріархальної традиції поведінки. Маруся оминає ризиковані молодіжні розваги, веде себе тихо і скромно, постійно перебуваючи під пильною батьківською опікою. Оксана позбавлена цього, а тому їі честь вже з самого початку перебуває в загроженій ситуації. Г.Квітка-Основ’яненко безчестя Оксани стає причиною не лише духовного, але й матеріального занепаду загалом заможної родини, оскільки ऑiі добробут тісно пов’язаний зі статусним становищем в громаді.

Гармонійність, злагодженість і постійна взаємодія всіх членів сім’ї, послух молодших і розумне наставництво старших на думку представників українського 
сентименталізму, є запорукою процвітання селянської родини. Ці уявлення простежуються в ідилічній сцені із «Подражанія Горацію» поета-романтика Левка Боровиковського, яке переспівом оди «Хвала сільському життю» античного поета:

Він тілько що на двір, а жінка на поріг -

Його із радощу вітає,

Вечеря на столі, - а дітвора, як рій

На матку, - батька обсідає.

Як смачно на печі, забравшись на черінь,

Після охоти відпочине!

Як завтра весело покине свій курінь

І знову до роботи кине!.. [568]

Цей образ рустикального раю співзвучний 3 виписаним Тарасом Шевченком у поезії «Садок вишневий біля хати». Однак у шевченківському варіанті відчувається усвідомлення поетом конечності ідеального селянського раю. Вона ледь усвідомлена, але кидає місток до руйнування патріархальної ієрархії, що ховається у невинних рядках: «...а мати хоче научати, / так соловейко не дає» [569, с.14]. 3 цього приводу Г.Грабович зауважує: «Первинність матері й формування навколо неї сім’ї стає для нього глибоко психологічною потребою й орієнтацією. Саме на цій основі витворює він ідеал справедливого ладу і згідно з цією уявною моделлю ставить у центр і поглиблює фольклорну традицію» [570, с.48]. Цей амбівалентний материнський світ розгортається трагедією руйнування родинного ідеалу в поемі «Катерина», де батьки під впливом приписів традиційної моралі вимушені вигнати 3 дому доньку-покритку, прирікаючи іï на загибель, а себе на сирітську старість.

Особливо виразно проблема розпаду патріархальної традиції виявляється в творчості Івана Нечуя-Левицького. Його повість «Кайдашева сім'я», попри поширене уявлення про ії комедійність, є глибоко трагічним вислідом глибоких болісних роздумів письменника над питаннями занепаду сімейної духовної традиції. Ключовим у цьому контексті є образ старого Кайдаша, котрий 
намагається стримати наступ нової моралі і утримати життя своєї родини в традиційному руслі. Але вже у сцені з синами спостерігається відсутність домінування батьківського авторитету в родині. Численні описи жіночих чвар остаточно унеможливлюють навернення Кайдашів до традиційних імперативів родинної моралі. Разом 3 деградацією глави сімейства, а пізніше i його безглуздою смертю нівелюється позитивна патріархальна традиція, а родина остаточно розпадається, атомізується, втрачає регулятивну функцію щодо поведінки іï членів. Тому в інтимний простір Кайдашів вимушена втручатися громада: «Волосний 3 писарем та кількома громадянами повели в волость Кайдашенків, їх жінок та Кайдашиху. Вони насилу розплутали їх справу i присудили карпові одірвати хату й поставити окроми на своєму городі, бо Лаврін, як менший син, мав право зостаться в батьковій хаті і за те був повинен додержать матір до смерті. Громада присудила розділити грунт між Кайдашенками пополовині» [19, II, с.263]. Таким чином саме громада перебирає на себе функцію, яка, як раніше було спостережено, виконувалася старшими в родині. І. Нечуй-Левицький таким чином фіксує перехід до загалом невластивої українській спільноті ситуації конфлікту поколінь.

Ще більш виразно згубний вплив відсутності твердих моральних принципів у батьків на долю їхніх дітей простежується в новелі Михайла Коцюбинського «Подарунок на іменини». Досить сумнівна моральність матері, колишньої повії, та батька, котрий задля просування по службі презентує інтимні послуги дружини начальству, вступають в гострий конфлікт зі світоглядом синагімназиста. Парадоксально, але батьки самі доклали зусилля для виховання дитини в зовсім відмінній від власної морально-етичній парадигмі, а отже момент втрати дитячих ілюзій щодо близьких людей стає для нього особливо травматичним, аж до суїцидальних намірів. Водночас батько неспроможний усвідомити причини такої гострої реакції сина, оскільки його життєва психологія дозволяє угоди $з$ совістю, абсолютно неприйнятні для сина. М. Коцюбинський остаточно фіксує розрив поколінь в в момент переходу українства до 
індустріального суспільства, якого в герметичному феодальному патріархальному світі не було.

Таким чином українська література протягом XIX - початку XX століть чітко фіксує зміну суспільних моральних імперативів в українському оціумі, передачу функцій їх вироблення, збереження і прищеплення молоді від родини до суспільних інституцій. 
DOI 10.46299/ISG.2021.MONO.PED.III.8.3

\subsection{Training future doctors of philosophy writing a scientific article}

Нагадаємо, що відповідно до Постанови Кабінету Міністрів України «Про затвердження Порядку підготовки здобувачів вищої освіти ступеня доктора філософії та доктора наук у закладах вищої освіти (наукових установах) від 23 березня 2016 р. №261 (Постанова ..., 2016) в Україні розпочато підготовку докторів філософії (ДФ). За минулі роки заклади вищої освіти накопичили певний досвід підготовки фахівців цього освітньо-наукового рівня у різних галузях знань, в тому числі галузі освіти 01 Освіта / Педагогіка спеціальності 011 Освітні, педагогічні науки. На жаль, стандарт з цієї галузі знань поки що не розроблено i університети та наукові установи готують ДФ згідно 3 розробленими ними освітньо-науковими програмами (ОНП) та робочими навчальними програмами.

Серед загальних компетентностей, зазначених в цих навчальнометодичних документах, фігурують, наприклад, такі: «Здатність презентувати результати своїх досліджень» або «Здатність готувати наукові статті, тези, доповіді, повідомлення, виступи, наукові звіти, посібники тощо» (Бедзір Н. П., 2017; Перепелиця О. М., 2016). У Київському національному лінгвістичному університеті, на базі якого реалізовано це дослідження, аспірантів готують за ОНП «Сучасні наукові освітні студії: педагогіка, методика навчання іноземних мов і культур, наукова англійська мова» (Ніколаєва С. Ю., 2017). Зазначена ОНП удосконалювалась протягом останніх чотирьох років і в іiі крайньому варіанті передбачено викладання навчальної дисципліни «Наукова комунікація: методи оприлюднення результатів дослідження в галузі освіти». Сутність цієї дисципліни схарактеризовано нами у публікації «Структура і зміст дисципліни «Наукова комунікація: методи оприлюднення результатів дослідження в галузі освіти»»» (Ніколаєва С. Ю., 2021).

Навчальною програмою 3 цієї дисципліни серед інших передбачено опрацювання таких тем, як: «Види та жанри наукових публікацій в галузі освіти», «Загальна характеристика наукових публікацій в галузі освіти», але 
моніторинг готовності аспірантів до написання та опублікування наукових статей з проблем їхнього дослідження свідчить про суттєві труднощі, що виникають в аспірантів у цьому виді наукової комунікації. Основні недоліки у написанні статей майбутніми докторами філософії досліджувались протягом багатьох років і узагальнені нами у публікації «Наукова комунікація: труднощі молодих науковців у написанні наукових статей» (Ніколаєва С. Ю., 2021a). Одержані результати дозволяють зробити висновок про необхідність упровадження в освітній процес курсу за вибором, присвяченого саме формуванню в аспірантів здатності писати наукову статтю. До програми курсу насамперед слід внести такі теми: вибір теми наукової статті; основні типи наукових статей; зміст і структура статей різних типів; стратегії написання наукової статті; вимоги до анотації до наукової статті; основні вимоги до статей у фахових виданнях України тощо. Розглянемо детальніше зміст лекцій такого курсу і завдання для самостійної роботи майбутніх докторів філософії в галузі освіти зі спеціальності 011 Освітні, педагогічні науки, спеціалізації «Теорія та методика навчання іноземних мов».

Лекція-бесіда 1. Основні типи публікацій майбутнього ДФ. Загальні вимоги до публікацій ДФ.

Теоретичні питання для розгляду. Основні типи публікацій (автореферат, наукова доповідь, препринт, тези доповіді, стаття наукова, збірник наукових праць, монографія одноосібна, розділ у колективній монографіï). Загальні вимоги до публікацій аспірантів згідно наказу № 1220 МОН України від 23 вересня 2019 року (Наказ МОН..., 2019). Необхідна мінімальна кількість публікацій. Публікації в періодичних наукових виданнях інших держав. Публікації у наукових фахових виданнях України категорій А і Б. Публікації у виданнях, проіндексованих у базах даних Web of Science Core Collection та/або Scopus. Поняття квартилів ((Q 1 - Q 3) відповідно до класифікації SCImago Journal and Country Rank або Journal Citation Reports. Вибір теми першої наукової статті з методики навчання іноземних мов і культур. 
Практичне завдання для виконання в аудиторії. Виберіть тему для Вашої першої наукової статті згідно «Змісту» Вашої дисертації (одного з підрозділів першого розділу). Сформулюйте іiі назву. Врахуйте, що вона має бути короткою, але зрозумілою. Бажано ще й такою, щоб викликала інтерес. Обговорення запропонованих назв статей.

Практичне завдання для самостійного позааудиторного опраџювання.

- Подивіться відеофільм «Робота із профілем автора в інформаційнопошуковій та наукометричній системі Гугл Академія» і визначіть іiі призначення.

Режим доступу: https://www.youtube.com/watch?v=qEsupJNMDD4

- Створіть свій профіль у системі Гугл Академія.

Лекція-бесіда 2. Види наукових статей. Вибір виду першої наукової статті 3 методики навчання іноземних мов і культур для опублікування.

Презентація аспірантами виконаних самостійно практичних завдань. Детальний опис аспірантами можливостей інформаційно-пошукової та наукометричної системи Гугл Академія. Демонстрація створених профілів у цій системі.

Теоретичні питання для розгляду. Загальна характеристика різних видів статей: дослідницької статті, статті-короткого повідомлення, статті-відгуку і відповіді, оглядової статті. Основні вимоги до кожного виду статті. Методична стаття як окремий підвид дослідницької статті. Фактори впливу на вибір виду першої наукової статті з методики навчання іноземних мов і культур. Вимоги до назви статті.

Практичне завдання для самостійного позааудиторного опрацювання.

- Знайдіть у Вісниках КНЛУ Серії «Педагогіка та психологія» за останні п’ять років десять статей з методики навчання іноземних мов і культур різного виду. Проаналізуйте їх зміст і структуру.

Режим доступу: http://visnyk-pedagogy.knlu.edu.ua

- Оберіть вид статті, яку Ви плануєте написати. Поясніть фактори, що зумовили обрання Вами цього виду статті. Запропонуйте назву статті. 
Лекція-дискусія 3. Структура наукових статей різних видів з методики навчання іноземних мов і культур. Функції наукової статті.

Презентація аспірантами виконаних самостійно практичних завдань. Обгрунтування аспірантами визначення видів обраних методичних статей. Пояснення аспірантів щодо вибраного виду статті для написання та ії̈ назви. Теоретичні питання для розгляду. Структура дослідницької статті, статтікороткого повідомлення, статті-відгуку і відповіді, оглядової статті. Дослідницька функція наукової статті. Презентаційна функція наукової статті. Оцінювальна функція наукової статті. Комунікативна функція наукової статті. Практичні завдання для самостійного позааудиторного опраџювання.

- Виберіть з науково-методичного журналу «Іноземні мови» за останні п’ять років по одній статті кожного з видів і визначіть їхню структуру і функцію. Підготуйте електронну презентацію у PowerPoint. Режим доступу: http://fl.knlu.edu.ua

- Запропонуйте структуру Вашої уявної оглядової статті.

Лекція-розгляд конкретної ситуації 4. Зміст і структура наукової статті у фахових виданнях України.

Презентація аспірантами виконаних самостійно практичних завдань.

Демонстрація з використанням презентації у PowerPoint підібраних статей різних видів (дослідницької статті, статті-короткого повідомлення, статтівідгуку і відповіді, оглядової статті) та опис їхньої структури та функції.

Опис і обгрунтування запропонованої аспірантами структури уявної оглядової статті.

Теоретичні питання для розгляду. Зміст статті: виклад проміжних або кінцевих результатів наукового дослідження; висвітлення конкретного окремого питання за темою дисертації чи наукового дослідження; Фіксація процесу наукового дослідження автора тощо. Структура статті: УДК, анотація, вступ, основна частина, завершальна частина, посилання на використані джерела (література). Практичне завдання для самостійного позааудиторного опраџюювання. 
- Подивіться відеолекцію «Як написати наукову статтю» і визначіть, що означає схема «MRCI Framework». Режим доступу https://www.youtube.com/watch?v=iEsk7N0spNI

- Визначіть структуру Вашої статті, обраного виду, яку Ви плануєте опублікувати у фаховому науковому виданні України. Підготуйтеся до іiі презентації та обгрунтування на наступній лекції.

Лекція-дискусія 5. Універсальна десяткова класифікація (УДК). Мета УДК та анотації наукової статті 3 методики навчання іноземних мов і культур та ключових слів.

Презентація аспірантами виконаних самостійно практичних завдань. Пояснення значення схеми «MRCI Framework» за переглянутою відеолекцією. Презентація-дискусія структур статей, підготовлених аспірантами.

Теоретичні питання для розгляду. Мета УДК і процедура ї̈ визначення. УДК онлайн. Вимоги до анотації наукової статті згідно з Міждержавним стандартом ГОСТ 7.9-95 (http://edumag.mrsu.ru/content/files/GOST_7.9-95.pdf) «Реферат i анотація. Загальні вимоги». Рекомендовані середній обсяг анотації (500 друкованих знаків) та елементи анотації відповідно до зазначеного стандарту (характеристика основної теми, визначення проблеми, конкретизація мети, опис результатів дослідження, виокремлення новизни у порівнянні 3 іншими роботами). Вимоги до характеру і кількості ключових слів (мінімум 5 позицій). Практичне завдання для самостійного позааудиторного опраиювання.

- Проаналізуйте елементи п’яти анотацій до статей з методики навчання іноземних мов і культур і ключових слів до них у різних наукових фахових виданнях України в галузі освіти.

- Укладіть анотацію та ключові слова до запланованої Вами до написання статті.

Лекція-бесіда 6. Вимоги до вступу, основної і завершальної частин статті з методики навчання іноземних мов і культур. Презентація аспірантами виконаних самостійно практичних завдань. Аналіз п’яти анотацій статей і ключових слів, обраних аспірантами. 
Демонстрація та обговорення укладених аспірантами анотацій статей і ключових слів.

Теоретичні питання для розгляду.

Складові вступу до наукової статті: постановка проблеми, аналіз останніх досліджень і публікацій; опис наукової гіпотези; пояснення передумов започаткування дослідження; зазначення мети та актуальності; перелік питань для розгляду тощо.

Складові основної частини статті: основний матеріал дослідження; власні наукові ідеї, виявлені закономірності; реалізовані методи дослідження; отримані результати тощо.

Складові завершальної частини статті: результати дослідження та їх значущість для теорії і практики методики навчання іноземних мов і культур; перспективи подальших досліджень з проблеми тощо.

Практичне завдання для самостійного позааудиторного опраџювання.

- Напишіть вступ до Вашої уявної статті.

- Підготуйте його п’ятихвилинну презентацію на наступній лекції.

Лекція-розгляд конкретної ситуації 7. Академічна доброчесність. Унікальність статті. Плагіат і самоплагіат.

Презентація аспірантами виконаних самостійно практичних завдань.

Розгляд підготовлених аспірантами вступів до запланованих статей.

Теоретичні питання для розгляду. Поняття «академічна доброчесність», «унікальність статті», «плагіат», «самоплагіат». Складові, норми та кодекс академічної доброчесності. Компетентності з академічної доброчесності. Форми проявів академічної недоброчесності (плагіат, самоплагіат, фабрикація, фальсифікація, обман тощо). Вимоги до унікальності статті з методики навчання іноземних мов і культур.

Перегляд і обговорення відеофільму «Як не попастися на плагіаті?» Режим доступу: https://www.youtube.com/watch?v=P6dbT3NuYOI Практичне завдання для самостійного позааудиторного опрачювання. 
- Подивіться фрагмент відеолекції «Етичні питання публікації результатів наукового дослідження».

Режим достуny: https://www.youtube.com/watch?v=Rxsz7TAZQZ4

- Перевірте на унікальність підготовлені Вами анотацію і вступ до запланованої статті за допомогою програми «Unicheck».

Режим доступу: https://ua.unicheck.com/

Лекція-дискусія 8. Редагування тексту наукової статті з методики навчання іноземних мов і культур.

Презентациія аспірантами виконаних самостійно практичних завдань.

Дискусія на тему «Проблеми етики наукових публікацій» за переглянутою відеолекцією.

Обговорення результатів перевірки анотацій і вступів до статей на унікальність. Теоретичні питання для розгляду. Уніфікація стилю формулювань і термінів. Перевірка наявності опису всіх завдань статті, заявлених у Вступі. Узгодження висновків статті зі змістом основної частини. Узгодження змісту Вступу зі змістом основної і завершальної частин. Перевірка дотримання технічних вимог до оформлення статті.

Практичне завдання для самостійного позааудиторного опращювання.

- Подивіться відеофільм «Editing: Things they don't tell you about what journal editors want.» і укладіть перелік наданих редактором рекомендацій щодо редагування наукової статті.

Режим доступу: https://www.youtube.com/watch?v=vLojaTRoBuc\&t=97s

- Відредагуйте фрагмент статті, який ви підготували, враховуючи прослухані рекомендації.

Лекція-розгляд конкретної ситуації 9. Вимоги до укладання та оформлення списку літератури з методики навчання іноземних мов і культур. Презентація аспірантами виконаних самостійно практичних завдань. Обговорення укладених переліків рекомендацій щодо редагування наукової статті.

Оцінювання відредагованих аспірантами фрагментів статей. 
Теоретичні питання для розгляду. Основні підходи до пошуку та укладання списку літератури з проблеми статті. Оформлення списку літератури згідно 3 чинним стандартом України (ДСТУ 8302:2015... 2015). Орієнтовні вимоги до оформлення рукописів (можливі розбіжності до оформлення статей у різних виданнях).

Практичне завдання для самостійного позааудиторного опращъювання.

- Подивіться відеозапис онлайн-семінару «Особливості оформлення літературних джерел до наукової статті».

Режим доступу: https://www.youtube.com/watch?v=8-GJpwcStPA\&t=72s

- Оформіть літературу до Вашої запланованої статті за опрацьованим стандартом.

Лекція-бесіда 10. Вибір наукового фахового видання України для опублікування підготовленої статті 3 методики навчання іноземних мов i культур. Категорії фахових видань. Вимоги до подання статті до видавництва. Презентація аспірантами виконаних самостійно практичних завдань. Демонстрація аспірантами оформленої згідно з чинним ДСТУ літератури. Теоретичні питання для розгляду. Умови зарахування публікації за темою дисертації (обгрунтованість отриманих наукових результатів відповідно до мети статті та висновків; наявність видання у переліку фахових видань України; опублікування не більше однієї статті в одному номері/випуску видання тощо. Умови зарахування статей, опублікованих у наукових періодичних виданнях інших держав з наукового напряму, за яким підготовлено дисертацію. Причини не зарахування опублікованих статей. Матеріали, які подаються до редакції (надрукований текст статті (факультативно); електронний варіант статті; відомості про автора (-ів) витяг з протоколу засідання кафедри/вченої ради 3 рекомендацією рукопису до друку та рецензію наукового керівника на подану статтю). Порядок формування Переліку наукових фахових видань України, затвердженого наказом МОН України від 15 січня 2018 року № 32 (Наказ МОН ... 2018). Реєстр наукових фахових видань України.

Практичне завдання для самостійного позааудиторного опрацуювання. 
- Знайдіть на сайті МОН України закладку «Реєстр наукових фахових видань України».

Режим доступу: https://mon.gov.ua/ua/nauka/nauka/atestaciya-kadriv-vishoyikvalifikaciyi/naukovi-fahovi-vidannya

- Випишіть: назви десяти видань 3 педагогіки та методики навчання іноземних мов; засновника або співзасновника цих видань; дату включення або внесення змін до цього видання; категорію видання (А чи Б).

- Подивіться відеолекцію «The Art of Scientific Publishing» і вирішіть, чи готові Ви до написання наукової статті.

Режим доступу: https://www.youtube.com/watch?v=ONdfTAOblJ8

Визначіться, до якого видання Ви будете подавати свою першу статтю. 


\section{DOI 10.46299/ISG.2021.MONO.PED.III.8.4}

\subsection{Development of aviation English skills in distance learning}

Modern scientific and technological progress in the form of the Fourth Industrial Revolution has radically changed the requirements for the development of the aviation sector all over the world and in Ukraine in particular. The importance of the professional skills reliability for the pilot of a modern aircraft has increased immeasurably. Requirements to increase the level of reliable training of pilots in Ukraine are due to the event that took place in October 2021: the signing of an agreement between Ukraine and the European Union on a common aviation area, opening a new air transport market, new opportunities for both consumers and operators.

According to the statistics of International Civil Aviation Organization (ICAO), the number of accidents caused by a technical system has decreased over the last 10 years, and at the same time, the number of those caused by humans has increased proportionally. Today in Ukraine the problem of the human factor has manifested itself especially acutely. This is due to a number of reasons. Analysing the list of erroneous actions of the aircraft crew, the Interstate Aviation Committee notes that with the entry of Ukrainian airlines on international routes, a significant increase in aviation accidents due to the admission of aviation personnel to work with insufficient training. [586]

Most cases of aviation accidents and crashes on international air routes are due to the following reasons: lack of reliable knowledge of standard and non-standard phraseology of the English language; insufficient mutual understanding in the process of radio communication of the flight crew with the control point; inadequate analysis of the abnormal situation; making erroneous decisions and transmitting them via radio to the air traffic controller; slow perception of information in situations that require a quick solution; insufficient level of spoken English; lack of English language skills the language of communication in aviation according to ICAO standards. [582]

Obviously, the problem is the lack of professional communication skills reliability in English. Professional reliability, thus, acts as a criterion for the ratio of aviation specialist to the requirements of the time. [586] This raises the issue of the quality of 
the pilot professional training on a modern fly-by-wire aircraft. Therefore, the search for ways to increase the efficiency and reliability of professional activities of flight crew members in the context of radio communication in English is an urgent problem of training flight crew for flights on international routes. The training process has become more difficult due to the spread of the COVID-19 pandemic.

Despite the fact that the search for ways to solve the problem of improving the professional reliability of the flight crew is conducted by scientists in various fields (improved methods of forming professional knowledge, skills and abilities; training technologies are formed) more attention should be paid today to the training of aircrew for international flights in the context of distance learning. Learning English according to ICAO standards and conducting radio communication in English today requires a different, integrated approach (mixed form of education - classroom, distance and simulator), which should take into account the specifics of joint activities (aircraft operation and radio communication in English). So, organizational, technological and didactic principles have been developed today exclusively for the traditional approach to learning. [583] But at the same time, within the current epidemiological situation, the question of classroom, distance and simulator training technologies on an integrative basis is particularly acute. The integrative effect in this form should be achieved through the completeness, adequacy of connections and focusing goals and objectives of English language training to obtain the successful result - the reliability of English radio communication in standard and non-standard flight conditions and free communication in English not less than 4 -th level according to the standards adopted by ICAO.

Thus, as classroom and training forms were and are traditional and even classic in the development of reliable knowledge skills and abilities of future pilots [586], distance learning technology is now accepted by us as relatively new and requires perfect study for reliable level of knowledge of English in the future specialist in flight operations.

The theoretical basis for the professional training development has been studied be many specialist in domestic and foreign science: Averyanov O. M., Anokhin P.K., 
Andreev I.D., Afanasyev V.G., Blauberg I.V., Ashby U.R., Yakovlev I.P. (reveal the patterns of a systematic approach to training); Antsiferova L.I, Leontiev O.M., Lomov V.F., Platonov K.K., Ponomarenko V.A. (express ideas about the unity of consciousness and activity of the individual, which is one of the main principles of forming a reliable specialist); Babansky Y.K., Batyshev S.Y., Gershunsky V.S., Davydov V.V., Lerner I.Y., Mahmutov M.I. (study the system, optimization and organization of problem-based learning); Aleksandrovsky Y.K., Garnaev O.V., Grimak L.P., Gromov M.M., Zhernakov V.F., Makarov R.M., Marishchuk V.L., Shandrikov V.D. (consider the problems of professional training of flight crew, psychophysiological reliability of operators, flight safety, taking into account the language aspect); Arkharova T.A., Bim I.L., Boeva I.V., Boldyrev M.M., Weizburd M.L., Kuzmina O.V., Vitryak A.M., Solovyova A.Y. (analyse pedagogical technologies of foreign language teaching). [581,586] But today none of the research in the field of professional pedagogy is devoted to the problem of forming reliable knowledge, skills and abilities in English for future pilots in the form of so-called a mixed learning (classroom, distance and simulator training). [587,590,592]

First, consider the very definition of distance learning. "Distance learning is an educational process in which a significant part of teaching is carried out by a teacher (or group of teachers), remote in space or time from the student (or group of students)." [587] (in our case from the cadets).

Distance learning technologies - a set of educational technologies, including psychological, pedagogical, information and communication, which provide an opportunity to implement the process of distance learning in educational institutions.

Subjects of distance learning are persons who study (in our case they are cadets) and persons who provide the educational process by distance learning (in our case they are teachers, methodologists and laboratory assistants, etc.) [584, 585].

Distance learning can take place in a synchronous mode - the interaction between the subjects of distance learning (cadets and teachers), during which all participants are simultaneously in the web environment of distance learning (chat, audio, video conferencing, social networks, etc.). 
Asynchronous mode - interaction between distance learning subjects, during which participants interact with each other with a delay in time, using e-mail, forum, social networks, etc. Therefore, it should be noted that we use both modes in the process of distance learning.

Distance learning methods that are most relevant in the process of training future pilots in aviation English:

case - method - based on the use of sets (cases) of text, audio-visual and multimedia teaching materials and their distribution for self-study and organization of regular consultations with the teacher; [594]

Internet network method - based on the use of Internet and telecommunications to provide teaching materials and interactive interaction between cadets and teachers. $[581$, c. 5]

Let`s review the case - method in more detail. This is exactly the most effective method in pilots` training. This method has been widely used by us before, even in the traditional form of education, as an element of distance technology.

Case - is a description of a particular situation or case in any field. As a rule, the case contains not just a description, but also a problem or contradiction and is based on real facts.

When training cadets, we offer them to analyse the proposed situation and find the optimal solution. Thematic case is sent to each cadet in advance. Such way, he has some time to get acquainted with the material. Sometimes the case-task (executivecase) is issued directly during the online lesson and, thus, connected "brainstorming" cadets solve it in a time limit, which is very useful for the reliable skills development in solving professional problems. Usually we offer a situation in the form of a video with a real emergency (You Tube) or movies ("Air Crash Investigations" or "1001 Air Crashes") or a real situation reflected in photo from the place of air crash. Cadets are asked to solve this case as follows: 1). Give a description of the image; 2). Assume the cause of the accident; 3) Analyse the hypothetical actions of the pilot and the air traffic controller; 4). Assume the outcome of the situation as if the pilot had acted differently; 5). Suggest your algorithm of actions in a similar situation. 
We can name the advantages of the case - method in comparison with traditional teaching methods:

Practical orientation. The case method allows you to apply theoretical knowledge to solve practical problems. This approach compensates exclusively for academic education and gives a broader view of the situation.

Interactive format. The case - method provides more effective assimilation of the material due to high emotional involvement and active participation of the cadet. the cadet is "immersed" in a situation with the head: the case has the main character, in whose place puts the cadet or team and solves the problem on his behalf. The emphasis in learning is not on mastering ready-made knowledge, but on its development.

Specific skills. The case - method allows to improve "soft skills" which are extremely necessary in real working process, and in our case in a real flight.

Thus, we can say that the case - method is one of the most effective t methods for training future pilots in distance learning.

Taking into account the force majeure of modern educationdue to pandemic, we have developed an additional special course in the discipline "Aviation English", where we considered the specifics of the job - the ability to operate the aircraft and conduct radio communication simultaneously. Case - method has found its place in every Module of this special course.

In the system of distance learning, the cadet has the main responsibility for the development of such skills. The teacher transfers the role of a source of knowledge to educational computer programs that serve these purposes. The organization and management of the educational process become the main function of the teacher. A full-fledged online learning project consists of:

-instructive unit, -information block (information content system of the resource), -control unit (testing and evaluation mechanism), -communicative block (systems of interactive communication both with the teacher and with other cadets);

-control system that combines all this together [581]. 
The Moodle educational platform used by Flight Academy of the National Aviation University is such a system. Appropriate organization of the educational process and distribution of material is the key to successful distance learning. Due to the fact that one of the aspects of the distance learning foreign language course is designed to develop skills of understanding aviation literature and mastering all types of reading (introductory, review, search), involving different degrees of reading comprehension, the material is selected according to the following criteria: relevance, authenticity, issues of content, professional orientation. Relevant teaching aids are an element of educational material. For example, the Department of Foreign Languages at the NAU Flight Academy has developed many textbooks in aviation English, English for professional purposes and English for scientific purposes in electronic format.

The structure of the course includes the following components:

- theoretical part, presented in the form of presentations, which creates figurative clarity;

- practical part, including training exercises that provide multiple repetitions of the material;

- intermediate tests necessary for the formation of professional skills;

- final test tasks to control the assimilation of the material;

- additional materials, including information about the course;

requirements for tests and exams;

manuals and reference materials necessary for successful mastering of the course program.

In the process of performing tasks, cadets can communicate with each other and with the teacher. As practice shows, the combination of automated control of knowledge and "live" communication is a powerful psychological factor that stimulates the quality of foreign language learning and leads to positive results.

So, due to its flexibility, distance learning creates the ground for the development of cadets' foreign language communicative competence, increases the efficiency of independent work, and the need for autonomous learning promotes, the development 
of skills of self-education and self-development. It should also be emphasized that the creation of special courses for so-called mixed learning today is a necessary condition for further learning in a pandemic, which greatly facilitates the educational process and contributes to the effective results of aviation English teaching for future pilots. 


\section{DOI 10.46299/ISG.2021.MONO.PED.III.8.5}

\subsection{Technique of development and teaching a subject matter at the higher school}

Lecturing technique. A lecture is the main form of carrying out studies in higher education institution which is intended for assimilation of theoretical material. As a rule, the lecture covers the main theoretical material of one or several topics of a subject matter. The subject of lecture course is defined by the working training program. Giving of problematic lectures which content concerns this discipline is possible, but it is not covered by the training program. Such lectures are given by the leading specialists scientists for students and employees of higher education institutions in specially allotted time. Lectures are given by professors and associate professors (tutors) of higher education institution. In exceptional cases lecturing is allowed for teachers after the corresponding decision of department [595, 597, 602].

The lecturer, who is entrusted to give a course of lectures, is obliged to provide the abstract of lectures (author's textbook, the manual) to the department before the corresponding semester, as well as control tasks for carrying out the final control provided by the curriculum and the program for this discipline. The lecturer is obliged to follow to the training program on subjects of lecture classes, but not to be limited in matter of interpretation of a training material, forms and ways of bringing it to students $[596,600,606]$.

The lecture with elements of problem training begins not with the announcement of a subject of a lecture, but with creation of a problem situation for students, solving of which together with audience, the lecturer immerses the listeners in the world of knowledge of new information. After it was succeeded to formulate a problem, it needs to be structured to $2-3$ problematic issues (in ordinary lectures it is equivalent to the main questions of a lecture). Now each problem has to be formulated independently. The quantity of problematic issues depends on the maintenance of a problem and ability of the teacher to separate information for independent "portions" of the completed information. Each problem has to be accurately formulated. After structuring a problem, single problematic issues are placed in the sequence determined by the importance in which the solution of one problem would promote statement of 
following. The sequence of problem situations which is developed presents the plan of a lecture in its traditional understanding [598, 599, 601].

Preparation for a performance at a lecture. Oratorical and pedagogical art is a mean of influencing people and at the same time a mean to manage them. Success comes if we consider the interests of people, their psychological features, requirements, perception and understanding of a situation. The oratory is an art of preparation to the speech with a concrete impact on mind, feelings and will of listeners [603, 607].

The main rule of the lecturer is to know what, where and how to tell. The famous Roman speaker Mark Tully Cicero in his work "On the Orator" noted that for achievement of the goal during the speech the speaker has to do three things: 1) it is persuasively to prove the ideas; 2) to affect will and feelings of listeners; 3 ) to give pleasure to audience. Therefore, success of a public performing, as well as thousands years ago, depends on knowledge of methods of oratory, the standard of speech and continued work. Let's remind an oratory precept: "Are born poets, and become speakers" [604].

The good speech is very often compared to the growing tree where a root is incentive motive, a trunk is the main issue and branches are auxiliary questions, leaves - comparison, flowers - rhetorical methods [605].

The effectiveness of a lecture depends on many factors, in particular on a situation in which it is given; type of audience with which the teacher works; individual qualities of the lecturer and others. Sign of the effective and successful lecturer who is able to work with audience is the ability to use a set of styles and genres of performances, all methods of impact on audience in the work, ability to adapt quickly in a new situation $[608,612,619]$.

The lecture should be considered not only as information passing from the teacher's head to the student's head. First of all, the lecture is: mean of exchanging opinions; mean of polemic (discussion) form of educational managing and creative activity of students. In this context there is a very important question; what is the oratorical skill of the teacher defined by? First of all the charisma level, the outstanding personality of the speaker, ability to influence audience, to interest students in the 
practical value of a subject, the standard of speech. At the same time full-time employment and improvement lecturing skill is a condition of a good result [609].

The more we will consider the interests of students, features of their perception of information, the level of readiness, requirement - the more chances the lecturer has for the success. A basis of it is the ability to own a word, teacher's ability to convince people. Successful mastering lecturing skill is promoted by studying experience of the best speakers, critical estimation of own experience and aspiration to self-improvement [596, $598,610]$.

According to contents and data representation form of a lecture is divided into the following types: problematic, informational, summarizing, consulting (survey), and as their given to listeners - monologues (without emphasis on reaction of audience) dialogues (continuous interaction with listeners) discussions (disclosure of contradictions during the lecture) [613].

\section{Training of the speaker for a lecture performance.}

This preparation includes the following stages [611]:

$\checkmark$ definition of type of a performance which can be: informational (gives the concrete description, the found regularity, offers certain results) propaganda (it is necessary to convince audience, to inspire, recruit, etc.); combinational;

$\checkmark$ choosing of a performance stile which can be: scientific (it is characterized by the reasonable argument and academism) business (it is used among businessmen, practicians) an interview (confidential conversation of the curator with audience)

$\checkmark$ definition of the speech variants: a) to read from the abstract, b) to reproduce on memory, c) to state freely or to improvise. Depending on type and a way of preparation the option of reading a lecture is chosen individually

$\checkmark$ definition of an accurate lecture of composite construction (introduction, main part, conclusion). 
At the same time, it is necessary to remember a psychological component of assimilation of information by students depending on a form of representation of information material. For example, if students perceive evident material then the visual memory works, perceive information aurally - acoustical memory, entering polemic they begin to argue. By many researches it is established that for increase in efficiency of perception of information the lecturer needs to use an integrated approach [614].

The teacher composes each next lecture material around the main idea ("main base"). It is desirable that the training material of one lecture could be sorted for 2 class periods (one couple) with its logical conclusion. During preparation for a performance it is necessary to remember that for increase in efficiency of assimilation of a training material it is necessary to observe the following requirements [605]:

- the average length of the sentence should not be more than 15 words;

- there has to be a variety in offers;

- it is desirable to put quite developed thought in one point;

- use the standard reductions;

- use evident graphic means of submission of information;

- revise the text several times and reduce it whenever is possible.

Psychologists note: there are three memorizing types of a training material for students: 1) direct reflection of sensory (sensual) information; 2) short-term; 3) longterm storing [607].

The teacher has to learn to polemize. Need of conducting discussions arises owing of disagreement in estimates and opinions on any given questions. The teacher needs to consider that students sometimes seek to disprove what is proved by the lecturer. For this purpose, it is necessary to be able to prove the truth.

\section{Reading lecture}

In a lecture the sense is defining. The speech should not be difficult. It is necessary to speak simply, convincingly, frankly, clear. Depending on the purpose of a lecture the structure and a method of material supply is adjusted, the plan is specified, necessary arguments are selected. Experienced lecturers seek to consider structure beforehand, level and the interests of listeners, their mood and possible reaction [602]. 
In a basis of a lecture, stated by means of a method of "main base", the principles of basic accumulation on each question of the most important material are put for the purpose to increase in performance of training process.

Basic principles of this method: material statement in big temporary "portions"; repetition stated several times; feedback from audience in the form of discussion of material [599].

For realization of these principles it is necessary that each next lecture began with the short informative review of earlier stated lecture material - quizzes, for assessment of entrance control of knowledge and full assimilation of information. It takes about 5-7 minutes.

The technology of holding quizzes is formed of short questions with a possibility of prompt replies. At the same time, it is expedient to encourage students with rating points for the correct answers.

The option when the teacher suggests students to prepare quizzes with their own before each lecture in turn is possible.

Psychologists define that in the lecturer there are three fixed assets of impact on audience $[614,618]$ :

- linguistic (contents of the speech);

- paralinguistic (speed, intonation, modulation of a voice, etc.);

- kinetic (gestures, mimicry, poses of the speaker).

While giving of lecture material mind grammatical norms and word usage. Avoid bureaucracy, formulaic - they complicate perception of information and quite often confuse listeners.

Appropriate speech speed is 120 words per $1 \mathrm{~min}$.

Significantly the content of a performance is influenced by pauses. On many researches of a pause make 10-15\% of time of the lecturer speech. Pauses during the performance are different: a breathing pause, grammatical (it is used for attentive reading of text information), pedagogical (for judgment and assimilation of information by listeners) "Full of holes" (the lecturer lost the point, forgot information or does not know what to tell further) [612]. 
General recommendations for the lecturer: try not to read, and to speak; logically express thoughts and offers; define the sequence and consistency of judgments; select the reasoned facts and proofs; be in good mood and friendly; pay attention to erudition; control audience be able to distinguish the critical moments of a lecture, analyze the performance [600].

\section{Technique of carrying out laboratory works.}

Laboratory works are one of forms of studies and one of practical methods of training in which the educational objectives are achieved at statement and carrying out experiments by pupils, researches with use of the special equipment, devices, use of special tools and other technical devices. At these classes the pupils perceive, observe, investigate natural phenomena, technological and other processes, study equipment objects, the device and the principle of operation of measuring and other equipment, a measurement technique $[603,611]$.

The subject and the purpose of laboratory works depend on specifics of specialty, a subject matter and a subject. At the same time, laboratory works perform also the general functions on achievement of the education goals, have extra-subject value at training of specialists.

Thus, introduction of laboratory works to educational process allows to carry out connection of the theory with practice, develops creative and independent activity of pupils, forms skills of use of the modern equipment, measuring and other technical devices and statements and carrying out experiments. At laboratory works the students join in process of knowledge of physical, chemical and other phenomena, being directly involved in carrying out various experiments. Carrying out laboratory works allows to form skills of work with devices, the equipment, assembly and installation of schemes, devices, use by the measuring equipment. Laboratory works contribute to the development of the general abilities to replenishment of knowledge the new facts, data of objects and the phenomena, learn to understand and apply these data, to analyze, synthesize and estimate the received results $[616,619]$. 
Laboratory works play a large role in achievement of the educational purposes at the level of specialty and also the didactic and developing purposes of subject matters and their components.

On the basis of activity approach to the analysis of laboratory works in their structure are allocated the following stages [617]:

- introduction and motivational;

- operational and informative;

- control and estimated;

-final.

The introduction and motivational stage includes definition and the message of a subject of laboratory work, formation of its didactic purpose and motivation of the purpose.

The central stage of laboratory work is operational and informative. It includes preparation for performance of practical tasks and their performance. By preparation for the lesson the teacher forms the list of practical tasks and also a technique of updating of basic knowledge and modalities of action, projects a technique of formation of the approximate basis of activity (ABA) and the organization of carrying out laboratory work. When carrying out laboratory work at this stage the list of tasks is submitted to pupils, basic knowledge and ways of action are updated, ABA is formed, implementation of the didactic project of a stage of work, performance of laboratory tasks by pupils will be organized [615].

At a stage of control and assessment the students carry out processing of experimental data and results of performance of laboratory tasks and also formulate conclusions.

The final stage includes registration and delivery of the report.

Though the specifics of laboratory work as form of lessons is defined by the central operational and informative stage, and other components have auxiliary character, it does not decrease their value for achievement of the goal of educational lesson. 
The structure of laboratory works defines the plan of holding such classes [615, 616]:

- the organization class beginning;

- announcing of a subject, purpose, tasks and motivation of the purpose;

- updating of basic knowledge;

- induction and acquaintance to the instruction;

- performance of tasks, exercises or tests, calculation of results;

- formation of conclusions and execution of the report;

- delivery of the report and assessment of results of work.

Classification of laboratory works is carried out depending on specifics of the tasks solved on occupation. It is allocated introductory, experimental and problematic researching works. At introductory laboratory works the it is held the studying of design features, devices of production mean of activity (equipment, tools, devices, etc.) and means of research activity (installations, devices, etc.) and also their control is carried out [602, 609, 616].

Experimental laboratory works surely include experimental research tasks. They can include tasks on study and working off a technique of carrying out various researches (for example, studying a technique of field experiment), on designing, redesigning and designing of various schemes and devices (for example, drawing up electric circuits for measurement of properties of objects, change of a design of the gear transmission for a variation of transfer number, etc.), on carrying out experiments which purpose is their carrying out, on studying influence of various factors on measurement of properties of objects, by definition of degree of compliance of experimental and design data, on checking, an illustration confirmation of laws and regularities (for example, a research of influence of biological medicines on development of mushroom diseases of plants, etc.) $[610,614,619]$.

Problematic and research works also include statement and carrying out an experiment. They differ only in degree of problematical character of an experimental task. At the same time, it is about levels of problematical character of these tasks for students: about novelty of objects, conditions in which the experiment is made, in 
comparison with studied earlier (theoretically and practically). Laboratory works on check of various hypotheses of educational and scientific level belong to this group of laboratory works [608].

Laboratory works is a form of studies and practical methods of training in which the educational objectives are achieved at statement and carrying out by students, experiments, researches with use of the special equipment, devices, measuring tools and other technical devices (laboratory works) and during the performing of settlement and other types of tasks and the solution of tasks (practical training). On such classes the students work practical actions and skills. For example, at laboratory works they observe, investigate natural phenomena, technical and other processes, study equipment objects, the device and the principle of operation of the measuring equipment, a measurement technique [617].

The scope of laboratory and practical works is determined by the training program by discipline, is concretized for each specialty in the working program for disciplines depending on specifics and the direction of training of specialists, the hours allocated for a workshop in the curriculum and existence of necessary laboratory base. At the same time, firstly the plan of work is done, the most significant for professional training and formations of practical modalities of action.

The wording of the name of work have to include necessary components of structure of the main objective solved at classes that is an object, subject of research; and also its task. At the same time an object, subject or its tasks have to be new to students.

Pay attention that as laboratory and practical works represent forms of studies, their purpose is to change the identity of the student. In cognitive area of structure of the students' identity these changes can be characterized by standards of educational actions with the indication of level of their formation according to taxonomy of the purposes. The motivation of the purpose of works is most often carried out by disclosure practical, professional value of result of work, ensuring interest in a subject, the organization of competitiveness when performing tasks [597, 602]. 
When performing laboratory works various types of algorithms of performance of tasks can be used [613]:

-reproduction algorithm;

- recognition algorithm;

- problem method.

When holding laboratory researches it is necessary to pay attention to their organization. It can differ depending on a form of their carrying out: frontal, cyclic, individual, and a practical training is given the most often by a frontal method. The organization of laboratory work includes also preparation of material resources: objects and means of educational activity.

\section{Technique of carrying out practical and seminar training.}

Practical class is a form of educational class on which the teacher will organize detailed memorizing by students of separate theoretical provisions of a subject matter, therefore skills of practical application of knowledge of theoretical material by individual performance by students of the corresponding tasks are formed [610].

Practical training is given according to the developed thematic plan and covers all material. The list that a practical training is defined by the working training program of discipline. Holding practical class is based on previously prepared methodical material (tests for identification of level of knowledge of students), practical tasks of varying complexity; evident material; methodical instructions. The mentioned methodical providing is prepared by the teacher, it is entrusted to them to give a practical training, in coordination with the lecturer of discipline [615].

Practical class includes carrying out preliminary control of knowledge of students, statement of a common problem by the teacher and its discussion, the solution of tasks with their discussion and assessment of results. The estimates received by the student on a separate practical training are considered at exposure of total assessment on discipline.

Practical occupation has to be formed according to the following scheme: the purpose, basic data, methodical instructions, an algorithm of the decision, a task for independent work (by analogy with the method considered earlier), control questions 
to students for fixing of material, assessment of level of formation of abilities, discussion of the course of training and a question to the teacher, the edition of homework to students [617].

In structure of class independent work dominates. The teacher participates at a problem statement stage, when developing methodical recommendations and exercises control. At the same time practical work can be organized by means of computers when performing tasks on optimization and with use of specialized application programs.

Practical classes can be given in the form of settlement work, a business or didactic game, the analysis of production situations, work with documents, a colloquium, a discussion, an examination. Here is given a form of the plan abstract of practical class which the teacher can use for his preparation [596, 602, 603, 609].

\section{PLAN ABSTRACT OF PRACTICAL CLASS IN DISCIPLINE:}

Class subject:

Date:

Class purposes:

Main problem of training:

Equipment (list of visual aids, posters, etc.):

The plan of training (list of the main points and time which is allowed for their realization):

Training course (detailed abstract):

stages and types of students' activity with constant structure;

formulation of tasks to students at each stage of class;

results of performance of the tasks provided;

references to materials on a training subject (numbering of pages of manuals, etc.);

drawings, tasks (with the decision), schemes, tables, etc.

Task to students from a reflection of their activity;

Forms of control and assessment of results of occupation;

Homework;

The list of the used literature; 
Form of the analysis of the given classes, results of its discussion with colleagues and teachers.

\section{Technique of holding seminar training.}

Seminar training - a form of educational occupation on which the teacher will organize a discussion on previously defined subjects. Students prepare theses of performances on the basis of individually performed tasks (papers) for classes. The list of seminar classes is defined by the working training program of discipline. On each seminar class the teacher estimates the prepared performances, activity of students at discussions, ability to formulate and defend the position. The teacher includes total estimates for each seminar occupation in the register [612].

Model of seminar class in an active form (SAF)

Training of creatively gifted experts of various spheres of production is impossible without activization of forms and methods of educational process. One of the main forms of practical preparation is seminar class which needs to be constructed in an active form of process of effective assimilation by students of educational information on model of management their educational and creative activity, thereby having intensified process of training [605].

The purpose of holding a seminar in an active form (SAF) is to intensify process of thinking of students by direct attraction them to the organization and the managements of occupation. This didactic form is also intended to create and set abilities of collective preparation, justification, adoption and assessment of management decisions, is an obligatory element of creative formation of heads and experts of the production sphere.

The active form of work assumes high-quality changes in relationship between teachers and students: not only the teacher and the corresponding educational and scientific literature, but also audience becomes a source of information. Students from object of management become subjects, in this case they teach each other. The teacher creates such didactic system at which pupils will independently organize holding educational occupation, performing not only retranslation functions on information transfer, but also develop a control algorithm of educational and creative activity, 
provides the general increase in efficiency of process of assimilation of knowledge and formation of creative experience of the personality. At the same time the relation of teachers with students become the subject - subject [614].

Modeling of specific situations is the cornerstone of carrying out SAF (production, social, economic, political). For future managers the active form of education is the most effective not only in the context of acquisition of skills of relationship in manufacturing execution system, but also for identification of reserves of improvement of methods and style of the management.

\section{Order of preparation and holding seminars in an active form (SAF)}

SAF includes two parts: preparatory and the main. Stages of a preparatory part (the teacher together with students carries out):

Acquaintance with a subject of seminar class.

Appointment of the leader (from among students) seminar class and the arbitrator for the leader (also from among listeners)

Development of seminar occupation by the host of regulations.

The first two stages are carried out by the teacher in advance, that is before holding seminar class (for example, at the end of the previous class). The regulations of seminar class are developed by the leader in advance and independently for that he has to get acquainted attentively with a subject of seminar class and study questions which have to be considered according to its plan.

Duration of time of a performance $(t)$ on a question depends on its complexity and the importance and also on the volume of material which needs to be considered according to the plan of seminar class. After drawing up regulations the leader in advance (prior to seminar class) tells speakers time which is allowed for the report. The leader is granted the right to appoint speakers on a subject of seminar class and also arbitrators on each speaker. At the same time each student for one question can be a speaker, and on another - the arbitrator $[609,616]$.

Seminar class in an active form will be organized and held by students. Its feature is that listeners estimate the actions independently, motivating and justifying the made 
decisions. The teacher gives an assessment to work of participants of seminar class (leader, speakers, arbitrators) at the end of class when summing up.

Seminar class in an active form assumes existence of the game moments, is reached by means of creation and support of "game mood". The game situation is set by the leader who has to have the corresponding abilities of the organizer and leadership skills. He has to plan, prepare and hold creatively a seminar that during all class the interest of audience did not weaken $[601,603,605]$.

\section{Functions and role of students when carrying out SAF}

The list of participants - students of the academic group from among whom are allocated: leader of a seminar; the arbitrator for the leader; speakers (the number of speakers has to be not less quantity of questions of the considered subject) arbitrators for speakers.

Functions of the leader. The main part of seminar class (after the previous recommendations of the teacher) begins with an opening speech of the leader. The leader has to report a seminar subject, to call issues which will be discussed, to make short introduction. After that he calls the name a question which will be considered, a surname of the speaker, reports acting regulations, calls the arbitrator on a question. After the end of a speech of the speaker the leader will organize dialogue in form of "question-answer", and then discussion of the report. After that the leader gives the word to the arbitrator who acquaints listeners with estimates of the students who were taking part in discussion of a question. Further the leader sums up the results, and then passes to discussion of the following question of seminar class [606].

After consideration and discussion of all questions of a subject of seminar occupation the leader sums up the general results by short generalization of all considered questions, focusing attention of audience on the key moments of a subject. After that gives the floor to the arbitrator and the teacher.

Functions of the arbitrator on the speaker. The arbitrator has to be guided well in a question on which it gives assessment review. Special attention of the arbitrator has to be paid to disclosure of maintenance of a question. If the speaker opened questions not completely or made mistakes (the passed highlights), then the arbitrator 
has to draw to it the attention of audience and make the relevant amendments and additions.

Functions of the arbitrator for the leader. The arbitrator for the leader estimates his performance on the specified scale. At the same time the leading SAF is estimated by two criteria: 1) for preparation and the organization of seminar occupation; 2) for holding occupation. The special attention of the arbitrator has to be concentrated on ability of the leader to organize discussion of all questions in order that the plan of seminar occupation was implemented completely [605].

In the course of holding seminar class an assessment of actions of participants is given by students, and at the end of class (when summing up) to the teacher.

Individual educational classes are given with certain students for the purpose of increase in level of their preparation and disclosure of individual creative abilities. Individual classes will be organized according to the schedule of the individual curriculum of the student and can cover a part or full volume of classes in a certain discipline, and in some cases the full volume of studies for concrete educational or qualification level [616].

Consultation - a form of educational class at which the student receives the answers or an explanation from the teacher on specific questions of certain theoretical provisions and aspects of their practical application. Consultation can be individual or be carried out for a group of students. Time volume given to the teacher for carrying out consultations on concrete discipline is defined by the curriculum. As a rule, it is 2 class periods. 
DOI 10.46299/ISG.2021.MONO.PED.III.8.6

\subsection{Structure of development of constructive skills of primary school teachers through collaborative learning}

The article discusses the problems of professional training of a modern primary school teacher by innovative means. The aim of the study is to develop a model for the formation and development of constructive skills of future primary school teachers using joint teaching methods and analyze its impact on the teacher's professional skills.

The method of joint learning involves joint solution of the problem, taking into account immersion in a common communicative context.

The developed model includes classroom and extracurricular cooperation at the stages of training constructive skills. One of the components of training is the formation of skills in designing educational material. The use of cooperation in the compilation of educational material is an important and effective way to form constructive skills in future primary school teachers.

Training of qualified specialists in the field of pedagogy is one of the main problems of the state education system.

The primary innovative school is characterized by the introduction of modern technologies and developing educational methods that require increasing the requirements for professional training of primary school teachers. In modern conditions, the requirements for training specialists are increasing from year to year. This fully applies to future specialists in the field of Education. The Russian education system is characterized by a high professional orientation of university graduates. Changes in the field of teacher training touched upon issues related to the training of specialists (primary school teachers) who are not only professionally competent, but also able to independently compile educational material and engage in continuous selfeducation, which determined the relevance of the study [620].

In modern conditions, an important skill of future specialists is constructive skills. Constructive skills include the teacher's ability to select and structure material for newly created academic subjects, as well as the selection and structuring of the content of educational and educational information in the upcoming lesson, taking into 
account the impact of the selected material on the development of certain qualities of students. Therefore, the problem of developing constructive skills of future specialists comes to the fore in modern didactics. In fact, universities do not have a clear model for implementing these skills in future specialists. The most convenient means of achieving the goal is the use of joint methods in the development of constructive skills [621, c.98].

Collaborative learning involves the use of joint teamwork of students in solving a task or developing a new product. In this case, students have the opportunity to interact with their colleagues, present and defend their ideas, and Exchange trust and doubt in choosing concepts. In addition, cooperation is a crucial factor in the development of the social, cognitive and emotional personality of future teachers.

There are five main elements of the cooperation strategy:

1. direct interaction;

2. developing social skills;

3. personal responsibility;

4. positive interdependence;

5.best information processing skills.

The organization of joint training contributes to the Coordination of students ' skills and the consolidation of their competencies. This, of course, contributes to the growth of knowledge used in the work when forming competencies that are a strategic asset. In the process of collaborative learning, the effect of "naturalness of learning" is created by combining knowledge and creating your own learning environment and integrating knowledge into competence. The combination of open and closed forms of education contributes to the stimulation of effective social interaction and creative activity in the educational process of future primary school teachers. The use of joint methods consists of several internal processes that include the process of transition: open knowledge hidden (external); hidden (socialization, combination); hidden open.

All internal processes contribute to the exchange of experience, in which mental models and technical skills are formed. They form the main elements of the model of formation of constructive knowledge in primary school teachers. 
The model includes the use of group projects, joint development, network interaction, and so on. a characteristic feature of co-learning is its duration over time, but at the same time maintaining constant access to communication with each other and with the teacher [623]. This fact determined the feasibility of using these methods in the formation of a model for the development of constructive skills in future primary school teachers. The most complete disclosure of these skills is shown in the project interaction, which forms the basis of our structure according to Table 1.

Table 1

Structure of development of constructive skills of future teachers

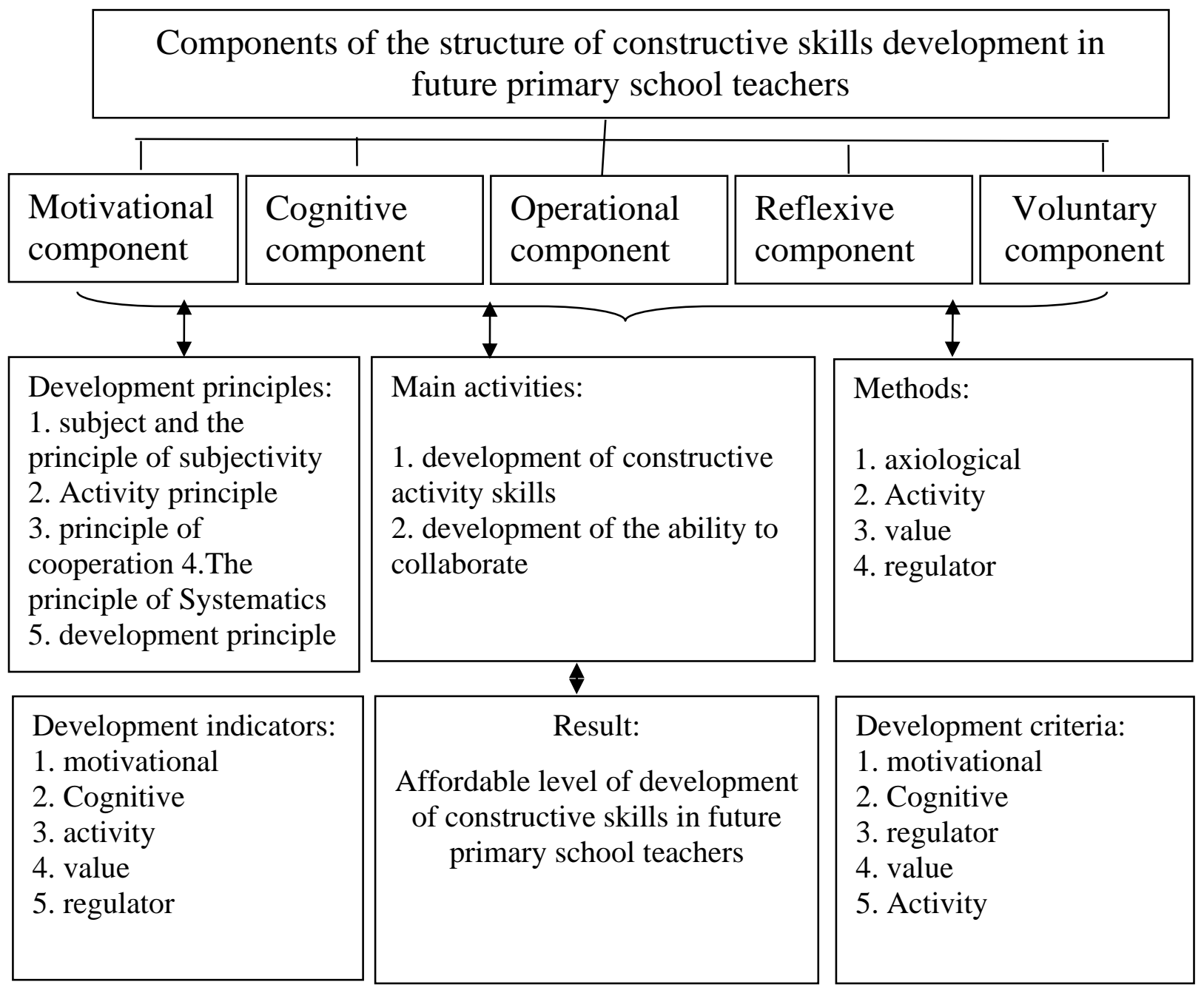

The above diagram shows in detail the main indicators of each component of the model. A generalized indicator of the motivational component is the psychological and pedagogical training of future teachers. An integrative indicator of the cognitive component is the theoretical readiness of future teachers for constructive activity. The 
design component summarizes the project preparation of future primary school teachers for constructive activities. The most appropriate methods and forms of implementation of the cognitive component of the model determine:

1.using non-traditional methods such as modeling, role-playing games, brainstorming, dialogues, and forums;

2. project activities;

3. using multimedia visualization tools;

4. preparation for activities that contribute to the development of decisionmaking abilities;

5.using the methods of front-end self-survey of students, interprover and interprocessor work.

The main purpose of using these methods is to activate creative abilities and develop constructive skills. For our model, the most innovative and student-orientedproject teaching methods were selected.

The basis of the project learning system was the works of American Scientists: D. Dewey, W. A. Lai, E. Thorndik. The method of project interaction involves the use of the entire surrounding student as a laboratory in which the process of cognition takes place. Project-based learning in the educational process involves creating special conditions in which students independently and willingly receive the necessary knowledge from various sources, increase their research skills and system thinking, and learn to use them in solving cognitive and practical problems. This implies an independent choice of the student's activity when working on a project in accordance with the material under study, but the possibility of going beyond it remains. The following components of the project activity can be distinguished, as shown in Table 2. 
Components of project activity

\begin{tabular}{|l|}
\hline \multicolumn{1}{|c|}{ Components of project activity } \\
\hline 1. problem analysis \\
2. formulate a topic \\
3. setting goals \\
4. defining tasks \\
5. selection of access tools \\
6. analysis of project resource support \\
7. Search and processing of information \\
8. evaluation of the results and conclusions \\
obtained \\
9. presentation and discussion of results \\
\hline
\end{tabular}

The structure and content of constructive skills are determined by the applied principles of teaching future primary school teachers [624]. We can distinguish six basic principles that allow us to build methodological components of the educational process:

1. the principle of Primary Education-the need for a sufficient level of education for Primary School;

2. The principle of integration-implies the design of materials by combining primary school subjects;

3. the principle of reflection-students ' analysis of personal experience and experience of teachers;

4.schematic principle - the use of graphic components in lessons requires poor sensitivity of modern students to text information.

5. the principle of consistency-in the course of training, it is assumed that there is a gradual increase in difficulties and the accumulation of constructive skills;

6.the principle of individualization-determines the possibility of building an independent educational trajectory of teaching future primary school teachers.

Let's look at some of the methods of the project learning method in collaborative learning. Methods of the design method include combining in pairs or small groups of four or five people. Spencer Kagan proposed the following methods of joint learning: 
1.the" think in pairs " method allows students to find solutions by writing down thoughts or thoughts. At the end of the allotted time, students express their ideas. The teacher then demands that the joint formulated answer be published.

2." zigzag " perception - some members of the group are members of two groups (House and expert) working on the same topic at the same time. In a group of experts, he studies new material, and then discusses it with members of his team. At the end of the discussion, the expert group should prepare a logically constructed plot, which the student returns to the Home Group, and the main questions aimed at understanding the topic under discussion. Returning to the group, the student talks about achievements in the project group and clarifies incomprehensible moments.

3. Take A"Reverse Zigzag";

4.Take "Zigzag 2".

Overall success is achieved through the interaction of team members:

- Information exchange;

- Provide and receive support;

- Feedback;

- Activation of efforts;

- Exchange of achievements;

- Interpersonal relationships;

- Take care of improving the effectiveness of the group.

The positive impact of social dependence on collaboration in groups conducted on the basis of digital technologies is well known. This highlights the importance of informal socialization to achieve high results in a collaborative learning environment.

Thus, the development of skills in designing educational material involves combining various forms of presentation of knowledge and didactic material. The main stage of drawing up the educational material is the structuring of the educational material, aimed at identifying the internal semantic connections of the studied Information [622, p. 24].

The developed model is implemented in several stages [625]: Initially, the project initiative appears (originally from the teacher); then the project participants 
determine the methods of interaction (meetings, creating groups in social networks or messengers, etc.); at the next stage, the project participants take the initiative; the development of the main ideas of the project and the organization of

The annual changes to the GEF require higher qualifications from primary school teachers at the University. The primary school teacher acts as an intermediary between science and the school, turning a scientific subject into an academic one. Only a competent assimilation by future teachers of the ideas of structuring the educational material will allow them to achieve the goal.

Collaborative learning methods contribute to the formation of a unique open learning environment in which students teach each other through the exchange of knowledge and common intellectual efforts and encourage each other to constantly strive for self-development. In collaborative learning, students look at different perspectives and thus clearly formulate their ideas and support their point of view.

Collaborative learning is based on four basic principles: interaction, positive mutual dependence, personal responsibility, organization of cooperation.

At the same time, it is important to understand that collaborative learning in school lessons cannot improve relationships in the classroom in general. The teacher should not sit the students down the way the teacher wants. Schoolchildren should independently determine for themselves a specific team in which they will feel more comfortable. It is this factor that determines that the students choose the group in which he previously communicated.

In the process of collaborative learning in school lessons, it is necessary to remember about simultaneous interaction. Of course, most of the time allotted for the lesson, only the teacher speaks. But it is necessary to give time for the interaction of students with the teacher. This time gives a specific opportunity to talk to everyone, which significantly increases the overall productivity of school time for students. In school lessons, students communicate with each other with increasing dynamics. This gives students the most confidence before starting to speak in front of the whole class.

In the production of collaborative learning, fundamental principles must be observed. 
1. Groups of students should be formed by the teacher before the start of the lesson, of course, taking into account the psychological compatibility of students. It is important to understand that in each group it is necessary to ensure the presence of a strong student, medium and weak, as well as girls and boys. In the event that the group has been working especially smoothly, amicably for several lessons and there is no urgent need to change its composition. If the activity does not add up for some reason, then the initial composition of the group must be changed from lesson to lesson;

2. The group must be given one task, but with such consideration that during the process of its implementation, roles are distributed directly between the working members of such a group.

3. It is important to evaluate the work of not only one student, but the whole group as a whole. At the same time, in some cases, it is possible to provide students with an independent assessment of the results of their own work; the teacher himself must choose a member of the student group who will be required to report for the completed task. In some cases, a weak student should be assigned to this position.

The work of a teacher is essentially a variety of pedagogical influences on students. The business relationship of a teacher with his students must begin from the very first days of the learning process. In the conditions of modern Russian pedagogy, the joint work of students is quite rare. This leads to negative results in the future. Without such work, students get used to sitting quietly, while not paying much attention to the activities of other students. He listens to the teacher, but does not catch the main essence of the educational material. 
DOI 10.46299/ISG.2021.MONO.PED.III.8.7

\section{7 Система методів і вправ для вивчення фразеологізмів у курсі української мови як іноземної}

Фразеологізми належать до стійких мовних конструкцій, характерною особливістю яких є національна маркованість. Вони становлять країнознавчу цінність і відображають національну культуру носіїв мови-джерела. У зв'язку з цим під час вивчення стійких висловів в іноземній авдиторії виникають значні труднощі. Адже завдання викладача української мови як іноземної (УМІ) відпрацьовувати знання, уміння й комунікативні навички, які визначають здатність особи, для якої українська мова $є$ іноземною, застосовувати ії для задоволення своїх суспільних, соціальних, побутових, освітніх, бізнесових, соціокультурних потреб. Нині для набуття громадянства України особа повинна підтвердити володіння українською мовою як іноземною на рівні В1. Це необхідний рубіжний рівень володіння УМІ, що уможливлює розгорнуте спілкування в повсякденних ситуаціях та в умовах комунікації з елементами непередбачуваности. Рубіжний рівень рекомендований для всіх іноземних громадян, щоб розпочати навчання в університетах України. Для здобуття ж ОКР «Бакалавр» необхідно володіти мовою на рівні В2 (середньому, достатньому), досягнення якого свідчить про можливість ефективного спілкування в українськомовному (і професійному) середовищі з усвідомленим використанням виражальних засобів та мовленнєвих умінь. 3 огляду на це вивчення українських фразеологізмів $\epsilon$ необхідним етапом в оволодінні мовою на достатньому рівні.

Дослідженням фразеологічних одиниць як аспектом вивчення лексики української мови в іноземній авдиторії займалися Т. Лагута, Ю. Сагата, М. Сціра, О. Тараненко, Н. Ядловська та ін. Фразеологію у формуванні мовної компетенції студентів у процесі викладання української мови як іноземної аналізували Ю. Жлуктенко, Г. Кузь, О. Кунін, Н. Скиба та ін. Фразеологічні еквіваленти й аналоги як засоби відтворення фразеологічних одиниць на позначення суб'єктів оцінки людини в українській та англійській мовах вивчали Р. Зорівчак, О. Кунін, Е. Солодуха та ін. Питання перекладу фразеологічних 
одиниць знайшли відображення в роботах А. Арсентєвої, Я. Баран, О. Білоуса, С. Флоріна, Ю. Шепеля та ін.

Незважаючи на те, що фразеологічні одиниці широко застосовуються в усному і писемному мовленні (художній літературі, публіцистиці та інших стилях мови), а особливості їхнього функціонування досліджено в різних наукових розвідках, аналіз методики вивчення цих стійких мовних конструкцій в іншомовній авдиторії потребує глибшого осмислення - з огляду на нові вимоги до рівнів володіння українською мовою як іноземною.

Мета дослідження - проаналізувати наявні й запропонувати оптимальні методи, які сприяють ефективному та поетапному вивченню фразеології на заняттях з української мови як іноземної; надати різні види завдань для вивчення, закріплення, повторення теми «Фразеологія», а також із метою перевірки знань і навичок студентів-іноземців.

Методисти вже запропонували декілька схем для системи опрацювання фразеологічних одиниць 3 іноземними студентами. Зокрема, Т. Лагута виокремила п’ять етапів вивчення української фразеології: 1) подання теоретичних відомостей про українську фразеологію; 2) пояснення нового фразеологічного матеріалу; 3) виконання різних видів вправ із метою закріплення вивченого; 4) повторення вивченого; 5) виконання певних видів роботи 3 метою перевірки знань і навичок іноземних студентів [628, с.с. 139]. Інші дослідники пропонують інтегрувати роботу з будь-яким текстом і в процес вивчення фразеологізмів [629, с.с.9]. Так, цей процес вони поділили на три етапи: 1) передтекстовий (передбачає мотивування студентів, підготовку до успішного виконання завдань, акцент на невідомій їм інформації, запитання, що сприяють формуванню навичок мовного прогнозування); 2) текстовий (пропонують низку завдань із метою розвитку комплексних комунікативних навичок, а також елементи однієї з форм контролю рецептивних навичок аудіювання); 3) післятекстовий (використання вихідного тексту як основи та опори для формування продуктивних умінь у різних видах мовлення; 
пропонують завдання, спрямовані насамперед на розвиток продуктивних умінь в усному мовленні, організовують мовленнєву діяльність студентів) [629, с.с. 9].

Правильне використання фразеологізмів сприяє поглибленню комунікативних умінь іноземних студентів, увиразнює їхнє мовлення, робить його живим, емоційним. Знання фразеології - це найвищий етап володіння студентами-іноземцями нерідною мовою, оскільки фразеологічні звороти - це одне із невичерпних джерел посилання експресивності та поглиблення логізації викладу [628, с.с. 137]. Тому вивчення фразеологізмів варто ретельно продумати й спланувати в такій, на наш погляд, оптимальній послідовності:

1. Надання теоретичних відомостей про українську фразеологію, фразеологічну одиницю, типи та джерела виникнення, ознайомлення студентів iз фразеологічними словниками, де подано значення цих стійких висловів, синонімійними чи антонімійними до них. Обсяг цих повідомлень має бути насиченим цікавими, доступними для сприйняття прикладами.

2. Пояснення нового фразеологічного матеріалу. Студенти-іноземці за допомогою викладача розтлумачують значення фразеологічних одиниць та вводять їх у контекст, який є матеріальним виразником ситуації, актуалізує значення фразеологізму. Опісля студенти повторюють уголос індивідуально або за викладачем наведений у контексті фразеологізм і записують його до спеціального фразеологічного словника, створеного ними. Це сприятиме кращому запам'ятовуванню.

3. Використання практичних завдань, різних видів вправ, узагальнювальних текстів із метою закріплення вивченого.

4. Використання проблемних завдань із системою перевірки знань і навичок іноземних студентів, а саме: проведення вибіркового фразеологічного диктанту, дискусій, рольових ігор, створення й розгадування кросвордів; складання діалогів та текстів. Така різноманітна робота поглиблює знання іноземних студентів, збагачує мовлення, розширює світогляд, виробляє навички українського мислення та уяви. 
На першому emani роботи 3 іноземними студентами викладач повинен зосередити увагу на фразеологізмах із дієсловами руху, зробити акцент на тому, що саме ці стійкі вислови уможливлять досягнення бажаного комунікативного рівня, оскільки за семантикою ці фразеологічні одиниці охоплюють аспекти найрізноманітнішої тематики. Рекомендуємо, наприклад, опрацювати такі фразеологізми: лізти у воду, не знаючи броду; налетіти, як мухи на мед; і вусом не повести; полетіти стрілою; залізти в петлю; нести тягар на своїх плечах; водити за ніс; тримати язик за зубами тощо.

Другим етапом роботи є пошук фразеологічних аналогів в інших мовах. Цей етап можна організувати за допомогою аналізу таких фразеологізмів: Попасти пальщем у небо - прийняти пухирі за ліхтарі (франц.); Ведмідь на вухо наступив - котяча музика (пол.); Теревені правити - австрійська розмова (пол.); Висіти на волоску - триматися на ниточці (англ.); Робити з мухи слона дивитися через збільшуване скло (ісп.); Червоний як рак - червоний як омар (англ.) тощо.

Пріоритетним способом перекладу фразеологічних одиниць $є$ переклад за допомогою фразеологічних еквівалентів. Це означає, що між співвідносними фразеологічними одиницями не повинно бути розходжень відносно змісту, метафоричності, емоційно-експресивного відмінку; еквіваленти повинні мати приблизно однаковий компонентний склад. Наприклад, рос.: взять быка за рога - узяти бика за роги (укр.) [630, с.с. 138].

На mpemьoмy emani варто розтлумачувати фразеологізми, які студентиіноземці зможуть використовувати в простих мовленнєвих конструкціях, наприклад: сидіти на телефоні, вийти сухим із води, біла ворона, водою не розлити, кров із молоком, крокодилячі сльози, пекти раків тощо.

На четвертому emani роботи можна використати фразеологічну синонімію та антонімію, зокрема запропонувати дібрати ці лексичні категорії-відповідники до вказаних одиниць: решетом у воді зірки ловити - байдики бити, ловити тави, ворон лічити; товкти воду у ступі - переливати з пустого в порожне, носити воду решетом; як n'яте колесо до возу - як собаці n'ята нога, як зайцеві бубон, 
як лисому гребінь (синоніми); жити чужим розумом - жити своїм розумом, мати свій розум; за тридев'ять земель - під носом, не за горами, рукою подати; купатися як сир у маслі - перебиватися з хліба на воду (антоніми).

Найбільш ефективним засобом для сприяння розумінню українських фразеологізмів в іноземній авдиторії є мотивування студентів до висловлювань 3 використанням фразеологічних одиниць. До того ж варто змоделювати в навчальному процесі умови спілкування, що наближені до реального життя. Сучасні інноваційні технології навчання надають можливість формувати навички усного мовлення іноземців із використанням українських фразеологізмів, зосередивши роботу на окремих навичках, які поступово об'єднуються в комплекс умінь. Це уможливить не тільки розуміння фразеологізмів у репліках співрозмовника, а й продукування висловів від свого імені $з$ доречним уживанням фразеологічних одиниць відповідно до ситуацій живої комунікації. Володіючи навичками спілкування 3 використанням фразеологізмів, студенти менш відчувають такі типові для говоріння чужою мовою проблеми, як недолік мовних і мовленнєвих засобів для розв'язання посталого завдання.

М. Сціра сформувала критерії добору фразеологічних одиниць для навчання студентів-іноземців на початковому рівні: 1) проста будова фразеологізму (слова в прямому значенні, 2 - 3 компоненти, проста морфемна структура); 2) прозора внутрішня форма (мотивація); 3) наявність країнознавчої інформації; 4) частотність уживання [631, с.с. 164].

Формування навичок усної комунікації із застосуванням фразеологічних одиниць передбачає передусім розвиток умінь діалогічного мовлення, тому на етапах закріплення та повторення вивченого матеріалу ефективною формою роботи є складання діалогу, що стимулює іноземних студентів до побудови зв’язного висловлювання, активізує вживання фразеологічних одиниць. Тут пропонуємо студентам-іноземцям завдання, які передбачають поступове збільшення самостійности студента в продукуванні власних висловлювань: відтворення діалогів-зразків із певними фразеологізмами, добір реплік у таких 
діалогах, конструювання діалогів із вказаними фразеологічними одиницями, інсценування складених діалогів тощо. Наприклад:

Завдання: прочитайте діалоги. Знайдіть фразеологізми, поясніть їхнє значення.

а) - Доброго дня, Мухамеде!

- Привіт, Омаре!

- Ти вже підготувався до сесії?

- Нi, я ще й за холодну воду не брався. А ти?

- А я вже не б'ю байдики, взявся за голову, як каже наша викладачка, $i$ прачюю з ранку до ночі. Тобі теж бажаю дати собі лад, бо сесія не за горами!

б) - Добридень, Амаду.

- Добридень, Макає.

- Як справи? Я телефоную тобі, а ти мовчиш, ніби в рота води набрав.

- Так, я вчора встав ні світ ні зоря, але, можливо, не на ту ногу, тому щьо бігав у справах увесь день як білка в колесі, потім до сьомих віників перекладав тексти, а ще довго ламав голову, у кого знайти конспект із математики; побіг світ за очі за ним, але не знайшов, врешті збився з ніг і не чую вже ні рук ні ніг, загалом, увесь день вертівся як бджола в окропі...

- Почекай, ти сиплеш словами як горохом і я нічого не розумію!

- Вчи фразеологізми - тоді ніколи не вскочиш у халепу, а будеш на коні!

в) - Привіт, Йомбу!

- Привіт, Луїсе!

- Ти вже склав іспит із фізики?

- Так, ие був мій зірковий час.

- Звичайно, ти нама ходяча енциклопедія! А я щуе не склав. Ти ж знаєш, щэо фізика - мій камінь спотикання. Мені ще треба пройти крізь вогонь, воду та мідні труби...

- Розумію, адже під лежачий камінь вода не тече, так?!

Складнішими є завдання відредагувати тексти поданих діалогів, змінивши в них соціальний або віковий статус учасників i, відповідно, змінивши 
використовувані етикетні формули. Замінити або додати також можна інші елементи, які мотивують вибір тієї або іншої мовленнєвої формули: мету, час, місце акту комунікації. Такі вправи будуть доцільними на просунутих рівнях вивчення мови - на етапі, коли студенти добре засвоїли базові конструкції українського мовного етикету [632, с.с. 178]. Студентам із високим рівнем мовленнєвих навичок можна запропонувати складання діалогів про життя студентів, використавши відомі їм фразеологізми.

Розвитку мовних та мовленнєвих навичок i вмінь, ефективно сприяє рольова гра - соціально-побутова або фахова, що передбачає наближене до реальности відтворення можливих життєвих ситуацій. Абсолютна перевага гри загалом та мовної зокрема в іiі здатності захоплювати, зацікавлювати, бути мотивувальним та розважальним чинником для учасників. Логічне мислення, здатність до пошуку відповідей на поставлені запитання, мовленнєвий етикет багато в чому покращуються саме внаслідок вивчення матеріалу за допомогою мовної гри. Крім того, завдяки ігровим моментам створюємо сприятливий психологічний клімат на заняттях, активізуємо мовленнєву діяльність іноземних студентів. Успішне проведення рольової гри можливе за умови поєднання методичних і психологічних чинників: 3 одного боку - відповідність рівню володіння мовою іноземних студентів, правильна організація гри, активізація необхідного лексико-граматичного матеріалу, з іншого - дружня атмосфера у групі, психологічна готовність студента взяти на себе роль і виконати їі (варто взяти до уваги психологічні особливості іноземних студентів різних країн та освітні традиції, до яких вони звикли [633, с.с. 20]), тактовність, коректність і творчі здібності викладача [634, с.с. 110].

Рольову гру можна проводити у двох варіантах:

- студенту пропонуємо роль іншої людини;

- студент зображує самого себе в певній ситуації.

Застосовуючи рольову гру, викладач повинен ретельно продумати, зі скількох етапів вона складатиметься, скільки часу триватиме і які утруднення, 
пов'язані з використанням запропонованих фразеологізмів, можуть виникнути в студентів. Фразеологічні одиниці, необхідні в пропонованій ситуації спілкування, доцільно написати на дошці й звернути на них увагу студентів до проведення гри. Потрібно також виділити час, щоб студенти обміркували свої дії та ролі. Можна дозволити зробити записи, необхідні для виконання ролі, але під час гри слід заохочувати імпровізацію, а не читання підготовленого тексту. Важливо, щоб студенти не боялися робити помилки, налаштувавшись на сприйняття помилки як невід’ємного елементу процесу навчання.

Під час вивчення української фразеології можна запропонувати такі ігрові ситуації і завдання:

1. Розмова в чаті. Після зустрічі з приятелями двоє друзів характеризують свого знайомого або знайому. Використайте фразеологізми, що позначають особливості характеру людини: золоте серцее,одні кістки та шкіра, як з гуски вода, як риба у воді, мухи не зобидить, грати першу скрипку, золоті руки, мокра курка, ні риба ні м'ясо, дитя природи, стріляний горобещьь, лихий на язик, майстер на всі руки, кров із молоком, ходячий довідник, аристократ духу, хоч свічки ліпи, $і$ за холодну воду не братися, палкий серияем, золота голова.

2. Проблемна ситуація. Студенти шукають ноутбук, що загубили. Використайте фразеологізми, які можна вживати в цій ситуації: як корова язиком злизала, вішати носа, збитися з ніг, ламати голову, за мить, битий час, багато води сплило, остання крапля, голова йде обертом, руки опустилися, бути на сьомому небі, думки колесом ходили, мов у воду впасти.

3. Гра «Заходьте в гості!» Використайте фразеологізми, які можна вживати в цій ситуації: добрий вечір,добридень вам, на добраніч, ваме здоров'я, добрий вечір вам у хату,усього найкращуого, здоровенькі були, спасибі за вашу милість, ласкаво просимо, слово честі, будьте так ласкаві, Бог на поміч.

4. Інтерв’ю на тему: «Правила життя справжнього студента», застосуйте фразеологізми, які можна вживати в цій ситуації: пройти вогонь $і$ мідні труби, вийти сухим із води, пройти крізь вогонь і воду, пускати в очі пилюку, плисти за 
течією, зупинити колесо історії, обіймати поглядом, сушити голову, хоч до рани прикладай, як мак прои̧вітає.

До найбільш продуктивних видів комунікативних заходів також належить дискусія, що має більш складну структуру й етапи підготовки та проведення. Дискусія дає змогу студентам обрати власну позицію, сприяє формуванню навичок відстоювати іï, тому для іiі проведення необхідно, щоб іноземні студенти, крім засвоєння певної кількости фразеологізмів, оволоділи вміннями формулювати, аргументувати, захищати свій погляд, дискутувати на цікаву для них тему. У процесі вивчення української фразеології студентам-іноземцям можна запропонувати такі теми для проведення дискусій:

1. Дерево сильне корінням, а людина - дружбою. Поясніть, що таке «дружба», використайте подані фразеологізми: вкласти душу, не розлий вода, жити чужим розумом, перебувати на короткій нозі, лікоть у лікоть, легкий на підйом, твердий горіх, золота душа, держати слово нерозлучний друг, друзі пізнаються в біді, світла голова, до кого пристанеш, такий і сам станеш.

2. Усе починається 3 любові. Висловіть свою позиціє 3 цього приводу, використавши подані фразеологізми: споріднена дуща, серце з перц̧ем, розуміти серцем, носити на руках, кам'яне серцее, одним миром мазані, знайти доріжку до серцุя, тернистий илях, розбити сериฺе, ходити одними стежками, небо прихилити, лицар серияя, втратити голову.

3. Два рази молодим не будеш. Для висловлення своєї думки використайте такі фразеологізми: золоте правило, народитися в сорочияі, жити своїм розумом, пан або пропав, майстер на усі руки, зірковий час, грати периу скрипку, місие під сонцем, легкий хліб, робота горить у руках, або все, або нічого, козел відпущеення, закопати талант у землю, камінь спотикання, сізіфова прачя,біла ворона.

4. Не соромно не знати - соромно не вчитися. Обгрунтуйте свою позицію за допомогою поданих фразеологізмів: вийти сухим із води, Альма-матер, джерело премудрости, ловити кожну хвилину, піти на свій хліб, працуювати до десятого 
поту, мати голову на плечах, золоті руки, брати бика за роги, знати, де раки зимують.

На завершальному етапі закріплення й систематизації вивченого пропонуємо творче завдання - скласти короткі розповіді, у яких доцільним було б уживання певних фразеологізмів. Це творче завдання не тільки дозволить викладачу визначити, наскільки засвоєно вивчений матеріал, але й виведе студентів на рівень самостійного висловлювання і створення мікротексту. А саме це і $є$ кінцевою метою навчання студентів-іноземців говоріння з використанням фразеологічних одиниць [635, с.с. 39] - формування здатності спілкуватися українською мовою в різноманітних ситуаціях, застосовуючи фразеологізми для пожвавлення процесу спілкування.

Отже, система методів та завдань для вивчення фразеологізмів у курсі УМІ передбачає ретельну підготовку кількома етапами, виважений підхід викладача на кожному рівні освоєння фразеологічних одиниць. Систематично організована робота з вивчення фразеологізмів в іншомовній авдиторії сприяє ефективному засвоєнню нових знань та практичному застосуванню їх у спілкуванні, адже вивчення фразеологізмів - один із найскладніших аспектів на заняттях з УМI. Водночас фразеологічні звороти є обов'язковою частиною лексичного i культурного мінімуму, який необхідний для адекватної комунікації іноземних студентів під час вивчення української мови як іноземної та для оволодіння мовою на середньому рівні В2. Без знання фразеологізмів іноземний студент не буде рівноправним учасником комунікації з носіями мови, яку він вивчає. Володіння фразеологічними одиницями сприяє відкритому діалогу культур, розширенню словникового запасу, формуванню лінгвокультурної компетенції іноземних студентів. 
DOI 10.46299/ISG.2021.MONO.PED.III.8.8

\section{8 Активізація пізнавальної діяльності учнів у навчальному процесі: елементи для успішного вивчення іноземної мови}

\section{Прийоми та методи активізації пізнавальної діяльності учнів у процесі іншомовної освіти}

Важливу роль у якісній іншомовній освіті відіграє інтерес учнів до вивчення предмету, який залежить від того, наскільки здобувач освіти усвідомлює значення матеріалу, що вивчається, а поставлені завдання безпосередньо пов’язані з його пізнавальною діяльністю.

Національна доктрина розвитку освіти в Україні [636], Національна стратегія розвитку освіти в Україні на період до 2021 року [637], Закон України «Про освіту» [638] та Концепція «Нова українська школа» [639] спрямовують педагогічну науку на пошук нових принципів та критеріїв вибору змісту освіти, нових технологій навчання, орієнтованих на розвиток особистості учня.

Нове покоління Державного стандарту базової середньої освіти визначає, що метою мовно-літературної освітньої галузі є, зокрема, розвиток компетентних мовців і читачів із гуманістичним світоглядом, які здатні спілкуватися іноземними мовами для духовного, культурного та національного самовираження та міжкультурного діалогу, для збагачення емоційно-чуттєвого досвіду, творчої самореалізації, формування ціннісних орієнтацій і ставлень [640]. Компетентнісний потенціал (здатність спілкуватися іноземними мовами як ключова компетентність) зазначеної галузі передбачає набуття учнями необхідних умінь (використовувати власний мовленнєвий досвід для вивчення іноземних мов; пояснювати роль/значення мовних явищ та системи понять, за допомогою яких формується картина світу носіїв іноземної мови; використовувати у разі потреби різноманітні стратегії для задоволення власних іншомовних комунікативних намірів; використовувати іноземні мови для розширення читацького досвіду, читацьких інтересів) та ставлень (готовність до міжкультурного діалогу; розуміння важливості оволодіння іноземними мовами для міжкультурного спілкування; 
відкритість до вивчення іноземних мов; готовність спілкуватися іноземними мовами; дотримання культури спілкування, прийнятої в сучасному суспільстві; повага до культурних та особистісних відмінностей співрозмовників; усвідомлення та урахування переваг та/або обмежень окремих груп чи осіб; виявлення розуміння і співпереживання, толерантність до представників іншого народу, носіїв іншої мови, культури, звичаїв і способу життя; розуміння потреби популяризації України у світі засобами іноземних мов) [там же].

Базові знання з іноземних мов передбачають оволодіння учнями: знання світу (значення іноземної мови для життя в мультилінгвальному та полікультурному світовому просторі; місця, установи, організації, люди, об'єкти та їх взаємозв'язок i процеси у відповідних ситуаціях спілкування); соціокультурних знань (суспільство та культура країни мови, яку вивчають) (повсякденне життя; умови життя; міжособистісні стосунки; цінності, переконання, ставлення до національної ідентичності, історії, традицій, мистецтва тощо; мова тіла; соціальні звички/умовності/стереотипи (пунктуальність, одяг, харчування, поведінка, звичаї, святкування тощо); інформацією (джерела та види інформації; достовірність та новизна інформації; критерії добору і способи пошуку інформації; явна і прихована інформація); комунікацією (комунікативна взаємодія; мета та ситуація спілкування; комунікативний намір; вербальні та невербальні засоби; типові стратегії спілкування; інтонаційні засоби; емоційний стан; формули мовленнєвого етикету; різноманітні стратегії продукування ідей; суспільно-культурний контекст комунікації; типові стратегії взаємодії; цифрове середовище; безпечна поведінка в цифровому просторі; соціально значущі запитання; онлайн-взаємодія); мовленнєвими функціями та мовними засобами (опис; розповідь; характеристика; аргументація власного вибору, погляду; запитування і надання інформації; розпитування для роз'яснення та уточнення інформації; пропонування, прийняття, відхилення пропозиції; прохання про допомогу; оцінювання подій, ситуацій, вчинків, дій, фактів; порівнювання подій, фактів, явищ; привертання уваги співрозмовника; висловлювання власних вражень, почуттів, емоцій, переконань, думок, згоди або незгоди; значення мовних явищ та іншої системи понять, за 
допомогою якої сприймається дійсність; лексичний діапазон відповідно до тематики ситуативного спілкування) [там же].

У час радикальних змін у суспільстві, реформування вітчизняної системи освіти роль педагога, його відповідальність у становленні майбутньої особистості зростає подвійно, набуває великого значення. Людина розвивається та накопичує життєвий, а також професійний досвід лише у процесі своєї діяльності, внаслідок отриманих знань та пізнань. Для того, щоб ця пізнавальна діяльність була активною та плідною, щоб приносила радість відкриттів i душевне задоволення здобувачам освіти, віру у свої сили та здібності, завдання педагога й полягає у тому, щоб допомогти учням на всіх етапах навчання активно включитися у процес освіти та самоосвіти, виявити та розкрити індивідуальні особливості та здібності кожного учня, допомогти відбутися у професії та працювати над тим, щоб випускник Нової української школи відповідав умовам та вимогам сучасного життя, був конкурентоздатним у 21-му столітті [639].

Залучення учнів до навчального процесу шляхом активізації їхньої пізнавальної діяльності - це головний шлях підвищення ефективності навчання. Психологи (Б. Ананьєв, В. Крутецький, П. Кудрявцев, Н. Менчинська, С. Рубінштейн) зробили висновок, що всі здібності людини розвиваються i вдосконалюються у ії діяльності. Перш за все, йдеться про організацію повсякденної діяльності учнів, про їі активізацію. Досвідчений педагог завжди знайде оптимальні прийоми та ефективні методи, поєднання яких дає результат у потрібному напрямку.

Ставлячи за мету розвиток пізнавальних творчих здібностей учнів, необхідно добре продумати засоби досягнення цієї мети, тверезо оцінити наявні можливості та здібності кожного учня, пред’являти адекватні вимоги для того, щоб не підірвати у них віру у власні сили, не дати в собі розчаруватися. Активізація пізнавальної діяльності - процес складний, багатогранний, що відбувається через сприйняття, відчуття, мислення здобувача освіти. Особливу роль тут відіграє мислення, оскільки всі ці процеси проходять в першу чергу через мислення або йдуть паралельно. Тому, впливаючи на мислення, учитель задіює весь ланцюжок перерахованих почуттів у відповідь на його вплив. 
Активізуючи пізнавальну діяльність учнів, педагог формує у них мотив учіння, бажання розвиватися, вдосконалюватися. Але мотиви можуть бути різні: навчання заради майбутньої улюбленої професії, почуття обов'язку перед батьками, бажання отримати високу оцінку тощо. Але найважливішим серед них $є$ інтерес до предмета. Якщо вчителю вдалося його досягти, то така важка праця, як пізнання, для учня стає доступною, захоплюючою і поступово переростає у високу якість, як допитливість. Допитливого учня у класі можна побачити відразу: він активний, постійно дискутує, готовий відповідати, вдома читає багато додаткової літератури з предмета. Завдання педагога - підживлювати цей інтерес. Тільки тоді можна говорити, що в учня склався стійкий інтерес до предмета, виник потяг до набуття знань, до пошуку шляхів самовдосконалення.

Науковці стверджують (I. Кондратюк [641], В. Краснопольський [642], Л. Ричкова [643], С. Рябчинська [644], Е. Шевченко [645]), що навчання проходить ефективніше, якщо учень відчуває інтерес до того, що вивчає, тобто виявляє пізнавальну активність. Більше того, активізація пізнавальної діяльності - це один із головних шляхів підвищення ефективності будь-якого навчання. Стимулювати пізнавальну активність здобувачів освіти - це знайти ключик, який допоможе розкрити і мобілізувати здібності кожного повною мірою, що неможливо зробити за умов традиційного репродуктивного навчання.

Умілий педагог завжди знайде необхідні засоби - методи та прийоми, для збудження й активізації пізнавальної діяльності учнів. Це й використання різних видів самостійних робіт, вирішення ситуаційних вправ, виконання індивідуальних завдань, лабораторних робіт, тестів, підготовка повідомлень і доповідей тощо. Важливу роль, якщо не основну, в активізації пізнавальної діяльності учнів відіграє й особистість учителя, його професіоналізм, ерудиція, захопленість предметом, вміння чітко та послідовно викладати матеріал, правильно ставити цілі уроку, формулювати правильно питання, уміння захоплювати учнів радістю пізнання, педагогічний такт, уміння підтримати своїх вихованців, вірити в їхній успіх. 
Прийоми та методи активізації пізнавальної діяльності різноманітні. Але їх об’єднує одне - вони передбачають поступовий і планомірний розвиток мислення учнів та одночасне формування у них мотивів учіння.

Як зауважує М. Фіцула, методи навчання слід відрізняти від методів учіння.

Методи навчання - це впорядковані способи взаємозв'язаної діяльності вчителя й учнів, направлені на досягнення мети освіти.

Метод учіння - спосіб пізнавальної діяльності учнів, зорієнтований на творче оволодіння знаннями, уміннями і навичками та вироблення світоглядних переконань на заняттях і під час самостійної роботи [646, с. 152].

Щоб розкрити поняття методу докладніше, О. Ортинський пропонує розглянути його на рівні прийомів - конкретних способів організації діяльності учня. Тоді метод навчання, як і метод виховання, стає «інструментом дотику до особистості» (А. С. Макаренко), способом спонукання й регулювання розвивальної діяльності здобувачів освіти [647, с. 185-186].

В. Гладуш та Г. Лисенко дають таке визначення: «Прийоми навчання - це складова методу, конкретні дії педагога й учнів, спрямовані на реалізацію вимог тих чи інших методів» [648, с. 88$]$.

Прийом, не маючи самостійного навчального завдання, підкоряється тому завданню, яке виконується певним методом. Але залежно від конкретних обставин кожен метод може стати прийомом або реалізуватися у своєрідних поєднаннях декількох прийомів. Наприклад, розповідь як метод навчання в лекції може бути прийомом активізації уваги учнів.

Засоби навчання - це сукупність предметів, ідей, явищ і способів дій, які забезпечують реалізацію навчально-виховного процесу (різноманітне навчальне обладнання: книги, словники, наочні посібники, письмове приладдя, лабораторне обладнання, технічні засоби навчання та ін.).

Учитель повинен мати розвинуте педагогічне мислення, уміння самостійно оцінити майбутні навчальні ситуації, можливості методів і прийомів, уміння зробити свій обгрунтований вибір методів чи прийомів навчання в конкретних умовах для кожного заняття, оскільки від цього залежить ефективність навчання 
в сучасному закладі загальної середньої освіти.

Класифікують методи навчання 3 урахуванням того, що вони мають вирішувати дидактичне завдання. У класифікації повинна виявлятися внутрішня сутність методу, форма взаємопов’язаної діяльності вчителя та учнів як засіб управління їхньою пізнавальною діяльністю.

При цілісному підході до питання класифікації методів навчання у сучасній педагогіці відзначається розподіл методів навчання на дві групи традиційні та нетрадиційні. Як ознака відмінності традиційних методів навчання використовується ступінь активності здобувачів освіти, характер їхньої пізнавальної діяльності, психологічні й логічні аспекти тощо. Розрізняють класифікації, в основу яких покладено такі ознаки:

- джерела передачі та сприймання навчального матеріалу (С. Петровський, Є. Голант, Д. Лордкіпарідзе, М. Верзілін): словесні (вербальні), наочні та практичні;

- логіка передачі та сприймання навчальної інформації (С. Шаповаленко): індуктивні та дедуктивні;

- ступінь керівництва навчальною роботою (П. Підкасистий, Б. Паламарчук, В. Паламарчук): робота під керівництвом педагога, самостійна робота учнів; - рівень самостійності пізнавальної діяльності (М. Скаткін, І. Лернер): пояснювально-ілюстративні, репродуктивні, методи проблемного викладу знань, частково-пошукові (евристичні), дослідницькі;

- дидактичні цілі, які необхідно вирішувати на конкретному етапі навчання (М. Данилов, Б. Ссипов): методи оволодіння знаннями, формування умінь i навичок, застосування отриманих знань, умінь і навичок;

Ю. Бабанський виокремлює три великі групи методів навчання, в основу яких покладено:

1) організацію та здійснення навчально-пізнавальної діяльності;

2) стимулювання і мотивацію навчально-пізнавальної діяльності;

3) контроль і самоконтроль навчально-пізнавальної діяльності.

На думку М.Фіцули, поширеною $є$ класифікація методів навчання за 
джерелами передавання i характером сприймання інформації. У iï межах виокремлюють словесні, наочні, практичні методи [646, с. 153].

\section{Характеристика окремих методів навчання}

1. Словесні методи. До них належать пояснення, інструктаж, розповідь, бесіда, навчальна дискусія й ін. [там же, с. 153-155].

Пояснення. Це словесне тлумачення понять, явищ, принципів дії приладів, слів, термінів тощо. Використовують переважно під час викладання нового матеріалу, а також у процесі закріплення, особливо тоді, коли учитель відчуває, що учні чогось не зрозуміли. Пояснення часто супроводжується різними засобами унаочнення, спостереженням, дослідами. Успіх пояснення залежить від його доказовості, логічності, чіткості, образності мовлення.

Інструктажс. Як метод навчання він має інформативно-локальний характер, близький до розпорядження алгоритмічного типу. Його застосовують на лабораторних, практичних заняттях, а також під час підготовки до самостійної роботи.

Розповідь. Це монологічна форма викладання. Застосовують іiі за необхідності викласти навчальний матеріал системно, послідовно. Елементами розповіді $є$ точний опис, оповідь, логічне обгрунтування фактів. Розповіді поділяють на художні, науково-популярні, описові. Художня розповідь - це образний переказ фактів, вчинків дійових осіб (наприклад, розповіді про географічні відкриття, створення мистецьких шедеврів тощо). Науковопопулярна розповідь передбачає теоретичний аналіз певних явищ. Описова розповідь є послідовним викладенням ознак, особливостей предметів і явищ навколишньої дійсності.

Бесіда. Це метод навчання, за якого вчитель за допомогою запитань спонукає учнів до відтворення набутих знань, формування самостійних висновків та узагальнень на основі засвоєного матеріалу.

За призначенням у навчальному процесі розрізняють: вступну бесіду (проводиться під час підготовки до заняття, екскурсії, вивчення нового матеріалу); бесіду-повідомлення (грунтується переважно на спостереженнях, організованих учителем на заняттях за допомогою наочних посібників, а також 
на матеріалах текстів літературних творів, документів); бесіду-повторення (використовують для закріплення навчального матеріалу); контрольну бесіду (вдаються до неї при перевірці засвоєних знань).

За характером діяльності учнів виокремлюють: репродуктивну бесіду (спрямована на відтворення засвоєного матеріалу); евристичну, або сократівську (учитель запитаннями спонукає учнів до формулювання нових понять, висновків, правил, використовуючи набуті ними знання, спостереження); катехізисну (спрямована на відтворення тверджень, що потребують дослівного запам’ятовування).

Ефективність будь-якого виду бесіди залежить від вмілого формулювання запитань, а також від якості відповідей (повнота, чіткість, аргументованість).

Навчальна дискусія. Дискусія є публічним обговоренням важливого питання і передбачає обмін думками між учнями або учителем та учнями. Вона розвиває самостійне мислення, вміння обстоювати власні погляди, аналізувати й аргументувати твердження, критично оцінювати чужі і власні судження. Під час навчальної дискусії обговорюють наукові висновки, дані, що потребують підготовки за джерелами, які містять ширшу інформацію, ніж підручник. Дискусія спрямована не лише на засвоєння нових знань, а й на створення емоційно насиченої атмосфери, яка б сприяла глибокому проникненню в істину.

2. Наочні методи навчання. Сутність їх полягає у використанні зображень об’єктів і явищ. До цих методів належать ілюстрування, демонстрування, самостійне спостереження [646, с. 155].

Ілюстрування. Полягає воно в застосуванні посібників, плакатів, географічних та історичних карт, схем, рисунків на дошці, картин, фотографій, моделей тощо. Ілюстрації до навчального матеріалу полегшують його сприймання, сприяють формуванню конкретних уявлень, точних понять.

Демонстрування. Цей метод передбачає показ матеріалів у динаміці (використання приладів, дослідів). Він ефективний, коли всі учні мають змогу сприймати предмет або процес. Учитель зосереджує увагу на основному, допомагає виокремити суттєві аспекти предмета, явища, супроводжуючи показ 
поясненням, розповіддю.

Самостійне спостереження. Це безпосереднє самостійне сприймання явищ дійсності у процесі навчання. Методика організації будь-якого спостереження передбачає кілька його етапів: інструктаж щодо мети, завдань і методики спостереження; фіксація, відбір, аналіз та узагальнення його результатів. Виконану роботу слід обов'язково оцінювати.

3. Практичні методи навчання. Ці методи передбачають різні види діяльності учнів та учителя, а також самостійність здобувачів освіти у навчанні. До них належать вправи, лабораторні і практичні роботи [646, с. 155-156].

Bnрави. За своєю суттю вони є багаторазовим повторенням певних дій або видів діяльності 3 метою їх засвоєння, яке спирається на розуміння $\mathrm{i}$ супроводжується свідомим контролем і корегуванням. У навчальному процесі використовують такі види вправ: niдzотовчі (готують учнів до сприймання нових знань і способів їх застосування на практиці); вступні (сприяють засвоєнню нового матеріалу на основі розрізнення споріднених понять і дій); пробні (перші завдання на застосування щойно засвоєних знань); тренувальні (сприяють формуванню навичок у стандартних умовах: за зразком, інструкцією, завданням); творчі (за змістом і методикою виконання наближаються до реальних життєвих ситуацій); контрольні (переважно навчальні: письмові, графічні, практичні вправи).

Лабораторні роботи. Їх цінність як методу полягає в тому, що вони сприяють зв'язку теорії з практикою, озброюють учнів методами дослідження у природних умовах, формують навички користування приладами, вчать обробляти результати вимірювань і робити правильні наукові висновки.

Практичні роботи. Як метод навчання вони спрямовані на формування вмінь і навичок, необхідних для життя і самоосвіти. Виконання таких робіт допомагає конкретизації знань, розвиває вміння спостерігати і пояснювати сутність явищ.

4. Методи навчання залежно від характеру пізнавальної діяльності учнів.

1. Пояснювальний (інформаційно-репродуктивний).

2. Репродуктивний, заснований на відтворенні знань, повторенні способів діяльності і завдань. 
3. Проблемний виклад.

4. Частково-пошуковий.

5. Дослідницький метод, завдяки якому учені беруть участь у науковому пізнанні.

5. Бінарні методи навчання. Останніми роками набула поширення класифікація, яка відштовхується від суті процесу навчання як двостороннього процесу, - бінарна, в якій виділяються методи навчання і методи учіння (М. Махмутов) (див. табл. 1).

Таблиця 1.

Бінарні методи навчання

\begin{tabular}{|c|c|}
\hline Методи навчання & Методи учіння \\
\hline Інформаційно-повідомлювальний & Виконавський \\
Пояснювальний & Репродуктивний (відтворюючий) \\
Інструктивно-практичний & Продуктивно-практичний \\
Пояснювально-спонукальний & Частково-пошуковий \\
Спонукальний & Пошуковий \\
\hline
\end{tabular}

6. Логічні методи навчання: аналітичний, синтетичний, аналітикосинтетичний, індуктивний, дедуктивний, традуктивний, метод аналогій.

7. Методи стимулювання і мотивації навчання (за Ю. К. Бабанським) [649, c. 202-204].

- Методи емочійного стимулювання $і$ розвитку пізнавального інтересу (створення ситуації успіху (підбір завдань зростаючої складності, диференційована допомога, заохочення в навчанні, використання дидактичних та ділових ігор).

- Методи стимулювання $i$ мотивачиї обов'язку $i$ відповідальності, що передбачають формування розуміння учнями особистої значущості навчання, пред’явлення вимог, оперативний контроль, гуманне покарання.

\section{Активні методи навчання}

Сьогодні для підвищення ефективності процесу навчання у закладах загальної середньої освіти (3ЗСО) дедалі частіше застосовують так звані активні 
методи. Як стверджує В. Ортинський, вони допомагають розкріпачити свідомість, активізувати інтелектуальний i розумовий потенціал особистості, набути необхідних практичних навичок і вмінь.

Активними методами навчання можна назвати ті, що відповідають таким умовам:

- ставлять учнів у становище активних учасників процесу навчання;

- дозволяють значно підвищити ефективність використання навчального часу;

- забезпечують реальний зріст знань, навичок і вмінь;

- формують соціально-ціннісні позиції, необхідні для психологічних якостей, акмеологічних інваріантів і практичного досвіду [647, с. 225226].

Залежно від формування системи знань, умінь і навичок класифікацію активних методів можна представити наступним чином:

- неімітаційні методи (проблемна лекція; лекція удвох; лекція 3 запланованими помилками; лекція-прес-конференція; евристична бесіда; навчальна дискусія; самостійна робота з літературою тощо);

- імітаційні методи (ділова гра; «мозковий штурм»; інсценізації; «круглий стіл» тощо).

А. Смолкін запропонував таку класифікацію методів активного навчання для закладів освіти. Він розрізняє імітаційні методи активного навчання, тобто форми проведення занять, у яких навчально-пізнавальна діяльність побудована на імітації професійної діяльності. Імітаційні методи діляться на ігрові й неігрові. До ігрових відносяться проведення ділових ігор, ігрового проєктування тощо, а до неігрових - аналіз конкретних ситуацій, рішення ситуаційних завдань й інші. Схематично дану класифікацію можна представити в такий спосіб $[650$, с. 86] (див. табл. 2). 
Таблиця 2.

Активні методи навчання

\begin{tabular}{|c|c|c|}
\hline \multirow{2}{*}{ Неімітаційні } & \multicolumn{2}{|c|}{ Імітаційні } \\
\cline { 2 - 3 } & Iгрові & Hеігрові \\
\hline проблемна лекція, лекція вдвох, & ділова гра; & \\
лекція із заздалегідь & педагогічні ситуації; & \\
запланованими помилками, & педагогічні завдання; & колективна \\
лекція прес-конференція; & ситуація & розумова діяльність \\
евристична бесіда; навчальна & інсценування різної & \\
дискусія; самостійна робота 3 & діяльності & \\
літературою; семінари; дискусії & . & \\
\hline
\end{tabular}

Залежно від змісту та організації навчання у педагогічній науці серед інших видів навчання виокремлюється проблемне навчання - така організація процесу навчання, в основі якої лежить створення вчителем проблемних ситуацій, визначення і формулювання проблем, їх розв'язання учнями самостійно або під керівництвом педагога. Так, В. Ортинський зазначає, що проблемний метод передбачає активізацію мислення учнів у процесі читання лекції через постановку проблем, які треба розв'язати. Розв'язуючи їх у взаємодії з учителем, аудиторія формулює теоретичні узагальнення, робить висновки [647, с. 225-226].

Проблема - такий різновид питання, відповідь на яке не міститься в накопичених суб'єктом знаннях і способах діяльності, тому вимагає відповідних практичних і теоретичних дій, відмінних від простого інформаційного пошуку. Проблема повинна містити пізнавальне утруднення, бути пов'язаною з емоціями суб'єкта, передбачити неможливість висувати гіпотези, відбивати специфіку науки, навчальної дисципліни.

Проблемна ситуація - це ситуація, яка виникає внаслідок такої організації взаємодії учнів з об'єктом пізнання, яка допомагає виявити пізнавальне протиріччя. Характеризується інтелектуальним утрудненням і потребою розв'язати його. Суть пізнавального протиріччя міститься в неможливості за допомогою тих знань і способів діяльності, якими володіє суб'єкт, вирішити протиріччя, що виникли. 
Головний метод проблемного навчання - логічно стрункий усний виклад, що точно і глибоко висвітлює основні положення теми. Монологічнопроблемний метод полягає в поданні навчального матеріалу через розв'язання проблемних ситуацій у монолозі вчителя, тобто педагог сам висуває, розкриває і розв'язує проблемні ситуації [647, с. 226].

Навчальна проблема i система супідрядних підпроблем, складених учителем, «вписуються» в логіку викладу. Педагог за допомогою відповідних методичних прийомів (постановка проблемних та інформаційних питань, висування гіпотез, їх підтвердження або спростування, аналіз ситуації та ін.) спонукає здобувачів освіти до спільних роздумів, пошуків невідомого знання. Спілкування діалогічного типу відіграє найважливішу роль у проблемному навчанні, оскільки монолог наближає навчання до інформаційної форми викладу.

Метод діалогічного викладення полягає в тому, як стверджує В. Ортинський, що вчитель, пояснюючи матеріал, залучає учнів до процесу не тільки пошуку розв'язання, а й формування проблем. Це складний метод, але він тісно пов'язаний із розвитком особистості, бо навчає розумових дій, виховує творчість. У результаті критичного осмислення учень вчиться «бачити» проблеми, задавати проблемні запитання, виховувати в собі почуття проблемної ситуації. Цей метод забезпечує найвищий рівень навчання [там же].

До основних методичних інновацій, пов'язаних із використанням активних, або як їх ще називають інтерактивних, методів навчання на основі активізації та інтенсифікації діяльності учнів науковці відносять і кейстехнології (кейс-метод, метод аналізу ситуацій - Case-Study), які посідають значне місце поруч із тренінгами, діловими та рольовими іграми, навчальними груповими дискусіями, мозковим штурмом тощо ([651], [652], [653], [654], [655], [656]). Кейс-метод можна назвати методичним і ментальним переломом в освіті.

Суть його полягає в тому, що учням пропонують осмислити реальну життєву ситуацію, опис якої одночасно відображає не тільки яку-небудь практичну проблему, але й актуалізує визначений комплекс знань, який необхідно засвоїти при розв'язанні даної проблеми. При цьому сама проблема не має однозначних рішень. 
М. Михайліченко та Я. Рудик характеризують кейс-метод як технологію через шість основних ідей.

По-перше, мета навчання відрізняється від класичної схеми - навчити, дати єдино «правильні», раз і назавжди визначені знання, вміння та навички. Навчальний процес орієнтований на усвідомлення не єдиної, а багатьох істин. Учні разом з учителем розв'язують пізнавальну проблему, яка має декілька варіантів вирішення, кожен із яких претендує на істину.

По-друге, кейс-методу властивий демократичний характер процесу одержання знань. Учень є рівноправним із іншими учасниками обговорення проблеми, у тому числі з учителем. Останній є не лектором, «ментором», «істиною в останній інстанції», а організатором, співбесідником. Головним у навчанні $є$ вироблення знань у процесі співтворчості учня й учителя.

По-третє, результатом застосування кейс-методу $є$ не лише знання, а й практичні навички. Здобувачі освіти мають можливість отримати інформацію про сучасні методи, прийоми, технології, а також спробувати їх застосувати, оволодіти навичками роботи за певною технологією.

По-четверте, технологія застосування кейс-методу $є$ досить чіткою i простою. За певними правилами розробляється модель конкретної ситуації, яка має місце в реальному житті, та комплекс знань, практичних навичок, необхідних для іiі вирішення. Ця модель має вигляд тексту обсягом від 10 до 50 сторінок, який і називається «кейсом». Учні попередньо вивчають його, залучаючи й інші джерела інформації. Потім зміст кейсу детально обговорюється на заняттях та диспутах, де вчитель виконує роль диспетчера процесу співтворчості - генерує запитання, фіксує відповіді, підтримує дискусію.

По-n'яте, перевагою кейс-методу є не лише отримання знань і формування практичних навичок, а й розвиток системи цінностей учнів, їхніх життєвих установок і позицій, своєрідного світосприймання.

По-шосте, кейс-метод дає можливість отримати задоволення від пізнання нового, адже долається такий «непоборний» дефект традиційного навчання, як сухий, неемоційний виклад матеріалу [653, с. 459-460]. 
Крім цього, кейс-технологія, як досить ефективна методика навчання, оптимально поєднує теоретичні знання учнів з умінням самостійно орієнтуватися в ситуації. Кейс-метод (метод аналізу ситуацій) на основі використання теоретичних знань дає змогу оволодіти також методологією аналізу ситуації, набути досвіду, чого інші методики не забезпечують із такою ж ефективністю [653, с. 459-460].

Метод ситуаційного навчання, як стверджують О. Сидоренко та В. Чуба, базується на суттєво інших принципах, які дають інше визначення ролей вчителя й учня. Обов’язок педагога - мотивувати зацікавлення учнів у предметі: створити таке середовище у класі, яке заохочує учнів ділитися власними ідеями, знаннями і досвідом і брати участь в аналітичному процесі. Обов’язком учня $є$ привнесення в навчальний процес своєї активної уваги. Учень повинен бути переконаним у тому, що він несе особисту відповідальність за своє навчання: «Вчитель знаходиться поруч, щоб допомогти мені, і я повинен використати цю допомогу, але кінцева відповідальність за це лежить на мені». Мета і вчителя, й учня - створити у класі таке середовище, в якому здобувачі освіти можуть розвинути чи хоча б застосувати ті навички пізнання і поведінки, які будуть їм потрібні для вирішення проблем, що чекатимуть їх у майбутній професійній діяльності. Педагоги заохочують учнів і тим самим стимулюють їхні зусилля взяти відповідальність за своє навчання. Відповідно, здобувачі освіти стимулюють зусилля вчителів щодо розвитку їхніх здібностей [654, с. 37$]$.

В основі цієї методики лежить розгляд, аналіз, пошук рішення у так званій ситуаційній вправі.

Ситуаційна вправа - це комплексний опис реальної ситуації, яка мала місце на практиці. Проблема, що розглядається в ситуаційній вправі, вимагає збирання відповідних даних, встановлення точного діагнозу i/aбо формування прогнозу та вибору «найкращого» рішення з огляду на прийняті критерії оцінки.

Як пише Х. Д. Граг, «ситуаційні вправи - це каталізатори, які прискорюють процес навчання на досвіді» [там же].

До діалогових технологій навчання - системи діяльності педагога й учнів, пов’язаної зі створенням комунікативного середовища, розширенням простору 
співпраці на рівні «учитель - учень», «учень - учень», «учень - автор», «учитель - автор» у ході постановки й вирішення навчально-пізнавальних завдань науковці відносять дискусію, яка є:

- процесом обговорення проблеми, способом її колективного дослідження, протягом якого кожна зі сторін, через аргументацію (відстоювання) або спростування (опонування) думки співрозмовника (опонента), претендує на монопольне встановлення істини;

- методом навчання, що підвищує інтенсивність й ефективність процесу сприйняття за рахунок активного включення учнів у колективний;

- спеціальним лінгводидактичним методом, кінцевою і головною метою застосування якого є комунікативно-стратегічна компетентність учня [657, с. 64];

- пошуком істини шляхом зіставлення різних точок зору [655, с. 175-184], [656, c. 16-18], [658, c. 70-76].

Групова дискусія - це колективне обговорення якої-небудь проблеми, кінцевою метою якого є досягнення певної загальної думки щодо неї. У ході дискусії відбувається колективне зіставлення думок, оцінок, інформації 3 обговорюваної проблеми (див. рис. 1).

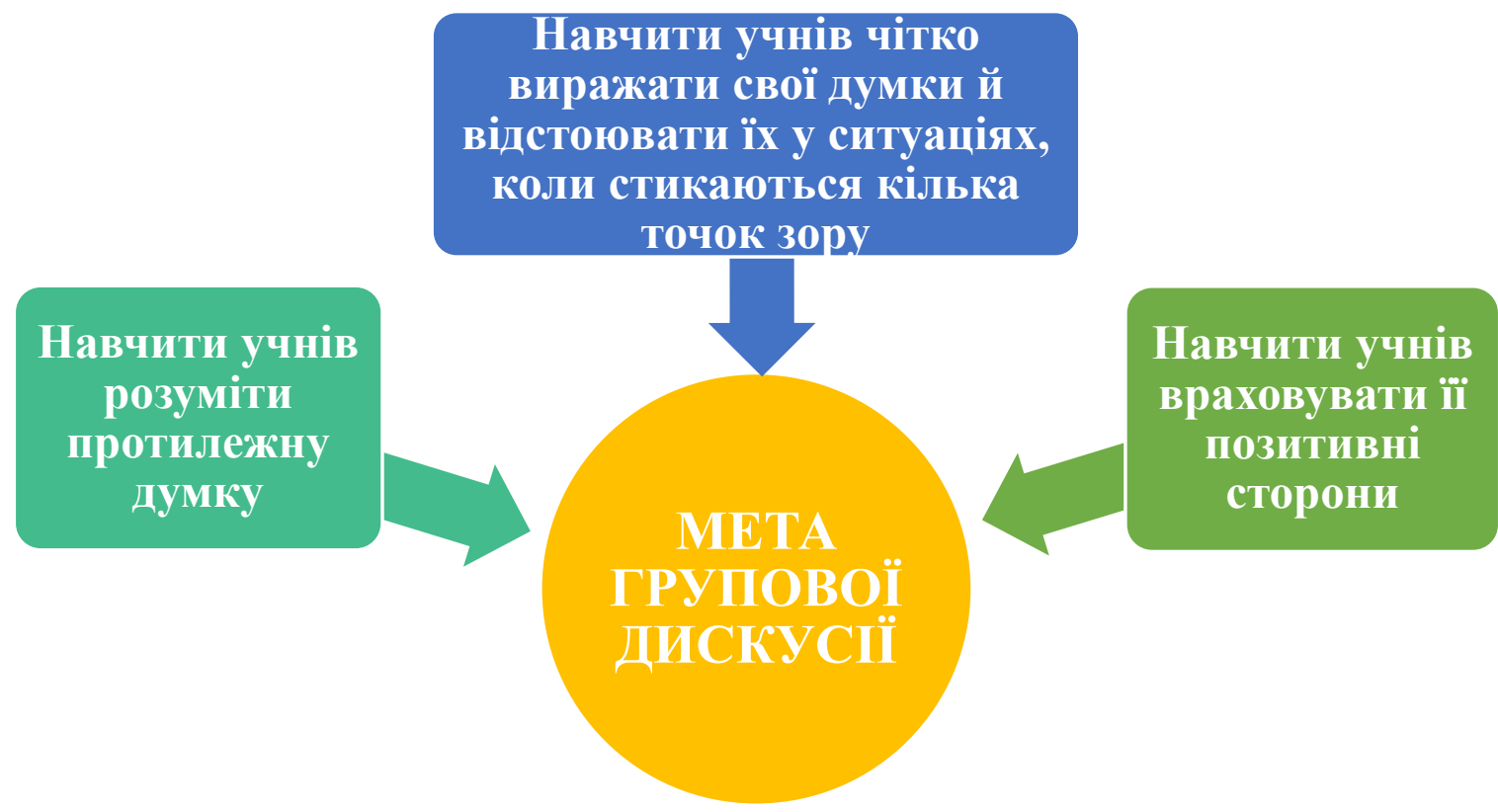

Рисунок 1. Мета групової дискусії 
П. Фенрих, визначаючи конкретну мету дискусії на занятті чи зустрічі, виділяє три важливих види розмови: власне дискусія, дебати та переговори (див. табл. 3) [658, с. 72].

\section{Таблиця 3.}

Види розмов. Використовується тоді, коли метою є спільний пошук істини, найкращого виходу із ситуації, коли потрібно розглянути проблему з багатьох позицій, перш ніж настане час для прийняття рішення, коли важливим є залучення у спільний процес мислення досвіду багатьох учасників. У дискусії необхідно слухати партнера чи вчителя, для того щоб

Дискусія якнайкраще зрозуміти, якнайповніше сприйняти його спосіб мислення та досвід. Намагатися бути найбільш відкритим до всього, що є новим і навіть незвичним. Не відкидати жодного почутого формулювання чи аргументу, поки його ретельно не обмірковано. Охоче погоджуватися на гіпотетичне продовження розмірковувань, $з$ якими можна не погоджуватися, оскільки важливо знати, куди це розмірковування веде...

Є чудовими, коли йдеться про гостре одночасне бачення проблеми, коли погляди розділені поміж учасниками групи, яка повинна здійснити вибір, а не узгодити позиції. Дебати - це форсування власної позиції, «війна словами», прагнення виграти, показати себе кращим перед третіми особами. У

Дебати дебатах треба слухати партнера (в певному сенсі суперника) 3 тим, щоб знайти найкращий аргумент проти його тези, уточнювати та відточувати власну позицію, намагатися показати абсурдність висловлювань іншої сторони, вказувати на всі слабкі сторони iї аргументації. У дебатах найчастіше не йдеться про переконання противника - ставкою є мислення та вибір, 
зроблений слухачами. Бувають провокаційні дебати, в яких противник намагається найгостріше висловитися проти тези лише для того, щоб захист, прихильники тези, могли їх відкинути і тим самим ще міцніше підтримати тезу. Добрим прикладом дебатів є оксфордські дебати.

Використовуються тоді, коли метою є узгодження спільної дії, коли необхідні знання вже зрештою має кожен з учасників групи, натомість потрібно почати спільну дію. У переговорах Переговори треба слухати партнера, щоб виловити всі спільні елементи, які вселяють надію на гармонію, співпрацю або хоча б можливий компроміс. Якщо в дебатах спеціально загострюється суперництво, то в переговорах іде пошук таких розв'язків, які створять можливості для співпраці, незважаючи на відмінності.

«Mозковий штурм» - переклад назви brainstorming, котру започаткував як метод активного пізнання дійсності американський психолог Алекс Осборн [659, c. 110]. Найпоширенішими перекладами назви, є такі: «мозкова атака», «атака мізків», «конференція ідей». Основна концепція мозкового штурму як методу навчання грунтується на теорії 3. Фройда, яка в той час була поширена в США.

Дискусія «мозковий шттрм» (метод аглютинації), як стверджують науковці - це форма дискусії, за допомогою якої колективно (у складі групи чи експертів) обговорюється наукова чи практична проблема/навчальне питання, здійснюється пошук шляхів щодо розв'язку через вільне висловлювання думок, ідей та пропозицій усіх учасників, використання великої кількості взаємних асоціацій між ними [655, с. 190], [656, с. 12], [658, с. 77], [659, с. 46]. Мета цієї технології - звільнити учнів від інерції та стереотипів мислення, забезпечити процес генерування ідей, без їх аналізу та обговорення, завдяки виникненню асоціацій в учасників, організувати колективну розумову діяльність із пошуку нетрадиційних шляхів щодо вирішення запропонованої проблеми. В освітньому процесі використання цього методу дозволяє вирішити наступні завдання: 
- активізувати навчально-пізнавальну діяльності учнів;

- сформувати здатність фокусування уваги i розумових зусиль на вирішенні актуального завдання;

- творче засвоїти навчальний матеріал;

- поєднати теоретичні знання із практикою;

- сформувати досвід колективної розумової діяльності. Проблема, що формулюється на занятті, за методикою мозкового штурму, повинна мати теоретичну або практичну актуальність і викликати активний інтерес учнів. Загальна вимога, яку необхідно враховувати при виборі проблеми для мозкового штурму, - можливість використання багатьох неоднозначних варіантів вирішення проблеми, яка висувається перед учнями як навчальне завдання.

Ще одним інтерактивним методом за участю виключно учнів $є$ «круглі столи» - один із активних методів проведення навчальних занять, який має на меті розвиток і вдосконалення самостійності учнів, їхнього логічного мислення, соціальної та моральної зрілості, формування поглядів і переконань, оволодіння методами аналізу та синтезу, уміннями робити висновки й вносити пропозиції, розв'язувати суперечки в процесі дискусії щодо попередньо визначених тем. Це форма публічного обговорення або висвітлення будь-яких питань, коли учасники висловлюються у визначеному порядку (спершу - сидячи за столом, який має круглу форму); нарада або обговорення певних питань, де присутнім надають рівні права стосовно один одного. Круглий стіл - це обмін думками з якогонебудь питання, проблеми, що цікавить учасників спілкування [656, с. 21-22].

Характерною рисою «круглого столу» є поєднання тематичної дискусії 3 груповою консультацією: поряд 3 активним обміном знаннями, в учнів виробляються вміння викладати думки, аргументувати свої міркування, обгрунтовувати запропоновані рішення і відстоювати свої переконання. При цьому відбувається закріплення інформації та самостійної роботи з додатковим матеріалом, а також виявлення проблем і питань для обговорення. Беручи участь у круглому столі, учень висловлюється від своєї особи. Проблеми, які 
обговорюються за «круглим столом», можуть бути різноманітними. Участь у круглому столі дозволяє закріпити отримані раніше знання, заповнити відсутню інформацію, сформувати вміння вирішувати проблеми, зміцнити позиції, навчити культурі ведення дискусії [660, с. 49].

У психолого-педагогічній науці немає чіткої визначеності щодо трактування сутності гри, яка використовується у навчальному процесі. Для позначення цього виду навчальної діяльності учнів учені використовують низку понять («ділова гра», «навчальна ділова гра», «навчальна гра», «рольова гра», «навчальна рольова гра», «дидактична гра» тощо).

Як стверджує С. Сисоєва, рольова гра є спрощеною модифікацією ділової гри, що моделює менш складну проблему професійної / навчальної діяльності. У процесі рольової гри відбувається знайомство з новими для учасників ролями (наприклад, керівника групи); потім опановуються нові форми спілкування i засоби прийняття рішень. «Гравці», спілкуючись один з одним, емоційно реагують, проявляють пізнавальний інтерес до проблеми і до самих себе. Рольова гра починається 3 аналізу конфліктної ситуації. Учитель ставить перед учасниками задачу щодо прийняття рішення в загальних рисах. Потім між учасниками розподіляються ролі, й після невеличкої підготовки проводиться ігровий етап і післярольовий аналіз [655, с. 188].

Групі експертів учитель доручає фіксувати роботу кожного учасника, його поведінку, креативність, адекватність засобів спілкування тощо. Готуючи і проводячи гру, педагог повинен бути готовий у будь-який момент включитись до неї і на якийсь проміжок часу замінити персонажа.

Учитель має можливість оцінити як індивідуальну діяльність кожного 3 учасників гри, так і групову взаємодію. У рольовій грі відпрацьовуються як горизонтальні соціальні зв'язки (однокласники, які займають однакові позиції) так і вертикальні (учитель - учень). Учні вчаться діловому спілкуванню, спільній діяльності, командному (якщо це передбачено сценарієм) прийняттю рішення, відповідальності за прийняте рішення, за точність його виконання незалежно від того, погоджується людина з ним чи ні (адже в неї роль підлеглого). Крім того, 
учасники гри повинні вчитися стримувати емоції, амбіції, будувати власну i спільну діяльність, орієнтуючись на кінцеву мету.

О. Дацків вважає драматизацію ефективним засобом формування комунікативних навичок і вмінь та визначає iї як сукупність прийомів взаємодії учителя та учнів у драматичних і рольових іграх, імпровізаціях, симуляціях та театральних проєктах, спрямованих на формування комунікативної компетентності. Науковиця виокремлює п’ять найпоширеніших прийомів драматизації: драматичні ігри, рольові ігри, імпровізащії, симуляияї, театральні проєкти [661, с. 54-57].

Драматична гра базується на дії, розвиває уяву, сприяє засвоєнню нових мовних структур і дозволяє виявляти емоції лінгвістичними та паралінгвістичними засобами. Драматичні ігри, як правило, є короткими, можуть проводитися на будьякому етапі заняття, хоча найчастіше застосовуються учителями як розминка на початку. Такі ігри є важливим засобом організації групової роботи. Вони можуть i повинні застосовуватися для підготовки учнів до участі у більш складних прийомах драматизації, таких як: рольова гра, імпровізація, симуляція та театральний проєкт.

Рольова гра-драматизація допомагає учням-учасникам уявити себе і діяти у нових обставинах, а також відчути і зрозуміти поведінку, думки й емоції іншої людини, роль якої вони гратимуть. Рольові ігри-драматизації мають важливу особливість: на відміну від рольових ігор, учасники яких виконують узагальнені, стандартизовані соціальні ролі (пасажир, поліцейський, пілот і т. д.), які не мають особистісних характеристик i відтворюють стандартні ситуації повсякденного життя, рольові ігри-драматизації передбачають наявність персонажів, наділених усіма особистісними характеристиками (стать, вік, соціальний і сімейний статус), певної їх кількості і проблемної / конфліктної ситуації, у якій діють учасники гри.

Iмпровізація - гра без планування чи підготовки. Метою імпровізації є повна спонтанність. У здобувачів освіти немає часу на підготовку, вони знайомляться зі своїми ролями та ситуаціями безпосередньо перед початком роботи. Вчителю потрібно підготувати лише список ситуацій для імпровізації. У методичній літературі зустрічається також термін «керована (guided) імпровізація». Цьому виду імпровізації передує підготовча робота, яку 
проводить учитель. Імпровізація $є$ необхідною, тому що у реальному спілкуванні iï учасники повинні вміти імпровізувати і бути готовими до цього в будь-який момент. В умовах навчання учень має бути повністю залучений у те, що відбувається на занятті, уявляти, що він має повідомити у навчальній ситуації і як відреагувати на повідомлення інших. Реальність навчальної комунікативної ситуації для імпровізації стимулює іiі учасників до використання уяви й активної участі у спілкуванні. Застосування цієї форми драматизації дозволяє здобувачам освіти формувати впевненість у собі, долати комунікативний бар'єр у спілкуванні з носіями мови.

Симуляція - драматизація, в основі якої лежить подія, учасники якої мають функціональні ролі, обов'язки та достатньо обізнані з проблемою, щоб виконувати ці обов'язки. Втілення повномасштабної симуляції у навчальний процес потребує цілого циклу занять. Кінцевою метою може бути відтворення, скажімо, світу компанії, телевізійної студії, редакції газети чи урядової структури. Зазвичай, учителі відмовляються від застосування цього прийому драматизації на заняттях через брак часу, але погоджуються з тим, що симуляції $\epsilon$ ефективними передусім у розвитку вмінь говоріння.

Tеатральний проєкт охоплює процес підготовки до постановки та відтворення на сцені для глядачів літературної або створеної самими учнями вистави. Метою такого проєкту є і процес підготовки, і результат - сама вистава. Цю форму драматизації дослідники визначають також як театралізацію. Однак, на думку О. Дацків, термін «театральний проєкт» більш вдалий, бо він включає у себе обидва компоненти, визначені вище - підготовку до вистави і їі сценічне втілення [661, с. 55]. 


\section{Характеристика основних елементів вивчення іноземної мови}

та особливості їх взаємодії

\section{Елементи для успішного вивчення іноземної мови.}

Більшість сучасних методів навчання мови намагаються запропонувати розумне поєднання багатьох ідей та елементів (методів і прийомів), розглянутих вище, як можна використовувати надзвичайно корисно.

Сучасна практика навчання мови загалом дає учням можливість подумати про те, як працює частина граматики, i водночас надає можливості для використання мови в комунікативних заходах та процедурах, заснованих на завданнях. Вона пропонує здобувачам освіти безпеку відповідної контрольованої практики (залежно від таких змінних, як вік учнів, особистий стиль навчання та мовлення, про яке йдеться), а також дає їм можливість використовувати будь-яку мову, яку вони знають.

Як стверджує відомий англійський науковець i тренер-викладач Дж. Хармер (J. Harmer) у своїй книзі «How to Teach English» (Як навчати англійської), така еклектика - вибір між найкращими елементами низки різних ідей і методів - є належною відповіддю на конкуруючі вимоги різних тенденцій. Однак небезпека еклектики полягає в тому, що, оскільки вчителі можуть використовувати фрагменти різних теорій і методів, уроки можуть стати неорганізованою формою різних видів діяльності без очевидної узгодженості чи філософії, що їх підкріплюють. Це може бути настільки ж шкідливим, як i методологічна жорсткість, яку прагне замінити еклектика [662, с. 51].

Однак еклектика, яка використовує основну філософію та структуру, тобто принципова еклектика, уникає цих ризиків. Вважаючи, що учні потребують експозиції, мотивації та можливостей для використання мови, і визнаючи, що різні учні можуть більш-менш добре реагувати на різні стимули, це говорить про те, що більшість навчальних послідовностей повинні мати певні характеристики або елементи, незалежно від того, чи відбуваються вони протягом кількох 
хвилин, півгодини, урок або цикл уроків. Такими елементами Дж. Хармер визначає залучення, навчання та активізацію (Engage, Study, Activate) [там же].

Проаналізуємо й охарактеризуємо ці поняття з точки зору Дж. Хармера, а також розглянемо, як вони можуть відбуватися і взаємодіяти в трьох типових послідовностях.

Залучення (Engage). Як вважає англійський науковець, залучення, яке емоційно захоплює учнів на уроці і робить їх пристрасними і допитливими, $\epsilon$ однією із життєво важливих складових успішного навчання. Діяльність і матеріали, які часто залучають учнів, включають: ігри (залежно від віку учнів та типу гри), музику, дискусії, стимулюючі картинки, драматичні історії, забавні анекдоти тощо. Навіть якщо такі дії та матеріали не використовуються, вчителі можуть зробити все можливе, щоб їхні учні залучалися до теми, вправи чи мови, 3 якою вони будуть мати справу, попрохати їх спрогнозувати або пов'язати матеріали уроку зі своїм життям. Багато що залежатиме від того, якими є окремі здобувачі освіти, і наскільки добре вчитель провокує та заохочує їх до участі. Тому причина, чому цей елемент настільки важливий у навчанні послідовностей, полягає в тому, що, коли учні правильно задіяні, їхня участь у етапах навчання та активізації, ймовірно, буде набагато більш вираженою, i, як наслідок, користь, яку вони отримають від цього буде значно більшою [662, с. 52].

Навчання (Study). Навчальна діяльність - це ті заняття, де учнів просять зосередитися на побудові чогось, чи то сама мова, способи іії використання чи те, як вона звучить і виглядає. Навчальна діяльність може варіюватися від зосередження на одному звуці та відпрацювання його до дослідження того, як письменник досягає певного ефекту в довгому тексті; від перевірки й відпрацювання часу дієслова до вивчення особливостей неформального мовлення з метою обговорення розмовного стилю. У процедурі PPP (Presentation, Practice and Production) (презентація, практика та продукування) і презентація, і практика (перші два етапи) зосереджені на побудові елемента граматики або лексики; контрольована практика (де учні повторюють багато фраз, використовуючи мову, на якій вони зосереджуються) покликана змусити учнів замислитися над 
побудовою мови. Коли вчитель змушує учнів повторювати слова із правильною вимовою (або вимовляти слова, які він хоче, щоб вони сказали на основі поданих ним сигналів), це відбувається задля того, щоб учні думали про найкращий спосіб сказати слова. Педагог ставить завдання, щоб здобувачі подумали про побудову вимови слів [там же].

Але навчання, як вважає Дж. Хармер, означає більше, ніж процедура $\boldsymbol{P P P}$ хоча вона $є$ одним із видів навчання. Учні можуть навчатися різними способами. Іноді на уроці вчитель може показати їм новий граматичний шаблон, повторюючи кожен елемент окремо або розміщуючи схему на дошці, перш ніж просити їх повторити речення, і це дуже нагадує процедуру РРР. Але на іншому занятті він може показати учням приклади мови і попросити їх спробувати відпрацювати правила. Такі пошукові заходи спрямовують школярів виконувати всю інтелектуальну роботу, а не залишати тї вчителеві. Іноді здобувачі освіти можуть разом прочитати текст і знайти слова та фрази, на яких вони хочуть зосередитися для подальшого вивчення. На іншому уроці вони можуть проводити час 3 учителем, слухаючи або дивлячись на мову, яку вони використовували, щоб побачити, наскільки вона була більш-менш успішною. Все це (і багато інших можливостей) є прикладами вивчення мовної конструкції [там же, с. 53].

Деякими типовими мовними аспектами для вивчення можуть бути вивчення та відпрацювання голосного звуку (наприклад, 'ship' - 'sheep' 'chip' - 'cheap', 'dip' - 'deep', 'bit' - 'beat', тощо), вивчення та відпрацювання граматичної конструкції (наприклад, the third person singular of the present simple - 'He sleeps', 'she laughs', 'it works' тощо), вивчення та відпрацювання лексичних фраз для запрошення ( 'Would you like to come to the cinema/to a concert?' тощо), вивчення та відпрацювання того, як ми використовуємо займенники в писемному дискурсі

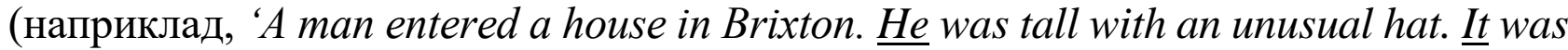
multicoloured ...' тощо), вивчення та практика організації абзацу (topic sentence, development, conclusion) або правил використання 'make’ i ‘do’ [там же].

Активізація (Activate). Цей елемент, як зазначає Дж. Хармер, описує вправи та види діяльності, спрямовані на те, щоб спонукати учнів 
використовувати мову якомога вільніше та більш комунікабельно. Мета активної діяльності полягає в тому, щоб здобувачі освіти використовували будь-яку мову, яка може бути доречною для певної ситуації або теми. Таким чином, школярі отримують можливість використовувати реальну мову з малими обмеженнями або без них - свого роду репетиція для реального світу.

Персоналізація (де учні використовують мову, яку вони вивчали, щоб розповісти про себе або створити власні оригінальні діалоги, часто як третій або продуктивний етап РРP) забезпечує зв’язок між етапами вивчення та активізації. Але вправи для більш справжньої активізації включають рольові ігри (учні розігрують, наприклад, якомога реалістичніше, діалог між туристичним агентом $\mathrm{i}$ клієнтом), створення реклами (наприклад, школярі пишуть, а потім записують радіо-/ відеорекламу), дебати й обговорення, опис і малюнок (Describe and draw) (учень описує оригінал картини/фотографії та пояснює товаришу, що тому потрібно намалювати), написання оповідань і віршів, обмін електронною поштою, групове виконання письмових завдань тощо [662, с. 53].

Однак, як зауважує Дж. Хармер, активізація полягає не тільки в створенні мови в мовленні та письмі. Коли учні читають / слухають на дозвіллі (або коли слухають / читають, щоб зрозуміти повідомлення, а не задумуються про форму мови, яку сприймають), вони залучаються до мовної активізації. Здобувачі освіти використовують будь-яку мову, яка є в їхньому розпорядженні, щоб зрозуміти прочитаний або прослуханий текст.

Школярі можуть, пройшовши етап активізації, повернутися до того, що вони сказали або до прочитаного тексту, і зосередитися на його побудові.

Активізація може бути прелюдією до навчання, а не обов’язково навпаки.

Усі три елементи $\boldsymbol{E S A}$ (Engage, Study and Activate) мають бути у структурі білышості уроків або навчальних послідовностей. Незалежно від основного фокусу уроку (наприклад, граматичної теми чи вправи на навички читання), учні завжди повинні бути залучені, якщо це можливо, щоб вони могли отримати максимальну користь від навчального досвіду. Більшість школярів із готовністю оцінять можливості активізувати свої мовні знання, але для багатьох із них включення навчальних елементів, навіть малих або нетривалих, переконає їх у корисності уроку [там же]. 
Дж. Хармер підкреслює, що деякі активні методи (дебати або рольова гра, тривала пошукова робота в Інтернеті або розширена письмова робота) займають багато часу, і тому за один урок вчителі можуть не захотіти переривати процес активізації певним методом навчання. Але вони можуть захотіти використати цю вправу як основу для вивчення, можливо, на іншому уроці. Те ж саме науковець зауважує і про тривалий період навчання, коли шанси на активізацію невеликі. Але в обох цих випадках єдиним обмеженням $€$ час. Відсутні елементи з'являться в інший час.

Однак навчання й учіння на нижчих рівнях не складається з такої тривалої діяльності. Натомість набагато ймовірніше, що в певній послідовності уроку або періоді буде більше однієї ЕSA послідовності.

\section{Послідовності ESA (залучення, навчання, активізація) уроків}

Як зазначає Дж. Хармер, використання трьох елементів ESA в послідовностях уроків, може відбуватися в різному порядку. По-перше, порядок неодмінно змінюється залежно від того, чого вчитель хоче досягти. Якщо урок проводиться на основі завдань (task-based lesson), то навчальна дія цілком може відбутися після активізації. 3 іншого боку, якщо вводиться частина граматики, то спочатку можна вивчити мову, перш ніж учням давати завдання на іiі використання. По-друге, існує небезпека: якщо вчитель завжди проводить урок в одному порядку, то учням стане нудно; передбачуваність може зменшити ентузіазм і мотивацію учнів - і вчителя також [662, с. 54].

Дж. Хармер пропонує різні послідовності навчання (використання елементів ESA різними способами), у нашій роботі розглянемо три можливості, щоб продемонструвати різноманітність їх застосування на уроках іноземної мови.

Перший тип послідовності навчання веде учнів по прямій i, як наслідок, називається прямими стрілками (straight arrows): спочатку вчитель зацікавлює клас і залучає його до навчання; потім учні вивчають щось; далі вони намагаються активізувати вивчене, запустивши у продукування. Дж. Хармер подає, як приклад, таку послідовність, розроблену для учнів початкових класів, щоб навчати 'can' i 'can't':

1. Залучення: учні та вчитель переглядають зображення, веб-сайт чи DVD iз роботами нового покоління. Можливо, вони зможуть переглянути короткий 
ролик із фільму «I, Robot» або якийсь інший сучасний фільм на подібну тематику. Діти говорять, подобається їм ідея про роботів чи ні.

2. Навчання: вчитель показує учням (малюнок) конкретного робота. Вони знайомляться 3 поняттями 'can' і 'can't' (як вони вимовляються та 3 чого складаються) і говорять такі речення, як 'It can use a cash machine' i 'It can't play the piano'. Вчитель повинен переконатися, що речення вимовляються правильно, а учні правильно користуються граматикою.

3. Активізація: учні працюють у групах, щоб створити та описати роботу своєї мрії. Вони роблять презентацію перед класом, розповідаючи, що їхній робот може, а що ні.

Цей урок можна представити так (див. рис. 2):

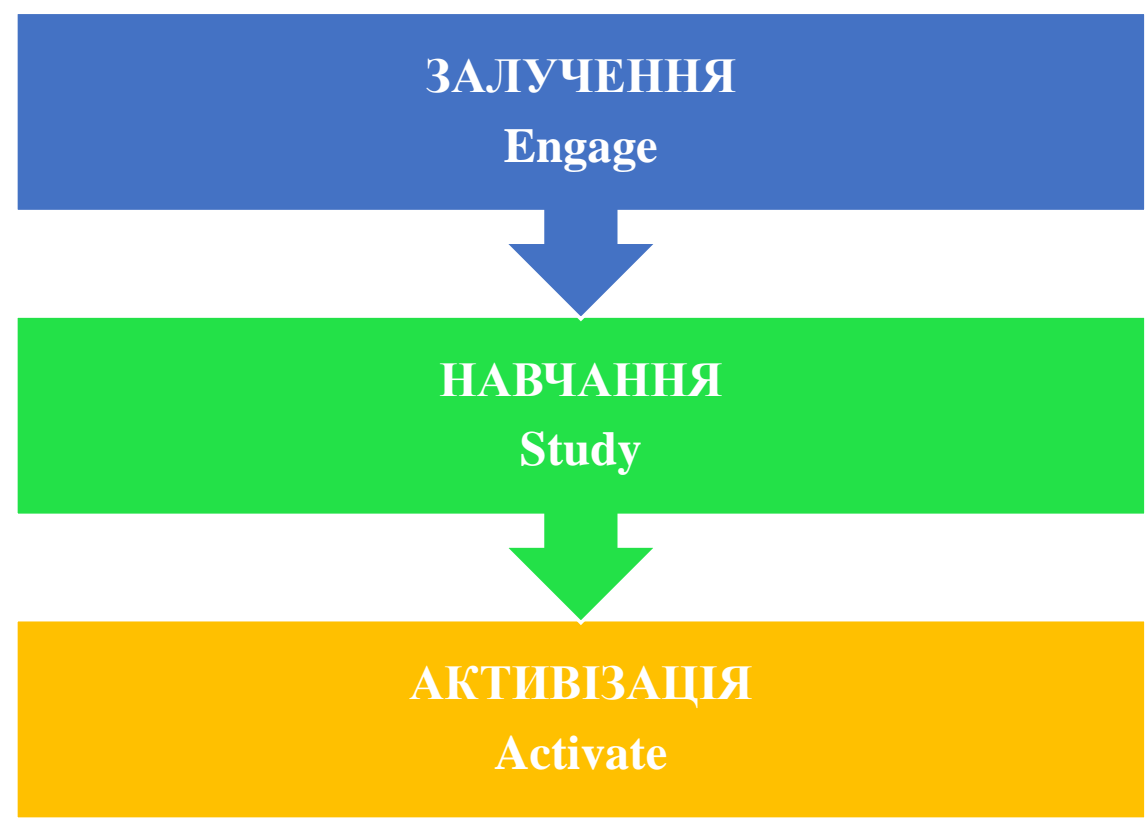

Рисунок 2. ESA straight arrows послідовність

Уроки прямих стрілок (straight arrows), як і процедури РPР (презентація, практика та продукування), дуже добре працюють для певних структур. Вище наведений приклад робота чітко показує, як створюються 'can' i 'can 't' і як вони використовуються. Це дає учням можливість контрольовано практикувати мову (під час фази вивчення), а потім діти можуть активізувати «нову» мову у приємний для них спосіб і ситуаціях. 
Однак, як стверджує Дж. Хармер, ТАКА процедура може працювати на нижчих рівнях для простої мови, але вона може бути не такою підходящою для більш «просунутих» учнів із більш складною мовою. Це не принесе великої користі, якщо вчитель хоче, щоб учні залучилися до читання чи щось обговорювали. Це також не буде дуже корисним, якщо більшість учнів уже вміють використовувати 'can' i 'can't'. Хоча, як зазначає науковець, немає нічого поганого у використанні послідовності прямих стрілок - для правильних учнів на правильному рівні, вивчення правильної мови - це не завжди доречно [662, с. 55].

Натомість, існують інші можливості для послідовності елементів ESA. Ось, наприклад, процедура бумеранга (boomerang procedure):

1. Залучення: учні та вчитель обговорюють проблеми, пов’язані зі співбесідами при прийомі на роботу. Що потрібно пошукачу роботи для хорошої співбесіди? Що хоче дізнатися інтерв’юер? Учням буде цікава ця тема.

2. Активізація: педагог описує ситуацію інтерв’ю, яку учні збираються розіграти в рольовій грі. Школярі готують типи питань, які вони збиратимуться поставити, і типи відповідей, які можуть дати (не зосереджуючи увагу конкретно на побудові мови, а розглядають це як завдання з реального життя). Потім учні розігрують інтерв’ю за ролями. Поки вони це роблять, учитель відзначає мовні труднощі, з якими вони стикаються й окремі помилки, над якими можна буде працювати пізніше.

3. Навчання: коли рольові ігри закінчуються, вчитель працює з учнями над граматикою та лексикою, які викликали у них проблеми. Наприклад, діти можуть порівнювати свою мову з більш правильним використанням і спробувати самостійно розібратися (відкрити), чому допустилися помилки. Учитель може пояснити, які були недоліки, або направити учнів до підручників із граматики тощо. Вони можуть виконувати певну контрольовану практику мови.

4. Активізація: через деякий час учні розігрують за ролями іншу співбесіду, засвоївши свої мовні помилки, яких допустилися минулого разу.

Процедуру бумеранга для такого типу уроків можна представити таким чином (див. рис. 3). У цій послідовності вчитель відповідає на потреби учнів. Їх 
не навчають мові до тих пір, поки вони не продемонструють (на фазі активізації), що їм це потрібно. Як підкреслює Дж. Хармер, це набагато краще, тому що зв'язок між тим, що учні мають вивчити, і тим, чого їх навчають, є більш прозорим. Це також може бути більш доречним для школярів середнього та просунутого рівнів, оскільки вони вже мають достатньо мовних знань, які їм уже доступні для використання на етапі активізації [там же, с. 56].

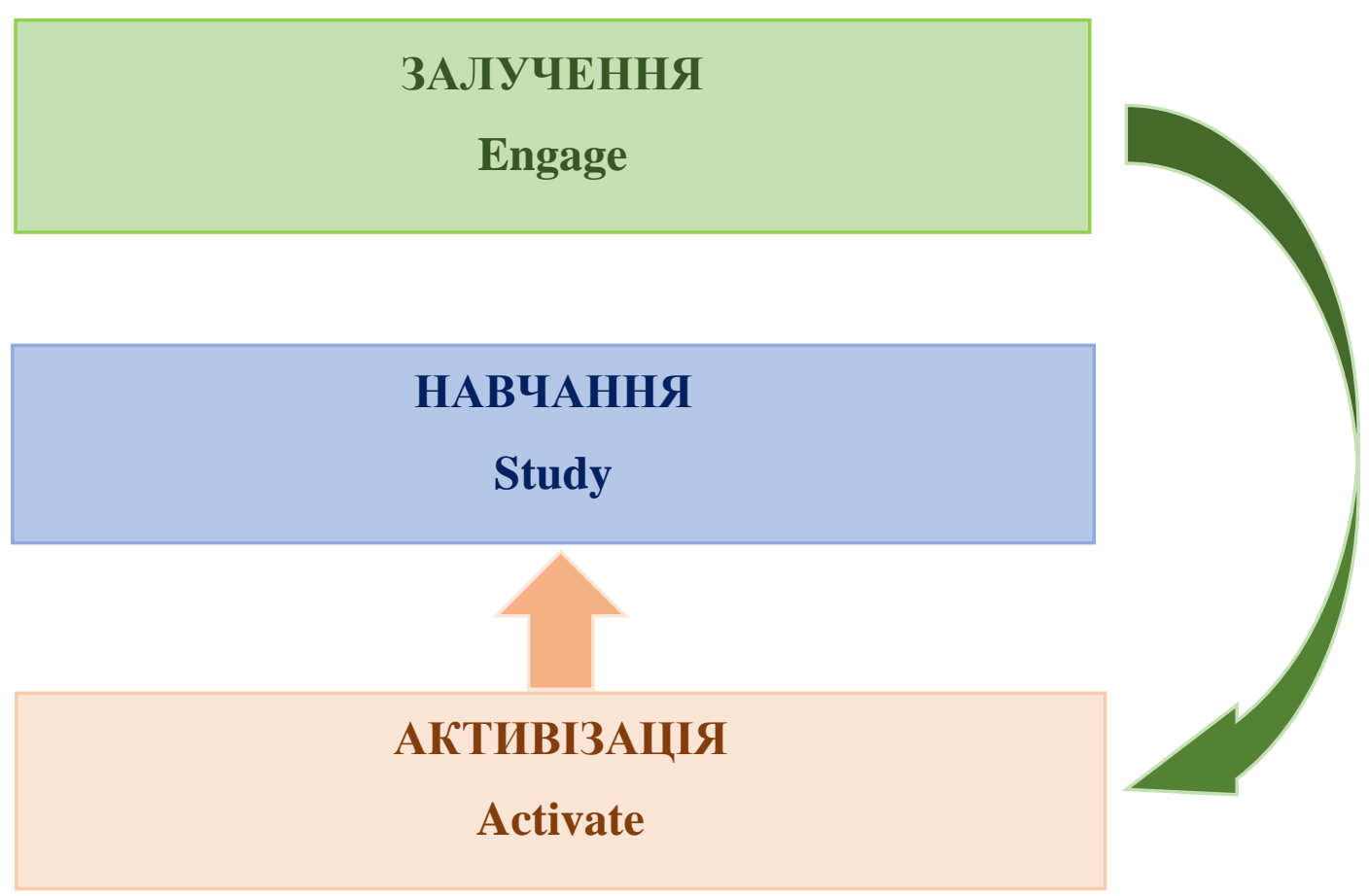

Рисунок 3. EAS(A) boomerang послідовність

Послідовності бумеранга більше схожі на процедури $T B L$ (урок на основі завдань); спочатку завдання, а не конкретна мова. Але потім бумеранг повертається (якщо він знадобиться вчителю), щоб нагадати вивчити частину мови, використану, більш-менш успішно, у завданні. Більш специфічний тип послідовності бумеранга іноді називають тестування-навчання-тестування (test-teach-test), де учнів спочатку просять використати мову на етапі активізації, а потім навчають, як справлятися із ситуаціями, у яких вони допустилися помилки, перш ніж знову спробувати частину тестування.

Однак, більшість уроків, зауважує Дж. Хармер, являють собою суміш процедур і міні-процедур, різноманітних коротких епізодів, що утворюють одне ціле. Ось приклад такого роду уроку-печворку (patchwork lesson): 
1. Залучення $\longrightarrow$ Активізація: учні дивляться на фотографію, на якій зображені відпочиваючі на пляжі, і реагують на неї, коментуючи людей i діяльність, у якій вони беруть участь. Або, діти розглядають принесені свої фотографії сімейних свят тощо. Потім вони розігрують діалог між лікарем і пацієнтом - жертвою сонячних опіків після проведеного дня на пляжі.

2. Активізація: учні проглядають текст, в якому описуються різні люди (3 різними типами шкіри) та вплив сонця на їх шкіру. Далі діти говорять, як вони ставляться до впливу сонця.

3. Навчання: вчитель опрацьовує з учнями лексику (наприклад, 'pale', 'fair-skinned', 'freckles', 'tan'), переконавшись, що вони розуміють значення та природу дефісу деяких із них, а також діти вміють вимовляти їх правильно у відповідних контекстах.

4. Активізація: учні описують свій досвід обгоряння на сонці або людей, яких вони знають, відповідно до прочитаного тексту.

5. Навчання: вчитель зосереджує увагу дітей на використаній у тексті конструкції підрядного речення (наприклад, 'I'm the type of person who always burns' i 'I'm the type of person who burns easily'). Використання такого підрядного речення ('who' clause) обговорюється, й учні практикують використання цієї конструкції (наприклад, 'They're the kind of people who enjoy movies' тощо).

6. Залучення: вчитель обговорює з учнями рекламу: Для чого вона? Якими різними способами реклама намагається досягти свого ефекту? Яку найефективнішу рекламу можуть придумати учні? Вчитель, наприклад, може відтворити якусь радіорекламу або продемонструвати якусь вражаючу візуальну рекламу на проєкторі.

7. Активізація: учні пишуть радіорекламу про сонцезахисний крем. Учитель дозволяє дітям зробити аудіозапис їхніх реклам, використовуючи звукові ефекти та музику.

Послідовність уроку-печворку представлена на Рис. 4). Такі уроки, як наголошує Дж. Хармер, дуже поширені, особливо на середньому та просунутому рівнях. Вони не тільки відображають те, як відбувається процес учіння - досить 
хаотично, не завжди по прямій, - але також забезпечують баланс між навчанням та активізацією, а також мовою та темою [там же, с. 57].

Залучення, навчання та активізація (Engage, Study and Activate) - це основні будівельні блоки для успішного навчання й учіння мови. Використовуючи їх у різних послідовностях, вчителі іноземних мов будуть робити все можливе, щоб сприяти успіху своїх учнів, оскільки різні теорії та процедури щодо вивчення мови, навколо яких сьогодні багато дискусій, відображаються в таких послідовностях, як прямі стрілки, бумеранг та уроки-печворки.

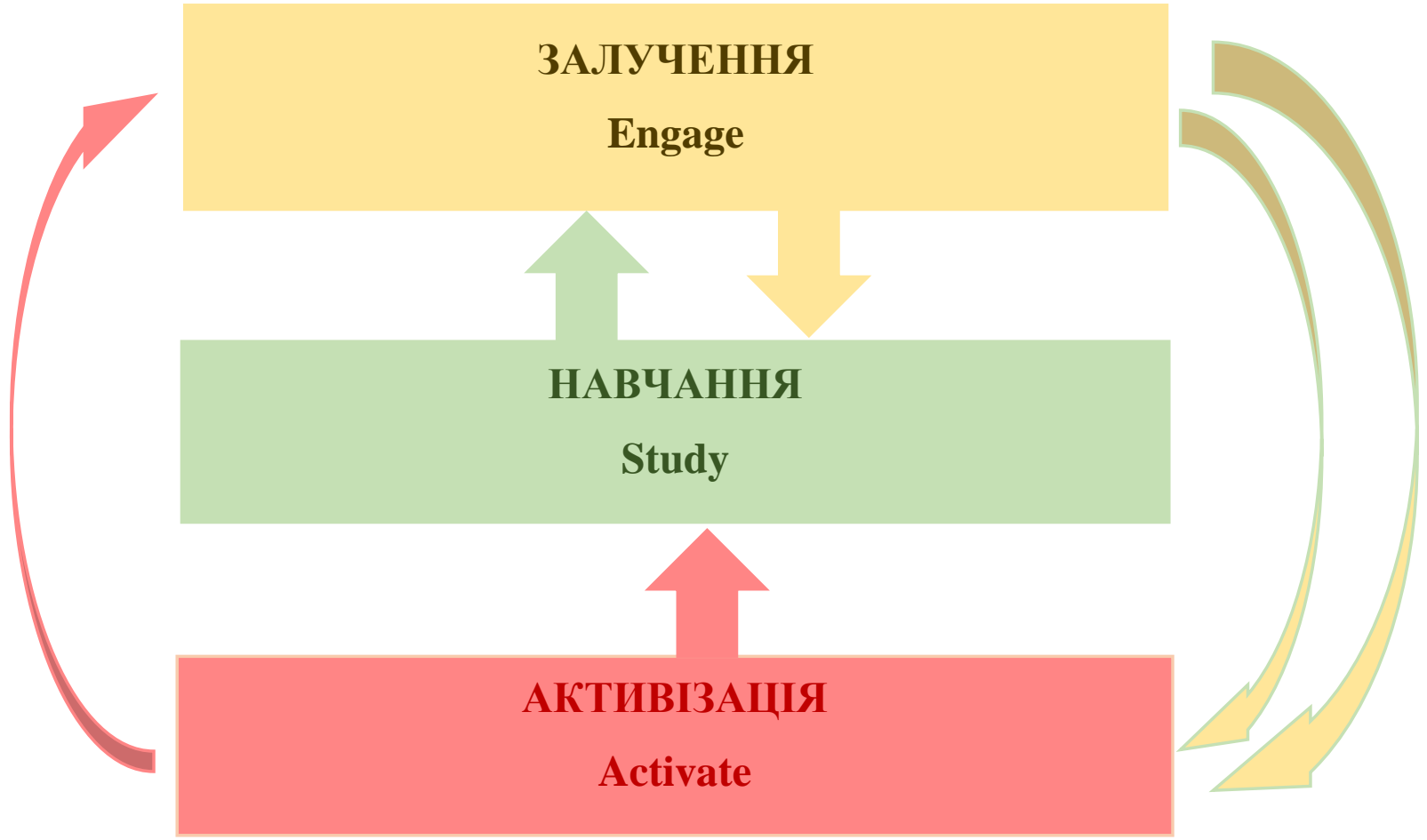

Рисунок 4. EAASASEA patchwork послідовність

\section{ESA та планування}

Плануючи свої уроки, вчителі повинні вирішити, яких очікуваних результатів їхні учні досягнуть до кінця уроку / тижня / місяця. Тоді вони повинні спланувати заняття так, щоб задіяні ними форми, методи та елементи навчання допомогли реалізувати поставлену мету. У цьому контексті, як зазначає Дж. Хармер, балансування трьох елементів ESA:

- нагадуватиме вчителю про необхідність залучення учнів до діяльності;

- спонукатиме забезпечити наявність навчальних заходів, закладених у план; 
- гарантуватиме, що майже на всіх уроках учні матимуть можливість використовувати мову, яку вони вивчають або вивчили. Коли діти намагаються використати мову (взаємодія 3 текстами, спілкування 3 іншими людьми, самостійне продукування мови), то у них задіюються такі ментальні процеси, які роблять їхнє навчання та засвоєння доцільними.

Багато вчителів планують уроки за підручником, який вони обрали для своїх класів. Але навіть якщо уроки базуються на матеріалі підручника, важливо маніпулювати запропонованими у книжці завданнями / активностями так, щоб три елементи (залучення, вивчення й активізація) були наявними у відповідній послідовності.

Отже, можемо зробити наступні висновки:

1. Прийоми і методи активізації пізнавальної діяльності різноманітні. Всіх їх об’єднує одне - вони передбачають поступовий і планомірний розвиток мислення учнів та одночасне формування у них мотивів навчання. Всі прийоми активізації пізнавальної діяльності містять питання, завдання або інше наочне завдання, яке стимулює розумову діяльність всього класу і кожної дитини окремо. Методи активізації пізнавальної діяльності здобувачів освіти умовно поділяються на три великі групи: словесні, наочні і практичні.

2. Метод проблемного навчання є яскравим прикладом словесних методів активізації пізнавальної діяльності здобувачів освіти: дає учням можливість міркувати, робити висновки, умовиводи. Виправданими є цікаві дискусії, доповіді та повідомлення на уроках іноземної мови. Важливо, щоб свої доповіді школярі не читали, а розповідали, вчилися говорити, міркувати, послідовно і логічно викладати свої думки.

3. При застосуванні наочних методів, учитель зазвичай керує роботою класу, а учні шляхом спостереження, вивчення обговорюють питання, вирішують поставлене завдання, роблять самостійні висновки зі спостереження. Схеми, таблиці й інший наочний матеріал повинен бути стандартним. Тут необхідно враховувати наочність, компактність - чітке і грамотне складання наочного робочого матеріалу, будь-то схема чи таблиця. Тобто, наочний метод активізації пізнавальної діяльності позбавляє від необхідності довгого викладу на словах, так і 
здобувачі освіти сприймають його краще, зважаючи також і на доступність такого методу навчання.

4. Інтерактив на уроках іноземної мови для вчителя - це найефективніший зворотний зв'язок, якісна інформація про те, як, що, на скільки розуміють учні пояснення педагога; можливість перевірити глибину сприймання, усвідомлення, обробки інформації, її «вбудову»у попередні знання, здатність оперувати нею. Можливість вільного спілкування із учителем, його поведінка під час дискусії, ставлення до школярів, вияви поваги (неповаги) до їхньої позиції, суджень $\epsilon$ вагомими факторами формування авторитету педагога у класі. Методика роботи з інтерактивними методами за участю вчителя створює позитивне підгрунтя для впровадження більш складних інтерактивних методів - методів, де спілкування відбувається вже між самими учнями, а педагог - тільки організуюча, спрямовуюча, коригуюча сила.

5. «Принципова еклектика», поєднуючи елементи різних підходів до навчання іноземної мови, передбачає використання всіх (або більшості) послідовностей уроків, які повинні містити три елементи: залучення, навчання й активізацію (Engage, Study та Activate). Ці три ESA елементи можуть зустрічатися в різному порядку / послідовності («прямі стрілки», «бумеранг» і «печворк»), залежно від основної теми уроку. 
DOI 10.46299/ISG.2021.MONO.PED.III.8.9

\section{9 Формування поліпредметних навчальних компетенцій на основі інтеграції предметів природничого циклу}

Природничий цикл включає систему наук про природу: фізику, хімію, біологію, географію, астрономію, екологію. В контексті даної праці, розглядаються такі науки як фізика, хімія та біологія. Кожна з цих наук має свій предметний зміст, структуру, методи дослідження, описує якусь одну сторону природи, будує її модель. Вивчаючи одну з цих наук, не можна забувати, що світ цілісний і єдиний.

В загальноосвітній школі предмети природничого циклу покликані розкрити перед учням сучасну наукову картину світу. Знання про природу становлять природничо-науковий фундамент світогляду сучасної людини. Таким чином, кожен момент отримання знань повинен бути одночасно i формуванням цілісності свідомості учня, єдиної системи знань про природу - iï інтегрального образу.

При осягненні великої правди природи, учні відчувають об'ємність недостатньо систематизованих знань про неї. Вирішити цю проблему дозволяє інтеграція предметів. Однією 3 форм реалізації інтегрованого підходу до навчання $є$ встановлення міжпредметних зв'язків на уроках природничого циклу (фізики, хімії та біологіі). Вони грають важливу роль в підвищенні практичної і науково-теоретичної підготовки учнів, істотною особливістю якої є оволодіння здобувачами освіти узагальненим характером пізнавальної діяльності. Інтегрований характер одержуваних знань дає можливість застосовувати їх в конкретних ситуаціях, при розгляді приватних питань, як у навчальній, так і в позаурочній діяльності, у майбутноьму виробничому, науковому та суспільному житті випускників закладів загальної середньої освіти.

У професійній діяльності вчителя завжди є простір для пошуку, педагогічної творчості на рівні інтеграції знань з предметів.

Так як інтеграція - це не самоціль, а певна система у діяльності вчителя, то вона повинна вирішувати певні завдання інтегрованого навчання: 
- підвищувати рівень знань учнів з предмета, який проявляється в глибині засвоюваних понять, закономірностей за рахунок їх багатогранної інтерпретації з використанням відомостей наук, що інтегруються;

- змінювати рівень інтелектуальної діяльності, шляхом розгляду навчального матеріалу з позиції провідних ідей, встановленням природних взаємозв'язків між досліджуваними проблемами;

- підвищувати пізнавальний інтерес учнів, що проявляється в бажанні активної і самостійної роботи на уроці та у позаурочний час;

- включати учнів у творчу діяльність.

У класичній педагогіці ідея міжпредметних, інтеграційних зв'язків народилася в ході пошуку шляхів відображення цілісності природи в змісті навчального матеріалу. Все, що знаходиться у взаємному зв'язку, повинно викладатися в такому ж зв'язку, вважав Я.А. Коменський. Він розумів, наскільки важливо встановлювати зв'язки між предметами для формування системи знань в учнів і забезпечення цілісності процесу навчання.

І.Г. Песталоцці розкрив різноманіття взаємозв'язків навчальних предметів. Він виходив 3 вимоги: «Приведи в своїй свідомості всі по суті взаємопов'язані між собою предмети в той самий зв'язок, в якому вони знаходяться у природі».

Найбільш повне психолого-педагогічне обгрунтування дидактичної значущості міжпредметних зв'язків дав К.Д. Ушинський. У книзі «Людина як предмет виховання» він виводить їх 3 різних асоціативних зв'язків, що відображають об'єктивні взаємозв'язки предметів і явищ. У його теорії ідея міжпредметних зв'язків виступає як частина проблеми системності навчання.

В даний час виділяють декілька можливих моделей формування навчальних компетенцій на основі інтеграції предметів природничого циклу:

1. Створення курсу, що об'єднує кілька предметів з однієї освітньої галузі. При цьому питома вага змісту різних предметів однакова, a їх взаємопроникнення виводить зміст на якісно новий рівень.

2. Об'єднання навчальних предметів з однієї освітньої галузі або блоку на базі переважно однієї дисципліни. 
3. Можливо поєднання різних, але близьких освітніх областей, які виступають на рівних, а також предметів близьких освітніх областей, де один 3 них зберігає предметну специфіку, а інші виступають в якості допоміжної основи.

4. У варіативній частині навчального процесу можливе створення інтегрованих курсів, в яких об'єднуються предмети 3 віддалених освітніх областей.

5. Загальноосвітній зміст переломлюється через профільну специфіку, яка представлена, наприклад, в курсах типу «Хімія і медицина», «Фізика i економіка»,«Прикладна хімія», « Біофізика», «Біохімія» та ін.

6. Можлива інтеграція, при якій подальша тема випливає 3 попередньої.

Педагогічні умови формування поліпредметних навчальних компетенцій можуть формуватися i здійснюватися на будь-якому уроці або етапі педагогічного процесу на основі інтеграції:

- $\quad$ на рівні педагогічних цілей (орієнтація на такі інтегральні властивості і характеристики особистості, як активність, самостійність, креативність);

- $\quad$ на рівні змісту (інтегрована програма, інтегровані навчальні курси);

- $\quad$ на рівні сфер активності школярів (інтегровані уроки, екскурсії, конференції, проекти);

- $\quad$ на рівні педагогічних технологій (варіативність інтеграційних форм і методів педагогічного впливу).

В сучасній школі 3 метою формування навчальних компетенцій як науково-методичної основи виділяють кілька рівнів інтеграції.

Перший рівень - інтеграція природничо-наукових та гуманітарних предметів. Важлива інтеграція цих навчальних дисциплін, пошук в їх взаємодії і натхнення нових підходів до цілісного бачення світу, для розкриття духовного потенціалу предметів.

Другий рівень - інтеграція дисциплін на основі розробки вчителями єдиних програм для формування провідних понять межпредметного, метапредметного 
характеру в процесі навчання. Така робота може бути здійснена на основі виділення головних освітніх ліній навчальних предметів.

Третій рівень - інтеграція за рахунок здійснення і посилення практичної спрямованості не тільки конкретного предмета, а й циклу предметів на основі реалізації горизонтальних взаємозв'язків навчальних дисциплін. Крім предметно-специфічних і практико- інтегрованих навчальних завдань, вельми актуальним є створення умов для освоєння учнями моральних, духовноморальних, патріотичних, соціально-економічних основ людського життя i діяльності на основі краєзнавчого підходу, що має стати одним із головних завдань школи. Це передбачає широке звернення вчителя безпосередньо до суб'єктного досвіду учнів і його осмислення.

Четвертий рівень - використання загальнонаукових методів пізнання, навчання цим методам учнів. Відомо, що до наукових методів пізнання, перш за все, відносяться: досвід, спостереження, гіпотеза, експеримент .

Орієнтація педагогічних колективів шкіл на структурування змісту освіти за рівнями, відповідно до методології наукового пізнання дозволить не тільки здійснити інтеграцію змісту навчального матеріалу всіх шкільних предметів, природничо-наукових в тому числі, але i:

1) раціонально скоротити обсяг інформації, пропонованої школярам;

2) більш чітко здійснити систематизацію досліджуваного навчального матеріалу;

3) створити у дітей більш повні уявлення про цілісну природничу картину світу.

У зв'язку з цим, через великий обсяг навчальної інформації з предметів, важливим стає включення учителем в план навчальних занять питань розвитку у школярів умінь і навичок використання наукових методів пізнання, вивчення технологій науково обгрунтованої організації навчальної праці з метою більш ефективного та комплексного освоєння навчального змісту.

Яким чином можливо здійснювати інтеграційний підхід в сучасній школі? Існуюча предметна система навчання відображає традиційно створившийся в 
науці поділ предметних областей знань на природні, технічні, гуманітарні. У світовій науковій педагогіці до сих пір йде дискусія з питання про те, як будувати навчальні плани і як проводити інтегровані уроки. На сьогоднішній день пропонується інтегрована побудова навчального процесу, зі збереженням предметами свого «предметного обличчя». Курс на варіативність, передбачений навчальним планом, створює для цього сприятливі умови. Можлива тематична, проектна інтеграція декількох предметів при вивченні окремих тем. Результативними $\epsilon$ інтегровані курси, які $\epsilon$ автономними науковими дисциплінами зі своїм специфічними об'єктами вивчення, включають в себе елементи різних дисциплін, що розглядаються комплексно і якісно. Інтегрований урок - якісно особливий тип уроку, що об'єднує в собі навчання і навчальну взаємодію одночасно по декількох дисциплінах при вивченні однієї теми або явища, процесу. До використання інтегрованих підходів учителя, нажаль вдаються не часто і головним чином в наступних випадках:

1) при виявленні дублювання одного і того ж матеріалу в навчальних програмах і підручниках;

2) при ліміті часу на вивчення теми і бажання скористатися готовим змістом з паралельної дисципліни;

3) при вивченні міжнаукових і узагальнених категорій (рух, час, розвиток, величина і інші), законів, принципів, що охоплюють різні аспекти людського життя і діяльності;

4) при виявленні протиріч в описі і трактуванні одних і тих же явищ, подій, фактів у різних науках;

5) при демонстрації більш широкого поля прояви досліджуваного явища, що виходить за рамки досліджуваного предмета;

6) при створенні проблемної, розвиваючої методики навчання предмету.

Переваги багатопредметного інтегративного уроку перед традиційним монопредметним очевидні:

- $\quad$ на такому уроці можна створити більш сприятливі умови для розвитку найрізноманітніших інтелектуальних якостей учнів; 
- через нього можна вийти на формування в учнів старших класів ширшого науково-теоретичного i науково-практичного мислення, розвиток кругозору, застосування теоретичних знань в практичному житті, в конкретних життєвих, професійних і наукових ситуаціях;

- інтегративні уроки наближають процес навчання до життя, натуралізують його, оживляють духом часу, наповнюють смислами;

- інтегровані уроки допомагають учням знайти i осягнути єдині закономірності різних наук, ефективно формують природничий світогляд;

- ці уроки взаємозбагачують учителів, зближують їх, сприяють поліпшенню психологічного мікроклімату в колективі і творчому росту.

Інтегративне завдання - різновид навчальних завдань, яке може застосовуватися на різних уроках. Їх особливість полягає в синтезі знань і умінь 3 різних наук, різних навчальних дисциплін, тем, проблем, в об'єднанні їх навколо і заради вирішення одного питання, однієї проблеми, заради пізнання одного об'єкта або предмета. Учні переконуються в прикладному значенні своїх знань 3 предметів. Ці ж навички можуть застосуються на уроках фізики, хімії та біології. Як правило, інтегративні завдання розробляються як міжпредметні, міжциклові або такі, що зв'язують теорію і особистий досвід здобувачів освіти.

Міжпредметна проблемна ситуація - спровокований (створений) учителем стан інтелектуального утруднення учня, коли він виявляє, що для вирішення поставленого перед ним завдання, йому недостатньо наявних предметних знань i умінь, а також усвідомлює необхідність їх внутрішньої і міжпредметної інтеграції. Виділяють кілька видів і способів створення на уроці міжпредметних проблемних ситуацій, їх успішно можна застосовувати на уроках біології, хімії, фізики:

1. Ситуації несподіванки, створюються при ознайомленні учнів 3 матеріалом, що викликає подив, що вражає своєю незвичайністю.

2. Ситуації конфлікту, виникають при наявності протиріччя між: 
а) теоретично можливим способом вирішення завдання, знайденим учнями на основі своїх знань внутрішнього і міжпредметного характеру, а також неможливістю його практичного здійснення;

б) практично досягнутим результатом (відомим фактом) і недостатністю тільки предметних знань для його теоретичного обгрунтування;

в) життєвим досвідом учнів, їх побутовими поняттями і уявленнями, науковими знаннями.

3. Ситуації спростування, створюються, коли учням на основі всебічного (внутрішнього і міжпредметного) аналізу пропонують довести неспроможність будь-якого припущення, ідеї, виведення, проекту та ін.

4. Ситуації припущення, створюються, коли передбачається існування якогось явища або закону, теорії, що розходиться з отриманими раніше знаннями (внутрішнього i міжпредметного характеру), або ж потрібно довести справедливість будь-якого припущення.

5. Ситуації невизначеності, виникають, коли учням пред'являють завдання з недостатніми або надлишковими даними для отримання однозначної відповіді.

Міжпредметні зв'язки - пов'язані поля різних навчальних предметів. Вони взаємно враховують загальне між предметами, як в змісті, так і в організації освітнього процесу. Вони припускають взаємну узгодженість змісту освіти 3 різних навчальних предметів, побудову і відбір матеріалу, які визначаються як загальними цілями освіти, так і оптимальним урахуванням навчальних завдань, обумовлених специфікою кожного навчального предмета.

Міжпредметні проекти можуть виступати в ролі інтегруючих факторів в освіті, допомагаючи долати традиційну дробність і уривчастість нашої освіти.

Оскільки більшість реальних навчальних проблем носить в даний час комплексний характер, то їх рішення стає можливим лише з залученням знань 3 різних навчальних дисциплін. Причому багато хто з цих знань часто доцільно не стільки актуалізувати, скільки безпосередньо формувати в процесі вирішення цих проблем. У свою чергу, це можна здійснити лише на основі більш глибокої інтеграції, що забезпечує необхідний рівень синтезу знань здобувачів освіти. 
Інтеграція знань 3 допомогою методу проектів призводить до більш зацікавленого, особистісно значущого і осмисленого сприйняття цих знань, що підсилює мотивацію і активність залучення учнів у навчальний процес. Кожне проектно-орієнтоване завдання представляє собою тісно пов'язану ланцюжок окремих актів в діяльності школярів. Це дозволяє їм розглядати проблему проекту в різних режимах діяльності, що природним чином вимагає інтеграції знань.

Таким чином, сучасна освіта як засіб освоєння світу має забезпечувати інтеграцію предметів і різних способів пізнання світу і тим самим збільшувати творчий потенціал людини для вільних та осмислених дій, цілісного і відкритого сприйняття й усвідомлення навколишньої дійсності.

Інтеграція предметів природничого циклу в загальноосвітній школі сприяє формуванню цілісних природничо-наукових знань у здобувачів освіти, укрупнення інформаційної ємності, якщо вона здійснюється на основі системного підходу і дидактичного синтезу. Інтегроване навчання являє собою систему використання стійких міжпредметних зв'язків, властивостей, навчальних блоків, логічно i природно пов'язаних між собою в змісті споріднених предметів. Слово «інтеграція», в перекладі з латинської мови означає об'єднання в ціле будь-яких частин. Інтегрований урок - це теж об'єднання знань з різних предметів з певної теми. I воно ефективно підвищує функціональну грамотність учня, розвиває його кругозір.

Найчастіше в школі використовується термін «Міжпредметні зв'язки», які розглядають лише $з$ точки зору раціоналізації процесу навчання, економії сил $\mathrm{i}$ часу учнів, більш міцного засвоєння школярами знань 3 досліджуваних предметів. Тим часом основна задача встановлення міжпредметних зв'язків полягає в тому, щоб якісно підняти рівень знань, умінь і розвитку учнів шляхом більш глибокого проникнення в існуючі закономірні зв'язки в явищах природи і суспільства. Це перш за все, інтеграція наукових знань в теоретичних дослідженнях і практичній діяльності в школі, на уроках. 
Ступінь реалізації інтеграційних, міжпредметних зв'язків може бути різною. Це залежить від змісту теми уроку. На найпростішому рівні, використання міжпредметних зв'язків виражено в загальному констатуючому вигляді. Наступний рівень - фрагментарний. Тут міжпредметні зв'язки здійснюються в побудові навчального матеріалу у вигляді елементів, прикладів, загальних фактів, понять і складають фрагмент в структурі уроку. Вищий має на увазі органічне включення в структуру уроку навчального матеріалу з інших предметів, без яких не може бути добре і багатоаспектно вивчити новий матеріал теми, з активною участю кількох предметників. На цьому інтегративному рівні проводяться і узагальнюючі уроки, де об'єднуються знання з різних предметів 3 позиції загальних світоглядних ідей.

У таблиці 1, наведеній нижче, показана можлива інтеграція за темами навчальної програми курсів фізики, хімії та біології.

Таблиця 1.

Інтегративне навчання (фізика, хімія, біологія)

\begin{tabular}{|c|c|c|}
\hline Теми 3 фізики & $\begin{array}{c}\text { Ключові питання біології та } \\
\text { хімії, що доповнюють зміст теми }\end{array}$ & $\begin{array}{c}\text { Форма навчальної } \\
\text { діяльності }\end{array}$ \\
\hline $\begin{array}{l}\text { Тиск твердих тіл, рідин } \\
\text { i } \\
\text { газів. }\end{array}$ & $\begin{array}{c}\text { Кореневий тиск. } \\
\text { Кров'яний тиск. } \\
\text { Вплив тиску на } \\
\text { швидкість і рівновагу } \\
\text { реакції. } \\
\end{array}$ & $\begin{array}{c}\text { Рішення якісних, } \\
\text { експериментальних задач. } \\
\text { Презентація до уроку. }\end{array}$ \\
\hline Звукові хвилі. & $\begin{array}{c}\text { Природа слуху: пристрій } \\
\text { вуха, слухове сприйняття. } \\
\text { заходи попередження } \\
\text { ослаблення слуху. }\end{array}$ & $\begin{array}{c}\text { Інформація та аналіз } \\
\text { конкретних ситуацій, } \\
\text { підготовлених } \\
\text { самостійно учнями. } \\
\text { навчальний } \\
\text { проектування. }\end{array}$ \\
\hline $\begin{array}{l}\text { Механічна енергія, } \\
\text { робота, } \\
\text { потужність }\end{array}$ & $\begin{array}{c}\text { Біомеханіка м'язів, енергія } \\
\text { і потужність м'язового } \\
\text { скорочення }\end{array}$ & $\begin{array}{c}\text { Розв'язання задач. } \\
\text { Практичні завдання по } \\
\text { визначенню роботи і } \\
\text { потужності м'язів при } \\
\text { виконанні фізичних вправ. }\end{array}$ \\
\hline $\begin{array}{l}\text { Закони збереження } \\
\text { енергії }\end{array}$ & $\begin{array}{c}\text { Енергетичний обмін в } \\
\text { клітці. закони збереження } \\
\text { і перетворення енергії в } \\
\text { хімічних реакціях. } \\
\text { Витрата енергї організмом. } \\
\text { Метаболізм і фотосинтез. }\end{array}$ & $\begin{array}{c}\text { Рішення якісних, } \\
\text { експериментальних } \\
\text { завдань. }\end{array}$ \\
\hline
\end{tabular}


Продовження таблиці 1

\begin{tabular}{|c|c|c|}
\hline Теми 3 фізики & $\begin{array}{c}\text { Ключові питання біології та } \\
\text { хімії, що доповнюють зміст теми }\end{array}$ & $\begin{array}{c}\text { Форма навчальної } \\
\text { діяльності }\end{array}$ \\
\hline $\begin{array}{l}\text { Агрегатні стани } \\
\text { речовини. } \\
\text { Вологість. }\end{array}$ & $\begin{array}{c}\text { Ліпідні мембрани живої } \\
\text { клітини. }\end{array}$ & $\begin{array}{l}\text { Інформація про властивості } \\
\text { рідинно-кристалічної } \\
\quad \text { структури мембран. }\end{array}$ \\
\hline $\begin{array}{l}\text { Молекулярно- } \\
\text { кінетична теорія. } \\
\text { Основне рівняння } \\
\text { МКТ. Температура. } \\
\text { Газові закони. }\end{array}$ & $\begin{array}{c}\text { Розміри органічних і } \\
\text { неорганічних молекул. } \\
\text { Дихання рослин, тварин і людини. } \\
\text { Захист організму від } \\
\text { переохолодження. Роль шкіри в } \\
\text { терморегуляції. } \\
\text { Кругообіг води в природі. } \\
\text { Тепловий ефект реакції. }\end{array}$ & $\begin{array}{c}\text { Рішення } \\
\text { експериментальних, } \\
\text { якісних і розрахункових } \\
\text { задач. }\end{array}$ \\
\hline $\begin{array}{l}\text { Електричне поле, } \\
\text { електричний струм. }\end{array}$ & $\begin{array}{c}\text { Біопотенціали спокою і } \\
\text { дії в живому організмі. Електричні } \\
\text { поля органів. Іонізація, іонна } \\
\text { провідність } \\
\text { клітинних мембран. } \\
\text { Гідроліз сахарози, глюкози, } \\
\text { крохмалю. } \\
\end{array}$ & $\begin{array}{c}\text { Рішення } \\
\text { експериментальних задач. } \\
\text { Порівняльний аналіз з } \\
\text { природними і технічними } \\
\text { пристроями. Створення } \\
\text { узагальнюючих таблиць. } \\
\text { Навчальне проектування. }\end{array}$ \\
\hline Магнітне поле. & $\begin{array}{l}\text { Магнітне поле Землі. Власне } \\
\text { магнітне поле людини. Вплив } \\
\text { магнітних полів на організм } \\
\text { людини. } \\
\end{array}$ & $\begin{array}{c}\text { Інформація та аналіз } \\
\text { конкретних ситуацій, } \\
\text { підготовлених учнями. } \\
\text { Навчальне проектування. }\end{array}$ \\
\hline $\begin{array}{l}\text { Електромагнітні } \\
\text { коливання і хвилі. Їх } \\
\text { використання. }\end{array}$ & $\begin{array}{c}\text { Електромагнітні хвилі } \\
\text { органів людини. Вплив } \\
\text { електромагнітних хвиль на } \\
\text { людину. }\end{array}$ & $\begin{array}{l}\text { Презентація до уроку. } \\
\text { Інформація та аналіз } \\
\text { конкретних ситуацій, } \\
\text { підготовлена учнями. } \\
\text { Семінар-практикум. } \\
\end{array}$ \\
\hline $\begin{array}{l}\text { Хвильова і } \\
\text { квантова оптика. }\end{array}$ & $\begin{array}{l}\text { Природа і механізм зору. Заходи } \\
\text { попередження ослаблення зору. }\end{array}$ & $\begin{array}{c}\text { Презентація до уроку. } \\
\text { Навчальне проектування. } \\
\text { Розв'язання задач. }\end{array}$ \\
\hline Фізика атомного ядра. & $\begin{array}{c}\text { Біологічна дія випромінювань на } \\
\text { живий } \\
\text { організм. Радіоізотопний } \\
\text { метод вимірювання інтервалів } \\
\text { часу. } \\
\end{array}$ & $\begin{array}{c}\text { Семінар-практикум. } \\
\text { Рішення якісних задач }\end{array}$ \\
\hline
\end{tabular}

Реалізацію цього підходу, треба починати напочатку навчального року, узгодженням навчальних планів 3 відповідних предметів. Спочатку визначаються і формулюються теми уроків інтегрованого курсу на весь навчальний рік. Потім намічається тематика міжпредметних питань, які будуть вивчатися на уроках інтегрованого курсу. Метою яких $є$ формування поліпредметних навчальних компетенцій на основі інтеграції. 
DOI 10.46299/ISG.2021.MONO.PED.III.8.10

\subsection{0 Формування пошуково-дослідницьких умінь майбутніх педагогів: практичний аспект}

Нова стратегія підготовки майбутніх педагогів зумовлена потребою в формуванні нового покоління вихователів дітей дошкільного віку, вчителів початкових класів, здатних реалізовувати освітні цілі в умовах освітніх трансформацій, навчатися впродовж життя.

Важливість означених положень увиразнюється Професійними стандартами за професіями «Вчитель початкових класів закладу загальної середньої освіти», «Вчитель закладу загальної середньої освіти», «Вчитель початкової освіти (з дипломом молодшого спеціаліста)» (2020) [667], Професійним стандартом «Вихователь закладу дошкільної освіти» (2021) [668], у яких визначено перелік компетентностей та трудових функцій, якими мають володіти педагоги. У зв’язку з цим, пріоритетним у підготовці майбутніх фахівців із дошкільної та початкової освіти є формування їхніх пошуководослідницьких умінь, які складають основу виконання ними трудових дій відповідно до нових освітніх стандартів.

Нині у педагогічній теорії $є$ значний масив джерел, автори яких опосередковано чи безпосередньо розкривають різні аспекти підготовки майбутніх педагогів (В. Андрущенко, О. Антонова, В. Бондар, О. Дубасенюк, Г. Іванюк, В. Огнев’юк, С. Сисоєва, Л. Хомич) в умовах реалізації нової освітньої стратегії. Репрезентативну базу окремих питань, що розглядаються у руслі тематики пропонованого дослідження, складають праці українських науковців. Так, питання підготовки майбутніх педагогів із урахуванням антропологічного, аксіологічного, діяльнісного підходу знайшли втілення у дослідженнях Г. Іванюк [669]. Питання формування у студентів педагогічних спеціальностей пошуково-дослідницьких, рефлексивних умінь, навичок XXI століття як складових їхнього особистісно-професійного розвитку є предметом дослідження Г. Іванюк, Є. Антипіна, О. Венгловської, Л. Куземко, І. Новик [670, с. 5]. Теоретичний інтерес становлять наукові розвідки І. Раєвської, О. Саган, які 
фокусують увагу на формуванні дослідницьких умінь майбутніх учителів початкової школи у перебігу викладання навчальних дисциплін [672]. Вивчення теоретичних напрацювань засвідчило, що попри значний пласт наукових публікацій, окремі питання щодо формування пошуково-дослідницьких умінь майбутніх педагогів у межах реалізації нової стратегії підготовки фахівців залишаються відкритими для наукового пошуку.

Вивчення нормативних документів про освіту, зокрема законів України «Про освіту» (2017), «Про вищу освіту» (2014), Державного стандарту початкової освіти (2019), Державного стандарту дошкільної освіти (Базовий компонент дошкільної освіти), 2021) засвідчило, що заклади дошкільної, загальної середньої освіти (початкова школа) потребують педагога, у якого сформовані здатності та готовність до роботи в умовах освітніх змін, організації розвивальної діяльності здобувачів освіти, що грунтується на врахуванні їхніх запитів і потреб, продукування тих освітніх продуктів, що є затребуваними серед учасників освітнього процесу.

У цьому контексті увиразнюється потреба в залучені здобувачів вищої освіти до пошуково-дослідницької діяльності на різних етапах навчання. Варто зазначити, що освітньо-професійні програми першого (бакалаврського), другого (магістерського) рівнів вищої освіти передбачають різні види пошуководослідницької діяльності студентів.

У пропонованій розвідці зосередимо увагу на особливостях формування пошуково-дослідницьких умінь майбутніх педагогів під час виконання ними магістерських робіт (проєктів). Означений вид пошуково-дослідницької діяльності виконується студентами на завершальному етапі навчання у закладі вищої освіти.

Професорсько-викладацьким складом кафедри педагогіки та психології Київського університету імені Бориса Грінченка напрацьовано значний досвід щодо здійснення педагогічного супроводу виконання майбутніми вихователями дітей дошкільного віку та вчителями початкових класів магістерських проєктів, що спрямовані на розроблення власних освітніх продуктів. 
Варто зазначити, що пошуково-дослідницька діяльність студентів грунтується на особистісній, аксіологічній стратегії, оскільки, як зазначає Г. Іванюк «підготовка педагогів в освітньому процесі закладу вищої освіти насамперед має відповідати суспільним потребам. Однак, варто пам'ятати, що студент є носієм і продуктом цінностей» [673, с. 73]. Відтак, тематика пошуководослідницьких проєктів формується з урахуванням потреб студентів - майбутніх фахівців із дошкільної та початкової освіти, а також запитів педагогів-практиків, оскільки саме вони визначають дієвість і практичну значущість цих проєктів.

У контексті пропонованого дослідження важливо було з'ясувати сутність поняття «пошуково-дослідницькі уміння», охарактеризувати особливості формування досліджуваних умінь на різних етапах роботи над пошуководослідницьким проєктом.

Вивчення різних груп джерел дало можливість 3'ясувати сутність поняття «пошуково-дослідницькі уміння», що у дослідженні розглядаються як комплекс здатностей майбутніх вихователів дітей дошкільного віку та вчителів початкових класів до виконання дій, що пов'язані із умінням визначати освітні цілі та завдання пошуково-дослідницького проєкту, планувати етапи виконання дослідницьких завдань, здійснювати систематизацію та аналіз джерел, пов’язаних із проблематикою дослідження, робити відбір необхідних ресурсів та інструментів, інтерпретувати, узагальнювати, презентувати результати дослідницького пошуку.

Процес формування пошуково-дослідницьких умінь здобувачів вищої освіти є системним, комплексним процесом й реалізується у продовж всього періоду навчання студентів у закладі вищої освіти. Зважаючи на те, що майбутнім педагогам доведеться працювати в швидкозмінних умовах, тематика пошуково-дослідницьких проєктів спрямована на розв'язання актуальних проблем дошкільної та початкової освіти, покращення освітнього процесу у закладах дошкільної та загальної середньої освіти (початкова школа).

Варто зазначити, що розв'язання завдань пошуково-дослідницького проєкту розпочинається вже на етапі планування вибору проблематики й формулювання 
теми проєкту. Першорядним є педагогічний супровід, під яким вбачаємо, взаємопов'язану систему заходів та стимулів, що спрямовані на розв’язання дослідницьких завдань у перебігу виконання магістерського проєкту. Педагогічний супровід здійснюється науковим керівником на всіх етапах виконання студентами магістерського проєкту.

На першому етапі роботи над проєктом важливо з’ясувати актуальні питання дошкільної та початкової освіти, вивчити потреби педагогів-практиків. Оскільки саме від запитів закладів дошкільної, загальної середньої освіти буде залежати форма кінцевого освітнього продукту (інформаційний ресурс, що представлений у формі сайту, блогу, електронного посібника, каталогу авторських дидактичних ігор, методичного кейсу, рекомендацій тощо). Так, схвальні відгуки від педагогів закладів дошкільної освіти та початкових шкіл отримали такі студентські проєкти як: «Історія дошкільної освітим. Києва в педагогічних портретах» (автор: К. Степаненко), «Педагогічні персоналії на тлі епох» (автори: М. Башта, С. Кірілішина, Д. Музичук, Л. Потапенко, М. Ткач), «Гортаючи сторінки часопису «Світло») (автор: М. Свяженіна), «Путівник за ідеями Софії Русової: формування базових якостей дітей дошкільного віку» (автор: М. Ткач), «Поспішаймо робити добро» (автор: А. Колчіна), «Вивчаємо математику з героями улюблених казок» (автор: I. Кочерга) та ін.

Важливою умовою формування пошуково-дослідницьких умінь на цьому етапі є залучення студентів до теоретичного аналізу першоджерел, наративних матеріалів, документів про освіту (закони, постанови, положення, звіти тощо), що зберігаються у фондах Державної науково-педагогічної бібліотеки України імені В.О. Сухомлинського, Педагогічного музею України, Державному архіві м. Києва, Центральному державному архіві вищих органів влади та управління України. Саме на цьому етапі відбувається засвоєння студентами специфіки організації і проведення теоретичного дослідження, удосконалюються вміння здійснювати аналіз, синтез отриманих знань, зіставляти, узагальнювати, систематизувати джерела, моделювати процеси i явища, створювати бібліографічний опис. 
На другому етапі - відбувається розроблення алгоритму розв'язання пошуково-дослідницьких завдань магістерського проєкту. 3 цією метою студенти створюють індивідуальний план дослідження, вивчають стан розробленості досліджуваної проблеми у педагогічній практиці, роблять узагальнення та висновки, що складають основу для розроблення і впровадження в практику авторського освітнього продукту. Реалізація означених завдань можлива за умови сформованості у студентів таких компонентів пошуководослідницьких умінь, як: уміння планувати етапи проведення дослідження, робити відбір та застосовувати діагностичний інструментарій для збору емпіричних даних, узагальнювати та інтерпретувати отримані результати. Варто зауважити, що пошуково-дослідницькі уміння формують дослідницьку культуру, яка $є$ важливою для особистісного і професійного зростання майбутніх педагогів.

Наведемо приклад алгоритму розв'язання пошуково-дослідницьких завдань, що виконувалися під час розроблення проєкту, що був зреалізований у формі електронного посібника «Вивчаємо математику з героями улюблених казок» (автор: І. Кочерга). Створенню електронного посібника передувало дослідження, що було проведене студенткою на базі закладу загальної середньої освіти (початкова школа). У перебігу дослідження був зібраний емпіричний матеріал щодо з'ясування особливостей формування математичної компетентності учнів початкової школи, вивчено форми, методи та засоби, яким надають перевагу вчителі у формуванні означеної компетентності, визначено критерії, рівні та показники іiі сформованості в учнів початкової школи. Досліджено потреби вчителів у змістовому-методичному забезпеченні, що сприятиме реалізації завдань з формування математичної компетентності учнів початкової школі. Узагальнення результатів дослідження сприяли розробленню електронного посібника «Вивчаємо математику з героями улюблених казок» (рис. 1.). 

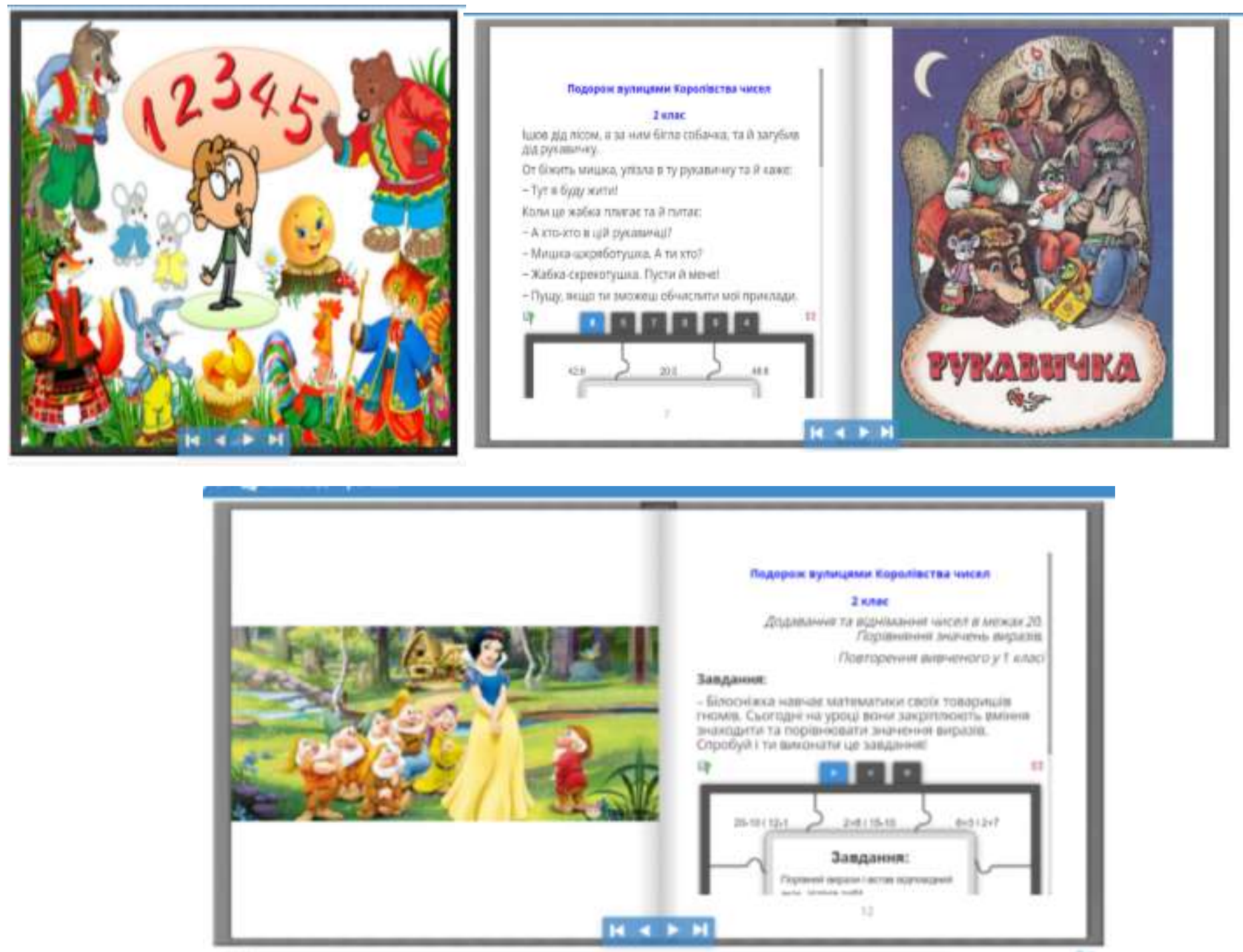

Рис. 1. Сторінки електронного посібника «Вивчаємо математику з героями улюблених казок» (автор: І. Кочерга)

Вивчення стану проблеми у практиці початкових шкіл сприяло удосконаленню умінь майбутніх педагогів розробляти стратегію ефективного вирішення дослідницького завдання, створювати й презентувати власні освітні продукти, продукувати нові знання задля їх використання у власній професійній діяльності.

На третьому етапі реалізації дослідницьких завдань відбувається апробація та впровадження створених освітніх продуктів. У перебігу впровадження проєкту в освітню практику здобувачі вищої освіти другого (магістерського) рівня вищої освіти мають можливість продемонструвати сформованість таких пошуково-дослідницьких умінь, як: уміння приймати виклики, що пов'язані із 
апробацією і впровадженням результатів дослідження, організовувати роботу команди задля ефективного впровадження проєкту, здійснювати рефлексію щодо визначення позитивних сторін результатів виконаного проєкту та окреслення питань, що потребують доопрацювання.

Варто зауважити, що окрім впровадження результатів проєктів у практику закладів освіти майбутні педагоги мають можливість їх презентувати публічно у формі виступів під час сесій історико-педагогічних студій, на всеукраїнських студентських науково-практичних конференціях, семінарах, круглих столах, педагогічних читаннях.

Позитивним $є$ те, що під час роботи над магістерським проєктом студенти мають можливість вивчати потреби педагогів-практиків, втілювати їхні запити у практичних матеріалах, що сприяють організації освітнього процесу у закладах дошкільної та початкової освіти з урахуванням принципу варіативності. В свою чергу, педагоги-практики мають можливість в зручний спосіб ознайомитися 3 проєктами, оскільки вони розміщені у відкритому доступі на сторінці кафедри педагогіки та психології Педагогічного інституту Київського університету імені Бориса Грінченка https://pi.kubg.edu.ua/struktura/kafedry-instytutu/kafedrapedahohiky/naukova-robota/studentska-nauka.html\#naukovi-publikatsii-studentiv. Зворотній зв'язок, який отримують майбутні педагоги від вихователів та вчителів, сприяє підсиленню практичної значущості їхніх розробок.

У підсумку зазначимо, що в умовах реалізації нових стандартів дошкільної та початкової освіти зростає потреба у переорієнтації підготовки фахівців у практичну площину, врахування особистісних сенсів здобувачів вищої освіти (студентоцентризм), а також формування загальних та фахових компетентостей, що забезпечать майбутнім педагогам кар'єрний розвиток.

Заслуговує на увагу те, що результати магістерських кваліфікаційних робіт, що виконуються у формі проєктів, мають практичну значущість, оскільки зорієнтовані на забезпечення варіативності організації розвивальної діяльності дітей дошкільного та молодшого шкільного віку, практичні матеріали 
зорієнтовані на потреби та інтереси здобувачів освіти, що в повній мірі відповідає Концепції Нової української школи.

Практика формування пошуково-дослідницьких умінь майбутніх педагогів у перебігу виконання магістерських проєктів доводить, що означені уміння $\epsilon$ важливою складовою їхнього особистісно-професійного розвитку. 
DOI 10.46299/ISG.2021.MONO.PED.III.8.11

\subsection{1 Педагогічні умови формування самооцінки молодших школярів в освітній діяльності}

Стаття $є$ теоретико-експериментальним дослідженням проблеми формування самооцінки молодших школярів у процесі навчання.

На основі вивчення й аналізу філософської і психолого-педагогічної літератури, здійснено системний аналіз теорії та практики формування самооцінки молодших школярів в освітній діяльності та визначено дидактичні умови, що сприяють ефективності цього процесу: мотивація учнів до самооцінної діяльності; включення педагогом учнів до систематичного i послідовного процесу самоаналізу в умовах спільної навчальної діяльності; поетапність формування мотиваційно-ціннісного, когнітивного та діяльніснопрактичного компонентів самооцінки; опора на традиції гуманістичної освіти, формування гуманних взаємин між учасниками освітнього процесу, підтримка позитивного емоційного стану молодших школярів у процесі самооцінювання навчальної діяльності, надання їм своєчасної допомоги.

У роботі узагальнено сутність поняття «самооцінка», її структуру, функції та особливості формування у процесі навчання; окреслено можливості спільної навчальної діяльності у формуванні самооцінки молодших школярів.

У дослідженні здобуто нові дані про зміни, що відбуваються в самооцінці молодших школярів під впливом систематичного введення у процес спільної навчальної роботи визначених дидактичних умов, доведено їх ефективність.

Ключові слова: педагогічні умови, самооцінка, молодші школярі, навчальна діяльність, мотиваційно-ціннісний, когнітивний, діяльніснопрактичний компоненти, спільна навчальна діяльність.

\footnotetext{
Комар О.А., Дячук П.В., Роенко Л.М. Педагогические условия формирования самооценки младших школьников в учебной деятельности

Статья содержит теоретико-экспериментальное исследование проблемы формирования самооценки младших школьников в процессе обучения.
} 
На основе анализа теоретических источников рассмотрена сущность и структура самооценки как составляющей учебно-познавательной деятельности учащихся, ее функции, определены дидактические условия формирования самооценки школьников в совместной учебной деятельности с учетом особенностей учащихся младшего школьного возраста и возможностей коллективной формы обучения.

Установлено, что самооценка детерминирует направление и уровень активности субъекта, становление его ценностных ориентаций, личностных смыслов и, в конечном итоге, «вершину» его достижений. Самооценка является важным психологическим фактором формирования учебной деятельности учащихся, играет важную роль в становлении их индивидуальных особенностей и возрастных характеристик. Выделены функции самооценки в развитии личности: мотивационная, ориентационная, регулятивная, рефлексивная и ее структурные компоненты: мотивационно-ценностный, когнитивный, деятельностно-практический.

На основании структурного построения учебной деятельности, характеризующейся органичным сочетанием трех составляющих ее блоков (частей) - информационно-ориентационного, операционно-исполнительного и контрольно-оценочного - показаны возможности всех этапов урока по формированию самооценки младших школьников.

Доказано, что использование совместных форм учебной деятельности вносит существенные позитивные изменения в формирование такого личностного образования, как самооценка, создает условия для коллективного анализа работы, развития умений и потребностей анализировать, доказывать свое мнение, оценивать свои действия с точки зрения других. Выяснено, что совместной считается деятельность, при которой ее задачи воспринимаются как групповые, нуждаются в кооперации при их решении. Другим признаком совместной работы является наличие взаимной зависимости при выполнении работы, взаимного контроля и ответственности. 
Рассмотрение вопросов исследования органически связано с определяющим вектором модернизации современной школы - направленности на общее развитие школьников в учебно-воспитательном процессе, на предоставлении каждому ученику оптимальных возможностей в личностном становлении, в расширении возможностей самореализации и раскрытии индивидуальных способностей. В непосредственном соотнесении с этой направленностью в исследовании в процесс формирования самооценки школьника заложен принцип личностно-ориентированного подхода к ребенку, утверждающий признание его уникальности, неповторимости, самоценности, и принцип педагогического оптимизма - высокого уровня ожиданий по отношению к ребенку, веры в его силы и возможности.

В исследовании доказывается, что процесс формирования адекватной самооценки учебной деятельности у младших школьников требует соблюдения следующих дидактических условий: мотивации учащихся к самооценочной деятельности; включение педагогом учащихся в систематический и последовательный процесс самоанализа в условиях совместной учебной деятельности; поэтапность формирования когнитивного, мотивационноценностного и деятельностно-практического компонентов самооценки; опора на традиции гуманистического образования, формирование гуманных взаимоотношений между участниками учебного процесса, поддержка положительного эмоционального состояния младших школьников в процессе самооценки учебной деятельности, оказания им своевременной помощи при анализе и оценке учебной деятельности в различных формах: совет, консультация, корректировка.

Экспериментальная работа представлена двумя последовательными этапами. На первом этапе формирующего эксперимента решались задачи: стимулирование желания оценивать себя, свою деятельность на уроке, формирование умений оценивать свою деятельность по «эталонам». В этот период ученики усвоили «эталоны», по которым можно адекватно оценить себя, оценочные критерии. Задачами второго этапа формирующего эксперимента 
было: закрепить полученные знания и умения в оценке и самооценке младших школьников, включить детей в совместную учебную деятельность, ознакомить учащихся с новой формой организации совместной учебной деятельности кооперативной, и выявить ее возможности в развитии самооценки.

В ходе эксперимента доказано, что учебная деятельность, построенная с соблюдением предложенных дидактических условий, способствует развитию адекватной самооценки младших школьников, что подтверждается положительными показателями в развитии ее когнитивного, мотивационноценностного и деятельностно-практического компонентов.

Ключевые слова: педагогические условия, самооценка, младшие школьники, учебная деятельность, мотивационно-ценностный, когнитивный, деятельностно-практический компоненты, кооперативная учебная деятельность.

Komap O., Dyachuk P. Roienko L. The didactic conditions of selfassessment of junior high school students in the training activities.

The thesis is dedicated to the theoretical grounds and experimental checks of the didactic conditions of junior high school students' self-assessment in the training activities.

On the basis of an analysis of theoretical sources, the essence of self-assessment, its functions, types and forms of organization in the teaching process are considered, ways of forming junior high school students' self-assessment in generic training are determined.

The usefulness of any lesson's stages on the junior high school students' selfassessment formation having specially organized work is shown.

The Didactic Conditions of junior high school students' self-assessment, under which primary schoolchildren have a real opportunity to train self-assessment activity, to learn different approaches to self-assessment skills are justified and experimentally proved. 
It is proved that the use of training general forms introduces substantial positive modifications to self-assessment formation, promotes the increase of the level of structural components: motivational, cognitive, practical, each of which includes phases of design, organization, regulation and correction.

Keywords: the didactic conditions, self-assessment, junior high school students, training activities, the motivational, cognitive, practical components, cooperative form of training.

Актуальність теми. Нова концепція початкової освіти, поряд 3 виконанням традиційних завдань, зобов'язує школу створити умови для різнобічного розвитку особистості дитини, іiі самоствердження та творчої самореалізації, формування людини з новим рівнем свідомості, яка володітиме новим мисленням, високою культурою життєвого самовизначення. Водночас усвідомлюватиме себе індивідуальністю, членом суспільства і представником людства. Така людина спроможна самостійно формувати цілі, знаходити оптимальні шляхи їх досягнення, брати на себе відповідальність за свої вчинки й діяльність, здатна до оцінки й самооцінки.

Новий Державний стандарт початкової загальної освіти (2018) зумовлює побудову навчання в початковій школі на засадах особистісно-орієнтованого, компетентнісно-діяльнісного підходів. Метою освіти стає загальнокультурний, пізнавальний i особистісний розвиток учнів, що забезпечує формування ключових компетентностей, і зокрема, такої ключової компетенції, як уміння вчитися, здатність до саморозвитку та самовдосконалення. Останнє вимагає сформованості у дитини уявлення про себе і свої можливості, вміння всебічно та об'єктивно оцінювати особливості своєї особистості і діяльності, приймати роль учня, правильно вибудовувати свої взаємини з оточенням. Тобто, йдеться про певний рівень сформованості самооцінки. Саме тому педагоги покликані не лише збагачувати учнів певним обсягом знань, способами дій, а й формувати в них критичне ставлення до своїх можливостей, успіхів, навички самооцінки у 
навчально-виховному процесі, що стає можливим за їх систематичного та цілеспрямованого формування.

Теоретичний аналіз психолого-педагогічної літератури показує, що в науці накопичено певні знання про сутність самооцінки і способи формування іiі у школярів.

Проблемі самооцінки присвячено численні дослідження зарубіжних учених (Р. Бернс [678], 3. Фройд [710], С. Фромм [711] та ін.).

Дослідники М. Андреєва [674], Л. Виготський [680], I. Кон [692], О. Леонтьєв [696], В. Столін [708], І. Чеснокова [713] та інші у своїх роботах розглядають самооцінку як внутрішнє ядро особистості, як їі свідомий початок, як згусток індивідуальної самосвідомості, як систему уявлень про себе.

Самооцінці як особистісному утворенню відводиться центральне місце в загальному контексті формування особистості, іiі можливостей, здібностей, спрямованості, активності, суспільної значущості (Г. Ліпкіна [697], М. Матюхина [700], Н. Пеньковська [702]). Дослідженню структури самооцінки, іiі форм, особливостей формування в онтогенезі присвячено роботи Т. Галкиної [681], П. Сресько [684], А. Захарової [686], І. Загурської [685]. Науковцями простежено динаміку самооцінки суб'єкта (О. Белобрикіна [677], С. Гончаренко [682], М. Казакина [689], А. Ларіна [694], М. Ярмаченко [715]. Також вивчаються функціональні зв'язки самооцінки із загальним процесом формування особистості школяра (І. Зязюн [688], Я. Коломинський [704], В. Рубцов [705]). Показано значення самооцінки у міжособистісному спілкуванні (Т. Каракуліна [691], О. Леонов [695], Н. Ліфарева [698]).

Низка досліджень самооцінки в освітній діяльності пов’язуються 3 вивченням самооцінної мотивації, зі співвідношенням особистісної і навчальної самооцінки, із взаємозв’язком самооцінки та рівнем домагань (О. Савченко [706], Г. Цукерман [712]), формуванню самооцінки в учнів (А .Захарова [687], Г. Ліпкіна [697], Т. Токарська [709], I. Чеснокова [713], В. Шапар [714]), 3 особливостями формування самооцінки в умовах 
міжособистісного спілкування (Г. Костюк [693], Н. Шевченко [707]), зі шляхами формування самооцінки в умовах навчальної діяльності.

Здійснений аналіз науково-методичних праць 3 проблеми формування самооцінки свідчить, що здебільшого увага акцентується на процесі виховання. Самооцінка розглядається багатьма науковцями як розуміння людиною своїх якостей, властивостей, а поза увагою дослідників залишається сам процес самооцінювання, у якому виникає, перевіряється, доповнюється уявлення дитини про себе.

У дослідженнях К. Бардіна [675], Л. Божович [679], Г. Ліпкіної [697], Г. Цукерман [712] переконливо показано, що сенситивним періодом для становлення самооцінки як особливого компонента самосвідомості є молодший шкільний вік. Основні досягнення цього віку обумовлені провідним характером навчальної діяльності, тож починати формувати адекватну, критичну самооцінку слід саме в початкових класах, у процесі навчальної діяльності молодших школярів, створюючи сприятливі умови, за яких діти стають у самооцінці самостійними.

Особливі функції у формуванні самооцінки учня відіграє навчальна співпраця. Це сприяє розвиткові у школяра потреби і здатності оцінювати i порівнювати себе з іншими. Завдяки цьому створюються умови, що оптимізують становлення позитивних характеристик самооцінки. У ході спільної навчальної роботи самооцінка учнів набуває більш виражену рефлексійність, критичність $\mathrm{i}$ обгрунтованість, що досягається зверненням дитини до аналізу своєї діяльності, iï процесу та результатів. Зміни в самооцінці пов'язані з усвідомленням учнями тих якостей своєї особистості, які забезпечують продуктивність навчальної роботи та іiі комунікативний характер. Визначальним моментом позитивних зрушень в самооцінці виступає зростання у дитини вимогливості до себе та доброзичливого ставлення до однолітків.

У результаті аналізу педагогічного досвіду загальноосвітніх навчальних закладів з формування самооцінки молодших школярів нами виявлено низку суперечностей між: 
- соціальною та особистісною значущістю формування самооцінки i низьким рівнем іiї сформованості у молодших школярів;

- необхідністю формувати самооцінку молодших школярів у процесі навчання і слабкою підготовленістю вчителів до керівництва цією діяльністю;

- потребою педагогів в опануванні технологіями формування самооцінки молодших школярів у навчальній діяльності та недостатнім їх відображенням у психолого-педагогічній і методичній літературі;

- значним потенціалом спільної навчальної діяльності та недостатнім іiї використанням при формуванні адекватної самооцінки молодших школярів.

Отже, актуальність дослідження зумовлена:

- соціальним замовленням суспільства на виховання майбутніх громадян, які здатні об’єктивно контролювати, оцінювати й коригувати свою діяльність;

- потребою визначення ефективних педагогічних технологій, спрямованих на формування самооцінки молодших школярів;

- необхідністю створення сприятливих умов задля формування самооцінки молодших школярів у навчальній діяльності.

Метою дослідження $\epsilon$ визначення й теоретичне обгрунтування педагогічних умов, що сприяють формуванню самооцінки молодших школярів у процесі навчання.

Для розуміння сутності самооцінки нами було проаналізовано іï трактування у філософському, психологічному і педагогічному аспектах. 3 аналізу філософських праць 3 проблеми самооцінки (Геракліт, Демокрит, Антифон, Антисфен, Плутарх, Платон, Аврелій М., Леонардо да Вінчі, Декарт Р., Локк Д., Юм Д., Кант І., Гегель та ін.) можна зробити висновок, що і в минулому, і сьогодні питання пізнання людиною самої себе викликають інтерес у рамках філософії освіти, дидактики і педагогічної практики. У працях педагогів і психологів (Б. Ананьєв, С. Батутіна, Р. Бернс, Л. Божович, Л. Виготський, М. Захарова, I. Кон, Г. Ліпкіна, С. Рубінштейн, В. Столін, І. Чеснокова, Г. Цукерман) самооцінка характеризується як основа процесу самоусвідомлення, показник індивідуального рівня розвитку, його особистісний аспект. Самооцінка 
як особистісне утворення бере участь у регуляції поведінки і діяльності, а як

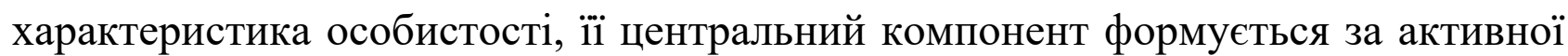
участі самої особистості і відображає своєрідність иї внутрішнього світу.

Виходячи зі змістового аналізу наукових джерел, ми послуговуємося трактуванням самооцінки як оцінювання особистістю себе, своїх можливостей, свого місця серед інших людей. Водночас аналіз підходів до визначення поняття «самооцінка» та численні його інтерпретації (Л. Бороздіна, М. Боцманова, Л. Виготський, А. Захарова, Г. Катрич, О. Леонтьєв, О. Молчанова) дали підстави розглядати ii як чинник навчально-пізнавальної діяльності учня, що становить складний рефлексійно-аналітичний процес, який є цілеспрямованим, внутрішньо мотивованим, структурованим і корегованим під час його здійснення та отримання результату, що зумовлюється дидактичними умовами, психологічними та особистісними особливостями учня як суб’єкта навчання, у якому виникає, перевіряється, доповнюється уявлення дитини про себе.

Огляд психолого-педагогічної літератури (Р. Бернс, О. Белобрикіна, Л. Божович, А. Дусавицький, О. Леонтьєв, Л. Поміткіна, С. Рубінштейн, Т. Токарська, І. Чеснокова, П. Якобсон) виявив неодностайність у поглядах на структурні компоненти самооцінки.

Здійснений теоретичний аналіз дав змогу нам подати структуру самооцінки у вигляді трьох компонентів: когнітивного, основу якого складають знання людини про себе - ситуативні чи стійкі, позитивні чи негативні, більш чи менш значущі для особистості; мотиваціийно-ц̧іннісного, що характеризується позитивним ставленням до дії самооцінювання, потребою довідатися про себе, свої позитивні і негативні характеристики, прагненням досягти успіху у спільній діяльності, пізнавати себе з кращої сторони; діяльнісно-практичного, який містить систему умінь самооцінювання, характеризується здатністю розрізняти ознаки, за якими діти оцінюють свої позитивні і негативні якості, діяльність у групі, уміння адекватно оцінити власну діяльність у групі, здатність критично ставитися до оцінки своїх умінь іншими учнями. 
У межах проблематики дослідження розглянуто функції самооцінки (Л. Виготский [680], В. Зинченко [690], Т. Каракуліна [691], К. Островська [701], Н. Пеньковська [702], О. Савченко [706]). На підставі здійсненого аналізу психолого-педагогічних наукових джерел ми виокремили такі функції самооцінки: мотиваційну, що забезпечує свідому, мотивовану поведінку, реалізацію обраної позиції, самореалізацію і містить всі види спонукань мотиви, прагнення, ідеали, цілі, усвідомлені спонукання до діяльності; орієнтаційну, яка передбачає орієнтування в ситуаціях оцінювання себе, своїх можливостей, своєї діяльності в групі; регулятивну, що забезпечує свідому саморегуляцію своєї поведінки за умов, які вимагають докладання свідомих зусиль для оцінювання себе і виконуваної діяльності, керування собою в умовах емоційного збудження чи втоми, здатність діяти відповідно до вимог ситуації, дорослого чи дитячого колективу; рефлексійну, яка виявляється в умінні людини усвідомлювати те, що вона робить, і аргументувати, обгрунтовувати свою діяльність.

Дослідження педагогів і психологів характеризують молодший шкільний вік як сенситивний для формування самооцінки, оскільки у цей віковий період відбуваються кардинальні зміни всіх ї̈ структурних компонентів, удосконалюється діяльність самооцінювання. До кінця молодшого шкільного віку самооцінка нерідко виступає домінувальним мотивом поведінки i діяльності. Це пов'язано зі зростанням пізнавальних можливостей дитини, посиленням інтересу до себе і схильності до самоспостереження.

Масова шкільна практика підтверджує відсутність цілеспрямованого досвіду формування у молодших школярів самооцінки у навчальній діяльності. Дослідження, які були проведені у школах Черкащини, показали, що у 55,2\% учнів рефлексійні уміння знаходяться на початковому рівні, у 34,9\% - на середньому, і тільки у 9,9\% - на високому. Самооцінка складається переважно стихійно, поза цілеспрямованим впливом з боку вчителя. Одна з причин цього, на нашу думку, - відсутність системних знань про природу самооцінки, умови, закономірності іï формування і розвитку. 
Аналіз психологічних і педагогічних досліджень дав змогу зробити припущення про значні можливості навчальної діяльності у формуванні самооцінки молодших школярів. У рамках концепції особистісно-орієнтованого, компетентнісно-діяльнісного підходів до навчання, у руслі якого виконане дослідження, важливу роль відіграє спільна (групова, колективна, кооперативна, спільно-розподільча) навчальна діяльність учнів, методологічні, філософські, соціально-психологічні аспекти якої знайшли висвітлення у працях Н. Бібік, О. Біди, В. Кузя, О. Комар, О. Коберника, Г. Коберник, М. Марусинець, I. Осадченко, Л. Пироженко, О. Пометун та ін.

Спільною вважається діяльність, за якої ії задачі сприймаються як групові і потребують кооперації у процесі розв'язання. Іншою ознакою спільної навчальної діяльності $є$ наявність взаємозалежності при виконанні робіт, що вимагають розподілу обов'язків, взаємного контролю.

Аналіз літератури, пов’язаної з вивченням спільної навчальної діяльності і iï впливом на формування адекватної самооцінки, свідчить про те, що використання спільних форм навчальної роботи вносить істотні позитивні зміни у формування такого особистісного утворення, як самооцінка А. Захарова [686], I. Кон [692], та ін.). Спільна діяльність дає дитині можливість порівнювати себе з однолітками, у ній створюються умови для розвитку умінь і потреб аналізувати, доводити свою думку, оцінювати свої дії з точки зору інших.

Численні дослідження (Р. Бернс [678], Г. Ліпкіна [697], Г. Цукерман [712] та ін.) доводять, що умови для розгорнутого формування самооцінки створюються лише у школі, де учіння як основний психологічний інструмент пізнавального розвитку дитини стає предметом спеціальних дидактичних, формувальних впливів учителя, об’єктом діяльності учня. Самооцінка учня утворюється поступово під впливом двох чинників: оцінки оточення (учителі, батьки, однокласники) і порівняння результатів своєї діяльності з результатом діяльності інших людей (однокласників). Самооцінка у цьому віці за традиційних умов навчання $\epsilon$ копією оцінки педагога, iï буквальним відтворенням. 
У процесі навчання молодший учень активно опановує найпростіші форми самоконтролю: контроль за результатом або підсумковий контроль та поточний або покроковий. У результаті цілеспрямованого формування, починаючи з 2-3 класу, можуть бути розвинуті як ретроспективна (оцінка вже виконаної роботи), так і прогностична (оцінка майбутньої роботи) форми самооцінювання учнів.

Вивчення процесу формування самооцінки учнів у навчальній діяльності показало, що адекватної оцінки учнями виконаної ними роботи, усвідомлення вимог, яким вона має відповідати, можна досягти лише шляхом включення самого учня до оцінного процесу, шляхом організації його роботи над критичним аналізом і оцінюванням своєї роботи. Оцінка власних дій виводить на самокорекцію та саморегуляцію - на показники формування особистості школяра, на рефлексію, коли особистість звітує перед собою про те, що і як зроблено, формує самооцінку.

Здійснене дослідження дало змогу виявити, що структура навчальної діяльності відзначається органічним поєднанням трьох складових іiі блоків (частин). Призначення першої частини навчальної діяльності (інформаційноорієнтаційної) - входження учня у конкретну навчальну ситуацію, іiї аналіз і визначення плану наступних навчальних дій. Здійснення продуманих та запланованих дій складає другу частину навчальної діяльності - операційнодіяльнісну. Перевірка правильності здійсненого й усунення допущених помилок складають третю частину навчальної діяльності - контрольно-оцінну.

У процесі дослідження доведено, що всі частини навчальної діяльності молодших школярів за спеціально організованої роботи та створення дидактичних умов мають значний потенціал формування самооцінки.

Синтез ідей, розроблених у вітчизняній i зарубіжній психологопедагогічній науці, аналіз передового педагогічного досвіду формування самооцінки молодших школярів у навчальній діяльності дали можливість визначити дидактичні умови, за яких цей процес відбувається успішніше. Першою такою умовою нами визначено мотивацію учнів до самооиінної діяльності. 
Щоб забезпечити формування самооцінки як важливої якості особистості молодшого школяра, вчителю необхідно своєчасно приділяти увагу саме мотиваційній сфері учнів, оскільки йому набагато легше налагоджувати діловий контакт, взаєморозуміння з учнями 3 позитивним ставленням до процесу самооцінювання. У результаті такої взаємодії молодші школярі охочіше виконують вимоги вчителя, у них швидше формується пізнавальний інтерес, 3 меншими фізичними і моральними зусиллями виробляються необхідні навички й уміння самооцінювання, що породжує прагнення систематично аналізувати $\mathrm{i}$ оцінювати власні досягнення в навчальній діяльності. У підсумку вони сприймають самооцінку як важливу якість особистості, що є для людини цінністю для самоствердження в соціумі.

У процесі організації навчальної діяльності учитель, озброюючи учнів знаннями та вміннями використання критеріїв оцінної діяльності, включає учнів у систематичний і послідовний процес взаємодії з аналізу та оцінки навчальних досягнень. Це породжує у молодших школярів бажання співвідносити власні досягнення навчальної діяльності 3 досягненнями інших учнів і сприймати власні успіхи в навчальній діяльності як внесок у спільну справу. У такий спосіб формується самооцінка учнів. Отже, другою, визначеною нами дидактичною умовою формування самооцінки молодших школярів у навчальній діяльності, $\epsilon$ включення педагогом учнів до систематичного $i$ послідовного процесу самоаналізу в умовах спільної навчальної діяльності.

На основі проаналізованої теоретично-прикладної літератури, власних експериментальних досліджень ми дійшли висновку, що адекватна самооцінка $€$ результатом процесу, в якому відбувається синтез знання молодших школярів про свої можливості у навчальній діяльності, про сутність поняття «адекватна самооцінка» (когнітивний компонент), усвідомлення цінності адекватної оцінки навчальної діяльності та інтересу до самооцінювання навчальної діяльності (мотиваційно-ціннісний компонент), вміння адекватно оцінювати власні досягнення в навчальній діяльності (діяльнісно-практичний компонент). 
Отже, процес формування адекватної самооцінки навчальної діяльності у молодших школярів вимагає дотримання такої дидактичної умови як поетапність формування мотиваційно-ціннісного, когнітивного, діяльніснопрактичного компонентів самооцінки.

Встановлено, що розгляд проблеми формування самооцінки молодших школярів у навчальній діяльності органічно пов'язаний із визначальним вектором модернізації сучасної школи - спрямованості на загальний розвиток школярів у навчально-виховному процесі, на створення для учнів оптимальних можливостей в особистісному становленні, самореалізації та розкритті індивідуальних здібностей. В основу формування самооцінки покладено принцип особистісно-орієнтованого підходу до дитини, що визнає іiі унікальність, неповторність, самоцінність та принцип педагогічного оптимізму - високого рівня очікувань щодо дитини, віри в ії сили і можливості. У такий спосіб було визначено ще одну дидактичну умову: опора на традиції гуманістичної освіти, формування гуманних взаємин між учасниками навчального процесу, підтримка позитивного емоційного стану молодших школярів у процесі самооцінювання навчальної діяльності, надання своєчасної допомоги.

Для перевірки гіпотези щодо дидактичних умов формування самооцінки молодших школярів у навчальній діяльності було проведено педагогічний експеримент, у якому брали участь 441 учень, 54 учителі, 155 батьків Городецької та Родниківської загальноосвітніх шкіл I-III ступенів Уманського району Черкаської області, Уманської загальноосвітньої школи I-III ступенів №9 Черкаської області, Комунального закладу освіти «Середня загальноосвітня школа №84» Дніпропетровської міської ради Дніпропетровської області, Миколаївської загальноосвітньої школи I-III ступенів №50 імені Г.Л. Дівіної Миколаївської області.

Необхідно зазначити, що експеримент проходив у природних умовах, не порушуючи логіки та ходу навчального процесу та передбачав такі етапи: 
- проєктування - діагностика сформованості самооцінки учнів, постановка мети й завдань щодо формування самооцінки учнів;

- організація формування самооцінки - роботу над формуванням структурних компонентів самооцінки в умовах спільної навчальної діяльності: когнітивного, мотиваційно-ціннісного, діяльнісно-практичного;

- регулювання й корекція формування самооцінки - систематичний рефлексійний аналіз та своєчасна корекція результатів процесу формування самооцінки в умовах спільної навчальної діяльності.

Визначені педагогічні умови, що забезпечують повноцінне формування самооцінки молодших школярів у процесі навчання: мотивація учнів до самооцінної діяльності; включення педагогом учнів до систематичного i послідовного процесу самоаналізу в умовах навчальної діяльності; поетапність формування мотиваційно-ціннісного, когнітивного, діяльнісно-практичного компонентів самооцінки; опора на традиції гуманістичної освіти, формування гуманних взаємин між учасниками навчального процесу, підтримка позитивного емоційного стану молодших школярів у процесі самооцінювання у навчальній діяльності, надання їм своєчасної допомоги.

Для одержання інформації про рівень сформованості когнітивного, мотиваційно-ціннісного й діяльнісно-практичного компонентів самооцінки молодших школярів було проведено констатувальний етап експерименту, у якому застосовувалися три групи діагностичних завдань.

Насамперед це мотиваційно-ціннісний компонент, що містить потребу в діяльності самооцінювання та інтерес до цієї діяльності.

У процесі дослідження були визначені рівні розвитку мотиваційноціннісного компонента.

Високий рівень характеризується сформованістю в учнів стійкого інтересу до самооцінювання. Вони проявляють усвідомлену діяльнісну активність в оцінній діяльності, намагаються проявляти ініціативу й самостійність, учитель виступає в ролі партнера-консультанта. 
Середній рівень відрізняється нестійким інтересом школярів до самооцінної діяльності, відзначається активність учнів, але переважно вона залежить від вказівок учителя (наслідувальна активність), який виконує функцію організатора самооцінної діяльності учнів. Потреба в саморозвитку, інтерес до особистісних якостей спонукає до діяльності самооцінювання.

Низький рівень пов'язаний 3 короткочасним інтересом до оцінної діяльності, що має ситуативний характер, або спостерігається відсутність потреби здійснювати самооцінювання в процесі навчання, тож учні не проявляють активності (є інертними), а лише виконують вказівки вчителя. Основні мотиви поведінки - запобігання неприємностей і мотив добробуту.

Когнітивний компонент включає: рівень уявлень молодших школярів про самооцінку; наявність знань про еталони, з якими порівнюється, оцінюється діяльність і їі результати.

Спираючись на діагностичні дані ми виокремили рівні у розвитку когнітивного компонента.

Високий рівень характеризується достатньою повнотою володіння як декларованими (про те, що оцінювати), так і процедурними (про те, як оцінювати) знаннями. Учень уміє самостійно обрати еталон і критерії оцінювання, знає операційний склад оцінних дій, виявляє загальні підходи застосування оцінних умінь, критично оцінює свої можливості, проявляє прагнення до удосконалення своїх оцінних умінь.

Середній рівень відрізняється частковою або мінімальною повнотою володіння знаннями, критерії й еталони оцінювання визначаються за допомоги вчителя. Школяр знає, як оцінювати, але оцінні дії відрізняються хаотичністю, не завжди може сформулювати своє судження, надати змістовну оцінку, не завжди критично ставиться до зовнішніх оцінок.

Низький рівень характеризується мінімальною повнотою знань. Учень не орієнтується в системі еталонів і критеріїв оцінювання, не може пояснити, як оцінювати роботу або відповідь, уникає здійснення оцінювання, оскільки не здатний співвіднести об'єкт оцінювання з еталоном, не може пояснити своєї 
точки зору, завжди погоджується з будь-якими зауваженнями, не може оцінити складність завдання, цілком залежить від допомоги вчителя

Діяльнісно-практичний компонент об'єднує: володіння різними способами самооцінювання; здатність до розгорнутої, диференційованої самооцінки.

Ці ознаки слугували критеріями для визначення рівнів розвитку самооцінки молодших школярів у навчальній діяльності.

Рівні розвитку особистісних якостей розглядалися в роботах О. Леонтьєва [696], О. Савченко [706] та ін. О. Леонтьєв, наприклад, зазначав, що «розвиток усіх психологічних властивостей людини проходить послідовними етапами, на яких відбувається формування окремих ланок, що складають обов’язкові умови того, щоб утворився кінцевий механізм, що складає основи даної властивості [696, с. 51]».

У дослідженні з метою виокремлення рівнів розвитку самооцінки учнів початкових класів ми застосовували аналіз, співвідносили ці рівні.

Виокремлено також ступінь розвитку діяльнісно-практичного компонента характеризується, за нашими даними, також трьома рівнями.

Високий рівень: прийоми самооцінювання стають навичками. Діяльність і спілкування в групі має позитивну динаміку розвитку у сфері самовивчення i самооцінювання. Спостерігається спрямованість на виконання завдань творчого характеру - де можна виявити свої здібності; розвинути співпереживання i здатність ставати на позицію інших.

Середній рівень: учні початкових класів використовують навчальний матеріал для самооцінювання своїх здібностей, володіють прийомами самооцінювання, але користуються ними епізодично. Під час навчальної діяльності одержують інформацію про себе, здатні ставати на позицію інших.

Низький рівень: прийоми самооцінювання в учнів не сформовані; вони рідко порівнюють себе 3 іншими, не здатні пристати на позицію інших у діяльності на уроці. Уникають завдань творчого характеру, що дають можливість перевірити свої здібності. 
Отже, у розвитку кожного компонента було виокремлено три рівні: високий, середній, низький.

Розглядаючи сутність, структуру i функції самооцінки молодших школярів, ми виокремили й описали компоненти самооцінки як інтегральної якості особистості, що знаходяться у визначеному взаємозв’язку один з одним, водночас кожний $з$ них є самостійним.

У дослідженні з метою виокремлення рівнів розвитку самооцінки учнів початкових класів ми застосовували аналіз, співвідносили ці рівні.

Отже, у розвитку кожного компонента було виокремлено три рівні: високий, середній, низький.

Для одержання інформації про рівень сформованості мотиваційноціннісного, когнітивного і діяльнісно-практичного компонентів самооцінки молодших школярів було проведено констатувальний етап експерименту, у якому було застосовано три групи діагностичних методик.

Частину методик ми адаптували відповідно до мети нашого дослідження. Частково було використано відомі методики діагностики самооцінки [681]. Водночас нами було розроблено власні діагностичні методики - у дослідженні було використано методи спостереження за учнями в ситуаціях навчальної діяльності, анкетування вчителів, батьків та ін.

Перша група діагностичних методик була спрямована на діагностику мотиваційно-ціннісного компонента самооцінки.

У широкому розумінні, мотиви - це те, що спонукає людину до діяльності, заради чого вона відбувається. Як мотиви можуть виступати потреби особистості, іiі інтереси, емоції, установки й ідеали. Мотивація - це сукупність мотивів поведінки та діяльності.

Серед соціальних мотивів, що істотно впливають на поведінку молодших школярів, можна виокремити: мотиви, пов'язані з інтересом дітей до світу дорослих і з прагненням бути схожими на них («бути як дорослий»); мотиви, пов'язані зі встановленням і збереженням позитивних взаємин $з$ дорослими в 
сім’ї, в школі; мотиви самоствердження, особистих досягнень; змагальні мотиви (виграти, перемогти, бути кращим за інших); різні процесуальні мотиви.

Майже всі названі мотиви є проявом потреби школярів у визнанні і схваленні, у спілкуванні. Саме ці потреби і мотиви роблять школяра чутливим до оцінок педагогів і батьків, викликають бажання виконувати їхні вимоги. Мотив встановлення і збереження позитивних взаємин 3 дорослими є одним 3 провідних, що визначає соціальний розвиток дитини. Значущість цього мотиву для позитивного розвитку особистості вирішальна; він орієнтує дітей на засвоєння того, що $є$ найбільш важливим у культурі, до якої належить особистість.

Ціннісне ставлення до себе й інших людей - основа психічного і морального здоров’я, одна 3 умов успішної самореалізації, життєвого самовизначення дитини.

На уроці математики ми використовували методику, умовно названу «Шкала самооиінки».

Метою цієї методики було визначення співвідношення мотивів навчання школяра. Учням було запропоновано уважно прочитати кожне з наведених речень і закреслити відповідну цифру праворуч, залежно від того, як вони почуваються в цей момент.

Методика показала, що багато дітей на уроках відчувають внутрішнє напруження: «Я стривожений» $(88,9 \%)$; «Не впевнений у собі» $(69,8 \%)$; «Думки про уроки мене турбують» (79,7\%). Можна зробити попередній висновок про те, що провідними мотивами навчання $є$ мотиви запобігання неприємностей i очікування удачі, а не пізнавальні мотиви.

Для більш точної діагностики потреби в діяльності самооцінювання ми використали анкетування батьків і вчителів.

Мета методики «Яка вама дитина?» - виявлення рівня самостійності дітей, мотивація навчання, ролі батьків у вихованні і розвитку умінь правильно оцінювати себе і свої вчинки. Результати анкетування показали, що 66,7\% батьків вважають своїх дітей самостійними і самокритичними. 57,6\% батьків 
говорять про своїх дітей як емоційних, що виявляють співчуття і вміють радіти успіхам своїх близьких, друзів.

Мета методики «Вама дитина» полягала у виявленні індивідуальних особливостей дітей, рис характеру, інтересів, ставлення до навчання, до батьків, взаємини батьків і дітей. На жаль, аналізуючи анкети, ми з’ясували, що 10,2\% батьків не знають, які навчальні предмети подобаються їхній дитині, яке в неї захоплення; 15,3\% відзначили, що відводять мало часу на спілкування 3 дитиною через зайнятість по роботі. Багатьох батьків дані анкети змусили замислитися: «А чи добре я знаю свою дитину?».

Аналіз результатів анкетування батьків показав, що в цілому вони досить об’ єктивно поставилися до характеристики своїх дітей. Так, було відзначено, що 23,8\% першокласників не завжди чуйні і турботливі, трудяться тільки під контролем і за заохочення. Не надто високо оцінено вміння бути критичними. Дуже рідко дитина висловлює свою думку, критичні судження - $(17,1 \%)$, вороже сприймає критику - (9,2\%), байдужа до критичних зауважень - (10,8\%). Майже 49,9\% батьків указують на позитивні і негативні сторони особистості своїх дітей.

Друга група діагностичних методик була орієнтована на визначення рівня сформованості когнітивного компонента самооцінки, і була спрямована на виявлення уявлень молодших школярів про самооцінку, умінь учнів оцінити себе, свій характер, свої позитивні і негативні якості, зокрема це методика незакінчених речень, написання учнями міні-творів, самоописи дітей, бесіди, малюнок «Мій ромашковий портрет», «Я і моя тінь», «Який я?», «Еквалайзер», «Визначення шести суджень».

За застосування методики незакінчених речень учням пропонувалося закінчити такі речення: «Якби я міг ... », «На мою думку, мені заважає ...», «Я відчуваю, що ...» та ін.

Аналіз відповідей допоміг нам краще зрозуміти переживання, труднощі, зони конфліктів, особливості сприйняття «світу дорослих» та ціннісні орієнтації учнів початкових класів. 
Матеріал для дослідження ми одержували з міні-творів, які виконувалися в класі. Вибір теми залежав від того, яке завдання хотіли виконати: «Розповідь про свого однокласника», «Познайомтеся з моїм другом», «Який я?», «Який я буду через двадцять років». Аналізуючи твори, ми звертали увагу на думки учнів про інших людей, на оцінку особистісних якостей, на їхнє ставлення до описаних ситуацій.

Протягом року ми мали можливість простежити динаміку уявлень учнів про самих себе. Це слугувало одним з показників результативності формування самооцінки дітей і уміння оцінювати інших. Аналіз творів дав змогу визначити зміст, характеристики їхніх знань про себе. Здобуті результати свідчать про те, що широтою охоплення різних сторін життя і диференційованого самоопису учні відрізняються одне від одного: одні діти оцінюють широкий спектр своїх проявів - від конкретних дій («Я вмію добре малювати», «Добре вчуся в школі», «Можу допомогти подрузі зробити домашнє завдання» та ін.) до засобів самовиховання («Я міг би вчитися краще, якби не лінувався», «Я не завжди буваю охайним при виконанні письмових завдань» та ін.), творчих моментів своєї діяльності («Можу складати вірші»), інші зовсім вузько («Я учень 2-го класу»).

Під час проведення дослідницької роботи на уроці рідної мови дітям було запропоновано намалювати контур яблука, а потім «розфарбувати» його словами. Після того, як учні виконали це завдання, їм роздали альбомні аркуші 3 намальованими силуетами дитини і запропонували «змалювати себе словами»один зараз, другий аркуш 3 намальованим таким самим силуетом діти отримали наприкінці навчального року і зробили ще один опис.

Наприкінці року, по завершенні експерименту у більшості учнів другий силует містив більш повну інформацію про себе, ніж перший. Це вказує на те, що збільшився обсяг знань i уявлень молодших школярів про себе i удосконалився процес самооцінювання.

3 метою виявлення здатності дітей до самооцінювання на уроці рідної мови ми використовували методику «Мій ромашковий портрет». 
Дітям ставили таке завдання: написати своє ім'я і намалювати свій портрет-смайлик у центрі ромашки. Потім повздовж пелюсток написати все краще, що можна сказати про себе. Якщо потрібно, можна додати пелюстки.

3'ясувалося, що в 1-му класі при використанні методики «Мій ромашковий портрет» не вдалося виявити справжню самооцінку дитини. Учні вказали на якості, які їм не притаманні, «рішучий», «самостійний», «сильний», «відповідальний». Завищена самооцінка склала 69,8\% від загальної кількості учнів.

У другому класі завищеною самооцінка виявилася у 58,0\% учнів.

У третьому і четвертому класах 43,8\% і 27,8\% відповідно.

Наступним кроком для вивчення самооцінки молодших школярів була діагностична методика «Я і моя тінь». Перед учнями ставилося завдання написати свої позитивні (Я) i негативні (Тінь) якості. Для багатьох першокласників це була нерозв'язна задача. Не змогли вказати свої «негативні якості» 26,1\% дітей. Інші показники були такими: «мені важко», «не хочу», «погано вчуся» та ін.

У другому класі не вказали свої «погані риси»- 115,8\% дітей.

У третьому класі дали собі позитивні оцінки всі діти, хоча у деяких класах самооцінка виявилася неадекватною, завищеною. Не зуміли дати собі негативну оцінку тільки 7,9\% третьокласників.

У четвертому класі негативну оцінку не змогли дати $3,8 \%$ учнів.

Для виявлення ступеня розуміння сутності такого особистісного утворення як самооцінка, можливості їі розвитку в себе, ми використовували метод бесіди. Дітям пропонувалося відповісти на такі запитання:

1. Що тобі подобається в людях?

2. Які позитивні якості знаходять у тебе інші, як ти вважаєш?

3. Які позитивні якості ти відзначаєш у себе сам?

4. Які знаходиш у себе недоліки?

5. У чому тобі потрібна допомога дорослих (учителів, друзів, батьків)? 
Бесіда 3 дітьми 1-4-х класів проходила індивідуально, щоб вони почувалися невимушено, не комплексували перед іншими учнями. За допомогою цієї методики ми змогли наочно представити визначені вікові особливості в розвитку уявлень про самооцінку у молодших школярів: якщо в першому класі оцінити себе, свої якості, характер не змогли 46,9\% учнів, то у другому - 31,9\%, у третьому $-227,9 \%$, а в четвертому лише $9,9 \%$.

Аналогічна бесіда була проведена 3 учнями 3 метою з'ясування їхніх уявлення про зміст поняття «самооцінка».

Як показує аналіз отриманого матеріалу, уміння пояснити поняття, проілюструвати його на конкретному прикладі багато в чому демонструє рівень уявлень учнів про певну якість особистості: якщо в 1-му класі не знають чи не можуть пояснити зміст поняття «самооцінка» 59,8\% учнів, то в 4-му класі 4,9\%. Уявлення третьокласників уже ближче до правильного змісту поняття «самооцінка».

На цьому етапі експерименту також використовувалася методика «Визначення шести суджень». На уроці рідної мови школярам пропонувалося написати відповіді на питання «Хто я?». Відповіді групувалися за шістьма різними категоріями: «Ім'я», «Соціально-рольова категорія», «Моя фізична підготовка», «Особистісні характеристики», «Моя зовнішність», «Інші судження».

Найчастіше молодші школярі пишуть своє ім'я, прізвище - 89,8\%, основне заняття: «навчаюся у школі», «граю в комп’ютерні ігри» - 79,8\%; позитивні риси характеру - 59,9\%, позитивні і негативні риси характеру - 11,7\%: «я погано розв'язую задачі, але я добрий», «я засмучую батьків поганими оцінками, але я їх дуже люблю».

У результаті аналізу отриманих відповідей можна зробити висновок, що діти молодшого шкільного віку намагаються описати себе за допомогою зовнішніх характеристик і звертають увагу на фізичні дані, натомість для учнів третього класу важливим стає акцентування на своїх внутрішніх здібностях $\mathrm{i}$ характері взаємин з іншими людьми. 
Важливо не тільки дати визначення поняттю, але й у конкретній дидактичній ситуації зуміти оцінити себе, свої уміння, якості. 3 цією метою використовували діагностичну методику «Який я?». Дітям пропонувалося 15 «позитивних» i 10 «негативних» якостей. Їм було дане таке завдання: «Поміркуйте, які з цих якостей ви могли б віднести до себе?». Мета проведення цієї методики - дослідження уявлень молодших школярів про себе, своє ідеальне «Я», ставлення до самого себе. При виконанні завдання 89,9\% першокласників вказали тільки на свої позитивні якості (добрий, розумний, охайний та ін.), 30,2\% учнів другого класу вказали на такі якості, як хвалькуватість, грубість, лінощі та ін. Учні третіх класів були самокритичніші - 38,7\%, а четвертих класах узагалі вказали не тільки на позитивні, але й негативні якості, що склало - 56,9\%.

При використанні на уроці математики методики «Еквалайзер» дітям пропонувалося зобразити стовпчики з особистісними характеристиками. За основу була взята методика Дембо-Рубінштейна [683], адаптована до завдань нашого дослідження. Вона заснована на безпосередньому оцінюванні школярами низки особистих якостей: здоров'я, здібності, характер, авторитет серед однолітків, зовнішність, упевненість у собі. Обстежуваним пропонується на шести вертикальних стовпчиках відзначити певними позначками рівень розвитку у них цих якостей.

Обробка результатів здійснювалася за шістьма шкалами. Кожна відповідь виражалась у балах. Розміри кожної шкали - 10 клітин зошита. Відповідно до цього відповіді школярів отримують кількісну характеристику.

За підсумками цієї методики виявилося $88,8 \%$ учнів 3 високою самооцінкою, 11,2\% - 3 середньою. Учнів 3 низькою самооцінкою не виявлено.

Описана група методик дала змогу виявити уявлення молодших школярів про зміст поняття «самооцінка», про готовність самооцінювання, про вміння шукати в собі позитивне і негативне.

На початку навчання (1-й клас) когнітивний компонент самооцінки виступав як менш розвинутий у порівнянні 3 емоційно-ціннісним. Для збагачення когнітивної частини самооцінки молодшого школяра фактичними 
знаннями про себе, свої здібності, можливості, якості - особливе значення починає відігравати його власний індивідуальний досвід, включення у спільну навчальну діяльність.

Поступово (2-гі, 3-ті, 4-ті класи) у молодшого школяра складається певна структура знань про себе, про що можуть свідчити такі показники: уміння дитини оцінювати себе, аргументувати свої оцінки, оцінювати себе 3 погляду інших людей.

Третя група діагностичних методик була спрямована на діагностику діяльнісно-практичного компонента самооцінки.

При вивченні цього компонента структури самооцінки, основну увагу було спрямовано на: а) вміння молодших школярів правильно оцінювати інших у спільній роботі; б) уміння адекватно оцінювати власну діяльність, вчинки, пов’язані з проявом почуття товариства, колективізму, уміння працювати в групі; в) уміння правильно ставитися до оцінки безпосередньої діяльності, яка була визначена для них їхніми товаришами по групі (навіть якщо оцінка негативна).

Для цих цілей на уроці читання було застосовано методику під назвою «Режисер».

Учням пропонувалось ідентифікувати себе i своїх товаришів (однокласників) з героями, що діють в умовній ситуації. Завдання цієї методики полягало в тому, щоб з'ясувати, як діти оцінюють себе і своїх товаришів у конкретному виді діяльності, або яка їхня конкретна самооцінка і чим вона відрізняється від загальної. Найбільш придатним видом діяльності було обрано сюжетно-рольову гру.

Здобуті в дослідженні матеріали показали, що існують розбіжності при виборі ролей за сценарієм і можливостями, які виявляються учнем в реальній ігровій ситуації.

Діти часто переоцінюють себе, свої можливості. Так, 52,9\% опитаних вважають себе здатними виконати позитивні ролі, 47,1\% - негативні. В умовах реальної гри виявляється, що головні ролі можуть виконувати лише 41,2\%, 
негативні - 58,8\%. Це обумовлено розбіжністю в оцінці дітьми своїх ігрових й організаторських здібностей.

Можна зробити висновок про розбіжність оцінних суджень учнів, умовно поділених на два типи.

1-й тип - учні при оцінці і самооцінці якостей особистості використовують досить широке коло критеріїв, схильні до співвіднесення й узагальнення. Ці діти доброзичливі в оцінці товаришів і самокритичні в оцінці самих себе. Їхній самооцінці притаманні диференційованість, адекватність, обгрунтованість.

2-й тип - учні при оцінці і самооцінці якостей особистості, як правило, використовують вузьке коло критеріїв, виявляють при цьому суб'єктивізм у підході до їх вибору: їм притаманна критичність в оцінних судженнях, упередженість у виборі основ, опори на одиничні факти поведінки однолітка. Характерна тенденція до переоцінки особистісних якостей.

Методика «Діагностика особистісного розвитку» дала змогу вивчити здатність до розгорнутої диференційованої самооцінки молодших школярів, зрозуміти їхнє уявлення про те, якими їх бачать інші.

Здобуті за допомогою цієї діагностики результати дали змогу стверджувати, що в учнів першого класу спостерігаються істотні суперечності між уявленням про себе як про хорошого учня і необхідністю давати собі негативні характеристики. Поступово у молодших школярів відзначена суперечність згладжується і на перший план виходить нова - між умінням давати адекватні самооцінки і застосуванням цих умінь у спільній навчальній діяльності. Проведена діагностика показала високий ступінь кореляції між рівнями розвитку окремих компонентів самооцінки, що уможливило в цілому визначити іiі рівень як середній показник рівнів розвитку ії складових.

Високий рівень характеризується тим, що учень здійснює самооцінну діяльність усвідомлено (знає, навіщо оцінювати), уміє самостійно визначити об’єкт оцінювання (знає, що оцінювати), уміє самостійно здійснювати оцінювання на основі обраного еталона й критеріїв (знає, як оцінювати), вміє висловити власне судження й обгрунтувати свою точку зору: мовлення учня 
змістовне й вправне. В учня з високим рівнем сформованості оцінної діяльності добре розвинуті аналітико-синтетичні уміння (правильно визначає смисл сказаного), він вміє спостерігати, порівнювати, ставити запитання по сутті проблеми, здатна застосовувати знання не лише у звичайних, але й у нових ситуаціях, у нього розвинута самокритичність, уміння оцінити свої можливості, визначати недоліки у відповіді та їх причини, формулювати корекційні пропозиції, здатність здійснювати рефлексію процесу оцінювання. Такі школярі відрізняються високим ступенем самостійності в мисленні й поведінці.

Середній рівень характеризується тим, що учень володіє частковою повнотою знань, частіше вони уривчасті: знає, що оцінювати і як оцінювати, але не завжди вміє застосувати свої знання, вміє порівнювати зі зразком (еталоном) і відзначати різницю між ним і результатом власної діяльності, знає критерії оцінки, які здебільшого пропонуються вчителем. Школяреві важко пояснити свої оцінні дії, цілеспрямоване оцінювання він здійснює лише за вказівками вчителя, самокритичність не розвинута: частіше погоджується, ніж висловлює свою точку зору. Така дитина вміє визначити недоліки у відповіді, але не завжди може пояснити їх причини, не вміє сформулювати корекційні пропозиції, часто припускається помилок, шукаючи слова для висловлення своїх думок, мовлення недостатньо виразне, слабо проявляється самостійність мислення. Учень потребує не лише спрямовуючої допомоги, але й навчальної допомоги вчителя.

Низький рівень визначається тим, що учень уникає самооцінювання, часто в нього відсутня потреба в оцінюванні й він не знає, як його здійснювати, оскільки несформоване вміння порівнювати зі зразком (еталоном), критерії оцінювання обирає несуттєві, критичність не розвинута: не вміє оцінити власні дії ні самостійно, ні за вказівками учителя. Школяр відчуває складність при визначенні недоліків у відповіді, не здатний здійснювати рефлексію процесу оцінювання, має обмежений світогляд, дуже уривчасті, безсистемні знання, мовлення його односкладне, невиразне, в ньому багато помилок. Дитина потребує систематичної спонукальної, спрямовуючої і навчальної допомоги, але сприймає іiї з утрудненнями. 
Для визначення сутності кожного рівня ми вивчали першокласників. Результати цієї роботи стали підгрунтям для виділення найбільш типових представників кожного рівня.

Характеристика учнів з високим рівнем самооцінки: вчаться переважно на відмінно, знання міцні, систематичні. Прагнуть до виконання нестандартних, творчих завдань. Самооцінювання відбувається в діяльності, через результати, які є для них цінними. Доброзичливі до товаришів, прислухаються до їхніх зауважень і думки класу про свої здібності. Провідні мотиви - пізнавальні. Хочуть довідатися якнайбільше про все, в тому числі і про себе. Володіють прийомами самооцінки. Можуть продуктивно, зацікавлено працювати над виконанням складніших завдань. Самооцінка адекватна. Постійно прагнуть до самовдосконалення. Можуть без сторонньої допомоги ставити цілі саморозвитку.

У школярів з високим рівнем розвитку самооцінка реалістична. Вони непогано знають свої особливості. Водночас вони бачать їх не тільки в окремих сьогоденних ситуаціях, це вже досить узагальнені знання («У таких випадках я завжди так роблю..»). Діти добре знають свої можливості і тому можуть прогнозувати свої дії - що вийде, а що ні. Причини своїх невдач вони відносять на рахунок своїх власних недоліків. Їм не властива категорична самовпевненість. Говорячи про себе, вони схильні використовувати обережні вирази, типу: «я вважаю», «мені видається», «можливо, що».

До середнього рівня розвитку самооцінки ми віднесли тих учнів, у яких знання про себе все ще відображають думку навколишніх. В основу виділення й оцінки власних якостей лягають конкретні факти, окремі випадки, а перелік цих якостей невеликий. Діти не завжди розуміють свої здібності і можливості, хоча й охоче включаються в ситуації самооцінювання, більш ніж діти низького рівня, схильні до сумнівів і міркувань стосовно себе. Основні мотиви: добробут, досягнення, самопізнавання. Володіють деякими прийомами оцінювання себе, але застосовують ці знання епізодично здебільшого на прохання вчителя. У 
спілкуванні здобувають інформацію про себе, здатні сприйняти критику, ставати на позицію інших.

Характеристика учнів середнього рівня самооцінки: вчаться добре, ставлення до себе позитивне. Можуть дати характеристику своїх зовнішніх якостей, своїх здібностей. Самооцінка у них не завжди адекватна, оцінку з боку інших сприймають, але рідко враховують у своїй діяльності. На уроках ініціативні, володіють прийомами самоаналізу, використовують завдання творчого характеру для виявлення своїх здібностей. Емоційні. Процес самооцінювання супроводжується радістю, переживанням, подивом. До думок інших не байдужі. Прагнуть враховувати побажання однокласників, учителя.

Характеристика учнів з низьким рівнем самооцінки: вчаться нерівно, не виявляють прагнення до самопізнання. Емоції при розкритті своїх можливостей і здібностей виражені слабко. Уникають завдань творчого характеру, завдань на кмітливість, логіку, що дають можливість перевірити свої інтелектуальні здібності, властивості характеру. Самооцінка в учнів переважно неадекватна: завжди хочуть оцінити себе вище, не роблячи при цьому ніяких обгрунтувань. Слабко розвинена здатність до вольових зусиль у самопізнанні. Оцінки себе іншими членами колективу не сприймають і не враховують, рідко порівнюють себе з іншими. Основні мотиви поведінки - запобігання неприємностей і мотив добробуту.

изька самооцінка внаслідок того, що учні щодня чують з вуст батьків і вчителів негативні оцінки, а це є причиною того, що вони вже не вважають себе здатними ні на що. Для самого себе учень не представляє ніякої цінності, а його ставлення до товаришів можна схарактеризувати як умовно позитивне. Потреба в самооцінці у таких дітей не виражена, прийоми самооцінювання не сформовані.

Підбиваючи короткий підсумок опису рівнів розвитку самооцінки молодших школярів, слід зазначити, що якщо учні з високим рівнем аналізують свої вчинки і стосунки, то середнього - більше довіряють стороннім судженням 
про себе. Діти з низьким рівнем не думають про себе і практично нічого не знають про свої реальні якості і можливості.

У процесі нашого дослідження було розглянуто динаміку рівня розвитку самооцінки учнів експериментальних класів у порівнянні 3 даними масового досвіду (контрольні класи).

У результаті аналізу й зіставлення результатів, отриманих у ході констатувального етапу експериментальної роботи, можна визначити високий, середній і низький рівні самооцінки молодших школярів: високий рівень характеризує достатність структурної повноцінності самооцінної діяльності учнів, а середній і низький рівні - недостатню структурну повноцінність.

Табличя 1

Розподіл учнів за рівнями розвитку самооцінки

\begin{tabular}{|l|c|c|c|}
\hline \multirow{2}{*}{ Класи } & \multicolumn{3}{|c|}{ Рівні (у\%) } \\
\cline { 2 - 4 } & Високий & Середній & Низький \\
\hline Експериментальні класи & 15,6 & 43,3 & 41,1 \\
\hline Контрольні класи & 16,2 & 35,4 & 48,4 \\
\hline
\end{tabular}

Як свідчать результати констатувального експерименту, тільки 15,6\% учнів експериментальних класів та 16,2\% контрольних класів мають високий рівень сформованості самооцінки. 41,1\% учнів експериментальних і 48,4\% контрольних класів мають низький рівень сформованості самооцінки. У цілому для учнів початкових класів характерним є середній і низький рівні оволодіння самооцінкою, що свідчить про недостатній рівень їі структурної повноцінності. Здобуті дані підтверджують необхідність спеціального формування в молодших школярів умінь здійснювати самооцінну діяльність у процесі навчання.

Отже, завдання нашого дослідження полягає в тому, щоб навчити дитину в конкретних навчальних ситуаціях аналізувати свої вчинки і стосунки, ставити перед собою питання і відповідати на них, бачити i виявляти в ситуаціях дружнього спілкування якості людей і свої власні, оцінювати ці якості, 
розв’язувати конфліктні ситуації, робити самостійний моральний вибір. Тільки реальні і досить повні знання про себе дадуть дитині справжню опору в житті, допоможуть підвищити свій статус, реалізувати свої можливості, реалізуватися як особистості.

Проведена діагностика показала високий ступінь кореляції між рівнями розвитку окремих компонентів самооцінки, що уможливило в цілому визначити іiі рівень як середній показник рівнів розвитку їі складових.

У контрольних класах навчальна діяльність здійснювалася традиційно. В експериментальних формування самооцінки молодших школярів передбачало спеціально організоване їх навчання 3 детально визначеними цілями та діагностичним інструментарієм. Визначені дидактичні умови дотримувалися.

У початковий період навчання в першокласників домінує суперечність між уявленням про себе як про хорошого і необхідністю давати адекватну оцінку собі. Згодом на зміну приходить нова суперечність: між розвитком рефлексійної сфери і діяльнісно-практичною сферою учня. Виникнення цієї суперечності пов'язане $з$ тим, що протягом першого року навчання свідомість молодших школярів значно збагачується запасом уявлень про самооцінку, способи оцінювання, оцінні еталони. Учні вже можуть розповісти про себе, свої позитивні і негативні риси. За цих умов самооцінка стає обгрунтованішою й адекватнішою.

Відповідно до виділених суперечностей процес формування самооцінки було розділено на дві послідовні стадії.

На першій стадії формувального експерименту нами розв'язувалося завдання: стимулювання бажання оцінювати себе, свою діяльність на уроці, формування умінь оцінювати свою діяльність за «еталоном».

Формуванню в школярів позитивної мотивації до процесу самооцінки не тільки у навчанні, але й у повсякденному житті сприяли бесіди про сутність самооцінки, форми і способи їі здійснення, рольові ігри.

Бесіди проводилися під час уроків з опорою на їхній вітагенний досвід. Запитання добирались у такий спосіб, щоб діти могли брати активну участь в 
обговоренні. Добір інформації (оповідання, казки, історії з життя) полегшував сприймання та розуміння молодшими школярами нових повідомлень, давав змогу подивитися на відомі ситуації по-іншому.

Серед засобів цієї стадії переважало використання ситуацій, що спонукали учнів до самооцінювання. У цей період учні засвоїли «еталони», за якими можна адекватно оцінити себе, оцінні критерії. Після цього було здійснено перехід до ситуацій, що вимагають оцінити свою діяльність. Було проведено серія уроків, де використовувалось уміння дітей оцінювати себе, свою роботу на уроці.

На другій стадії формувального експерименту учні ставилися в ситуації спільної навчальної діяльності задля закріплення здобутих знань й умінь із самооцінки. Водночас включення дітей у спільну навчальну діяльність виявило потенційні можливості спільної навчальної діяльності для розвитку самооцінки. Провідним засобом на цьому етапі була організація спільної навчальної діяльності на уроках.

Групи для спільної діяльності складалися з двох (початковий етап), трьох, чотирьох дітей. Ця робота вибудовувалася на основі усвідомлення учнями користі і переваг спільної роботи в навчальному процесі, одержання радості від спілкування у процесі навчальної діяльності, стимулювання бажання оцінювати свою діяльність.

Проведена дослідно-експериментальна робота дала змогу дійти висновків, що під час спільної діяльності в учнів проявляються можливості: 1) спостерігати за діяльністю інших учнів у групі; 2) вільного спілкування; 3) співвідносити свою діяльність 3 діяльністю інших; 4) формувати потребу давати власні оцінки спільній діяльності; 5) правильно сприймати оцінки своєї діяльності іншими. У ході експерименту з'ясувалося, що діяльність, побудована в режимі кооперації, сприяє розвиткові адекватної самооцінки молодших школярів.

Формування самооцінки молодших школярів здійснювалося у практичнодіяльнісному контексті. Зміст діяльнісного блоку в процесі формування в учнів самооцінної діяльності полягав у залученні їх до активного формування самооцінки засобами різних їі видів і форм; здійснення змістовного оцінювання; 
виконання вибору еталонів, їх розроблення й корекції; вибір за пропозицією вчителя або самостійне визначення критеріїв оцінювання; модифікація критеріїв оцінки відповідно до різних навчальних предметів й оцінних ситуацій; застосування шкал переходу від оцінки до оцінки-балу, розроблення власних шкал під керівництвом учителя; здійснення рефлексії власної оцінної діяльності й себе як іï суб’єкта, засвоєння прийомів рефлексії.

В організації формувального етапу експерименту значну увагу було приділено формуванню гуманних взаємин між учасниками навчального процесу, підтримці позитивного емоційного стану молодших школярів у процесі самооцінювання навчальної діяльності, наданню своєчасної допомоги в самооцінювальній діяльності (порада, консультація, коригування).

На завершальному етапі експериментального дослідження було визначено динаміку сформованості самооцінки молодших школярів у навчальній діяльності на основі усереднених показників (табл. 1).

Таблиия 2

Динаміка сформованості самооцінки молодших школярів

\begin{tabular}{|c|c|c|c|c|}
\hline \multirow{2}{*}{ Рівні } & \multicolumn{2}{|c|}{ Експериментальні класи } & \multicolumn{2}{|c|}{ Контрольні класи } \\
\hline & $\begin{array}{l}\text { До } \\
\text { експерименту }\end{array}$ & $\begin{array}{l}\text { Після } \\
\text { експерименту }\end{array}$ & $\begin{array}{l}\text { До } \\
\text { експерименту }\end{array}$ & $\begin{array}{l}\text { Після } \\
\text { експерименту }\end{array}$ \\
\hline Високий & $14,9 \%$ & $24,8 \%$ & $15,8 \%$ & $17,9 \%$ \\
\hline Середній & $43,2 \%$ & $60,1 \%$ & $35,3 \%$ & $37,8 \%$ \\
\hline Низький & $41,9 \%$ & $15,1 \%$ & $48,9 \%$ & $44,3 \%$ \\
\hline
\end{tabular}

Отже, формувальний етап експерименту підтвердив ефективність визначених дидактичних умов формування самооцінки молодших школярів у навчальній діяльності. В учнів експериментальних класів відбулися статистично достовірні кількісні та якісні зміни, що проявились у позитивній динаміці рівнів сформованості самооцінки. Зокрема, зменшилася кількість учнів з низьким рівнем самооцінки (з 41,9\% до 15,1\%). Натомість зросла кількість школярів 3 високим рівнем (з 14,9\% до 24,9\%). Динаміка спостерігається також у зміні кількості учнів 3 
середнім рівнем самооцінки: перед проведенням формувального експерименту їх було 43,2\%, після його завершення - 60,1\%. Такі зміни пояснюються тим, що певна кількість учнів з низького рівня перейшла на цей рівень, і певна частина учнів 3 середнього рівня досягла вищого рівня самооцінки. У контрольних класах за час проведення формувального експерименту також сталися певні зрушення, проте вони не досягають рівня статистичної значущості.

Проведене дослідження підтвердило основні положення висунутої гіпотези та дало змогу сформулювати висновки відповідно до поставлених завдань.

У процесі системного аналізу науково-педагогічних джерел з'ясовано, що проблема формування самооцінки особистості була актуальною в усі періоди розвитку вітчизняної та світової педагогічної науки.

Аналіз філософської та психолого-педагогічної літератури дав змогу розглядати самооцінку як основу процесу самоусвідомлення особистості, як показник індивідуального рівня розвитку, його особистісний аспект. Самооцінка як особистісне утворення позначається на регуляції поведінки і діяльності; як характеристика особистості, іiі центральний компонент формується за активної участі самої особистості і відображає своєрідність їі внутрішнього світу.

Проведений теоретичний аналіз дав змогу представити структуру самооцінки у вигляді трьох компонентів:

- мотиваційно-ціннісного, що характеризується позитивним ставленням до діï самооцінювання, потребою довідатися про себе, свої позитивні і негативні характеристики, прагненням досягти успіху у спільній діяльності, пізнавати себе 3 кращого боку;

- $\quad$ когнітивного, основу якого складають знання людини про себе - ситуативні чи стійкі, позитивні чи негативні, більш або менш значущі для особистості;

- діяльнісно-практичного як системи вмінь самооцінювання, що характеризується здатністю розрізняти ознаки, за якими діти оцінюють свої позитивні і негативні якості, діяльність у групі, уміння адекватно оцінити власну діяльність у групі, здатність критично ставитися до оцінки своїх умінь іншими учнями. 
На підставі здійсненого аналізу психолого-педагогічних наукових джерел було виокремлено функції самооцінки:

- мотиваційну, що забезпечує свідому, мотивовану поведінку, реалізацію обраної позиції, самореалізацію і охоплює всі види спонукань - мотиви, прагнення, ідеали, цілі, усвідомлені спонукання до діяльності;

- орієнтаційну, яка передбачає орієнтування в ситуаціях оцінювання себе, своїх можливостей, своєї діяльності в групі;

- регулятивну, що забезпечує свідому саморегуляцію своєї поведінки умовах, які вимагають докладання свідомих зусиль для оцінювання себе i виконуваної діяльності, керування собою в умовах емоційного збудження чи втоми, здатність діяти відповідно до вимог ситуації, дорослого чи дитячого колективу;

- рефлексійну, яка виявляється в умінні людини усвідомлювати те, що вона робить, й аргументувати, обгрунтовувати свою діяльність.

У дослідженні доведено потенційні можливості спільної навчальної діяльності у формуванні самооцінки молодших школярів. 3'ясовано, що спільною вважається діяльність, за якої ії завдання сприймаються як групові. Це потребує об'єднання учнів для розв'язання поставлених завдань. Іншою ознакою спільної діяльності є наявність взаємної залежності, взаємоконтролю та відповідальності.

Доведено, що використання спільних форм навчальної діяльності вносить істотні позитивні зміни у формування самооцінки, дає можливість порівнювати себе з однолітками, у ній створюються умови для колективного аналізу роботи, розвитку умінь і потреби аналізувати, доводити свою думку, оцінювати свої дії 3 погляду іншого.

Синтез ідей, розроблених у вітчизняній і зарубіжній психолого-педагогічній науці, аналіз передового педагогічного досвіду формування самооцінки молодших школярів у навчальній діяльності дали можливість визначити дидактичні умови, за яких цей процес відбувається успішніше:

- мотивація учнів до самооцінної діяльності;

- включення педагогом учнів до систематичного і послідовного процесу самоаналізу в умовах спільної навчальної діяльності; 
- поетапність формування мотиваційно-ціннісного, когнітивного, діяльнісно-практичного компонентів самооцінки;

- опора на традиції гуманістичної освіти, формування гуманних взаємин між учасниками навчального процесу, підтримка позитивного емоційного стану молодших школярів у процесі самооцінювання навчальної діяльності, надання їм своєчасної допомоги.

На підставі діагностичних даних у сформованості кожного компонента самооцінки було виділено три рівні: високий, середній, низький. Проведена діагностика показала високий ступінь кореляції між рівнями сформованості окремих компонентів самооцінки, що дало змогу в цілому визначити рівень сформованості самооцінки як середній показник рівнів сформованості іiї складових.

Здійснено експериментальну роботу, спрямовану на перевірку висунутої гіпотези, результати якої свідчать про ії ефективність.

Комплексне застосування визначених дидактичних умов уможливило одержання даних, які склали основу об'єктивно статистичного узагальнення: у результаті заключного діагностування було виявлено, що в експериментальних класах зросла кількість учнів, що мають високий рівень сформованості самооцінки ( 3 14,9\% під час констатувального етапу експерименту до $24,8 \%$ під час контрольного зрізу); зросла кількість учнів з середнім рівнем - 3 43,2\% до 60,1\%; зменшилася кількість учнів з низьким рівнем сформованості самооцінки - 3 41,9\% до $15,1 \%$.

Отже, проведене нами дослідження дає змогу стверджувати, що саме у початковій школі формується самооцінка молодших школярів. Це відбувається у взаємодії усіх учасників навчального процесу під керівництвом (і направленням дій школярів) учителя. 
DOI 10.46299/ISG.2021.MONO.PED.III.8.12

\subsection{2 Проблема моделювання розвитку особистісної надійності у навчанні майбутніх підприсмців}

Підприємництво, як особливий вид світогляду, характеризується унікальними поглядами і методами до прийняття домінантних рішень, які реалізуються на практиці, що потребує приділяти велику увагу у навчальному процесі при підготовці майбутніх фахівців підприємницької діяльності.

Значні зміни в соціально-економічних умовах життя суспільства спричинила сучасна світова економічна криза. Вона посилила динаміку процесів суспільно-політичного життя нашої країни, а це призвело до значних зміни у виробничих силах, що вплинуло на організаційні стосунки у малих групах і тим самим детермінувало зміни психічних структур особистості. Трансформаційні процеси сьогодення ще 3 більшою силою висвітлили як актуальну та надзвичайно необхідну для дослідження з боку науковців проблему особистісної надійності суб'єкта професійної діяльності, бо особистісна надійність має вагоме значення в регуляції життєдіяльності різних індивідуальних та групових суб'єктів.

Особистісна надійність $є$ фундаментальною, атрибутивною ознакою особистості, яка характеризує іiі здатність до прогнозованої відповідальної поведінки, пов'язаної з реалізацією соціальних взаємин відповідно до групових норм та цінностей. Відомо, що здатність до прогнозованої відповідальної поведінки вимагає значних зусиль навчального процесу майбутніх фахівців.

Аксіомою $є$ те, що спроби швидко створити вільну ринкову економіку в країні, в якій десятиліттями панував авторитарний режим, заздалегідь приречені на провал. Така країна повинна пройти етап поступової лібералізації й виховання поваги до свободи особистості, щоб у суспільстві розвинулися прагнення до незалежності й дух підприємництва.

Підприємництво розглядається як діяльність людини в інтенсивних суспільно-значущих ситуаціях, підсумком яких $є$ нова структура в господарській та інших сферах матеріально - духовного виробництва, в яких реалізується суб'єктний потенціал людини [718, с. 15-16]. 
Підприємництво передбачає діяльність підприємця, який є творцем власної справи і який може започаткувати як нову професію, так і галузь в існуючих професіях, де він $\epsilon$ соціальним новатором та трансформатором соціокультурного середовища.

Вважаємо, що онтогенез розвитку надійності корелює із розвитком суб'єктності, як властивості людини бути джерелом власної свідомої активності, творити свій внутрішній та зовнішній світ. Цьому повинний сприяти i навчальний процес майбутніх фахівців.

Таким чином, надійність, надаючи свободу в межах певної діяльності, водночас покладає відповідальність за виконання системи дій, операцій. Рольова надійність обмежує свободу заданою ззовні соціальною роллю, відповідальність - за виконання цієї ролі; при особистісній надійності людини індивідуальна свобода - у межах самостійно створеної ролі, моральна відповідальність; діяльнісний рівень розвитку надійності та їі межі свободи опосередковуються межами власного життя, відповідальністю за власну життєтворчість. Рефлексивний рівень розширює свободу до меж заданої історичної культури, а змістом відповідальності є розвиток власної надійності. Діалогічна надійність розширює свободу до міжкультурного простору, покладаючи тягар відповідальності на розвиток людства.

Отже, особистісна надійність людини - це властивість людини, яка характеризує ії здатність до прогнозованої поведінки, пов'язаної з реалізацією соціальних взаємин у відповідності з суспільними нормами та ідеалами, а також власним відповідальним вибором.

Особистість, яка характеризується особистісною надійністю, здатна бути автономним носієм загальнолюдського досвіду та історично вироблених людством і відображених у культурі форм поведінки й діяльності. Діалектика взаємодії особистісної надійності людини та культури полягає, на наш погляд, у тому, що культура детермінує розвиток та становлення особистісної надійності людини, а особистість є носієм та творцем культури. В. Франкл довів за результатами досліджень у галузі неврології та психіатрії міру залежності 
людини від біологічних, психічних і соціальних умов; водночас людина здатна кинути виклик найбільш важким умовам, які лише тільки можливо собі уявити [719].

Узагальнюючи теоретичні дослідження проблеми особистісної надійності людини, зазначимо, що змістовими властивостями, які складають іï основу, є певні віково-статеві, нейродинамічні властивості, конституційні та фізіономічні особливості, риси характеру, особливості когнітивної сфери, ціннісні орієнтації людини, зокрема, відповідальність, стійкість, вольові якості, почуття обов'язку, дисциплінованість.

Окрім цього, вагомим аспектом питання, що розглядається, є власне визначення особистісної надійності людини як нормативно-ціннісного поняття в контексті самоактуалізації особистості. Так, до найважливіших особистісних характеристик Г. Балл, виходячи з розуміння особистості як системної якості людського індивіда, включає, передусім, найбільш істотні його характеристики, а саме «особистісні орієнтири», що забезпечують функціонування людини як автономного учасника суспільного буття й суб’єкта культури. До таких характеристик учений зараховує особистісну надійність людини, розуміючи під цим терміном таку цілісну якість особистості, що визначає готовність останньої до доброчесного виконання конкретних суспільних функцій.

Автор зазначає, що «кількісно особистісну надійність людини можна оцінити ймовірністю, з якою вдається передбачити поведінку особи з реалізації взаємин, що склалися в неї з іншими учасниками суспільного буття (індивідами, групами, організаціями), а також з нормами та ідеалами, котрі регулюють (або мають регулювати) їі поведінку» [720, с. 461-474]. Отож, даній характеристиці надається, поряд із концептуальним, також функціональне, суто поведінкове, визначення.

Формуючи сутність і психологічний зміст особистісної надійності, дослідник Г.О. Балл виходить «із розуміння особистості як такої системної якості людського індивіда, що охоплює стійкі (принаймні сталі) характеристики, 
істотні для його функціонування, як відносно автономного учасника суспільного буття, а також... як суб’єкта культури» [720].

Звертаючись до питання про надійність працівника на виробництві, в своїх дослідженнях Г.О. Балл розглядає ії як окремий вид особистісної надійності. «Адже в даному разі з'ясовується, чи можна розраховувати на достатню стійкість працівника в реалізації взаємин, у які він увійшов із нормами, що регулюють виробничий процес (прийнявши їх до виконання), а також з організатором виробництва і з партнерами по праці». Конкретизуючи психологічний зміст особистісної надійності як феномену, український психолог пов'язує його 3 вимогами щодо виконання діяльності в тих чи інших іiі аспектах, зокрема, на рівнях: а) правильного виконання чітко заданих операцій (скажімо, при роботі на конвеєрі); б) успішного розв'язання задач різного характеру, різного ступеня складності і проблемності; в) реалізації певних смислів, пов'язаних зі ставленням до конкретних людей, соціальних спільнот, сфер діяльності, культурних і духовних цінностей; г) пошуку й реалізації людиною особливого смислу, а саме - унікального сенсу свого життя [721, с. 109-114].

У навчальному процесі слід чітко розуміти, що у даному випадку 3'ясовується, чи можливо планувати необхідну стійкість співробітника в реалізації відносин, в які він увійшов із загальновизнаними нормами, що регулюють виробничий процес (прийнявши їх до виконання), а також 3 організатором виробництва і з партнерами по праці.

Поняття особистісної надійності, в окресленому вище трактуванні, постає, попри його операціональності, гуманітарно й етично навантаженим. Тому у навчальному процесі слід зосередитися на психологічному змісті особистісної надійності. Залежно від вимог до результатів діяльності особи, від того, які саме параметри цих результатів мають бути надійно передбачувані, найбільш потрібними постають ті чи інші компоненти у структурі діяльності (і поведінки як іiї зовнішнього вияву). Відповідно зазнає змін і психологічна конкретизація загальної вимоги передбачуваності поведінки (а отже, особистісної надійності). У своїй сукупності (точніше, інтегрувавшись у єдину систему) ці якості 
утворюють той конкретний вияв особистісної надійності, який відповідає високій мірі професіоналізму: - на рівні виконання певних смислів, пов’язаних зі ставленням до конкретних людей (зокрема, з переживанням щодо них почуттів дружби, любові, морального обов'язку), а також із подібним ставленням до соціальних спільнот, сфер діяльності, культурних і духовних цінностей; - на рівні знайдення (часом через довгі пошуки) й реалізації людиною особливого смислу, а саме унікального сенсу свого життя. У наведеному переліку рівні розміщено в напрямку підвищення ступеня узагальненості управління поведінкою. Певних коментарів потребує найвищий у запропонованій ієрархії рівень, який передбачає вірність сенсові свого життя. Слід зазначити, що цей сенс може й не фіксуватися чітко у свідомості його носія (не говорячи вже про інших людей) і лише інтуїтивно вгадуватися ним - i тим не менш слугувати могутнім регулятором, критерієм оцінювання й важелем удосконалення поведінки.

Стосовно сенсу життя, як специфічного смислу, окремі смисли, що були раніше основою «зобов’язань» особи, можуть або постати (можливо, перетворившись) його гранями чи гармонійними доповненнями, або бути подолані як несумісні з ним, або, попри наявні суперечності, зберігатися, створюючи напруги в житті особистості. Продуктивним може бути такий сенс життя, який, становлячи своєрідний відгук на нагальні потреби навколишнього світу, водночас узгоджується з індивідуальністю людини, передусім зі сталими, такими, що не можуть бути цілеспрямовано змінені, рисами їі особистості. За цієї умови сенс життя збігається 3 покликанням людини. Досягнувши вершин професіоналізму, людина «робить не те, що схвалюють інші, не те, що інші чекають від неї, не те, за що інші іiі засуджують. Вона робить те, до чого призначена». У вказаному визначенні згадуються «норми..., котрі регулюють (або мають регулювати) їі (особи) поведінку». Тож до них, безумовно, належать, поряд із нормами, що накладаються ззовні й розраховані на багатьох осіб, також особистісні норми, модифіковані або сформовані самою особою. Узгодженість поведінки із сенсом життя становить чи не найважливішу особистісну норму. $€$ 
цілком закономірним, що вірність сенсові життя часом виражається в манері виконання, яка зовні здається непослідовною й, отже, не подібною до фактів, що їх найчастіше пов’язують із поняттям особистісної надійності. Адже в науці досить часто теоретичне осмислення й узагальнення понять (таких, наприклад, як «число» або «множина» в математиці) дозволяє поширити їх на об’єкти, багато в чому не схожі на ті, з якими ці поняття пов’язувалися спочатку [722, с. 93-97].

Світоглядною й методологічною основою розуміння Г.О. Баллом особистості є принцип раціогуманізму, який становить у найширшому контексті важливу передумову «успішного розвитку й позитивного впливу на суспільну практику» психологічної науки в цілому. Вчений уважає, що відповідно до цього принципу є актуальним «з’ясування того, як поєднати у психологічній царині гуманістичну налаштованість із конструктивним використанням засобів раціонального пізнання». Водночас він зазначає, що «раціоналізм, трактований у загальному сенсі як цінування розуму і спирання на нього, постає однією зі сторін гуманізму». При цьому слід орієнтуватися не на механістичні, дисгармонійні форми інтелекту людини, що дискредитували себе «у війнах i готуванні до них, у насаджуванні екологічно шкідливих технологій, у корисливому маніпулюванні свідомістю і поведінкою великих мас людей і т.П.», а на «збалансований, гармонійний інтелект», окреслений у контексті поняття культури. І це закономірно, адже культура - це «сукупність людських функцій (та засобів їх реалізації), спрямованих на забезпечення соціальної пам'яті та соціально значущої творчості; носіями культури є: по-перше, людство в цілому; по-друге, людські спільноти; по-третє, окремі особи». Відповідно, культура постає як «єдність складників двох типів: а) нормативно-репродуктивних, тих, що забезпечують усталеність засобів і способів функціонування людських спільнот та окремих осіб, зв’язок між попередніми і наступними поколіннями (ці складники часто пов’язують із поняттям цивілізації, в одному з його численних, як і в поняття культури, тлумачень); б) діалогічно-творчих, завдяки яким відбувається оновлення й розвиток людського суспільства» [721, с. 112]. 
Г.О. Балл звертає увагу на величезну суспільну вагомість особистісної надійності. Вона має також й економічне значення, тому що постає передумовою формування й функціонування так званого соціального капіталу. За концепцією Дж. Коулмена, подібно до фізичного капіталу, втіленого в тих чи інших матеріальних формах, і людського капіталу, що знаходить вияв у навичках i знаннях індивідів, наявний у їхніх взаєминах, соціальний капітал «полегшує виробничу діяльність. Наприклад, група, всередині якої існує повна надійність і абсолютна довіра, здатна здійснити набагато більше, порівняно із групою, що не має таких якостей» [721, с. 114].

Зараз, в умовах розвитку та становлення у навчальному процесі економіки «знань», головною рисою людини, що розвивається у ринкових відносинах, вважається дієздатність до незмінного саморозвитку, інноваторської зміни реальності, пошуку та реалізації сучасних способів здійснення соціальноекономічної, підприємницької, управлінської, комерційної діяльності. Заміна змісту діяльності з репродуктивної, властивої для промислової, ресурснозалежної економіки, на творчий процес - головна ознака сучасних економічних процесів та тенденція в суспільстві, які визначають роль і простір людини в новітній економіці. Особистість виступає рушійною силою становлення соціального розвитку за рахунок соціально-економічної активності та підприємливості, які постають як результат перебудови структури внутрішнього світу людини. При цьому економічний прогрес, природно, залишається важливою умовою формування нового господарського порядку, втім сутнісною умовою вважається зміна ціннісних орієнтирів людини, створення умов, в яких ключовим моментом стає реалізація ії внутрішнього потенціалу [723, с. 164-175].

Таким чином, людина, як феномен ринкової економіки, вважається не лише виробником і споживачем, не лише власником і найманим працівником, але й людиною-творцем, джерелом інноваційної енергійності, носієм духовновольового потягу до перетворення, до самореалізації власних внутрішніх необхідностей i уподобань. Розвиток такого особистісне міцного суб'єкта підприємницької енергійності в нашій країні, яка розташовується під впливом 
згаданих нами вище архаїчних ідейних та ідейно-ціннісних конструктів, вважається дуже важким і важливим завданням. Це обумовлює загальну потребу теоретичної розробки способів адаптаційно-креативної соціалізації української сучасності до системи ринкових відносин, що розвиваються в нашому суспільстві і в світі. Сучасні обставини формування культури ринкової економіки в Україні вимагають від особистості інтенсивної позиції в системі фінансових відносин, креативної взаємодії з іншими їі суб’єктами [723, с. 166]. Модифікація ціннісних уявлень, масова перебудова суспільних стандартів та зміна систем цінностей вважається важливою соціально-психологічною задачею. Зміна стандартів у глобальній свідомості буває складною і нерідко розуміється окремими групами людей як зміна стандартів, втрата сенсу життя. Утворені новітні стандарти непросто пристосовуються, суперечливо сприймаються, часом навіть заперечуються. Власне, що стосується системи цінностей, то вона в цьому процесі засновує новітні і потрібні соціумом ціннісні орієнтації, нові ієрархії цінностей підприємницької діяльності.

Зараз виділяють три полюса в глобальній оцінці моралі у свідомості людей: стан морального вакууму, де домінує вседозволеність; погоджуються лише тільки значення ринкових відносин, де всесвіт оцінюється категоріями вартості, ціни, коштів, ділових комунікацій; малозначна частка соціуму продовжує наслідувати класичні знання нашої культури з відповідним негативним ставленням до людей 3 іншим ставленням до духовних цінностей. У XXI столітті людина, як носій цінностей класичної культури, втрачає власні колишні значущі якості, потрапляє в жорстку підневільність від стандартів нав'язуваній їй поведінки. В силу об'єктивних подій вона повинна підключатися в сувору конкурентну боротьбу за виживання, речові блага, дотримання незвичайних форм духовно-практичної роботи. Ставши жертвою цих подій, люди страждають від дискомфорту, автономності духовного життя, класичних еталонів державної та світової культури [723, с. 168]. Усвідомлюючи, що найвищою цінністю передового цивілізаційного процесу вважається людина, іiі права і свободи, слід підкреслити, 
що власне в критеріях становлення глобалізаційного передового світу набуваються нові спільні значення, які важливі для життя в єдиному соціумі.

Поміж групи універсальних соціально-економічних цінностей - це право будь-якої людини на самозабезпечення. Маючи головні права i свободи передового демократичного суспільства, людина має можливість проектувати й будувати своє майбутнє в системі реальної життєдіяльності та професійній сфері. Зараз у світі проблематика підприємницької сутності стоїть перед людиною досить гостро, в тому числі, і в економічно розвинених державах. Питання про суть бізнесу, ієрархію цінностей, роль і простір людини в сфері підприємницької діяльності все частіше задають для себе як окремі робітники, так і очільники компаній. Ключовим завданням передового бізнесу вважається створення специфічної для певної компанії фінансової культури, яка була б адекватним вираженням іiі ділової стратегії. На базі нової підприємницької культури лежить принцип людино-центричності та моральності всякого передового бізнес-процесу [723, c. 168-172].

Кожна людина, група або суспільство в цілому перебувають на певному етапі свого особистого й духовного розвитку. Залежно від цього цілі, яких людина або група досягають, ставлячи перед собою, відповідають тим рівням свідомості й буття, у контексті яких такі цілі ставляться. Так, для підприємця цілі концентруються навколо постачання матеріальними й фінансовими ресурсами власної фірми, отримання прибутку від бізнесу, забезпечення власного добробуту, родини, певною мірою турботу про місце свого проживання (місто, область), процвітання економіки власної держави. У такому контексті можна виділити, як мінімум, чотири рівні цілепокладання - особистий, родинний, підприємства, регіону і держави. Ні в якому разі жодна 3 них не $\epsilon$ «гіршою» або «кращою» 3 погляду соціуму в цілому, але вони ставляться з різних рівнів буття, усвідомлених самою людиною. Цілі висуває будь-яка людина, однак, для правильного розуміння їх необхідно, напевно, чітко знати, з яких рівнів вони формулюються. Цілі людини визначаються іiі цінностями, осмисленими відповідно до певної системи потреб, в утворенні якої головну роль, як правило, відіграє оточення. 
Допомогти в оцінці рівня цінностей людини може концепція вертикального розвитку, котра була сформульована Ж. Гебстером, який висунув ідею, що в своєму розвитку як людство в цілому, так і окрема людина проходить через певні етапи, що характеризуються радикальними змінами структури свідомості [724]. Дослідник Ж. Гебстер передбачив бурхливе розповсюдження різноманітних вертикальних систем розвитку в другій половині XX століття - від моделі ієрархії потреб А. Маслоу до комплексної інтегральної карти AQAL (All Quadrant All Level) К. Уілбера [725].

Одним із учених, який здійснив найбільший внесок в остаточне оформлення концепції вертикального розвитку, $є$ видатний американський психолог К. Грейвз [726]. Він назвав свою концепцію «теорією емерджентних циклічних рівнів існування» (соціально-еволюційна теорія спіральної динаміки). В якості основної характеристики розвитку К. Грейвз обрав ціннісні орієнтири особистості. Дослідник не тільки описує поступальну зміну рівнів розвитку особистості, які характеризуються якісними змінами ціннісних орієнтирів людей у міру зростання складності їх мислення, а й формулює закономірності зміни етапів цього розвитку.

Спіральна динаміка інтегрується та трансформується до загальної моделі, не спростовуючи попередні теорії. Вона може включати й основні акценти піраміди А. Маслоу (задоволення базових потреб) та постулати, які засновані на моделі життєвого циклу І. Адізеса, що охоплює еволюцію потреб від інстинктів виживання, рівня «розвинутого егоїзму», індивідуалізму, раціоналізму й передбачає перехід до інтегрального рівня [727].

Сьогодні модель спіральної динаміки - це така модель, яка динамічно розвивається і привертає увагу вчених і громадськості як на Заході, так і в Україні, зокрема, у роботах В.О. Пекаря [728]. Він популярно виклав теорію спіральної динаміки у прикладному аспекті розуміння підприємництва, бізнесу, менеджменту, стилів лідерства та управлінських культур, інструменти їх зміни. К.О. Линьовим було використано пояснювальні можливості моделі спіральної динаміки щодо розумінні феномена лідерства в системі державного управління [729]. В.В. Ворожбит простежив зв'язок між стилем управління, ринковим 
середовищем, видами діяльності підприємств та рівнем корпоративної культури відповідно моделі спіральної динаміки [730]. Спираючись на методологію теорії спіральної динаміки, Є. Пулман визначив рівень розвитку людини стосовно до політики й соціальної сфери в українському суспільстві, використовуючи матеріали Європейського соціального дослідження, дослідження «Український характер» ЦСД «Софія» i результати опитування Українського Інституту Майбутнього (опитування проводилося серед людей виборчого віку) [731].

Інтегральна модель спіральної динаміки відображає виникнення й розвиток систем цінностей, які існують спільно, по черзі визначаючи стратегію розвитку та впливаючи на вибір системи управління. Концепція передбачає схему основних ціннісних мімів світу. Міми - інформаційні пакети, які, подібно до вірусів, переносяться від одного розуму до іншого, від громади до громади. Рухи й зупинки у процесі спіральної еволюції можуть відбуватися в будь-якому 3 напрямків - як вгору, так і вниз (еволюція чи інволюція). Спіраль моделі науковця К. Грейвза не має верхньої межі; до неї необхідно додавати нові літери, цифри й кольори як нові рівні психологічного існування, що проявляються в людській природі. Під цінностями розуміються традиційні і ключові цінності соціальних корпорацій, загальнолюдські й сімейні, тобто, не матеріальна сторона справи. Відповідно до теорії К. Грейвза, управління цінностями допомагає визначати причини виникнення конфліктів і розширює можливості мотивації, стимулювання персоналу [726].

Ось ще кілька постулатів, на яких базується модель вертикального розвитку К. Грейвза:

- людина - це відкрита система, що розвивається; можливості до розвитку та адаптації щодо різних обставин безмежні;

- у процесі розвитку людина (як і суспільство в цілому) послідовно проходить через рівні розвитку, кожен з яких якісно відрізняється від інших;

- стани на одному рівні розвитку стають навичками на наступному рівні. Те, що на більш низькому рівні $є$ разовим досягненням, вимагаючи від людини 
спеціальних зусиль, на наступному рівні розвитку стає звичним, легко відтвореним навиком;

- кожен наступний рівень не відкидає, а включає в себе попередній. Стереотипи поведінки на більш низькому рівні можуть вільно відтворюватися на наступному рівні. Тобто, у міру розвитку людина стає більш вільною у виборі найбільш доречних стратегій поведінки й застосування тих чи інших навичок відповідно до ситуації;

- людина (або суспільство в цілому) адекватно й позитивно сприймає тільки ті способи мотивації, методи управління, правила поведінки та етичні принципи, які відповідають їхньому рівню розвитку;

- на кожному рівні можна перебувати нескінченно довго. Якісний розвиток і перехід з одного рівня розвитку на інший не гарантований, він вимагає певних зусиль в освоєнні нових навичок, необхідних для переходу на наступний рівень [726, c. 148-150].

При цьому розвиток відбувається не поступово. Наприклад, за мірою свого розвитку людина долає послідовність криз. Криза розвитку - це стан, при якому подальший розвиток стає неможливим у межах сформованих стереотипів поведінки й набору існуючих навичок.

Рівні розвитку в теорії К. Грейвза описуються за допомогою парадигм свідомості (які для зручності кодуються різними кольорами: бежевий, фіолетовий, червоний, синій, помаранчевий, зелений, жовтий, бірюзовий). Це система координат у просторі картин світу. Ці парадигми свідомості, або ціннісні комплекси, що включають духовні вірування, культурні ідеї, моральні принципи, моделі навчання тощо, з’являються по мірі виникнення потреби в них у процесі соціокультурної еволюції.

Парадигми виникають спочатку в окремих найбільш «просунутих» людей, а в міру зміни умов життя поширюються подібно хвилям. Без внутрішнього спонукання людина легко застрягає в першому ж світі, що забезпечує їй мінімальний зовнішній комфорт, і може залишитися там назавжди. Так само одні 
й ті ж умови життя породжують різні картини світу, різні системи поведінкових стереотипів - залежно від особистого рівня розвитку людини.

На наш погляд, цікаво розглянути рівні спіральної динаміки з погляду того, як економічні механізми використовуються для побудови економічних систем на кожному рівні [732]. Перші шість рівнів розглядаються як «рівні існування», для яких характерне так зване мислення першого порядку (у т.ч. економічне). Потім відбувається «революційне зрушення» в індивідуальній і суспільній свідомості: з’являються рівні буття й мислення другого порядку з відповідною економічною еквівалентною.

Відштовхуючись від опису дев’яти хвиль буття К. Грейвза, можна простежити наступні соціально-економічні особливості кожного рівня в аспекті формування особистісної надійності суб’єктів підприємницької діяльності, що постає передумовою формування й функціонування соціального капіталу [733].

Бежевий колір - біовиживальний рівень. Для забезпечення й продовження життя формуються групи виживання. Основний і єдиний вид економічної ренти, що отримується на цьому рівні, - абсолютна рента від володіння природним ресурсом. Біовиживальний рівень буття і примітивне використання природних ресурсів (дешевих або відходів) спостерігається в основному на нижчих щаблях суспільної ієрархії в країнах, що розвиваються (пострадянські країни на початку 90-х років XX століття, балканські країни під час міжнаціональних конфліктів, Африка, Індія, окремі країни Близького Сходу, Азійсько-Тихоокеанського регіону тощо).

Фіолетовий колір - кровно-племінний рівень. Життя особистості в соціумі організується відповідно до принципів кровного й племінного споріднення. На цьому рівні з'являється й активно використовується механізм диференціальної ренти (в основному першого типу, пов'язаного 3 якістю ресурсу, що використовується) нарівні 3 абсолютною. Кланово-племінна боротьба відбувається за володіння більшою кількістю кращого ресурсу. Нарівні із природним ресурсом на перший план виходить людський (на рівні рабської або близької до рабської, кабальної, мало оплачуваної праці) і починає поступово 
проявлятися просторовий (регіональна рента). Спостерігається в багатьох країнах Азії, Африки, превалює в суспільних системах балканських держав, у багатьох пострадянських країнах на побутовому рівні.

Червоний колір - силовий рівень. Прояв окремої самості, відділеної від племені - могутньої, імпульсивної й героїчної - припускає силові методи захоплення ресурсу. Серед видів економічної ренти, як і раніше, превалює абсолютна рента, але різко зростає роль монопольної ренти на ресурс - через необмежені права феодала або іншого абсолютного господаря на розпорядження ресурсом - як природним, так і людським капіталом. Роль диференціальної ренти проявляється подвійно: 3 одного боку, йде боротьба за оволодіння кращим ресурсом (диференціальна рента першого типу), з іншого - власник поступово стає зацікавлений в охороні й поліпшенні ресурсу, що створює передумови для розвитку диференціальної ренти другого типу. Найбільш успішні володарі стають власниками казкових багатств за рахунок формування регіональної ренти (Іспанія часів конкістадорів, нацистська Німеччина), однак настільки ж швидко ці багатства втрачають через недосконалість механізмів конвертації ресурсів.

Синій колір - системно-ієрархічний рівень. У житті є зміст, напрям, мета і все це обумовлюється всемогутнім «Порядком», що визначає закони «правильного» i «неправильного» поводження, правила економічної гри. Найбільший інтерес цей рівень викликає з погляду використання всіх переваг економічної диференціальної ренти, що знаходить прояв у всіх видах ресурсів, які застосовуються для отримання доходу. На цьому рівні з'являються й розвиваються всі види ренти, що використовуються в сучасному світі: технологічна, інформаційна, фінансова, організаційно-управлінська, інноваційна, а також екологічна антирента. Особливу роль відіграє регіональна рента, що дає можливість окремим країнам і регіонам домінувати, ставати регіональними $\mathrm{i}$ світовими лідерами, уміло використовуючи територіальні переваги (Римська імперія, Британська імперія, США до Другої світової війни, Радянський Союз, пострадянська Росія, імператорська Японія, Бразилія, Індія, Китай кінця 90-х початку 2000-х років). 
Помаранчевий колір - рівень «вільного ринку». Цей рівень орієнтований на особистий успіх і кар'єру, що, в першу чергу, в США та розвинених країнах Заходу розуміється, насамперед, як отримання матеріальних благ. Рівень характеризується найширшим розвитком усіх видів ренти й рентних механізмів до ступеня високої досконалості. На перший план в умовах глобалізації виходять фінансова й інтелектуальна рента, регіональна рента стає одним із факторів геополітики, однак при цьому втрачається багато в чому іï первісний зміст як результат дії природно-ресурсних факторів. Роль регіонів, як акумуляторів ренти, визначається геоекономічними чинниками, належністю до певного макрорегіону, на які ділиться вся система світового економічного простору. Провідною стає роль екологічної антиренти, екстенсивна експлуатація природних ресурсів, заради досягнення стратегічної переваги, призводить до швидкої деградації природного середовища. Це соціально-економічні системи, що сформувалися після Другої світової війни у США, Західній Європі, після падіння СРСР - у Східній Європі й частково на пострадянському просторі (Україна, Прибалтика, Грузія) унаслідок застосування жорстких механізмів конкуренції i спроб повернення до використання переваг монопольної ренти, а також хижацької експлуатації природних ресурсів й забруднення навколишнього середовища, спричиняючи поляризацію суспільства й деградацію суспільних і державних інститутів при видимих економічних успіхах. Наслідком «помаранчевих» економічних процесів часто $є$ «перегрів» економіки. Результатом останнього багато в чому і стала перманентна іпотечна та банківська криза в США, яка переросла у 2008 році в глобальну рецесію світової економіки.

Зелений колір - екологічний рівень. Ідеали спільності, зв’язку між людьми, усвідомлення екологічних проблем, «мережеве» мислення створюють передумови для боротьби з монополізацією й абсолютизмом в економічних процесах. На перший план виступають нова екологічна й інтелектуальна рента, різко зростає роль диференціальної ренти другого типу. Власники унікальних ідей і технологій, які модернізують ідеї і поліпшують природні або інші ресурси, стають «новими володарями» світу (ідеї сталого розвитку, потужні мережеві 
компанії, корпорації, що діють у сфері інтернет-технологій, єдина Європа, розгалужені інфраструктурні центри на пострадянському просторі).

Роль регіональної ренти трансформується із природно-ресурсного й геоекономічного аспекту в новий - транзитний. Роль територій, як «воріт для пропуску ресурсів», стає важливішою, ніж роль «джерел ресурсів». Зростає значення технопарків і технополісів, вільних економічних зон. Суб'єктивне, нелінійне мислення висуває на перший план інтелектуальну ренту, роялті й людський капітал як джерело прибутку. Високоприбутковою індустрією стають спорт, відпочинок, навчання й медичне обслуговування. Однак обмеженість мислення першого порядку проявляється в явищі протистояння, витрачанні більших енергій на процес «боротьби з негативом», наприклад, із забруднювачами довкілля, з полюванням на диких тварин тощо. Сутність цього яскраво відображає фраза відомого суспільного діяча матері Терези про те, що на антивоєнних мітингах народжуються війни. Протиставити цьому можна інший, альтернативний підхід до цілісного використання всіх ресурсів розвитку індивіда й суспільства, заснований на інтеграції, - так зване «мислення другого порядку».

Буття і свідомість другого порядку, що мислить і намагається діяти в категоріях всієї спіралі буття, а не тільки категоріями будь-якого окремо взятого рівня, використовує всі відомі соціальні й економічні механізми. Це мислення поєднує в собі два рівні - жовтий колір (інтегративний) і бірюзовий колір холістичний (цілісний). На цих рівнях домінуючою є роль диференціальної ренти третього типу та інтелектуальної ренти. Окрім того, виникають, зароджуючись і розвиваючись, елементи нового економічного мислення, що орієнтується, перш за все, на духовне виробництво як основу для товарного виробництва. Можливою $є$ поява елементів духовно-економічної ренти i, так зване, духовне лідерство, духовне наставництво. Прикладом таких лідерів у політиці XX століття були М. Ганді, М.Л. Кінг та ін., які запропонували в системі певної духовної традиції (наприклад, гуманізму, рівноправ'я, національної чи расової свободи тощо) концепції соціально-економічного розвитку суспільства або країни в цілому. У XXI столітті лідерами в новому економічному мисленні стали всесвітньо відомі 
діячі Б. Гейтс, Б. Шеффер, Р. Гейдж, Р. Шарма, Б. Трейсі та ін. Їх ідеї об’єднують спрямованість на розвиток унікальних якостей фірми і працівника та максимальну віддачу в соціум від економічної діяльності, отримання прибутків за системою «зворотного зв’ язку» від власного внеску в економічну систему, в якій функціонує корпорація. Буття й парадигми свідомості другого порядку співвідносяться 3 подальшим удосконаленням ідей сталого розвитку та міждержавної співпраці в галузі охорони довкілля. Для таких економічних систем, поки сформованих на рівні окремих корпорацій (такою корпорацією вважається, зокрема, «Google»), деяких мережевих співтовариств характерне, з одного боку, сприйняття світу, природи та економіки як єдиного організму, а з іншого - орієнтація на цінність кожної людини - працівника і клієнта, клієнт-центрована робота. Компанії з таким мисленням широко використовують логістичний підхід, ведуть потужну добродійну діяльність, упроваджують технології особистісного зростання, коучингу в управлінні персоналом. Їм притаманна орієнтація на позитивний зворотний зв'язок і формування цілей з урахуванням інтересів індивідуума й системи в цілому. В оцінці персоналу таких компаній нарівні з поняттям IQ (інтелекту як міри інтелектуального капіталу) використовується поняття EQ (емоціонального інтелекту, запропонованого П. Саловеєм та Дж. Майером у 1990 році як міри соціального або духовного капіталу), за рахунок чого забезпечується реалізація інтелектуального потенціалу особистості в соціумі. Через наявність двох складових, що формують соціальний капітал - емоціональної та інтелектуальної, і відбувається формування та отримання інтелектуальної ренти.

Побудова економічної системи на парадигмі свідомості другого порядку в глобалізованому світі обумовлює виникнення нової духовності як альтернативи ортодоксальної духовної традиції. Така духовність містить у собі елементи всіх духовних традицій, трансперсональний рівень соціально-економічної взаємодії усередині глобальних систем уможливлює існування економічних систем поза народами, державами й расами, духовно-економічне лідерство в кризових ситуаціях стає важливішим за традиційне ресурсно-господарське лідерство. Мислення другого порядку досить вільно оперує традиційними поняттями 
«гарного» і «поганого», використовує системно-цілісні підходи до організації економічного процесу, інтегративне за своєю сутністю й активно використовує переваги всіх попередніх рівнів розвитку індивідуальної й суспільної свідомості та продуктивних сил у цілому [733, с. 98-101].

К. Грейвз виявив, що парадигми «рухаються зигзагом» між темами самовираження й самопожертви. Теплі кольори маркують парадигми самовираження (індивідуалістичні, матеріалістичні), а холодні - парадигми самопожертви (колективістські, ідеалістичні). Власне, саме тому він назвав свою теорію «спіральною», бо щоразу йде повернення до попереднього, але на більш високому рівні. Ще більш важливе в назві теорії слово «динаміка»- адже для людства воно означає характерний розвиток. Рух вгору завжди йде в бік ускладнення життя. Розширюється психологічний простір, широта погляду на світ, росте число «ступенів свободи» і граней особистості, різноманітність альтернативних способів зробити щось, ускладнюються потреби людини.

Особистісна надійність - це здатність людини контролювати, захищати й розбудовувати свій психологічний простір. Тому особистісна надійність базується на узагальненому досвіді успішної автономної поведінки. Вона являє собою форму суб'єктності людини й дає змогу в різних формах спонтанної активності реалізувати їі потреби. Надійність має прояв у переживанні власної самості й авторства власного буття (упевненості особистості в тому, що вона діє згідно 3 власними бажаннями й переконаннями), відчутті своєї доречності у просторовотимчасових і ціннісних обставинах свого життя, які вона створює або приймає. Особистісна надійність є цілісною функцією і як процес, і як стан збалансованості, гомеостатичності організуючих рівнів. Рівень психічного розвитку особистості, особливості онтогенезу, рівень розвитку соціальних навичок, культури й свідомості мають самостійне значення для ефективності процесів адаптації, становлення особистісної надійності. Ці рівні також значимі для здатності особистості до самоадаптації [734].

Ненадійність характеризується переживанням особистісної нестабільності й підпорядкованості, відчуженості, фрагментарності власного життя й 
характеризується труднощами в пошуку об’єктів середовища, з якими особа себе ідентифікує, відчуваючи себе «на чужій території» і не у своєму часі. Особистісна надійність являє собою еволюційно й соціально усталену системну якість особистості, що є необхідною умовою її нормального функціонування й розвитку. Виокремлено такі рівні досліджуваної якості, як наднадійність, нормальна (помірна) надійність, ненадійність і розбалансованість.

На відміну від традиційного уявлення про прояви самостійності й незалежності, які залишалися усередині інтрапсихічної парадигми, І.О. Котик розглядає особистісну надійність як стан меж психологічного простору [735]. Психологічний простір особистості - це суб’єктивно значущий фрагмент буття, що визначає актуальну діяльність і стиль життя особистості, включаючи комплекс фізичних, соціальних і психологічних явищ, з якими особистість себе ототожнює. Особистісна надійність викарбовується станом меж психологічних (ціннісносмислових, мотиваційних, когнітивних, емоційно-вольових і поведінкових) позначок, що відокремлюють сферу психологічного простору особистості. Межі зумовлюють ідентичність людини, презентують інструмент рівноправної взаємодії й вибору зовнішніх впливів, позначають границі особистої відповідальності, визначають специфіку особистісної надійності. Як порушення, так і підтримка меж закріплюються в «Я-концепції» і виражаються в об’єктивній поведінці людини [736].

Особистісна надійність людини - динамічне явище; одиницею виміру надійності є психологічна ситуація, яка вирішується за допомогою психологічних захистів і психологічного опанування. Активні способи опановуючої поведінки поєднуються з досягненням особистісної надійності, а пасивні - ненадійності. Фрустрація прагнення до надійності, певним чином, психологічного простору через символічний характер останнього, призводить або до заміщення цього виміру іншим, або до зниження рівня надійності (ненадійність), або його надмірного посилення (наднадійність). Такі порушення, як ненадійність i наднадійність, можуть компенсуватись у процесі життєдіяльності або цілеспрямованого розвивального впливу, що полягає, відповідно, в посиленні 
особистого контролю над різними сферами буття або у визнанні соціальних та особистісних меж іншої людини як цінності [737, с. 26-31].

Отже, особистісна надійність - це складне, динамічне явище; це здатність людини контролювати, захищати й розбудовувати свій психологічний простір; це те, що архіважливо у підприємницькій діяльності, яка вимагає високий гатунок відповідальності за все виробництво та його інфраструктуру.

Відомо, що джерелом усякого руху є єдність і боротьба протилежностей. Породжуючи протиріччя як у самому предметі, речі, так і в їх взаєминах із зовнішнім середовищем, вони розв’язують їх і спонукають предмет чи річ до руху. Проте не кожен рух слід уважати розвитком і не кожне розв’язання протиріч може стати джерелом цього розвитку. Наукова практика свідчить, що рушійною силою розвитку, його джерелом стають лише ті протиріччя, які об'єктивно й безпосередньо пов'язані із сутністю самого предмета, речі чи процесу. Протиріччя, що є первісними моментами в бутті цих речей, такий розвиток не зумовлюють. Тільки протиріччя сутності породжують розвиток якості.

В контексті особистої надійності суб'єкта підприємницької діяльності означене положення дозволяє припустити, що джерелом розвитку цих властивостей вважається заперечення між можливостями, уподобаннями, цінностями особистості, які вона втілює в життя в обраній діяльності, й зовнішніми, соціальними життєвими обставинами, які визначають вимоги до даної діяльності та місце їі втілення. Це логічно, тому що кожна сутність виявляє себе лише крізь своє існування або ж спосіб буття. Особистісна надійність підприємця оцінюється тільки в тій мірі, в якій враховуються умови, при яких здійснюється підприємницька діяльність.

На відміну від сутності, що породжена протиріччями всередині самої речі, ii iснування обумовлене протиріччями серед різноманітних речей. Існування особистісної надійності суб’єкта підприємницької діяльності як буття речі, іiі якісне визначення, яке було взяте з боку власного зовнішнього опосередкування або детермінації, котра передбачає, що вона обгрунтована суспільною значущістю, потребує затребуваність у суспільстві. Без даної затребуваності 
якість надійності особистості втрачає значення власного існування, що призводить до іï руйнування. Пояснюється це тим, що будь-яка конфігурація переміщення матерії вважається одночасно сутністю й існуванням. Внаслідок цього вона підпорядкована двом типам протиріч - внутрішнім і зовнішнім. Якшо у разі річ співвіднесена не лише сама з собою, але і з усілякими іншими речами, то вона неминуче потрапляє під їх вплив, опосередковується між ними, що власне і призводить до протиріччя самого прецеденту та до їх існування.

Сутність особистісної надійності суб’єкта підприємницької діяльності не виявляється без потреби свого існування, одного не може бути без іншого. При цьому вони органічно пов’язані 3 якостями особистості, їх визначеністю й цілісністю. Вони представляють різні аспекти механізму породження надійності як якості особистості, що ідеально представлені в плані внутрішньої й зовнішньої взаємодії.

Повнота науково-теоретичного осмислення феномена особистісної надійності не може бути обмежена означеними категоріями. Вони утворюють початкові орієнтири, що задають онтологічну картину досліджуваного об'єкта й загальні гносеологічні принципи його вивчення. Означені категорії, з одного боку, дозволяють з’ясувати ті прогалини у змісті науково-педагогічного знання, наповнення яких сприятиме розробці загальної теорії надійності та концепцій іiі становлення. 3 іншого боку, вони створюють необхідне підгрунтя для аналізу особистісної надійності суб'єкта підприємницької діяльності на рівні його безпосереднього буття.

Сутність особистісної надійності суб’єкта підприємницької діяльності, як системного явища, може бути розкрита під час полісистемного аналізу, який передбачає розгляд явища з різних боків, у рамках різних систем, на різних рівнях. Можна виділити кілька рівнів аналізу особистісної надійності суб’єкта підприємницької діяльності.

Перший, провідний, рівень - теоретико-методологічний аналіз особистісної надійності суб’єкта підприємницької діяльності як психологічної категорії: вивчення історії розвитку ідей надійності; характеристика підприємницької праці 
3 позиції надійності; визначення галузі наукового знання про особистісну надійність суб’єкта підприємницької діяльності; розробка структури й понятійного апарату концепції особистісної надійності суб'єкта підприємницької діяльності. Встановлено, що особистісна надійність виступає динамічною системою, яка розвивається у процесі діяльності підприємців. Складність і різноманіття зв’язків особистості у фаховій діяльності робить систему особистісно-діяльнісних взаємин підприємців досить динамічною, що проявляється у розвитку компонентів психологічної структури особистісної надійності. Теоретичний аналіз концепції та наукових підходів до розвитку особистісної надійності підприємців і підвищення їх професіоналізму дозволило обгрунтувати психологічну структуру особистісної надійності фахівців підприємницької діяльності і визначити основні теоретико-методологічні підходи (системності, гуманістичності, діяльності, інтегральної суб’єктності, детермінізму, компетентності) та принципи (індивідуальності, спільності, співдружності, організації, вибору, балансу цінностей, професійного розвитку), що зумовили добір методів та заходів вивчення компонентів і змісту цієї структури (рис. 1).

Домінуючою ідеєю усього навчального процесу проходить ідея, що змістовна модель особистісної надійності суб’єктів підприємницької діяльності інтегрує в собі концепти професіоналізму (підприємливість як наскрізна компетентність, професійна роль та функції, загальні здібності до підприємницької діяльності), суб’єктності (рівні світогляду, соціальноекономічна активність), особистісної культури (психологічна, комунікативна, інноваційна, правова, організаційна та корпоративна), психофізіологічні, професійні та особистісні якості.

Другий рівень - феноменологічний аналіз особистісної надійності суб’єкта підприємницької діяльності як психологічного явища, яке пізнається шляхом опису підприємницької діяльності: нормування особистісної надійності підприємця; диференціація перешкод у професійній праці підприємця; класифікація порушень особистісної надійності суб’єкта підприємницької 
діяльності; типологія детермінант особистісної надійності суб’єкта підприємницької діяльності; типологія особистісної надійності суб’єкта підприємницької діяльності.

Результатом вивчення особистісної надійності суб’єкта підприємницької діяльності на перших двох рівнях $є$ iï функціональний аналіз 3 точки зору внутрішньої організації й механізмів функціонування (визначення критеріїв і показників оцінки особистісної надійності суб’єктів підприємницької діяльності).

Третій рівень передбачає генетичний аналіз особистісної надійності суб’єкта підприємницької діяльності з позиції категорії розвитку: опис змісту, етапів, закономірностей системогенезу особистісної надійності підприємця; розроблення моделі та програми розвитку особистісної надійності суб'єктів підприємницької діяльності.

Результатом вивчення особистісної надійності суб’єкта підприємницької діяльності на третьому рівні виступила розробка моделі розвитку мотиваційного, когнітивного, поведінкового, ціннісно-смислового, емоційно-вольового компонентів, які впливають на розвиток особистісної надійності суб'єктів підприємницької діяльності, що відображає: принципи розвитку особистісної надійності фахівця; змістові компоненти особистісної надійності; професійні функції (ролі); програму розвитку особистісної надійності; форми, методи та засоби розвитку особистісної надійності; моніторинг психологічної ефективності програми з розвитку особистісної надійності; рівні та критерії сформованості особистісної надійності суб'єктів підприємницької діяльності (показники змістовних компонентів особистісної надійності: ціннісно-смисловий; мотиваційний; поведінковий; емоційно-вольовий; когнітивний). Кожен 3 перерахованих рівнів аналізу особистісної надійності суб'єктів підприємницької діяльності має свою специфіку, в той же час вони в тій чи іншій мірі перетинаються між собою, не вичерпуючи один одного. Це дозволяє виявити всю багатоплановість і багатовимірність особистісної надійності суб'єктів підприємницької діяльності як реального психологічного явища [738]. 


\section{ПРОФЕСІОНАЛІЗМ:}

- підприємливість як наскрізна компетентність (узяття на себе ініціативи, планування та управління, робота 3 неоднозначністю, невизначеністю та ризиками, співпраця 3 іншими особами, навчання через досвід у процесі діяльності; самосвідомість і самоефективність, фінансова та економічна грамотність, виявлення можливостей, прогнозування);

- професійна роль (функції): «новатор-підприємець» (інноваційна); «господарник-виробник результатів» (економічна, ризикова); «керівник-адміністратор» (управлінська); «лідерінтегратор» (соціальна, ресурсна);

- загальні здібності до підприємницької діяльності (потреба в досягненнях, потреба в незалежності/автономії, схильність до творчості, уміння йти на розумний (зважений) ризик, цілеспрямдваність та рішучість

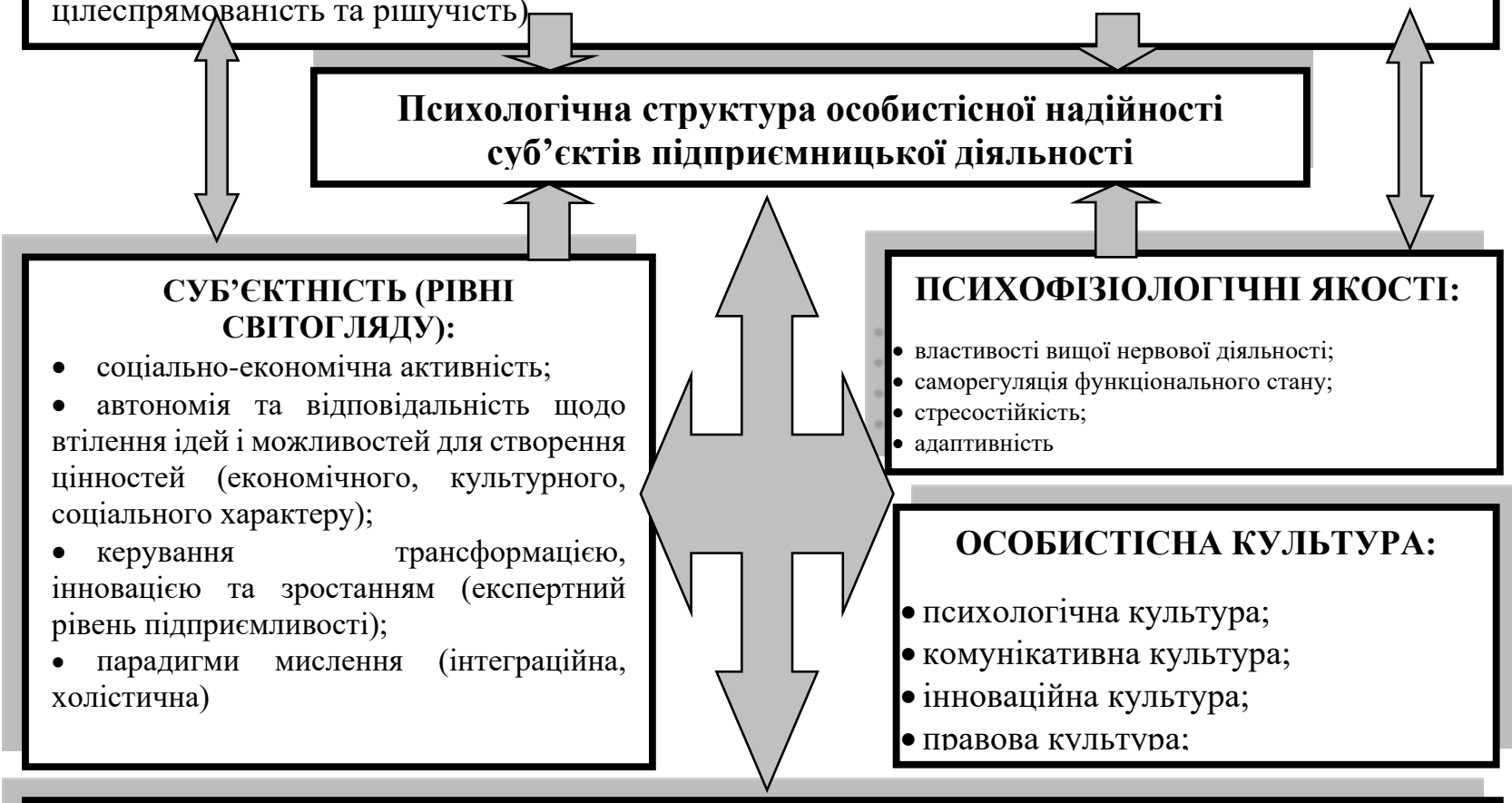

\section{ПРОФЕСІЙНІ ТА ОСОБИСТІСНІ ЯКОСТІ:}

морально-правові цінності, сенсожиттєві орієнтації, показники самоактуалізації (ціннісно-смисловий компонент);

- мотиваційні тенденції, тип спрямованості, потреба в: досягненнях, подальшому розвитку, автономії (мотиваційний компонент);

- особливості пізнавальних процесів та інтелектуальних якостей, рівень професійних знань та компетентностей, соціальний інтелект (когнітивний компонент);

- емоційна зрілість, стійкість до емоційного вигорання, емоційний інтелект (емоційно-вольовий компонент);

модель подолання стресових ситуацій, тип реакцій на дію стресорів (поведінковий компонент).

\section{Рис. 1. Змістовна модель особистісної надійності суб'єктів підприємницької} діяльності

Таким чином, концепція особистісної надійності суб’єктів підприємницької діяльності - це напрям наукового психологічного знання, що дає цілісне уявлення про структуру, функції, детермінанти, закономірності та суттєві зв’язки особистісної надійності підприємця. 
Сучасний стан України потребує професіоналів, які активно здійснюють свій внесок у розвиток економіки суспільства. Провідну роль у цьому аспекті відіграють фахівці підприємницької діяльності, які можуть упроваджувати в практику сучасної економіки нові наукові дослідження через свій професіоналізм та особистісну надійність. У значних наукових напрацюваннях учених звернуто увагу на те, що аспектом пильного розгляду сьогодні $\epsilon$ психологічні особливості структури особистісної надійності та професіоналізму підприємців і їхня роль у продуктивній професійній діяльності на благо України.

Надійність підприємців розглядається як інтегральна якість особистості, яка може впливати на професійну активність фахівця незалежно від складних умов праці. Надійність підприємця проявляється у професійній діяльності й формує стійкий стан об'єктивної та суб'єктивної здатності до співпраці та підвищення іiі ефективності. Дослідник В.А. Криволапчук [739] у структурі психологічної надійності виділяє наступні компоненти: мотиваційні, когнітивні, емоційно-вольові, поведінкові, які впливають на розвиток та реалізацію професійної надійності підприємців. Автор звертає увагу на те, що особистісна надійність лежить в основі формування здібностей ефективно виконувати професійну діяльність у складних умовах трудового процесу. Це підтверджує у своїх дослідженнях В.А. Крутецький [740].

На думку 3.Р. Кісіль [741], накопичені сучасною теорією і практикою психологічної науки теоретичні й емпіричні дослідження можуть слугувати відправним пунктом для використання інтегрального підходу до розробки професіоналізму фахівців підприємницької діяльності. Важливе значення автор надає проблемі самоконтролю, самореалізації й надійності підприємців у професійній діяльності.

У системі особливостей професійної діяльності фахівців С.О. Климов [742] висвітлює проблеми самовизначення, самовідношення та їх адаптаційних можливостей. Дослідник В.О. Толочек [743] вивчає проблеми ризику і стилю професійної діяльності фахівців та їх професійне довголіття. 
Успішне виконання професійної діяльності підприємцями пов'язане 3 внутрішнім і зовнішнім професійним потенціалом особистості, який допомагає суб'єктам підприємницької діяльності реалізувати себе в складних, нестандартних умовах та екстремальних ситуаціях. Накопичений внутрішній потенціал підприємець використовує для отримання успішного результату в професійній діяльності. Сучасні теоретичні розробки дають можливість виявити головні напрями дослідження проблеми надійності суб’єктів підприємницької діяльності.

Значним внеском $є$ роботи науковців, які зосереджують увагу на розробці концептуальних підходів до вивчення психології надійності та професіоналізму суб’єктів підприємницької діяльності. Як зазначає 3.Р. Кісіль [741], теоретичну основу психологічних концепцій дослідження фахівців у професійній діяльності складають наступні підходи: - концепџія діяльності, як цілеспрямованої відкритої системи і людини як суб’єкта діяльності, що реалізує й розвиває свій професійний потенціал; - концепиія інформащійних і конщептуальних підходів; трансформаційна теорія навчання та концепція впливу екстремальних умов; кониепиія забезпечення професійної надійності людини; - концепції вимог до властивостей людини-професіонала, професійного відбору, тренажерної підготовки і спеціальної реабілітації людей після напруженої й небезпечної професійної діяльності; - конщепція збереження здоров'я $i$ професійного довголіття; - концепиія проектування діяльності. На думку автора, ці виділені теоретичні підходи вивчення психології надійності підприємців у професійній діяльності дозволяють через арсенал концепцій, категорій, методик та методів отримати широкий спектр результатів досліджень. Він висловлює положення, що провідними методологічними принципами дослідження надійності можуть бути: техніко-економічна, природничо-наукова, культурно-історична парадигми, що дозволяють поєднувати гуманістичні цінності 3 якіснопрофесійними моделями фахової діяльності особистості. У цих дослідженнях системно-утворюючим принципом є професійна спрямованість і особистісна 
надійність, які є основою формування професійної успішності та розвивають особистий потенціал підприємців.

Цілісне розкриття феномена психологічної надійності суб’єктів підприємницької діяльності науковці здійснюють з урахуванням як позитивних, так і негативних якостей, що впливають на особистість професіонала. Важливе значення в підвищенні працездатності підприємців має мотивація на успіх у виконанні професійної діяльності. На розвиток надійності підприємця активно впливає його «Я-концепція», яка розглядається як система уявлень фахівця про себе, своє ставлення до успіху та невдач у професійній діяльності. Розвиток «Яконцепції» професіонала пов’язаний з формуванням соціально-психологічного самопочуття підприємця, як емоційно-ціннісного ставлення до себе, до діяльності, і це $\epsilon$ інтегральною характеристикою збалансованості й гармонійності внутрішнього світу суб’ єктів підприємницької діяльності [735].

Науковець М.А. Ажажа [744] описує основні положення вивчення шляхів корекції особистісних якостей менеджера-професіонала i презентує їх наступних теоріях: 1) теорія рис - обгрунтовує особистісні якості, які необхідні фахівцю для успішної професійної діяльності; 2) факторний підхід - передбачає аналіз окремих чинників, які впливають на розвиток професійної надійності різних досліджуваних груп; 3) ситуащійна теорія - стверджує, що лідерство є продуктом ситуації групового життя, в яких виокремлюють осіб, що мають перевагу над іншими і керують ними у професійній діяльності. Це формує у лідера стійкий стан, котрий забезпечує об’єктивну і суб’єктивну здатність до співпраці й ефективної діяльності; 4) париุіальна концุепцุiя - передбачає дослідження й корекцію особистісних способів та методів орієнтації підприємців у соціальному середовищі, спрямовану на зміну поведінки та самооцінки; 5) системний підхід - полягає у вивченні досліджуваного феномена як цілісної системи, в якій сукупність окремих компонентів у взаємодії дає змогу виявити нові якості особистості, що забезпечують ефективне функціонування всієї системи; 6) поведінковий niдxid - означає, що підприємець володіє формами поведінки, необхідними в соціумі та для групи, якою він керує. 
Таким чином, сучасні дослідження особистісної надійності підприємців 3 позиції різних теорій, концепцій та підходів доповнюють систему знань про іiі психологічні особливості, що дозволяє впливати на їі розвиток у підприємця 3 метою його ефективної професійної діяльності. Наукові пошуки молодої незалежної України, в умовах демократизації суспільства, потребують ураховувати зміни в особистості щодо нових умовах буття та професійної діяльності. Сучасний підприємець повинен не тільки адаптуватися до нової суспільної реальності в Україні, але й бути, зокрема, активним, ініціативним та ефективним у своїй професійній діяльності. Теоретичний та практичний досвід науки служить основою для розробки інтегрального підходу до вивчення особистісної надійності суб'єктів підприємницької діяльності.

О.В. Кобець [745], вивчаючи професійну діяльність фахівців, зосередив увагу на принципові професіоналізму, який, на його думку, передбачає комплексне вивчення професіонала, його властивостей, професійного стану у фаховій діяльності. Розглядаючи проблему професіоналізму фахівця, він стверджує, що його стан, як професіонала, характеризується внутрішньо й зовнішньо. Характеристика професіоналізму, як системи, описується автором на основі функціонального, морфологічного та емоційного підходів. Професіоналізм, як об'єкт вивчення, викликає інтерес до того, яке місце він посідає серед інших психологічних явищ суб'єкта фахової діяльності. Враховуючи ці підходи, професіоналізм фахівця треба вивчати, починаючи 3 опису його функцій і критеріїв. Розглядаючи професійні функції фахівців, варто звернути увагу на те, що ці функції вивчаються з урахуванням обов'язків, які виконує фахівець у професійній діяльності, а також кола тих завдань, які необхідно йому вирішувати. Розроблені автором критерії професіоналізму дозволяють мати уявлення про сутність виконання узагальнених і конкретних функцій об’єкта, що вивчається 3 процесуального напряму. Функції професіоналізму спрямовані на якісне перетворення суб'єкта діяльності й орієнтовані на ефективне виконання професійних завдань: - створення таких професійних умов, за яких продуктивність і якість праці будуть знаходитись не 
нижче нормативного рівня; - збереження нормативно схваленого способу конкретного професійного напряму на основі індивідуальних якостей; - розвиток надійності професіоналів та спільноти, що $є$ частиною професійного співтовариства, учасником якого є фахівець.

У загальному випадку виконання професійних функцій підприємцем супроводжується отриманням не тільки нормативних результатів підприємницької діяльності, але й певних витрат, які можуть бути як матеріально-економічними, так і соціально-психологічними. Такі підходи потребують вивчення умов розвитку психологічної надійності суб’єктів підприємницької діяльності для підвищення їхнього професіоналізму та ефективності праці [739].

Інтенсивність психологічного аналізу феномена «надійність» у конкретній галузі соціального буття надає можливості внести своєчасні корективи та покращити етико-емоційний стан у суспільстві. Такі дослідження дають поглиблений аналіз суті та значущості надійності як феномена взаємодії та довіри в суспільстві [746]. Дослідження надійності сприяє систематизації знання про розуміння надійності та іiі значущості в національному й культурному просторі України. На основі огляду різних теоретичних досліджень та методологічних практик утвердилась думка про те, що надійність є ключовою категорією для конструювання моделей суспільного життя, що потребує іiі присутності в людських взаєминах як на благо особистості, так і на благо розвитку українського суспільства [747].

Соціально-особистісна надійність $є$ провідним, системотворчим чинником, що окреслює цілі, характер, емоційно-психологічну спрямованість майбутнього фахівця на процес і результати навчально-професійної діяльності, зумовлює рівень функціонування всієї системи професійної надійності загалом. У соціально-особистісній надійності унаочнено провідні потреби, мотиви, ціннісні установки та спрямованість майбутніх фахівців на професійну діяльність. 
У структурі соціально-особистісної надійності відображено такі загальнолюдські якості, як гуманізм, відповідальність, емпатія, почуття обов'язку, прагнення прийти на допомогу, колективізм, товариськість тощо [748].

Аналіз рефлексії надійності суб’єктів підприємницької діяльності у соціокультурному дискурсі України показав інтерес науковців до цієї проблеми і спробу ввести її в національний науковий дискурс. Науковий аналіз надійності дає змогу залучати цей феномен до раціонального дискурсу ціннісних трансформацій українського суспільства. Особистісна надійність стала предметом наукової дискусії, що дозволило корелювати ії з такими практиками як економіка, соціологія, державне управління, психологія у наступному сенсі: причини ï кризи; - потреби iï обгрунтування у відповідному українському соціумі; - прогнозування механізмів підвищення рівня надійності суб'єктів економічної діяльності в суспільстві [749].

До переліку найбільш значущих проблем підприємців потрапили такі, як: - неефективність психолого-економічної взаємодї; - неефективність організащійно-управлінських засобів; - ціннісно-інституційна деградація важливих сегментів фінансового ринку; - причини глобальної економічної кризи; - зміна логіки функиіонування взаємин у боротьбі з корупиією [750].

Потреба у вирішенні актуальних питань надійності суб'єктів підприємницької діяльності стає умовою оздоровлення економіки і іiі здатності консолідувати суспільство у розв'язанні проблем його розвитку. В економічній підприємницькій діяльності надійність розглядається як компонент ціннісної основи раціонального вибору діяльності, прийняття рішень в умовах суперечливої інформації, оптимізації результатів господарювання. Надійність у підприємницькій діяльності зменшує трансактивні витрати за умов налагодження взаємин контрольно-перевірочної діяльності партнерів і самоконтролю.

Таким чином, особистісна надійність формує відчуття взаємної довіри, що створює ситуацію ефективних взаємин у підприємницькій діяльності. Подолання 
соціально-економічних негараздів в українському суспільстві не може відбутися без високорозвиненої надійності фахівців господарської діяльності. Відродження надійності в підприємців та у суспільстві взагалі є запорукою поглиблення демократизації співпраці як норми буття, що позитивно впливає на рівень ділової активності, успішної професійної діяльності, підвищення емоційного самопочуття, покращуючи виробництво і його обсяг. Особливий акцент у сучасних дослідженнях надійності робиться на тому, що вона сприяє соціальній інтеграції та підтримує інновації в економічному розвиткові країни. У той же час механізмом збереження надійності вважається відкритий, толерантний, чесний діалог у комунікативній системі суб’єктів підприємницької діяльності. На думку дослідників, надійність фахівців відіграє провідну роль у мінімізації рівня корупції в суспільстві і створює умови для прозорості, відкритості, чесної конкурентоспроможності в розбудові економіки.

Із вищевикладеного для нашого дослідження ми виділяємо наступні теоретико-методологічні принципи та концепції:

1. Принциип професійного розвитку особистості. Він потребує вирішення зовнішніх і внутрішніх протиріч суб'єктів підприємницької діяльності. Ці протиріччя можуть виникати між інтересами і спрямованістю фахівців та їх професійними можливостями. Професійне становлення фахівця потребує збагачення його внутрішніх ресурсів, що пов’язано з перетворенням особистісних якостей, його індивідуального потенціалу [751]. У фаховій діяльності підприємців відбуваються різні моделі професійної свідомості, що допомагає вирішувати складні професійні завдання. На цій підставі розвиток професійної надійності спонукає до підвищення ефективності праці.

2. Принu̧ип організаціï. Показує, що особистість організує свій досвід i свої якості, які мають індивідуальні відмінності та утворюють систему, відмінну від інших суб'єктів діяльності, а також функціонують у цій системі, долаючи життєві труднощі. Особистісна надійність розширює індивідуальні можливості підприємців в організації професійної діяльності. 
3. Принцип вибору. Свідчить, що особистість розвивається в напрямі корисному для себе або для соціуму. Для особистості використання одних якостей може бути пріоритетними над іншими, що дає змогу ефективно розвивати свій бізнес. Оскільки професійні стосунки в підприємницькій діяльності не є постійними, то це обумовлює організаційні зміни з формуванням нової системи взаємодії.

4. Принциип індивідуальності. Вказує, що кожна людина створює коло своєї професійної діяльності на основі унікальної системи особистісних якостей, що відкриває можливості для активної діяльності в підприємницькій сфері. Проявляючи надійність, кожний підприємець підвищує індивідуальний авторитет серед своїх колег-фахівців.

5. Принции спільності. Підкреслює, що підприємці мають широке коло взаємодії, але спілкуються більше 3 тими, до яких $є$ професійний або особистісний інтерес та які мають надійний досвід або одну культуру взаємодії.

6. Принции співдружності. Наголошує, що для продуктивної взаємодії в підприємницькій діяльності необхідно, щоб партнери правильно інтерпретували взаємні дії, забезпечуючи позитивний результат. Успішна соціальна взаємодія дає бажаний ефект, коли партнери мають взаємне розуміння та погляди на життя, соціальні прогнози й підтримуються іншими.

7. Принции конкуренції. Презентує те, що в професійній діяльності у підприємців є бажання знайти краще соціальне середовище для збільшення прибутку або кращого вирішення фахових питань. Зіткнення різних поглядів суб'єктів і груп у мікро- і макросередовищі посилює конкуренцію й потребує від підприємців уміння не тільки вистояти, а й підвищити свою конкурентоздатність. На міжособистісному, міжгруповому й мікросоціальному рівнях можуть відбуватися як негативні, так і позитивні наслідки конкуренції. Найбільш успішні й конкурентностійкі ті фахівці, які мають високорозвинену професійну надійність.

8. Принциип балансу изінностей. Означає визнання в суб'єктів різних підходів, гіпотез, протилежних стратегій, особистісних та суспільних цінностей, 
які пропонуються партнерами або різними групами взаємодії. Такий стан може як розвивати, так і негативно впливати на розвиток підприємницької діяльності, знижувати успіхи та змінювати цінності міжособистісної та соціальної взаємодії. Високорозвинена професійна надійність допомагає підприємцям збалансовувати цінності взаємодії у професійній діяльності.

9. Принц̧ип пульсаціiі. Показує, що особистісна система суб’єктів підприємницької діяльності має не тільки постійний розвиток цієї системи, але й періодичних ціннісних їі змін. Це обумовлює проявлення особистістю різних своїх станів як глибинних, так і поверхневих, і створює умови приписування певних рис партнерам по взаємодії, підтримку звичних смислових стратегій, зняття суперечностей. Усе це вимагає активно розвивати особистість підприємця й підвищувати його надійність.

10. Принu̧ип dianaзону. Звертає увагу на те, що підприємці, які мають набір об’єктивних та суб'єктивних якостей, плідно працюють і взаємодіють 3 такими партнерами, які найбільш надійні. Це дозволяє суб’єкту підприємницької діяльності успішно працювати, розширювати діапазон взаємодії й мати підтримку партнерів.

11. Інформаційний принщ̧ип. Дозволяє виявити динаміку розвитку підприємства, вибрати найбільш надійних та успішних підприємців, як партнерів, і мати інформацію про загальний стан розвитку підприємницької діяльності в регіоні та суспільстві. Прогнозування надійності, виконання професійних завдань вимагає виділяти основні принципи іiі побудови. Такий підхід прогнозування надійності для успішної діяльності фахівців дозволяє передбачити тенденції їі розвитку й хід процесів у професійній діяльності.

Слід звернути особливу увагу у навчальному процесі на аналіз існуючих підходів, щодо складання прогнозів, який дозволив виділити наступні їхні види: 1) основні типи: - нормативні (визначення напрямів і термінів досягнення); пошукові (можливих станів, явищ у майбутньому); 2) періоди попередження: оперативні; - короткострокові; - середньострокові; - довгострокові; - не довгострокові. Прогнозування успішної професійної діяльності підприємців є 
найбільш актуальними за довгостроковими прогнозами. Дослідники виділяють наступні параметри прогнозу: - термін попередження або глибина прогнозу; період прогнозу, що будує ретроспекцію; - прогнозний горизонт - це період встановлення точності прогнозу; - точність прогнозу - визначається оцінкою довільного інтервалу прогнозу; - вірогідність прогнозу - це прогноз у заданому інтервалі; - надійність прогнозу - стійкість, статичність прогнозованого явища [752].

При розробці прогнозу надійності професійної діяльності підприємців необхідно отримати інформацію про особливості психологічного складу фахівців через бесіди, спостереження, експертні оцінки. Отримана оцінка часто має описовий характер про особистість, її кваліфікацію, їі поведінку. На практиці використання психологічних методик дозволило активно досліджувати надійність фахівців. Високий рівень сформованості інтелектуальної діяльності фахівця складається із стійкості таких психологічних характеристик, як повнота та точність інформації, готовність до її оперативного використання. Незважаючи на значну кількість спеціальної інформації, відмічається ускладнення процедури прогнозування професійної надійності особистості, що вимагає всебічного об’єктивного вивчення професійно важливих якостей підприємців [750].

У ролі важливого компонента професійної надійності виступає емоційновольова стійкість, як здатність виконувати професійні завдання в умовах емоційного впливу, шляхом співставлення результатів діяльності. Принципово важливим є положення використання психічних моделей емоційних ситуацій, в основі яких покладені специфічні емоційні чинники, характерні для діяльності підприємців. Важливість прогностики в діяльності підприємців є очевидною, бо складання прогнозів надійності допомагає покращити професійну діяльність фахівців [749].

Теоретико-методологічну основу дослідження феномена особистісної надійності суб’єктів підприємницької діяльності склали системний підхід у психології. Це означає, що особистісна надійність підприємця може бути відображена як складна багаторівнева система, набір компонентів якої 
визначається їхніми регуляторними функціями у вигляді структурнофункціональної моделі.

Ряд дослідників вивчають механізми регуляції надійності діяльності особистості на різних рівнях іï буття: біологічного, психологічного та соціального. Так, до біологічного рівня зараховують як генетичні, так i фізіологічні регуляторні механізми забезпечення надійності людини, іiї стійкого і стабільного пристосування до довкілля, гомеостатичної й адаптивної регуляції процесів забезпечення ii життя й діяльності в нормальних і екстремальних умовах.

Психологічний рівень забезпечення надійності підприємців полягає у визначені ролі деяких психологічних феноменів у формуванні й прояві надійності - індивідуальні, що стосуються конкретного суб'єкта та їх проявів у забезпеченні активації результативних процесів роботи, покриття недостатнього розвитку деяких процесів, мобілізації операціональних функцій, реалізації планів і стратегій поведінки [753, с. 80].

Соціальний рівень регуляції надійності підприємців відображає особливості спільної діяльності, міжособистісних стосунків і групових процесів у трудовому колективі [738]. Психологічний клімат, сумісність і згуртованість членів групи, стиль керівництва, конфлікти, лідерство та інші соціальнопсихологічні феномени визначають рівень професійної придатності колективного суб'єкта діяльності й залежать від ряду індивідуальнопсихологічних особливостей членів групи та відбиваються на рівні особистої і групової надійності [754, с. 253-254].

Вищою формою регуляції діяльності суб'єкта виступають смисли та ідеали. Тим самим феномен готовності може бути результатом взаємодії смислообразів, суб’єктно-орієнтованих мислення образів та емоційно-вольової цілеспрямованості особистості. У цьому контексті виконують функції спонукання й підтримки в необхідному для вирішення завдань діяльності стану психіки людини, але при цьому не можуть повністю визначати ідейно-смислове завантаження активності суб’єкта [755, с. 19-20]. 
Виокремлення рівнів вивчення особистісної надійності грунтується на ідеї багаторівневої психологічної організації особистості й отримало осмислення в роботах дослідників Б.Г. Ананьєва [756], Б.Ф. Ломова [757], Н.Ф. Шевченко [758], згідно яких людина - це біосоціальна істота, наділена свідомістю і здатністю до діяльності. Відповідно до неї надійність можна розглядати на індивідному, суб'єктному та соціальному рівнях. Індивідний рівень передбачає врахування вікових, статевих, конституціональних особливостей, нейродинамічних властивостей, динаміки психофізіологічних функцій, особливостей темпераменту фахівця.

Розгляд надійності на суб'єктному рівні стає можливим за допомогою використання уявлень про суб'єктність людини як складної психічної якості, що об’єднує різні рівні прояву активного, ініціативного, інтеграційного, системного початків. Розуміння суб'єктності у психології пов'язане з тлумаченням суті даного поняття як перетворення людини на суб'єкт власної життєдіяльності і як особливий рівень розвитку її самосвідомості.

На соціальному рівні об’єктом дослідження є стійка система соціально значущих рис, які особа виробляє у процесі соціалізації й засвоєння соціокультурного досвіду та реалізує у процесі соціальних зв'язків через активну предметну діяльність та спілкування.

Кожний рівень надійності пов'язаний зі всіма іншими, залежить від них і системи в цілому. Системний підхід дозволяє розглядати особистісну надійність підприємців як складне утворення, що має ієрархічну будову, в якій виділяються компоненти (структурні та змістові), функції та критерії оцінювання (рис. 2).

Системність надійності суб'єктів підприємницької діяльності визначає можливість відображення іiї як багаторівневої системи, що складається з трьох структурних компонентів, виділених відповідно до трьох рівнів ії вивчення суб'єктна, діяльнісна та функціональна надійність. 


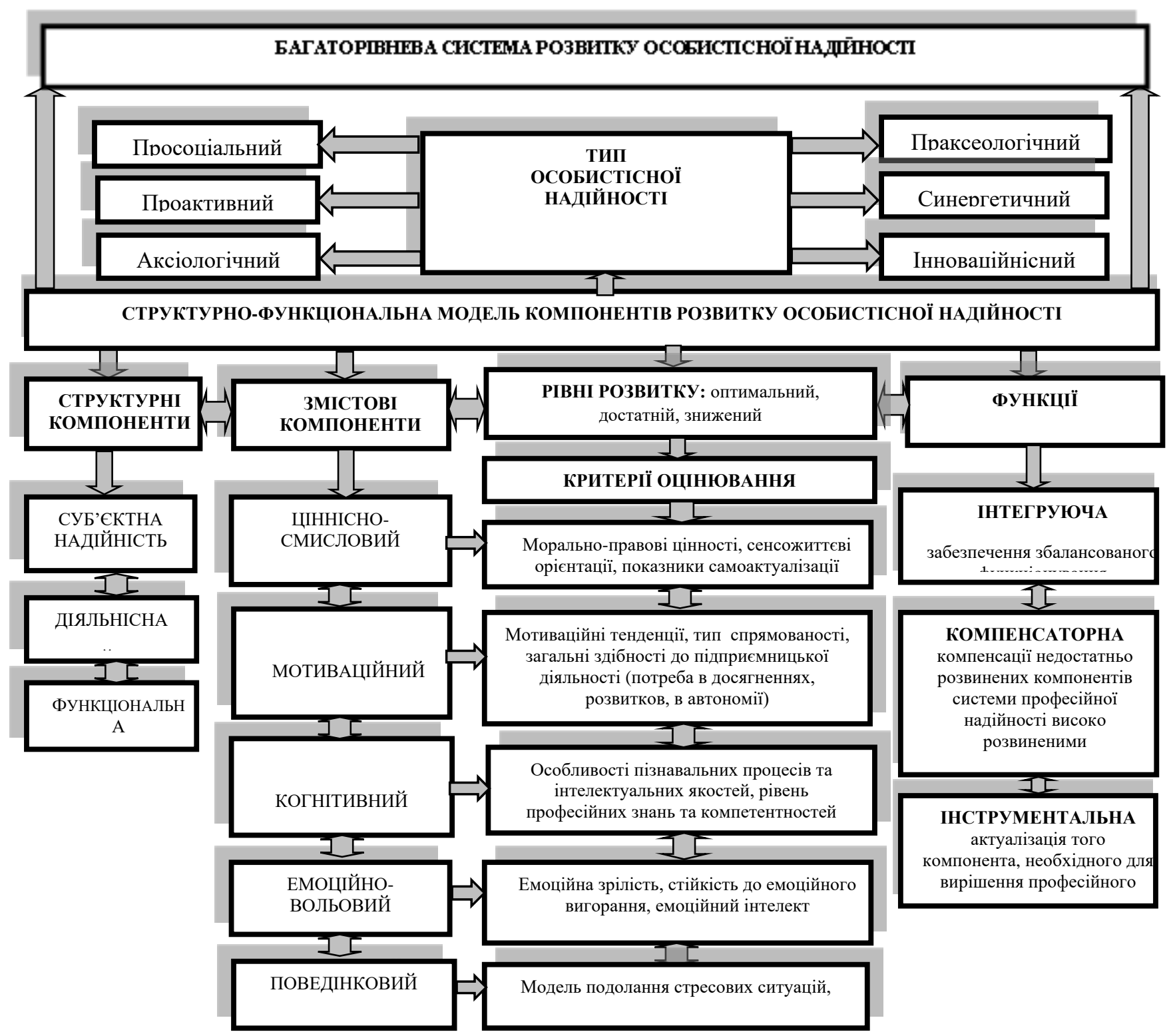

\section{Рис. 2. Функціональна модель розвитку компонентів особистісної надійності суб'сктів підприємницької діяльності}

Так, суб’єктна надійність включає в себе морально-правові та просоціальні, гуманістично-орієнтовані значення, які відповідають етиці обраної ними роботи і передбачають розуміння соціальної значущості та особистісної відповідальності за підсумками підприємницької роботи, соціальну, відомчу і групову нормативність поведінки як найважливішої умови успішності професійної діяльності та попередження порушень. Діяльнісна надійність визначає особистість як суб’єкта підприємницької діяльності й передбачає безпомилковість і своєчасність виконання професійних функцій у різних режимах та умовах праці. Діяльнісна надійність обумовлена включенням до 
структури особистості підприємця: професійних та спеціальних знань, умінь та навичок; досвіду реалізації бізнес-проектів і забезпечення їх ефективності та успішності. Функціональна надійність характеризує особистість як біологічного індивіда: відображає функціональний стан його організму, об’єм енергетичних ресурсів, необхідних для ефективного виконання трудової діяльності.

О.Л. Осадчук вважає, що визнаючи правомірність особливого, виділеного розгляду окремих підсистем надійності особистості, слід акцентувати їх зв'язок і взаємообумовленість: будучи самі системними утвореннями, вони отримують власну змістовну і активну визначеність тільки у цілісній структурі [738].

Відповідно до структури особистісної надійності суб’єктів підприємницької діяльності слід зарахувати такі змістові компоненти, як: ціннісно-смисловий, мотиваційний, когнітивний, емоційно-вольовий та поведінковий. Змістові компоненти обумовлюють розвиток i реалізацію особистісної надійності в діяльності [752].

Когнітивний компонент особистісної надійності підприємця є результатом пізнання і засвоєння змісту підприємницької діяльності та складання системи знання щодо персональних можливостей набуття професійного досвіду 3 урахуванням наявності чи відсутності необхідних для цього професійно важливих якостей та здібностей. Когнітивна складова передбачає певний рівень розвитку пізнавальних процесів, що складають інтелектуально-пізнавальну сферу суб’єкта, необхідних для успішної реалізації підприємницької діяльності. Розвиток інтелектуально-пізнавальної сфери передбачає розширення категоріальної та понятійної структури свідомості індивіда, що надає можливість набути навички інтерпретації отриманої інформації та іiі застосування в підприємницькій діяльності, підвищуючи якість виконання професійних функцій.

Емоційно-вольова складова особистісної надійності $€$ процесом відображення емоційного ставлення особистості до професійної діяльності або до окремих, професійно значущих якостей своєї особистості відповідно до потреб та мотивів. Показниками емоційно-вольової складової надійності 
особистості є: інтереси, самооцінка, задоволення професійною діяльністю, емпатія та емоційна стійкість. Далі детальніше зупинимося на характеристиці кожного з показників: інтереси мотивують до подальшого навчання, розвитку вмінь та навичок; самовідношення особистості стимулює професійний та особистісний саморозвиток та самовдосконалення; самооцінка відображає потенційні можливості та прагнення особистості; емпатія та емоційна стійкість відображають особистісну значимість всього, що відбувається в реальності та внутрішні переживання особистості. В основі переживань знаходиться ціннісносмислова перебудова свідомості підприємця.

Мотиваційна складова надійності підприємця є процесом відображення ступеня готовності працівника до виконання професійних дій, дотримання принципів та відповідної етики у професійній діяльності, відповідальності за правомірність дій. Рівень особистісної активності підприємців пов'язаний 3 такими якостями особистості як сила волі, цілеспрямованість, енергійність та витримка. Важливими складовими вольової регуляції поведінки $є$ самооцінка особистості підприємця, тип локалізації контролю, ціннісні орієнтації, рівень емоційного та інтелектуального розвитку, а також професійна рефлексія. Остання надає об'єктивного значення діяльності та призводить до усвідомлення впливу на процес професійної діяльності.

Ціннісно-смисловий компонент надійності характеризується усвідомленням своєї відповідальності перед моральними цінностями та ідеалами, що дозволяє суб'єктам підприємницької діяльності протистояти нормам вузькогрупової та егоїстичної моралі. Ціннісно-смислова сфера особистості вміщує в собі систему уявлень, особистісних конструктів, які наповнюють семантичний простір професійної свідомості, результатом чого $\epsilon$ формування образу «Я», образу «Професії», що сприяє самопізнанню, самовідношенню, самоідентичності.

Якісне рішення професійних завдань можливе за рахунок цілеспрямованого аналізу ситуації та ймовірних різновидів поведінки, вироблення стратегії вирішення проблемної ситуації, планування особистих 
вчинків 3 урахуванням неупереджених критеріїв, попереднього досвіду й наявних ресурсів, а також подолання несприятливих ситуацій у зв'язку iз завданням за рахунок мінімізації впливу емоційного стану на прийняття рішення та самоконтролю [741, с. 35].

При дослідженні об’єкта, як системи, кожен компонент описується не лише $з$ урахуванням його місця, але й ролі в цілому. Існування системи особистісної надійності здійснюється за допомогою реалізації властивих їй функцій. Функції особистісної надійності суб'єкта відображають його призначення, роль у підприємницькій діяльності. Стосовно системного підходу до вивчення надійності фахівця можуть бути виділені як загальні функції, властиві системі професійної надійності в цілому, так і специфічні функції іiі окремих компонентів. Особистісна надійність реалізується за допомогою трьох загальних системних функцій:

- інтегруюча - координація компонентів особистісної надійності як певної цілісності, що виявляється в забезпеченні збалансованого функціонування всіх іiі рівнів, кожен з яких час від часу виходить зі стану рівноваги, але система в цілому цей стан стабільності зберігає;

- інструментальна - актуалізація того компонента, який необхідний для вирішення актуального завдання, що стоїть перед підприємцем;

- компенсаторна - консолідується в заміні недостатньо розвинених компонентів надійності особистості більш розвиненими [738, с. 35].

Через психологічний механізм компенсації або деформації психофізичного ресурсу спостерігається така закономірність: чим менші показники психофізичного благополуччя, тим менш нормативною може бути поведінка в деяких ситуаціях поза нею. Так само як і поведінка, яка є нормативною в деяких ситуаціях професійної діяльності, може стати ненормативною в інших ситуаціях, тому нормативність оцінюється з інших позицій або носіями інших норм [752].

Таким чином, проблема становлення надійності суб'єктів підприємницької роботи повинна вирішуватися через дослідження тих особистих структур, що забезпечують стабільність і відповідний ступінь особистісно-функціонально- 
діяльнісних характеристик підприємців на важливих рівнях соціокультурного простору.

Особистісна надійність суб'єктів підприємницької діяльності включає в себе морально-правові та просоціальні, гуманістично-орієнтовані цінності, які відповідають етиці обраної ними професійної діяльності та усвідомлюють суспільну значущість і особисту відповідальність за підсумки підприємницької діяльності [759, с. 57-58].

Виділені змістові компоненти особистісної надійності в реальному життєвому просторі взаємозв'язані і взаємодетерміновані, обумовлюючи інтегральне особистісне утворення. Компоненти при входженні в ціле, з одного боку, втрачають певні характеристики, властивості, а з іншого - набувають нових властивостей. В якості базового компонента особистісної надійності виступають ціннісно-світоглядні орієнтації особистості. Вони утворюють фундамент змістової сторони надійності суб'єкта й виражають внутрішню основу його ставлення до дійсності.

Кожен компонент системи особистісної надійності володіє своїми локальними можливостями й, узятий окремо, не може повністю забезпечити ефективність функціонування підприємця. Лише їхня діалектична єдність дає можливість фахівцю досягти найкращих результатів. Проблеми у функціонуванні будь-якого 3 компонентів особистісної надійності завдають збитків системі в цілому. Рівень особистісної надійності суб’єкта підприємницької діяльності може бути визнаний оптимальним лише за умови високого рівня розвитку всіх складових даної структури.

Виділені психологічні компоненти особистісної надійності суб’єктів підприємницької діяльності ієрархічно збудовані, мають різну міру узагальненості й конкретизації на різних рівнях світогляду, розвитку підприємливості та типу надійності. Ефективність психологічних компонентів, щодо формування особистісної надійності, зростає, коли вони виступають єдиною взаємопов’язаною системою. 
Розвиток дослідження в цьому напрямі визначив необхідність виділення критеріїв для встановлення рівня розвитку особистісної надійності суб'єктів підприємницької діяльності. Відомо, що критерієм у системному аналізі є інструмент (спосіб) для порівняння альтернатив, тобто, будь-яка ознака, значення якої можна зафіксувати кількісно або якісно. Критерій - це об’ єктивна міра деякого явища, у нашому випадку - особистісної надійності фахівців соціономічної сфери діяльності. Як певна міра критерій повинен задовольняти умові адитивності. У змістовому плані до критеріїв висувають додаткові вимоги. Так, критерій має бути адекватний тому явищу, вимірювачем якого він слугує: у критерії має бути відображена природа вимірюваного явища й динаміка змін властивості, яку критерій виражає. Критерій має бути виражений однозначно: одні й ті самі фактичні значення різних явищ при застосуванні до них критерію повинні давати однакові кількісні значення величин, що вимірюються. Критерій має бути простим, тобто припускати найпростіші способи вимірювання [752]. Важливо, що можна використовувати декілька критеріїв, що описують одну ціль 3 різних боків і доповнюють один одного. 3 урахуванням методологічних і теоретичних підстав дослідження нами були розроблені кваліметричні характеристики оцінки показників розвитку особистісної надійності суб'єктів підприємницької діяльності. Вони представленні у таблиці 1.

На думку автора О.Л. Осадчук, розуміння розвитку надійності особистості як природного, тобто органічного феномена, що витікає з внутрішньої логіки руху системи зміни, зовсім не означає визнання некерованості даного процесу [738].

Таблиия 1

Критерії оцінки рівня розвитку особистісної надійності суб'єктів підприсмницької діяльності

\begin{tabular}{|c|c|c|c|}
\hline Рівні & \multicolumn{1}{|c|}{ Якісні характеристики } & $\begin{array}{l}\text { Оцінка } \\
\text { в балах }\end{array}$ \\
\hline \multicolumn{4}{|c|}{ Поведінкові характеристики } \\
\hline Оптимальний & $\begin{array}{l}\text { Високо розвинені поведінкові характеристики, які забезпечують } \\
\text { успішне виконання професійних завдань, дозволяють успішно } \\
\text { справлятися 3 професійною роллю. Використання переважно } \\
\begin{array}{l}\text { «просоціальних» стратегій подолання стресу. Провідними } \\
\text { моделями подолання стресових ситуацій є «вступ у соціальний } \\
\text { контакт» та «пошук соціальної підтримки». Домінуючими }\end{array}\end{array}$ \\
\hline
\end{tabular}




\begin{tabular}{|c|c|c|}
\hline & $\begin{array}{l}\text { типами реакцій на дію стресорів } \epsilon \text { «самоконтроль» та } \\
\text { «планування». Високий рівень особистісного адаптаційного } \\
\text { потенціалу. }\end{array}$ & \\
\hline Достатній & $\begin{array}{l}\text { Ключовими типами реакцій на дію стресорів є «прийняття } \\
\text { відповідальності» та «позитивна переоцінка». Використання } \\
\text { переважно «просоціальних» стратегій подолання стресу. } \\
\text { Провідними моделями подолання стресових ситуацій є «вступ у } \\
\text { соціальний контакт». Розвинені на достатньому рівні } \\
\text { поведінкові характеристики, які забезпечують успішне } \\
\text { виконання професійних завдань, дозволяють успішно } \\
\text { справлятися } 3 \text { професійною роллю. Низький рівень } \\
\text { особистісного адаптаційного потенціалу. }\end{array}$ & $7-5$ \\
\hline Знижений & $\begin{array}{l}\text { Використання таких стилів і стратегії свідомої соціальної } \\
\text { поведінки } 3 \text { подолання життєвих труднощів як } \\
\text { «дистанціювання» та «уникнення». Використовуються } \\
\text { переважно «прямі» та «пасивні» стратегії подолання стресу. } \\
\text { Провідними моделями подолання стресових ситуацій є } \\
\text { «імпульсивні дії» та «обережні дії». Відсутність виражених } \\
\text { поведінкових характеристик, які забезпечують успішне } \\
\text { виконання професійних завдань, рідко справляються з } \\
\text { професійною роллю. Низький рівень особистісного } \\
\text { адаптаційного потенціалу. }\end{array}$ & $4-1$ \\
\hline \multicolumn{3}{|c|}{ Когнітивні характеристики } \\
\hline Оптимальний & $\begin{array}{l}\text { Високий рівень розвитку пізнавальної сфери та інтелектуальних } \\
\text { якостей особистості, який виявляється у «інноваторському» } \\
\text { когнітивному стилі. Переважно характерним є наявність } \\
\text { креативного, образного та знакового типу мислення. Високий } \\
\text { рівень розвитку за композитною оцінкою соціального інтелекту. } \\
\text { Сформовані підприємницькі компетентності у сферах: } \\
\text { «трансформації в дії» (взяття на себе ініціативи, планування та } \\
\text { управління, робота } 3 \text { неоднозначністю, невизначеністю та } \\
\text { ризиками, співпраця з іншими особами, навчання через досвід); } \\
\text { «ресурси» (самосвідомість і самоефективність, мотивація та } \\
\text { наполегливість, мобілізація ресурсів, фінансова та економічна } \\
\text { грамотність, мобілізація інших осіб); «ідеї та можливості» } \\
\text { (креативність, оцінювання ідей, етичне та обгрунтоване } \\
\text { мислення, виявлення можливостей, прогнозування). }\end{array}$ & $10-8$ \\
\hline Достатній & $\begin{array}{l}\text { Необхідний рівень розвитку пізнавальної сфери та } \\
\text { інтелектуальних якостей особистості, який виявляється у слабко } \\
\text { вираженому «адапторському» когнітивному стилі. Переважно } \\
\text { характерним є наявність символічного типу мислення. Вище } \\
\text { середнього - рівень розвитку за композитною оцінкою } \\
\text { соціального інтелекту. Сформовані підприємницькі } \\
\text { компетентності у сферах: «трансформації в дії» (взяття на себе } \\
\text { ініціативи, планування та управління, робота з неоднозначністю, } \\
\text { невизначеністю та ризиками); «ресурси» (мотивація та } \\
\text { наполегливість, мобілізація ресурсів, фінансова та економічна } \\
\text { грамотність); «ідеї та можливості» (оцінювання ідей, виявлення } \\
\text { можливостей, прогнозування). }\end{array}$ & $7-5$ \\
\hline
\end{tabular}




\begin{tabular}{|c|c|c|}
\hline Знижений & $\begin{array}{l}\text { Інтелектуально-пізнавальні процеси знаходяться на середньому } \\
\text { рівні, що виявляється в домінуванні «адапторського» } \\
\text { когнітивного стилю. Переважно характерним є наявність } \\
\text { знакового типу мислення. Середній рівень розвитку за } \\
\text { композитною оцінкою соціального інтелекту. Не сформовані } \\
\text { підприємницькі компетентності у сфері: «трансформації в дії» } \\
\text { (взяття на себе ініціативи, планування та управління, робота } 3 \\
\text { неоднозначністю, невизначеністю та ризиками, співпраця } 3 \\
\text { іншими особами, навчання через досвід); «ресурси» } \\
\text { (самосвідомість і самоефективність, мобілізація інших осіб); } \\
\text { «ідеї та можливості» (креативність, етичне та обгрунтоване } \\
\text { мислення, прогнозування). }\end{array}$ & $4-1$ \\
\hline \multicolumn{3}{|c|}{ Ціннісно-смислові характеристики } \\
\hline Оптимальний & $\begin{array}{l}\text { Високий рівень моральної нормативності - високий рівень } \\
\text { соціалізації, адекватна оцінка своєї ролі в колективі, орієнтація } \\
\text { на дотримання загальноприйнятих норм поведінки. Рівень } \\
\text { морально-правової надійності високий. Високий рівень } \\
\text { ціннісних орієнтацій у кар’єрі за показником «Служіння», } \\
\text { «Професійна компетентність» та «Підприємництво». За } \\
\text { смисложиттєвими орієнтаціями характерна висока насиченість } \\
\text { життя, задоволеність самореалізацією, відчуття продуктивності } \\
\text { й осмисленості проживання, уявлення про себе як про сильну } \\
\text { особистість, яка має достатню свободу вибору, щоб побудувати } \\
\text { своє життя відповідно до своїх цілей і уявлень про його сенс, } \\
\text { усвідомленість життя тісно пов'язана з внутрішнім локусом } \\
\text { контролю. Високий рівень самоактуалізації. }\end{array}$ & $10-8$ \\
\hline Достатній & $\begin{array}{l}\text { Середній рівень морально-правової надійності. Високий рівень } \\
\text { ціннісних орієнтацій у кар'єрі за показником «Менеджмент» та } \\
\text { «Підприємництво». За смисложиттєвими орієнтаціями } \\
\text { характерна відсутність цілей у майбутньому, які надають життю } \\
\text { осмисленості, спрямованості й тимчасову перспективу, } \\
\text { уявлення про себе як про сильну особистість, яка має достатню } \\
\text { свободу вибору, щоб побудувати своє життя відповідно до своїх } \\
\text { цілей і уявленнями про його сенс, усвідомленість життя тісно } \\
\text { пов’язана } 3 \text { внутрішнім локусом контролю. Високий рівень } \\
\text { самоактуалізації. }\end{array}$ & $7-5$ \\
\hline Знижений & $\begin{array}{l}\text { Схильність сприймати образ підприємця, спираючись на } \\
\text { індивідуальні особливості та професійну оцінку діяльності. } \\
\text { Наявність прагматичної та корисливої стадії розвитку морально- } \\
\text { правової надійності. Високий рівень ціннісних орієнтацій у } \\
\text { кар’єрі за показником «Виклик», «Автономія (незалежність)» та } \\
\text { «Інтеграція стилів життя». За смисложиттєвими орієнтаціями } \\
\text { характерна захопленість нездійсненими проектами, плани яких } \\
\text { не мають реальної опори в сьогоденні і не підкріплюються } \\
\text { особистою відповідальністю за їх реалізацію; обрання життєвої } \\
\text { позиції, в основі якої лежить уявлення про насолоду, як мету } \\
\text { людського існування; невіра у свою здатність контролювати } \\
\text { події власного життя; невпевненість у принциповій можливості } \\
\text { самостійного здійснення життєвого вибору. Середній та низький } \\
\text { рівень самоактуалізації. }\end{array}$ & $4-1$ \\
\hline
\end{tabular}




\begin{tabular}{|c|c|c|}
\hline \multicolumn{3}{|c|}{ Мотиваційні характеристики } \\
\hline Оптимальний & $\begin{array}{l}\text { Провідними мотиваційними тенденціями є прагнення до } \\
\text { прийняття та прагнення до взаємодії і служіння. Домінуючий } \\
\text { тип спрямованості - спрямованість на діяльність, на завдання. } \\
\text { Розвинуті на високому рівні загальні здібності до } \\
\text { підприємницької діяльності: «потреба в досягненнях } \\
\text { (подальшому розвитку)», «потреба в незалежності / автономії», } \\
\text { «схильність до творчості (творчі здібності / нахили)», «уміння } \\
\text { йти на розумний (зважений) ризик», «цілеспрямованість та } \\
\text { рішучість». }\end{array}$ & $10-8$ \\
\hline Достатній & $\begin{array}{l}\text { Мотиваційний профіль характеризується орієнтацією на } \\
\text { альтруїстичну мотивацію, мотивацію позитивного ставлення до } \\
\text { людей, спілкування і прагненням допомагати людям. } \\
\text { Домінуючий тип спрямованості - спрямованість на спілкування. } \\
\text { Висока пізнавальна та трудова мотивація. Розвинуті загальні } \\
\text { здібності до підприємницької діяльності: «потреба в } \\
\text { досягненнях (подальшому розвитку)», «потреба в незалежності } \\
\text { / автономії». }\end{array}$ & $7-5$ \\
\hline Знижений & $\begin{array}{l}\text { Мотиваційний профіль характеризується, у першу чергу, } \\
\text { гедоністичними, егоцентричними тенденціями. Домінуючий } \\
\text { тип спрямованості на себе. Високий рівень орієнтації на } \\
\text { матеріальну мотивацію, пізнавальну мотивацію, мотивацію } \\
\text { прагнення до досконалості та низький рівень уникнення } \\
\text { неприємностей. Розвинуті такі загальні здібності, як потреба в } \\
\text { незалежності / автономії та потреба в досягненні. }\end{array}$ & $4-1$ \\
\hline \multicolumn{3}{|c|}{ Емоційно-вольові характеристики } \\
\hline Оптимальний & $\begin{array}{l}\text { Високий рівень емоційної зрілості, саморегуляція свого } \\
\text { емоційно-вольового стану, толерантність у спілкуванні й } \\
\text { поведінці. Дуже високий загальний рівень емоційного інтелекту. } \\
\text { Розвинуті на високому рівні загальні здібності до } \\
\text { підприємницької діяльності: «уміння йти на розумний } \\
\text { (зважений) ризик», «цілеспрямованість та рішучість». }\end{array}$ & $10-8$ \\
\hline Достатній & $\begin{array}{l}\text { Достатньо високий рівень емоційної зрілості, саморегуляція } \\
\text { свого емоційно-вольового стану, толерантність в спілкуванні і } \\
\text { поведінці. Високий загальний рівень емоційного інтелекту. } \\
\text { Розвинуті загальні здібності до підприємницької діяльності: } \\
\text { «вміння йти на розумний (зважений) ризик», } \\
\text { «цілеспрямованість та рішучість». }\end{array}$ & $7-5$ \\
\hline Знижений & $\begin{array}{l}\text { Середній та низький рівень емоційної зрілості, емоційного } \\
\text { інтелекту, саморегуляція свого емоційно-вольового стану, } \\
\text { толерантність у спілкуванні й поведінці. }\end{array}$ & $4-1$ \\
\hline
\end{tabular}

Для розуміння сутності розвитку надійності може виявитися плідним перенесення в галузь iї дослідження широко відомого уявлення про зону найближчого розвитку [760].

Згідно цього надійність має свій рівень актуального, тобто досягнутого, й реалізованого розвитку. Проектування ж зони найближчого, тобто можливого 
розвитку i траєкторії руху до iï верхнього кордону - важливе завдання управління процесом розвитку системи особистісної надійності [738].

Згідно формули О.М. Леонтьєва - «внутрішнє діє через зовнішнє і цим само себе змінює» - джерело перетворень системи особистісної надійності знаходиться в самій системі [761]. Рушійними силами розвитку особистісної надійності суб’єктів підприємницької діяльності є зовнішні протиріччя невідповідності між об’ єктивною реальністю та її суб’ єктивним віддзеркаленням підприємцем, а також внутрішні протиріччя в самій системі особистісної надійності - розбіжності між цільовими функціями окремих ii підсистем (їх різна спрямованість). Вирішення цих протиріч утворює процес розвитку особистісної надійності суб'єктів підприємницької діяльності і є основним змістом управління цим процесом.

Розгляд питання багаторівневості системи розвитку особистісної надійності через призму концепції вертикального розвитку Ж. Гебстера [724] та соціально-еволюційної теорії спіральної динаміки К. Грейвза [726] дозволяє прослідкувати взаємозв’язок між парадигмами свідомості, підприємливістю як компетентності та типами особистісної надійності.

Знання, накопичені людством протягом багатьох тисяч років, усі культури, народжені людьми, усі ціннісні орієнтири однаково активно присутні в нашому тепер уже загальному інформаційному полі, породжуючи і руйнівні потрясіння, i нові форми людяності. На глобальному просторі смислового хаосу народжуються і вмирають 3 дивовижною швидкістю нові ідеї. Ми живемо в насиченому часі, коли протягом життя одного покоління встигають змінюватися цілі епохи. Тому усвідомлення множинності світів - перший крок до усвідомлення своєї парадигми мислення і властивих їй обмежень, а значить стимул до подальшого розвитку, відкриття для себе нових, вищих світів і відкриття себе для них. Кожна парадигма мислення, кожен рівень повинен бути освоєний і заповнений, адже він надає людині важливих життєвих навичок, наскрізних компетентностей, без яких вона не зможе далі розвиватися [728]. 
Так, EntreComp визначає підприємливість як наскрізну компетентність, яка затребувана в усіх сферах життя: від турботи про особистісне благополуччя та становлення до реалізації соціальної ролі громадянина в житті суспільства, входження (повторного входження) на ринок праці в якості співробітника організації або ж самозайнятої особи - підприємця. Це поняття базується на широкому визначенні підприємливості, яке грунтується на створенні культурної, соціальної чи економічної цінності [762].

Спираючись на модель становлення EntreComp, яка виходить 3 того, що підприємливість розвивається в процесі діяльності окремих осіб чи установ 3 метою створення благ для інших, сутність підприємливості складається 3 двох аспектів: 1) становлення більшої автономії та відповідальності у втіленні думок і ймовірностей для створення цінностей; 2) становлення можливості генерувати значення - від нескладних та передбачуваних контекстів і до специфічних типів середовища, яке щодня змінюється.

Типи розвитку особистісної надійності суб'єктів підприємницької діяльності, спираючись на теорію К. Грейвза, можна охарактеризувати залежно від прояву різних рівнів світогляду та розвитку підприємливості. Нами було визначено взаємозв'язок рівнів світогляду (за моделлю спіральної динаміки), рівнів підприємливості (за моделлю поступу EntreComp) та типів особистісної надійності (табл. 2). Психосоціокультурний прояв феномена особистісної надійності, як виду соціально-економічної активності суб'єктів підприємницької діяльності, неможливий з першого по третій рівні свідомості, яким притаманні, відповідно, інстинктивна, племена та егоцентрична парадигми мислення.

Особистісна надійність за «праксеологічним» типом знаходить свій прояв на четвертому та п’ятому рівнях світогляду, згідно теорії спіральної динаміки, і відповідає основному й середньому рівню розвитку підприємливості, згідно моделлю поступу EntreComp. Цей тип надійності забезпечує ефективне управління діяльністю через іiі всебічний самоаналіз, самооцінювання, цілеспрямоване моделювання умов і засобів удосконалення на основі синтезу теоретичних знань та емпіричного досвіду. Він відображає залежність 
результатів роботи, насамперед, від попередньої ретельної підготовки до іiі виконання, ступень підготовленості дій у широкому розумінні, що охоплює оволодіння знаннями, свідомий вибір засобів, методів аналізу й регулювання, критерії емоційного і практичного оцінювання результатів.

Особистісна надійність за «аксіологічним» та «просоціальним» типом знаходить свій прояв на шостому рівні світогляду, згідно теорії спіральної динаміки, й відповідає вищому рівню розвитку підприємливості, згідно моделлю поступу EntreComp.

Так, особистісна надійність за «аксіологічним» типом передбачає розвиненість гуманістично спрямованої системи ціннісних орієнтацій, що забезпечує надійність особистості й формування світоглядних позицій, ціннісносвітоглядних ідеалів і стандартів: наявність чіткої системи індивідуальних норм поведінки; сформованість соціальної відповідальності та зрілості. Цим визначається особистісний зміст підприємницької діяльності.

Особистісна надійність за «просоціальним» типом, у першу чергу, обумовлює просоціальні поведінки суб'єктів підприємницької діяльності, яка за своїм змістом, механізмами й формами має багато різновидів. До основних належать: альтруїстична та допомагаюча поведінка, співробітництво, емпатія, гуманні взаємини; суто в економічній площині це фандрайзинг, донорство, благодійність, меценатство.

Особистісна надійність за «просоціальним» типом забезпечує здійснення соціального підприємництва, заснованого на соціальній відповідальності та соціальному партнерстві як протидії затяжній соціально-економічній кризі в суспільстві.

Його орієнтованість на високе споживання та матеріальне процвітання, прагматичність та конкуренцію ринкових відносин, прагнення до власного благополуччя при ігноруванні інтересів інших людей продукує зростання егоїстичної домінанти в соціальній поведінці та руйнування фундаментальних морально-етичних цінностей, ідеалів. Тому можна констатувати, що повноцінне 
життя людини і як громадянина, і як особистості неможливе без набуття особистісних смислів просоціального рівня.

Особистісна надійність за «проактивним» та «синергетичним» типом знаходить свій прояв на сьомому рівні світогляду, згідно теорії спіральної динаміки, і відповідає експертному рівню розвитку підприємливості, згідно моделлю поступу EntreComp. «Проактивний» тип виявляється в усвідомленні суб'єктом своїх глибинних цінностей та цілей, підпорядкованості дій життєвим принципам незалежно від умов та обставин, прийнятті відповідальності за себе і своє життя, у таких поведінкових особливостях, як: ініціативність і активність; переконаність у наявності вибору, можливості щось змінити; готовність брати відповідальність; принциповість, цілеспрямованість; зміна (або вибір) обставин під свої завдання.

Особистісна надійність за «синергетичним» типом характеризує особистісний розвиток суб'єкта підприємницької діяльності не тільки як поступовий, лінійний, безконфліктний процес, а як такий, що супроводжується суперечностями, які зумовлюють трансформацію ціннісних орієнтацій, самопізнавальну й самовиховну активність. 
Таблиия 2

Взаємозв'язок рівнів світогляду за моделлю спіральної динаміки, рівнів підприсмливості за моделлю поступу

EntreComp та типів особистісної надійності

\begin{tabular}{|c|c|c|c|c|c|}
\hline $\begin{array}{c}\text { Рівень } \\
\text { світогляду }\end{array}$ & Характеристика цінностей & $\begin{array}{c}\text { Парадигма } \\
\text { мислення }\end{array}$ & Стратегії організації діяльності & $\begin{array}{c}\text { Рівні } \\
\text { підприсмливості } \\
\text { за моделлю } \\
\text { поступу } \\
\text { EntreComp } \\
\end{array}$ & $\begin{array}{c}\text { Типи } \\
\text { особистісної } \\
\text { надійності }\end{array}$ \\
\hline $\begin{array}{l}\text { Перший } \\
\text { (бежевий } \\
\text { колір) }\end{array}$ & Задоволення фізіологічних потреб & Інстинктивна & $\begin{array}{c}\text { Інстинктивна стратегія виживання. } \\
\text { Етична стратегія - це те, що сприяє } \\
\text { виживанню. }\end{array}$ & \multirow{3}{*}{$\begin{array}{c}\text { Покладання на } \\
\text { підтримку інших }\end{array}$} & \\
\hline $\begin{array}{c}\text { Другий } \\
\text { (фіолетовий } \\
\text { колір) }\end{array}$ & $\begin{array}{c}\text { Людина зв'язана безліччю табу, } \\
\text { правил та обмежень, позбавлена } \\
\text { індивідуального мислення та } \\
\text { права на вчинок. Сімейні, родинні, } \\
\text { кланові зв'язки мають абсолютну } \\
\text { силу й містичне забарвлення. Рід, } \\
\text { як група, збільшує вірогідність } \\
\text { виживання та має більше } \\
\text { значення, ніж окремий його член. } \\
\text { Мають значну вагу дружба, } \\
\text { кумівство. }\end{array}$ & Племінна & $\begin{array}{c}\text { Внутрішньокорпоративні стратегії: } \\
\text { формування ритуалів та обрядів, } \\
\text { установлення табу, сильні традиції, } \\
\text { сімейність всередині компанії }\end{array}$ & & \\
\hline $\begin{array}{c}\text { Третій } \\
\text { (червоний } \\
\text { колір) }\end{array}$ & $\begin{array}{c}\text { Життя, як у джунглях, де сильний } \\
\text { перемагає слабкого. Природа - це } \\
\text { щось таке, що може бути } \\
\text { завойоване }\end{array}$ & Егоцентрична & $\begin{array}{c}\text { Жорстокі конкурентоспроможні } \\
\text { ринкові стратегії, рейдерство, рекет. } \\
\text { Зовнішній тиск, імпульсивність у } \\
\text { схваленні рішень, виживання ціною } \\
\text { життя інших людей, співробітники } \\
\text { - ніхто в компанії не товаришує, усі } \\
\text { відносини прагматичні }\end{array}$ & & \\
\hline
\end{tabular}


Продовження таблиці 2

\begin{tabular}{|c|c|c|c|c|c|}
\hline \multirow[b]{2}{*}{$\begin{array}{c}\text { Рівень } \\
\text { світогляду }\end{array}$} & \multirow[b]{2}{*}{ Характеристика цінностей } & \multirow[b]{2}{*}{$\begin{array}{c}\text { Парадигма } \\
\text { мислення }\end{array}$} & \multirow[b]{2}{*}{ Стратегії організації діяльності } & \multirow[b]{2}{*}{\begin{tabular}{|c|} 
Рівні \\
підприємливост \\
i \\
за моделлю \\
поступу \\
EntreComp \\
\end{tabular}} & \multirow[b]{2}{*}{$\begin{array}{c}\text { Типи } \\
\text { особистісної } \\
\text { надійності }\end{array}$} \\
\hline & & & & & \\
\hline $\begin{array}{c}\text { Четвертий } \\
\text { (синій колір) }\end{array}$ & $\begin{array}{c}\text { Усе контролюється вищою } \\
\text { силою, яка карає зло і } \\
\text { нагороджує добро, стежить за } \\
\text { дотриманням правил і виявляє } \\
\text { відхилення від них }\end{array}$ & $\begin{array}{c}\text { Авторитарна, } \\
\text { патріотична }\end{array}$ & $\begin{array}{c}\text { Стратегії регламентації діяльності } \\
\text { компанії: опис бізнес-процесів, } \\
\text { посадові інструкції, положення, } \\
\text { правила, методики, корпоративні } \\
\text { стандарти }\end{array}$ & $\begin{array}{c}\text { Покладання на } \\
\text { підтримку інших }\end{array}$ & \multirow{2}{*}{ Праксеологічний } \\
\hline $\begin{array}{c}\text { П'ятий } \\
\text { (помаранчевий } \\
\text { колір) }\end{array}$ & $\begin{array}{c}\text { Світ повний ресурсів і } \\
\text { можливостей зробити все } \\
\text { кращим і досягти процвітання }\end{array}$ & $\begin{array}{c}\text { Матеріалісти } \\
\text { чна }\end{array}$ & $\begin{array}{c}\text { Досягнення успіху, важливий } \\
\text { імідж і зростання доходів; це } \\
\text { супроводжується упровадженням } \\
\text { нових технологій, обгрунтуванням } \\
\text { будь-якого рішення мовою чисел }\end{array}$ & $\begin{array}{c}\text { Розвиток } \\
\text { незалежності }\end{array}$ & \\
\hline $\begin{array}{l}\text { Шостий } \\
\text { (зелений } \\
\text { колір) }\end{array}$ & $\begin{array}{c}\text { Основними цінностями є } \\
\text { гармонія і взаємовідносини. } \\
\text { Оточення, в якому людина } \\
\text { може знайти любов і виконати } \\
\text { своє призначення. }\end{array}$ & $\begin{array}{c}\text { Згоди, } \\
\text { консенсус } \\
\text { міжособистіс } \\
\text { них зв'язків }\end{array}$ & $\begin{array}{l}\text { Упровадження корпоративної } \\
\text { соціальної відповідальності, } \\
\text { розробка соціальних пакетів, } \\
\text { відкриття благодійних фондів }\end{array}$ & Відповідальність & $\begin{array}{l}\text { Просоціальний, } \\
\text { аксіологічний }\end{array}$ \\
\hline $\begin{array}{c}\text { Сьомий } \\
\text { (жовтий колір) }\end{array}$ & $\begin{array}{c}\text { Найбільшими цінностями, } \\
\text { важливішими за ранг і статус, } є \\
\text { компетентність, незалежність, } \\
\text { свобода, гідність. Хаос, зміни є } \\
\text { нормою, а невизначеність } \\
\text { прийнята як стан буття }\end{array}$ & $\begin{array}{l}\text { Системності } \\
\text { та інтеграції }\end{array}$ & $\begin{array}{c}\text { Розробка декількох сценаріїв } \\
\text { розвитку компанії, принцип } \\
\text { самостійності структурних } \\
\text { одиниць, постійне навчання для } \\
\text { оптимізації процесів }\end{array}$ & \multirow{2}{*}{$\begin{array}{l}\text { Керування } \\
\text { зміною, } \\
\text { інновацією та } \\
\text { зростанням }\end{array}$} & $\begin{array}{l}\text { Проактивний, } \\
\text { синергетичний }\end{array}$ \\
\hline $\begin{array}{l}\text { Восьмий } \\
\text { (бірюзовий } \\
\text { колір) }\end{array}$ & $\begin{array}{c}\text { Баланс взаємопов’язаних сил, } \\
\text { де управління ризиками } \\
\text { знаходиться в руках людини }\end{array}$ & Холістична & $\begin{array}{c}\text { Глобальні стратегії, колективний } \\
\text { розум, створення глобальної } \\
\text { мережі }\end{array}$ & & Інноваційнісний \\
\hline
\end{tabular}


«Інноваційнісний» тип особистісної надійності суб’єктів підприємницької діяльності знаходить свій прояв на восьмому рівні світогляду, згідно теорії спіральної динаміки, і відповідає експертному рівню розвитку підприємливості, згідно моделлю поступу EntreComp.

«Інноваційнісний» тип особистісної надійності суб’єктів підприємницької діяльності відповідає найвищому експертному рівню розвитку підприємливості - управління зміною, інновацією і зростанням завдяки компетентностям, необхідних для реагування на складні виклики життя, середовища, яке постійно міняється і має високий рівень прогнозованості (розширення) і сфокусованість на нових викликах шляхом отримання нових знань, досліджень, розвитку та інноваційних здібностей для досягнення майстерності i трансформації соціокультурного простору.

Рівні світогляду, або ціннісні комплекси, що включають у себе духовні вірування, культурні ідеї, моральні принципи, моделі навчання тощо, 3'являються по мірі виникнення потреби в них у процесі соціокультурної еволюції.

Кожна парадигма мислення, кожен рівень повинен бути освоєний i заповнений, адже він надає людині важливих життєвих навичок, наскрізних компетентностей, без яких вона не зможе далі розвиватися. Цьому сприяє навчальний процес майбутніх фахівців [763].

Щодо питання особистісної надійності підприємців, то такою наскрізною компетентністю є підприємливість, яка грунтується на усвідомленні створення культурної, соціальної чи економічної цінності для інших. Створення цінності це узагальнюючий підсумок людської діяльності через втілення цілеспрямованих дій.

Таким чином, навчання майбутніх фахівців активізує розвиток як їх професіоналізму, так і особистісних якостей. Відповідно до цього навчання майбутніх підприємців розвиває одночасно їх як суб’єктів підприємницького середовища так і колективної взаємодії. Як член майбутнього підприємницького колективу він навчається бути проектувальником, конструктором, організатором 
i безпосереднім учасником у взаємодії, а також носієм певної особистісної позиції, що припускає навчитися необхідності проявляти фахівцем професійної надійності. Як суб'єкт підприємницької діяльності, майбутній підприємець повинен володіти відповідними етичними нормами, способами й засобами реалізації професійної надійності. На підставі зазначеного у майбутніх фахівців формується інтерес до розвитку професійної надійності як суб’єктів підприємницької діяльності.

Висновки.

1. Дослідження показало, що навчання розвитку особистісної надійності формує іiі як особливий феномен, в якому на суб'єктному рівні виявляється інтегративні якості підготовленості майбутнього фахівця до досягнення позитивних підсумків роботи у сфері людина-людина.

2. Моделювання стосовно проблеми розвитку особистісної надійності у навчальному процесі призводить до розуміння того, що розвиток цього феномену являє собою не пасивну інтеграцію впливу зовнішніх і внутрішніх умов існування особистості, а $є$ результатом навчання способам досягнення адаптивних можливостей $\mathrm{i}$ розширення репертуару стратегії поведінки подолання критичних ситуацій, які формуються в індивіда у процесі навчання професійної та особистісної самореалізації.

3. У досліджені виявлено, що навчання розвитку i формуванню особистісної надійності майбутніх підприємців дозволяє їм проявляти активну діяльність, особистісну надійність та спільність у взаємодії. Навчання професійної діяльності підприємців $є$ інтерсуб'єктивне, а формування професійної надійності грунтується на позитивному самовизначенні у взаємодії, у професійній спільності, що обумовлено розвитком підприємців у колективній діяльності, яка грунтується на позитивному самовизначенні, самоорганізації, самосвідомій та професійній діяльності. 
DOI 10.46299/ISG.2021.MONO.PED.III.8.13

\subsection{3 Мовленнсва підготовка майбутніх педагогів до професійної діяльності в умовах нової української школи}

\subsubsection{1. Професійне мовлення вчителя початкової школи як наукова проблема}

Перехід вітчизняної вищої освіти від парадигми викладання (передачі інформації) до парадигми навчання (формування компетенцій - потенціалу до дій) вносить корективи в підготовку майбутніх учителів початкової школи. Зокрема, орієнтація на всебічний розвиток мовлення студентів, посилення зв’язку змісту навчання 3 подальшою професійною діяльністю $є$ підгрунтям їхньої фахової підготовки.

Життєві і професійні практики підтверджують значимість комунікативної компетентності майбутніх педагогів, які виразно прослідковуються у рекомендаціях втілення Зальзбурзьких принципів [764]. У контексті досліджуваної проблеми актуальні аналітичні міркування і висновки, презентовані в пораднику для вчителя “Нова українська школа”(Н. Бібік, 2017) [791]. Методологічні засади проблематики цієї публікації узгоджуються 3 концептуальними засадами реформування середньої освіти “Нова українська школа" [783]. Важливими комунікативними рисами майбутніх учителів початкової школи є вільне володіння державною мовою у будь-яких ситуаціях професійного спілкування, уміння планувати таку комунікацію, виховувати в собі ділові комунікативні якості та розвивати мовну стійкість. Досконалого рівня розвитку професійного мовлення студентів засобами української мови можна досягти лише за умови створення системної технології навчання мови в процесі фахової підготовки.

Цікаві міркування щодо компетентнісного підходу презентовано в наукових працях Т. Пантюк, М. Пантюка, І. Гамерської, Ю. Десиняк (2020) [793], Т. Сорочан (2018) [800]. У публікаціях [767, с. 14, с. 32, с.40] подано матеріали, які використовувалися для проведення аналогій у підходах вивчення освітніх компонентів підготовки майбутнього педагога. 
У вітчизняних і зарубіжних наукових працях $є$ різні підходи та тлумачення сутності змісту, обсягу, структури поняття «професійне мовлення»; думки про те, що немає потреби у формуванні професійного мовлення, оскільки «студенти володіють достатньою комунікативною компетенцією і це дає їм можливість вільно спілкуватися в суспільстві» [781, с. 43].

3 часу виникнення педагогіки як науки вимоги до вчительського мовлення неодноразово перебували в центрі уваги дослідників. Розробляючи теорію методів навчання, Я. Коменський приділяв особливу увагу словесним методам. Їх цінність він вбачав у тому, що вони активізують дитяче мислення й мовлення, підтримують увагу, сприяють успішному засвоєнню учнями зразків дій (читання, письмо, малювання тощо). Необхідною умовою реалізації всіх цих завдань $є$, на думку великого педагога, досконале вчительське мовлення. Саме на нього розраховував Я. Коменський, коли писав: «Нехай учитель змушує дітей наслідувати те, що він говорить, нехай він звертає увагу на те, як вони наслідують, і нехай того, хто помиляється, він відразу виправляє».

Творчий розвиток ідей видатного педагога минулого бачимо в численних працях К. Ушинського. Класифікуючи методи навчання, він зіставляв результативність використання вчителем бесіди й розповіді на уроці, віддаючи перевагу діалогові. При побудові запитань для бесіди вчений радить чітко продумувати їх зміст і логіку, ясно й зрозуміло формулювати. Педагог вважав, що бесіда має бути фронтальною.

К. Ушинським визначено основні вимоги до зв“язного викладу, а саме: усна розповідь вчителя має бути недовгою й обов“язково доступною для дитячого сприймання, а головна думка має легко визначатися учнями. Текст повідомлення, якщо він узятий з наукового джерела, повинен трансформуватися вчителем так, щоб учні відчували живе слово, а не «чужу фразу».

Звісно, заслугою К. Ушинського є глибоке усвідомлення ним ролі вчительського мовлення в навчально-виховному процесі, визначення основних вимог до нього, а також розробка конкретних методичних рекомендацій щодо користування бесідою й розповіддю як основними словесними методами 
навчання молодших школярів. Знання, на думку видатного вченого, треба доводити до свідомості учня, а для цього необхідна жива мова вчителя, його вміння захопити, зацікавити, змусити розмірковувати. Мовлення вчителя, його ерудиція, вміння вчасно навести приклад яскравого переконливого факту, скористатися прислів'ям, приказкою, іноді вдалим жартом, а там, де потрібно, показати, як досліджуване мовне явище застосовується на практиці.

Професійне мовлення вчителя початкової школи перебувало в центрі уваги послідовників К. Ушинського - М. Бунакова, В. Вахтерова, В. Водовозова, Д. Тихомирова та ін., які поділяли погляди видатного педагога щодо необхідності досконало володіти навчальним діалогом. Заслуговує на увагу їхня спроба визначити основні якості вчительського мовлення, які узагальнено можна подати так: доступність, варіативність, ясність, простота, точність, логічність, емоційність.

Про якості вчительського мовлення свого часу говорив і Л. Толстой. Спираючись на власні педагогічні спостереження, він зауважував: «Чим легше вчителю вчити, тим важче учням учитися. Чим важче вчителю, тим легше учням». Учений зазначає, що вчителеві необхідно суворо і вимогливо підходити до відбору лексичних засобів для повідомлення чи пояснення на уроці, уникати «незрозумілих слів,... знаходити слова простіші і доступніші».

Отже, аналіз поглядів видатних педагогів і методистів минулого дає підстави зробити висновки про те, що прогресивна наука завжди обстоювала думку про важливу соціальну значущість діяльності вчителя початкової школи і ставила високі вимоги до його підготовки - теоретичних знань та практичних умінь. На одному з перших місць було володіння професійним мовленням.

Надзвичайно великого значення надавав слову вчителя В. Сухомлинський: «У руках вихователя слово - такий же могутній засіб, як музичний інструмент в руках музиканта, як фарби в руках живописця, як різець i мармур в руках скульптора» [802]. Культура слова, за В. Сухомлинським, виховує емоційну культуру, яка впливає на загальну поведінку людини. Педагог прагнув того, щоб «це життєдайне джерело - багатство рідної мови - було відкрите для дітей 3 
перших кроків їхнього шкільного життя», домагався, щоб «діти відчували красу слова, дбали про його чистоту» [802].

В. Сухомлинський закликає вчителів бути надзвичайно обережними, «щоб слово не стало батогом, який, торкаючись ніжного тіла, обпалює, залишаючи на все життя грубі рубці. Слово оберігає душу... тільки тоді, коли воно правдиве i йде від душі вихователя, коли воно позбавлене фальші, упередженості...» [802].

Більшість рекомендацій стосовно вироблення цінних якостей вчительського мовлення не втратила свого значення і нині.

Пізніше різні аспекти проблеми культури вчительського мовлення висвітлювалися на сторінках численних монографій (Н. Бабич, В. Гриньова, А. Капська, Н. Кічук, А. Ліненко, С. Сисоєва та ін.), дисертаційних досліджень (А. Азарова, Д. Балдинюк, Л. Головата, Л. Дерев“янко, Л. Зінченко, О. Кретова, В. Каплінський, О. Попова, Л. Струганець, В. Усатий та ін.).

Не залишалися осторонь цієї проблеми й автори статей у науковометодичних фахових журналах (Н. Бабич, Л. Батюк, О. Біляєв, М. Васильєва, А. Коваль, Р. Колесникова, Я. Король, Т. Ладиженська, М. Лазарев, В. Мельничайко та ін.).

Аналіз праць свідчить про широту діапазону проблематики професійної підготовки вчителя початкової школи (О. Абдулліна, Є. Бєлозерцев, В. Беспалько,
С. Домбровський,
В. Кан-Калик,
Л. Коваль,
В. Козлова, А. Крамаренко, Н. Кузьміна та ін.). Окремі 3 них присвячено питанням готовності фахівця до викладання різних навчальних предметів у початковій ланці школи (С. Звєрева, Н. Істоміна, Л. Кейран, Ю. Колягін, М. Львов, А. Пишкало, В. Разумовський, А. Усова та ін.).

Вивчення наявної літератури дозволяє визначити основні напрямки проведення досліджень, а саме:

- розробка професіограми і кваліфікаційної характеристики вчителя
(Г. Михалевська,
Є. Осовський,
Л. Подимова,
В. Сластьонін,
Л. Спірін,
О. Щербаков та ін.); 
- дослідження проблеми формування особистості педагога в процесі його професійної підготовки (Т. Амельченко, Т. Ахмаєв, С. Баранов, Г. Волікова, В. Докучаєва та ін.);

- дослідження змісту, форм і методів засвоєння теоретичних знань і формування педагогічних умінь 3 окремих видів діяльності вчителя початкової школи (Н. Воскресенська, Т. Зацепіна, Л. Коваль, Н. Лаврова, М. Львов, Н. Максименко, А. Пишкало, Л. Стойлова, С. Тадіян, І. Шапошнікова та ін.); - забезпечення готовності студентів педвузу до розвитку творчої активності молодших школярів (Д. Іванова), педагогічного спілкування (О. Кіліченко, Г. Ковтун);

- 3`ясування умов формування монологічного мовлення майбутніх учителів початкових класів (М. Соловейчик, Н. Мартинович та ін.).

Розвиткові професійного мовлення студентів присвячені дослідження Л. Барановської， Г. Бондаренко， С. Вдовцової， Л. Головатої， І. Дроздової, О. Златів, Н. Івашкіної, О. Кретової, Л. Лучкіної, Т. Окуневич, Л. Струганець, Н. Тоцької та ін. Професійне мовлення вивчали науковці різних галузей (лінгвісти, психологи, соцолінгвісти, лінгводидакти тощо), тому й характеризують його, підкреслюючи саме ті особливості, які властиві конкретній науці або пов'язані з тим чи іншим видом професійної діяльності. Зокрема, у працях Н. Бабич, Ф. Бацевича, О. Біляєва, А. Богуш, Б. Головіна, О. Заболоцької, М. Ілляша, А. Коваль, Л. Мацько, Т. Ладиженської, Л. Паламар, М. Пентилюк, О. Пономарева, Г. Сагач, О. Семеног, Т. Симоненко, Л. Струганець, Н. Тоцької та ін. подані характеристики мовлення, сформованість яких є передумовою його дієвості, а отже, дає підстави вважати їх основою професійного мовлення. Чимало досліджень присвячено формуванню професійного мовлення студентів у процесі вивчення української мови, але вчені переконували, що однієї лінгвістичної підготовки для цього замало, необхідні спецкурси, дисципліни вільного вибору студентів, комплекс яких забезпечить вироблення необхідних умінь і навичок. 
Професійне мовлення - це спілкування певної групи людей, лексика яких спирається на професіоналізми відповідного фаху. Професіоналізмами вважаються слова, словосполучення або звороти, властиві певній групі людей, об’єднаних спільною діяльністю. Вони виконують важливу номінативнокомунікативну функцію, оскільки точно називають предмети, явища, процеси. Значна частина професіоналізмів з часом стає термінами, які позначають поняття певної галузі науки, культури тощо [775, с. 56-57]. Ми погоджуємося з думкою I. Дроздової про те, що одним 3 найважливіших показників професійного мовлення студентів має бути точність. Це пов'язано глибиною знань, фаховою та науковою ерудицією, знанням мови професії [777, с. 44].

Дослідники (Г. Апресян, Н. Бабич, Б. Головін, А. Коваль, Л. Мацько, М. Пентилюк та ін.) до комунікативних якостей мовлення, що визначають рівень професійного мовлення студентів, сприяють саморозвитку й самореалізації, формуванню фахової досконалості особистості, відносять такі: правильність (нормативність), логічність, ясність, чистоту, виразність, доречність, достатність, емоційність (експресивність). Учителеві початкової школи в процесі фахової підготовки слід набути на високому рівні усіх зазначених якостей. Зокрема, дотримання орфоепічних, акцентуаційних, морфологічних, синтаксичних норм і використання відповідних ритміко-інтонаційних моделей забезпечить передачу важливих смислових та емоційних відтінків висловлювань, стану і настрою мовця, його ставлення до предмета повідомлення i слухачів. Прагматична спрямованість мовлення, його впливовий ефект визначаються набором професійних компетентностей, якими володіє майбутній учитель початкової школи.

Учені намагалися обгрунтувати парадигму видів, форм та рівнів професійного мовлення. Так, під видами мовлення майбутніх учителів початкової школи розумітимемо різні аспекти його мовленнсвої діяльності, що виділяються залежно від характеру мовлення (внутрішнє/зовнішнє), способу організації мовлення (усне/писемне), міри активності (продуктивне/перцептивне) [765, с. 321]. 
Мовлення вчителя досліджувалося в зарубіжній і вітчизняній педагогіці, зокрема вимоги до нього визначені в працях Л. Толстого, К. Ушинського, В. Водовозова, М. Пентилюк, М. Стельмаховича, В. Сухомлинського та ін. Його розглядали в контексті комунікативного компонента педагогічної діяльності такі відомі педагоги й психологи: В. Кан-Калик, Н. Кузьміна, О. Леонтьєв, Л. Спірін та ін. Проблеми, пов'язані з оволодінням мовленням, висвітлювалися в працях, присвячених вивченню компонентів педагогічної техніки й педагогічного спілкування. Спинимося детальніше на характеристиці кожного аспекту формування професійного мовлення майбутніх учителів сучасної початкової школи.

Психологи переконують, що професійне спілкування обов'язково супроводжується певними змінами в стосунках, мотивах поведінки як з боку молодших школярів, так і самого педагога. Залежно від характеру взаємодії учні позитивно або негативно реагують на почуту інформацію, що, безумовно, не може не впливати на вчителя. У діалозі він дізнається про нові аспекти стосунків, що неминуче призводить до роздумів, узагальнення професійного досвіду, необхідності додаткової інформації тощо. Усе це, безумовно, спонукає вчених приділяти належну увагу стилям педагогічного спілкування, професійно значущим якостям педагога (любов і повага до дітей, громадянське почуття обов'язку, справедливість, довіра до молодших школярів тощо), перцептивногностичним умінням i навичкам, педагогічним здібностям, тренінгам спілкування, заняттям 3 техніки мовлення. Відзначаємо, що в контексті спілкування залишається не розробленою проблема професійного мовлення, його внутрішньої ланки, вдосконалення якої $є$ пріоритетним порівняно із зовнішнім. Відповідно психологами розроблена концепція професійного мовлення, складовою якого є внутрімовленнєва ланка, яка містить інформацію про специфіку, класифікацію основних мовленнєвих засобів, емпіричні дані про ступінь їх вираження в поєднанні з характеристикою сприйняття молодшими школярами, теоретичне обгрунтування понятійного апарату процесів говоріння й розуміння. 
Аналіз наукової літератури дозволив сформулювати основні положення, які забезпечать успішне розв’язання проблеми:

основний критерій ефективності мовлення - рівень глибини й повного розуміння слухачами;

професійне мовлення вчителя - єдність внутрімовленнєвої ланки і зовнішнього мовлення; причому перевага віддається внутрімовленнєвому компоненту, який визначає зміст висловлювання, його адекватність умовам взаємодіі;

професійне мовлення вчителя має за мету взаєморозуміння; важливою умовою iї досягнення $\epsilon$ знання про характер функціонування відповідних психічних механізмів;

- рефлексивне відношення до власного мовлення формується ефективніше, якщо оптимально поєднувати загальний і конкретний матеріал, які розкривають суть професійного мовлення [778, с. 16].

Ураховуючи те, що мовлення є важливим знаряддям діяльності для багатьох професій, особливу роль ми все ж таки відвели дослідженню мовленнєвої специфіки. У результаті аналізу наукових джерел констатуємо, що мовленню вчителя притаманні такі ж якості, як лекторському, акторському, але в кожній 3 цих професій йому відводиться своя роль. Професійне мовлення виконує досить унікальні функції, але характерне для конкретної діяльності їх відношення може визначити мовленнєву специфіку - інтенсифікувати розвиток певної групи мовленнєвих якостей. Оскільки відомі з них не піддавалися систематизації, на нашу думку, не завадило б визначити таку основу для впорядкування їх. Вивчення наукової літератури дозволило зробити висновок, що таким підгрунтям можуть бути образи, емоції й знаки, кожен 3 яких виконує відображувальну й регулятивну функції. Одні якості системи виявилися більше пов'язаними 3 образною (образність, мовне багатство, доступність для розуміння), інші - $з$ емоційною (емоційність, наказовість, тактовність), треті - зі знаковою (свідомість, інформативність, точність) сферами психіки. Крім того, особливе місце в цій системі відведено динамічності й непідготовленості, які 
характеризують мовлення й водночас є свого роду суб’єктивними умовами, що забезпечують оптимальну реалізацію зазначених вище груп якостей.

Вважаємо за доцільне спинитися на встановленні зв’язків між мовою і мисленням, оскільки, на нашу думку, вони відіграють важливу роль у формуванні вчительського мовлення. Цілком погоджуємося 3 думкою О. Леонтьєва про те, що мовленнєвий механізм складається з шести частин:

- механізму мотивації та ймовірного прогнозування мовленнєвої діяльності;

- механізму програмування мовленнєвої діяльності;
— $\quad$ механізму переходу від плану програмування до граматичносинтаксичної структури речення;

- механізму пошуку потрібного слова за семантичними й звуковими ознаками;

$$
\begin{aligned}
& \text { - } \quad \text { механізму моторного програмування до заповнення їі звуками; } \\
& \text { — } \quad \text { механізму забезпечення реального звучання мови }[788, \text { с. } 10] .
\end{aligned}
$$

Як зазначає Л. Паламар, існує два типи мовлення: розгорнуте і внутрішнє. Розгорнуте - це мовлення просте, яке характеризується спрощеним синтаксисом, мінімумом синтаксичних членувань.

Внутрішнє мовлення - це пошукове мислення, якому вчитель під час професійної підготовки прагне навчитися [792, с. 81].

Кваліфікувати мовлення як діяльність уможливлюють, по-перше, різні варіанти введення його в життєві ситуації (в одних мовлення виконує функцію діяльності, а в інших - виду діяльності), а, по-друге, характеристика джерел мотивації мовлення, що свідчить про активну діяльність людини у своїх прагненнях досягти певної мети.

Мовлення в системі діяльності може займати різне місце, зокрема, засобу планування мовних чи немовних дій, мовних висловів.

О. Леонтьєв, розглядаючи діяльність як засіб соціальної детермінації психіки людини, пропонує таку будову діяльності: 
○ «це те, що відрізняє одну діяльність від іншої. Воно складається 3 розмежування предметів, які називаються мотивами»;

○ у структуру діяльності входять їі складники - «дії». Вони розуміються як процес, підпорядкований свідомій меті, а способи здійснення мети - операції [786, c. 161].

Професійне мовлення - це процес та результат мовленнєвої діяльності, яка, крім реалізації загальних вимог до культурного мовлення, передбачає педагогічну цілеспрямованість, спирається на обумовлені нею розуміння i врахування причиново-наслідкових зв’язків під час добору та компонування мовних засобів і орієнтується на професійні умови, де вона реалізується, коли перебудовує чи закріплює виховні стосунки.

Безумовно, на будь-який з аспектів педагогічного мовлення впливають три фактори:

\section{- педагогічна діяльність; \\ - педагогічне спілкування; \\ - ова, яка обумовлює можливості й специфіку цієї діяльності.}

Оскільки мовлення — це процес говоріння, тобто користування мовою (як знаковою системою) кожною конкретною особистістю, то професійне мовлення вчителя - це процес, спрямований на оптимальне вирішення як конкретних педагогічних завдань, так і на досягнення мети виховання особистості учня загалом. Підставою для такого визначення можна вважати слова О. Леонтьєва про те, що проблема формування професійного мовлення має два аспекти: «...3 одного боку, слід відпрацьовувати мовленнєві навички, мовленнєві автоматизми, необхідні для будь-якого мовлення незалежно від його призначення та способу побудови; з іншого - формування мовленнєвих умінь, тобто саме ті, які роблять мовлення відповідним меті, придатні для вирішення певного завдання» [787, с. 75]. Саме цим, на нашу думку, професійне мовлення вчителя відрізняється від усіх інших типів мовлення, наприклад, мовлення інженера, науковця, лікаря тощо. Мета, на досягнення якої спрямований процес взаємодії, і визначає його специфіку. 
Основою формування мовленнєвої діяльності вчителя є обмін репліками, практична діяльність, осмислення власного мовлення й розуміння співбесідника.

Цілком співзвучне 3 нашими міркуваннями розуміння О. Леонтьєвим мовлення як діяльності. Кваліфікувати дозволяють, по-перше, різні варіанти введення мови в життєві ситуації, причому в одних мовлення виконує функцію діяльності, а в інших - ii виду; по-друге, характеристика джерел мотивації мовлення свідчить про активну діяльність людини у своїх прагненнях досягти певної мети [787, с. 77].

Мовлення в системі діяльності може займати різне місце, зокрема, i планування мовних і немовних дій, тобто формування плану дій у мовній формі.

О. Леонтьєв слушно пропонує розрізняти «внутрішнє мовлення», «внутрішнє програмування», «внутрішнє промовляння», «внутрішній вислів», бо спочатку вислів програмується, а потім реалізується в мовному коді. Механізми програмування такі: вибір слова; перехід від відібраного матеріалу до його реалізації; граматичне прогнозування; закріплення граматичних закономірностей.

Важливим стимулом вислову $\epsilon$ мовна інтенція, яка не ідентична семантичній стороні висловлювання, бо семантична сторона формується на поєднанні лексем, необхідних для висловлення думок. Мовна інтенція спонукає мовця до участі в спілкуванні.

Л. Виготський називав мовну інтенцію «відчуттям завдання», «туманним бажанням мовця висловитися» [771, с. 107]. Окрім того, вчений назвав такі факти, що формують мовну інтенцію: мотивація мовної діяльності; обставинна ситуація; попередній мовний досвід; завдання, яке необхідно реалізувати, ураховуючи вид мовлення та його форму.

У свою чергу В. Сухомлинський у багатьох своїх працях наголошував на ролі вчительського мовлення: «Кожне слово, яке звучить у стінах школи, має бути продуманим, мудрим, цілеспрямованим» [801, с. 140]. 
Для відомого психолога Л. Виготського в проблемі мислення і мовлення основним $€$ питання відношення думки і слова. Слово - єдність звуків і значення, а також усіх засобів, притаманних мовленню і мисленню загалом [771].

Як доказ того, що думки існують лише в мовленнєвій формі, у психологічній літературі стверджується: немає іншої форми існування думок, крім мовлення, оскільки тоді можна будо б говорити про наявність «оголених думок», не втілених у мовленнєвій формі.

Думки людини - це скорочені дії, які спираються на ті чи інші знакові опосередкування; а мовленнєві форма існування думки - це найбільш виправдана соціально контрольована форма думки, пристосована для трансляції в просторі і часі [766, с. 18].

Розуміння мовлення як певного виду мовленнєвої діяльності вперше було дано Л. Виготським і знайшло своє подальше розкриття в дослідженнях О. Леонтьєва. Мовленнєва діяльність починається мотивом і планом, a завершується результатом, досягненням поставленої мети.

Спосіб створення і формулювання думки за допомогою мови може суттєво змінюватися, перш за все, залежно від мети комунікації, тобто від того, кому адресоване висловлювання - собі чи співбесіднику. За умови адресування мовлення співбесіднику обов'язковою є його присутність. У кожному з названих випадків спосіб формування і формулювання думки виявляється по-різному, наприклад, внутрішньому і зовнішньому (усному чи писемному) мовленні.

Ф. Гоноболін у своїх працях виділяє такі якості вчительського мовлення:

- ті, які забезпечують його правильність (відповідність лексичним, акцентуаційним, граматичним нормам);

- такі, що обумовлюють дієвість мовлення, зокрема змістовність (ясність, простота, доступність), чітка система викладу, послідовність думок, дотримання поступовості в труднощах тощо;

- спрямованість мовлення на слухача, яке вимагає врахування його сприйняття і розуміння;

- емоційність, переконливість і навіювання [773]. 
Розвиваючи цю думку, відомий психолог і педагог I. Синиця у своїх працях неодноразово відзначав, що «слово - головна зброя вчителя». Крім того, тезу «яке мислення людини, таке i його мовлення» [799, с. 13-14] можна переформулювати так: «Яке мовлення у людини, таке його мислення».

У структурі інтелекту вчителя значна роль відведена внутрішньому мовленню, за допомогою якого відбувається логічна перебудова чуттєвих даних, їх усвідомлення і мотивація в певну систему понять і суджень.

Як свідчать наукові джерела, вчені по-різному розглядають поняття «професійне мовлення». Так, В. Наєр характеризує його як певну «зміну мовного регістра». Загалом мова (інструмент) залишається такою ж національною мовою, але в конкретних (професійних) умовах вона змістовно репродукується, стає залежно від галузі знань і предмета спілкування монотематичною, насичується спеціальними словами і виразами, використання яких передбачає такий же професіоналізм, тобто компетентність [790].

В. Даниленко відзначає, що в професіоналів конкретної галузі знань подібна «зміна регістрів» здійснюється природно й автоматично, однак у спілкуванні фахівців різних сфер діяльності механізм залучення мови зі спеціальною метою не спрацьовує автоматично, особливо тоді, коли сфери професійної діяльності достатньо далекі одна від іншої [776].

Дещо іншої думки притримується М. Грабовський, вважаючи, що важливим компонентом професійного мовленнєвого акту є адресат, партнер по комунікації. Психологічні й соціальні особливості статусу мовця та адресата дозволили вченому виокремити як самостійні інтерпрофесійну та інтрапрофесійну комунікації. «Інтерпрофесійна комунікація $є$ мовленнєвим актами, у яких професійні ролі комунікантів не збігаються» [775]. Прикладом може слугувати спілкування типу лікар - пацієнт, учитель - батьки. «Інтрапрофесійна комунікація здійснюється в межах певної соціально-професійності спільноти» [775, с. 15]. Хоча, як зауважує дослідник, слід ураховувати, що комунікація за моделлю «спеціаліст - спеціаліст» неоднорідна, вона включає і однодисциплінарні, і різнодисциплінарні напрями. 
Ми погоджуємося 3 думкою вчених про те, що в професійній сфері спілкування фахівець користується усталеними знаннями засобами спеціальної мови. Розглядаючи цю особливість комунікації, розроблені своєрідні моделі професійних мов, які складаються, по-перше, з наукової мови; професійної розмовної мови, яка включає, перш за все, певні професійні слова i словосполучення і слугує переважно для повсякденного спілкування людей, які працюють у певній галузі.

Нам імпонує таке визначення професійного мовлення: «Це мовна комунікація, яка здійснюється в процесі професійної діяльності». Тому ми розумітимемо під професійним мовленням вчителя початкової школи будь-яке мовне спілкування, що здійснюється під час професійної діяльності педагога [775].

Отже, незважаючи на різноманітність підходів до визначення поняття «професійне мовлення», суть їх збігається в одному: професійне мовлення - це, перш за все, комунікація, яка здійснюється за допомогою спеціальних професійно маркованих засобів мови. Основою всіх визначень є компоненти, які характеризують професійне мовлення:

- установка на специфічне спілкування;

- орієнтація на процес безпосередньої комунікації;

- зв'язок професійного мовлення з мовною системою;

- відповідність професійних висловлювань різним стилям і жанрам мови.

Фахівці різних галузей, здійснюючи свою професійну діяльність, використовують, окрім мовлення, різноманітні засоби: інструменти, прилади, машини тощо. Професія педагога - одна серед небагатьох, де слово - єдиний дієвий засіб фахової самореалізації, що вимагає досконалого володіння мовленням. Як засіб передачі інформації професійне мовлення вчителя в той же час $є$ інструментом, за допомогою якого розв’язуються завдання навчання i виховання. Тому будь-яке педагогічне спілкування передбачає словесну взаємодію між учителем та учнями, що визначає особливий підхід до вибору інформації та її інтерпретації. Таким чином, головне в мовленні вчителя - якість 
його змісту, що забезпечує високі результати педагогічної діяльності, а згодом і педагогічну майстерність.

Суспільство висуває такі вимоги до мовлення вчителя початкової школи:

- визначати зміст і форму передачі думок відповідно до рівня розвитку молодших школярів (мислення, загальна та мовна культура);

- дотримуватися законів мови під час спілкування;

- ураховувати мовленнєві і психологічні закони до успішного досягнення мети спілкування.

Професійне мовлення вчителя початкової школи передбачає індивідуалізацію й диференціацію педагогічного впливу у зв'язку з різними функціями і конкретними діями педагога, що дозволяють йому гнучко й адекватно до ситуації реалізувати професійні позиції й ролі.

Управлінський потенціал мовленнєвого впливу розширюється на різних спілкування (з молодшими школярами, колегами, батьками), що забезпечує різноманітність наукових досліджень.

Слід відзначити, на нашу думку, серед інших концепцію М. Вашуленка щодо адаптації професійного мовлення вчителя початкової школи, пов’язаної 3 побудовою синонімічних рядів у дидактичному мовленні шляхом гнучкості, партнерства й динамічності структури та змісту мовленнєвих дій комунікативного впливу. Це дозволяє педагогові повноцінно реалізувати навчальні функції залежно від освітньої мети, типу уроку, можливостей педагога й підготовленості учнів.

Усе зазначене вище переконливо доводить необхідність особливої уваги до мовленнєвої підготовки майбутнього вчителя початкової школи. До умов ефективності цього процесу у вищій школі, а згодом і досягнення необхідного рівня професійного мовлення слід віднести такі:

- пріоритет особистісного навчання, коли педагогічна технологія розглядається як засіб самовираження суб'єкта в професії;

- організація повноцінної дидактичного впливу на всебічний розвиток особистості студентів; 
- діалогізація й рефлективність в організації педагогічної взаємодії суб’ єктів освітнього процесу на основі співробітництва;

- проблемність і творчість у засвоєнні змісту освіти й цілеспрямоване оволодіння технологіями спілкування;

- етапи професійної підготовки реалізуються в логіці становлення комунікативної програми педагога: вплив, взаємовплив, взаємодія;

- акцентування уваги на вміннях педагога гнучко перебудовувати позиції та ролі в спілкуванні, адекватно ситуації діяти з позиції об'єкта й суб'єкта.

Як свідчить досвід викладацької роботи, випускники педагогічних факультетів і вчителі початкової школи мають труднощі під час спілкування 3 молодшими школярами. Це відбувається найчастіше тоді, коли учні порушують дисципліну на уроці, оскільки вчитель не приділяє належної уваги залученню дітей до співпраці; порушення дисципліни молодшими школярами на уроці та перервах; проявах дитячої заздрості тощо.

Неправильна етично-педагогічна поведінка вчителя може спровокувати виникнення конфліктів. На основі зазначеного вище можна виокремити такі помилкові дії вчителя:

- маніпулювання сприйняттям ситуації, що свідчить про неправильне усвідомлення чи викривлення фактів. Про таке сприйняття ситуації вчителем свідчать його фрази: «Ти ніколи не виконуєш домашні завдання», «Ти завжди забуваєш свій щзоденник дома», «У твоєму диктанті безліч помилок» тощо. Категоричність висловлювань посилює їх негативний зміст, викликає у вихованця образу, бажання помститися, а головне зневіру у власні можливості. У результаті таких дій вчитель важко спрогнозувати ситуацію, але точно можна стверджувати, що вона буде діаметрально протилежною очікуваній;

- актуалізація неприємних ситуацій, коли вчитель нагадує учневі про минулі проблеми, які ще досить болісні для нього. Позбавлені будь-якого виховного впливу такі фрази вчителя: «Я думала. Що цее був поодинокий випадок, а, виявлясться, це твій характер», «Я тебе захищала від однокласників, а тепер 
розумію, щуо цього не варто було робити» тощо руйнують особистість, на підсвідомому рівні поновлюють негативні відчуття;

- безпосереднє протиставлення типове для ситуацій, коли педагог намагається продемонструвати свою перевагу, але робить це, принижуючи гідність вихованців, їхнє право на самостійність і самовизначення. Така позиція завуальована за словами: «Я вчитель, а ви - тільки учні», «Я людина доросла, тому краще знаю» тощо;

- різні погляди виникають і тоді, коли оцінка за знання базується, перш за все, на оцінці поведінки або занижується без будь-яких пояснень вчителем.

Отже, вчитель початкової школи не повинен припускатися етикопедагогічних помилок у спілкуванні з учнями, оскільки такі дії закріплюються на рівні свідомості, негативно впливаючи на професійну кар'єру, формування стратегії педагогічної діяльності загалом і спілкування зокрема.

В умовах особистісно-орієнтованого навчання виникає необхідність в основу критеріїв ефективної педагогічної діяльності ввести не тільки оцінки успіхів у навчанні дитини, а й відповідні виміри зусиль педагога щодо мотивації цієї діяльності, педагогічної культури, професійного мовлення.

Ефективність формування професійного мовлення майбутніх учителів початкової школи суттєво залежить від організаційних форм навчальної роботи у вищій школі. Основними на сьогодні є лекції; практичні, семінарські, лабораторні заняття; спецкурси; педагогічна практика, консультації; контрольні, курсові, дипломні та магістерські роботи. Особливий вплив на вироблення професійного мовлення, на нашу думку, має педагогічна практика і спецкурси та спецсемінари (дисципліни вільного вибору студента), які передбачають завдання, виконання яких забезпечить готовність педагогів до професійного спілкування. 


\subsubsection{2. Удосконалення мовленнсвих умінь майбутніх педагогів як} основа готовності їх до професійної діяльності в умовах Нової української школи

На основі аналізу наукових джерел (психологічних, лінгвістичних, психолінгвістичних) та власного викладацького досвіду ми запропонували здобувачам першого (бакалаврського) рівня вищої освіти освітньо-професійної програми 013 Початкова освіта факультету психолого-педагогічної освіти та мистецтв Бердянського державного педагогічного університету вибірковий освітній компонент «Професійне мовлення майбутніх учителів початкової школи» [795]. Він сприятиме вдосконаленню вчительського мовлення в процесі професійної підготовки майбутніх учителів початкової школи, а саме тих умінь і навичок, які сприятимуть повноцінному спілкуванню з учнями. Дисципліна передбачає 3 кредити СКТС, тобто 6 змістових модулів.

На лекціях ще раз наголошуємо на тому, що професійне спілкування вчителя початкової школи з учнями - це багатоаспектне педагогічне явище, яке забезпечує результативний процес організації взаємодії та взаєморозуміння між учасниками його учасниками. Зміст i характер педагогічного спілкування вчителя початкової школи відрізняється високим рівнем довіри між суб'єктами взаємодії; динамічністю характеру стосунків; урахуванням вікової та індивідуальної диференціації у взаємовідносинах. Педагогічне спілкування впливає на стан і характер комунікації молодших школярів між собою та іншими однолітками і старшими.

Крім того, на нашу думку, майбутнім учителям початкової школи не завадить нагадати, що на ефективність педагогічного спілкування впливає врахування соціальної значущості педагогічної професії; актуальними потребами молодших школярів у спілкуванні, пов’язаними 3 їх віковими особливостями розвитку; потенційними можливостями навчальних дисциплін початкової школи, визначеними Державним стандартом початкової загальної освіти, особливостями впровадження ідей Концепції НУШ. 
На практичних заняттях основну увагу зосереджуємо на формуванні в майбутніх учителів початкової школи вмінь, які забезпечать повноцінне професійне спілкування з учнями:

на етапі моделювання комунікативної взаємодії педагога 3 дітьми він має володіти такими вміннями: вибирати найбільш доцільний щодо класу загалом і кожного учня зокрема спосіб поведінки й спілкування, який підготував би молодших школярів до сприйняття інформації; правильно планувати своє мовлення (тобто зміст самого повідомлення), добирати необхідні засоби для його корекції (тон, лексику тощо);

на етапі організації безпосереднього спілкування 3 учнями початкової школи педагогові необхідні такі вміння: налаштовувати дітей на спілкування, привертати їхню увагу, інтерес до предмета, який вивчається; оптимально побудувати власне мовлення відповідно до психологічних особливостей молодших школярів;

на етапі управління педагогічним спілкуванням педагог застосовує уміння: розподіляти і підтримувати увагу учасників взаємодії; цілеспрямовано підтримувати спілкування застосуванням елементів бесіди, риторичних питань;

на етапі аналізу проведеної системи спілкування і моделювання подальшої комунікації вчителеві потрібний комплекс таких умінь: аналізувати вчинки i мовленнєву поведінку молодших школярів; вносити необхідні корективи у процес взаємодії тощо.

Крім того, потенційними можливостями практичних занять з вибіркового освітнього компонента «Професійне мовлення майбутніх учителів початкової школи» для формування вмінь студентів $\epsilon$ :

реалізація комунікативного підходу, а саме особистісноорієнтованого навчання, яке передбачає толерантне ставлення до них, створення позитивного емоційного настрою; надання зразків мовленнєвої взаємодії учителя початкової школи та учнів; набуття досвіду мовленнєвого партнерства; 
організація занять 3 урахуванням прагматичного, когнітивного i педагогічного компонентів, які визначають зміст i характер комунікації, роботу з різними видами інформації;

навчання техніці спілкування, яка базується на використанні слухання і виголошування (монологічна та діалогічна форми мовлення) текстів як засобу формування педагогічного спілкування майбутніх учителів початкової школи.

На практичних заняттях студенти поглиблюють свої знання про техніку спілкування, яка, на нашу думку, відіграє важливу роль в ефективності взаємодії вчителя початкової школи з учнями. Зокрема майбутні вчителі початкової школи визначають техніку спілкування як сукупність умінь, навичок, прийомів, які дозволяють управляти педагогічним процесом. Комплекс можна поділи на дві групи компонентів:

ті, які пов'язані 3 умінням педагога керувати своєю поведінкою (мовлення, міміка, пантоміміка, вираження своїх емоцій, увага, спостережливість тощо);

уміння впливати на особистість і колектив.

На практичних заняттях майбутні вчителі мали змогу попрацювати над формуванням блоків техніки спілкування:

звертання (нейтральне, ніжне, раціональне, жартівливе, абсурдне, суворе);

ступінь причиновості (ігнорування етикету, коректність, люб’язність, делікатність, тактовність);

стиль поведінки (суто формальний, неформальний, простий); вираження почуттів (перебільшене, вільне, стримане);

мовлення: а) дикція (коректна, вільна); б) діалогізація (симетрія у спілкуванні, асиметрія в бік учня, асиметрія в бік учителя); в) жестикуляція (помірна, надмірна, відчайдушна); г) мовлення (правильне, літературне, народне); г) стиль мовлення (науково-навчальний, лаконічний, патетичний, риторичний). 
Контрольний зріз, а також анкетування студентів після проведення занять 3 вибіркового освітнього компонента «Професійне мовлення вчителя початкової школи» і виробничої практики в початковій школі дозволили визначити педагогічні умови, які забезпечать ефективність педагогічного спілкування 3 молодшими школярами:

організаційне перетворення занять зі студентами 3 використанням методів і прийомів, спрямованих на зміну форм, змісту, характеру діяльності і спілкування учасників педагогічної взаємодії;

провідна роль викладача під час організації суб'єктсуб’єктної взаємодії зі студентами, яка забезпечує трансляцію цілісного ставлення до партнерів по спілкуванню;

усвідомлення майбутніми вчителями початкової школи значущості умінь, які забезпечать успішне професійне спілкування з учнями, що стимулюватиме формуванню такими вміннями;

збагачення власного комунікативного досвіду студентів за рахунок реалізації взаємозв'язку ділового і дружнього спілкування на заняттях.

Важко переоцінити й значення праць 3 культури мовлення для формування іiї в майбутніх учителів початкової школи. Адже вони мають ознайомити учнів із законами і правилами мови, дати перші уявлення про «хороше і правильне» мовлення, навчити читати й розуміти художні тексти, сформувати основу писемного мовлення. Усе це може забезпечити лише авторитетний педагог, який є взірцем для наслідування молодшими школярами.

На жаль, рівень мовленнєвої культури майбутніх і молодих учителів початкової школи, як свідчать анкетні дані, щоденники спостережень студентівпрактикантів, конспекти уроків та позакласних заходів тощо, гальмує якісне педагогічне спілкування з учнями і батьками. Протягом останніх 5 років ми спостерігали й аналізували мовлення студентів денної й заочної форм навчання, проводили спеціальні зрізи, вивчали типові й індивідуальні помилки й недоліки, щоб у процесі подальшої роботи над формуванням професійного мовлення враховувати їх. Окрім того, ми зробили такі висновки: 
1. Формування професійного мовлення майбутніх учителів початкової школи слід розглядати як процес оволодіння комплексом узагальнених мовленнєвих умінь i навичок, що забезпечать створення ефективних усних і письмових текстів з урахуванням мети, завдань і суб’єктів комунікації.

Зважаючи на універсальний характер узагальнених мовленнєвих умінь і навичок, що забезпечують професійне мовлення учителів початкової школи, під час визначення змісту роботи над його формуванням у процесі фахової підготовки необхідна конкретизація. Здійснювати їі доцільно на основі визначення актуальних соціальних ролей (студента і вчителя початкової школи) і кінцевої мети вищої педагогічної освіти, яка передбачає комплекс компетентностей педагога, де комунікативна є однією з основних.

3. Формування професійного мовлення майбутніх учителів початкової школи буде ефективним, якщо максимально реалізувати міжпредметні зв’язки лінгвістичних і психолого-педагогічних дисциплін, які сприятимуть виробленню компонентів мовленнєвої культури; забезпечити наявність зразкового мовленнєвого середовища і єдиних вимог до мовлення впродовж усього періоду навчання; підгрунтям вироблення умінь і навичок буде теоретичне осмислення законів мови і мовлення; пріоритетними в процесі навчання обрати комунікативно-діяльнісний, особистісно-орієнтований та індивідуальний підходи.

Найбільші труднощі виникли під час створення зразкового мовленнєвого середовища і забезпечення єдиних вимог до мовлення студентів. Це можна пояснити, по-перше, тим, що частина здобувачів вищої освіти послуговується російською мовою в повсякденному житті, ураховуючи зрусифікованість регіону; по-друге, мало свій вплив явище білінгвізму. Звичайно, це, з одного боку, знизило ефективність роботи, а 3 іншого, дозволило переконатися на практиці в іï значущості.

Для того, щоб об’єктивно оцінити професійне мовлення майбутніх учителів початкової школи, використовували методи, традиційні для наукового 
дослідження: спостереження, різноаспектний аналіз усного (відеозаписи уроків студентів-практикантів) й писемного мовлення (твори на різні теми, есе, конспекти уроків, щоденник спостережень, реферати, доповіді тощо), анкетування першокурсників і випускників. Судячи 3 того, що критично оцінюють власне мовлення випускники, називаючи його «далеким від взірцевого», проблема формування професійного мовлення майбутніх педагогів не вирішується під час їхньої фахової підготовки. Тому, уточнюючи запитання, адресоване випускникам «З якими мовленнєвими труднощами Ви зіткнулись під час педагогічної практики?», ми 3‘ясували: майбутнім учителям початкової школи найбільше бракувало вмінь точно формулювати думки, доступно викладати матеріал (особливо той, який вивчався ними у процесі навчання в 3ВО), тобто провести трансформацію навчального матеріалу відповідно до вікових особливостей молодших школярів, логічно викладати думки. Це свідчить про недосконалість мовленнєвої підготовки здобувачів вищої освіти та недостатність її професійного спрямування.

Отже, аналіз досліджуваного матеріалу дозволив зробити висновок про те, що професійне мовлення майбутніх учителів початкової школи потребує вдосконалення. Так, у конспектах уроків і виховних справ студенти денної й заочної форм (а це вчителі початкової школи) припускаються на трьох сторінках у середньому 5-7 орфографічних і пунктуаційних помилок; 6 мовленнєвих недоліків; в усних і письмових текстах часто немає плану й порушена послідовність викладу думок, часті тавтологія та мовленнєві штампи; неправильно вживаються слова іншомовного походження, терміни. Звичайно, таке мовлення важко назвати взірцевим, тому під час професійної підготовки майбутніх учителів початкової школи варто цілеспрямовано формувати їхню мовленнєву компетентність.

Такі завдання вимагали розглядати професійне мовлення як об'єкт педагогічної роботи й конкретизації мовленнєвих умінь i навичок, які забезпечать комунікативну компетентність учителя початкової школи. При цьому ми враховували психолінгвістичний аспект породження й сприйняття 
мовленнєвого висловлювання. Зокрема, ураховувалася теорія мовленнєвої діяльності, яка дозволяє розглядати мовлення як сукупність дій, об’єднаних певною метою й підпорядкованих діяльності. Кожна така дія складається 3 окремих операцій і є різновидом інтелектуального акту, який включає 4 етапи: орієнтування, планування, реалізацію і контроль.

Не завадить здобувачам вищої освіти усвідомити й те, що здатність здійснювати мовленнєву дію згідно з оптимальними параметрами називається мовленнєвим умінням, а здатність здійснювати оптимальним способом ту чи іншу операцію - мовленнєвою навичкою. Як правило, навички забезпечують технічний і граматичний аспект мовлення й характеризуються автоматизмом; уміння мають творчий характер, передбачають свідоме й гнучке використання навичок, ураховуючи мету, завдання й адресата спілкування.

Спираючись на етапи мовленнєвої дії (орієнтування, планування, реалізація, контроль), ми визначили ті вміння i навички, які забезпечать формування професійного (усного і писемного) мовлення майбутніх учителів початкової школи. При цьому бралося до уваги те, орієнтирами виступали мета і зміст вищої педагогічної освіти, необхідність усвідомлення ролі вчителя початкової школи.

Перелік умінь і навичок професійного мовлення свідчив про те, що сформувати їх лише на заняттях 3 однієї або кількох окремих навчальних дисциплін не можливо. Зрозуміло, що робота над виробленням умінь і навичок професійного мовлення, які $\epsilon$ частиною фахової компетентності вчителя початкової школи, відкриває реальні можливості міжпредметних зв’язків сучасної вищої школи. Тлумачення професійного мовлення як найважливішого складника фахової компетентності майбутнього вчителя початкової школи, яке забезпечує всі сфери педагогічного спілкування, дозволяє стверджувати, що саме воно є фундаментом його професійної майстерності. Відповідно й процес формування професійного мовлення здобувачів вищої освіти доцільно організувати так, щоб спочатку засвоїлися універсальні знання мови й мовлення (лінгвістичні дисципліни), а потім на їх основі створювалися багатокомпонентні педагогічні вміння (психолого-педагогічні, методичні дисципліни, спецкурси). 
Здійснення наступності в цьому може реально сприяти усвідомленню майбутніми вчителями об'єктивного взаємозв’язку між лінгводидактичними й психолого-педагогічними дисциплінами, що, у свою чергу, сприятиме педагогізації перших і результативності других.

Оскільки такий підхід не суперечить загальній логіці здійснення фахової підготовки в закладах вищої освіти, вважали за потрібне, вивчивши навчальні програми традиційних для освітньо-професійних програм 013 Початкова освіта освітніх компонентів, поділити процес формування професійного мовлення майбутніх учителів початкової школи на три етапи: початковий, основний, заключний.

На початковому етапі здобувачі вищої освіти систематизують знання понять «культура мовлення»; знайомляться з вимогами, які висуваються до мовлення майбутніх учителів початкової школи; засвоюють норми сучасної української літературної мови. Окрім того, визначається вихідний рівень володіння необхідними уміннями й навичками усного та писемного мовлення, встановлюються типові й індивідуальні недоліки мовленнєвого розвитку кожного здобувача, здійснюється корекція; удосконалюються вміння виразного читання, ораторської майстерності, складання усних і письмових текстів різних стилів, але особливо акцентується увага на науковому стилі і його під стилях (реферат, доповідь, презентація, повідомлення, усна відповідь, конспект тощо). Важливим завданням, яке ставили на цьому етапі, - сформувати в майбутніх учителів початкової школи адекватну оцінку свого усного і писемного мовлення та усіляке заохочення їх у процесі вироблення відповідних умінь і навичок.

Другий етап передбачав відпрацювання й професіоналізацію мовленнєвих умінь і навичок. Спираючись на знання, засвоєні на попередньому етапі, майбутні вчителі початкової школи безпосередньо формують професійне мовлення: складають конспекти уроків, бесід, планів; аналізують учнівське писемне (зошити, щоденники молодших школярів) й усне (аудіо- та відеозаписи уроків з різних навчальних дисциплін 1-4 класів) мовлення; виразно читають твори різних жанрів тощо. Продовжується робота над виробленням умінь 
складати тексти, ураховуючи адресата спілкування (молодші школярі, батьки, колеги, адміністрація школи тощо), обставини (офіційні/неофіційні) й мету (інформування, переконування, емоційний вплив, спонукання до дії); готувати доповіді для виступів на батьківських зборах, методичних об’єднаннях учителів. Не менш важливою, на нашу думку, є активна педагогічна практика й написання курсових робіт, які логічно завершують цей етап, що дозволяють оцінити значення професійного мовлення майбутнього вчителя початкової школи складника його фахової компетентності.

Заключний етап передбачав узагальнення й осмислення на вищому рівні знань про професійне мовлення, його роль у педагогічній діяльності педагога. Студенти вдосконалюють вироблені на попередніх етапах мовленнєві вміння й навички в процесі виконання складних педагогічних і навчальних завдань. Це залікові уроки з мови й виразного читання, інших дисциплін, проведення різних видів позакласної роботи з молодшими школярами, підготовка виступів перед батьками молодших школярів. Здобувіачі залучаються до участі в проблемних наукових групах, наукових гуртках 3 різних педагогічних, психологічних i методичних проблем; готують тезові повідомлення на наукових і науковопрактичних конференціях; працюють над курсовими й магістерськими (забажанням) роботами. Усе це актуалізує вимоги до професійної культури майбутніх учителів початкової школи.

Отже, аналіз психологічних і лінгводидактичних джерел, а також досвід викладацької роботи на факультеті психолого-педагогічної совіти та мистецтв Бердянського державного педагогічного університету, де готують фахівців спеціальності 013 Початкова освіта, дозволили констатувати необхідність формування професійного мовлення здобувачів вищої освіти як визначального складника їхньої професійної компетентності. Цей процес триває впродовж усього терміну навчання бакалаврату, орієнтовно поділений нами на три етапи: початковий, основний, заключний.

Найбільш вдалим є комунікативно-діяльнісний підхід, який дозволяє не лише збагачувати знання здобувачів, а й формувати необхідні для майбутньої 
професійної діяльності вміння й навички шляхом активного залучення їх до виконання завдань в умовах, максимально наближених до реальних. Саме так можна навчити майбутніх педагогів добирати відповідні мовні засоби, ураховуючи конкретну ситуацію спілкування, адресата, мати й завдань.

Загалом, важливим для нашого експериментального навчання було довести майбутнім учителям початкової школи необхідність постійного вдосконалення професійного мовлення не лише під час фахової підготовки, а й після закінчення навчання у ЗВО. На нашу думку, це актуалізує принципи особистісного й індивідуального підходів у процесі вдосконалення мовленнєвої культури.

Найбільш доцільними формами й методами у формуванні професійного мовлення студентів є проблемні, пошукові, навчально-дослідницькі, інноваційні, тренінгові, метод продукування (комунікативний метод), зокрема такі, що імітують актуальні професійні ситуації, спонукають майбутніх учителів початкової школи контролювати й оцінювати чуже і власне мовлення, активно спиратися самоаналіз і рефлексію, використовувати різні форми співпраці викладача й здобувачів як у навчальній, так і позааудиторній роботі (спілкування за допомогою Інтернет листування), поєднувати групову та індивідуальну роботу. 
DOI 10.46299/ISG.2021.MONO.PED.III.8.14

\subsection{4 Сучасні лекція та семінар: інноваційні методологічні підходи до їх проведення}

Досягнення сучасної науки ставлять перед вищою медичною освітою цілу низку проблем, серед яких є збільшення кількості інформації, якою повинен оволодіти майбутній спеціаліст. Без підвищення рівня фундаментальної підготовки на теперішній час неможливо досягти головної мети перебудови освіти - суттєвого покращання якості підготовки фахівців. Рівень викладання навчального матеріалу має забезпечити опанування студентами та лікарями на етапі безперервного професійного розвитку великого за обсягом інформації матеріалу за одиницю часу та їі використання в процесі як навчання, так і в подальшій практичній діяльності.

Чільне місце у теоретичній підготовці спеціалістів, як на додипломному так i післядипломному етапі, посідає лекція. Нові тенденції, що намітились в реформуванні системи додипломної і післядипломної підготовки, обумовлюють необхідність впровадження в навчальний процес нових форм і методів навчання, які мають сприяти його інтенсифікації, стимулювати розумову діяльність студентів i слухачів установ післядипломного навчання. Сучасна лекція покликана озброїти слухачів знаннями методологічних основ даної дисципліни, ознайомити їх 3 основними етапами становлення i розвитку теоретичних концепцій, i, нарешті, тільки на лекції студент чи слухач може сформулювати чітке уявлення про сучасний стан тієї чи іншої проблеми. 3 огляду на надзвичайно високий темп розвитку сучасної науки, ні один із самих сучасних підручників, посібників чи монографія аналогічного завдання вирішити не зможуть. Не зможуть замінити лекцію навіть найкращим методологічним чином організовані семінарські чи практичні заняття.

Однією із основних форм організації систематичних навчальних занять при викладанні як клінічних, так і теоретичних дисциплін у закладах вищої освіти (ЗВО) є лекція, як носій необхідної інформації 3 того чи іншого розділу відповідної дисципліни. Крім того, лекція є незамінною для систематизації та 
структурування всього обсягу знань, отриманих слухачами з кожної конкретної навчальної дисципліни.

Згідно Вікіпедії (вільна енциклопедія) дано наступне визначення лекції: «лекція - це основна форма проведення навчальних занять, призначених для подальшого засвоєння теоретичного матеріалу».

Залежно від мети та форми або методів викладу навчального матеріалу лекції поділяються на вступні, навчальні, інформаційні, оглядові, проблемні, відкриті, підсумкові, комплексні, клінічні тощо.

Основною дидактичною метою лекції є забезпечення орієнтовної основи для засвоєння слухачами навчального матеріалу. Доцільно відмітити, що наявність певної частини самостійної роботи слухачів на сьогодні є вимогою до організації навчального процесу у вищій школі.

Кожна лекція виконує ряд функцій: інформаційну, стимулюючу, виховну, розвиваючу, методологічну, пояснювальну та сприяє активізації процесу мислення і уваги слухачів; створює умови для самостійного вивчення навчального матеріалу за підручниками, посібниками, керівництвами; формує мотивацію для роботи в пошукових мережах INTERNET.

Лекція повинна мати відповідну структуру і містити такі елементи як: вступ, у якому формулюється мотивація навчання, мета лекції та основні питання даної теми; виклад основного матеріалу; висновки, які надають можливість систематизувати навчальний матеріал і виділити основну ідею; відповіді на запитання слухачів та рекомендації щодо поглиблення самостійного вивчення теми.

Вузловими критеріями оцінки лекції є: зміст, методика, керівництво роботою слухачів, лекторські дані та результативність лекції.

На ефективність лекції позитивно в пливають і деякі чинники довкілля (оптимальне освітлення, відсутність сторонніх звуків, чисте повітря аудиторії, зручні робочі місця, добра акустика, естетичне оформлення аудиторії тощо) та мистецтво лектора (відмінне знання предмету, бажання бути добрим лектором, культура мови, вміння логічно викладати свої думки, наполеглива праця 3 
підготовки кожної лекції, практика і тренування, зовнішній вигляд, вміння налагодити контакт з аудиторією, педагогічний такт тощо).

При підготовці до лекції лектору необхідно чітко визначити цілі і задачі лекції, дати назву у відповідності з навчальним планом і програмою предмета чи курсу, скласти план лекції, а потім конспект з вказівкою переліку літератури i необхідних цифрових даних, підготувати відповідні ілюстративні матеріали тощо.

При читанні лекції викладач зобов’язаний дотримуватись зовнішнього і внутрішнього регламенту занять (початок, кінець, розділи лекції), чіткої структури та виконання плану лекції, доступності та пояснення нових термінів і понять, виділення головних думок і висновків, підведення підсумків в кінці окремих питань та по всій лекції, використовувати технічні засоби навчання тощо.

До читання кожного виду лекції необхідно підходити індивідуально, 3 творчою наснагою, оскільки лекції суттєво відрізняються між собою за метою, змістом та інформацією.

Наприклад, вступна лекціiя знайомить слухачів з метою циклу (курсу), його місцем у системі навчальних дисциплін. Вступна лекція висуває та обгрунтовує основні методологічні позиції курсу, визначає предмет і методи дисципліни, що вивчається. Дуже важливим для вступної лекції є зв’язок теоретичного матеріалу з практичними аспектами роботи спеціаліста. Під час вступної лекції викладач має можливість охарактеризувати підручник та навчальний посібник, які пропонуються для опрацювання; ознайомити слухачів 3 обов'язковою (рекомендованою) літературою. Таким чином, дана лекція орієнтує студентів і слухачів на подальшу самостійну роботу та знайомить з методикою засвоєння циклу.

Тематична лекція - найбільш поширений вид лекції для вищої школи, у якій всебічно розкривається те чи інше питання, висвітлюються головні аспекти наукової проблеми, взаємозв’язок між різними розділами та темами курсу. 
Оглядова лекиія - передбачає систематичне узагальнення та аналіз головних проблем курсу. Як правило, аналіз має бути пов'язаний з практичною роботою слухачів. Таку лекцію рекомендується проводити у кінці вивчення декількох тем, оскільки вона є узагальнюючою. Але оглядова лекція може передбачати також загальне ознайомлення 3 навчальним матеріалом, який не планується для більш детального вивчення. Крім того, такі лекції дуже важливі для активізації самостійної роботи слухачів з метою опанування певних тем.

Квінтесенцією курсу є оглядово-повторювальна лекція, яка читається у кінці курсу та відображає всі положення, які складають науково-понятійну основу курсу.

Інформаційна лекція - надає головну інформацію 3 теми відповідно до навчального плану та програми.

Підсумкова (або заключна) лекиія - завершує лекційний курс, систематизує одержані знання, підводить підсумки прочитаного курсу.

Слід зазначити, що у ВМНЗ післядипломної освіти крім вищенаведеної класифікації можуть використовуватись і інші види лекцій, які поділяють залежно від методів викладання навчального матеріалу.

Монолекція - $є$ начитуванням навчального матеріалу.

Проблемна лекція - найбільш складний вид лекції, який вимагає від викладача глибокого володіння матеріалом, вміння створити проблемну ситуацію. При цьому теоретичний матеріал подається у вигляді проблемної задачі, що має певні протиріччя, які викриваються і розв'язуються разом зі слухачами.

Лекиія-візуалізація. Така лекція є носієм усної інформації, перетвореної у візуальну форму. Можуть бути використані такі форми наочності, як: символічні (таблиці, схеми), образотворчі (фото, малюнки, слайди), натуральні (реактиви, препарати, апаратура і ін.). Загалом читання даної лекції - це розгорнутий коментар підготовлених візуальних матеріалів.

Клінічна лекція. Особливістю даного різновиду лекцій є іï структура. Проведення ії потребує певної організації як навчального, так і лікувального 
процесу. Асистент лектора напередодні вивчає історії хвороб пацієнтів у базовому відділенні, вибирає, на його погляд, історію із класичним перебігом хвороби і готує коротку презентацію з даного клінічного випадку. Із згоди пацієнта можлива його демонстрація під час доповіді. Звертають увагу на патогномонічні прояви хвороби, за участю лектора проводять огляд хворого, акцентуючи увагу на певних симптомах. Аналізують дані лабораторних, інструментальних і спеціальних досліджень. Завершують презентацію формулюванням діагнозу згідно сучасної класифікації захворювання. Дана частина лекції не має перевищувати 15 хвилин. Далі лектор переходить до викладення етіології, патогенезу, клініки, класифікації, діагностики та лікування захворювання. Звертають особливу увагу на особливі клінічні варіанти його перебігу. Під час проведення клінічної лекції можливе інтерактивне опитування слухачів.

Майстер-клас - уроком це назвати примітивно. Після такого майстер-класу ти сам можеш виконувати те чи інше.

Лекція - прес-конференція також достатньо складний вид лекції, що потребує від викладача високого професійного рівня, вміння швидко аналізувати та узагальнювати дані, які надходять. Під час такої лекції викладач називає ії тему та просить слухачів надати письмові запитання з теми. Викладач впродовж $3-5$ хвилин отримує питання стосовно змісту та починає лекцію. При цьому лекція не повинна виглядати як відповіді на запитання, а бути повноцінним текстом, в процесі викладання якого даються відповіді на запитання, що надійшли. Така лекція цікава тим, що вона надає можливість отримати зріз знань слухачів.

Необхідно, щоб слухачі були залучені до дискусії, задавали питання, наводили випадки із практичної діяльності, висловлювали власну думку. Важливою частиною лекції є відповіді на запитання слухачів.

Як правило, на цей елемент лекції відводиться мало часу, але нерідко питання після прочитаної лекції перетворюються в окремий вид роботи лектора. Виходячи $з$ цього виділяють наступні активні форми лекцій: 
Лекиія-брифінг - складається з двох частин: короткого повідомлення лектора (до 20 хвилин) і відповідей на запитання слухачів (до 60 хвилин). Дуже важливим $\epsilon$ зміст та форма повідомлення, тому викладач повинен ретельно підготуватись до нього. Принципова методична структура лекції-брифінгу: повідомлення лектора $\rightarrow$ запитання слухачів $\rightarrow$ відповіді лектора.

Лекиія-бесіда будується по-іншому. Якщо лекція-брифінг не передбачає виступів слухачів, а тільки запитання, то при цьому виді лекції допускаються виступи слухачів, викладення їх позиції, обмін досвідом т. ін. Таким чином, методична специфіка лекції-бесіди в тому, що викладач надає певну інформацію, ставить питання слухачам, щоб почути їх висловлювання, направляє діалог у потрібне русло.

Цікавим видом лекції є лекція-диспут. Вона також має короткий вступ на початку, а потім перетворюється у полемічну бесіду. Функції лектора передбачають організацію лекції таким чином, щоб виникали зіткнення думок, аналіз проблем, які розглядаються. Методична особливість лекції такого типу полягає в тому, що викладач повинен не тільки вміти вести бесіду, відповідати на запитання, але й мати навички організації диспуту та керування ним.

Існує ще один вид лекції - лекиія-анкета. Викладач складає анкету опитувач з 20 - 25 питань за темою лекції. На початку лекції, отримавши анкету, слухачі під керівництвом лектора видаляють ті питання, які не викликають складностей. Питання, які залишились, ранжують за ступенем складності, актуальності, тематикою, і таким чином складають план лекції. 3 методичної точки зору така лекція досить складна як на етапі підготовки, так і на етапі проведення. Від лектора вимагаються значні зусилля при складанні анкет, ерудованість, вміння аналітично мислити.

Практикується також бінарна лекиія чи лекиія-дует. Вона читається одночасно двома викладачами. Важливою умовою успішного проведення такої лекції є розподіл навчального матеріалу та попередня підготовка лекторів. Крім того, від викладачів вимагається вміння співпрацювати та імпровізувати. Не менш важливим є також глибока професійна підготовка викладачів. 
В лекційній практиці також описується ситуація під назвою «круглий стіл». В цьому випадку два або більше лектори розглядають одну загальну тему в одній аудиторії. Викладачі повинні і вести бесіду зі слухачами, і відповідати на їх питання. Вважається, що такий вид лекції максимально демократизує взаємовідносини лекторів та слухачів при обговоренні будь-якої проблеми.

У ВЗО читаються також лекиійні спещкурси. Як правило, вони виходять за рамки навчальної програми, поглиблюють знання, отримані під час засвоєння програми. Завдяки лекційному спецкурсу слухачі знайомляться 3 певною науковою тематикою, науково-дослідною роботою кафедри тощо.

У структурі всіх лекцій, що присвячені певній дисципліні чи вивченню певного курсу, для забезпечення підвищення якості навчального процесу, переважати мають лекції проблемного характеру, комплексні лекції. Сучасна лекція має бути добре ілюстрованою, вона не повинна мати описовий характер. Для більшої інформативності мають використовуватися слайди, навчальні фільми, відеотехніка, а клінічні лекції мають ілюструватися тематичними розборами. Однак широке впровадження та використання технічних засобів навчання у навчальний процес не повинно замінювати живе слово педагога, применшувати значення особистості викладача-лектора. Сучасна підготовка висококваліфікованих спеціалістів передбачає оволодіння ними фундаментальними теоретичними знаннями, а також практичними вміннями та навичками. Професіоналізм викладача В3О, без сумніву, включає володіння предметом викладання та уміннями і навичками, що базуються на практичному досвіді. Саме професіоналізм лектора, як фахівця і як педагога, є запорукою забезпечення підготовки висококваліфікованого та всебічно освіченого спеціаліста. Звичайно, з впровадженням дистанційного навчання, суттєво зміниться методологія проведення занять із слухачами, але живе слово лектора завжди буде залишатися запорукою розвитку професійного та наукового мислення у слухачів.

У навчальні плани додипломного і післядипломного навчання входить певна кількість семінарських занять. 
Iсторичний аспект. Слово і поняття «seminarium» (у перекладі «semen» 3 латинської значить «сім'я (для зачаття)») - означає розсада, розсадник, саджанець. Вперше в історії навчання, прообраз сучасного семінару був у вигляді діалогу, що зафіксовано в історичних давньогрецьких джерелах. У ті часи дійство називалося і мало форму симпозіуму. «Simposium» (із слів «sim» та «роsitio») у перекладі із грецької значить бенкет. Спільними у обох поняттях симпозіуму і семінару є установка, посадка, розсадник, причина. Але означені форми спілкування мають ще глибше спільне смислове значення - турбота про саджанець знань, розвиток пізнання [804].

Організації та якості їх проведення слід приділяти значну увагу, оскільки саме семінарські заняття значно підвищують мотивацію до навчання. Впровадження в педагогічний процес нових інноваційних технологій диктує необхідність зміни дидактичних та методологічних підходів при підготовці до їх проведення [804-806]. Наразі певна кількість педагогів, незважаючи на трансформації в навколишньому світі і впровадження новітніх технологій, переконані в тому, що навчати лікаря за допомогою дистанційних або електронних технологій взагалі неможливо. На їх думку, всупереч реальним змінам обличчя освітніх систем у всьому світі, підготовлювати лікаря можна лише біля ліжка хворої людини. Не можна не погодитись, що підготовлений таким чином лікар є результатом діяльності системи освіти відповідно до існуючих стандартів, що забезпечує формування відповідних професійних навичок та вмінь і професійно-соціальної компетентності [805]. Слід зауважити, що майже всі викладачі системи післядипломної підготовки лікарів не мають грунтовної базової педагогічної освіти, тому вони прагнуть шляхом самоосвіти опанувати щонайповнішу інформацію щодо сучасного розуміння суто педагогічних понять - моделі, методів і стратегії навчання, методики і засобів викладання, критеріїв оцінювання знань, впровадження освітніх стандартів та контролюючих тестових програм. Новітні інформаційні технології служать інструментом у викладацькій діяльності педагога для передачі і засвоєння знань слухачами, зокрема і при проведенні семінарів. Необхідно завчасно інформувати 
слухачів про мету семінарського заняття, план та умови його проведення, перелік рекомендованої літератури для самостійного вивчення, що без сумніву має сприяти формуванню на базі отриманих знань певних професійних навиків та вмінь. Застосування новітніх технологій при проведенні семінарів сприяє більш ефективному передаванню знань тому, кого навчають. Щоб бути компетентним фахівцем, необхідно безперервно підвищувати рівень теоретичної підготовки та вдосконалювати практичні навики та вміння.

Семінари за змістом розподіляють на інформаційні, дослідницькі та контрольні. На семінарах лікарі можуть здійснювати поглиблене вивчення певного курсу, розділу, теми, причому, семінар за тематикою інформаційно може бути не пов'язаним з лекцією. За формою проведення семінари можуть бути: семінар-конференція, семінар-дискусія, семінар-колоквіум, семінар з клінічного розбору історії хвороби хворого, семінар-екскурсія, семінар з обговорення попередньо підготованих слухачами рефератів, семінар 3 обговорення контрольних робіт, семінар-конференція, семінар з обміну досвідом роботи, семінар-тренінг, семінар ділова гра, семінар-підсумок. Окремої уваги заслуговують телесемінари. Всі перераховані види семінарів повинні мати свою мету, форму організації, і методику проведення [804, 806].

Для проведення семінарів у системі післядипломного навчання ставлять такі вимоги. Семінар має мати чітко визначену мету i завдання, поєднувати інформаційне навантаження 3 дослідженням проблеми та елементи контролю, стимулювати слухачів до засвоєння матеріалу і підвищення своєї професійної майстерності, активізувати слухачів до здобуття грунтовних і міцних знань, умінь та навичок, поєднувати індивідуальну та колективну роботу слухачів, забезпечувати тісну співпрацю викладача і слухачів, сприяти демократизації і об’єктивізації навчального процесу, підвищувати вимогливість до професійної та педагогічної діяльності викладача, поєднувати усталені стратегії і методи із новітніми технологіями [805].

До проведення семінарів ставлять певні вимоги щодо якості проведення, тематики, методичного плану. При складанні плану кожного семінарського 
заняття визначають його основну мету, структуру, зміст, методи, форми та прийоми заохочення слухачів до активної дискусії. Логічним завершенням семінару повинно бути підведення підсумків, оцінювання участі кожного слухача при його проведенні та формулювання загальних висновків із кола питань, що обговорювались.

Таким чином, лекція і семінар $є$ незамінними елементами у функції систематизації і структурі всього масиву знань з будь-якої дисципліни та служать головною ланкою дидактичного циклу навчального процесу.

Семінар і лекція $є$ ефективним методом інтерактивної передачі нової інформації, який дозволяє систематизувати власний накопичений досвід iз новими знаннями, вміло їх аналізувати. Під час проведення лекцій і семінарів можливо відстежувати досвід інших слухачів, отримувати додаткову інформацію, аналізувати, моделювати ситуації, спільно шукати шляхи вирішення різних питань. 
DOI 10.46299/ISG.2021.MONO.PED.III.8.15

\subsection{5 Деякі питання навчання фізики в інтегрованому курсі 3 природничих наук}

Природничі науки змінюють наше життя і є життєво важливими для сталого розвитку не лише для нашої країни, а в цілому для світу. Саме тому в багатьох країнах світу пильна увага приділяється вдосконаленню системи природничої освіти, що полягає у розробленні їі варіативності, різнорівневості вимог до навчальних результатів учнів, урізноманітненні форм і методів організації навчальної діяльності. Така диференціація навчання найповніше реалізується у старшій профільній школі, де вивчення кожного 3 природничих предметів передбачено за двома рівнями (рівень стандарту і профільний рівень), а також у вигляді інтегрованого курсу «Природничі науки».

Навчання інтегрованого курсу 3 природничих наук пов'язане iз систематизацією та узагальненням знань про явища реального світу.

Концепцією структури та змістом загальної освіти у школі є: особистісна орієнтація змісту освіти; гуманізація та гуманітаризація, що забезпечують фізичну, інтелектуальну, духовно-моральну освіту учнів; фундаментальність змісту освіти, що забезпечує універсальність здобутих знань; пріоритетність збереження здоров'я учнів, у тому числі за рахунок розвантаження навчального матеріалу; забезпечення практичної орієнтації загальної середньої освіти шляхом раціонального поєднання продуктивної та репродуктивної діяльності учнів; забезпечення цілісності уявлення учнів про світ шляхом інтеграції змісту освіти.

Фізика, поруч із розв'язанням цих завдань, формує творчі здібності учнів, ïx світогляд i переконання, тобто сприяє розвитку та вихованню високоморальної особистості. Ця мета навчання може бути досягнута тільки тоді, коли в процесі навчання фізики учень отримує певні знання та вміння їх набувати.

Систематичний курс фізики, як фундамент природничих наук, формує, уточнює та розвиває знання, отримані в курсі вивчення географії, біології та 
природознавства. Створюється уявлення про цілісність всесвіту, взаємозв'язки та взаємодії його частин, матеріальних та енергетичних перетвореннях у часі та просторі, про різноманітні природні зв'язки, що важливо для інтелектуального розвитку учнів.

Фізика - основа техніки, тому широко використовується для досліджень у біології, географії, історії та екології. У наші дні радіо, телебачення, популярна література активно знайомлять із новими досягненнями науки та техніки. Цю інформацію необхідно використовувати, узагальнювати, застосовувати на уроках та позакласних заняттях і заходах. Цілий ряд фізичних відомостей отримують учні під час уроків біології, географії, природознавства, хімії, екології, історії, а також за рахунок власних спостережень за рослинним світом, природними умовами. Це дає можливість урізноманітнити уроки, зробити їх захоплюючими, цікавими, незабутніми. Активізувати діяльність учнів, розвивати в них творчі можливості, логічне мислення дозволяють завдання, що мають зв'язок з дисциплінами природничого, історичного та гуманітарного циклу.

Міжпредметні зв'язки сприяють формуванню в учнів цілісного ставлення до явищ природи, допомагають їм використовувати знання щодо різних предметів. Адже світ, що нас оточує, цікавить школярів, спонукає їх відповідати на питання, які перед ними ставить життя. Тому введення у навчальний процес ілюстративних відомостей з історії, екології, географії, біології дає можливість вчителю під час навчання фізики більше пов'язати предмет із важливими аспектами життя природи, з діяльністю людини, з історією.

Застосування прикладів та завдань, практичних та дослідницьких робіт 3 елементами історії, географії, біології, екології на уроках та у позаурочний час допоможе кращому засвоєнню навчального матеріалу. Залучення цього матеріалу служить розвитку у дітей творчих здібностей, вміння спостерігати, формує вміння роботи $з$ додатковою літературою, формує вміння застосовувати знання з пояснення явищ природи у житті. 
Поява природи взаємно пов'язані. Цей взаємозв'язок необхідно розкривати перед учнями щодо всіх природничих дисциплін.

Велику роль у формуванні цілісної картини світу під час уроків фізики грає складання і розв'язання задач. Ці задачі повинні задовольняти певним вимогам: вони повинні бути пов'язані з темою, що вивчається, і сприяти більш міцному і глибокому засвоєнню фізичних закономірностей, повинні навчити практичному застосуванню цих закономірностей в біології, хімії, географії, історії, екології. Дуже корисна робота 3 додатковою та довідковою літературою, на основі якої школярі самостійно можуть складати завдання та повідомлення до уроку. Звичайно, доцільніше викладати цей матеріал з використанням комп'ютерних технологій, відеотехніки, плакатів та ілюстрацій, географічних та історичних карт, таблиць та наочних посібників.

Так щодо теми «Капілярні явища» можна показати уривки відеофільму «Кровоносна система», «Будова кореня». Під час вивчення теми «Око - оптична система» можна показати плакат «Зір у тваринному світі» тощо. Найголовніше це не перевантажити урок наочними посібниками, щоб він не втратив фізичну сутність.

Для багатьох учнів ці приклади можуть стати засобом прищеплення інтересу до фізики. Залучення фрагментів з елементами біології, хімії, географії, історії, екології покликане формувати в учнів любов до природи, збагачувати образне мислення, розвивати фантазію, що є чинником успішного засвоєння навчального предмета. Вирішення фізичних завдань допоможе пробудити у школярів інтерес до предмета, розширити їх знання та кругозір, краще зрозуміти фізику.

Створення поглядів на основні поняття навколишнього світу починається з 5 класу. Для формування уявлень про дискретну будову речовини на початку вводиться поняття «маса» як властивість тіла. На наступному етапі, в 7 класі, вводиться поняття речовини, яке складається з величезної кількості часток, що хаотично рухаються, що підтверджується експериментально дослідами з дифузії. Цей процес розглядається в біології стосовно функціонування живих організмів. 
Подальший розвиток уявлення про дискретну будову речовини учні отримують у темах електромагнітні явища та будова речовини.

Вся система знань про дискретну будову тіл і речовин дозволяе і в курсі природничих наук зробити важливий у методологічному відношенні висновок про пізнаваність та невичерпність матерії.

Важливим етапом у пізнанні учням навколишнього світу $є$ введення поняття про взаємодію матеріальних об'єктів, який починається 3 простого експерименту зі свинцевими циліндрами і триває при вивченні теми «Сили природи».

Початкові відомості про силу учні отримують із повсякденного досвіду. Вони зазвичай пов'язують ії з м'язовим зусиллям. Тому в курсі природничих наук дається наукове визначення сили як характеристики дії одного тіла на інше. У основній школі учні повинні засвоїти, що 3 кожної сили вказується точка докладання, напрями і модуль. Крім того, вводиться позначення сили та одиниця виміру. У результаті складається уявлення про цілісність навколишнього світу, про взаємодію тіл між собою, розглядаються прояви різних сил у природі, техніці, побуті.

Формування ключового питання існування пов'язане 3 поняттям «Енергії». Починається воно з введення поняття роботи як міри вимірювання енергії при трансформації стану тіла і процесом, що відбувається на землі. 3 цієї точки зору можна говорити про екологічну безпеку зміни форми поверхні суші, втрати родючих земель, заболочування тощо.

При вивченні теми «Світлові явища» надається можливість обговорити питання про перетворення сонячної енергії на хімічну при фотографуванні. Закони, що вивчаються в цій темі, можуть допомогти пояснити: забруднення атмосфери при згорянні палива; вплив випромінювань (ультрафіолетового та інфрачервоного) на життєдіяльність людини, тварин, рослин; зміна світлового режиму морів та океанів через забруднення поверхні води нафтопродуктами. У курсі фізики вивчення цієї теми дозволяє учням отримати такі знання (затребувані й у курсі природознавства): різні джерела світла; закон 
прямолінійного поширення світла та його прояви; закон відображення світла та його застосування; прояв та використання явища заломлення світла у природі, техніці, побуті; розкладання білого світла на спектр; веселка; будова та функції ока людини; причини виникнення дефектів зору; особливості зору комах, птахів, звірів, тощо.

У процесі вивчення теми «Звукові явища» учні переконуються, що звук джерело різноманітної інформації.

Фізика, як наука, робить особливий внесок у вирішення загальних завдань освіти та виховання особистості. У цьому курсі учні отримують початкові відомості про електрику та магнетизм, 3 наступним переходом до електромагнітних явищ. До них відносяться і світлові явища, знання законів яких важливе не лише для вивчення природничих наук, а й для художників, кінематографістів та інших людей творчих професій. Таким чином, саме при вивченні фізики створюється цілісне уявлення про світ, оскільки вся система знань про явища природи, властивості простору та часу, речовину та поле формує науковий світогляд. Інтеграція природничих знань дозволила б:

- сформувати уявлення школярів про цілісну картину світу з його єдністю та різноманіттям властивостей живої та неживої природи

- показати єдність законів природи, застосування законів і теорії фізики до різних об'єктів (від елементарних частинок до далеких галактик)

- розглянути різні рівні організації речовини (мікроскопічний, макроскопічний)

• розглянути кругообіг речовин та перетворення енергії

- розглянути людину як фізичний об'єкт, людину як складну фізичну систему, людину як суб'єкт пізнання

- показати вплив на живий організм довкілля (теплове, світлове, шумове, електромагнітне, радіаційне).

Тому наукова картина світу повинна створюватися у школярів за рахунок інтеграції наукового пізнання всіх наук складових природничого циклу. 
Методика використання текстів, пов'язаних із біологією, географією, екологією, історією може бути різноманітною. Якщо повідомлення містить опис будь-якого явища або приклад фізичного явища в природі, його доцільно використовувати на уроці як ілюстрацію.

Наприклад, щодо теми «Прості механізми» можна навести такі приклади використання простих механізмів.

1. Вчені вважають, що перші колеса були створені в Шумері приблизно 5200 років тому. До винаходу колеса тяжкі предмети по суші переміщали за допомогою котків та важелів. 3 розвитком скотарства почали використовувати в'ючних тварин, з'явилися безколісні волокуші, що стали прообразом саней. Перші зображення колісного візка, що дійшли до нас, знайдені в Месопотамії; датуються вони 4 тисячоліттям до нашої ери.

2. Стародавні єгиптяни залишили по собі величні пам'ятки архітектури знамениті піраміди, гробниці фараонів. Європейці дізналися про ці грандіозні споруди після Єгипетського походу (1798-1801рр.) генерала Бонапарта (майбутнього імператора Франції): саме тоді було зроблено перші описи устрою гробниць. Доведено, що будівельна техніка давнини дозволяла зводити такі монументальні споруди. Блоки з вапняку вирубані у каменоломнях і на місці їх обробляли - обтісували та полірували. Виконували цю операцію мідними інструментами. Камінь обробляли так старанно, щоб у подальшому блоки щільно прилягали один до одного. Майстри домагалися дивовижних результатів - i через тисячоліття між гранями сусідніх плит не можна протягнути навіть нитку. Потім багатотонні блоки, використовуючи полозья-волокуші і прості важелі, вантажили на баржі і в період повені спеціально проритими каналами відправляли до місця будівництва. Втягували блоки на канаті мідними гаками. Головною таємницею пірамід є працьовитість та талант людини. Насправді висота піраміди фараона Хуфу (Хеопса) досягає 146.59 м, складена вона 3 величезних кам'яних блоків масою 2.5 т кожен.

При вивченні теми «Тертя» дуже цікавий приклад, який ілюструє переваги тертя кочення. 
3. Храм Артеміди в Ефесі (побудований близько 550 р. до нашої ери) був одним із найкрасивіших і найзнаменитіших творінь грецької архітектури i вважався третім дивом світу. Керівники будівництва Херсіфрон та Метаген при зведенні храму зіштовхнулися зі складною проблемою: як перевезти по рихлому грунту важкі колони та блоки 3 каменоломні до місця роботи? Вихід був знайдений: колону, особливим чином прикріплювали до дерев'яної рами, ніби перетворювали на кам'яну ковзанку. А перекочувати тяжкості набагато легше, ніж тягти. Для прямокутних блоків Метаген придумав інший спосіб: кожен блок, як вісь, вставляли у величезні дерев'яні колеса близько 4м в діаметрі і котили до місця будівництва.

Дуже цікавий приклад, що ілюструє застосування закону Паскаля, його можна запропонувати на уроках щодо теми: «Тиск газів».

4. Батьківщиною скла вважається багатий кварцовим піском Єгипет, де протягом багатьох століть виготовляли скляні намисто. Греки запозичили це ремесло у єгиптян, удосконалили його і почали робити скляні вази. Техніка видування скла за допомогою спеціальних труб і форм з'явилася в Сирії в 1 столітті до н.е. і швидко поширилася по всій Римській імперії. Скляні вироби кубки, келихи - стали набагато дешевшими і перетворилися на предмети масового попиту. Нові центри склоробства в Італії та римських провінціях. На території Іспанії, Франції, Німеччини.

Але ефективнішим $є$ вирішення фізичних завдань 3 увикористанням текстів, складених з урахуванням повідомлень з біології, хімії, географії, історії, екології.

Ось приклади деяких завдань, які пропонуються школярам під час уроків на тему «Швидкість. Поступовий рух».

1. Гриб райдуга (phallus), звичайний у наших краях, росте зі швидкістю 5 мм за хвилину і виростає до висоти 30 см. За який час гриб досягає вказаної висоти? (1 година)

2. Хоча рослина банан (Musa) досягає висоти 10 м і має ствол завтовшки до 1 м, воно є травою. Банан від початку розвитку до десятиметрової висоти 
зростає лише за 8-10 місяців. Листя банана росте зі швидкістю 0.1 мм за хвилину. Кожна рослина дає три врожаї на рік, що становить загалом 100 кг плодів. Визначте, на скільки сантиметрів збільшується лист банана на добу? (14,4 см)

3. Бамбуки - загальна назва для більш ніж 100 родів та 600 видів трав'янистих рослин. Їх особливістю є швидке зростання. Так, бамбуки В'єтнаму ростуть зі швидкістю 2 м на добу. Бамбук, що відноситься до сімейства злакових, у себе на батьківщині може досягати висоти 50 м і мати стебло діаметром до 40 см. На скільки метрів змінюється довжина бамбука за тиждень? (на 14 м)

Можна на цю тему запропонувати учням творче завдання. Наприклад, пропонується таблиця, в якій вказані швидкості руху живої природи. Школярам пропонується скласти завдання за цими даними.

Ось такі завдання складають школярі.

1. Гепарди полюють поодинці. Вони біжать за здобиччю зі швидкістю до 30 м/с, але досить швидко втомлюються. Якщо протягом хвилини вони не наздоганяють здобич, то припиняють гонитву. Антилопа знаходиться на відстані 100 м від гепарду і біжить зі швидкістю 72 км/год. Чи наздожене іiї гепард?

Відповідь: Якщо рухатиметься з максимальною швидкістю, то наздожене через $10 \mathrm{c}$.

2. Африканські страуси, нанду та ему - це великі безкрилі птахи. Вони досить швидко бігають, щоби втекти від небагатьох хижаків, які ризикують нападати на них. Страуси біжать зі швидкістю 80 км/год. Всі вони неяскраво пофарбовані, крім чорно-білого африканського страуса, який є найбільшим птахом у світі. За який час африканський страус подолав би стометрівку?

Відповідь: Приблизно за 4,5 с.

Дуже цікаво можна робити уроки «Рішення задач» 3 використанням цікавих повідомлень. Так учням пропонується цікавий факт, а вони мають скласти по ньому задачу чи питання. А потім запропонувати відповісти на нього своїм товаришам. Наприклад, деякі повідомлення на тему «Маса. Щільність».

Сейшельська віялова пальма дає горіхи масою до 25 кг та діаметром до 0,5 м. Вперше такий горіх потрапив до Європи наприкінці XVI століття. Європейці 
вважали його талісманом, який оберігає від нещасть, і високо цінували: за один «Мальдівський горіх» можна було отримати цілий корабель, завантажений товарами. Імператор «Священної Римської імперії» Рудольф II (1552-1612) заплатив за кубок з горіха сейшельської пальми стільки золота, скільки в нього вмістилося - 100 кг.

Ось такі задачі були складені на уроці цього уривку:

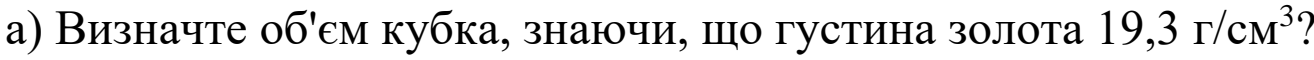

б) Вважаючи, що сейшельський горіх має форму кулі, визначте іiі середню густину. 3 якою речовиною може зрівнятися ця густина?

Цератонія із сімейства цезальпінієвих дає однакове насіння, масою завжди рівно 0,2 г. Таким насінням як гирєю із давнини користувалися ювеліри. Цей захід маси назвали каратом.

Ось які завдання було складено за цим фактом.

а) Які одиниці маси ви знаєте? Скільки карат за 100 г?

б) Алмаз масою 20 карат має об'єм 0,63 см. Визначте середню густину цього каменю? Вас нічого не дивує?

в) Скільки насіння цератонії потрібно взяти, щоб урівноважити брусочок срібла розмірами $1 * 2 * 2 \mathrm{~cm}^{3}$ ? Щільність срібла 10500 кг $/ \mathrm{M}^{3}$.

Такі завдання дозволяють учням застосувати свої знання практично, розвивають мислення і логіку учнів. Допомагають краще зрозуміти фізику. Усі учні, які активно беруть участь у цій роботі, заохочуються.

За запропонованою методикою можна проводити не лише окремі уроки, а й позакласні заняття та заходи. Такі заняття позитивно впливають на засвоєння основного шкільного курсу фізики, і навіть сприяють розвитку умінь вирішувати задачі творчого характеру. Вирішення таких задач спонукають учнів читати більше, самим знаходити цікаві факти, а потім використовувати їх на уроці або на позакласному занятті. Це розвиває в учнів мислення, увагу, спостережливість.

Слід зазначити, що з практичного досвіду, завдання, пов'язані з біологією, хімією, географією чи екологією допоможуть вчителю урізноманітнити уроки та 
заняття з фізики, залучити учнів до активної творчої діяльності, розвинути у школярів любов до рідної природи.

Важливим завданням під час уроків 3 формування знань 3 фізики стає ознайомлення школярів 3 недостатнім розвитком сучасної науки, створення уявлень учнів сучасної картини світу.

На сьогодняшній день існує багато посібників для вчителів 3 викладання дисциплін природничого циклу, в яких представлені завдання та короткі довідки, практичні та дослідницькі роботи з фізики з елементами біології, географії, екології, які можуть використовуватися вчителем на уроках з формування знань з фізики та позаурочній діяльності, а також учнями при підготовці до уроків, при написанні доповіді, для саморозвитку та самопідготовки, для розширення кругозору, а також для творчої роботи. На основі коротких довідок, представлених у таких посібниках, школярі привчаються ілюструвати закони фізики прикладами суміжних предметів.

Мета посібників запровадити в урок елементи цікавості та пізнавальні моменти, підвищити інтерес до вивчення фізики та збільшити кругозір школярів, залучити до пошуку та спонукати учнів до читання додаткової літератури. Матеріали, що представлені у посібниках, можуть бути використані на різних етапах уроку: під час перевірки домашнього завдання, при дачі нового матеріалу, при закріпленні нового матеріалу; як короткі повідомлення на тему, цікавих завдань, матеріалу, що розвиває характер, для складання питань і завдань самими школярами.

3 усього вище сказаного можна дійти висновку, що необхідність звернення до інтегрованого навчання викликана низкою об'єктивних причин, які дедалі частіше виявляються у середній школі.

Однією з найважливіших проблем є помітне зниження інтересу учнів до предметів природничо-наукового циклу, що обумовлено об'єктивною складністю таких наук як фізика, хімія і біологія. До того ж, викликає незадоволеність недостатня продуманість та розробленість діючих програм та підручників для загальноосвітніх шкіл. 
Сама специфіка цих наук на їх сучасному рівні спонукає до комплексного підходу у навчанні школярів цим предметам, тобто логіка даних наук веде до їх об'єднання - інтеграції.

Наступною проблемою, яку можна вирішити у процесі інтегрованого навчання, є неузгодженість, роз'єднаність етапів формування в учнів загальних понять фізики, хімії та біології; вироблення у них узагальнених умінь і навичок. Практика показує, що нерідко те саме поняття у межах кожного конкретного предмета визначається по-різному - така багатозначність наукових термінів ускладнює сприйняття навчального матеріалу. Неузгодженість пропонованих програм призводить до того, що та сама тема з різних предметів вивчається у час. Ці протиріччя легко знімаються в інтегрованому навчанні, яке вирішує ще одну проблему - економії навчального часу.

Необхідно також відзначити ще один важливий момент: інтегроване навчання покликане відобразити інтеграцію наукового знання, яка об'єктивно відбувається у суспільстві. Однак, не висвітлювати міжнаукові зв'язки або показувати їх поверхово було б великим недоліком сучасної школи. Інтегроване навчання дозволяє найбільш ефективно показати міждисциплінарні зв'язки та природничо метод дослідження, що використовується на стику наук. 


\section{REFERENCES}

1. Диагностика и коррекция психического развития дошкольников/Под ред. Я.Л. Коломинского, Е.А. Панько. - Минск., 1997.

2. Карабанова О.А. Игра в коррекции психического развития ребенка: Учебное пособие.- М., 1997.

3. Выготский Л. С. Роль игры в психическом развитии ребенка // Вопр. психол. 1966. № 6. С. $62-76.2$

4. Чиркова М.А. Формирование коммуникативных качеств учащихся профессионального лицея: автореферат дис. ... кандидата педагогических наук : 13.00.08 / Ин-т развития проф. образования М-ва образования РФ. - Москва, 2001. $-25 \mathrm{c}$.

5. Гиппенрейтер Ю.Б. Общаться с ребенком. Как? - Издательство: АСТ, Астрель, Харвест. - Москва. - 2008

6. Клюева Н. В., Касаткина Ю. В. Учим детей общению - М - 2014

7. Полякевич Ю.В., Осинина Г.Н. Формирование коммуникативных навыков у детей 3 - 7 лет: комплексные занятия на основе игровых технологий. - М.- 2016.-160 c

8. Диагностика и коррекция психического развития дошкольников/Под ред. Я.Л. Коломинского, Е.А. Панько. - Минск., 1997.

9. Алямовская В.Г., Петрова С.Н. Предупреждение психоэмоционального напряжения у детей дошкольного возраста. - М.: Скрипторий, 2002.

10. Марцинковская Т.Д. Детская практическая психология. - М.: Гардарики, 2004. - 255 c.

11. Урунтаева Г.А. Детская психология. - М.: Академия, 2006. - 366с.

12. Широкова Г.А. Развитие эмоций и чувств у детей дошкольного возраста. - Ростов н/Д: Феникс, 2005. - 304 с.

13. Минаева В.М. Развитие эмоций дошкольников. Занятия. Игры. Пособие для практических работников дошкольных учреждений.-М.-2010 - 48 с.

14. 14. Чернецкая Л. В. Развитие коммуникативных способностей у дошкольников: практическое руководство для педагогов и психологов дошкольных образовательных учреждений / Л. В. Чернецкая. - Ростов н/Д.: Феникс, 2005. — 256 с.: ил. - (Школа развития).

15. Абстрактне мислення URL: https://uk.wikipedia.org/wiki/ Абстрактне_мислення (дата звернення: 18.08.2020 р.). 
16. Аквилева Г. Н., Клепинина 3. А. Методика преподавания естествознания в начальной школе. Москва : Гуманитарный изд. Центр : ВЛАДОС, 2004. 240 с.

17. Аквилева Г. Н., Клепинина 3. А. Наблюдения и опыты на уроках природоведения : пособие для учителя начальной школы. Москва : Просвещение, 1988. 96 c.

18. Брушлинский А. В. Мышление как процесс и проблема деятельности. Вопросы психологии. 1982. № 2. С. 28-40.

19. Гальперин П. Я. Основные результаты исследований по проблеме «формирование умственных действий и понятий». Москва : МГУ, 1965. 51 с.

20. Гонина О. Психология младшего школьного возраста : учебное пособие. Москва : ФЛИНТА : Наука, 2016. 272 с.

21. Гончаренко С. У. Український педагогічний енциклопедичний словник. Вид. 2-ге, доповн. й випр. Рівне : Волинські обереги, 2011. 552 с.

22. Давыдова О. В. Развитие творческого воображения учащихся на основе межпредметных связей : дис ... канд. пед. наук: 13.00.01./ Магнитогорский государственный ун-т. Магнитогорск, 2006. 188 с.

23. Дроздов А., Севериновская Е., Родинский А. Психофизиологическое восприятие и отражение: понятия и терминология. Методическое пособие. Днепр : ПБП «Экономика», 2017. 50 с.

24. Концепція реалізації державної політики у сфері реформування загальної середньої освіти «Нова українська школа» на період до 2029 року : схвалено розпорядженням Кабінету Міністрів України від 14 грудня 2016 р. № 988-p URL: https://osvita.ua/legislation/Ser_osv/54258/ (дата звернення 16.03.2020 p.).

25. Лазарева О. Н. Методика преподавания естествознания. Часть 1. Теоретические основы методики обучения естествознанию в начальных классах : учебное пособие. Екатеринбург, 1999. 262 с.

26. Скрипченко О. В., Долинська Л. В., Огороднійчук 3. В. Загальна психологія. Київ : Либідь, 2005 р. 464 с.

27. Словник української мови : [в 11 т.] / АН Української РСР, Ін-т мовознав. ім. О. О. Потебні; редкол.: І. К. Білодід (голова) [та ін.]. Київ : Наук. думка, 1970-1980. Т. 8 : Природа-Ряхтливий / ред. В. О. Винник [та ін.]. 1977. $927 \mathrm{c}$.

28. Соловйов С. М. Основи наукових досліджень. Навчальний посібник. Київ : Центр учбової літератури, 2007. 176 с.

29. Теплов Б. М. Психология. Москва : Учпедгиз, 1953. 121 с. 
30. Формування URL: https://ru.wikipedia.org/wiki/Формування (дата звернення: 16.08 .2020 р.).

31. Зарічний О. А. Участь громадськості у здійсненні публічної влади: теоретико-правове дослідження: дис.... канд. юрид. наук: 12.00.01 - теорія та історія держави і права; історія політичних і правових учень. Львів: [Б. в.], 2017.

32. Взаємодія держави і суспільства в процесах публічної політики: наук. розробка / авт. кол.: С. О. Телешун, І. В. Рейтерович, С. В. Ситник та ін. Київ: НАДУ, 2013. 44 с.

33. Становлення та розвиток громадянського суспільства. URL:https:// pryiutivka-community.gov.ua/news/1576495264/

34. Кравчук В. М. Взаємовідносини громадських організацій і держави в умовах формування громадянського суспільства в Україні (теоретико-правові аспекти):дис... канд. юрид. наук: 12.00.01. Київ: 2008. 229 с.

35. Національна стратегія сприяння розвитку громадянського суспільства в Україні на 2021-2026 роки. URL: https://zakon.rada.gov.ua/laws/show/487 /2021\#n18

36. Угода про асоціацію між Україною, з однієї сторони, та Європейським Союзом, Свропейським співтовариством $з$ атомної енергії і їхніми державамичленами. URL: https://zakon.rada.gov.ua/laws/show/984_011/page12\#Text

37. Платформа громадянського суспільства. URL: https://www.kmu.gov.ua/ diyalnist/yevropejska-integraciya/vikonannya-ugodi-pro-asociaciyu/ dvostoronniorgani-asociaciyi-ukrayina-yes/platforma-gromadyanskogo-suspilstva

38. Постанова Кабінету Міністрів України від 24 лютого 2016 р. № 198 «Про внесення змін до деяких постанов Кабінету Міністрів України». URL:https: //zakon.rada.gov.ua/laws/show/198-2016-\%D0\% BF\#Text

39. СемьоркінаО. М. Взаємодія держави та інститутів громадянського суспільства. URL:https://minjust.gov.ua/m/str_33679

40. Калашник М. В. Генезис форм взаимодействия милиции и населения // Проблемы правоохранительной деятельности, 2013. № 2. С. 126-130.

41. Закон України «Про Національну поліцію».2015. №580-VIII. // ВідомостіВерховноїРадиУкраїни, 2015. №40-41. С. 1970. Ст. 379.

42. Кожухар О. В. Адміністративно-правове забезпечення взаємодії інститутів громадянського суспільства з органами і підрозділами Національної поліції України: автореф. дис.... канд. юрид. наук: 12.00.07. Київ, 2021. 23 с.

43. Бех І. Д. Виховання особистості: у 2 кн. Київ: Либідь, 2003. Кн. 1: Особистісно-орієнтований підхід: теоретико-технологічні засади. 280 с

44. Закатнов Д. О. Технології підготовки учнівської молоді до професійного самовизначення : монографія. Київ : Педагогічна думка, 2012.160с. 
45. Кваліфікаційна мапа України URL: http:/www. futureskills.org.ua /ua /news /86 (дата звернення: 20.10.2021).

46. Коропецька О. М. Профорієнтація та профвідбір: навч. посіб. ІваноФранківськ, 2005. 236 с.

47. Охріменко 3. Виховні профорієнтаційні технології як умова ефективного професійного самовизначення старшокласників Профорієнтація: стан і перспективи розвитку: зб. мат. Х ювілейних Всеукраїнських психологопедагогічних читань, присвячених пам'яті доктора педагогічних наук, професора Федоришина Б. О. Київ: Інститут педагогічної освіти і освіти дорослих імені Івана Зязюна НАПН України, 2020. С. 78-82.

48. Професійна орієнтація: підручник / Єгорова Є. В. та ін.; за ред. О. М. Ігнатович. Кіровоград: Імекс-ЛТД, 2014. 240 с.

49. Технологія професійної орієнтації в умовах ринку праці : монографія / Н. А. Побірченко та ін. Київ: Педагогічна думка, 2011. 256 с.

50. Щербакова Н. В. Трансформація ціннісних орієнтацій сучасної української молоді: соціально-філософський аналіз: автореф. дис. ... канд. філософських наук: 09.00.03. Київ, 2017. 16 с.

51. Мойсеюк Н. Є. Педагогіка : навчальний посібник. Київ, 2007. 656 с.

52. Гуманістична психологія. Антологія в 3-х т. Т. 1: навчальний посібник / Упорядники Р. Трач, Г. Балл. Київ: Університетське вид-во «Пульсари», 2001. $252 \mathrm{c}$.

53. К. Роджерс. Становление личности. Взгляд на психотерапию. М.:ИОИ, 2016. $240 \mathrm{c}$.

54. Гроздева В. И. Пути совершенствования умений и навыков самостоятельной работы студентов / В. И. Гроздева, Р. И. Недзельская, И. К. Зотова [и др]. - Вып. 3. - М. : НИИВШ, 1982. - 45 с. - (Обзор информ. НИИ пробл.высш.школы).

55. Козловський М. И. Самостоятельные занятия в курсе физике / М. И. Козловский, Я. Г. Гендлер // Вестник высшей школы. - 1971. - № 4. - С. 77 - 79.

56. Леонов И. И. Кафедра намечает правильное соотношение между формами занятий / И. И. Леонов // Вестник высшей школы. - 1958. - № 2. - С. 61 $-63$.

57. Гержод Г. И. Использование проблемных ситуаций в самостоятельной работе студентов / Г. И. Гержод, А. К. Курас // Самостоятельная работа студентов как приоритетная форма учебного процесса : межвед. науч. сб. - Вып. 92. - Киев : Лыбидь, 1992. - С. 23 - 29. 
58. Головко Л. Л. Формування досвіду самостійної діяльності студентів вищої сільськогосподарськоі школи : автореф. дис. на здобуття наук. ступеня канд. пед. наук : спец. 13. 00. 04 „Теорія і методика професійноі освіти” / Л. Л. Головко. - Київ, 2000. -20 с.

59. Гарунов М. Г. Развитие самостоятельности и творчества студентов в условиях перестройки высшей школы / М. Г. Гарунов // Самостоятельная работа студентов: поиски, проблемы, решения : сб. научн. трудов. - Ростов-на-Дону : издательство Ростовского университета, 1991. - С. 15 - 21.

60. Головко Л. Активізація самостійної роботи студента під час лекційних занять / Л. Головко // Освіта і управління. - 2002. - Т.5. - № 1. - С. 147 - 150.

61. Лаптева В. И. Роль семинаров в организации самостоятельной работы студентов физического факультета / В. И. Лаптева // Организация самостоятельной работы студентов : мат-лы пятой метод конф. : тезисы докл.Саранск, 1972. - С. 107 - 109.

62. Назарова С. Н. Взаимосвязь самостоятельной работы и семинарских занятий / С. Н. Назарова // Самостоятельная работа студентов как приоритетная форма учебного процесса : межвед. науч. сб. - Вып. 92. - Киев : Лыбидь, 1992. C. $81-85$.

63. Вагин А. А. О методике семинарских занятий / А. А. Вагин // Вестник высшей школы. - 1954. - № 5. - С. 16 - 23.

64. ДАХО. - Р 2792. - Оп. 7. - Спр. 547 (Материалы (доклады, сведения, приказы и др.) об итогах городского смотра научных работ студентов вузов г. Харькова. 1951). - 34 арк.

65. Иостсон Э. А. К вопросу активизации самостоятельной работы студентов / Э. А. Иостсон // Планирование и организация самостоятельной работы студентов: межвуз. сб. науч.-метод. статей. - Рига : Рижский политехнический институт, 1979. - С. $87-89$.

66. Козырев Ю. Н. Повышаем теоретический уровень семинаров по финансовым дисциплинам / Ю. Н. Козырев // Вестник высшей школы. - 1957. № 2 . - С. $54-56$.

67. Кошелев Г. А. Семинары-конференции / Г. А. Кошелев, М. А. Юмашев // Вестник высшей школы. - 1962. - № 12. - С. 60 - 62.

68. Болгова Л. С. Самостоятельная и индивидуальная работа студентов / Л. С. Болгова, В. Ф. Яровая // Вопросы методики преподавания иностранных языков. - 1970. - Вып 2. - С. $72-85$.

69. Панько Е. А. Формирование готовнности к педагогической деятельности в процессе самостоятельной работы студентов по психологии / Е. А. Панько // Педагогика высшей и средней специальной школы : межвед. сб. Вып.4 - Минск : Университетское, 1990. - С. 42 - 49. 
70. Борбат А. М. НИРС при выполнении комплексных лабораторных работ / А. М. Борбат, С. Н. Рудько // Проблемы высшей школы. - 1983. - Вып. 51. - С. $54-57$.

71. Латышева К. Я. Активизация студентов на занятиях по математике / К. Я. Латышева // Вестник высшей школы. - 1953. - № 8. - С. 30.

72. Шатуновский В. Л. Возможности интенсификации / В. Л. Шатуновский // Вестник высшей школы. - 1987. - № 6. - С. 47 - 49.

73. Махинько В. А. Самостоятельная работа студента - основа глубокого усвоения знаний, гражданского и профессионального становления личности специалиста / В. А. Махинько. - Харьков : РИО ХГУ, 1981. - 76 с. (Методические указания по курсу „Введение в специальность” для студентов первого курса университета).

74. Касьяненко М. Д. Овладевая исследовательскими навыками / М. Д. Касьяненко // Вестник высшей школы . - 1976. - № 12. - С. 54 - 56.

75. Розанов А. Я. Педагогические и эстетические основы работы со студентами, ведущими научные исследования / А. Я. Розанов // Проблемы высшей школы. - 1975. - Вып. 21. - С. 17 - 24.

76. Кононенко П. П. Студенческим научным обществам - прочую организационную основу / П. П. Кононенко // Вестник высшей школы. - 1960. № $3 .-$ C. $42-47$.

77. Тихонова Н.В. Педагогическое образование в Канаде: современное состояние и тенденции развития. Высшее образование в России. 2020. Т. 29. №. 4. C. 155-166.

78. Sandal L. A comparative study on educational system in Canada and the Philippine. Munich. 2020. 61 p.

79. Crocker R., Dibbon D. Teacher education in Canada. Society for the Advancement of Excellence in Education, 2008.140 p.

80. Gambhir M., Broad K., Evans M. Characterizing initial teacher education in Canada: Themes and issues. Ontario Institute for Studies in Education, 2008. 30 p.

81. Thomas L. What is Canadian about teacher education in Canada? Multiple perspectives on Canadian teacher education in the twenty-first century. Canadian Association for Teacher Educators, 2013. 445 p.

82. Queen's University. Faculty of Education. Concurrent Education Degree Requirements. URL: https://educ.queensu.ca/con-ed-reqs

83. Perlaza A.M., Tardif M. Pan-Canadian Perspectives on Teacher Education: The State of the Art in Comparative Research. Alberta Journal of Educational Research. 2016. Vol. 62. No. 2. P. 199-219. 
84. Walker J., Berggman H. V. Teacher education policy in Canada: Beyond professionalization and deregulation. Canadian Journal of Education. 2013. 34 .P. 6592.

85. The University of British Columbia. Faculty of Education. URL: https://educ.ubc.ca/about/

86. The University of British Columbia. Faculty of Education. Department of Curriculum and Pedagogy. URL: https://edcp.educ.ubc.ca/about/

87. The University of British Columbia. Faculty of Education. Department of educational and counselling Psychology, and special education. URL: https://www.grad.ubc.ca/unit/department-educational-counselling-psychologyspecial-education

88. The University of British Columbia. Faculty of Education. Department of Educational studies. URL: https://edst.educ.ubc.ca/about/

89. The University of British Columbia. Faculty of Education. Department of Language and Literacy education. URL: https://lled.educ.ubc.ca/

90. The University of British Columbia. Faculty of Education. School of Kinesiology URL: https://kin.educ.ubc.ca/about/

91. The University of British Columbia. Faculty of Education. Okanagan School of Education. URL: https://education.ok.ubc.ca/degrees-programs/

92. University of Toronto. The Ontario Institute for Studies in Education. URL: https://www.oise.utoronto.ca/oise/Home/

93. Young, J., Halb, C. Clarke, T. Challenges to university autonomy in initial teacher education programmes: The cases of England, Manitoba and British Columbia. Teaching and Teacher Education, 2007. 23. P. 81-93.

94. Sorensen, P., Young, J., \& Mandzuk, D. Alternative routes into the teaching profession. Interchange. 2005. 36(4). P 371-403.

95. University of Manitoba. Faculty of Education. Programs of Study. . URL: https://umanitoba.ca/education/programs-study

96. Naqvi, R., Coburn, H. Assessment policy in teacher education: Responding to the personnel implications of language policy changes. Current Issues in Language Planning. 2008. 9(3). P. 235-248

97. University of Alberta. Faculty of Education. URL: https://www.ualberta.ca/education/about-us/index.html

98. Association of Canadian Deans of Education (ACDE). Accord on initial teacher education. Delta, BC: ACDE. 2005

99. Aitken, A., Webber, C., Lupart, J., Scott, S., \& Runté, R. Assessment in Alberta: Six areas of concern. The Educational Form. 2011. 75. P 192-209. 
100. Андрущенко В.П. Педагогіка майбутнього - педагогіка компромісу / В.П. Андрущенко // Педагогіка вищої школи : методологія, теорія, технології. Київ - Кіровоград, 2014. - С. 16 - 18.

101. Выготский Л. С. Психология искусства / Л. С. Выготский; под ред. М. Г. Ярошевского. - М. : Педагогика, 1987. - 345 с.

102. Гончаренко С. У. Український педагогічний словник / С. Гончаренко. - К. : Либідь, 1997. - 367 с.

103. Гуренко Е. Г. Проблемы художественной интерпретации : философский анализ / Е. Г. Гуренко. - Новосибирск : Наука, 1982. - 256 с.

104. Дичківська I. М. Інноваційні педагогічні технології : Навчальний посібник / I. М. Дичківська. - К. : Академвидав, 2004. - 352 с. (Альма-матер)

105. Енциклопедія освіти / Акад. пед. наук України; головний ред. В. І. Кремень. - К. : Юрінком Інтер, 2008. - 1040 с.

106. Сременко О. В. Підготовка магістрів музичного мистецтва : теорія і методика навчання : [монографія] / О. В. Сременко. - К. : НПУ імені М. П. Драгоманова, 2009. - 434 с.

107. Кевішас I. Становлення музичної культури школяра / I. Кевішас. Кіровоград, 2008. - 287 с.

108. Луговий В. I. Педагогічна освіта в Україні : структура, функціонування, тенденції розвитку / В. І. Луговий. - К. : МАУП, 1994. - 196 с.

109. Масол Л. М. Загальна мистецька освіта : теорія і практика / Л. М. Масол. - К. : Промінь, 2006. - 432 с.

110. Михайличенко О. В. Основи загальної та музичної педагогіки : теорія та історія / О. В. Михайличенко. - Суми : Наука, 2004. - 210 с.

111. Ничкало Н. Г. Українська наукова школа педагогічної майстерності скарбниця сьогодення і майбутнього / Н. Г. Ничкало // Педагогіка вищої школи : методологія, теорія, технології. - Київ - Кіровоград, 2014. - С.22 - 29.

112. Олексюк О. М. Музична педагогіка : навч. посіб. / О. М. Олексюк. K., 2006. - 188 c.

113. Орлов В. Ф. Педагогічна майстерність викладача мистецьких дисциплін : навч.-метод. посіб. / В. Ф. Орлов, О. О. Фурса, О. В. Баніт. - К. : Едельвейс, 2012. - 272 с.

114. Отич О. М. Мистецтво у системі розвитку творчої індивідуальності майбутнього педагога професійного навчання: теоретичний та методичний аспекти : [монографія] / О.М. Отич; за наук. ред. І.А. Зязюна. - Чернівці: Зелена Буковина, 2009. - 752 с. 
115. Падалка Г. М. Педагогіка мистецтва : теорія і методика мистецьких дисциплін : [навч. посіб.] / Падалка Галина Микитівна. - К. : Освіта України, 2008. -274 c.

116. Ржецкий Н. Н. Лекции по педагогике : фундаментальные основы / Н. Н. Ржецкий. - К., 2003. - Ч. 3. - 40 с.

117. Ростовський О. Я. Теорія і методика музичної освіти : Навч.-метод. посібник / О. Я. Ростовський. - Тернопіль : Навчальна книга. - Богдан, 2011. $640 \mathrm{c}$.

118. Рудницька О. П. Педагогіка загальна та мистецька : навч. посіб. / Оксана Рудницька. - Тернопіль : Навчальна книга - Богдан, 2005. - 358 с.

119. Семеног О.М. Професійна підготовка майбутнього вчителя на основі поліпарадигмального підходу / О. М. Семеног // Педагогіка вищої школи : методологія, теорія, технології. - Київ - Кіровоград, 2014. - С. 77 - 82.

120. Становлення і розвиток науково-педагогічних шкіл : проблеми, досвід. Перспективи : зб. наук. праць / [за ред. В.Г. Кременя, Т. Левовицького]. Житомир : Вид-во ЖДУ імені І. Франка, 2012. - 692 с.

121. Хомич Л.О. Аксіологічні основи змісту навчання і виховання майбутніх вчителів / Л. О. Хомич // Педагогіка вищої школи : методологія, теорія, технології. - Київ - Кіровоград, 2014. - С. 89 - 93.

122. Щолокова О. П. Проблема якості вищої музично-педагогічної освіти в контексті системного аналізу / О. П. Щолокова // Наук. записки НДУ ім. М. Гоголя. - Серія : Психол.-пед. науки. - 2008. - № 4. - С. 16 - 19.

123. Закон України «Про вищу освіту» від 01.07.2014 № 1556-VII у редакції № 2745-VIII від 06.06.2019.

124. Кузьмина Н.В. Методы системного педагогического исследования. Ленинград : Изд-во ЛГУ, 1980. 172 с.

125. Педагогічна майстерність: підручник для вищих пед. навч. закладів / за ред. І.А. Зязюна. Київ: Вища школа, 1997. 349 с.

126. Змеев С.И. Технология обучения взрослых. Педагогика, 1998. №7. С. $42-45$.

127. Самойленко П.И. Системно-деятельностный подход к разработке и внедрению обобщенных технологий обучения. Среднее профессиональное образование, 1998. №3. С. 25-38.

128. Алексюк А.М. Педагогіка вищої освіти України. Київ : Либідь, 1998. $558 \mathrm{c}$.

129. Нісімчук А.С., Падалка О.С., Шпак О.Т. Сучасні педагогічні технології: навч. посіб. Київ : Видавництво центр «Просвіта», Пошуково-видав. агентство «Книга Пам’яті України», 2000. 368 с. 
130. Фокин Ю.Г. Преподавание и воспитание в высшей школе: методология, цели и содержание, творчество: учеб. пособ. для студ. высш. учеб. завед. Москва : Издательский центр «Академия», 2002. 224 с.

131. Ковальчук В.Ю. Професійна та світоглядно-методологічна підготовка сучасного вчителя: модернізаційний аналіз. Київ-Дрогобич : Коло, 2004. 264 с.

132. Гура O.I. Теоретико-методологічні основи формування психологопедагогічної компетентності викладача вищого навчального закладу в умовах магістратури: дис. ...докт. пед. наук: 13.00.04. Запоріжжя, 2008. 753 с.

133. Ортинський В.Л. Педагогіка вищої школи : підручник. Львів : Видавництво Львівської політехніки, 2017. 500 с.

134. Великий тлумачний словник сучасної української мови / укл. і гол. ред. В.Т. Бусел. Київ, Ірпінь : ВТФ „Перун”, 2003. С. 252-253.

135. Тульчинский Г.Я. Разум, воля, успех: о философии поступка. Ленинград : ЛГУ, 1990. 216 с.

136. Коновалова В.Б. Педагогічні умови успішності професійної діяльності викладача вищого навчального закладу: дис. ...канд. пед. наук: 13.00.04. Харків, 2005. $230 \mathrm{c}$.

137. Белкин А.С. Ситуация успеха. Как ее создать: Кн. для учителя. Москва : Просвещение, 1991. 176 с.

138. Киселев А.Ф., Савельев А.Я., Сазонов Б.А. Образовательный потенциал России: состояние и развитие : монография. Могилев : Могилевский государственный университет продовольствия, 2004. 136 с.

139. Шишов С.Е., Кальней В.А. Мониторинг качества образования в школе. Москва : Российское педагогическое агентство, 1998. 354 с.

140. Поташник М.М. Управление качеством образования : монография. Москва : Педагогическое общество России, 2004. 448 с.

141. Жебровський Б.М. Формування професійної готовності директора школи до управління якістю освіти: автореф. дис... канд. пед. наук: 13.00.04. Київ, 2002. $22 \mathrm{c}$.

142. Запесоцкий А. Образование: философия, культурология, политика. Москва : Наука, 2002. 456 с.

143. Владимирська Є.Ю. Науково-методичне забезпечення якості дистанційного навчання у технічному університеті: дис. ...канд. пед. наук: 13.00.01. Київ, 2006. 214 с.

144. Global Monitoring Reports. The 2005 year report: Education for All. Quality Imperative. UNESCO publishing, 2004. 430 p. 
145. Внутрішні стандарти забезпечення якості освітньої діяльності та вищої освіти. Частина I / за ред. професора Ю.Я. Бобала. Львів : Видавництво Львівської політехніки, 2019. 448 с.

146. Степко М.Ф. Компетентнісний підхід: його сутність. Що $\epsilon$ прийнятним, а що проблемним для вищої освіти України? Вища освіта України, 2009. № 1 . C. 43-52.

147. Варданян Ю.В. Строение и развитие профессиональной компетентности специалистов с высшим образованием (на материале подготовки педагога и психолога) : автореф. дис. ... докт. пед. наук : 13.00.01. Москва, 1998. 38 с.

148. Огарев Е.И. Компетентность образования : социальный аспект. СанктПитербург : Изд-во РАО ИОВ, 1995.170 с.

149. Чошанов М.А. Гибкая технология проблемно-модульного обучения : метод. пособие. Москва : Народное образование, 1996. 160 с.

150. Браже Т.Г. Профессиональная компетентность специалиста как многофакторное явление. Тезизы к семинару 25-29 июля 1990 г. Москва : НИИОВ, 1990. С. 39-62.

151. Quality education and competencies for life. Background Paper, 2004. P. 6. URL : http://cutt.ly/jfndBLM.

152. Spector, J. Michael - de la Teja, Ileana. ERIC Clearinghouse on Information and Technology Syracuse NY. Competencies for Online Teaching. ERIC Digest. Competence, Competencies and Certification. Pp. 1-3.

153. Вяликова Г.С. Педагогическое стимулирование профессиональной компетентности учителя в условиях заочной формы обучения : автореф. дис. ... д-ра пед. наук: 13.00.01. Коломна, 2006. 44 с.

154. Шадриков В.Д. Новая модель специалиста: инновационная подготовка и компетентностный подход. Высш. образование сегодня. 2004. № 8. C. 26-31.

155. Зимняя И.А. Ключевые компетентности как результативно-целевая основа компетентностного подхода в образовании. Москва : Исслед. центр проблем качества подготовки специалистов, 2004. 40 с.

156. Хуторской А. Ключевые компетенции как компонент личностноориентированной парадигмы образования. Народное образование, 2003. № 2. C. 58-64.

157. Hutmacher W. Key competencies for Europe: Report of the Symposium Berne, Switzerland. Council for Cultural Cooperation (CDCC). Secondary Education for Europe Strasburg, 1997. P. 11. 
158. Байденко В., Стандартов И. Компетентностный подход к проектированию государственных образовательных высшего профессионального образования (методологические и методические вопросы). Москва : Исслед. центр проблем качества подготовки специалистов, 2005. 114 с.

159. Tuning Educational Structures in Europe. 2007. URL: https://cutt.ly/4fnfiCC.

160. Мешко Г.М. Вступ до педагогічної професії : навч. посіб. Київ : Академвидав, 2010. 200 c.

161. Гнезділова К.М. Формування особистісних якостей майбутнього фахівця. Вища школа України в умовах глобалізації та інтеграції : зб. матер. Всеукр. наук.-прак. конф. (27-28 березня 2008 р.). Черкаси : Вид-во ЧНУ, 2008. C. 150-152.

162. Мескон М.Х., Альберт М., Хедоури Ф. Основы менеджмента. Москва : Дело, 2000. 704 с.

163. Dietorich. Elbing. Peagitsch. Ritseher. Psychology de der Zehreгрегsonlichkiet. Munchen, Base1, 1983. 200 p.

164. Шадриков В.Д. Психология деятельности и способности человека : учебное пособие. 2-е изд, перераб. и доп. Москва : Издательская корпорация «Логос», 1996. 320 c.

165. Хрестоматия по возрастной и педагогической психологии. Работы советских психологов периода 1946-1980 гг. / Под ред. И. И. Ильясова, В. Я. Ляудис. Москва : Изд-во Московского университета, 1981. 404 с.

166. Теплов Б.М. Избранные труды: В 2 т. Москва, 1985. Т.1. 328 с.

167. Шадриков В.Д., Дружинин В.Н. Формирование подсистемы профессионально важных качеств в процессе профессионализации. Проблемы индустриальной психологии. Ярославль : Из-во Ярославского гос. ун-та, 1979. С. 3-18.

168. Подласый И.П. Педагогика. Новый курс : уч. для студ. пед. вузов: В 2 кн. Москва : гуманит. изд. центр. ВЛАДОС, 2000. Кн. 1. 576 с.

169. Смирнов С.Д. Педагогика и психология высшего образования: от деятельности к личности : учеб. пособие для студ. высш. пед. учеб. заведений. Москва : Издательский центр «Академия», 2003. 304 с.

170. Дружинин В.Н. Психология общих способностей. Санкт-Петербург : Питер, 1999. 368 с.

171. Занюк С.С. Психология мотивации: Теория и практика мотивирования. Мотивационный тренинг. Киев : Ника-Центр, 2001. 352 с.

172. Додонов Б.И. Структура и динамика мотивов деятельности. Вопросы психологии, 1984. № 4. С. 126-130. 
173. Сочивко Д.В. Расколотый мир. Опыт анализа психодинамики личности человека в экстремальных условиях жизнедеятельности. Москва : ПЕРСЕ, 2002.

174. Маслоу А. Мотивация и личность. Санкт-Петербург : Питер, 2006. 352 c.

175. Зимняя И.А. Педагогическая психология : учеб. пособ. Ростов-наДону: Феникс, 1997. 480 с.

176. Семиченко В.А. Психологія педагогічної діяльності: навч. посіб. Київ : Вища школа, 2004. 335 с.

177. Кузьмина Н. В. Профессионализм деятельности преподавателя и мастера производственного обучения. Москва : Высшая школа, 1989. 119 с.

178. Бойко В.В. Синдром «эмоционального выгорания» в профессиональном общении. Санкт-Питербург : Питер-Пресс, 1999. 105 с.

179. Хорошкина Е. Профессиональное «выгорание» специалистов. Отдел Кадров, 2005. №5. С.3-5.

180. Диагностика профессионального «выгорания» (К. Маслач, С. Джексон) / Н.П. Фетискин, В.В. Козлов, Г.М. Мануйлов. Социальнопсихологическая диагностика развития личности и малых групп. Москва : Издво Института Психотерапии, С. 360-362.

181. Водопьянова Н.Е. Синдром выгорания: диагностика и профилактика / Н.Е. Водопьянова, Е.С. Старченкова. 2-е изд. Санкт-Петербург : Питер, 2005. 336 c.

182. Чепелева Н.А. Психологические особенности эмоционального выгорания преподавателей высших учебных заведений: дис. ... канд. псих. наук: 19.00.01. Краматорск, 2010. 195 с.

183. Новая философская энциклопедия: В 4-х т. Том 2. Москва : Мысль, $2001.636 \mathrm{c}$.

184. Новейший философский словарь / сост. А.А. Грицанов. Минск : Изд. В. М. Скакун, 1998. 896 с.

185. Великий тлумачний словник сучасної української мови / укл. і гол. ред. В.Т. Бусел. Київ, Ірпінь : ВТФ „Перун”, 2003.

186. Краткий словарь по логике / под ред. Д.П. Горского. Москва : Просвещение, 1991. 201 с.

187. Катренко А.В. Системний аналіз об’єктів та процесів комп'ютеризації : навч. посіб. Львів : Науковий світ, 2000. 424 с. 
188. Уемов А.И. Формальные аспекты систематизации научного знания и процедур его развития. Системный анализ и научное знание. Москва : Наука, 1978. C. 95-141.

189. Загвязинский В.И. Исследовательская деятельность педагога : учеб. пособие для студентов высш. учеб. заведений. Москва : Издат. центр «Академия», 2006. $176 \mathrm{c}$.

190. Кудіна В.В. Педагогіка вищої школи. Київ : Ленвіт, 2006. 170 с.

191. Семушина Л.Г. Моделирование профессиональной деятельности в учебном процессе. Специалист, 2004. № 6. С. 23-28.

192. Сердюкова О.Я. Формування педагогічної компетентності майбутніх інженерів-педагогів у навчальному процесі вищого навчального закладу : дис. ... канд. пед. наук : 13.00.04. Луганськ, 2011. 281 с.

193. Гура О.І. Теоретико-методологічні основи формування психологопедагогічної компетентності викладача вищого навчального закладу в умовах магістратури: дис. ...докт. пед. наук: 13.00.04. Запоріжжя, 2008. 753 с.

194. Кремень В. Вища освіта і наука - пріоритетні сфери розвитку суспільства у ХXI столітті. Вища школа, 2002. № 4-5. С. 3-33.

195. Глоссарий терминов рынка труда, разработки стандартов, образовательных программ и учебных планов. ETF (European Training Foundation), 1997. $160 \mathrm{c}$.

196. Делор Ж. Образование: сокрытое сокровище. Доклад Междунар. комиссии по образованию для XXI века, представленный ЮНЕСКО. Paris : UNESCO, 1996. 297 c.

197. Банько Н.А. Формирование профессионально-педагогической компетентности у будущих инженеров : дис. ... канд. пед. наук: 13.00.08. Волгоград, 2002. 203 с.

198. Гершунский Б.С. Философия образования для XXI века (в поисках практикоориентированных образовательных концепций. Москва : Изд-во «Совершенство», 1998. 608 с.

199. Подоляк Л.Г., Юрченко В.І. Психологія вищої школи : підруч. 3-те вид., випр. і доп. Київ : Каравела, 2011. 360 с.

200. Теплов Б.М. Избранные труды: В 2 т. Москва, 1985. Т.1. 328 с.

201. Ковальов А.Г. Психология личности. Москва : Просвещение, 1970. $230 \mathrm{c}$.

202. Мотозюк Л.М. Формування організаторських здібностей у майбутніх керівників прикордонних підрозділів (психологічний аспект): автореф. дис. ... канд. психол. наук: спец. 19.00.09. Хмельницький, 2006. 20 с. 
203. Кузнецов В.М. Коллектив и личность. Москва : Наука, 1975. 166 с.

204. Жуков Ю.М. Методы диагностики и развития коммуникативной компетентности: общение и оптимизация совместной деятельности. Москва : Изд-во Московского университета, 1987. С. 64-74.

205. Зимбардо Ф., Лейппе М. Социальное влияние. Санкт-Петербург : Питер, 2000. 448 c.

206. Панфилова А.П. Деловая коммуникация в профессиональной деятельности: учебн. пособ. Санкт-Петербург : Знание, 2001. 496 с.

207. Почебут Л.Г., Чикер В.А. Организационная социальная психология: учебн. пособ. Санкт-Петербург : Изд-во «Речь2, 2002. 298 с.

208. Орбан-Лембрик Л.Е. Психологія управління. Київ : Академвидав, 2003. $695 \mathrm{c}$.

209. Ильин Е.П. Мотивация и мотивы. Санкт-Петербург : Издательство «Питер», 2006. 508 с.

210. Маркова А.К. Психология профессионализма. Москва : Просвещение, 1996. $190 \mathrm{c}$.

211. Ковалев В.И. Мотивы поведения и деятельности. Москва : Наука, 1988. $192 \mathrm{c}$.

212. Ломов Б. Ф. Методологические и теоретические проблемы психологии. Москва : Наука, 1984. 445 с.

213. Алексюк А.М. Педагогіка вищої освіти України. Київ : Либідь, 1998. $558 \mathrm{c}$.

214. Якунин В.А. Педагогическая психология: учеб. пособ. СанктПетербург : Изд-во «Полиус», 1998. 639 с.

215. Педагогика: Учеб. пособие / В.А. Сластенин, И.Ф. Исаев, А.И. Мищенко, Е. Н. Шиянов. 4-е изд. Москва : Школа-Пресс, 2002.

216. Вікова та педагогічна психологія: навч. посіб. / О.В. Скрипченко, Л.В. Долинська, 3.В. Огороднійчук та ін.; 2-е вид. Київ : Каравела, 2008. 400 с.

217. Нісімчук А.С., Падалка О.С., Шпак О.Т. Сучасні педагогічні технології: навч. посіб. Київ : Видавництво центр «Просвіта», Пошуково-видав. агентство «Книга Пам’яті України», 2000. 368 с.

218. Найдьонов М.I. Формування системи рефлексного управління в організаціях. Київ : Міленіум, 2008. 484 с.

219. Зинченко В. П. Наука о мышлении. Психологическа наука и образование, 2002. № 3. С. 18-24. 
220. Гудвин Дж. Исследование в психологии: методы и планирование. Санкт-Петербург : Питер, 2004. 558 с.

221. Москалець В.П. Структурно-функціональна організація особистості. Психологія і суспільство, 2010. № 2. С. 20-25.

222. Блейк Р., Моутон Дж. С. Научные методы управления. Київ : Наукова думка, 1990. 247 с.

223. Чепелева Н.А. Психологические особенности эмоционального выгорания преподавателей высших учебных заведений: дис. ... канд. псих. наук: 19.00.01. Краматорск, 2010. 195 с.

224. Артемова Е. С. Чинаева О. П. Некоторые теоретические и практические проблемы эстетического воспитания / Вопросы философии. 1987. № 4. С. 63 - 67.

225. Борин $Г$. Обдарована дитина: психолого-педагогічний аспект діяльності педагога в умовах ДНЗ // Матеріали II науково-практичної конференції «Соціальні трансформації у кризовий період». - Вінниця, 2017. С. 33-37.

226. Горошко. Н. Зображувальна діяльність в дошкільному навчальному закладі. Київ, 2007. 208 с.

227. Запорожець І. Д. Виховання емоцій і почуттів у дошкільника. Москва, 1985. 186c.

228. Морозова Л., Бикова I. Робота 3 батьками: Сучасний підхід до організації / Палітра педагога, 2011. №4. С. 13 - 16.

229. Полякова Л. Нетрадиційні техніки малювання - стимул до творчості / Вихователь-методист. 2013 р. № 8. С. 43 - 46.

230. Сухорукова Г. В. Образотворче мистецтво з методикою викладання в дошкільному навчальному закладі. Київ, 2010. 376 с.

231. Формування художньо-продуктивної компетенції дітей дошкільного віку : методичний посібник / упоряд. Т. М. Корж, М. Д. Нельзіна, А. М. Батуринець; КВНЗ. Біла Церква, 2016. 113 с.

232. Циганова С. В Образотворча діяльність - джерело естетичних емоцій та розвитку дошкільників /Дитячий садок. 2007. №23. С.2-42.

233. Шевчук С. Картинки з пластиліну / Дошкільне виховання. 2007. №8. C. $18-20$.

234. Ватченко О.Б., Ільченко В.М. Виникнення та аналіз поняття «сталий розвиток». Вісник Дніпропетровської державної фінансової академії. 2016 [online] URL: http://biblio.umsf.dp.ua/jspui/handle/123456789/1506 (дата звернення 28.10.2021). 
235. Каверин А.В., Массеров Д.А. Роль экологического образования в устойчивом развитии общества. Интеграция образования. 2014. №3 (76). С. $46-$ 51.

236. Базовий компонент дошкільної освіти. Нова редакція та поради для організації освітнього процесу. [online] URL: https://ezavdnz.mcfr.ua/book?bid=37876 (дата звернення 12.11.2021).

237. Пометун О. Програма «Дошкільнятам - освіту для сталого розвитку». [online] URL: https://www.pedrada.com.ua/article/2343-programa-doshklnyatamosvtu-dlya-stalogo-rozvitku (дата звернення 02.12.2021).

238. Гайдамак А., Тійтанен Т. Соціально-екологічний ідеал. Методика ознайомлення дітей з природою. Хрестоматія / Укладач Н.М. Горопаха. Київ: Видавничий дім «Слово», 2012. С. 34-43

239. Горопаха Н.М. Виховання екологічної культури дітей. Рівне: «Волинські обереги», 2001.212 с.

240. Терещенко А. П. Музыкальное развитие подростка. Семья и школа. 1989. № 1. C. 23.

241. Талызина Н. Ф. Педагогическая психология. Москва, 1998. С. 34.

242. Изучение личности школьника учителем / Под ред. 3. И. Васильевой и др.; [3. И. Васильева, Н. В. Бочкина, Е. С. Заир-Бек и др.]. Москва, 1991. С. 87.

243. Izard C. The psychology of emotions. New York: Plenum Press, 1991.

244. Професійний стандарт за професіями «Вчитель початкових класів закладів загальної середньої освіти», «Вчитель закладу загальної середньої освіти», «Вчитель 3 початкової освіти (з дипломом молодшого спеціаліста)»: наказ Міністерства розвитку економіки, торгівлі та сільського господарства України № 2736 від 23.12.2020 p. URL: https://cutt.ly/HTMMmZl

245. Стангвик Г. Интегрированное обучение : мировой опыт / под ред. С. Пейла, К. Нейера и С. Хегерта. Лондон, 1997. 156 с.

246. Богинская Ю. В. Социально-педагогическая поддержка студентов с ограниченными возможностями в высших учебных заведениях : теория и практика : монография. Ялта : РИО РВУЗ «КГУ», 2012. 384 с.

247. Малік М. В. Функціональний компонент підготовленості майбутніх менеджерів освіти до управління загальноосвітнім навчальним закладом інклюзивного типу. Наша школа. 2014. № 4. С. 25-28.

248. Миронова С. П., Буйняк М. Г., Плохотнюк Н. С. Професійна компетентність керівника як умова створення інклюзивного простору закладу. Актуальні питання корекційної освіти. 2018. № 11. С. 169-173. 
249. Данілавічютє Е. А., Литовченко С. В. Стратегії викладання в інклюзивному навчальному закладі: навчально-методичний посібник / за ред. А. А. Колупаєвої. К. : Видавнича група «А.С.К.», 2012. 360 с.

250. Хафизулина И. Н. Формирование инклюзивной компетентности будущих учителей в процессе профессиональной подготовки : автореф. дис. ... канд. пед. наук : 13.00.08. Астрахань, 2008. 22 с.

251. Хитрюк В. В. Готовность педагогов к инклюзивному образованию : ценностный аспект. Вестник Московского городского педагогического университета. 2013. № 4. С. 102-111.

252. Чайковський M. $€$. Інклюзивна компетентність як складова професійної компетентності суб'єктів навчально-виховного процесу. Педагогіка і психологія професійної освіти. 2012. № 2. С. 15-21.

253. Чайковський М. Є., Соловей Т. В. Змістовні компоненти професійної компетентності соціального працівника інклюзивного закладу освіти. Збірник наукових праць Хмельницького інституту соціальних технологій Університету «Україна». Хмельницький, 2013. № 1 (7). С. 220-224.

254. Бойчук Ю. Д., Бородіна О. С., Васильєва К. І. Інклюзивна компетентність майбутнього вчителя основ здоров'я : теоретико-методичні аспекти / за заг. ред. Ю. Д. Котчуна. Харків : ХНПУ ім. Г. С. Сковороди, 2014. 32 c.

255. Інструктивно-методичні рекомендації щодо організації навчання осіб 3 особливими освітніми потребами у закладах загальної середньої освіти у 2020/2021 навчальному році: додаток до листа Міністерства освіти і науки України від 31 серпня 2020 р. № 1/9-495. URL : https://cutt.ly/GTMMF14

256. Асистент учителя в інклюзивному класі: навчально-методичний посібник / Н. М. Дятленко та ін. ; за заг. ред. М. Ф. Войцехівського. Київ : ТОВ Видавничий дім «Плеяди», 2015. 172 с.

257. Огляд ролі асистентів учителів у канадських школах. Досвід провінцій Манітоба, Нова Шотландія та Альберта: посібник / за ред. Е. Чорнобой, О. Красюкова-Еннз. К. : Паливода А. В., 2012. 32 с.

258. The Bologna Process 2020: The European Higher Education Area in the new decade. Communique of the Conference of European Ministers Responsible for Higher Education. Leuven and Leuven-la-Neuve, 28-29 April [Electronic resource]. Mode of access: http://europa.eu/rapid/press-release_IP-09-675_en.htm

259. Haerens, L., Kirk, D., Cardon, G., \& De Bourdeaudhuij, I. (2011). Toward the development of a pedagogical model for health-based physical education. Quest, 63(3), 321-338. https://doi.org/10.1080/00336297.2011.10483684. 
260. Ivashchenko, O., Muszkieta, R., \& Potop, V. (2020). Didactics: Methodological Approaches to Determining the Content of Physical Education Teacher Training. Journal of Learning Theory and Methodology, 1(1), 40-47. https://doi.org/ 10.17309/j1tm.2020.1.

261. Karapetyan, A.O. (2015). Increasing academic mobility as a strategic task of state policy in the field of education. Aspects of public administration, 1-2, 48-55. [Electronic resource]. Access mode: http://nbuv.gov.ua/UJRN/aplup_2015_1-2_8

262. Mukan, N., Noskova, M., \& Baibakova, I. (2017). The formation of school principals' readiness to use internet technologies in their work in the system of continuous pedagogical education. Science and education, 4, 123-132.

263. Thorburn, M., \& Stolz, S. (2017). Embodied learning and school-based physical culture: implications for professionalism and practice in physical education. Sport, Education and Society, 2(6), 721-731. https://doi.org/10.1080/13573322.2015.1063993

264. Pedagogy theory: collective monography (2020). / Aksonova O., Avdieieva S., Kobets V., etc. International Science Group. Boston : Primedia eLaunch, 321 p. https://doi.org/: 10.46299/isg.2020.MONO.PED.I

265. Porto Cardoso, G. M., Figueredo, W. N. (2015). Universidade e sociedade: o papel do professor na (re) construção do conhecimento. Revista Intersaberes, 14(31), 129-144. https://doi.org/: 10.22169.

266. Психодиагностические методики изучения гендерных особенностей личности [Электронный ресурс]: метод. рекомендации для студентов, обуч. по специальностям 1-86 0101 «Социальная работа (по направлениям)» и 1-230104 «Психология» / сост. Е. Д. Беспанская-Павленко. - Минск: БГУ, 2013.

267. Лопухова О.Г. Опросник «Маскулинность, феминность и гендерный тип личности» (российский аналог «Bem sex role inventory») // Вопросы психологии, №1, стр. 147-154, 2013.

268. Polskaya I. I. Musical culturology as a science and university specialty // Sociocultural communications in the information society: abstracts of the international scientific conference. Kharkiv: KhDAK, 2003. P. 177-178.

269. Educational and scientific program «Musical Art» of the third (educational and scientific) level of higher education in the specialty 025 Musical Art in the field of knowledge 02 Culture and Art, qualification: Doctor of Philosophy in Music / Developers: Ryabukha N. O., Konovalova I. Yu., Polska I. I., Roschenko O. G., Shchepakin V. M., Dontsova-Pushenko K. Yu. Kharkiv: Kharkiv State Academy of Culture, 2021. 29 p. URL: https://ic.ac.kharkov.ua/navchannya/mm/tim/materials/onp2021-1.pdf 
270. Sirotynska N. Review of the educational-scientific program «Musical Art», implemented at the Department of Theory and History of Music of the Kharkiv State Academy of Culture for training third-level $(\mathrm{PhD})$ higher education in specialty 025 «Musical Art» in the field of knowledge «02 Culture and Art». URL: https://ic.ac.kharkov.ua/navchannya/mm/tim/materials/syrotynska.pdf

271. Nemkovych O. Review of the educational-scientific program «Musical Art» of training of applicants for higher education of the third (educational-scientific) level in the specialty 025 «Musical Art» in the field of knowledge «02 Culture and Art», qualification «Doctor of Philosophy in Music» (developer - Department of Theory and History of Music, Kharkiv State Academy of Culture). URL: https://ic.ac.kharkov.ua/navchannya/mm/tim/materials/nemkovich.pdf

272. Polska I. I. Innovative teaching methods in higher education: syllabus of the discipline for postgraduate study (PhD) in the specialty «Musical Art» / Kharkiv State Academy of Culture. Kharkiv: KhDAK, 2021. P. 9-29. URL: https://ic.ac.kharkov.ua/navchannya/mm/tim/materials/nmz/s025_imv2.pdf

273. Konovalova I. Yu. The Methodology of Theoretical Musicology: syllabus of the discipline for postgraduate study $(\mathrm{PhD})$ in the specialty «Musical Art» / Kharkiv State Academy of Culture. Kharkiv: KhDAK, 2021. 18 p. URL: https://ic.ac.kharkov.ua/navchannya/mm/tim/materials/nmz/s025_mtm2.pdf

274. Polska I. I. Problems of Performing Musicology: syllabus of the discipline for postgraduate study $(\mathrm{PhD})$ in the specialty «Musical Art» / Kharkiv State Academy of Culture. Kharkiv: KhDAK, 2021. 20 p. URL: https://ic.ac.kharkov.ua/navchannya/mm/tim/materials/nmz/s025_pvm2.pdf

275. Konovalova I. Yu. Traditional musical culture of the Asian region countries: syllabus of the discipline for postgraduate study $(\mathrm{PhD})$ in the specialty "Musical Art" I Kharkiv State Academy of Culture. Kharkiv: KhDAK, 2021. 16 p. URL: https://ic.ac.kharkov.ua/navchannya/mm/tim/materials/nmz/s025_tmk.pdf

276. Polska I. I. History of Chinese Musical Art: syllabus of the discipline for postgraduate study $(\mathrm{PhD})$ in the specialty «Musical Art» / Kharkiv State Academy of Culture. Kharkiv: KhDAK, 2021. 10 p. URL: https://ic.ac.kharkov.ua/navchannya/mm/tim/materials/nmz/s025_ikmm.pdf

277. Konovalova I. Yu. Philosophy of Music: syllabus of the discipline for postgraduate study $(\mathrm{PhD})$ in the specialty «Musical Art» / Kharkiv State Academy of Culture. Kharkiv: KhDAK, 2021. 15 p. URL: https://ic.ac.kharkov.ua/navchannya/mm/tim/materials/nmz/s025_fm2.pdf

278. Polska I. I. Sociology of Music: syllabus of the discipline for postgraduate study $(\mathrm{PhD})$ in the specialty «Musical Art»/ Kharkiv State Academy of Culture. Kharkiv: KhDAK, 2021. 10 p. https://ic.ac.kharkov.ua/navchannya/mm/tim/materials/nmz/s025_sm.pdf 
279. Академічна доброчесність: проблеми дотримання та пріоритети поширення серед молодих вчених : кол. моногр. / за заг. ред. Н. Г. Сорокіної, А. Є. Артюхова, І. О. Дегтярьової. - Дніпро : ДРІДУ НАДУ, 2017. - 169 с.

280. Академічна чесність як основа сталого розвитку університету / Міжнарод. благод. фонд «Міжнарод. фонд. дослідж. освіт. політики»; за заг. ред. Т. В. Фінікова, А. С. Артюхова. - К.: Таксон, 2016. - 234 с.

281. Kyrychenko Mykola. On the scientific, scientific and methodical activity of the State higher education institution "University of educational management" under the educational management decentralization. Scientific report at the meeting of the Presidium of the National Academy of Educational Sciences of Ukraine, December 17, 2020 // Вісник НАПН України. - 2020. - 2(2). - https://doi.org/10.37472/2707$305 X-2020-2-2-2-6$

282. Методичні рекомендації для закладів вищої освіти з підтримки принципів академічної доброчесності / упоряд.: В. Бахрушин, Є. Ніколаєв. - К., 2019. - 41 c.

283. Професійний розвиток фахівців в умовах цифровізації суспільства: сучасні тренди : наук.-практ. конф. 3 міжнар. участю : Матеріали конф. / наук. ред. О. М. Спірін, О. А. Острянська. - Житомир: ЖДУ ім. І. Франка, 2021. - 279 c.

284. Рекомендації для закладів вищої освіти щодо розробки та впровадження університетської системи забезпечення академічної доброчесності (затверджено Рішенням Національного агентства із забезпечення якості вищої освіти від 29 жовтня 2019 р., протокол № 11). - К., 2019. - 24 с.

285. Рекомендації щодо забезпечення принципів академічної доброчесності. Підкомісія 303 «Академічна доброчесність» Науково-методичної комісії 15 з організаційно-методичного забезпечення вищої освіти. - К.: МОН України, 2016. - 24 с.

286. Сайт ДЗВО «Університет менеджменту освіти». Внутрішні нормативні документи. - URL: http://umo.edu.ua/vnutrishni-normativni-dokumenti

287. Стратегія розвитку ДЗВО «Університет менеджменту освіти» на період до 2024 року. - К., 2020. - 15 с. - URL: http://umo.edu.ua/strateghijarozvitku-do-2024-roku

288. Войтко, В. И. (Ред.). (1982). Психологический словарь. Киев: Высшая школа.

289. Джидарьян, И. А. (1974). О месте потребностей, эмоций и чувств в мотивации личности. Теоретический проблемы в психологии личности. Москва: Наука. 
290. Карпенко, Т. П. (2012). Формування музично-слухової спостережливості - складової виконавських навичок майбутніх учителів музики. Педагогічна освіта: теорія і практика, 12, 347-353.

291. Леонтьев, А. Н. (1983). Избранные психологические произведения. (2х тт.). Москва: Педагогика.

292. Миколінська, С. І. (2013). Методика формування слухової уваги молодших школярів на уроках музики. (Аавтореф. дис. канд. пед. наук). Нац пед. ун-т ім. М. П. Драгоманова, Київ.

293. Прохоров, А. М. \& Гусаева, А. А. (Ред.). (1987). Советский энциклопедический словарь. (4-е изд., доп.). Москва: Сов. энцикл.

294. Теплов, Б. (1947). Психология музыкальных способностей. Москва; Ленинград: АПН РСФСР.

295. Гончаренко С. У. Український педагогічний енциклопедичний словник. Видання друге, доповнене й виправлене - Рівне: Волинські обереги, 2011. - 552c.

296. Лимаренко Л.І. Студентський театр у системі професійної підготовки майбутніх педагогів [Текст]: монографія / Лідія Лимаренко ; Херсон. держ. ун-т. - Херсон : ХДУ, 2015. - 483 с.

297. Олексюк О.М. Музична педагогіка: навч. посіб. / О.М. Олексюк. - К.: Київ, ун-т ім. Б. Грінченка, 2012. - 188 с., с.125.

298. Олексюк О.М., Бондаренко Л.А. Методика викладання музичних дисциплін у вищій школі: навч. посіб. / О.М. Олексюк.,Л.А. Бондаренко. - К.: Київ, ун-т ім. Б. Грінченка, 2018. - 112с., с.78.

299. Рудницька О.П. Педагогіка: загальна і мистецька: [навч. посіб.] / Оксана Петрівна Рудницька. - К.: 2002. - 270 с., с. 155.

300. Театральная педагогика как средство создания розвивающей образовательной среды: образовательная программа повышения квалификации педагогов и руководителей образования. - Екатеринбург, АМБ, 2005. - 160 с.

301. Абрамов, Р. Н. Менеджериализм и академическая профессия. Конфликт и взаимодействие. Социологические исследования. 2011. № 7. С. 37 47.

302. Акции, стартапы, недвижимость: куда инвестируют Гарвард, Йель, Стэнфорд и другие зарубежные университеты. URL : https://www.rvc.ru/pressservice/media-review/venture/157912/

303. В уряді розповіли про плани перебудови фінансування освіти і науки URL:

https://www.unn.com.ua/uk/news/1834855-v-uryadi-rozpovili-pro-planiperebudovi-finansuvannya-osviti-i-nauki 
304. Гумбольдт В. О внутренней и внешней организации высших научных учреждений в Берлине. Неприкосновенный запас. 2002. № 2 (22). URL : http: //ecsoc

305. Дим Р. «Новый менеджериализм» и высшее образование: управление качеством и продуктивностью работы в университетах Великобритании. Вопросы образования. 2004. № 3. С. 44-56.

306. Захаров И. В., Ляхович Е. С. Миссия университета в европейской культуре.

M., 1994. 85 c.

307. Кухаренко В. ТЕНДЕНЦІЇ РОЗВИТКУ ЕЛЕКТРОННОЇ ОСВІТИ http://education-ua.org/ua/analytics/438-tendentsiji-rozvitku-elektronnoji-osviti-v2015-r

308. Мирча М. Институциональные подходы к предпринимательству: анализ и опыт университета Бабеш-Больяй в Клуж-Напоке. Высшее образование в Европе. 2006. Т. XXXI, № 2.

309. Морин Э.Образование для будущего: семь уроков прошлого // Alma mater.2008. №3. C. 44-50

310. Офіційний сайт Харківського національного університету імені О. М. Бекетова. URL : https://www.kname.edu.ua/index.php/ru/

311. Прохоров А. В. Влияние ценностей академического капитализма на функционирование современных университетов. Вестник ТГУ. Сер. «Гуманитарные науки». 2012. № 5. С. 271-278.

312. Радионова Л. А. Теория поколений и воспитательная работа в современном вузе. URL : https://core.ac.uk/download/pdf/78068467.pdf

313. Рейтинги ВУЗов URL: https://ru.osvita.ua/vnz/rating/64752/

314. Сайт университета Халмерс. - URL : http://www.chalmers.se/en/

315. Стало відомо, скільки українці витрачають на їжу URL : https://economics.unian.ua/finance/10250745-stalo-vidomo-skilki-ukrajincivitrachayut-na-jizhu.html

316. Цілі у сфері сталого розвитку.

https://www.un.org/sustainabledevelopment/ru/education/

317. Шамис Е., Антипов А. Теория поколений. Маркетинг Менеджмент. 2007. № 6. URL: http://old.e-xecutive.ru/publications/

318. Botkin J.W., Elmanda M., Malitza M., 1979 
319. Wissema J. Towards the Third Generation University: Managing the University in Transition. Cheltenham: Edward Elgar, 2009. 272 p. from

320. Clark B. Collegial Entrepreneurialism in Proactive Universities: Lessons

Europe. Change. 2000. Vol. 32. No. 1. Pp. 10-19. URL : man. hse.ru/univman/msg/144983.html

321. Slaughter S., Leslie L. Academic Capitalism: Politics, Policies and the Entrepreneurial University. Johns Hopkins UP: 1997. 296 p.

322. Ryan Jenkins, HR Daily Advisor. Generation $Z$ vs. Millennials: The 8 Differences You Need to Know By Ryan Jenkins, Author. International Keynote Speaker Sep 25, 2017 HR Management URL :

https://hrdailyadvisor.blr.com/2017/09/25/generation-Z-vs-millennials-8differences-need-know/

323. Lee, J. Key Trends in Higher Education. Academic American. 2004. V. 1, № 1. P. 21-36.

324. Кармаев А.Г. Организационно-педагогические основы инновационных образовательных процессов в школе: автореферат дис. д-ра пед. наук. М., 1997.

325. Nicholls A. Managing Educational Innovations [Текст] / A. Nicholls London, 1983. $-276 \mathrm{p}$.

326. Ляудис В.Я. Психология инновационного обучения в диалоге с культурно-исторической психологией Л.С. Выготского // Известия академии педагогических наук. М., 1996. С. 74-81.

327. Словник базових понять 3 курсу «Педагогіка»: навч. посіб. для студ. вищ. навч. закл. / уклад. О. Є. Антонова. вид. 2-ге, доп. і перероб. Житомир: Видво ЖДУ імені Івана Франка, 2014. 100 с.

328. Бабенко А. Л. Сутність і зміст понять «інтеграція» та «інтеграційне заняття». Науковий вісник Ужгородського національного університету. Сер.: Педагогіка. Соціальна робота. 2015. №37. С. 9-12.

329. Мариновська О. Інтегральна технологія навчання: від теорії до практики. Початкова освіта. 2011. No32 (608). С. 3-5.

330. Сакун А.Ж., Якайтіс I. Організаційно-структурне удосконалення механізмів державного управління інноваційним розвитком освіти та науки в Україні // Наукові записки Інституту законодавства Верховної Ради України. 1(1), 2018.- C. 94-101 
331. Коновальчук I. I. Інноваційне середовище як засіб розвитку інноваційної компетентності педагогів загальноосвітніх закладів. Вісник Житомирського державного університету імені Івана Франка. Педагогічні науки. Житомир, 2014. Вип. 4 (76). С 62-66.

332. Інновації як основа змін освітньої практики. Інформаційнометодичний збірник /Упорядник Г.О. Сиротенко. - Полтава: ПОІППО, 2005. $160 \mathrm{c.}$

333. Мяленко В. В. Психологія професійної самореалізації молоді: монографія. Київ : Міленіум, 2016. 104 с.

334. Дубасенюк О. А., Вознюк О. В. Концептуальні підходи до професійнопедагогічної підготовки сучасного педагога. Житомир: Вид-во ЖДУ ім. I. Франка, 2011. 114 с.

335. Пуховська Л. Сучасні підходи до професіоналізму вчителя в різних освітніх системах. Шлях освіти. 2001. №1. С. 21-25.

336. Ребуха Л. 3. Інноваційні процеси вищої школи: технологічний аспект. Теорія і практика розвитку наукових знань (частина III): матеріали II Міжнар. наук.-практ. конф. (Київ, 28-29 груд. 2017 р.). Київ: МЦНД, 2017. С. 35-36.

337. Освіта України. Збірник законів: додаткове видання / за ред. Борисенко С.О. - Х.:Бурун книга, 2007. - С.4.

338. Ніколаєнко С.М. Теоретико-методологічні основи управління інноваційним розвитком системи освіти України. [монографія]. - К, 2008. - С. 9.

339. Енциклопедія освіти / Акад.пед.наук. України. /за ред.. Кремень В.Г. - К.: Юрінком інтер, 2009. - С. 339.

340. Ващенко Л.М. управління інноваційними процесами в загальній середній освіті. [монографія]. - К: Видавниче об'єднання «Тираж», 2005. - 380с.

341. Дичківська I.M. Інноваційні педагогічні технології: навч. посіб. К.:2004. - 352c.

342. Попова О.В.Становлення і розвиток інноваційних педагогічних ідей в Україні. - Харьків: ОВС, 2001. - 256с.

343. .Радкевич О.В. Дослідницькі засади діяльності педагога професійної школи. Професійно-технічна освіта. 2006. №4.

344. Гнеденко Б.В. О специальных курсах и семинарах естественнонаучного и прикладного характера //Сборник научно-методических статей по математике. Вып.15. - М.: Высшая школа, 1988. - С.4-9.

345. Семенишина I.В. Деякі шляхи реалізації прикладної спрямованості навчання математики при підготовці військових спеціалістів вищої кваліфікації. / Наук. праці Кам-Под. нац.універ. імені Івана Огієнка. Збір. Звітної конференц.Вип.9.Том.2. - С.112-116. 
346. Бахтіярова Х. Ш. Інноваційні технології навчання: навч. посібник / X. Ш. Бахтіярова, А. В. Арістова, С. В. Волобуєва. - Київ: НTУ, 2017. URL: https://ukreligieznavstvo.wordpress.com/2019/01/18/itn/

347. Стратегія розвитку вищої освіти в Україні на 2021-2031 роки. (Проєкт) URL: $\quad$ https://mon.gov.ua/storage/app/media/rizne/2020/09/25/rozvitku-vishchoiosviti-v-ukraini-02-10-2020.pdf.

348. Луценко Г. В. Аналіз особливостей впровадження проблемноорієнтованого навчання у системі вищої освіти України [Електронний ресурс] / Г. В. Луценко, Л. В. Козуля // Вісник Чернігівського національного педагогічного університету. Серія: Педагогічні науки. - 2016. - Вип. 138. - С. 9195. URL: http://nbuv.gov.ua/UJRN/VchdpuP_2016_138_21

349. Полат Е. С. Метод проектов / Полат Е. С. // Метод проектов в университетском образовании / [под общ. ред. М. А. Гусаковского]. - Минск : БГУ, 2008. - С. 34-42.

350. Юханов Ю. В. Методические аспекты применения кейс-метода в обучении студентов физике : (на примере темы "Электромагнитные волны радиодиапазона") / Ю. В. Юханов, Е. В. Донскова, Д. В. Семенихина // Известия Волгоградского государственного педагогического университета. - 2020. - № 5 . - C. 49-54.

351. Сурмин Ю. П. Кейс-метод: становлення та розвиток в Україні / Ю. П. Сурмин // Вісник НАДУ. -2015 -№2.- С.19-28.

352. Активізація навчально-пізнавальної діяльності студентів на основі методу аналогії у навчанні фізики (на нефізичних факультетах): монографія. Полтава : Полтавський університет споживчої кооперації України, 2008. - 109 с.

353. Шевчук М. О. Синектика як метод активізації творчого мислення студентів / М. О. Шевчук // Наукові записки НДУ ім. М. Гоголя. Психологопедагогічні науки. - 2012. - № 1. - С. 111-114.

354. Терещенко Н. В. (2012). Інтелект-карти - сучасні інноваційні соціальні технології навчання в системі освіти / Н. В. Терещенко // Вчені записки. 1. - 2012. -4. C. 139-145.

355. Юрченко А. О. Віртуальна лабораторія як складова сучасного експерименту / А. О. Юрченко, Ю. В. Хворостіна // Науковий вісник Ужгородського університету. Серія: «Педагогіка. Соціальна робота». - Ужгород: Видавництво УжНУ «Говерла». - 2016. - Вип. 2 (39) . - С. 281-283.

356. Гулінський О. Г., Совкова Т. С. Віртуальні лабораторії у сучасних технологіях навчання шкільного курсу фізики // Trends in the development of modern scientific thought: the Proc. of the $X$ th International scientific and practical conference «Trends in the development of modern scientific thought», November 2326, 2020 p., Vancouver, Canada. - P. 221-223. 
357. Жалдак М. І. Вступ до теорії ймовірності і математичної статистики в шкільному курсі математики / М. І. Жалдак // Математика в рідній школі. - 2017. - №5 (187). C. 16-21.

358. Воробьев А. Е. Основы технологии «перевернутого обучения» в вузах [Электронный ресурс]. - URL: https://cyberleninka.ru/article/n/osnovy-tehnologiiperevernutogo-obucheniya-v-vuzah/viewer.

359. Морзе Н. В. Використання технологій «перевернутого» навчання на основі відео-матеріалів / Н. В. Морзе , Л. О. Варченко-Троценко // Науковий часопис НПУ імені М. П. Драгоманова. Серія 2 : Комп'ютерно-орієнтовані системи навчання. - 2019. - 21. - C. 9-17. URL: http://nbuv.gov.ua/UJRN/Nchnpu_2_2019_21_4.

360. Григорьева О. Н. Превернутое обучение в образовательном процессе: сущность, преимущества, ограничения / О. Н. Григорьева // Вышэйшая школа. 2018. - № 6. - C. 50-53.

361. Бухарестская декларация по этическим ценностям и принципам высшего образования в Европейском регионе [Електронний ресурс] // CEPES, Бухарест. - 2004. - http://www.sde.ru/files/t/pdf/2.pdf2.

362. Конституція України: подарункове видання / упоряд.: Л. І. Бірюк, Н. І. Адамчик, Є. Г. Кудлай [та ін.]. Київ: BAITE, 2021. 324 с

363. Там же, с. 59

364. Бывальцев В.А., Степанов И.А., Белых Е.Г., Калинин А.А., Бардонова Л.А. Плагиат и академическая добросовестность в науке // Вестник РАМН. 2017. №4.

365. Закон України «Про освіту» [Електронний ресурс]. https://zakon.rada.gov.ua/laws/show/2145-19\#Text.

366. Закон України «Про вищу освіту» [Електронний ресурс]. http://zakon5.rada.gov.ua/laws/show/1556-18

367. Варава I. М. Проблема академічної доброчесності у сучасному суспільноосвітньому середовищі. Науковий часопис НПУ ім. М. П. Драгоманова (66)2019. Київ, 2019. С. 22-26.

368. Бойченко Н.M. Етичні аспекти університетських цінностей https://revolution.allbest.ru/ethics/01127466_0.html

369. Мовчан В. С. Етика: навч. посіб. / В. С. Мовчан. К.: Знання, 2007. 483 c. 398$)$.

370. Зінченко О.В. Деякі аспекти професійної етики викладача / О.В. Зінченко // Тези доповідей та повідомлень учасників VI конференції "Школа професійної майстерності". - Х. : Нац. ун-т "Юрид. акад. України ім. Ярослава Мудрого", 2012. - С. 18-21. 
371. Академічна доброчесність: проблеми дотримання та пріоритети поширення серед молодих вчених / за заг. ред. Н. Г. Сорокіної, А. С. Артюхова, І. О. Дегтярьової. Дніпро : ДРІДУ НАДУ, 2017. 169 с.

372. Тодорова I. Психологічні чинники толерантності студентів до академічної недоброчесності. Психологія і особистість. 2019. № 2. С. 116-131. DOI: https://doi.org/10.33989/2226-4078.2019.2.177352.,

373. Колесніков А. Академічна доброчесність в українському освітньонауковому просторі: проблеми та соціальні загрози / А.Колесніков //Регіональні аспекти розвитку продуктивних сил України. - 2019. вип.24. :http://dspace.wunu.edu.ua/bitstream/316497/38304/1/\%D0\%9A\%D0\%BE\% D0\%BB\%D0\%B5\%D1\%81\%D0\%BD\%D1\%96\%D0\%BA\%D0\%BE\%D0\%B2.pdf

374. Етичний кодекс ученого України // Бюлетень ВАК. 2009. № 6. С. 1518

375. Як посилити політику доброчесності 3ВО? Академічна доброчесність. Інформаційний бюлетень Випуск №12, лютий $2021 \mathrm{p}$. https://www.skeptic.in.ua/wp-content/uploads/Integrity-bulletin-12.pdf

376. Прес-конференція "Презентація проєкту "Ініціатива академічної доброчесності та якості освіти”, 23.10.2020,

https://saiup.org.ua/novyny/pres-konferentsiya-prezentatsiya-proyektuinitsiatyva-akademichnoyi-dobrochesnosti-ta-yakosti-osvity/

377. Ромакш, В. В. Академічна чесшсть як политична проблема / В. В. Ромакш // Наук. пр. / Микола1'в. держ. гумашт. ун-т ім. Петра Могили. Микола1'в, 2002. - Вип. 12. - С. 165-170.

378. Култаєва М. Д., Прокопенко І. Ф., Радіонова І. О., Троцко Г. В. Соціологія глобалізації. Харків: ХНПУ імені Г. С. Сковороди, 2007. 266 с.

379. Великий тлумачний словник сучасної української мови / уклад. та голов. ред. В. Т. Бусел. К. Ірпінь: Перун, 2005. 1728 с.

380. Сушенцева Л. Професійна мобільність як сучасна педагогічна проблема. Креативна педагогіка: наук.-метод. журн. 2011. Вип. 1. С. 129-136.

381. Хом’юк I. В. Теоретико-методичні засади формування базового рівня професійної мобільності майбутніх інженерів: монографія. Вінниця: ВНТУ, 2012. 379 c.

382. Кузьміч Т.А. Проектування педагогічного простору для стимулювання внутрішньої і зовнішньої мобільності учасників навчальновиховного процесу: метод. рек. Херсонська академія неперервної освіти. Херсон, 2012. 18 c. 
383. Андрущенко В. Академічна мобільність в українському просторі вищої освіти: реалії, виклики та перспективи розвитку. Вища освіта України. 20016. №2 c. 5-11.

384. Стрельніков В. Підготовка викладачів до проектування дидактичних систем. Педагогіка і психологія професійної освіти. 2006. № 2. С. 9-23

385. Сушенцева Л. Л. Формування професійної мобільності майбутніх кваліфікованих робітників у професійно-технічних навчальних закладах: теорія і практика: монографія / за ред. Н. Г. Ничкало. Інститут професійно-технічної освіти НАПН України. Кривий Ріг: Видавничий дім, 2011. 439 с.

386. Special Features in City School Systems. United States Bureau of Education. Washington: Govt. Print. Off., 1913. (Statistics of land-grant colleges and universities, Vol. 3, Issues 31-45).

387. Концепція розвитку неперервної педагогічної освіти: Наказ Міністерства освіти i науки України від 14.08.2013 p. № 1176. URL: http://osvita.ua/legislation/Ser_osv/36816/

388. Закон України «Про вищу освіту»: від 05.02.2021p. № 1216-IX. URL:https://zakon.rada.gov.ua/laws/show/1556-18\#Text (дата звернення: 26.02.2021).

389. Закон України «Про освіту»: від 05.11.2020 p. № 978-IX. Законотворчість: база даних/Верхов. Рада України. URL:https://zakon.rada.gov.ua/laws/show/2145-19 (дата звернення: 01.01.2021).

390. Budagov R.A. Man and his language / R.A. Budagov. - M .: Izd-vo MGU, 1970.

391. Gamkrelidze T.V. Linguistic typology and Indo-European reconstruction. Izvestiya AN SSSR. - Sir. lit. and language. 1977. № 3. V. 36.

392. Humboldt von W. Language and philosophy of culture. M., 1985. P. 378.

393. Zhayvoronok V.V. Word in the ethnological context // Linguistics. 1996, № 1 . Pp. 12 - 13.

394. Zhayvoronok V.V. Ukrainian ethnolinguistics: some aspects of research // Linguistics. 2001, № 5. Pp. 48 - 63.

395. Krasnykh V.V. Ethnopsycholinguistics and linguoculturology: Course of lectures. M .: ITDGK "Gnosis", 2002. 284 p.

396. Potebnya A.A. Thought and language. K., 1991. P. 98.

397. Potebnya A.A. About some symbols in Slavic folk poetry: a fragment // Aesthetics and poetics. M.: Iskusstvo, 1996. P. 223 - 227.

398. Sapir E. Selected works on linguistics and culturology. M., 1993. P.243.

399. Stepanov Yu. S. French stylistics. M .: Higher School, 1995. 120 p. 
400. Tolstoy N.I. Ethnolinguistic dictionary of Slavic antiquities. M., 1984. - 172 p.

401. Tomakhin G.D. Realities in language and culture // Foreign languages in school, 1997, № 3 .

402. Tomasheva I.V. The concept of "lacuna" in modern linguistics. Emotional lacuna // Language and emotions: Sb. scientific tr. / VGPU. Volgograd: Peremen, 1995. $125 \mathrm{p}$.

403. Ethnocultural stereotypes in the Slavic folk tradition. M., "Indrik", 2005. $288 \mathrm{p}$. İstanbul.

404. Vendryes, J. V. (2001). Dil ve Düşünce, Çev: Berke Vardar, Multilingual,

405. Kozan, O. (2019). Dil Dizgesinde Eşdizimlilik: Öğretim Odaklı Dilbilimsel Betimleme Örneği, Dil Eğitimi ve Araştırmaları Dergisi, 5(2), 251-266.

406. Şahmatov, A.A. (2001). Sintaksis russkogo yazıka, URSS Moskva.

407. Lekant, P.A. (2004). Sintaksis prostogo predlojeniya v sovremennom russkom yazıke, Uçebnoe posobie, Vısşaya şkola, Moskva.

408. Glazunova, O.İ. (2011). Grammatika russkogo yazıka v uprajneniyah i kommentariyah, Sintaksis, Zlatous, St. Petersburg.

409. Zolotova, G. A., Onipenko, N. K., Sidorova M. Yu. (2004). Kommunikativnaya grammatika russkogo yazıka, M., 1998, 2 izd. M., 2004.

410. Zavyalova, O. S. (2005). Sposob1 vrajeniya subyekta v russkom yazıke (k metodike prepodavaniya), Mir russkogo slova, No:3-4, 62-68.

411. Yakushko K.H..Anglijska mova AI sk .URL: https://elearn.nubip.edu.ua/ course/ view.php? id $=723$

412. Yakushko K.H. Anglijska mova GIZ. URL:https:// elearn. nubip.edu. ua/course /view. php?id=2316

413. Neil O' Sullivan, James D. Libbin Agriculture/ Career Paths Express Publishing, 2011. $40 \mathrm{p}$

414. Yakushko K.H. Rol' terminosystemy tekstu Vehicle parts u formyvanni inshomovnoi kultury spilkuvannia majbutniogo agroinzhenera [The role of «Vehicle Parts» text term system to form the future agrarian engineer's foreign language communicative culture] / URL http://journals. nubip. edu.ua/ index. php/ Filol/ article/ view/11980 
415. Yakushko K.H., Marcin Szwiec Morpheme «land» nesting analysis on the basis of educational texts/ URL: http://pnap.ap.edu.pl/index.php/pnap/article/view/565/534

Scientific Journal of Polonia University Periodyk Naukowy Akademii Polonijnej 39 Czestochowa, Poland № 2, pp.93-99

416. YakushkoK.H., Pazynych B. (2020) Osnovni pidchody do doslidzhennia terminu «Agronomya» [The main approaches to to investigate the term «Agronomy»] /URL: https://molodyivchenyi.ua/index.php/journal/article/view/900/8 Молодий Вчений №6(82) червень,2020 С.170-172

417. Yakushko K.H., Petrenko M.I. The stages to involve the English statements in order to discuss the achievements of agrochemistry /URL: http://molodyvcheny .in.ua /files/journal/2019/5/26.pdf 5(69)May,2019 13-125 Філологічний часопис

276(2017)

418. 35 inspiriting Gardening Quotes to Encourage You to Grow Plants

/URL: https://ecowarriorprincess.net/2020/05/best-inspiring-gardening-quotesgrow/

419. 171 inspirational gardening quotes and sayings/URL: https://www.backyardboss.net/171-inspirational-gardening-quotes-and-sayings

420. Анисимова, Е. Е. (1996). О целостности и связанности креолизованного текста (к постановке проблемы). Филологические науки, (5), 74-85.

421. Головина, Л. В. (1985). Креолизованный текст: закономерности построения. Речевое общение: цели, мотивы, средства. Москва: Институт языкознания.

422. Зирка, В. В. (2005). Языковая парадигма манипулятивной игры в рекламе.(Дис. док. филол. наук). Днепропетровский национальній университет, Днепропетровск.

423. Сорокин, Ю. А. (1990). Креолизованные тексты и их коммуникативная функция. Москва:Наука.

424. Эко, У. (1998). Отсутствующая структура. Введение в семиологию. Москва: ТОО ТК "Петрополис". Логос

425. Пирс Ч. С. (2000). Избранные филосовские произведения . Москва:

426. Статкевич Л. П. Екологічні виклики сучасності. / Л. П. Статкевич. // Художні феномени в історії світової літератури: перехід мови в письменництво («Екоцентризм: культура і природа»): Тези доповідей III Міжнародної наукової конференції. - Харків : ХНУ імені В. Н. Каразіна, 2017. - С. 101-102. 
427. Ягодзінський С. М. Синергетика як методологічний принцип коеволюції суспільства і природи [Електронний ресурс] / С. М. Ягодзінський Режим доступу //er.nau.edu.ua/bitstream/NAU/10854/1/Ягодзінський\%20C.\%20 - Назва 3 екрана. - (Дата звернення: 04.11.2021).

428. Криловець Н. В. Мотив осені в натурфілософській поезії Ліни Костенко [Електронний ресурс] / Н. В. Криловець - Режим доступу : http://eprints.zu.edu.ua/7500/1/61\%2B\%2B47.pdf - Назва 3 екрана. - (Дата звернення: 04.11.2021).

429. Костенко Л. В. Вибране / Ліна Костенко. - К. : Дніпро, 1989. - 559 с.

430. Костенко Л. В. Річка Геракліта / Ліна Костенко. - К. : Либідь, 2011. $244 \mathrm{c}$.

431. Дзюба І. Є поети для епох / Іван Дзюба. - К. : Либідь, 2011. - 208 с.

432. Поліщуки. [Електронний ресурс] / Режим доступу: http://ukrtur.narod.ru/geonas/naselukr/etno/etnogrup/polishuky.htm - Назва з екрана. - (Дата звернення: 04.11.2021).

433. Енциклопедія історії України: Т 8. Па - Прик / Редкол.: В. А. Смолій (голова) та ін. НАН України. Інститут історії України. - К. : Наукова думка, 2011. - 520 с. [Електронний ресурс] / Режим доступу: http://history.org.ua/LiberUA/978966-00-1142-7/978-966-00-1142-7.pdf - Назва 3 екрана. - (Дата звернення: 04.11.2021).

434. Костенко Л. В. Мадонна Перехресть / Ліна Костенко. - К. : Либідь, 2012. $-112 \mathrm{c}$.

435. On education: Law of Ukraine of September 5, 2017 № 2145-VIII. Access mode: https://zakon.rada.gov.ua/laws/show/2145-19\#Text.

436. On higher education: Law of Ukraine of July 1, 2014 №1556-VII. Access mode: https://zakon.rada.gov.ua/laws/show/1556-18\#Text.

437. On approval of the License conditions for educational activities: Resolution of the Cabinet of Ministers of Ukraine of December 30, 2015 № 1187 (as amended by the resolution of the Cabinet of Ministers of Ukraine of May 3, 2020 № 180). Access mode:https://zakon.rada.gov.ua/laws/show/1187-2015-\%D0\%BF\#Text.

438. On approval of the National Qualifications Framework: Resolution of the Cabinet of Ministers of Ukraine of November 23, 2011 № 1341 (as amended by the Resolution of the Cabinet of Ministers of Ukraine of June 25, 2020 № 519). 
439. On the peculiarities of the introduction of the list of branches of knowledge and specialties for which higher education students are trained, approved by the Cabinet of Ministers of Ukraine dated April 29, 2015 № 266: Order of the Ministry of Education and Science of Ukraine dated November 6, 2015 № 1151. Access mode:

https://zakon.rada.gov.ua/laws/show/z1460-15\#Text

440. Classifier of professions DK 003: 2010: The National Classifier of Ukraine was approved by the Order of Derzhspozhyvstandart dated July 28, 2010 № 327 (as amended on August 18, 2020 № 1574). Access mode:

https://zakon.rada.gov.ua/rada/show/va327609-10\#Text.

441. Горлов А. С. Проблемы совершенствования системы индивидуальной подготовки юных бегунов на короткие дистанции 100-200 м: монография / А. С. Горлов. - Х. : Изд-во «Підручник НТУ "НТУ"», 2014. - 240 с. - На рус. яз.

442. Платонов В. М., Сахновський К. П. Підготовка юного спортсмена. Київ: Радянська школа, 1988. - 288 с.

443. Платонов В. М., Булатова М. М. Фізична підготовка спортсмена: Навчальний посібник. - Київ: Олімпійська література, 1995. - 336 с.

444. Платонов В. М. Адаптація в спорті. - Київ: Здоров'я, 1988. - 216 с.

445. Планирование и организация подготовки бегунов на короткие дистанции в годичном цикле: Методическая разработка / Сост. Е. Е. Аракелян, А. В. Левченко, Н. Н. Романова. - Москва: ГЦОЛИФК, 1986. - 30 с.

446. Воробьев А. Н. Принцип индивидуализации - фикция или закономерность в современном тренировочном процессе! // Теория и практика физической культуры, 1986. № 6. - С. 29-31.

447. Аршавский И. А. Роль А. А. Ухтомского в разработке проблем врабатывания, работоспособности и утомления (особенности, характеризующие эти состояния в различные периоды) // Физиологический журнал СССР им. Сеченова. - 1975. № 6. - С. 61.

448. Верхошанский Ю. В. Принципы организации тренировки спортсменов высокого класса в годичном цикле. // Теория и практика физической культуры. - 1991. №2. - С. 32-34.

449. Волков Н. И. Работоспособность и управление тренировочным процессом. Спорт в современном обществе. Всемирный научный конгресс: Биология, биомеханика, биохимия, медицина, физиология. - Москва: ГЦОЛИФК, 1980. - С. 249.

450. Функція серця у юних спортсменів / С. А. Душанін, В. В. Шигалевський. - Київ: Здоров'я, 1988. - 168 с.

451. Верхошанский Ю. В. Программирование и организация тренировочного процесса. - Москва: Физкультура и спорт, 1985. - 176 с. 
452. Набатникова М. Я. Развитие научных основ юношеского спорта // Теория и практика физической культуры. - 1983. № 11. - С .45.

453. Основы управления подготовкой юных спортсменов / Под общ. ред. М. Я. Набатниковой. - Москва: Физкультура и спорт, 1982. - 280 с.

454. Сахновський К. П. Теоретико-методичні основи системи багаторічної спортивної підготовки: автореф. дис. на здобуття наукового ступеня д-ра пед. наук: спец. 13.00.04 «Теорія і методика фізичного виховання, спортивного тренування та оздоровчої фізичної культури». - Київ: ДУФВСУ, 1998. - 48 с.

455. Горлов А. С. Програмування тренувального процесу юнаківспринтерів у відновлювальних мікроциклах підготовчих періодів: автореф. дис. на здобуття наук. ступеня канд. пед. наук: спец. 13.00.04 «Теорія і методика фізичного виховання, спортивного тренування та оздоровчої фізичної культури». - Київ: УДУФВС, 1994. - 24 с.

456. Сахновський К. П. Підготовка спортивного резерву. - Київ: Здоров' я, 1990. - 189 с.

457. Топчиян В. С. Педагогический контроль в системе многолетней подготовки юных бегунов на короткие дистанции. Москва: ВНИИФК, 1979. С. 44-53.

458. Горлов А. С. Изменение педагогических показателей двигательной функции у бегунов-спринтеров 14-17 лет под влиянием восстановительных микроциклов подготовительных периодов. Физическое воспитание студентов: науч. журнал ХГАДИ под ред. С. С. Ермакова. - Харьков: ХГАДИ, 2011. № 4. C. 22-26.

459. Горлов А. С. Изменение физиологических показателей двигательной функции у бегунов-спринтеров 14-17 лет под влиянием восстановительных микроциклов подготовительных периодов // Фізичне виховання, спорт і культура здоров'я у сучасному суспільстві: Збірник наук. праць ВНУ ім. Лесі Українки. Луцьк, 2011. № 3(15). - С. 92-96. 11.

460. Абрикосова М. А. и др. Исследования кумулятивного эффекта восстановительных мероприятий в недельном тренировочном цикле // Жур-л ВНИИФК СССР: Физиологические основы управления восстановительными процессами в условиях спортивной деятельности. 1980. - С. 53-67.

461. Волков В. М. Восстановительные процессы в спорте. - Москва: Физкультура и спорт, 1977. - 144 с.

462. Горкін М. Я. Деякі функціональні показники відновного періоду після вправ на швидкість // Матеріали наукової конференції по підсумках НДР КДІФК. - Київ, 1969. - С. 49-50.

463. Зотов В. П. Відновлення працездатності в спорті. - Київ: Здоров’я, 1990. $-200 \mathrm{c}$. 
464. Солодков А. С. Физиологические закономерности адаптации спортсменов к физическим нагрузкам: Тезисы докл. XIX Всесоюз. конф. «Физиологические механизмы адаптации к мышечной деятельности» (Волгоград, 20-23.09. 1988 г). - Волгоград: ВИФК, 1988. - С. 335-337.

465. Фомин В. С. Системные механизмы адаптации организма к спортивной деятельности: Тезисы докл. XIX Всесоюз. конф. «Физиологические механизмы адаптации к мышечной деятельности» (20-23.09. 1988 г). - Волгоград: ВИФК, 1988. - С. 361-362.

466. Горлов А. С. Обоснование динамики работоспособности юношейспринтеров 14-15 лет в подготовительных периодах годичного цикла тренировки // Педагогіка, психологія та медико-біологічні проблеми фізичного виховання і спорту: наукова монографія за ред. проф. Срмакова С. С. - Харків: ХДАДМ, 2008. №7. - C. 34-37.

467. Годик М. А. Педагогические основы нормирования и контроля тренировочных и соревновательных нагрузок: автореф. дисс. На соискание ученой степени д-ра пед. наук: спец. 13.00 .04 «Теория и методика физического воспитания, спортивной тренировки и оздоровительной физической культуры». - Москва, 1982. - 48 с.

468. Андрухів І. Західноукраїнські молодіжні товариства «Сокіл», «Січ», «Луг», «Пласт»- Івано-Франківськ, 1992.- 79 с.

469. Вацеба О. Нарис з історії західноукраїнського спортивного руху / О. Вацеба. - Івано-Франківськ, 1997. - 230 с.

470. Гуйванюк М. Січовий рух у Галичині та Буковині (1900 - 1914 рр.) Чернівці, зелена Буковина, 2009. - 254 с.

471. Животко А. Історія української преси: Навчальний посібник для студентів факультетів журналістики вищих закладів освіти. - К.: Наша культура і наука, 1999 - 368 с.

472. Історія українського футболу. www.ukrsoccerhistory.com

сайт: http://chervone.com/forum/46-790-1

473. Кобрин Б., Михалюк Ю. Львівське коріння українського футболу. Львів: Літературна агенція «Піраміда», 2005. - 72 с.

474. Леник В. Українська організована молодь (молодіжні організації від початків до 1914 р.). - Львів:, 1993. - 181 с.

475. Михалюк Ю. Таємниці львівського футболу (Книга I). — Львів: ЛА «Піраміда», 2004. - 192 с.

476. Михалюк Ю., Мелех Р., Назаркевич Ю. Історія українського футболу - Львів , 1999. 
477. Нога О. П. Світ львівського спорту 1900-1939 рр. Спорт досягнення, товариства, архітектура, вбрання, мистецтво. - Львів: НВФ «Українські технології», 2004. - 784 c.

478. Папенко Є.M. Зародження чеських i польських сокільських організацій в Австро-Угорській імперії у другій половині XIX ст. та їхній вплив на створення українського «Соколу» - Наукові праці історичного факультету Запорізького національного університету, 2015, вип. 43. - с. 140 - 144

479. Спортове Товариство «Україна» (Львів). До 80-річчя заснування: Альманах. Ред. кол. Й. Лось та ін. - Львів: Світ, 1991. - 136 с.

480. Трофимяк Б. Гімнастично-спортивні організації в національновизвольному русі Галичини (друга пол. XIX - перша пол. XX ст.) - Тернопіль: Економічна думка, 2001. - 696 с.

481. Усі шляхи ведуть до Львова. Спорт UA. Олена Садовник, «Спортивна газета» -1917

482. Футбольний атлас України. Довідково - статистичне видання за підсумками десяти чемпіонатів України з футболу (1992 - 2001)

483. Шах С. Львів - місто моєї молодости .- Ч.3, с. 84

484. Бондаренко О.М. Цінність здоров'я серед пріоритетів студентської молоді / О.М. Бондаренко, М.Г. Чобітько // Вісник Кам'янець-Подільського національного університету імені Івана Огієнка «Фізичне виховання, спорт і здоров'я людини», 2010. - Випуск 3. - С.160-166.

485. Бутов Р.С. Здоровий спосіб життя, як один 3 основних чинників збереження та зміцнення здоров'я / Р.С. Бутов // Вісник Кам'янець-Подільського національного університету імені Івана Огієнка «Фізичне виховання, спорт і здоров'я людини», 2009. - Випуск 2. - С.144-146.

486. Бойко Ю. С. Формування аксіологічних установок до здорового способу життя у студентів вищих навчальних закладів: дис. ... канд. пед. наук: 13.00.07 «Теорія і методика виховання». Умань, 2015. - 268 с.

487. Футорный С. М. Здоровьесберегающие технологии в процессе физического воспитания студенческой молодежи : монография. Киев : Полиграфсервис. 2014. 304 с.

488. О. Адаменко · Шляхи реалізації моделі формування здорового способу життя студентської молоді засобами фізичної культури у закладах вищої освіти / О. Адаменко, О. Литвиненко, Н. Борецька // Науковий вісник МНУ імені В. О. Сухомлинського. Педагогічні науки. - № 2 (65), травень 2019, с. 11.15.

489. Аносов I. П. Здоров'язбережувальні освітні технології у професійнопедагогічній підготовці вчителя / I. П. Аносов, С. С. Ізбаш // Педагогіка здоров'я : зб. наук. праць IV Всеукраїнської наук.-практ. конф. / [за заг. ред. І. Ф. Прокопенка]. — Х. : ХНПУ ім. Г. С. Сковороди, 2014. - С. 22-28. 
490. Литвиненко О.М. Формування здорового способу життя в студентської молоді / О.М. Литвиненко // Педагогіка. Наукові праці. - 2013. Вип. 146, Том 158. - С. 42-46.

491. Лобань Г.А. Формування здорового способу життя студентів як запорука суспільного та економічного розвитку держави / Лобань Г.А., Зачепило С.В., Коваленко Н.П., Ганчо О.В., Комишан І.В. // ВІСНИК ВДНЗУ «Українська медична стоматологічна академія». - Том 15, Випуск 2(50). - С.30-32.

492. Підлісна В. Принципи здорового способу життя студентської та учнівської молоді / В. Підлісна, М. Гуска // Фізичне виховання, спорт і здоров'я людини. Вісник Кам'янець-Подільського нац. ун-ту ім. Івана Огієнка : зб. наук. пр. - 2010. - Вип. 3. - С. 149-153.

493. Герасименко С. Особливості формування мотивації до здорового способу життя в студентів / Актуальні питання гуманітарних наук. Вип 27, том 1, 2020. - С. 265-269.

494. Закон о спорте KHP: http://www.npc.gov.cn/wxzl/gongbao/200012/05/content_5004646.htm

495. Національної програми КНР щодо зміцнення здоров'я на 2014-2020 (2013). https://www.cnki.com.cn/Article/CJFDTotal-WSGB201404007.htm

496. Куріпка Т.I., Бондаренко А.О.. Ключові компоненти професійної компетентності вчителя. Управління школою» № 19-21 (427-429) липень 2014 р. - C.63-65

497. Навчальна програма вибіркової дисципліни «Теорія i методика викладання оздоровчої ходьби та бігу», ХНПУ імені Г. С. Сковороди, 2020.8 с. https://drive.google.com/drive/folders/12_HvlUKXaf3AJ17edr0Jijh266tbiVVM

498. Cullum, B. (2016). Is China's Paralympic Dominance Reflected In Their Support For DisabledPeople? Retrieved from https://www.vice.com/en_uk/article/mgzb54/is-chinasparalympic-dominancereflected-in-their-support-for-disabled-people

499. School of Education (Normal School for Physical Education). https://en.bsu.edu.cn/Schools/AcademicDivisionofSportsandHealth/0dadd68119f842 9ea2fd17e1394cef74.htm

500. School of Phycology. https://en.bsu.edu.cn/Schools/AcademicDivisionofSportsandHealth/98779e7fc29343 2789c6c6ed28709a05.htm

501. School of Sports Science and Physical Education. Nanjing Normal Universityhttp://schools.njnu.edu.cn/sports

502. School of Strength and Conditioning/ https://en.bsu.edu.cn/Schools/AcademicDivisionofSportsandHealth/2446e0bbe28b46 519b16d30556302800.htm 
503. Capital University of Physical Education and Sports. http://cupes.admissions.cn/

504. Shanghai University of Sport. http://sus.admissions.cn/info/Shanghai\%20University\%20of\%20Sport

505. Сайт факультету фізичної культури та спорту Нанкінського педагогічного університету http://schools.njnu.edu.cn/sports/

506. Магістратура факультету фізичної культури та спорту Нанкінського педагогічного університетуhttp://en.njnu.edu.cn/academics/physical-education-ms

507. Робоча програма курсу «Принципи спортивної науки» факультету фізичної культури та спорту Нанкінського педагогічного університету“体育学原 理”教学大纲南京师范大学体育科学学院, 2020, 24 页

508. Робоча програма курсу «Логіка» факультету фізичної культури та спорту Нанкінського педагогічного університету“逻辑学”教学大纲南京师范大 学体育科学学院, 2019, 18 页

509. Робоча програма курсу «Фізичне виховання» факультету фізичної культури та спорту Нанкінського педагогічного університету“体育”教学大纲南 京师范大学体育科学学院, 2021, 20 页

510. Робоча програма курсу «Теорія та методика основних наукових досліджень» факультету фізичної культури та спорту Нанкінського педагогічного університету“基础研究的理论与方法”教学大纲南京师范大学体 育科学学院, 2019, 21 页

511. Робоча програма курсу «Вивчення спортивної навчальної програми та фізичного виховання» факультету фізичної культури та спорту Нанкінського педагогічного університету“体育课程与体育研究”教学大纲南京师范大学体育科 学学院, 2020, 22 页

512. Абрамов С.В. Адаптація військовослужбовців, звільнених в запас як інструмент забезпечення їх конкурентоспроможності на ринку праці. Економіка і організація управління. 2016. № 22. - С. 259-265.

513. Буряк О.О. Гіневський М.I. Соціальна адаптація армії України до нових умов існування . Збірник наукових праць Харківського національного університету Повітряних Сил. - 2014. № 4(41). - С. 160-166.

514. Довга тінь Донбасу: Реінтеграція ветеранів та зміцнення суспільної єдності в Україні. Global Public Policy Institute. Berlin P.60.

515. Красильщиков А.Л. Соціальна адаптація звільнених у запас військовослужбовців (проблеми та досвід їх вирішення в Україні та зарубіжних країнах). Демографія та соціальна економіка .2005. № 2. - С. 117-125. 
516. Про внесення зміни до статті 6 Закону України «Про статус ветеранів війни, гарантії їх соціального захисту»: Закон України від 06.05.2014 № 1233- VII. - https://zakon.rada.gov.ua

517. «Про громадські об'єднання» Закон України від 22 бер. 2012 р. №4572-VI/Офіц. вісн. України. 2012. 27 квіт. (№ 30). С. 26.

518. Шумейко А.П. Види реадаптації і психореабілітації учасників бйових дій. Проблеми екстремальної та кризової психології. 2017. Вип. 21. С. 220-229.

519. Бутенко В., Пономаренко Г. Актуальні проблеми профілактики злочинності серед молоді. Соціально-правовий захист молоді: зб. наук. статей / заг. ред.: І. В. Козубовська, В. М. Великий. Ужгород, 2002. С. 39-47.

520. Дахно Р. Девіантна поведінка учнів загальноосвітніх навчальновиховних закладів як психолого-педагогічна проблема. Рідна школа. 2005. № 11. C. $10-13$.

521. Гурлева Т. Г. Діагностика та корекція відповідальності у підлітків. Практична психологія та соціальна робота. 1999. № 5. С. 2-4.

522. Шандрук С. Формування ціннісних орієнтацій молоді та їі соціалізація засобами масової інформації. Наукові записки Кіровоградського державного педагогічного університету. Серія. Педагогічні науки. 2001. Вип. 38. С. 169-174.

523. Оржеховська В. М., Пилипенко О. І. Сучасні орієнтири превентивної педагогіки. Педагогіка і психологія. Вісник АПН України. 2005. № 2. С. 17-25.

524. Соціологія : підручник для студ. вищ. навч. закл. / за ред. В. Г. Городяненка. Київ : Академія, 2005. 560 с.

525. Парфанович I. І. Теоретико-методичні засади профілактики девіантної поведінки дівчат загальноосвітніх шкіл: дис. ... д-ра пед. наук: 13.00.05 / Іванна Іванівна Парфанович К., 2014. 478 с.

526. Охрімчук Р. Багатолика агресія. Початкова школа. 2003. № 6. С. 4-7.

527. Курс кримінології: особлива частина: підручник : у 2 кн. Кн. 2; за заг. ред. О. М. Джужи. Київ : Юрінком Інтер, 2001. 480 с.

528. Лактіонова Г. М. Велике місто як середовище соціалізації (теоретикометодологічний аспект). Соціально-педагогічні та медико-психологічні заходи протидії вживанню наркогенних засобів неповнолітніми і молоддю: наук.-метод. посібник / упоряд. О. І. Пилипенко. К.: А.Л.Д., 1995. С. 16-32.

529. Кайдалова Л. Г. (2010) Професійна підготовка майбутніх фахівців фармацевтичного профілю у вищих навчальних закладах: монографія. Харків: НФаУ, 411 с. Доступно: http://dspace.nuph.edu.ua/handle/123456789/8112

530. Чорнописка, О. (2016). Особливості викладання елективного курсу Психологія спілкування" студентам фармацевтичного факультету заочної форми 
навчання. Збірник наукових праць Національної академії Державної прикордонної служби України. Серія: Психологічні науки, (2), 255-263.

531. Рева Т. (2016) Теоретичні концепти компетентнісного підходу у фармацевтичній освіті. Неперервна професійна освіта: теорія і практика, Вип. 12, 127-131. Доступно: http://nbuv.gov.ua/UJRN/NPO_2016_1-2_26.

532. Чхало О. М. (2018) Удосконалення навчальних посібників 3 аналітичної хімії з використанням можливостей мережних технологій. Проблеми сучасного підручника, Вип. 21, 423-431. Доступно: http://nbuv.gov.ua/UJRN/

533. Сафонов Є.І., Чернавський А.Ю. (2019). Автоматизація складання робочих програм навчальних дисциплін. Вісник Югорського державного університету, 15 (2), 33-40. DOI: https://doi.org/10.17816/byusu20190233-40

534. Dyussembayeva A.N., Sultanova B. K. (2019) Research of the process of creating a work program for an academic discipline. Colloquium-journal, 2-1 (26), 2627. Available at: https://www.elibrary.ru/item.asp?id=36850749

535. Nagro, Sarah A., Fraser, Dawn W., Hooks, Sara D. (2019). Lesson Planning With Engagement in Mind: Proactive Classroom Management Strategies for Curriculum Instruction. Intervention in School and Clinic. 54 (3), 131-140. DOI:10.1177/1053451218767905.

536. Bolotnikova, A. (2021). TEACHING ELECTIVE COURSES USING THE CASE STUDY METHOD. Збірник наукових праць $\Lambda$ 'ОГО https://doi.org/10.36074//ogos-01.10.2021.v2.04

537. Bolotnikova , A. (2021). BUSINESS GAMES AS A METHOD OF LEARNING IN MODERN REALITIES. Proceeding of the I International Scientific and Theoretical Conference «FEATURES OF THE DEVELOPMENT OF MODERN SCIENCE IN THE PANDEMIC'S ERA. https://doi.org/10.36074/scientia-03.12.2021

538. Keevy, James; Chakroun, Borhene (2015). Level-setting and recognition of learning outcomes: The use of level descriptors in the twenty-first century (PDF). Paris, UNESCO. pp. 129-131. ISBN 978-92-3-100138-3. Available at: https://unesdoc.unesco.org/ark:/48223/pf0000242887.

539. Bolotnikova A., Pushkarova Ya. Feedback in distance learning // III International Science Conference "Using the latest technologies", Groningen, Netherlands, February 26-27, 2021, p. 62-63.

540. King, Alison (1993). From sage on the stage to guide on the side. College Teaching. 41 (1), 30-35. doi:10.1080/87567555.1993.9926781.

541. Abeysekera, Lakmal; Dawson, Phillip (2015). Motivation and cognitive load in the flipped classroom: definition, rationale and a call for research. Higher Education Research \& Development. 34(1), 1-14. doi:10.1080/07294360.2014.934336 
542. Sharma, Neel, Lau, C.S, Doherty, Iain, Harbutt, Darren (2015). How we flipped the medical classroom. Medical Teacher. 37(4), 327-330. doi:10.3109/0142159x.2014.92382

543. Kettle, Maria (2013). Flipped Physics. Physics Education. 48(5), 593-596. Bibcode:2013PhyEd..48..593K. doi:10.1088/0031-9120/48/5/593.

544. Mastmeyer, A. (2020). Quantitative and Qualitative Evaluation of Transforming to Flipped-Classroom from Instruction Teaching using Micro Feedback Loops. Manuscript Work in Progress: 1-42. doi:10.5281/zenodo.4000357.

545. Europass Teacher Academy. Flipped classroom (2020). Available at: https://www.teacheracademy.eu/course/flipped-classroom/

546. Bolotnikova, A., \& Pushkarova , Y. (2021). THE MODEL OF «FLIPPED» CLASS. ГРААЛЬ НАУКИ, (1), 329-332. Https://doi.org/10.36074/grail-ofscience.19.02.2021.070

547. Bolotnikova A.O. (2021) COMPILATION OF THE CURRICULUM ACADEMIC SUBJECT OF THE ELECTIVE THEORETICAL COURSE FOR TRAINING IN DISTANCE CONDITIONS. Interaction of society and science: problems and prospects. Abstracts of III International Scientific and Practical Conference, 231-233. URL: https://isg-konf.com. Available at : DOI: 10.46299/ISG.2021.II.III

548. Нагро, Сара А., Фрейзер, Доун В., Хукс, Сара Д. (2019). Планування уроків із залученням розуму: проактивні стратегії управління класом для викладання навчальних програм. Втручання в школу та клініку. 54 (3), 131-140. DOI: $10.1177 / 1053451218767905$.

549. Safonov E.I., Chernavskij A.YU. (2019). Avtomatizaciya sostavleniya rabochih programm uchebnyh disciplin. Vestnik Yugorskogo gosudarstvennogo universiteta, 15 (2), 33-40. DOI: https://doi.org/10.17816/byusu20190233-40

550. Пушкарьова Я. М., Зайцева Г. М., Калібабчук В. О. (2021) Особливості викладання елективного курсу “Основи хімічної метрології” студентам фармацевтичного факультету заочної форми навчання на основі онлайнконтенту. Матеріали Міжнародної науково-практичної конференції "PLANTA+. Наука, практика та освіта", 579-582.

551. Зайцева Г. М. Я. М. Пушкарьова, В. О. Калібабчук (2020) Робоча програма навчальної дисципліни «Основи хімічної метрології» для студентів за напрямом підготовки 22 «Охорона здоров’я», спеціальністю 226 «Фармація, промислова фармація» заочної форми навчання. Київ: НМУ імені О. О. Богомольця, 9 с. 
552. Pushkarova Ya., Chkhalo O., Reva T., Zaitseva G., Bolotnikova A. (2021) Teaching of the course "Analytical Chemistry" using tools of the Moodle in Bogomolets National Medical University. Abstracts of XXXII International Scientific and Practical Conference "Actual problems of modern science and practice", p. 198200.

553. Авдіянц Г. Г. Формування духовних потреб молодших школярів у сім'ї: автореф. дис... на здобуття наук. ступ. канд. пед. наук: спец. 13. 00. 07 «Теорія і методика виховання». Луганськ, 2001. 20 с.

554. Словник української мови: В 11 томах. К. : Наукова думка, 1970-1980.

555. Словник іншомовних слів Мельничука [Електронний ресурс] URL: http://slovopedia.org.ua/42/53382/282825.html

556. Категоричний імператив Канта [Електронний ресypc] URL: https://uk.wikipedia.org/wiki

557. Філософський енциклопедичний словник [ред. кол.: В. І. Шинкарук, Є. К. Бистрицький та ін. ]. Київ: Абрис, 2002. 742 с.

558. Чупрій Л. Моральні цінності як основа відродження української нації // Рідна школа. 2003. № 10. С. 23-25.

559. Ващенко Г. Виховний ідеал: підруч. для педагогів, виховників, молоді i батьків. 3-є вид. Полтава: Полтавський вісник, 1994. URL: https://studfile.net/preview/8947890/page:7/

560. История педагогики на пороге XXI века: историография, методология, теория: [в 2 ч.]. М.: Ин-т теории образования и педагогики РАО, 2000. Ч. 2: Теоретические проблемы истории педагогики / ред. Г.Б.Корнетов, В. Г. Безрогов. 2001. 328 c.

561. Франко І. Одвертий лист догал[лицької] української молодежі // Зібрання творів : У 50-ти томах. К. : Наукова думка, 1976. Т. 45: Філософські праці. С. 401-409.

562. Скельчик С. Українофіли: світ українських патріотів другої половини XIX ст. Київ: КIC, 2010. 272 с.

563. Винайдення традиції / За ред. Е. Гобсбаума та Т. Рейнджера. 2-ге вид., випр. 2010. 448 с.

564. Зеров М. Українське письменство. К.: Основи, 2002. 1301 с.

565. Винниченко В. Краса і сила / Авт. передм. І. Дзеверін. К.: Дніпро, 1989. $752 \mathrm{c}$.

566. Лопушан Т. В. Десакралізація образу українського селянства в творчості Володимира Винниченка // Восточнославянские языки и литературы в европейском контексте - 2015 : сборник научных статей / под ред. Е. Е. Иванова. Могилев : МГУ имени А. А. Кулешова, 2016. С. 328-336. 
567. Квітка-Основ'яненко Г. Повісті та оповідання. Драматичні твори. К.: Наук. думка, 1982. 389 с.

568. Боровиковський Л. Подражаніє Горацію. URL: https://ukrlit.com/levko-borovikovskij-podrazhaniye-goraciyu/

569. Шевченко Тарас. «Садок вишневий коло хати»// Твори в п`ятьох томах. К.: Дніпро, 1970-1971. Т. 2. С. 14.

570. Грабович Г. Поет як міфотворець. Семантика символів у творчості Тараса Шевченка. 2-е випр., авториз. вид. / Перекл. 3 англ. С. Павличко. К.: Часопис «Критика», 1998. 207 с.

571. Нечуй-Левицький I. С. Твори : в 2 т. Т. 2 : Повісті та оповідання [упорядкув. і прим. Н. О. Вишневської ; ред. Н. С. Крутікова]. К. : Наукова думка, $1986.638 \mathrm{c}$.

572. Постанова Кабінету Міністрів України № 261 від 23 березня 2016 р. «Про затвердження Порядку підготовки здобувачів вищої освіти ступеня доктора філософії та доктора наук у закладах вищої освіти (наукових установах). Режим доступу: https://zakon.rada.gov.ua/laws/show/261-2016-п

573. Бедзір Н. П. (2017). Наукова комунікація: методи оприлюднення результатів наукового дослідження: робоча навчальна програма. Ужгород: Ужгородський національний університет. 17 с. Режим доступу: https://www.uzhnu.edu.ua/uk/infocentre/get/24746

574. Перепелиця О. М. (2016). Підготовка наукових публікацій та презентація результатів дослідження: програма навчальної дисципліни. Харків: Харківський національний університет ім. Каразіна. 20 с. Режим доступу: https://www.univer.kharkov.ua/docs/work/033philos-r3.pdf

575. Ніколаєва С. Ю. (2017). Підготовка доктора філософії: загальна характеристика освітньо-наукової програми зі спеціальності 011 «Освітні, педагогічні науки». Іноземні мови. 3, 36-47. Режим доступу: http://fl.knlu.edu.ua/article/view/122613

576. Ніколаєва С. Ю. (2021). Структура і зміст дисципліни «Наукова комунікація: методи оприлюднення результатів дослідження в галузі освіти». Іноземні мови. 2, 3-9. Режим доступу: http://fl.knlu.edu.ua/article/view/2356732021

577. Ніколаєва С. Ю. (2021a). Наукова комунікація:труднощі молодих науковців у написанні наукових статей. «AD ORBEM PER LINGUAS. ДО CBITУ ЧЕРЕЗ МОВИ». Матеріали міжнародної науково-практичної відеоконференції «Світ цінностей і цінності у світі», 13 - 14 травня 2021 року. Київ : Видавничий центр КНЛУ, 2021, С. 262 - 264. 
578. Наказ МОН України № 1220 від 23 вересня 2019 р. «Про опублікування результатів дисертацій на здобуття наукових ступенів доктора і кандидата наук». Режим доступу: https://zakon.rada.gov.ua/laws/show/z108619\#Text

579. ДСТУ 8302:2015. Бібліографічне посилання. Загальні положення та правила складання / Нац. стандарт України. Вид. офіц. [Уведено вперше; чинний від 2016-07-01]. Київ : ДП «УкрНДНЦ», 2016. 17 с. (Інформація та документація). - 3 внесеними поправками. Режим доступу: https://library.nlu.edu.ua/services/naukovtsyam/item/1806.html

580. Наказ МОН України від 15 січня 2018 року № 32 «Про затвердження Порядку формування Переліку наукових фахових видань України". Режим доступу:https://www.google.com/search?client=opera\&q=Порядок+формування+ Переліку + наукових + фахових + видань + України $\% 2 \mathrm{C}+$ затвердженого + наказом + $\mathrm{MOH}+$ України + від $+15+$ січня $+2018+$ року + № $+32 \&$ sourceid $=$ opera\&ie=UTF$8 \&$ oe $=\mathrm{UTF}-8$

581. Allardis R. Distance education in Canada / R. Allardis // International Cooperation, 1999. №1. Pp. 20-23.

582. Arkharova TA Aviation English and its application on the international air routes. M.: Higher. school, 2012. 215p.

583. Bim IL, Sadomova lv Some topical problems of organizing foreign language teaching in universities. Foreign languages, 2010. №6. P.4-10

584. Vyshnivsky V.V. Organization of distance learning. Creation of electronic training courses and electronic tests: textbook. manual / V.V. Vyshnivsky, M.P. Gnidenko, G.I. Gaidur, O.O. Ilyin. Kyiv: DUT, 2014. 140 p.

585. Polat E.S. Theory and practice of distance learning: [textbook. manual for students. higher ped. textbook institutions] / ES Polat, M. Yu. Bukharkina, MV Moiseeva; under. ed. E. S. Polat. M.: Akademiya, 2004. 416 p.

586. Makarov R.N. Fundamentals of formation of professional reliability of civil aviation flight crew. M: Vozdushnyi transport, 2001. 530 p.

587. Ogienko O.I. Distance pedagogical education: foreign and domestic experience. Guidelines. Kyiv, 2012. 66 p.

588. Anderson T., Elloumi A. Theory and Practice of Online Learning / Eds. T. Anderson, F. Elloumi. - Athabasca University. 2009. 454p.

589. Börje Holmberg. Status and Trends of Distance Education. - London: Kogan Page, 1990. 200 p.

590. Dean P. Effectiveness of combined delivery modalities for distance learning and redent learning. Quarterly Review of Distance Education, 2001.2 (3), P. 247-254 
591. Keegen D. Foundations of distance education / D. Keegen. - London and New York: Routleage. - 3 rd revised edition, 1996. 224 p.

592. Rumble G. The planning and management of distance education. - London: Croon Helm, 1986. 90p.

593. Smyrnova-Trybulska E. About Some Basic Aspects of Distance Learning / E. Smyrnova-Trybulska. // Theoretical and Practical Aspects of Distance Learning / Collection of scholarly Papers. Scientific Editor Eugenia Smyrnova-Trybulska. Visegrad Fund. - Cieszyn, 2009. P. 13-36.

594. Williams, P. E. Defining Distance Education Roles and Competencies for Higher Education Institutions: A Computer-Mediated Delphi Study: Doctoral Dissertation / P. E. Williams. - Texas: A\&M, 2000. 182 p. (Dissertation Abstracts International, UMI No. AAT9969029).

595. Vitvytska S. S. Osnovy pedahohiky vyshchoi shkoly: pidruchnyk za modulno-reitynhovoiu systemoiu navchannia dlia studentiv mahistratury. Kyiv : Tsentr navchalnoi literatury, 2006. 384 s. (in Ukrainian).

596. Dychkivska I. M. Metodyka vykladannia u vyshchii shkoli. Innovatsiini pedahohichni tekhnolohii : navchalnyi posibnyk. Kyiv : Akademvydav, 2004. $352 \mathrm{~s}$. (in Ukrainian).

597. Kuzminskyi A. Pedahohika vyshchoi shkoly : navchalnyi posibnyk. Kyiv :Znannia, 2005. 486 s. (in Ukrainian).

598. Nahaiev V. M. Metodyka vykladannia u vyshchii shkoli : navchalnyi posibnyk. Kyiv : Tsentr uchbovoi literatury, 2007. 232 s. (in Ukrainian).

599. Ortynskyi V. L. Pedahohika vyshchoi shkoly : navchalnyi posibnyk. Kyiv : Tsentr uchbovoi literatury, 2009. 472 s. (in Ukrainian).

600. Piatnytska V., Pozdniakova I. Osnovy naukovykh doslidzhen u vyshchii shkoli. Kyivm : Tsentr navch. lit-ry, 2003. 116 s. (in Ukrainian).

601. Pedahohika vyshchoi shkoly: navchalnyi posibnyk / [Kurliand Z. N., Khmeliuk R. I., Semenova A. V. ta in.]; za red. Z. N. Kurliand. 2-he vyd., pererob. i dop. Kyiv : Znannia, 2005. 399 s. (in Ukrainian).

602. Perspektyvni osvitni tekhnolohii: naukovo- metodychnyi posibnyk / za red. T. S. Sazonenko. Kyiv : Hopak, 2000. 560 s. (in Ukrainian).

603. Rezvan O. O. Metodyka vykladannia u vyshchii shkoli. Kharkiv, KhNADU : «Miskdruk», 2012. 152 s. (in Ukrainian).

604. Sliepkan Z. Naukovi zasady pedahohichnoho protsesu u vyshchii shkoli. Kyiv : NPU, 2005. 239 s. (in Ukrainian).

605. Turkot T. I. Pedahohika vyshchoi shkoly : navchalnyi posibnyk dlia studentiv vyshchykh navchalnykh zakladiv. Kyiv : Kondor, 2011. 628 s. (in Ukrainian). 
606. Fitsula M. M. Pedahohika vyshchoi shkoly : navchalnyi posibnyk. Kyiv : Akademvydav, 2006. 351 s. (in Ukrainian).

607. Tsekhmistrova H. S. Osnovy naukovykh doslidzhen : navchalnyi posibnyk. Kyiv : Vydavnychyi Dim «Slovo», 2004. 240 s. (in Ukrainian).

608. Yaksa N. Osnovy pedahohichnykh znan : navchalnyi posibnyk. Kyiv : Znannia, 2007. 357 s. (in Ukrainian).

609. Stynska V. V. Metodyka vykladannia u vyshchii shkoli : metodychni rekomendatsii. Ivano-Frankivsk, 2016. 65 s. (in Ukrainian).

610. Garcia E., Arias M., Murri N., Serna C. Developing responsive teachers: A challenge for a demographic reality. Journal of Teacher Education. 2010. Vol. 61. P. $132-142$.

611. Gregory J., Salmon G. Professional development for online university teaching. Distance Education. 2013. Vol. 34. P. 256-270.

612. Mc Quiggan C. Faculty development for online teaching as a catalyst for change. Journal of Asynchronous Learning Networks. 2012. Vol. 16. P. $27-61$.

613. Neumann R., Parry S., Becher T. Teaching and learning in their disciplinary contexts: A conceptual analysis. Studies in Higher Education. 2002. Vol. 27(4). P. 405417. doi: 10.1080/0307507022000011525.

614. Pike G., Smart J., Ethington C. The mediating effects of student engagement on the relationships between academic disciplines and learning outcomes: An extension of Holland's Theory. Research in Higher Education. 2012. Vol. 53. P. $550-575$.

615. Salmon G., Wright P. Transforming future teaching through "Carpe Diem" learning design. Education Sciences. 2014. Vol. 4(1). P. 52-63. doi: 10.3390/educsci4010052.

616. Shulman L. S. Signature pedagogies in the professions. Daedalus. 2005. Vol. 134(3). P. 52-59. doi: 10.1162/0011526054622015.

617. Sari Lindblom-Ylännea, Keith Trigwellb, Anne Nevgia and Paul Ashwinc How approaches to teaching are affected by discipline and teaching context. Studies in Higher Education. 2006. Vol. 31, No. 3, P. 285-298.

618. John Loughran Is teaching a discipline? Implications for teaching and teacher education. Teachers and Teaching. Vol. 15(2). P. 189-203. doi: $10.1080 / 13540600902875290$

619. Lillis T., Turner J. Student writing in higher education: contemporary confusion, traditional concerns. Teaching in Higher Education. 2001. Vol. 6(1). P. 5768 .

620. Dyachkova O. V. application of Joint Information Technologies in the educational process / Dyachkova O. V. URL: http://bit.ly/1WIJVdB 
621. Zakieva L. R., Khadieva F. I. project activity of a teacher [text] / / pedagogy: traditions and innovations: materials of the III International Conference. scientific. conf. (Chelyabinsk, April 2013). - Chelyabinsk: bi Komsomol, 2013.p. 6-7. - URL https://moluch.ru/conf/ped/archive/69/3674 / (application date: 29.01.2018).

622. Ivanova Z. Z. methodology of formation of constructive skills in future primary school teachers / / Bulletin of Agu. 2010, No. 2(4), pp. 92-96.

623. Ivanova, E. M. The concept of subjective activity of E. A. Klimov's professional work and its scientific and practical value / / Bulletin of Moscow University. -2010, No. 2, pp. 15-22.

624. Mitrofanov G. G. preparation of future teachers for project activities as a result of training at the present stage of the development of vocational education / / international scientific conference: XVII Vishnyakov readings university science: conditions for the effectiveness of socio-economic and cultural development of the region. 2014, pp. 131-135.

625. Nosko I. V. student-centered education as the main principle of the Bologna reform of the Higher School / Nosko I. V. // Vector nauki TSU. 2011, No. 1(4), pp. 136-138.

626. Perova A. K. socio-cultural training and education of the teacher's personality in the context of preparation for professional activity / / collection of articles of the international scientific and Practical Conference: prospects for the development of Science in the field of pedagogy and psychology. 2015, pp. 47-49.

627. Poroshin A. A., Shishkov M. V., Streltsova O. V. assessment of the readiness of graduates of educational institutions of higher professional education for professional activity // Bulletin of St. Petersburg University, State Fire Service of the Ministry of emergency situations of Russia. No. 1, 2016, pp. 166-173.
628. Лагута Т. М. Фразеологізми як аспект вивчення лексики української мови іноземними студентами. URL: http://dspace.univer.kharkov.ua/bitstream/123456789/3123/2/08lagfra.pdf.

629. Азарова Л. Є., Пустовіт Т. М., Горчинська Л. В. Використання мультимедійних технологій у вивченні фразеологізмів на заняттях з української мови як іноземної. Закарпатські філологічні студії. 2020. Вип.13. Т.1. С. 7 - 12.

630. Шепель Ю. О. Особливості перекладу фразеологізмів з російської мови українською. Науковий вісник Міжнародного гуманітарного університету. Серія: Філологія. 2016. № 24. Т.2. С. 138 - 142.

631. Сціра М. Фразеологізм як об'єкт вивчення в іншомовній аудиторії (доцільність використання і критерії добирання). STUDIA UKRAINICA POSNANIENSIA. T. VIII/1. 2020. C. $157-166$. 
632. Кузь Г. Фразеологія у формуванні мовної компетенції студентів у процесі викладання української мови як іноземної. Теорія і практика викладання української мови як іноземної. 2009. Вип. 4. С. 172 - 179.

633. Овдіюк В.В. Роль інтерактивних методів навчання у формуванні комунікативної компетенції української мови іноземних студентів. Актуальні проблеми викладання іноземних мов (української, російської, англійської, китайської, турецької) у вищих навчальних закладах: матеріали Міжнародної науково-практичної конференції, м. Київ, 24 квітня 2015 р. Київ : КНУ ім. Тараса Шевченка, 2015. С. 17 - 22.

634. Швець Г. Д. Ігрові технології в навчанні української мови як іноземної. Науковий вісник Південноукраїнського національного педагогічного університету імені К. Д. Ушинського. 2016. № 5. С. 106 - 112. URL: http://dspace.pdpu.edu.ua/bitstream/123456789/3560/1/18.pdf.

635. Azarova L., Pustovit T., Radomska L., Horchinska L. Use of information technologies in studying phraseology in the course of Ukrainian as a foreign language. Advanced Education. 2020, 16, 39 - 48.

636. Про Національну доктрину розвитку освіти. Указ Президента України від 17.04.2002 р. № 347/2002. Офіційний вісник України. 2002. № 16. С. 11. URL: https://zakon.rada.gov.ua/laws/show/347/2002\#Text

637. Про Національну стратегію розвитку освіти в Україні на період до 2021 року. Указ Президента України від 25.06.2013 р. № 344/2013. Офіційний вісник Президента України. 2013. № 17. C. 31. URL: https://zakon.rada.gov.ua/laws/show/344/2013\#Text

638. Про освіту : Закон України від 05.09.2017 р. № 2145-VIII. Голос України. 2017. 27 верес. (№ 178-179). С. 10-22. URL: https://zakon.rada.gov.ua/laws/show/2145-19.

639. Концептуальні засади реформування середньої освіти «Нова українська школа» / За заг. ред. М. Грищенка. Київ, 2016. 40 с. URL: https://mon.gov.ua/storage/app/media/zagalna\%20serednya/nova-ukrainska-shkolacompressed.pdf.

640. Про деякі питання державних стандартів повної загальної середньої освіти : Постанова Кабінету Міністрів України від 30 вересня 2020 р. № 898. URL: https://www.kmu.gov.ua/npas/pro-deyaki-pitannya-derzhavnih-standartiv-povnoyizagalnoyi-serednoyi-osviti-i300920-898.

641. Кондратюк І. Г. Активізація навчальної діяльності учнів на уроці. Англійська мова та література. 2006. № 15. С. 2-7.

642. Краснопольський В. Е. Активізація пізнавальної діяльності учнів засобами комп'ютерної техніки (на матеріалі викладання англійської мови) : автореф. дис. ... канд. пед. наук : 13.00.01. Луганськ, 2000. 20 с. 
643. Рачкова Л. В. Управління навчально-пізнавальною діяльністю школярів у процесі вирішення ними дидактичних ситуацій : автореф. дис. ... канд. пед. наук. Харків, 1996. 23 с.

644. Рябчинська Є. М. Організація навчально-пізнавальної діяльності школярів у умовах комп’ютерного навчання : автореф. дис. ... канд. пед. наук. Харків, 1994. 24 с.

645. Шевченко Е. Б. Використання інтерактивних технологій для розвитку пізнавального інтересу на уроках англійської мови. Англійська мова та література. 2005. № 24. С. 4-6.

646. Фіцула М. М. Педагогіка вищої школи : навч. посіб. / 2-е вид., доп./. Київ : «Академвидав», 2014. 352 с.

647. Ортинський В. Л. Педагогіка вищої школи : навч. посіб. Київ : Центр учбової літератури, 2009. 472 с.

648. Гладуш В. А., Лисенко Г. І. Педагогіка вищої школи : теорія, практика, історія : навч. посібник. Дніпропетровськ : Акцент ПП, 2014. 416 с.

649. Зайченко I. В. Педагогіка : підруч. / 3-тє вид., перероб. та доп. Київ : Вид-во Ліра-К, 2016. 608 с.

650. Хилько Є. С. Вплив активних методів навчання на формування позитивної мотивації студентів у процесі фахової підготовки майбутніх бакалаврів соціальної педагогіки. Вісник Національного університету оборони України. 2011. №3 (22). С. 83-87.

651. Інноваційні педагогічні технології : посібник / За ред. О. І. Огієнко. Київ, 2015. 314 с.

652. Креативні методи навчання в кредитно-модульній системі організації навчального процесу : навч.-метод. посібник / За загальною редакцією проф. С. М. Гончарова. Рівне : НУВГП, 2007. 116 с.

653. Михайліченко М. В., Рудик Я. М. Освітні технології : навчальний посібник. Київ : ЦП «КОМПРИНТ», 2016. 583 с.

654. Сидоренко О., Чуба В. Ситуаційна методика навчання : теорія i практика. Київ : Центр інновацій та розвитку, 2001. 256 с.

655. Сисоєва С. О. Інтерактивні технології навчання дорослих : навч.-метод. посіб. Київ : ВД «ЕКМО», 2011. 320 с.

656. Січкарук О. I. Інтерактивні методи навчання у вищій школі : навч.метод. посібник. Київ : Таксон, 2006. 88 с.

657. Азимов Э. Г., Щукин А. Н. Новый словарь методических терминов и понятий (теория и практика обучения языкам). Москва : Издательство ИКАР, 2009. 448 c. 
658. Інтерактивні методи навчання : навч. посібник / За заг. ред. П. Шевчука і П. Фенриха. Щецін : Вид-во WSAP, 2005. 170 с.

659. Сорочан Т. М., Скрипник М. I. Технології професійного розвитку педагогів : методичний порадник /навч.-метод. посіб. Київ : ДВНЗ «Ун-т менедж. освіти», 2016. 231 с.

660. Комунікативні методи та матеріали для викладання англійської мови (Communicative methods and materials) / перекл. і адапт. Л. В. Биркун. Oxford : Oxford University Press, 1998. 49 c.

661. Дацків О. П. Використання прийомів драматизації на заняттях 3 іноземної мови у педагогічному ВНЗ. Вісник Чернігівського національного педагогічного університету. Серія : Педагогічні науки. 2016. Вип. 141. С. 54-57.

662. Harmer J. How to Teach English / 2-nd ed. Harlow, England : Pearson Education Limited, 2007. 288 p.

663. Даниленко Л.І. Теорія і практика інноваційної діяльності в загальній середній освіті.//Управління освітою 2001 - 3 - С. 9/2

664. Навчально-методичне забезпечення впровадження інтегрованого курсу «Природничі науки» у профільну школу в умовах упровадження Концепції «Нова українська школа» : навч.-метод. посібник / укл. Л. В. Васильченко ; КЗ «ЗОІППО» ЗОР. — Запоріжжя : СТАТУС, 2018. - 124 с.

665. Навчально-методичне забезпечення впровадження інтегрованого курсу «Природничі науки» у профільну школу НУШ: практичні дослідження: навч.-метод. посібник. / укл. Л. В. Васильченко. — Запоріжжя : СТАТУС, 2018. $-76 \mathrm{c}$.

666. Нарочна Л.К., Ковальчук Г.В., Гончарова К.Д. Методика викладання природознавства: Навч.посібник.-2-ге вид, перероб. I допов. -К.: Вища школа, 1990. - 302c.

667. Про затвердження професійного стандарту за професіями «Вчитель початкових класів закладу загальної середньої освіти», «Вчитель закладу загальної середньої освіти», «Вчитель початкової освіти (з дипломом молодшого спеціаліста)» : Наказ Міністерства розвитку економіки, торгівлі та сільського господарства України від 23.12.2020 № 2736 . URL: https://www.me.gov.ua/Documents/Detail?lang=uk-UA\&id=22469103-4e36-4d41b1bf-288338b3c7fa\&title=RestrProfesiinikhStandartiv (дата звернення: 20.11.2021).

668. Про затвердження професійного стандарту «Вихователь закладу дошкільної освіти»: Наказ Міністерства розвитку економіки, торгівлі та сільського господарства України від 19 жовтня 2021 року № 755-21. URL: https://mon.gov.ua/ua/npa/pro-zatverdzhennya-profesijnogo-standartu-vihovatelzakladu-doshkilnoyi-osviti (дата звернення: 20.11.2021). 
669. Іванюк, Г. (2017). Нова стратегія професійно-педагогічної освіти: Європейський вимір. Педагогічний процес: теорія та практика, 4 (59), 21-26.

670. Ivaniuk, H., Venhlovska, O., Antypin, Y., \& Vovchok, Y. (2020). SelfDevelopment as a Factor in the Professional Growth of Future Teachers. Journal of History Culture and Art Research, 9(4), 77-86. doi:http://dx.doi.org/10.7596/taksad.v9i4.2873.

671. Іванюк Г.І., Куземко Л.В., Новик І.М. (2020). Тренінг «Проєктування мультимедійного середовища закладів загальної середньої та дошкільної освіти» як засіб формування цифрових навичок майбутніх педагогів. Інформаційні технології і засоби навчання, 79 (5), 73-89.

672. Раєвська I.М., Саган О.В. (2021). Формування дослідницьких умінь майбутніх учителів початкової школи у процесі викладання дисципліни «Методика навчання освітньої галузі «Математика». Педагогічні науки: збірник наукових праць, 95, 27-32. URL: https://ps.journal.kspu.edu/index.php/ps/article/view/4433.

673. Іванюк Г. I. (2018). Аксіологічний концепт нової освітньої стратегії підготовки педагогів. Освітологічний дискурс: електронне наукове фахове видання, 3-4, 68-82.

674. Андреева М. Н. Моделирование системы педагогического стимулирования самооценки младших школьников : дисс. на соискание ученой степени канд. пед. наук : 13.00.01. Москва, 2007. 207 с.

675. Бардин К. В. Как научить детей учиться : книга для учителя. 2-ге вид. Москва : Просвещение, 1987. 112 с.

676. Белкин А. С. Общая характеристика младшего школьного детства: основы возрастной педагогики. Москва : Академия, 2000. 188 с.

677. Белобрыкина О. А. Психологические условия и факторы развития самооценки личности на ранних этапах онто- и социогенеза : дисс. на соискание ученой степени канд. психол. наук : 19.00.01. Новосибирск, 1998. 368 с.

678. Бернс Р. Развитие Я-концепции и воспитание. Москва : Прогрес, 1986. $422 \mathrm{c}$.

679. Божович Л. И. Личность и ее формирование в детском возрасте : психологические исследования. Москва : Просвещение, 1968. 464 с.

680. Выготский Л. С. Воображение и творчество в детском возрасте (психологический очерк). 3-е изд. Москва : Просвещение, 1991. 93 с.

681. Галкина Т. В. Самосознание и самооценка человека: теория, диагностика, коррекция : учебное пособие. Москва : Изд-во МГУ, 2011. 206 с.

682. Гончаренко С. Самооцінка. Український педагогічний словник. Київ : Либідь, 1997. 296 с. 
683. Дембо Т. В. Приспособление к увечью - проблема социальнопсихологической реабилитации : Рукопись. пер. с англ., 1962.

684. Ересько П. В. Формирование самооценки школьника в процессе контроля знаний, умений, навыков : дисс. на соискание ученой степени канд. пед. наук : 13.00.01. Саратов, 2004. $233 \mathrm{c}$.

685. Загурська I. С. Розвиток самооцінки творчих здібностей у молодшому шкільному віці : автореф. дис. на здобуття наукового ступеня канд. психол. наук : 19.00.07. Київ, 2006. 20 с.

686. Захарова А. В. Генезис самооценки : автореф. дисс. ... д-ра психол. наук : 19.00.07. Москва, 1989. 44 с.

687. Захарова А. В. Психология формирования самооценки. Минск : Новое знание, 1993. 99 с.

688. Зязюн І. А. Педагогічна майстерність : підручник. 2-ге вид. допов. і переробл. Київ : Вища школа, 2004. 422 с.

689. Казакина М. Г. Самооценка личности школьника и педагогические условия ее формирования : учебное пособие к спецкурсу. Ленинград : Изд-во Ленинград. гос. пед. ун-та, 1981. 68 с.

690. Как построить свое «Я» / под ред. В. П. Зинченко. Москва, 1991. 131 c.

691. Каракулина Т. А. Формирование самооценки младших школьников в условиях совместной учебной деятельности : дисс. на соискание ученой степени канд. пед. наук : 13.00.01. Волгоград, 1998. 149 с.

692. Кон И. С. В поисках себя: личность и ее самосознание. Москва : Политиздат, 1984. $335 \mathrm{c}$.

693. Костюк Г. С. Навчально-виховний процес і психічний розвиток особистості. Київ, 1989.

694. Ларина А. Б. Психолого-педагогические условия формирования познавательной самооценки младших школьников : дисс. на соискание ученой степени канд. пед. наук : 13.00.01. Калининград, 2011. 276 с.

695. Леонов Н. Ф. Новая эффективная дидактика. Технология учебного процесса без пробелов в знаниях и умениях учащихся, основанная на автоматизированной психологической системе управления познавательной деятельностью учащихся. Москва : Изд-во «Спутник+», 2009. 176 с.

696. Леонтьев А. Н. Проблемы развития психики. 4-е изд. Москва, 1981. $584 \mathrm{c}$.

697. Липкина А. И. Как формировать и изменять самооценку текст. Возрастная и педагогическая психология : хрестоматия. Москва : Изд. центр «Академия», 1998. 368 с. 
698. Ліфарєва Н. В. Психологія особистості : навчальний посібник для студентів вищих навчальних закладів. Київ : Центр навчальної літератури, 2003. $240 \mathrm{c.}$

699. Марусинець М. М., В. Сухомлинський про трудове виховання: сучасний контекст осмислення. Науковий часопис НПУ імені М. П. Драгоманова. Серія 5 : Педагогічні науки : реалії та перспективи : збірник наукових праць. Київ : Вид-во НПУ ім. М. П. Драгоманова, 2018. Вип. 63. С. 117-121.

700. Матюхина М. В. Мотивация учения младших школьников. Москва : Педагогика, 1984. 144 с.

701. Островська К. О. Взаємозв'язок образу «Я», самооцінки і ціннісних орієнтацій молодших школярів : дис. на здобуття наукового ступеня канд. психол. наук : 19.00.07. Київ, 2003. 196 с.

702. Пеньковська Н. М. Психологічні умови розвитку рефлексії у молодших школярів : дис. на здобуття наукового ступеня канд. психолог, наук : 19.00.07. Київ, 2003. 204 с.

703. Пометун О. І. Нова українська школа: розвиток критичного мислення учнів початкової школи: навчально-методичний посібник. Київ : Видавничий дім «Освіта», 2020. 192 с.

704. Психология педагогического взаимодействия : учебное пособие. / Я. Л. Коломинский и др. СПб. : Речь, 2007. 240 с.

705. Рубцов В. В. Психологические основы организации совместной учебной деятельности : автореф. дисс. ... д-ра психол. наук : 19.00.07. Москва, 1986. 38 c. URL: http://psychlib.ru/mgppu/disers/RPo-1986/RPo-428.htm (Дата звернення 23.10.2021)

706. Савченко О. Я. Дидактика початкової школи : підручник для студентів педагогічних факультетів. Київ : Абрис. 1997. 416 с.

707. Самооцінка учня / С. Максименко, Н. Шевченко, О. Главник. Київ : Главник, 2004. 112 с.

708. Столин В. В. Самосознание личности. Москва : Изд-во Московского ун-та, 1983. 284 с.

709. Токарская Т. С. Формирование адекватной самооценки младших школьников в процессе обучения и межличностного общения : автореф. дисс. на соискание ученой степени канд. психол. наук : 13.00.01. Київ, 1988. 23 с.

710. Фрейд 3. Психоаналитеские этюды. Минск : Попурри, 2007. 608 с.

711. Фромм Э. Гуманистический психоанализ. URL: https://cutt.ly/1T5DxYq (Дата звернення 23.10.2021) 
712. Цукерман Г. А. Введение в школьную жизнь: Программа адаптации детей к школьной жизни. Москва : Московский центр качества образования, 2010. $120 \mathrm{c}$.

713. Чеснокова И. И. Проблема самосознания в психологии. Москва : Наука, 1977. 144 с.

714. Шапар В. Самооцінка. Психологічний тлумачний словник. Харків : Прапор, 2004. 640 c.

715. Ярмаченко М. Самооцінка. Педагогічний словник. Київ : Педагогічна думка, 2001. С. 409.

716. Bouffard T. Quand se juger meilleur ou moins bon qu'il ne l'est s'avere profitable ou nuisible a l'eleve. Revue francaise de pedagogie : recherches en education, 2013. №182. P. 117-139.

717. Rogers C. H. Client - Centered Therapy. Boston, 1965. 560 p.

718. Красилова Ю.В. Досвід психологічного забезпечення діяльності малого підприємництва. Проблеми загальної та педагогічної психології Інституту психології ім. Г.С. Костюка АПН України. Київ, 2002. Т. IV. Ч. 3. С. $15-16$.

719. Франкл В. Человек в поисках смысла: сборник; пер. с англ. и нем.: Д.А. Леонтьева, М.П. Папуша, Е.В. Эйдмана. Москва: Прогресс, 1990. 368 с.

720. Балл Г.О. Особистісна надійність у гуманістичному тлумаченні: психологічні, етичні та педагогічні аспекти. Професійна освіта: педагогіка i психологія: Польсько-український щорічник, IV. Київ; Ченстохова, 2003. С. 461474.

721. Рибалка В. Психологічна теорія особистості Г.О. Балла. Психологія і суспільство. 2017. № 2. С. 104-118. - Режим доступу: http://nbuv.gov.ua/UJRN/Psis_2017_2_14.

722. Балл Г.А. Психология в рациогуманистической перспективе. Избранные работы. Киев: Изд-во «Основа», 2006. 256 с.

723. Олексенко P.І., Молодиченко В.В. Концептуальні пріоритети формування сучасної людини економічної. Гуманітарний вісник Запорізької державної інженерної академії. 2017. Вип. 70. С. 164-175.

724. Gebser J. The Ever-Present Origin/ Jean Gebser. Authorized translation by Noel Barstad with Algis Mickunas. Athens: Ohio University Press, 1991. 145 p.

725. Wilber K. (2001). Quantum Questions / K. Wilber. Shambhala, 2001. 221 p.

726. Graves, Clare W. (1970). Levels of Existence: An Open System Theory of Values. The Journal of Humanistic Psychology. Fall 1970. Vol. 10. No. 2. P. 131-154. 
727. Легомінова С.В. Стійкість інноваційного розвитку підприємства 3 позицій холістичного підходу. Економіка. Менеджмент. Бізнес. 2017. № 3. С. 4451.

728. Пекар В.О. Різнобарвний менеджмент: Еволюція мислення, лідерства та керування. Київ: ДОВЖЕНКО БУКС, 2017. 191 с.

729. Линьов К.О. Лідерство в державному управлінні крізь призму теорії спіральної динаміки. Теорія і практика підвищення кваліфікації: аспекти державної податкової служби: наук. журн./ Центр перепідгот. та підвищ. кваліфікації керівних кадрів органів Державної податкової служби України. 2018. № 1 (15). C. 9-16.

730. Ворожбит В.В. Система цінностей у корпоративній культурі як засіб підтримки економічної безпеки підприємства. Економіка розвитку. 2013. № 1(65). C. $127-131$.

731. Пулман Е. Причины инфантильно-феминного состояния украинцев. [Електронний ресурс]. Сайт «Хвиля». 2016. 23 апреля. - Режим доступу: http://hvylya.net/analytics/society/ prichinyiinfantilno-feminnogo-sostoyaniyaukraintsev.html.

732. Бек Д., Кован К. Спиральная динамика [пер. с англ. И. Фрейман, П. Миронов]. Санкт-Петербург: «Бест Бизнес Букс», 2006. 419 с.

733. Клиновий Д.В. Рентно-економічні аспекти функціонування суспільних систем у світлі теорії спіральної динаміки розвитку продуктивних сил. Економіка природокористування і охорони довкілля: зб. наук. пр. РВПС України НАН України. Київ: РВПС України НАН України, 2009. С. 95-102.

734. Завацька Н.С., Харченко В.Є. Соціально-психологічні аспекти адаптації молоді до умов ринкової економіки: монографія [під ред.. Н.С. Завацької]. Луганськ: СНУ ім.. В. Даля, 2012. 228 с.

735. Котик I.O. Ціннісно-смислова регуляція соціальних меж i автентичності в системі особистісної надійності людини. Актуальні проблеми психології: збірник наукових праць Інституту психології імені Г.С. Костюка НАПН України. Екологічна психологія. Київ, 2017. Т. 7. Вип. 43. С. 71-83.

736. Бернс Р. Я-концепция и Я-образы. Самосознание и защитные механизмы личности. Хрестоматия. Самара: Издательский Дом «БАХРАХ-М», 2006. C. 133-211.

737. Котик І.О. Психологічний простір буття й особистісна надійність людини. Науковий вісник Херсонського державного університету. Серія «Психологічні науки». 2017. Т. 2. № 2. С. 26-31. 
738. Осадчук О.Л., Максименко Л.А. Понятие «надежность» в различных сферах жизнедеятельности человека: философские и этико-психологические аспекты. Международный журнал прикладных и фундаментальных исследований. 2016. № 3-1. С. 167-173.

739. Криволапчук В.А. Концептуальные подходы к разработке программы формирования профессиональной психологической надёжности сотрудников криминальной милиции МВД Украины. Психопедагогика в правоохранительных органах. 2013. № 3 (54). С. 63-67.

740. Крутецкий В.А. Проблема формирования и развития способностей. Вопросы психологии. 1978. № 2. С. 5-12.

741. Кісіль 3.Р. Психологічна надійність професіонала як фактор протидії деформації. Університетські наукові записки. 2007. № 4 (24). С. 551-556.

742. Климов Е.А. Психология профессионала: Избранные психологические труды. Москва: Изд-во «Институт практической психологии», 2003. $456 \mathrm{c}$.

743. Толочек В.А. Стили профессиональной деятельности в условиях взаимодействия субъектов: автореф. дис. д-ра психол. наук. Москва, 1998. 24 с.

744. Ажажа М.А. Соціально-психологічний портрет майбутнього менеджера соціальної служби. Гуманітарний вісник Запорізької державної академії. 2010. Вип. 42. С. 236-246.

745. Кобець О.В., Лантух І.В. Психологічні особливості формування професійної надійності та професіоналізму суб'єктів підприємницької діяльності Вісник Харківського національного університету імені В.Н. Каразіна: зб. наук. праць. Вип. 66. Серія «Психологія». Харків: Вид-во ХНУ ім. В.Н. Каразіна, 2019. C. 67-74.

746. Василець Н.М. Довіра як підгрунтя толерантності у психологопедагогічний взаємодії. Науковий вісник Львівського державного університету внутрішніх справ. Серія психологія. 2012. № 1. С. 114-121.

747. Карамушка Л.М., Шевченко А.М. Організаційний розвиток як детермінанта розвитку організаційної культури загальноосвітніх навчальних закладів. Теоретичні і прикладні проблеми психології: збірник наукових праць / Гол. ред. Н.Є. Завацька. Луганськ: НОУЛІДЖ, 2014. № 1 (33). С. 196-205.

748. Діденко О.В. Сутність, зміст і структура поняття «професійна надійність фахівця». Збірник наукових праць Національної академії Державної прикордонної служби України. Серія: Педагогічні науки. 2015. № 1. С. 90-101. Режим доступу: http://nbuv.gov.ua/UJRN/znpnadpcpn_2015_1_10.

749. Панчук М.Т. Ціннісні орієнтації як системоутворюючий фактор соціально активної позиції майбутнього фахівця. Проблеми сучасної психології. 2017. Вип. 21. С. 542-551. 
750. Шадриков В.Д. Проблемы системогенеза профессиональной деятельности [Отв. ред. К. Абульханова-Славская]. Москва: Наука, 1982. 185 с.

751. Поваренков Ю.П. Уточнение метода и основных задач психологии профессионального становления личности. Ярославский педагогический вестник. 2013. T. II. № 2. С. 156-164.

752. Малєєв Д.В. Психологічні чинники розвитку професійної надійності працівників підрозділів превентивної діяльності Національної поліції України: дис. ... канд. псих. наук: 19.00.06/Харківський національний ун-т внутрішніх справ. Харків: Харк. нац. ун-т внутр. справ, 2016. 334 с.

753. Бодров В.А. Психология профессиональной деятельности: теоретические и прикладные проблемы. Москва: Институт психологии РАН, 2006. $622 \mathrm{c}$.

754. Практикум по дифференциальной психодиагностике профессиональной пригодности: учебное пособие [под общ. ред. В.А. Бодрова]. Москва: ПЕРСЭ, 2003. 768 с.

755. Крук В.М. Психология обеспечения личностной надёжности специалиста: монографія. Москва: Изд-во: НИИ радиоэлектроники и лазерной техники МГТУ им. Н.Э. Баумана, 2012. 376 с.

756. Крук В.М. Психология обеспечения личностной надёжности специалиста: монографія. Москва: Изд-во: НИИ радиоэлектроники и лазерной техники МГТУ им. Н.Э. Баумана, 2012. 376 с.

757. Ломов Б.Ф. Методологические и теоретические проблемы психологии. Москва: Наука, 1999. 350 с.

758. Шевченко Н.Ф. Професійна свідомість: специфіка психологічного явища. Вісник Харківського національного педагогічного університету ім. Г.С. Сковороди. Серія: Психологія. 2005. № 14. С. 98-106.

759. Лантух І.В. Структурно-функційна модель розвитку особистісної надійності суб'єктів підприємницької діяльності. Наукові записки Національного університету «Острозька академія». Серія «Психологія»: збірник наукових праць. Острог: Вид-во НаУОА, листопад 2018. № 7. С. 53-58.

760. Выготский Л.С. Психология развития как феномен культуры. МоскваВоронеж, 1996. 281 с.

761. Леонтьев А.Н. Деятельность. Сознание. Личность. Москва: Смысл; Издательский центр «Академия», 2004. 352 с.

762. Bacigalupo, M., Kampylis, P., Punie, Y., Van den Brande, G. (2016). EntreComp: The Entrepreneurship Competence Framework: Publication Office of the European Union; EUR 27939 EN; doi:10.2791/593884. 
763. Сидоров Н.Р. Философия образования. Введение. Санкт-Петербург: Питер, 2007. 304 с.

764. Salzburg II recommendations. European universities' achievements since 2005 in implementing the Salzburg principles. 2010 by the european university association/URL : www.eua.be.

765. Бацевич Ф. С. Основи комунікативної лінгвістики : підручник. Київ : ВЦ «Академія», 2004. 344 с.

766. Бірюк Л.Я. Формування комунікативно компетентної особистості майбутнього вчителя початкової школи у процесі професійної підготовки. Вісник ГНПУ імені Олександра Довженка: зб. наук. пр. Вип. 17. 2011. С.114-119.

767. Бірюк Л.Я. Формування комунікативно компетентної особистості майбутнього вчителя початкової школи у процесі професійної підготовки. Вісник ГНПУ імені Олександра Довженка: зб. наук. пр. Вип. 17. 2011. С.114-119.

768. Вашуленко М.С. Мовленнєва підготовка вчителя початкових класів. Психолого-педагогічні проблеми сільської школи: зб. наук. пр. УДПУ імені Павла Тичини. Умань: РВЦ "Софія", 2008. Випуск 20. С. 6-12.

769. Вашуленко М.С. Орієнтація професійної лінгводидактичної підготовки майбутніх учителів початкових класів на основну мету шкільної мовної освіти. URL: http://abc-lab.ucoz.ua/load/0-0-0-13-20 (дата звернення 10.11.2021).

770. Вашуленко М.С. Українська мова і мовлення в початковій школі: метод. посібник. Київ: Освіта, 2006. 268c.

771. Выготский Л. С. Мышление и речь. Избранные психологические исследования. Москва : Педагогика, 1996. 416 с.

772. Гальперин И. Р. Текст как объект лингвистического исследования. Москва : Наука, 1981. 138c.

773. Гоноболин Ф. Н. Психология : уч. пособ. Москва : Просвещение, 1973. $240 \mathrm{c}$.

774. Гончаренко С. У. Педагогічні закони, закономірності, принципи. Сучасне тлумачення. Рівне : Волинські обереги, 2012. 192 с.

775. Грабовский Н. К. Профессиональная речь (функциональностилистический аспект). Функционирование языка и речи. Москва, 2009.

776. Даниленко В. Д Язык для специальных целей. Культура речи и эффективность общения. Армавир : Редакционно-издательский центр АГПУ, 2007. $108 \mathrm{c}$.

777. Дроздова І. П. Наукові основи формування українського професійного мовлення студентів ВНЗ нефілологічних спеціальностей : монографія. Харків : ХНАМГ, 2010. $320 \mathrm{c}$. 
778. Дудик П. С. Стилістика української мови : навч. посіб. Київ : ВЦ «Академія», 2005. $368 \mathrm{c}$.

779. Жайворонок В. В. Українська мова в професійній діяльності : навч. посіб. Київ : Вища школа, 2006. 431 с.

780. Жинкин Н. И. Механизмы речи. Москва : Изд. АПН, 1985. 372 с.

781. Заболоцька О. О. Формування індивідуальності майбутніх учителівсловесників у професійній підготовці : монографія. Херсон : Айлант, 2016. 304 с.

782. Індивідуальні особливості мислення: вебсайт. URL: http://www.studbase.com (дата звернення 12.11.2021).

783. Концептуальні засади реформування середньоїосвіти «Нова українська школа». URL: https://mon.gov.ua/storage/app/media/zagalna\%20serednya/nova-ukrainska-shkolacompressed.pdf (дата звернення 02.11.2021)

784. Концепція мовної освіти в Україні. URL: http://osvita.ua/files.news/Concept_L_education (дата звернення 10.11.2012).

785. Концепція розвитку педагогічної освіти. URL:https://mon.gov.ua/ua/npa/pro-zatverdzhennya-koncepciyi-rozvitkupedagogichnoyi-osviti (дата звернення 01.11.2021)

786. Леонтьев А Н. Язык. Речь. Речевая деятельность. Москва : Красанд, 2010. $216 \mathrm{c}$.

787. Леонтьев А. А. Речевое воздействие. Москва : Просвещение, 1972. 146 c.

788. Леонтьев А. Н. Деятельность, сознание, личность. Москва, 1975.

789. Мацько Л. І., Кравець Л. В. Культура української фахової мови. Київ : ВЦ «Академія», 2007. 360 с.

790. Наер В. Л. Дискурс и речь: речевое произведение. Москва, 2006. С. 7 15.

791. Нова українська школа: порадник для вчителя /за заг. ред. Бібік Н. М. Київ: ТОВ «Видавничий дім «Плеяди», 2017. 206 с.

792. Паламар Л. М. Функціонально-комунікативний принцип мовної особистості : дис. ... канд.. пед.. наук : 13.00 .02 - теорія та методика навчання української мови. Київ, 1997. 213 с.

793. Пантюк Т., Пантюк М., Гамерська І., Десиняк Ю. Інновації в освіті: необхідність, сутність, зміст. Молодь і ринок. Дрогобич, 2020. №6/185. DOI: https://doi.org/10.24919/2308-4634.2020.225537

794. Пасинок В. Г. Основи культури мовлення: навч. посіб. Київ : Центр учбової літератури, 2020. 245 с. 
795. Професійне мовлення майбутніх учителів початкової школи : навчально-методичний комплекс / упор. Ольга Попова. Бердянськ : Видавець Ткачук О. В., 2016. 190 с.

796. Семеног О. М. Культура наукової української мови : навч. посібн. Київ : ВЦ «Академія», 2010. 216 с.

797. Семеног О. М. Українська культуромовна особистість учителя (шляхи іiі формування в системі професійної підготовки) : монографія. Київ : Педагогічна думка, 2007. 278 с.

798. Сербенська О. Культура усного мовлення. Практикум : навч. посіб. Київ : Центр навч. літератури, 2004. 216 с.

799. Синиця I. О. Педагогічний такт та майстерність вчителя : посіб. для вчителя. Київ, 1981. 248 с.

800. Сорочан Т.М. Підготовка вчителів до реалізації концепції НУШ. Методист. 2018. №6. С.4-9.

801. Сухомлинский В. А. Как воспитать настоящего человека : педагогическое наследие. Москва : Педагогика 1990. 288 с.

802. Сухомлинський В. О. Слово рідної мови. Зібр. тв. у 5-и томах. Т.3. Київ : Рад. шк., 1980. 719 с.

803. Хижняк I.A., Ворожбіт-Горбатюк В.В. Міжуніверситетські комунікаційні заходи як спосіб формування регіонального дослідницького середовища. Професіоналізм педагога: теоретичні й методичні аспекти. Слов'янськ, 2021. С. 5-18. http://profped.ddpu.edu.ua/article/view/236444/234962 (дата звернення 11.11.2021).

804. Вороненко Ю.В., Бойченко Т.С. Стратегії і методи навчання в післядипломній медичній освіті: навчально-методичний посібник. К.: Вересень, 2004: $160 \mathrm{c}$.

805. Вороненко Ю.В., Мінцер О.П., Краснов В.В. Електронні навчальні посібники для відображення медичних процедурних знань: принципи, етапи створення, методологія.- К., 2009: 160 с.

806. Вороненко Ю.В., Бойко А.І., Гойда Н.Г. та ін. Дидактичні технології викладання питань репродуктивного здоров'я.- К.: Книга-плюс, 2011: 192 с.

807. Інтерактивні технології навчання: теорія, практика, досвід : [метод. посіб.] / авто-уклад. О. І. Пометун, Л. В. Пироженко. - К. : А.П.Н. 2007. - 136 с.

808. Концепція нової української школи [Електронний ресурс] / Міністерство освіти і науки України : Нова українська школа. - Режим доступу : http://mon.gov.ua/activity/ education/zagalna-serednya/ ua-sch-2016/ konczepcziya.html 
809. Лабораторні роботи 3 шкільного курсу фізики та методики іiі викладання. Частина III: [методичні рекомендації для студентів, вчителів і викладачів фізики] / С.П. Величко, В.П. Вовкотруб; за ред., С.П. Величка. Кіровоград: РВВ КДПУ ім. В. Винниченка, 2009. - Ч.3. - 80 с.

810. Підготовка майбутніх учителів фізики, хімії. Біології та природничих наук у контексті вимог Нової української школи : Матеріали міжнародної науковопрактичної конференції. 20-21 травня 2019 р., м. Тернопіль. - Тернопіль: Вектор, 2019. - $258 \mathrm{c}$. 